\title{
Electric Power Supply and Demand for the Contiguous United States 1980-1989
}

June 1980

\section{U.S. Department of Energy}

Economic Regulatory Administration

Division of Power Supply and Reliability

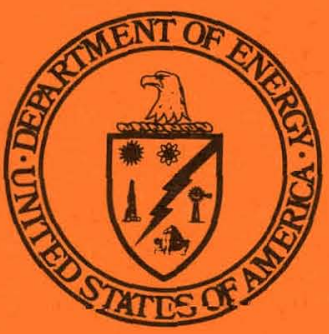




\section{DISCLAIMER}

This report was prepared as an account of work sponsored by an agency of the United States Government. Neither the United States Government nor any agency Thereof, nor any of their employees, makes any warranty, express or implied, or assumes any legal liability or responsibility for the accuracy, completeness, or usefulness of any information, apparatus, product, or process disclosed, or represents that its use would not infringe privately owned rights. Reference herein to any specific commercial product, process, or service by trade name, trademark, manufacturer, or otherwise does not necessarily constitute or imply its endorsement, recommendation, or favoring by the United States Government or any agency thereof. The views and opinions of authors expressed herein do not necessarily state or reflect those of the United States Government or any agency thereof. 


\section{DISCLAIMER}

Portions of this document may be illegible in electronic image products. Images are produced from the best available original document. 


\section{Electric Power Supply and Demand for the Contiguous United States 1980-1989}

June 1980

U.S. Department of Energy

Economic Regulatory Administration

Division of Power Supply and Reliability

Washington, D.C. 20585
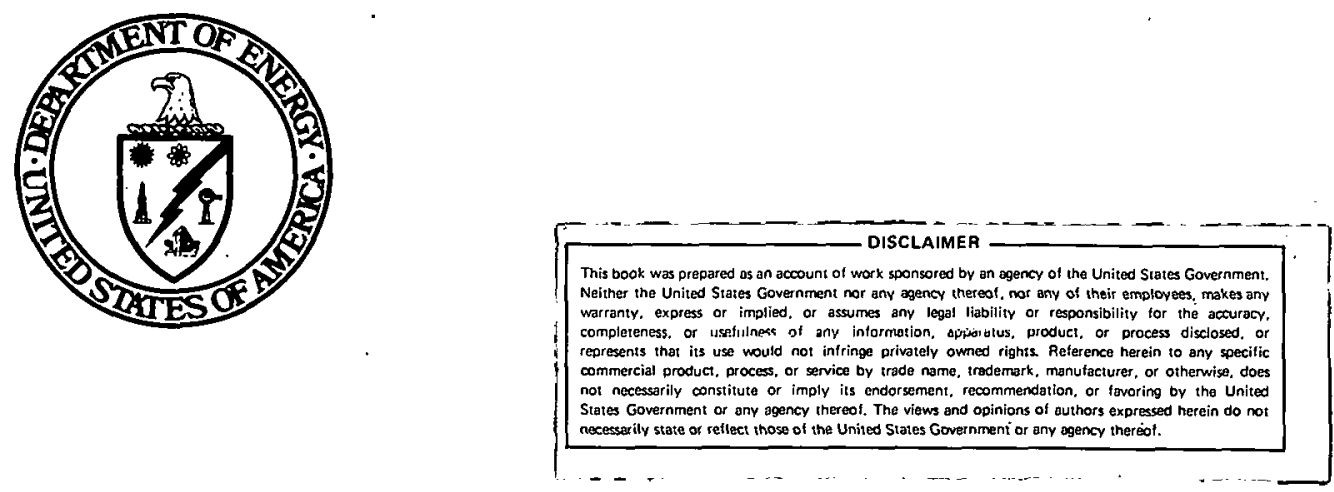


\section{$\underline{\text { PURPOSE }}$}

The purpose of this report is to present a limited review of the outlook for electric power supply and demand during the period 1980-1989. This report considers only the adequacy and reliability aspects of bulk electric power supply in the contiguous United states. We recognize that the economic, financial and environmental aspects of electric power system planning and the distribution of electricity (below the transmission level) are topics of prime importance, but they are outside the scope of this report. 


\section{Report Organization}

Sections I through $x$ deal generally with electric power supply and adequacy as projected for the nine Reliability Council areas and the total contiguous United States. Section XI discusses those topics as projected in detail for each of the 29 Electric Regions (sub-areas of the nine Council areas) in the contiguous United States.

A glossary of terms used in the report follows Section XI, and is followed by two appendices. Appendix $A$ describes the structure of the Reliability Councils. Appendix B lists the utilities for which data is included in this report.

This copy of the report is a preliminary issuance, circulated in order to make available quickly the conclusions and data of the study. The final version of the report may be published shortly after all data have been checked for accuracy. While minor changes and corrections may be made, we are sure that no changes in the conclusions and general text of the report will be needed. 


\section{CONTENTS}

SECETION

General Conclusions

I. Summary

1. Highlights

Maps of Electric Region and Reliability

Council Boundaries

2. Discussion

3. Summary Tables and Graphs

II. Introduction

III. Energy Forecasts

IV. Peak Demand Forecasts

V. Generating Capacity

VI. Reserve Margins

VII. Nuclear Capacity

1. General Overview

2. Detailed Regional Analysis-Impact of Delays in the Issuance of Nuclear Operating Licenses through 1985

VIII. Transmission

IX. Inter-regional Transfers

1. Scheduled

2. Emergency

X. Coal Unit Delays

XI. Electric Region Analyses

1. ECAR

A. Allegheny Power system (APS)

B. American Electric Power System (AFP)

C. Central Area Power Coordination "Group (CAPCO)

D. Cincinnati, Columbus, Dayton Group (CCD)

E. Kentucky

F. Indiana (Except AEP Systems)

G. Michigan Electric Coordinated Systems (MFCS)

2. ERCOT

A. Texas Interconnected systems (TIS) 
3. MAAC

A. Pennsylvania-New Jersey-Maryland Interconnection ( $P J M$ )

4. MAIN

A. Commonwealth Edison Company (CECO)

B. Illinois-Missouri Pool (ILLMO)

C. Wisconsin-Upper Michigan Systems (WUMs)

5. MARCA

A. Mid-Continent Área Power Poúl (MAPP)

6. NPCC

A. New Fingland Power Pool (NEPOOL)

B. New York Power Pool (NYPP)

7. SERC

A. Florida Coordinating Group (FCG)

B. Southern Company (SoCo)

C. TVA

D. Virginia-Carolinas (VACAR)

8. SPP
A. Middle South Utilities (MSU)
B. Gulf States Utilities (GSU)
C. Missouri-Kansas Pool (MOKAN)
D. Oklahoma

9. WSCC
A. Rocky Mountain Power Area (RMPA)
B. Northwest Power Pool (NWPP)
C. Arizona-New Mexico (AZ-NM)
D. Southern California-Nevada (SC-N)
E. Northern California-Nevada (NC-N)
F. Idaho-Utah (included in NWPP)

\section{Glossary}

Appendix A The Reliability Councils

Appendix B Utilities Included in this Report

Participants in this Report 
- Load growth for 1980-1983 is projected to average 2.18 annually for energy (MWh) and, in the range of 2.18 to 2.98 annually for summer peak demand (Mw). These projections, made by the Division of Power Supply and Reliability, are about half the increases projected by the Reliability Councils.

- Generating capacity reserve margins, based on the loads and construction schedules projected by the Reliability Councils, are adequate to provide reliable service in most areas of the contiguous United states for the period 1980-1989. Reserve margins in some rlectric Fegions (sub-areas of the Council areas) however, may be insufficient over specific time intervals to assure reliable electric service in those Regions.

- Failure of nuclear and coal-fired generating units to meet projected schedules for commercial operation could have a serious negative effect on power supply reliability and adequacy in many areas.

- To assure reliable energy supply and provide for significant reduction of fuel oil consumption, every effort should be made to maintain the current schedules for construction and licensing of the following nuclear units. All of these units are scheduled for commercial operation by the end of 1981 .

Diablo Canyon 1
Diablo Canyon 2
San Cnofre 2
LaSalle County 1
Lasalle County 2

Diablo Canyon 1

Diablo Canyon 2

Lasalle county 1

Lasalle county 2
Farley 2

McGuire 1

Summer 1

Watts Bar 1

Sequoyah 2 
- The following coal-fired units are considered prime candidates for accelerated completion and operation:

$\begin{array}{ll}\text { Erandon Shores } 2 & \text { California Coal } 2 \\ \text { Brandon Shores } 1 & \text { Coho } 1 \\ \text { Sears Island } & \text { H. Allen } 1 \\ \text { Seward } 7 & \text { H. Allen ? } \\ \text { California Coal 1 } & \text { H. Allen } 3: . .\end{array}$

- The reserve margin projections of Section XI indicate that some Electric Regions may experience difficulty in supplying customer demands at the time of summer peak load in 1980. Since the major difficulty is expected to be a lack of sufficient generating capacity (including currently scheduled capacity purchases from other regions), special measures to maintain system viability may be necessary. These measures could include: emergency purchases from other regions, voltage reductions, appeals to consumers to reduce their use of electric power, disconnection of contractually interruptible loads. Those regions in which reliability problems may occur are listed in Table $A$, below.

\section{Taㅡ므르ㄹㅛㅗ}

\section{ELECTRIC REGIONS WITH PCSSIRLE CAPABILITY PRORLEMS PROJECTED FOR THE 1980 SUMMER PEAK}

\begin{tabular}{|c|c|c|c|}
\hline №ᅳ. & El & 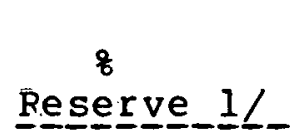 & 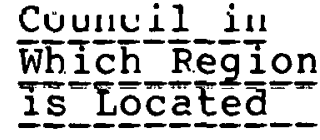 \\
\hline $\begin{array}{l}12 \\
10\end{array}$ & $\begin{array}{l}\text { VACAR. } \\
\text { Gulf States Utilities }\end{array}$ & $(1.7)$ & SERC \\
\hline $\begin{array}{r}28 \\
11 \\
7\end{array}$ & $\begin{array}{l}\text { Group } \\
\text { Northern California-NEV } \\
\text { TVA } \\
\text { Florida Coordinating } \\
\text { Group }\end{array}$ & $\begin{array}{l}1.6 \\
2.3 \\
5.4 \\
\vdots \\
6.6\end{array}$ & $\begin{array}{l}\text { SWYY } \\
\text { WSCC } \\
\text { SERC } \\
\text { SERC }\end{array}$ \\
\hline
\end{tabular}

$(1)=$ Negative_ Number

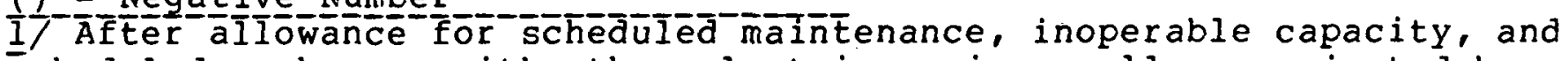
scheduled exchanges with other electric regions, all as projected by Council and utility report, and allowance for probable forced outages as computed by staff. 
- For the Electric Regions not listed in Table A, projected generating capacity appears to be adequate for meeting contingencies of the kind normally encountered. However, even for these regions, unusual occurrences resulting in damage to transmission system facilities (e.g., storms, fires) could adversely affect the network's ability to supply capacity to the load centers for brief periods of time. 


\section{SUMMARY}

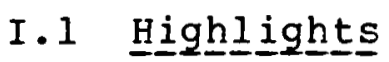

- Power supply reliability in most regions of the contiguous U.S. is expected to be adequate for the period 1980-1985, but problems exist in some areas.

- Requirements for electric energy and feak demand can reasonably be expected to increase at a rate in the $r$ ange of 2.18 to 2.98 per year through the end of 1983.

- Failure to have in operation (as now scheduled) those nuclear units slated for completion by the end of 1985 could result in the use of some 700 million additional barrels of oil.

- The timely licensing and construction of nuclear power plants, consistent with all applicable safety and environmental considerations, could flay a key role in the improvement of power supply adeguacy and reliability in several regions.

- Acceleration of coal unit construction could save some 70 million barrels of oil by the end of 1989. 


\section{DEPARTMENT OF ENERGY - ENERGY INFORMATION ADMINISTRATION}

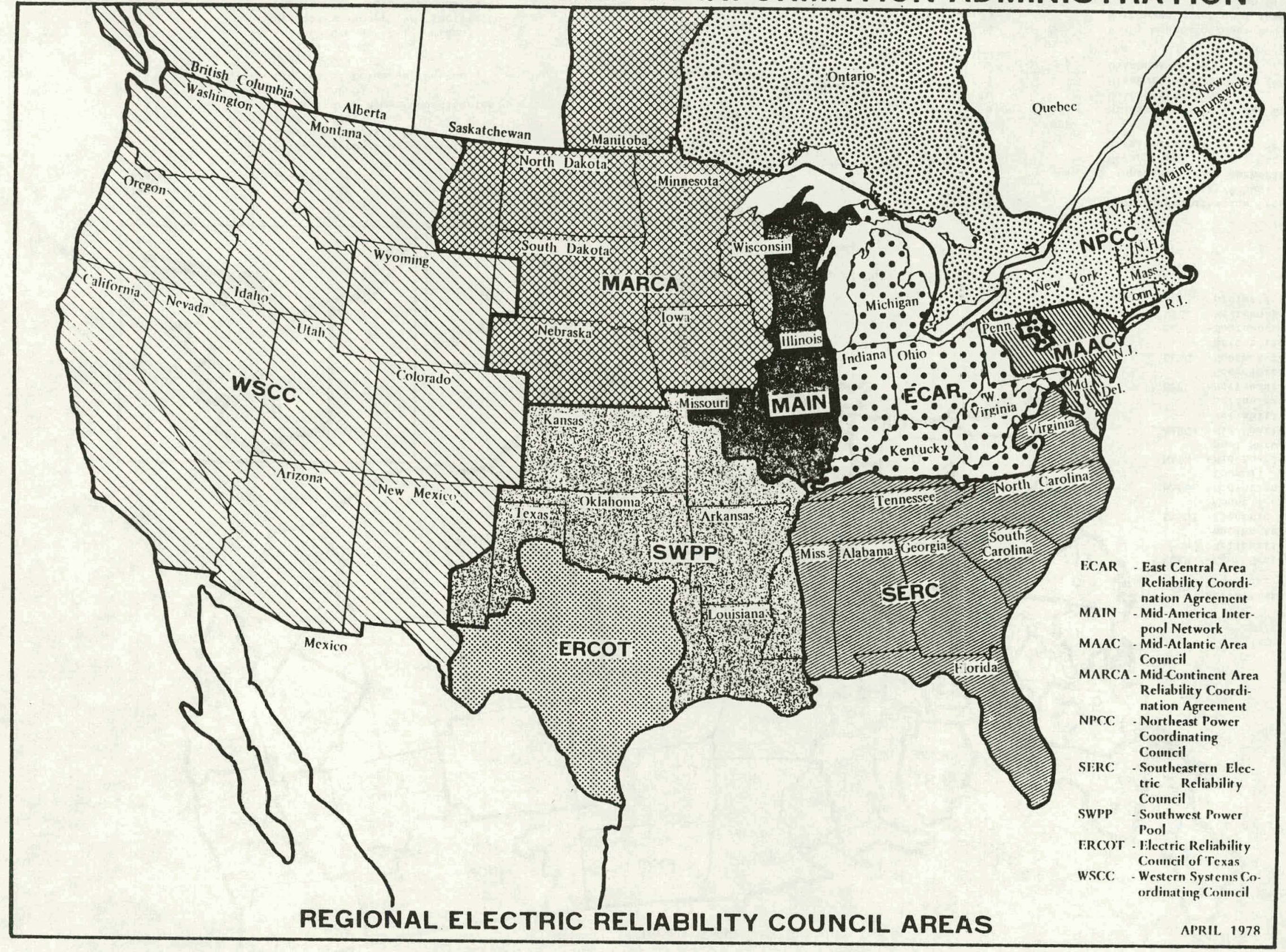


Department of Energy - Economic Regulatory Administration

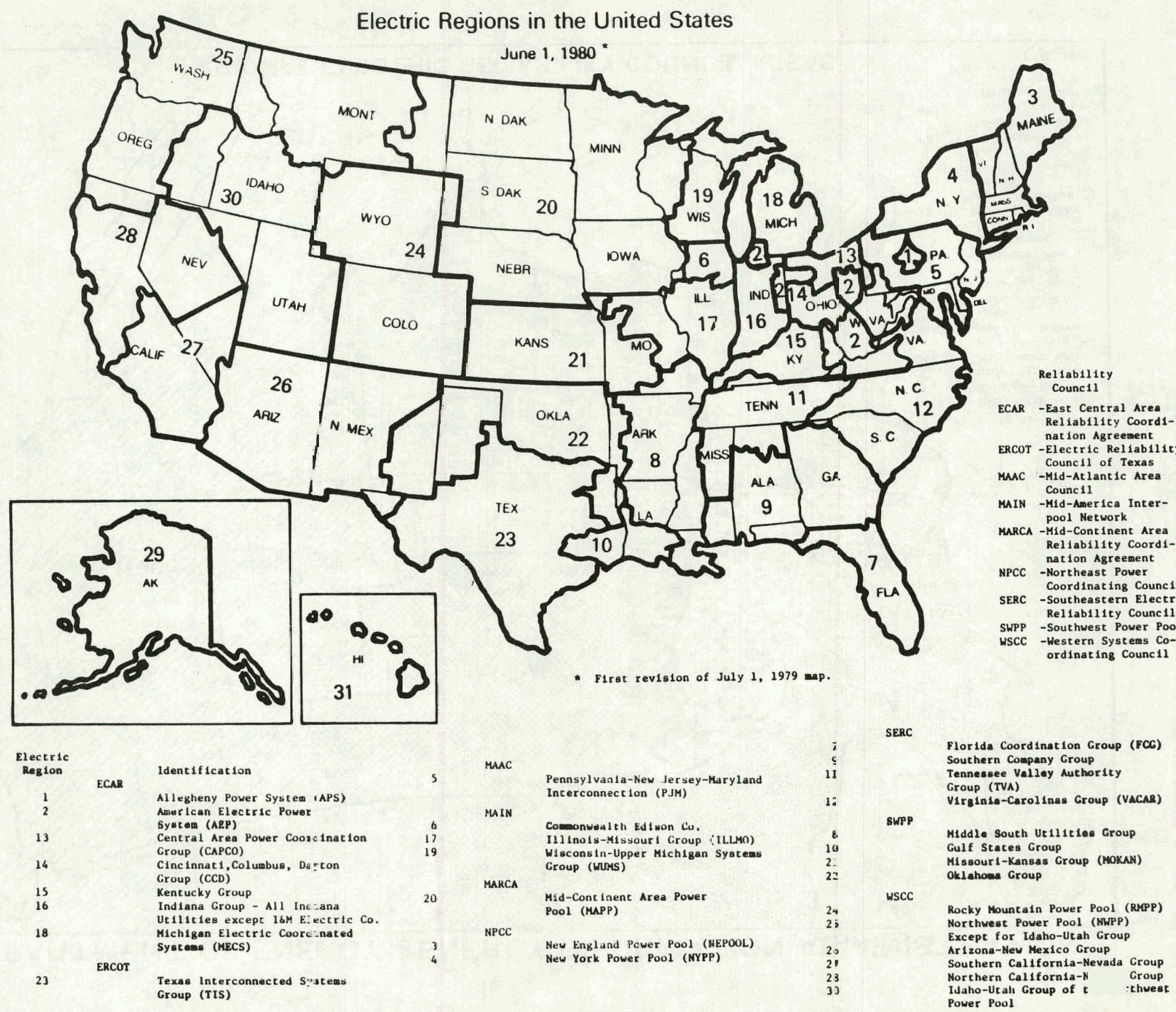




\section{I.2 - DISCUSSION}

The growth rates for peak demand, generating capability and electric energy requirements, as projected by the Reaional Electric Reliability Councils 1 in their April 1, 1980, Coordinated Bulk Power Supply programs, except for the Texas Reaion, are less than the rates projected in 1979. The Division of Power supply and Reliability concurs in the general expectation of a lower rate of growth for electric power, without necessarily endorsing the specific forecasts reported by the Councils. Reliability Council area-wide reserves, as projected, are adeơuate for all councils except MARCA. MARCA's summer reserve margin appears low from 1986 on, and in 1989 becomes too low to assure reliable service. The low projected reserves of several Electric Regions are discussed in section $X I$.

For the contiguous U. S. as a whole, the average annual rate of increase of salient power system characteristics as projected hy the Councils in their reports dated April 1, 1979 and April 1, 1980, are compared in the table below:

\section{Table I.2.1}

Summer Peak Demand Winter Peak Demand Annual Net Energy Reguirement Capability at Time of summer Peak Capability at Time of Winter Peak
Projected Average Annual o Increase \begin{tabular}{r}
$1978-8$ \\
\hline 4.9 \\
4.9 \\
4.8 \\
4.1 \\
4.2
\end{tabular} $\frac{1979-89}{4.3}$ 4.6 4.2

3.6

3.7

17 See Appendix $\bar{A}$ for a gener $\bar{r} \bar{l}$ description of the Regional Electric Reliability Councils. 
Projected increases in capability, peak demand and energy requirements differ among the NERC Council Regions $1 /$. The ten-year energy and demand growth rates as projected by each Council in 1979 and in 1980 are shown in the table below. ERCOT is the only council which currently projects a higher rate of growth than was projected a year earlier.

Table I.2.2

Projected Average Annual \& Increase

$\frac{\text { Annual Energy }}{\underline{1978-88}}$

$\frac{\text { Summer }}{1978-88} \frac{\text { Peak Demand }}{1979-89}$

$\begin{array}{ll}\text { MAAC } & 3.5 \\ \text { NPCC } & 3.5 \\ \text { ECAR } & 4.5 \\ \text { MAIN } & 4.7 \\ \text { WSCC } & 4.8 \\ \text { SERC } & 4.8 \\ \text { ERCOT } & 4.9 \\ \text { MARCA } & 5.5 \\ \text { SWPP } & 6.2\end{array}$

3.2

2.1

$\begin{array}{ll}4.5 & 3.8 \\ 4.7 & 4.0\end{array}$

$4.8 \quad 4.5$

$4.8 \quad 4.6$

$4.9 \quad 5.2$

$5.5 \quad 4.8$

5.2
5.8

3.3

2. 9

3.4

1.9

4.4

4.0

4.8

4.2

5.0

4.5

5.7

4.5

5.2

5.6

5.6

5.5

SWPP

Summer peaking is expected to continue as a characteristic of total U.S. demand, although some Council regions do expect winter peaks. For, summer 1989 , total U.S. demand is expected to be $610,682 \mathrm{Mw} /$; this is an increase of $209,526 \mathrm{Mw}$ over the summer 1979 value of $401,156 \mathrm{Mw}$. The generating capability to supply the 1989 summer peak is projected by the councils to reach $778,058 \mathrm{Mw}$. In summer 1979, the U.S. generating capability was $544,560 \mathrm{Mw}$. Although the national instalied (planned) reserve margin is not a valid criterion of reliability, its magnitude is nevertheless of interest. The summer 1979 reserve margin was $35.8 \%$; the margin is expected to drop to 27.48 by summer 1989 .

I/ "NERC Council Regions" refers to the respective areas of the nine Regional Electric Reliability Councils. "Electric Regions" refers to the 29 areas which ERA has established as subdivisions of the nine Reliability Council areas.

2/ Non-coincident sum of Council area peaks. 
On the basis of the capacity, demand and energy reouirements currently projected by the Reliability council reports, it appears that adequate electric power will be available in most Flectric Regions through the end of 1989. Critical to this assessment is the assumption that the rate of load growth is no greater than the Council reports indicate. If the average annual rates of peak demand and energy growth should be greater than projected, power system reliability will, in general, decline. For instance, an average annual increase of 4.58 in summer peak demand, instead of the $4.3 \%$ projected, would cause the national summer installed (planned) reserve margin to drop to 24.98 in 1989 . That is, an increase of 0.28 in the average annual rate of demand growth has a cumulative negative effect of 2.58 on reserve margin by 1989 . The level to which reliability would fall will be a function of the magnitude of the demand increase, provided construction of generating capacity is maintained at the pace projected in the April 1, 1980 Council reports.

The matter of projected additions to the bulk power supply. system is of great concern to the Department of Energy. Adecuacy of power supply is strongly dependent on the maintenance of a prudent balance between projected demand and projected supply, with due allowance for the uncertainties of the future. The reserve margins projected by the Regional Reliability Councils rely on continued construction, and completion on schedule, of hundreds of new generating units through 1989. Of the projected units, 86 totalling nearly $94,000 \mathrm{MW}$, are nuclear. In reviewing the dates projected in the Counsil Reports for completion of these units, we have concluded that many of the in-service dates are highly optimistic. Our appraisal indicates the strong possibility that 53 of the nuclear units scheduled for operation by the end of 1985, with-a total capability of about $57,000 \mathrm{Mw}$, are not likely to be operational on the dates given in the Pegional Council reports. Failure of these units to be available as scheduled will degrade the projected reserve margins, (as discussed in section VII) and will result in increased consumption of oil and gas. Coal-fired units comprise a large portion of future capacity construction, and delays in completion of these units will also degrade the prospective reserve margins and will increase reliance on scarce fuels. 
Fuel supply is of course a critical factor in the planned operation of generating units. The Reliability Council reports consider fuel only to the extent of identifying the primary and alternate type of fuel for existing and projected generating units. No estimate is given of the fuel ouantities needed. It is necessary to point out that any restrictions on primary energy supply (nuclear, coal, oil, natural gas, water) have a negative impact on the ability of a utility system to operate its generating units. Coal storage piles and oil storage tanks are intended to smooth out temporary fluctuations in the flow of fuel from source to generating unit. They cannot cope with long-term restrictions on fuel supply. Extended and widespread stoppage, such as results from strikes and embargoes, can disrupt the orderly operation of even the best-planned power system. Both the reliablitty and the economy of system operation are reduced when adequate fuel of the type for which generating units are designed is not avallable.

Electric energy supply from a power system is to a certain extent independent of interruptions in supply of o epecific type of fuel, provided alternate fuel sources are available and ran be utilized. For instance, increased use of coal-fired and nuclear units can compensate to a limited degree for reduced energy production by oil-fired units. The amount of compensation depends on the "mix" of unit types in the area with an oil-supply shortage, transmission interconnections with other areas, the current degree of loading on coal-fired and nuclear capacity and other factors. In November 1979, as an example, oil fuel provided 12.98 of the electric energy generated in the contiguous U.S. But this average value masks the regional variations: in the six-state New England region, oil provided $53.6 \%$ of the regional electric generation whereas in the area covered by ohio, Indiana, Illinois, Michigan and wisconsin oil provided only 5.48 of the electric generation. In the total washington-oregon-California area, 28.98 of electric energy was provided by oil, but in Arkansas-Louisiana-OklahomaTexas, only $4.0 \%$ of electric energy production was oil-based.

Fixcept for the Northwest Power Pool (NWPP) area, adecuacy of energy supply appears reasonably secure in the various clectric regions, if fuel supply is provided as now contemplated for projected units, at least through the summer of 1985. In the NWPP region, the large amount of hydro capacity places $1 \%$ heavy dependence on precipitation and run-off for year-round energy supply.

İ As of January l, $1980,7 \overline{0 \%}$ of NWPP capability (including Canada) was hydro-electric. In 1985 hydro is expected to constitute 65\% of NWPP capability. 
This reliance on uncertain weather conditions, combined with delays in completion of the five WNP units l/ (which can provide energy independent of weather conditions) makes energy adeouracy uncertain. The West Group of the Northwest Power Pool (which covers Washington, Oregon, part of Idaho and part of Montana) projects $2 /$ a $36 \%$ probability of an energy deficiency for its area in 1980-81; the probability of an energy deficiency increases to 958 for $1984-85$.

As loads increase and the number of large, dispersed generating units becomes greater, transmission facilities assume a more important role in power supply adequacy and reliability. Adeouate transmission is important in providing flexibility of operation in the event of interruptions to fuel supply, drought, large-scale generating unit outages and other situations affecting system operation. Transmission sufficient to move energy in necessary amounts from coal-based areas to oil-based areas can be effective in helping utilities to respond to interruptions to oil supply and. in reducing the use of oil even in periods of adequate supply.

The same transmission can help oil-fired areas supply energy to coal-based areas in the event of interruptions in coal supply. It is necessary to maintain a reasonable program of transmission construction in order to assure adequate future reliability of power supply. It is entirely possible that by building additional transmission system facilities, utilities could in selected instances avoid the need to build new generating facilities that would impose financial burdens or create environmental problems. In other instances, overall system reliability could possibly be more cost-effectively enhanced by construction of transmission lines than by the addition of a generating unit. The Reliability Council reports include detailed data on construction of necessary transmission lines.

The ten charts following show graphically the annual net energy; summer peak demands and net capability; and reserve margin at the time of summer peak demand, as projected by each council (and in the aggregate for the contiguous U.S.) for the years 1980 through 1989. Actual data for 1976 through 1979 are also shown in the charts.

Tables of the capacity, demands, energy reouirements and reserves of each Council are provided following the charts, for the years 1976 through 1979 (actual), and 1980 through 1989 (projected).

I/ Washington Nuclear Project Ūnits 1 through 5, under construction by the washington Public Power supply system.

2/ Pacific Northwest Utilities Conference Committee, "West Group Forecast of Power Loads and Resources, July 1980-June 1991" March 1980. Table 1-l. 
I. 6

I.3 Summary Tables and Graphs 
Table 1

PROJECTED GROWTH OF COUNCIL REGICN NET ANNUAL ENERGY REQUIREMENTS 1980-1989

AS REPORTED BY THE REGIONAL ELECTRIC RELIABILITY COUNCILS

TO THE DEPARTMENT OF ENERGY -

CONTIGUOUS UNITED STATES

$\underline{1930} \quad \underline{1981} \quad \underline{1.182} \quad \underline{1983} \quad \underline{1984} \quad \underline{1985} \quad \underline{1986} \quad \underline{1987} \quad \underline{1588} \quad \underline{1989}$

Gigawatthours $(=1,000 \times \text { Megawatthours })^{*}$

\begin{tabular}{|c|c|c|c|c|c|c|c|c|c|c|}
\hline ECAR $1 /$ & 384,200 & 406,400 & 427,600 & 444,500 & 61,400 & 78,900 & 496,100 & 513,400 & 532,000 & 550,000 \\
\hline$A A C$ & 7,848 & 176 & & 578 & & & & 997 & 162 & 236 \\
\hline $\operatorname{IIN} \frac{\mathrm{a}}{2}$ & 8 & 78 & & 79 & 6 , & 03, & 36 & 66 & 21 & 30 \\
\hline $\mathrm{ARCA}_{2} \frac{2}{1}$ & 35 & 107 & 12,274 & 3,079 & 24,320 & 130 & 13 & 90 & & \\
\hline $\mathrm{CC} \leq-1$ & 3 & 10 & 05 & & 5 & & & & & \\
\hline $\begin{array}{l}\text { ERC } \\
\text { WPP }\end{array}$ & 482, & $\begin{array}{l}50 \\
22 \\
\end{array}$ & & & & & & & & \\
\hline Subt & 730,135 & $1,809,034$ & 890 & 85 & 89 & 06 & 784 & & & \\
\hline $\mathrm{CC}-$ & & & & & & & & & & \\
\hline$c 0$ & 160 & & 179,349 & 188 & $\begin{array}{r}198,129 \\
\end{array}$ & 207,937 & 217,885 & 227,639 & & $(49,91$ \\
\hline & 347,337 & $2,456,116$ & $, 567,436$ & $.677,637$ & $?, 795,454$ & $2,909,107$ & 022,769 & 38,964 & 261,898 & 383,253 \\
\hline
\end{tabular}

\section{Annual Percent Increase Jver Preceding Year}

Average \& Increase $3 /$ $1979-1989$

\begin{tabular}{|c|c|c|c|c|c|c|c|c|c|c|}
\hline \multirow[b]{2}{*}{ ECAR $1 /$} & \multirow[b]{2}{*}{1.37} & \multirow[b]{2}{*}{5.78} & \multirow{2}{*}{5.22} & & \multirow[b]{2}{*}{3.62} & \multirow{2}{*}{3.38} \\
\hline & & & & 3.95 & 3.80 & 3.79 & 3.59 & 3.49 & & \\
\hline MAAC a/ & 3.08 & 3.73 & 3.75 & 3.23 & 3.28 & 3.27 & 3.23 & 2.97 & 2.84 & 2.85 \\
\hline MAIN $\frac{2}{21}$ & 1.12 & 1.91 & 3.97 & 3.88 & 3.42 & 3.61 & 3.79 & 3.60 & 3.99 & 19 \\
\hline $\operatorname{MARCA}_{2} \frac{27}{1}$ & 5.98 & 5.55 & 3.99 & 5.17 & 5.29 & $4.5 \varepsilon$ & 4.54 & 4.54 & 4.35 & 4.31 \\
\hline NPCC $\underline{\prime}$ & 1.15 & 1.26 & 2.18 & 2.35 & 2.37 & 2.26 & 2.39 & 2.49 & .2 .46 & 2.40 \\
\hline SERC a/ & 6.54 & 4.78 & 5.18 & 4.55 & 5.58 & 3.95 & 3.76 & 3.82 & 3.91 & \\
\hline SWPP 따 & $\underline{7.52}$ & 7.50 & $\underline{5.35}$ & 5.84 & 5.47 & 5.28 & $\underline{5.20}$ & 5.27 & $\underline{5.25}$ & 5.00 \\
\hline Subtotal & 3.88 & 4.56 & 4.53 & 4.17 & 4.36 & 3.84 & 3.76 & 3.74 & 3.81 & \\
\hline wscc $\underline{2}$ & 7.26 & 4.56 & 4.21 & 4.46 & 4.32 & 4.60 & 4.14 & 4.02 & 3.99 & \\
\hline ERCOT & 6.95 & $\underline{5.65}$ & 5.45 & 5.14 & 5.07 & 4.95 & 4.78 & 4.48 & 4.83 & \\
\hline U. S. Total & 4.72 & 4.63 & 4.53 & 4.29 & 4.40 & 4.07 & 3.91 & 3.84 & 3.92 & \\
\hline
\end{tabular}

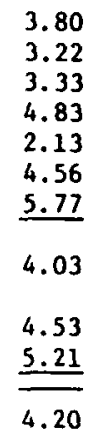

‡ As reported in Item 1 of the Council reports. Net energy is the electric energy required from all power scurces during the reporting period to satisfy the energy requirements of customers and supply losses in the transmission and distribution system. It includes the net energy from installed power sources and energy supplied by uther sources such as interconnected utility systems. and industrial scurces. It does not include the energy
required for pumping of pumped storage plants.

a/ Reflects transfer of Asscciated Electric Cooperative from MANN to SWPP.

1/ Total of Bulk Power and Liaison System Members.

2/ U. S. portion of Council only.

$3 /$ Average of ten annual increases from (1980/1979) to $(1989 / 1988)$. 
Table 2

PROARCTED GROWTH JF C.JUNCIL TEGION SUMMER PEAK DEMANDS 1980-1989

AS REPORTED BY THE REGIONAL ELECTRIC RELIABILITY COUNCILS

TO THE DEPARTMENT OF ENERGY--APRIL 1,1980

CONTKGUOUS UNITED STATES

$\underline{1980} \quad \underline{1981} \quad \underline{1982} \quad \underline{1983} \quad \underline{1984} \quad \underline{1985} \quad \underline{1986} \quad \underline{1987} \quad \underline{1988} \quad \underline{1999}$

\begin{tabular}{|c|c|c|c|c|c|c|c|c|c|c|}
\hline \multirow[b]{2}{*}{$\operatorname{BCAR}^{2 / 1 /}$} & \multirow[b]{2}{*}{64,628} & \multirow[b]{2}{*}{68,176} & \multicolumn{8}{|c|}{ weodwatco } \\
\hline & & & 71,752 & 74,649 & 77,404 & 80,246 & 83,177 & 86,056 & 89,012 & 92,042 \\
\hline MAAC & 33,550 & 34,550 & 35,610 & 36,590 & 37,600 & 38,600 & 39,600 & 40,550 & 41,440 & 42,370 \\
\hline MAIN $\frac{a}{2}$ & 34,650 & 35,973 & 37,362 & $38,6.82$ & $39,9=6$ & 41,363 & 42,782 & 44,301 & 45,792 & 47,360 \\
\hline MARCE 21 & 19,949 & 21,275 & 22,529 & 23,678 & 24,911 & 26,096 & 27,257 & 28,417 & 29,636 & 30,865 \\
\hline NPCC $=$ & 35,420 & 35.820 & 36,470 & 37,110 & 37,760 & 38,430 & 39.250 & 40,150 & 41,010 & 41,960 \\
\hline SERC & 87,510 & 91,486 & 97.103 & 101,238 & 106,563 & 110,712 & 114,887 & 119,600 & 224,297 & 128,813 \\
\hline SWPP 9 & 43,273 & 45,538 & 47,952 & 50,754 & 53,449 & 56,253 & 59,065 & 62,099 & 65,257 & 68,461 \\
\hline Subtotal & 318,980 & 332,818 & 348,778 & 362,701 & $377, \in 33$ & 391,700 & 406,018 & 421,173 & 436,444 & 451.871 \\
\hline $\mathrm{wscc}^{2 /}$ & 77.286 & 80,600 & 83,713 & 87,168 & 90,710 & 94,697 & 98,333 & 102,086 & 105,802 & $\begin{array}{r}109,650 \\
49,161\end{array}$ \\
\hline ERCOT & 31,621 & 33,306 & 35.089 & 36,873 & $38, .996$ & 90,194 & 42,135 & $\stackrel{20}{2}$ & 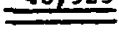 & \\
\hline U.s. Total & 427,887 & 446,724 & 467.580 & 486,742 & 507,189 & 527,141 & 547,086 & 568,038 & 589,171 & 610,682 \\
\hline
\end{tabular}

Annual Percent Increase Over Preceding Year

\begin{tabular}{|c|c|c|c|c|c|c|c|c|c|c|}
\hline ECAR $^{1 /}$ & 3.93 & 5.49 & 5.25 & 4.04 & 3.69 & 3.67 & 3.65 & 3.46 & 3.43 & 3.40 \\
\hline MAAC & 5.57 & 2.98 & 3.07 & 2.75 & 276. & 2.66 & 2.59 & $2 . \infty 0$ & 2.19 & 2.24 \\
\hline MAIN $\frac{\partial}{2}$ & 2.51 & 3.82 & 3.86 & 3.53 & 3.40 & 3.42 & 3.43 & 3.55 & 3.37 & 3.42 \\
\hline MARCA $\frac{2 /}{1}$ & 9.84 & 6.65 & 5.89 & 5.10 & c.21 & 4.76 & 4.45 & 4.26 & 4.29 & 4.15 \\
\hline $\begin{array}{l}\text { NPCC } \\
\text { SERC }\end{array}$ & $\begin{array}{l}1.95 \\
5.10\end{array}$ & $\begin{array}{l}1.13 \\
4.54\end{array}$ & $\begin{array}{l}1.81 \\
6.14\end{array}$ & $\begin{array}{r}1.75 \\
9.26\end{array}$ & $\begin{array}{l}3.75 \\
5.26\end{array}$ & $\begin{array}{l}1.77 \\
3.89\end{array}$ & $\begin{array}{l}2.13 \\
3.77\end{array}$ & $\begin{array}{l}2.79 \\
4.10\end{array}$ & $\begin{array}{l}2.14 \\
3.93\end{array}$ & $\begin{array}{l}2.32 \\
3.63\end{array}$ \\
\hline SWPP & 14.72 & 5.23 & 5.30 & 5.84 & S. 31 & 5.25 & 5.00 & 5.14 & 5.09 & 4.91 \\
\hline Subtotal & 5.74 & 4.34 & 4.80 & 3.99 & 4.13 & 3.71 & 3.66 & 3.73 & 3.63 & 3.53 \\
\hline $\begin{array}{l}\text { wsce } 2 / \\
\text { ERCor }\end{array}$ & $\begin{array}{r}8.93 \\
10.73 \\
\end{array}$ & $\begin{array}{r}4.29 \\
5.33 \\
\end{array}$ & $\begin{array}{r}3.86 \\
5.35 \\
\end{array}$ & $\begin{array}{r}4.13 \\
5.08 \\
\end{array}$ & $\begin{array}{r}1.06 \\
5.22 \\
\end{array}$ & $\begin{array}{l}4.40 \\
5.02 \\
\end{array}$ & $\begin{array}{r}3.84 \\
4.89 \\
\end{array}$ & $\begin{array}{l}3.32 \\
4.78 \\
\end{array}$ & $\begin{array}{r}3.64 \\
4.79 \\
\end{array}$ & $\begin{array}{r}3.64 \\
4.27 \\
\end{array}$ \\
\hline U.s. Total & 6.66 & 4.40 & 4.67 & 4.10 & 4.20 & 3.93 & 3.78 & 3.83 & $3.7 \%$ & 1.65 \\
\hline
\end{tabular}

Average Increase ${ }^{Y}$ $1979-1989$
4.00
2.92
3.43
5.46
1.90
4.46
6.18
4.13
4.46
$\underline{5.60}$
4.29

-As reported in Item 1 of the counc1l reports. The peak demands of the Councils are not necessarily coincident in time. The actual 7-oouncil subtotals and the U.S. totals will be less than the totals shown here jecause the council peaks occur at different times. The totals are shom only to indicate the approximate level of 7-Council and naticnal peak power use. The demands include interruptible loads and exclude interreqlonal purchases and sales. The ERCOT demand for 1989 is as reported on line 7 of item 34 .

1/ Total of Bulk Power and Liaison System Menbers.

$2 /$ U.s. portion of council only.

3/ Average of 10 annual increases from $(1980,197 \mathrm{c})$ to $(1989 / 1988)$.

a/ Doflects transfer of Associated Electric Cooperative from MA:N to SWPP. 
TABLE 3

PRONECTED GROMTH OF COUNCIL REGION HINTER PFAK DRUANS 1980-81 TO 1989-90

AS REPORTED BY THE RECIONML ELECTRIC RELIABILITY COUICILS

TO THE DEPARTMENT OF ENERCY--APRIL 1,1980

CONTICUOUS UNITED STATES

$\underline{1980-81} \underline{1981-82} \quad \underline{1982-83} \quad \underline{1983-84} \quad \underline{1984-85} \quad \underline{1985-86} \quad \underline{1986-87} \quad \underline{1987-88} \quad \underline{1988-89} \quad \underline{1989-90}$

\begin{tabular}{|c|c|c|c|c|c|c|c|c|c|c|}
\hline & & & \\
\hline 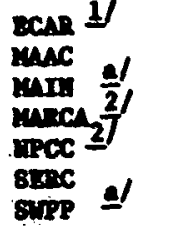 & $\begin{array}{l}66,476 \\
29,850 \\
28,142 \\
18,687 \\
35,640 \\
89,336 \\
32,069 \\
\end{array}$ & $\begin{array}{l}70,390 \\
30,980 \\
29,293 \\
19,636 \\
36,440 \\
94,482 \\
33,782 \\
\end{array}$ & $\begin{array}{l}73,264 \\
32,000 \\
30,620 \\
20,634 \\
37,390 \\
98,644 \\
35,202 \\
\end{array}$ & $\begin{array}{r}76,338 \\
33,080 \\
31,771 \\
21,797 \\
38,180 \\
102,996 \\
37,895 \\
\end{array}$ & $\begin{array}{r}79,414 \\
34,230 \\
33,061 \\
22,887 \\
39,020 \\
108,198 \\
40,026 \\
\end{array}$ & $\begin{array}{r}82,534 \\
35,370 \\
34,450 \\
24,001 \\
39,940 \\
112,418 \\
42,235 \\
\end{array}$ & $\begin{array}{r}85,655 \\
36,530 \\
35,835 \\
25,096 \\
40,970 \\
116,914 \\
44,477 \\
\end{array}$ & $\begin{array}{r}88,704 \\
37,560 \\
37,337 \\
26,226 \\
42,060 \\
121,879 \\
46,843 \\
\end{array}$ & $\begin{array}{r}92,234 \\
38,610 \\
38,910 \\
27,423 \\
43,100 \\
126,677 \\
49,362 \\
\end{array}$ & $\begin{array}{r}95,621 \\
39,670 \\
40,459 \\
28,736 \\
44,300 \\
131,498 \\
51,807 \\
\end{array}$ \\
\hline subtotal & 300,200 & 315,003 & 328,254 & 342,057 & 356,836 & 370,948 & 385,475 & 400,609 & 416,296 & 432,091 \\
\hline$\frac{\sec 2}{\cos }$ & $\begin{array}{r}76,432 \\
23,456 \\
\end{array}$ & $\begin{array}{r}79,745 \\
24,795 \\
\end{array}$ & $\begin{array}{l}83,176 \\
26,014 \\
\end{array}$ & $\begin{array}{l}86,797 \\
27,386 \\
\end{array}$ & $\begin{array}{l}90,648 \\
28,802 \\
\end{array}$ & $\begin{array}{l}94,498 \\
30,028 \\
\end{array}$ & $\begin{array}{r}98,318 \\
31,827 \\
\end{array}$ & $\begin{array}{r}102,094 \\
33,389 \\
\end{array}$ & $\begin{array}{r}106,019 \\
35,079 \\
\end{array}$ & $\begin{array}{r}107,968 \\
36,881 \\
\end{array}$ \\
\hline 0. 8. & $\infty 0,0 \leq 8$ & 419,543 & 37,644 & 456,240 & 476,286 & 495,476 & 515,620 & 536,092 & 557,394 & 576,940 \\
\hline
\end{tabular}

(5)

trang $11 \quad 12.17 \cdot 5.89$

5.89

4.20

Annual Percent Increage Over Preced1ng Year

Average $x$ Increane $3 /$

$\begin{array}{ll}7.15 & 3.79 \\ 0.14 & 4.09\end{array}$

4.08
3.29

3.38

4.03

3.93

3.78
3.28

3.56
2.82

3.98
2.80

4.19

5.08

5.64

4.06

4.20

4.02

4.51

$\begin{array}{lll}4.00 & 4.87 & 4.55 \\ 2.20 & 2.36 & 2.58\end{array}$

$2.24 \quad 2.61$

2.11

$4.41 \quad 4.41$

2.20
5.05

3.90

2.58
4.00

$4.46 \quad 5.76$

$\frac{5.68}{4.21}$

$\frac{6.14}{4.20}$

$\frac{5.62}{4.32}$

$\frac{5.52}{3.95}$

$\frac{5.31}{3.92}$

2.66
4.25

$\frac{5.32}{3.93}$

4.21

4.56

2.47

3.96

$\frac{5.33}{3.92}$

$4.30 \quad 4.35$

4.64

$4.25 \quad 4.04$

3.84

3.84

3.67
2.75

2.75
3.98

4.79
2.78

2.78

2.78
3.81

5.00

4.93

3.61
3.72

3.72
5.18

2.50

4.40

6.22

sec $y$

$14.94 \quad 4.33$

8. 8. Iotal

$0.24+4.46$

$\frac{4.92}{4.27}$

$\frac{5.27}{4.30}$

$\frac{5.17}{4.39}$

$\frac{4.26}{4.03}$

$\frac{5.99}{4.07}$

$\frac{4.91}{3.97}$

$\frac{1.84}{3.26}$

5.02 me

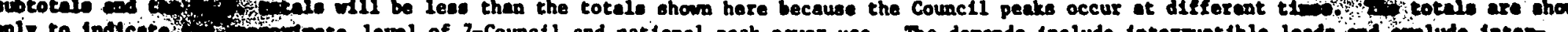

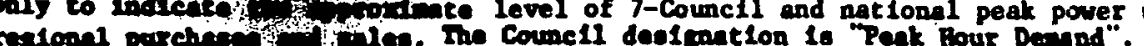

a/ Deflecto trangier of Appociated Blectric Cooperative frod MIN to sWPP.

If Iotal of bulk poure and Lialeon 8yaten rabers.

2) U. 8. portion of Council only.

3/ Averege of ten anual locrencee fron (1980-81/1979-80) to (1989-90/1988-89). 
Table 4
PROJECTED GRO'NTH OF COUNCIL REGION SUMMER NET DEPENDABLE CAPABILITY 1980-1989 $\frac{\text { RE REPORTED 3Y THE FEGIONAL ELECTRIC RELIABILITY COUNCILS }}{\text { TO THE DEFARTMENT OF ENERGY -. APRIL I, } 980}$

$$
\frac{\text { TO THE DEFARTMENT OF ENERGY - AP ATI }}{\text { CONTIGUOUS UNITED STATES }}
$$

\begin{tabular}{|c|c|c|c|c|c|c|c|c|c|c|}
\hline & 1980 & 1981 & 1982 & 198. 3 & 1987 & 1985 & 1986 & 1987 & 1988 & 1989 \\
\hline $\begin{array}{l}\text { ECAR / } \\
\text { MAAC 4/a/ } \\
\text { MAIN } \\
\text { MARC 2/ } \\
\text { NPCC } 2 / \\
\text { SERC a/ } \\
\text { SWPP } \\
\text { Subtotal }\end{array}$ & $\begin{array}{r}86,113 \\
43,099 \\
41,993 \\
25,645 \\
51,187 \\
114,256 \\
52,651 \\
414,944\end{array}$ & $\begin{array}{r}92,661 \\
45,130 \\
43,195 \\
27,619 \\
51,997 \\
121,817 \\
53,616 \\
438,035\end{array}$ & $\begin{array}{r}94,940 \\
46,421 \\
44,701 \\
28,707 \\
52,312 \\
126,680 \\
60,815 \\
454,576\end{array}$ & $\begin{array}{r}99,413 \\
47 ., 33 \\
48.388 \\
29,749 \\
53,551 \\
130,763 \\
63,529 \\
472,626\end{array}$ & $\begin{array}{r}103,207 \\
48,205 \\
51,452 \\
29,642 \\
53,641 \\
136,985 \\
64,737 \\
487,469\end{array}$ & $\begin{array}{r}\text { awatts* } \\
107,711 \\
50,146 \\
52,562 \\
31,274 \\
55,694 \\
142,938 \\
69,794 \\
510,119\end{array}$ & $\begin{array}{r}111,274 \\
52,347 \\
53,059 \\
31,593 \\
58,035 \\
146,811 \\
71,569 \\
524.688\end{array}$ & $\begin{array}{r}114,647 \\
54,868 \\
53,496 \\
33,497 \\
60,725 \\
154,553 \\
74,564 \\
546,350\end{array}$ & $\begin{array}{r}119,361 \\
55,661 \\
54,761 \\
34,026 \\
60,567 \\
160,118 \\
77,720 \\
56 c, 214\end{array}$ & $\begin{array}{r}120,552 \\
56,546 \\
56,456 \\
34,726 \\
61,366 \\
164,952 \\
80,866 \\
575,4,48\end{array}$ \\
\hline $\begin{array}{l}\text { WSCC } \frac{21}{1} \\
\text { ERCOT }\end{array}$ & $\begin{array}{r}97,676 \\
42,379\end{array}$ & $\begin{array}{r}101,381 \\
44,012 .\end{array}$ & $\begin{array}{r}108,357 \\
44,327\end{array}$ & $\begin{array}{r}113.541 \\
45.995\end{array}$ & $\begin{array}{r}116,540 \\
46,992\end{array}$ & $\begin{array}{r}121,717 \\
\triangle B, 486\end{array}$ & $\begin{array}{r}130,484 \\
50,638 \\
\end{array}$ & $\begin{array}{r}134,727 \\
52,617 \\
\end{array}$ & $\begin{array}{r}138,705 \\
56,523 \\
\end{array}$ & $\begin{array}{r}143,737 \\
59,433 \\
\end{array}$ \\
\hline U.S. & $\overline{554,999}$ & $\overline{583,428}$ & $\overline{607,260}$ & $\bar{b} \bar{c} \bar{c} .162$ & 651,101 & 22 & 810 & 694 & 442 & 78,058 \\
\hline
\end{tabular}

\begin{tabular}{|c|c|c|}
\hline 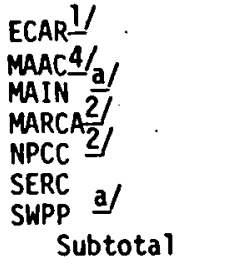 & $\begin{array}{c}\left(\begin{array}{l}1.31 \\
4.83\end{array}\right) \\
(5.84) \\
9.27 \\
1.20 \\
4.05 \\
10.56 \\
7.55\end{array}$ & $\begin{array}{l}7.60 \\
4.71 \\
2.86 \\
7.70 \\
1.58 \\
6.62 \\
5.63 \\
5.56\end{array}$ \\
\hline $\begin{array}{l}\text { WSCC ? } \\
\text { ERCOT }\end{array}$ & $\begin{array}{l}3.10 \\
2.88 \\
\end{array}$ & $\begin{array}{r}3.79 \\
3.85 \\
\end{array}$ \\
\hline Tota & 7.92 & .72 \\
\hline
\end{tabular}

\begin{tabular}{l}
2.46 \\
2.86 \\
3.49 \\
3.94 \\
0.61 \\
3.99 \\
9.35 \\
\hline 3.78 \\
6.88 \\
$\frac{0.72}{4.08}$
\end{tabular}

\section{Annual Percent Increase Over Preceding Year}

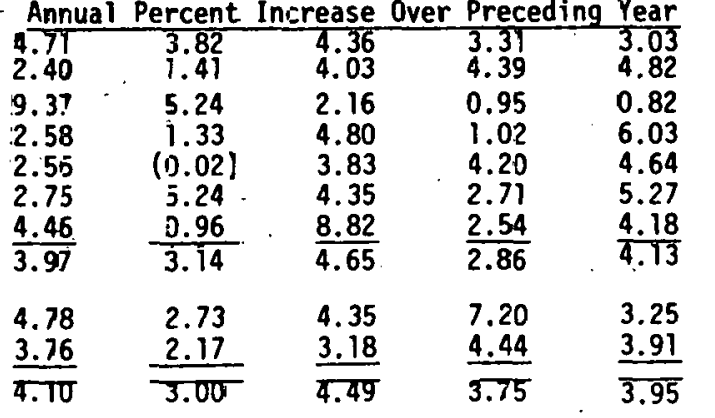

$\begin{array}{lr}4.11 & 1.00 \\ 1.45 & -1.59 \\ 2.36 & 3.10 \\ 1.58 & 2.06 \\ (0.26) & 1.28 \\ 3.60 & 3.02 \\ \frac{4.23}{2.90} & \frac{4.05}{2.35} \\ 2.95 & 3.23 \\ \frac{1.42}{3.24} & \frac{5.15}{3.72}\end{array}$

AVERAGE $\%$ INCREASE $3 /$ $1979-1989$

3.31

2.10

3.73

3.73

1.96

$\frac{5.48}{3.49}$

3.49

4.23

$\underline{3.75}$

$\overline{3.64}$

*As reported in Item 3-A, Line 01 of the Councill reports. Net dependable capability is the steady hourly output which generating equipment is expected to supply to system load, exclusive of auxiliary power. For tie purposes of this table "Net Dependable Capability" includes punped storage units and other sources which may have energy supply liritations, b.jt which are expected to be available during the peak demand period.

1/ Total of Bulk Power and Liaison System Members.

a Reflects transfer of Associated Electric Coaperative from ME.IN to SWPP.

2) U.S. portion of Council only.

3/ Average of 10 annual increases from (1980/1979) to (1989/19:8).

4/ Staff has modified the data reported by. MAA: by assuming that TMI 1 will be out of service in 1980, and TMI 2 will be out of service in 1980

through 1985 .

$($ ) $=$ negative number 
TAB $=5$

PROJECTED GROWTH OF COUNCIL REGION WINTER NET DEPENDABLE CAPABILITY 1981)-81 TO 1989-90

AS REPORTED BY THE REGIONAI ELECTRIC RELIABILITY COUNCILS

TO THE DEPARTMENT OF ENERGY--APRIL 1,1980

CONTIGUOUS UN-TED STATES

$\underline{1980-81}$

$\underline{1981-82}$

$\underline{1982-83}$

1983-84

$\underline{1984-85}$

1985-86

$\underline{1987-88}$

1988-89

1989-90

Megawatts

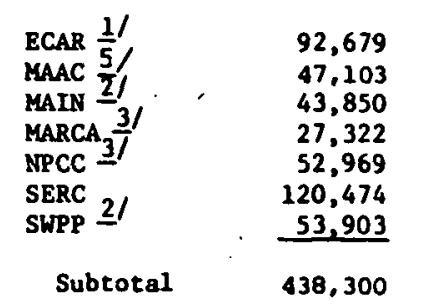

$\begin{array}{r}95,043 \\ 47,682 \\ 45,108 \\ 29,093 \\ 54,122 \\ 125,385 \\ 55,669 \\ \hline 452,102 \\ \hline\end{array}$

99,316

102,309

$\begin{array}{ll}48,963 & 50,094\end{array}$

108,181

111,729

115,415

$29,500 \quad 30,712$

50,777
53,516

52,897

53,307

54,984

117,601
57,448

57,448

122,321

58,245
56,594

54,441
34,853

$54,343 \quad 55,533$

31,343
56,397

58,730

32,362

62,853

$\begin{array}{r}62,415 \\ 158,586 \\ \hline\end{array}$

35,382

62,456

$141,012 \quad 146,012 \quad 149,641$

61,070 63,309 :64,918 $\quad$ 70,229

71,612

75,534

77,846

525,303

538,898

560,878

575,854

109,856

$489,481 \cdots 506,144$

125,589

131,705

135,851

140,621

$\begin{array}{r}105,045 \\ 43,927 \\ \hline\end{array}$

$\frac{45,455}{626,499}$

$\frac{45,742}{650,786}$

$\frac{48,014}{673,414}$

$\overline{699,580}$

$\underline{721,834}$

$\frac{55,232}{751,961}$

$\frac{57,918}{774,393}$

Annual Percent Increase Over Preceding Year

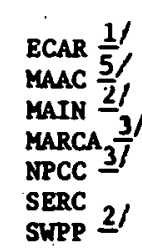

Subtatel

wscc $3 /$

ERCOT

U. S. Total

$\begin{array}{r}4.93 \\ 5.54 \\ (2.16) \\ 10.80 \\ 1.27 \\ 7.22 \\ 11.07 \\ \hline\end{array}$

\begin{tabular}{l}
2.55 \\
1.23 \\
2.87 \\
6.48 \\
2.18 \\
4.08 \\
3.28 \\
\hline
\end{tabular}

4.50

2.69

9.68

1.40
0.41

0.41
2.50

9.70

3.01

2.31

5.12

5.74

1.36

2.90

3.28

4.13

3.30

3.95

0.93
0.51

2.19

1.56

2.73

0.51
3.66

5.44
3.67

4.06

4.14

3.66
2.49

8.55

\begin{tabular}{l}
2.49 \\
1.97 \\
\hline
\end{tabular}

1.89

4.48
0.81

0.81
7.70

2.52

5.98

3.88

3.40

3.79

2.58

4.48

3.20

5.20

1.17

$\underline{5.01}$

5.44

4.58

$\underline{3.48}$

$\underline{\underline{0.63}}$

3.88

4.97

5.31

1.40

3.89

4.87

3.48

$\underline{5.22}$

3.18

3.15

\begin{tabular}{l}
3.15 \\
7.81 \\
\hline
\end{tabular}

4.17
124,540

59,110

57,949
35,582

35,582

63,783
168,633

81,306

590,903

146,091

$\frac{60,215}{797,209}$ * As reported In Item $3 A$, Line 01 of the Council reports. Net dependable cepability is the steady hourly output which generating
equipment to expected to supply to gystem load, exclusive of auxiliary power.

1/ Toṭal of Bulk Power and Liaison System Members.

2/ Reflects transfer of Associated Blectric Cooperstive from MAIN to SWPP.

3/ U. S. portion of Counc1l only.

4/. Average of ten annual increases from (1980-81/1979-80) to (1989-90/1988-85).

5/ Staff has modified the data reported by MAAC by assuming that TMI 1 will be out of servie for winter 1983-81 and TMI 2 will be out of service for

(1) indicates negative number 
Table 6

PROAECIED COUNCII REIION RESERVE CPNERATING CAPABIIITY

AS A PERCONTACE OF PEAK DEMAND, SUMMER AND WINIER

AS REPORTED BY THE RESIONAL ETDCTRIC RETIABAITTYY COCNCIIS

TO THE DEPARIM NI CF ENERGI-APRIL 1, 1980

CONTIGUOUS UNITED STAIES

8 Teserve Marcin At Time of Summer Peak Demand 1 '

\begin{tabular}{|c|c|c|c|c|c|c|c|c|c|c|}
\hline & $\underline{1980}$ & 1981 & 1982 & 1993 & 1984 & 1985 & $\underline{1986}$ & 1987 & $\underline{1988}$ & 1999 \\
\hline $\operatorname{ECAR}^{2}$ & 33.24 & 35.91 & 32.32 & 33.17 & $3 \Xi .34$ & 34.23 & 33.78 & 33.22 & 34.10 & 30.98 \\
\hline $\operatorname{MAAC}_{3 /}$ & $\begin{array}{r}28.46 \\
21.19\end{array}$ & 30.62 & 30.36 & 29.91 & $\begin{array}{l}28.20 \\
28.64\end{array}$ & $\begin{array}{l}29.91 \\
27.07\end{array}$ & $\begin{array}{l}32.19 \\
24.02\end{array}$ & $\begin{array}{l}35.31 \\
20.76\end{array}$ & $\begin{array}{l}34.32 \\
19.59\end{array}$ & $\begin{array}{l}33.46 \\
19.21\end{array}$ \\
\hline $\begin{array}{l}\text { MAIN } \\
\text { MARCA } 4 /\end{array}$ & $\begin{array}{r}21.19 \\
2855\end{array}$ & $\begin{array}{l}20.08 \\
29.82\end{array}$ & $\begin{array}{l}19.64 \\
27.42\end{array}$ & $\begin{array}{l}26.38 \\
24.37\end{array}$ & $\begin{array}{l}28.64 \\
19.79\end{array}$ & $\begin{array}{l}27.07 \\
19.84\end{array}$ & $\begin{array}{l}24.02 \\
15.91\end{array}$ & $\begin{array}{l}20.76 \\
17.88\end{array}$ & $\begin{array}{l}19.59 \\
14.81\end{array}$ & $\begin{array}{l}19.21 \\
12.51\end{array}$ \\
\hline MARCA & $\begin{array}{l}28.55 \\
44.51\end{array}$ & $\begin{array}{l}29.82 \\
45.16\end{array}$ & 43.44 & 44.57 & 42.06 & 44.92 & 47.86 & 51.25 & 47.69 & 46.19 \\
\hline $\operatorname{SERC}_{3 /}$ & 30.56 & 33.25 & 30.46 & 28.57 & 28.55 & 29.11 & 27.79 & 29.23 & 28.82 & 28.06 \\
\hline SwPp & 21.67 & 22.13 & 26.82 & 25.17 & 20.00 & 24.07 & 21.17 & 20.07 & 19.10 & 18.12 \\
\hline Subtotal & 30.08 & 31.61 & 30.33 & 30.31 & 29.07 & 30.23 & 29.23 & 29.72 & 28.82 & 27.35 \\
\hline $\operatorname{wscc}^{4 /}$ & 26.38 & 25.78 & 29.44 & 30.26 & 28.59 & 28.53 & 32.70 & 31.97 & 31.10 & 30,59 \\
\hline ERCOI & 34.02 & 32.14 & 26.33 & 24.74 & 21.13 & 19.00 & 18.49 & 17.50 & 20.45 & 2090 \\
\hline I.s. & 29.71 & 30.60 & 29.87 & 29.88 & 28.37 & 29.06 & 29.01 & 29.16 & 28.56 & 27.41 \\
\hline
\end{tabular}

8 Reserve Margin At Time Of Winter Peak Demand 1

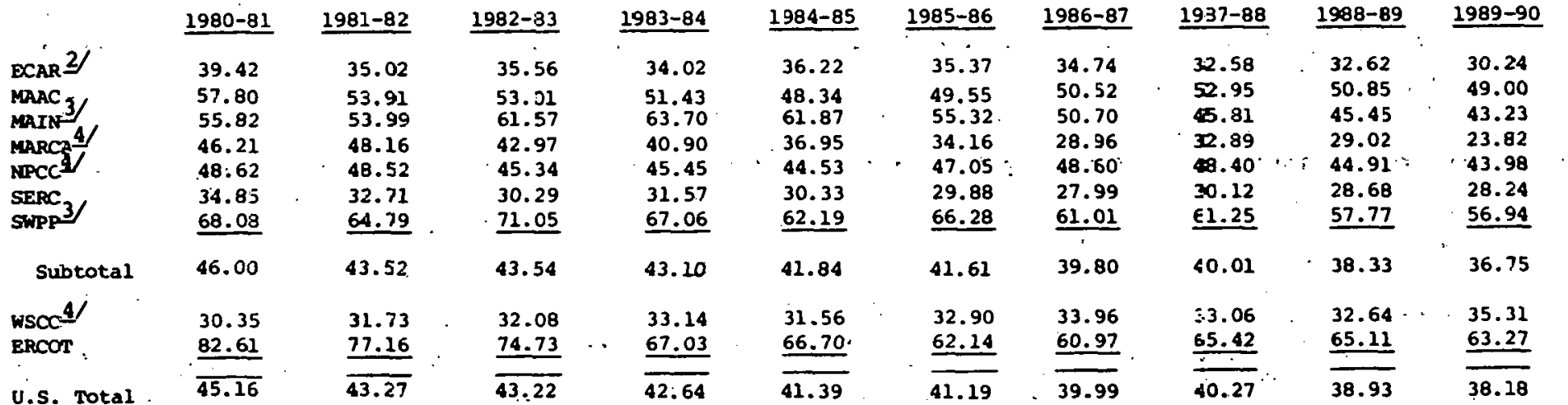

1. \& Reserve Margin $=\left(\frac{\text { Net Dependable Capability }}{\text { Peak Demand }}-1\right) \times 100$.

2/ Total of Bulk Power and Liaison System Menoers.

3/ Reflects transfer of Associated Electric Coperative from MAIN to SWPP.

4. U. S. partion of Council anly. 
Table 7

ACTUAL NET ENERGY, DEMAND, AND CAPABILITY 1976-1979 AS REPORTED BY THE REGIONAL ELECTRIC RELIABILITY COUNCILS TO THE DEPARTMENT OF ENERGY CONTIGUOUS UNITED STATES

\begin{tabular}{|c|c|c|c|c|c|c|c|c|c|c|c|c|}
\hline \multirow{3}{*}{$\mathrm{ECAR}^{2}$} & \multicolumn{4}{|c|}{ Net Annual Energy Requirements (GMH) } & \multicolumn{4}{|c|}{ Summer Peak Demand (MW) } & \multicolumn{4}{|c|}{ Summer Net Dependable Capability (MN) } \\
\hline & $\underline{1976}^{1 / 1}$ & $\underline{1977}$ & $\underline{1978}$ & $\underline{1979}$ & $\underline{1976}$ & $\underline{1977}$ & $\underline{1978}$ & $\underline{1979}$ & $\underline{1976}$ & $\underline{1977}$ & $\underline{1978}$ & 1979 \\
\hline & 338,320 & 365,526 & 369,108 & 379,018 & 55,219 & 62,306 & 62,454 & 62,182 & 76,497 & 79,184 & 85,730 & 87,257 \\
\hline $\mathrm{MAAC}_{3 /}$ & 159,716 & 164,135 & 169,766 & 172,540 & 29,264 & 32,306 & 31,812 & 31,780 & 41,358 & 44,084 & 43,748 & 45,285 \\
\hline $\operatorname{MAIN}^{3} / 4$ & 161,769 & 161,081 & 168,808 & 171,052 & 30,150 & 33,404 & 33,222 & 33,803 & 38,619 & 40,830 & 43,006 & 44,596 \\
\hline MARCA $\frac{y}{4}$ & 78,349 & 85,738 & 92,477 & 96,518 & 14,938 & 17,549 & 18,012 & 18,162 & $19,63 ?$ & 20,383 & 21,941 & 23,470 \\
\hline NPCC ${ }^{9 /}$ & 189,061 & 194,212 & 198,918 & 201,708 & 32,614 & 35,448 & 34,876 & 34,743 & 49,272 & 49,803 & 49,356 & 50,582 \\
\hline $\begin{array}{l}\text { SERC } \\
\text { SWPP }\end{array}$ & $\begin{array}{l}419,555 \\
165,561\end{array}$ & $\begin{array}{l}442,233 \\
179,549\end{array}$ & $\begin{array}{l}452,750 \\
191,550\end{array}$ & $\begin{array}{l}452,989 \\
191,762\end{array}$ & $\begin{array}{l}75,116 \\
33,764\end{array}$ & $\begin{array}{l}79,332 \\
36,514\end{array}$ & 80,475 & 83,260 & 98,181 & 101,891 & 107,447 & 109,811 \\
\hline & & 10,040 & 191,550 & 191,162 & 33,764 & 36,514 & $\underline{39,191}$ & $\underline{37,722}$ & 44,115 & 44,883 & 46,680 & 47,622 \\
\hline Subtotal & $1,512,331$ & $1,592,474$ & $1,643,377$ & $1,665,587$ & 271,065 & 296,859 & 300,042 & 301,652 & 367,67 ؟ & 381,058 & 397,908 & 408,623 \\
\hline wscc $\frac{4}{-}$ & 382,170 & 385,887 & 410,135 & 425,349 & 65,503 & 64,926 & 68,719 & 70,948 & 85,262 & 87,500 & 91,487 & 94,743 \\
\hline ERCOT & 120,098 & 136,413 & 147,371 & 150,533 & $\underline{25,330}$ & 26.819 & 28,645 & 28,556 & 32,906 & 35,561 & 37,759 & 41,194 \\
\hline \multirow[t]{2}{*}{ U.S. Total } & $2,014,599$ & $2,114,774$ & $2,200,883$ & $2,241,469$ & 361,898 & 388,604 & 397,406 & 401,156 & 485,847 & 504,119 & 527,154 & 544,560 \\
\hline & \multicolumn{4}{|c|}{ Winter Peak Demand (MW) } & & & & & \multicolumn{4}{|c|}{ Winter Net Dependable Capability (MW) $1 /$} \\
\hline & $\underline{1976-77^{1 /}}$ & 1977-78 & $\underline{1978-79}$ & $\underline{1979-80}$ & & & & & $\underline{1976-77}$ & $1977-78$ & $1978-79$ & $\underline{1979-80}$ \\
\hline $\begin{array}{l}\mathrm{ECAR}^{2 /} \\
\mathrm{MAAC}\end{array}$ & $\begin{array}{l}58,129 \\
27,073\end{array}$ & 59,136 & 63,450 & 59,263 & & & & & 79,951 & 83,793 & 86,736 & 88,326 \\
\hline $\begin{array}{ll}M_{A A C} 3 / \\
\text { MAIN }\end{array}$ & 27,123 & $\begin{array}{l}26,723 \\
26,439\end{array}$ & $\begin{array}{l}28,655 \\
28,099\end{array}$ & $\begin{array}{l}27,858 \\
28,102\end{array}$ & & & & & 41,405 & 44,212 & 44,660 & 44,631 \\
\hline MARCE $\frac{4}{1 /}$ & 14,120 & 15,097 & 16,631 & $\begin{array}{l}28,102 \\
17,341\end{array}$ & & & & & 38,986 & 41,624 & 44,060 & 44,816 \\
\hline NPCC & 34,689 & 33,767 & 34,267 & 34,622 & & & & & 20,050 & 21,227 & 22,787 & 24,658 \\
\hline SERC & 79,829 & 73,861 & 81,527 & 85,525 & & & & & $\begin{array}{r}50,993 \\
101,838\end{array}$ & 51,646 & 52,323 & 52,306 \\
\hline SWPP & 25,286 & $\underline{25,226}$ & $\underline{28,350}$ & $\underline{28,404}$ & & & & & $\begin{array}{r}101,838 \\
43,321 \\
\end{array}$ & $\begin{array}{r}106,640 \\
45,689 \\
\end{array}$ & $\begin{array}{r}110,484 \\
46,786 \\
\end{array}$ & $\begin{array}{r}112,358 \\
48,530 \\
\end{array}$ \\
\hline Subtotal & 266,249 & 260,249 & 280,979 & 281,115 & & & & & 376,544 & 394,831 & 407,836 & 415,625 \\
\hline $\mathrm{wscc}^{4 \prime}$ & 61,985 & 61,525 & 70,069 & 66,495 & & & & & 86,955 & 87,637 & & \\
\hline ERCOT & $\underline{\underline{18,355}}$ & 17,950 & $\underline{21,505}$ & $\underline{22,119}$ & & & & & 34,501 & 36,942 & 39,552 & 40,788 \\
\hline U.s. Total & 346,589 & 339,724 & 372,553 & 369,729 & & & & & 498,000 & 519,410 & 540,917 & 554,886 \\
\hline
\end{tabular}

1/ As reported in the EPC Form $12 \mathrm{E}-2$ reports.

$\frac{1}{3}$, Total of Bulk Power and Liaison System Members.

3/ Includes Associated Electric Cooperative (AEC). AEC transferred from MAIN to SWPP effective June 1, 1980 . Projected data for AEC is included in SWPP. 


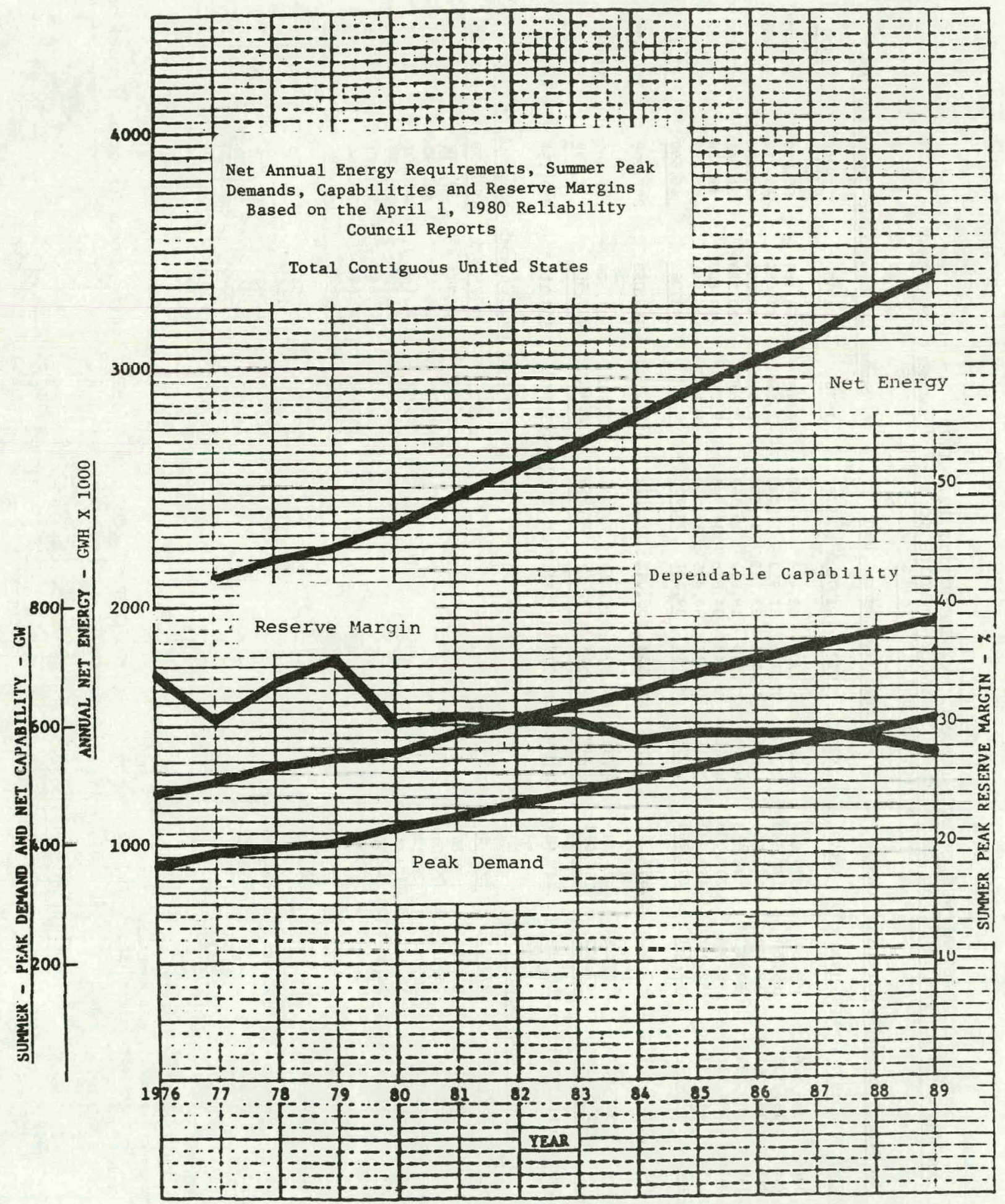




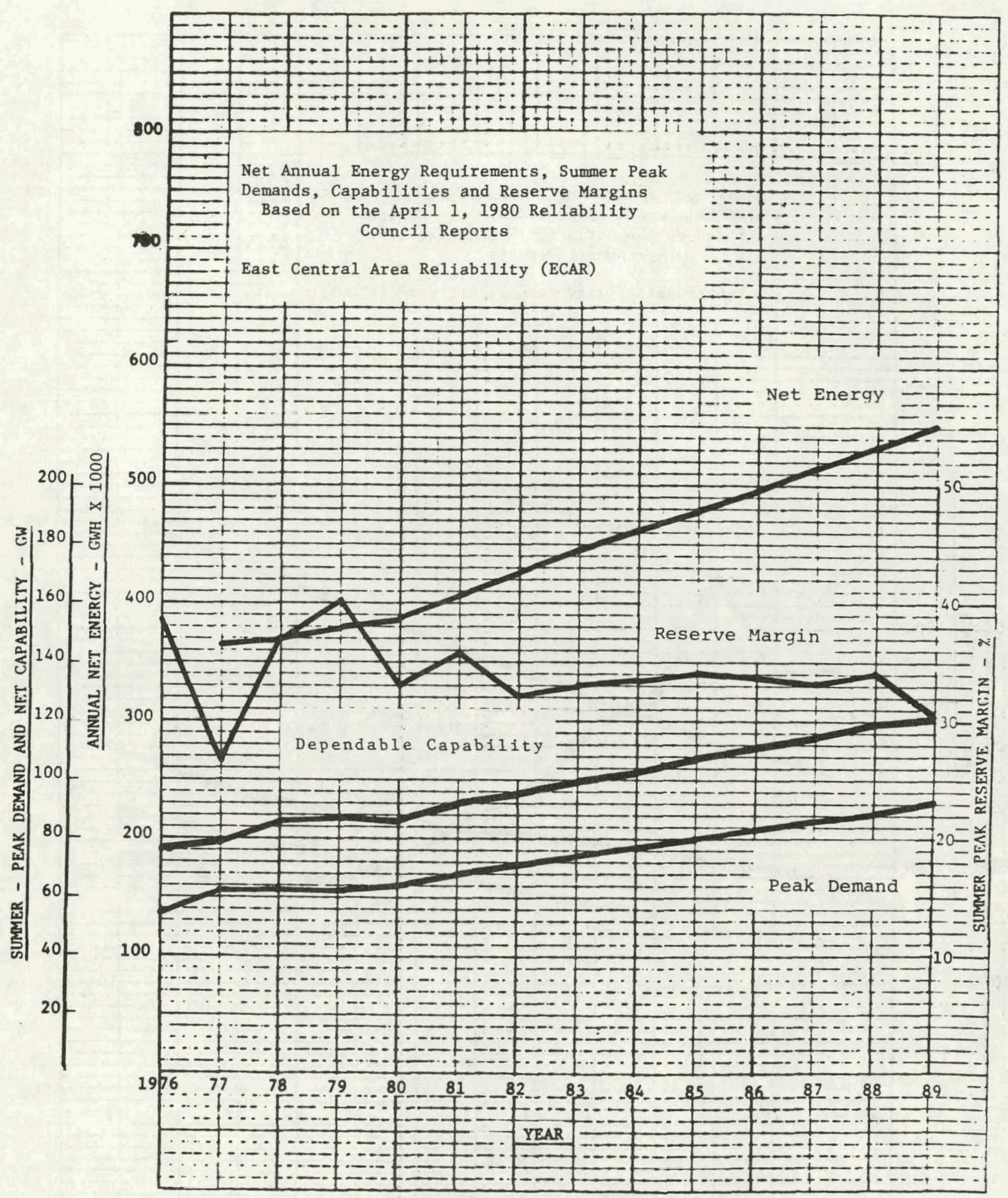




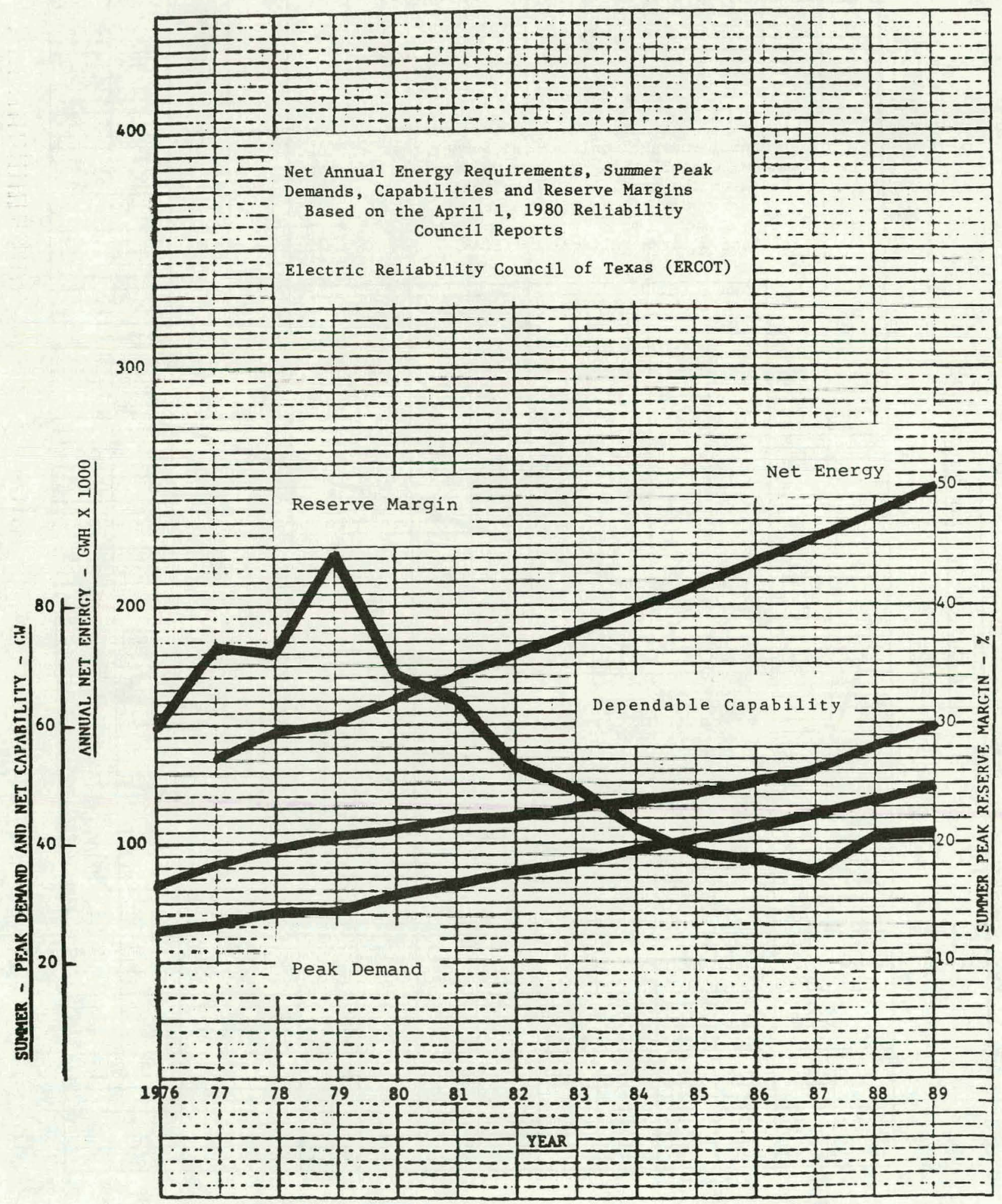




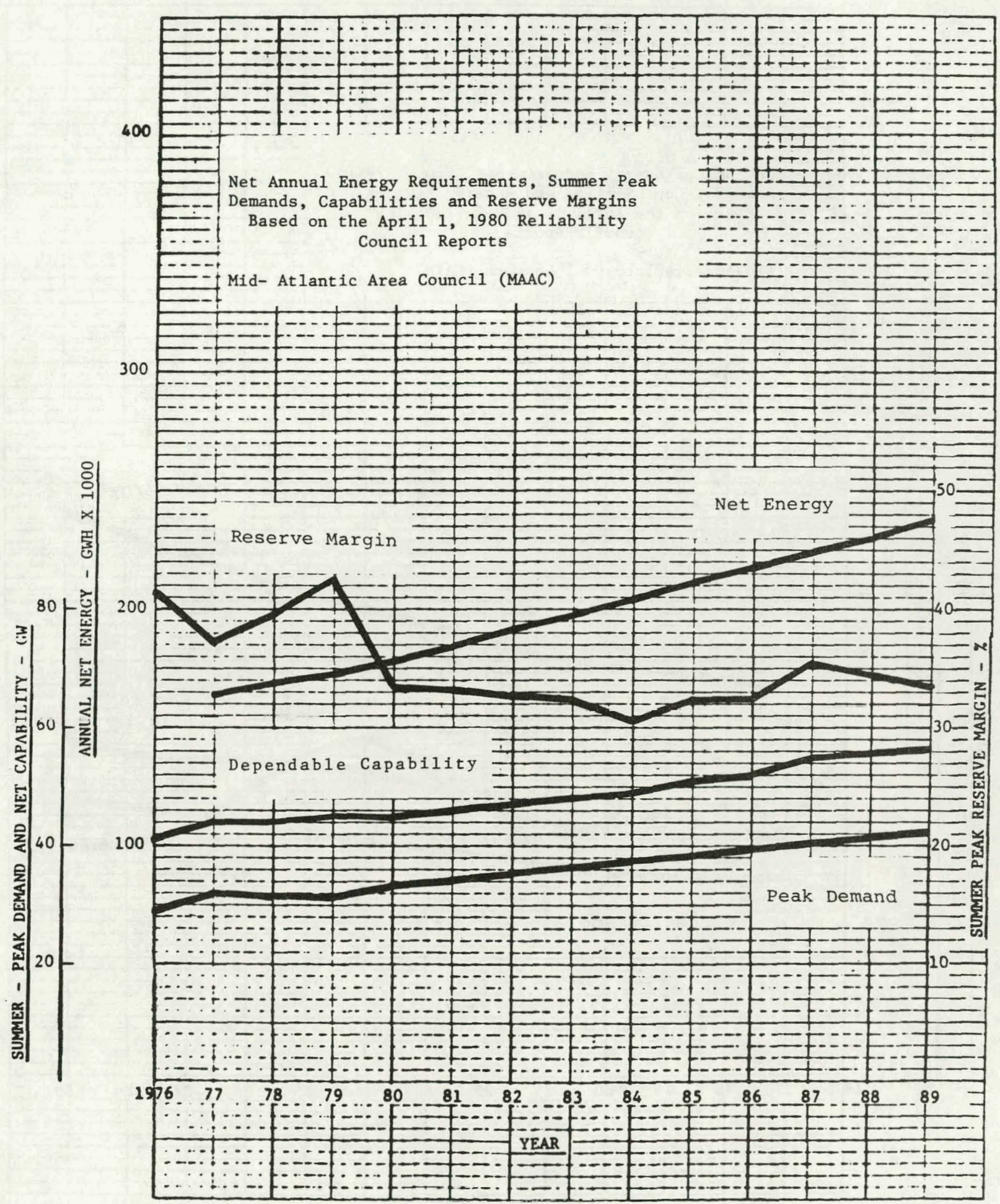




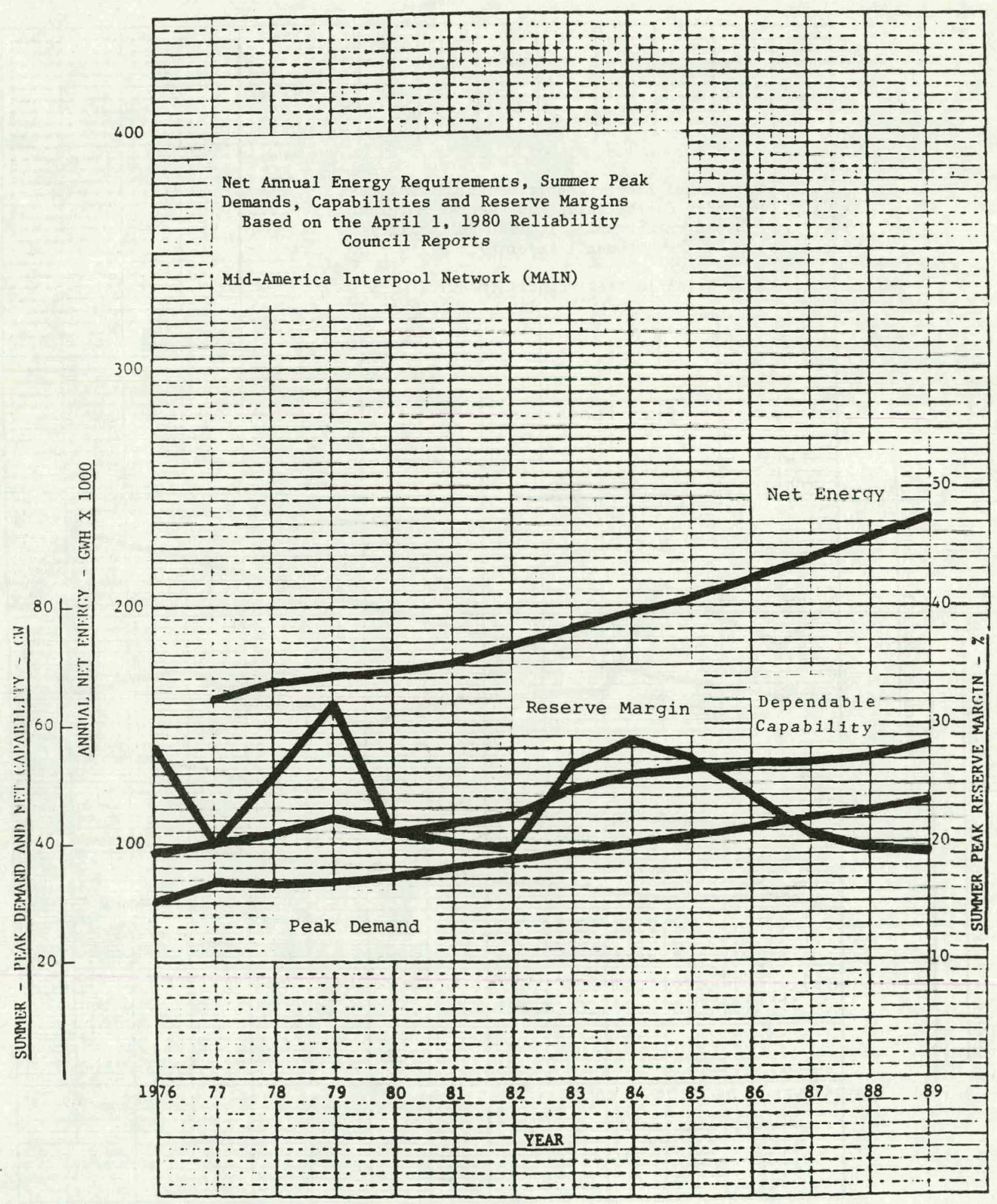




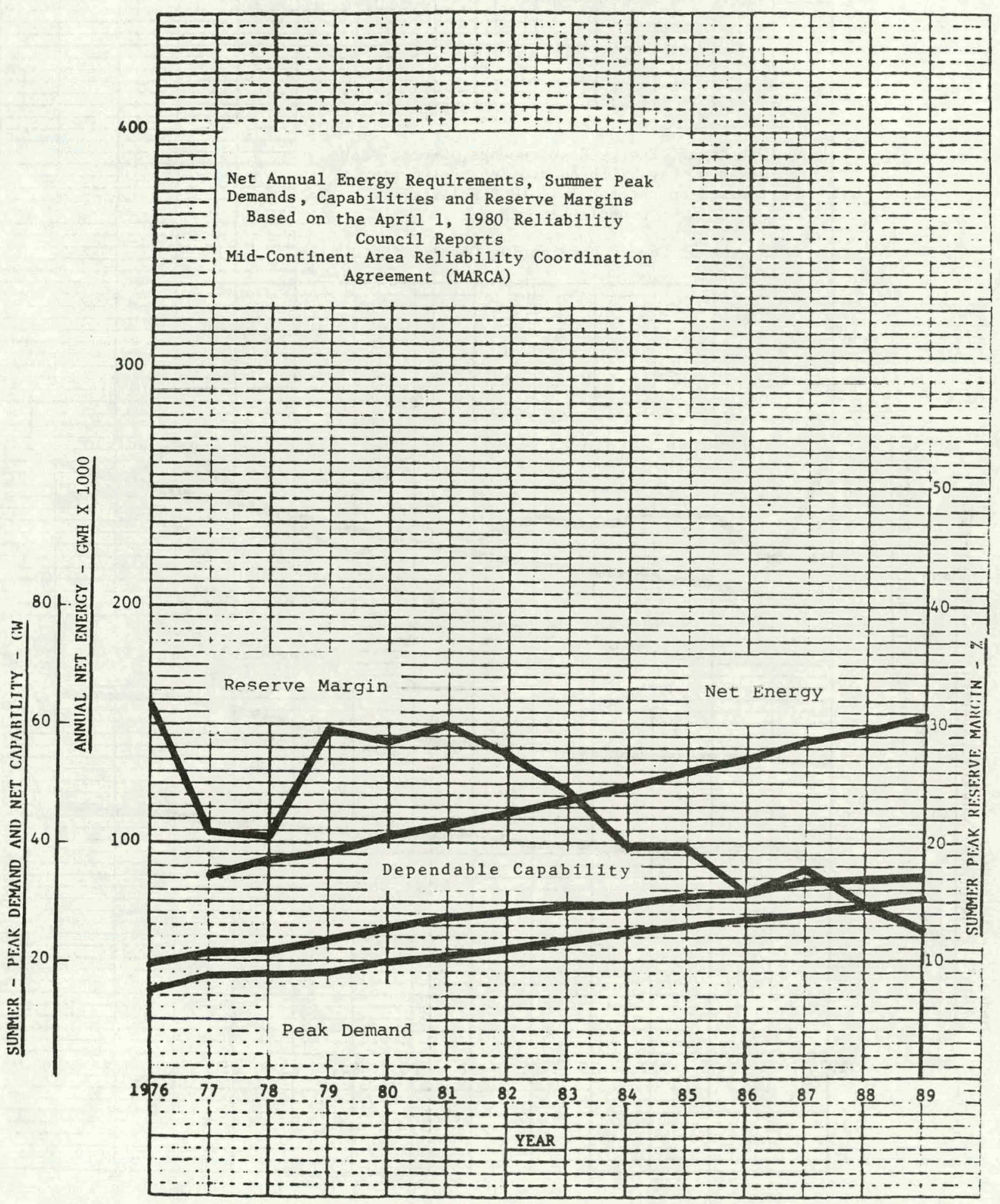




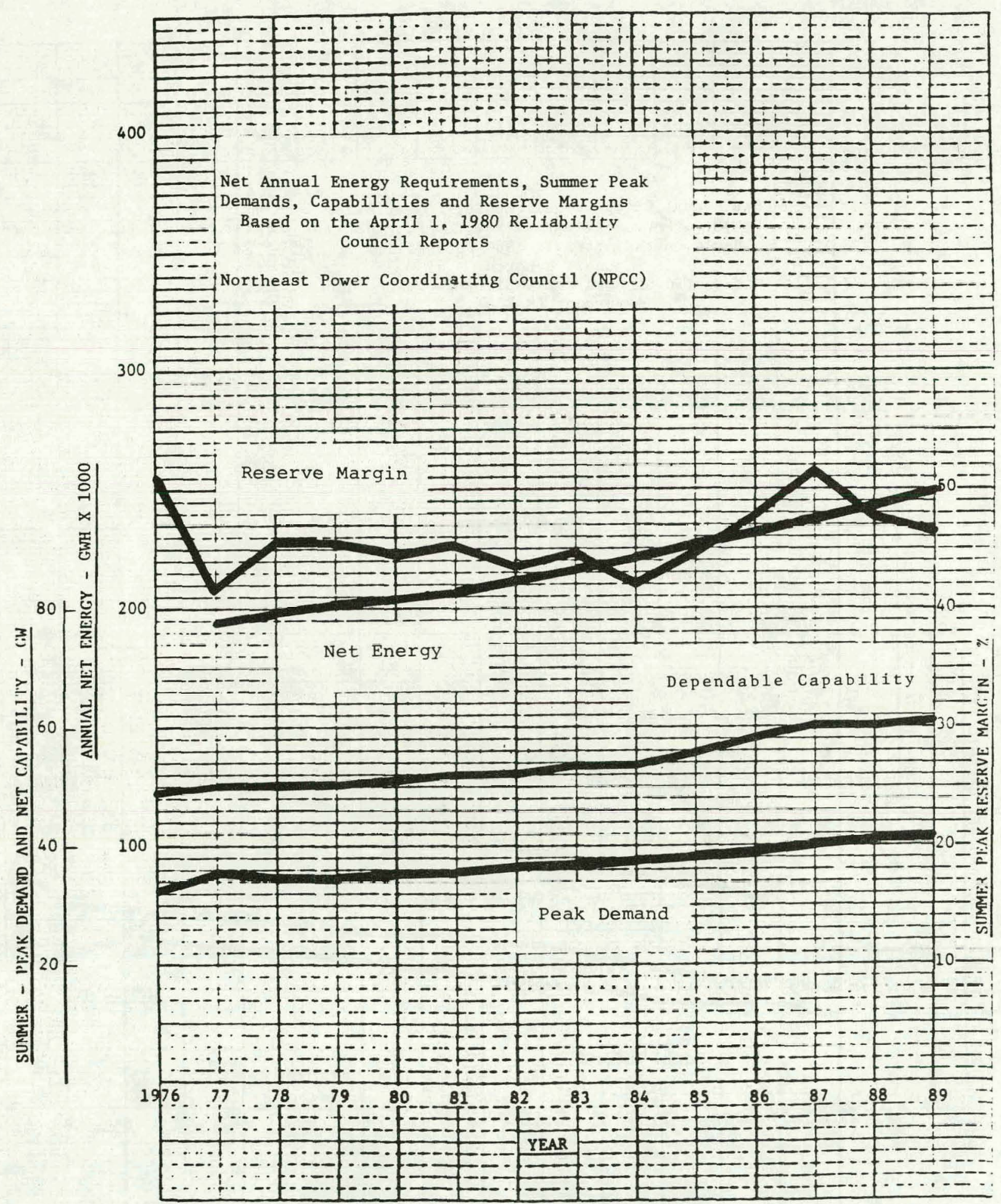




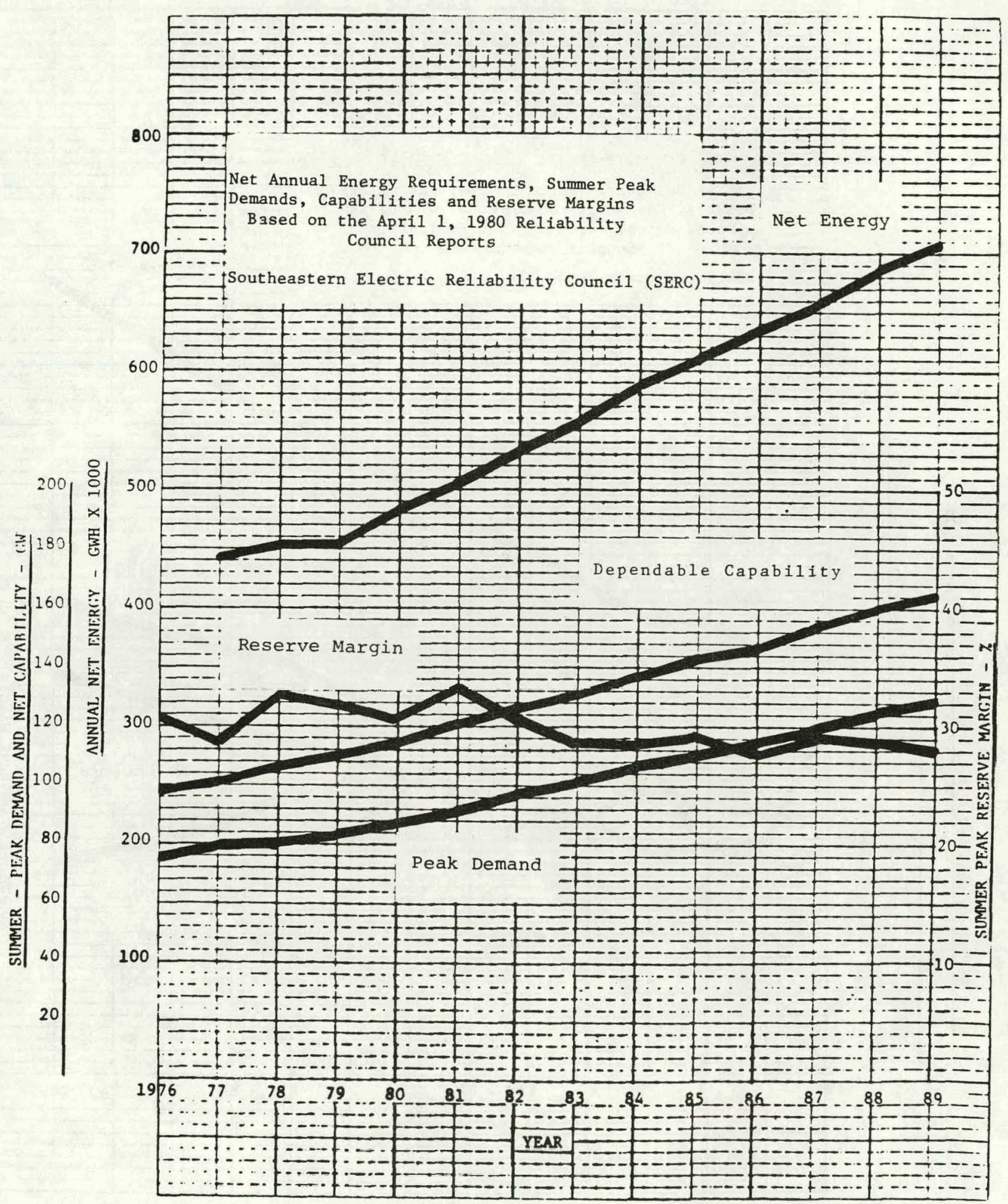




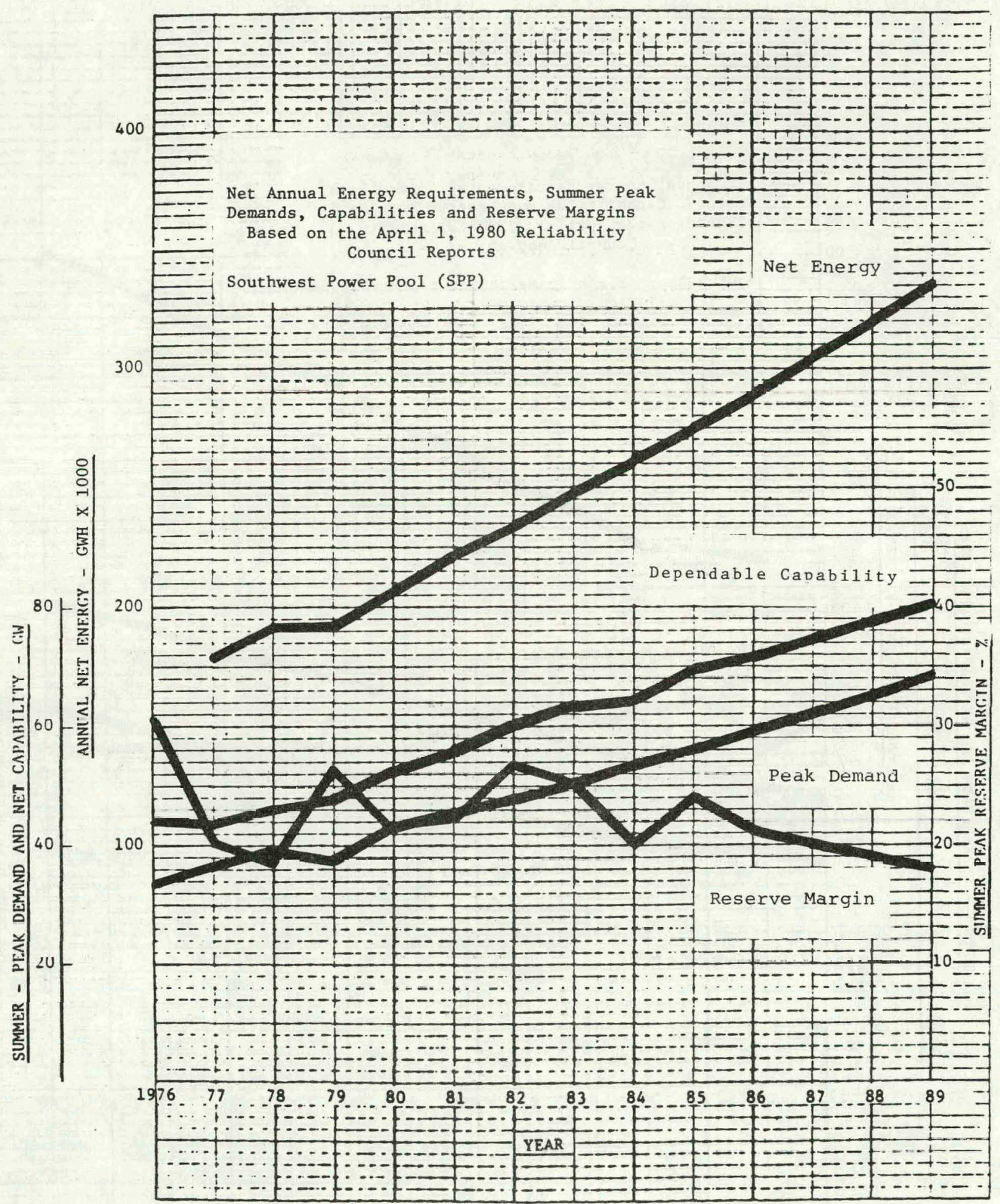




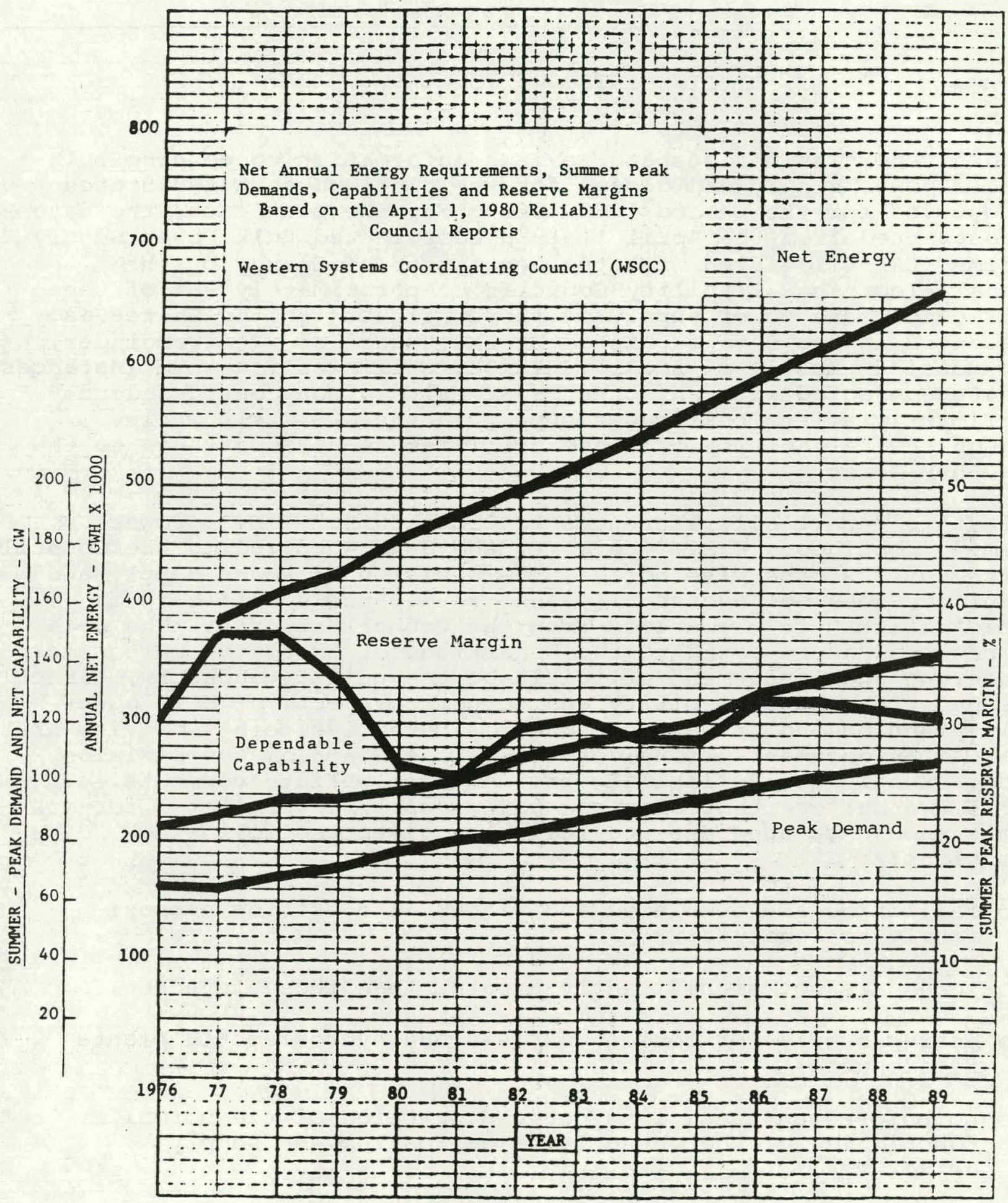




\section{INTRODUCTION}

This report summarizes and reviews information concerning bulk electric power supply and demand for the contiguous United states as projected for the period 1980-1989. For the most part, the data are abstracted from the April 1, 1980 Coordinated Bulk Power Supply Programs (ERA-411) filed with the Department of Energy by the Regional Electric Reliability Councils. Approximately $98 \%$ of the electric load and power supply of the contiguous United States is represented in the data furnished by the councils. The remainder, which consists mostly of small municipal utilities (in some instances not interconnected with any other systems), is not considered to significantly affect bulk power supply in the U.S. as a whole, although the reliability of those utilities is of importance to the areas they serve.

In this report all references Lo "Total U.S.", "U.S. Power System," "Contiguous U.S.," refer to the data supplied in the Council reports, unless otherwise noted. The Division of Power Supply and Reliability does not necessarily endorse all the specific items of information here summarized from the Council reports. The data are presented as reported to the Department of Energy by responsible engineering and management officials of the utility industry, directly concerned with the reliability and economic aspects of bulk power supply planning and operation. Where alternative points of view are supported by documented considerations, the staff of the Division of Power Supply and Reliability has made appropriate comments. In general, we believe that electric power supply as projected for most regions should be adequate and reliable, given the following assumptions:

- facilities are completed and placed in operation approximately as scheduled;

- loads are not signiticantly greater than thuse lulecást;

o energy supply for fossil, nuclear and hydroelectric plants is adequate;

o no unforeseen conditions cause disruption of the normal functioning of the three large national power supply networks. $1 /$

I/ "Network" as used here includes all facilities for generation, transmission and distribution of electric power. 
In the contiguous United states there are three electric utility power supply systems, of large geographic extent, that together cover the entire country. Largest of the three, and possibly the largest in the world in terms of generating capacity and load, is the Seven-Council Interconnection, which covers all or part of 39 states and 3 Canadian provinces. Of the seven Regional Council areas which comprise this network (ECAR, MAAC, MAIN, MARCA, NPCC, SERC, SWPP), three are interconnected with Canadian systems: ECAR, MARCA, NPCC. All data and discussion in this report refer only to U.S. loads and facilities. Interconnection among utilities in this large area has progressed to the point where capacity and energy in significant amounts can be and is routinely exchanged among systems for economic purposes, for emergency purposes, and for other reasons.

The next largest network is a single council Region, the Western Systems Coordinating council (WSCC). It covers all or part of 13 western states and extends into the Canadian province of British Columbia. All data and discussion herein refer only to the U.S. portion of WSCC. Within WSCC there are many inter-utility connections but there is only minor power transfer capability between WSCC and other Council areas.

The smallest of the three networks is ERCOT, which covers a large part of the state of Texas. ERCOT utilities are interconnected within Texas but have no interconnections with systems in any other state, nor are they interconnected with those Texas systems, not in ERCO'l, that are part of an inter-state system. $1 /$

1/ Studies are underway to examine the costs and benefits of interconnections between ERCOT utilities and utilities in the Southwest Power Pool. 


\section{ENERGY FORECASTS}

The Reliability Council projections of net annual energy requirements, 1/ extending through 1989, are summarized in Table 1. For the nine individual Council regions, the average annual growth rate for the decade 1979-1989 ranges from the 2.1 percent projected by NPCC to the 5.8 percent estimated by SWPP. Total U.S. electric energy needs are projected to increase at an average annual rate of 4.2 percent. A review of previous energy projections by the Councils shows that their estimates have been declining for some time. As an illustration, the table below shows the totals of the projections made by the Councils, in each year from 1976 through 1980, for the year 1985 .

\section{Table III.1 \\ Energy projections for 1985} Council projections
made in

1976

1977

1978

1979

1980
Total U.S. Net Energy

Projected for 1985 (Gwh)

(Excludes Alaska \& Hawaii)
용 Reduction From

Projection of

Preceding Year

Ratio of 1980 projection to 1976 projection $=0.8344$

1/ Net annual energy requirements refers to energy provided by generating plants to the system. It excludes energy used within power plants. It includes transmission and distribution losses, and the net of energy purchases and sales between the United States, Canada and Mexico. 
For the past several years, the near-term annual energy reguirements forecast in the council reports have been higher than the actual energy requirements that finally transpired. Table III.2 is a comparison of the projections made in 1976, 1977, 1978, and 1979 with the actual energy reguirements later reported by the councils for those years.

Table III 2
Comparison of Actual and Projected Energy Reguirements
Cont

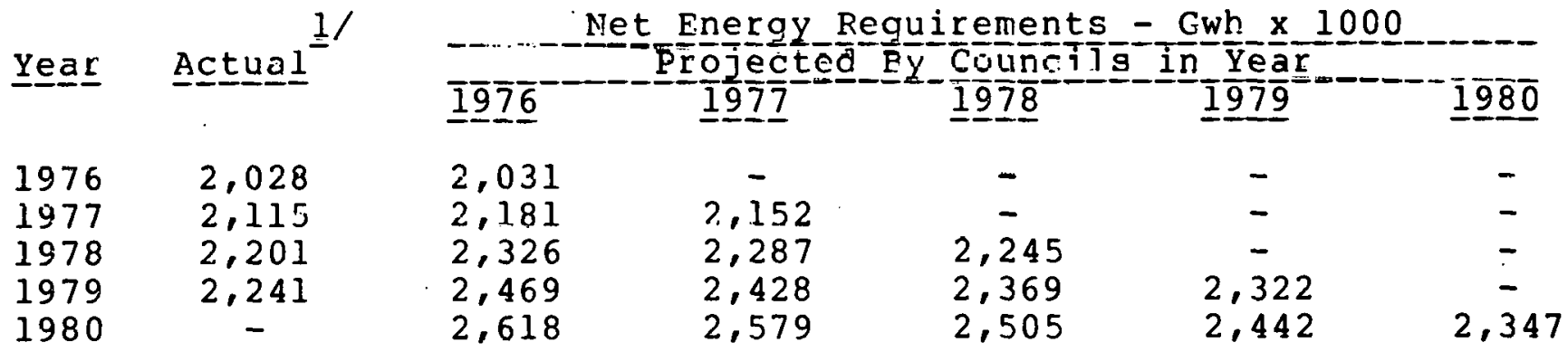

İ $\bar{A}$ reported in the $\bar{A}$ pril 1 annual Reliability Council Reports, except for 1976. The 1976 Actual energy is as reported in FPC News Release 23017 dated March 23, 1977, after deduction of Alaska and Hawaj i. data.

The percentage by which the council energy projections exceeded the actual energy reguirement is shown in Table III.3, which is based on Table III. 2 . 
Table III.3

Percentage Err $\underline{x}$ or in Projection of Energy $1 \overline{9} \overline{6} \overline{6}=\overline{1} \overline{9} \overline{9}$

Contiguoús United states

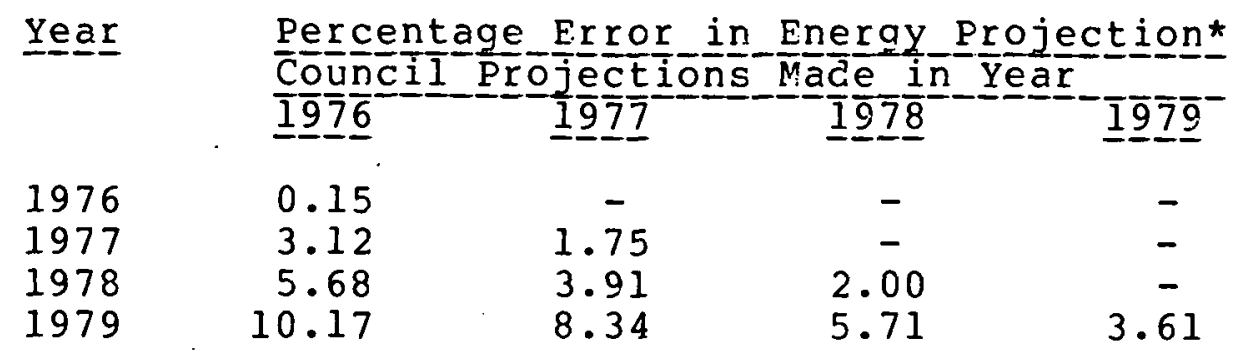

\footnotetext{
*( $\begin{aligned} & \text { Projection for Y Year" } " \mathrm{X} " \\ & \text { Actual Energy for Year "X" }\end{aligned}$
}

The evidence of Table III.3 is that:

(1) Reliability Council projections of net annual energy requirements for the near term have exceeded the actual energy reguirements.

(2) In any one year, the Council projections of net annual energy for future years become increasingly incorrect as the target year becomes further away.

(3) The Council projections of energy for the year in which the projection is made have become increasingly incorrect from 1976 through 1979.

The aggregate annual increases in net annual electric energy requirements projected by the Councils are shown in the graph of Figure III.l together with the actual increases experienced since 1969. While the projected increases are well within the range of recorded experience, they appear higher than can now reasonably be expected. The graph of Figure III.l shows, on the average, a cyclical pattern with each successive peak lower than the preceding one. If this pattern were to continue, the 4.728 increase projected for 1980 over 1979 would approximately follow the trend. There are several factors, however, which indicate this projection is too high: 
(1) Table III.3 shows that the aggregate of Council projections has been higher than the actual energy requirement in each of the years 1976 through 1979, with an increasing percentage of error.

(2) Current economic conditions do not appear conducive to a large increase in electric energy use in the near future. $1 /$

(3) Continuing and increasing emphasis on conservation will tend to decrease energy use.

(4) The increased cost of producing electric power, resulting in an insrease in the general level of rates, has a neyalive effcct on consumption ot electric energy.

(5) According to the Edison Electric Institute Electric Output Report for the week ended May 31; 1980, net electric energy distributed by the total electric utility industry of the contiguous U.S. for the first 22 weeks of 1980 was $1.2 \%$ less than the net electric energy for the corresponding period of 1979 .

The foregoing factors lend support to the belief that the increase of the 1980 net energy requirement over the 1979 requirement will be less than the 4.728 projected by the Regional Councils, if indeed there is an increase, and that in subsequent years there will also be smaller annual increases than are projected by the Councils. Therefore, the staff of DPSR has reduced the aggregate of the Regional Council energy projections for the years $1980-1983$ as discussed below.

If Consideration is being given to large-scale electrification strategies to reduce the use of oil and gas. Such strategies would have a major impact on future growth. 
With the data of Takle III.3 and the aggregate council energy projections as guides, staff has developed the modified energy projections for 1980 through 1983 shown in Table III.4 below.

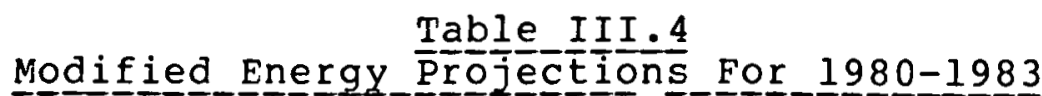

$$
\begin{aligned}
& \text { Contiguous U. }
\end{aligned}
$$

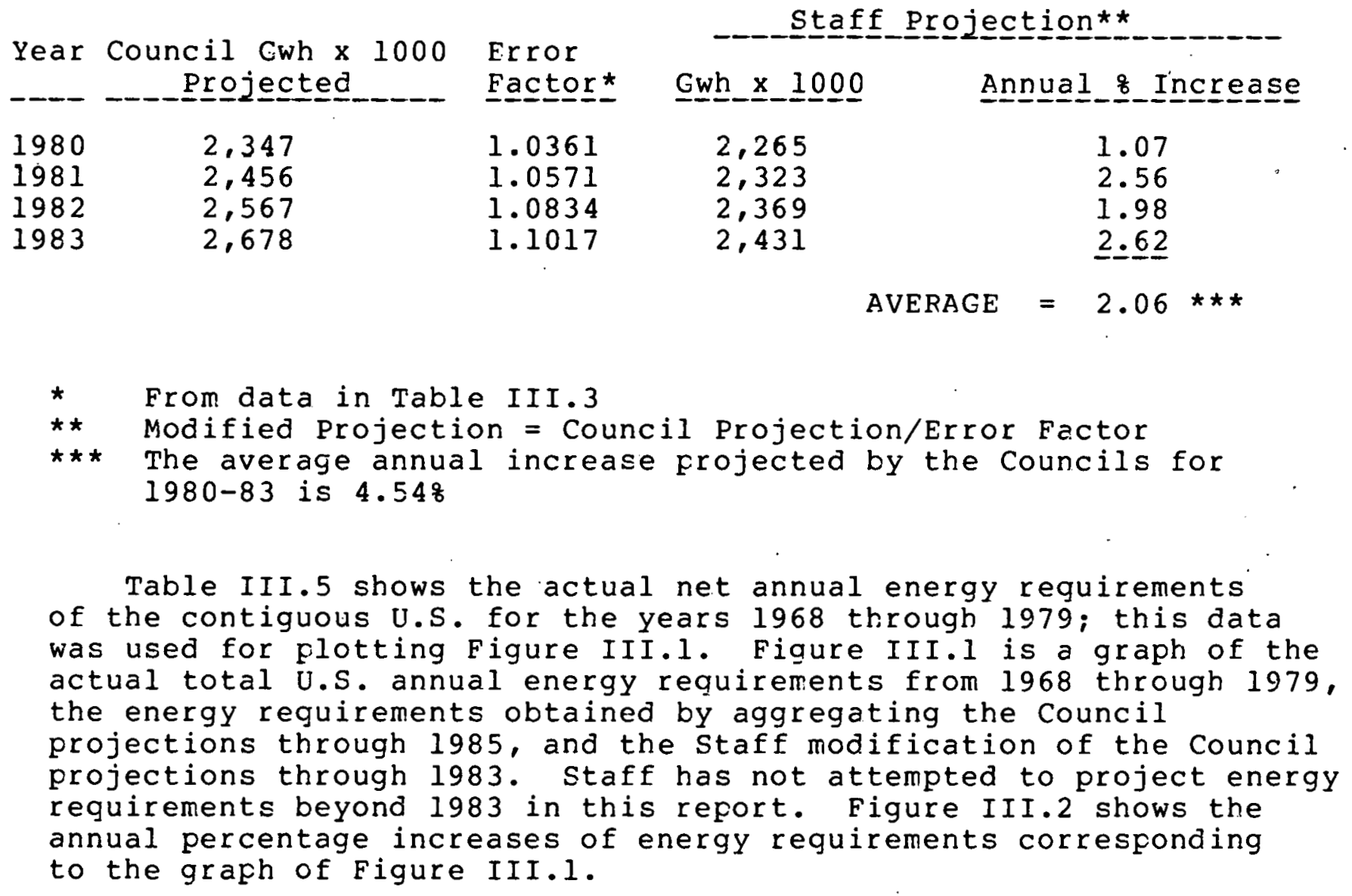




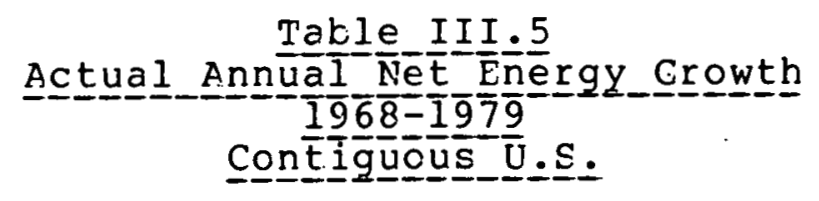

Year

1968

1968

1969

1970

1971

1972

1973

1.974

1975

1976

1977

1978

1979
Net Annual Energy Thuus

1,327

1,440

1,527

1,608

1,741

1,849

1,858

1,910

2,029

2,115

2,197

2,238
Annual

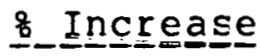

8.52

6.04

5.30

8.27

6.20

0.49

2.80

6.23

4.24

3.88

$\underline{1} . \underline{8} 7$

AVERAGE: $\quad 4.89$

* From DOE Reports of total U.S. energy reguirements rounded to Gwh after data for Alaska and Hawai have been removed. This data differs slightly from the energy data reported by the Regional Councils; the differences are not considered significant. 
Figure III. 1

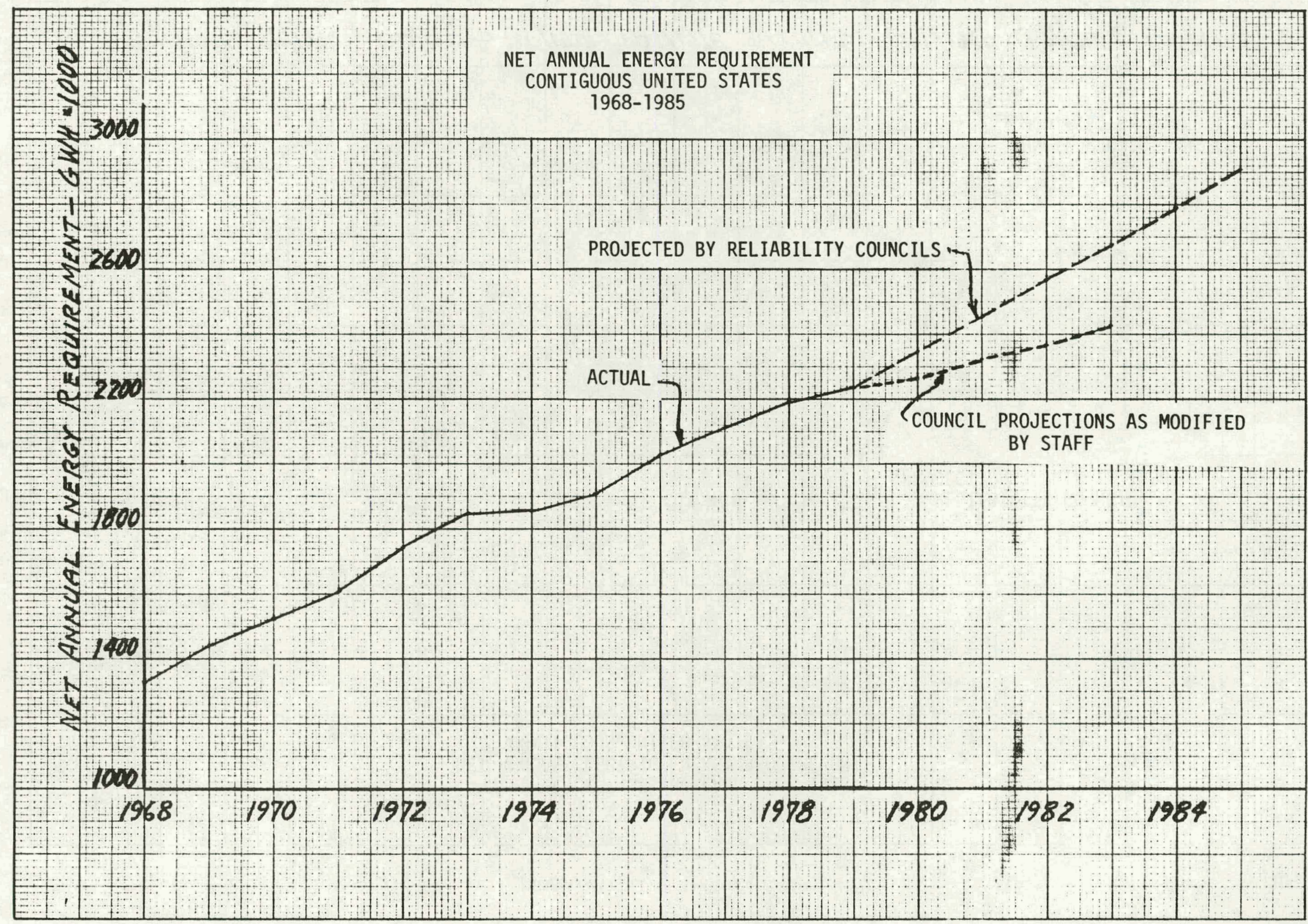


Figure III. 2

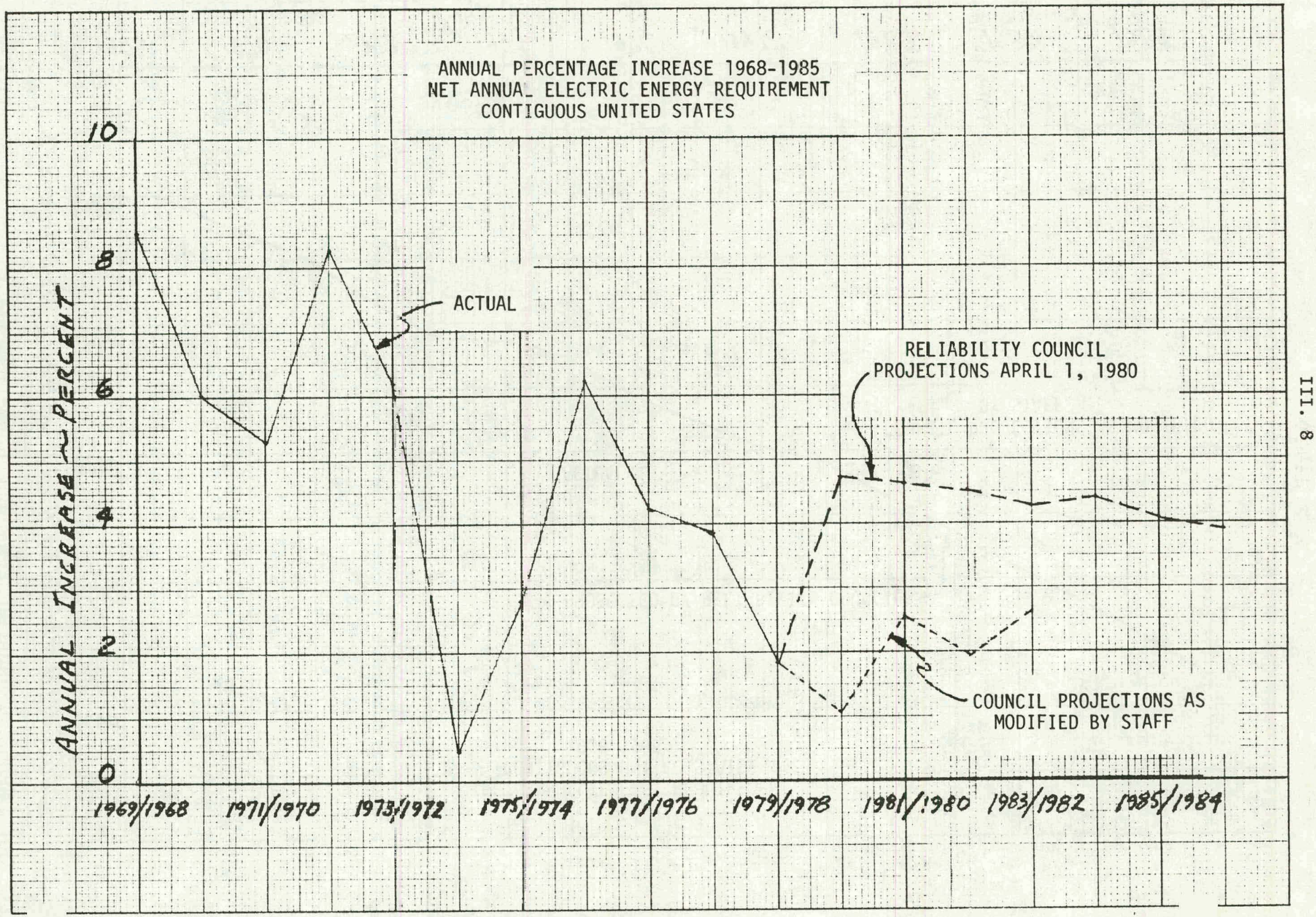


The $2.06 \%$ average annual growth rate for energy requirements of the contiguous U.S. through the summer of 1983, as obtained in the foregoing discussion, masks the regional variations that are sure to exist. Therefore, the procedure outlined above has been applied to the forecasts made by each of the nine councils. The resulting projections, which staff considers more probable than those put forward by the Councils, are shown in Table III.6 below. In the same table, in order to provide an appropriate context for the staff estimates, are shown the council projections averaged for 1980-83, the actual average growth reported for 1976-79 and the actual growth of 1979 over 1978 energy requirements. The staff estimates in Table III.6 are less than the Council projections in all cases, and are less than the actual 1976-79 average growth rate for all Councils except SWPP. The staff estimates are also less than the 1978-79 repurted 1ncrease for all Councils except ERCOT, SERC and SWPP. 
TAPLE IIT. 6

Actual and Projected Average_Annual Growth Rates

Annual Electric Energy Reguirements

For Re 1 iability Councí1

$19 \underline{9} \underline{6}=19$

Sounc모느

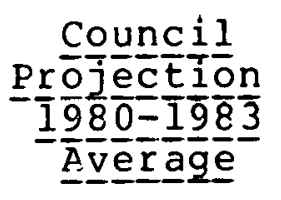

Actual Growth

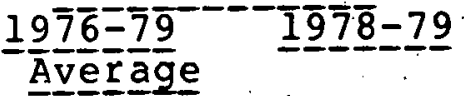

Staff Eetimate l/

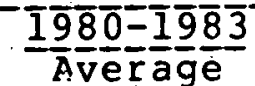

스르므

ECAR

ERCOT

MAAC

MAIN

MAKCA

NFCC

SERC

SWPP

WSCC

TOTAL U.S.
4.08

5.80

3.45

2.72

5.17

1.74

5.26

6.55

$-\frac{5}{4} \div \frac{1}{5} \frac{2}{4}$
3.90

7.91

2.61

1.90

7.23

2.18

2.61

5.08

$-\frac{3}{3} \div \frac{6}{6} \frac{5}{3}$
2.68

2.10

1.59

1.36

4. 32

1.41

0.04

0.10

$-\frac{3}{1} \div \frac{7}{8} \frac{1}{4}$
2.28

3.87

1.11

0.28

3.13

$(0.20) 2 /$

1.02

5.71

$-\frac{2}{2} \div \frac{6}{0} \frac{7}{6}$

I/ Based on analysis of differences between the annual energy requirements projected by the Councils in the years 1976-1979 for those years, and the actual energy requirements as later reported.

2/ Although the error analysis procedure yields a negative growth rate here, a zero growth rate would not be an unreasonable estimate. 
The Regional Reliability Council forecasts of peak demand (see Tables 2 and 3 ) show that each is expected to have a different rate of growth for the next ten years. NPCC projects its summer feak demand to increase at an average annual rate of 1.98 and its winter peak demand to increase at an average rate. of 2.58. These are the lowest growth rates projected by any Council and are lower than the corresponding growth rates projected by NPCC a year ago. At that time, NPCC also projected the smallest growth rate of the nine Council areas. In the current forecast SWPP projects the largest growth rate of the nine Councils, 6.28 for winter and summer peak demands. In 1979 SWPP also projected the largest growth rate of all the Councils: 6.08 for summer and 5.98 for winter. For comparison, the actual summer Feak demand for NPCC was $0.4 \%$ less in 1979 than in 1978. In SWPP, the 1979 summer peak demand was 3.8 o less than in 1978. For the winter of 1979-80, NPCC showed an increase of 1.08 over the peak demand of the preceding winter and SWPP showed an increase of 0.28 . It is to be noted that the current SWPP projection is not comparable to that of the previous year because data for Associated Electric Cooperative, previously reported under MAIN, is now reported, in the tables in this report, under SWPP. The transfer is effective as of June 1, 1980. Although the MAIN and SWPF Long Range Flanning Programs, as filed with LOE on April 1, 1980, do nol show the effects of the transfer, staff has made the necessary changes in all the tables of this report. 
Aggregation of the Council demand projections for the summer and winter peak periods results in lesser rates of grow.th for the total U.S. than were projected last year. The ten-year average annual increase for summer demand is now projected at 4.38 , and for winter at 4.68 . The 1979 projection was 5.28 for summer and 5.48 for winter. The lower growth rates now projected continue a trend that has been evident for the last several years, as shown in Tables IV.1 and IV. 2 below:

$$
\begin{aligned}
& \text { Average Annual } \frac{\text { Table IV.l }}{\text { Increase of Summer Demand }} \\
& \text { As Projected By The Reliability Councils }
\end{aligned}
$$

Council

ECAR
MAAC
MAIN
MAFCA
NPCC
SERC
SWFP Subcotal
WSCC
ERCOT
U.S. Total

Ten-Year Average Ánnual Fercent Incteare As Projected April 1 in Year

$\begin{array}{lllll}\frac{1976}{1 /} & \frac{1977}{5.7} & \frac{1978}{5.2} & \frac{1979}{4.3} & \frac{1980}{4.0} \\ \frac{1}{1} / & 4.3 & 3.8 & 3.1 & 2.9 \\ \frac{1}{1} / & 5.8 & 5.2 & 4.3 & 3.4 \\ \frac{1}{1} / & 6.5 & 5.7 & 5.4 & 5.5 \\ \frac{1}{1 /} & 4.4 & 3.5 & 3.1 & 1.9 \\ \frac{6.3}{6.4} & \frac{7.1}{5.8} & \frac{6.0}{5.3} & \frac{6.4}{4.7} & \frac{6.5}{4.1}\end{array}$

\begin{tabular}{l}
5.6 \\
6.7 \\
\hline 6.3
\end{tabular}

5.2

$\frac{5.7}{5.7}$

\begin{tabular}{l}
4.7 \\
5.4 \\
\hline 5.2
\end{tabular}

4.4

4.5

$\frac{5 \cdot 1}{4 \cdot 7}$

$\frac{5 \cdot 6}{4 \cdot 3}$ 
Table IV. 2

Average Annual Increase of Winter Demand

As Projected Ey The Reliability Councils

Council

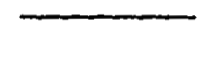

Ten-Year Average Annual Percent. Increase As Projected April I In Year

$$
1976
$$

$\frac{1}{1 /}$

I/

$\frac{1}{1 /}$

II

$\frac{\overline{1} /}{6 \cdot 4}$

Subtotal

WSCC

ERCOT

U.S. Total \begin{tabular}{l}
5.8 \\
6.8 \\
\hline 6.3
\end{tabular}

1977

5.9

4.9

6.1

6.3

4.6

6.4

$\frac{7.1}{6.0}$

1978

5.6

4.3

5.9

6.0

3.7

6.1

$\frac{6 \cdot 3}{5 \cdot 5}$

5.3

$\frac{5.8}{5.8}$ $\begin{array}{r}4.7 \\ 5.4 \\ \hline 5.4\end{array}$
1979

4.8

3.6

5.0

5.8

3.6

5.8

$\frac{5.9}{5.0}$

4.4

$\frac{4.9}{4.9}$
1980

4.9

3.6

3.7

5.2

2.5

$$
4.4
$$$$
\frac{6.2}{4.4}
$$

5.0

$\frac{5.3}{4.6}$

I/ Not readily available 
As in the case of recent energy forecasts, the aggregate of Council projections of summer peak demand has exceeded the actual value for the last several years. Table IV.3 below compares the actual summer peak demand with the sum of the Council forecasts for the years 1976 through 1979, and Table IV.4 translates the megawatt data of Table IV. 3 into percentage of error.

Table IV. 3

Comparison of Actual and Projected Summer Demands $1976-1979$

Contiguous United States

Year

Peak Summer Demand - Megawatts

\begin{tabular}{llllll}
\hline Actual & \multicolumn{4}{c}{ Projected by Councils in Year } \\
\cline { 2 - 5 } & $\underline{1976}$ & $\underline{1977}$ & $\underline{1978}$ & $\underline{1979}$ & $\underline{1980}$
\end{tabular}

$1976 \quad 361,898$

1977388,604

379,103

407,413

397,406

435,577

1978

401,156

463,060

491,808

$\underline{1978}$

1980

1980

396,359
421,948
447,693
475,307

-
-
412,364
436,029
460,077

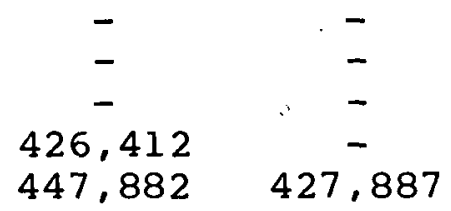

Table IV. 4

Percentage Error in Projection of Summer Demand 1976-1979

Contiguous United states

Year

Percentage Error in Demand Projection*

Council Projections Made in Year 1976 1977 $\underline{1978}$

1979

1976

1977

1978

1979

4.75

4.84

9.61

15.43

2.00

6.18

11.60

3.76

8.69

$-$

6.30

* $\frac{\text { (Projection for Year "X" }}{\text { (Actual Demand for Year "X" })}-1 \times 100 \%=\%$ Error 
For winter peak demand, the aggregate of Council projections also liffers from the actual value for the contiguous. U.S., as shown in rables IV. 5 and IV. 6 .

Table IV. 5

Comparison of Actual and Projected Winter Demands

1976-1979

Contiguous United states

Year

Peak Winter Demand - Megawatts

\begin{tabular}{lllll} 
Actual & \multicolumn{3}{c}{ Projected by Councils in Year } \\
\hline$\underline{1976}$ & $\underline{1977}$ & 1978 & 1979 & 1980
\end{tabular}

$1976-77 \quad 346,589 \quad 343,427$

$1977-78 \quad 339,724$

$1978-79 \quad 372,553$

$1979-80 \quad 369,729$

$1980-81$

$\begin{array}{lc}343,427 & - \\ 367,355 & 360,447 \\ 391,931 & 383,688 \\ 416,630 & 408,154 \\ 442,419 & 433,614\end{array}$

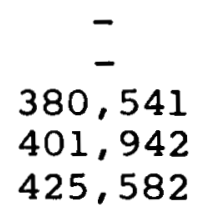

Year

$1976-77$

1977-78

1978-79

$1979-80$
Percentage Error in Projection of Winter Demand*

Council Projections Made in Year

$19 \overline{76}$

1977

1978

1979

$(0.91)$

8.13

5.20

12.69

6.10

2.99

10.39

2.14

8.71

$-$

6.78

*( $\left(\frac{\text { Projection for Year "X") }}{\text { Actual Demand for Year "X") }}-1 \times 100 \%=. \%\right.$ Error 
A well-known difficulty in the projection of peak demand, wincer or summer, is the effect of temperature. Careful construction of a comprehensive model for demand, with thorough research into the historic magnitudes of the various parameters and detailed consideration of possible changes in the relevant faccors, may give an accurate forecast for normal weather condicions. But unusual weather conditions may affect the demand so greatly that the forecast of a single number for peak demand will be greatly in error. An unusually cold period of only several days, in some areas, will be sufficient to create an exceptionally high winter peak. An unusual warm period of only a few days can in some areas raise the summer peak demand to a level much higher than normal. The effect in summer would be increased by high humidity and lack of wind: Short periods of unusual weather have a greater effect on peak demands than on annual energy requirements. Therefoce, in the reporting of demand forecasts, a range of values would be more suitable than a single number. The range of summer peak demand could be given in cerms of a conl, normal or hot summer. The range of winter peak demand could be given for a warm, normal or cold winter. The effect of weather on generator output is discussed in section $V$.

Further analysis of Tables 2 and 3 shows that five councils firmly expect to remain as summer peaking areas (summer peak greater than the following winter peak); these are MAAC, MAIN, MARCA, SWPP and ERCOT. In the MAAC region, however, the winter peak increases gradually from 898 of the summer peak in 1980 to 948 in 1989. Three regions (ECAR, SERC and NPCC) are winter-peaking and project they will remain so. NPCC, in fact projects increasing dominance of the winter peak, from $100.6 z$ of the summer peak in 1980 to 105.68 in 1989 . The wscc ared projects winter and summer peak demands to be nearly equal, with the winter peak fluctuating between 988 and 1008 of the summer peak during the entire 1980-1989 period. The U.S. as a whole is expected to remain summer-peaking. Table. IV. 7 shows the data relating winter peak demand to summer peak demand. 
Table IV.7

Ratio of Projected Winter Peaks to Summer Peaks Based on Reliability Counci

Ratio winter Peak/Summer Peak

\begin{tabular}{|c|c|c|c|c|c|c|c|c|c|c|c|}
\hline . & $19 \frac{8}{1} \frac{8}{9} \frac{\overline{0}}{8} \overline{0}-1$ & $1 \frac{9}{1} \frac{\overline{8}}{9} \overline{1} \overline{1}$ & $1=\frac{1}{1} \overline{8} \overline{9} \overline{8} \overline{2} \overline{2}$ & $\frac{19}{1} \frac{8}{9} \frac{3}{8} \overline{3} \frac{8}{4}$ & $\frac{1}{1} \frac{8}{1} \frac{4}{8}=6$ & $=\frac{19}{1} \frac{8}{9}=\overline{8}=$ & $=\frac{1}{1} \overline{9} \frac{6}{6}=\overline{3}=$ & $=\frac{1}{1} \frac{8}{9} \overline{8}=8$ & $\frac{19}{1} \overline{9} \frac{8-89}{8}$ & 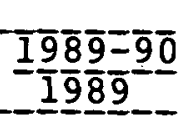 & \\
\hline $\begin{array}{l}\text { ECAR } \\
\text { MAAC } \\
\text { MAIN } \\
\text { MARCA } \\
\text { NPCC } \\
\text { SERC } \\
\text { SWPP } \\
\text { Subtotal }\end{array}$ & $\begin{array}{r}1.029 \\
0.89 \\
0.81 \\
0.94 \\
1.006 \\
1.021 \\
-\frac{0.79}{0.9} \frac{7}{4}\end{array}$ & $\begin{array}{r}1.032 \\
0.90 \\
0.81 \\
0.92 \\
1.017 \\
1.033 \\
-0.77 \frac{7}{5}\end{array}$ & $\begin{array}{r}1.021 \\
0.90 \\
0.82 \\
0.92 \\
1.025 \\
1.016 \\
0.74 \\
0.9 \frac{74}{4}\end{array}$ & $\begin{array}{r}1.023 \\
0.90 \\
0.82 \\
0.92 \\
1.029 \\
1.017 \\
-0.7 \frac{7}{4}\end{array}$ & $\begin{array}{r}1.026 \\
0.91 \\
0.83 \\
0.92 \\
1.033 \\
1.015 \\
-0.75 \\
-0.94\end{array}$ & $\begin{array}{r}1.029 \\
0.92 \\
0.83 \\
0.92 \\
1.039 \\
1.015 \\
-0.75 \\
-0.95\end{array}$ & $\begin{array}{r}1.030 \\
0.92 \\
0.84 \\
0.92 \\
1.044 \\
1.018 \\
-0.75 \\
-0.95\end{array}$ & $\begin{array}{r}1.031 \\
0.93 \\
0.84 \\
0.92 \\
1.048 \\
1.019 \\
-\frac{0}{0} \div \frac{75}{5}\end{array}$ & $\begin{array}{r}1.036 \\
0.93 \\
0.85 \\
0.93 \\
1.051 \\
1.019 \\
-0.76 \\
-0.95\end{array}$ & $\begin{array}{r}1.039 \\
0.94 \\
0.85 \\
0.93 \\
1.056 \\
1.021 \\
-0.76 \\
-0.96\end{array}$ & \\
\hline $\begin{array}{l}\text { WSCC } \\
\text { ERCOT }\end{array}$ & $\begin{array}{r}0.99 \\
0.74 \\
\end{array}$ & $\begin{array}{l}0.99 \\
0.74 \\
\end{array}$ & $\begin{array}{r}0.99 \\
0.74\end{array}$ & $\begin{array}{l}1.00 \\
0.74 \\
\end{array}$ & $\begin{array}{r}1.00 \\
0.74 \\
\end{array}$ & $\begin{array}{r}1.00 \\
-0.74 \\
\end{array}$ & $\begin{array}{l}1.00 \\
0.74 \\
\end{array}$ & $\begin{array}{r}1.00 \\
0.76 \\
\end{array}$ & $\begin{array}{r}1.00 \\
0.75 \\
\end{array}$ & $\begin{array}{l}0.98 \\
0.75 \\
\end{array}$ & \\
\hline U.S. Tota & 4 & 0.94 & 0.94 & 0.94 & 0.94 & 0.94 & 0.94 & 0.94 & 0.94 & 0.94 & \\
\hline
\end{tabular}


Because of the magnitude of the previous differences between actual and forecasted values (shown in Tables IV. 3 , IV.4; IV.5 and IV.6), staff has adjusted the summer peak demand forecasts downward to more accurately reflect what appears to be a continuing trend toward lower load growth rates. On the assumption that load factor for the contiguous U.S. will remain substantially constant through 1983, staff has used its projected percentage annual increase in energy requirements (derived in section III), to obtain. summer peak demand projections through 1983; these are shown in Table IV.8 as the "Low" staff estimate.

In order to obtain a range of annual increase, instead of a single number, the period following the 1973 "oil embargo" was selected for study. In the period 1973-1977 the annual increase in summer peak demand averaged 2.948. Staff has used this percentage increase to obtain the "High" Staff estimate in Table IV.8. Table IV.8 data has been used to plot Figure IV.l. The figure also shows the Council projections through 1985 and the actual reported peaks for the years 1968 through 1979.

Table IV. 8

Range of Sumer per For Contiguous U.

Yea ar

Council Projections

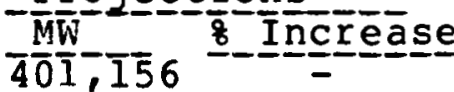

1.979

1980

1981

427,887

446,724

6.66

467,580

1982

486,742

4.40

4.67

-4.1은

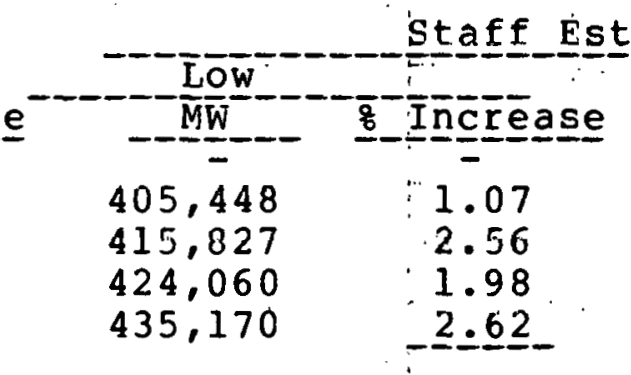

Staff Estimates

AVERAGE :

4.96

2.06

$\begin{array}{cc} & \\ 412,050 & 2.94 \\ 425,091 & 2.94 \\ 437,589 & 2.94 \\ 450,454 & 2.94\end{array}$

2.94 
Figure IV. 1

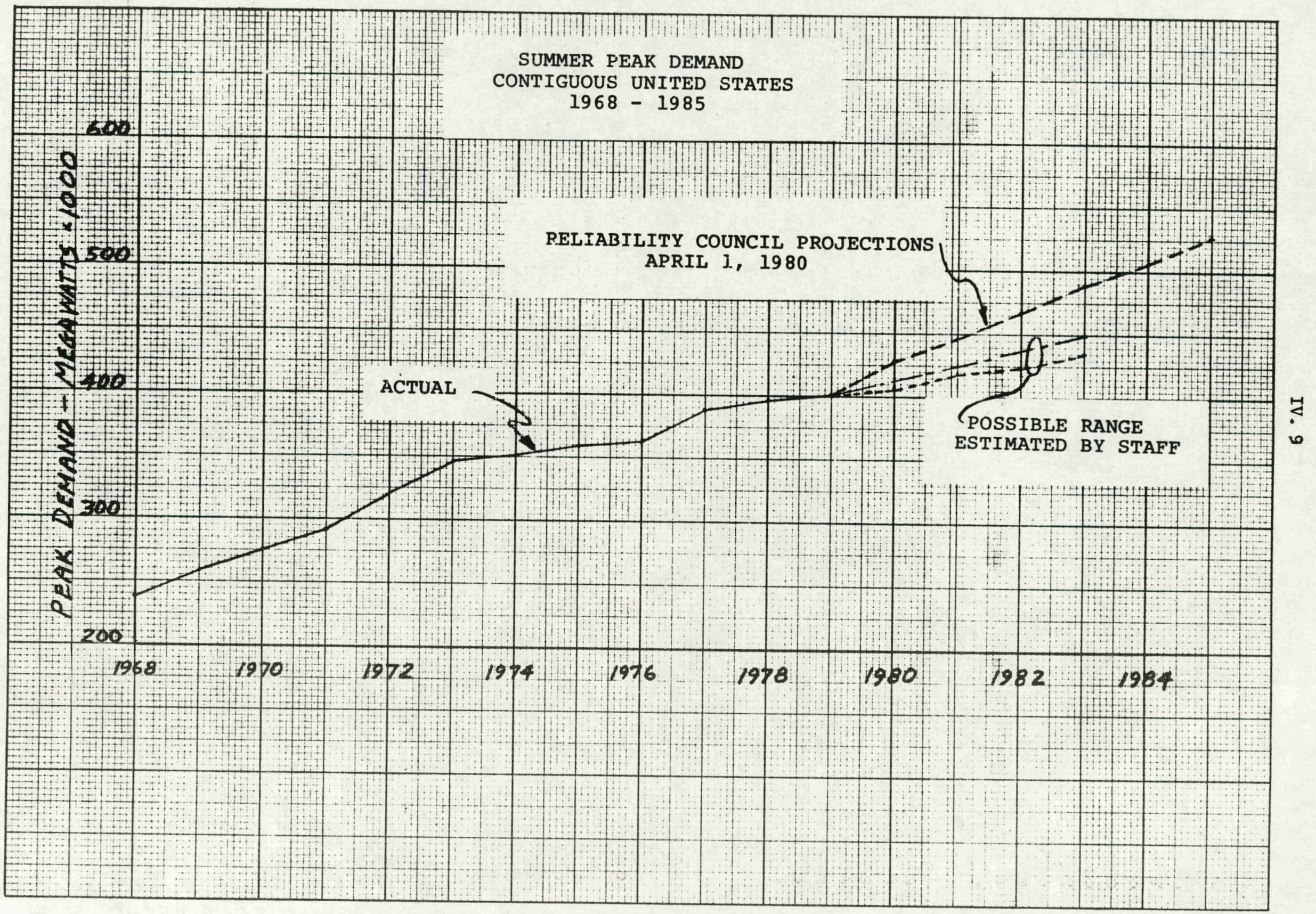




\section{Generating Capacity}

According to the Council reports, total net dependable generating capacity in the United States will increase from a reported $544,560 \mathrm{MW}$ in summer 1979 to a projected $778,058 \mathrm{MW}$ in summer 1989. This increase is the net of additions to capacity in the form of new units and upratingsl/ and subtractions from capacity caused by retirements and deratings. 2/ The magnitude of the net increase $(778,058-544,560=233,498)$ indicates the average annual completion of approximately 23,350 . MW of generating capacity. For purposes of comparison, the average annual increase of capacity for the past several years is tabulated below:

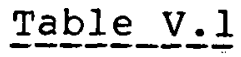

Net_Eegendable Generating Capability A $\bar{t}$ T 1 me of

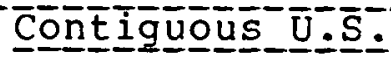

Yeㅡㅁㅗ

1976

1977

1978

1979

\section{Capability} (MW)

485,847

506,193

530,902

544,560
Annual Increase (MW)

20,346

24,709

13,658

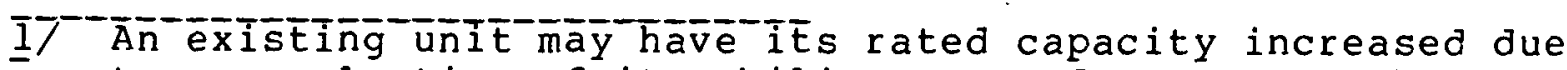
to re-evaluation of its ability to produce power, changes in the structure and operation of some of its components, a change to higher-quality fuel, or other reasons.

2/ An existing unit may have its rated capacity decreased due to re-evaluation of its ability to produce power, installation of more effective air pollution controls, a change to lower-quality fuel, conversion from oil to coal, or other reasons. 
SERC projects the largest increase of all the councils and wSCC projects the next largest increase, as shown in Table V.2. The smallest increase in capacity for the 1979-89 period is that projected by NPCC, which also projects the smallest increase in growth of energy requirements and peak demand. Although in terms of 1979 annual energy reguirements, MAAC was nearly 79 o larger than MARCA, and MAAC's summer demand exceeded that of MARCA by almost $75 \%$, MARCA and MAAC project practically the same magnitude of net capability increase between 1979 and 1989 . This may be due to MARCA's having a larger projected rate of growth than MAAC.

$\underline{T a b l e} \cdot \underline{V} \cdot \underline{2}$

Capacity Increases projected by Councils Summer $1 \bar{g} 7 \bar{g}$ to Surmiter I

Councili

ECAR

MAAC

MAIN I/

MARC.A

NPCC

SERC

SWPP 1/

sub Tōtal

WSCC ERCOT

U.S. Total

\begin{tabular}{|c|c|}
\hline$-\overline{1} \bar{g} \bar{g} \underline{\underline{g}} \underline{\underline{g}}$ & mer $\overline{1} \bar{g} \bar{g}$ \\
\hline $\begin{array}{r}120,552 \\
56,546 \\
56,456 \\
34,726 \\
61,340 \\
164,952 \\
80, \pm 866 \\
5 \frac{8}{5}, \frac{6}{3} \frac{6}{8}\end{array}$ & $\begin{array}{r}87,257 \\
45,285 \\
42,769 \\
23,470 \\
50,582 \\
109,811 \\
4 \frac{4}{40}, \frac{4}{8}, 6 \frac{4}{3}\end{array}$ \\
\hline
\end{tabular}

$$
143,187
$$

59,433

$7 \overline{7} \frac{5}{0} \div \frac{4}{5}$

$$
\begin{array}{r}
99,743 \\
\frac{41}{544}, \frac{1}{56} \frac{94}{0}
\end{array}
$$

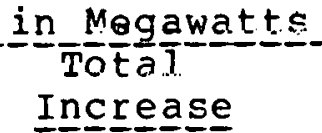

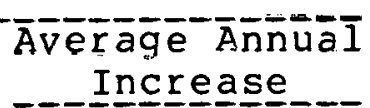

33,295

11,261

13,687

11,256

10,758

55,141

31,417

$\frac{1}{16} \frac{1}{6} \div \frac{1}{8} \frac{1}{5}$

48.444

$\frac{1}{2} \frac{1}{3} \frac{8}{3} \div \frac{2}{4} \frac{39}{9}$
3,330

1,126

1,369

1,126

1,076

5,514

$1 \frac{3}{6} \div \frac{1}{6} \frac{4}{8} \frac{1}{2}$

4,844

$\frac{1}{2} \div, \frac{1}{3} \frac{2}{5} \frac{4}{0}$

İ from MAIN to SWPP effective June 1, 1980. The 1979 capability has also been adjusted to reflect this transfer for the purposes of this table. 
Most of the total increase in U.S. generating capacity is projected to be nuclear and coal-fired, although not all areas project the same percentages of these units. MARCA, for instance, projects no new nuclear units for the entire period 1980-89, ECAR. projects about $26 \%$ of its capacity changes to be new nuclear units and MAAC has scheduled some $72 \%$ of its projected capacity changes to be new nuclear units. MAAC has also scheduled the retirement and derating of existing capacity at about 178 of the total changes. ECAR's retirement and derating program amounts to barely 18 of its total capacity changes for 1980-1989. Table V.3 shows the Council-by-Council capacity changes by percentage, for a selected group of Councils.

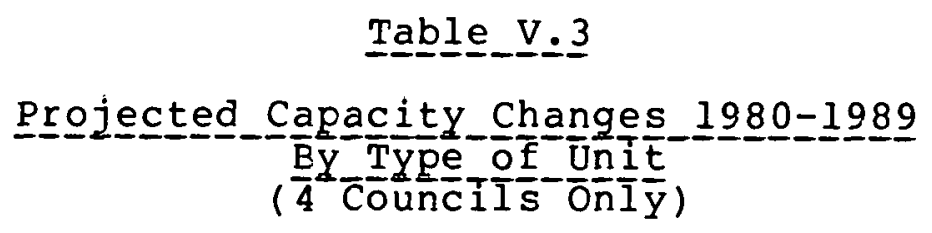

Approximate Percentage by Type

\begin{tabular}{|c|c|c|c|c|c|c|c|c|}
\hline ounci & Nuuc $\bar{l} \overline{\mathrm{e}} \underline{\mathrm{a}} \overline{\mathrm{r}}$ & $\underline{\underline{\mathrm{F}}} \underline{\mathrm{o}} \overline{\mathrm{s}} \overline{\mathrm{s}} \mathbf{I} \overline{\mathrm{I}}$ & Hydro & $\underline{\mathrm{P}}-\overline{\mathrm{S}}=$ & $\mathrm{GT} I \mathrm{I} \mathrm{C}$ & óther & $\bar{U}, \bar{E}, \bar{R}, \bar{I}$ & TOÉ̄ \\
\hline $\begin{array}{l}\text { ECAK } \\
\text { MAAC } \\
\text { MARCA } \\
\text { SWPP }\end{array}$ & $\begin{array}{r}26.2 \\
72.4 \\
0 \\
23.2\end{array}$ & $\begin{array}{r}70.1 \\
42.6 \\
103.8 \\
82.8\end{array}$ & $\begin{array}{l}0.2 \\
1.8 \\
0.7 \\
0.1\end{array}$ & $\begin{array}{r}3.3 \\
0 \\
0 \\
0.6\end{array}$ & $\begin{array}{r}1.1 \\
0.1 \\
0 \\
1.0\end{array}$ & $\begin{array}{r}0 \\
0 \\
0 \\
1.4\end{array}$ & $\begin{array}{r}(0.9) \\
(17.0) \\
(4.5) \\
(9.0)\end{array}$ & $\begin{array}{l}100 \\
100 \\
100 \\
100\end{array}$ \\
\hline
\end{tabular}

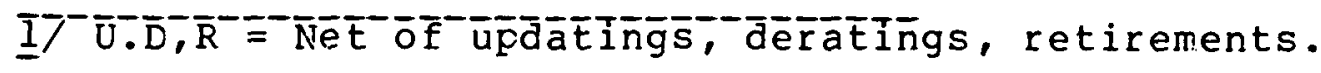


VI._- Reserg ve Marging

The installed reserve (planned reserve) margins for each Council area and the contiguous U.S. are shown in Table 6 for the summer and winter peak load periods from 1980 through 1989 . Inter-regional transfers of capacity, l/ and transfers within a region between council members and non-members, are excluded from the reserve margins of Table 6. At the time of peak demand the actual margin available will be affected by capacity reductions due to maintenance and forced outages of generating and transmission facilities, by lower-than-normal fuel quality, operating problems and other factors. For the entire period, the margins are large enough in all Councils but MARCA to indicate that bulk power supply should be reasonably reliable, under normal conditions. MARCA's summer reserve is low from 1986 on. Electric Region margins are reviewed in section XI.

The margins were computed on the basis of the peak demands and generating unit construction schedules projected by the Councils. Deviations from the projections will affect the margins. To the extent that peak demands are less than those projected by the Councils, margins will be improved. 2/ If the average annual increase of summer peak demand is close to the range projected by staff, $3 /$ margins will certainly improve if the projected construction schedules are met. However, to the extent that generating units and transmission 1 ines are delayed, and construction schedules are not adhered to, margins will be decreased. The margin at the time of peak demand, as can be seen, will be affected by the two factors: annual rate of load growth and completion of projected units. The various probability measures used to relate margin to reliability indicate that reliability is more sensitive to a decrease in margin than it is to an increase.

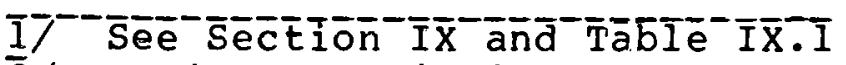

2/ An increase in installed reserve margin does not of itself guarantee an increase in bulk power supply reliability, although it is probable that reliability would increase.

3/ See section IV of this report. 
For example, at a 15 percent reserve margin, 1/ a decrease of 28 in the reserve margin would reduce the reliability level more than a 28 increase in margin would increase the reliability level. This effect supports the argument that generating unit construction should not be slackened too hastily in anticipation of a large decline in demand, if reliability is to be maintained. Because resumption of suspended construction is not always easy, and is likely to lag behind sudden increases in demand, reserve margins should be planned more to the higher values than to the lower values. Since nuclear flants are the center of much controversy currently, it is pertinent to show how national reserve margins would be affected if no new nuclear units were to be 1 icensed. Tables VII. 3 and.VII.4 show, for 1985 and 1989 , the summer reserve margins for the U.S., with and withnut operation of nuclear units as currently scheduled.

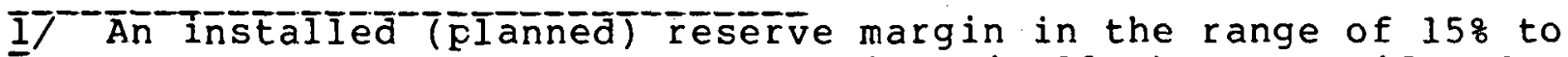
$25 \%$ of annual peak demand has historically been considered sufficient for reliable service. 
VII. I

VII. NUCLEEAR CAEFACITY

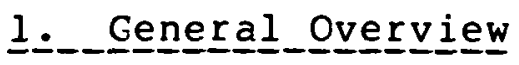

New nuclear units are projected to constitute a large portion of the planned net increase in total. U.S. capability between 1979 and 1989. Eighty-six nuclear units now under construction or planned for construction, totalling 93,619 MW (summer net capability), are listed by the Councils, with initial commercial operating dates between January 1,1980 and December 31, 1989. This capacity amounts to 40.098 of the total net increase in generating capability in that period. Table VII.l below shows the capacity of new nuclear units projected by each council and the fraction of total capability increase represented by these units.

Table VII.I

Projected Nuclear Capacity

Repor ted

F

Council

New_Nuclear Capacity
No. of Units (Summer)

Total Net $1 /$

Capacity

Increase

New Nuclear MW

( Summer )

As Percent

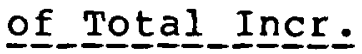

$\begin{array}{lc}\text { ECAR } & 10 \\ \text { MAAC } & 8 \\ \text { MAIN } & 9 \\ \text { MARCA } & -0- \\ \text { NPCC } & 6 \\ \text { SERC } & 28 \\ \text { SWPP } & \overline{7} \\ \text { Subtotal } & 6 \frac{7}{8} \\ \text { WSCC } & 13 \\ \text { ERCOT } & \overline{8} \frac{5}{6} \\ \text { U.S. Total } & \end{array}$

$$
\begin{array}{r}
8,871 \\
8,577 \\
9,764 \\
-0- \\
6,500 \\
30,675 \\
7 \frac{7}{7}, \frac{76}{1} \frac{2}{4} \\
15,540 \\
\frac{5}{9}, \frac{9}{3} \frac{30}{1} \frac{1}{9}
\end{array}
$$

33,295
11,261
11,860
11,256
10,758
55,151
$3 \frac{3}{6}, \frac{24}{6} \frac{4}{5}$
48,444
$1 \frac{8}{3} \div \frac{239}{4}, \frac{39}{8}$

26.64

76.17

82.33

$-0-$

60.42

55.63

$\frac{2}{4} \frac{3}{3} \div \frac{3}{2} \frac{5}{5}$

32.08

32.51

$\frac{3}{4} \div \div \div \overline{0}$.

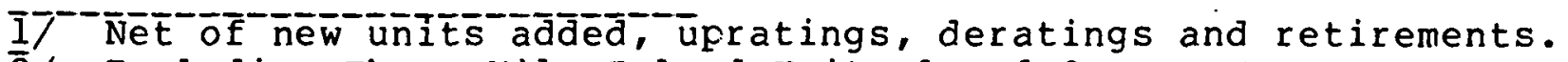
2/ Excluding Three Mile Island Units 1 and 2 . 
It is evident that the Regional Councils differ greatly in the proportion of nuclear capacity which is planned in relation to the total capacity increase. MARCA projects no new nuclear units at all, while SERC projects 28 . Although SERC projects by far the largest increment of new nuclear generating capacity, this will constitute only 55.68 of SERC's total capacity increase. MAIN is the Council which projects that nuclear capacity will make un the largest portion ( $82.3 \%$ ) of its net capacity increase.

The implication of Table VII.l with respect to reserve margins is that delays in completion and licensing of nuclear units will have different effects on the nine Regional Councils. 1/ In MARCA there will be no direct effect, discounting the possibility that MARCA may need capacity support from other Council areas in which nuclear capacity reliance is heavy. In MAAC and MAIN it appears that the impact on reserves would be greatest. In NPCC the effect would certainly be significant, as it would be in SERC. What is not shown in Table VII.l is the distribution of proposed new nuclear units among the subregions of the Council areas. TVA, for instance, one of the four sub-regions of SFRC, projects that all of its new capacity in the period 1980-1989 will be nuclear. Therefore, delay of nuclear licensing would indeed penalize the TVA region heavily. Table VII.2 shows the sub-regional (Electric Region) distribution of the projected new nuclear capacity.

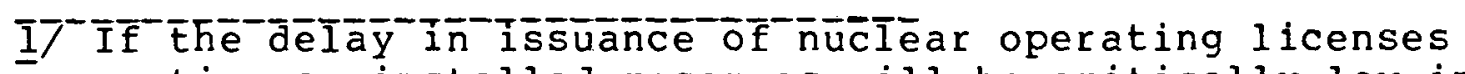
continues, installed reserves will be critically low in nine electric Regions. The most heavily impacted areas in the near term (1980-1982) are the Northwest Power Pool, the Northern California-Nevada Electric Region and the Commonwealth Edison Co. A detailed discussion of the Electric Regions is contained in part 2 of this section and in section XI. 
New Table VII.2

Projecte$\underline{1} \overline{9} \overline{8} 0-1 \overline{9} \overline{8} \overline{9}$

Council

\&_Region.

ECAR

1. APS

2. $A E P$

13. CAPCO

14. CCD

15. Kentucky

16. Indiana

18. MECS

MAAC

5. PJM

MAIN

v. CECO

17. ILLMO

19. WUMS

MARCA

20. MAPP

$\underline{N} \underline{\text { CC }}$

3. NEPOOL

4. NYPP
0

0

3

1

0

3

3

8

8,577

3,178

792

2,520

2,381

6,516

3,248

3 0 ,

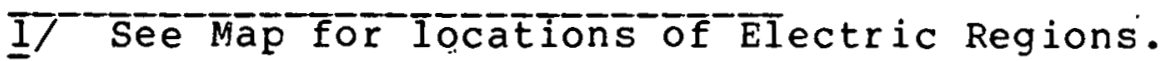




\section{Table VII.2 (Continued) \\ New Nuclear Capacity \\ projected For $\overline{1} \overline{8} \overline{0}-1 \overline{9} \overline{8}$}

Council

\& Region

\section{SERC}

7. Florida

9. Southern

11. TVA

12. VACAR

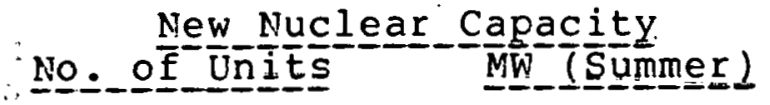

1

13

11
795

3,107

15,811

10,962

\section{SWPP}

8. MSU

10. Gulf

21. MOKAN

22. Oklahoma

$\begin{array}{rr}4 & 4,522 \\ 1 & 940 \\ 1 & 1,150 \\ 1 & 1,150\end{array}$

$\underline{\text { WSCC}}$

24. RMPP

25. NWPP (Part)

0

6

7,340

26. $\mathrm{Az}-\mathrm{Nm}$

27. So Cal-N

28. No Cal-N

30. Id-Ut (Ralance of NWP $\ddot{P}$ )

\section{ERCOT}

\section{TIS}

5

5,930

No exact knowledge of how a delay of nuclear licensing would affect system reliability can be gained from mere tabulation of the nuclear capacity under consideration. Only a preliminary indication is obtainable, through examination of the reserve margins. Table VII.2 shows that projected nuclear units are scattered among the councils and Electric Regions in a random pattern. 
Reliability analysis of the effect on a region of a long-term nuclear licensing delay would require review of projected loads (peak demands and energy), existing capacity and projected capacity other than nuclear within the region and within adjoining regions, and the transmission system. Here we have provided only a preliminary indication of reliability problems by showing the effect on reserve margins of delays in commercial operation of nuclear units. Estimates of the inter-regional transfers which could increase reliability are discussed in Section IX. A major difficulty in this analysis stems from the uncertainty associated with the projected commercial operating dates of the nuclear units, since lack of projected nuclear units might cause cancellation of some inter-regional power transfers. Several of the dates given in the Council reports (for Marble Hill Units 1 and 2 , for instance) are unrealistic in the view of Staff, but information on more realistic dates is unavailable. In order to bound the problem, two estimates have been made, as described below.

One estimating procedure is to assume that none of the nuclear units projected for 1980-89 will achieve commercial operation in that period, and to compute the resulting reserve margins. This may appear to be an extreme view of the situation, but it does provide a maximum boundary for delineating the effect of projected nuclear capacity curtailments. To indicate the magnitude of this effect, two target years have been chosen, 1985 and 1989 . Table VII.3 shows the Council reserve margins in summer 1985 with and without all the nuclear units. 
Table VII. 3

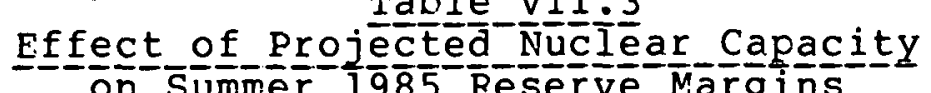

on summer 19 -

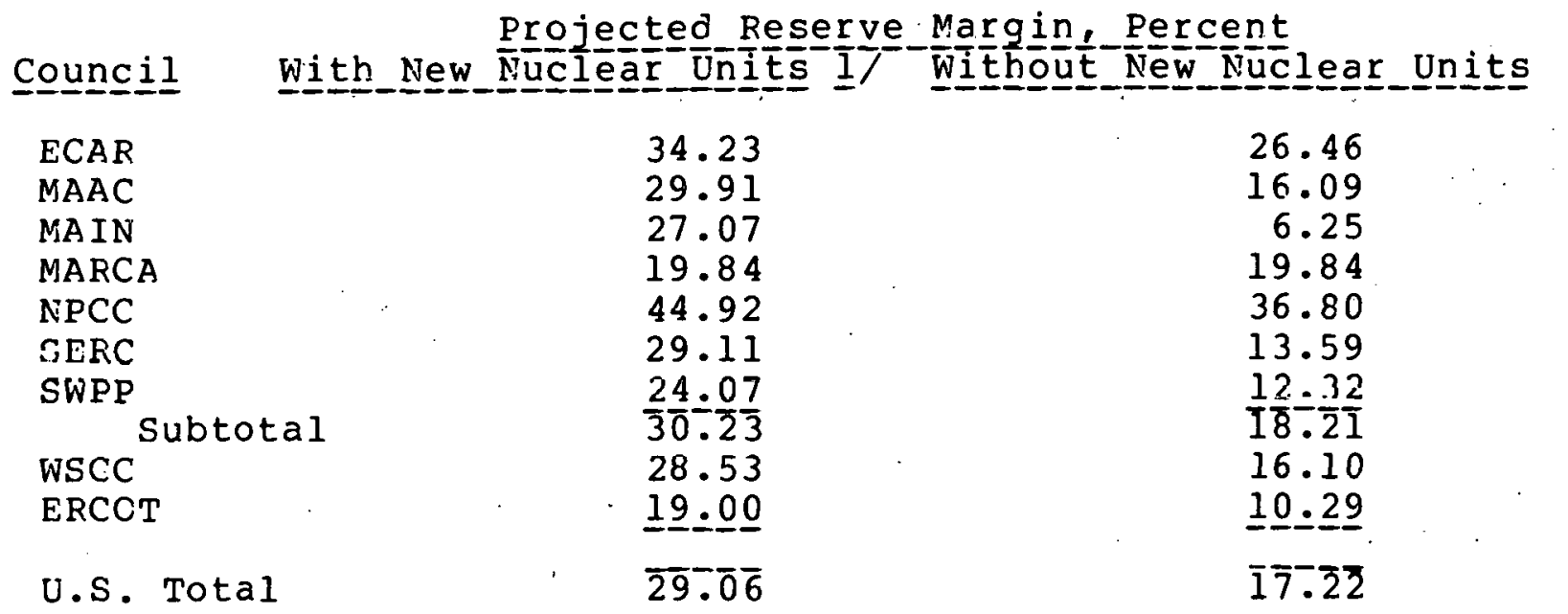

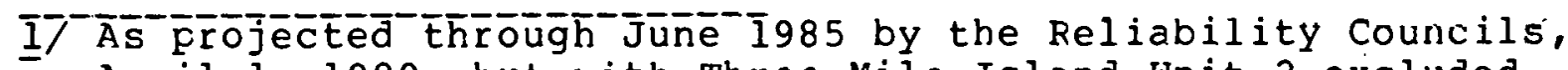
April 1, 1980, but with Three Mile Island Unit 2 excluded by staff.

Table VII $4 \underline{4}$

Effect of Projecte on summer 1989 Reserve_Marg

Projested Reserve Margin, Percent

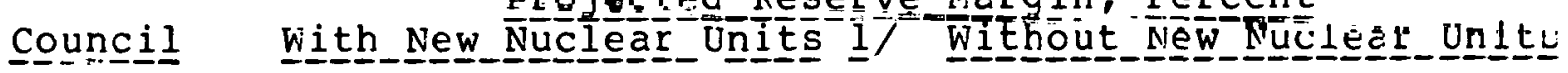

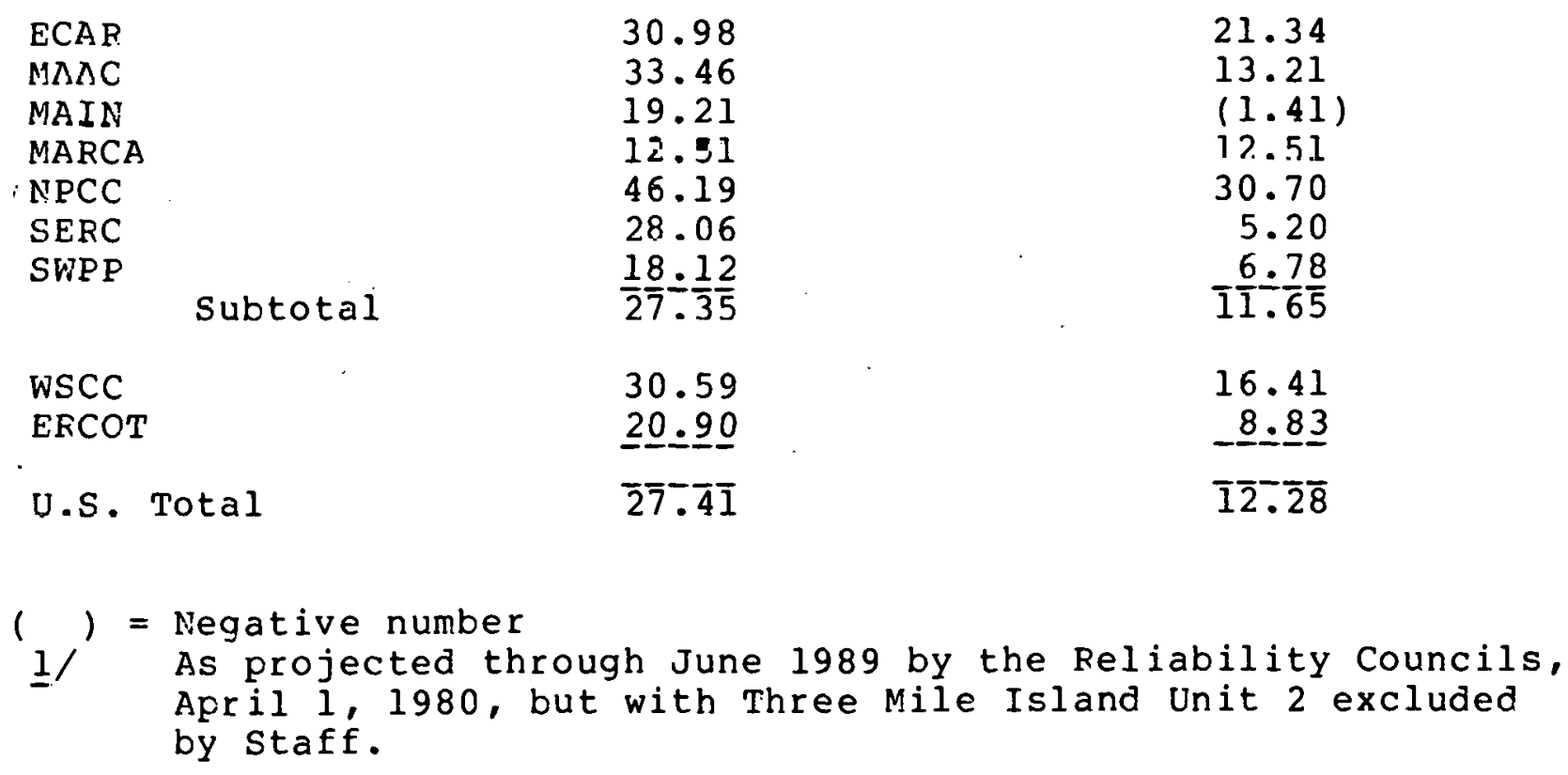


Inspection of Table VII.3 shows that if no new nuclear units were to be added in the period 1980-1985, MAIN and ERCOT would have reserve margins below 12.8 and SWPP would be barely above that level; 1/ it could be expected that these council areas would have less than satisfactory reliability. If no new nuclear units are added from 1980 through 1989, Table VII.4 shows, MAIN's reserve would actually be negative in 1989 and SERC, SWPP and ERCOT would have margins below $12 \%$. MARCA projects a low margin, even without nuclear problems. All these low margins are of course predicated on the assumption that the summer peak demands would occur as projected by the councils.

A second procedure for estimating reserves has been applied only to 1985. Staff has reviewed the latest data available, concerning nuclear construction and licensing as of early May 1980, and has established possible commercial operating dates different from those reported by the Councils in their April 1 , 1980 reports. On the basis of these dates, Staff has computed Council area reserve margins that differ from those projected by the Councils. The council projections and the staff estimates of new nuclear capacity in commercial operation year by year through June 1985 are compared in Table VII.5. The summer 1985 reserve margin for the total U.S., with the staff-estimated nuclear units in place, is estimated to be 28.23\%. Part 2 of this section discusses in detail the specific nuclear units projected and how lack of operating licenses for them will affect the various Electric Regions.

1/ An installed (planned) reserve margin of 158 has historically been regarded as minimal, for a reasonable level of reliability. For the purposes of this report, staff has used 128 as the minimum acceptable. Below the 128 level, in staff opinion, many systems could not maintain consistently reliable service on a long-term basis. 


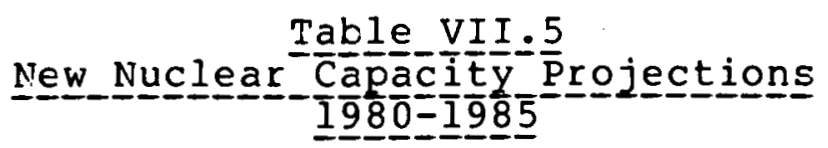

Yea $\underline{a}$

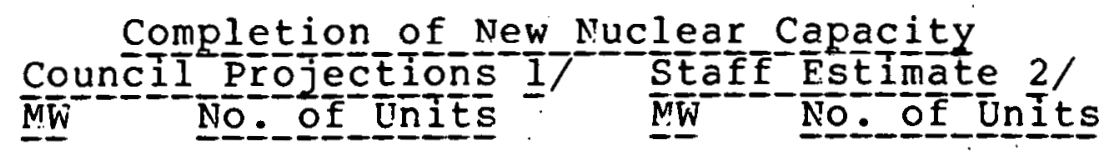

1980

1981

1982

1983

1984

1985

Total

$\begin{array}{rrr}8,008 & 8 & 3,935 \\ 10,525 & 10 & 9,381 \\ 12,116 & 11 & 10,078 \\ 12,383 & 11 & 14,153 \\ 11,953 & 11 & 10,841 \\ \frac{w}{62}, \frac{42}{40} \frac{1}{6} & -\frac{7}{8} & -\frac{8}{7}, \frac{790}{17}\end{array}$

4
9
9
13
10
$5 \frac{8}{3}$

A detailed analysis of the effect of nuclear units on regional reserves is given in section VII part 2 .

1/ As projected in the April 1, 1980 Council Reports.

2/ As estimated by Division of Power Supply and Reliability on the basis of information available as of early May 1980. Includes Three Mile Island No. I as of January 1, 1981; excludes Three Mile Island No. 2 for the period 1980-1985. 

2. Eetailed Regional Analysis - Impact of Delays in the

An analysis was conducted to determine the regional power supply outlook, assuming the delay in issuing nuclear operating licenses continues through 1985. The load and capacity data used was reported by the Regional Electric Reliability Councils to the Department of Energy, April 1, 1980, for the contiguous U.S.. This data was updated, in some instances, to reflect new generating capacity schedule changes that occurred after the April 1, 1980 date. Greater detail on the methods used in this analysis will be given at the end of this section. The results of the analysis are as follows:

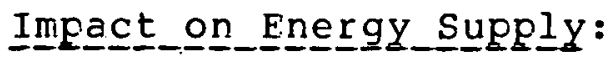

Table VII-2-1 shows the "lost" nuclear generation by electric region for the years 1980-1985. By 1985 the lost generation is nearly $10 \%$ of the total electric energy requirement for the contiguous U.S. This energy reguirement must be made up by some combination of coal, oil, and gas generation. The approximate allocation of fossil energy to replace this generation is shown in Table VII-2-2. These percentages take into account both the relative amounts of coal, oil, and gas generation in a particular region, and also the existing capacity factors of each lype of generation. These two factors together determine the relative ability of a particular type of generation to pick up additional energy.

Table VII-2-3 indicates the areas that will most 1 ikely not be able to completely make up the loss of planned nuclear geñeration, even with imports from other regions and therefore, be in a position to suffer an energy supply shortfall. These areas are the Gulf States Utilities Group (1984-1985), the Texas Interconnected Systems Group (1984-1985), and the Northern California-Nevada Group (1985).

The Northwest Power Pool (East and West group combined) will likely have an energy supply shortage even if the nuclear units are built as planned. Eetter than "adverse" hydro conditions may alleviate some of the energy shortage, but the loss of some 2300 MW by 1985 will greatly aggravate the energy supply situation in the Pacific Northwest. 


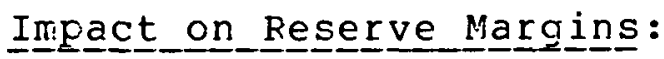

As shown in Table VII-2-4 total reserve margins will be critically low in nine electric regions by 1985, if the delay in the issuance of oferating 1 icenses continues. The worst areas the Northern California-Nevada Group, and the Commonweal.th Edison Co. A region was designated as having "critically low" reserves if the summer or winter total reserve margin, (adjusted for net transfers), was below $12 \%$. l/ These figures reflect interregional transfers to areas having énergy shortages.

The Northwest Power Fool Group has critically low winter reserve margins in the 1980-82 timeframe even though no nuclear units are planned in this period. The loss of WNP \# $1 \approx W I P$ \#2 2/ in the 1983-85 timeframe further aggravates an already tight capacity situation in the fecific Northwest.

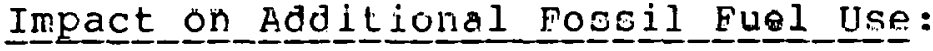

The "lost" nuclear generation shown in Table VIr-2-1 must be made uf by some combination of increased coal, oil, and gas generation. Tables VII-2-5, 6, and 7 list the estimated increased coal, oil, and gas use, respectively, which would be requirea to make up this "lost" nuclear energy. These tables include the impacts of interregional transfers, to the extent possible, in a attempt to relieve areas with supply shortages.

coal

Thr areas having the largest increases in cual use arc the Virginia-Carolinas Group, the Tennessee Valiey Autluuity Group, and the Commonwealth Edison Co. These three areas above will use nearly 47 응 of all the additional coal use through 1985 , as shown in Table VII-2-5. Ey 1985 the total coal use would increase by approximately 151,000 Lons/day, which represents an increase in total utility coal use of over $7 \%$.

İ A totà reserve margin of 12 percent was considered by ERA staff to be the minimum reserve required to cover such events as unit deratings, forced outages, and spinning reserve requirements for most systems. Normally, utilities plan for higher total reserve margins than this to allow for unexpected events, such as extremely hot weather.

2/ WNF = Washington Nuclear Plant 
VII. 11

Cil

The areas with the largest increases in oil use in the 1980-1985 time frame are the Pennsylvania-New JerseyMaryland Interconnection; the Northern California-Nevada Group, the Commonwealth Edison Co., and the Southern California-Nevada Group. These four areas will use over $60 \%$ of the total increased oil use shown in Table VII-2-6. Py 1985 the total utility oil use would increase by approximately 697,000 barrels/cay, which represents an increased utility oil use of over 33․

\section{Gaㅗ}

By 1985 Gas use will increase by $932,000 \mathrm{mcf} / \mathrm{day}$, which is a 228 increase over NERC's projections. Almost all (908) of the increased gas use in the 1980-85 time frame will occur in two regions; the Middle South Utilities Group and the Texas Interconnected Systems Group.

\section{Nucleaa Unit Licensing Priorities:}

Table VII-2-8 Iists the nuclear units that would be affected by a continued delay in issuing operating licenses.

These units were placed on a frinrity list according to the following criteria:

(1) Unit is necessary to relieve energy shortfall (Table VII 2-3).

(2) Unit is necessary to relieve low reserve situation (Táble VII-2-4).

(3) Unit is located in oil decendent Region (Table II-2-6) Table VII-2-9 shows a priority list of nuclear unity for the 1980-85 time frame. These units were frioritized using a combination of the three above mentioned criteria. Units needed to relieve an energy supply shortfall or low reserve margin situation were generally given a higher weight than units needed frimarily to reduce oil consumption. 
VII. 12

Impacts of Lower Than Forecasted_Crowth_Fates on Energergy Shor

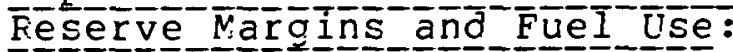

A sensitivity analysis was performed for those regions having either energy supply or reserve major problems to determine the extent to which lower growth rates might alleviate these problems. It was assumed that the schedule of capacity additions would remain unchanged.

Table VIIm2-10 compares the 1980-95 growth rates projected by the reliability councils with the lower growth rates Frojected by ERA staff for the purposes of this sensitivity analysis.

The lower growth rates were chosen by examining the historical forecasting errors made by each of the nine reliatility councils, and scaling down their current forecasts accordingly. see section III and IV fur d further deecription of this method. The exceptions to this method were TVA and VACAR where a "lower linit" growth rate of 1.08 was used.

Impact_of

The origional analysis projected three areas as having energy shortage in the 1980-85 timeframe (see Table VII-2-3). Using lower growth rates than those projected by the reliability councils, no eneryy shortagc problems would be anticipated.

\section{Impact of Iower Growth Kate on Réserve Marging}

Table VII-2-4 list.s nine areas having reserves below $12 z$ under the origional growth assumptions. Using lower gruwth rates reduces the number of crleical aread to three as shown on Table VII-2-11. Those areas are the commonwealth Edison Co., the Middle South Utilities Group, and the Northern California-Nevada Group. 
Impact_of Lof Lower Growth Rates on Fuel_Use

Tables VII-2-5, VII-2-6, and VII-2-7 lists the acditional coal, oil, and gas use that would result, under the original growth rates, if the nuclear units do not come on 1 ine as planned. These same increases in coāl, oil and gas use would occur, even with reduced growth rates, because nuclear units are operated in base load. Eelays in bringing these units on line would necessitate some other type of base load generation taking its place resulting in the increased fossil fuel use shown.

These increases in fossil fuel use are due to the nuclear units not coming on line as planned. If energy growth rates are lower than those projected by the reliability councils, there would be a partially offselling reduction in fossil use due to the lower system energy requirements. The total energy reguirement for the contigucus U.S., as reported by the reliability councils, is projected to increase from $2,421,676 \mathrm{GWH}$ in 1980 to $3,072,369 \mathrm{CWH}$ in 1985. This represents a compound annual growth rate of $4.87 \%$. If the coumpound annual growth rate of $2.06 \%$, the reauction in the energy requirement in 1985 would be $390,770 \mathrm{GWH}$. Allocating this reduction in generation over available coal, oil, and gas units would result in the following approximate decreases in fossil fuel use: Coal 316,300 tons/day; oil - 460,400 ERL/day; and Gas - 976,400 MCF/day.

This reduction in coal would more than offset the coal increases shown in Table VII-2-5. Similarly, the reduction in gas use would effectively cancel out the increases shown in Table VII-2-7.

The sitution for oil is different. Combining the increases in oil use due to licensing delays in $1965(697,400$ EBLS/day) and the decrease in oil use if lower growth occurs $(460,400 \mathrm{BBL} / \mathrm{day})$ results in an net increase in oil use of 237,000 BEL/day.

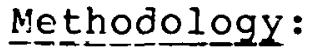

The immediate impact of further delays in issuing nuclear unit 1 icenses would be a reduction in the future amount of nuclear energy generated by the electric utility industry. Since customer energy requirements must still be supplied, this will produce a corresponding increase in fossil-fueled generation 
and fossil fuel consumption. The underlying assumption in this refort is that all energy that would have been produced by nuclear generation if there were no 1 icensing delays would now need to be made up by some combination of additional coal, oil and gas fired generation.

\section{Calculalation of Unprovided Nucle lear Energy}

The first task was to calculate the amount of nuclear energy that would be "lost" because of continued licensing delays. The projected commercial in-service dates for all nuclear units due to come on-line between January 1980 and Lecember 1985 were extracted from the April 1980 submissions of the Form ERA-4II. This information was supplemented with telephone calls to the appropriate utilities and with information received from the NRC. The amount of energy these units would have produced was calculated as:

(i) UNIT SUMMER CAPACITY IN MVi $X$ PERIOD HOURS $X$ ANNUAL CAPACITY FACTOR.

The annual capacity factor $1 /$ for these units was developed by examining the historical performance of existing nuclear units $700 \mathrm{MW}$ and larger from 1974 to 1979. The results of these studies showed that the average annual capacity factor for all units ccrsidered was approximately $57 \%$ for the inservice year and the first full calendar year of operation after the in-service year. A $64 \%$ capacity factor was considered representative for all subsequent years of operation.

Period hours (the number of hours to be considered) for the first year of operation was calculated from the first day of the month of commercial operation to the last day of that calendar year. The capacity used was the summer copacity as reforted in the Reliability Council Reports.

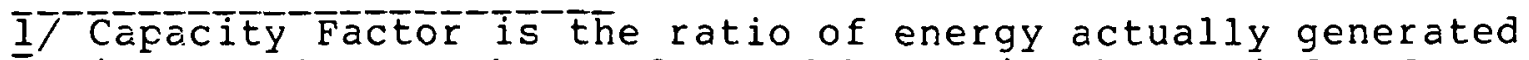
in a period to the product of hours in the period and rated capacity of the unit. 


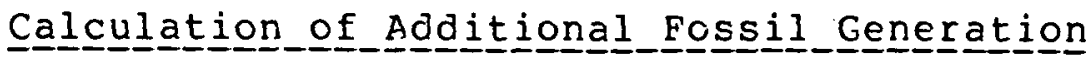

As stated above it was assumed that a MWH of nuclear energy not generated would be replaced by some combination of coal, oil and gas generation. A rigorous method for determining how much more of each of these fuels would be used is to perform a production cost study for each of the many operating groups affected by the delay in licensing a nuclear unit. However, the time constraints imposed on the study would not allow such an ambitious undertaking, and it is possible that such precision would not yield more credible results. Therefore, an alternate technigue was developed.

It was assumed that the probability of a particular type of fossil capacity (coal, oil, gas) picking up additional load would be proportional to the amount of that type of capacity in a region. However, if that type of generating capacity was already opearting at a very high capacity factor, other constraints such as load profile, forced outages and maintenance would prevent substantial increases in its output. Based on these considerations, the following formula was developed to calculate the amount of the "lost" nuclear energy that would be picked-up by each of the remaining fossil fuels:

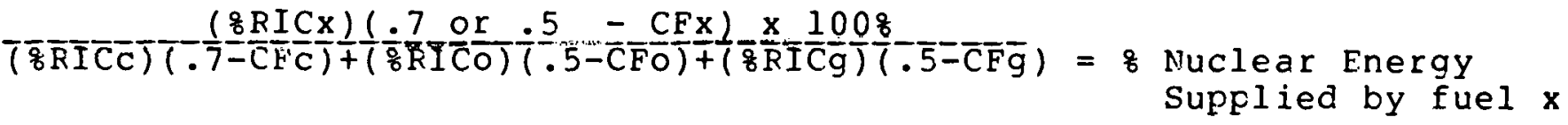

where, 8 RIC = Percentage of Regional Installed Capacity

$\mathrm{CF}=$ Capacity Factor

$\mathrm{c}=$ Coal

$0=0 i 1$

$\mathrm{g}=\mathrm{GaS}$

The data on regional capacity factors was extracted from the generation and capacity projections appearing in the NERC 9 th Annual keview. 1/ Information on Fercentage, of Regional installed capacity was obtained from the 1980 Form ERA-4ll. Table VII-2-2 shows the projection of the percentage of "lost" nuclear energy that would be supplied by each fossil fuel (coal, oil, gas) in each Electric Region if the total "lost" energy were to be supplied by generating units in that region.

İ $\overline{9} \overline{t h} \bar{A} \bar{n} \bar{u} \bar{a} \bar{l}$ Review $\overline{\text { Of }}$ Cverall Reliability and Adequacy of the North American Eulk Power System. NERC. August 1979. 


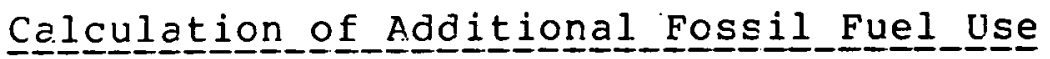

Once the amount of replacement energy for each fuel type for each region was calculated, the next step was to convert this energy to additional fossil fuel reguirements.

It was assumed that additional coal fired generation would be at a $10,000 \mathrm{RTU} / \mathrm{KWH}$ heat rate; additional oil and gas generation was assumed to be $12,000 \mathrm{ETU} / \mathrm{KWH}$. The heat content of fossil fuels was assumed to be 24 million ETU per ton for coal $(12,000 \mathrm{PTU} / 1 \mathrm{~b}), 1 / 6 \mathrm{mill}$ ion ETU per barrel for oil and 1 million BTU per MCF (thousand cubic feet) for gas.

Applying the above heat rates and heat contents to the additional fossil fuel generation yields additional fossil fuel consumption. Two effects were considered that modify the additional fossil fuel consumption;

(1) The effects of energy shortages, and

(2) The effects of inter-regional transfers.

The Effects of Energy Shortage on Fossil Euel

Feak demand, energy requirements, and total capacity on an Electric Fegion basis was obtained from the April 1980 submissions of Form ERA-4ll by the Reliability Councils. This information is provided by year and then divided into. summer and winter. The projected nuclear unit capacities were subtracted from these values and adjusted seasonal yearly installed capacity reserve maryins were calculatcd. Total reserve margin is defined as the difference between the total generating capacity (including net transactions) and peak customer demiand and is stated either in $M W$ or percent of peak demand.

In determining the ability of an Electric Region to replace lost nuclear generation, it was assumed that the maximumi amount of replacement energy would be equivalent

I $\bar{I} \bar{I} \bar{i} \bar{s} \bar{r} \bar{e} \bar{c} \bar{n} \bar{i} \bar{z} \bar{e}$ that the national average heat content of coal has been less than $12,000 \mathrm{BTU} / \mathrm{lb}$ for several years. However, this is a reasonable 
to the adjusted system capacity (without the nuclear units) operating at a 608 capacity factor, $1 /$ minus the actual system energy requirement. If this maximum amount of replacement energy is greater than the amount of lost nuclear energy, there is no energy shortage. If, however, the maximum amount of replacement energy is less than the lost nuclear energy, the difference is the energy shortage. This energy shortage will reduce the amount of additional fossil fuel consumed by permitting replacement of only part of the lost nuclear energy.

Therefore, the additional fuel use is the additional amount of coal, oil and gas needed to replace lost nuclear energy minus the amount of fuel that would have been required to supply that portion of. lost nuclear energy identified as "energy shortage."

\section{The Effects of Inter-regional Transfers on Energy Shortages} and

This analysis examined the existing transmission grid to determine if a region with an energy shortage could import from another region having excess capacity. Only those regions with reserves greater than 128 in summer and winter were considered as possible energy exporters. These inter-regional trarsfers have the effect of reducing the energy shortage in importing region and increasing the coal, oil and gas use in the exporting region. Table VII-2-3 thru Table VII-2-7 take these two factors into account..

İ $\bar{A}$ survey ố unit câácity factors indicates that large base load fossil units operate with annual capacity factors in the 608-708 range. Thus, it was felt that operating an entire system's installed capacity (including peak load generation) at 608 annual capacity factor would likely be an upper bound for the maximum energy one could expect from a system. Any energy requirement in excess of this upper bound would have to be served by another region's generation or else there would be unserved energy. 
VII. 18

TABLE VII-2-1

ANNUAL POTENTIAL LOST NUCLEAR ENERG:Y (GWH)

EUE TO OPERATING LICENSE DELAYE

BY ELECTRIC REGION

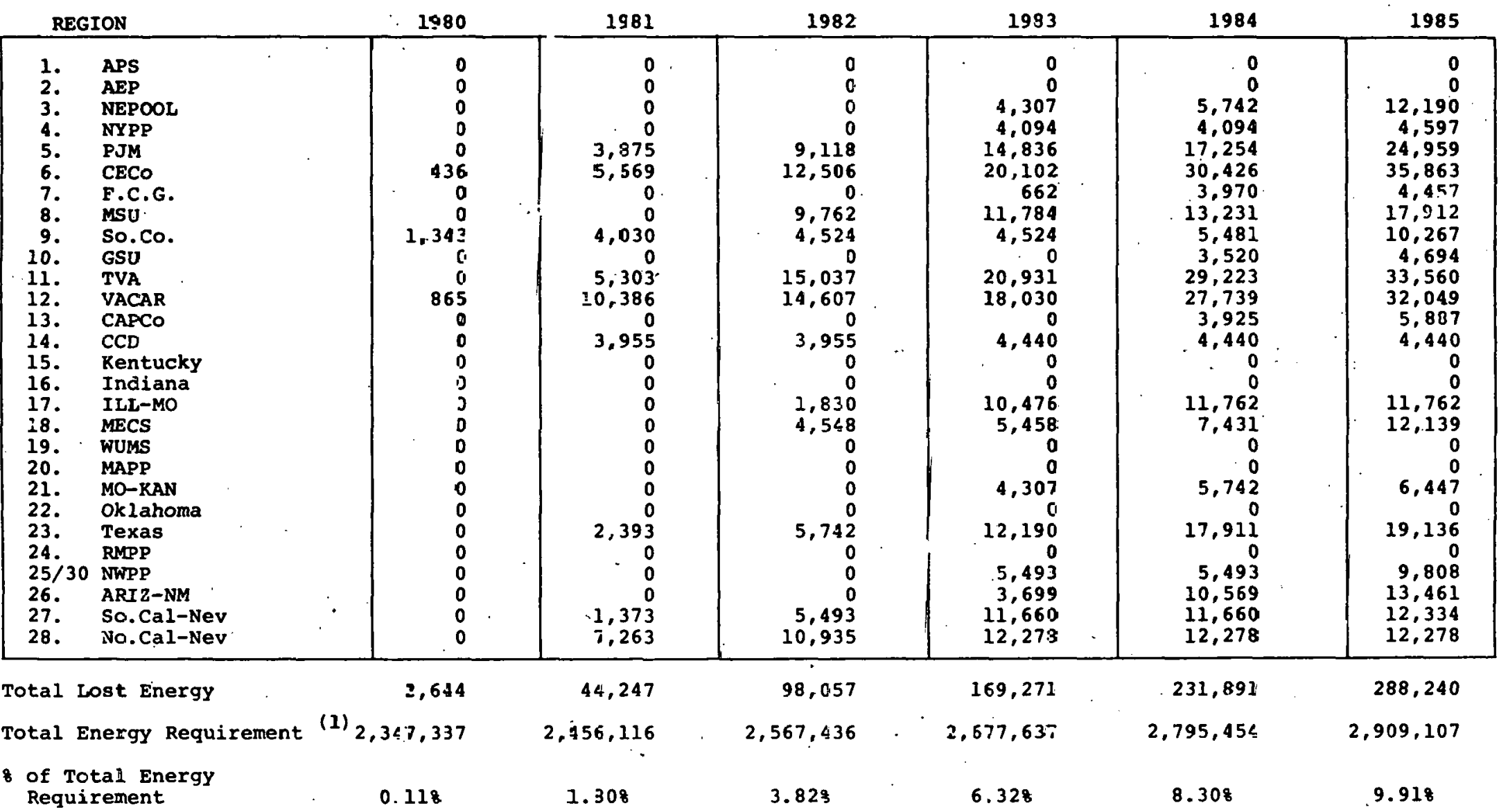
(1) Data As Reported By The Regional Electric Reliability Councils To the Jepartmezt of Energy, April 1, 1980, For The 
VII. 19

TABLE VII-2-2

ALLOCAT $\bar{I} O \bar{N} \bar{O} \bar{F}$ F $\bar{O} \bar{S} \bar{S} \bar{I} \bar{L}$ ENERGY

TOQ

Region

1. APS

2. AEP

3. NEPOOL

4. NYPP

5. PJM

6. CECO

7. F.C.G.

8. MSU

9. So.Co.

10. GSU

11. TVA

12. VACAR

13. CAPCO

14. CCD

15. Kentucky

16. Indiana

17. ILL-MO

18. MECS

19. WUMS

20. MAPP

21. MO-KAN

22. Ok lahoma

23. Texas

24. RMPP

$25 / 30$ NWPP

26. ARIZ-NW

27. SO.Cal-Nev

28. No.Cal-Nev

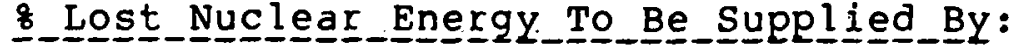

\section{으믄}

오노

$\underline{G}$ as

100

0

5

15

45

15

25

80

25

80

70

95

100

100

90

80

55

80

70

80

40

20

75

25

40

0

0

\section{0}

10

95

85

55.

85

0 .

20

0

20

30 .

5

0

10

20

45

20

30

0

0

25

75

60 .

100

100 


\section{20}

TAELE VII-2-3

EXPECTED ENERGY SHORTAGE (GWH)

IN CRITICAL REGIONS

DUE TO NUCLEAR LICENSING DELAYS

(Includes Impact of Interregional Transfers To peduce Energy shortagel

\section{ELECTRIC \\ REGION}

1980

1981

1982

1983

1984

1985

10. GSU

$0 \quad 0$

0

0

1,183

186

23. Texas

0

0

0

0

1,219

2,744

28. No. CalNev.

0

0

0

0

529

TOTAL

0

0

0

0

2,402

3,456

\section{(1)}

Total NERC

Energy

$$
2,347,337 \quad 2,456,116
$$

$2,567,436$

$2,677,637 \quad 2,795,454$

$2,909,107$

8 of Total

NERC

Energy

08

08

08

$0 ㅇ$

$0.09 \%$

$0.12 \%$

(1) Data as reported by the Regional Electric Reliability Councils to the Department of Energy, April 1, 1980, for the contiguous United states. 
VII. 21

TABLE VII-2-4

REGIONS WITH CRITICALLY LOW TOTAL RESERVES

AD JUSTED FOR INTERREGIONAL TRANSFER

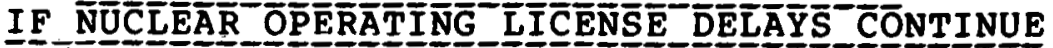

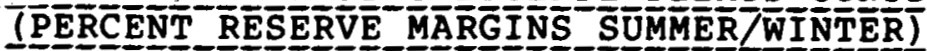

\section{ELECTRIC $\underline{3 /}$ \\ REGION}

1. APS (2)

6. CECO

8. MSU

11. TVA

12. VACAR

13. CAPCO

$25 \& 30$. N.W.P.P.

37 $/ 11$

33 19

6

$/ 51$

$/ 45$

1982

1983

1984

26

/11

(2)

140

(6)

$/ 35$

5

139

3

137

18

112

$10 / 6$

8

14

13

11

$/ 21$

33

25

18

$32 / 6$

28

17

8

147

8

140

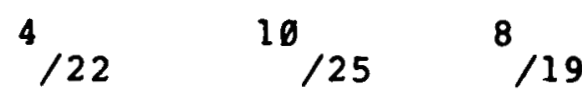

$7 / 13$

6

$/ 12$

1/. The reglons listed are those for whlch the summer or winter (or both) reserve margin is less than $12 \%$, including net purchases and sales.

2/ No nuclear units are scheduled for this area in the 1980-85 period.

3/ These Electric Regions were delineated by ERA for the purpose of implementing the Power Plant and Industrial Fuel Use Act of 1978 . The same regional arrangement is logical and useful for the analysis of electric power supply problems. Analysis of some power pools or control areas within these regions may show more severe problems because of local transmission constraints or generator avallability.

$4 /($ ) denotes negative reserves. 
TABLE VII $-2-5$

REGIONAL INCREASE IN COAL USE

DŨE TO

(Includes Impact of Inter-regional Transfers

to Reduce Energy Shortages)

PROBABLE_ADDITIONAL_COAL_CONSUMPTION_(TONS/DAY)

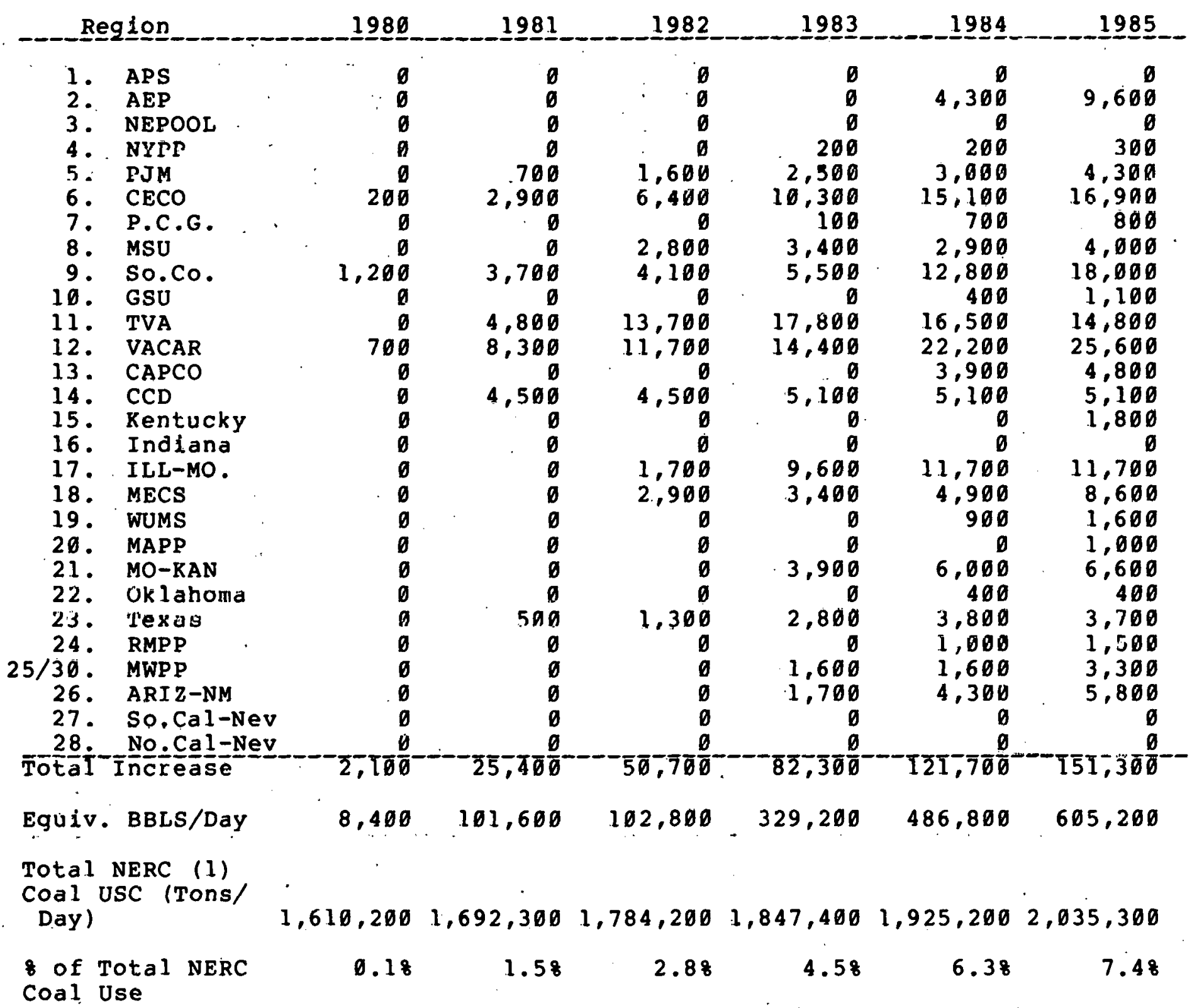

(1) Data from "Summary of Projected Peak Load,.Generating Capability, and Fossel Fuel Reguirements," NERC, July, 1979. 
TABLE VII-2-6

REGIONAL INCREASE IN OIL USE

DUE TO NUCLEAR LICENS ING DELAYS

(Includes Impact of Interregional Transfers

to Reduce Energy shortage)

PROBARLE ADDITIONAL OIL CONSUMPTION

(BBL/DAY)

\section{REGION}

1. APS

2. AEP

3. NEPOOL

4. NYPP

5. PJM

7. F.C.G.

8. MSU

9. So. Co.

10. GSU

11. TVA

12. VACAR

13. CAPCO

14. CCD

16.. Indiana

17. ILL-MO.

18.' MECS

19. WUMS

20. MAPP

21. MO-KAN

22. Oklahoma

23. Texas

24. RMPP

25/ NWPP 30

26. Ariz-NM

27. So. Cal-Nev.

28. No. Cal-Nev.
6. CECO

15. Kentucky

$1980^{\circ} \cdot 1981$

1982

1983

1984

1985

\begin{tabular}{|c|c|c|c|c|c|}
\hline 0 & 0 & 0 & 0 & 0 & 0 \\
\hline 0 & 0 & 0 & 0 & 0 & 0 \\
\hline 0 & 0 & 0 & 23,600 & 31,500 & 66.800 \\
\hline 0 & 0 & 0 & 21,300 & 21,300 & 23,900 \\
\hline 0 & 18,000 & 42,500 & 69,100 & 80,400 & 116,200 \\
\hline 1,300 & 17,100 & 37,700 & 60,600 & 88,600 & 99,200 \\
\hline 0 & 0 & 0 & 3,100 & 18,500 & 20,800 \\
\hline 0 & 0 & 0 & 0 & 0 & 0 \\
\hline 1,500 & 4,400 & 5,000 & 6,600 & 15,300 & 21,500 \\
\hline 0 & 0 & 0 & 0 & 0 & $-2.0 \mathrm{c}$ \\
\hline 0 & 5,800 & 16,500 & 21,300 & 19,800 & 17,700 \\
\hline 1,400 & 17.100 & 24,000 & 29,600 & 45,600 & 52,700 \\
\hline 0 & 0 & 0 & 0 & 1,000 & 1,200 \\
\hline 0 & 0 & 0 & 0 & 0 & \\
\hline 0 & 0 & 0 & 0 & 0 & 0 \\
\hline 0 & 0 & 0 & 0 & 0 & \\
\hline 0 & 0 & 0 & 0 & 1,200 & 1,200 \\
\hline 0 & 0 & 11,200 & 13,500 & 19,100 & 33,600 \\
\hline 0 & 0 & 0 & 0 & 1,100 & 1,900 \\
\hline 0 & 0 & 0 & 0 & 0 & 2,100 \\
\hline 0 & 0 & 0 & 0 & 0 . & 0 \\
\hline 0 & 0 & 0 & 0 & 0 & \\
\hline 0 & 0 & 0 & 0 & 0 & $\cdot 0$ \\
\hline 0 & 0 & 0 & 0 & 1,600 & 2,400 \\
\hline 0 & 0 & 0 & 22,600 & 22,600 & 47,700 \\
\hline 0 & 0 & 0 & 12,200 & 31,000 & 42,000 \\
\hline 0 & $\begin{array}{l}22,000 \\
25,300\end{array}$ & 32,200 & 70,900 & 77,300 & 71,200 \\
\hline
\end{tabular}

Total Increase

$4,200 \quad 109,700.227,000$

431,500

546,600

697,400

Total NERC

(1)

Oil Use (BBL/DAY)

8 of Total NERC

oil use

$1,852,300 \quad 1,974,900 \quad 2,036,300$

$2,027,600$

$2,001,600$

$2,082,500$

0.28

5.68

11.18

21.38

27.38

33.58

(1) Data from "Summary of projected Peak Load, Generating Capability, and fossil fuel Requirements", NERC, July, 1979. 
Table VII-2-7

REGIONAL INCREASE IN GAS USE

DUE TO NUCLEAR LICENSING DELAYS

(Includes Impact of Interregional Transfers

to Reduce Energy Shortage)

PROBABLE ADDITIONAL GAS CONSUMPTION (MCE/DAY)

REGION

1980

1981

1982

1983

1984

1985

1. APS

0

2. AEP

3. NEPOOL

4. NYPP

5. PJM

6. CECO

7. F.C.G.

8. MSU

9. So. Co.

10. GSU

11. TVA

12. VACAR

13. CAPCO

14. CCD

15. Rentucky

16. Indiana

17. ILL-MO.

18. MECS

19. WUMS

20. MAPP

21. MO-KAN

22. Oklahoma

23. Texas

24. RMPP

25/ NWPP 30

0

0

0

0

0

0

0

0

0

0

0

0

$\therefore 0$

0

0

0

0

0

0

0

0
0
0
0
0

0

0

0

0

0

0

0

0

0

0

0

0

0

0

62,900

0
0

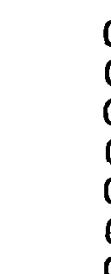

240,700

0
0

0

0

0

0

0

0

0

0

0

0

$\begin{array}{ll}\because & 0 \\ & 0 \\ & 0 \\ & 0 \\ & 0 \\ & 0 \\ & 0\end{array}$

0

0
0
0
0
0
0
0
0
0

0

0

0

0

0

0

0

0

0

0

0

28.300

$151,000: 320,500$

0

0
0

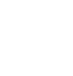

n

n

27. So. Cal-Nev. 0

28. No. Cal-Nev.

0

0

0
0

0

$62,900 \quad 391,700$

$639,500 \quad 787,900$

932,100

Total Increase 0

10,500

65,300

106,600

131,300

155,400

Day

(1)

Total NERC

(1)

Gas (MCF/Day)

Total 8 of NERC 08

Gas Use

$6,649,700 \quad 5,776,100 \quad 5,413,200 \quad 5,263,200 \quad 5,068,700$

$4,223,400$

(1) Data from "Summary of Projected Peak Load Generating Capability, and Fossil Fuel Requirements", NERC, July, 1979 . 
Table VII-2-8

Nuclear Units Affected by an cperating

License Delays Through 1985

ELECTRIC FEGION

NO. - NAME

3-NEPOCL

4-NYPP

5-PJM

6- CECO

-FCG

8-MSU

9-Soco

$10-\mathrm{GSU}$

11-TVA
SUMMER

UNIT NAME

CAPACITY

(MW)

1,150

1,150

1,150

PILGRIM \#2

SHOREHAM \# 1

3 MILE IS. \#I

SUSQUEHANNA \#I

SUSQUEHANNA \# 2

HOPE CREEK \# I

LIMERICK \# I

LA SALLE \# I

LA SALLE \#2

PYRON \# 1

BRAIDWOOD \# 1

EYRON \# 2

BRAIDWOOD \# 2

ST. LUCIE \# 2

GRAND GULF \#I

WATERFORD \# 3

GRAND GULF \#2

FARLEY \# 2

VOGTLIE \# 1

RIVER BEND \#I

WATTS PAR \#I

SEQUOYAH \# 2

WATTS EAP \# 2

BELLEFONTE \# 1

BELLEFONTE \#2

YELLOW CREEK \# 1
820

776

1,050

1,066

1,055

1,048

1,048

1,120

1,090

1,120

1,090

795

1,250

1,110

1,250

807

1,150

940

1,177

1,148

1,177

1,213

1,213

1,285
1,050
PRCJECTED

IN-SERVICE

DATE

MONTH-YEAP

$4-8 \cdot 3$

$2-85$

$12-85$

$1-83$

$1-81$

$1-82$

$1-83$.

$9-84$

$5-85$

12-80:

$12-81$

$10-82$

$10-83$

$10-83$

$10-84$.

$11-83$

4-82:

$2-82$

$4-85^{:}$

9-80

$11-84$

$4-84$

$9-81$

$6-81$

$6-82$

$9-83$

$6-84$. 
ELECTRIC REGION

NO.'- NAME

12-VACAR

$13-\mathrm{CAPCO}$

$14-C C D$

17-ILL-MO

18-MECS

21-MOKAN

23-TIS

25-NWPP

26-ARI Z-NM.

27-So. Cal-Nev.

28-No Cal. Nev.
SUMMER

UNIII_NAME

MC GUIRE \# I

SUMMER \#

MC GUIRE \#2

CATAWBA \#1

CATAWBA \#2

HARRIS \# 1

PERRY \# I

ZIMMER \# I

CALLOWAY \# 1

CALLOWAY \# 2

MIDLAND \# 2

FERMI \# 2

MIDLAND \# 1

WOLF CREEK \# 1

COMANCHE PEAK \# I

COMANCHE PEAK \# 2

SOUTH TEXAS \#l

WNP \# 2

WNP \# 1

YALO VERDE \# I

PALO VERDE \# 2

SAN ONOFRE \#2

SAN ONOFRE \#3

DIABLO CANYON \# 1

DIABLO CANYON \#2
CAPACITY

(MW)

1,180

900

1,180

1,145

1,145

900

1,179

792

1,150

948

783

1,093

505

1,150

1,150

1,150

1,250

1,100

1,250

1,270

1,270

1,100

1,100

1,084

1,106
IN-SERVICE

DATE

MONTH-YEAR

$12-80$

$12-80$

$7-82$

$12-83$

$7-85$

$3-84$

$5-84$

$1-81$

$10-82$

$12-82$

$9-84$

$3-82$

$3-85$

$4-83$

$8-81$

$1-83$

2-84

I-83

$6-85$

$6-83$

$5-84$

$10-81$

$1-83$

2-81

$8-81$

Iy Councils April 1, 1980, updated by ERA staff where possible to reflect most recent schedules. 
TABLE VII-2-9

NUCLEAR UNIT PRIORITY LIST BY YEAR $\underline{1980-85}$

\section{ELECTRIC UNIT \\ REGION NAME}

LaSalle \#1

McGuire \#1

Summer 非1

Farley \#2 \begin{tabular}{ll} 
SUMMER & PROJECTED \\
CAPABILITY & COMMERCIAL \\
$(\mathrm{MW})$ & OPERATION DATE \\
\hline
\end{tabular}

UNITS SCHEDULED FOR 1980

$\begin{array}{rr}1048 & 12 / 80 \\ 1180 & 12 / 80 \\ 900 & 12 / 80 \\ 807 & 9 / 80\end{array}$

UNITS SCHEDULED FOR 1981

Diablo Canyon \#2 1106
Diablo Canyon 非 1084

LaSalle \#2

Sequoyah \#2

Watts Bar \#1

Comanche Peak 非

San Onofre \#2

Three Mile

Island 非 1

Zimmer \#1

1084
1048

1148

1177

1150

1100

776

792

\section{UNITS SCHEDULED FOR 1982}

Byron 非 1

McGuire \#2

Watts Bar \#2

Waterford \#3

Grand Gulf \#1

Susquehanna \#1

Fermi 非

Calloway 非

Ca11oway \#2

$8 / 81$
$2 / 81$
$12 / 81$
$6 / 81$
$9 / 81$
$8 / 81$
$10 / 81(2)$
$1 / 81$
$1 / 81$

1

2

3

4

5

6

7

8

9

15,800

9,700

7,400

1,400

POTENTIAL : OIL SAVED $\mathrm{BBL} / \mathrm{DAY}$. (3) 
TABLE VII-2-9

NUCLEAR UNIT PRIORITY LIST BY YEAR

1980-85

\begin{tabular}{ll} 
ELECTRIC & UNIT \\
REGION & NAME \\
\hline
\end{tabular}

St. Lucie 非 2

Wolf Creek $\# \perp$

\begin{tabular}{ll} 
SUMMER & PROJECTED \\
CAPABILITY & COMMERCIAL \\
(MW) & OPERATION DATE \\
\hline
\end{tabular}

UNITS SCHEDULED FOR 1983 (CONT 'D)

$$
795
$$$$
1150
$$

1150

$$
\begin{array}{r}
11 / 83 \\
4 / 83
\end{array}
$$

\section{UNITS SCHEDULED FOR 1984}

$$
\begin{aligned}
& \text { Palo Verde \#2 } \\
& \text { Braldwood \#2 } \\
& \text { Harris \#1 } \\
& \text { Bellefonte \#2 } \\
& \text { Perry \#1 } \\
& \text { South Texas \#1 } \\
& \text { River Bend \#I } \\
& \text { Hope. Creek \#1 } \\
& \text { Midland \#2 } \\
& \text { Vogt1e \#1 }
\end{aligned}
$$

5
18

9

$\begin{array}{rr}1270 & 5 / 84 \\ 1090 & 10 / 84 \\ 900 & 3 / 84 \\ 1213 & 6 / 84 \\ 1179 & 5 / 84 \\ 1250 & 2 / 84 \\ 940 & 4 / 84 \\ 1066 & 9 / 84 \\ 783 & 9 / 84 \\ 1150 & 11 / 84\end{array}$

UNITS SCHEDULED FOR 1985

\begin{tabular}{cl}
$\begin{array}{c}\text { YEAR-BY - YEAR } \\
\text { WEIGHTED (1) } \\
\text { RANK }\end{array}$ & \begin{tabular}{l} 
POTENTIAL \\
OIL SAVED (3) \\
\hline
\end{tabular} \\
\hline
\end{tabular}

18,500

0
20,800
16,400
7,400
6,600
1,600
0
0
24,800
9,600
6,300

25
12
11
3
8
3
5
18

WNP 非
Catawha \#2
Yellow Creek \#1
Seabrook. 非?
Grand Gulf \#2
Pilgrim 非
Limerick \#1
Mid1and \#1.

1250
1145
$128 !$
1150
1250
1150
1055
505

$6 / 85$

$7 / 85$

$11 / 85$

$2 / 85$

$4 / 85$

$12 / 85$

$5 / 85$

$3 / 85$

$$
\begin{gathered}
25,700 \\
9,400 \\
7,000 \\
31,500 \\
0 \\
31,500 \\
24,500 \\
6,200
\end{gathered}
$$

(1) Rank is based on a weighted factor which considers oil saving potential, energy shortage, and low reserve margins; and is only valid within a given year. For licensing purposes, it may be desirable to give preference to top ranked units in a subsequent year over the lower ranked units in the current year.

(2) Three Mile Island \#1 has been shutdown for an indefinate perlod because of the accident at Three Mile Island 非. January 1981 was assumed by ERA staff to be the earliest possible on-line date.

(3) Potential oil saved assuming a full year of operation at 57\% capacity factor, divided by 365. Total oil saved the first year depends on the number of days of operation. These figures reflect an adjustment to account for the regional dependency on oil. 
VII.29

TABLE VII-2-Iø

(l)

Lower_Growth Rates $\underline{1} \underline{9} \overline{8} \underline{0}=\underline{1} \overline{9} 8 \overline{5}$

Electric

Region

$1-$ APS
6 - CECO
$8-$ MSU
$10-$ GSU
$11-$ TVA
$12-$ VACAR
$13-$ CAPCO
$23-$ TEXAS
$25 / 30-$ NWPP
$26-$ ARIZ - NM
$28-$ NO.Cal-NeV

1 - APS

6 - CECO

10 - GSU

11 - TVA

12 - VACAR

13 - CAPCO

23 - TEXAS

26 - ARIZ - NM

28 - No.Cal-Nev
Peak Demand

Growth Rate

$19 \underline{8} \underline{\theta}=85$ (Council Projojection)

4.68 (Winter)

4.48 (Summer)

5.68 (Summer)

6.08 (Summer)

$4.0 \%$ (Winter)

5.18 (Summer)

3.78 (summer)

5.28 (Summer)

4.38 (winter)

6.38 (Summer)

3.38 (Summer)
Lower Growth Rate

Assumed by ERA Staff $1980-85$
2.68
1.78
4.88
5.28
1.08
1.08
2.18
3.58
2.28
3.38
1.78

(1) Same growth rate assumed for peak demand and energy. 
TABLE VII-2-ll

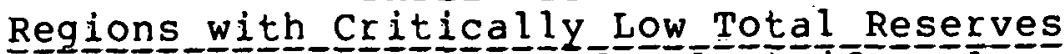

\section{(Adjusted for Net pux chases and}

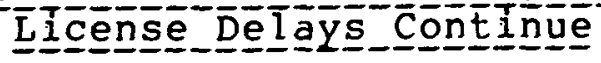

(Percent Reserve Margins Summer/Winters)

Electric $2 /$
Region

(Low Growth Ratie Scenario)

\section{CECO \\ 8. MSU}

28. No. Cal-Nev
1981

1982 1983

1984 $198 \underline{8}$

$11 / 56$

$9 / 53$

$7 / 51$

$8 / 44$

$7 / 42$
$5 / 25$
$11 / 25$

1/ The regions listed are those lof which the summer or winter (or both) reserve margin is less than $12 \%$ including net purchases and sales. Lower growth rates than those projected by the utilities were assumed in computing these reserves - see text.

2/ These Electric Regions were delineated by ERA for the purpose of implementing the Power Plant and Industrial Fuel use Act of 1978. The same regional arrangement is logical and useful for the analysis of electric power supply problems. Analysis of some power pools or control areas within these regions may show more severe problems because of local transmission constraints or generator availability. 
VIIII. TRANSSMISSIONN

Transmission facilities are of great importance in establishing electric system reliability because they knit together the power-producing generating facilities and the power-consuming devices of the system customers. Transmission, in a sense, constitutes the fabric of a fower system; the strength and function of each line is supported by that of every other line in the whole complex. The dispersion of transmission lines and equipment throughout the entire service area of a system, and the interdependence of the lines, make the adequacy of transmission more difficult to evaluate than the adequacy of generation.

Generating facilities are concentrated at points in a system' $\varepsilon$ area; generatjing capacities are independent of one another and can be added to obtain a meaningful total. On the other hand, transmission facilities are spread over the entire system area; transmission line capacities are interdependent to a certain extent; transmission line capacities cannot be added to obtain a meaningful total. It is because transmission lines form a network of paths over which electricity may flow, in which each line flow must be considered in relation to every other line flow, that the mathematical analysis of transmission reliability is more complex.

In the analysis of generating capacity adequacy, there are several generally accepted measures that provide at least an approximate index of sufficiency, but no such indices are available for the transmission function. One guantifiable measure of the transmission system is the number of miles of line. Table VIII.1.is a summary of the Council projections of $l$ ines to be added at various voltage levels. The construction of additional transmission lines implies that the ability to transfer power within a region and between regions becomes greater, but this is not necessarily the case in all instances. Line location on the system is a major factor in determining the degree of improvement effected. That is, the terminals of the line (the points on the system which it ties together) must be considered in an evaluation of the line's contribution to reliability. The lines whose mileage is summarized in Table VIII.l constitute only those considered significant for interconnected operation of the systems reporting. Additional construction for various local purposes may also be planned. 
VIII. 2

Every transmission line serves at least one purpose; some may serve multiple purposes. As indicated in the council reports the functions of the lines reported can be grouped under the following headings:

1. Increased interchange capability

2. Provide a path for moving generator output into the system.

3. Improve system stability. This function may also improve the power transfer capability of this system.

4. Relieve overloads on existing 1 ines by providing alternate paths for power to flow over.

5. Provide ability to serve anticipated load increases.

6. Frovide general support to an area. This could include provision for some future loads, relief of existing overloads, voltage improvement, flexibility to permit maintenance outages, greater power transfer capability to an area.

7. Improve voltage level at some specific substation. 
It is recognized that lines constructed for higher voltages have greater capability for transfer of power than lines constructed for lower voltages. However, line capacity is determined by other factors in addition to the voltage. 1/ Considerations which modify transfer capability are at least the following: number of conductors; conductor size and type; the length of the line; the ambient temperature range in which the line operates; the limitations of the facilities (circuit breakers, transformers, etc.) at the terminals; the network of lines into which the line is flaced; the generating facility characteristics of the system; the effect on system stability, and on loading of other lines, if the line should fail in service; allowable voltage difference (magnitude and phase angle) between the line terminals.2/ Several examples can be cited of the effect of these considerations on the allowable loading of a line. These examples are cited only to illustrate practical situations arising in the planning and operation of lasge power networks; no evaluation, criticism or approval of specific instances is intended or implied.

- 1 Power $\bar{r}$ Technologies, Inc., Report for Electric Power Research Institute, "Synthetic Electric Utility Systems for Evaluating Advanced Technologies", EPRI EM-285, February, 1977, $\mathrm{pF}$. 439-444.

2/ R.D. Dunlop, R. Gutman, P.F. Marchenko, "Analytical Development of Loadability Characteristics for EHV and UHV Transmission Lines," I.E.E.E. Transactions on Power Apparatus and Systems, Vo1. PAS-98, No. 2, March/April 1979, pp. 606-617, and correction in Vol. PAS-98, No. 3, May/June 1979, p. 699. 
1. Alabama Power Co. (Southern Co. area of SERC)

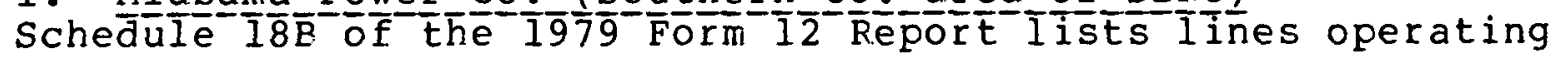
at $500 \mathrm{Kv}, 230 \mathrm{Kv}, 161 \mathrm{Kv}$ and $115 \mathrm{Kv}$. One $500 \mathrm{Kv}$ line has a maximum possible loading of $1,225 \mathrm{MW}$. Another, shorter, $500 \mathrm{KV}$ line has a maximum possible loading of 1,195 MW, limited by transformer capacity. The maximum possible loadings of the $230 \mathrm{Kv}$ lines range from $280 \mathrm{MW}$ to $986 \mathrm{MW}$, with several of the lines being limited by transformer capacity. For the $161 \mathrm{KV}$ lines the maximum possible loading runs from $112 \mathrm{MW}$ to $192 \mathrm{MW}$. At the $115 \mathrm{Kv}$ level the heaviest loading allowable is $274 \mathrm{MW}$ on a line 3.24 miles long; the minimum loading allowed is $53 \mathrm{MW}$ on a $20.40 \mathrm{mile}$ line, with loading limited by a transformer. Several lines are load-limited because of disconnect switch ratingc.

\section{Central Hudson Gas_\& Electric_Corp._(New_York Power_Pool I}

Schedule $18 \mathrm{R}$ of the 1979 Form 12 lists three lines of $345 \mathrm{KV}$, of lengths from 17 miles to 30 miles, each with maximum possible loading of $1,589 \mathrm{MW}$. Many $115 \mathrm{KV}$ lines at various maximum allowable loadings from $93 \mathrm{MW}$ to $265 \mathrm{MW}$ are 1 isted.

3. Cincinnati Gas \& Electric Co. (ECAR)

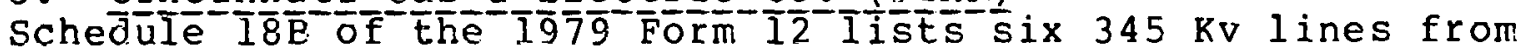
3.68 to 23.33 miles long. Four of these 1 ines have a maximum possible loading of 1,235 Mh, limited by line trap l/ rating; one line has a maximum fossible loading of $1,270 \mathrm{MW}$, I imited by a current transformer 2/ rating; one line is limited to only 440 MW hncause of power transformer capacity limitations. Additional $345 \mathrm{Kv}$ lines have maximum possible lnodings hetween $55 y$ MW and 1,375 MW, limited by power transformers, current transformers, line traps or disconnect switches. A number of $138 \mathrm{KV}$ lines are 1 isted, with maximum possible loadings from $58 \mathrm{MW}$ ( 1 imited by generating station caparity) up to $382 \mathrm{MW}$.

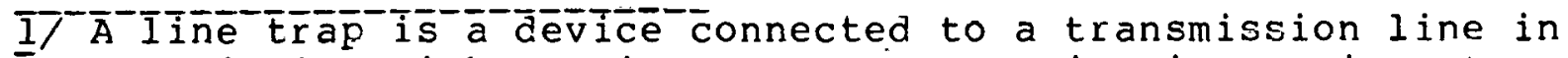
association with carrier current communication equipment.

2/ A current transformer is a transformer used in association with metering and relaying equipment. 
The 3 illustrations above show that line capability is not necessarily determined solely by voltage level. Alabama Power Co. has 1 ines at $500 \mathrm{KV}$ with maximum possible loading less than that of several $345 \mathrm{Kv}$ lines reported by Cincinnati Gas \& Electric Co. Conversely, Alabama Co. has some $230 \mathrm{KV}$ lines with maximum possible loading greater than that of some $345 \mathrm{Kv}$ lines on the Cincinnati Gas \& Electric system.

Transmission capacity should in general be sufficient to transmit all generated power from generating plants to loads at reasonably small voltage drops and energy losses; maintain stability under various contingencies; allow for inter-utility transfers of power and energy both intra-regionally and inter-regionally so as to facilitate over-all economic operation and assistance in emergencies. Transmission facilities in appropriate circumstances may partially substitute for generating capacity, but such substitution must be carefully considered in relation to the need for adequate over-all installed ( cannot create electric energy but could overcome a local supply problem and eliminate the need for a small generating unit.

As discussed above, transmission system reliability is strongly affected by topological considerations as well as by the characteristics of individual circuits and items of equipment. Just as the reliability of power supply from generating units is closely related to the probability of forced outages and reduction of capacity, and the time pattern of maintenance outages, the reliability of the transmission network is related to the probability of 1 ine and equipment forced outages and maintenance outages. $1 /$ The mathematical complexity of the necessary system analyses, the uncertainties associated with the parameters and data, the uncertain correspondence between models and reality, and the flexibility of utility operating procedures in unforeseen circumstances, all have an effect on transmission system reliability.

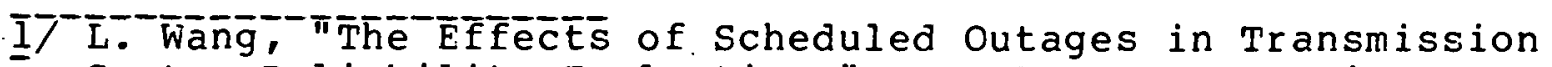
System Reliability Evaluation." I.E.E.E. Transactions on Power Apparatus and Systems, Vol. PAS-97, No. 6, Nov./Lec. 1978, pp. 2346-2353. 
VIII. 6

Table VIII.I

Projected Bulk Power Transmission Lines 1980-1989

Significant For Interconnected operation

As Reported by the Regional Electric Reliability Councils April 1,1980

Miles of Line at Each Voltage Level*

\begin{tabular}{|c|c|c|c|c|c|c|}
\hline Council & $230 \mathrm{Kv}$ & $345 \mathrm{Kv}$ & $500 \mathrm{Kv}$ & $765 \mathrm{Kv}$ & Other & Total \\
\hline ECAR & 327 & 2,998 & 302 & 1,194 & $-0-$ & 4,821 \\
\hline MAAC & 943 & 16 & 459 & $-0-$ & $-0-$ & 1,418 \\
\hline MAIN & $-0-$ & 1,325 & 55 & $-0-$ & $-0-$ & 1,380 \\
\hline MARCA & 1,378 & 2,463 & 1,348 & 0 & $1,823 \frac{1}{1}$ & 7,012 \\
\hline $\mathrm{NPCC} \underline{5}$ & 8 & 1,141 & $-0-$ & 74 & $494 \frac{2}{9}$ & 1,717 \\
\hline SERC & 3,818 & 0 & 2,596 & 2 & $26 \frac{3}{\prime}$ & 6,442 \\
\hline $\begin{array}{l}\text { SWPP } \\
\text { Subtotal }\end{array}$ & $\frac{2,508}{8,982}$ & $1 \frac{3,409}{1,352}$ & $\frac{1,292}{6,052}$ & $\frac{-0-}{1,270}$ & $\frac{-0-}{2,343}$ & $\frac{7,209}{29,999}$ \\
\hline wscc $\underline{6} /$ & 5,812 & 4,426 & $7,7 / 0$ & $n$ & 2,07041 & 20,048 \\
\hline ERCOT & $-0-$ & 3,311 & $-0-$ & $-0-$ & $-0-$ & 3,311 \\
\hline U.S. Total & & $\overline{089}$ & $\overline{3,792}$ & 1,270 & $\overline{4,413}$ & $\overline{53,358}$ \\
\hline
\end{tabular}

*All voltages are A.C. unless otherwise stated.

$1 / 835 \mathrm{miles}$ at $115 \mathrm{Kv}$ and $988 \mathrm{miles}$ at $161 \mathrm{Kv}$.

2/ 115 and $138 \mathrm{Kv}$.

3/ 10 miles at $69 \mathrm{Kv} ; 10$ mileg $n \mathrm{t} 115 \mathrm{Kv} ; 6$ miles at $138 \mathrm{Kv}$.

4/ $69 \mathrm{miles}$ at 115 and $161 \mathrm{Kv}$; net of $800 \mathrm{Kv}$ D.C. upgraded

to $1000 \mathrm{Kv} \mathrm{D.C.,} \mathrm{and} \mathrm{addit10nal} 1000 \mathrm{Kv} \mathrm{D.C.} \mathrm{construction;}$

$(-41)$ miles at $287 \mathrm{Kv}$.

5/ U.S. porlion of Council only.

帛/ Tnciudes projected lines of Canadian systems. Reviaed totals as reported by WSCL on May 12,1980 . 


\section{Inter}

At the time that the Reliability Council annual reporting arrangements were initiated, l/ there was great interest in the magnitude of feasible inter-regional transfers of power under normal and emergency conditions. The reforts therefore provide information on scheduled transfers in Item $2 \mathrm{C}$, and on emergency transfer capability in Item 6A. Scheduled transfers are those for which arrangements have been made in advance as to magnitude and time of occurrence. Emergency transfers by their very nature cannot be scheduled in advance.

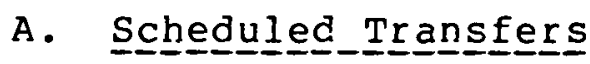

Electric utilities arrange well in advance for scheduled purchases and sales of capacity when such transactions appear to be technically and economically feasible. A transaction may be planned when one utility foresees a temporary excess of capacity and another utility wishes to defer construction of a generating unit. A transaction may be arranged when a utility or group of utilities in one area and a utility or group of utilities in another area discover a consistent pattern of load diversity between them. If the diversity is of large enough magnitude, and it is believed that the diversity will endure for $a$ reasonable lenth of time, interchange arrangements can be made for the period of the expected diversity. An example of diversity interchange is the agreement between TVA and the south Central Electric Companies (SCEC) group. This agreement, negotiated in the 1960's, called for TVA to provide $1500 \mathrm{MW}$ and associated energy to SCEC during the summer and for SCEC to provide $1500 \mathrm{MW}$

İ 
and associated energy to TVA during the winter.1/ Changes in the diversity between the two areas involved have led to a reduction in the amount of the exchange. From the winter of 1981-82 on, the capacity. exchanged will be only $700 \mathrm{MW}$.

Two or more utilities may agree to construct a single large unit (or a plant with several large units) and share the output, instead of each constructing a small unit. The advantages of scale are thereby obtained, with lower investment cost per unit of capacity for each participant. The large unit (or plant) can be operated by one of the parties on behalf of all. Contractual arrangements of various types can be develofed for such a situation, one being for each particlpant to treat the power flow as a capacity purchase. In all instances, the transactions are arrangements between utilities, not between Regional Councils, although the council organizational structure facilitates recognition of the opportunities for such arrangements.

The inter-utility transactions in capacity, when effected between members of one Council, will not in general change the Council area reserve margin (although area capacity will be more effectively used). When the utilities participating in a capacity exchange are in two different councils or in different electric regions, the regional reserve margins will be modified if the transactions are scheduled to occur at the time of peak load in either or both regions. Table IX.l summarizes data on net inter-regional capacity transfers scheduled for the winter and summer peak periods from summer 1980 through winter 1989-90.

There are large differences among the councils in the pattern of capacity transfers. ECAR shows a net export of power, both winter and summer, for the entire period. WSCC shows only a small net export in summer 1980, with minor net imports for 1981,1982 and 1983. After the summer of 1983 WSCC has zero net transfers through 1989-90 winter. Like ECAR, SERC power transfers result in a net export in each summer of the study periou, but unlike. ECAR, the net transfer is into SERC in each winter period. The patterns of the other Councils are also different.

1/ See I.E.E.E. Transactions on Fower Apparatus and Systems, November 1967 , Vol. PAS-86, No. 11 --

H.R. Koen, Jr.," "South Central Electric Companies Information Processing System," pp. 1334-1343.

T.C. Erwin, F.E. Linton, T. Niessink, "EHV Protective Relaying on SCEC Systems." pp. 1384-1388. 
Long-term scheduling of capacity transactions among utilities requires joint consideration by at least two parties, with detailed attention being given to costs, capacity reguirements and generating unit construction, frojected loads, transmission availability and system operating considerations, among other trings.

In some instances, projected capacity transfers may require construction of new facilities, or agreements to "wheel" power through the facilities of a utility which is neither the provider nor the user of the power. When power is wheeled from one utility to another through a third utility's system, adequate consideration must be given to the effects upon the wheeling system. These effects may include distortion of normal power flow and.voltage patterns, increased losses, overloads of some facilities at certain times, or stability problems.

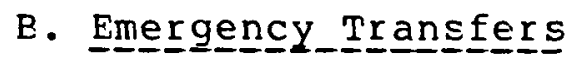

Emergency transfer of power from one region to another may be needed for various reasons whose nature can be described, but whose time of occurrence cannot be specified in advance. These reasons include large-scale loss of generating capacity, transmission system accidents, unforeseen increases in demand, or other situations in which a region finds that its total of generating capacity and net scheduled purchases is significantly less than its customer demand. The situation may affect an entire region or may be localized to some part of a region.

The magnitude and occurrence of need for emergency power transfers are random quantities. The data reported in Item $6 \mathrm{~A}$ relate only to the probable maximum emergency capability available. In the determination of the power flows possible, complex mathematical and engineering analyses are needed, involving theoretical and practical considerations. 1/ The meaning of "Emergency Transfer Capability" is defined by the Regional Councils as - "The total amount of power (above the net contracted purchases and sales) which can be scheduled with an assurance of adequate system reliability, for interregional or multiregional transfers over the transmission network for periods up to several days, based on the most limiting of the following $2 /:$

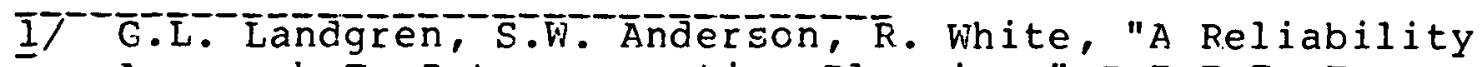
Approach To Interconnection Planning," I.E.E.E. Transactions on Power Apparatus and Systems, Vol. FAS-94, No. 5, Sept./Oct. 1975, pp. 1644-1651.

2/ National Electric Reliability Council "9th Annual Review of Cverall Reliability and Adequacy of the North American Pulk Power System" August 1979. 
(A) All transmission loadings initially within long-time emergency ratings and all voltages initially within acceptable limits.

(B) The bulk power system capable of absorbing the initial power swings and remaining stable upon the loss of any single transmission circuit, transformer or generating unit.

(C) All transmission loadings within their respective shorttime emergency ratings and voltages within emergency limits after the initial power swings following the disturbance, but before system adjustments are made. (In the event of a permanent outage of a facility, transfer schedules may need to be revised.)"

It is apparent from the definition of Emergency Transfer Capability that complete reliance upon emergency transfers as a substitute for adequate qenerating capacity reserves within a reginn would not result in reliable power supply. under tle definition given, studies of power flows can be made thal will yield an approximation to the maximum power transferable from one council region to another under specified conditions. The results of the studies, as reported by the Reliability Councils, are shown in Table IX.2 below. In a review of the maximum emergency support that any Council area could obtain from adjacent councils, the non-simultaneous nature of the transfers must be kept in mind. The physical laws that govern power transfer over a large interconnected network of utilities cannot be evaded. Circuit conditions that permit maximum power flow from one region to another will in general be different for different pairs of regions. For instance, the circult conditions under which SERC could receive maximum emergency power from ECAR die not necessarily the same as those which would allow SERC to receive maximum power flow from SWPP. Therefore, the maximum emergency power that SERC could receive from those regions together would not be the sum of the powers transferable from ECAR and SWPP separately. 
Taile IX:1

PROJECTED NET SCHEDULED INTER-REGIONAL EXCHANGES OF CAPACITY, SUMMER AND WINTER

AS REPORTED BY THE REGIONAL ELECTRIC RELIABILITY COUNCILS

TO THE DEPARTMENT OF ENERGY - -APRIL 1,1980 I7

CONTIGUOUS UNITED STATES

Summer Peak Period - Net of Schedulied Imports and Exports (Mw) $\underline{2}$ $\underline{3}$

\begin{tabular}{|c|c|c|c|c|c|c|c|c|c|c|}
\hline & 1980 & 1981 & 1982 & $\underline{1983}$ & $\underline{1984}$ & $\underline{1985}$ & 1986 & 1987 & 1988 & $\underline{1989}$ \\
\hline ECAR 4 & (806) & (777) & (874) & (906) & (644) & (631) & (338) & (345) & (352) & (47) \\
\hline ERCOT & 145 & 550 & 550 & 604 & 575 & 703 & $680^{\circ}$. & 665 & 665 & 665 \\
\hline MAAC 6 & 157 & 107 & 107 & 107 & 107 & 107 & 107 & 107 & 107 & 107 \\
\hline MAIN 67 & 1,066 & 1,246 & 585 & 272 & 267 & 267 & 136 & 135 & (61) & (62) \\
\hline $\operatorname{MARCA}_{5} \frac{3}{7}$ & 670 & 565 & 525 & 660 & 651 & 643 & 738 & 730 & 626 & 615 \\
\hline NPCC $\underline{3}$ & 1,277 & 1,270 & 1,274 & 1,276 & 1,280 & 1,263 & 1,064 & 864 & 863 & 863 \\
\hline SERC & $(1,060)$ & $(1,060)$ & $(660)$ & $(660)$ & $(660)$ & $(660)$ & $(960)$ & $(960)$ & $(960)$ & $(960)$ \\
\hline SWPP $\frac{7}{5} /$ & 518 & (36) & 206 & 173 & (298) & (375) & (201) & (186) & (185) & $(300)$ \\
\hline WSCC 2 & (36) & 182 & 75 & 75 & 0 & 0 & 0 & 0 & 0 & 0 \\
\hline
\end{tabular}

Winter Peak Pexiod - Net of Scheduled Imports and Exports (Mw) $2 / 3 /$

\begin{tabular}{|c|c|c|c|c|c|c|c|c|c|}
\hline 1980-81 & 1981-82 & $1982-83$ & 1983-84 & 1984-85 & $\underline{1985-86}$ & 1986-87 & $1987-88$ & $1988-89$ & $\underline{1989-90}$ \\
\hline$(105)$ & (276) & (278) & (39) & (48) & (33) & (339) & (345) & (40) & (46) \\
\hline $145^{\circ}$ & 550 & $550^{\circ}$ & $604^{\circ}$ & 575 & 703 & $680^{\circ}$ & 665 & $665^{\circ}$ & 665 \\
\hline 157 & 107 & 107 & 107 & 107 & 107 & 107 & 107 & 107 & 107 \\
\hline 537 & 367 & 66 & (247) & $(250)$ & (251) & (381) & (382) & $(578)$ & (579) \\
\hline (184) & (219) & (291) & (228) & (235) & $(240)$ & (246) & (353) & (356) & (264) \\
\hline $\begin{array}{l}450 \\
660\end{array}$ & $\begin{array}{l}452 \\
660\end{array}$ & $\begin{array}{l}453 \\
660\end{array}$ & $\begin{array}{l}455 \\
660\end{array}$ & $\begin{array}{l}436 \\
660\end{array}$ & 236 & 36 & 35 & 35 & 35 \\
\hline$(1,282)$ & $(1,436)$ & $(1,193)$ & $\begin{array}{c}660 \\
(727)\end{array}$ & $\begin{array}{c}660 \\
(698)\end{array}$ & $\begin{array}{c}660 \\
(775)\end{array}$ & $\begin{array}{c}960 \\
(601)\end{array}$ & $\begin{array}{c}960 \\
(586)\end{array}$ & $\begin{array}{c}960 \\
(585)\end{array}$ & $\begin{array}{c}960 \\
(700)\end{array}$ \\
\hline 31 & 75 & 75 & 0 & 0 & 0 & 0 & $\begin{array}{c}300 \\
0\end{array}$ & $\begin{array}{c}0 \\
(303)\end{array}$ & \\
\hline
\end{tabular}

1/ From Item $2 \mathrm{C}$ of the Counc1l reports. In some Instances the data Include capacity. exchanges between members of a Counc1l and non-members within the geographic boundaries of that Counctl.

$\frac{2}{3}$ Net = Imports - Exports.

3/ The net of scheduled 1mports and exports for any Council does not neciessarily occur at the same time as the net for any other Council.

Therefore, a total for all councils. In any peak period, would not be a meaningful quantity.

4/ Total of Bulk Power and Lialion System Members.

5/ U. S. portion of Council only. Does not include exchanges occurring with in Canada.

6/ Data do not reflect transfer of Associated Electríc Cooperative (AEC) from MAIN to SWPP due to a discrepancy in capacity exchanges reported for AEC. 
Table IX.2

Inter-Council Emergency Transfer Capability

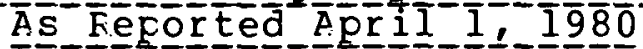

Ey_Théregional-Reli

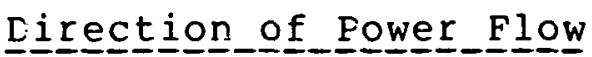

$\begin{array}{ll}\text { Frgm } & \text { Tn } \\ \text { ECAR } & \text { MAAC } \\ \text { ECAR } & \text { NPCC (NYFP) } \\ \text { ECAR } & \text { MAIN } \\ \text { ECAR. } & \text { SERC (TVA) } \\ \text { ECAR } & \text { SERC (VACAR) } \\ \text { NPCC (NYPP) } & \text { ECAR } \\ \text { NPCC } & \text { MAAC } \\ \text { MAIN } & \text { ECAR } \\ \text { MAIN } & \text { MARCA } \\ \text { MAIN } & \text { SERC (TVA) } \\ \text { MAIN } & \text { SPP } \\ \text { MAAC } & \text { ECAR. } \\ \text { MAAC } & \text { NPCC } \\ \text { MAAC } & \text { SERC (VACAR) } \\ \text { MARCA } & \text { MAIN } \\ \text { MARCA } & \text { WSCC } \\ \text { MARCA } & \text { SPP }\end{array}$

Emergency

Summer 1979

\begin{tabular}{|c|c|}
\hline $\begin{array}{l}3300 \\
2200 \\
3450 \\
1800 \\
1250\end{array}$ & $\begin{array}{l}(4350 \text { in } 1984) \\
(1950 \text { in } 1984) \\
(2900 \text { in } 1984) \\
(2200 \text { in } 1980)\end{array}$ \\
\hline $\begin{array}{l}330 \\
225\end{array}$ & $\begin{array}{l}(2900 \text { in } 19 \\
(\text { in } 1984)\end{array}$ \\
\hline $\begin{array}{r}4000 \\
1000 \\
750 \\
2000\end{array}$ & $\begin{array}{l}(4000 \text { in } 1984) \\
(550 \text { in } 1984) \\
(3200 \text { in } 1984) \\
(1800 \text { in } 1984)\end{array}$ \\
\hline $\begin{array}{l}2450 \\
1650 \\
1800\end{array}$ & $\begin{array}{l}(\text { in } 1984) \\
(\text { in } 1980)\end{array}$ \\
\hline $\begin{array}{l}600 \\
100 \\
700\end{array}$ & $\begin{array}{l}(800 \text { in } 1984 \\
\text { l } / \\
(\text { In } 1980)\end{array}$ \\
\hline
\end{tabular}

1/ Total of scheduled and emergency capability 
Table IX.2 (continued)

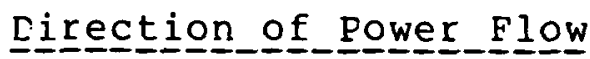

\section{Fr므므}

SERC (TVA)

SERC (VACAR)

SERC (VACAR)

SERC

SERC

SPP

SPP

SPP

WSCC

WSCC (U.S.)

WSCC (Canada)
T으

ECAR

ECAR

MAAC

MAIN

SPP

SERC (TVA)

MARCA

MAIN

MA RCA

WSCC (Canada)

WSCC (U.S.)
Emergency_Transfer Capabilitty, MW

Suummer 19 므모

2000

$2700(3300$ in 1980$)$

$2000(4850$ in 1984)

$1100(2800$ in 1984)

1550 (in 1980; 4000 in 1984)

2650 (in 1980; 3000 in 1984)

800

2000 (1900 in 1984)

100 (in 1980 and in 1985)

2000 (in 1980 and in 1985) $1 /$

2000 (in 1980 and in 1985) 1 /

Note : All transfers to a Council (or from a Council) are not simultaneous. The total of all transfers to a Council (or from a Council) does not represent the total emergency fower actually transferable because circuit conditions are different for each individual transfer.

1/ Total of scheduled and emergency capability. 


\section{COEEI_UNITI_DELA}

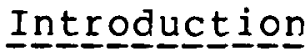

This analysis is an update of the Division of Power supply and Reliability staff report dated March 24, 1980, 'The Effects of Delays in Construction of Coal-Fired Generating Units on Electric Utility Use of Coal, Oil and Natural Gas'. The time period covered is 1980 through the end of 1989 .

\section{Summar $\underline{\underline{y}}$}

This refort compares coal unit completion schedules as reported in the April 1, 1979 and April 1, 1980 Coordinated Planning Reports of the nine Regional Electric Reliability Councils. The data in the Council Reports is as of December 31, 1978 and December 31, 1979, respectively.

In the twelve-month period covered by the two sets of reports, schedules were changed for 100 coal-fired generating units totalling $52,676 \mathrm{mw}$. Completion time was shortened for 10 units totalling $4,794 \mathrm{mw}$ and was lengthened for 90 units totalling 47,882 $\mathrm{mw}$. In terms of megawatt-months (defined as the algebraic sum of the products of each unit's capability multiplied by the number of months change in its completion schedule), there was a cumulative gain of $41,104 \mathrm{mw}-\mathrm{m}$ and a loss of $692,630 \mathrm{mw}-\mathrm{m}$, resulting in a net loss of $651,526 \mathrm{mw}-\mathrm{m}$. Eighty-six of the schedule changes involve units $300 \mathrm{mw}$ or larger. Coal units have been delayed in every Council Region.

The net loss of $651,526 \mathrm{mw}-\mathrm{m}$ in coal-supplied energy, for the years 1980 through 1989 , will result in the use of additional oil and natural gas.

Ten units whose early completion would appear to offer the greatest benefits in reduction of oil consumption (approximately 76 million barrels) are offered as candidates for accelerated construction. These units are: Erandon Shores No. 2, Erandon Shores No. 1, Sears Island, Seward No. 7, California Coal No. 1, California Coal No. 2, Coho No. I, E. Allen No. I, H. Allen No. 2, and H. Allen No. 3. 
Ten units whose early completion would appear to offer the greatest benefits in reduction of gas usage (approximately $324 \mathrm{million}$ mcf $1 /$ ) $\mathrm{e}$ listed as candidates for accelerated construction: Forest Grove No. - . Twin Oak No. 1, Unsited No. 1, R. S. Nelson No. 5, Coleto Creek No. 2, Muskogee No. 6, Unsited No. 1, Pirkey No. 1, F. P. F. No. 3, and Lovelady No. 1 .

Oil and gas savings could also be realized if completion schedules were advanced for those units currently showing no delays.

\section{Det_aiㅛㅁㅗ}

Tahle $x .1$ is a summary of the changes in coul unit schedulan in-service dates. It shows that the changes range frull duvancement of 18 months to delay of 48 months. The total capacity delayed is $47,882 \mathrm{mw}$, distributed among 79 units $300 \mathrm{mw}$ or larger and Il units of size less than $300 \mathrm{mw}$. Of the 10 units whose schedules have been advanced, 7 are in the $300 \mathrm{mw}$ or larger category; 3 are smaller than $300 \mathrm{mw}$ in size. The table also shows, for each category of delay or advancement, the total megawatt-months in that group.

Tables X.2 and X.3 are detailed listings showing for each unit the net expected capability and the in-service dates as reported in the April 1, 1979 and April 1, 1980 Council Reports. The tables also show the total megawatt-months associated with the schedule change of each unit listed. Table X.2 lists units $300 \mathrm{mw}$ or larger; Table X.3 lists those smaller than $300 \mathrm{mw}$.

The additional oil that could be consumed because of a coal unit delay depends upon the capability of the unit and the "mix" of generating capacity of the system on which the unit operates, among other things. For the purposes of this report, it was assumed that the "system" would be the Electric Region in which the unit is located. The oil consumption also depends upon the capacity factor of the unit and upon the averaqe use of oil per megawatt-hour of generation in the region. The "mix" of generating capacity for each reyion, as determined by analysis of installed capacity and probable incremental loading considerations, is shown in Table VII-2-2. This table, which was developed for the nuclear capacity analysis of this report (Section VII), is considered satisfactory for use in this analysis. The potential oil consumption due to each coal unit was computed by means of the following formula: 
Earrels displaced $=\mathrm{C} \times 732 \times \mathrm{CF} \times 1.7 \times \mathrm{M} \times \mathrm{MO}$ where

$C$ = unit capability in megawatts

732 = number of hours in a month

$\mathrm{CF}$ = capacity factor, assumed here as 0.60

$1.7=$ U.S. average barrels of oil burned per megawatt-hour generated". This differs from region to region, but the average U. S. value was assumed satisfactory for this report.

$M$ = regional generation by oil, as a decimal fraction of total generation, shown in Table VII-2-2.

MO = months change in schedule

The results of the application of (1) to each of the coal units whose schedule was changed were used to produce a list of the ten units that would make a significant contribution to oil conservation (Table X.4).

The 1 ist of ten units whose early completion would make a large contribution to gas conservation (Table X.5) was obtained by the application of (I) with two modifications. The number 1.7 was replaced by 10.5 (U.S. average mcf of gas burned per megawatt-hour generated $1 / /$, and regional generation by oil as expressed in $M$ above was replacéd by the regional generation by gas, as a decimal fraction of total generation, as shown in Table VII-2-2.

İy Āverage ố by electric utilities for the years 1977, 1978, and 1979. 
Table X.1

SUMMARY OF CHANGES IN SCHEDULED

IN-SERVICE DATES OF COAL-FIRED GENERATING UNITS 1 /

(1980-1989)

$300 \mathrm{Mw}$ or Larger

\begin{tabular}{l} 
Slippage \\
(Months) \\
\hline
\end{tabular}

No. of

Units

48

$36-47$

24-35

$12-23$

$1-11$

Total

Advancement

(Months)

$$
12-18
$$

$1-11$

Total

Net Slippage
1

5

13

36

$\underline{24}$

79

45,492

1,400

$\underline{2,764}$

4,164

41,328

23,100

11,594

34,694

636,511

Less Than $300 \mathrm{Mw}$

No. of Units

Mw

$-$

$107,0282 /$

201,992

272,298

60,127

671,205

\section{$-$}

$\overline{2}$

2

3

6

11
500

463

$\underline{1,427}$

2,390

280

350

3,360

$\underline{2}$

3

630

$\underline{3,050}$

6,410

8

1,760

15,015
Megawatt-Months (Mw x Months)

12,000

5,756

3,669

21,425

1/ Comparison of scheduled in-service dates in the April 1, 19/9 and April 1, 1980 Regional Reliability Council. Reports.

2/ 18,792 megawatt-months excluded for period after December 31, 1989. 
COAL-FIRED GPNERATING INNITS 300 MW OR LARILAR

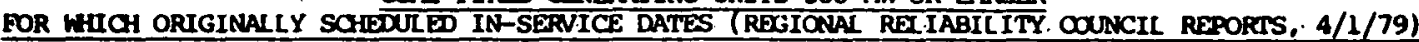

HAVE BEDN MODIFIED (REGIONAL REI LABILITY OOUNCIL REPORIS, 4/1/80)

\begin{tabular}{c} 
Dor/ERA \\
Electric \\
Region \\
\hline 1 \\
1 \\
1 \\
1 \\
2 \\
3 \\
5 \\
5 \\
5 \\
5 \\
5 \\
7 \\
7 \\
7 \\
7 \\
7 \\
9 \\
9 \\
9 \\
9 \\
9 \\
9 \\
9 \\
10 \\
10 \\
10 \\
10 \\
\hline
\end{tabular}

Generating Unit.

Pleasants No. 2

Lower Armstrong to. 1

Lower Armstrong No, 2

Lower Armetrang No. 3

Lewis Co. No. 2

\section{Sears Island}

Brandon Shores No. 1

Brandon Shores No. 2

Sewand No. 7

Dickerson to. 4

Coho No. 1

McIntooh No. 3

Cryatal River No. 5

Fossil coal No. 1

Unknown No. 1

coal A No. 1

Miller No. 2

Miller No. 3

Miller No. 4

Scherer No. 3

Scherer No. 4

Unsited - Site A No. 1

Unsited - Site A NO. 2

Rodenacher No. 2

R. S. Nelson No. 5

Lovelady No. 1

Lovelady No. 2

\begin{tabular}{|c|c|c|}
\hline $\begin{array}{c}\text { Net Expected } \\
\text { Capábility } \\
\text { (Mw) }\end{array}$ & $\begin{array}{l}\text { In-Servi } \\
\text { 4/1/79. } \\
\text { Report }\end{array}$ & $\begin{array}{l}\text { Date } \\
4 / 1 / 80 \\
\text { Peport }\end{array}$ \\
\hline $\begin{array}{l}626 \\
630 \\
630 \\
630\end{array}$ & $\begin{array}{l}3 / 80 \\
5 / 84 \\
3 / 85 \\
3 / 86\end{array}$ & $\begin{array}{r}10 / 80 \\
9 / 86 \\
9 / 87 \\
9 / 88\end{array}$ \\
\hline 1,300 & $12 / 88$ & $6 / 88$ \\
\hline 568 & $11 / 87$ & $11 / 89$ \\
\hline $\begin{array}{l}620 \\
620 \\
625 \\
400 \\
625\end{array}$ & $\begin{array}{r}1 / 82 \\
1 / 84 \\
12 / 85 \\
1 / 87 \\
5 / 88\end{array}$ & $\begin{array}{l}5 / 84 \\
1 / 883 \\
5 / 87 \\
5 / 87 \\
5 / 89\end{array}$ \\
\hline $\begin{array}{l}334 \\
670 \\
668 \\
350 \\
600\end{array}$ & $\begin{array}{l}11 / 81 \\
5 / 84 \\
10 / 85 \\
5 / 87 \\
6 / 871 /\end{array}$ & $\begin{array}{r}10 / 81 \\
6 / 84 \\
6 / 86 \\
5 / 86 \\
12 / 85\end{array}$ \\
\hline $\begin{array}{l}654 \\
654 \\
654 \\
808 \\
808 \\
783 \\
783\end{array}$ & $\begin{array}{l}6 / 82 \\
6 / 83 \\
6 / 84 \\
2 / 85 \\
2 / 87 \\
6 / 87 \\
6 / 84\end{array}$ & $\begin{array}{l}6 / 83 \\
6 / 85 \\
6 / 87 \\
2 / 87 \\
2 / 89 \\
6 / 90 \\
6 / 91\end{array}$ \\
\hline $\begin{array}{l}530 \\
540 \\
400 \\
400\end{array}$ & $\begin{array}{l}3 / 82 \\
3 / 84 \\
9 / 85 \\
9 / 87\end{array}$ & $\begin{array}{r}1 / 82 \\
4 / 85 \\
10 / 86 \\
10 / 87\end{array}$ \\
\hline
\end{tabular}

Schedule Change

Megawatt - Months Net For

Months . (MW $\times$ Months) Pegion

Allegheny Power System, Inc.

Al legheny Power System, Inc.

Alegheny Power System, Inc.

Allegheny Power Systen, Inc.

American Electric Power $\infty .$, Inc.

Central Maine Power Company.

Baltimore Gas \& Electric $\infty$.

Baltimore Gas Electric $\infty$.

GPU: Pennsylvania Electric $\infty$.

Potcrmac Electric Power $\infty$.

GPU: Pennsylvania Electric $\infty$.

City of Lakeland (FL)

Florida Power Corporation

Plorida Power Corporation

City of Lakeland (FL)

Florida Power Light $\infty$.

So. Oo.: Alabama Power $\infty$.

So. Co.: Alabama Power Co.

So. Co.: Alabana Power $\infty$.

So. Co.: Georgia Power $C$.

so. Co.: Georgia Power $\infty$.

D.: Alabana Power D.

so. Co.: Alabama Power $\infty$.

Central Laiisiana Electric co., Inc

Qulf States Utilities Oompany

aulf states Utilities company

Gulf States Utilities Oampany
4.382

17.640

18,900

18,900

$59 ; 822$

(6)

$(7,800)$

$(7,400)$

13,632

13,632

$17,360^{\circ}$

29.760

10,625

1,600

7,500

66.845

(1) (334)

670

5,344
$(4,200)$

$(10,800)$

7,848

15,696

23,544

19,392

19,392

28.188

28,188

$(1,060)$

7.020

5,200

400 
Table X.2

COAL-FIRE' LIENERATING UNITS 300 MW OR LARGER

FOR WHOH ORIGINALLY SAIETULED IN-3EFVICE DATES (REGIUNAI REL IABILITY COUNCIL REPORIS, 4/1/79)

HAVE BESN MODIEIED (REGIONAL REL IABILITYY COUNCIL REPORTS, 4/1/80)

DOE/ERA

Electric

Region

12

12

12
Generating Unit

Proxboro No. 4

Mayo No. 1

cross Site No. 1

Cross Site No. 2

Insited Coal No. I

cross Site No. 3

Unsited coal No. 2

Bast Bend No. 1

Killen Station No. 1

East Bend No. 3

D. B. Wilsan No. 1

Hancock Co. No. 1

Trimble oounty No. 2

Meron No. 2

Meron No. 1

Petersburng No. 4

A. B. Brom no. 3

Patriot No. 1

Newton No. 2

auck Creak No. 2

Pleasant Prairie No. 2

Edgewater blo. 5

\section{Utility}

Carolina Power Light Company

Carolina Power o Light Company

South Carolina Public Service Authority

south Carolina Public Service Authority

South Canolina Electric \& Gas $c 0$.

South Carolina Public Service Authority

South Camolina Electric Gas Oo.

Cincinnati Gas E Electric $C_{0}$.

Dayton Pewer \& Light ompany

Cincinnati Gas Electric $C_{0}$.

Big Rivers Electric Corp.

Kentucky Utilities Company

Louisville Gas E Electric oo.

Hoosier Energy Div. IINI Coop.

Hoosier Energy Div. I INI Coop.

Indianapolis Power sight o.

Southem Indiane Gas Electric $\infty$

indianapolis power \&ight $\infty$.

$$
\begin{aligned}
& \text { Net Expected } \\
& \text { Capability }
\end{aligned}
$$

(Mw)

720
450
450

Central Illinois Pubic Service $\infty$.

central Ilinois Iight do.

Wisconsin Electric Power $\infty$.

Wisconsin Power \& Light. $\infty$.
720

450

500

450

500

600

600

600

395

495

500
500

515

500

650

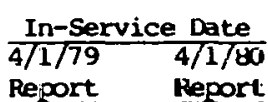

$\begin{array}{ll}4 / 1 / 79 & 4 / 1 / 80 \\ \text { Report } & \text { Report }\end{array}$

$3 / 80$

$3 / 82$

$5 / 83$

$5 / 85$

$5 / 85$

$5 / 87$

$5 / 8$

$10 / 84$

$4 / 86$
$4 / 88$

$9 / 80$
$3 / 83$

$11 / 86$

$11 / 83$

$.11 / 88$

$5 / 89$

$6 / 84$

$10 / 85$

$10 / 85$

$12 / 85$

$10 / 89$

$7 / 64$
$10 / 87$

6/48

$6 / 81$

$4 / 82$

$10 / 83$

$4 / 86$

$10 / 41$.

$7 / 82$
$10 / 84$

$10 / 84$

$12 / 81$

$10 / 84$

400

580

400

$4 / 82 \quad 4 / 83$

$6 / 83 \quad 3 / 84$
Schedule Change

Megawatt-Months Net For

Months (Mw $x$ Months) Region

64.320

8.640

1d, 900

$(0,100)$

12,000

12,000

12,100

55,860

7,200

$(2,400)$

10,800

15,600

395
15,600

11,800

27,875

2,000

1,500

6.180

10,500

7,800

27.980

6,900
9,600

16,500

6,960

3,600

10,560 
Table $x .2$

COAL-FIRED GPNERATING UNITS 300 MW OR LARGER

POR WHIOH ORIGINALLY SOHETULEO IN-SERVICE DATES (REGIONAI REI IABILITY COUNCIL PEPORTS, 4/1/79)

HAVE BEEN MODIFIED (REGIONAL REI IABILITY COUNCIL REPORTS, 4/1/BC)

\begin{tabular}{l} 
DOE/E \\
Electr \\
Regio \\
\hline 20 \\
20 \\
20 \\
20 \\
20 \\
20 \\
20 \\
21 \\
21 \\
21 \\
22 \\
22 \\
22 \\
22 \\
22 \\
22 \\
22 \\
22 \\
23 \\
23 \\
23 \\
23 \\
23 \\
23 \\
23 \\
23 \\
23
\end{tabular}

Cenerating Unit

Laramie River No. 2 Gentleman No. 2

Louisa

Colstrip No. 3

Colstrip No. 4

Sherburne Oanty to. 3

possil No. 3

Jeffrey Bergy Ctr. No. 3 Kansas Power o light $\infty$.

Jeffrey Energy Ctr. No. 4 Kansas Power \& Light Co.
Iatan No. 2

Socner No. 2

Northeastern No. 4

Hugo No. 1

muskogee No. 6

Pirkey No. 1

Unsited Coal No: 1

Unsited Coal tho. 2

Doleto creek No. 2

W. A. Parish No. 8

Twin cak to. 1

parest Grove No. 1

Martin Lake Ho.

Twin Oak No. 2

F. P. P. No. $35 /$

Unsited No. 1

Coleto Creek No. 2

Unsited No. 1
Utility

City of Lincoln (NE)

Nebraska Public Power District

Iowa-Illinois Gas \& Electric 0

Montana Power Company

Montana Power Company

brthem States Power $\infty$. (MN)

Nebraska Public Power District

Oklahoma Gas \& Electric co.

$$
\begin{aligned}
& \text { Net Expected } \\
& \text { Capability } \\
& \text { (Mw) } \\
& \hline
\end{aligned}
$$

Cen. E Sw.: Public Service co. of Oklahoma

Western Farmers Electric coop. (OK)

Oklahoma Gas Electric Co.

Cen. E Sw.: Southwestern Electric Pwr. $\infty$.

Oklahoma Gas Electric Co.

Oklahoma Gas \& Electric $\infty$.

Cen. Sw.: Central Power light do.

Houston lighting \& Power $C_{0}$

Texas Util.: Texas Power is Light $\infty$.

Texas Utilities Company System

Texas Utilities Company System

Texas Util.: Texas Power \& Light $\infty$ a.

Lower Colorado River Authority

Texas Utilities Company System

Cen. Sw.: Central Power \& Light $\infty$.

San Antonio Public Service Board
500

600

650

$70 \frac{21}{2}$

800

800
600

600

680
680
6503

\section{In-Service Date \\ $\begin{array}{ll}4 / 1 / 79 & 4 / 1 / 80 \\ \text { Report } & \text { Report }\end{array}$}

$10 / 80$
$5 / 81$

$1 / 83$

$7 / 83$

$5 / 84$
$5 / 84$

$5 / 84$
$5 / 86$

4/81

7/83

$1 / 84$

$11 / 84$

$5 / 85$
$5 / 87$

$6 / 82$

$3 / 84$

$6 / 83$

$6 / 85$

$6 / 89$

$\begin{array}{rrr}515 & 6 / 80 & 10 / 80 \\ 450 & 6 / 80 & 9 / 80\end{array}$

376

515

640

640
500
500

500

$325 \underline{4} /$

$4 / 81$

$6 / 83$ 1/ $11 / 84$

$6 / 861 / 3 / 85$

$6 / 86 \frac{1 / 1}{1 /} \quad 6 / 87 \frac{1 /}{1 / 8}$

$6 / 87$ 1/ 6/88 1

$\begin{array}{rr}540 & 12 / 82 \\ 750 & 1 / 84\end{array}$

750

750
750
750

750
400

750

$3154 /$

$1 / 84$
$1 / 84$
$1 / 85$

$5 / 83$

$1 / 85$

$4 / 86$

$1 / 87$

$4 / 88$.

2/85

$1 / 87$
$2 / 85$

$2 / 85$

$6 / 87$

\begin{tabular}{|c|c|c|}
\hline Monthe & $\begin{array}{l}\text { Megawatt-Months } \\
\text { (MW X Months) }\end{array}$ & $\begin{array}{l}\text { Net For } \\
\text { Region }\end{array}$ \\
\hline $\begin{array}{r}6 \\
6 \\
6 \\
6 \\
6 \\
6 \\
12 \\
12\end{array}$ & $\begin{array}{r}3,000 \\
3,600 \\
3,900 \\
420 \\
420 \\
9,600 \\
7,200\end{array}$ & 28,140 \\
\hline $\begin{array}{l}12 \\
12 \\
15\end{array}$ & $\begin{array}{l}8,160 \\
8,160 \\
9,750\end{array}$ & 26,070 \\
\hline $\begin{array}{r}4 \\
3 \\
11 \\
17 \\
12 \\
12 \\
12\end{array}$ & $\begin{array}{l}2,060 \\
1,350 \\
4,136 \\
8,755 \\
7,600 \\
6,000 \\
6,000\end{array}$ & \\
\hline 12 & 3,900 & 39,881 \\
\hline $\begin{array}{r}5 \\
13 \\
36 \\
1 \\
1 \\
14 \\
12 \\
12\end{array}$ & $\begin{array}{r}2,700 \\
9,750 \\
27,000 \\
750 \\
750 \\
5,600 \\
9,000 \\
3,780\end{array}$ & \\
\hline 12 & 6,000 & 65,330 \\
\hline
\end{tabular}

$1 / 88$

$1 / 89$
$4 / 89$ 
COALFIRED GENERATING INITS 300 MW OR IARGER

FOR WHTCH ORIGINAUYY SCHBDULED IN-SERVI.E DATFS (REXIONAL REIIABILITY COINCIL REPORTS, 4/1/79)

HAVE BGEN MODIFIED (RDGISNAL RFILABILITY OCONCIL REPORIS, 4/1/80)

DOS/ERA

Region

24

24

25

25

26
26

27

27

27

27

27

California Coal No. 2

H. Allen No. 1

H. Allen No. 2

H. Allen No. 3

Califormia Coal Na. 1

H. Allen No. 4

callifornia coal No. :

\begin{tabular}{|c|c|c|}
\hline $\begin{array}{l}\text { Net Expected } \\
\text { Capahility } \\
(\text { Ma) }\end{array}$ & $\begin{array}{l}\text { In-Ser } \\
4 / 1 / 79 \\
\text { Peport }\end{array}$ & $\begin{array}{l}\text { e Date } \\
4 / 1 / 80 \\
\text { Report }\end{array}$ \\
\hline $\begin{array}{l}470 \\
470 \\
470\end{array}$ & $\begin{array}{l}7 / 80 \\
4 / 84 \\
4 / 85\end{array}$ & $\begin{array}{l}1 / 81 \\
4 / 85 \\
7 / 86\end{array}$ \\
\hline $\begin{array}{l}630 \\
630 \\
630\end{array}$ & $\begin{array}{l}7 / 83 \\
5 / 84\end{array}$ & $\begin{array}{r}1 / 84 \\
11 / 84\end{array}$ \\
\hline $\begin{array}{l}245 \\
350\end{array}$ & $\begin{array}{l}4 / 80 \\
5 / 85\end{array}$ & $\begin{array}{r}10 / 80 \\
6 / 85\end{array}$ \\
\hline 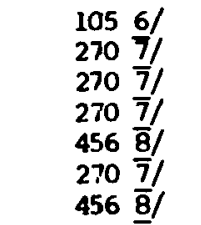 & $\begin{array}{l}4 / 80 \\
6 / 85 \\
6 / 86 \\
6 / 87 \\
6 / 87 \\
6 / 88 \\
6 / 88\end{array}$ & $\begin{array}{r}10 / 80 \\
6 / 86 \\
6 / 87 \\
6 / 89 \\
9 / 89 \\
6 / 89 \\
9 / 89\end{array}$ \\
\hline $\begin{array}{rl}230 & 7 / \\
230 & \overline{7} / \\
230 & \frac{71}{4} \\
44 & \frac{8}{7} \\
230 & \frac{7}{7} \\
44 & \frac{8}{8}\end{array}$ & $\begin{array}{l}6 / 85 \\
6 / 86 \\
6 / 87 \\
6 / 87 \\
6 / 88 \\
6 / 88\end{array}$ & $\begin{array}{l}6 / 86 \\
6 / 87 \\
6 / 88 \\
9 / 88 \\
6 / 89 \\
9 / 89\end{array}$ \\
\hline
\end{tabular}

Schodule Change.

Mayatethonths Net For

Monthe (Nw x Montha) Pegion

Public Service 0 . of Colarado

Public Service $\infty$ of of colorado

Publtc Service $\infty$. of colorado

Montana Power Company

Montana Power Company

Salt River Proj. kgri. Imo. Pwr. Dist.

Tucsian Gas \& Electric Dompany

Salt River Proj. Mgri. Inp. Pwr. Dist.

Nevada Power Company

Nevada Power Company

vevada Power Company

Southern California Ectison Co.

Nevade Power Company

Southern Callformia EAtion $C_{0}$.

\section{Nevada Power Canpamy}

Nevada Porer Company

Nevada Power Company

Southern California Edison Co.

Nevada Pover Company

Southern California Edison $\infty$.

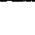

6
12
15

\section{2,820}

5,640
$.7,050$

3,780

3.780

15.510

6
6

1,470
350

7,560

350

1,820

630
3,240

3,240
3,240

3,240
3,240

3,240
6.840

6,840
3,240

6,840

2,760

2,760

2, 760

660
2.760

660

12,360

Month was not reported, DOE arbitrarily used 5.

Total net expected capability is $700 \mathrm{~m} ; 70$ in region 20 and 630 in region 25.

Total net expected capability is $650 \mathrm{~m}$; of tie $650 \mathrm{mw}, 73$ is unassigned; for purposes here, DOE includes it in region 21 .

4/ Total net expected capability is $640 \mathrm{Mv} ; 325$ in region .22 and 315 in region 23.

5/ Formerly Seymour No. 3.

6) Total net expected capability is $350 \mathrm{Mw} ; 245$ in region $2 \epsilon$ and 105 in region 27.

7 Total net expected capability is $500 \mathrm{mw} ; 270$ in region 27 and 230 in region 28 .

$\overline{8}$ / Total net expected capability is $500 \mathrm{Mw}$. 456 in region 27 and 44 in region 28 .

$T$ ) Indicates negative number. 
COALFIRED GENERAT-NG UNITS LFSS THAN $300 \mathrm{MW}$ FOR WHICH ORIGINALLY SCHEDUIED IN-SERVICE DTTSS (RFGIONAL RFIIABILITY OOUNCIL REPORTS, 4/1/79)

HAVE BEDAN MODIFIED (REGIONAL RELIABILITY OOUNCIL REPORTS, 4/1/80)

\begin{tabular}{|c|c|}
\hline $\begin{array}{l}\text { DOE/ERA } \\
\text { Electric } \\
\text { Region } \\
\end{array}$ & Generating Unit \\
\hline 7 & Deerhaven No. 2 \\
\hline 9 & Effingham Station No. 2 \\
\hline 12 & Winyah No. 4 \\
\hline 16 & A. B. $\operatorname{arann}$ No. 2 \\
\hline $\begin{array}{l}20 \\
20\end{array}$ & $\begin{array}{l}\text { Oaage No. } 4 \\
\text { Fosail No. } 1\end{array}$ \\
\hline 21 & Holoanb No. 1 \\
\hline $\begin{array}{l}24 \\
24\end{array}$ & $\begin{array}{l}\text { Rawhide No. } 1 \\
\text { Ray D. Nixon No. } 2\end{array}$ \\
\hline $\begin{array}{l}26 \\
26 \\
26\end{array}$ & $\begin{array}{l}\text { Crolla No. } 3 \\
\text { Escalante No. } 1 \\
\text { Escalante No. } 2\end{array}$ \\
\hline $\begin{array}{l}27 \\
27\end{array}$ & $\begin{array}{l}\text { Warmer Valley No. } 1 \\
\text { Warmer Valley No. } 2\end{array}$ \\
\hline $\begin{array}{l}28 \\
28\end{array}$ & $\begin{array}{l}\text { Warner Valley No. } 1 \\
\text { Warner Valley No. } 2\end{array}$ \\
\hline $\begin{array}{l}30 \\
30\end{array}$ & $\begin{array}{l}\text { Warner Valley No. } 1 \\
\text { Warner Valley No. } 2\end{array}$ \\
\hline
\end{tabular}

\begin{tabular}{|c|c|c|c|}
\hline Utility & $\begin{array}{c}\text { Net Expected } \\
\text { Capability } \\
\text { (Mw) }\end{array}$ & $\begin{array}{l}\text { In-Service } \\
\text { 4/1779 } \\
\text { Report }\end{array}$ & $\begin{array}{l}\text { Date } \\
4 / 1 / 80 \\
\text { Report }\end{array}$ \\
\hline Gainesville-Alachua County (FL) & 235 & $1 / 81$ & $2 / 81$ \\
\hline Savannah Electric \& Power Co. & 163 & $3 / 86$ & $3 / 87$ \\
\hline South Carolina Public Service Authority & 280 & $5 / 82$ & $5 / 81$ \\
\hline Southern Indiana Gas \& Electric iso. & 250 & $4 / 83$ & $1 / 84$ \\
\hline $\begin{array}{l}\text { Black Hills Pawer of Light } \infty \text {. (SD) } \\
\text { Montana-Dakota Utilities } \infty \text {. }\end{array}$ & $\begin{array}{l}100 \\
100\end{array}$ & $\begin{array}{l}6 / 85 \\
5 / 86\end{array}$ & $\begin{array}{r}10 / 84 \\
5 / 87\end{array}$ \\
\hline Sunflower Electric Coop. (ks) & 280 & $5 / 83$ & $6 / 83$ \\
\hline $\begin{array}{l}\text { Platte River Pawer Authority } \\
\text { City of Colorado Springs }\end{array}$ & $\begin{array}{l}250 \\
200\end{array}$ & $\begin{array}{r}1 / 85 \\
11 / 86\end{array}$ & $\begin{array}{r}4 / 84 \\
12 / 87\end{array}$ \\
\hline $\begin{array}{l}\text { Arizona Public Service Campany } \\
\text { Plains Electric Gen. Trans. Coop., Inc. } \\
\text { Plains Electric Gen. Trans. Coop., Inc. }\end{array}$ & $\begin{array}{l}242 \\
210 \\
210\end{array}$ & $\begin{array}{l}6 / 80 \\
5 / 84 \\
5 / 88\end{array}$ & $\begin{array}{l}8 / 80 \\
6 / 84 \\
6 / 88\end{array}$ \\
\hline $\begin{array}{l}\text { Nevada Power Company } \\
\text { Nevada Power Company }\end{array}$ & $125 \frac{1 /}{1 /}$ & $\begin{array}{l}6 / 83 \\
6 / 84\end{array}$ & $\begin{array}{l}6 / 85 \\
6 / 86\end{array}$ \\
\hline $\begin{array}{l}\text { Nevada Power Company } \\
\text { Nevada Power Company }\end{array}$ & $62.5 \frac{1}{1} /$ & $\begin{array}{l}6 / 83 \\
6 / 84\end{array}$ & $\begin{array}{l}6 / 85 \\
6 / 86\end{array}$ \\
\hline $\begin{array}{l}\text { Nevada Power Company } \\
\text { Nevada Power Company }\end{array}$ & $62.5 \frac{11}{11}$ & $\begin{array}{l}6 / 83 \\
6 / 84\end{array}$ & $\begin{array}{l}6 / 85 \\
6 / 86\end{array}$ \\
\hline
\end{tabular}

\begin{tabular}{|c|c|c|}
\hline Months & $\begin{array}{l}\text { Schedule Change } \\
\text { Meyawatt-Months } \\
\text { (Mw } \times \text { Months) }\end{array}$ & $\begin{array}{l}\text { Net For } \\
\text { Region }\end{array}$ \\
\hline 1 & 235 & 235 \\
\hline 12 & 1,956 & 1,956 \\
\hline (12) & $(3,360)$ & $(3,360)$ \\
\hline 9 & 2,250 & 2.250 \\
\hline $\begin{array}{l}(8) \\
12\end{array}$ & $\begin{array}{r}(800) \\
1,200\end{array}$ & 400 \\
\hline 1 & 280 & 280 \\
\hline $\begin{array}{l}(9) \\
13\end{array}$ & $\begin{array}{c}(2,250) \\
2,600\end{array}$ & 350 \\
\hline $\begin{array}{l}2 \\
1 \\
1\end{array}$ & $\begin{array}{l}484 \\
210 \\
210\end{array}$ & 904 \\
\hline $\begin{array}{l}24 \\
24\end{array}$ & $\begin{array}{l}3,000 \\
3,000\end{array}$ & $6, \infty 00$ \\
\hline $\begin{array}{l}24 \\
24\end{array}$ & $\begin{array}{l}1,500 \\
1,500\end{array}$ & 3,000 \\
\hline $\begin{array}{l}24 \\
24\end{array}$ & $\begin{array}{l}1,500 \\
1,500\end{array}$ & 3,000 \\
\hline
\end{tabular}

1/ Total net expected capability is $250 \mathrm{~m} ; 125$ in region 27, 62.5 in region 28, and 62.5 in region 30.

$T$ ) Indicates negative number. 
Table X.4

TEN COALFIRED GENERATING UNITS

WITH LARGE OIL DISPLACEMENT POTENTIAL

(THROUGH 1989)

Generating Unit

Brandon Shores No. 2

Brandon Shores No. I

Sears Island

Seward No. 7

California Coal No. 1

California coal No. 2

Coho No. 1

H. Allen No. 1

H. Allen No. 2

H. Allen No. 3

Total

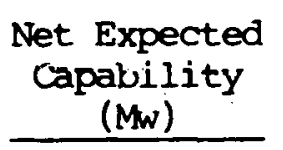

Expected

In-Service

Date

$1 / 88$

$5 / 84$

$11 / 89$

$5 / 87$

$9 / 88$

$9 / 89$

$5 / 89$

$6 / 86$

$6 / 87$

$6 / 88$

$$
\text { Capability }
$$

$\left(M_{w}\right)$

620

620

568

625

500

500

625

500

500

500

5,558
Electric

Region.

\section{5}

5

3

5

27,28

27,28

5

27.28

27,28

27,28
Oil Displaced 1/

(Total Bbls) (BBIs/Day)

$18,887,005$

$11,017,420$

$10,178,196$

$6,743,093$

$5,599,800$

$5,599,800$

$4,759,830$

$4,479,840$

$4,479,840$

$4,179,840$

$76,224,664$
12,901

12,901

13,905

13,005

12,240

12,240

13,005

12,240

12,240

12,240
126,917

1/ The use of this oil could be avolded if the completion schedules reported in the April 1, 1979 Regional Reliability Council reports. are followed. 


$$
\mathrm{X} .11
$$

Table X.5

TEN COAL-FIRED GENERATING UNITS

WITH LARGE GAS DISPLACEMENT POTENTIAI

(THROUGH 1989)

Generating Unit

Forest Grove No. 1

Twin Oak No. 1

Unsited No. 1

R. S. Nelson No. 5

Coleto Creek No. 2 '

Muskogee No. 6

Unsited No. 1

Pirkey No. 1

F. P. P. No. 3

Lovelady NO. 1
Net Expected

Presently

Expected

In-Service

Date

$1 / 87$

$2 / 85$

$1 / 88$

$4 / 85$

$1 / 89$

$11 / 84$

$4 / 89$

$3 / 85$

$6 / 87$

$10 / 86$

$$
\begin{gathered}
\text { Capability } \\
(\mathrm{Mw})
\end{gathered}
$$

750

750

750

540

640

515

500

640

400

400

5,885

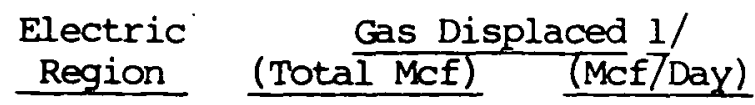

23

23

23

10

22,23

22

23

22

23

10
$99,610,560$

$35,970,480$

$33,203,520$

$24,280,074$

$24,736,622$

$24,224,735$

$22,135,680$

$21,250,253$

$20,659,968$

$17,985,240$

$324,057,132$
90,720

90,720

90,720

61,236

67,586

46,721

60,480

58,061

48,384

45,360

Total

(2)

$\begin{array}{llll}5,885 & 324,057,132 & 659,988\end{array}$

1/ The use of this gas could be avoided if the completion schedules reported in the April 1, 1979 Regional Reliability Council reports are followed. 


\section{GLOSSARY}

The purpose of this glossary is to define for the purposes of this report those terms which may be unfamiliar, or whose meaning may not be clear, to non-technical readers. It is not intended that this glossary replace technical dictionaries.

\section{AVAILAEILITY FACTOR}

- the ratio of the time a machine or equipment is ready for or in service, to the total time interval under consideration. "Total time interval" refers to calendar time and is not affected by a unit being in service or not.

\section{CAPABILITY}

- a general term for the maximum load which a generating unit, power plant or system can supply under specified conditions for a given time interval, without exceeding approved limits of temperature and stress. When used in reference to a system or plant, capability includes all generating units and is known as "installed capability". It includes the capability of units that may be temporarily inoperable because of maintenance, forced outage or other reasons, or only operabile at less than full output.

Summer nct dependable planned capability refers to the capability during the summer peak period. This period usually occurs on most systems between June 1 and september 30 ; it may last for several days. It is expected that the unit, plant or system will be able to supply the stated power output for the duration of the peak period.

Winter net dependable planned capability refers to the capability during the winter peak period. This period occurs on most systems between December 1 of any year and March 31 of the following year. It is expected that the unit, plant or system will be able to supply the stated power output for the duration of the peak period. Steam units and combustion turbines may have capabilities greater in winter than in summer, in those locations where the ambient temperature is significantly lower in winter than in summer. 


\section{CAPACITY}

- the load for which a generating unit is rated. That is, the load which a unit has been designed to supply under strictly specified conditions relating to height above sea level, ambient temperature, cooling water temperature, fuel type and characteristics, condition of heat transfer surfaces, power factor, duration and constancy of the load to be carried and possibly other factors. This is a nominal value that may not correspond exactly to "capability". In general discussions of the ability of a system to supply electric power, "capacity" and "capability" are frequently used interchangeably. The magnitude of the difference between "capability" and "capacity" is usually not great.

\section{CAPACITỸ (INOPERARLE)}

- capacity which could not be operated for the period specified because of lack of fuel, lack of personnel, becauce it is in deactivated shut-down status or for similar reasons. This category does not include forced or scheduled outages.

\section{CAPACITY FACTOR}

- the ratio of the average demand on a machine or ecuipment for the period of time considered, to the capacity rating of the machine or equipment. The meaning can be extended to a plant or a system.

\section{DEMAND}

- the rate at which electric energy is delivered tu oi by a system, part of a system, or piece of eouipment, expressed in kilowatts or other suitable unit, at a given instant or averaged over any designated period of time.

Coincident Demand--any demand that occurs simultaneously with any other demand; also the sum of any set of coincident demands.

Instantaneous Demand--the demand at any instant, usually determined from the reading of an indicating or recording instrument.

Integrated Demand--the demand averaged over a specified period, usually determined by an integrating demand meter or by the integration of a load curve. 
Peak Demand--the greatest of a particular type of demand occurring within a specified period.

Noncoincident Lemand--the sum of the individual maximum demands regardless of time of occurrence within a sfecified period, usually not more than 1 year.

\section{EEMAN!E INTERVAL}

- the period of time during which the electric energy flow is averaged in determining demand, such as 60-minute, 3p-minute, or instantaneous.

\section{DISTRIIEUUTION_S SYSTIEM}

- that portion of an electric system used to deliver electric energy from points on the transmission or hulk fower system to the consumers.

\section{EIVEEESITY}

- the ratio of the sum of the noncoincident maximum demands of the various subdivisions of a system, or part of a system, to the maximum coincident demand of the whole system, or part under consideration.

\section{EIVEERSITIY, LIOAD}

- the difference between the peak of coincident and noncoincident demands of two or more individual loads.

Seasonal Diversity--load diversity between two (or more) electric systems which cccurs when their annual peaks are in different seasons of the year.

Time Zone Liversity--ioad diversity between electric systems in different time zones resulting from the tine difference as it affects the demanos for power.

\section{ELEECTRIC $R E$ REION}

- A subarea of a Reliability Council area. The 29 Electric Regions in the Contiguous U.S. (plus one for Alaska) were established. by ERA for the furposes of the Fuel Use Act and have proven useful for analyses of electric power supply adequacy and reliability.

\section{ELECTRIC SYSTEM}

- physically connected electric generating, transmission, and distribution facilities operated to provide electricity to customers. The facilities need not be all 
under control of a single organization, as the term is used in this report. Thus, for the purposes of this report the Detroit Edison Company is a system, Consumers Power Company is a system and the two together comprise a system. The term "utility" or "electric utility" is used in this report to describe a system under single control, whether privately-owned, publicly-owned or cooperatively-owned. Thus, the Los Angeles Department of Water and Power, a municipal organization, is an electric utility, as are the Tennessee Valley Authority, the Power Authority of the State of New York and the Louisville Gas \& Electric Company, for example. The Tristate G.\& T. Association, Inc., is also a system and an electric utility in the sense that those.terms are used in this report.

\section{ENERGY}

- that which does or is capable of doing work. It is measured in terms of the work it is capable of doing; clcctric energy is usually measured in kilowatt-hours or megawatt hours.

Economy Energy--electric energy produced from a source in one system and substituted for energy that would otherwise have been produced by a less economical source in another system.

Interchange Energy--electric energy received by one electric utility system in exchange for energy delivered to the other system at another time or place. Interchange is to be distinguished from a direct furrhase or sale, although energy balances accumulated under interchange agreements are süretres setlled for in caeh.

Net Energy for system--the electric energy requirements of a system, including losses, defined as: (i) net generation of clle system, pluc (2) energy received from others, less (3) energy delivered to other systems for resale.

Off-Peak Energy--electric energy supplied during periods of relatively low system demands as specified by the supplier.

On-Peak Energy--electric energy supplied during periods of relatively high system demands as specified by the supplier.

LOAD

- the amount of electric power demanded at a given point or from a given system. 
Base Load--the minimum load in a stated period of time.

Connected Load--the sum of the ratings of the electric power consuming apparatus connected to the system, or part of the system, under consideration.

Intercuptible Load--electric load which may be curtailed at the supplier's discretion, or in accordance with a contractual agreement.

Peak Load--the maximum load in a stated period of time.

Plant Factor--the ratio of the average demand on a power plant for the period of time considered to the aggregate rating of all the generating eơuipment installed in the plant.

LOSS

Electric system Loss--total electric energy loss in the electric system. It consists of transmission, transformation, and distribution losses, and unaccounted-for-energy-losses between sources of supply and points of delivery.

Energy Loss--the difference between energy input and output as a result of transfer of energy between two points.

Line Loss--energy loss and power loss on a transmission or distribution line.

No-Lodd-Loss--power and energy losses in an electric system, or portion thereof, when energized at rated voltage and frequency, but not supplying load.

\section{NETWORK}

- a system of transmission or distribution lines so connected and operated as to permit multiple power supply to any principal point on it.

\section{NUCLEAR REACTOR}

- an apparatus by means of which a fission chain reaction can be initiated, maintained, and controlled. Its essential component is a core with fissionable fuel. It usually has a moderator, reflectors, shielding, and control mechanisms. 
OUT'AGE

- the out-of-service condition of a generating unit, transmission line, or other facility.

Forced Cutage--the shutdown of a generating unit, transmission line, or other facility, for emergency reasons. The nature of the emeraency is such that the shutdown must be effected immediately or not later than the very next weekend.

Scheduled Outage (maintenance)--the shutdown of a generating unit, transmission line, or other facility, for inspection or maintenance, in accordance with an advance schedule. The shutdown may be postponable within certain limits.

HEAT RATE

- a measure of generating station thermal efficiency, generally expressed as BTU per net kilowatt-hour. it is computed by dividing the total BTU content of the fuel burned (or of heat released from a nuclear reactor) by the resulting net kilowatt-hours generated.

\section{INTERCONNECTION}

- a transmission line, transformer or other device or equipment permitting a flow of energy between the facilities of two electric systems.

Emergency Interconnection--an interconnection established to meet an emergency need.

INTERTIE--same as INTERCONNECTION.

GENERATING UNIT

- an electric generation together with its prime mover.

\section{GENERATION}

- the act or process of producing electric energy from other forms of energy; also the amount of electric energy so produced.

Gross Generation--the total amount of electric energy produced by a generating station or stations, measured at the generator terminals.

Net Generation--gross generation less plant use. 
Nonutility Generation--generation by producers havina generating plants for the purpose of supplying electric power required by their own industrial, commercial, or military operations.

Utility Generation--generation by electric systems engaged in the business of selling or supplying electric energy for use by the general public.

POWER

- the time rate of transferring energy. The term is frequently used in a broad sense, as a commodity of capacity and energy, having only general association with the scientific meaning.

Electric Power--a term used in the electric power industry to mean inclusively power and energy.

Interruptible Power--power made available under agreements which permit curtailment or cessation of delivery by the supplier under conditions specified in the agreement.

POWER PLANT

- A location at which one or more generating units are located.

Base Load Plant--a power plant which is normally operated to provide base load and which, consequently, operates at essentially a constant load.

Fossil-Fuel Plant---an electric power plant utilizing fossil fuel, such as coal, lignite, oil or natural gas, as its source of energy.

Hydroelectric Plant--an electric power plant utilizing falling water for the motive force of its orime movers.

Nuclear Power Plant--an electric generating station utilizing the energy from a nuclear reactor as the source of power.

Peak Load Plant--a power plant which is normally operated to provide power during maximum load periods.

Power Plant (Generating Station)--a generating station at which are located prime movers, electric generators, and auxiliary equipment for producing electric energy. 
Pumped Storage Plant--a power plant utilizina an arranqement wher eby electric energy is cienerated for Deak. load use, by utilizing water pumped into an elevated storage reservoir usually during off-peak periods.

Run-of-River Plant--a hydroelectric power plant utilizing the flow of the stream as it occurs.

Steam-Electric Plant--an electric power olant utilizina steam for the motive force of its orime movers.

RESERVE MARGIN

- as used in this rebort, "Peserve Margin" is the difference between system capability at the time of peak demand and the system peak demand. When this difference is expressed as a percentage of the peak demand, the margin is called "Percent Reserve". The summer reserve margin and the winter reserve margin usually are different. When "Reserve Margin" or "Percent Reserve" are used without being qualified, the reference is to "Installed Feserve" (also called "planned Reserve" in this report), meaning the difference between the sum of the capabilities of all units on the system, including those temporarily inoperable, and the system peak demand.

\section{RESERVE (OPERATING)}

- generating capacity (or capability) that can be made available to take load within a short time. The time limitation is usually stated to be "ten minutes or less" but in some instances miy he as much as one-half hour. "Operating Reserve" consists of "Spinning Reserve" and "Non-Spinning Reserve". The Soinning Rcccrve, as defined above, is in operation and is connected to the bus. The Non-Spinning Reserve is cabability that can be started, connected to the bus and loaded within the specified time limitation.

\section{RESERVE (SPINNING)}

- generating capacity (or capability) connected to the bus and ready to take load. This includes the capability of units running unloaded and the capability available in units that are loaded to less than their capability and which can be loaded further.

\section{RESERVE (PLANNED)}

- the reserve which is planned for a given peak load period. It includes allowances for all foreseeable continqencies affecting capacity. 
RESERVE (ACTUAL)

- the actual reserve at time of peak demand after deduction of all foreseeable cabacity contingencies.

RESERVE (COLD)

- generating capability that requires several hours, or possibly a day, to bring into operation.

RESERVE (DE-ACTIVATED)

- generating capability which will take several weeks at best to become operable. This is capability that a system does not expect to operate under normal conditions because it is obsolescent, inefficient, may violate environmental quality restrictions, may require extensive maintenance, may require fuel not readily available, or for other reasons.

RESERVE (AVAILABLE)

- this is a term that has been developed in the course of preparation of this report, intended to take into account the effect of scheduled maintenance and orobable forced outages on installed capability. It is the installed (planned) reserve margin less the capability that is inoperable because of forced outages, maintenance work or other reasons, olus the net of imports less exports, at the time of system peak (summer or winter) demand. "Available Reserve" is intended to be the difference between system capability actually available to meet peak demand, and peak demand.

\section{WATER CONDITIONS}

- Adverse Water Conditions--water conditions which limit the output of hydroelectric generating units because of insufficient water supply or reducer head. Insufficient water supoly may be due to low precipitation, diversion of water for nurposes other than power production or other reasons. The availability of water under adverse conditions is usually determined from analysis of historical studies extending over a long period of years. Adverse conditions may also result from reduced net head caused by high water on the downstream side of a plant.

- Average Water Conditions--conditions of precinitation and runoff which provide water for hydroelectric plants approximating the average amount and distribution available over a long time perion, usually the period of record. 
THEFMAL

- a term used to identify a type of electric aenerating station or power plant, or the capacity or cabability thereof, in which the source of energy for the prime mover is heat. The heat may be obtained from combustion of coal, oil, gas, waste or other material, from geothermal sources (heat from the earth's core) or from nuclear fission or other nuclear process. Heat for electric generation may also be obtained from solar radiation, but generation using that source is usually referred to as one of the types of "solar energy".

\section{TRANSMISSION}

- the movement or transfer of electric energy in bulk. Ordinarily the transmission movement is considered to end when the voltage level of the energy is transformed for distribution to ultimate corisumers. The term is also used to refer to the aggregate of system tranemission facilities.

Transmission Line Capacity--the maximum continuous rating of a transmission line. The rating may be limited by thermal considerations, capacity of associated equioment, voltage regulation, system stability or other factors.

Transmission System-an interconnected aroup of electric transmission lines and associated equioment for the movement or transfer of elcctric energy in bulk between oinls of supply and mintr. at which it is transformer for delivery to ultimate consumers, or is delivered to electric systems of others. 


\section{The Reliability Councils}

The Regional Electric Reliability Councils were established during the period 1963 through 1969, first as twelve groups and ultimately, through consolidation, to the present nine. Each Council is a voluntary association of electric utilities in a geographic area of the United states defined mainly by historic operating practices and patterns of interconnection growth. The nine councils together, covering the contiguous united states, comprise the National Electric Reliability Council (NERC).

The Regional Councils and the National Council are industry organizations, with no connection to the Federal, state or local governments. All operations of the councils are financed by assessments on the utility members.

Annually on April 1 each Regional Council provides a report to the Economic Regulatory Commission (ERA) summarizing the coordinated plans and forecasts of the regional utilities for a ten-year advance period, with additional load and capacity forecasts for a further ten-year period. The National Council usually publishes a summary and review of the nine Regional Council reports.

A detailed review of the history, structure and functions of the Reliability Councils is provided in Appendix $A$ of the ERA report "Electric Power Supply and Demand 1979-1988 for the Contiguous United States", published December 1979. 


\section{DEPARTMENT OF ENERGY - ENERGY INFORMATION ADMINISTRATION}

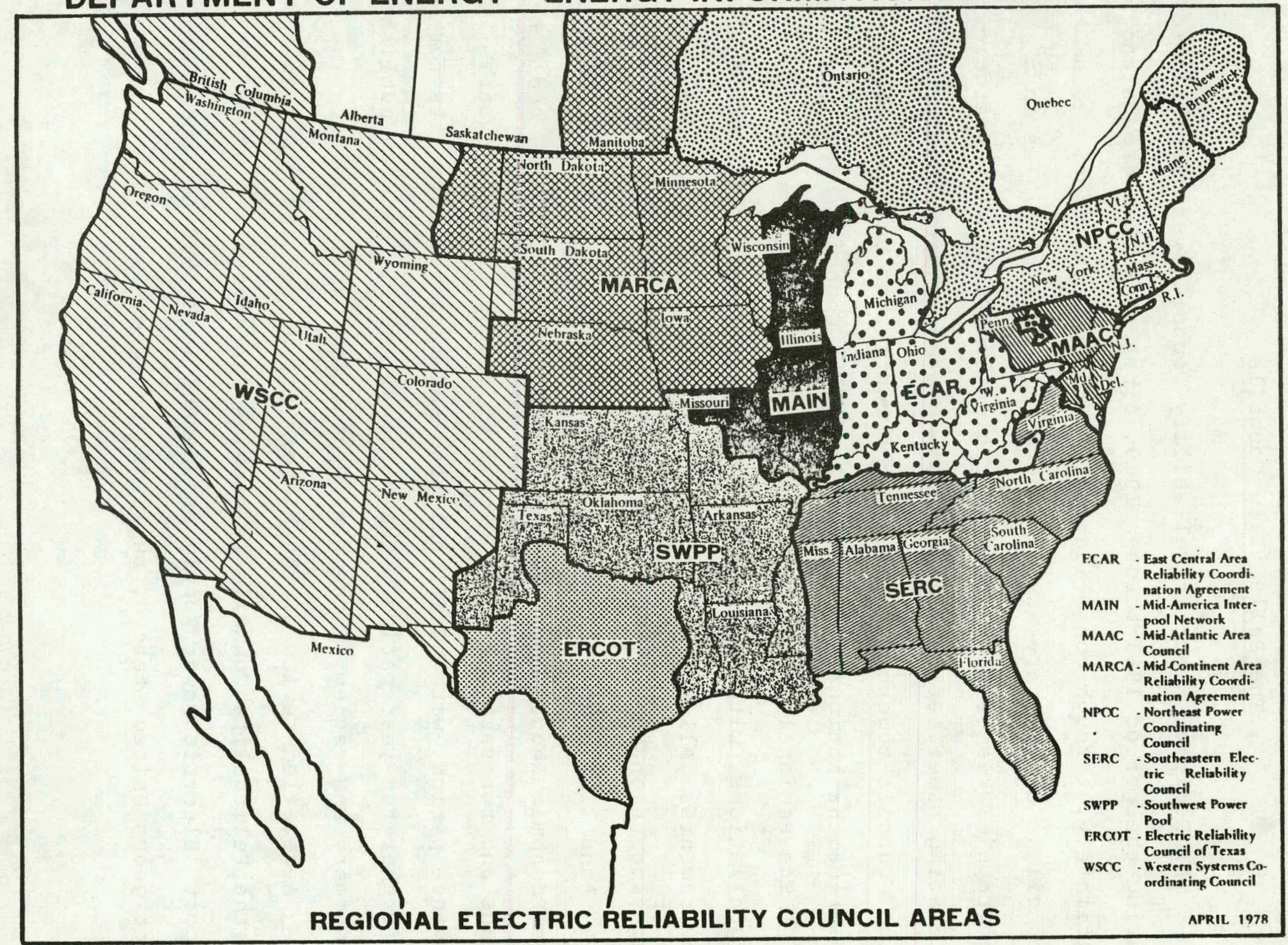

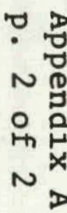




\section{APPENDIX B}

\section{Utilities Included In This Report}

The Feliability council member utilities, and other utilities for which data have been included in this report, are tabulated on the following pages. The lists have been produced from the April 1, 1980, Coordinated Bulk Power supply programs of the nine Regional Reliability Councils. 
Bulk Power membership currently consists of 26 companies ( 1.9 systems) as follows:

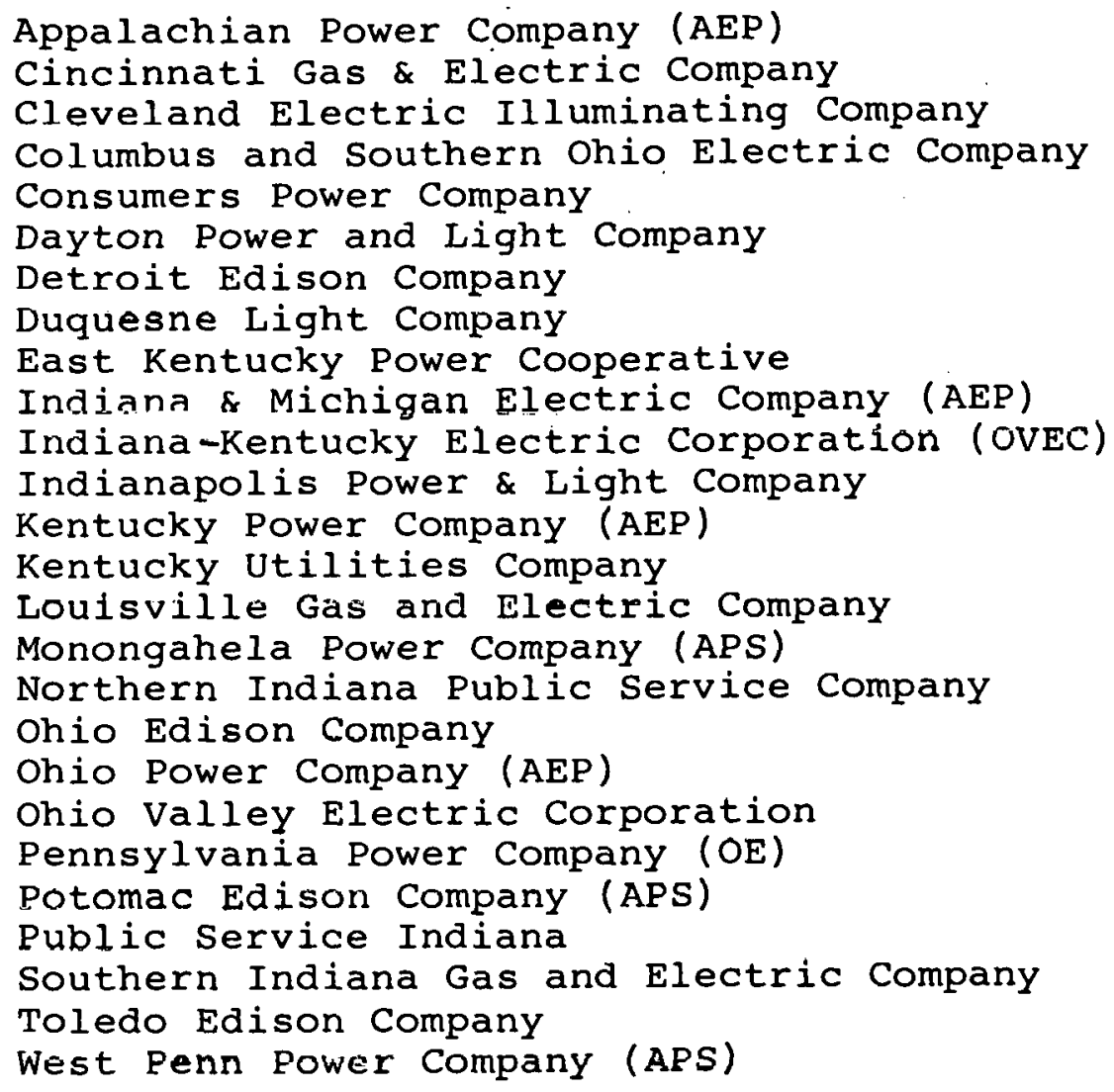

The ECAR Liaison system membership currently consists of the following systems:

Big Rivers Electric Corporation Buckeye Power, Incorporated City of Cleveland - Vivision of Light and Power City of Detroit - Public Lighting Department Edison Sault Electric Company Hamilton Department of Public Utilities - Electric Div. Henderson Municipal Power \& Light Hoosier Energy Division of Indiana Statewide REC, Inc. Lansing Board of Water and Light 
Michigan Municipal Cooperative Pool Conalco

Grand Haven Board of Light \& Power

Hart Hydro Electric

Lowell Light \& Power

Northern Michigan Electric Coop., Inc.

Traverse City Light \& Power Department

Wolverine Electric Cooperative

zeeland Board of public Works

Owensboro Municipal utilities

Richmond power and Light

wabash Valley Power Association 
City of Austin Electric Utilities

City of Erownsville

Central power \& Light Company

Callas Power \& Light Company

Houston Lighting \& Power Company

Lower Colorado River Authority

rity of San Antonio Public service

South Texas and Medina Electric Cooperative, l'ool

South Texas Electric Cooperative, Inc.

Medina Electric Cooperative, Inc.

Texas Electric Service Company

Texas Power \& Light Company

Texas Utilities Company system, Comprising

Dallas Power \& Light Co., Texas Power \& Light Co. and Texas Electric service Co.

Texas Municipal Power pool

City of Bryan

Brazos Electric Power Cooperative, Inc.

City of Denton

City of Garland

city of Greenville

west Texas Utilities company 
MID-ATLANTIC AREA COUNCIL (MAAC)

\section{PJM}

Atlantic City Electric Company

Baltimore Gas and Electric Company

Delmarva Power \& Light Company

* Jersey Central Power \& Light Company

* Metropolitan Edison Company

* Pennsylvania Electric Company

Pennsylvania Power and Light Company

Philadelphia Electric Company

Potomac Electric Power Company

Public Service Electric \& Gas Company

UGI Corporation

\section{Associates}

Allegheny Electric Cooperative

representing the Pennsylvania and

New Jersey Cooperatives

The Easton Utilities Commission

representing the Maryland Municipals

The City of Vineland Electric Utility

representing the New Jersey Municipals

The City of Dover representing the

Delaware Municipals

* Subsidiaries of the General Public Utilities Corporation 
The Mid-America Interpool Network (MAIN) was formally organized in November 1.964 to promote maximum coordination of planning, construction, and utilization of generation and transmission facilities of its members in order to improve the reliability of electric bulk power supply in the Middle West.

Regular membership is open to any power supplier who has a high capacity interconnection (115 kV or above) with a regular member and whose operations have a significant effect on the reliability of the interconnected system of the region. MAIN's regular membership is presently composed of investorowned, rural cooperative and municipal power suppliers. The members are arranged in geographical groups to expedite operation of the council. The regular members and the group assignments are:

Groups

Commonwealth Edison

Illinois Group

Missouri Group

Wisconsin-Upper Michigan Systems (wUMS) Group

\section{Members}

Commonwedth Edison Company

Central Illinois Light Company Central Illinois Public Service Company* Illinois Power Company* City water, Light \& Power, Springfield, IL Southern Illinois Power Cooperative

Associated Electric Cooperative, Inc. Union Electric Company*

Madison Gao and Electric Company Wisconsin Electric Power Company system Wisconsin Power and Light Company Wisconsin Fublic Service Corporation Upper Peninsula Power Company

*Illinois-Missouri Pool

Associate membership is open to municipal or other small electric systems operating in the MAIN region, but not eligible for regular membership because their operations do not have a significant effect on the reliability of the interconnected system of the region. The associate members are:

Groups

Illinois Group

Wisconsin-Upper Michigan Systems (WUMS) Group
Associate Members

Association of Illinois Electric Cooperatives Western Illinois Power Cooperative, Inc. Soyland Power Cooperative

Municipal Electric Utilities of Wisconsin 
This report includes information for member systems of MAIN and for other systems in the MAIN region with generation of $25 \mathrm{MW}$ or more: Some non-member systems meeting this limitation did not submit information.

Associated Electric Cooperative has membership in both MAIN and the Southwest Power Pool (SPP); agreement has been reached for Associated to report through MAIN. I/

The power suppliers included in this report are:

\section{Illinois}

Central Illinois Light Company Central Illinois Public Service company City Water, Light \& Power, Springfield Commonwealth Edison Company Illinois Power Company Southern Illinois Power Cooperative Western Illinois Power Cooperative, Inc. Soyland Power Cooperative Village of Winnetka Rochelle Municipal Utilities

\section{Missouri}

Associated Electric Cooperative, Inc. City of Columbia, Missouri Union Electric Company

\section{Wisconsin-Upper Michigan}

Madison Gas \& Electric Company Upper Peninsula Power Company Wisconsin Electric Power Company system Wisconsin Power and Light Company Wisconsin Public Service Corporation Kaukauna-Menasha Interconnected Systems City of Manitowoc City of Marquette City of Marshfield

1/ As of June 1, 1980, Associated will drop its membership in - MAIN and will report through Southwest Power Pool. 
MID-CONTINENT AREA POWER POOL (MAPP) MEMPERS

Easin Electric Power Cooperative

Cooperative Power Association

Dairyland Power Cooperative

Eastern Iowa Light and Power Cocperative

Heartland Consumers Power District

Interstate Power Company

Iowa Electric Light and Power cooperative

Central Iowa power Cooperative

Iowa-Illinois Gas and Electric Company

Iowa power and Light Company

Iowa public service company

Corn Belt Power Cooperative

Iowa southern Utilities Company

Lake superior District Power Company

Lincoln Electric system

Minnesota Power \& Light Company

Minnkota Power Cooperative, Inc.

Missouri Easin Municipal Power Agency

Montana-Dakota Utilities co

Muscatine Power and water

Nebraska Public Power District

Northern states Power Company

Northwest Iowa Power Cooperative

Northwestern Public Service Company

Omaha Public Power District

otter Tail power Company

Inited Power Association

Western ARea Power Administration - Billings Area 
NORTHEAST POWER COORDINATING CCUNCJL (NPCC)

New England Power Pool (NEPOCI)

System Identification

(1) Bangor Hydro Electric Company

Eoston Edison Company

Braintree Electric Light Department

Burlington Electric Department

Cambridge Electric Light Company

Canal Electric

Central Maine Power Company

Central Vermont Public service Corporation

(1) Chicopee Electric Light Department

(1) Citizen's Utilities

Cunnecticut Light \& Power Company

Connecticut Yankee Atomic Power Company

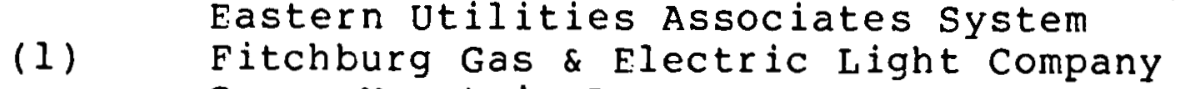

Green Mountain Power

Hartford Electric Light Company

(1) Holyoke Gas \& Electric Department

Holyoke water power Company

(1) Hudson Light \& Power Department

(1) Ifswich Municipal Light Department

Maine Electric Power Company

(1) Maine Public service Company

Maine Yankee Atomic Power Company

Mass. Municipal Wholesale Electric Company

(1) Marblehead Municipal Light Department

Montaup Electric Company

New Bedford Gas \& Edison Light Company

New England Electric System

New England Gas \& Electric Association.

(1) Newport Electric Corporation

Northeast Utilities

(1) Norwalk, Second Taxing District

(1) Norwich, City of

(1) Peabody Municipal Light Department

Public Service Company of New Hampshire

(1) Shrewsbury Electric Light Department

(1) Taunton Municipal Light Department

United Illuminating Company

Vermont Group

(1) Vermont Yankee Nuclear Power Corp

Western Massachusetts Electric Company

Yankee Atomic Electric Company

(1) Non-Member of NPCC 


$$
\begin{gathered}
\text { NPCC (Cont.) } \\
\text { New York Power pool (NYPP) }
\end{gathered}
$$

System Identification

Central Hudson Gás \& Electric Corporation Consolidated Edison Company of New York, Inc.

(1)

(1) Village of Freeport Jamestown Municipal Electric system Long Island Lighting Company New York State Electric \& Gas Corporation Niagara Mohawk Power Corporation

(1) Orange and Rockland Utilities, Inc. City of Plattsburgh Power Authority of the state of New York Rochester Gas and Electric Corporation

(1) Non-Member of NPCC 


$$
\text { (SERC) }
$$

\section{FLORIDA SUBREGION}

Florida Power Corporation

Florida Power \& Light Company

Fort Pierce Utilities Authority

City of Gainesville

City of Homestead

Jacksonville Electric Authority

Lake Worth Utilities Authority

City of Lakeland

New Smyrna Beach Utilities Commission

Orlando Utilities Commission

Sebring Utilities Commission

Seminolc Electric Cuuperative

Southeastern Power Administration

City of Tallahassee

Tampa Electric Company

City of Vero Beach

\section{SOUTHERN COMPANIES SUBREGION}

Alabama Electric Cooperative, Inc.

Alabama Power Company

Crisp County Power Commission

Georyia Power company

Gulf Power Company

Mississippi Power Company

Savannah Electric \& Power Company

Southeastern Power Administration

South Mississippi Electric Power Assn.

\section{TENNESSEE VALLEY SUBREGION}

Nantahala Power \& Light Company

Tapoco, Inc.

Tennessee Valley Authority

VIRGINIA - CAROLINAS SUBREGION

Carolina Power \& Light Company

Duke Power Company

South Carolina Electric \& Gas Company

South Carolina Public Service Authority

Southeastern Power Administration

Virginia Electric \& Power Company

Yadkin, Inc. 
SOUTHWEST POWER POOL.

(SPP) Or (SWPP)

SEPF $=$ GFOUF $A$

Arkansas Electric Cooperative corporation

Cajun Electric Power cooperative, Inc.

Central Louisiana Electric company, Inc.

Gulf states Utilities Company

Middle South Utilities, Inc.

Arkansas Power \& Light Company

Arkansas-Missouri Power Company

Louisiana Power \& Llyht Cumpany

Mississippi Power \& Light Company

New orleans public service Inc.

City of Ruston, Louisiana

Greenwood Utilities

$\underline{S P P}-\underline{G R O U P} \underline{P}$

Grand Piver Dam Authority

Oklahoma Gas and Electric Company

Public Service Company of Oklahoma

Southwestern Electric Power Company

Southwestern Power Administration

Southwestern Public service Company

western Farmers Electric Cooperative

$\underline{S P P-G R O U P C C}$

Eoard of Public Utilities, Kansas City, KA

Central Kansas power Company, Inc.

Chanute Municipal utilities

Coffeyville Municipal Water \& Light Department

City Power \& Light, Iudejendence, Mo

The Empire nistrict Electric Company

Kansas City Power \& Light Company

Kansas Gas and Electric Company

The Kansas Power \& Light Company

Missouri Public Service Company

St. Joseph Light \& Power Company

Sunflower Electric Cooperative

Winfield Municipal Light \& Water

Western Power Division - Central Telephone \& utilities Corp. 
$\underline{S P P}-$ GROUP $D$

City Utilities, springfield, MO

SPF - GROUP E (Non-Members)

Ponca City (OK) Water \& Light

Jonesboro (AR) City water \& Light

This report includes data from 33 of SPP's 41 member systems. By prior arrangement, the following members have submitted their adid to the councils indicated:

Associated Electric Cooperative, Inc. $(\text { MAIN })^{\underline{I} /}$

Missouri Utilities Company

(MAIN)

Missouri Power \& Light Company

(MAIN)

Missour ị Edison Company

(MAIN)

West Texas Utilities company

(ERCOT)

1/ Transferred to SPP as of June 1, 1980 
WESTERN SYSTEMS COORDINATING COUNCIL

$$
\text { (WSCC) }
$$

MEMEER SYSTEMS (47)

Arizona Electric Power Cooperative, Inc.

Arizona Power Authority

Arizona Public Service Company

Black Hills Power \& Light Company

Eonneville Power Administration

British Columbia Hydro \& Power Authority (Canadian System)

Calgary Power Ltd. (Canadian System)

Colorado springs, City of

Colorado-Ute Electric Association; Inc.

Corps of Engineers (North Pacific vivision)

Department of Water Resources/California

EL Paso Electric Company

Eugene water \& Electric Board (Oregon)

Glendale Public Service Department

Idaho Power Company

Los Angeles Department of Water and Power

Metropolitan water District/Southern California

Montana Power Company, The

Nevada Power Company

Pacific Gas \& Electric Company

Pacific Power \& Light Company

Pasadena, City of

Plains Electric Generation and Transmission Cooperative, Inc.

Platte River Power Authority

Portland General Electric Company

Public service Company of Colorado

Public service Company of New Mcxico

PUD No. 1 of Chelan county

PUD No. 1 of Cowlitz County

PUD No. 1 of Douglas County

PUD of Grant County

Puget Sound Power \& Light Company

Sacramento Municipal Utility District

Salt River Project

San Diego Gas \& Electric Company

Seattle Department of Lighting (seattle City Light)

Sierra Pacific Power Company

Southern California Edison Company

So. Colorado Power Division, Central Tele. \& Util. Corp.

Tacoma Department of Public Utilities (Tacoma City Light)

Tri-state G\& T Association, Inc.

Tucson Electric Power Company

Utah Power \& Light Company

washington water Power Company, The

Water and Power Resources Service

(Denver Federal Center)

(Lower Colorado)

(Lower Missouri)

(Mid-Pacific)

(Southwest)

(Upper Colorado)

(Upper Missouri)

(Pacific Northwest) 
West Kootenay Power \& Light Company (Canadian System) Western Area Power Administration

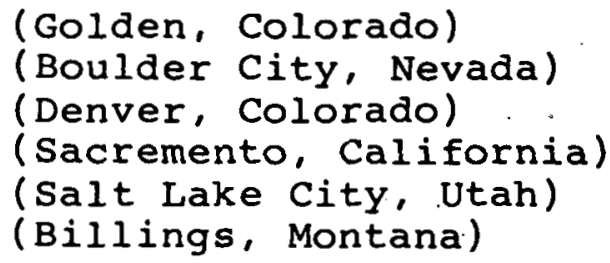

\section{AFFILIATE MEMBERS (14)}

Anaheim, City of

Bountiful City Light and Power

Electrical District No. 2, Coolidge, Arizona

Garkane Power Association, Inc.

Lamar Utilities Board (City of Lamar)

Lodi, City of

Navajo Tribal Utility Authority

Northern California Power Agency

Palo Alto, City of

PUD of Clark County, Vancouver, Washington

Redding, City of

Riverside, City of

st. George, City of

Santa Clara, city of 


\section{PAFTICIPANTS IN THIS FEFCRT}

This report has been prepared by personnel of the Power supply Planning Branch, Division of Power Supply and Reliability. All references to "Staff" mean the personnel of the washington Office of the Branch. The Electric Region Analyses of section $X I$ were prepared by personnel of the Division's Field cffices and were reviewed by hashington office staff. Fach Field office was assigned a Reliability Council area and the Flectric Regions within that Council, according to the following schedule:

$\begin{array}{cl}\text { Atlanta, Ca. (SERC) } & \text { William F. Scott } \\ & \text { Thomas R. Hitz, Jr } \\ \text { Chicago, Ill. (ECAR, } & \text { Herbert R. Rinder } \\ \text { MAIN, MARCA) } & \text { Harold H. Krefft } \\ \text { Fort Worth, TX. } & \text { Johnny Ray Johnson } \\ \text { (ERCOT, SWPP) } & \text { Raymond P. Mullikin } \\ \text { New York, N.Y. } & \text { Gilbert J. Cigal } \\ \text { (ECAE, MAAC, NPCC) } & \text { Vincent Hom } \\ & \text { Jonds Rarish } \\ \text { San Francisco, Cal. } & \text { Robert Van Slambrook } \\ \text { (WSCC) } & \text { Melvin L. Cone } \\ & \text { Donald Rushton }\end{array}$

Sections I through IX (except for part 2 cf section VII) were prepared by Norton Savage with the assistance of John Emami and Samuel J. Ferraro, Jr. Section $X$ is mainly the work of Samuel J. Ferraro, Jr. Fart 2 of Section VII is the work of Anthony $J$. Como and Clark spitler. Peviews of the Regional analyses Freparea by the Field offices were accomplished by Anthony $J$. Como, Clark Spitler and John Emami with assistance from $M_{i}$ ichael Sheehan. Anthony J. Como was responsible for liaison between the Field offices and the Washington office and for coordination of the regional analyses.

Direct responsibilicy for organization and completion of the report was given to William Graban, Chief of the Power Supply Planning Branch. Over-all review of the document on behalf of the Division Director was undertaken by Phillif Layfield, Assistant to the Division Director. Ceneral managerial responsibility for scope, focus, contents and work assignments was exercised by Richard F. Weiner, Director of the rivision of Fower supply and Reliability.

Skilled assistance in the onerous task of typing and re-typing the text and the many tabular presentations was provided by the secrecarial personnel of the Livision: Theresa Eiser, Elnora Douglas, 
Joan Hairston, Ruby Randall, Mary Rivers, Jeanne Posar and Debbie Bezanson. The help of the following secretaries in other groups within the Economic Regulatory Administration, is also gratefully acknowledged: Margaret Blackledge, Diane Davis, Shirley Fitzgerald, Alice Latter, Beverly Montgomery, Jill Ruoff, Helen Shamwell, and Donna Williams. Appreciation is also expressed to Ingrid Springer and Judith L. Wood of EIA for their dedicated work in typing the numerous orafts and revisions of this report.

Jerry L. Pfeffer

Assistant Administrator

Office of Utility systems 
XI.1.1

SECTION XI.I

EAST CENTRAL AREA RELIABILITY COORDINATION AGREEMENT (ECAR) 
The East Central Area Reliability Coordination Agreement (ECAR) was consummated January 14, 1967. This agreement created an organization, the purpose of which is to augment reliability of bulk power supply through coordination of planning and operation of generation and transmission facilities in the East Central area. The ECAR area covers all or portions of nine states: Indiana, Kentucky, Maryland, Michigan, Ohio, Pennsylvania, Tenneseae, Virginia, and West virginia.

The bulk power membership currently consists of 26 companies (19 systems); 25 are investor-owned and 1 is a cooperative. They are as follows:

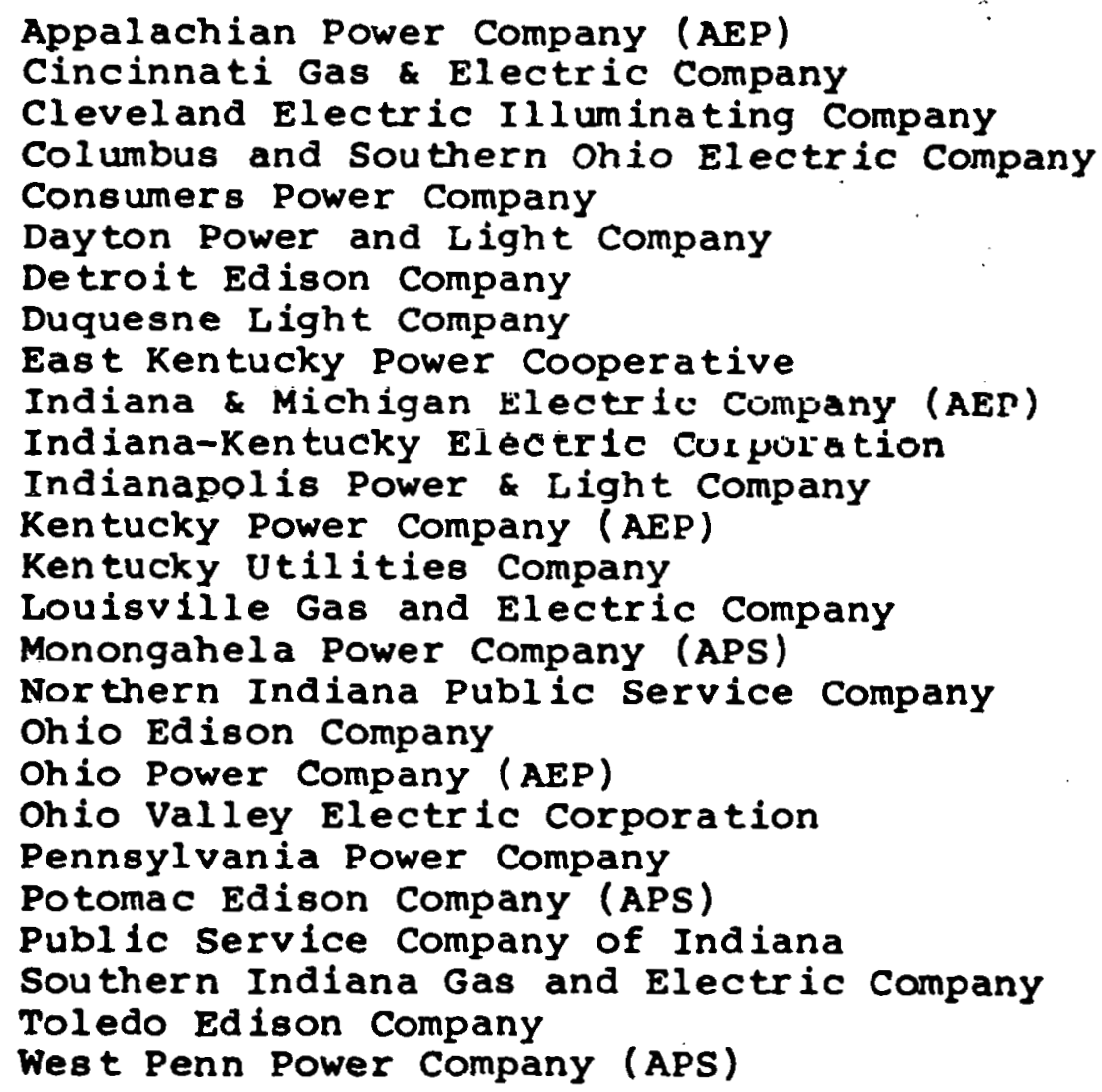


XI. 1.3

Seven power pooling groups are located within ECAR, and can be geographically grouped within the following Department of Energy/ Economic Regulatory Administration Electric Region boundaries:

Electric Region

1

2

13

14

15

16

18

\section{Identification}

Allegheny Power System (APS)

American Electric Power System (AEP)

Central Area Power Coordination Group (CAPCO)

Cincinnati, Columbus, Dayton Group (CCD) Kentucky Group

Indiana Group (includes all Indiana utilities

- except Indlana \& Michigan Electric Co.)

Michigan Electric Coordinated Systems (MECS)

The data and information included in the following sections include not only those of the power pool members within the Electric Regions, but also those of other electric systems which are within the region and report data to ECAR.

The Ohio Valley Electric' Corp. (OVEC) was orginally formed by a consortium of ten electric companies in ECAR to provide electric power to the Department of Energy Uranium Enrichment Plant at Portsmouth, Ohio. OVEC and its subsidiary Indlana-Kentucky Electric Corp. have two coalfired steam electric plants to supply the load. For the purposes of this report, the OVEC load and capacity are considered as separate entities, not assigned to an Electric Region but included in the total ECAR figures. 


\section{American Electric Power system (AEP) ELECTRIC REGION 2}

\section{Historical Perspective}

The American Electric Power System Region includes American Electric Power Company and Buckeye Power Inc. The American Electric Power Company is an electric utility holding company comprising seven wholly-owned subsidiary companies operating in parts of the seven states of Ohio, Indiana, Michigan, West Virginia, Virginia, Kentucky and Tennessee.

The principal operating companies comprising of AEP system arc: Ohio Power Company, Indiana \& Michigan Electric Company, Appalachian Power Company, Wheeling Electric Company, Kingsport Power Company, and Michigan Power Company. In adaltion, the American Electrir. Power service Corporation has been established, as a subsidiary of the AEP Company, to furnish engineering and other specialized services to the operating companies.

The American Electric Power system, while comprising the seven principal operating companies, functions as a single, integrated power system. Buckeye Power $c o$. is included. This objective is accomplished administratively by the fact that the president of the parent company is also the president of each of the operating subsidiaries as well as of the AEP Service corporation. In addition, the major Buckeye power plant output is dispatched by AEP. The centralized planning, engineering design, construction and operation of major generation and trarsmission facilities assures the most economic and reliable design and operation of the AEP region as an integrated unit. Furthermore, this arrangement permits coordination of load projections, planning for reserves, system stability studies, joint or staggered participation in facilities development, exchanges of capacity and energy, maintenance, and economic dispatch.

Operations of the intregrated system are coordinated from a single dispatch center located in Canton, Ohio.

The seven AEP operating companies in 1978 served almost 2 million customers, of which 1,750,000 were residential 204,000 commercial, 13,000 were industrial, and 9,000 others. Buckeye does not serve individual consumers directly. 
The AEP System though geographically spread out among seven states and seven companies, still is a highly integrated system with major transmission ties of $765 \mathrm{KV}, 500 \mathrm{KV}, 345 \mathrm{KV}$ and $138 \mathrm{KV}$. Many interconnections exist with ECAR systems and with the neighboring power pools of SERC, MAAC, and MAIN.

Buckeye Power Inc. is essentially an association of all of the electric cooperatives in the state of ohio. Its mission is to generate electric power for the State's Co-op customers. As such, Buckeye has generating facilities consisting of 2 units, a $630 \mathrm{MW}$ and a $600 \mathrm{MW}$ at the Cardinal electric generating plant. Also located at this plant is a third unit owned by Ohio Power Company, a subsidiary of American Electric Power Company. The station is managed and operaled by cardinal operating Company for the individual owners. Through an agreement between Buckeye and AEP, Buckeye is allowed to purchase power from ohio Power Company in the event that Buckeye's units are unable to satisfy the company's requirements. The agreement also provides for ohio Power to use excess generating capacity from Buckeye's Cardinal Plant units until the Buckeye load requirements grow to meet the plant capability.

The AEP region has historically been a winter peaking region. Shown below are the region's summer and winter peaks for the period 1977-1979.

TALBE 1B. 1

$\frac{\text { HISTORICAL PEAK DEMAND - MW }}{\text { AEP REGION }}$

Summmer

1978
1979

1979

\begin{tabular}{llll} 
June & July & Aug & Sep \\
\hline 10595 & $\frac{11735}{11025}$ & 1129 \\
11161 & $\frac{11494}{111421}$ & 11685 \\
10813 & 11568 & $\underline{11981}$ & $\frac{11236}{1123}$
\end{tabular}

Underline indicates seasonal peak
Winter

$\begin{array}{lll}\text { Dec } & \text { Jan } & \text { Feb } \\ 12457 & \frac{13192}{13913} \\ 12486 & \frac{13824}{13129} & 13773 \\ 13035 & 13571\end{array}$


The summer peak demands are highly dependent on climate conditions and are ter.ferature/humdity sensitive. In the three reported years the peak has occurred in three different months.

The winter peak usually occurs in January or February. A shift in the winter peak from these months is generally the result of a weather bias. There is occasionally some sensitively to unusual economic conditions in the region as well.

The following table shows generating capacity down for schedule maintenance performed each period and also the capability unavailable because of forced unit and partial unit outages.

\section{TARLE 1P. 2}

\section{SCHEDULED_MA INTENANCE $\overline{\mathrm{A}} \overline{\mathrm{E}} \overline{\mathrm{E}}-\overline{\mathrm{R}} \overline{\mathrm{E}} \overline{\mathrm{G}} \overline{\mathrm{I}} \overline{\mathrm{C}} \overline{\mathrm{N}}$}

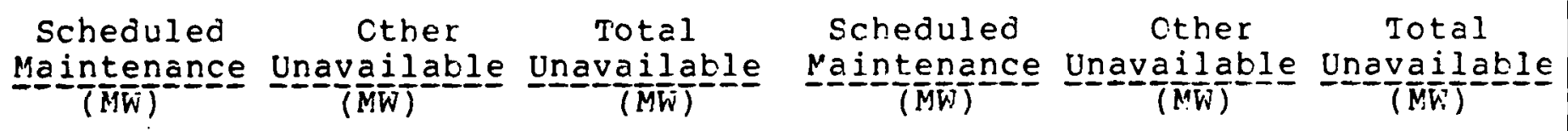

$\begin{array}{rll}350 & 1936 & 2286 \\ 1030 & 2390 & 3420 \\ 1898 & 1770 & 3668\end{array}$

2286

3668

295

189

1190
4418

2508

2773
4713

2697

3963

The percentage of installed capability that was unavailable for reasons other than scheduled maintenance varied from 9-12\% during 1977-1979 in the summer and from 13-248 in the winter. For the lst guarter of 1980 daily forced rates averaged about 138 .

The reserve margins for the 1977-1979 period are shown beluw. The table indicates the effects of scheduled maintenance and other outages. 
TABLE 1B. 3

\section{HISTORICA $\bar{L}$ SEASONAL RESERVES \\ AEP REGION}

\section{Summer}

\begin{tabular}{|c|c|c|c|c|c|c|c|}
\hline & $\begin{array}{c}\begin{array}{c}\text { Peak } \\
\text { Demand }\end{array} \\
M W\end{array}$ & $\begin{array}{c}\text { Total } \\
\text { Capability } \\
(M W)\end{array}$ & $\begin{array}{c}\begin{array}{c}\text { Total } \\
\text { Reserves }\end{array} \\
(8)\end{array}$ & $\begin{array}{c}\text { Capability } \\
\text { After } \\
\text { Maintenance } \\
(\mathrm{MW})\end{array}$ & $\begin{array}{l}\text { Available } \\
\frac{\text { Reserves }}{(8)}\end{array}$ & $\begin{array}{c}\text { Actual } \\
\text { Capability } \\
(M W)\end{array}$ & $\begin{array}{l}\text { Actual } \\
\frac{\text { Reserves }}{(q)}\end{array}$ \\
\hline $\begin{array}{l}1977 \\
1978 \\
1979\end{array}$ & $\begin{array}{l}11735 \\
11685 \\
11981\end{array}$ & $\begin{array}{l}15604 \\
18131 \\
18312\end{array}$ & $\begin{array}{l}33.0 \\
55.5 \\
52.8\end{array}$ & $\begin{array}{l}15254 \\
17101 \\
16414\end{array}$ & $\begin{array}{l}30.0 \\
46.7 \\
37.0\end{array}$ & $\begin{array}{l}13318 \\
14711 \\
14644\end{array}$ & $\begin{array}{l}13 \cdot 5 \\
26 \cdot 2 \\
22.2\end{array}$ \\
\hline \multicolumn{8}{|c|}{ Winter } \\
\hline $\begin{array}{l}1977 \\
1978 \\
1979\end{array}$ & $\begin{array}{l}13192 \\
13824 \\
13603\end{array}$ & $\begin{array}{l}18724 \\
18738 \\
18170\end{array}$ & $\begin{array}{l}41.9 \\
35.5 \\
33.6\end{array}$ & $\begin{array}{l}18429 \\
18549 \\
16980\end{array}$ & $\begin{array}{l}39.7 \\
34.2 \\
24.8\end{array}$ & $\begin{array}{l}14011 \\
16041 \\
14207\end{array}$ & $\begin{array}{r}6.2 \\
16.0 \\
4.4\end{array}$ \\
\hline
\end{tabular}

Winter actual reserves were adequate even considering the effects of scheduled and forced outages. Summer operating reserves were high but not excessive.

AEP's policy of large installed reserves of coal-fired generation is used to advantage by selling capacity to other utilities in the region.

Shown below are the energy requirements, summer and winter demands and annual load factors for the 1977-1979 period.

TABLE 1B. 4 HISTORICAL ENERGY, PEAKS AND LOAD FACTORS AEP REG ION

\begin{tabular}{|c|c|c|c|c|}
\hline & & sumer & Winter & $\begin{array}{l}\text { Annual } \\
\text { Load }\end{array}$ \\
\hline$\frac{\text { nergy }}{(\text { Gwh })}$ & $\frac{\text { Requirements }}{\text { (Growth-g) }}$ & $(\mathrm{MW}) \frac{\text { Peak Demand }}{\left(\mathrm{Growth}-\mathbf{q}^{\prime}\right)}$ & $(\mathrm{MW})$ Peak Demand & $\frac{\text { Factor }}{(8)}$ \\
\hline
\end{tabular}

$\begin{array}{llllcccc}1977 & 74203 & 2.6 & 11735 & - & 13192 & - & 64.2 \\ 1978 & 76143 & 4.3 & 11658 & (0.7) & 13824 & 4.8 & 62.9 \\ 1979 \quad 79420 & 3.5 & 11981 & 2.8 & 13603 & (1.6) & 66.6 \\ 8 \text { Growth } 1977-79 & 3.5 & & 1.0 & & 1.5 & \end{array}$


Energy requirements over the period 1977-1979 have grown at a compound rate of $3.5 \%$. This is higher than most other regions in ECAR and reflects AEP's geographical dispersal and diversity in sales, including sales to other utilities. It also is indicative of the economic stability in the service area.

Summer peak demand growth rates for 1977-1979 are considerably less than their tradition patterns. This is due in part to cool summers but mainly to conservation techniques and the increased cost of energy. Load factors were high, because. of AEP's large round the clock industrial load segment, and because of the greater growth of energy requirements in relation to demands.

\section{Current Perspective}

The projected 1980 summer and winter non-coincident peak demand requi rements are shown below.

$\frac{\text { PROJECTED } 1980 \frac{\text { TABLE 1B.5 }}{\text { SEASONAL PEAK DEMAND - MW }}}{\text { AEP REGION }}$

\begin{tabular}{|c|c|c|c|c|c|}
\hline \multicolumn{3}{|c|}{ Summer } & \multicolumn{3}{|c|}{ Winter } \\
\hline Tune & July & August & December & January & February \\
\hline
\end{tabular}

The summer demand is projected to be $16 \%$ less than the winter demand, which affords the opportunity for the performance of scheduled maintenance.

The 1980 winter installed capability of the AEP region is estimated to be $20031 \mathrm{MW}$ and the winter non-coincident AEP/Buckeye peak demand requirements are projected to be $14322 \mathrm{MW}$ excluding $315 \mathrm{MW}$ of AEP interruptible demand. After adjustments for scheduled receipts and.deliveries, net teserves aro 5566 or $33.8 \%$.

In the ECAR ERA-411 report for the future (1980-1989) AEP does not list inoperable capability either for scheduled maintenance or possible forced outages. However, ECAR provides an indication of scheduled maintenance for the entire region.

The estimate prepared for the 411 report, is based on the level of planned maintenance that is currently projected for the periods of heaviest load demand during the upcoming sumer and winter seaons, i.e., five percent of total installed capability during the summer of 1980 and five percent of total installed capability during the winter of 1980-1981. 
The summer and winter 1980 reserve margins for the AEP electric region are shown below.

TARLE IP. 6

$$
\begin{aligned}
& \text { 19요을 } \bar{E} \bar{S} \overline{\mathrm{E}} \overline{\mathrm{R}} \overline{\mathrm{V}} \overline{\mathrm{E}} \overline{\mathrm{S}} \overline{\mathrm{A}} \mathrm{RCINS*} \\
& \underline{A} \bar{E} \bar{P}-\bar{R} \bar{E} \bar{G} \bar{O} \bar{N}
\end{aligned}
$$

\begin{tabular}{|c|c|c|}
\hline Planned & Total & Available \\
\hline Reserves & Reserves & Reserves * * \\
\hline
\end{tabular}

SUMNER

$\begin{array}{llllll}6484 & 54.1 & 6590 & 55.0 & 5666 & 47.3\end{array}$

\begin{tabular}{|c|c|c|}
\hline Flanned & Total & Planned \\
\hline 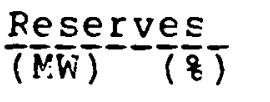 & $\left(\frac{R e}{M W}\right)=\frac{r v e s}{\left(\frac{e}{q}\right)}$ & 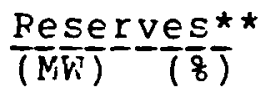 \\
\hline 5709 & 5566 & 4564 \\
\hline
\end{tabular}

WINTEP

* Eased on ERA Form 411

* * 58 of total installed capability assumed - from ECAR ERA-4li Refort of Scheduled Outages

The margins shown above have not been adjusted for unscheduled outages of generating equipment since the amount of these outages are generaliy unknown ahead of time, but have run as high as 248 in 1977. As previously indicated the recent experienced forced outage rate is about 138 . If these outages for 1980 do not exceed the maximum outages of the 1977-79 period, 128 of installed capacity during the summer period and $23 \%$ during the winter, the resultant available reserves would be 3450 or 28.88 for the summer, and (43) MW or $(-0.3)$ \& for the winter.

The winter $1980 / 81$ capability of the generating facilities installed in the AEP region will be $20031 \mathrm{MW}$. The capability breakdown by fuel types is shown below.

$$
\text { 1980/81 WINTER } \frac{T A R L E}{T} \bar{N} \frac{1 P}{T}-7
$$

Nuclear Coal Combustion Hydro Pumped Total

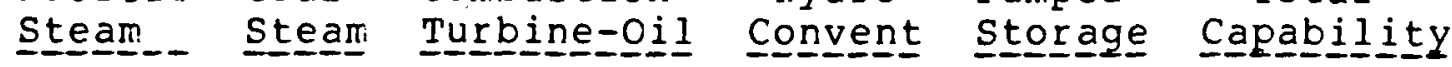

$\begin{array}{rrrrrrr} & 2105 & 17080 & 18 & 223 & 560 & 20031 \\ 8 \text { of Total } & 10.7 & 85.3 & 0.1 & 1.1 & 2.8 & 100.0\end{array}$


of the current capability, 858 is coal-fired-steam capability, 118 nuclear-steam, 3.08 pumped storage, 18 conventional hydroelectric and less than 0.18 is oil-fired combustion turbine. Included in the $1980 / 81$ capability are two units; Mountainer \# 1 a coal-fired unit $1300 \mathrm{MW}$ capability to be installed in December 1980 and Smith Mountain \#3 a pumped storage unit-100 MW capability to be installed in February 1980 but now delayed until 1981.

The projected 1980 energy requirements, summer and winter demand requirements and annual load factor for the region are shown below:

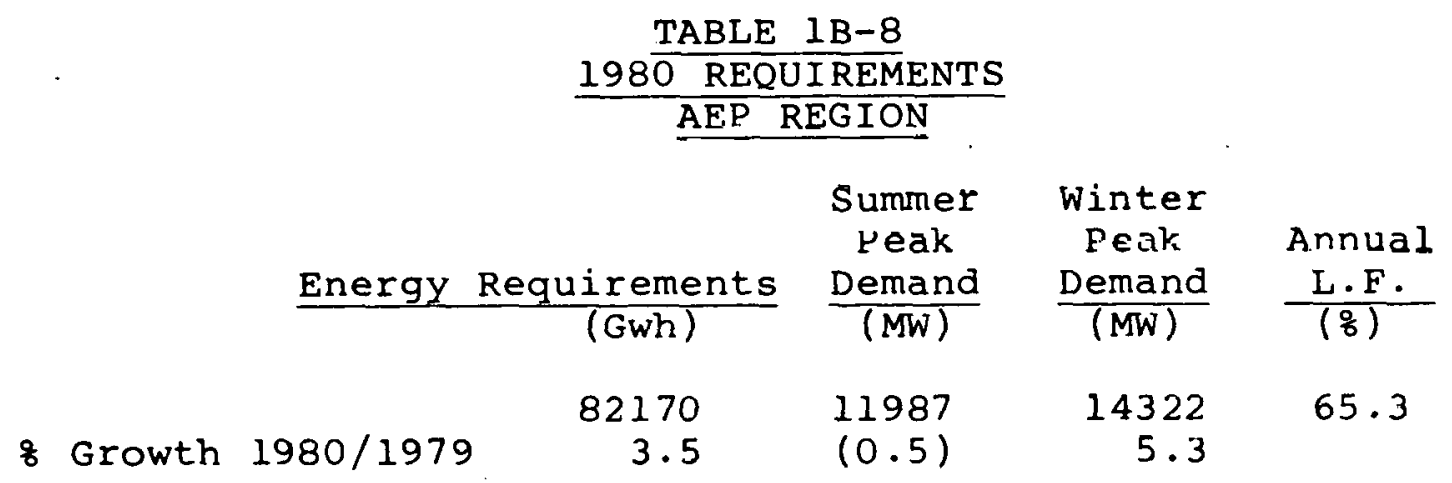

The anticipated 1980 projected energy requirements indicate a projected growth rate of $3.5 \%$ the same rate as the 1977-1979 period. The summer peak is expected to decline slightly and the winter peak is expected to gruw 5.38 . The winter peak's growth has been erratic, at 4.8\% fivii 1977-1978 and a decline of 1.68 from 1978-1979.

Delays of future critical bulk power transmission facilities that will not be in service when needed are reported under Item 5-C of the ERA-411 report. Two such lines, that impact adversely the system were orginally scheduled for 1980 installation but have been delayed. These are discussed below. 


\section{Culloden-wyoming $765 \mathrm{kV}$ Line}

The completion of the $57 \mathrm{mile}$ long Culloden-Wyoming $765 \mathrm{kV}$ line of the Appalachian Power Company -- extending from a new switching station to be located near the existing Amos-Baker $765 \mathrm{kV}$ circuit in the vicinity of Culloden, West Virginia, to a new $765 / 138 \mathrm{kV}$ station to be located near oceana, in wyoming County, West Virginia -- is presently scheduled for November 1981. The most recent delay of this line from November 1980 to November 1981 was necessitated by the Company's inability to raise funds through the sale of senior securities. This line is intended to establish a third EHV channel into the central portion of the Appalachian Power Co. (APCO) network, thereby maintaining an adequate level of reliability of bulk power supply to the ATCo lodd south of Charlcston, West virginia. In addition, it will enhance the reliability of power plant outlets from the Amos-Gavin-Mountaineer generating complex.

In the absence of this line for the winter 1980/81 peak loads, it is anticipated that -- during certain transmission outages involving the existing facilities supplying APCo's load areas south of Charleston, WV. -- serious overloads may occur on some of the remaining transmission facilities. Should any of the overloaded facilities fail, or be taken out of service by their protective equipment, other facilities may become overloaded and, in turn, may become subject to failure or disconnection. As a result, a cascading interruption in electric service to portions of Appalachian Power Co., Kingsport Power Co., and Kentucky Power Co., is becoming a real possibility. Furthermore, the flexibility of dispatching on an economic basis, some 6,800 MW of generating capacity in the Amos-Gavin-Mountaineer area could be severely hampered with potential forced curtailments necessary under certain contingency conditions.

While minor upgrading of transmission facilities during the 1980 to 1982 period is being initiated in order to minimize the risk of a cascading disturbance, any further delay of the cullodenWyoming $765 \mathrm{kV}$ line beyond November 1981 as a result of continuing financial restrictions will increase the possibility of a major areas wide interruption of electric power supply. 
XI.1.12

\section{Gaving-Cullioden $76 \underline{6}$ kV}

The 33 mile Gavin-Culloden $765 \mathrm{kV}$ line of the Appalachian Power Company (APCO), associated with the Mountaineer \#1 1,300 M.W generating unit, was scheduled for service in May 1980. This line is required to provide the needed transmission capacity for carrying the electric power generated at the Gavin-Mountaineer complex $(3,900 \mathrm{MW})$-- located on the Chio River in the vicinity of Cheshire, Ohio, and New Haven, west Virginia -- to various load centers on the system. In the absence of this line, generating capacity curtailments will be necessary - following the permanent outage of one of the existing $765 \mathrm{kV}$ transmission nutlets from this generating complex - so as to avoid the total loss of 3,900 M:W of capacity due to instability, should a subsequent fault occur on one of the remaining $765 \mathrm{kV}$ lines.

In 1977, Appalachian Power Co. (A.PCo) filed with the west Virginia Public Service Commission a petition for a Certification of Convenience and Necessity for the subject line. Following extensive hearings, the record was closed in June 1978 and a certificate was granted by the public service Commission in May 1979. This decision was appealed to the West Virginia Supreme Court which uphead the Public Service Commission in a December 1979 order. As a result of the delay in receiving the final decision, the in-service date for this line has been rescheduled to December 1982 - more than two years after the start-up of the Mountaineer $1,300 \mathrm{MK}$ generating unit.

\section{Futurie PépisEective}

The range of total reserves for the AEP region for the period 1981-1985 and 1986-1989 are tabulated below:

$$
\begin{aligned}
& \text { TARLE } 18 \cdot 9
\end{aligned}
$$

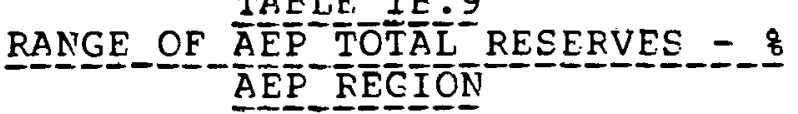

$$
\begin{aligned}
& \text { Summe } \frac{1}{r} \underline{9} \underline{1}=-\frac{1}{\text { Winter }} \\
& \text { 48.0-58.0 25.5-31.7 } \\
& \text { Summer } \frac{198}{6}=-1 \frac{9}{6} \frac{9}{\mathrm{i}} \frac{9}{\mathrm{n}} \text { ter } \\
& 42.1-47.9 \quad 21.9-27.7
\end{aligned}
$$


As seen above, the net reserves spans a large range from 21.98 in the winter $1989 / 90$ to 58.08 in the summer of 1981. Indications are there will be no difficulty in meeting obligations, if there are no unusual delays in completing scheduled capacity additions. However, new in-service dates for four $1300 \mathrm{MW}$ coal-fired units furnished after the ERA 411 report was finalized may have altered the conclusions derived from the ERA 4 lI report. Total unavailable capacity including scheduled maintenance in the 1977-1979 period ranged from 14-25\% of installed capability for the winter peak season. If an average outage rate of $20 \%$ is assumed for the 1981-89. period only in the winter of $1989 / 90$ would available reserves be deficient, using the ERA 411 in-service dates. Using the new in-service dates provided by AEP, deficits would occur in all the winter seasons starting in 1983. These would range from $536 \mathrm{MW}$ to $1542 \mathrm{MW}$ in 1989. All summer actual reserves throughout the study period would be adequate.

Shown below are the projected growth rates of demand and capability for each period and the overall rates for 1981-1989.

$\frac{\text { PROJECTED ENERGY AND DEMAND GROWTH RATES }}{\text { AEP REGION }}$

\begin{tabular}{|c|c|c|c|}
\hline Energy & Summer & Winter & Annua 1 \\
\hline $2 t s$ & Peak Demand & k Demand & ad Facto \\
\hline WH) & (MW) & (MW) & 8 \\
\hline
\end{tabular}

$\begin{array}{lrlll}1981 & 85,760 & 12,414 & 15,067 & 65.0 \\ 1982 & 89,360 & 12,995 & 15,710 & 64.5 \\ 1983 & 93,190 & 13,497 & 16,330 & 65.1 \\ 1984 & 97,130 & 13,992 & 16,961 & 65.4 \\ 1985 & 101,280 & 14,950 & 17,781 \ldots & 64.8\end{array}$

Growth $81-85$

$\begin{array}{ll}1986 & 105,720 \\ 1987 & 108,350 \\ 1988 & 111,980 \\ 1989 & 115,620\end{array}$

Growth $86-89$

$3 \cdot 1$

3.7

Growth $81-89$
4.7

4.2

15,515
16,075
16,657
17,261

18,437

19,114

19,808

20,527

3.6

3.7
$4 \cdot 3$

3.9
$65 \cdot 5$

64.7

64.5

64.3 
The 1981-1985 summer demands are projected to grow at a compound rate of growth of 4.78, 1986-1989 3.68; and overall 1981-89, at 4.38. These rates are considerable higher than the summer 19771979 growth of 18 .

The winter demand growth rates are projected to grow at a compound rate of 4.2 for the 1981-1985 period, 3.78 for the 1986-1989 period, with an average overall 1981-89 rate of 3.98 as compared to the $1977-79$ rate of $1.5 \%$.

Energy requirements are projected to grow 4.28 from 1981-1985, $3.1 \%$ from $1986-1989$ and 3.78 for the overall period from 19811989. Historically 1977-1979, the eneryy gruwth was at 3.58. This would indicate continued optimistic economic activity in the region.

During the 1981-1985 period four generating units are expected to be placed in service. Two of these units will be conventional hydro, and two are coal-fired steam. The conventional hydro units are at Racine and Gallipolis, rated at $40 \mathrm{MW}$ each with an in-service dates of December 1981 and July 1985 respectively. The two steam electric units are at Rockport, and each is rated at $1300 \mathrm{MW}$, with in-service dates of June 19831// and December 1984.1/

In the 1986-1989 period, two $1300 \mathrm{MW}$ coal-fired steam-electric units, located in Lewis county, are scheduled for installation during July 1986ㅌ/ and December 1988.1/

The winter capability of units installed in the region for the period 1980-1989 is shown by fuel type in Table 1B.18. Major generating unit additions during the period are given in Table 1B.19. The percentages of each type of capability for the target years 1980,1984 and 1989 are given below.

$\frac{\text { PLANNED GENERATING CAPABILITY BY TYPE OF FUEL - } 8}{\text { AEP REGION }}$ 2/

\begin{tabular}{cccccc}
$\begin{array}{l}\text { Nuclear } \\
\text { Steam }\end{array}$ & $\begin{array}{l}\text { Coal } \\
\text { Steam }\end{array}$ & $\begin{array}{c}\text { Combustion } \\
\text { Turbine-Oil }\end{array}$ & $\begin{array}{c}\text { Hydro } \\
\text { Conv. }\end{array}$ & $\begin{array}{l}\text { Pumped } \\
\text { Storage }\end{array}$ & $\begin{array}{c}\text { Total } \\
\text { Capability }\end{array}$ \\
\cline { 1 - 1 } 10.7 & 85.3 & 0.1 & 1.1 & 2.8 & 100.0 \\
9.4 & 86.9 & 0.1 & 1.2 & 2.4 & 100.0 \\
8.4 & 88.1 & 0.1 & 1.2 & 2.2 & 100.0
\end{tabular}

1/ See Table 1B.19 for new in-service dates.

$\underline{2} /$ Uses 411 in-service dates. 
Coal presently is the primary fuel for about $85 \%$ of the installed capacity of the region. Only a slight change to about 888 is forecasted for the future, due to the addition of $5200 \mathrm{MW}$ of coal-fired capacity after 1980. Nuclear-steam capacity will decline from $11 \%$ to $8 \%$ since no new nuclear capacity is scheduled. The remaining 48 of capacity in 1989 will be provided by pumped storage, conventional hydroelectric and one small oil-fired combustion turbine.

There is one critical bulk power transmission facility that will not be in service when desired during the period 1981-1989, the Appalachian Power Company's (APCo) 72 mile Jackson's FerryAxton $765 \mathrm{kV}$ line. This is intended to extend EHV supply eastward from the existing Jackson's Ferry Station $\S$ located near Axon, Virginia to the new Axton $765 \mathrm{kV}$ Station, located near Axon, Virginia. The line and the associated $138 \mathrm{kV}$ facilities -planned for service by November 1982 just prior to the most recent delay -- will provide the necessary transmission reinforcement to APCo's eastern area so as to maintain an adequate level of reliability for the bulk power supply system serving that region. In addition, these facilities will provide local support to the Martinsville and Danville, Virginia, load centers located in the vicinity of the new Axton station. In the absence of the Jackson's Ferry-Axton $765 \mathrm{kV}$ line, local and area-wide electric service interruptions are becoming a very real possibility.

APCO applied in early 1974 to the Virginia state Corporation Commission (SCC) for a Certificate of Public Convenience and Necessity to construct the Jackson's Ferry-Axton $765 \mathrm{kV}$ line. On July 5, 1974, the SCC found that the line was needed and in October 1979, following extensive hearings, approved a line route. However, before APCo can begin right-of-way acquisition and construction, a permit to cross the Blue Ridge Parkway must be granted by the National Park Service of the United States Department of the Interior. The National Park Service is now in the process of carrying out investigations regarding the crossing of the Blue Ridge Parkway.

An appraisal of anticipated transmission system performance in ECAR is prepared immediately prior to each summer and winter peak load period. Each member system participates in the appraisal procedure and the material which appears in the 
final ECAR report is normally limited to those items which are of particular significance to the overall region. The appraisal is based on a careful analysis of various studies carried out by the ECAR Transmission system Performance Working Group under the direction of the Transmission system Performance Panel and by individual ECAR companies, either among themselves or jointly with systems adjacent to ECAR. Where the appraisal procedure indicates a potential contingency which could lead to localized problems, the matter is referred to the affected system(s) for further study and development of appropriate operating instructions where necessary. These reports are intended as a supplement to, and not a substitute for, internal studies by the individual systems in ECAR.

A wide range of postualted system conditions was considered during the course of the various studies referred to above and the following operating procedures were developed (only AEP described below).

\section{AEP--Central Appalachian Area}

Heavy facility loadings may be experienced in AEP's Central Appalachian area during projected winter 1979-80 peak load conditions, and may limit the transfer of power to the south (TVA) and southeast (Duke Power Co.; Carolina Power and Light, and Virginia Electric and Power Co.) during certain transmission outage conditions. Since the central Appalachian load area is winter peaking, this local problem is not anticipated during summer peak load conditions.

The performance of the Central Appalachian area is under continuing stury by AEP, and detailed information has been developed for system operators so that all adverse system conditions can be fully assessed, and appropriate remedial action can be taken. EHV reinforcement to the area is presently planned for the fall of 1981 . 


\section{AEEE=-Ridgeway Ser}

Transfers of power into ECAR from the southeast may be limited by loadings on the Lan River Ridgeway (Duke-AEP) $138 \mathrm{kV}$ interconnection following an outage of the Jackson's Ferry-McGuire $500 \mathrm{kV}$ circuit. Power flows on the $138 \mathrm{kV}$ tie can be reduced, however, by insertion of series reactors located at A.EF's Pidgeway station. These reactors are inserted by remote control whenever the tie line loadings approach the circuit capability.

The most recent ECAR appraisal studies were for summer 1979 and winter 1979-80. These studies showed that timely completion of the scheduled transmission facility additions would insure that the reliability of the bulk power transmission systems within ECAR would be maintained at a high level.

Emergency Transfer Capabilities to adjacent regions, based on thc NCRC definition, were reforted as follows:

\section{TABLE 1 IP.12}

\section{EMEEGENCY TRANSFER CAPARILITY = MW \\ $\underline{A} \bar{E} \bar{P} \bar{R} \bar{E} \bar{C} \bar{I} \bar{C} \bar{N}$}

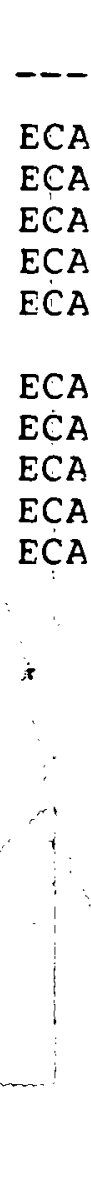

\section{Transfer}

ECAF to MAAC

ECAR tO NPCC

ECAR to MAIN

ECAR to SERC (TVA)

ECAF to SERC (VACAF)

ECAR from MAAC

ECAR from NPCC (NYPP)

ECAR from MAIN

ECAR from SERC (TVA)

EĆAR frorr. SERC (VACAR)

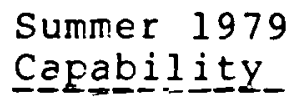

$3300+$

2200

3450

1800

1250

2450

$3300+$

$4000+$

2000

2700
Winter 1979-80

C-

$3300+$

2950

3950

1600

1900 *

3300

2900

3800

2100

2950

- ETC Values determined with established operating procedures in effect. 
All ECAR systems evaluate their individual network performance using the testing criteria presented in ECAR Document No. 1. Based on an analysis of these studies, it has been concluded that the ECAR bulk power transmission network as now projected for the 1984 period is capable of withstanding the contingencies listed in E.CAR Document No.I without suffering area-wide break-up and/or collapse of the network. This appraisal is based on the assumption that current financial and environmental problems will be resolved in a timely manner and that ECAR member systems will be able to provide the facilities shown. Should any of the EHV transmission facilities planned for the 1980-1984 period be delayed as a result of excessive lag in the certification process or as a result of difficulties in financing these projects due to inadeguate rate relief, then appropriate short term operating procedures will need to be developed in order to maintain, to the greatest extent fossible, the reliability of electric power supply within ECAR. Such procedures, if invoked, may jeopardize the reliability of the power supply in the affected area.

Emergency Transfer Capabllities to adjacent regions, based on the NERC definition, are as follows:

TARLE 1E. 13

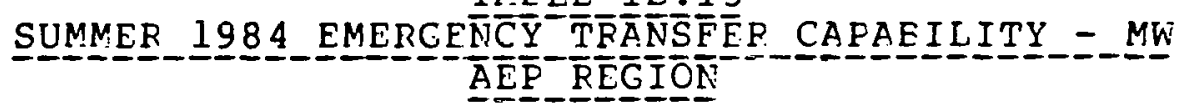

\begin{tabular}{llllc} 
& ETC & & & ETC \\
\hline EGAR to MACC & MW & - & Transfer \\
ECAR to NPCC (NYPF) & 4350 & ECAR from MAAC & 2600 \\
ECAR to MAIN & 1950 & ECAR from NPCC & 2000 \\
ECAR to SERC (TVA) & 2900 & FCAR from MAIN & $4000+$ \\
ECAR to SERC (VACAR) & 2500 & ECAR from SERV (TVA) & 3200 \\
& 2250 & ECAR from SERC (VACAR) & 5500
\end{tabular}

The fullowing table is a list of proposed bulk. power lines to be constructed by AEP. IL Inelud s interconnections with other utilities and areas as well as internal transmission, mang of these lines may become critical to AEP and its sales to other utilities in the region, thus impacting the reliability of neighboring systems. 


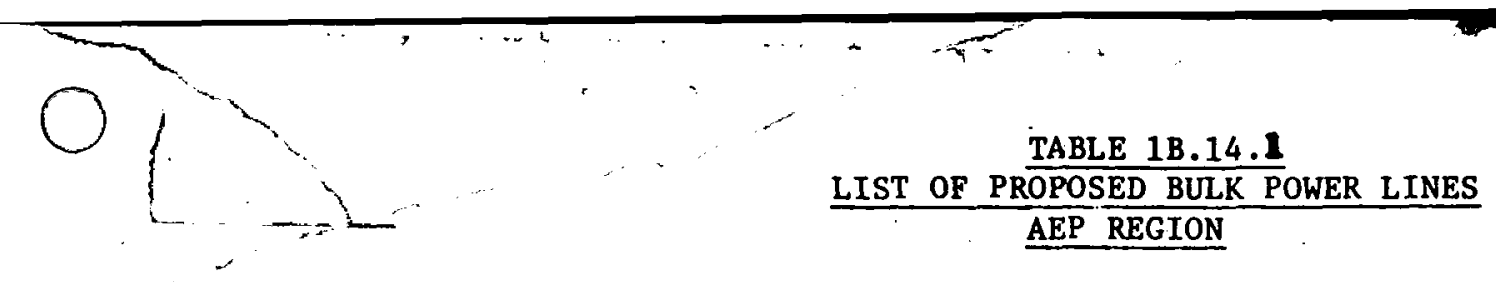

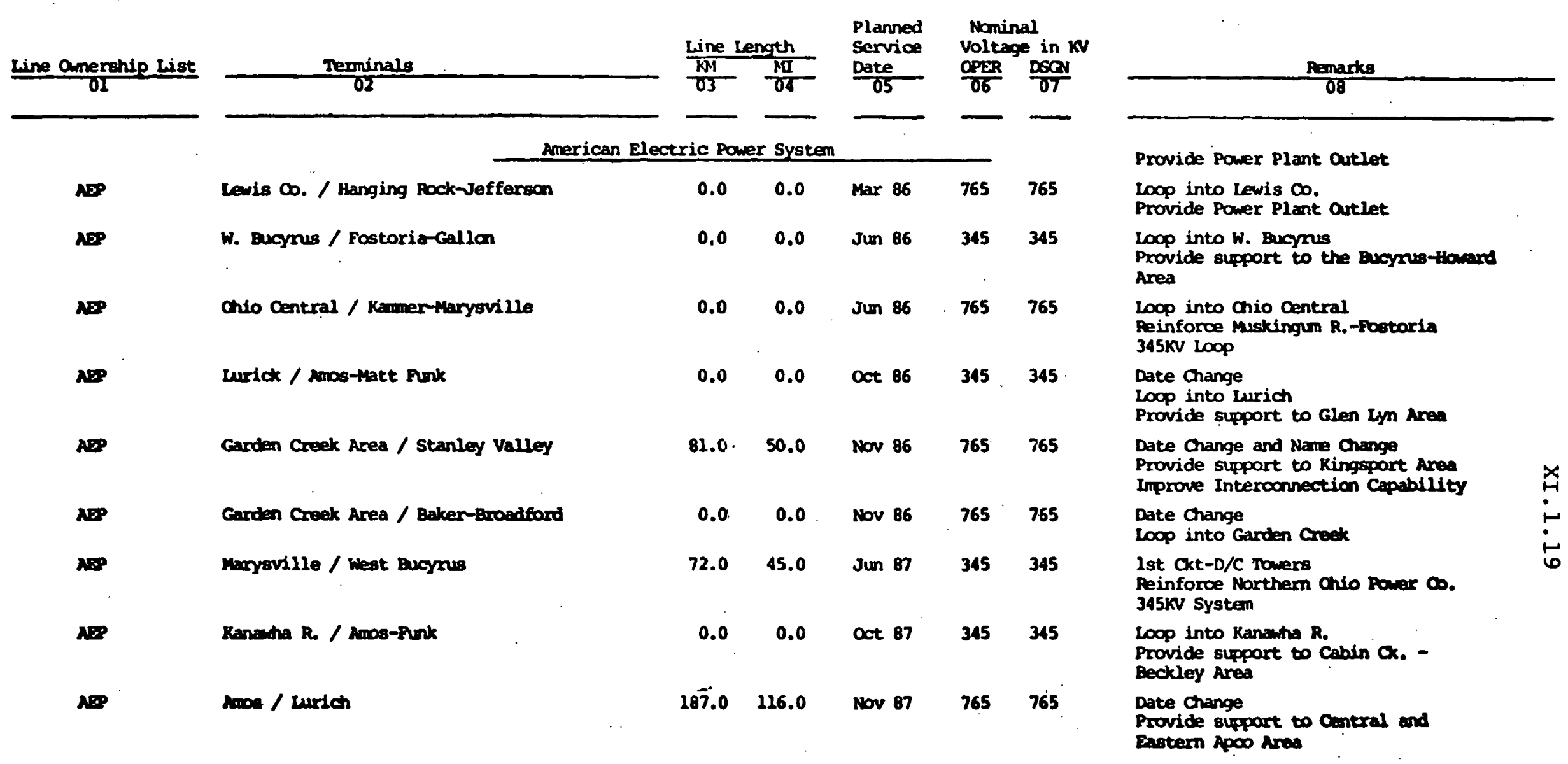


TABLE 1B.14.2

LIST OF PROPOSED BULK POWER LINES AEP REGION

\begin{tabular}{|c|c|c|c|c|c|c|}
\hline \multirow[b]{2}{*}{$\frac{\text { Line Omership List }}{\text { OI }}$} & \multirow[b]{2}{*}{$\frac{\text { Terminals }}{02}$} & \multicolumn{2}{|c|}{ Line Length } & \multirow{2}{*}{$\begin{array}{l}\text { Planned } \\
\text { Service } \\
\text { Date } \\
05\end{array}$} & \multicolumn{2}{|c|}{$\begin{array}{l}\text { Nominal } \\
\text { Voltage in }\end{array}$} \\
\hline & & $\frac{\mathrm{KM}}{\text { O3 }}$ & $\frac{M I}{04}$ & & $\frac{C P E R}{0 \sigma}$ & $\frac{\mathrm{DSO}}{07}$ \\
\hline & & ic Power & System & & & \\
\hline AEP & Karmer / South Canton & 129.0 & 80.0 & Jun 81 & 765 & 765 \\
\hline AEP & Oulloden / Mmos-Baker & 5.0 & 3.0 & Now 81 & 765 & 765 \\
\hline ADP & Oulloden / Myoming & 92.0 & 57.0 & Nov 81 & 765 & 765 \\
\hline AEP & Allen / Sorensan-Robinson Park & 0.0 & 0.0 & Dec 81 & 345 & 345 \\
\hline AEP & Rockport / Jefferson & 179.0 & 212.0 & Sep 82 & 765. & 765 \\
\hline AISP & Mountainer / Culloden & 67.0 & 42,0 & Dec 82 & 765 & 765 \\
\hline AEP & Hanging Rock / Jefferson & 259.0 & 161.0 & $\operatorname{Jun} 83$ & 765 & 765 \\
\hline ASP & Jackson's Ferry / Axtor. & 216.0 & 72.0 & Nov 83 & 765 & 765 \\
\hline AEP & Baker / Pigeon poost & 109.0 & 68.0 & Nov 83 & 345 & 3 \\
\hline$A \equiv P$ & Pockpart / Sullivan & 155.0 & 97.0 & Jun 84 & 765 & 10 \\
\hline
\end{tabular}

Provide surport to Canton Area

Date Change

Loop into Culloden

Provide support to Oentral apoo

Area

Date Change

loop into Allen

Improwe Ft. Wayne Area Reliability

Line Length Change

Provide Power Plant outlet

Date Change

Line Length Change

Use with Gavin-Amos to form inountaio

-EER-Amios \& Culloden-Gavin Circuits

Provida Power Plant autlet.

Provide Rower Plant Outlets

Provide East-thest Transmission Cap.

Provide Puture Porer Plant outlets

Date Change

Provide sumport to the Martinsville

Danville Area

Date, Nare, Line Iength Change

Double circuit

Initial Jperation at $138 \mathrm{KV}$

Provide support to Eprigg-Iogan Ara.

Ine rength chans 
TABLE 1B.1.4.4

LIS_ OF PROPOSED BULK POWER LINES

AEP REGION

\begin{tabular}{|c|c|c|c|c|c|c|}
\hline$\frac{\text { Line Ownership List }}{01}$ & $\frac{\text { Terminals }}{02}$ & $\frac{\frac{L i}{k} \frac{\mathrm{L}}{\mathrm{M}}}{\mathrm{DJ}}$ & $\frac{\text { Length }}{\frac{M 1}{04}}$ & $\begin{array}{l}\text { Planned } \\
\text { Service Date }\end{array}$ & \multicolumn{2}{|c|}{$\begin{array}{l}\text { Nominal } \\
\text { Voltage in KV } \\
\text { OPER } \frac{\text { DSGN }}{06} \text { OT }\end{array}$} \\
\hline & & \multicolumn{4}{|c|}{ Interconnections } & \\
\hline ASP TVA & $\begin{array}{l}\text { Stanley valiey / Phipps Bend-Sullivan } \\
\text { Name Change } \\
\text { Lop into Stanley Valiey Station } \\
\text { Improve Area Reliability } \\
\text { Increase Interchange Capatility }\end{array}$ & 0.0 & 0.0 & $\operatorname{Jun} 83$ & 500 & 500 \\
\hline AEP PSI & $\begin{array}{l}\text { Jeffersan ' Marble Hill } \\
\text { Deliver Gemerator Output }\end{array}$ & 24.1 & 15.0 & $\operatorname{Jan} 84$ & 765 & 765 \\
\hline PSI AXP & $\begin{array}{l}\text { Grynneville / Jefferson-Creentown } \\
\text { Loop into Jwyrneville } \\
\text { Deliver Generator Output }\end{array}$ & 0.0 & ${ }^{\prime} 0.0$ & $\operatorname{Jan} 84$ & 765 & 765 \\
\hline ATP TV & $\begin{array}{l}\text { Rockport i TVA (Total Lize) } \\
\text { Date Change } \\
\text { Provide Pawer Plant Outlet }\end{array}$ & 161.0 & 100.0 & 89 & 765 & 765 \\
\hline
\end{tabular}


Table 1 B. 15

HISTORICAL CAPABILITY (MW) AND RESERVES (MW AND PERCEN'S)

\section{AEP F.EGION}

$\begin{array}{cc}\text { Summer } & 1977 \\ & \\ & \\ 17566 & 18466 \\ 11735 & 13192 \\ 5831 & 5274 \\ 19.7 & 40.0 \\ -1952 & 258 \\ 15604 & 18724 \\ 3869 & 5532 \\ 33.0 & 41.9 \\ 350 & 295 \\ 15254 & 18429 \\ 3519 & 5237 \\ 30.0 & 39.7 \\ 0 & 0 \\ 15254 & 18429 \\ 3519 & 5237 \\ 30.0 & 39.7 \\ 1936 & 4418 \\ 13318 & 14011 \\ 1583 & 819 \\ 13.5 & 6.2\end{array}$

$\begin{array}{cc}\text { Summer }^{1978} & \text { Winter } \\ & \\ 19315 & 19561 \\ 11658 & 13824 \\ 7657 & 5737 \\ 6.5 .7 & 41.5 \\ -1184 & -823 \\ 18131 & 18738 \\ 6473 & 4914 \\ 55.5 & 35.5 \\ 1035 & 189 \\ 17101 & 18549 \\ 5443 & 4725 \\ 45.7 & 34.2 \\ 0 & 0 \\ 17101 & 18549 \\ 5443 & 4725 \\ 46.7 & 34.2 \\ 2390 & 2508 \\ 14711 & 16041 \\ 3053 & 2217 \\ 26.2 & 16.0 \\ & \end{array}$

\begin{tabular}{cc} 
& \multicolumn{2}{l}{1979} \\
Summer & Winter \\
18754 & 19029 \\
11981 & 13603 \\
6773 & 5426 \\
56.5 & 39.9 \\
-442 & -859 \\
18312 & 18170 \\
6331 & 4567 \\
52.8 & 33.6 \\
1898 & 1190 \\
16414 & 16980 \\
4433 & 3377 \\
37.0 & 24.8 \\
0 & 0 \\
16414 & 16980 \\
4433 & 3377 \\
37.0 & 24.8 \\
1770 & 2773 \\
14644 & 14207 \\
2263 & 604 \\
22.2 & 4.4
\end{tabular}

13.5 
Table 1B.16

CURRENT CAPABILITY (MW) AND RESERVES (MW AND PERCENT)

AEP REGION

1980

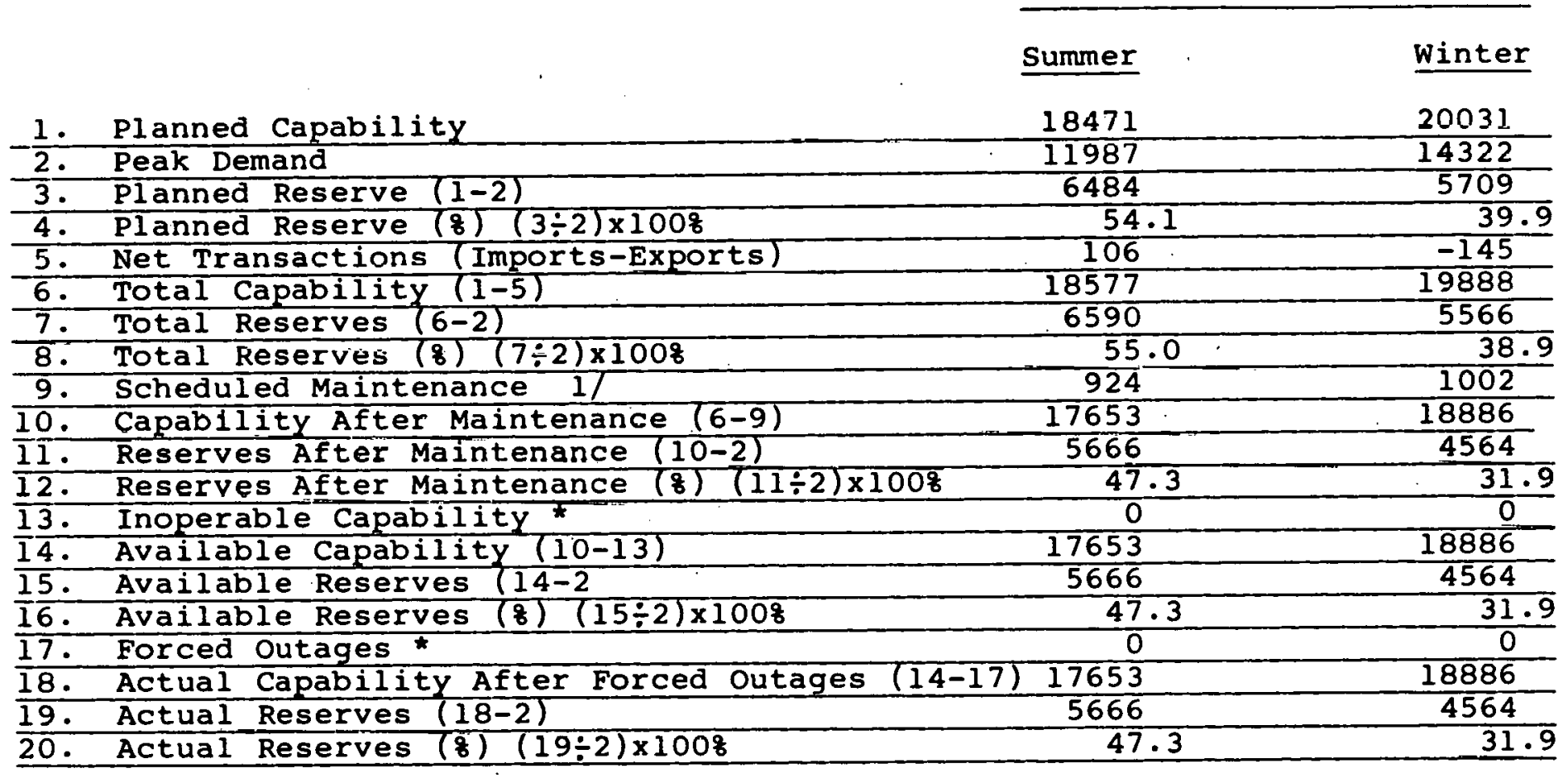

I/Five percent of total planned capability assumed by ERA from ECAR-ERA 411 repo:

* No information supplied. 
Table 1 B. 17

FUTURE CAPABILITY (MW) AND RESERVES (MN AND PERCENT)

AEP REGION

1. Planned Capabilit

2. Peak Demand

3. Planned Reserves (1-2)

4. Planned Reserves (8)

$$
(3 \div 2) \times 1008
$$

5. Net Transactions (Imports-Exports)

6. Total Capability $(1+5)$

7. Total Reserves (6-2)

8. Total Reserves (\&)

$$
(7 \div 2) \times 1008
$$

9. Scheduled Maintenance

10. Capability After

Maintenance (6-9)

Maintenance (10-2)

Reserves After Maintenance (z) $(11 \div 2) \times 1008$

13. Inoperable Capability *

14. Available Capability

(10-13)

$$
\text { vailable Reserves }
$$

(14-2)

16. Available Reserves (8) $(15 \div 2) \times 1008$

17. Foroed Outages

18. Actual Capability After Foroed Outages (14-17)

19. Actual Reserves (18-2)

20. Actual Reserves (8)

$$
(19 \div 2) \times 1008
$$

21. Possible Coal Delays

22. Actual Capability with

23. Coal Delays (18-21)

23. Actual Reserves with

24. Actual Reserves with

Caal Delays $(23 \div 2) \times 1008$

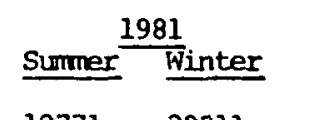

Summer $\frac{1982}{r}$

Summer $\frac{1983}{w}$

1977120211

$12412 \quad 15067$

$19951 \quad 20211$

$21251 \quad 21511$

$\begin{array}{rrrr}12995 & 15710 & 13497 & 16330\end{array}$

Surmer $\frac{1984}{\text { Winter }}$

Surmer $\frac{1985}{\text { Winter }}$

$7357 \quad 5144$

$\begin{array}{ll}53.5 & 28.7\end{array}$

57.4

31.7

21251

22811

$13992 \quad 16961$

$22591 \quad 22851$

$59.3 \quad 34.1$

$\begin{array}{rr}-457 \quad-457 \\ -19494 & 19754\end{array}$

$19617 \quad 19754$

$\begin{array}{rr}19494 & 19754\end{array}$

$\begin{array}{lr}-457 & -457 \\ 20794 & 21054\end{array}$

$51.9 \quad 34.5$

$14950 \quad 17781$

$58.0 \quad 31.1$

$\begin{array}{cc}50.0 & 25.7 \\ 0 & 0\end{array}$

$\begin{array}{cc}54.1 & 28.9 \\ 0 & 0\end{array}$

$-457 \quad-465$

$20794 \quad 22346$

$51.1 \quad 28.5$

00

19494

$19617 \quad 19754$

$\begin{array}{lll}19754 & 20794 & 21054\end{array}$

$\begin{array}{llll}6499 & 4044 & 7297 & 4724\end{array}$

$7203 \quad 4687$

$50.0 \quad 25.7$

$54.1 \cdot 28.9$

02

5385

$-465 \quad-542$

$22126 \quad 22309$

$\begin{array}{cccc}48.6 & 31.7 & 48.0 & 25.5 \\ 0 & 0 & 0 & 0\end{array}$

$\begin{array}{cc}58.0 & 31.1 \\ 0 & 0\end{array}$

$19617 \quad 19754$

$19494 \quad 19754 \quad 20794 \quad 21054$

$\begin{array}{llll}20794 & 22346 \quad 22126 \quad 22309\end{array}$

$\begin{array}{llll}6802 & 5385 & 7176 & 4528\end{array}$

$7203 \quad 4687$

$\begin{array}{llll}6499 & 4044 & 7297 & 4724\end{array}$

$\begin{array}{cc}58.0 & 31.1 \\ 0 & 0\end{array}$

$19617 \quad 19754$

$54.1 \quad 28.9$

$\begin{array}{rr}0 & 0 \\ 19494 & 19754\end{array}$

$0 \quad 0$

$7203 \quad 4687$

6499

$58.0 \quad 31.1$

$50.0 \quad 25.7$

$20794 \quad 21054$

$7297 \quad 4724$

COAL UNTT DELAYS PRDIECTED BY ERA

$\begin{array}{rrrrrrrrrr}0 & 0 & 0 & 0 & 1300.0 & 1300.0 & 1300.0 & 1300.0 & 1300.0 & 1300.0 \\ 19617 & 19754 & 19494 & 19754 & 19494 & 19754 & 19494 & 21046 & 20826 & 21009 \\ 7203 & 4687 & 6499 & 4044 & 5997 & 3424 & 5505 & 4085 & 5876 & 3228 \\ 58.0 & 31.1 & 50.0 & 25.7 & 44.4 & 21.0 & 39.3 & 24.1 & 39.3 & 18.2\end{array}$

* No information supplied. 
Table 1 B. 17.1

FUTUFE CAPABILITY (MW) AND RESERVES (MW AND PERCENT)

AEP REGION

1. Planned Capability

2. Peak Demand

3. Planned Reserves (1-2)

4. Planned Reserves (8) $(3 \div 2) \times 1008$

5. Net Transactions (Imports-Exports)

6. Total Capability $(1+5)$

7. Total Reserves $(6-2)$

8. Total Reserves (8) $(7 \div 2) \times 1008$

9. Scheduled Maintenance *

10. Capability After Maintenance (6-9)

11. Reserves After Maintenance (10-2)

12. Reserves After Maintenance $(8)(11 \div 2) \times 1008$

13. Inoperable Capability *

14. Available Capability (10-13)

15. Available Reserves (14-2)

16. Available Reserves (8) $(15 \div 2) \times 1008$

17. Forced Outages *

18. Actual Capability After Forced Outages

$$
(14-17)
$$

19. Actual Reserves (18-2)

20. Actual Reserves $(8)(19 \div 2) \times 1008$

21. Possible Coal Delays

22. Actual Capability with Coal Delays

$$
(18-21)
$$

23. Actual Reserves with Coal Delays

$(22-2)$

24. Actual Reserves with Coal Delays $(23 \div 2) \times 1008$

No information supplied.

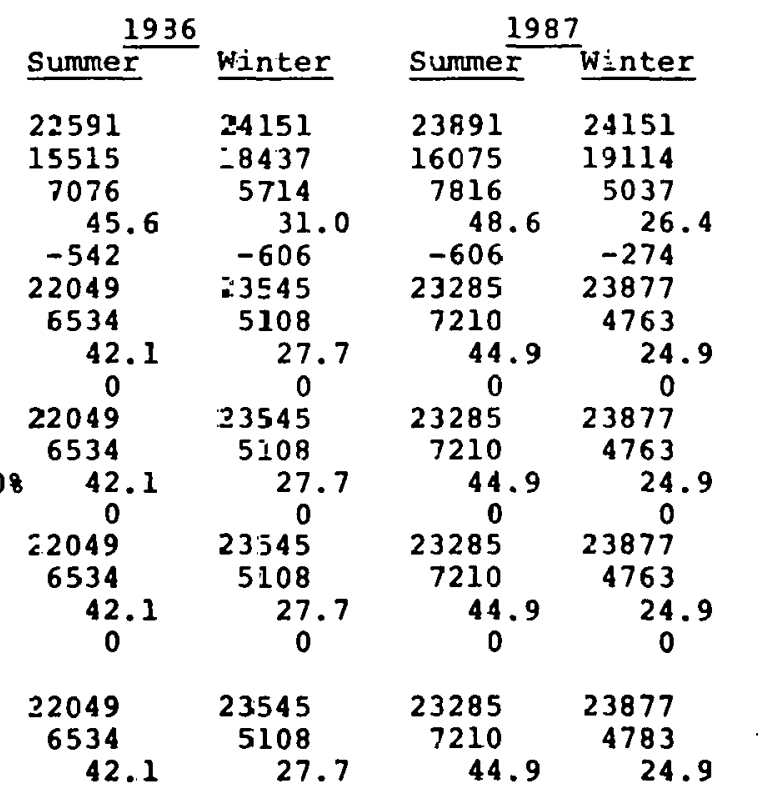

COAL INIT DELAYS PROJECTED BY ERA

$\begin{array}{rrrr}0 & 1300 & 1300 & 1300 \\ 22049 & 22245 & 21985 & 22577 \\ 6,534 & 3808 & 5910 & 3463 \\ 42.1 & 20.7 & 36.8 & 18 .=\end{array}$

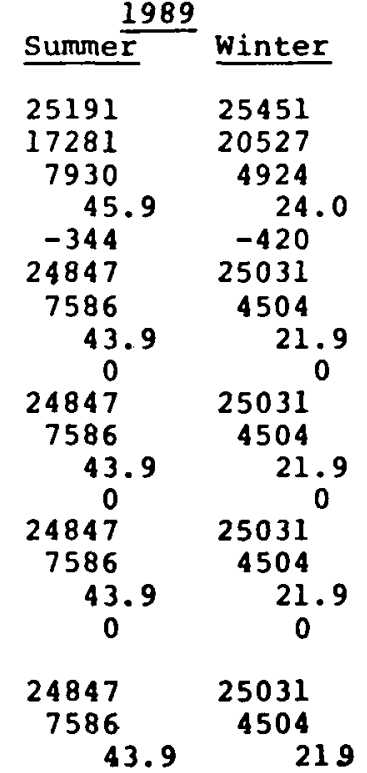

$\begin{array}{rr}2600 & 1300 \\ 22317 & 23807 \\ 5660 & 3999 \\ 34.0 & 20.2\end{array}$

$\begin{array}{rr}1300 & 1300 \\ 23547 & 23731 \\ 6286 & 3204 \\ 36 & 15.6\end{array}$

$36.4 \quad 15.6$ 
IABLE $1 \mathrm{~B} .18$

INSTALLED NET CAPABILITY BY TYPE OF FUEL - MW AEP REGION

Winter Capatility

\begin{tabular}{|c|c|c|c|c|c|c|c|c|c|c|c|}
\hline \multirow{2}{*}{$\begin{array}{l}\text { Electric } \\
\text { Reqion } \\
\text { AEP it: BUPI }\end{array}$} & \multirow[b]{2}{*}{$\begin{array}{l}\text { Nuclear } \\
\text { Steam }\end{array}$} & \multirow[b]{2}{*}{$\begin{array}{l}\text { Coal } \\
\text { stearn }\end{array}$} & \multicolumn{3}{|c|}{$0 \mathrm{il}$} & \multicolumn{3}{|c|}{ Natural Gas } & \multicolumn{2}{|c|}{ Hydro } & \multirow[b]{2}{*}{$\begin{array}{l}\text { Total } \\
\text { Capability }\end{array}$} \\
\hline & & & steam & $\begin{array}{l}\text { Combust. } \\
\text { Turbine: }\end{array}$ & $\begin{array}{l}\text { Internal } \\
\text { Combust. }\end{array}$ & steam & $\begin{array}{l}\text { Comb. } \\
\text { Turb. }\end{array}$ & L.C. & Convent. & $\begin{array}{l}\text { Pumped } \\
\text { Storage }\end{array}$ & \\
\hline 1980 & 2,150 & 17,080 & & 18 & & & & & 232 & 560 & 20,031 \\
\hline Total & 10.7 & 85.3 & & 0.1 & & & & & 1.1 & 2.8 & 100 \\
\hline 1981 & 2,150 & 172.20 & & 18 & & & & & 263 & 560 & 20,211 \\
\hline - Total & 10.6 & 85.2 & & 0.1 & & & & & 1.3 & 2.8 & 100 \\
\hline 1982 & 2.150 & 17220 & & 18 & & & & & 263 & 560 & 20,211 \\
\hline Total & 10.6 & 85.2 & & 0.1 & & & & . & 1.3 & 2.8 & 100 \\
\hline 1983 & 2,150 & 18,520 & & 18 & & & & & 263 & 560 & 21,511 \\
\hline Total & 10.0 & 86.1 & & 0.1 & & & & & 1.2 & 2.6 & 100.0 \\
\hline 1984 & 2,150 & 19,820 & & 18 & & & & & 263 & 560 & 22,811 \\
\hline Total & 9.4 & 86.9 & & 0.1 & & & & & 1.2 & 2.4 & 100.0 \\
\hline 1985 & 2.150 & 19,820 & & 18 & & & & & 303 & 560 & 22,851 \\
\hline Total & 9.4 & 86.7 & & 0.1 & & & & & 1.3 & 2.5 & 100.0 \\
\hline 1986 & 2,150 & 21,120 & & 18 & & & & & 303 & 560 & 24,151 \\
\hline I Total & 8.9 & 87.4 & & 0.1 & & & & & 1.3 & 2.3 & 100.0 \\
\hline 1987 & 2,150 & 21,120 & & 18 & & & & & 303 & 560 & 24,151 \\
\hline - Total & 8.9 & 87.4 & & 0.1 & & & & & 1.3 & 2.3 & 100.0 \\
\hline 1988 & 2,150 & 22,420 & & 18 & & & & & 303 & 560 & 25.451 \\
\hline I Total & 8.4 & 88.1 & & 0.1 & & & & & 1.2 & 2.2 & 100 \\
\hline 1989 & 2.150 & 22,420 & & 18 & & & & & 303 & 560 & 25,451 \\
\hline - Total & 8.4 & 88.1 & & 0.1 & & & & & 1.2 & 2.2 & 100.0 \\
\hline
\end{tabular}




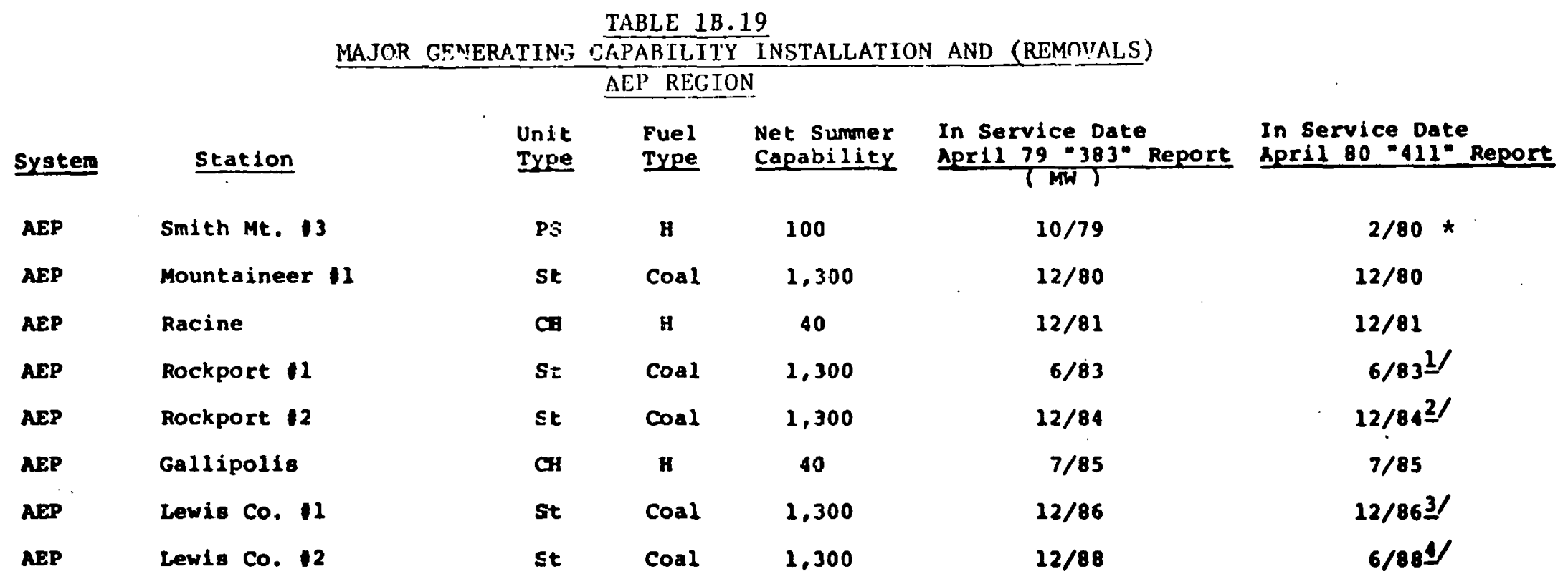

No. Installation and Removals 82, 87. 89

The following changes were reporte. 1 after the 1980 ERA 411 report was finalized.

1/ Rescheduled for $12 / 84$

2/ Rescheduled for $6 / 86$

3/ Rescheduled for $12 / 88$

4/ Rescheduled for $6 / 90$.

* Delayed unt11 1981 


\section{Allegheny Power System (APS)}

\section{Historical Perspective}

Allegheny Power system includes the southwestern corne'r and northcentral portions of Pennsylvania, about 508 of the northern portion of West Virginia, the western portion of Maryland and a small portion of northwestern Virginia. The Allegheny Power System, Inc. is the parent company for this integrated electric system comprising the properties of the Monongahila Power Company, the Potomac Edison Company, West Penn Power Company; and their subsidiaries. As such, it is the owner of the operating companies in the system and is the vehicle through which equity capital for the system is ohtained. The integraled operation of APS permits economic and other advantages in matters such as: planning of generating and transmission facilities; exchange of technical knowhow; experience and information; uniformity of practice in construction; emergency and economic power exchanges; the scheduling of spinning reserve and maintenance scheduling.

In 1978 the three operating companies served 1,084,000 customers in Pennsylvania, Maryland, West Virginia, and Virginia, of which 967,000 were residential 101,000 were commercial and 16,000 were industrial customers.

The three companies are heavily interconnected through $500 \mathrm{KV}, 345 \mathrm{KV}$ and $230 \mathrm{KV}$ transmission lines. There are similar interconnections with other systems in ECAR and also with General Public Utilities, Baltimore Gas \& Electric Company, and Potomac Electric Power Company in the MAAC Council and with Virginia Electric Power Company in SERC Council.

APS has historically been a winter peaking region. Table $1 \mathrm{~A} . \mathrm{l}$ shows the region's summer and winter peaks for the period 1977-1979.

TABLE $1 A \cdot 1$

HISTORICAL PEAK DEMAND-MW ALLEGHENY POWER SYSTEM REGION

\begin{tabular}{|c|c|c|c|c|c|c|}
\hline \multirow[b]{2}{*}{ Year } & \multicolumn{3}{|c|}{ Summer } & \multicolumn{3}{|c|}{ winter } \\
\hline & June & July & August & December & January & February \\
\hline $\begin{array}{l}1977 \\
1978 \\
1979\end{array}$ & $\begin{array}{l}4139 \\
4362 \\
4378\end{array}$ & $\begin{array}{l}4524 \\
4575 \\
4621\end{array}$ & $\frac{4539}{\frac{4632}{4676}}$ & $\begin{array}{l}4883 \\
4921 \\
5221\end{array}$ & $\begin{array}{l}\frac{5174}{5331} \\
5263\end{array}$ & $\begin{array}{l}4937 \\
5335 \\
5272\end{array}$ \\
\hline
\end{tabular}

Underline indicates Seasonal Peak 
The summer peak demands are dependent upon climatic conditions and are especially sensitive to temperature/humidity. Usually the peak will occur in July or August. The winter peak can occur in any. of the winter months depending on the combination of weather and economic activities in the region.

Table IA.2 shows the capacity out-of-service due to scheduled maintenance for each summer and winter period and also the unavailable capability due to forced outages.

TABLE $1 \mathrm{~A} .2$

SCHEDULED MAINTENANCE AND UNAVAILABLE CAPABILITIES ALLEGHENY POWER SYSTEM REGION

Year

1977

1978

1979

\begin{tabular}{c} 
Scheduled \\
Maintenance \\
$(\mathrm{MW})$ \\
\hline
\end{tabular}

\section{6}

500

669 summer

Forced

outages

(MW)

947
1,685
1,834

Total

Unavailable (MW)

1,543
2,185
2,503

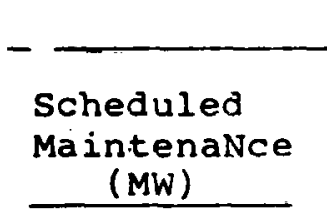

1,195

186 winter

Forced

Outages

(MW)

3,359

1,308

1,987
Total Capacity Unavailable (MW)

4,554

1,308

2,173

The capacity unavailable for reasons other than scheduled maintenance in 1977-1979 varied from 15-278 of the planned capability in summer and from 20-528 in winter.

The reserve margins for the 1977-1979 period aro shown on Table $1 \mathrm{~A}, 3$, These values include the effects of scheduled maintenance and forced outages on the reserve margins. The. "total capability" shown in Table $1 \mathrm{~A} .3$ is the "planned capability" plus the net of all capacity purchases and sales. 
$X I .1 .31$

TABLE IA. 3

HISTORICAL SEASONAL RESERVES

ALLEGHENY POWER SYSTEM REGION

Summer

Yea

Peak

Total Total

Demand Capability Reserve

(MW)

(MW)

\begin{tabular}{c} 
Reserve \\
8 \\
\hline
\end{tabular}

1977

1978

4.539

5,890

29.8

4,632

6,153

32.8

6,726

43.8

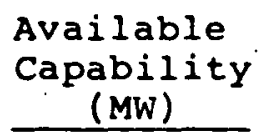

Available
Capability

(MW)

5,294

5,653

6.057

Winter

1977

1978

1979
5,174
5,335
5,272

6,378

6,367

7,247
Reserve

\author{
After
}

Maintenanc

8

\begin{tabular}{c}
8 \\
\hline 16.6 \\
22.0 \\
29.5
\end{tabular}

Actual

Capability Reserve

8

4,347

$(4.2)$

3,968

$(14.3)$

4,223

$(9.7)$

$\begin{array}{lllll}23.3 & 5.183 & 0.1 & 1.824 & (64.7) \\ 19.3 & 6.367 & 19.3 & 5.059 & (5.2) \\ 37.4 & 7.061 & 33.9 & 5.074 & (3.8)\end{array}$

( ) Indicates negative reserves

Reserve after maintenance appeared to have been adequate, however, large amounts of forced outages caused actual reserve to be negative during this pexiod. However, the situation appears to be improving. The critical condition during winter $1977 / 1978$ was precipitated by the coal strike and a high number of forced outages. Fortunately, APS had adequate interconnections with neighboring utilities and was able to secure short-term purchases and emergency transfers to cover capacity shortages.

Listed below are annual load and energy requirements for the 1977-79 period.

TABLE IA. 4

HISTORICAL ENERGY, PEAKS AND LOAD FACTORS

ALLEGHENY POWER SYSTEM REGION

Annual

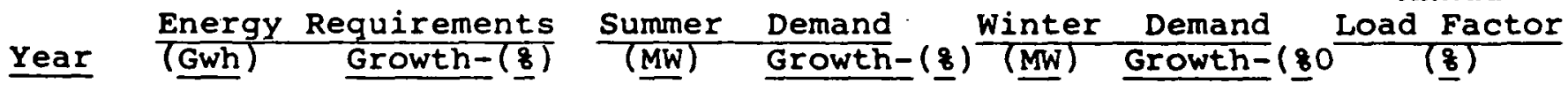

$\begin{array}{llllllll}1977 & 29.551 & - & 4,539 & - & 5.174 & - & 65.2 \\ 1978 & 30,166 & 2.1 & 4,632 & 2.0 & 5,335 & 3.1 & 64.6 \\ 1979 & 31.813 & 5.5 & 4,676 & 0.9 & 5.272 & (1.2) & 68.9\end{array}$

$\begin{array}{llll}8 \text { Growth } 1977-79 & 3.8 & 1.5 & 0.9\end{array}$ 
Energy requirements over the $1977 / 1979$ period have grown at a compound rate of 3.88 , this is a higher rate than most other regions in ECAR. This is the result of the APS diversity in sales and is indicative of economic stability in their service area. Peak demand growth rates were considerably lower than their traditional patterns. This is due in part to conservation techniques and the increased cost of energy.

Current Perspective

The projected 1980 summer and winter demands are shown below.

TABLE 1 A. 5

PROJECTED 1980 SEASONAL PEAK DEMAND-MW ALLEGHENY POWER SYSTEM REGION

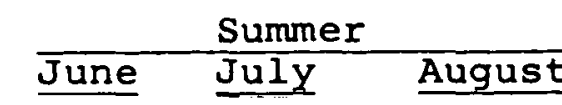

$4,488 \quad 4,833 \quad \underline{4,868}$

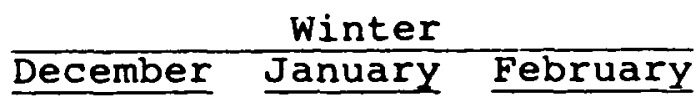

5,743

5,933

5,823

Underline indicates seasonal peak

The 1980 summer and winter demands are projected to occur in August and January, respectively. This is consistent with previous occurrences. However the peak may still occur in any month of the particular season depending on economic and climatic conditions.

The extremely high rate of growth (12.58) between the $1979 / 80$ and $1980 / 81$ winter peak demand is probably due to an overestimation of the 1979/80 winter peak before the fact. There is a difference nf $2.71 \mathrm{MW}$ between forecasted $1979 / 80$ and the actual winter peak. If indeed the $1980 / 81$ forcasted winter peak is inflated due to this forecast error, reserve margins would increase throughout the 1980-1989 period.

The summer demand is projected to be 228 less than the winter demand, which affords the opportunity for the performance of scheduled maintenance.

The 1980 winter planned capability in the APS region is estimated to be $7,671 \mathrm{MW}$ and the winter coincident peak demand is projected to be $5,933 \mathrm{MW}$. After adjustment for receipts and deliveries, total reserve is $2,142 \mathrm{MW}$ or 36.18 . 
In the ECAR ERA-411 report for the (1980-1989) period, APS does

$t$ list inoperable capability for either scheduled maintenance $\sim$ possible forced outages. However, ECAR provides an indication of planned maintenance for the entire region in the ERA 411 report. This estimate is based on the level of planned maintenance that is currently projected for the peak demand periods during the upcoming summer and winter seasons, $i . e .$, five percent of total planned capability during the winter of $1980 / 81$.

The following table indicates forced outage rates experienced by APS.

TABLE 1 A. 6

FORCED OUTAGE RATES

ALLEGHENY POWER SYSTEM REGION

Year
$1976-5.84$
$1977-5.49$
$1978-16.80$
$1979-19.01$

Trends indicates a dramatic increase in forced outage rates on the APS system during 1978 and 1979 as a result of persistant and lengthly outages of the large units on the system. The units at Harrison ( 3 units - $640 \mathrm{MW}$ each) and at Hatfield's Ferry ( 3 units - $555 \mathrm{MW}$ each) in total represent over 508 of the APS system capability. At times during the 1978-1979 period, three units were out concurrently at these facilities. Some single units at these facilities were out for periods as long as six months. In the first quarter of 1980, the high forced outage rate continues with units at these facilities still experiencing difficulties. No single problem is evident, but rather a series of unrelated occurrences.

The summer and winter 1980 reserve margins for the electric region are shown below.

TABLE $1 \mathrm{~A} .7$

RESERVE MARGINS

ALLEGHENY POWER SYSTEM REGION

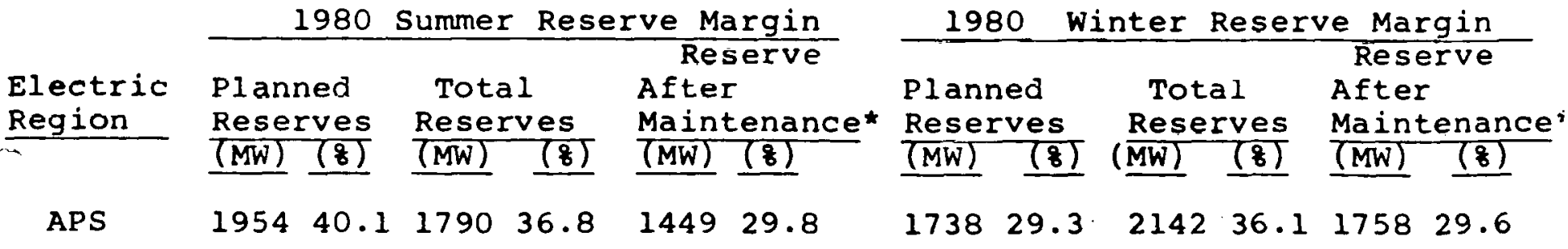

$5 \%$ of total planned capability assumed from ECAR-ERA-411

Report for scheduled maintenance. 
The reserve margins shown above have not been adjusted for unscheduled outages since the amount of these outages are generally unknown. However, these outages have been running as high as 198 . As long as unscheduled outages do not exceed about 20-25\% of the seasonal capability, the resultant available reserves should be a positive number.

The systems in APS region are governed by ECAR Document No.2 Daily Operating Reserve agreement which specifies that each system, as a minimum must provide, (I) an amount of reserve equal to three percent of the maximum 60-minute integrated clock hour internal load predicted for the day to provide for load regulation and for system frequency regulation. This portion of the operating reserve shall be spinning reserve within the control area of the system; (2) An amount of reserve equal to three percent of the maximum 60-minute integrated clock hour native load predicted for the day times the system's allocating constant to provide for protection against an unexpected loss of generation. This portion of the operating reserve may be allocated in any desired combination with the following limits and is fully applicable within ten minutes:

1) 0-100 percent spinning reserves.

2) 0-100 percent non-spinning reserves either interruptible or quick-start.

3) 0-100 percent prescheduled assistance from another $\operatorname{system}(s)$.

The winter $1980 / 81$ capability of the generating facilities installed in the APS region will be $7671 \mathrm{MW}$. The capability breakdown by fuel type is shown below.

TABLE IA.

$1980 / 81$ WINTER PLANNED CAPABILITY ALLEGHENY POWER SYSTEM REGION

\begin{tabular}{|c|c|c|c|c|c|}
\hline $\begin{array}{l}\text { Electric } \\
\text { Region }\end{array}$ & $\begin{array}{c}\text { (Steam) } \\
\text { Nuc } \\
(\overline{\mathrm{MW}}) \\
\end{array}$ & $\begin{array}{c}\text { (Steam) } \\
\text { Coal } \\
(\mathrm{MW}) \\
\end{array}$ & $\begin{array}{l}\text { (Steam) } \\
\text { Oil } \\
\text { (MW) }\end{array}$ & $\begin{array}{c}\text { (Conv.) } \\
\text { Hydro } \\
\text { (MW) }\end{array}$ & $\begin{array}{c}\text { Total } \\
\text { Capability } \\
(\mathrm{MW})\end{array}$ \\
\hline $\begin{array}{l}\text { AP } \\
\& \text { Total }\end{array}$ & 0 & $\begin{array}{l}7123 \\
92.9\end{array}$ & $\begin{array}{l}486 \\
6.3\end{array}$ & $\begin{array}{l}62 \\
0.8\end{array}$ & $\begin{array}{l}7,671 \\
100.0\end{array}$ \\
\hline
\end{tabular}


$\mathrm{XI} .1 .35$

Almost 938 of the current capacity is coal-fired steam capacity; 68, oil-fired steam; and 18 hydroelectric. There are no nuclear facilities installed in the Region and hydroelectric generation is an insignificant portion of the total. There is only one coal-fired unit scheduled to be placed in service during the 1980 , Pleasants \#2 with a rating of $626 \mathrm{MW}$, in october.

The projected 1980 energy requirements, summer and winter demands and annual load factor for the region are shown in Table $1 \mathrm{~A} .9$.

TABLE 1 A. 9

1980 ENERGY REQUIREMENTS, PEAK DEMAND AND LOAD FACTOR ALLEGHENY POWER SYSTEM REGION

Energy

Requirements (Gwh)

8 Growth $1980 / 89$
Summer

Demand

(MW)

33,600

5.6
4,868

4.1 winter

Demand (MW)

5,933

12.5
Annual L.F.

66.8

The 1980 estimated energy requirements and peak demands are projected to grow at considerably higher rates than they did during the 1977-79 period.

Delays of future critical bulk power transmission facilities that will not be in service when needed is required to be reported under Item 5-C of the ERA 411 report. There are no transmission lines in this category reported by APS in the April 1, 1980 ECAR report.

\section{Future Perspective}

The range of total reserve for APS for the periods 1981-1985 and 1986-1989 are shown in Table 1A.10.

TABLE 1A.10

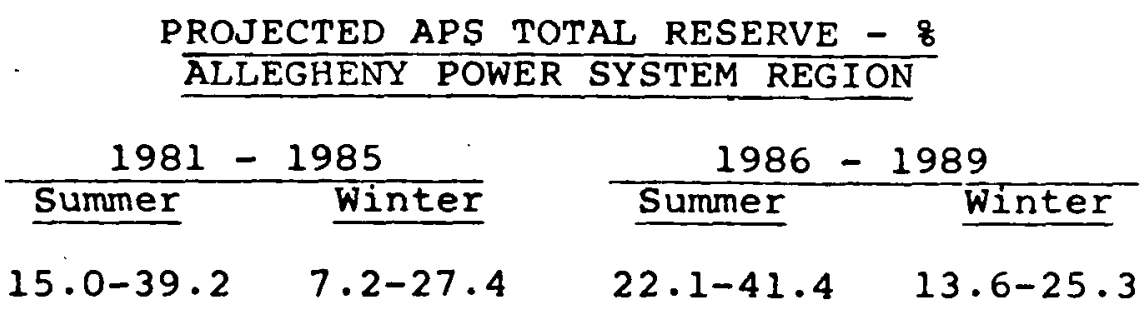


As shown in the Table, the total reserve vary from a low of 7.28 in the winter 1985-86 to a high of 41.48 in the summer of 1989 . As indicated in Table $1 \mathrm{~A} .20$ for the winter peak, for the years 1984,85 , and 86 APS could have difficulty meeting its obligations. Should the scheduled maintenance run as indicated previously, at 58 of planned capability the reserve after maintenance would be as little as 150 MW or less than 2\%. This leaves very little margin for unscheduled outages or other capability unavailable.

Shown below are the projected growth rates of demand and capability for each period and the overall rates for 1981-89.

\section{TABLE 1A.II}

PROJECTED GROWTH RATES - $\frac{8}{6}$
ALLEGHENY POWER SYSTEM REGION

$\begin{array}{ccc}\text { Summer } & \text { Winter } & \text { Energy } \\ \text { Peak Demand } & \text { Peak Demand } & \text { Requirement }\end{array}$

$\begin{array}{llll}1981-1985 & 4.5 & 4.4 & 4.2 \\ 1986-1989 & 3.9 & 4.5 & 4.0 \\ 1981-1989 & 4.3 & 4.4 & 4.1\end{array}$

The summer peak demands are projecrted to increase at a compound rate of growth of $4.5 \%$ during $1981-1985$ period, $3.9 \%$ during 19861989 period and at $4.3 \%$ during $1981-1989$ period. The rates are considerably higher than the summer 1977-1979 growth of 1.58 .

No new capacity is projected for the $1981-1985$ period. Winter capability is expected to increase by 6.38 in the 1986-89 period and summer capability is expected to increase by $9.2 \%$ during this period. For the 1981-89 time frame, winter and summer capability increases are about equal to demand projection increases of $4.3 \%$ and $4.4 \%$.

The energy requirements are projected to grow 4.28 from $1981-85,4.0 \%$ from 1986-1989, and 4.18 for the overall period 1981-1989. These rates of growth are similar to the past trends which indicate a balance of economic activities.

The winter capability of units installed in the Region for the period 1980-1989 is listed by type of fuel in Table 1A.20. Major generating unit additions during the period are given in Table $1 \mathrm{~A} .21$. The percentages of each type of capacity for the target years 1980, 1984 and 1989 are indicated below. 
TE-

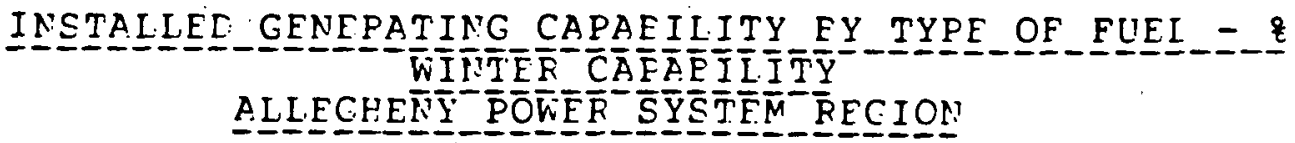

\begin{tabular}{|c|c|c|c|c|}
\hline & $\begin{array}{l}\text { Coal } \\
\text { Steㅡㅍㅡ }\end{array}$ & $\begin{array}{l}\text { Oil } \\
\text { Steam }\end{array}$ & $\begin{array}{l}\text { Hydro } \\
\text { Conv. }\end{array}$ & $\begin{array}{l}\text { Pumped } \\
\text { Storage }\end{array}$ \\
\hline $\begin{array}{l}1980 \\
1984 \\
1989\end{array}$ & $\begin{array}{l}92.9 \\
92.9 \\
85.3\end{array}$ & $\begin{array}{l}6.3 \\
6.3 \\
4.6\end{array}$ & $\begin{array}{l}0.8 \\
0.8 \\
0.6\end{array}$ & $\begin{array}{r}0 \\
0 \\
9.5\end{array}$ \\
\hline
\end{tabular}

Currently, coal is the frimary. fuel for about 938 of the planned capability of the region. This percentage is projected to decrease to 858 by 1989 , due to the proposed installation of the 1000 Mh Lavis Pumped storage plant. Two units (250 $\mathrm{MW}$ each) are to be installed in 1986 and two units (250 MV each). in 1987.

Only one additional plant is projected for the Pegion, a triree-unit coal-fired flant - Lower Armstrong $(630 \mathrm{Mh}$ each). Th.e units are scheduled for installation in 1986, 1987, and 1988. The installation of these units apeear to be critical in meeting the APS obligations. If the first $630 \mathrm{MW}$ unit is not on line to meet the 1986-87 winter peak demand, the peak demand of $7.738 \mathrm{Mh}^{\mathrm{T}}$ will rcduce the planned reserve from 13.68 to 5.58. This assumes that the Lavis pumped Storage plant, whose construction is highly speculative, will not te on line. Even if the two Lavis units (500 MW) scheduled for 1986 were in service the situation would still be precarious. It appears that under this situation APS, which shows no purchases fromi 1985 to 1989, may have to turn to capacity imports from neighboring systems.

The most recent ECAR appraisal studies on the APS transmission line status for Summer 1979 and winter 1979-80 indicates that timely completion of the scheduled transmission facility additions would insure that the reliabilty of the bulk power transmission systems within ECAR would be maintained at a high level. 
Emergency Transfer Capabilities to adjacent regions, based on the NERC definition, were reported as follows:

TAEELE_IA. 13

\section{EMEFGENCY TRANSFER CAPAEILITY MW

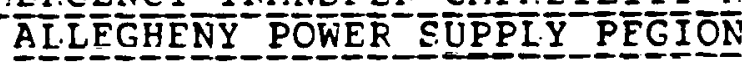

$\begin{array}{lcc}\text { Transfer Parties } & \text { Summer } 19 \underline{9} 9 & \text { winter } \\ \text { ECAR to MAAC } & 3300+ & 3300+ \\ \text { ECAR to NPCC (NYPP) } & 2200 & 2950 \\ \text { ECAF to MAIN } & 3450 & 3950 \\ \text { ECAF to SERC (TVA) } & 1800 & 1600 \\ \text { ECAK to SERC (VACAF) } & 1250 & 1900^{\star} \\ \text { ECAR from MAAC } & 2450 & 3300+ \\ \text { ECAR from NPCC (NYPP) } & 3300+ & 2900 \\ \text { ECAR from MAIN } & 4000+ & 3800+ \\ \text { ECAR from SERC (TVA) } & 2000 & 2100 \\ \text { ECAR from SERC (VACAR) } & 2700 & 2950 \star\end{array}$

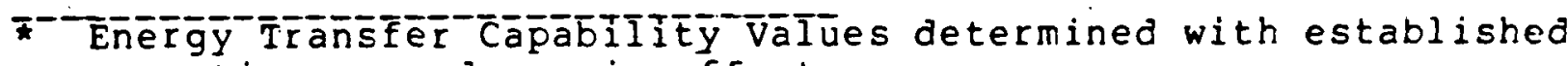
operating procedures in effect.

Should any of the EHV transmission facilities planned for the 19801984 period be delayed due to regulatury or financiul reasons would necessitate appropriate short term operating procedures to be developed in order to maintain the reliability of electric power supply within FS.AR. Such procedures, if invoked, may jeopardize the reliability of the power supply in the affecled area.

Emergency Transfer Capabilities to adjacent regions, based on the NERC definition, are as follows: 
TAPLE_IA.14

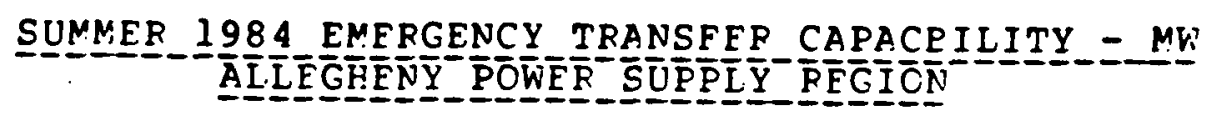

$\begin{array}{llll}\text { Transfer Parties } & \text { ML: } & \text { - Transfer_Parties } & \text { M. } \\ \text { ECAR to MAAC } & -4350 & \text { ECAR from MAAC } & 2600 \\ \text { ECAR to NPCC (NYPP) } & 1950 & \text { ECAF from NPCC } & 2900 \\ \text { ECAR to MAIR! } & 2900 & \text { ECAR from MAIN } & 4000+ \\ \text { ECAR to SEFC (TVA) } & 2500 & \text { ECAR from SERC (TVA) } & 3200 \\ \text { ECAR to SEFC (VACAR) } & 2250 & \text { ECAR from SEPC (VACAF) } & 5500+\end{array}$

Table lA.15 shows a list of proposed bulk power lines to be constructed by APS. It includes internal transmission as well as interconnections with other utilities. Nany of these intercornection will become critical, since APS's low reserve margins in the mid-1980s may make them heavily dependent on capacity imports. 


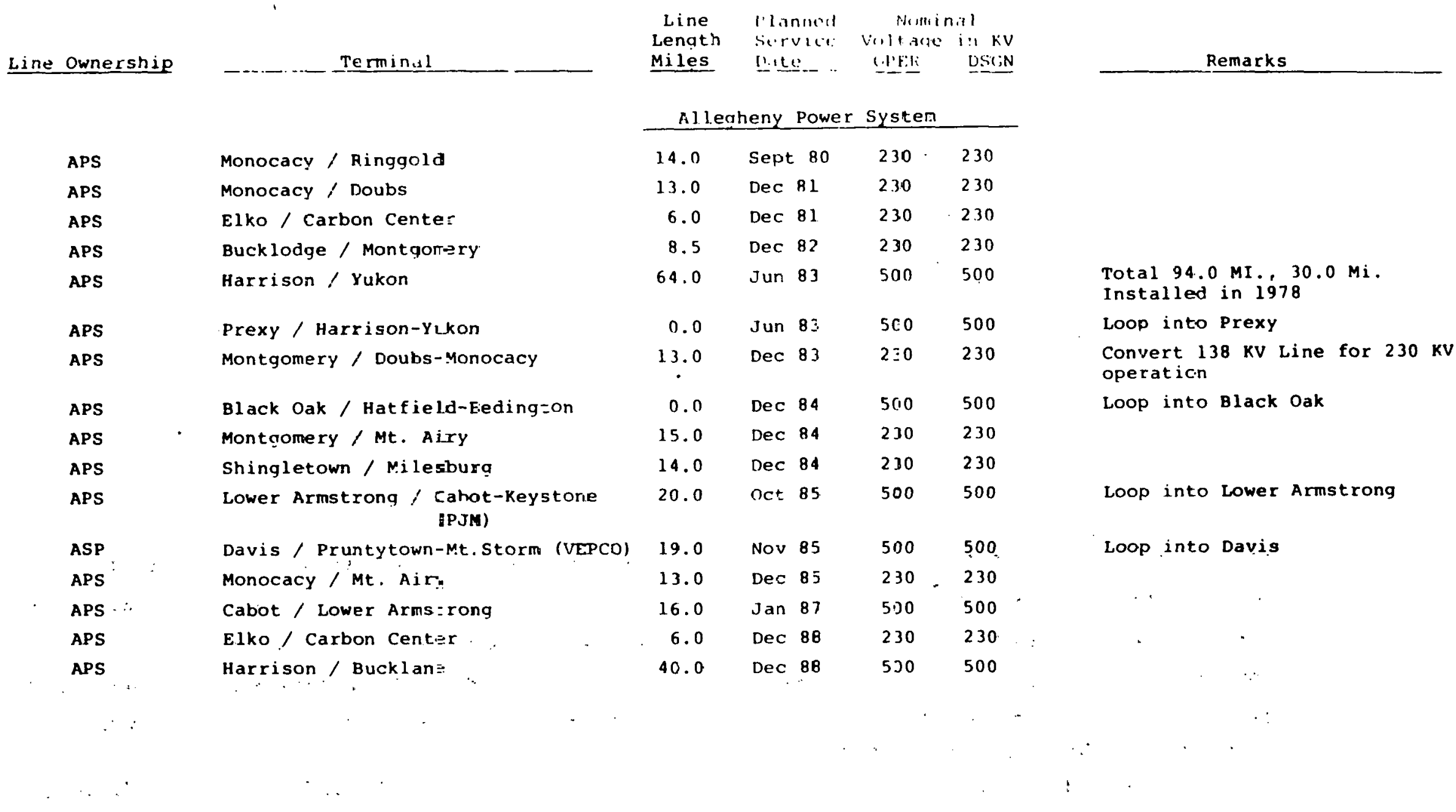


FROPOSED BULK POWE:R IINES

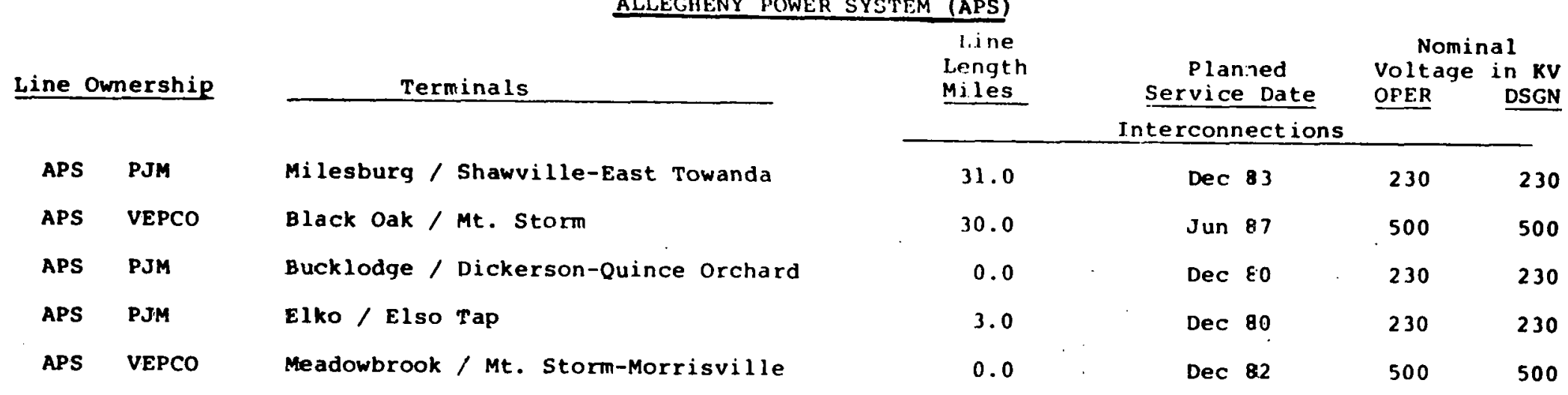


Table 1 A.16

HISTORICAL CAPABILITY AND RESERVE MARGINS

ALLFGHEINY POWER SYSTEM REGION

\section{Summer 1977/1978 Winter 1978 Surmer $1978 / 1979$ Winter}

(1) Planned Capability (MW)

(2) Peak Demand (MW)

(3) Planned Reserve (MW) (1-2)

(4) Planned Reserve (8) (3-2) × 100

(5) Net Transactions 1/ (MW)

(6) Total Capability (MW) $(1+5)$

(7) Total Reserve (MW) (6-2)

(8) Total Reserve (8) (7-2) × 100

(9) Scheduled Maintenance (MW)

(10) Capability after Maintenance (Mil (6-9)

(11) Reserve after Maintenance (MW) $(10-2)$

(12) Reserve after Maintenance $(8)(11-2) \times 100$

(13) Inoperable Capability (MW)

(14) Available Capability (MW) (10-1引)

(15) Available Reserve (MW) (14-2)

(16) Available Reserve (8) (15-2) × 100

(17) Forced Outages (F.O.) (MW)

(18) Available Capability after F.O. (MN) (14-17I

(19) Actual Reserve (MW) (18-2)

(20) Actual Reserve (8) $(19-2) \times 100$

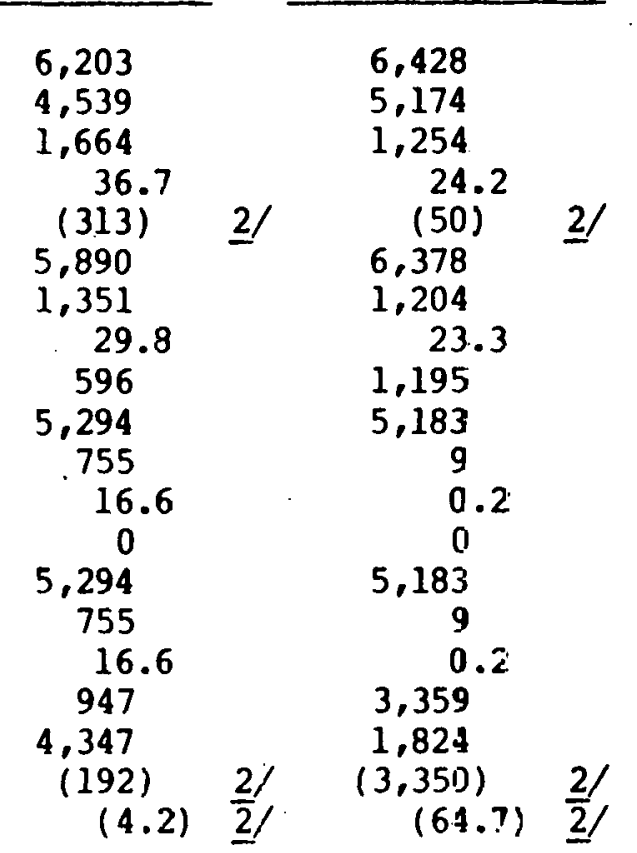

6,203
4,632
1,571
33.9
$(50) \quad 2 i$
6,153
1,521
32.8
500
5,653
1,021
22.0
0
5,653
1,021
22.0
1,685
3,968
$(664) \quad 2 /$
$(14.3) \quad \underline{2}$

6,417
5,335
1,082
20.3
$(50) \quad 2 /$
6,367
1,032
19.3
0
6,367
1,032
19.3
0
6,367
1,032
19.3
1,308
5,059
$(276) \quad 2 /$
$(5.2) \quad \underline{2} /$


Table 1A.17

HISTORICAL AND CURRENT CAPABILITIES AND RESERVE MARGINS ALLEGHENY POWER SYSTEM REGION

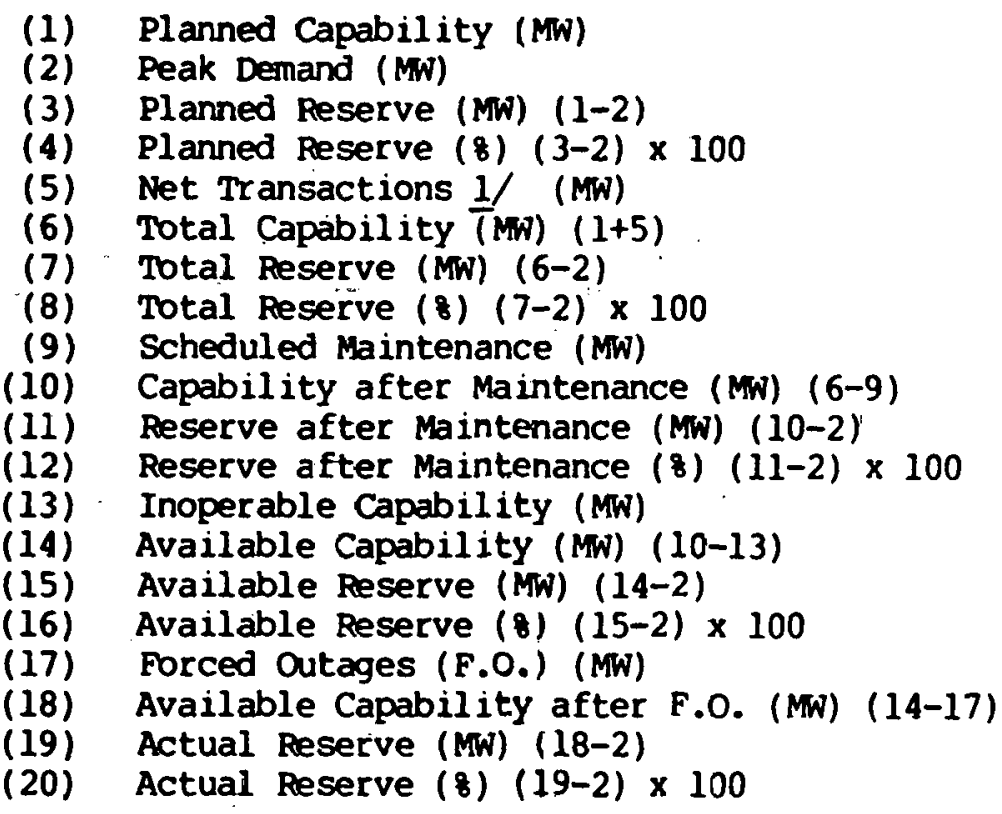

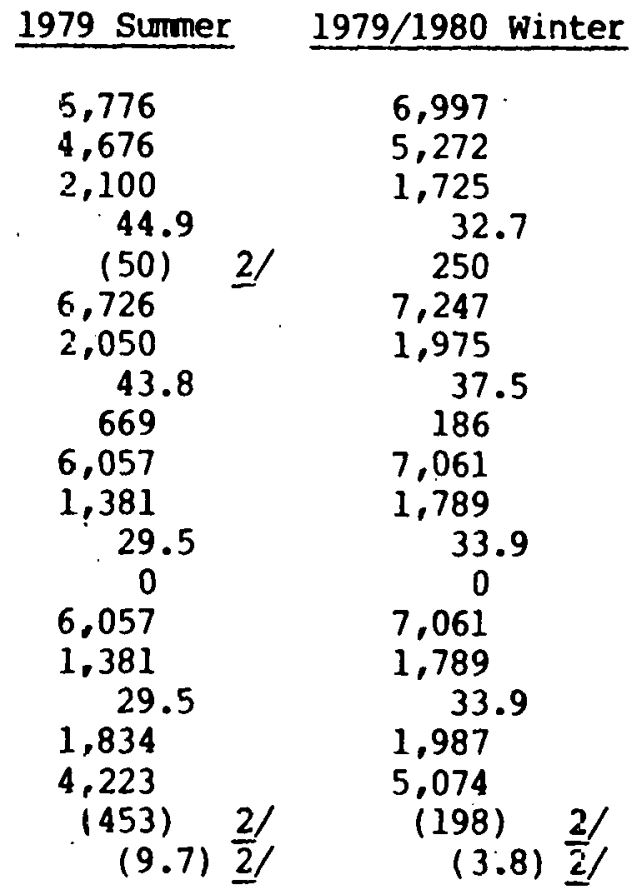

1980 Summer

$\underline{1980 / 1981 \text { Winter }}$

1/ Net Transactions $=$ Purchases - Sales

2/ ( ) denotes negative number 
FUTURE CAPABILITY MND RESERVE, MARGINS 1981-1989 ALI.EXHIFNY POWER SYSTEM RFOION

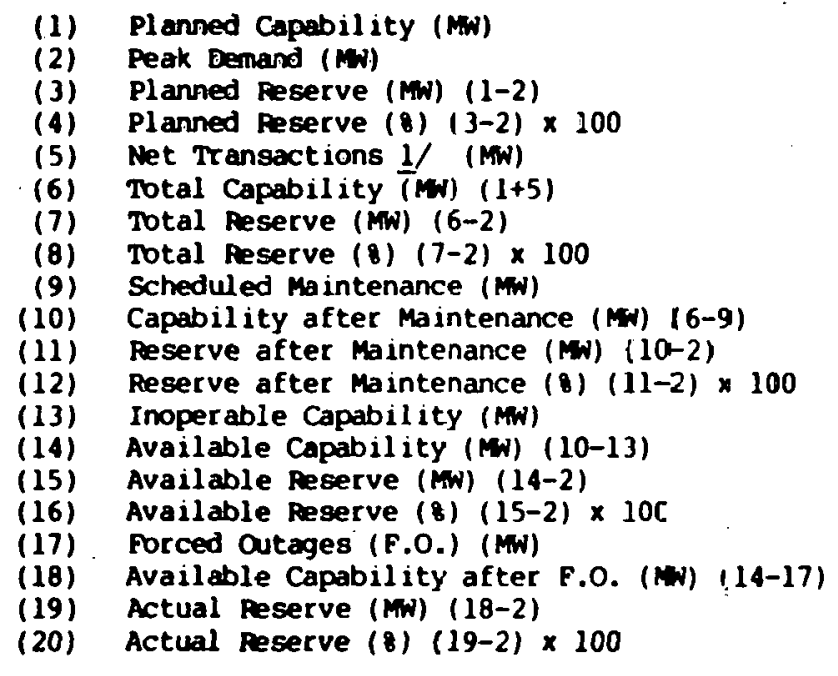

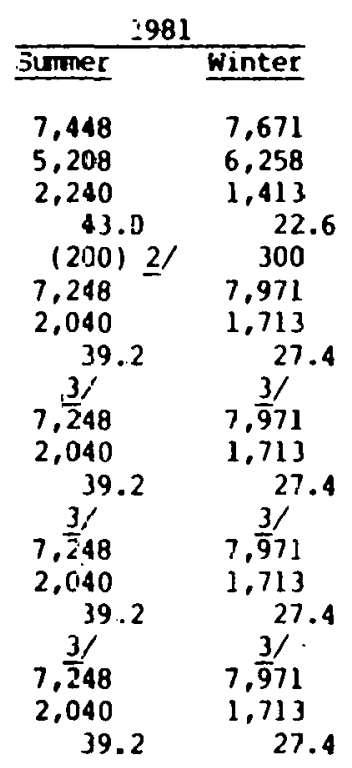

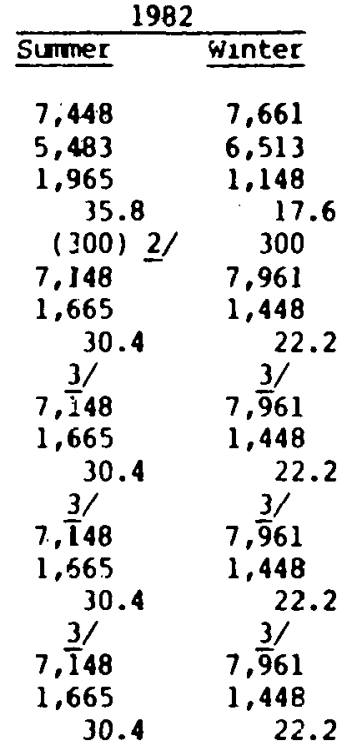

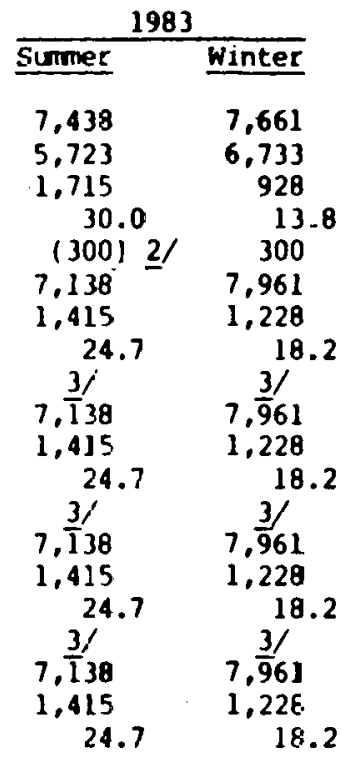

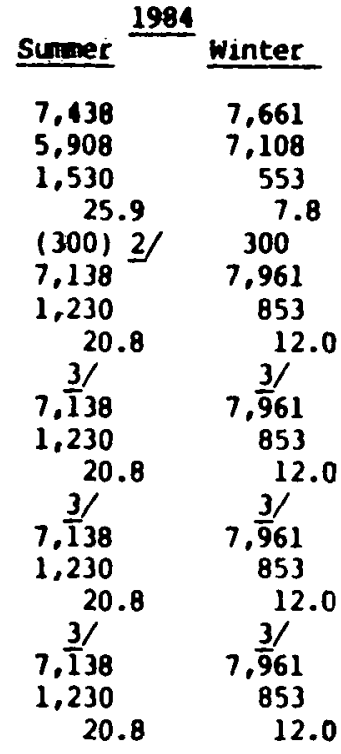

1/. Net Transactions = Purchases - Sales

$\frac{1}{2}$ ( ) denotes negat ive number

3/ Information on scheduled main'enance, inoperable capability and forced outages are not avallable 
Table 1A.18

Page 2 of 2

FUTURE CAPABILITY AND RESERVE MANGINS 1981-1989 ALLEGHFNY POWER SYSTEM RFGIO

(1) Planned Capability (Mi)

(2) Peak Demand (MW)

(3) Planned Peserve (MN) (1-2)

(4) Planned Reserve (8) (3-2) $\times 100$

(5) Net Transactions $1 /$ (MAN)

(6) Total Capability $($ (N) $(1+5)$

(7) Total Peserve (iw) (6-2)

(8) Total Reserve (8) $(7-2) \times 100$

(8) Total Reserve (8) (7-2) × 100

Capability after Maintenance (w) (6-9)

11) Reserve after maintenance (MW) $(10-2)$

12) Reserve after Maintenance (8) $(11-2) \times 100$

13) Inoperable Capability (iwi)

14) Available Capabil ity (1w) (10-13)

15) Available Reserve (ivi) $(14-2)$.

16) Available Reserve (8) $(15-2) \times 100$

17) Forced autoges (F.O.) (I.)

18) Available Capability after

19) Actual Reserve (iv) (18-2)

Actual Reserve (1) $(19-2) \times 100$

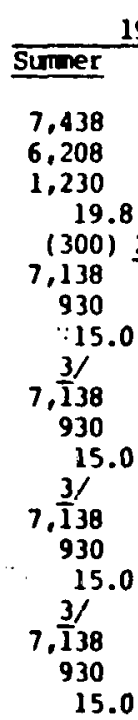

Winter

7,661

7,428

$\begin{array}{ll}230 & 233 \\ 19.8 & 3.1\end{array}$

(300) $2 / \quad 300$

7,961

15.0

, 138

7.2

$3 /$
761
533

15.0

$\frac{3 /}{138}$

7.2

$7, \frac{3 / 961}{561}$

533
.7 .2

$7, \frac{3}{961}$

7,961
533

15.0

\begin{tabular}{cc}
\multicolumn{2}{c}{1986} \\
\hline Summer & Winter \\
, 938 & 8,791 \\
6,503 & 7,738 \\
1,435 & 1,053 \\
22.1 & 13.6 \\
$3 /$ & $3 /$ \\
$7, \overline{9} 38$ & 8,791 \\
1,435 & 1,053 \\
22.1 & 13.6 \\
$\frac{3 /}{938}$ & 8,791 \\
1,435 & 1,053 \\
22.1 & 13.6 \\
$3 /$ & $3 /$ \\
$7, \overline{9} 38$ & 8,791 \\
1,435 & 1,053 \\
22.1 & 13.6 \\
$3 /$ & $3 /$ \\
$7, \overline{9} 38$ & 8,791 \\
1,435 & 1,053 \\
22.1 & 13.6
\end{tabular}

s.

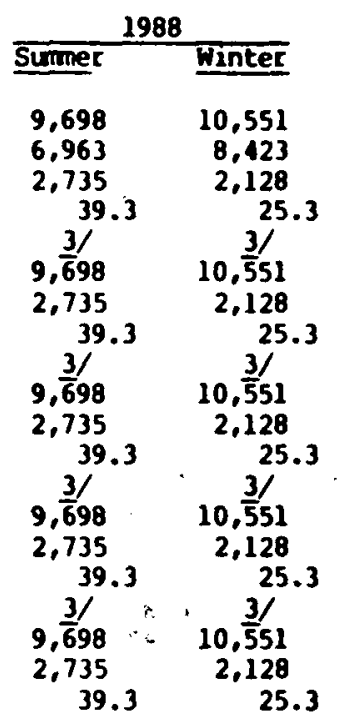

$\frac{1989}{\text { Sumer }}$

$10,328 \quad 10,551$

$7,303 \quad 8,823$

$41.4 \quad 1.728$

$3 /$

$10, \frac{3}{328}$

$3 /$

$3 /$

2,310

34.2

$9, \overline{0} 68$

2,310

34.2

$9, \frac{3 /}{068}$

2,310

34.

$9, \frac{3 /}{068}$

2,310

$3 /$

9,921

3,025

41.4

$\frac{3}{3} / 8$

10,328
3.025

1,728

$3 /$

1,388

23.5

$9, \frac{3 /}{921}$

1,888

23.5

$9, \frac{3}{5}$

9,521

23.5

41 .

3

10,551

1,728

$10, \frac{3 / 328}{3 / 2}$

$3,025 \quad 10,551$

$41.4 \quad 19.6$

$10, \frac{3}{328}$

10,328

19.

$41.4 \quad 19.6$

1 Wet Transactions - purchoses - Sales

2/ ( ) denotes negative number

3/ Information on net transactions, scheduled maintenance, inoperable capability, and

forced outages are not available 
Table $1 \wedge .19$

ACTUAL AND PROJECTED ENERGY, DEMAND AND CAPABELITY ALLEGHEVY POWER SYSTEM (APS)

\begin{tabular}{|c|c|c|c|c|c|c|c|c|c|c|c|c|}
\hline \multirow{2}{*}{\multicolumn{2}{|c|}{$\begin{array}{l}\text { Electric } \\
\text { Reqion } \\
\text { (APS) }\end{array}$}} & \multicolumn{2}{|c|}{ Energy Requi rements } & \multirow{2}{*}{$\begin{array}{l}\text { summer } \\
(\mathrm{mW})\end{array}$} & \multirow{2}{*}{$\begin{array}{l}\text { Demand } \\
\text { Growth }\end{array}$} & \multirow{2}{*}{$\frac{\text { Winter }}{\text { ( MW ) }}$} & \multirow{2}{*}{ 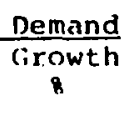 } & \multirow{2}{*}{$\begin{array}{l}\text { Annual } \\
\text { Load Factor }\end{array}$} & \multicolumn{2}{|c|}{ Sumner Capabilits: } & \multicolumn{2}{|c|}{ Wintex Capability } \\
\hline & & $(\mathrm{mWh})$ & cowth & & & & & & $(M W)$ & $\begin{array}{c}\text { Growth } \\
8\end{array}$ & & $\underset{8}{\text { Growth }}$ \\
\hline & 1977 & $29,551,313$ & & 4.539 & - & 5.174 & - & 67.1 & 6,203 & - & 6,428 & - \\
\hline & 1978 & $30,166,454$ & 2.1 & 4,632 & $2 . c$ & 5,335 & 3.1 & $6 \epsilon .6$ & 6,203 & 0 & 6,417 & $(0.2)$ \\
\hline & 1979 & $31,813,206$ & 5.5 & $4,6.76$ & 0.5 & 5,272 & $(1.2)$ & $6 \varepsilon .1$ & 6.776 & 9.2 & 6,997 & 9.0 \\
\hline Growth & $77-79$ & - & 3.8 & - & i. 5 & - & 0.9 & - & - & 4.5 & - & 4.3 \\
\hline & 1980 & $33,600,000$ & 5.6 & 4,868 & $4 . i$ & 5,933 & 12.5 & 65.8 & 6,822 & 0.7 & 7,671 & 9.6 \\
\hline & 1981 & $35,700,000$ & 6.3 & 5,208 & 7.0 & 6.258 & 5.5 & 65.1 & 7,448 & 9.2 & 7.671 & 0 \\
\hline & 1982 & $37,200,000$ & 4.2 & 5,483 & 5.3 & 6,513 & 4.1 & $65.2 \hbar$ & 7,448 & 0 & 7.661 & $(0.1)$ \\
\hline & 1983 & $38,700,000$ & 4.0 & 5,723 & 4.4 & 6,733 & 3.4 & $65.6 *$ & 7,438 & $(0.1)$ & 7,661 & 0 \\
\hline & 1984 & $40,400,000$ & 4.4 & 5,908 & 3.2 & 7,108 & 5.5 & $6.4 .9 *$ & 7,438 & 0 & 7,661 & $\mathbf{0}$ \\
\hline & $\ln 85$ & $42,100,000$ & 4.2 & 6,208 & 5.0 & 7,428 & 4.5 & $64.7^{\circ}$ & $7,4 \vdots 8$ & 0 & 7,661 & 0 \\
\hline Growth & $81-85$ & - & 4.2 & - & 4.5 & - & 4.4 & - & - & 0 & - & 0 \\
\hline & 1986 & $43,800,000$ & 4.0 & 6,503 & 4.7 & 7,738 & 4.1 & $6.4 .6 *$ & 7.938 & 6.7 & 8,791 & 14.8 \\
\hline & 1987 & $45,400,000$ & 3.7 & 6.758 & 3.9 & 8,033 & 3.8 & $64.5 *$ & 9.058 & 14.2 & 9,921 & 12.9 \\
\hline & 1988 & $47,200,000$ & 4.0 & 6,963 & 3.0 & 8,423 & 4.8 & $64.0^{\circ}$ & 9.638 & 6.9 & 10.551 & 6.4 \\
\hline & 1989 & $49,200,000$ & 4.2 & 7.303 & 4.9 & 8,823 & 4.7 & $63.7^{\star}$ & 10,328 & 6.5 & 10,551 & 0 \\
\hline Growth & $86-89$ & - & 4.0 & - & 4.0 & - & 4.4 & - & - & 9.2 & - & 6.3 \\
\hline Growth & $81-89$ & - & 4.1 & - & 4.3 & - & 4.4 & - & - & 4.2 & - & 4.1 \\
\hline
\end{tabular}

\footnotetext{
Based on winter peak rather than annual peak.
} 
Table 1A. 20

INSTALLED NET CAPABILITY BY TYPE OF FUFL - MW

ALLEGHENY POWER SYSTEM (APS)

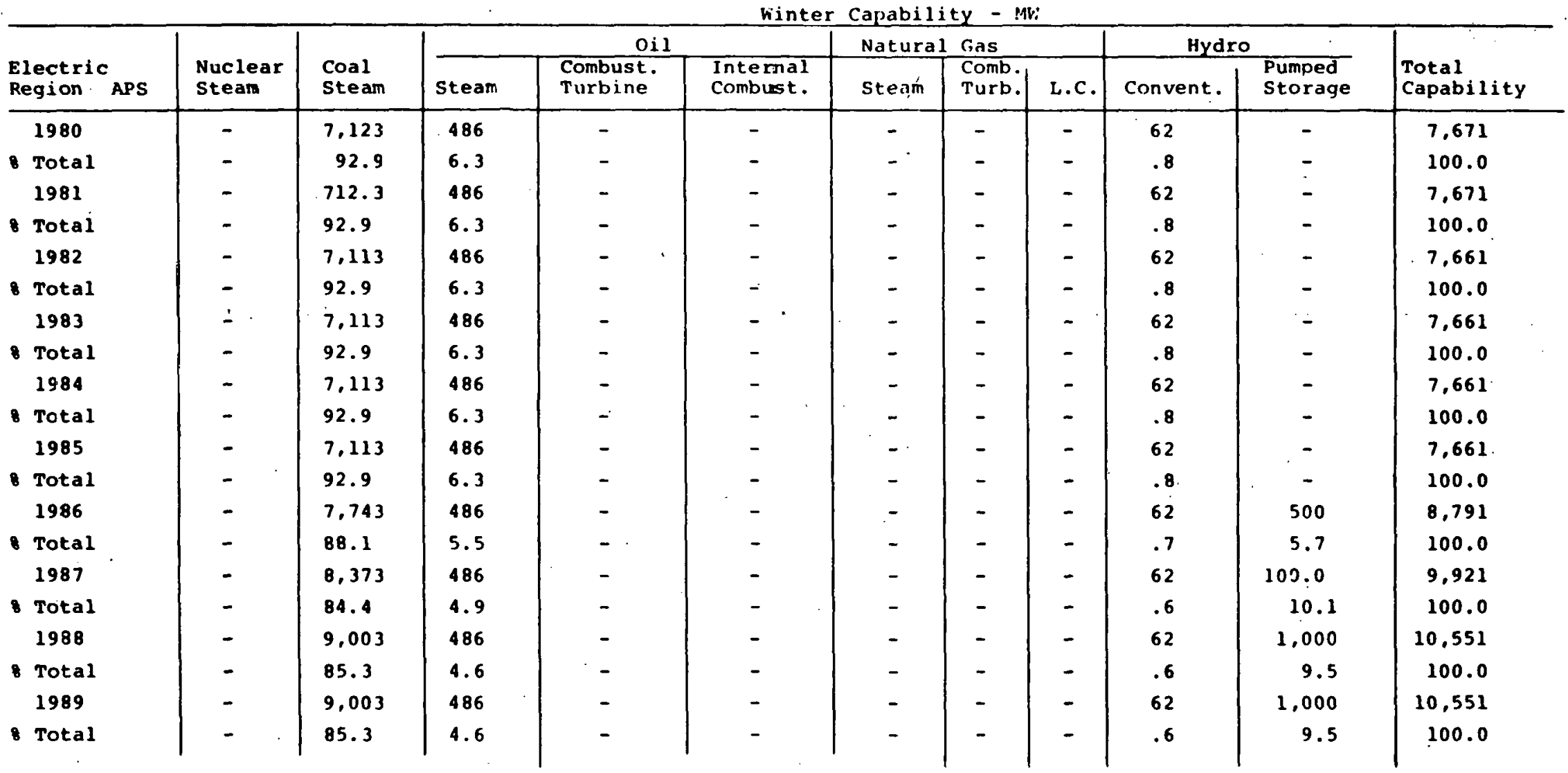


Table $1 \mathrm{~A} .21$

MAJOR GENERATING UNIT ADIITIGNS AND REMOVALS

ALEEGIIENY POWER SYSTEII (APS)

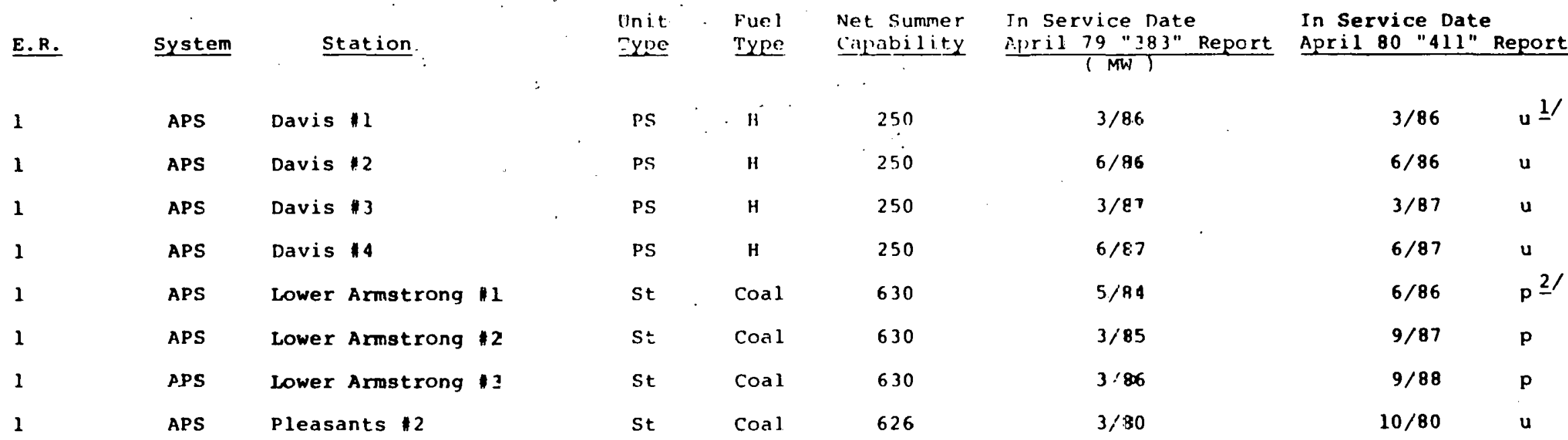

NOTE: No installations or removals durina 1981-1935 and 1989

$1 / \mathrm{u}$ - Under construction, less than 508 complete

2/ p - Planned for installation but not (utility) authorized 


\title{
Central Area Power Coordination Group (CAPCO)
}

\author{
ELECTRIC REGION 13
}

\section{Historical Perspective}

Region 13 includes the Central Area Power Coordination Group and the Cleveland Municipal System.

The Central Area Power Coordination Group (CAPCO) is a coordinating group with activities in two principal areas: planning and operation. CAPCO was originally formed in 1964, and now consists of five major investor-owned electric utilities providing service in northern ohio and western Pennsylvania. The five member systems are: The Cleveland Electric Illuminating Company, Duquesne Light Company, Onio Edison Company, Pennsylvania Power Company, and the Toledo Edison Company.

The CAPCO organization is headed by an Executive Committee which is responsible for basic policy and development of new opportunities for mutual economic and reliability benefits.

Practices in the Planning and Development of Facilities have included coordinated; (1) load forecasts, (2) planning for reserves, (3) system stability studies, (4) joint or staggered participation in facilities development, and (5) pooling arrangements. Operating Practices have included coordination of; (1) capacity and energy exchange, (2) reserves including spinning reserves, (3) maintenance, and (4) economic dispatch including description of control facilities. Each of the five CAPCO companies has its own system dispatch center. Under the terms of the CAPCO Basic Operating Agreement the members of CAPCO can purchase or interchange power and energy, economy exchange, and unit capacity and energy from the other members of the pool. The sales or exchanges are subject to the mutual consent of the buyer and seller, but if a transaction is made it must be in accordance with the schedules set forth in the Basic Operating Agreement. The members of CAPCO are also free to buy, sell, or exchange power and energy with utilities outside of CAPCO.

A utility not included in CAPCO but within the CAPCO region is the Division of Light and power of the City of Cleveland. It is a liaison member of ECAR and included in subsequent tables.

In 1978, the utilities in the CAPCO region served almost $2,489,000$ customers, of which $2,230,000$ were residential, 219,000 commercial, 13,000 were industrial, and 27,000 others. The CAPCo companies, although widely dispersed, are highly interconnected internally and with other ECAR systems at $345 \mathrm{KV}$ and $138 \mathrm{KV}$. Since the CAPCO region is in the extreme northeast corner of ECAR, its only interconnections with other regions are to the east, with utilities in MAAC. 
The CAPCO region has historically been a summer peaking area. Shown below are the region's summer and winter peaks for the period 1977-1979.

Table 1C.1

Historical Peak Demands - MW CAPCO REGION

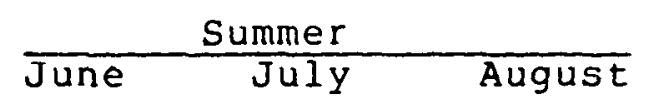

$1977 \quad 10280$

$1978 \quad 10873$

$1979 \quad 10294$
Winter

$\frac{\text { December January February }}{\text { Janter }}$

10260

$\frac{10347}{10841}$

$10428 \quad \underline{10442} \quad 10304$

9909

$10254 \quad 10732$

NOTE: underline indicates seasonal peak.

The summer peak demands are usually dependent on climate conditions and are temperature/humidity sensitive. However, in the three reported years the peak demand has occurred in the month. of July.

The winter peak during the 1977-1979 period occurred in January. These peaks were 3 to 9 percent lower than the corresponding summer peaks, a normal situation.

The following table shows generating capacity down for scheduled maintenance performed each period and also the capability unavailable due to forced unit and partial unit outages.

Table 1C.2

Scheduled Maintenance and Unavailable Capabilities - (Mhi) CAPCO REGION

\begin{tabular}{|c|c|c|c|c|c|c|}
\hline & & Summer & & & WINLEi & \\
\hline & SCHEDULED & OTHER & TOTAL & SCHEDULED & OTHER & TOTAL \\
\hline & $\begin{array}{l}\text { MAINTE- } \\
\text { NANCE }\end{array}$ & $\begin{array}{l}\text { UNAVA IL- } \\
\text { ABLE. }\end{array}$ & $\begin{array}{l}\text { UNAVA IL- } \\
\text { ABLE }\end{array}$ & $\begin{array}{l}\text { MAINTE- } \\
\text { ANACE }\end{array}$ & $\begin{array}{l}\text { UNAVAIL- } \\
\text { ABLE }\end{array}$ & $\begin{array}{l}\text { UNAVAIL- } \\
\text { ABLE }\end{array}$ \\
\hline $\begin{array}{l}1977 \\
1978 \\
1979\end{array}$ & $\begin{array}{r}414 \\
1005 \\
830\end{array}$ & $\begin{array}{l}2002 \\
3742 \\
3808\end{array}$ & $\begin{array}{l}2416 \\
4747 \\
4638\end{array}$ & $\begin{array}{r}656 \\
1075 \\
2353\end{array}$ & $\begin{array}{l}5118 \\
5622 \\
2227\end{array}$ & $\begin{array}{l}5774 \\
6997 \\
4580\end{array}$ \\
\hline
\end{tabular}


The percentage of planned capability that was unavailable

for reasons other than scheduled maintenance varied from 14 to

25 percent during 1977-1979 in the summer and from 14 to 36 percent

in the winter.

The reserve margins for the 1977-1979 period are shown below,

the table indicating the effects of scheduled maintenance and other outages.

Table 1C. 3

Historical Seasonal Reserves CAPCO REGION

\begin{tabular}{|c|c|c|c|c|c|c|}
\hline $\begin{array}{l}\text { Peak } \\
\text { Demand } \\
(\mathrm{MW})\end{array}$ & $\begin{array}{c}\text { Total } \\
\text { Capability } \\
\text { (MW) }\end{array}$ & $\begin{array}{c}\text { Total } \\
\text { Reserves } \\
(8)\end{array}$ & $\begin{array}{l}\text { Capability } \\
\text { After Main- } \\
\text { tenance } \\
\text { (MW) }\end{array}$ & $\begin{array}{l}\text { Available } \\
\text { Reserves } \\
(8)\end{array}$ & $\begin{array}{c}\text { Actual } \\
\text { Capability } \\
(M W)\end{array}$ & $\begin{array}{c}\text { Actual } \\
\text { Reserves } \\
\text { ( } 8)\end{array}$ \\
\hline
\end{tabular}

SUMMER

\begin{tabular}{|c|c|c|c|c|c|c|}
\hline $\begin{array}{l}1977 \\
1978 \\
1979\end{array}$ & $\begin{array}{l}11384 \\
11194 \\
10809\end{array}$ & $\begin{array}{l}13672 \\
15118 \\
15556\end{array}$ & $\begin{array}{l}20.1 \\
35.1 \\
43.9\end{array}$ & $\begin{array}{l}13258 \\
14113 \\
14726\end{array}$ & $\begin{array}{l}16.5 \\
26.0 \\
36.2\end{array}$ & $\begin{array}{l}11256 \\
10371 \\
10918\end{array}$ \\
\hline
\end{tabular}

WINTER

$\begin{array}{rrrrrrrr}1977 & 10357 & 14544 & 40.6 & 13888 & 34.2 & 8770 & (15.2) \\ 1978 & 10841 & 15615 & 44.0 & 14540 & 34.1 & 8918 & (17.7) \\ 1979 & 10442 & 15434 & 47.8 & 13081 & 25.3 & 10854 & 3.9\end{array}$

Available reserve margins were adequate in 1977-1979; however, during the peak periods, large amounts of forced and other outages

- especially in 1977 and 1978 - caused actual reserves to fall well below desirable levels. The situation in 1979 improved significantly and available reserves were 1 percent in the summer and rose to 3.9 percent in the winter. 
Listed below are annual load and energy requirements for the 1977-1979 period.

Table 1C.4

Historical Energy, Peaks, and Load Factors

CAFCO RECIOIN

\begin{tabular}{|c|c|c|c|c|c|c|}
\hline $\begin{array}{r}\text { Reg } \\
(\text { GWh }) \\
\end{array}$ & $\begin{array}{l}\text { Energy } \\
\text { direments } \\
\text { (Growth-8) }\end{array}$ & $\begin{array}{r}\text { Su } \\
(\mathrm{NiW}) \\
\end{array}$ & $\begin{array}{l}\text { imer Peak } \\
\text { Demand } \\
\text { (Crowth- } 8 \text { ) }\end{array}$ & $\begin{array}{l}\text { Win } \\
(M W) \\
\end{array}$ & $\begin{array}{l}\text { Eer Peak } \\
\text { Demand } \\
\text { (Growth-8) }\end{array}$ & $\begin{array}{c}\text { Annual Load } \\
\text { Factor } \\
(8)\end{array}$ \\
\hline $\begin{array}{l}64570 \\
64777 \\
65900\end{array}$ & $\begin{array}{l}- \\
0.3 \\
1.7\end{array}$ & $\begin{array}{l}11279 \\
11087 \\
10715\end{array}$ & $\begin{array}{c}- \\
(1.7) \\
(3.4)\end{array}$ & $\begin{array}{l}10252 \\
10750 \\
10351\end{array}$ & $\begin{array}{c}- \\
4.9 \\
(3.7)\end{array}$ & $\begin{array}{l}65 \cdot 4 \\
66 \cdot 7 \\
70 \cdot 2\end{array}$ \\
\hline
\end{tabular}

1.7

$(2.6)$

0.5

Energy requirements over the period 1977-1979 have grown at a modest compound rate of 1 percent. This is lower than most other regions in ECAR. This generally reflects the effects of conservation, and an economic slowdown in this heavily industrialized area. Low peak demand growth was a result of these same conditions plus mild temperatures. Peak demands grew at a lower rate than the energy requirements resulting in an increase in annual system load factors.

\section{Current Perspective}

Projected 1980 summer and winter peak demands for the CAPCO region are shown below.

Table 1C.5

Projected 1980 Seasonal Peak Demands - MW CAPCO REGION

\begin{tabular}{cccccc}
\hline June & $\begin{array}{c}\text { SUMMER } \\
\text { July }\end{array}$ & August & December & January & February \\
\hline 11159 & $\underline{11434}$ & 11378 & 10627 & 10904 & 10614
\end{tabular}


The 1980 summer planned generating capability for the CAPCO region is estimated to be $14,611 \mathrm{MW}$ and the summer non-coincident peak demand requirements are projected to be $11,434 \mathrm{MW}$ excluding $170 \mathrm{MW}$ of interruptible demand. After adjustments for scheduled receipts and deliveries, total reserves are $3455 \mathrm{MW}$ or 30.2 percent.

In the ECAR ERA-411 report for the future (1980-1989) CAPCO does not list inoperable capability either for scheduled maintenance or possible forced outages. However, ECAR provides an indication of planned maintenarice for the entire region.

The estimate prepared for the ERA-4ll report is based on the level of planned maintenarice that is currently projected for the periods of heaviest load during the upcoming summer and winter seasons, i.e., five percent of total planned capability during the summer of 1980 and five percent of total planned capability during the winter of $1980 / 1981$.

The summer and winter 1980 reserve margins for the CAPCO Region are shown on Table 1C.6.

\section{Table IC. 6}

\section{Reserve Margins*}

CAPCO REGION

\begin{tabular}{l} 
Sum \\
Reserves \\
\hline MW
\end{tabular}

Summer

$\begin{array}{llllll}3177 & 27.8 & 3455 & 30.2 & 2589 & 22.6\end{array}$

Total

$\begin{array}{rl}\frac{\text { Available }}{8} & \frac{\begin{array}{l}\text { Reserves } \\ \text { Rh }\end{array}}{8} \\ 0.2 & 2589 \quad 22.6\end{array}$

:

* Based on ERA Form 411

** $5 \%$ of total installed capability assumed - from

ECAR ERA-4li Report of Scheduled Outages. winter

\begin{tabular}{|c|c|c|}
\hline $\begin{array}{l}\text { Planned } \\
\text { Reserves }\end{array}$ & $\begin{array}{l}\text { Total } \\
\text { Reserves }\end{array}$ & $\begin{array}{l}\text { Available } \\
\text { Reserves* }\end{array}$ \\
\hline MW & $M W$ & $\overline{\mathrm{MW}}$ \\
\hline
\end{tabular}

$\begin{array}{llllll}4860 & 44.6 & 5030 & 46.1 & 4107 & 37.7\end{array}$

The margins shown above havé not been adjusted for unscheduled outages of generating equipment since the amounts of these outages are generally unknown ahead of time, but have $r$ un as high as 36 percent in 1978. For the forecast period 1980-89, Cleveland Municipal will have 135 MW of coal-fired steam capability unavailable. If unscheduled outages for 1980 are equal to the average outage rates of the 19771979 period, $20 \%$ of the planned capability during the summer period 
and 25 percent during the winter period, the resultant actual reserves would be deficient by $333 \mathrm{MW},(2.9)$ percent for the summer peak, but $166 \mathrm{MW}$ or 1.5 percent for the winter peak.

The 1980 summer capability of the planned generating capacity in the CAPCO region will be $14,611 \mathrm{MW}$. The capacity breakdown by fuel. type is shown on Table 1C. 7 .

\section{Table 1C. 7}

\section{Summer Capability \\ CAPCO REGION}

\begin{tabular}{|c|c|c|c|c|c|c|c|}
\hline \multirow{2}{*}{$\begin{array}{l}\text { Nuclear } \\
\text { Steam }\end{array}$} & \multirow{2}{*}{$\begin{array}{l}\text { Coal } \\
\text { Steam }\end{array}$} & \multicolumn{3}{|c|}{ Oil } & \multicolumn{2}{|c|}{ Hyaro } & \multirow{2}{*}{$\begin{array}{c}\text { Total } \\
\text { Capability }\end{array}$} \\
\hline & & Steam & $\mathrm{CT}$ & IC & Conv. & PS & \\
\hline 1776 & 11076 & 672 & 727 & 30 & 0 & 330 & 14611 \\
\hline 12.1 & 75.8 & 4.6 & 5.0 & 0.2 & 0 & 2.3 & 100.0 \\
\hline
\end{tabular}

Almost 76 percent of the current capacity within CAPCO is coalfired steam capacity; 12 percent is nuclear, 5 percent, oil-fired steam, 5 percent, oil-fired combustion turbine and diesels, and 2 percent pumped storage. There are no conventional hydroelectric units in the region. A $780 \mathrm{MW}$ coal-fired steam unit, Mansfield \#3, is schedulcd for installation in October 1980 .

The projected 1980 energy requirements, sumuler and winter demands, and annual load factors of the region are shown below:

Table $1 \mathrm{C} .8$

1980 Load Requirements

CAPCO REGION

$\begin{array}{llll}\text { Energy } & \begin{array}{l}\text { Summer Peak } \\ \text { Reguirements }\end{array} & \begin{array}{l}\text { Winter Peak } \\ \text { Demand }\end{array} & \frac{\begin{array}{l}\text { Annual } \\ \text { Demand }\end{array}}{(\mathrm{MW})}\end{array} \quad \begin{aligned} & \text { Load Factor } \\ & (\mathrm{MW})\end{aligned}$

8 Growth

68390

$\underline{11434}$

10904

68.1

$1980 / 79$

2.9

5.8

4.4 
The 1980 projected energy requirements are projected to grow at a rate of 2.9 percent which is considerably higher than the rate of growth between 1977-1979 of 1 percent. The 1980 summer peak is expected to increase 5.8 percent over 1979. This will reverse the declining summer demand in the 1977-1979 period. The 1980 winter peak is forecasted to grow by 4.4 percent over 1979. The winter peak has been erratic, at 4.8 percent from $1977-1978$ and a decline of 3.7 percent from 1978-1979.

Delays of future critical bulk power transmission facilities that will not be in service when needed, are reported under Item 5-C of the ERA-4ll Report. One such line adversely impacting the system: was originally scheduled for 1977 but has been delayed. This line is the Mansfield-Juniper $345 \mathrm{kV}$ line, an extension of the existing Mansfield-Hanna $345 \mathrm{kV}$ line, which will complete the third $345 \mathrm{kV}$ interconnection between the Ohio Edison system (Akron area) and the Cleveland Electric Illuminating Company's southern interface.

This Iine, which was originally scheduled for April 1977 completion, is currently scheduled for June 1980 operation. The delay of this extension to CEI severely restricts their import capability, thus hampering their ability to conduct emergency power and normal economy energy transfers.

The construction on sections of this line has been repeatedly delayed because of local area right-of-way problems and the lack of cooperation by two local municipalitica to gain approval on the routing of said line through these areas. A Declaratory Judgement action to resolve the routing controversy is before the summit county Court of Common pleas.

\section{Future Perspective}

The range of total reserves of the CAPCO region for the periods 1981-1985 and 1986-1989 are shown below.

\section{Table 1C.9}

Range of Total Reserves - 8

CAPCO REGION

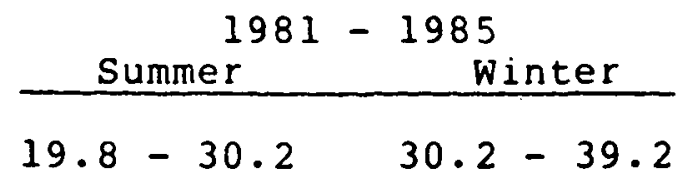

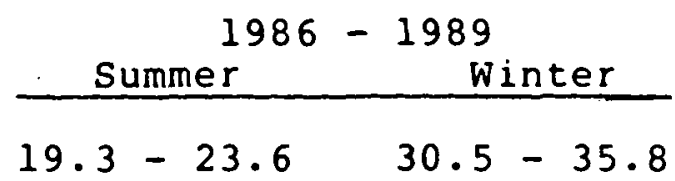


As seen in Table 1C.9, the total reserves for summer range from 20-30 percent and winter net reserves from 30-40 percent.

Indications are that there may be difficulties in meeting future obligations, even. if all future capacity additions are completed on schedule, which is questionable with nuclear plants. Total unavailable capability including scheduled maintenance averaged about 25 percent of planned capability for the 1977-1979 summer peak season. Assuming this for the future would make the CAPCO region deficit in actual reserves for the summer of 1982.

Deficits could approach $1500 \mathrm{MW}$ by 1987 . However, summer peak demand forecasts do indicate a comparatively higher rate of growth than historical patterns. This would mitigate the problem if the estimates are on the high side. The CAPCO region which shows no capacity imports after 1980 in the ECAR 411 Report, will have to obtain capacity purchases trom nelghboring utilitice.

Shown below are the projected growth rates of demand and capability for each period and the overall rates for 1981-1989.

$\frac{\text { Table 1C.10 }}{\text { Projected Energy and Demand Growth Rates }}$

CAPCO REGION

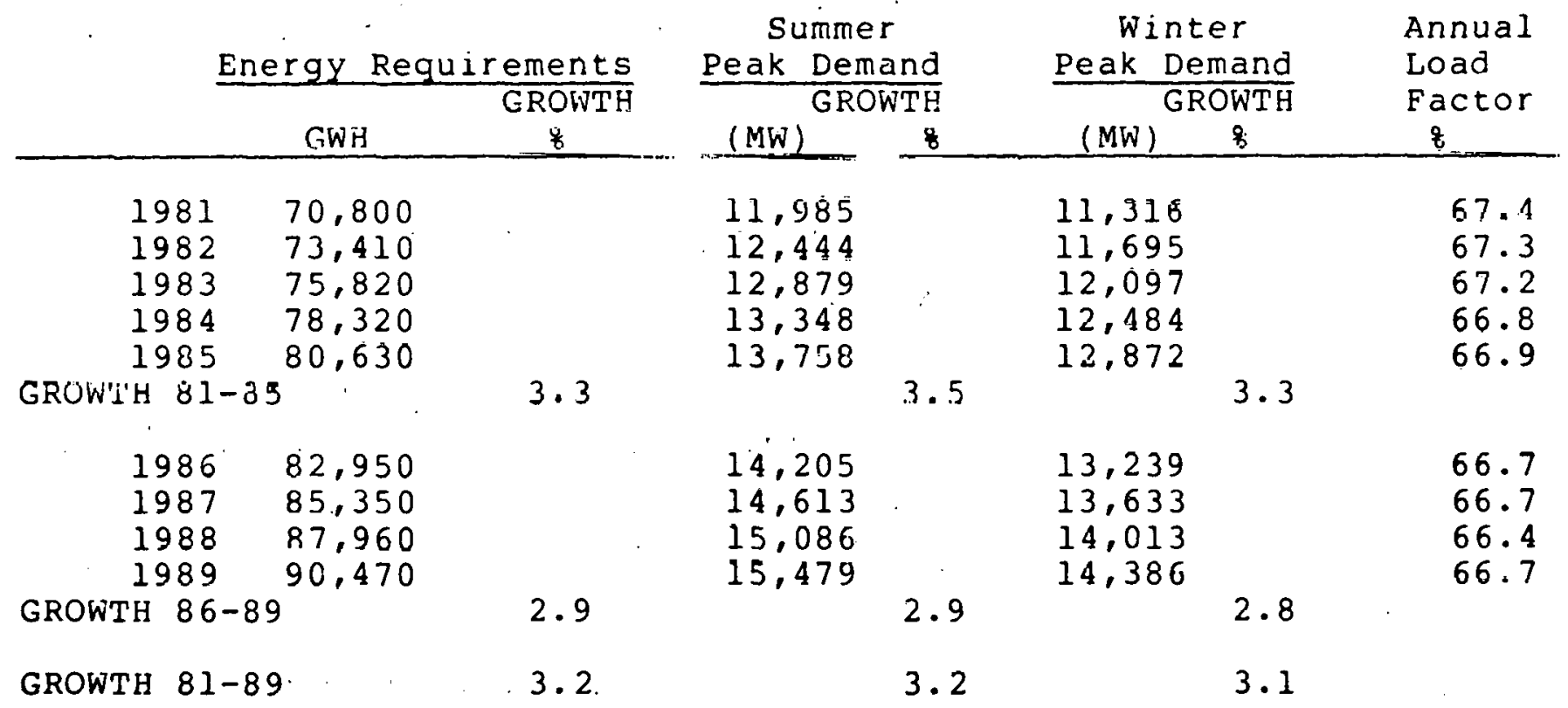

The 1981-1985 summer demands are projected to grow at a compound rate of 3.5 percent; 1986-89, 2.9 percent; and overall 1981-89 rates of 3.2 percent. These rates, as discussed previously, are considerably higher than the summer 1977-79 period which experienced a 2.5 percent decline. 
The winter demands are projected to grow at slightly slower rates; 3.3 percent for 1981-85, 2.8 percent for the 1986-1989 period, and 3.1 percent overall. This reflects an optimistic growth when compared to the 0.5 percent rate for the 1977-79 period.

Energy requirements are projected to grow 3.3 percent from 1981-85, 2.9 percent from 1986-89, and 3.2 percent for the overall period from 1981-89. Historically 1977-1979, the energy growth was 1 percent.

During the 1981-1985 period, only one major generating unit is expected to be placed in service. The nuclear unit, Perry \#l, with net capability of $1205 \mathrm{MW}$, and an in-service date of May 1984. Shippingport, a $60 \mathrm{MW}$ nuclear unit, is scheduled to be placed on inactive reserve in January 1982.

In the 1986-1989 period, two nuclear units are scheduled for installation; Beaver Valley \#2 (833 MW) and Perry \#2 (1205 MW), with in-service dates of May 1986 and May 1988 respectively.

There are no major installations or removals of capacity in 1983 , 1985,1987 or 1989.

The summer capability of units planned for the region in the period 1980-1989 is shown by fuel type in Table 1C.19. Major generating unit additions and retirements during the period are given in Table 1C.20. The fuel percentages for each type of capacity for the target years 1980,1984 , and 1989 are given below.

\section{Table 1D.11}

\section{Planned Generating Capability by Type of Fuel (- 8$)$ summer Capability \\ CAPCO REGION}

\begin{tabular}{|c|c|c|c|c|c|c|c|c|}
\hline \multirow{2}{*}{\multicolumn{2}{|c|}{$\begin{array}{l}\text { Nuclear } \\
\text { Steam }\end{array}$}} & \multirow{2}{*}{$\begin{array}{l}\text { Coal } \\
\text { Steam }\end{array}$} & \multicolumn{3}{|c|}{ Oil } & \multicolumn{2}{|c|}{ Hydro } & \multirow{2}{*}{$\begin{array}{c}\text { Total } \\
\text { Capability }\end{array}$} \\
\hline & & & Steam & $\mathrm{CT}$ & IC & Conv. & PS & \\
\hline $\begin{array}{r}34 \\
39\end{array}$ & $\begin{array}{l}12.1 \\
17.7 \\
26.6\end{array}$ & $\begin{array}{l}75.8 \\
71.6 \\
63.8\end{array}$ & $\begin{array}{l}4.6 \\
4.0 \\
3.6\end{array}$ & $\begin{array}{l}5.0 \\
4.5 \\
4.0\end{array}$ & $\begin{array}{l}0.2 \\
0.2 \\
0.2\end{array}$ & $\begin{array}{l}0 \\
0 \\
0\end{array}$ & $\begin{array}{l}2.3 \\
2.0 \\
1.8\end{array}$ & $\begin{array}{l}100.0 \\
100.0 \\
100.0\end{array}$ \\
\hline
\end{tabular}

Coal presently is the primary fuel for about 76 percent of the installed capacity of the region. Its percentage will decline to 64 percent by 1989 while nuclear capacity will rise from 12 percent to almost 27 percent by 1989 . Oil-fired capacity will decline slightly from about 10 percent to 8 percent in the same period. 
Pumped storage will decline from just over 2 percent of the total capability to slightly under 2 percent. The decline of the oil and hydro capability is the result of no new installations in these categories in an expanding generating base.

There is only one critical bulk power transmission facility that will not be in service when desired during the period 1981-1989, the double circuit $345 \mathrm{kV}$ Harding supply (also referred to as the Juniper-Harding Line). It was originally scheduled for service in December 1973 in order to provide the initial $345 \mathrm{kV}$ supply to CEI's Harding substation. The major portion ( 5.7 miles) of the 1 ine has been constructed and currently remains idle. Completion of the Harding supply has been delayed by a series of court decisions and denial of a permit by the National Park Service since a portion of the planned line route would have traversed the Cuyahoga Valley National Recreation Area. Discussions continue with the National Park Service on determining a mutually satisfactory route.

In June 1977, as an expediency occasioned by the delay in the Harding Supply, the planned second step of the supply to the central area was constructed in advance and placed in service. This single line currently supplies three $345 / 138 \mathrm{kV}$ substations serving the major load center in northeast ohio. The continued inability to complete the Harding supply restricts CEI's ability to import power under various contingency situations, posing a catastrophic threat to their central load area.

The projected in-service date for the Harding supply is now April 1984. That date assumes the timely receipt of the necessary approvals to cumplete the line along a mutually satisfactory route.

An appraisal of anticipated transmission system perfurmance in ECAR is prepared immediately prior to 8 ach summer and winter peak load period. Each member system participates in the appraisal procedure and the material which appears in the final ECAR report is nnrmally limited to those items which are of particular significance to the overall leglun. The appraisal is hased on a careful analysis of various studies carried out by the ECAR Transmission System Performance Working Group under the direction of the Transmission System Performance Panel and by individual ECAR companies, either among themselves or jointly with systems adjacent to ECAR. Where the appraisal procedure indicates a potential contingency which could lead to localized problems, the matter is referred to the affected system(s) for further study and development of appropriate operating instructions where necessary. These reports are intended as a supplement to, and not a substitute for, internal studies by the individual systems in ECAR. 
A wide range of postulated system conditions were considered during the course of the various studies referred to above but no localized transmission problems were apparent in the CAPCO region.

The most recent ECAR appraisal studies were for summer 1979 and Winter 1979-80. These studies showed that timely completion of the scheduled transmission facility additions would insure that the reliability of the bulk power transmission systems within ECAR would be maintained at a high level.

Emergency Transfer Capabilities to adjacent regions, based on the NERC definition, were reported as follows:

Table 1D.12

Emergency Transfer Capability - MW CAPCO REGION

\begin{tabular}{|c|c|c|c|c|c|}
\hline \multicolumn{3}{|c|}{ Transfer } & $\cdot$ & $\begin{array}{l}\text { Summer } 1979 \\
\text { Capability }\end{array}$ & $\begin{array}{c}\text { Winter } 1979-80 \\
\text { Capability }\end{array}$ \\
\hline $\begin{array}{l}\text { ECAR } \\
\text { ECAR } \\
\text { ECAR } \\
\text { ECAR } \\
\text { ECAR }\end{array}$ & $\begin{array}{l}\text { to MAAC } \\
\text { to NPCC } \\
\text { to MAIN } \\
\text { to SERC } \\
\text { to SERC }\end{array}$ & $\begin{array}{l}(\text { NYPP }) \\
(\text { TVA ) } \\
(\text { VACAR) }\end{array}$ & . & $\begin{array}{l}3300+ \\
2200 \\
3450 \\
1800 \\
1250\end{array}$ & $\begin{array}{l}3300+ \\
2950 \\
3950 \\
1600 \\
1900 *\end{array}$ \\
\hline $\begin{array}{l}\text { ECAR } \\
\text { ECAR } \\
\text { ECAR } \\
\text { ECAR } \\
\text { ECAR }\end{array}$ & $\begin{array}{l}\text { from MAAC } \\
\text { from NPCC } \\
\text { from MAIN } \\
\text { from SERC } \\
\text { from SERC }\end{array}$ & $\begin{array}{ll}C & \\
C & (N Y P P) \\
N & \\
C & (T V A) \\
C & (\text { VACAR })\end{array}$ & . & $\begin{array}{l}2450 \\
3300+ \\
4000+ \\
2000 \\
2700\end{array}$ & $\begin{array}{l}3300+ \\
2900 \\
3800 \\
2100 \\
2950 *\end{array}$ \\
\hline
\end{tabular}

* ETC Values determined with established operating procedures in effect.

All ECAR systems evaluate their individual network performance using the testing criteria presented in ECAR Document No. 1 . Based on an analysis of these studies, it has been concluded that the ECAR bulk power transmission network as now projected for the 1984 period is capable of withstanding the contingencies listed in ECAR Document No. I without suffering area-wide break-up and/or collapse of the network. This appraisal is based on the assumption that current financial and environmental problems will be resolved in a timely manner and that ECAR member systems will be able to provide the facilities shown. 
Should any of the EHV transmission facilities planned for the 1980-1984 period be delayed as a result of excessive lag in the certification process or as a result of difficulties in financing these projects due to inadequate rate relief, then appropriate short term operating procedures will need to be developed in order to maintain, to the greatest extent possible, the reliability of electric power supply within ECAR. Such procedures, if invoked, may jeopardize the reliability of the power supply in the affected area.

Emergency Transfer Capabilities to adjacent regions, based on the NEKC definition, are as follows:

Table 1D.13

Summer. 1984 Emergency Transfer Capability - MW CAPCO REGION

\begin{tabular}{lllll} 
Transfer & $\begin{array}{c}\text { ETC } \\
\text { MW }\end{array}$ & & Transfer & $\begin{array}{l}\text { ETC } \\
\text { MW }\end{array}$ \\
\cline { 3 - 3 } & 4350 & ECAR from MAAC & 2600 \\
ECAR to NPCC (NYPP) & 1950 & ECAR from NPCC & 2900 \\
ECAR to MAIN & 2900 & ECAR from MAIN & $4000+$ \\
ECAR to SERC (TVA) & 2500 & ECAR from SERC (TVA) & 3200 \\
ECAR to SERC (VACAR) & 2250 & ECAR from SERC (VACAR) & $5500+$
\end{tabular}

The following table is a list of proposed bulk power lines to be constructed by CAPCO companies. It includes internal transmission facilities as well as interconnections with utilities in other regions. Many of these interconnections will become critical, since the CAPCO region's low reserve margins in the study perlod indicace a heavy dependence on capacity imports and therefore make the whooling of large blocks of energy through the system necessary. 
TABLE 1C.14

LIST OF PROPOSED BULK POWER LINES

CAPCO FEGION

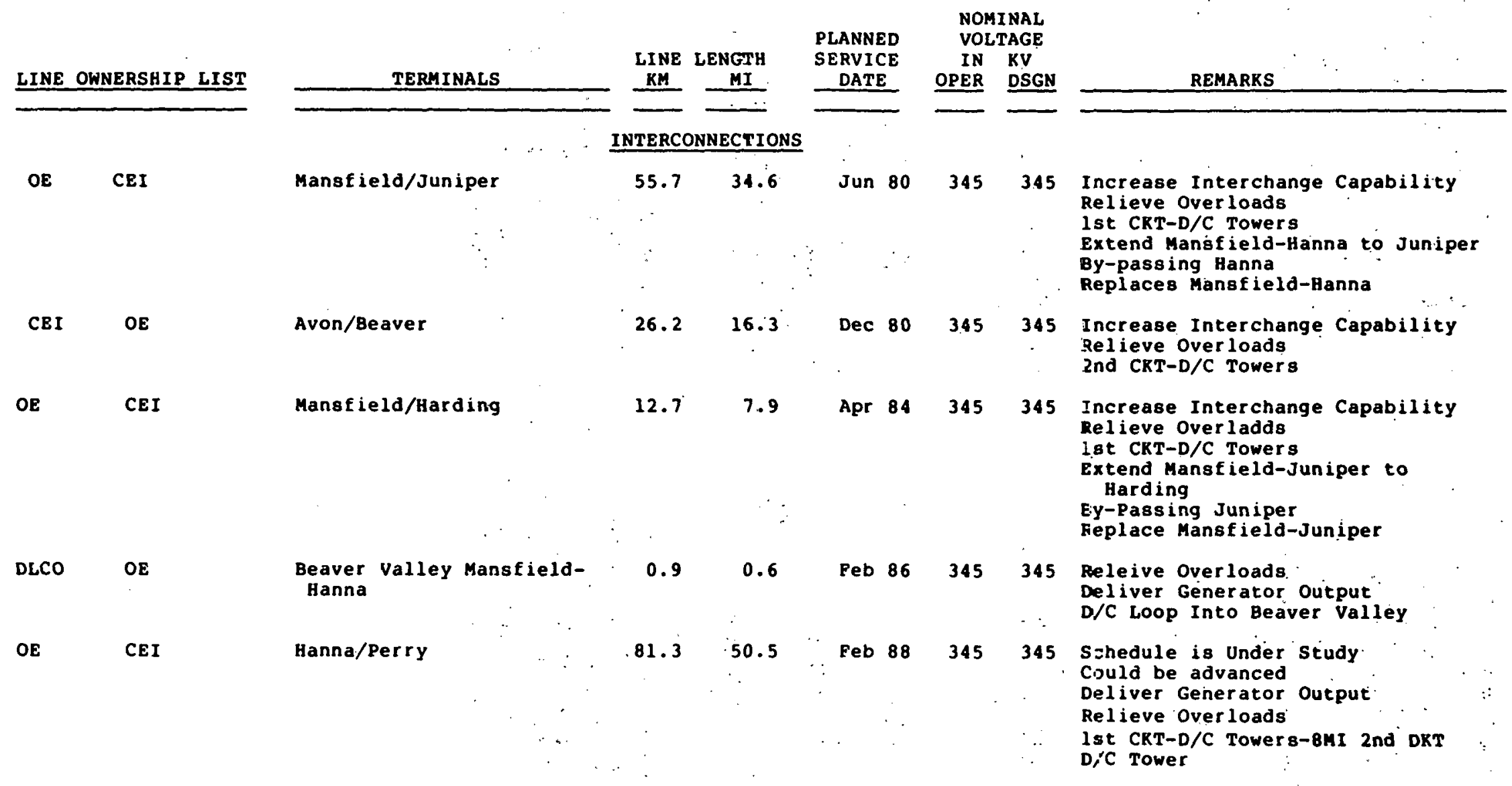


LIST OF PROPOSED BULK POHER LINES

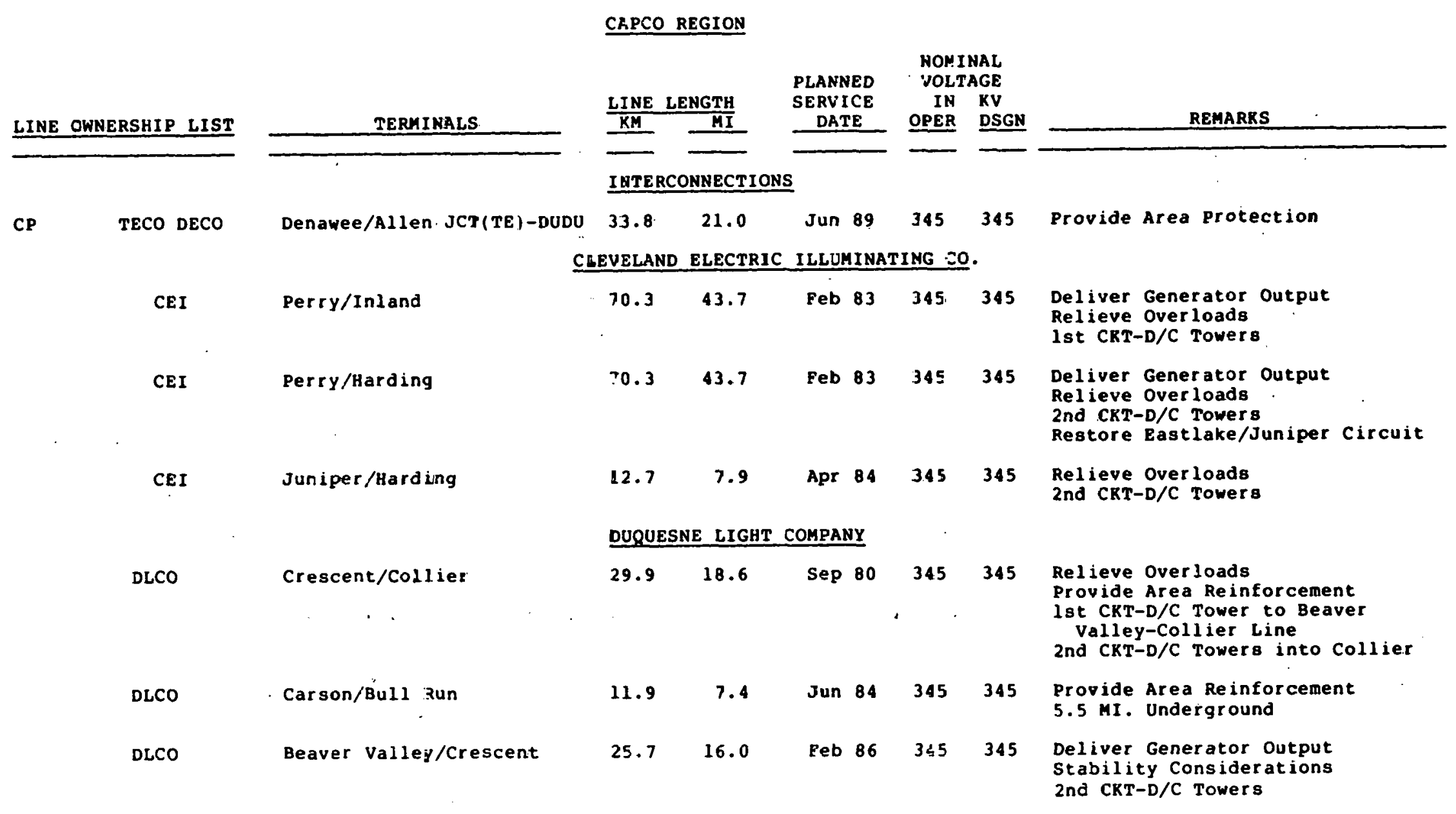


TABLE 1C.14

LIST OF PROPOSED BULK POWER LINES

\begin{tabular}{|c|c|c|c|c|c|c|c|c|}
\hline LINE & OWNERSHIP LIST & TERMINALS & $\frac{\mathrm{LINE}}{\mathrm{KM}}$ & $\frac{\text { LENGTH }}{\text { MI }}$ & $\begin{array}{l}\text { PLANNED } \\
\text { SERVICE } \\
\text { DATE } \\
\end{array}$ & $\begin{array}{l}\text { NOMII } \\
\text { VOLTR } \\
\text { IN } \\
\text { OPER } \\
\end{array}$ & $\begin{array}{l}\text { AL } \\
\text { TE } \\
\text { KV } \\
\text { DSGN }\end{array}$ & REMARKS \\
\hline \multicolumn{9}{|c|}{ DUQUESNE LIGHT COMPANY } \\
\hline & DLCO & Collier/Bull Run & $24-1$ & 15.0 & Apr 86 & 345 & 345 & $\begin{array}{l}\text { Privide Area Reinforcement } \\
\text { Underground }\end{array}$ \\
\hline & DLCO & Brunot Island/Collier-Carson & 0.1 & 0.1 & Feb 87 & 345 & 345 & $\begin{array}{l}\text { Provide Area Reinforcement } \\
\mathrm{C} / \mathrm{C} \text { Loop into Brunot Island }\end{array}$ \\
\hline & DLCO & Brunot Island/Crescent & 20.9 & 13.0 & Feb 89 & 345 & 345 & $\begin{array}{l}\text { Relieve } 138139 \mathrm{KV} \text { Heavy } \\
\text { Loadings } \\
\text { lot } \mathrm{CKT}-\mathrm{D} / \mathrm{C} \text { Tower Line }\end{array}$ \\
\hline & - & \multicolumn{7}{|c|}{ TOLEDO EDISON COMPANY } \\
\hline . & TECO & Midway/Lemoyne-Allen Junction & 0.0 & 0.0 & Apr 85 & 345 & 345 & $\begin{array}{l}\text { Provide Area Reinforcement } \\
\text { Relieve Overloads } \\
\text { D/C Loop into Midway }\end{array}$ \\
\hline \multicolumn{9}{|c|}{ OHIO EDISON SYSTEM (INCLUDES PENASYLVANIA POKER CO.) } \\
\hline & $\mathrm{OE}$ & Carlisle/Star-Beaver & 6.4 & 4.0 & Mar 80 & 345 & 345 & $\begin{array}{l}\text { Relieve Overloads } \\
\text { Provide Area Reinforcement } \\
\text { D/C Loop to Carlisle }\end{array}$ \\
\hline & DE & Mansfield/Hanna & 94.9 & 59.0 & Jul 80 & 345 & 345 & $\begin{array}{l}\text { Deliver Generator Output } \\
\text { Relieve Overloads } \\
\text { 2nd CKT-D/C Towers }\end{array}$ \\
\hline . & $\mathbf{D E}$ & $\begin{array}{c}\text { Hoytdale/Mansfield-Highland } \\
\text { : }\end{array}$ & 45.0 & 28.0 & Jun 85 & 345 & 345 & $\begin{array}{l}\text { Relieve Over loads } \\
\text { Increase Interchange } \\
\text { Capability } \\
\text { D/C Loop to Hoytdale }\end{array}$ \\
\hline
\end{tabular}


Table 1C.15

HISTORICAL CAPABILITY (MW) AND RESERVES (MW AND PERCENT)

CAPCO REGION

\begin{tabular}{|c|c|c|c|c|c|c|c|}
\hline$\because \quad \ldots$ & & $\begin{array}{c}1977 \\
\text { summer } \\
\end{array}$ & $\begin{array}{r}1977 / 78 \\
\text { Winter } \\
\end{array}$ & $\begin{array}{c}1978 \\
\text { Summer } \\
\end{array}$ & $\begin{array}{r}1978 / 79 \\
\text { winter }\end{array}$ & $\begin{array}{l}1979 \\
\text { Summer }\end{array}$ & $\begin{array}{r}1979 / 80 \\
\text { Winter }\end{array}$ \\
\hline 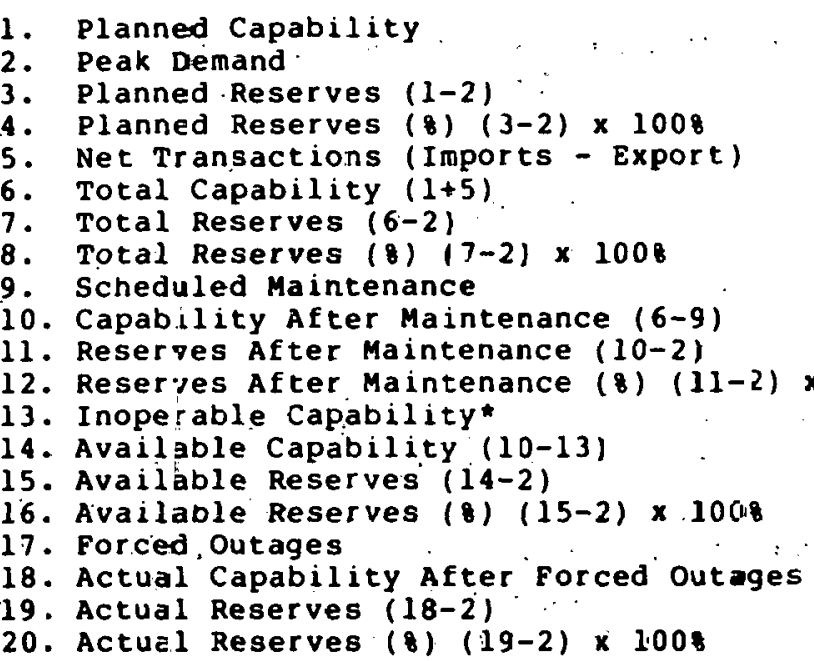 & $\begin{array}{l}\times 1008 \\
(14-17)\end{array}$ & $\begin{array}{r}13,648 \\
11,384 \\
2,262 \\
19.0 \\
26 \\
13,672 \\
2,288 \\
20.1 \\
414 \\
13,258 \\
1,874 \\
16.5 \\
0 \\
13,258 \\
1,874 \\
16.5 \\
2,002 \\
11,256 \\
-128 \\
-1.1\end{array}$ & $\begin{array}{r}15,000 \\
10,347 \\
4,653 \\
45 \\
-456 \\
14,544 \\
4,197 \\
40.6 \\
656 \\
13,888 \\
3,541 \\
34.2 \\
0 \\
13,888 \\
3,541 \\
34.2 \\
5,118 \\
8,770 \\
-1,577 \\
-15.2\end{array}$ & $\begin{array}{r}15,164 \\
11,194 \\
3,976 \\
35.5 \\
-46 \\
15,118 \\
3,924 \\
35.1 \\
1,005 \\
14,113 \\
2,910 \\
26.1 \\
14,113 \\
14,919 \\
26.1 \\
3,742 \\
10,371 \\
-823 \\
-7.4\end{array}$ & $\begin{array}{r}15,547 \\
10,641 \\
4,706 \\
43.4 \\
68 \\
15,615 \\
4,774 \\
44.0 \\
1,075 \\
14,543 \\
3,699 \\
34.1 \\
0 \\
14,540 \\
3,699 \\
34.1 \\
5,622 \\
8,938 \\
-1,923 \\
-17.7\end{array}$ & $\begin{array}{r}15,391 \\
10,809 \\
4,582 \\
42.4 \\
165 \\
15,556 \\
4,747 \\
43.9 \\
830 \\
14,726 \\
3,917 \\
36.2 \\
0 \\
14,726 \\
3,917 \\
36.2 \\
3,808 \\
10,918 \\
109 \\
1.0\end{array}$ & $\begin{array}{r}15,423 \\
10,442 \\
4,981 \\
47.7 \\
11 \\
15,434 \\
4,992 \\
47.8 \\
2,353 \\
13,081 \\
2,639 \\
25.3 \\
0 \\
13,081 \\
2,639 \\
25.3 \\
2,227 \\
10,854 \\
412 \\
3.9\end{array}$ \\
\hline
\end{tabular}

Included. in Item 17 
1. Planned Capability

2. Peak Demand

3. Planned Reserves $(1-2)$

4. Planned Reserves (8) (3-2) x 1008

5. Net Tranactions (Imports - Exports)

6. Total Capability $(1-5)$

7. Total. Reserves $(6-2)$

8. Total Reserves (8) (7-2) x 1008

9. Scheduled Maintenance $1 /$

10. Capability After Maintenance (6-9)

11. Reserves After Maintenance (10-2)

12. Reserves After Maintenancwe (8) (11-2) x 1008

13. Inoperable Capability

14. Available Capability (10-13)

15. Available Reserves (14-2)

16. Available Reserves (8) (15-2) x 1008

17. Forced Outages *

18. Actual Capability After Forced Outages (14-17)

19. Actual Reserves $(18-2)$

20. Actual Reserves (8) $(19-2) \times 1008$

\begin{tabular}{rr}
\multicolumn{2}{c}{1980} \\
\hline Summer & Winter \\
14,611 & 15,764 \\
11,434 & 10,904 \\
3,177 & 4,860 \\
27.8 & 44.6 \\
278 & 170 \\
14,889 & 15,934 \\
3,455 & 5,030 \\
30.2 & 46.1 \\
731 & 788 \\
14,158 & 15,146 \\
2,724 & 4,242 \\
23.8 & 38.9 \\
135 & 135 \\
14,023 & 15,011 \\
2,589 & 4,107 \\
22.6 & 37.7 \\
0 & 0 \\
14,023 & 15,011 \\
2,589 & 4,107 \\
22.6 & 37.7
\end{tabular}

I/ 58 of Total Planned Capability Assumed by ERA-From ECAR ERA 411 Report

* No data available. 
Table 1C.17

FUTURE CAPABILITY (MW) AND RESERVES :MW AND PERCENT)

CAPCO REGION

1981

Summer Winter

1. Planned Capability

2. Peak Demand

3. Planned Reserves $(1-2)$

4. Planned Reserves (8)(3-2) x 1008

5. Net Transactions (Imports-Export5)

6. Total Capability $(1+5)$

7. Total Reserves $(6-2)$

8. Total Reserves $(8)(7-2) \times 1008$

9. Scheduled Maintenance*

10. Capability After Maintenance (6-9)

11. Reserves After Maintenance $(10-21)$

12. Reserves After Maintenance (8) (1-2) × 1008

13. Inoperable Capability

14. Available Capability (10-13)

15. Available Reserves (14-2)

16. Available Reserves (8) $(15-2) \times 1008$

17. Forced Outages*

18. Actual Capability After Forced outages (14-17)

19. Actual Reserves $(18-2)$

20. Actual Reserves $(8)(19-2) \times 1008$

- No data provided.

$\begin{array}{rr}15445 & 15747 \\ 11985 & 11316 \\ 3460 & 4431 \\ 28.9 & 39.2 \\ 164 & 0 \\ 15609 & 15747 \\ 3624 & 4431 \\ 30.2 & 39.2 \\ 0 & 0 \\ 15609 & 15747 \\ 3624 & 4431 \\ 30.2 & 39.2 \\ 135 & 135 \\ 15474 & 15612 \\ 3489 & 4296 \\ 29.1 & 38.0 \\ 0 & 0 \\ 15474 & 15612 \\ 3489 & 4296 \\ 29.1 & 38.0\end{array}$

1983

1984

1985

$\frac{1982}{\text { Summer Wirter Summer Winter Summer Winter Summer Winter }}$

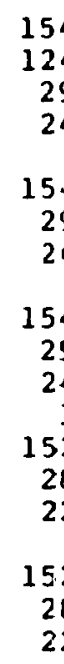

\section{7}

$444 \quad 11695 \quad 15431$

$\begin{array}{rrr}2983 & 4055 & 2552 \\ 24.0 & 34.7 & 19.8\end{array}$

24.0

0

5427

29834055

$4.0 \quad 34.7$

34.7
0

15427

983

2983

24.0
135

5292

2848

2.9

22.9
0
5292

0

2848

22.9

0

$34.7 \quad 19.8$

135

19.8
135

15296

\section{3}

12097
3656

$16610 \quad 16958$

13348
326

3262

12484

16610

3758
3758

6958

4872

15753

$24.4 \quad 35.8$

$2852 \quad 4086$

$52 \quad 3656$

16610

35.8

20.7

31.7

$\begin{array}{llll}0 & 16958 & 16610 & 16958\end{array}$

$\begin{array}{rrrr}3262 & 4474 & 2852 & 4086\end{array}$

$\begin{array}{llll}3262 & 4474 & 2852 & 4086 \\ 24.4 & 35.8 & 20.7 & 31.7\end{array}$

0

$\begin{array}{ll}15431 & 15753\end{array}$

3656

16610

35.8
0

20.7
0

1.7

$\begin{array}{lrrr}3262 & 4474 & 2852 & 4086\end{array}$

30.2
135

24.4

4474
35.8

$20.7 \quad 4086$

$\begin{array}{lllll}15618 & 16475 & 16823 & 16475 & 1682\end{array}$

3127

4339

$2717 \quad 3951$

0

$\begin{array}{lll}15296 & 15618\end{array}$

0

34.8

19.7

3951
30.7
0

$\begin{array}{llll}16475 & 16823 & 16475 & 16823\end{array}$

$\begin{array}{lllllll}3920 & 2417 & 3521 & 3127 & 4339 & 2717 & 3951\end{array}$

$\begin{array}{lllllll}33.5 & 18.2 & 29.1 & 23.4 & 34.8 & 19.7 & 30.7\end{array}$ $\begin{array}{llll}6610 & 16958 & 16610 & 16958\end{array}$ 
Table 1C.18

FUTURE CAPABILITY (MW) AND RESERVES (MW AND PERCENT)

CAPCO REGION

1. Planned Capability

2. Peak Demand

3. Planned Reserves (1-2)

4. Planned Reserves (8)(3-2) x 1008

5. Net Transactions (Imports-Exports)

6. Total Capability $(1+5)$

7. Total Reserves (6-2)

8. Total Reserves $(\$(7-2) \times 1008$

9. Scheduled Maintenance *

10. Capability After Maintenance (6-9)

11. Reserves After Maintenance $(10-2)$

12. Reserves After Maintenance 8$)(11-2) \times 1008$

13. Inoperable Capability

14. Available Capability (10-13)

15. Available Reserves (14-2)

16. Available Reserves (8) $(15-2) \times 1008$

17. Forced Outages ${ }^{\star}$

18. Actual Capability After Forced Outages (14-17)

19. Actual Reserves $(18-2)$

20. Actual Reserves (8)(19-2) $\times 1008$

* No data provided.

$$
1986
$$

Summer Winter Summer Winter

$\begin{array}{rrrr}17430 & 17791 & 17430 & 17791 \\ 14205 & 13239 & 14613 & 13633 \\ 3225 & 4552 & 2817 & 4158 \\ 22.7 & 34.4 & 19.3 & 30.5 \\ 0 & 0 & 0 & 0\end{array}$

$\begin{array}{llll}17430 & 17751 & 17430 & 17791\end{array}$

$\begin{array}{llll}3225 & 4552 & 2817 & 4158 \\ 22.7 & 34.4 & 19.3 & 30.5\end{array}$

$\begin{array}{rrrr}0 & 0 & 0 & 0 \\ 17430 & 17791 & 17430 & 17791\end{array}$

$\begin{array}{rrrr}3225 & 4552 & 2817 & 4158\end{array}$

$22.7 \quad 34.4 \quad 19.3 \quad 30.5$

13517655

$\begin{array}{rrrr}3090 & 4417 & 2682 & 4023\end{array}$

21.8 . 33.418 .429 .5

17295

3090

$\begin{array}{rrr}0 & 0 & 0 \\ 17656 & 17295 & 17656 \\ 4417 & 2682 & 4023\end{array}$

$\begin{array}{rrr}17656 & 17295 & 17656 \\ 4417 & 2682 & 4023 \\ 33.5 & 18.4 & 29.5\end{array}$
1988

1989

Summer Winter Summer Winter

$\begin{array}{llll}18639 & 19025 & 18639 & 19025\end{array}$

$\begin{array}{rrrr}15086 & 14013 & 15479 & 14386 \\ 3553 & 5012 & 3160 & 4639\end{array}$

$\begin{array}{llll}3553 & 5012 & 3160 & 4639\end{array}$

$\begin{array}{rrrr}0 & 35.8 & 20.4 & 32.2\end{array}$

$\begin{array}{llll}18639 & 9025 \quad 18639 \quad 19025\end{array}$

$\begin{array}{llll}3553 & 5012 & 3160 & 4639\end{array}$

$\begin{array}{llll}23.6 & 35.8 & 20.4 & 32.2\end{array}$

$\begin{array}{rrrr}8639 & 19025 & 18639 & 19025\end{array}$

$\begin{array}{llll}3553 & 5012 & 3160 & 4639\end{array}$

$\begin{array}{llll}23.6 & 35.8 & 20.4 & 32.2\end{array}$

$18504 \quad 18890 \quad 18504 \quad 18890$
3418

$\begin{array}{lrrr}3418 & 4877 & 3025 & 4504\end{array}$

$22.7 \quad 34.8 \quad 19.5 \quad 31.3$

$\begin{array}{rrrr}0 & 0 & 0 & 0 \\ 18504 & 13890 & 18504 & 18890\end{array}$

$\begin{array}{llll}3418 & \$ 877 & 3025 & 4504\end{array}$

$\begin{array}{llll}22.7 & 34.8 & 19.5 & 31.3\end{array}$ 
Table 1C. 19

INSTALLED NET CAPABILITY BY TYPE OF FUEL - MW

CAPCO REGION

SUMMER CAPABILITY.

\begin{tabular}{|c|c|c|c|c|c|c|c|}
\hline & & & & \multicolumn{2}{|c|}{$\overline{\mathrm{OIL}}$} & \multirow[b]{2}{*}{$\begin{array}{l}\text { PUMPED } \\
\text { STORAGE } \\
\end{array}$} & \multirow[b]{2}{*}{$\begin{array}{l}\text { TOTAL } \\
\text { CAPABILITY }\end{array}$} \\
\hline & $\begin{array}{l}\text { NUCLEAR } \\
\text { STEAM } \\
\end{array}$ & $\begin{array}{l}\text { COAL } \\
\text { STEAM } \\
\end{array}$ & STEAM & $\begin{array}{l}\text { COMBUST. } \\
\text { בURBINE }\end{array}$ & $\begin{array}{l}\text { INTERNAL } \\
\text { COMBUST. }\end{array}$ & & \\
\hline $\begin{array}{l}1980 . \\
8 \text { TOTAL } \\
1981 \\
8 \text { TOTAL } \\
1982 \\
8 \text { TOTAL } \\
1983 \\
8 \text { TOTAL } \\
1984 \\
8 \text { TOTAL } \\
1985 \\
8 \text { TOTAL } \\
1986 \\
8 \text { TOTAL } \\
1987 \\
8 \text { TOTAL } \\
1988 \\
8 \text { TOTAL } \\
1989 \\
8 \text { TOTAL }\end{array}$ & $\begin{array}{r}1,776 \\
12.1 \\
1,786 \\
11.6 \\
1,754 \\
11.4 \\
1,754 \\
11.4 \\
2,933 \\
17.7 \\
2,933 \\
17.7 \\
3,753 \\
21.5 \\
3,753 \\
21.5 \\
4,962 \\
26.6 \\
4,962 \\
26.6\end{array}$ & $\begin{array}{r}11,076 \\
75.8 \\
11,894 \\
77.0 \\
11,904 \\
77.2 \\
11,964 \\
77.1 \\
11,904 \\
71.6 \\
11,904 \\
71.6 \\
11,904 \\
68.2 \\
11,934 \\
68.2 \\
11,904 \\
63.8 \\
11,904 \\
63.8\end{array}$ & $\begin{array}{l}672 \\
4.6 \\
672 \\
4.4 \\
672 \\
4.4 \\
672 \\
4.4 \\
672 \\
4.0 \\
672 \\
4.0 \\
672 \\
3.8 \\
672 \\
3.8 \\
672 \\
3.6 \\
672 \\
3.6\end{array}$ & $\begin{array}{l}727 \\
5.0 \\
733 \\
4.7 \\
737 \\
4.7 \\
741 \\
4.8 \\
741 \\
4.5 \\
741 \\
4.5 \\
741 \\
4.3 \\
741 \\
4.3 \\
741 \\
4.0 \\
741 \\
4.0\end{array}$ & $\begin{array}{r}30 \\
0.2 \\
30 \\
0.2 \\
30 \\
0.2 \\
30 \\
0.2 \\
30 \\
0.2 \\
30 \\
0.2 \\
30 \\
0.2 \\
30 \\
0.2 \\
30 \\
0.2 \\
30 \\
0.2\end{array}$ & $\begin{array}{l}330 \\
2.3 \\
330 \\
2.1 \\
330 \\
2.1 \\
330 \\
2.1 \\
330 \\
2.0 \\
330 \\
2.0 \\
330 \\
2.0 \\
330 \\
2.0 \\
330 \\
1.8 \\
330 \\
1.8\end{array}$ & $\begin{array}{r}14,611 \\
100.0 \\
15,445 \\
100.0 \\
15,427 \\
100.0 \\
15,431 \\
100.0 \\
16,610 \\
100.0 \\
16,610 \\
100.0 \\
17,430 \\
100.0 \\
17,430 \\
100.0 \\
18,639 \\
100.0 \\
18,639 \\
100.0\end{array}$ \\
\hline
\end{tabular}


TABLE 1C. 20

MAJOR FUTURE GENERATING CAPABILITY INSTALLATIONS AND (REMOVALS)

CAPCO REGION

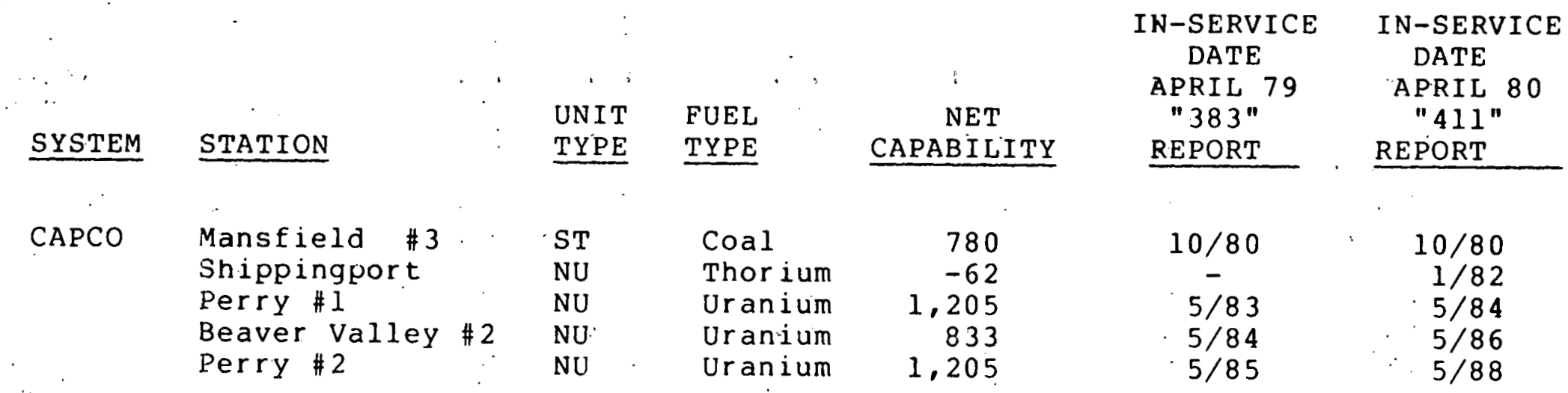

No. Installation and Removals: $83,85,87,89$ 


\author{
$X I .1 .70$ \\ Cincinnati, Columbus, Dayton Group - CCD \\ ELECTRIC REGION 14
}

\title{
Historical Perspective
}

Electric Region 14 includes the Cincininati, Columbuc, Dayton Group (CCD) and the municipal system of Hamilton, Ohio.

The CCD group is comprised of three separate companies: Cincinnati Gas and Electric Company, Columbus and Southern Ohio Electric Company, and the Dayton Power and Light Company. There are no formal requirements tor participalion in the group. The companies comprising the CCD group have agreed to coordinate their generation and transmission programs and to build certain generation and bulk transmission facilities as tenants in common. The three companies currently share share generating units in four plants and 15 to 20 . transmission lines with varying percentages of ownership. In addition to co-ownership of facilities, the members participate in coordination of load projections spinning reserves, exchange capacity and energy, scheduled maintenance programs, and economic dispatch of generating units.

The municipal system of the city of Hamilton, Ohio also lccated in the CCD Group is interconnected with. Cincinnati Gas and Electric Company. The system has generating capability and purchases energy when required.

In 3.978 , utilities in the CCD region served 1,347,000 customers in ohio, of which 1,207,000 were residential, 121,000 commercial, 8,000 were industrial, and 9,000 others.

The CCD companies, located in the Central portion of the ECAR keliability Council are highly interconnected internally and with neighboring ECAR utilities by $345 \mathrm{KV}$ and $138 \mathrm{kV}$. It's geographical position in the ECAR region does not lend itself to interconnections with neighboring Councils.

The CCD region has historically been a summer peaking region. shown below are the region's summer and winter peaks for the period 1977-79. 
Table 1D.1

$\frac{\text { Historical Peak Demands* }-M W}{\text { CCD REGION }}$

SUMMER

$\begin{array}{llll} & \text { June } & \text { July } & \text { Aug. } \\ 1977 & 5776 & & 6737 \\ 1978 & 6602 & \frac{6643}{6431} & 6226 \\ 1979 & 6048 & 6769\end{array}$

WINTER

Dec. Jan. Feb.

6118

5533

5839 $\frac{6312}{6403}$

$\overline{5971}$
5587

6232

$\underline{5986}$

Underline indicates seasonal peak.

* Non-coincident

The summer peak demands are usually dependent on climate conditions and are temperature/humidity sensitive. In the last three years peaks have been in July and August.

The winter peak usually occurs in January or February. A shift in the winter peak from these months is generally the result of a weather bias. There is occasionally some sensitivity to unusual economic conditions in the region as well.

The winter peak during the $1977-79$ period was 4-128 lower than the corresponding yearly summer peaks, a normal situation.

The following table shows the amount of generating capacity down for scheduled maintenance performed each period and also the capability unavailable because of forced unit and partial unit outages.

\section{Table 1D.2}

Scheduled Maintenance And Unavailable Capabilities - (MW) CCD REGION

\begin{tabular}{lcc}
\multicolumn{3}{c}{ SUMMER } \\
\hline SCHEDULED & OTHER & TOTAL \\
MAINTENANCE & UNAVAILABLE & UNAVAILABLE \\
\cline { 2 - 2 }
\end{tabular}

613

1977

1978

1979
1,266

998
639
1,210
1,244

1,252

2,476

2,242

\begin{tabular}{lcc}
\multicolumn{3}{c}{ WINTER } \\
\hline SCHEDULED & OTHER & TOTAL \\
MAINTENANCE & UNAVAILABLE UNAVAILABLE \\
\hline
\end{tabular}

2,224

910

1,230

2,050

1,750

764

4,274

2,660

1,994 
The percentage of planned capability that was unavailable for reasons other than scheduled maintenance varied from 8-148 in the summer and from $8-248$ in the winter.

The reserve margins for the 1977-79 period are indicated below. The table shows the effects of scheduled maintenance and other outages.

\section{Table 1D.3}

\section{Historical Seasonal Reserves}

CCD REGION

\section{SUMMER}

\begin{tabular}{|c|c|c|c|c|c|c|}
\hline $\begin{array}{l}\text { Peak } \\
\text { Demand }\end{array}$ & $\begin{array}{c}\text { Total } \\
\text { Capability }\end{array}$ & $\begin{array}{c}\text { Total } \\
\text { Reserves } \\
\end{array}$ & $\begin{array}{l}\text { Capability } \\
\text { After Main- } \\
\text { tenance } \\
\end{array}$ & $\begin{array}{l}\text { Available } \\
\text { Reserves }\end{array}$ & $\begin{array}{l}\text { Actual } \\
\text { Capability }\end{array}$ & $\begin{array}{l}\text { Actual } \\
\text { Reserve } \\
\end{array}$ \\
\hline$(M W)$ & $(M W)$ & $(z)$ & (MW) & $(8)$ & $(M W)$ & $(8)$ \\
\hline $\begin{array}{l}6,737 \\
6,647 \\
6,769\end{array}$ & $\begin{array}{l}8,411 \\
9,279 \\
8,909\end{array}$ & $\begin{array}{l}24.8 \\
39.6 \\
31.6\end{array}$ & $\begin{array}{l}7,798 \\
8,013 \\
7,911\end{array}$ & $\begin{array}{l}15.7 \\
20.6 \\
16.9\end{array}$ & $\begin{array}{l}7,159 \\
6,803 \\
6,667\end{array}$ & $\begin{array}{l}6.3 \\
2.3 \\
(1.5)\end{array}$ \\
\hline
\end{tabular}

\section{WINTER}

$\begin{array}{rllllllc}1977 & 6,312 & 8,718 & 38.1 & 6,494 & 2.9 & 4,444 & (29.6) \\ 1978 & 6,403 & 9,422 & 47.1 & 8,512 & 32.9 & 6,762 & 5.6 \\ 1979 & 5,991 & 9,164 & 53.0 & 7,934 & 32.4 & 7,170 & 19.7\end{array}$

Summer actual reserves were barely adequate when considering the effects of scheduled and forced outages. Winter actual reserves were adequate except for the winter 1977/78. 'In 1 s was due pirimarily to the coal strike, and a combination of high scheduled maintenance to take advantage of low plant output due to fuel constraint and forced outages.

Show below are the CCD regions energy requirements, summer and winter demands and annual load factors for the 1977-79 period. 
Table 1D. 4

Historical Energy, Peaks* and Load Factors

CCD REGION

Energy Reguirement (GWH) (Growth-8)

Summer Demand (MW) (Growth-8)

Winter Demand ( $\overline{M W}$ ) (Growth-8)

Annual Load Factor 6,737 6,647

6,769
6,312

6,403

5,991
57.7

59.3

60.2
1.4

$(6.4)$

$(2.5)$

$\begin{array}{lrl}1979 & 35,677 & 3.4 \\ \text { Growth } 77-79 & 2.4\end{array}$

0.2

* Non-coincident

Energy requirements over the period 1977-79 have grown at a compound rate of 2.48 . This is slightly higher than the average for the ECAR region.

Summer peak demand growth rates for 1977-79 are less than tradition patterns. This is due in part to cool summers, but mainly to conservation techniques and increased cost of energy.

Winter peak demands have shown a 2.58 decline from 1977 to 1979. This was the result of a $4 \cap n M W$ derrease in the 1979 wintcr peak. Gimilar winter declines in 1979 are evident in other ECAR systems which could indicate a weather related situation.

Load factors were lower than other ECAR systems which is indicative of utilities that serve large urban loads.

\section{Current Perspective}

The projected 1980 summer and winter non-coincident peak demand requirements are shown below:

Table 1D. 5

Projected 1980 Seasonal Peak Demand* - MW CCD REGION

Summer

June July Aug.

$6,706 \quad \underline{7,324} \quad 6,958$

* Non-coincident winter

\begin{tabular}{lll}
\multicolumn{3}{c}{ Winter } \\
\hline Dec. & Jan. & Feb. \\
6,635 & $\underline{6,904}$ & 6,411
\end{tabular}


The extremely high rate of growth between the actual 1979 and the projected 1980 peak demands was probably the result of over estimation of the 1979 peaks (summer and winter) If, indeed, the 1980

forecast is inflated due to forecast error, reserve margins could benefit throughout the $1980 / 89$ period.

The 1980 summer planned capability of the CCD region is estimated to be $8,948 \mathrm{MW}$ and the summer non-coincident peak demand requirements are projected to be $7,324 \mathrm{MW}$ excluding $12 \mathrm{MW}$ of Columbus \& Southern Ohio interruptible demana. After adjustments for scheduled receipts and deliveries, total reserves are 1,868 or 25.58 .

In the ECAR ERA-4ll report for the future (1980-1989) the CCD region does not list inoperable capability either for scheduled maintenance or possible forced outages. However, ECAR provides an indication of scheduled maintenance for the entire region.

The estimate prepared for the "411" report is based on the level of scheduled maintenance that is currently projected for the periods of neaviest load during the upcoming summer and winter seasons, i.e., five percent of total planned capability during the summer of 1980 and five percent of total planned capability during the winter of $1980 / 81$.

The summer and winter 1980 reserve margins for the CCD electric region are shown below:

Table $1 D .6$

$\frac{1980 \text { Reserve Margins* }}{\text { CCD REGION }}$

\begin{tabular}{|c|c|c|c|c|c|}
\hline \multicolumn{3}{|c|}{ Summer } & \multicolumn{3}{|c|}{ winter } \\
\hline $\begin{array}{r}\text { Planned } \\
\text { Reserves }\end{array}$ & $\begin{array}{c}\text { Total } \\
\text { Reserves }\end{array}$ & $\begin{array}{l}\text { Availahle } \\
\text { Reserves } \star\end{array}$ & $\begin{array}{l}\text { Planned } \\
\text { Reserves }\end{array}$ & $\begin{array}{c}\text { Total } \\
\text { Reserves }\end{array}$ & $\begin{array}{l}\text { Available } \\
\text { Reserves** }\end{array}$ \\
\hline 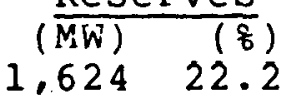 & 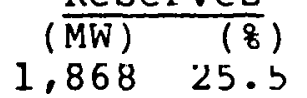 & $\begin{array}{rr}(M W) & (8) \\
1.416 & 19.3\end{array}$ & $\begin{array}{rr}(\mathrm{MW}) & (8) \\
2,991 & 43.3\end{array}$ & $\begin{array}{l}(\mathrm{MW}) \\
3,246 \quad 47.0\end{array}$ & $\begin{array}{r}(\mathrm{MW}) \\
2.74639 .8\end{array}$ \\
\hline
\end{tabular}

* Based on ERA Form 411

* * 58 of Total Installed Capability Assumed - From ECAR ERA Form 411 Report of Scheduled Outages.

The margins shown above have not been adjusted for forced outages of generation equipment since the amount of these outages are generally unknown ahead of time, but have run as high as 248 in 1977 . If these outages for 1980 do not exceed the maximum outages of the 1977-79 period, 148 of planned capability during the summer and 248 during the winter, the resultant actual reserve would be $163 \mathrm{MW}$ or 2.28 for the summer and $371 \mathrm{MW}$ or 5.48 for the winter. 
The summer 1980 capability of the generating facilities planned in the CCD region will be $8,948 \mathrm{MW}$. The capability breakdown by fuel type is shown below:

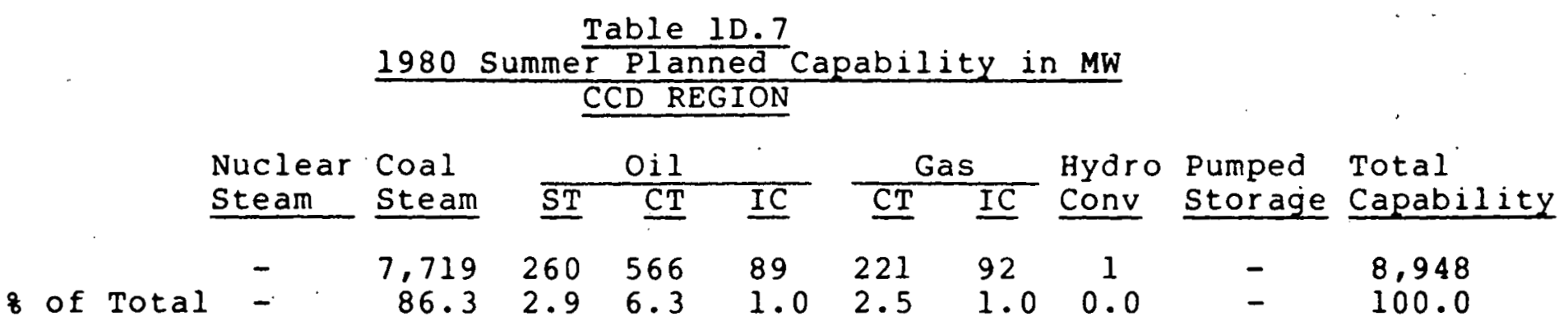

Of the current capability, $86 \%$ is coal-fired steam capacity, $10 \%$ is oil-fired steam, combustion turbine and internal combustion capacity, and $4 \%$ is gas-fired combustion turbine and internal combustion capacity. There is only $I \mathrm{MW}$ of hydroelectric capacity. No new capacity is scheduled to be installed in the CCD region in 1980.

The projected 1980 energy requirements, summer and winter demand requirements and annual load factor for the region are shown below:

Table 1D.8

$\frac{1980 \text { Load Requirements }}{\text { CCD REGION }}$

$\frac{\text { Energy Requirement }}{(\mathrm{GWH})} \frac{\text { Summer Peak. Demand* }}{(\mathrm{MW})} \frac{\text { Winter Peak Demand* }}{(\mathrm{MW})} \frac{\text { Annual L.F }}{(8)}$
37,410
7,324
6,904
58.2

8 of Growth

$4 \cdot 9$

8.2

15.2

$1980 / 79$

* Non-coincident

The high rates of growth have been discussed previously. 


$$
\mathrm{XI} .1 .76
$$

Delays in future critical bulk power transmission facilities that will not be in service when needed are reported under Item 5-C of the ERA-411 report. There are no lines in this category in the CCD region.

\section{Future Pperspective}

The range of total reserves for the CCD region for the periods 1981-85 and 1986-1989 are tabulated below:

\section{Table 1D.9}

Range of Total Reserves-8

\section{CCD REGION}

$$
\underline{1981-1985}
$$

$$
\frac{\text { Summer }}{23.7-35.9} \quad \frac{\text { Winter }}{39.3-48.9}
$$

$$
1986-1989
$$

\section{Summer}

$2 \frac{5}{2.8-31.4}$

As seen above the total reserves span a large range from 23.78 in the summer of 1985 to 48.98 in the winter of $1982 / 83$. Indications are that the CCD region will have no serious difficulties in meeting obligations, if there are no unusual delays in completing scheduled capacity additions. Total unavailable capacity including scheduled maintenance in 1977-79 varied from 158 to 278 of installed capability for the summer peak season, and from 22 to 508 for the winter.

If a total average non-availability rate of 228 is assumed for the summer in the 1981-89 period, only in 1985 and 1989 would actual reserves be deficient at $226 \mathrm{MW}(-2.58)$ and $434 \mathrm{MW}(-4.28)$ respectively. Assuming a total outage rate of $30 \%$ for the winter peaks, after $1986 / 87$ actual reserves would be deficient in the winter of $1987 / 88,1988 / 1989$, and 1939/90. The maximum deficiency would be $522 \mathrm{MW}$ or $(-5.58)$ in $1988 / 89$. As discussed previously, since peak estimates in the early portion of the forecast peiriod appear high, these deficiencies both summer and winter, may not materialize.

Shown below are the projected growth rates of energy and demand for each period and the overall rates for 1981 - 1989. 
Table 1D.10

Projected Energy and Demand Growth Rates CCD REGION

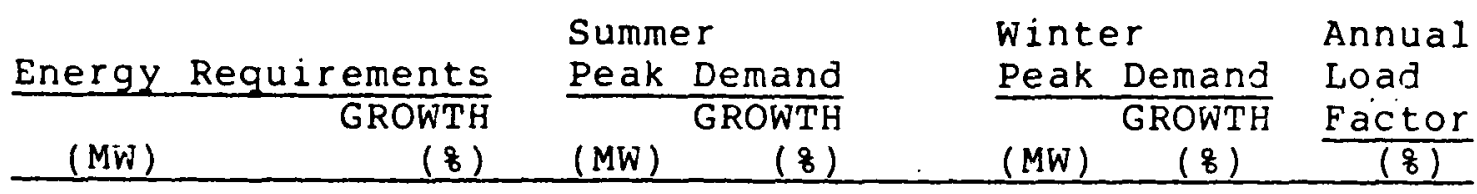

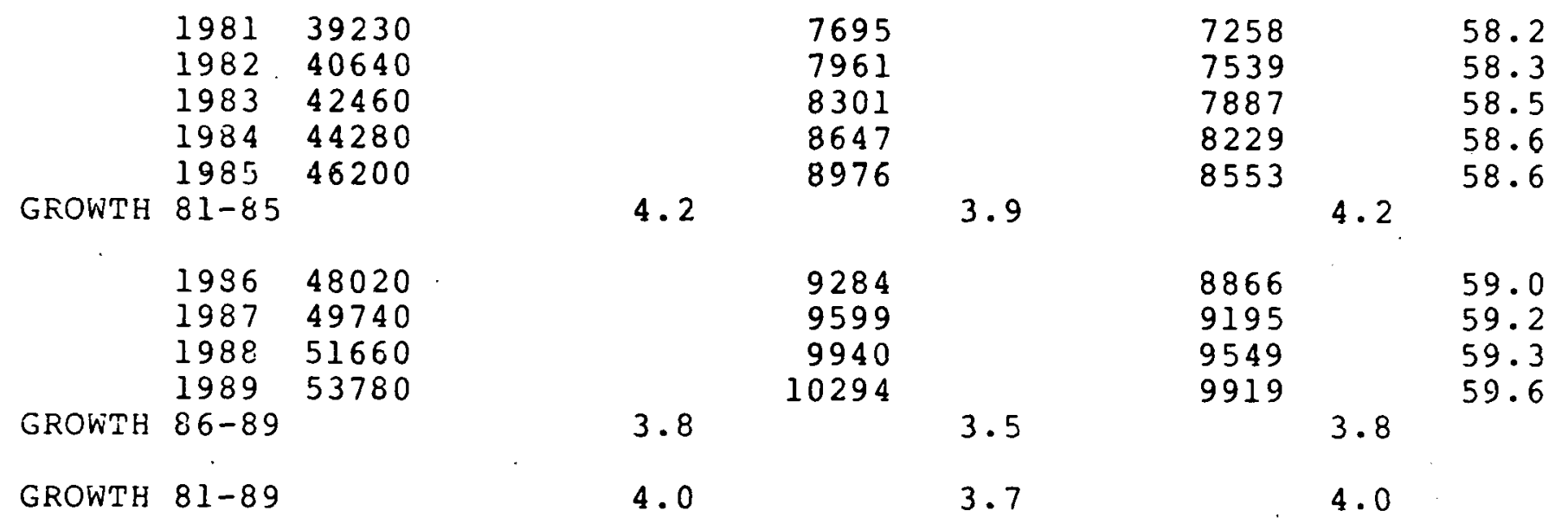

The 1981-1985 summer demands are projected to grow at a compound rate of 3.98 , 1986-1989 growth is forecasted at 3.58 with an overall growth in 1981-1989, of 3.78. These rates are considerably higher than the summer 1977-79 growth of less than 18.

The winter demand growth rates are projected to grow at a compound rate of 4.28 for the 1981-85 period, 3.88 for the 1986-89 period, with an overall average 1981-89 rate of 4.08 as compared to the 1977-79 reduction of 2.58 .

The summer peak is expected to decline from about 68 higher than the corresponding winter peak to about 38 higher than the winter peak within the forecast period.

Energy requirements are projected to grow 4.28 from $1981-85,3.88$ from 1986-89 and 4.08 for the overall period from 1981-89. Historically, 1977-79, the energy growth was 2.48 . The forecast indicates continued optimistic economic activity in the region.

During the 1981-85 period, six generating units are expected to be placed in service. 
Four of these are base-load coal-fired steam units, and each is rated at $600 \mathrm{MW}$. The units, East Bend \#2, Killen \#2, East Bend $\# 1$, and Killen \#1, will be installed in January 1981, October 1982, October 1985 and December 1985 respectively. Zimmer \#l, a nuclear unit rated at $807 \mathrm{MW}$ has an in-service date of January 1981. A 237 MW oil-fired combustion turbine, Hayden, is also scheduled for installation in January 1984 .

In the 1985-39 period, three units are scheduled: 2 coal-fired steam units and an oil-fired combustion turbine. The coal units, poston \#5, and East Bend \#3 are rated at $375 \mathrm{MW}$ and $600 \mathrm{MW}$ respectively and have in-service dates of January 1987 and October 1989. The $79 \mathrm{MW}$ Walnut combustion turbine, is scheduled for installation in January 1988.

There are no installations or retirements in 1980,1983 , or 1986.

The summer capability of units planned in the region for the period 1980-1989 is shown by fuel type in Table 1D.19. Major generating unit additions and retirements during the period are given in Table 1D.20. The percentages of each rype uf capdiliy for the targct ycarc $1980,1984,1989$ are given below.

\section{Table 1D.11}

Planned Generating Capacity by Type of Fuel (- $₹$ ) CCD REGION

Summer Capability

\begin{tabular}{|c|c|c|c|c|c|c|c|c|c|c|}
\hline \multirow[b]{2}{*}{ YedI } & \multirow{2}{*}{$\begin{array}{l}\text { Nuclear } \\
\text { SLéam }\end{array}$} & \multirow{2}{*}{$\begin{array}{l}\text { Coal } \\
\text { Steam }\end{array}$} & \multicolumn{3}{|c|}{ Oil } & \multicolumn{2}{|c|}{ Gas } & \multirow{2}{*}{$\begin{array}{l}\text { Hydro } \\
\text { Sonv. }\end{array}$} & \multirow{2}{*}{$\begin{array}{l}\text { Pumped } \\
\text { Storage }\end{array}$} & \multirow{2}{*}{$\begin{array}{c}\text { Total } \\
\text { Capability }\end{array}$} \\
\hline & & & $\overline{S T}$ & $\mathrm{CT}$ & $\underline{I C}$ & $\overline{\mathrm{CT}}$ & $\underline{I C}$ & & & \\
\hline & $\begin{array}{l}- \\
7.1 \\
6.3\end{array}$ & $\begin{array}{l}80.1 \\
82.8\end{array}$ & $\begin{array}{l}2.9 \\
2.3 \\
1.3\end{array}$ & $\begin{array}{l}6.3 \\
6.9 \\
6.5\end{array}$ & $\begin{array}{l}1.0 \\
0.8 \\
0.7\end{array}$ & $\begin{array}{l}2.5 \\
2.0 \\
1.7\end{array}$ & $\begin{array}{l}1.0 \\
0.8 \\
0.7\end{array}$ & $\begin{array}{l}0.0 \\
0.0 \\
0.0\end{array}$ & $\begin{array}{l}- \\
-\end{array}$ & $\begin{array}{l}100.0 \\
100.0\end{array}$ \\
\hline
\end{tabular}

Coal presently is the primary fuel for about 868 of the installed capacity of the region. Only a slight change tu abuul $83 z$ is forecasted for 1989. The slight decline is due to the addition of the first nuclear unit in the region in 1981. This will bring the percentage of nuclear up to 6.38 in 1989 . Oil-fired capacity is expected to decline from about 108 to about 98 and gas-fired from 3.58 to 2.58 in the 1981 period. There is no pumped storage and only $I \mathrm{MW}$ of conventional hydroelectric in the region. 
An appraisal of anticipated transmission system performace in ECAR is prepared immediately prior to each summer and winter peak load period. Each member system participates in the appraisal procedure and the material which appears in the final draft represents facilities of particular significance to the overall region. The appraisal is based on a careful analysis of various studies carried out by the ECAR Transmission system Performance Panel and by individual ECAR companies, either among themselves or jointly with systems adjacent to ECAR. Where the appraisal procedure indicates a potential contingency which could lead to localized problems, the matter is referred to the affected system(s) for further study and development of appropriate operating instructions where necessary. These reports are intended as a supplement to, and not a substitute for, internal studies by the individual systems in ECAR.

A wide range of postulated system conditions were considered during the course of the various studies referred to above and the following operating procedures were developed: (only CCD described below).

CSOE--Hyatt-Delaware $138 \mathrm{kV}$ Circuit

The $138 \mathrm{kV}$ Hyatt-Delaware transmission line is loaded slightly above its emergency rating of 287 MVA in the 1979-80 winter base case. In order to relieve this condition, it may become necessary to open Delaware-Tangy interconnection if problems develop during periods of heavy interregional or transregional power transfers.

The most recent ECAR appraisal studies were for summer 1979 and winter 1979-80. These studies snowed that timely completion of the scheduled transmission facility additions would insure that the reliability of the bulk power transmission systems within ECAR would be maintained at a high level.

Emergency Transfer Capabilities to adjacent regions, based on the NERC definition, were reported as follows:

$\frac{\text { Table 1D.12 }}{\text { Emergency Transfer Capability-MW }}$

Summer 1979

Transfer

Capability

ECAR to MAAC

ECAR to NPCC(NYPP)

ECAR tO MAIN

ECAR to SERC (TVA)

ECAR to SERC (VACAR)
3300 *

2200

3450

- 1800

1250
Winter $1979-80$

Capability

3300 *

2950

3950

1600

1900 *

*ETC Values determined with established operating procedures in effect. 


\section{Transfer}

ECAR from MAAC

ECAR from NPCC (NYPP)

ECAR from MAIN

ECAR from SERC (TVA)

ECAR from SERV (VACAR)
Summer 1979

Capability

2450

3300 *

4000 *

2000

2700
Winter $1979 / 8^{n}$

Capability
3300
2900
3800
2100
2950*

^ETC Values determine with established operating procedures in effect.

All ECAR systems eveluate their individual network performance using the testing criteria presented in ECAR Document No.l. Based on an analysis of these studies, it has been concluded that the ECAR bulk power transmission network as now piojected for the 1984 period is capable of withstanding the contingencies 1 isted in ECAR Document No. I without suffering area-wide break-up and/or collapse of the network. This appraisal is based on the assumption that current financial and environmental problems will be resolved in a timely manner and that ECAR member systems will be able to provide the facilities shown. Should any of the EHV transmission facilities planned for the 1980-84 period be delayed as a result of excessive lag in the certification process or as a result of difficulties in financing these projects due to inadequate rate relief, then appropriate short term operating procedures will need to be developed in order to maintain, to the greatest extent possible, the reliatility of electric power supply within ECAR. Such procedures, if invoked, may jeopardize the reliability of the power supply in the affected area.

Table 1D.13

Summer 1984 Emergency Transfer Capabil1ty - MW CCD REGION

\begin{tabular}{llll}
\multicolumn{1}{c}{ Transfer } & $\begin{array}{c}\text { ETC } \\
\text { MW }\end{array}$ & \multicolumn{1}{c}{ Transfer } & $\begin{array}{c}\text { ETC } \\
\text { MW }\end{array}$ \\
\cline { 1 - 2 } to MAAC & & ECAR Erom MAAC & 2600 \\
ECAR to NPCC (NYPP) & 1950 & ECAR from NPCC & 2900 \\
ECAR to MAIN & 2900 & ECAR from MAIN & $4000^{*}$ \\
ECAR to SERC (TVA) & 2500 & ECAR from SERC(TVA) & 3200 \\
ECAR to SERC(VACAR) & 2250 & ECAR from SERC(VACAR) & $5500^{*}$
\end{tabular}


TABLE 1.D.14

LINE

OWNERSHIP

LIST

TERMINALS

CG\&E DP\&L Miami Fort / Miami

Bath / Greene-Miami

Rillen / Stuart-Marquis (Marquis Madison / Miami Fort-Miami (DPL) killen Station / Bath

DPEL

DP\&L

DPEL

DPEL

Richland / Rillen-Bath

West Milton / Madison-Miami

Rillen / Stuart-Marquis (stuart)

$\underline{T}$

East Bend / Miami Fort

West End / Terminal

East Bend / Silver Grove

2 immer / Port Union

East Bend / Terminal

East Bend / Tanners

Todhunter / Miami Fort

Red Bank / Silver Grove-Terminal

East Bend / West-End

CG\&E

CG\&E

$\operatorname{csos}$

Walnut / Bixby

CSOE

CSOE

Chillicothe / Marquis-Bixby

Poston / Kirk-Bixby
List of Proposed Bulk Power Lines

$$
\text { CCD Group }
$$

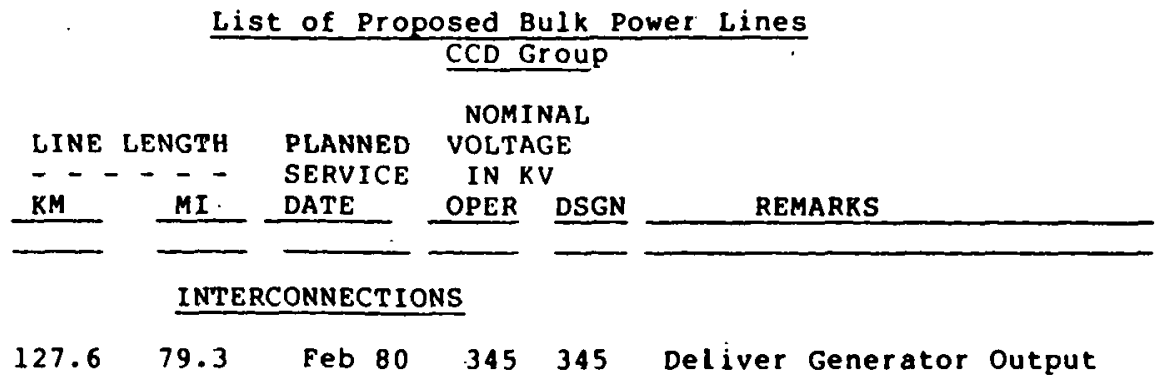

THE DAYTON POWER AND LIGHT COMPANY

\begin{tabular}{|c|c|c|c|c|}
\hline $\begin{array}{r}0.0 \\
10.4 \\
0.0 \\
142.3\end{array}$ & $\begin{array}{r}0.0 \\
6.5 \\
0.0 \\
88.4\end{array}$ & $\begin{array}{l}\text { May } \\
\text { Jul } \\
\text { May } \\
\text { May }\end{array}$ & $\begin{array}{l}82 \\
82 \\
85 \\
86\end{array}$ & $\begin{array}{l}345 \\
345 \\
345 \\
345\end{array}$ \\
\hline $\begin{array}{l}0.0 \\
0.0 \\
8.8\end{array}$ & $\begin{array}{l}0.0 \\
0.0 \\
5.5\end{array}$ & $\begin{array}{l}\text { May } \\
\text { May } \\
\text { Jan }\end{array}$ & $\begin{array}{l}86 \\
89 \\
81\end{array}$ & $\begin{array}{l}345 \\
345 \\
345\end{array}$ \\
\hline
\end{tabular}

Increase Interchange Capability De:iver Generator Output

Increase Interchange Capability

Deliver Generator Output

$$
\text { Pelieve Overloads }
$$

prcvide Area Protection

Increase Interchange Capability

Provide Initial Station Power and

Deliver Generator Output

\section{THE CINCINNATI GAS \& ELECTRIC COMPANY}

$\begin{array}{rrrrrl}24.6 & 15.3 & \text { Sep } 85 & 345 & 345 & \text { Deliver Generator Output } \\ 17.3 & 10.8 & \text { Sep } 89 & 345 & 345 & \text { Deliver Generator Output } \\ 57.3 & 35.6 & \text { Sep } 89 & 345 & 345 & \text { Deliver Generator Output } \\ 74.0 & 46.0 & \text { Jan } 80 & 345 & 345 & \text { Deliver Generator Output } \\ 22.5 & 14.0 & \text { Apr } 80 & 345 & 345 & \text { Deliver Generator Output } \\ 22.5 & 14.0 & \text { Apr } 80 & 345 & 345 & \text { Deliver Generator Output } \\ 66.8 & 41.5 & \text { Jun } 80 & 345 & 345 & \text { Deliver Generator Output } \\ 0.0 & 0.0 & \text { Oct } 80 & 345 & 345 & \text { Relieve Area Overloads } \\ 50.7 & 31.5 & \text { May } 84 & 345 & 345 & \text { Deliver Generator Output }\end{array}$

COLUMBUS \& SOUTHERN OHIO ELECTRIC CO.

$\begin{array}{rrrrrrr}0.6 & 0.4 & \text { Oct } 83 & 345 & 345 & \begin{array}{c}\text { Deliver Generator Output } \\ \text { (Nct required if alternate } \\ \text { generator site is used.) }\end{array} \\ 0.0 & 0.0 & \text { Oct } 84 & 345 & 345 & \begin{array}{l}\text { Local Area Support } \\ \text { Deliver Generator Output }\end{array}\end{array}$


TABLE 1.D.15

Historical Eapability (MW) and Reserves (MW and Percent)

CCD REGION

1. Planned Capability

2. Peak Demand

3. Planned Reserves $(1-2)$

4. Planned Reserves (8) (3-2) * 1008

5. Net Transactions (Imports - Exगor=s)

6. Total Capability $(1+5)$

7. Total Reserves $(6-2)$

8. Total Reserves (8) $(7-2) \times 1008$

9. Scheduled Maintenance

10. Capability After Maintenance $(5-9)$

11. Reserves After Maintenance $(10-2)$

12. Reserves After Maintenance (8) $(11-2 i \times 1008$

13. Inoperable Capability *

14. Available Capability (10 - 13)

15. Available Reserves $(14-2)$

16. Available Reserves (8) $(15-2) \times 1008$

17. Forced Outages

18. Actual Capability After Forced Outages $(16-17)$

19. Actual Reserves $(18-2)$

20. Actual Reserves (8) $(19-2)=1008$

- Included in Item 17

\begin{tabular}{rr}
\multicolumn{2}{c}{1977} \\
\hline Summer & Winter \\
8290.0 & 8502.0 \\
6737.0 & 6312.0 \\
1553.0 & 2290.0 \\
23.1 & 36.3 \\
121.0 & 116.0 \\
8411.0 & 8718.0 \\
1674.0 & 2406.0 \\
24.8 & 38.1 \\
613.0 & 2224.0 \\
7798.0 & 6494.0 \\
1061.0 & 182.0 \\
15.7 & 2.9 \\
0.0 & 0.0 \\
7798.0 & 6494.0 \\
1061.0 & 182.0 \\
15.7 & 2.9 \\
639.0 & 2050.0 \\
7159.0 & 4444.0 \\
422.0 & -1868.0 \\
6.3 & -29.6 \\
&
\end{tabular}

\begin{tabular}{rr}
\multicolumn{2}{c}{1978} \\
Summer & Winter \\
9165.0 & 9312.0 \\
6647.0 & 6403.0 \\
2518.0 & 2909.0 \\
37.9 & 45.4 \\
114.0 & 110.0 \\
9279.0 & 9422.0 \\
2632.0 & 3019.0 \\
39.6 & 47.1 \\
1266.0 & 910.0 \\
8013.0 & 8512.0 \\
1366.0 & 2109.0 \\
20.6 & 32.9 \\
0.0 & 0.0 \\
8013.0 & 8512.0 \\
1366.0 & 2109.0 \\
20.6 & 32.9 \\
1210.0 & 1750.0 \\
6803.0 & 6762.0 \\
156.0 & 359.0 \\
2.3 & 5.6 \\
&
\end{tabular}

\begin{tabular}{rr}
\multicolumn{2}{c}{1979} \\
\hline Summer & winter \\
8999.0 & 9258.0 \\
6769.0 & 5991.0 \\
2230.0 & 3267.0 \\
32.9 & 54.5 \\
-90.0 & -94.0 \\
8909.0 & 9164.0 \\
2140.0 & 3173.0 \\
31.6 & 53.0 \\
998.0 & 1230.0 \\
7911.0 & 7934.0 \\
1142.0 & 1943.0 \\
16.9 & 32.4 \\
0.0 & 0.0 \\
7911.0 & 7934.0 \\
1142.0 & 1943.0 \\
16.9 & 32.4 \\
1244.0 & 764.0 \\
6667.0 & 7170.0 \\
-102.0 & 1179.0 \\
-1.5 & 19.7
\end{tabular}


1. Planned Capability

2. Peak Demand

3. Planned Reserves $(1-2)$

4. Planned Reserves (8) $(3-2) \times 1008$

5. Net Transactions (Imports - Exports)

6. Total Capability $(1+5)$

7. Total Reserves $(6-2)$

8. Total Reserves (8) $(7-2) \times 1008$

9. Scheduled Maintenance 1/

10. Capability After Mainténance (6 - 9)

11. Reserves After Maintenance $(10-1)$

12. Reserves After Maintenance (8) (11-2) x 1008

13. Inoperable Capability

14. Available Capability $(10-13)$

15. Available Reserves $(14-2)$

16. Available Reserves (8) (15 - 2) x 1008

17. Forced Outages $2 L$

18. Actual Capability After Forced Outages (14 - 17)

19. Actual Reserves $(18-2)$

20. Actual Reserves (8) $(19-2) \times 1008$

\begin{tabular}{|c|c|}
\hline \multicolumn{2}{|c|}{1980} \\
\hline Summer & winter \\
\hline 8948.0 & 9895.0 \\
\hline 7324.0 & 6904.0 \\
\hline 1624.0 & 2991.0 \\
\hline 22.2 & 43.3 \\
\hline 244.0 & 255.0 \\
\hline 9192.0 & 10150.0 \\
\hline 1868.0 & 3246.0 \\
\hline 25.5 & 47.0 \\
\hline 447.0 & 495.0 \\
\hline 8745.0 & 9655.0 \\
\hline 1421.0 & 2751.0 \\
\hline 19.4 & 39.8 \\
\hline 5.0 & 5.0 \\
\hline 8740.0 & 9650.0 \\
\hline 1416.0 & 2746.0 \\
\hline 19.3 & 39.8 \\
\hline 0.0 & 0.0 \\
\hline 8740.0 & 9650.0 \\
\hline 1416.0 & 2746.0 \\
\hline 19.3 & 39.8 \\
\hline
\end{tabular}

1/ Five percent of total planned capability assumed by ERA from ECAR 411 Report.

2f No information supplied. 
TABLE 1.D.1T

Future Capability (UW) and Reserves (MW and Percent)

CCD REGION

\author{
1. Planned Capability \\ 2. Peak Demand \\ 3. Planned Reserves (1-2) \\ 4. Planned Reserves (8)(3-2) $\times 1008$ \\ 5. Net Transactions (Imports - Exports) \\ 6. Total Capability $(1+5)$ \\ 7. Total Reserves $(6-2)$ \\ 8. Total Reserves (8)(7-2) x 1008 \\ 9. Scheduled Maintenance * \\ 10. Capability After Maintenanze (6-9) \\ 11. Reserves After Maintenance $(10-2)$ \\ 12. Reserves After Maintenance (8) (11-2) $\times 1008$ \\ 13. Inoperable Capability \\ 14. Available Capability (10-13) \\ 15. Available Reserves (14-2) \\ 16. Available Reserves $(8)(15-2) \times 1008$ \\ 17. Forced Outages \\ 18. Actual Capability After Forced outages \\ 19. Actual Reserves $(18-2)$ \\ 20. Actual Reserves (8) $(19-2) \times 1008$
}

- No Information supplied.
1981

1982

1983

1984

er Winter

$\begin{array}{rrrrrrrrrr}10313 & 10632 & 10313 & 11232 & 10913 & 11469 & 11108 & 11469 & 11108 & 12669 \\ 7595 & 7258 & 7961 & 7539 & 8301 & 7887 & 8647 & 8229 & 8976 & 8553 \\ 2518 & 3374 & 2352 & 3693 & 2612 & 3582 & 2461 & 3240 & 2132 & 4116 \\ 34.0 & 46.5 & 29.5 & 49.0 & 31.5 & 45.4 & 28.5 & 36.4 & 23.8 & 48.1 \\ 141 & -4.0 & -4.0 & -4.0 & -4.0 & -4.0 & -4.0 & -4.0 & -4.0 & -4.0 \\ 10454 & 10628 & 10309 & 11228 & 10909 & 11465 & 11104 & 11465 & 11104 & 12665 \\ 2759 & 3370 & 2348 & 3689 & 2608 & 3578 & 2457 & 3236 & 2128 & 4112 \\ 35.9 & 46.4 & 29.5 & 48.9 & 31.4 & 45.4 & 28.4 & 39.3 & 23.7 & 48.1 \\ 0 & 0 & 0 & 0 & 0 & 0 & 0 & 0 & 0 & 0 \\ 10454 & 10628 & 10309 & 11228 & 10909 & 11465 & 11104 & 11465 & 11104 & 12665 \\ 2759 & 3370 & 2348 & 3689 & 2608 & 3578 & 2457 & 3236 & 2128 & 4112 \\ 35.9 & 46.4 & 29.5 & 48.9 & 31.4 & 45.4 & 28.4 & 39.3 & 23.7 & 48.1 \\ 5.0 & 5.0 & 5.0 & 5.0 & 5.0 & 5.0 & 5.0 & 5.0 & 5.0 & 5.0 \\ 10449 & 10623 & 10304 & 11223 & 10904 & 11460 & 11099 & 11460 & 11099 & 12660 \\ 2754 & 3365 & 2343 & 3684 & 2603 & 3573 & 2452 & 3231 & 2123 & 4107 \\ 35.8 & 46.4 & 29.4 & 48.9 & 31.4 & 45.3 & 28.4 & 39.3 & 23.7 & 48.0 \\ 0 & 0 & 0 & 0 & 0 & 0 & 0 & 0 & 0 & 0 \\ 10449 & 10623 & 10304 & 11223 & 10904 & 11460 & 11099 & 11+60 & 11099 & 12660 \\ 2754 & 3365 & 2343 & 3684 & 2603 & 3573 & 2452 & 3231 & 2123 & 4107 \\ 35.8 & 46.4 & 29.4 & 48.9 & 31.4 & 45.3 & 28.4 & 39.3 & 23.7 & 48.0\end{array}$


TABLE 1.D.18

Future Capability (MW) and Reserves (MW and Percent)

CCD REGION

1. Planned Capability

2. Peak Demand

3. Planned Reserves $(1-2)$

4. Planned Reserves (8)(3-2) x 1008

5. Net Transactions (Imports-Exports)

6. Total Capability $(1+5)$

7. Total Reserves $(6-2)$

8. Total Reserves $(8)(7-2) \times 1008$

9. Scheduled Maintenance *

10. Capability After Maintenance (6-9)

11. Reserves After Maintenance (10-2)

12. Reserves After Maintenance (8)11-2) $\times 1008$

13: Inoper able Capability

14. Available Capability $(10-13)$

15. Available Reserves $(14-2)$

16. Available Reserves $(8)(15-2) \times 1008$

17. Forced Outages

18. Actual Capability After Forced Outages (14-7)

19. Actual Reserves $(18-2)$

20. Actual Reserves $(8)(19-2) \times 1008$

"No information supplied
1986

Summer winter \\ Summer Winter}

$12206 \quad 12942$

\begin{tabular}{l}
9284 \\
2922 \\
\hline 8076
\end{tabular}

$31.5 \quad 46.0$

$-4.0 \quad-4.0$

$12202 \quad 12938$

$29: 8 \quad 4072$

$31.4 \quad 45.9$

0

12202

$31.4 \quad 45.9$

5.0

12197

$2913 \quad 4067$

$31.4 \quad 45.9$

0

2913
31.4
1987

$\frac{1987}{\text { Summer Winter Summer Winter summer Winter }}$

12581

$\begin{array}{rrrrrr}9599 & 9295 & 9940 & 9549 & 10294 & 9917\end{array}$

$\begin{array}{llllll}2982 & 3826 & 2706 & 3472 & 2352 & 4079\end{array}$

$\begin{array}{llllll}31.1 & 41.6 & 27.2 & 36.4 & 22.8 & 41.1\end{array}$

$\begin{array}{llllll}-4.0 & -4.0 & -4.0 & -4.0 & -4.0 & -4.0\end{array}$

$\begin{array}{llllll}12577 & 13017 & 12642 & 13017 & 12642 & 13992\end{array}$

$\begin{array}{rrrrrr}2978 & 3822 & 2702 & 3468 & 2348 & 4075\end{array}$

$\begin{array}{llllll}31.0 & 41.6 & 27.2 & 36.3 & 22.8 & 41.1\end{array}$

$\begin{array}{rrrrrr}0 & 0 & 0 & 0 & 0 & \\ 12577 & 13017 & 12642 & 13017 & 12642 & 13992\end{array}$

$\begin{array}{llllll}2978 & 3822 & 2702 & 3468 & 2348 & 4075\end{array}$

$\begin{array}{llllll}31.0 & 41.6 & 27.2 & 36.3 & 22.8 & 41.1\end{array}$

$\begin{array}{rrrrrr}31.0 & 41.6 & 27.2 & 36.3 & 22.8 & 41.1 \\ 5.0 & 5.0 & 5.0 & 5.0 & 5.0 & 5.0\end{array}$

$\begin{array}{rrrrrr}5.0 & 5.0 & 5.0 & 5.0 & 5.0 & 5.0 \\ 12572 & 13012 & 12637 & 13012 & 12637 & 13987\end{array}$

$\begin{array}{llllll}2973 & 3817 & 2697 & 3463 & 2343 & 4070\end{array}$

$\begin{array}{llllll}31.0 & 41.5 & 27.1 & 36.3 & 22.8 & 41.0\end{array}$

$\begin{array}{rrrrrr}0 & 0 & 0 & 0 & 0 & 0\end{array}$

$\begin{array}{llllll}2973 & 3817 & 2697 & 3463 & 2343 & 4070\end{array}$ 
TABLE 1.D.19

Flangec Capability by Type of Fuel - MW CCD GROUP

Summer Capability

\begin{tabular}{|c|c|c|c|c|c|c|c|c|c|c|c|c|}
\hline & & \multirow{2}{*}{$\begin{array}{l}\text { NUCLEAR } \\
\text { STEAM }\end{array}$} & \multirow{2}{*}{$\begin{array}{l}\text { COAL } \\
\text { STEAM }\end{array}$} & \multicolumn{3}{|c|}{$\overline{\text { OIL }}$} & \multicolumn{3}{|c|}{ NATURAL GAS } & \multicolumn{2}{|c|}{ HYDRO } & \multirow{2}{*}{$\begin{array}{c}\text { TOTAL } \\
\text { CAPABILITY }\end{array}$} \\
\hline & & & & STEAM & $\begin{array}{l}\text { COMBUST. } \\
\text { TURBINE }\end{array}$ & $\begin{array}{l}\text { INTERNAL } \\
\text { COMBUST. }\end{array}$ & STEAM & $\begin{array}{l}\text { COMB. } \\
\text { TURB. }\end{array}$ & $\overline{\text { I.C. }}$ & CONVENT. & $\begin{array}{l}\text { PUMPED } \\
\text { STORAGE }\end{array}$ & \\
\hline 8 & $\begin{array}{r}1980 \\
\text { TOTAL }\end{array}$ & - & $\begin{array}{l}7719 \\
86.3\end{array}$ & $\begin{array}{l}260 \\
2.9\end{array}$ & $\begin{array}{l}566 \\
6.3\end{array}$ & $\begin{array}{l}89 \\
1.0\end{array}$ & & $\begin{array}{r}221 \\
2.5\end{array}$ & $\begin{array}{l}92 \\
1.0\end{array}$ & $\begin{array}{l}1 \\
0.0\end{array}$ & & $\begin{array}{l}8948 \\
100\end{array}$ \\
\hline 8 & $\begin{array}{r}1981 \\
\text { TOTAL }\end{array}$ & $\begin{array}{l}792 \\
7.7\end{array}$ & $\begin{array}{l}8292 \\
80.4\end{array}$ & $\begin{array}{l}260 \\
2.5\end{array}$ & $\begin{array}{l}566 \\
5.5\end{array}$ & $\begin{array}{l}89 \\
0.9\end{array}$ & & $\begin{array}{l}221 \\
2.1\end{array}$ & $\begin{array}{l}92 \\
0.9\end{array}$ & $\begin{array}{l}1 \\
0.0\end{array}$ & & $\begin{array}{c}10313 \\
100\end{array}$ \\
\hline 8 & $\begin{array}{r}1982 \\
\text { TOTAL }\end{array}$ & $\begin{array}{l}792 \\
7.7\end{array}$ & $\begin{array}{l}8292 \\
80.4\end{array}$ & $\begin{array}{l}260 \\
2.5\end{array}$ & $\begin{array}{l}566 \\
5.5\end{array}$ & $\begin{array}{l}89 \\
0.9\end{array}$ & & $\begin{array}{l}221 \\
2.1\end{array}$ & $\begin{array}{l}92 \\
0.9\end{array}$ & $\begin{array}{l}1 \\
0.0\end{array}$ & & $\begin{array}{c}10313 \\
100\end{array}$ \\
\hline 8 & $\begin{array}{r}1983 \\
\text { TOTAL }\end{array}$ & $\begin{array}{l}792 \\
7.3\end{array}$ & $\begin{array}{l}8892 \\
81.5\end{array}$ & $\begin{array}{l}260 \\
2.4\end{array}$ & $\begin{array}{l}566 \\
5.2\end{array}$ & $\begin{array}{l}89 \\
0.8\end{array}$ & & $\begin{array}{l}221 \\
2.0\end{array}$ & $\begin{array}{l}92 \\
0.8\end{array}$ & $\begin{array}{l}1 \\
0.0\end{array}$ & & $\begin{array}{c}10913 \\
100\end{array}$ \\
\hline 8 & $\begin{array}{r}1984 \\
\text { TOTAL }\end{array}$ & $\begin{array}{l}792 \\
7.1\end{array}$ & $\begin{array}{l}8892 \\
80.1\end{array}$ & $\begin{array}{l}260 \\
2.3\end{array}$ & $\begin{array}{l}761 \\
6.9\end{array}$ & $\begin{array}{l}89 \\
0.8\end{array}$ & & $\begin{array}{l}221 \\
2.0\end{array}$ & $\begin{array}{l}92 \\
0.8\end{array}$ & $\begin{array}{l}1 \\
0.0\end{array}$ & & $\begin{array}{c}11108 \\
100\end{array}$ \\
\hline 8 & $\begin{array}{r}1985 \\
\text { TOTAL }\end{array}$ & $\begin{array}{l}792 \\
7.1\end{array}$ & $\begin{array}{l}8892 \\
80.1\end{array}$ & $\begin{array}{l}260 \\
2.3\end{array}$ & $\begin{array}{l}761 \\
6.9\end{array}$ & $\begin{array}{l}89 \\
0.8\end{array}$ & & $\begin{array}{l}221 \\
2.0\end{array}$ & $\begin{array}{l}92 \\
0.8\end{array}$ & $\begin{array}{l}1 \\
0.0\end{array}$ & & $\begin{array}{c}11108 \\
100\end{array}$ \\
\hline 8 & $\begin{array}{r}1986 \\
\text { TOTAL }\end{array}$ & $\begin{array}{l}792 \\
6.5\end{array}$ & $\begin{array}{r}10092 \\
82.7\end{array}$ & $\begin{array}{l}158 \\
1.3\end{array}$ & $\begin{array}{l}761 \\
6.2\end{array}$ & $\begin{array}{l}89 \\
0.7\end{array}$ & & $\begin{array}{l}221 \\
1.8\end{array}$ & $\begin{array}{l}92 \\
0.8\end{array}$ & $\begin{array}{l}1 \\
0.0\end{array}$ & & $\begin{array}{c}12206 \\
100\end{array}$ \\
\hline 8 & $\begin{array}{r}1987 \\
\text { TOTAL }\end{array}$ & $\begin{array}{l}792 \\
6.3\end{array}$ & $\begin{array}{r}10467 \\
83.2\end{array}$ & $\begin{array}{l}158 \\
1.3\end{array}$ & $\begin{array}{l}761 \\
6.0\end{array}$ & $\begin{array}{l}89 \\
0.7\end{array}$ & & $\begin{array}{l}221 \\
1.8\end{array}$ & $\begin{array}{l}92 \\
0.7\end{array}$ & $\begin{array}{l}1 \\
0.0\end{array}$ & & $\begin{array}{c}12581 \\
100\end{array}$ \\
\hline 8 & $\begin{array}{r}1988 \\
\text { TOTAL }\end{array}$ & $\begin{array}{l}792 \\
6.3\end{array}$ & $\begin{array}{r}10467 \\
82.8\end{array}$ & $\begin{array}{l}158 \\
1.3\end{array}$ & $\begin{array}{l}826 \\
6.5\end{array}$ & $\begin{array}{l}89 \\
0.7\end{array}$ & & $\begin{array}{l}221 \\
1.7\end{array}$ & $\begin{array}{l}92 \\
0.7\end{array}$ & $\begin{array}{l}1 \\
0.0\end{array}$ & & $\begin{array}{c}12646 \\
100\end{array}$ \\
\hline 8 & $\begin{array}{r}1989 \\
\text { TOTAL }\end{array}$ & $\begin{array}{l}792 \\
6.3\end{array}$ & $\begin{array}{r}10467 \\
82.8\end{array}$ & $\begin{array}{l}158 \\
1.3\end{array}$ & $\begin{array}{l}826 \\
6.5\end{array}$ & $\begin{array}{l}89 \\
0.7\end{array}$ & & $\begin{array}{l}221 \\
1.7\end{array}$ & $\begin{array}{l}92 \\
0.7\end{array}$ & $\begin{array}{l}1 \\
0.0\end{array}$ & & $\begin{array}{c}12646 \\
100\end{array}$ \\
\hline
\end{tabular}


TABLE 1.D. 20

Major Future Generating Capability Installations and (Removals) CCD REGION

\begin{tabular}{|c|c|c|c|c|c|}
\hline STATION & $\begin{array}{l}\text { UNIT } \\
\text { TYPE } \\
\end{array}$ & $\begin{array}{l}\text { FUEL } \\
\text { TYPE } \\
\end{array}$ & $\begin{array}{l}\text { NET } \\
\text { CAPAB I L ITY } \\
\end{array}$ & $\begin{array}{l}\text { IN-SERVICE DATE } \\
\text { APRIL } 79 \\
\text { "383" REPORT } \\
\end{array}$ & $\begin{array}{r}\text { IN-SERVICE DATE } \\
\text { APRIL } 80 \\
4411 " \text { REPORT } \\
\end{array}$ \\
\hline $\begin{array}{l}\text { W. H. Zimmer } \# 1 \\
\text { Hayden } \\
\text { Poston \#5 } \\
\text { Walnut } 10-4 \\
\text { East Bend \#2 } \\
\text { Killen \#2 } \\
\text { East Bend \#1 } \\
\text { Killen \#1 } \\
\text { East Bend \#3 }\end{array}$ & $\begin{array}{l}\text { BWR } \\
\text { C.T. } \\
\text { ST } \\
\text { C.T. } \\
\text { ST } \\
\text { ST } \\
\text { ST } \\
\text { ST } \\
\text { ST }\end{array}$ & $\begin{array}{l}\text { Uranium } \\
\# 2 \text { Oil } \\
\text { Coal } \\
\# 2 \text { Oil } \\
\text { Coal } \\
\text { Coal } \\
\text { Coal } \\
\text { Coal } \\
\text { Coal }\end{array}$ & $\begin{array}{r}807 \\
237 \\
375 \\
79 \\
600 \\
600 \\
600 \\
600 \\
600\end{array}$ & $\begin{array}{c}1 / 80 \\
1 / 84 \\
1 / 87 \\
- \\
1 / 81 \\
10 / 82 \\
10 / 84 \\
4 / 86 \\
4 / 88\end{array}$ & $\begin{array}{l}1 / 81 \\
1 / 84 \\
1 / 87 \\
1 / 88 \\
1 / 81 \\
10 / 82 \\
10 / 85 \\
12 / 85 \\
10 / 89\end{array}$ \\
\hline
\end{tabular}




\section{HISTIORICAL_PERSPEECTIVE}

Electric Region 15 consists of the electric systems in the state of Kentucky excluding the Kentucky Power Co., a subsidary of American Electric Power, and TVA. The major power suppliers in the region are Big Rivers Electric Corp., East Kentucky Power Cooperative, Kentucky utilities Comfany. Data in this section are also included for the Henderson Kentucky and Owensboro, Kentucky municipal electric systems which are within the region.

All of the systems for which data are included are regular or liaison members of the ECAR organization. The two investor-owned utilities and the two municipal systems collectively scrve about 489,000 residential customers, 60,000 commercial customers, 82,000, rural customers, and 3800 industrial customers. The two cooperative systems, Eig Rivers and East Kentucky, serve 22 member cooperative systemis.

The major transmission voltages in the Kentucky region are $138 \mathrm{kV}$ and $161 \mathrm{kV}$. There is a $345 \mathrm{kV}$ interconnection between Louisville Gas Electric Co., and the Ohio Valley Electric Corporation (OVEC). In addition to OVEC, the systems in Electric Region (ER) 15 have transmission ties with the Chio Power CO., in ER 2-AEF; with the Central Illinois Public Service Co., and Flectric Energy, Inc., in ER 17-ILLMO; with the public service Company of Indiana and the Soutern Indiana Gas and Electric Co., in ER 16-IN; with Cincinnati Cas and Electric Co.. in ER 14-CCD; and TVA in EP 11-TVA. The Kentucky region has historically been a summer peaking area. Shown below are the region's summer and winter peaks for the period 1977-1979.

\section{$\underline{\text { Tab }} \underline{\underline{1}} \underline{\mathrm{e}} \underline{\mathrm{l}} \underline{\mathrm{E}} . \underline{1}$}

Histor ical Peak Demand-Mwi K $\bar{E} \bar{N} \bar{T} \bar{L} \bar{K} \bar{Y}-\bar{R} \bar{E} \bar{G} \bar{I} \bar{O}$

\begin{tabular}{|c|c|c|c|c|c|c|}
\hline & \multicolumn{3}{|c|}{ SUMMER } & \multicolumn{3}{|c|}{ WINTER } \\
\hline & Juuㅡㄹㅡ & JuIY & Pug. & Eec. & Jan. & Feb. \\
\hline $\begin{array}{l}1977 \\
1978 \\
1979\end{array}$ & $\begin{array}{l}4,432 \\
5,115 \\
4,881\end{array}$ & $\begin{array}{l}\frac{5}{5}, \frac{0}{0} \frac{31}{4} \frac{1}{5} \\
5,013\end{array}$ & $\begin{array}{l}4,859 \\
5,1 \frac{39}{5}, \frac{4}{9}\end{array}$ & $\begin{array}{l}4,687 \\
4,432 \\
4,823\end{array}$ & $\frac{4}{5}, \frac{9}{4}, \frac{0}{9} \frac{2}{5}$ & $\begin{array}{l}4,688 \\
4,943 \\
5,040\end{array}$ \\
\hline
\end{tabular}

Underline indicates seasonal peak. 
The summer peak demands are dependent.on climatic conditions and are temperature/humidity sensitive. Usually the peak will occur in July or August.

The winter peak usually occurs in January, but it may occur in any winter month, depending on the combination of weather and economic activity in the region. The winter peak during the 1977-79 period was 3-8 less than the corresponding summer peak.

The following table shows the scheduled maintenance cerformed each period and also the capability unavailable because of forced outages or otherwise inoperable.

Table $\underline{1} \underline{\underline{E}} \underline{2}$

Schheduled Maintenance And Unavailable_Cagabilities KE $\bar{E} \bar{N} \bar{T} \bar{C} \bar{K} \bar{Y}-\bar{R} \bar{E} \bar{G} \bar{I} \bar{O} \bar{N}$

-
- WINTER

Scheduled other Total Scheduled Other Total Maintenance Unavailable Unavailable Maintenance Unavailable Unavailable $(\bar{M} \bar{W})---\frac{(\bar{M} \bar{W})}{}$ $(M W)$ $(\bar{M} \bar{W})$ $(\bar{M} \bar{W})$

$\begin{array}{rrrrrrr}1977 & 0 & 318 & 318 & 23 & 796 & 819 \\ 1978 & 281 & 620 & 901 & 616 & 565 & 1,181 \\ 1979 & 55 & 553 & 608 & 900 & 1,134 & 2,034\end{array}$

The capability unavailable for reasons other than scheduled maintenance varied from 5-98 of the planned cafability in summer and from $8-168$ in winter.

The reserve margins for the 1977-79 period are shown below. The table indicating the effects of scheduled maintenance and other outages.

$$
\text { Table IE. } 3
$$

\section{Historical Seasonal Peserves}

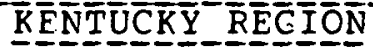

\begin{tabular}{|c|c|c|c|c|c|c|c|}
\hline \multirow[b]{2}{*}{$\begin{array}{l} \\
1977 \\
1978 \\
1979\end{array}$} & \multicolumn{5}{|c|}{ Summer } & \multirow[b]{2}{*}{$\begin{array}{c}\text { Actual } \\
\text { Capability } \\
(\bar{M})= \\
5,696 \\
5,863 \\
6,373\end{array}$} & \multirow[b]{2}{*}{$\begin{array}{c}\text { Actual } \\
\text { Reserves } \\
\left.\frac{1}{8} \frac{1}{8}\right) \\
13.2 \\
13.1 \\
17.0\end{array}$} \\
\hline & $\begin{array}{c}\text { Peak } \\
\text { Demaand } \\
(\bar{M} \bar{w}) \\
5,031 \\
5,183 \\
5,449\end{array}$ & $\begin{array}{c}\text { Total } \\
\text { Capabil ity } \\
(\bar{M}) \\
6,014 \\
6,764 \\
6,981\end{array}$ & $\begin{array}{c}\text { Total } \\
\text { Reserves } \\
\left(\frac{8}{8}\right) \\
19.5 \\
30.5 \\
28.1\end{array}$ & $\begin{array}{c}\text { Available } \\
\text { Capability } \\
(\bar{M} \bar{W}) \\
6,014 \\
6,483 \\
6,926\end{array}$ & $\begin{array}{c}\text { Available } \\
\text { Reserves } \\
\begin{array}{c}\left(\frac{8}{8}\right) \\
19.5 \\
25.1 \\
27.1\end{array}\end{array}$ & & \\
\hline $\begin{array}{l}1977 \\
1978 \\
1979\end{array}$ & $\begin{array}{l}4,904 \\
5,045 \\
5,040\end{array}$ & $\begin{array}{l}6,968 \\
7,220 \\
8,062\end{array}$ & $\begin{array}{l}42.1 \\
43.1 \\
60.0\end{array}$ & $\begin{array}{l}6,945 \\
6,604 \\
7,162\end{array}$ & $\begin{array}{l}41.6 \\
30.9 \\
42.1\end{array}$ & $\begin{array}{l}6,149 \\
6,039 \\
6,028\end{array}$ & $\begin{array}{l}25.4 \\
19.7 \\
19.6\end{array}$ \\
\hline
\end{tabular}


The reserve margins shown above indicate that for the 1977-79 period sufficient capability was available to meet the demand requirements in both the summer and winter periods.

Listed below are annual load and energy reguirements for the 1977-79 period for the Kentucky Group.

\section{Table 1 E.}

\section{Historical Energy, Peaks And Load_Factors} KEN TUECEY

\begin{tabular}{|c|c|c|c|}
\hline & $\begin{array}{l}\text { Summer } \\
\text { Peak Demand }\end{array}$ & & $\begin{array}{c}\text { Actual } \\
\text { Load Factor }\end{array}$ \\
\hline$\overline{8} \overline{7}$ & $\overline{\left(\bar{N}_{\mathrm{W}} \overline{\mathrm{W}}\right)}(\overline{\mathrm{GrOwt}} \overline{\mathrm{g}})$ & (Growth $\bar{q})$ & \\
\hline
\end{tabular}

$\begin{array}{llllllll}1977 & 28,010 & - & 5,031 & - & 4,904 & - & 63.6 \\ 1979 & 28,543 & 1.9 & 5,183 & 3.0 & 5,045 & 2.9 & 62.9 \\ 1979 & 29,240 & 2.4 & 5,449 & 5.1 & 5,040 & (0.1) & 61.3 \\ \text { 8Growth; } 1977-79 & 2.2 & & 4.1 & & 1.4 & \end{array}$

Over the period, the energy requirements grew at a compound growth rate of 2.28 , the summer demand at 4.18 and the winter demand at 1.48 . The low growth rate of the energy requirements and the winter peak demand is consistent with that of other regions in ECAR. The summer demand was not as defressed in the Kentucky region as in other ECAR regions. The slow growth rate of the region show the effects of cunservation, economic activity and typical weather conditions.

\section{CURRENT PERSPECTIVE}

The projected 1980 summer and winter non-coincident demands for the Kentucky Group are shown below: 
Table 1E. 5

Projected 1980 Seasonal Peak Demand*-MW KENTUCKY REGION

\begin{tabular}{lll}
\multicolumn{3}{c}{ SUMMER } \\
\hline June & July & Aug. \\
5,391 & 5,669 & 5,780
\end{tabular}

ॠNon-coincident
WINTER

\begin{tabular}{lll} 
& \multicolumn{3}{c}{ WINTER } \\
\hline Dec. & Jan. & Feb. \\
5,560 & 5,919 & 5,661
\end{tabular}

The winter demand is projected to be 2.48 greater than the summer demand. This is the first seasonal shift of the peak since the 1977 and the area in the future is forecasted to be a winter peaking region. The 1980 winter planned capability is estimated to be $7583 \mathrm{MW}$ and the non-coincident winter peak demand is projected to be $5918 \mathrm{MW}$, resulting in planned reserves of 1665 or 28\%. After adjustments for scheduled receipts and deliveries total reserves are increased to $2469 \mathrm{MW}$ or 41.78 .

In the ECAR. ERA-4ll report for the future 1980-89 the Kentucky Group does not list inoperable capability either for scheduled maintenance or possible forced outages. However, ECAR provides an overall Council indication of scheduled maintenance.

The estimate prepared for the 411 report, is based on the level of planned maintenance that is currently projected for the periods of heaviest load during the upcoming summer and winter seasons, i.e., five percent of total planned capability during the summer of 1980 and five percent of total planned capability during the winter of 1980/1981. The summer and winter 1980 reserve margins for the electric region are shown below.

$$
\frac{\frac{\text { Table 1E.6 }}{1980 \text { Reserve Margins* }}}{\text { KENTUCKY REGION }}
$$

\begin{tabular}{|c|c|c|}
\hline 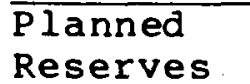 & $\begin{array}{l}\text { Total } \\
\text { Reserve }\end{array}$ & $\begin{array}{l}\text { Avallable } \\
\text { Reserves* }\end{array}$ \\
\hline $\begin{array}{ll}(\mathrm{MW}) & (\mathrm{q}) \\
1184 & 20 .\end{array}$ & $\begin{array}{ll}(M W) & (8) \\
2014 & 34 .\end{array}$ & $\begin{array}{l}\text { (MW) } \\
1666\end{array}$ \\
\hline
\end{tabular}

SUMMER

\begin{tabular}{|c|c|c|}
\hline & TER & \\
\hline $\begin{array}{l}\text { Planned } \\
\text { Reserves }\end{array}$ & $\begin{array}{c}\text { Total } \\
\text { Reserves }\end{array}$ & $\begin{array}{l}\text { Available } \\
\text { Reserves* }\end{array}$ \\
\hline $\begin{array}{ll}\text { (MW) } & \left(\frac{8}{8}\right) \\
1665 & 28.0\end{array}$ & $\begin{array}{ll}(\text { MW }) & (8) \\
2469 & 41.7\end{array}$ & $\begin{array}{l}(M W) \\
2090\end{array}$ \\
\hline
\end{tabular}

WINTER

\footnotetext{
*Based on ERA Form 411

$\star \star 58$ of Total Installed Capability assumed - from ECAR ERA

Form - 411 Report of scheduled outages.
} 
The margins shown above have not been adjusted for unscheduled outages of capacity. If these outages do not exceed the maximum outages of the 1977-79 period, 98 of planned capacity during the summer period and 168 during the winter, then resultant actual reserves would be $1035 \mathrm{MW}(18.08)$ and $8.77 \mathrm{MW} \mathrm{(14.8 \% )}$ respectively.

The summer capability of the generating capacity planned in the Kentucky Region as of January 1, 1980 was 6964 MW. The capacity is shown below by type of fuel.

\section{Table IE. 7}

$\frac{\text { Planned Summer Capability, January 1, 1980-(MW) }}{\text { KENTUCKY REGION }}$

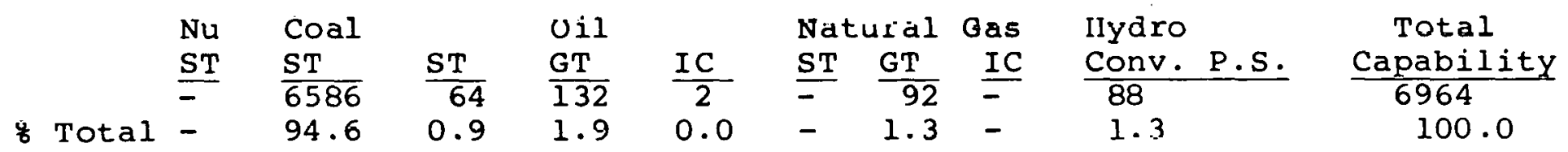

About $95 \%$ of the current capability is coal-fired steam capacity, less than 18 is oil-fired steam; and 1.98 is oil-fired combustion turbine capacity. There are no nuclear units installed in the Electric Region. There are no new units scheduled. for service before December, 1980. The unit scheduled for December, 1980 is a $210 \mathrm{MW}$ coal unit. A delay of this unit beyond the beginning of the winter 1980 peak perfod would reduce the winter 1980 available reserve to 31.88 which should be sufficient to supply the demand requirements after contingency outages. Also scheduled for the 1980 winter are two coal units totaling $984 \mathrm{MW}$ in January, 1981.

If these two units were delayed past the peak period, the reserves would be reduced from 31.88 to 15.18 . It forced outages of 168 (maximum rate 1977-79 winter season) occurred the reserve margin would be deficient by $229 \mathrm{MW}$. Under these conditions, additional purchases would have to be made. The projected 1980 energy requirements, summer and winter demands, and annual load factor of the region are shown in Table $1 E .8$. 


\section{Table_le $\underline{1} . \underline{8}$ \\ 1980 Load Feguirements

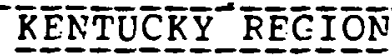

\section{Energy Reguirement \\ ( $\overline{\mathrm{C}} \overline{\mathrm{N}} \overline{\mathrm{H}})$}

31700

$\begin{array}{lr}8 \text { Gowth } 1980 / 89 & 8.4\end{array}$
Summer

Peak Demand

5780

6.1
Winter

Peak Demand

5918

17.4
Actual

Load $\frac{F}{(z)}$ act 느도

61.0

The 1980 summer and winter demands are projected to grow at considerably higher rates than they did during the 1977-79 period ( 4.18 and $1 n 48$, respectively). The 1980 winter peak demand growth of 17.48 seems unrealistic in light of historical trends and conservation techniques, as does the 8.48 growth of the energy recuirements. It may be that the 1980 data was extrapolated from a long term growth trend.

Futuruse_perspective

The range of total reserves of the Kentucky Group for the periods 1981-1985 and 1986-1989 are shown in Table 1E.9.

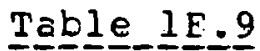

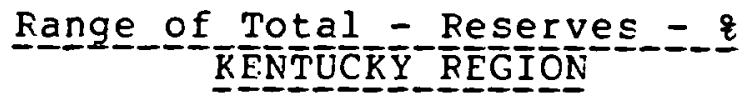

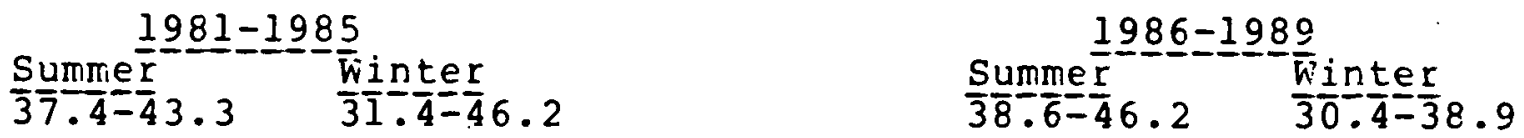

As seen in Table $1 \mathrm{E} .9$ the total reserves for summer range from 37-46\%. Indications are that the kentucky group will have no serious difficulties in meeting obligations. Total unavailable capability including scheduled maintenance averaged 98 of planned capability for the 1977-79 summer peak season and 198 for the winter peak season. Based on the stated assumptions the actual reserves are more than ample in all years of each period. Shown below are the projected growth rates of demand and capability for each period and the overall rates for 1981-89. 


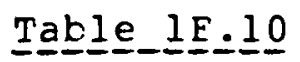

Projejected_Energy and Demand Growth Rates

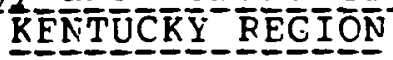

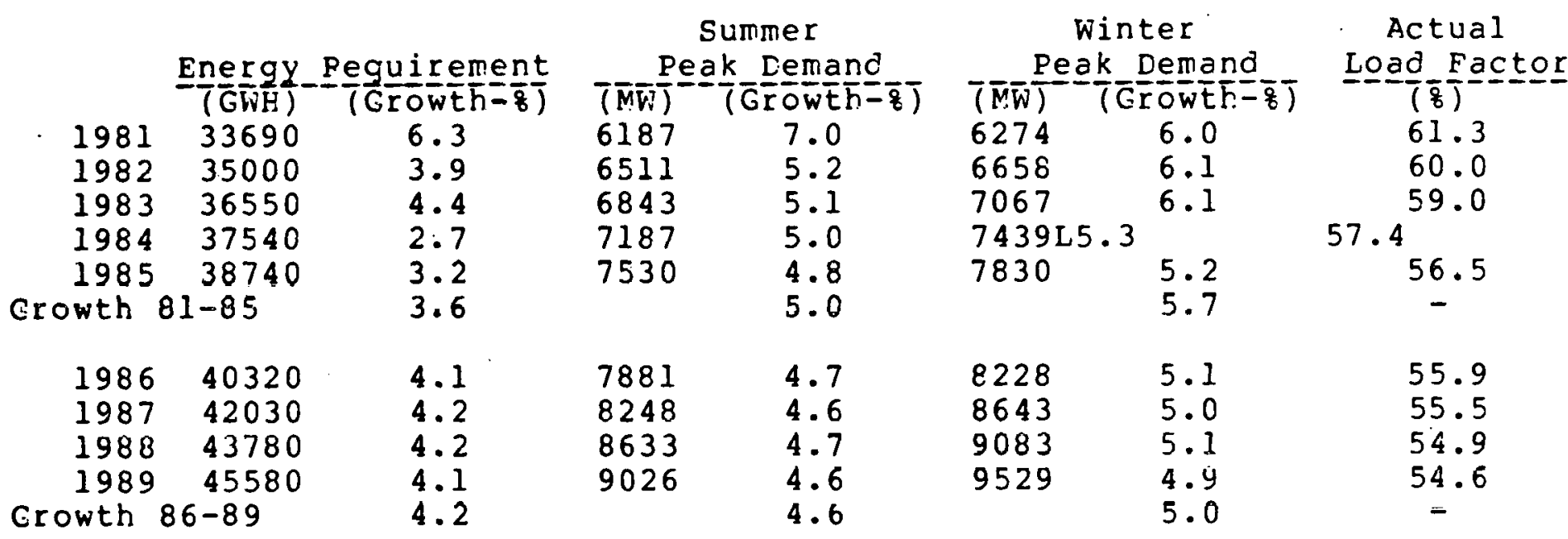

The 1981-1985 summer demands are projected to grow at a compound rate of 5.08; 1986-1989, 4.68; and overall, 1981-1989, at 4.88. The winter demands are projected to grow at a rate of 5.78 during the 1981-85 period; 5.08 in the 1986-89 period; with an overall 1981-89 rate of 5.48 .

The summer demand growth rates for each time period are considerably greater than the 1977-1979 rate of 4.18. Whereas, the ECAR region is projected to have a $1981=89$ growth rate of only 3.88. The winter demands growth rates also are consideraly greater than the 1977-79 rate of 1.48 . The ECAR region's growth rate is projected to be only 3.98 .

The 1980 wintcr pcak is projected to exceed the summer peak by 2.48. The winter peak is projected to grow faster than the summer peak and to be 4.08 greater by 1985 and 5.68 greatel by 1989 .

The energy reguirements are projected to grow at a rate of $3.6 \%$ from 1981-85; 4.28 from 1986-89. The overall growth rate is consistent with the projected growth rate of 3.88 for systems as a whole in ECAF. 
The annual load factors are projected to decrease from 61.08 in 1980 to 54.68 in 1989. This is due to the high growth rate projected for the winter peak compared to the energy requirements. During the $1981-85$ period, 7 coal-fired steam units are scheduled to be placed in service with a total capability of $3469 \mathrm{MW}$. Two older coal-fired units will be retired in 1985 with a present capability of $217 \mathrm{MW}$. In the period 1986-89, 4 coal-fired steam units are scheduled for installation with a total capability of $2140 \mathrm{MW}$. One coal-fired unit of $142 \mathrm{MW}$ will be retired in 1987.

The summer and winter capability of units planned in the region during the period 1980-1989 is shown by type of fuel in Table 1E.19. Major generating unit additions during the period are given in Table 1E.20. The percentages of each type of capacity for the target years 1980, 1984 and 1989 are given below:

\section{Table 1E.II}

\section{Planned Generating Capability by Type of Fuel - ( 8$)$ winter Capability \\ KENTUCKY REGION}

$\begin{array}{ccccccccc}\begin{array}{l}\text { Nuclear } \\ \text { Steam }\end{array} & \begin{array}{l}\text { Coal } \\ \text { Steam }\end{array} & \begin{array}{l}\text { Sil } \\ \text { ST }\end{array} & \text { GT } & \text { IC } & \begin{array}{c}\text { Nat. Gas } \\ \text { GT }\end{array} & \begin{array}{c}\text { Hydro } \\ \text { Conv. }\end{array} & \begin{array}{c}\text { Pumped } \\ \text { Storage }\end{array} & \begin{array}{c}\text { Total } \\ \text { Capability }\end{array} \\ - & 94.6 & 0.9 & 1.9 & 0.0 & 1.3 & 1.3 & - & 100.0 \\ - & 95.8 & 0.7 & 0.7 & 0.0 & 1.0 & 1.0 & - & 100.0 \\ - & 96.4 & 0.5 & 1.6 & 0.0 & 0.8 & 0.7 & - & 100.0\end{array}$

Currently, coal is the primary fuel for about $95 \%$ of the installed capacity of the region. This percentage is projected to increase to 968 by 1989 .

There is only $64 \mathrm{MW}$ of oil-fired steam capacity in the region and $136 \mathrm{MW}$ of oil-fired combustion turbine capacity with only a slight increase in the combustion turbine capacity during the 1986-89 period. Natural gas capacity and hydroelectric plants are insignificant and will remain so throughout the 1981-89 
period. There are no nuclear units installed in the region nor planned throughout the study period.

An appraisal of anticipated transmission system performance in ECAR is prepared immediately prior to each summer and winter peak load feriod. Each member system farticipates in the appraisal frocedure and the material which appears in the final ECAR report is normally limited to those items which are of particular significance to the overall region. The appraisal is based on a careful analysis of various studies carried out by the ECAF Transmission systemi performance working Group under the direction of the Transmission system Ferformance panel and by individual ECAF companies, either among themselves or jointly with systems adjacent to ECAR. Where the appraisal procedure indicates a potential contingency which could lead to localized froblems, the mattcr is refcrred to the affocted system(s) for further study and development of appropriate oferating instructions where necessary. These reports are intended as a supplement to, and not a substitute for, internal studies by the individual systems in ECAF.

A wide range of postulated system conditions were considered during the course of the various studies referred to above. No localized transmission problems were apparent in the Kentucky group region.

The most recent ECAF appraisal studies were for summer 1979 and Vinter 1979-80. These studies showed that timely completion of the scheduled transmission facility additions would insure that the reliability of the bulk power transmission systems within the ECA.F region would be maintained.

Emergency Transfer Capabilities to adjacent regions, based on the NERC definition, were reported as follows: 
Table 1E.12

Emergency Transfer Capability - MW

KENTUCKY REGION

\section{Transfer}

ECAR to MAAC

ECAR to NPCC (NYPP)

ECAR to MAIN

ECAR to SERC (TVA)

ECAR to SERC (VACAR)

ECAR from MAAC

ECAR from NPCC (NYPP)

ECAR from MAIN

ECAR from SERC (TVA)

ECAR from SERC (VACAR)
Summer 1979

Capability

$3300+$

2200

3450

1800

1250

2450

$3300+$

4000

2000

2700
Winter 1979-80

Capability

$3300+$
2950
3950
1600
$1900 *$
$3300+$
2900
3800
2100
$2950 *$

*ETC Values determined with established operating procedures in effect.

All ECAR systems evaluate their individual network performance using the testing criteria presented in ECAR Document No. 1 . Based on an analysis of these studies, it has been concluded that the ECAR bulk power transmission network as now projected for the 1984 period is capable of withstanding the contingencies listed in ECAR Document No. I without suffering area-wide break-up and/or collapse of the network. This appraisal is based on the assumption that current financial and environmental problems will be resolved in a timely manner and that ECAR member systems will be able to build the facilities shown. Should any of the EHV transmission facilities planned for the 1980-1984 period be delayed as a result of excessive lag the certification process or as a result of difficulties in financing these projects, then appropriate short term operating procedures will need to be developed in order to maintain the reliabilty of electric power supply within ECAR. Such procedures, if invoked, may jeopardized the reliability of the power supply in the affected area. 


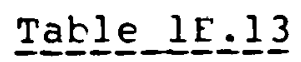

Summer_l1984_Emergency Transfer Capäbility_= MW

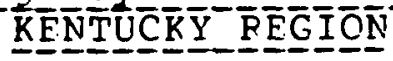

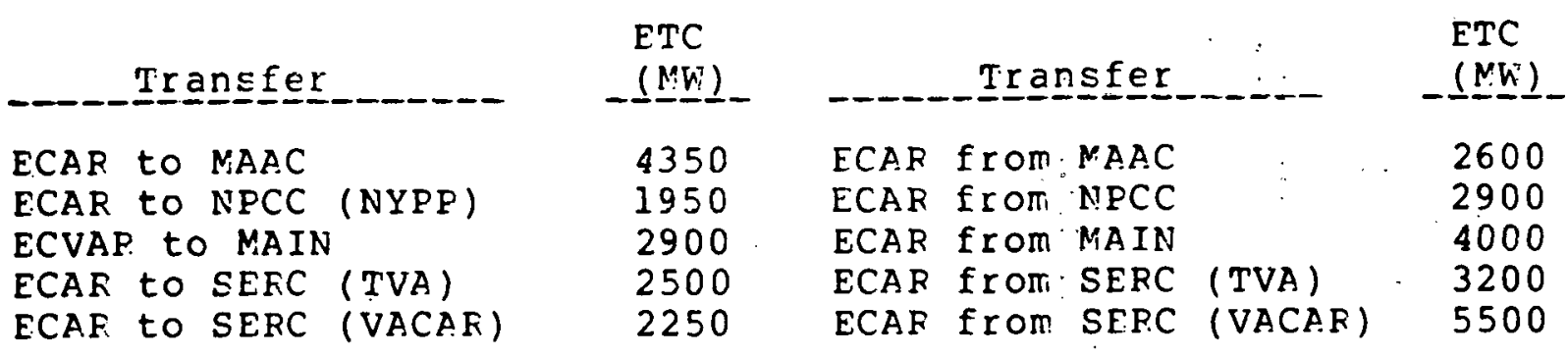

The following table is a list of proposed bulk power lines to be constructed by Kentucky Group companies. It includes internal transmission facilities as well as interconnections with utilities in other regions. Many of these interconnections will become critical to maintain reliability in the area and also provide routes for wheeling of large blocks of energy across council boundaries. 


\section{Table 1E.14}

List of Proposed Bulk Power Lines KENTUCKY REGION

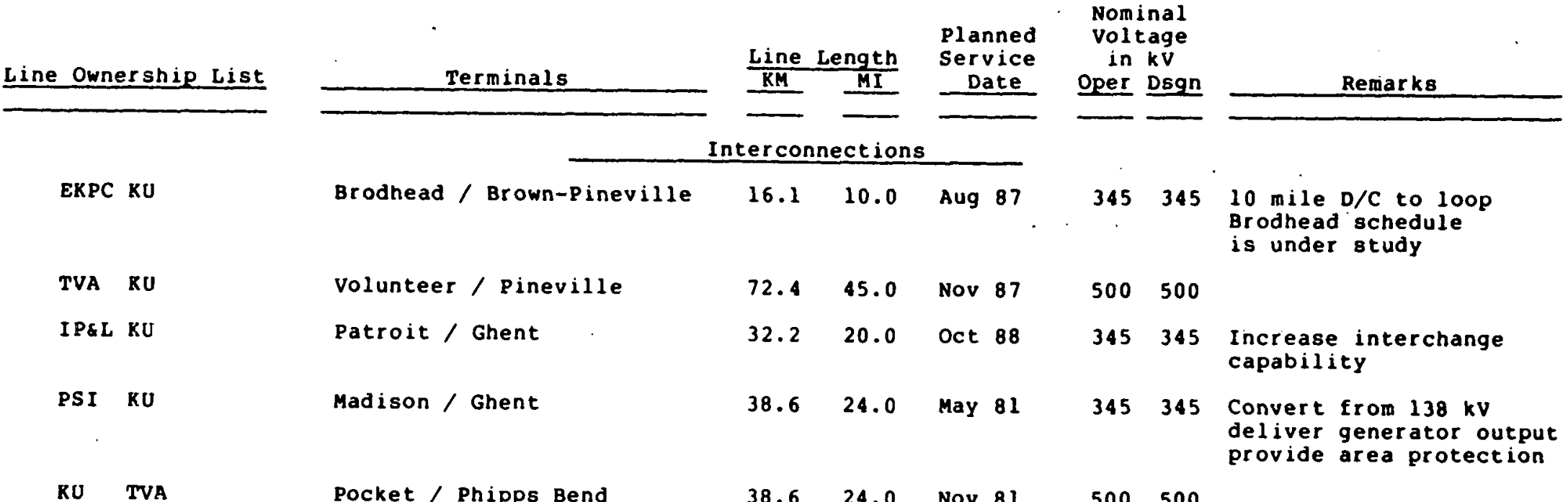


Table 1E.14.1

List of Proposed Bulk Power Lines KENTUCKY REGION

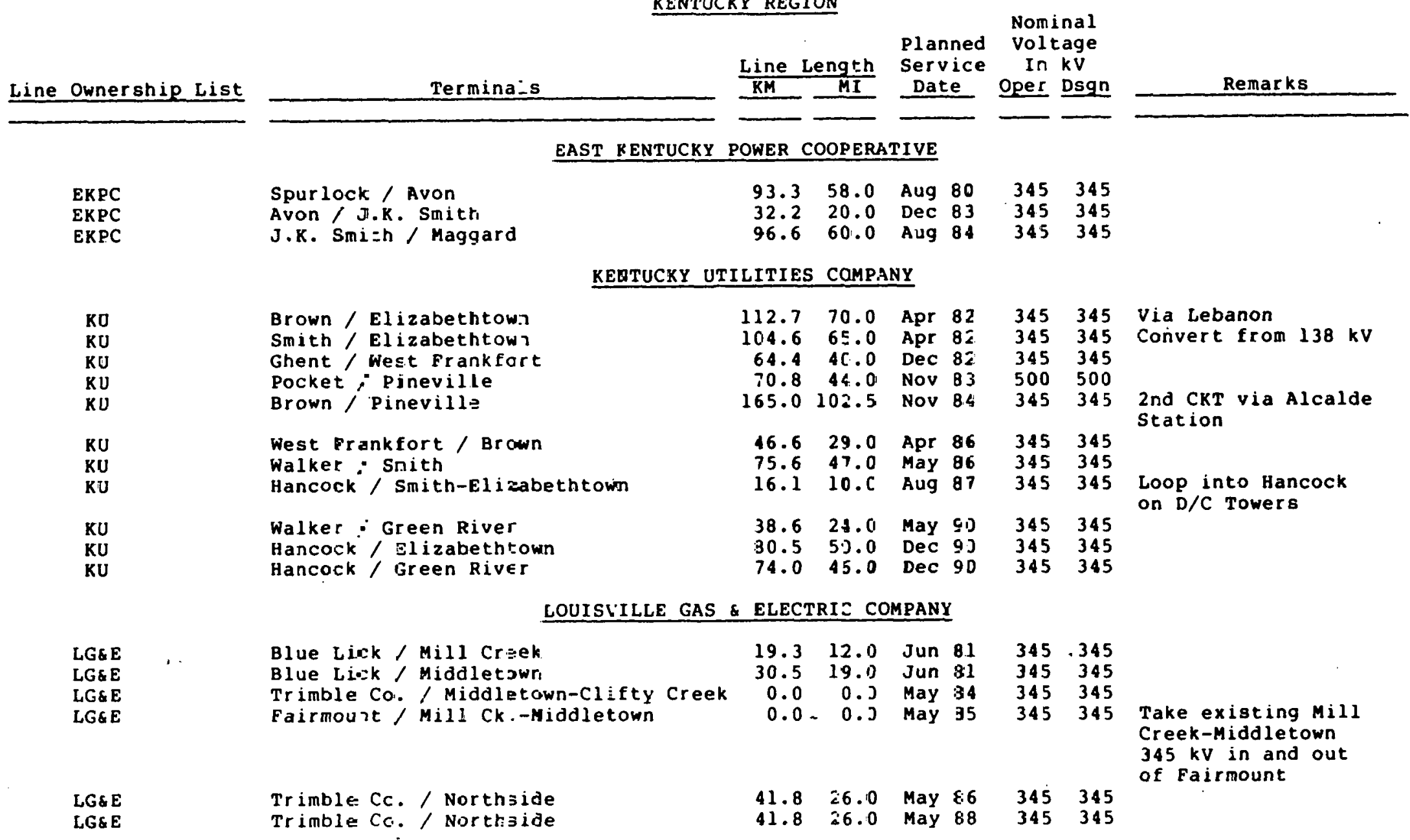


Table 1E.15

Historical Capability (MW) and Reserves (MW and Percent)

KENTUCKY REGION

1. Planned Capability

2. Peak Demand

3. Planned Reserves $(1-2)$

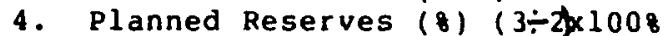

5. Net Transactions (Imports - Exports)

6. Total Capability $(1+5)$

7. Total Reserves $(6-2)$

8. Total Reserves (8) $(7 \div 4 \times 1008$

9. Scheduled Maintenance

10. Capability after Maintenance (6-9)

11. Reserves after Maintenance (10-2)

12. Reserves after Maintenance (8) (11-4x1008

13. Inoperable Capability (Included in 17)

14. Available Capability $(10-13)$

15. Available Reserves (14-2)

16. Available Reserves (8) (15+4×1008

17. Forced Outages

18. Actual Capability after forced Outages (14-17)

19. Actual Reserves $(18-2)$

20. Actual Reserves (8) $(19 \div 2) 1008$

\begin{tabular}{|c|c|c|c|c|c|}
\hline $\begin{array}{c}\text { Summer } \\
\text { Ju1Y } \\
1977 \\
\end{array}$ & $\begin{array}{c}\text { Winter } \\
\text { Jan } \\
1978 \\
\end{array}$ & $\begin{array}{c}\text { Summer } \\
\text { Aug } \\
1978 \\
\end{array}$ & $\begin{array}{c}\text { Winiter } \\
\text { Jan } \\
1979 \\
\end{array}$ & $\begin{array}{c}\text { Summer } \\
\text { Aug } \\
1979 \\
\end{array}$ & $\begin{array}{c}\text { Winter } \\
\text { Feb } \\
1980 \\
\end{array}$ \\
\hline $\begin{array}{c}6284 . \\
5031 . \\
1253 . \\
24.9 \\
-270 . \\
6014 . \\
983 . \\
19.5 \\
0 . \\
6014 . \\
983 . \\
19.5 \\
0 . \\
6014 . \\
983 . \\
19.5 \\
318 . \\
5696 . \\
665 . \\
13.2\end{array}$ & $\begin{array}{c}6481 . \\
4904 . \\
1577 . \\
32.2 \\
487 . \\
6968 . \\
2064 . \\
42.1 \\
23 . \\
6945 . \\
2041 . \\
41.6 \\
0 . \\
6945 . \\
2041 . \\
41.6 \\
796 . \\
6149 . \\
1245 . \\
25.4\end{array}$ & $\begin{array}{c}6587 . \\
5183 . \\
1404 . \\
27.1 \\
177 . \\
6764 . \\
1581 . \\
30.5 \\
281 . \\
6483 . \\
1300 . \\
25.1 \\
0 . \\
6483 . \\
1300 . \\
25.1 \\
620 . \\
5863 . \\
680 . \\
13.1\end{array}$ & $\begin{array}{c}6997 . \\
5045 . \\
1952 . \\
3.3 .7 \\
223 . \\
7220 . \\
2175 . \\
43.1 \\
616 . \\
6604 . \\
1559 . \\
30.9 \\
0 . \\
6604 . \\
1559 . \\
30.9 \\
565 . \\
6039 . \\
994 . \\
19.7\end{array}$ & $\begin{array}{c}6892 . \\
5449 . \\
1443 . \\
26.5 \\
89 . \\
6981 . \\
1532 . \\
28.1 \\
55 . \\
6926 . \\
1477 . \\
27.1 \\
0 . \\
6926 . \\
1477 . \\
27.1 \\
553 . \\
6373 . \\
924 . \\
17.0\end{array}$ & $\begin{array}{c}7163 . \\
5040 . \\
2123 . \\
42.1 \\
899 . \\
8062 . \\
3022 . \\
60.0 \\
900 . \\
7162 . \\
2122 . \\
42.1 \\
0 . \\
7162 . \\
2122 . \\
42.1 \\
1134 . \\
6028 . \\
988 . \\
19.6\end{array}$ \\
\hline
\end{tabular}


Table IE.16

Current Capability (MW) and Reserves (MW and Percent)

KENTUCKY REGION

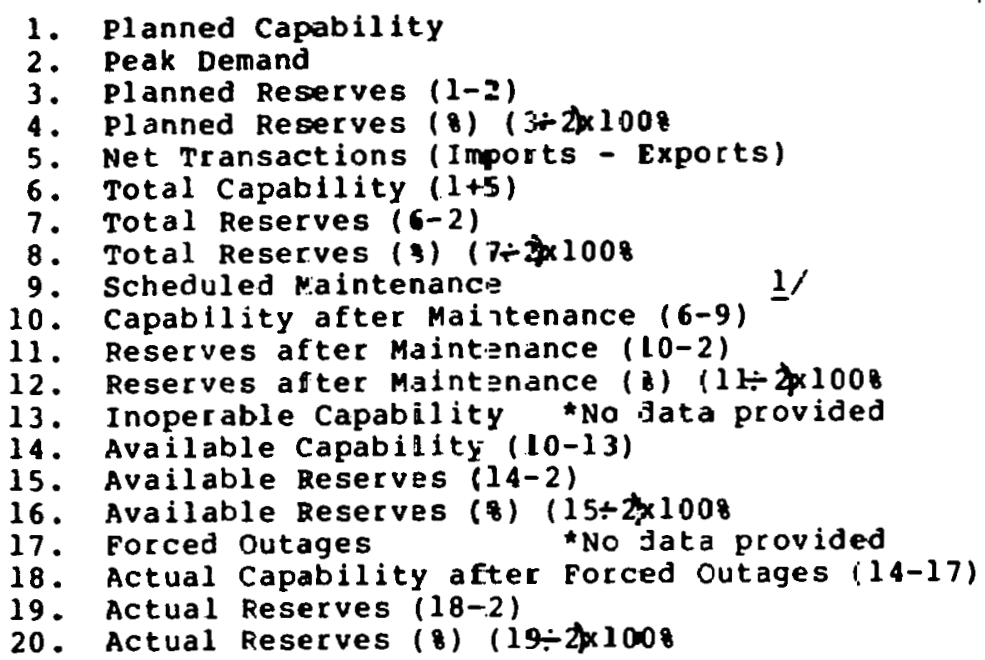

\begin{tabular}{cc}
\multicolumn{2}{c}{1980} \\
\hline Summer & Winter \\
\hline 6964. & 7583. \\
5780. & 5918. \\
1184. & 1665. \\
20.5 & 28.1 \\
830. & 804. \\
7794. & 8387. \\
2014. & 2469. \\
34.8 & 41.7 \\
348. & 379. \\
7446. & 8008. \\
1666. & 2090. \\
28.8 & 35.3 \\
0. & 0. \\
7446. & 8008. \\
1666. & 2090. \\
28.8 & 35.3 \\
0. & 0. \\
7446. & 8008. \\
1666. & 2090. \\
28.8 & 35.3
\end{tabular}

1/ 58 of total planned capability assumed by ERA-Form ECAR ERA-411 Report. 
Table 1E.17

Future Capability (HW) and Reserves (MW and Percent)

KENTUCKY REGION

1. Planned Capability

2. Peak Demand

3. Planned Reserves $(1-2)$

4. Planned Reserves ( 8 )

$(3 \div 2) \times 1008$

5. Net Transactions

(Imports-Exports)

6. Total Capability $(1+5)$

7. Total Reserves $(6-2)$

8. Total Reserves (8)

$$
(7 \div 2) \times 1008
$$

9. Scheduled Maintenance*

10. Capability After

Maintenance $(6-9)$

11. Reserves After

Maintenance $(10-2)$

12. Reserves After Mainten-

ance (8) $(11 \div 2) \times 1008$

13. Inoperable Capability

14. Available Capability

$$
\text { (10-13) }
$$

15. Available Reserves (14-2)

16. Available Reserves (8) $(15 \div 2) \times 1008$

17. Forced Outages

18. Actual Capability After

Forced Outages (14-17)

19. Actual Reserves $(18-2)$

20. Actual Reserves (8) $(19 \div 2) \times 1008$

\begin{tabular}{|c|c|c|c|c|c|}
\hline \multicolumn{2}{|c|}{1981} & \multicolumn{2}{|c|}{1982} & \multicolumn{2}{|c|}{1983} \\
\hline Summer & Winter & summer & Minter & Summer & Winter \\
\hline $\begin{array}{r}8536 . \\
6187 . \\
2349 . \\
38.0\end{array}$ & $\begin{array}{r}8462 . \\
6274 . \\
2188 . \\
34.9\end{array}$ & $\begin{array}{r}8530 . \\
6511 . \\
2019 . \\
31.0\end{array}$ & $\begin{array}{r}8956 . \\
6658 . \\
2296 . \\
34.5\end{array}$ & $\begin{array}{r}8960 . \\
6843 . \\
2117 . \\
30.9\end{array}$ & $\begin{array}{r}8905 . \\
7087 . \\
1818 . \\
25.7\end{array}$ \\
\hline 332. & 480. & 481. & 481. & 442 . & 399. \\
\hline $\begin{array}{r}8868 . \\
2681 . \\
43.3\end{array}$ & $\begin{array}{r}8942 . \\
2668 . \\
42.5\end{array}$ & $\begin{array}{l}9011 . \\
2500 . \\
38.4\end{array}$ & $\begin{array}{r}9437 . \\
2779 . \\
41.7\end{array}$ & $\begin{array}{r}9402 . \\
2559 . \\
37.4\end{array}$ & $\begin{array}{l}9284 \\
2217 \\
31.4\end{array}$ \\
\hline
\end{tabular}

* No data provided.

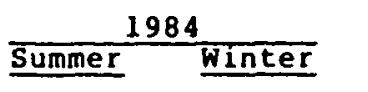

$\frac{1985}{\text { Summer }}$

9783. 10307. 10168. 11085.

7187.7439 .7530 .7876$.

2596. 2868. 2638. 3255.

$387.381 . \quad 373.363$.

$\begin{array}{rrrr}0 . & 0 . & 0 . & 0 . \\ 8868 . & 8942 . & 9011 . & 9137 .\end{array}$

$\begin{array}{rr}0 . & 0 . \\ 9402 . & 9284 .\end{array}$

10170.10688 .

2983.3249 .

10541. 11448 .

3011 . 3618 .

$10170^{\circ} 10688^{\circ}$ 10541. $1144^{\circ}$

2681. 2668 .

2500. 2779 .

2559. 2217.

2983.3249.

3011 . 3618 .

$43.3 \quad 42.5$

$38.4 \quad 41.7$

$37.4 \cdot 31.4$

41.5

43.7

40.0

46.2

$\begin{array}{rrrrr}0 . & 0 . & 0 . & 0 . & 0 .\end{array}$

2681.2668 .

9011. 9437.

0.

0 .

0 .

$\begin{array}{rr}43.3 & 2668.5\end{array}$

$\begin{array}{rr}2500 . & 2779 . \\ 38.4 & 41.7\end{array}$

2559. 2217 .

10170 . 10688 .

10541

11448 .

0.0.

$41.5 \quad 3249$.

8868. 8942. 9011. $9437^{\circ}$

90.00.

43.7

40.0

3618.2
46.2

2681. 3668. 2500. 2779. 2559. 2817.

$43.3 \quad 42.5$

$38.4 \quad 41.7$

$37.4 \quad 39.4$

0.0 . 0.

$2983 . \quad 3249$.

$41.5 \quad 43.7$

$10541 . \quad 11448$.

3011 . 3618 .

$40.0 \quad 46.2$ 
Table 1E.1B

Fucure Capability (MW) and Reserves (MW and Percent)

KENTUCKY REGION

1. Planned Capability

2. Peak Demand

3. Planned Reserves $(1-2)$

- Planned Reserves (8) $(3 \div 2 \times 1008$

- Net Transactions (Imports - Exports)

. Total Capability $(1+5)$

Total Reserves $(6-2)$

. Total Reserves $(8)(7 \div 4 \times 1008$

- Scheduled Maintenance*

10. Capability after Maintenance (6-9)

11. Reserves after Maintenance (10-2

12. Reserves after Maintenance (8) $(\vdots \div 2) \times 1008$

13. Inoperable Capability

14. Available Capability (10-13)

15. Available Reserves (14-2)

16. Available Reserves (8) $(15 \div 2) \times 1003$

17. Forced Outages"

18. Actual Capability after Forced 0utajes (14-1:)

19. Actual Reserves $(18-2)$

20. Actual Reserves (8) (19:201008

* No data provided.

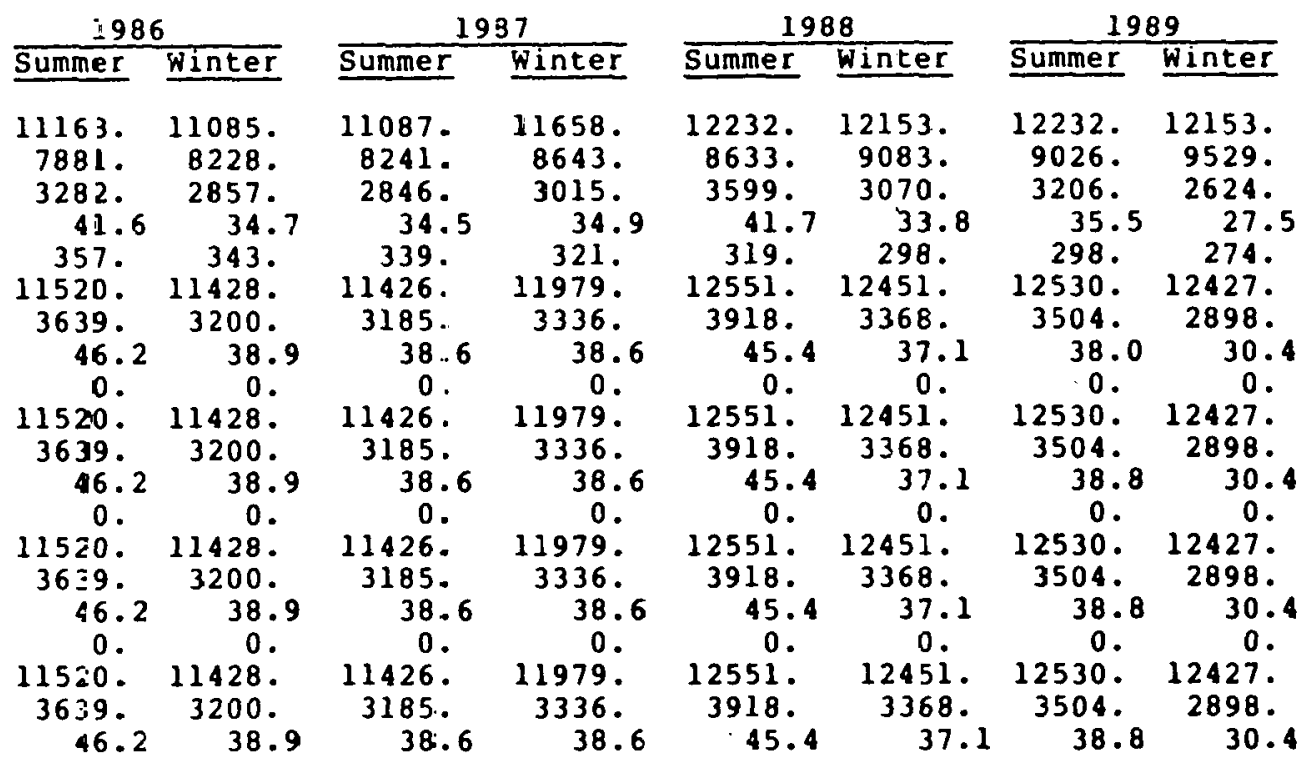


Table IE.19

Installed Capability as of January I, EY Type of Fuel - MW summer Capability

Electric Region 15-KY

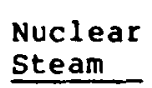

Coal

steam

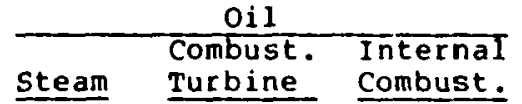

$\frac{\text { Natural Gas }}{\text { Somb. }}$

Hydro

Pumped
Storage

Total

132
1.9
132
1.9
132.9
1.6
132.6
1.6
132.5
1.5
132
1.4
132
1.3
132
1.2
197
1.7
197
1.6

2
0.0
2
0.0
2
0.0
2.0
0.0
2
0.0
2.0
0.0
2
0.0
2
$0 . C$
2
0.0
2
0.0

$\begin{array}{lcl}- & 92 & - \\ - & 1.3 & - \\ - & 92 & - \\ - & 1.3 & - \\ - & 92 & - \\ - & 1.1 & - \\ - & 92 & - \\ - & 1.1 & - \\ - & 92 & - \\ - & 1.0 & - \\ - & 92 & - \\ - & 0.9 & - \\ - & 92 & - \\ - & 0.9 & - \\ - & 92 & - \\ - & 0.8 & - \\ - & 92 & - \\ - & 0.8 & - \\ - & 92 & - \\ - & 0.8 & -\end{array}$

$\begin{array}{lc}- & 6964 \\ - & 100.0 \\ - & 7174 \\ - & 100.0 \\ - & 8539 \\ - & 100.0 \\ - & 8537 \\ - & 100.0 \\ - & 8967 \\ - & 100.0 \\ - & 9790 \\ - & 100.0 \\ - & 10175 \\ - & 100.0 \\ - & 11170 \\ - & 100.0 \\ - & 11744 \\ - & 100.0 \\ - & 12239 \\ - & 100.0\end{array}$


Table 1E.19.1

Installed Capability as of January 1 , BY Type of Fuel - MW WENTUCKY REGION

Electric Region $15-K Y$

Nuclear Steam
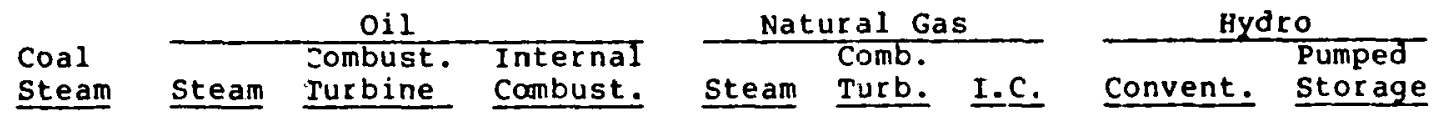

$\begin{array}{ll}1980 & - \\ 8 \text { Total } & - \\ 1981 & - \\ \text { Total } & - \\ 1982 & - \\ \text { Total } & - \\ 1983 & - \\ 8 \text { Total } & - \\ 1984 & - \\ \text { Total } & - \\ 1985 & - \\ \text { Total } & - \\ 1986 & - \\ 8 \text { Total } & - \\ 1987 & - \\ \text { Total } & - \\ 1988 & - \\ 8 \text { Total } & - \\ 1989 & - \\ \text { Total } & -\end{array}$

$\begin{array}{cc}6619 & 65 \\ 94.5 & 0.9 \\ 6829 & 65 \\ 94.7 & 0.9 \\ 8192 & 6.5 \\ 95.5 & 0.8 \\ 8186 & 65 \\ 95.5 & 0.8 \\ 8615 & 65 \\ 95.7 & 0.7 \\ 9437 & 65 \\ 96.1 & 0.6 \\ 9820 & 65 \\ 96.2 & 0.6 \\ 10815 & 65 \\ 96.5 & 0.6 \\ 11323 & 65 \\ 96.2 & 0.5 \\ 11818 & 65 \\ 96.3 & 0.5\end{array}$

2
0.0
2
0.0
2
0.0
2
0.0
2
0.0
2
0.0
2
0.0
2
0.0
2
0.0
2
0.0

$\begin{array}{ccc}- & 107 & = \\ - & 1.5 & = \\ - & 107 & = \\ - & 1.5 & = \\ - & 107 & = \\ - & 1.2 & = \\ - & 107 & = \\ - & 1.2 & = \\ - & 107 & = \\ - & 1.2 & = \\ - & 107 & = \\ - & 1.1 & = \\ - & 107 & = \\ - & 1.1 & = \\ - & 107 & = \\ - & 1.0 & = \\ - & 107 & = \\ - & 0.9 & = \\ - & 107 & = \\ - & 0.9 & -\end{array}$

$\begin{array}{cc}67 & - \\ 1.0 & - \\ 67 & \\ 0.9 & - \\ 67 & - \\ 0.8 & - \\ 67 & - \\ 0.8 & - \\ 67 & - \\ 0.8 & - \\ 67 & - \\ 0.7 & - \\ 67 & - \\ 0.7 & - \\ 67 & - \\ 0.6 & - \\ 67 & - \\ 0.6 & - \\ 67 & - \\ 0.6 & -\end{array}$

100.0
7214
100.0
8577
100.0
8571
100.0
9000
100.0
9822
100.0
10205
100.0
11200
100.0
11773.0
100.0
12268
100.0


Table 1E.20

Major Future Generating Capability

Installations and (Removals)

KENTUCKY REGION

\begin{tabular}{|c|c|c|c|c|c|c|c|}
\hline System & Station & $\begin{array}{l}\text { Unit } \\
\text { Type }\end{array}$ & $\begin{array}{l}\text { Fue } 1 \\
\text { Type }\end{array}$ & $\begin{array}{l}\text { Ne } \\
\text { Capabi } \\
\text { Summer }\end{array}$ & $\frac{c y-M W}{\text { Winter }}$ & $\begin{array}{c}\text { In-Service } \\
\text { Date } \\
\text { April } 79 \\
\text { - } 383^{\circ} \\
\text { Report }\end{array}$ & $\begin{array}{c}\text { In-Service } \\
\text { Date } \\
\text { April } 80 \\
\text { "411" } \\
\text { Report }\end{array}$ \\
\hline $\begin{array}{l}\text { BIRI } \\
\text { EKPC } \\
\text { KU } \\
\text { LG\&E } \\
\text { KU } \\
\text { LGSE } \\
\text { BIRI } \\
\text { EKPC } \\
\text { LG\&E } \\
\text { EKPC } \\
\text { BIRI } \\
\text { LGEE } \\
\text { KU } \\
\text { LG\&E } \\
\text { KU }\end{array}$ & $\begin{array}{l}\text { Green } 2 \\
\text { H.L. Spurlock } 12 \\
\text { Ghent } 3 \\
\text { Mill Creek } 4 \\
\text { Ghent } 4 \\
\text { Trimble Cty. 1 } \\
\text { D.B. Wilson } 1 \\
\text { J.K. Smith } \\
\text { Cane Runlt } 2 \\
\text { J.K. Smith } \\
\text { D.B. Wilson } 2 \\
\text { Cane Run } 3 \\
\text { Hancock Cty. } 1 \\
\text { Trimble Cty. } 2 \\
\text { Hancock Cty. } 2\end{array}$ & $\begin{array}{l}\text { ST } \\
\text { ST } \\
\text { ST } \\
\text { ST } \\
\text { ST } \\
\text { ST } \\
\text { ST } \\
\text { ST } \\
\text { ST } \\
\text { ST } \\
\text { ST } \\
\text { ST } \\
\text { ST } \\
\text { ST } \\
\text { ST }\end{array}$ & $\begin{array}{l}\text { Coal } \\
\text { Coal } \\
\text { Coal } \\
\text { Coal } \\
\text { Coal } \\
\text { Coal } \\
\text { Coal } \\
\text { Coal } \\
\text { Coal } \\
\text { Coal } \\
\text { Coal } \\
\text { Coal } \\
\text { Coal } \\
\text { Coal } \\
\text { Coal }\end{array}$ & $\begin{array}{l}210 \\
484 \\
500 \\
495 \\
500 \\
495 \\
395 \\
600 \\
(215) \\
600 \\
395 \\
(141) \\
650 \\
495 \\
650\end{array}$ & $\begin{array}{l}210 \\
484 \\
500 \\
495 \\
500 \\
495 \\
395 \\
600 \\
(217) \\
600 \\
395 \\
(142) \\
650 \\
495 \\
650\end{array}$ & $\begin{array}{l}12 / 80 \\
1 / 81 \\
\epsilon / 81 \\
\epsilon / 81 \\
1 / 83 \\
6 / 84 \\
7 / 85 \\
1 / 85 \\
6 / 85 \\
1 / 86 \\
- \\
6 / 87 \\
10 / 85 \\
6 / 86 \\
10 / 87\end{array}$ & $\begin{array}{c}12 / 80 \\
1 / 81 \\
6 / 81 \\
6 / 81 \\
1 / 83 \\
6 / 84 \\
7 / 85 \\
1 / 85 \\
6 / 85 \\
1 / 86 \\
1 / 86 \\
6 / 87 \\
10 / 87 \\
6 / 88 \\
1 /\end{array}$ \\
\hline
\end{tabular}

$1 /$ Not shown on April 80 " 411" Report 
$\mathrm{XI} .1 .108$

INDIANA REGION - (IN)

Electric Region 16

Historical Perspective

Electric Region 16 consists of all Indiana electric systems, except for the Indiana and Michigan Electric Co., which is part of the AEP system, Electric Region-2, and the IndianaKentucky. Corporation--a subsidiary of OVEC, which owns a $1300 \mathrm{MW}$ generating plant at Madison, Indiana. Data are included in this section for the following electric systems: Hoosier Energy Division, Indiana Statewide Rural Electric Cooperative, Inc.; Indianapolis Power and Iight Co.; Northern. Indiana Public Service Co.: Public Service Co. , of Indiana; Richmond, Indiana Municipal; and Southern Indiana Gas and Electric. Co.

All of the systems for which data are included in the following are regular or liaison members of the ECAR organization.

The utilities in the Indiana Region serve about 1.3 million customers, of which 1.1 million are residential customers; 135,000 are commercial customers; and 13,000 are industrial customers. The major transmission voltage in the region is $138 \mathrm{kV}$, with $345 \mathrm{kV}$ ties to the Indiana and Michigan Electric co., Electric Reyion-2, and the Commonwealth Edison r.n., Electric Region -6 . There are also transmission ties with the Big Rivers Electric Corporation and the Louisville Gas and Electric Co., in Electric Region- 15.

The Wabash Valley Power Association (WVPA) was formed in 1963 to represent its member systems in all wholesale power cost matters. Its members consists of 22 distribution cooperatives, all but two of which are in Indiana. The WVPA has a $1 \%$ percent interest (192 MW) in the Marble Hill nuclear plant (1130 MW) under construction by the Public service Company of Indiana and scheduled for October 1982. WVPA has scheduled the delivery of its share of the unit to Northern Indiana Public Service and to public service of Indiana; and the loads of the WVPA member cooperatives are included in the load data of those two companies. 
Shown below are the summer and winter peak demands of the Indiana region for the period 1977-79:

Table 1F.I

\section{HISTORICAL PEAK DEMAND * - MW Indiana Region}

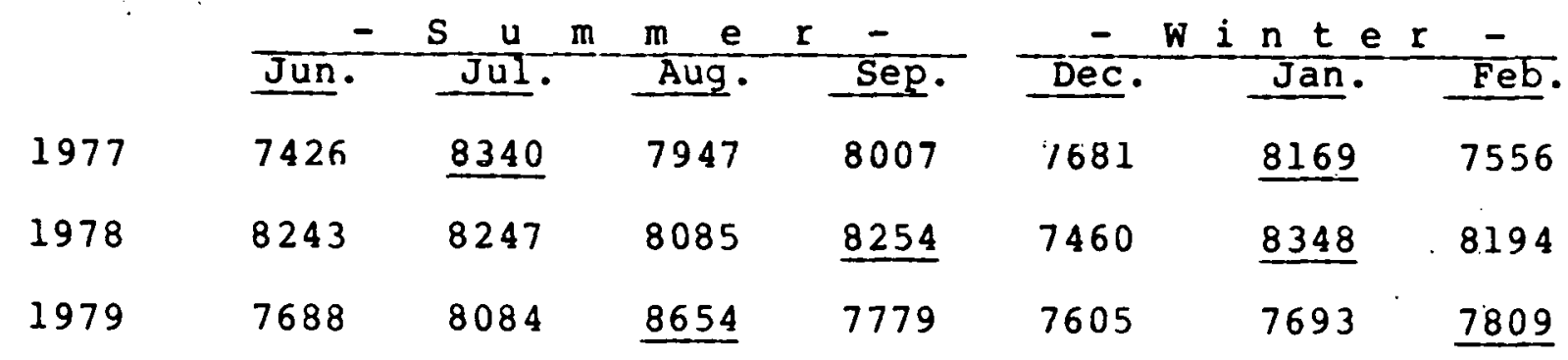

NOTE: Underline indicates seasonal peak.

* Non-coincident

The summer peak demands are dependent on climatic condidions and are temperature/humidity sensitive. Usually the peak will occur in July or August; but in 1978, it occurred in september.

The winter peak usually occurs in January; but it may occur in any winter month, depending upon the combination of weather and economic activity, and it occurred in February in the winter of 1979-80 in the region. The winter peak during the 1977-79 period was 2.18 and 9.88 less than the corresponding summer peak in 1977 and 1979 , respectively, but was 1.18 greater in 1978. Since the summer and winter peaks are nearly equal, scheduled maintenance is performed during both peak seasons. The following table shows the scheduled maintenance performed each period and also the capability unavailable because of forced outages, or otherwise inoperable. 
Table 1F.2

SCHEDULED MAINTENANCE AND UNAVAILABLE CAPABILITIES Indiana Region

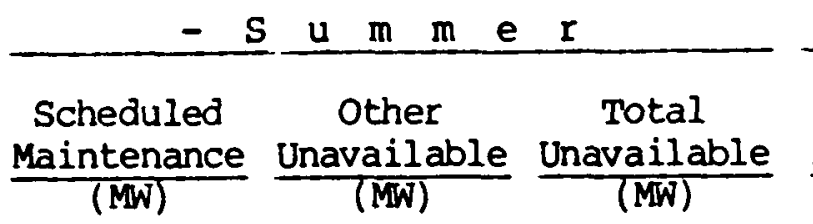

$\frac{-w i n \text { i } n \in t}{\text { Other }}$

\begin{tabular}{|c|c|c|c|c|c|c|}
\hline & $\frac{\text { Maintenance }}{(M W)}$ & $\frac{\text { Unavailable }}{(M W)}$ & $\frac{\text { Unavailable }}{(M W)}$ & $\frac{\text { Maintenance }}{(M(\mathcal{N})}$ & $\frac{\text { Unavailable }}{\text { (MW) }}$ & $\frac{\text { Unavail }}{(M W)}$ \\
\hline 1977 & 83 & 1626 & 1709 & 1032 & 1918 & \\
\hline 1978 & 427 & 1955 & 2382 & 555 & 1318 & 187 \\
\hline 1979 & 586 & 1673 & 2259 & 1375 & 1527 & \\
\hline
\end{tabular}

Table 1F.3

HISTORICAL SEASONAL RESERVES

Indiana Region

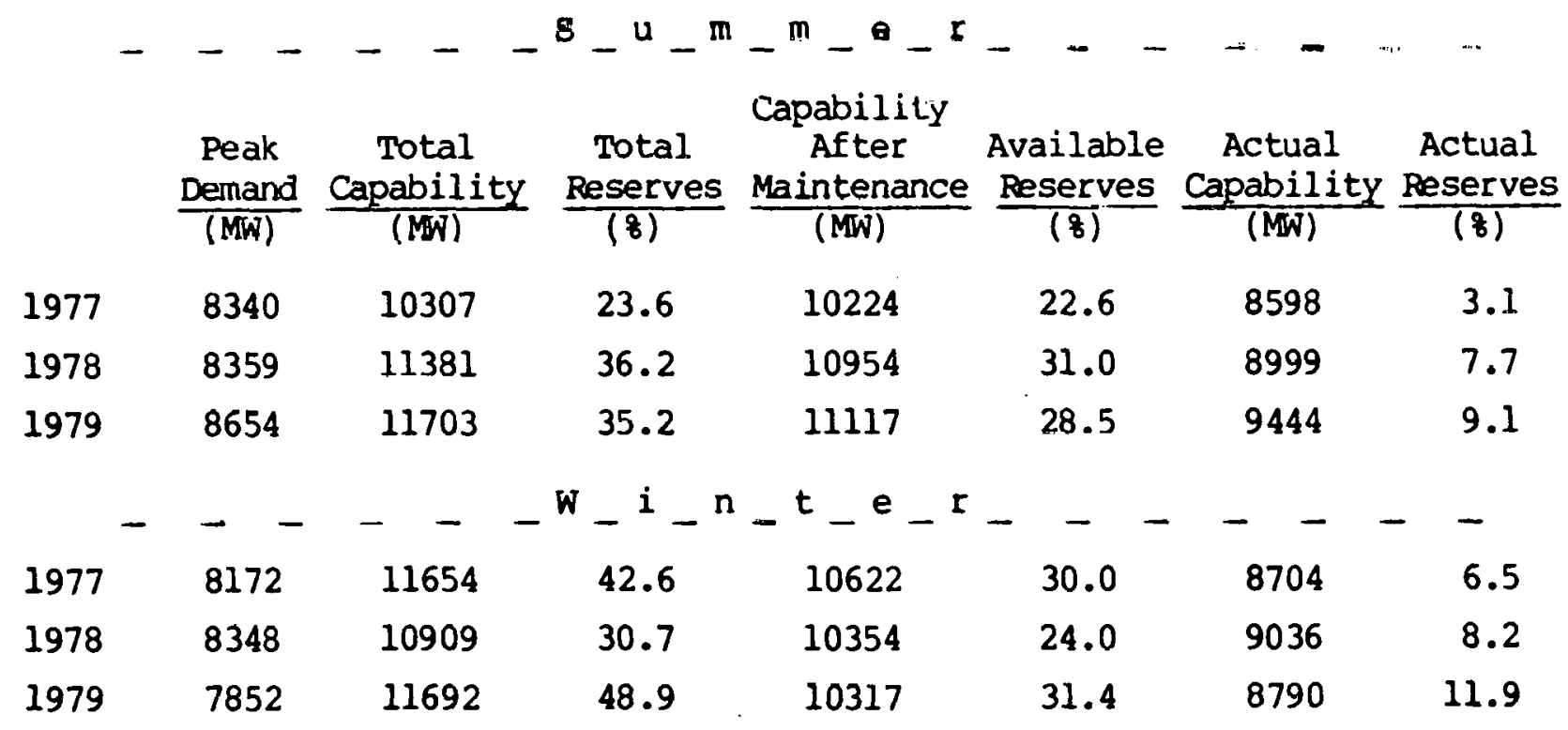


The reserve margins shown above indicate that for the 1977-79 period sufficient capability was available to meet the demand requirements in both the summer and winter periods, after taking into account both scheduled and forced outages, and still have ample available reserves to meet other contingencies.

Shown in Table IF.4 are the Indiana Region's energy requirements, summer and winter demands, and annual load factors for the 1977-79 period.

\section{Table 1F.4}

\section{HISTORICAL ENERGY, PEAKS * AND LOAD FACTORS} Indiana Region

Annual

Load

Energy Requirement Summer Demand (GWH)

(8)

$(\mathrm{MW})(\mathrm{B})$

$\frac{\text { Winter Demand }}{(\mathrm{MW})}$

Factor

$\begin{array}{llllllll}1977 & 46192 & - & 8340 & - & 8172 & - & 63.2 \\ 1978 & 46967 & 1.7 & 8359 & 0.2 & 8348 & 2.2 & 64.1 \\ 1979 & 48604 & 3.5 & 8654 & 3.5 & 7852 & (5.9) & 64.1\end{array}$

8 Growth 1977-79

2.6

1.9

$(2.0)$

* Non-Coincident

Over the period, the energy requirements grew at a compound growth rate of 2.68 , the summer demand at 1.98 , and the winter demand at a decreased rate of 2.08 .

The large decrease in the winter peak from 1978-79 is evident in other ECAR systems which indicates it is probably weatherrelated. 


\section{Current Perspective}

The projected 1980 summer and winter non-coincident Indiana Region peak demands are shown below:

\section{Table 1F.5}

PROJECTED 1980 SEASONAL PEAK DEMAND - MW Indiana Region

$\frac{s}{\text { Jun. }} \frac{\text { m m e }}{\text { Jul. }}$ Aug.

8700

9126

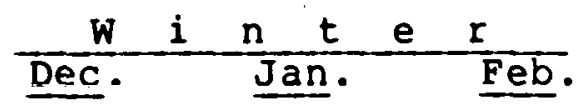

$8896 \quad 9403$

9084

The 1980 winter peak is projected to be slightly greater than the summer peak. Historically, the region has peaked in either season. However, the projections for the period 1981-89 indicate that the region will be winter peaking throughout the period.

The 1980 summer installed capability of the Indiana Reyion is estimated to be $11,722 \mathrm{MW}$ and the summer non-coincident peak demand is projected to be $9315 \mathrm{MW}$, resulting in planned reserves of $2,407 \mathrm{MW}$ or 25.88 . After adjustments for scheduled receipts and deliveries, total reserves are increased to $2,610 \mathrm{MW}$ or 28.08 .

In the ECAR ERA-411 report for the future 1980-1989, the Indiana Region companies do not list inoperable capability either for scheduled maintenance or possible forced outages. However, ECAR provides an indication of planned maintenance for the entire region.

The estimate prepared for the ERA-411 report is based upon the level of planned maintenance that is currently projected for the periods of heaviest load demand during the upcoming summer and winter seasons; i.e., five percent of total planned capability during the summer of 1980 and five percent of total planned capability during the winter of $1980 / 81$. 
The summer and winter 1980 reserve margins for the electric region are shown below:

Table 1F.6

RESERVE MARGINS *

Indiana Region

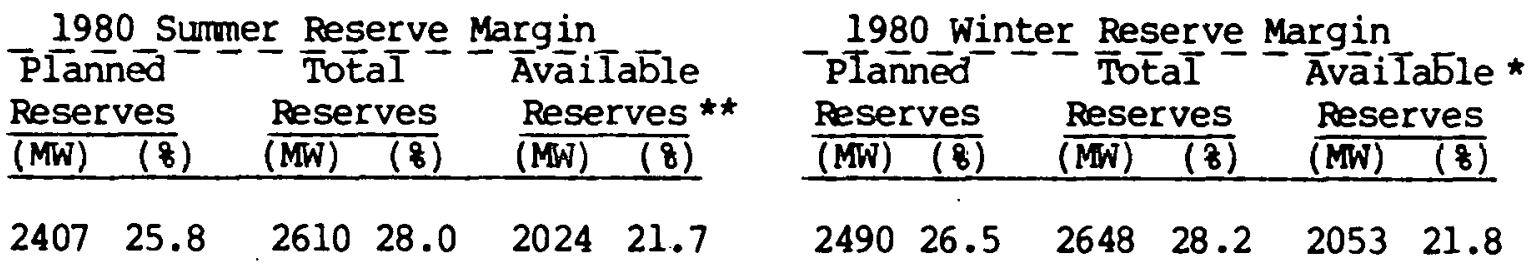

* Based upon ERA-411 Form.

** 58 of Total installed capability assumed from ECAR ERA-4ll Form, Report of Scheduled Outages.

The summer capability of the generating facilities installed in the Indiana Region area in 1980 is 11,732 MW. The capability breakdown by fuel type is shown below:

\section{Table 1F.7}

\section{PLANNED SUMMER CAPABILITY - (MW) Indiana Region}

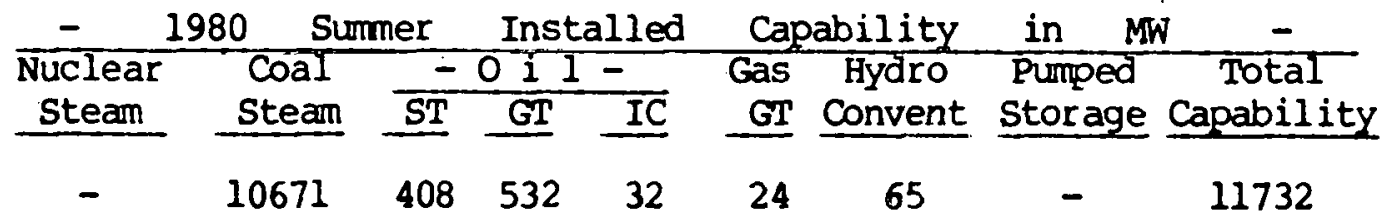
8 of Total
91.0
$\begin{array}{lll}3.5 & 4.5 & 0.3\end{array}$
0.2
0.5
- 100.0 
Over 908 of the current capacity is coal-fired steam capacity; 3.58 oil-fired steam; and 4.58 oil-fired combustion turbine capacity. There are no nuclear units installed in the Electric Region. No new generating units are scheduled to be installed in the region until May 1981.

The projected 1980 energy requirements, summer and winter demand requirements, and annual load factor for the region are shown below:

\section{Table 1F.8}

\section{LOAD REQUIREMENTS Indiana Region}

\begin{tabular}{|c|c|c|c|c|}
\hline Energy & $\frac{\text { Requirement }}{\text { (GWH })}$ & $\frac{\text { Sumuner }_{\text {Peak }}-}{(M W)}$ & $\frac{\begin{array}{l}\text { Winter } \\
\text { Demand }\end{array}}{\text { (MW })}$ & $\begin{array}{c}\text { Annual } \\
\text { Load } \\
\text { Factor } \\
\frac{(8)}{(8)}\end{array}$ \\
\hline & 52120 & 9315 & 9403 & 63.1 \\
\hline & 7.3 & 7.6 & 19.8 & - \\
\hline
\end{tabular}

The 1980 projected summer and winter demands are estimated to grow at considerably higher rates than they did during the 1977-79 period -1.98 and $(2.0) \%$, respectively.

The projected 1980 energy requirements growth rate of 7.38 over 1979 requirements is considerably greater than the historic 1977-79 rate of 2.68 .

These 1980 projected figures for energy and peak demands seem highly inflated and unrealistic based on historical trends and conservation techniques. It may be that the 1980 dala was extrapolated from long-term growth trends and is not indicative of short term growth rates.

If reduced demands do develop in 1980 , the reserve situation in the region will be improved for the study period. Delays of future critical bulk power transmission facilities that will not be in service when needed are required to be reported under Item 5-6 of the ERA-411 report. In the April 1, 1980, ECAR report, the Public service of Indiana ${ }^{\circ}$ s Gibson-Dresser-Cayuga $345 \mathrm{kV}$ transmission $\mathrm{l}$ ine is reported as having been delayed from its scheduled in-service date of December 31, 1977, to a 
tentative date of June 30,1980 , for the Gibson-Dresser section and September 30,1980 , for the Dresser-Cayuga section. The line was originally scheduled with the third 650 MW generating unit at the Public Service of Indiana's Gibson Plant. The delay was caused by litigation to acquire the necessary right-of-way. The delay in completion of the line will necessitate a reduction in the generation level at the Gibson plant in order to maintain system reliability for certain single contingency situations.

\section{Future Perspective}

The range of total reserves for the Indiana Region for the periods $1981-85$ and 1986-89 are tabulated below:

\section{Table 1F.9}

RANGE OF TOTAL RESERVES

Indiana Region

$\frac{1981-1985}{27.1-48.1} \frac{\text { Winter }}{28.6-46.9}$

$\frac{1986-1989}{40.0-42.5} \frac{29.1-35.6}{\text { Summer }}$

The available reserves have been determined after deducting a nominal amount ( 58 of the planned capability) from the reserve margin each period. No adjustments have been made for forced outages, as these are unknown. However, if the maximum outage rates of 188 and 198 which occurred during the 1977-79 summer. and winter peak periods, respectively, are deducted from the available reserves, actual reserve margins would become negative in the summer of 1981 and 1982 by $61 \mathrm{MW}$ and 12 MW, respectively; and by $147 \mathrm{MW}$ in the winter of 1981. Positive reserve margins result in all other years except for the winter of 1989 which has a deficit of $227 \mathrm{MW}$. These amounts are not large, and supplemental power receipts should be available to offset the deficits if they are needed.

Shown below are the projected growth rates of demand and. energy. for each period and the overall rates for 1981-89. 
PROJECTED ENERGY AND DEMAND GRONTH RATES

$$
\text { Indiana Region }
$$

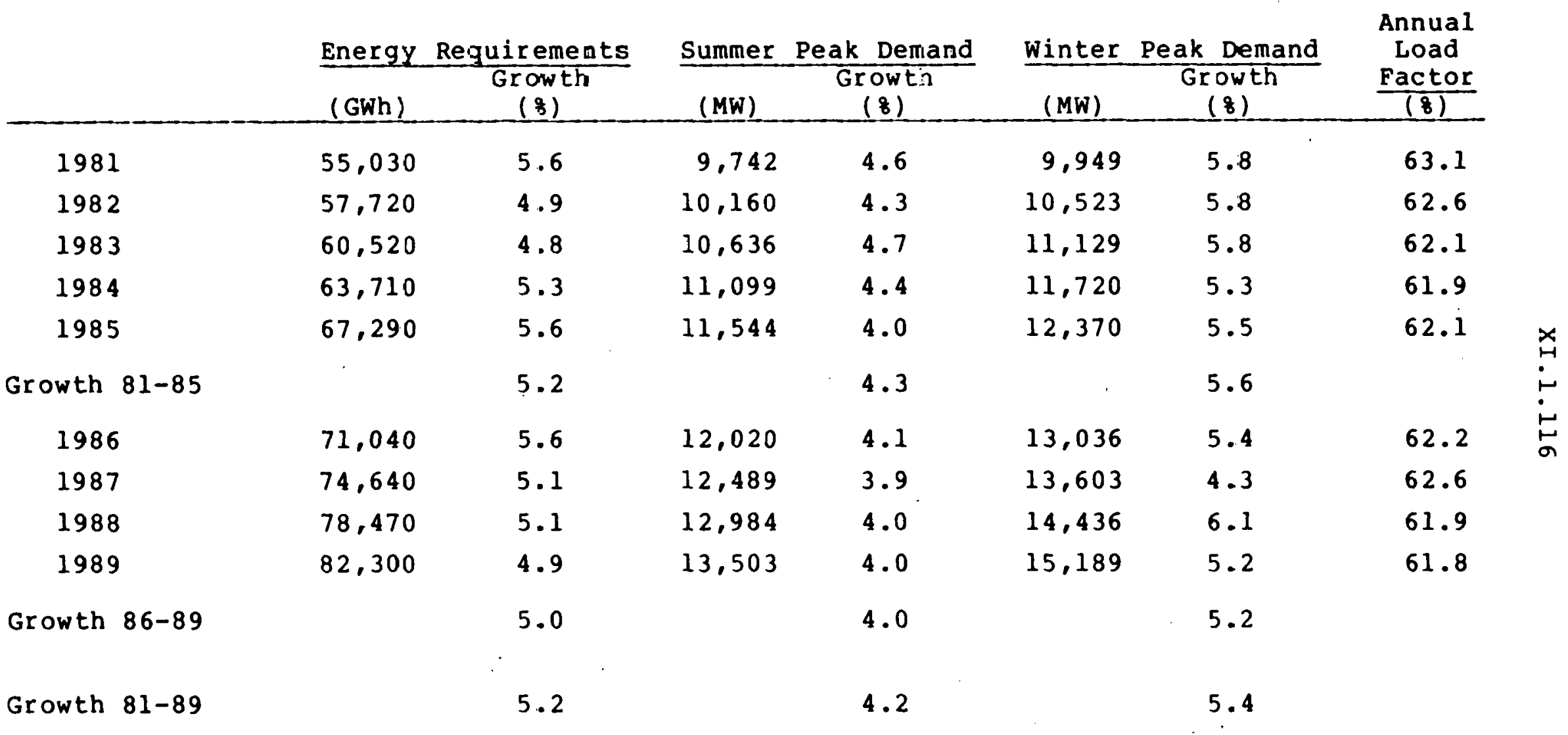


The 1981-1985 summer demands are projected to grow at a compound rate of 4.38; 1986-1989, 4.008; and overall, 1981-1989, at 4.28 . The winter demands are projected to grow 5.68 during the 1981-85 period; 5.28 during the 1986-89 period; with an overall 1981-89 growth rate of 5.4\%.

The summer and winter demand growth rates of each period is considerably greater than the 1977-79 rates of 1.98 and $(-2.0) 8$. These rates are also considerably greater than the ECAR region as a whole, which is projected to have a 1981-89 growth rate of 3.88 for the summer demands and a 3.98 growth rate for the winter demands. However, if the projected demands are greater than those which do occur, the reserve margins will be better than shown in the preceding tables.

The winter peak is projected to grow faster than the summer peak and to be 7.28 greater by 1985 and 12.58 greater by 1989 .

The energy requirements are projected to grow at a rate of 5.28 from 1981-85; 5.08 from 1986-89; and at an overall rate of 5.28 from $1981-89$.

These rates are considerably greater than the 1977-79 rate of 2.68 and the 1981-89 growth rate of 3.88 for the systems as a whole in ECAR.

The annual load factors are projected to decrease slightly from 63.18 in 1981 for 61.88 in 1989 .

During the 1981-85 period, six coal-fired steam units are scheduled to be placed in service with a total capability of $2,573 \mathrm{MW}$. Two nuclear units--Marble Hill No ${ }^{\circ} \mathrm{s} .1$ and 2 , $938 \mathrm{MW}$ each, are also scheduled for installation in october 1982 and January 1984.

In the period 1986-89, five coal-fired units are scheduled for installation with a total capability of $2,650 \mathrm{MW}$. Also scheduled in this period is the Bailly Nuclear unit, $644 \mathrm{MW}$, for installation in October 1987.

The summer and winter capability of units installed in the region during the period 1980-1989 is shown by type of fuel in Table 1F.18. Major generating unit additions during the period are given in Table 1F.19. The percentages of each type of capacity for the target years 1980, 1984, and 1989, are given below: 
Table 1F.11

PLANNED GENERATING CAPABILITY BY TYPE OF FUEL - ( 8 ) Indiana Region

\begin{tabular}{|c|c|c|c|c|c|c|c|c|c|}
\hline & $\begin{array}{l}\text { Nuclear } \\
\text { Steam }\end{array}$ & $\begin{array}{l}\text { Coal } \\
\text { Steam }\end{array}$ & $\frac{-}{\mathrm{ST}}$ & $\frac{\partial i}{G T}$ & $\frac{-}{I C}$ & $\begin{array}{l}\text { Natural } \\
\text { Gas }\end{array}$ & $\begin{array}{l}\text { Hydro } \\
\text { Convent }\end{array}$ & $\begin{array}{l}\text { Pumped } \\
\text { Storage }\end{array}$ & $\begin{array}{c}\text { Total } \\
\text { Capability }\end{array}$ \\
\hline 1980 & - & 91.0 & 3.5 & 4.5 & 0.3 & 0.2 & 0.5 & - & 100.0 \\
\hline 1984 & 6.4 & 86.1 & 2.5 & 4.2 & 0.2 & 0.2 & 0.4 & - & 100.0 \\
\hline 1989 & 13.5 & 80.7 & 1.8 & 3.4 & 0.2 & 0.1 & 0.3 & - & 100.0 \\
\hline
\end{tabular}

Currently, coal is the primary fuel for about 918 of the planned capacity of the region. This percentage will decrease to 818 due to the addition of three nuclear units in the period. There are $408 \mathrm{MW}$ of oil-fired steam capacity in the region and 532 MW of oil-fired combustion turbine capacity, with only a slight increase planned in the combustion turbine capacity during the 1981-89 period. Natural gas and hydroelectric plants are insignificant and will remain so throughout the 1981-89 period.

There are three nuclear units planned, which will increase the nuclear capacity in the region from none in 1980 to $2,520 \mathrm{MW}$ or 13.58 of the total capability in 1989.

An appraisal of anticipated transmission system performance in ECAR is prepared immediately prior to each summer and winter peak load period. Each member system-participates in the appraisal procedure, and the material which appears in the final ECAR report is normally limited to those items which are of particular significance to the uverall region. The appraisal is based on a careful analysis of various studies carried out by the ECAR Transmission system Performance Working Group under the direction of the Transmission System Performance Panel and by individual ECAR companies, either among themselves or jointly with systems adjacent to ECAR. Where the appraisal procedure indicates a potential contingency which could lead to localized problems, the matter is referred to the affected system(s) for further study and development of appropriate operating instructions where necessary. These reports are intended as a supplement to, and not a substitute for, internal studies by the individual systems in ECAR. 
A wide range of postulated system conditions were considered during the course of the various studies referred to above, and the following operating procedures were developed:

\section{PSI--Greentown Transformer}

The outage of the Greentown $765 / 138 \mathrm{kV}$ transformer may, for certain system conditions, overload the $138 \mathrm{kV}$ winding of the Kokomo $230 / 138 / 69 \mathrm{kV}$ transformer. To remedy this situation, the following operating procedure has been established. Upon loss of the Greentown $765 / 138 \mathrm{kV}$ transformer, the Greentown $138 \mathrm{kV}$ bus is split, isolating the PSI $138 \mathrm{kV}$ circuits from the IME $138 \mathrm{kV}$ circuits. To further reduce the Kokomo transformer loading, the Miami-Wabash peaking generation ( $70 \mathrm{MW}$ ) may be placed on line.

The most recent ECAR appraisal studies were for the summer 1979 and the winter 1979-80. These studies showed that timely completion of the scheduled transmission facility additions would insure that the reliability of the bulk power transmission systems within ECAR would be maintained at a high level.

Emergency Transfer Capabilities to adjacent regions, based on the NERC definition, were reported as follows:

\section{Table IF.12}

\section{EMERGENCY TRANSFER CAPABILITY - MW}

\section{Indiana Region}

\begin{tabular}{|c|c|c|c|}
\hline & Transfer & $\begin{array}{c}\text { Summer } 1979 \\
\text { Capability }\end{array}$ & $\begin{array}{c}\text { Winter } 1979-80 \\
\text { Capability }\end{array}$ \\
\hline $\begin{array}{l}\text { ECAR } \\
\text { ECAR } \\
\text { ECAR } \\
\text { ECAR } \\
\text { ECAR }\end{array}$ & $\begin{array}{l}\text { to MAAC } \\
\text { to NPCC (MYPP) } \\
\text { to MAIN } \\
\text { to SERC (TVA) } \\
\text { to SERC (VACAR) }\end{array}$ & $\begin{array}{l}3300 \\
2200 \\
3450 \\
1800 \\
1250\end{array}$ & $\begin{array}{l}3300 \star \\
2950 \\
3950 \\
1600 \\
1900 \star\end{array}$ \\
\hline $\begin{array}{l}\text { ECAR } \\
\text { ECAR } \\
\text { ECAR } \\
\text { ECAR } \\
\text { ECAR }\end{array}$ & $\begin{array}{l}\text { from MAAC } \\
\text { from NPCC (MYPP) } \\
\text { from MAIN } \\
\text { from SERC (TVA) } \\
\text { from SERC (VACAR) }\end{array}$ & $\begin{array}{l}2450 \\
3300 \star \\
4000 \star \\
2000 \\
2700\end{array}$ & $\begin{array}{l}3300 \star \\
2900 \\
3800 \\
2100 \\
2950 \star\end{array}$ \\
\hline
\end{tabular}

* ETC Values determined with established operating procedures in effect. 
All ECAR systems evaluate their individual network performance using the testing criteria presented in ECAR Document No. 1 . Based on an arialysis of these studies, it has been concluded that the ECAR bulk power transmission network as now projected for the 1984 period is capable of withstanding the contingencies listed in ECAR Document No. I without suffering area-wide breakup and/or collapse of the network. This appraisal is based on the assumption that current financial and environmental problems will be resolved in a timely manner and that ECAR member systems will be able to provide the facilities shown. Should any of the EHV transmission facilities planned for the 1980-1984 period be delayed as a result of excessive lag in the certification process or as a result of difficulties in financing these projects due to inadequate rate relief, then appropriate short-term operating procedures will need to be developed in order to maintain, to the greatest extent possible, the reliability of electric power supply within ECAR. such proccdurco, if invoked, may joopardize the reliahility of the power supply in the affected area.

Emergency Transfer Capabilities to adjacent regions, based on the NERC definition, are as follows:

Table $1 \mathrm{~F} \cdot 13$

SUMMER 1984 EMERGENCY TRANSFER CAPABILITY - MW Indiana kegíon

\begin{tabular}{lllll} 
Transfer & $\begin{array}{c}\text { ETC } \\
\text { MW }\end{array}$ & Transfer & $\begin{array}{c}\text { ETC } \\
\text { MW }\end{array}$ \\
\cline { 2 - 2 } to MAAC & 4350 & ECAR from MAAC & 2600 \\
ECAR to NPCC (NYPP) & 1950 & ECAR from NPCC (NYPP) & 2900 \\
ECAR to MAIN & 2900 & ECAR from MAIN & 4000 * \\
ECAR to SERC (TVA) & 2500 & ECAR from SERC (TVA) & 3200 \\
ECAR to SERC (VACAR) & 2250 & ECAR from SERC (VACAR) & $5500 *$
\end{tabular}


The following table is a list of proposed bulk power lines to be constructed by Indiana Region companies. It includes internal transmission facilities as well as interconnections with utilities in other regions. Many of these interconnections will become critical, since the Indiana Region's low reserve margins in portions of the study period indicate a reliance on capacity imports and therefore may make the wheeling of large blocks of energy through the system necessary. 


\section{Table 1F.14}

LIST OF PROPOSED BULK PCWER LIMES

Indiana Region

$$
\text { - Interconnections }
$$

Line Ownership List

HED PSI

HED PSI

PSI KU

IP\&L PSI

Petersburg /. Gibson-Bedford

AEP PSI

Jefferson / Marble Hil]

PSI AEP

Gwynneville / Jefferson-Greentown

IP\&L KU

Patriot / Ghent

PSI LG\&E Speed / Northside

IP\&L PSI Sunnyside / Gwynneville

\begin{tabular}{|c|c|c|c|c|c|}
\hline \multicolumn{2}{|c|}{$\begin{array}{l}\text { Line } \\
\text { Length } \\
\end{array}$} & \multirow{2}{*}{$\begin{array}{l}\text { Planned } \\
\text { Service } \\
\text { Date } \\
\end{array}$} & \multicolumn{2}{|c|}{$\begin{array}{l}\text { Nominal } \\
\text { Voltage } \\
\text { in KV }\end{array}$} & \multirow[b]{2}{*}{ Remarks } \\
\hline KM & MI & & & Dsg? & \\
\hline 3.2 & 2.0 & Jun ' 80 ' & 345 & 345 & $\begin{array}{l}\text { Loop into Merom } \\
\text { Deliver Generation Output }\end{array}$ \\
\hline 0.0 & 0.0 & Sep ' 80 & 345 & 345 & $\begin{array}{l}\text { Loop into Ramsey } \\
\text { Provide Area Support }\end{array}$ \\
\hline 38.6 & 24.0 & May ' 81 & 345 & 345 & $\begin{array}{l}\text { Convert from } 138 \mathrm{kV} \\
\text { Deliver Generator Output } \\
\text { Provide Area Protection }\end{array}$ \\
\hline 16.1 & 10.0 & Aug ' 82 & 345 & 345 & $\begin{array}{l}\text { Coordinated Agreement } \\
\text { Loop int } 0 \text { Petersburg. } \\
\text { Deliver Generator Output }\end{array}$ \\
\hline 24.1 & 15.0 & Jan' 84 & 765 & 765 & Deliver Generator Output \\
\hline 0.0 & 0.0 & Jan' 84 & 765 & $7 \in 5$ & $\begin{array}{l}\text { Loop into Gwynneville } \\
\text { Deliver Generator Output }\end{array}$ \\
\hline 32.2 & 20.0 & Oct ' 88 & 345 & 345 & Increase Interchange Capability \\
\hline 11.2 & 7.0 & Jun ' 84 & 345 & $3<5$ & Provide Area Protection \\
\hline 70.8 & 44.0 & Aug ' 84 & 345 & 345 & $\begin{array}{l}\text { Coordinated Agreement } \\
\text { Deliver Generator Output }\end{array}$ \\
\hline
\end{tabular}


Line

Ownership List

PSI

PSI

PSI

PSI

PSI

PSI

PSI

PSI

PSI

PSI

PSI

PSI

-PSI

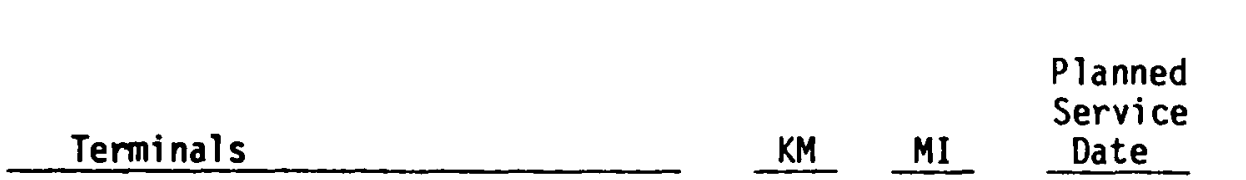

Públic_Service_Co. of Indiana, Inc.

Gallagher / Gibson-Speed

$32.2 \quad 20.0 \quad$ Apr ' $84 \quad 345$

North / Columbus-Five Points

Gwynneville / Connersville

Cayuga / Thorntown

Gibson / Dresser

Marble Hill / Speed

Dresser / Cayuga

Marble Hill / Madison

Kokomo Webster St. / Greentown

Peru / Greentown

Marble Hill / Columbus

Gwynneville / New Castle

Columbus / Gwynneville
Nominal

Voltage

in $\mathrm{kV}$

Oper Dsgn

Remarks
$0.0 \cdot 0.0$, Apr ' 86.230

$45.028 .0^{\circ} \quad \operatorname{Jan}$ ' 87

345 Loop into Gallagher.

Provide Area Support

230 Loop into North

Provide Area Support

345

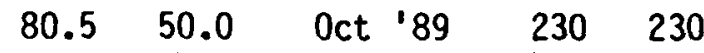

$144.990 .0 \quad$ Jun. ' $80 \quad 345 \quad 345$

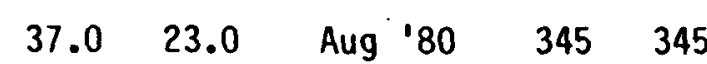

$\begin{array}{lllll}67.6 & 42.0 & \text { Sep ' } 80 & 345 & 345 \\ 26.5 & 16.5 & \text { Mar '81 } & 345 & 345\end{array}$

32.

$40.2 \quad 25.0 \quad$ Dec ' $81 \quad 230$

$83.7 \quad 52.0 \quad$ Mar '82 $765 \quad 765$

$38.6 \quad 24.0 \quad$ Apr ' $82 \quad 345 \quad 345$

$\begin{array}{lllll}64.4 & 40.0 & \text { Jan ' } 84 & 765 & 765\end{array}$
Provide Area Support

Deliver Generator Output

Deliver Generator Output

Convert $138 \mathrm{kV} \mathrm{D} / \mathrm{C}$ to

1-138 kV \& 1-345 kV Circuit Deliver Generator Output

Provide Area Protection

Provide Area Protection

Convert $138 \mathrm{kV} \mathrm{D/C}$ to 1-138 kV \& 1-345 kV Circuit Deliver Generator Output

Provide Area Protection

Provide Area Support

Provide Area Support

Deliver Generator Output

Provide Area Support

Provide Area Protection 


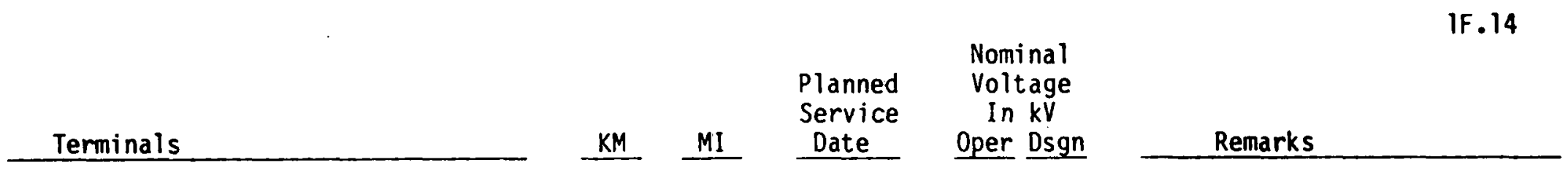

\section{Northern_Indiana_Public Service Company}

$\begin{array}{llccccc}\text { NIPS } & \text { Luchtman Rd. / Mich. City-Babcock } & 0.0 & 0.0 & \text { Jun ' } 87 & 345 & 345 \\ \text { NIPS } & \text { Chicago Ave. / Dune Acres-Sheffield } & 0.0 & 0.0 & \text { Jun ' } 80 & 345 & 345 \\ \text { NIPS } & \text { Stillwell / Babcock-Durmat (AEP) } & 0.0 & 0.0 & \text { Jun ' } 81 & 345 & 345 \\ \text { NIPS } & \text { Munster / Lake George-Burnham (JE) } & 0.0 & 0.0 & \text { Jun ' } 82 & 345 & 345 \\ \text { NIPS } & \text { Schahfer / St. John } & 64.4 & 40.0 & \text { Jun ' } 83 & 345 & 345 \\ \text { NIPS } & \text { Dune Acres / Miller } & 19.3 & 12.0 & \text { Jun ' } 84 & 345 & 345 \\ \text { NIPS } & \text { Miller / Green Acres } & 14.4 & 9.0 & \text { Jun ' } 84 & 345 & 345 \\ \text { NIPS } & \text { Dune Acres / Lake Georse } & 30.5 & 19.0 & \text { Jun ' } 86 & 345 & 345 \\ \text { NIPS } & \text { New Site / Burr Oak } & 80.5 & 50.0 & \text { Jun ' } 87 & 345 & 345 \\ \text { NIPS } & \text { New Site / Schahfer } & 72.4 & 45.0 & \text { Jun ' } 87 & 345 & 345 \\ \text { NIPS } & \text { New Site / Reynolds } & 27.3 & 17.0 & \text { Jun ' } 87 & 345 & 345 \\ \text { NIPS } & \text { Leesburg / Lagrange } & 53.1 & 33.0 & \text { Jun ' } 87 & 345 & 345\end{array}$


Page 4 of 4

Line

Ownership

List

HED

HED

Merom / Worthington

Worthington / Bloomington

IP\&L Columbus / Gwynneville

IP\&L Stout / Hanna-Thompson

IP\&L Hanna / Prospect

IP\&L Patriot / Sunnyside

\section{Indianapolis Power_\&_Light_Company}

$\begin{array}{rrrrrl}41.8 & 26.0 & \text { Apr '82 } & 345 & 345 & \text { Coordinated Agreement } \\ 1.6 & 1.0 & \text { Apr '84 } & 345 & 345 & \text { Relieve Overloads } \\ 8.0 & 5.0 & \text { Apr '88 } & 345 & 345 & \text { Relieve Overloads } \\ 173.8 & 108.0 & \text { 0ct '88 } & 345 & 345 & \text { Transmission for New Generation }\end{array}$

45.5 28.3 Sep ' $80 \quad 345 \quad 345$ Deliver Generator Output

$51.0 \quad 31.7 \quad$ Sep ' $80 \quad 345 \quad 345 \quad$ Deliver Generator Output

Increase Interchange Capability 
HISTORICAL CAPABILITY (MW) AND RESERVES (MW and Percent) Indiana Region

1. Planned Capability

2. Peak Demand

3. Planned Reserves (1-2)

4. Planned Reserves $(\%)(3 / 2) \times 100$

5. Net Transactions (Imports-Exports)

6. Total Capability $(1+5)$

7. Total Reserves (6-2)

8. Total Reserves $(\%)(7 / 2) \times 100$

9. Scheduled Maintenance

10. Capability after Maintenance (6-9)

11. Reserves after Maintenance (10-2)

12. Reserves after Maintenance $(\%)(11 / 2) \times 100$

13. Inoperable Capability I/

14. Available Capability (10-13)

15. Available Reserves (14-2)

16. Available Reserves (\%) (15/2) $\times 100$

17. Forced Outages

18. Actual Capability after Forced Dutages (14-17)

19. Actual Reserves (18-2)

20. Actual Reserves (\%) (19/2) ×100

I/ Included in forced outages.

\begin{tabular}{rrrrrrr}
\multicolumn{2}{c}{1977} & \multicolumn{2}{c}{1978} & \multicolumn{2}{c}{1979} \\
Summer & Winter & Summer & Winter & & Summer & Winter \\
9598 & 10336 & 10861 & 10753 & 11636 & 12197 \\
8340 & 8172 & 8359 & 8348 & 8654 & 7852 \\
1258 & 2164 & 2502 & 2405 & 2982 & 4345 \\
15.1 & 26.5 & 29.9 & 28.8 & 34.5 & 55.3 \\
709 & 1318 & 520 & 156 & 67 & -505 \\
10307 & 11654 & 11381 & 10909 & 11703 & 11692 \\
1967 & 3482 & 3022 & 2561 & 3049 & 3840 \\
23.6 & 42.6 & 36.2 & 30.7 & 35.2 & 48.9 \\
83 & 1032 & 427 & 555 & 586 & 1375 \\
10224 & 10622 & 10954 & 10354 & 11117 & 10317 \\
1884 & 2450 & 2595 & 2006 & 2463 & 2465 \\
22.6 & 30.0 & 31.0 & 24.0 & 28.5 & 31.4 \\
0 & 0 & 0 & 0 & 0 & 0 \\
10224 & 10622 & 10954 & 10354 & 11117 & 10317 \\
1884 & 2450 & 2595 & 2006 & 2463 & 2465 \\
22.6 & 30.0 & 31.0 & 24.0 & 28.5 & 31.4 \\
1626 & 1918 & 1955 & 1318 & 1673 & 1527 \\
8598 & 8704 & 8999 & 9036 & 9444 & 8790 \\
258 & 532 & 640 & 688 & 790 & 938 \\
3.1 & 6.5 & 7.7 & 8.2 & 9.1 & 11.9 \\
& & & & & &
\end{tabular}


Table IF.16

CURRENT CAPABILITY (MW) AND RESERVES (MW and Percent) Indiana Region

1. Planned Capability

2. Peak Demand

3. Planned Reserves (1-2)

4. Planned Reserves $(\%)(3 / 2) \times 100$

5. Net Transactions (Imports-Exports)

6. Total Capability $(1+5)$

7. Total Reserves $(6-2)$

8. Total Reserves (\%) $(7 / 2) \times 100$

9. Scheduled Maintenance $1 /$

10. Capability after Maintenance (6-9)

11. Reserves after Maintenance (10-2)

12. Reserves after Maintenance (\%) (11/2) $\times 100$

13. Inoperable Capability $2 /$

14. Available Capability (10-13)

15. Available Reserves (14-2)

16. Available Reserves (\%) (15/2) ×100

17. Forced Outages $\underline{21}$

18. Actual Capability after Forced Outages (14-17)

19. Actual Reserves (18-2)

20. Actual Reserves (\%) (19/2) ×100

1/ $5 \%$ of total planned capability assumed by ERA, from ECAR ERA-411 Report.

2/ Information not available.
$1980 / 81$

Winter

11893

11722

9315

2407

25.8

203

11925

2610

28.0

586

11339

2024

21.7

0

11339

2024

21.7

0

11339

2024

21.7
9403

2490

26.5

158

12051

2648

28.2

595

11456

2053

21.8

0

11456

2053

21.8

0

11456

2053

21.8 
FUTURE CAPAEILITY (MW) AND RESERVES (MW and Percent) - 1981-84 Indiana Region

1. Planned Capability

2. Peak Demand

3. Planned Reserves (1-2)

4. P.lanned Reserves (\%) (3!2) $\times 100$

5. Net Transactions (Imports-Exports)

6. Total Capability $(1+5)$

7. Total Reserves (6-2)

8. Total Reserves $(\%)(7 / 2) \times 100$

9. Scheduled Maintenance 1/

10. Capability after Maintenance (6-9)

11. Reserves after Maintenance (10-?)

12. Reserves after Maintenance (\%) $(11 ; 2) \times 100$

13. Inoperable Capability I/

14. Available Capability (10-13)

15. Available Reserves (14-2)

16. Available Reserves (\%) (15/2) $\times 100$

17. Forced Outages I/

18. Actual Capability after Forced Outages (14-17)

19. Actual Reserves (18-2)

20. Actual Reserves (\%) $(19 / 2) \times 100$

\begin{tabular}{rrrrr}
\multicolumn{2}{c}{1981} & \multicolumn{2}{c}{1982} \\
Sumer & Winter & & Summer & Winter \\
\cline { 5 - 5 } 11782 & 12478 & 12312 & 14607 \\
9742 & 9949 & 10160 & 10523 \\
2040 & 2529 & 2652 & 4048 \\
20.9 & 25.4 & 26.1 & 38.5 \\
598 & 319 & 307 & 407 \\
12380 & 12797 & 13119 & 14978 \\
2638 & 2848 & 2959 & 4455 \\
27.1 & 28.6 & 29.1 & 42.3 \\
0 & 0 & 0 & 0 \\
12380 & 12797 & 13119 & 14978 \\
2638 & 2848 & 2959 & 4455 \\
27.1 & 28.6 & 29.1 & 42.3 \\
0 & 0 & 0 & 0 \\
12380 & 12797 & 13119 & $14 \subseteq 78$ \\
2638 & 2848 & 2959 & 4455 \\
27.1 & 28.6 & 29.1 & 42.3 \\
0 & 0 & 0 & 0 \\
12380 & 12797 & 13119 & 14978 \\
2638 & 2840 & 2959 & 4755 \\
27.1 & 28.6 & 29.1 & 42.3
\end{tabular}

$\frac{1983}{\text { Summer Winter }} \frac{1984}{\text { Summer Winter }}$

$\begin{array}{llll}14714 & 15848 & 15647 \quad 16322\end{array}$

$\begin{array}{llll}10636 & 11129 \quad 11099 & 11720\end{array}$

$\begin{array}{llll}4078 & 4719 & 4548 & 4602\end{array}$

$\begin{array}{llll}38.3 & 42.4 & .41 .0 & 39.3\end{array}$

$\begin{array}{llll}410 & 502 & 505 & 619\end{array}$

$\begin{array}{llll}15124 & 16350 & 16152 & 16941\end{array}$

$\begin{array}{llll}4488 & 5221 & 5053 & 5221\end{array}$

$\begin{array}{llll}42.2 & 46.9 & 45.5 & 44.5\end{array}$

$\begin{array}{rrrr}0 & 0 & 0 & 0 \\ 15124 & 16350 & 16152 & 16941\end{array}$

$\begin{array}{llll}4488 & 5221 & 5053 & 5221\end{array}$

$42.2 \cdot 46.9 \cdot 45.5 \quad 44.5$

$0 \quad 0 \quad 0 \quad 0$

$\begin{array}{llll}15124 & 16350 & 16152 & 16941\end{array}$

$4488 \quad 5221 \quad 5053 \quad 5221$

$\begin{array}{llll}42.2 & 46.9 & 45.5 & 44.5\end{array}$

$\begin{array}{rrrr}0 & 0 & 0 & 0\end{array}$

$\begin{array}{llll}15124 & 16350 & 16152 & 16941\end{array}$

$\begin{array}{llll}4488 & 5221 & 5053 & 5221\end{array}$

$\begin{array}{llll}42.2 & 46.9 & 45.5 & 44.5\end{array}$

1/ Information not available. 
FUTURE CAPABILITY (MW) AND RESERVES (MW and Percent) - 1985-89 Indiana Region

1. Planned Capability

2. Peak Demand

3. Planned Reserves (1-2)

4. Planned Reserves $(\%)(3 / 2) \times 100$

5. Net Transactions (Imports-Exports)

6. Total Capability $(1+5)$

7. Total Reserves $(6-2)$

8. Total Reserves $(\%)(7 / 2) \times 100$

9. Scheduled Maintenance 1/

10. Capability after Maintenance (6-9)

11. Reserves after Maintenance (10-2)

12. Reserves after Maintenance (\%) (11/2) $\times 100$

13. Inoperable Capability II

14. Available Capability (10-13)

15. Available Reserves (14-2)

16. Available Reserves ( $(1)(15 / 2) \times 100$

17. Forced Outages 1/

18. Actual Capability after Forced Outages (14-17)

19. Actual Reserves (18-2)

20. Actual Reserves ( $\%)(19 / 2) \times 100$

1/ Information not available.

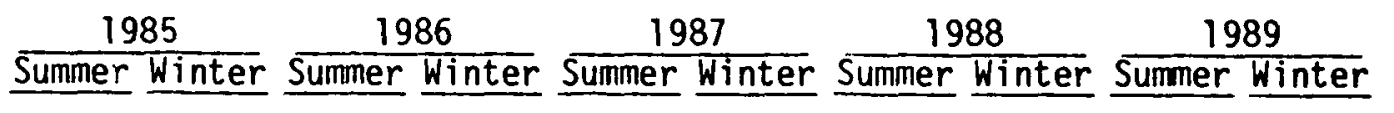

\begin{tabular}{|c|c|c|c|c|c|c|c|c|c|}
\hline 16474 & 16666 & 16474 & 16666 & 17118 & 17810 & 18118 & 18871 & 18679 & 19371 \\
\hline 544 & 12370 & 12020 & 13036 & 12489 & 13603 & 12984 & 14436 & 13503 & 15189 \\
\hline 4930 & 4296 & 4.454 & 3630 & 4529 & 4207 & 5134 & 4435 & 5176 & 4182 \\
\hline 42.7 & 34.7 & 37.1 & 27.8 & 37.1 & 30.9 & 39.5 & 30.7 & 38.3 & 27.5 \\
\hline 620 & 623 & 623 & 627 & 576 & 631 & 229 & 235 & 232 & 239 \\
\hline 17094 & 17289 & 17097 & 17293 & $17 ? 94$ & 18441 & 18347 & 19106 & 18911 & 19610 \\
\hline 5550 & 4919 & .5077 & 4257 & 5305 & 4838 & 5363 & 4670 & 5408 & 4421 \\
\hline 48.1 & 39.8 & 42.2 & 32.7 & 42.5 & 35.6 & 41.3 & 32.3. & 40.1 & 29.1 \\
\hline 0 & 0 & 0 & 0 & 0 & 0 & 0 & 0 & 0 & 0 \\
\hline 7094 & 17289 & 17097 & 17293 & 17794 & 18441 & 18347 & 19106 & 18911 & 19610 \\
\hline 5550 & 4919 & 5077 & 4257 & 5305 & 4838 & 5363 & 4670 & 5408 & 4421 \\
\hline 48.1 & 39.8 & 42.2 & 32.7 & 42.5 & 35.6 & 41.3 & 32.3 & 40.1 & 29.1 \\
\hline 0 & 0 & 0 & 0 & 0 & 0 & 0 & 0 & 0 & 0 \\
\hline 17094 & 17289 & 17097 & 17293 & 177.74 & 18441 & 18347 & 19106 & וו189 & 19610 \\
\hline 5550 & 4919 & 5077 & 4257 & 5305 & 4838 & 5363 & 4670 & 5408 & 4421 \\
\hline 48.1 & 39.8 & 42.2 & 32.7 & 42.5 & 35.6 & 41.3 & 32.3 & 40.1 & 29.1 \\
\hline 0 & 0 & 0 & 0 & 0 & 0 & 0 & 0 & 0 & 0 \\
\hline 17094 & 17289 & 17097 & 17293 & 17794 & 18441 & 18347 & 19106 & 18911 & 19610 \\
\hline 5550 & 4919 & 5077 & 4257 & 5305 & 4838 & 5363 & 4670 & 5408 & 4421 \\
\hline 48.1 & 39.8 & 42.2 & 32.7 & 42.5 & 35.6 & 41.3 & 32.3 & 40.1 & 29.1 \\
\hline
\end{tabular}


Page 1 of 2

Table 1F.18.1

PLANNED NET CAPABIL:TY AS OF JANUARY 1, BY TYPE OF FUEL - MW

Indiana Region

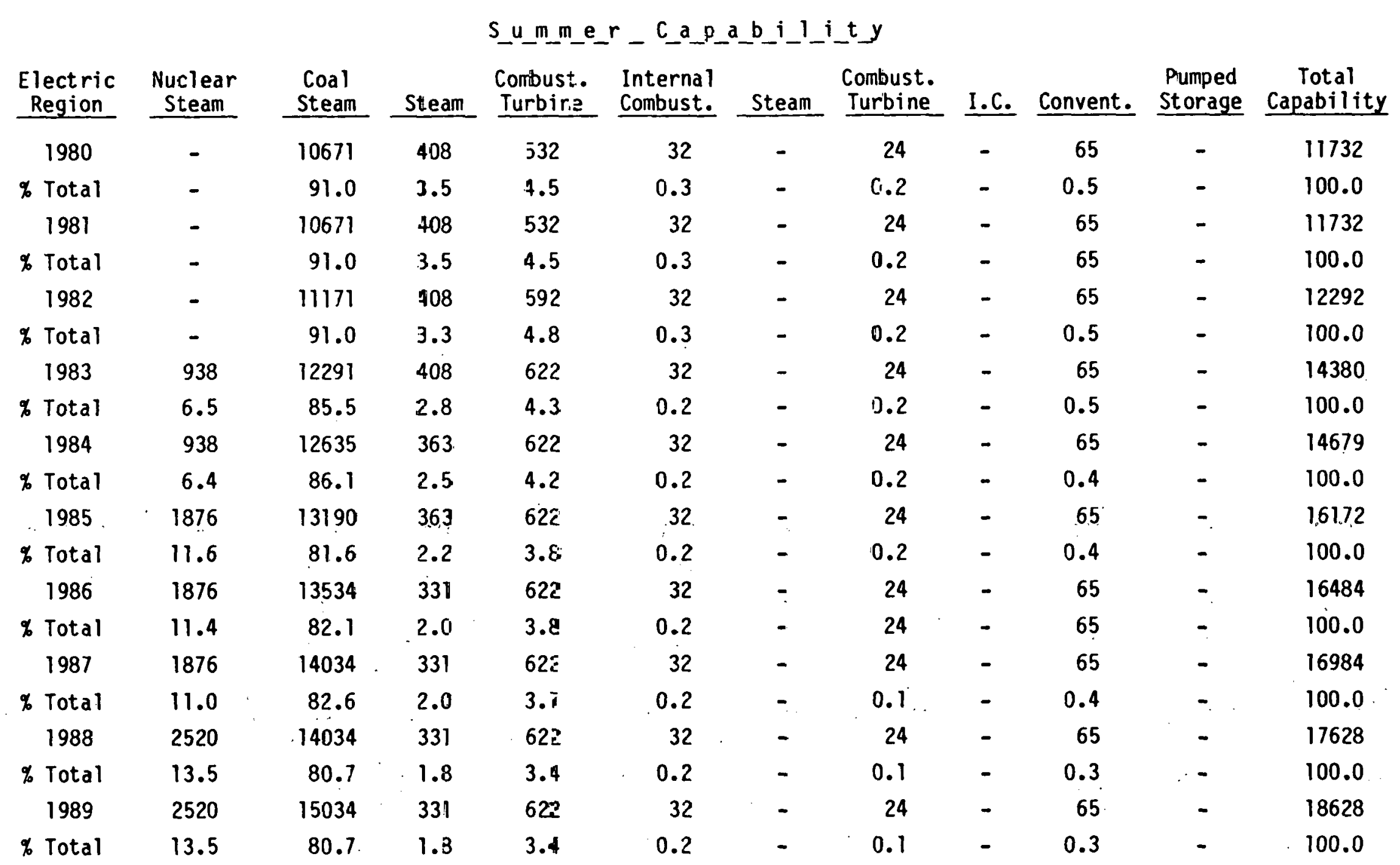


Table 1F.18.2

PLANNED NET CAPABILITY AS OF JANUARY I, BY TYPE OF FUEL - MW Indiana Region

\begin{tabular}{|c|c|c|c|c|c|c|c|c|c|c|c|}
\hline $\begin{array}{l}\text { Electric } \\
\text { Region } \\
\end{array}$ & $\begin{array}{l}\text { Nuclear } \\
\text { Steam } \\
\end{array}$ & $\begin{array}{c}\text { Coa } 1 \\
\text { Steam } \\
\end{array}$ & Steam & $\begin{array}{l}\text { W_in_t_e } \\
\text { Combust. } \\
\text { Turbine }\end{array}$ & $\begin{array}{l}r-C_{-} p_{-} \\
\text {Internal } \\
\text { Combust. }\end{array}$ & $\begin{array}{l}\text { b_i_l } \\
\text { Steam } \\
\end{array}$ & $\begin{array}{l}-t y \\
\text { Combust. } \\
\text { Turbine }\end{array}$ & I.C. & Convent. & $\begin{array}{c}\text { Pumped } \\
\text { Storage } \\
\end{array}$ & $\begin{array}{c}\text { Total } \\
\text { Capability } \\
\end{array}$ \\
\hline 1980 & - & 10741 & 426 & 628 & 33 & - & - & - & 65 & - & 11893 \\
\hline \% Total & - & 90.3 & 3.6 & 5.3 & 0.3 & - & - & - & 0.5 & - & 100.0 \\
\hline 1981 & - & 10741 & 426 & 628 & 33 & - & - & - & 65 & - & 11893 \\
\hline \% Total & - & 90.3 & 3.6 & 5.3 & 0.3 & - & $\therefore$ & - & 0.5 & - & 100.0 \\
\hline 1982 & - & 11241 & 426 & 713 & 33 & - & - & - & 65 & - & 12478 \\
\hline \% Total & - & 90.1 & 3.4 & 5.7 & 0.3 & - & - & - & 0.5 & - & 100.0 \\
\hline 1983 & 938 & 12366 & 476 & 743 & 33 & - & - & - & 65 & - & 14571 \\
\hline \% Total & 6.4 & 84.7 & 2.9 & 5.1 & 0.2 & - & - & - & 0.5 & - & 100.0 \\
\hline 1984 & 938 & 12710 & 381 & 743 & 33 & - & - & - & 65 & - & 14870 \\
\hline$\%$ Total & 6.3 & 85.5 & 2.6 & 5.0 & 0.2 & - & - & - & 0.4 & - & 100.0 \\
\hline 1985 & 1876 & 13265 & 381 & 743 & 33 & - & - & - & 65 & - & 16363 \\
\hline \% Total & 11.5 & 81.1 & 2.3 & 4.5 & 0.2 & - & - & - & 0.4 & - & 100.0 \\
\hline 1986 & 1876 & 13609 & 349 & 743 & 33 & - & - & - & 65 & - & 16675 \\
\hline \% Total & 11.2 & 81.6 & 2.1 & 4.5 & 0.2 & - & - & - & 0.4 & - & 100.0 \\
\hline 1987 & 1876 & 14109 & 349 & 743 & 33 & - & - & - & 65 & - & 17175 \\
\hline$\%$ Total & 10.9 & 82.2 & 2.0 & 4.3 & 0.2 & - & - & - & 0.4 & - & 100.0 \\
\hline 1988 & 2520 & 14109 & 349 & 743 & 33 & - & - & - & 65 & - & $17819^{\circ}$ \\
\hline \% Total & 14.1 & 79.2 & 1.9 & 4.2 & 0.2 & - & - & - & 0.4 & - & 100.0 \\
\hline 1989 & 2520 & 15109 & 349 & 743 & 33 & - & - & - & 65 & - & 18819 \\
\hline$\%$ Total & 13.4 & 80.3 & 1.9 & 3.9 & 0.2 & - & - & - & 0.3 & - & 100.0 \\
\hline
\end{tabular}


Table 1F.19

MAJOR FUTURE GENERATING CAPABILITY INSTALLATIONS AND (REMOVALS) Indiana Region

\begin{tabular}{|c|c|c|c|c|c|c|c|}
\hline & & & & Net Capal & lity - MW & - Effective & $\mathrm{Da}$ \\
\hline System & Station & Unit Type & Fuel Type & Summer & Winter & & 979 ERA-383 \\
\hline HED & Merom 2 & ST & $\operatorname{Coal}$ & $500:$ & 500 & $10 / 81$ & $10 / 82$ \\
\hline PSI & Gibson 5 & ST & Coal & 620 & 625 & $10 / 82$ & $10 / 82$ \\
\hline PSI & Marble Hill I & PWR & UR & 938 & 938 & $10 / 82$ & $06 / 83$ \\
\hline NIPS & R.M. Schahfer 17 & ST & Coal & 344 & 344 & $06 / 83$ & $10 / 83$ \\
\hline IP\&L & Petersburg 4 & ST & Coal & 515 & 515 & $10 / 83$ & $01 / 84$ \\
\hline PSI & Marble Hill 2 & PWR & UR & $938^{\circ}:$ & 938 & $01 / 84$ & $04 / 83$ \\
\hline SIGE & A.B. Brown 2 & ST & Coal & 250 & 250 & $01 / 84$ & $06 / 85$ \\
\hline NIPS & R.M. Schahfer 18 & ST & Coal & 344 & 344 & $06 / 85$ & $12 / 86$ \\
\hline HED & Undesignated & ST & Coal & 500 & 500 & $12 / 86$ & $12 / 84$ \\
\hline NIPS & Bailly N-1 & BWR & UR & 644 & 644 & $06 / 87$ & $10 / 88$ \\
\hline IP\&L & Patriot 1 & ST & Coal & 650 & 650 & $10 / 87$ & $01 / 88$ \\
\hline NIPS & Unknown & ST & Coal & 500 & 500 & $01 / 88$ & $10 / 88$ \\
\hline SIGE & A.B. Brown 3 & ST & Coal & 500 & 500 & $01 / 88$ & $04 / 86$ \\
\hline PSI & IIndesignated & Unknown & Unknown & 500 & 500 & $10 / 89$ & $10 / 88 *$ \\
\hline
\end{tabular}

$\star 1130$ MW given as capability 


\section{MICHIGAN ELECTRIC COORDINATED SYSTEMS (MFCS) ELECTRIC RFGION 18}

\section{Historical Perspective}

Electric Region 18 (ER 18-MECS) consists of the electric systems in Lower Michigan, excluding the AEP subsidiary in the southeast corner, and one system in the eastern corner of upper Michiqan. The following systems are included in the data of this section: Consumers Power Co.; Detriot Edison Co.; Edison Sault Electric Co; Lansing, Michigan Municipal; and the Michigan Municidal and Cooperative Pool.

All of the systems for which data are included in the following are regular or liaison members of the ECAR organization

(East Central Area Reliability Coordination).

The Detroit Edison Company and Consumers Power Combany are Michigan's two largest electric utility companies, servina about 90 percent of the state's population. In necember 1962 the two companies entered into an Ellectric Power Pooling Agreement and subsequently formed the Michigan Flectric Coordinated systems (MECS) in 1973. The agreement orovides for mutual assistance and coordination of the expansion of generating and major transmission facilities. Also, oderation and maintenance of electric facilities are coordinated for economy as well as reliabilty of service. The michiqan Electric Power Coordination Center has been constructed at Ann Arbor, Michigan to facilitate the coordination of the generation and transmission facilities of the two combanies. Coordination with Ontario Hydro is also conducted at the center as well as coordination with other regions.

The Michigan Municipal and Cooperative Pool (MMCP) initially was estabiished in 1968, the current members are: Conalco (Consolidated Aluminum Co); Grand Haven, MI Municipal; Hart Hydro Electric; Lowell, MI Municipal; Northern Michiqan Electric Cooperative; and Zeelana, MI Municipal. The objective of the pooling agreement is that the participants collectively shall provide capacity adequate to carry the total annual demands of all participants with adequate reserve capacity, through the coordination of their planning and construction of additional generating and transmission facilities. MMCP operates a control center for economic dispatch of qenerating units.

Shown below are the summer and winter peak demand of the MECs region for the period 1977-79: 
TABI.E 1 G.I

Historical Park Demand* $-M W$

MECS Region

\begin{tabular}{rrrrrrrr} 
& June & \multicolumn{2}{c}{ July $\frac{\text { Summer }}{\text { Aug. }}$} & Seot. & Dec. & $\frac{\underline{\text { Winter }}}{\text { Jan }}$ & $\underline{\text { Feb }}$ \\
1977 & 11570 & $\underline{12634}$ & 11336 & 11091 & 10992 & $\underline{11140}$ & 10987 \\
1978 & 11777 & 12369 & 12043 & $\underline{12626}$ & 11250 & $\underline{11433}$ & 11141 \\
1979 & 11533 & 11917 & $\underline{11976}$ & 11324 & $\underline{10857}$ & 10715 & 10495
\end{tabular}

Underline Indicates Seasonal Peak

*Non-Coincident

The summer peak demands are dependent on climatic conditions and are temperature/humidity sensitive. Usually the peak will uccur in July or August but occurred in september in 1978 .

The winter peak usually occurs in January, but it may occur in any winter month, depending on the combination of weather and economic activity in the region and occurred in December in 1979.

The following table shows the scheduled maintenance verformed each period and also the capability unavailable because of forced outaqes or otherwise inoperable.

TABLE 1 G. 2

Scheduled Maintenance and Unavailable Capabilities MECS kegion

\begin{tabular}{|c|c|c|c|c|c|c|}
\hline \multirow[t]{2}{*}{$\vdots$} & \multicolumn{3}{|c|}{ Summer } & \multicolumn{3}{|c|}{ Winter } \\
\hline & $\begin{array}{l}\text { Schieduled } \\
\text { Mainte- } \\
\frac{\text { nance }}{(M W)}\end{array}$ & $\begin{array}{l}\text { Other } \\
\text { Unavail- } \\
\frac{\text { able }}{(\mathrm{MW})}\end{array}$ & $\begin{array}{l}\text { Total } \\
\text { Unavil- } \\
\frac{\text { able }}{(\mathrm{MW})}\end{array}$ & $\begin{array}{l}\text { Scheduled } \\
\text { Mainte- } \\
\text { nánce } \\
\frac{(M \bar{W})}{\bar{W}}\end{array}$ & $\begin{array}{l}\text { Other } \\
\text { Unavail- } \\
\frac{\text { able }}{(M W)}\end{array}$ & $\begin{array}{l}\text { Total } \\
\text { Unavail- } \\
\text { at le } \\
(M)\end{array}$ \\
\hline 1977 & 401 & 1939 & 2340 & 1341 & 3626 & 4967 \\
\hline 1978 & 790 & 3301 & 4091 & 431 & 2100 & 2531 \\
\hline 979 & 624 & 1644 & 2268 & 936 & 1922 & 2858 \\
\hline
\end{tabular}


The capability unavailable for reasons other than scheduled maintenance varied from 10-208 of the installed capability in summer and from 12-228 in winter.

The reserve margins for the $1977-79$ seasonal peak periods are shown below, considering the effects of scheduled maintenance and other outages.

TABLE 1 G. 3

Historical Seasonal Reserves MECS Region

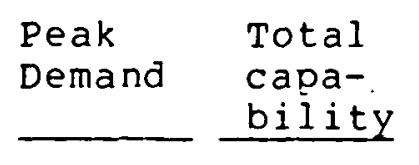

$(\mathrm{MW})$

$$
(M W)
$$

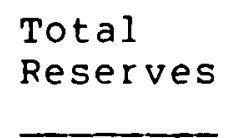

(8)

38.2

47.8

$47 . \%$

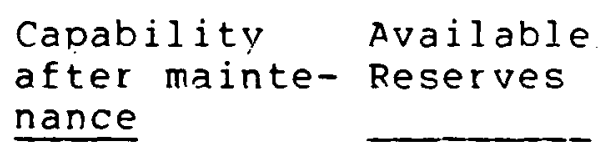

(MW)

17079

17924

17121
Actual actual capa- Peserves bilitv

$(M \bar{w})$

$\left(\frac{8}{8}\right)$

$15140 \quad 19.7$

$14623 \quad 15.6$

$15477 \quad 28.8$

\section{winter}

$\begin{array}{llllllll}1977 & 11157 & 18116 & 62.4 & 16775 & 50.4 & 13149 & 17.9 \\ 1978 & 11434 & 16623 & 45.4 & 16192 & 41.6 & 14092 & 23.2 \\ 1979 & 10872 & 17160 & 57.8 & 16224 & 49.2 & 14302 & 31.5\end{array}$

The reserve margins shown above indicate that for the 1977-79 Deriod sufficient capabiltiy was available to meet the demand reauirements in both the summer and winter periods. 
Shown in Table 1 G.4 are the MECS regions eneray reauirements, summer and winter demands and annual load factors for the 1977-79 period.

$$
\begin{aligned}
& \text { TABLE } 1 \text { G.4 } \\
& \frac{\text { Historlcal Eneryy, Peaks and Load Factors }}{\text { MECS Region. }}
\end{aligned}
$$

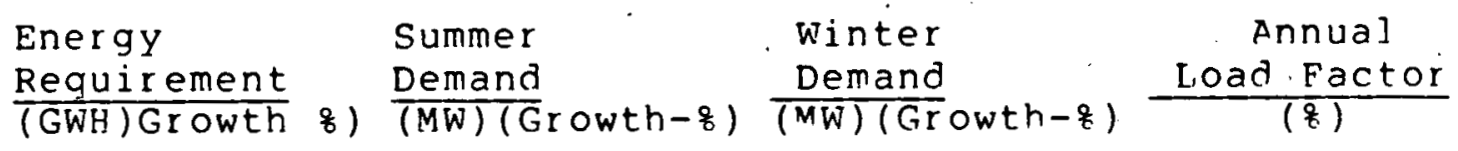

$\begin{array}{llllllll}1977 & 70075 & - & 12645 & & 11157 & 63.3 \\ 1978 & 71700 & 2.3 & 12652 & 0.1 & 11434 & 2.5 & 64.7 \\ 1979 & 72010 & 0.4 & 12018 & (5.0) & 10872 & (4.9) & 64.4\end{array}$

\&Growth $1977-79 \quad 1.4$

Over the period, the energy requirements grew at a compound growth rate of $1.4 \%$, the summer demand declined $2.5 \%$ and the winter demand declined 1.3\%. The low growth rate of the energv requirements reflects the depressed economic conditions of the area, which is greatly dependent on the auto industry. The demands decreased because uf tcullumit conditions, conccrvation effects, and milder winter conditions in $197 y$.

\section{CURRENT PERSPECTIVF.}

The projected 1980 summer and winter non-coincident MECs reqion peak demands are shown on Table 1 G.j

$$
\text { TAELE } 1 \text { G. } 5
$$

$\frac{\text { Projected } 1980 \text { Seasonal Peak Demand*-MW }}{\text { MECS Region }}$

Summer

\begin{tabular}{llll}
\hline June & July & Aug & Sep \\
12136 & 12697 & 12261 & 11766
\end{tabular}

*Non Coincident

\section{Winter}

Dec Jan Feb

$11356 \quad 11255 \quad 11071$ 
The 1980 summer and winter demands are projected to occur in July and December, respectively, this is consistent with previous occurrences. However, the peak may occur in any month of the season depending on economic and climatic condictions.

The 1980 summer planned capability of the MEcs reqion is estimated to be $16451 \mathrm{MW}$ and the summer non-coincident peak demand is projected to be $12735 \mathrm{MW}$, resulting in olanned reserves of $3716 \mathrm{MW}$ or 29.28 . After adjustments for scheduled receipts and deliveries, total reserves decrease to $3131 \mathrm{MW}$ or 24.68 .

In the ECAR ERA 411. report for the future 1980-1989 the Michjaan Group companies do not list inoperable capability either for scheduled maintenance or possible forced outages. However, FCAR provides an indication of scheduled maintenance for the entire region.

The estimate prepared for the 411 report is based on the level of planned maintenance that is currently projected for the periods of heaviest load demand during the upcoming summer and winter season, i.e., five percent of total installed capability during the summer of 1980 and five percent of total installed capability during the winter of $1980 / 81$.

The summer and winter reserve margins for the MFcs elective region are shown below:

$$
\begin{gathered}
\text { TABLE } 1 \text { G.6 } \\
\frac{1980 \text { Reserves Margins * }}{\text { MECS Region }}
\end{gathered}
$$

Summer

$\begin{array}{lll}\overline{\text { Planned }} & \text { Total } & \text { Available* } \\ \frac{\text { Reserves }}{(M W)(8)} & \frac{\text { Reserves }}{(M W)\left(\frac{8}{8}\right)} & \frac{\text { Reserves }}{(M W)(8)}\end{array}$

$\begin{array}{lllllll}3716 & 29.2 & 3131 & 24.6 & 2309 & 18.1\end{array}$

\begin{tabular}{|c|c|c|}
\hline $\begin{array}{l}\text { Planned } \\
\text { Reserves }\end{array}$ & $\begin{array}{l}\text { Total } \\
\text { Reserves }\end{array}$ & $\begin{array}{l}\text { Available } \\
\text { Reserves }\end{array}$ \\
\hline$(M \bar{W})(Z)$ & $(\overline{M W})(8)$ & (या?) (क) \\
\hline 626155.0 & 568349.9 & 480142.2 \\
\hline ty assumed & rom ECAR & ERA for $m-411$ \\
\hline
\end{tabular}

winter

* Based on ERA Form 411

$\star \star 58$ of total installed capability assumed-from ECAR ERA form-411 report of scheduled outages. 
The margins shown above have not been adjusted for forced outages of capacity, as the amount of these outaqes are unknown ahead of time. If these outages do not exceed the maximum outages of the 1977-79 periods 20\% of planned capacity durina summer period and 228 during the winter, the resultant actual deficit would be $981 \mathrm{MW}(-7.7 \%)$ and $919 \mathrm{MW}(-8.1 z)$, respectivelv. In order to meet the deficit in the 1980 summer reserves, if it. occurs, about $1000 \mathrm{MW}$ will have to imported from other reqions. It is noted that it is common practice for the region to import large amounts of power.

During 1977-1979, from $1550 \mathrm{MW}$ to 2600 were imported to increase the summer reserve situation.

The summer capability of the generating facilities olanned in the MECS Region by January 1, 1980 is $16438 \mathrm{MW}$. The capability breakdown by fuel type is shown below.

TABLE: $1 G .7$

Planned Summer Capability, January $1,1980-(\mathrm{MW})$

\begin{tabular}{|c|c|c|c|c|c|c|c|c|c|c|c|}
\hline \multirow[b]{2}{*}{$\begin{array}{l}\text { Electric } \\
\text { Region }\end{array}$} & \multirow[b]{2}{*}{$\begin{array}{l}\text { Nuclear } \\
\text { Steam }\end{array}$} & \multirow[b]{2}{*}{$\begin{array}{l}\text { Coal } \\
\text { steam }\end{array}$} & \multicolumn{3}{|c|}{ Oil } & \multicolumn{3}{|c|}{ Natural Gas } & \multicolumn{2}{|c|}{ Hydro } & \multirow{2}{*}{$\begin{array}{l}\text { Total } \\
\text { Capa- } \\
\text { bility }\end{array}$} \\
\hline & & & $\overline{S T}$ & $\overline{\mathrm{CT}}$ & IC & $\overline{S T}$ & $\mathrm{CT}$ & $I^{-}$ & $\begin{array}{l}\text { Conv. } \\
\text { Conv. }\end{array}$ & $\begin{array}{l}\text { Pumped } \\
\text { Stor ade }\end{array}$ & \\
\hline & 69 & 8807 & 3747 & 316 & 189 & 29 & 559 & 5 & 167 & & 38 \\
\hline ot & .3 & 3.6 & 22.8 & 1.9 & 1.1 & 0.2 & 3.4 & 0.3 & 1.0 & 11.4 & 100.0 \\
\hline
\end{tabular}

About 53.68 of the current capability is coul-fired steam canacity; 22.82, oil-fired steam; and 1.98 is oil-fired combustion turbine capacity. There is $698 \mathrm{MW} 4.3 \%$ of nuclear cavacity installed in the Electric Region. There is a $1872 \mathrm{MW}$ pumped storage hydroelectric plant (Ludington) in the reqion which is a portion of the plant (624 MW) is currently contracted to the Commonwealth Edision Company in MAIN and is hanoled ds an export in the data. There are no new units scheduled before September 1980. Thus, there is no effect on the summer 1980 reserve margin from Dossible delay in service of such units. The unit scheduled for september 1980 is a $791 \mathrm{MW}$ coal unit. A delay of this unit beyond the beqinning of the winter 1980 peak period could increase the winter 1980 actual deficit from an estimated $-919 \mathrm{MW}$ or -8.18 to $1710 \mathrm{MW}$ or $-15.0 \%$. The projected 1980 energy reguirements, summer and winter demands, and annual load factor of the region are shown below. 
TABLE 16.8

\section{Load Reauirements \\ MECS Region}

\section{Energy Requirement Summer Demand} (GWH)

71300

12735 winter Demand

(MWT)

Annual L.F.

11384

63.7

8 Growth
$(1.0)$
$1980 / 79$
6.0
4.7

The 1980 projected summer and winter demands are projected to arow. at considerably higher rates than they did during the 1977-79period-(2.58) and (1.3) 8 , respectively. However, the projected 1980 summer demand is $(0.8) \%$ less than the 1979 demand which had been decreased in 1979 ( $12840 \mathrm{MW}$ ) and the projected 1980 winter demand is (2.5) 8 less than that which had been orojected for the 1979 winter season $(11,678 \mathrm{MW})$ the projected 1980 energy growth rate of (1.0)\& over 1979 actual requirements reflects the depressed economic activity in the region, which is highly dependent on the auto industry.

Delays of future critical bulk power transmission facilities are required to be reported under Item 5-C of the ERA 411 report. In the April 1, 1980 ECAR report, no delays are reported for this Electric Region.

FUTUKE PERSPECTIVE

The range of total reserves for the MECS region for the Deriods 1981-85 and 1986-89 are tabulated below.
Table 1G.9
$\frac{\text { Range of Total Reserves }-8}{\text { MECS Reqion }}$
$1981-1985$
$1986-1989$
$\frac{\text { Summer }}{26.4-38.0} \frac{\text { winter }}{45.2-60.0}$
$2 \frac{\text { Summer }}{0.8-34.3} \quad 4 \frac{\text { winter }}{4.4-5 \overline{5}} .2$.
The available reserves have been determined after deductina a nominal amount for scheduled maintenance ( 58 of the planned capability) from the reserve margin each period. No adjustments have been made for outages, as these are unknown. However, if the maximum outage rates of $20 \%$ and 228 which occurred during the summer and winter peak periods, respectively, are deducted 
from the available reserves, reserve margins are sufficient in each winter period. However, negative reserves would occur in all years in the summer period, except for 1985 and $198 \mathrm{~F}$. Imoorts of $400 \mathrm{MW}-1600 \mathrm{MW}$ would be required if additional capacity is not installed. It should be noted that it is customary for the region to import large amounts of nonscheduled power. In 1977$1979,1550-2600 \mathrm{MW}$ of power were imported.

Shown below are the projected growth rates of demand and energy for each period and the overall rates for 1981-89.

TABLE $1 \mathrm{G} .10$

\section{Projected Energy and Demand Growth Rates}

\section{MECS Region}

Energy Requirements Summer Peak Demand winter Peak Demand GWH

$$
\text { Growth }
$$

$\mathrm{MW}$

Growth

Annual
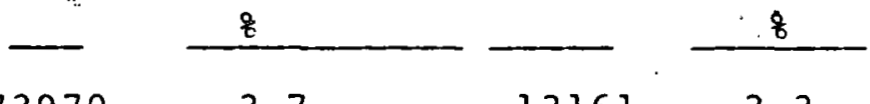

13161

3.3

11747

$1981 \quad 73970$

198276830

3.9

13627

3.4

14199

4.0

14652

3.1

15162

3.4

$3 \cdot 6$

15686

3.3

16206

3.2

16718

3.1

17173

2.7

2.4

2.9

3.1

Growth $86-89$ MW

\section{Growth}

路

Load

Factor

64.2

64.4

$121 \cap 5 \quad 3.0$

3.7

64.3

12574

12952

2.9

64.1

$133573 . n$

64.1

$3 \cdot 3$

$13773 \quad 3.0$

54.1

$14154 \quad 2.7$

63.8

14620

3.2

63.8

14940

2.1

63.8 The 1981-1985 summer demands projected to qrow at a compound rat
of 3.68; 1986-1989, 2.98; and overall, 1981-1989, at 3.38. The The 1981-1985 summer demands projected to qrow at a compound rate
of 3.68; 1986-1989,2.98; and overall, 1981-1989, at 3.38. The winter demands are projected to grow at a rate of $3.3 \%$ during the 1981-1985 period; 2.88 in the 1986-89 period; with an overall 1981-89 of 3.08 . 
The summer demand arowth rates for each time period is considerably greater than the 1977-79 rate of $17.5 \%$, but. is less than ECAR region as a whole, which is projected to have a 1981-1989 growth rate of.3.8\%. The winter demands growth rates also are considerably qreater than the 1977-79 rate of (1.38), but less than the ECAR region rate of 3.98 .

If actual demands are lower than those which are orojected to occur, the reserve margins will be increased from those indicated above.

The energy requirements are projected to qrow at a rate of 3.68 from 1981-1985; 2.98 from 1986-89; and at an overall rate of 3.38 from 1981-1989. The overall growth rate is lese than the projected growth rate of 3.88 for systems as a whole in ECAR.

During the 1981-85, period three nuclear units are scheduled to be placed in service Fermi \#2-1093MW, Midland \#1-522 MW, and Midland \#2-505 MW. Two coal-fired units Relle River \#1 and \#2, $664 \mathrm{MW}$ each are also scheduled for installation.

Only one unit is scheduled for installation after 1985 Frickson \#2 a $150 \mathrm{MW}$ coal-fired steam faculty. Palisades \#1 a nuclear unit will be shutdown in Auaust 1987 for 24 months for steam generator replacement.

It is important that in-service dates of major installaitons be met.

Under the conditions stated, with the historical 1977-1979, maximun forced outage $r$ ate of 208 of the summer installed capability and 228 of the winter capability, negative reserve margins will result in each year, except the winter of 1984, if the generating units planned are delayed beyond the Deak period. This would require additonal non-scheduled Dower imports of 105-2244 M.W. As noted before, the region has historically depended on large power imports to maintain adequate reserves.

The summer and winter capability of units installed in the region during the period 1980-1989 is shown by type of fuel in table 1G.18. The percentages of each tyoe of capacity for the target years 1980,1984 and 1989 are given below. 
TABLE I G.11

Planned Generating Capability By Type of Fuel - (₹)

Summer Capability

\begin{tabular}{|c|c|c|c|c|c|c|c|c|c|c|c|}
\hline & $\begin{array}{l}\text { Nuclear } \\
\text { Steam }\end{array}$ & $\begin{array}{r}\text { Coal } \\
\text { Steam } \\
\end{array}$ & $\mathrm{ST}^{\mathrm{O}}$ & CT & $\underline{I C}$ & $\begin{array}{l}\mathrm{Nat} \\
\mathrm{S} \text { T }\end{array}$ & $\begin{array}{l}\text { ura } \\
\text { CT }\end{array}$ & $\mathrm{C}^{\text {Gas }}$ & $\begin{array}{r}\text { Hyo } \\
\text { Conv. }\end{array}$ & P.S. & $\begin{array}{l}\text { Total } \\
\text { Canability }\end{array}$ \\
\hline 1980 & 4.3 & 53.6 & 22.8 & 1.9 & 1.1 & 0.2 & 3.4 & 0.3 & 1.0 & 11.4 & $100 . n$ \\
\hline 984 & 9.6 & 51.9 & 20.9 & 1.7 & 1.0 & 0.5 & 3.0 & 0.4 & 0.9 & 10.1 & $\ln n .0$ \\
\hline 989 & 12.2 & 52.2 & 19.4 & 1.6 & 0.9 & 0.5 & 2.8 & $\cap .3$ & 0.8 & 9.3 & $1 \cap 0.0$ \\
\hline
\end{tabular}

Currently, coal is the primary fuel for about 54 of the installed capability. Oil-fired capacity represents $26 z$, numbed storaae 11\%, nuclear 4\%, natural gas 48 and conventional hydroelectric 1 . The only majnr change for the further 1989 target date is that nuclear capacity will rise to 128 all other fuel sources will decline slightly, since only nuclear and coal-fired capacity represent major additions.

An appraisal of anticipated transmission system performance in ECAR is prepared immediately prior to each summer and winter peak load period. Each member system participates in the appraisal procedure and the material which appears in the final ECAR report is normally limited to those items which are of particular significance to the overall region. The appraisal is based on careful analysis of various studies carried out bv the ECAR Transmission System Performance working Grouv umner the direction of the Transmission System Pelformance Fancl and by individual ECAR companies, either among themselves or jointly with systems adjacent to ECAP. Where the appraisal procedure indicates a potential contingency which could lead to localized problems, the maller is referrcd to the affected system(s) for further study and development of aporopriate operating instructions where necessary. These reports are intended as a supplement to, and not a substitute for, internal studies by the individual systems in ECAR.

A wide range of postulated system conditions were considered during the course of the various studies referred to above but no localized transmission problems were apparent in the MECS region. 
The most recent ECAR appraisal studies were for summer 1979 and winter 1979-80. These studies showed that timely combletion of the scheduled transmission facility additions would insure that the reliability of the bulk power transmission systems within ECAR would be maintained at a high level.

Emergency Transfer Capabilities to adjacent reaions, based on the NERC definition, were reported as follows:

$$
\text { TABLE } 1 \text { G. } 12
$$

\section{Emergency $\frac{\operatorname{Transfer} \text { Capability-MW }}{\text { MECS Region }}$}

$\underline{\operatorname{Tr} a n s f e r}$

ECAR to MAAC

ECAR to NPCC (NYPP)

ECAR to MAIN

ECAR to SERC (TVA)

ECAR to SERC(VACAR)

ECAR frOM MAAC

ECAR from NPCC(NYPP)

ECAR frOm MAIN

ECAR frOM SERC (TVA)

ECAR from SERC(VACAR)

*ETC Values determined with established operating in effect.
Summer 1979

Capability

$3300+$

2200

3450

1800

1250

2450

$3300+$

$4000+$

2000

2700 Capability

$3300+$

2950

3950

1600

$1900 *$

$330 n+$

2900

3800

2100

2950 * 
All ECAR systems evaluate their individual network performance using the testing criteria presented in ECAR Document No.l. A listing of a representative number of the tests which were made to evaluate 1984 conditions accopanies this discussion. Based on an analysis of these studies, it has been concluded that the ECAR bulk power transmission network as now projected for the 1984 period is capable of withstanding the continaencies listed in ECAR Document No. 1 without suffering area-wide break-up and/or collapse of the network. This appraisal is based on the assumption that current financial and envirmomental problems will be resolved in a timely manner and that FCAR member systems will be able to provied the facilities shown. Should any of th EHV transmission facilities blanned fur the 1980-1984 period be delayed as a result of excessive laq in the certification process or as a result of difficulties in financing these projects due to inadequate rate relief, appropriate short term operating procedure will need to be developed in order to maintain, to the greatest extent possible, the reliability of electric oower supply within ECAR. Such procedures, if invoked, may jeopardize the realiability of the power supoly in the affected area.

TABLE 1 G.13

\section{$\frac{\text { Summer } 1984 \text { Emergency Transfer Capabilty-MW }}{\text { MECS Region }}$}

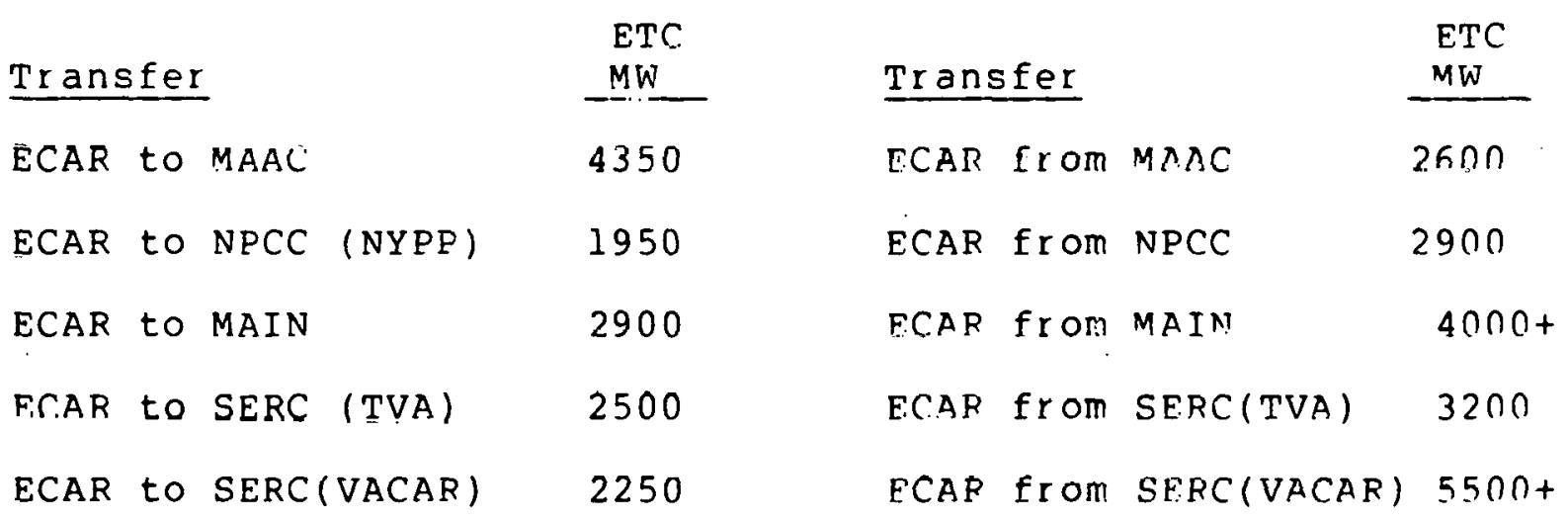


TABLE $1 \mathrm{G} .14$

HIstorical Capability (MW) and Reserves (MW and Percent)

MECS Region

1. Planned Capability

2. Peak Demand

3. Planned Reserves $(1-2)$

4. Planned Reserves (8) (3-2) x 1008

5. Net Transactions (Imports-Exports)

6. Total Capability $(1+5)$

7. Total Reserves $(6-2)$

8. Total Reserves (8) $(7-2) \times 1008$

9. Scheduled Maintenance

10. Capability after Maintenance (6-9)

11. Reserves after Maintenance (10-2)

12. Reserves after Maintenance (8)(11-2) x 1008

13. Inoperable Capability Included in 17

14. Available Capability (10-13)

15. Available Reserves (8) (14-2)

16. Available Reserves (8) $(15-2) \times 1008$

17. Forced Outages

18. Actual Capability after Forced Outages (14-17)

19. Actual Reserves $(18-2)$

20. Actual Reserves (8) $(19-2) \times 1008$
1977

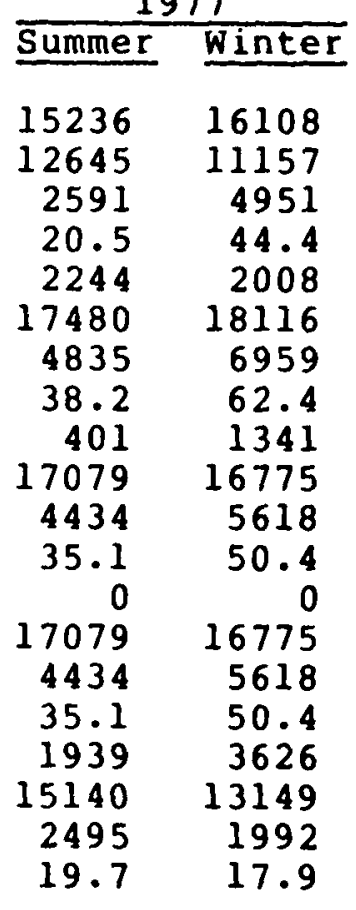

1978

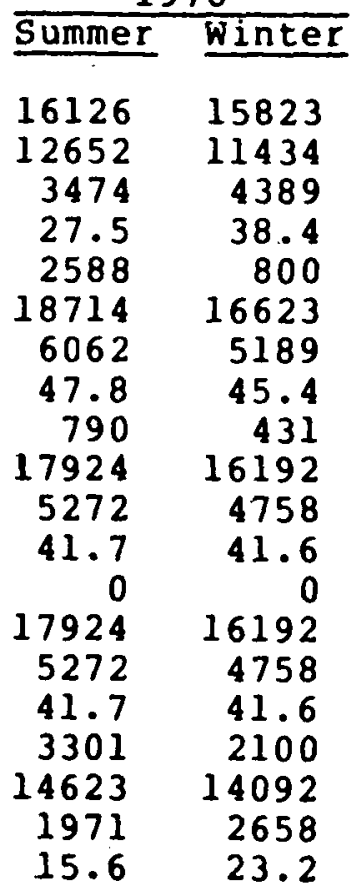

1979

\begin{tabular}{rr}
\hline Summer & Winter \\
\cline { 1 - 2 } 16192 & 16057 \\
12018 & 10872 \\
4174 & 5185 \\
34.7 & 47.7 \\
1553 & 1103 \\
17745 & 17160 \\
5727 & 6288 \\
47.7 & 57.8 \\
624 & 936 \\
17121 & 16224 \\
5103 & 5352 \\
42.5 & 49.2 \\
0 & 0 \\
17121 & 16224 \\
5103 & 5352 \\
42.5 & 49.2 \\
1644 & 1922 \\
15477 & 14302 \\
3459 & 3430 \\
28.8 & 31.5
\end{tabular}


TABLE 1G. 15

Current Capability (MW) and Reserves (MW and Percent)

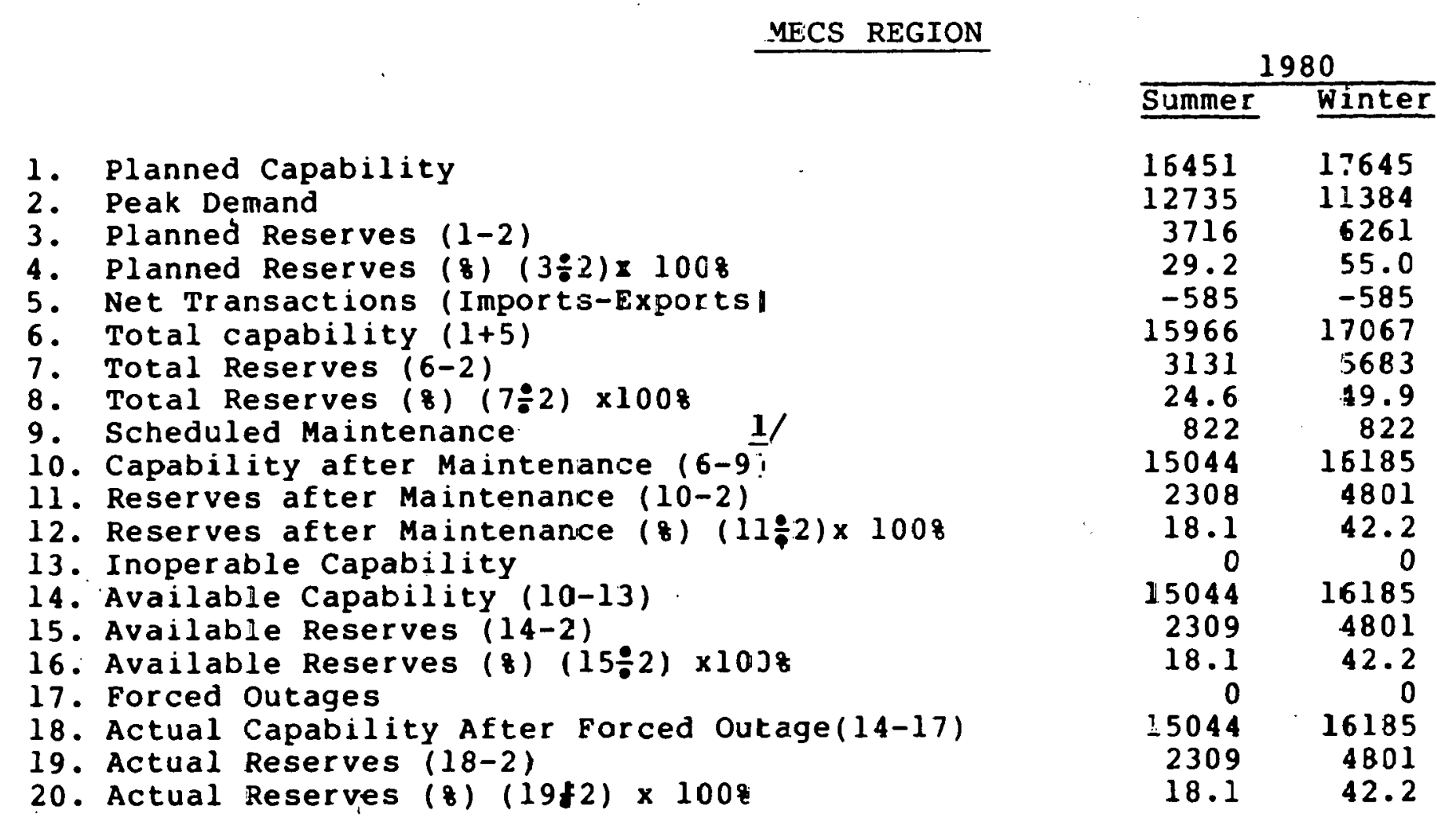

1/ 58 of total planned capabi-ity assumed by ERA-From ECAR ERA 411 report. 
TABLE 1G. 16.1

Future Capability (MW) And Reserves (MW and Percent) MECS Region

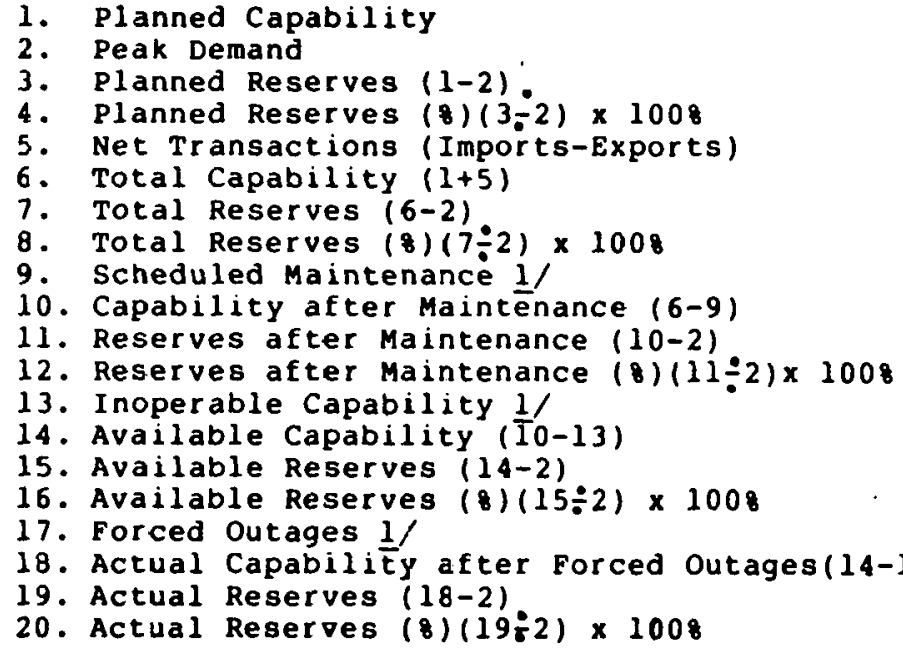

\begin{tabular}{rr}
\multicolumn{2}{c}{1981} \\
\cline { 2 - 2 } Summer & Winter \\
\cline { 1 - 2 } 17242 & 17645 \\
13161 & 11747 \\
4081 & 5898 \\
31.0 & 50.2 \\
-602 & -583 \\
16640 & 17062 \\
3479 & 5315 \\
26.4 & 45.2 \\
0 & 0 \\
16640 & 17062 \\
3479 & 5315 \\
26.4 & 45.2 \\
0 & 0 \\
16640 & 17062 \\
3479 & 5315 \\
26.4 & 45.2 \\
0 & 0 \\
16640 & 17062 \\
3479 & 5315 \\
26.4 & 45.2 \\
&
\end{tabular}

1982 Summer Winter

$18333 \quad 18738$

$\begin{array}{ll}18333 & 18738 \\ 13627 & 12105\end{array}$

$4706 \quad 6633$

$34.5 \quad 54.8$

$-604-601$

$17731 \quad 18137$

$4104 \quad 6032$

30.1

49.8

$17731 \quad 18137$

$4104 \quad 6032$

$30.1 \quad 49.8$

$\begin{array}{rr}0 & 0 \\ 17731 & 18137\end{array}$

$4104 \quad 6032$

$30.1 \quad 49.8$

$\begin{array}{rr}0 & 0 \\ 17731 & 18137\end{array}$

$4104 \quad 6032$

$\begin{array}{ll}40.1 & 49.8\end{array}$ $\frac{1983}{\text { Summer Winter }}$

$18582 \quad 18985$

$14199 \quad 12574$

43836411

$30.9 \quad 51.0$

$\begin{array}{rr}-607 & -292 \\ -7975 & 18693\end{array}$

$17975 \quad 18693$

$3776 \quad 6119$

$\begin{array}{rr}26.6 & 48.7 \\ 0 & 0\end{array}$

$\begin{array}{rr}0 & 0 \\ 17975 & 18693\end{array}$

$3776 \quad 6119$

26.648 .7

$17975 \quad 18693$

$3776 \quad 6119$

$26.6 \quad 48.7$

$\begin{array}{rr}0 & 0 \\ 17975 & 18693\end{array}$

$3776 \quad 6119$

$\begin{array}{ll}26.6 & 48.7\end{array}$ $\frac{1984}{\text { Summer Winter }} \frac{1985}{\text { Summer Winter }}$

\section{$9246 \quad 20456$}

$14652 \quad 12952$

$4594 \quad 7504$

$\begin{array}{rr}31.4 & 57.9 \\ -300 & -296\end{array}$

$18946 \quad 20160$

$4294 \quad 7208$

$29.3 \quad 55.7$

$\begin{array}{rr}0 & 0 \\ 18946 & 20160\end{array}$

42947208

29.355 .7

$18946 \quad 20160$

$4294 \quad 7208$

$29.3 \quad 55.7$

$\begin{array}{rr}0 & 0 \\ 18946 & 20160\end{array}$

$4294 \quad 7208$

$29.3 \quad 55.7$
$21198 \quad 21642$

$15162 \quad 13357$

$6036 \quad 8285$

$\begin{array}{ll}-279-276 \\ 20919 & 21366\end{array}$

2091921366

$5757 \quad 8009$

$38.0 \quad 60.0$

$\begin{array}{rr}0 & 0 \\ 20919 & 21366\end{array}$

$5757 \quad 8009$

$38.0 \quad 60.0$

2091921366

$5757 \quad 8009$

$38.0 \quad 60.0$

$\begin{array}{rr}0 & 0 \\ 20919 & 21366\end{array}$

$5757 \quad 8009$

$38.0 \quad 60.0$
$39.8 \quad 62.0$ 
TABLE 1G. 16.2

Future Capability (MW) and Reserves (MW and Percent)

MECS Region

1. Planned Capability

2. Peak Demand

3. Planned Reserves $(1-2)$

4. Planned Reserves (8) $(3 \div 2) \times 1008$

5. Net Transactions (Imports-Exports

6. Total Capability $(1+5)$

7. Total Reserves (6-2)

8. Total Reserves (8) $(7 \div 2) \times 1008$

9. Scheduled Maintenance $1 /$

10. Capability after Maintenance $(6-9)$

11. Reserves after Maintenance $(10-2)$

12. Reserves after Maintenance (8)(11:2: $\times 1008$

13. Inoperable Capability $1 /$

14. Available Capability (I0-13)

15. Available Reserves (14-2)

16. Available Reserves $(8)(15 \div 2) \times 100$

17. Forced Outages $1 /$

18. Actual Capability after Forced Outages (14-17)

19. Actual Reserves $(18-2)$

20. Actual Reserves $(8)(19 \div 2) \times 1008$

1/ Information not available.
Summer Winter

$\begin{array}{ll}21348 & 21792 \\ 15686 & 18773\end{array}$

$5662 \quad 8019$

$36.1 \quad 58.2$

$-280-276$

$21068 \quad 21516$

$5382 \quad 7743$

34.3

56.2

21068

21516

7743

56.2

0

$21068 \quad 21516$

$5382 \quad 7743$

34.3

7743
56.2

21068

5382

34.3

21516

7743

56.2
1987

Summer Winter

Summer

88

21052

20723

Winter

$\frac{1989}{\text { Eummer }}$

21348

$5142 \quad 6898$

31.748 .7

$-281$

21067

4861

$-277$

16718

0.0

21067

4861

6621

4005
24.9

14602

2.0713

21792

24.9
-281

20442

44.2

\begin{tabular}{l}
74940 \\
\hline
\end{tabular}

$3540 \quad 6852$

$\begin{array}{ll}30.6 & 45.9\end{array}$

35

30

45.9
34

$2108720743 \quad 21826$

6485
$4570 \quad 6886$

$\begin{array}{lllll}46.8 & 22.3 & 44.4 & 20.8 & 46.1\end{array}$

20775

0
20442

0

0
$0743 \quad 21826$

6621

372

21087

$20743 \quad 21826$

46.8

22.3

3570

20.8

6886

$21067 \quad 20775$

20442

0
21087

07

46.1

6621

3724
22.3

6485

21826

$3570 \quad 6886$

$\begin{array}{rr}30.0 & 46.8 \\ 0 & \end{array}$

21067

0
20775

0
20442

44.4

21087

0

20743

46.1

3724

6485
44.4

20.8

21826

6886

46.1 
TABLE 1G. 17.1

Installed Net capability as of January 1, By type of Fuel -MW

MECS Region

summer Capability

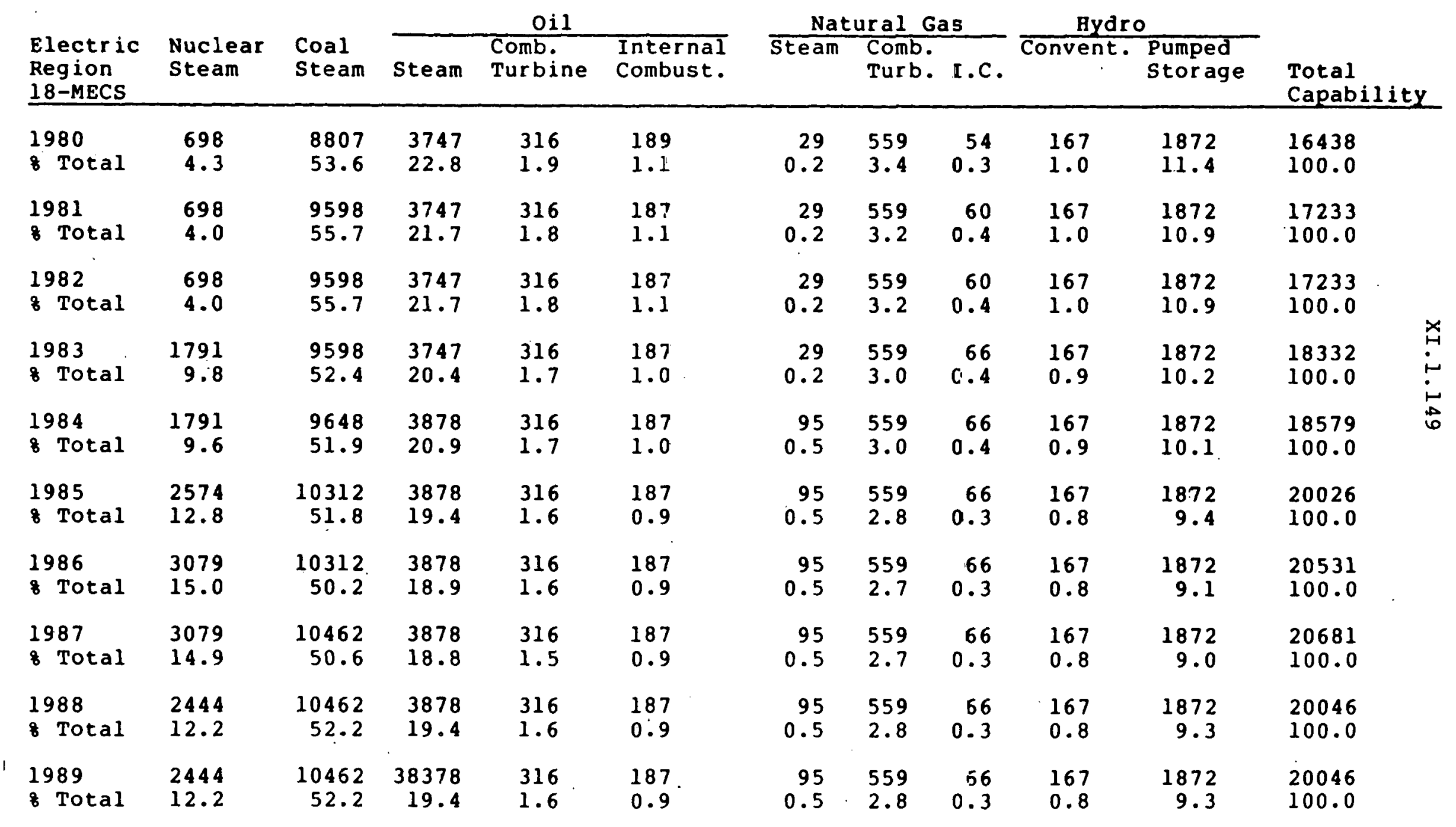


TABLE 1G. 17.2

Installed Net capability as of January 1, By type of Fuel -MW

MECS Region

winter Capability

\begin{tabular}{|c|c|c|c|c|c|c|c|c|c|c|c|}
\hline \multirow[b]{2}{*}{$\begin{array}{l}\text { Electric } \\
\text { Region } \\
18 \text {-MECS } \\
\end{array}$} & \multirow[b]{2}{*}{$\begin{array}{l}\text { Nuclear } \\
\text { Steam }\end{array}$} & \multirow[b]{2}{*}{$\begin{array}{l}\text { Coal } \\
\text { Steam }\end{array}$} & \multicolumn{3}{|c|}{ Oil } & \multicolumn{3}{|c|}{ Natural Gas } & \multicolumn{2}{|c|}{ Hydro } & \multirow[b]{2}{*}{$\begin{array}{c}\text { Total } \\
\text { Capability }\end{array}$} \\
\hline & & & steam & $\begin{array}{l}\text { Comb. } \\
\text { Turbine }\end{array}$ & $\begin{array}{l}\text { Internal } \\
\text { Combust. }\end{array}$ & steam & $\begin{array}{l}\text { Comb } \\
\text { Turb. }\end{array}$ & I.C. & Convent. & $\begin{array}{l}\text { Pumped } \\
\text { Storage }\end{array}$ & \\
\hline $\begin{array}{l}1980 \\
8 \text { Total }\end{array}$ & $\begin{array}{l}803 \\
4.8\end{array}$ & $\begin{array}{l}8830 \\
52.4\end{array}$ & $\begin{array}{l}3769 \\
22.3\end{array}$ & $\begin{array}{l}408 \\
2.4\end{array}$ & $\begin{array}{l}190 \\
1.1\end{array}$ & $\begin{array}{r}29 \\
0.2\end{array}$ & $\begin{array}{l}736 \\
4.4\end{array}$ & $\begin{array}{r}54 \\
0.3\end{array}$ & $\begin{array}{l}168 \\
1.0\end{array}$ & $\begin{array}{l}1872 \\
1.1\end{array}$ & $\begin{array}{l}16859 \\
100.1\end{array}$ \\
\hline $\begin{array}{l}1981 \\
8 \text { Total }\end{array}$ & $\begin{array}{l}803 \\
4.6\end{array}$ & $\begin{array}{l}9621 \\
54.5\end{array}$ & $\begin{array}{l}3769 \\
21.3\end{array}$ & $\begin{array}{l}408 \\
2.3\end{array}$ & $\begin{array}{l}188 \\
1.1\end{array}$ & $\begin{array}{r}29 \\
0.2\end{array}$ & $\begin{array}{l}736 \\
4.2\end{array}$ & $\begin{array}{r}60 \\
0.3\end{array}$ & $\begin{array}{l}168 \\
0.9\end{array}$ & $\begin{array}{l}1872 \\
10.6\end{array}$ & $\begin{array}{l}17654 \\
100.0\end{array}$ \\
\hline $\begin{array}{l}1982 \\
8 \text { Total }\end{array}$ & $\begin{array}{l}803 \\
4.6\end{array}$ & $\begin{array}{l}9621 \\
54.5\end{array}$ & $\begin{array}{l}3769 \\
21.3\end{array}$ & $\begin{array}{l}408 \\
2.3\end{array}$ & $\begin{array}{l}188 \\
1.1\end{array}$ & $\begin{array}{r}29 \\
0.2\end{array}$ & $\begin{array}{l}736 \\
4.2\end{array}$ & $\begin{array}{r}60 \\
0.3\end{array}$ & $\begin{array}{l}168 \\
0.9\end{array}$ & $\begin{array}{l}1872 \\
10.6\end{array}$ & $\begin{array}{l}17654 \\
100.0\end{array}$ \\
\hline $\begin{array}{l}1983 \\
8 \text { Total }\end{array}$ & $\begin{array}{l}1896 \\
10.1\end{array}$ & $\begin{array}{l}9621 \\
51.3\end{array}$ & $\begin{array}{l}3769 \\
21.1\end{array}$ & $\begin{array}{l}408 \\
2.2\end{array}$ & $\begin{array}{l}188 \\
1.0\end{array}$ & $\begin{array}{r}29 \\
0.2\end{array}$ & $\begin{array}{l}736 \\
3.9\end{array}$ & $\begin{array}{r}60 \\
0.3\end{array}$ & $\begin{array}{l}168 \\
0.9\end{array}$ & $\begin{array}{l}1872 \\
10.0\end{array}$ & $\begin{array}{l}18753 \\
100.0\end{array}$ \\
\hline $\begin{array}{l}1984 \\
8 \text { Total }\end{array}$ & $\begin{array}{l}1896 \\
10.1\end{array}$ & $\begin{array}{l}9671 \\
50.9\end{array}$ & $\begin{array}{l}3300 \\
20.5\end{array}$ & $\begin{array}{l}408 \\
2.1\end{array}$ & $\begin{array}{l}188 \\
1.0\end{array}$ & $\begin{array}{r}95 \\
0.5\end{array}$ & $\begin{array}{l}736 \\
3.9\end{array}$ & $\begin{array}{r}66 \\
0.3\end{array}$ & $\begin{array}{l}168 \\
0.9\end{array}$ & $\begin{array}{r}1872 \\
9.8\end{array}$ & $\begin{array}{l}19000 \\
100.0\end{array}$ \\
\hline $\begin{array}{l}1985 \\
8 \text { Total }\end{array}$ & $\begin{array}{l}2703 \\
13.2\end{array}$ & $\begin{array}{r}10335 \\
50.5\end{array}$ & $\begin{array}{l}3900 \\
19.1\end{array}$ & $\begin{array}{l}408 \\
2.0\end{array}$ & $\begin{array}{l}188 \\
0.9\end{array}$ & $\begin{array}{r}95 \\
0.5\end{array}$ & $\begin{array}{l}736 \\
3.6\end{array}$ & $\begin{array}{r}66 \\
0.3\end{array}$ & $\begin{array}{l}168 \\
0.8\end{array}$ & $\begin{array}{r}1872 \\
9.1\end{array}$ & $\begin{array}{l}20471 \\
100.0\end{array}$ \\
\hline $\begin{array}{l}1986 \\
8 \text { Total }\end{array}$ & $\begin{array}{l}3225 \\
15.4\end{array}$ & $\begin{array}{r}10335 \\
49.2\end{array}$ & $\begin{array}{l}3.900 \\
18.6\end{array}$ & $\begin{array}{l}408 \\
1.9\end{array}$ & $\begin{array}{l}188 \\
0.9\end{array}$ & $\begin{array}{r}95 \\
0.5\end{array}$ & $\begin{array}{l}736 \\
3.5\end{array}$ & $\begin{array}{r}66 \\
0.3\end{array}$ & $\begin{array}{l}168 \\
0.8\end{array}$ & $\begin{array}{r}1872 \\
8.9\end{array}$ & $\begin{array}{l}20993 \\
100.0\end{array}$ \\
\hline $\begin{array}{l}1987 \\
8 \text { Total }\end{array}$ & $\begin{array}{l}3225 \\
15.2\end{array}$ & $\begin{array}{r}10485 \\
49.6\end{array}$ & $\begin{array}{l}3900 \\
18.4\end{array}$ & $\begin{array}{l}408 \\
1.9\end{array}$ & $\begin{array}{l}188 \\
0.9\end{array}$ & $\begin{array}{r}95 \\
0.5\end{array}$ & $\begin{array}{l}736 \\
3.5\end{array}$ & $\begin{array}{r}66 \\
0.3\end{array}$ & $\begin{array}{l}168 \\
0.8\end{array}$ & $\begin{array}{r}1872 \\
8.9\end{array}$ & $\begin{array}{l}21143 \\
100.0\end{array}$ \\
\hline $\begin{array}{l}1988 \\
8 \text { Total }\end{array}$ & $\begin{array}{l}2485 \\
12.2\end{array}$ & $\begin{array}{r}10485 \\
51.4\end{array}$ & $\begin{array}{l}3900 \\
19.1\end{array}$ & $\begin{array}{l}408 \\
2.0\end{array}$ & $\begin{array}{l}188 \\
0.9\end{array}$ & $\begin{array}{r}95 \\
0.5\end{array}$ & $\begin{array}{l}736 \\
3.6\end{array}$ & $\begin{array}{r}66 \\
0.3\end{array}$ & $\begin{array}{l}168 \\
0.8\end{array}$ & $\begin{array}{r}1872 \\
9.2\end{array}$ & $\begin{array}{l}20403 \\
100.0\end{array}$ \\
\hline $\begin{array}{l}1989 \\
8 \text { Total }\end{array}$ & $\begin{array}{l}2485 \\
12.2\end{array}$ & $\begin{array}{r}10485 \\
51.4\end{array}$ & $\begin{array}{l}\$ 900 \\
19.1\end{array}$ & $\begin{array}{l}408 \\
2.0\end{array}$ & $\begin{array}{l}188 \\
0.9\end{array}$ & $\begin{array}{r}95 \\
0.5\end{array}$ & $\begin{array}{l}736 \\
3.6\end{array}$ & $\begin{array}{r}66 \\
0.3\end{array}$ & $\begin{array}{l}168 \\
0.8\end{array}$ & $\begin{array}{r}1872 \\
9.2\end{array}$ & $\begin{array}{l}20403 \\
100.0\end{array}$ \\
\hline
\end{tabular}


SECTION XI. 2

ELECTRIC RELIABILITY COUNCIL OF TEXAS (ERCOT) 


\section{ELECTRIC RELIABILITY COUNCIL OF TEXAS}

\section{Introduction}

The members of the Electric Reliability Council of Texas (ERCOT) supply electric power within the state of Texas only and do not operate in synchronism with any of the other nine Electric Reliability Council areas. The entire ERCOT area is included in the Texas Interconnected Systems Group (TIS) (Electric Region 23). The area internally is divided into the North and South Texas areas for planning and operating purposes, and each area is monitored by a security center. There are eight control centers in the south Texas area and four in the North Texas area.

ERCOT usually experiences its peak electric load in July or August during periods of prolonged hot dry weather. Its winter peak occurs in December or January and is approximately 75 percent of the summer peak load.

During the year 1978 , ERCOT obtained 78.9 percent of its electric generation from natural gas, 18.6 percent from coal and 1 ignite, 2.3 percent from fuel oil and 0.2 percent from hydro.

The existing high voltage transmission system is at the $345 \mathrm{kV}$ level and extends east to west in the North Texas portion of the area and north to south between North and South Texas areas. The $345 \mathrm{kV}$ system between North and South Texas was constructed primarily for reliability and until recently was not used for economy energy transactions.

Texas is presently isolated electrically from other Electric Regions in the nation. The Central \& South west Corporation (CSW) has petitioned the Federal Energy Regulatory Commission to order ERCOT to interconnect with the Southwest Power Pool Relability Council. As a result of this petition, systems in ERCOT and SPP are currently involved in a joint voluntary study to test the feasibility of such a connection. Transmission lines proposed by CSW were shown on the transmission map furnished with ERCOT's 1980 ERA-4ll report, but were not included in the list of bulk power line additions nor were they used in the load flow and stability studies furnished in the report. Consumation of this interconnection would have some effect on the load and supply situation in future years. 
$\mathrm{XI} .2 .2$

TEXAS INTERCONNECTED SYSTEMS GROUP (REGION 23)

\title{
Historical Perspective
}

Historically, the Texas Interconnected systems (TIS) area has been a high growth area with an annual compound rate of growth of approximately 10 percent for both peak demand and energy during the period 1950 through 1976. During the early years of this period, electric usage increased rapidly due to low electric rates, which were attributable to an abundance of low cost natural gas. However, as a result of the decline in natural gas reserves, other fuel related problems and the general effects of inflation, the annual growth rate of electric usage has been declining as shown in the following table:

\author{
Table 2 A.I
}

COMPOUND ANNUAL GROWTH RATE

Texas Interconnected Systems Group

$\begin{array}{lcc}\text { Period } & \frac{\text { Compound Annual Growth Rate }}{\text { Peak Demand }} & \frac{1}{(8)} \\ 1950-60 & 12.9 & 11.8 \\ 1960-70 & 10.1 & 10.5 \\ 1970-76 & 6.4 & 6.3\end{array}$

Táble 2A.3 tabulates the actual summer and winter peak demands and the annual net energy for load for the years 1977 through 1979. The annual growth rates of demand and energy for 1977 to 1978 and 1978 to 1979 and the annual load factors are also tabulated.

The TIS area's peak demand occurs in the summer months during periods of prolonged hot dry weather, and therefore, is extremely temperature sensitive. As shown on Table 2A.3 the 1979 summer peak demand was 0.7 percent less than the 1978 summer peak demand.

Although not shown on Table $2 \mathrm{~A} .3$, the summer energy requirements in 1979 were 3 percent lower than 1978. This reduction in both peak and energy was attributed to three factors listed in order of importance: (1) lower than normal temperatures during the summer of 1979; (2) implementation of the President's 78 degree Fahrenheit temperature rule; and (3) customer conservation. 
The following table shows the actual mid-1978 summer generating capability by fuel type and the resulting 1978 actual energy production:

Table $2 \mathrm{~A} .2$

GENERATING CAPABILITY \& ENERGY GENERATION (1978) Texas Interconnected Systems Group

\begin{tabular}{|c|c|c|c|c|c|}
\hline Capacity Type & $\begin{array}{l}\text { Fuel } \\
\text { Type }\end{array}$ & $\frac{\text { Capabi }}{(\mathrm{MW})}$ & $\frac{\text { ity (Summer) }}{\text { (8of Total) }}$ & $\frac{\text { Annual }}{\text { (GWh) }}$ & $\begin{array}{l}\text { Generation } \\
\text { (gof Total) }\end{array}$ \\
\hline Steam & Gas & 31,105 & 79.79 & 111,581 & 75.74 \\
\hline Steam & Oil & 0 & 0.0 & 3,354 & 2.27 \\
\hline steam & Coal & 6,046 & 15.51 & 27,342 & 18.56 \\
\hline Hydro & Water & 230 & 0.59 & 288 & 0.19 \\
\hline Gas Turbine & Gas & 1,363 & 3.50 & 721 & 0.50 \\
\hline Gas Turbine & Oil & 58 & 0.15 & 37 & 0.03 \\
\hline Combined Cycle & Gas & 182 & 0.46 & 3,982 & 2.70 \\
\hline Combined Cycle & Oil & 0 & 0.0 & 8 & 0.01 \\
\hline Total & & 38,984 & 100.00 & 147,313 & 100.00 \\
\hline
\end{tabular}

As shown above, the TIS area is still heavily dependent on natural gas for the production of energy. During 1978, the TIS area burned 1,172 million Mcf of natural gas ( 84 percent of which was under firm contract) and only $5.6 \mathrm{million}$ barrels of oil. Residual oil represented 79 percent of the oil burned, and the remainder was distillate. A total of 22 million tons of coal was consumed with the majority, 86 percent, being supplied from utility owned intrastate lignite mines. There are presently no nuclear-fueled generating units in service in the TIS area although five units are scheduled for operation during the 1980's.

The bulk power system planning criteria for TIS states that sufficient generating capacity will be provided, as nearly as practicable, to insure total reserves of at least 15 percent of the forecasted maximum hour demand of the Interconnected system. The TIS Planning Subcommittee is presently conducting a reserve study to determine if the 15 percent criteria should be increased. Historically, the total reserves of TIS have been much greater than 15 percent. The operating reserve policy of TIS is for both the North Texas and the South Texas group of companies to each malntain spinning reserve equal to the sum of the capability of the largest unit in operation plus $100 \mathrm{MW}$. Tables $2 \mathrm{~A} .4 .1$ and $2 \mathrm{~A} .4 .2 \mathrm{give}$ the actual reserve 
situations that occurred in the TIS area for 1977 through 1979 for each of the three summer months (June, July and August) and the three winter months (December, January and February). In 1979 the largest generating units in both the North and South Texas subareas were $750 \mathrm{MW}$ for a total spinning reserve requirement of $1,700 \mathrm{MW}$. Operating reserves exceeded this amount $(1700 \mathrm{MW})$ in each of the historical periods listed. Total reserves varied from a high of 102.7 percent of demand in December of 1977 to a low of 31.6 percent in July of 1978 .

Transmission in TIS is normally constructed on a service territory basis and most of the $345 \mathrm{kV}$ backbone lines were built to serve new generating capacity and for reliability. At the end of 1979, there were approximately $3,900 \mathrm{miles}$ of lines in operation. As the coaloil cost spread increases, so does economy energy exchanges. TIS has adopted Transmission Facilities Services Policy Guidelines to assist in arrangements for wheeling and the use of transmission facilities on other systems.

Table $2 A .3$

HISTORICAL PEAK DEMAND AND ENERGY GROWTH Texas Interconnected Systems Group (Region 23)

\begin{tabular}{|c|c|c|c|c|c|c|c|}
\hline & $\frac{\overline{\text { Summer }}}{(\mathrm{MW})}$ & $\frac{\text { De m }}{\text { Growth }}$ & $\frac{\frac{a n d}{w 1 n t e r}}{(M W)}$ & $\frac{\overline{\mathrm{Gr}} \mathrm{Ow} \mathrm{th}}{(\mathrm{g})}$ & $\begin{array}{l}\text { Annual } \\
\text { Requir } \\
\frac{\text { Amount }}{\text { (GWh) }}\end{array}$ & $\begin{array}{l}\text { Energy } \\
\text { ments } \\
\frac{\text { Growth }}{(\delta)}\end{array}$ & $\begin{array}{c}\begin{array}{c}\text { Annual } \\
\text { Load } \\
\text { Factor }\end{array} \\
\frac{(8)}{8}\end{array}$ \\
\hline 1977 & 26,894 & - & 20,203 & - & 136,743 & - & 58.0 \\
\hline 1978 & 28,645 & 6.51 & 21,521 & 6.52 & 147,608 & 7.95 & 58.8 \\
\hline 1979 & 28,455 & -0.66 & 22,052 & 2.47 & 150,231 & 1.78 & 60.3 \\
\hline
\end{tabular}




\section{Current Perspective}

Table $2 A .5$ gives the current projected generating capability and reserves for the summer of 1980 and the $1980 / 81$ winter peak period for the Texas Interconnected Systems Group (TIS). As stated earlier, the summer peak demand for TIS is extremely temperature sensitive and as such can occur during either of four summer months, June, July, August or September, although it usually occurs in July or August. In the TIS region, the lowest demands of the year occur on the system in the winter (December 1 through the end of February for this report) with the peak hour demands remaining fairly flat during this period.

The systems in TIS are planning to install 1,670 MW of coal-fired generating capacity before the 1980 summer peak period as stated in their ERA-4ll report. They also plan to add a $545 \mathrm{MW}$ lignite unit and reactivate a $30 \mathrm{MW}$ gas unit before the winter peak. According to up-to-date information, no delays in these schedules are anticipated.

Total reserves are projected to be 34.5 percent during the summer of 1980 and 83.2 percent in the winter. Available reserves, considering capability reductions due to scheduled maintenance and inoperable capability, are expected to be 32.3 percent and 38.7 percent for the summer and winter peak, respectively. Actual reserves of 20.5 percent and 23.9 percent for summer and winter are estimated by the ERA staff based on historical forced outages averaged for the period 1977 through 1979. All reserve amounts are well above the TIS reserve criteria.

The total summer planned capability of $42,379 \mathrm{MW}$ includes almost 23 percent of coal-fired generation and over 76 percent of natural gas capacity (see Table 2A.9). This compares to a coal-gas mix of 16 and 80 percent, respectively, in 1978 .

During 1980, and before the summer peaking season, TIs plans to place eleven $345-\mathrm{kV}$ circuits totaling $277 \mathrm{miles}$ in service. The primary purpose of most of these transmission additions is to provide a path for generator output, although several are needed for overload relief on the system or to serve increased loads. Two are being constructed to increase interchange capability, one to provide area support and one for stability requirements.

The TIS Group (Region 23) should experience no capacity problems during the 1980 summer and $1980 / 81$ winter peak periods. 


\section{Future Perspective}

During the 1981-1984 period, TIS plans to instali $3,550 \mathrm{MW}$ of nuclear-fueled capacity and $2,253 \mathrm{MW}$ of coal and lignite-fired capacity. This additional capacity is being installed to serve a projected annual load growth of 5.2 percent between the summer of 1980 and the summer of 1984 .

As shown on Table $2 \mathrm{~A} .6$, the summer total reserves for TIS varies from a $1 \mathrm{ow}$ of 22.6 percent in 1984 to a high of 33.8 percent in 1981. Winter total reserves are much highcr than the summer since this is the low load period for 'l'L, valying from 68.7 percent in 1984 to 79.4 percent in 1981. These tolal rescrve figures are well above the TIS reserve criteria. Available reserves, which includes the effects of scheduled maintenance and inoperable capability, are also well above the TIS total reserve criteria (158) with the lowest available reserve of 21.7 percent occurring in the summer of 1984 . Actual reserves, which includes the effect of forced outages estimated by ERA, are expected to range between 8.5 percent during the winter of 1983 and 22.8 percent during the winter of 1981 .

If nuclear delays (projected by the Nuclear Regulatory Commission) and possible delays in coal units (assumed possible by ERA) are also considered, the resulting actual reserves would range between 4.3 percent in the winter of 1983 and 18.2 percent during the winter of 1981. Table $2 \mathrm{~A} .10$ provides a list of scheduled nuclear units and includes the NRC projected in-service dates. The ERA staff assumed that the $400 \mathrm{MW}$ Gibbons Creek Unit No. I (LIgnite) could possibly be delayed beyond the 1982 summer peak period since construction is less than 50 porcent complete.

During the 1981-1984 period, TIS expects to construct approximately 1,753 miles of $345-k V$ transmission circuits. Although about onehalf of these circults ait beiry conotrunted to transmit power from existing and scheduled generating units, a large number are also needed for overload relief, stability requirements, and increased interchange capability.

TIS appears to have an excellent reserve posture during the 1981 through 1984 period. This is due, to a great extent, to its program for phasing down the use of natural gas as a boiler fuel as evidenced by the number of scheduled coal-fired units listed in Table 2A.11. 
Available reserves, including only the effect of inoperable capability, for the Eive year period 1985-1989 are shown on Table 2A.7. The projected reserves are approximately 20 percent during the summer peak periods and 58 percent during the winter. An NRC projected delay in the in-service date of the 1,130 MW Allens Creek nuclear unit starting in the winter of 1987 and extending beyond the winter of 1989 reduces reserve margins to approximately 54 percent during the winter and 19 percent during the summer for these years.

TIS is planning to install $1,380 \mathrm{MW}$ of nuclear capacity, 10,940 MW of coal and lignite capacity and retire a total of $1,673 \mathrm{MW}$ of gas-fired capacity between the summer of 1985 and the summer of 1989. The summer peak demand is estimated to increase by $8,417 \mathrm{MW}$ during the same period.

There are approximately 1,220 miles of $345-k V$ transmission circuits planned in service during the 1985-1989 period. The purpose of these lines is about evenly divided between generator output, overload relief or load growth, and stability requirements. In addition, several lines are planned for increased interchange capability, area support, and voltage relief.

The Texas Interconnected Systems Group (Region 23) appears to have excellent reserves throughout the lo-year period covered in this report.

The growth in summer and winter peak demand and annual energy as reported in the 1980 ERA-411 are shown on Table $2 A .8$. TIS is projecting an average annual growth for the summer peak demand and annual energy of 5 percent and a 5.2 percent growth for the winter peak during the lo-year report period. The annual load factor as projected is approximately 58 percent and remains nearly constant throughout the period.

Based on the projected planned capability shown on Tables $2 A .5$, $2 A .6$, and $2 A .7$, annual energy requirements can be met throughout the 10-year period assuming a stable fuel supply. For example, the average annual plant factor in 1989 based on the total installed capability is approximately 48 percent. If natural gas and oil capability were reduced by one-half in 1989 due to a shortage of these fuels, the remaining fuels would be required to make up the difference, which in effect would mean that the average annual plant factor must be increased to about 64 percent. 
HISTORICAL CAPAEILITY (MW) AND RESERVES (MW and Percent)

Texas Interconnected Systems Group (Region 23)

1. Planned Capability

2. Peak Demand

3. Planned Reserves (1-2)

4. Planned Reserves $(\%)(3 / 2) \times 100$

5. Net Transactions (Imports-Exportsi

6. Total Capability. $(1+5)$

7. Total Reserves (6-2)

8. Total Reserves $(\%)(7 / 2) \times 100$

9. Scheduled Maintenance

10. Capability after Maintenance (5-9)

11. Reserves after Maintenance $(1 C-2)$

12. Reserves after Maintenance (\%) (11/2) ×100

13. Inoperable Capability

14. Available Capability (10-13)

15. Available Reserves (14-2)

16. Available Reserves (\%) (15/2) ×i00

17. Forced Outages

18. Actual Capability after Force: Outages (1:-17)

19. Actual Reserves (18-2)

20. Actual Reserves (\%) (19/2) ×100

\begin{tabular}{|c|c|c|c|c|c|c|c|c|c|}
\hline \multirow{2}{*}{\multicolumn{2}{|c|}{$\frac{-}{1977 / 73}$}} & $\mathrm{~S}$ & \multirow{2}{*}{\multicolumn{2}{|c|}{$\begin{array}{c}M \\
1978 / 79 \\
\end{array}$}} & \multirow{2}{*}{$E$} & \multirow{2}{*}{\multicolumn{2}{|c|}{$\frac{-}{1979 / 80}$}} & & \\
\hline & & & & & & & & & \\
\hline Dec. & Jan. & Feb. & Dec. & Jan. & Feb. & Dec. & Jan. & Feb. & \\
\hline 35273 & 35188 & 35565 & 37621 & 37649 & 38569 & 40847 & 40847 & 40827 & \\
\hline 24664 & 26327 & 26894 & 27280 & 28645 & 28177 & 27943 & 28455 & 28429 & \\
\hline 10609 & 8861 & $867^{\circ}$ & 10341 & 9004 & 10392 & 12904 & 12392 & 12398 & \\
\hline 43.0 & 33.7 & 32.2 & 37.9 & 31.4 & 36.9 & 46.2 & 43.5 & 43.6 & \\
\hline 120 & 18 & -24 & 136 & 35 & -111 & 250 & 236 & 399 & \\
\hline 35393 & 36206 & 35541 & 37757 & 37684 & 38458 & 41097 & 41083 & 41226 & \\
\hline 10729 & 8879 & 8647 & 10477 & 9039 & 10281 & 13154 & 12628 & 12797 & \\
\hline 43.5 & 33.7 & 32.2 & 38.4 & 31.6 & 35.5 & 47.1 & 44.4 & 45.0 & \\
\hline 2037 & 344 & 224 & 1763 & 797 & 1588 & 2859 & 1201 & 1770 & \\
\hline 33356 & 34862 & 35317 & 35994 & 36887 & 36870 & 38238 & 39882 & 39456 & \\
\hline 8692 & 8535 & 8423 & 8714 & 8242 & 8693 & 10295 & 11427 & 11027 & \\
\hline 35.2 & 32.4 & 31.3 & 31.9 & 28.8 & 30.9 & 36.8 & 40.2 & 38.8 & \\
\hline 1328 & 1678 & $24 \mathrm{C} 6$ & 1173 & 2010 & 1263 & 1413 & 1894 & 2032 & \\
\hline 32028 & 33184 & 32911 & 34821 & 34877 & 35607 & 36825 & 37988 & 37424 & \\
\hline 7364 & 6857 & 6017 & 7541 & 6232 & 7430 & 8882 & 9533 & 8995 & \\
\hline 29.9 & 26.0 & 22.4 & 27.6 & 21.8 & 26.4 & 31.8 & 33.5 & 31.6 & \\
\hline 1252 & 1668 & 1821 & 2596 & 2024 & 2095 & 3311 & 961 & 1446 & \\
\hline 30776 & 31516 & 31090 & 32225 & 32853 & 33512 & 33514 & 37027 & 35978 & \\
\hline 6112 & 5189 & 4196 & 4945 & 4208 & 5335 & 5571 & 8572 & 7549 & \\
\hline 24.8 & 19.7 & 15.6 & 18.1 & 14.7 & 18.9 & 19.9 & 30.1 & 26.6 & \\
\hline
\end{tabular}


HISTORICAL CAPABILITY (MW) AND RESERVES (MW and Percent)

Texas Interconnected Systems Group (Region 23)

1. Planned Capability

2. Peak Demand

3. Planned Reserves $(1-2)$

4. Planned Reserves (\%) (3/2) $\times 100$

5. Net Transactions (Imports-Exports)

6. Total Capability $(1+5)$

7. Total Reserves (6-2)

8. Total Reserves $(\%)(7 / 2) \times 100$

9. Scheduled Maintenance

10. Capability after Maintenance (6-9)

11. Reserves after Maintenance (10-2)

12. Reserves after Maintenance (\%) $(11 / 2) \times 100$

13. Inoperable Capability

14. Available Capability (10-13)

15. Available Reserves (14-2)

16. Available Reserves (\%) (15/2) x 00

17. Forced Outages

18. Actual Capability after Forced Outages (14-17)

19. Actual Reserves (18-2)

20. Actual Reserves $(\%)(19 / 2) \times 100$

\begin{tabular}{|c|c|c|c|c|c|c|c|c|}
\hline & $577^{-7}$ & W & {[} & 97810 & $\mathrm{E}$ & \multicolumn{3}{|c|}{$\frac{-}{979 / 80}$} \\
\hline Dec. & Jan. & $\overline{\mathrm{Feb} .}$ & Dec. & Jan. & $\overline{\text { Feb. }}$ & Dec. & Jan. & Feb. \\
\hline 36282 & 36833 & 36818 & 38839 & 39479 & 39478 & 40833 & 40777 & 40177 \\
\hline 17950 & 20203 & 19733 & 20817 & 21521 & 20904 & 21782 & 22052 & 21749 \\
\hline 18332 & 16630 & 17085 & 18022 & 17958 & 18574 & 19051 & 18725 & 18428 \\
\hline 102.1 & 82.3 & 86.6 & 86.6 & 83.4 & 88.9 & 87.5 & 84.9 & 84.7 \\
\hline 94 & 189 & 301 & 19 & 297 & 73 & -0s & 164 & -50 \\
\hline 36376 & 37022 & 37119 & 9358 & 39776 & 39551 & 40768 & 40941 & 40127 \\
\hline 18426 & 16819 & 17386 & 8541 & 18255 & 1864 & 18986 & 18889 & 18378 \\
\hline 102.7 & 3.3 & 88. & 89.1 & 84.8 & 89.2 & 87.2 & 85.7 & 84.5 \\
\hline 6719 & 159 & 6009 & 8237 & 5871 & 5908 & 7717 & 6509 & 6032 \\
\hline 29657 & 30563 & 31110 & 31121 & 33905 & 33643 & 33051 & 34432 & 34095 \\
\hline 11707 & 10360 & 11377 & 10304 & 12384 & 12739 & 1269 & 2380 & 76 \\
\hline 65.2 & 3 & 57.7 & 49.5 & 57.5 & 60.9 & 51.7 & 1 & 56.8 \\
\hline 2342 & 3088 & 2365 & 2085 & 4039 & 3451 & 15 & 3411 & 3006 \\
\hline 27315 & 27 & 28745 & 29036 & 29866 & 30192 & 30136 & 31021 & 31089 \\
\hline 9365 & 7272 & 9012 & 8219 & 8345 & 9288 & 8354 & 8969 & 9340 \\
\hline 52.2 & 36.0 & 45.7 & 39.5 & 38.8 & 44.4 & 38.4 & 40.7 & 42.9 \\
\hline 2689 & 2376 & 2453 & 1802 & 2950 & 1859 & 472 & 240 & 483 \\
\hline 24626 & 25099 & 26292 & 27234 & 26916 & 28 & 28664 & 28781 & 28606 \\
\hline 6675 & 6 & 6559 & 117 & 395 & 7429 & 382 & 6729 & 6857 \\
\hline 37.2 & 24.2 & 33.2 & 30.8 & 25.1 & 35.5 & 31.6 & 30.5 & 31. \\
\hline
\end{tabular}




\begin{tabular}{|c|c|c|c|}
\hline & & $\begin{array}{c}1980 \\
\text { Summer Peak } \\
\end{array}$ & $\begin{array}{c}1980 / 81 \\
\text { Winter Peak }\end{array}$ \\
\hline 1. & Planned Capability I/ & 42379 & 42832 \\
\hline 2. & Peak Demand & 31621 & 23456 \\
\hline 3. & Planned Reserves $(1-2)$ & 10758 & 19376 \\
\hline 4. & Planned Reserves $(\%)(3 / 2) \times 100$ & 34.0 & 82.6 \\
\hline 5. & Net Transactions (Imports - Exports) & 145 & 145 \\
\hline 6. & Total Capability $(1+b)$ & 42524 & 42977 \\
\hline 7. & Total Reserves $(6-2)$ & 10903 & 19521 \\
\hline 8. & Total Reserves $(\%)(7 / 2) \times 100$ & 34.5 & 83.2 \\
\hline 9. & Scheduled Maintenance & 305 . & 8059 \\
\hline 10. & Capability after Maintenance (6-9) & 42219 & 34918 \\
\hline 11. & Reserves after Maintenance $(10-2)$ & 10598 & 11462 \\
\hline 12. & Reserves after Maintenance $(\%)(11 / 2) \times 100$ & 33.5 & 48.9 \\
\hline 13. & Inoperable Capability & 383 & 2379 \\
\hline 14. & Available Capability $(10-13)$ & 11836 & 325.39 \\
\hline 15. & Available Reserves (14-2) & 10215 & 9083 \\
\hline 16. & Available Reserves $(\%)(15 / 2) \times 100$ & 32.3 & 38.7 \\
\hline 17. & Forced Outages $\underline{2} /$ & 3727 & 3485 \\
\hline 18. & Actual Capability after Forced Outages (14-17) & 38109 & 29054 \\
\hline 19. & Actual Reserves (18-2) & 6488 & 5598 \\
\hline 20. & Actual Reserves $(\%)(19 / 2) \times 100$ & 20.5 & 23.9 \\
\hline$\underline{1}$ & $\begin{array}{l}\text { No delays anticipated in new generating units } \\
\text { since submission of } 1980 \text { ERA-411. }\end{array}$ & & \\
\hline$\underline{2}$ & Estimated by ERA staff based on historical for & & \\
\hline
\end{tabular}


FUTURE CAPABILITY (MW) AND RESERVES (MW and Percent) - 1981-84

Texas Interconnected Systems Group (Region 23)

1. Planned Capability

2. Peak Demand

3. Planned Reserves (1-2)

4. Planned Reserves $(\%)(3 / 2) \times 100$

6. Total Capability $(1+5)$

7. Total Reserves $(6-2)$

8. Total Reserves $(\%)(7 / 2) \times 100$

9. Scheduled Maintenance

10. Capability after Maintenance (6-9)

11. Reserves after Maintenance $(10-2)$

12. Reserves after Maintenance (\%) (11/2) x100

13. Inoperable Capability

14. Available Capability (10-13)

15. Available Reserves (14-2)

16. Available Reserves $(\%)(15 / 2) \times 100$

17. Forced Outages 1/

18. Actual Capability after Forced Outages (14-17)

19. Actual Reserves (18-2)

20. Actual Reserves (\%) $(19 / 2) \times 100$
5. Net Transactions (Imports-Exports)

\begin{tabular}{rr}
\multicolumn{2}{c}{1981} \\
\cline { 1 - 1 } Summer & Winter \\
44012 & 43927 \\
33306 & 24795 \\
10706 & 19132 \\
32.1 & 77.2 \\
550 & 550 \\
44562 & 44477 \\
11256 & 19682 \\
33.8 & 79.4 \\
305 & 7824 \\
44257 & 36653 \\
10951 & 11858 \\
32.9 & 47.8 \\
1326 & 2466 \\
42931 & 34187 \\
9625 & 9392 \\
28.9 & 37.9 \\
3000 & 3730 \\
39931 & 30457 \\
6625 & 5662 \\
19.9 & 22.8
\end{tabular}

\begin{tabular}{rr}
\multicolumn{2}{c}{1982} \\
\cline { 1 - 1 } Summer & Winter \\
\cline { 3 - 3 } 44327 & 45455 \\
35089 & 26014 \\
9238 & 19441 \\
26.3 & 74.7 \\
550 & 550 \\
44877 & 46005 \\
9788 & 19991 \\
27.9 & 76.8 \\
160 & 8728 \\
44717 & $372 ? 7$ \\
9628 & 11263 \\
27.4 & 43.3 \\
176 & 22.0 \\
44541 & 35007 \\
9452 & 8993 \\
26.9 & 34.6 \\
4380 & 4230 \\
40161 & 30777 \\
5072 & 476.3 \\
14.5 & 18.3
\end{tabular}

1983

Summer Winter

$45995 \quad 45742$

$36873 \quad 27386$

$9122 \quad 18356$

$24.7 \quad 67.0$

604

46599

9726

26.4

160

46439

9566

25.9

176

46263

9390

25.5

4610

41653

4780

13.0
1984

Summer Winter

\section{2}

38796

8196

$21.1 \quad 66.7$

$\begin{array}{rr}575 & 575 \\ 47567 & 48589\end{array}$

$8771 \quad 19787$

$22.6 \quad 68.7$

$160 \quad 9431$

$47407 \quad 39158$

$8611 \quad 10356$

$22.2 \quad 36.0$

$176 \quad 2065$

$47231 \quad 37093$

$8435 \quad 8291$

$21.7 \quad 28.8$

$4860 \quad 5135$

$42371 \quad 31958$

$\begin{array}{rrr}2336 & 3575 & 3156 \\ 8.5 & 9.2 & 11.0\end{array}$

Nuclear Unit_Delays as Projected_by Nuclear Regulation_Conmission

21. Nuclear Delays

$\begin{array}{rrrrr}1150 & 1150 & 1150 & 1150 & 1150 \\ 38781 & 29307 & 39011 & 29627 & 40503 \\ 5475 & 4512 & 3922 & 3613 & 3630 \\ 16.4 & 18.2 & 11.2 & 13.9 & 9.8\end{array}$

1150
28572
1186
4.3

$\begin{array}{rr}1150 & 0 \\ 41221 & 31958 \\ 2425 & 3156 \\ 6.3 & 11.0\end{array}$

22. Actual Capability (18-21)

23. Actual Reserves with Nuclear Delays $(22-2)$

24. Actual Reserves with Nuclear Delays '(\%) (23/2) x100

1/ Estimated by ERA staff based on historical forced outage amounts. 
Table 2A.7

FUTURE CAPABILITY IMW) AND RESERVES (MW and Percent) - 1985-89

Texas Interconnected Systems Group (Region 23)

1. Planned Capability

2. Peak Demand

3. Planned Reserves $(1-2)$

4. Planned Reserves $(\%)(3 / 2) \times 100$

5. Net Transactions (Imports-Exports)

6. Total Capability $(1+5)$

7. Total Reserves $(6-2)$

8. Total Reserves $(\%)(7 / 2) \times 100$

9. Scheduled Maintenance

10. Capability after Maintenance (6-9)

11. Reserves after Maintenance (10-2)

12. Reserves after Maintenance $(\%)(11 / 2) \times 130$

13. Inoperable Capability

14. Available Capability $(10-13)$

15. Available Reserves (14-2)

16. Available Reserves (\%) (15/2) $\times 100$

17. Forced Outages 1/

18. Actual Capability after Forced Outages (14-17)

19. Actual Reserves (18-2)

20. Actual Reserves $(\%)(19 / 2) \times 100$
1986

1985 Summer Winter

$$
\begin{array}{r}
48486 \\
40744 \\
19 \\
19
\end{array}
$$

$48486 \quad 48688-506$

$\begin{array}{lll}0744 \quad 30028 & 42735\end{array}$

$7742 \quad 18660$

$\begin{array}{rr}19.0 & 62.1 \\ 703 & 703\end{array}$

$\begin{array}{llllrl}8445 & 19363 & 8583 & 20084 & 8503 & 22508\end{array}$

$\begin{array}{lllrrr}20.7 & 64.5 & 20.1 & 63.1 & 19.0 & 67.4\end{array}$

4918949391$$
4918
$$

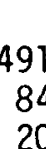

\section{7}

\begin{tabular}{ll}
176 & 64.5 \\
\hline 1842
\end{tabular}

$49013 \quad 47549$

$\begin{array}{llll}47549 & 51142 & 49646 & 531\end{array}$

$\begin{array}{lll}17521 & 8407 & 17819\end{array}$

$$
20.3
$$

$\begin{array}{rrrr}0 & 0 & 0 & 0 \\ 49013 & 47549 & 51142 & 49646 \\ 8269 & 17521 & 8407 & 17819\end{array}$

$\begin{array}{rrrr}8269 & 17521 & 8407 & 17819 \\ 20.3 & 58.3 & 19.7 & 56.0\end{array}$
1987

0

53282

22508

$53126 \quad 52406$

$8347 \quad 19017$

$18.6 \quad 57.0$

0

53126

8347
18.6 \begin{tabular}{rr}
0 & 0 \\
6 & 52406 \\
\hline 7 & 19017
\end{tabular}

19017
57.0
$19.0 \quad 67.4$

$156 \quad 3491$

1988

989

\section{Nuclear Unit_Delays as Projected_by Nuclear Reguiation_Commission}

21. Nuclear Delays

22. Actual Capability (18-21)

$\begin{array}{rrrrrrrrrr}0 & 0 & 0 & 0 & 0 & 1130 & 1130 & 1130 & 1130 & 1130 \\ 49013 & 47549 & 51142 & 49646 & 53126 & 51276 & 5902 & 54253 & 58812 & 57232 \\ 8269 & 17521 & 8407 & 17819 & 8347 & 17887 & 8977 & 19174 & 9651 & 20351 \\ 20.3 & 58.3 & 19.7 & 56.0 & 18.6 & 53.6 & 19.1 & 54.7 & 19.6 & 55.2\end{array}$

23. Actual Reserves with Nuclear Delays $(2 \hat{\imath}-\hat{c})$

20.358 .3

1/ Estimated by ERA staff based on histor:cal forced outage amounts. 
XI.2.13

\section{Table 2A.8}

Texas Interconnected Systems Group (Region 23)

\begin{tabular}{|c|c|c|c|c|c|c|c|}
\hline & $\begin{array}{c}\text { Summer } \\
(\mathrm{MW})\end{array}$ & $\begin{array}{c}\frac{-D \text { e I }}{\text { Growth }} \\
(\%)\end{array}$ & $\begin{array}{c}n d- \\
\text { Winter } \\
\text { (MW) }\end{array}$ & $\begin{array}{c}\text { Growth } \\
(\%)\end{array}$ & $\begin{array}{c}\text { Energy } R \\
\text { Amount } \\
\text { (GWh) }\end{array}$ & $\begin{array}{l}\text { irements } \\
\text { Growth } \\
(\%)\end{array}$ & $\begin{array}{c}\text { Annual } \\
\text { Load } \\
\text { Fact or } \\
(\%)\end{array}$ \\
\hline 1980 & 31621 & - & 23456 & - & 161000 & - & 58.0 \\
\hline 1981 & 33306 & 5.3 & 24795 & 5.7 & 170100 & 5.7 & 58.3 \\
\hline 1982 & 35089 & 5.4 & 26014 & 4.9 & 179300 & 5.4 & 58.3 \\
\hline 1983 & 36873 & 5.1 & 27386 & 5.3 & 188600 & 5.2 & 58.4 \\
\hline 1984 & 38796 & 5.2 & 28802 & 5.2 & 198100 & 5.0 & 58.1 \\
\hline 1985 & 40744 & 5.0 & 30028 & 4.3 & 207900 & 4.9 & 58.2 \\
\hline 1986 & 42735 & 4.9 & 31827 & 6.0 & 217900 & 4.8 & 58.2 \\
\hline 1987 & 44779 & 4.8 & 33389 & 4.9 & 227600 & 4.5 & 58.0 \\
\hline 1988 & 46925 & 4.8 & 35079 & 5.1 & 238600 & 4.8 & 57.9 \\
\hline 1989 & 49161 & 4.8 & 36881 & 5.1 & 250000 & 4.8 & 58.1 \\
\hline
\end{tabular}

1980-89

5.0

5.2

5.0 
$\mathrm{XI} .2 .14$

Table $2 A .9$

Summer 1980, 1985, 1989, Generation Mix By Fuel Type

IEXAS INTERCONNECTED SYSTEMS GROUP (REGION 23)

Type Fuel

Summer 1980

$\frac{\text { Summer } 1985}{\frac{\text { Capabilitity }}{\text { (MW) of Total }}} \frac{\text { (\%) }}{(\%)}$

$\frac{\text { Capability }}{\text { (MW) } \frac{\text { of of Total }}{(\%)}}$

Summer 1989

(MW) $(q)$

Capability q of Total

Nuclear

0

3,550

7.3

5,930

10.0

Coal

9,677

22.8

13,175

27.2

23,415

39.4

Gas

32,375

76.4

31,434

64.8

29,761

50.1

$0 \mathrm{i} 1$

97

0.2

97

0.2

97

0.1

Hydro

230

0.6

230

0.5

230

0.4

Total

$42,379 \quad 100.0$

48,486

100.0

59,433

100.0 
$X I .2 .15$

Table 2A. 10

Projected Nuclear Generating Units for the Period 1980-1989

As Reported April 1, 1980 to the Department of Energy

Texas Interconnected Systems Group (Region 23)

\begin{tabular}{|c|c|c|c|c|}
\hline Unit Name & $\frac{\frac{\text { Capability }}{(M W)}}{(10)}$ & $\begin{array}{c}\text { In-Ser } \\
\text { As Repor } \\
1979\end{array}$ & $\begin{array}{l}\text { ce Date } \\
\text { ed April } \\
1980 \\
\end{array}$ & $\begin{array}{c}\text { NRC } \\
\text { In-Service Date } \\
\end{array}$ \\
\hline Comanche Peak No. 1 & $1,150 \underline{1 /}$ & $1-81$ & $8-81$ & $8-82$ \\
\hline Comanche Peak No. 2 & $1,150 \underline{I}$ & $1-83$ & $1-83$ & $8-84$ \\
\hline South Texas Project No. 1 & $1,250 \underline{2 /}$ & $4-82$ & $2-84$ & $3-84$ \\
\hline South Texas Project No. 2 & $1,250 \underline{2 /}$ & $4-83$ & $2-86$ & $3-86$ \\
\hline Allens Creek No. 1 & $1,130 \underline{3} /$ & $6-85$ & $11-87$ & Beyond 1989 \\
\hline
\end{tabular}

1/ Joint ownership: Texas Utilities Company Systems (90\%) and Texas Municipal Power Pool (10\%).

2/ Joint ownership: Houston Lighting \& Power Co. (30.8\%), City of San Antonio (28\%), Central Power \& Light Company (25.2\%), and City of Aust in (16\%).

3/ Owned by Houston Lighting \& Power Company. 
$X I .2 .16$

Table 2A. 11

Projected Coal-fired Generating Units for the Period 1980-1989

As Reported April 1, 1980, to the Department of Energy

Texas Interconnected Systems Group (Region 23)

In-Service Date

\begin{tabular}{|c|c|c|c|c|}
\hline Unit Name & $\frac{\text { Capabil ity }}{(M W)}$ & $\frac{\text { As } \operatorname{Re}_{1}}{198}$ & $\begin{array}{l}\text { ed April } \\
1979\end{array}$ & Company \\
\hline $\begin{array}{l}\text { Coleto Creek No. } 1 \\
\text { F.P.P. No. } 2 \\
\text { W.A. Parrish No. } 7 \\
\text { Sandow No. } 4 \\
\text { Gibbons Creek No. } 1 \\
\text { W.A. Parrish No. } 8 \\
\text { Martin Lake No. } 4 \\
\text { Twin Oaks No. } 1 \\
\text { Limestone No. } 1 \\
\text { Twin Oaks No. } 2 \\
\text { Limestone No. } 2 \\
\text { Oklaunion No. 1 } \\
\text { Forest Grove No. } 1 \\
\text { Undetermined } \\
\text { F.P.P. No. } 3 \\
\text { Unassigned } \\
\text { Unassigned } \\
\text { Unassigned } \\
\text { Undetermined } \\
\text { Unassigned } \\
\text { Unassigned } \\
\text { Unassigned } \\
\text { Unassigned } \\
\text { Unassigned } \\
\text { Undetermined }\end{array}$ & 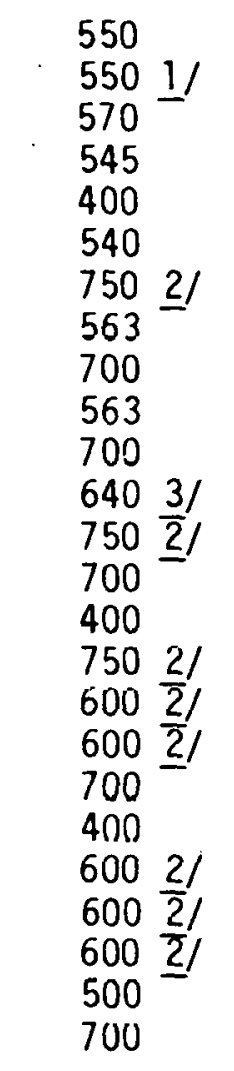 & $\begin{array}{l}3-80 \\
6-80 \\
6-80 \\
1-81 \\
6-82 \\
5-83 \\
2-85 \\
2-85 \\
4-85 \\
2-86 \\
4-86 \\
1-87 \\
1-87 \\
3-87 \\
6-87 \\
1-88 \\
1-88 \\
1-88 \\
3-88 \\
6-88 \\
1-89 \\
1=89 \\
1-89 \\
4-89 \\
4-89\end{array}$ & $\begin{array}{r}12-79 \\
6-79 \\
6-80 \\
1-81 \\
6-82 \\
12-82 \\
1-85 \\
1-84 \\
4-85 \\
1-86 \\
4-86 \\
1-87 \\
1-84 \\
4-86 \\
4-86 \\
1-87 \\
1-88 \\
1-88 \\
- \\
6-87 \\
- \\
- \\
- \\
- \\
-\end{array}$ & $\begin{array}{l}\text { Central Power \& Light Co. } \\
\text { Lower Colorado River Authority } \\
\text { Houston Lighting \& Power Co. } \\
\text { Texas Power \& Light Co. } \\
\text { Texas Municipal Power Pool } \\
\text { Houston Lighting \& Power Co. } \\
\text { Texas Utilities Co. } \\
\text { Texas Power \& Light Co. } \\
\text { Houston Lighting \& Power Co. } \\
\text { Texas Power \& Light Co. } \\
\text { Houston Lighting \& Power Co. } \\
\text { West Texas Utilities Co. } \\
\text { Texas Utilities Co. } \\
\text { Houston Lighting \& Power Co. } \\
\text { Lower Colorado River Authority } \\
\text { Texas Utilities Co. } \\
\text { Texas Utilities Co. } \\
\text { Texas Utilities Co. } \\
\text { Houston Lighting \& Power Co. } \\
\text { lexas Muntcipal Puwer Pool } \\
\text { Texas Utllities Co. } \\
\text { Texas Utilities Co. } \\
\text { Texas Utilities Co. } \\
\text { San Antonio Public Service Board } \\
\text { Houston Lighting \& Power Co. }\end{array}$ \\
\hline
\end{tabular}

I/ Joint ownership: Lower Colorado River Authority (275 MW) and City of Aust in (275 MW).

2/ Joint ownership: Texas Power \& Light Company (33 1/3 percent), Texas Electric Service Company ( $33 \mathrm{l} / 3$ percent), and Dallas Power \& Light Company ( $33 \mathrm{l} 1 / 3$ percent).

3/ Joint ownership: West Texas Utilities Company ( $307 \mathrm{MW}$ ), Central Power \& Light Company (135 MW), Southwestern Electric Power Company (148 MW) (Region 22), and Public Service Company of Oklahoma (50 MW) (Region 22). 
SECTION XI. 3

MID-ATLANTIC AREA COUNCIL

(MAAC) 


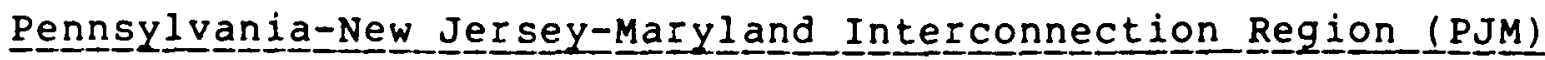

Electric $\underline{\text { E Region }} \underline{5}$

Hiistorical

The Mid-Atlantic Area Council (MAAC) region is synonymous with the Pennsylvania-New Jersey-Maryland Interconnection (PJM) operating group; thus, there are no sub-regional groups. PJM has the distinction of being the oldest inter-connected group in continuous operation in the United States. There are eleven privately-owned utility operating companies and several municipal systems and electric cooperatives associated with the group.

The PJM operations are coordinated from a single operating center with each company's resources and loads committed as a single operating entity covering the States of New Jersey (978), Maryland (608), Delaware (1008), Pennsylvania (758), and Washington, D.C. (1008). While this represents only 1.48 of the total United States area, it includes 9.38 of the total population.

The region includes a substantial area of the densely populated Northeast corridor and, as such, has considerable residential and commercial loads within several of the member companies. This is partirularly true of the potomac Electrie Power Co., which serves Washington, D.C., and has no industrial load. Several other large cities are located in the region,. including the Camden/Philadelphia area, Newark, New Jersey, and Baltimore, Maryland. There are some large industrial complexes, such as the oil refineries in New Jersey. As a result of heavy air conditioning loads, this is a summer peaking system, and presently, the winter peak is equal to about 908 of the summer peak.

The geographic location of this region is such that it is the bridge between the coal-burning utilities of the west and the imported oil-dependent utilities of the Northeast. It has a good $\mathrm{mix}$ of coal and oil generating capability with a somewhat higher base coal capability than base oil. However, oil fuel for this region is primarily imported from the Mid-East and, therefore, there is a constant pressure to reduce the use of oil as much as possible. Table $3 A .1$ indicates percentages of generation by fuel types for the years 1977 through 1979 and the percent of capability by fuel type for 1979 . 
$\mathrm{XI} \cdot 3.2$

Table 3 A. . I

Actual 1979 Capability and 1977-1979 Generating

Capacity by Fuel Type

Pennsylvania-New Jersey-Maryland Interconnection Region

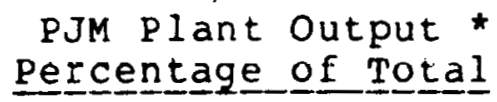

Year ㅁuclear ㅂygaro Coal oil

$\begin{array}{llllll}1977 & 20 & 3 & 49 & 28 & 1 / \\ 1978 & 22 & 2 & 46 & 30 & 0 \\ 1979 & 20 & 2 & 55 & 21 & 2\end{array}$

Plant Capability * $2 /$

Percentage of Total

1979

16

5

32

46

1

* Based on EIA Form 4 data.

$1 /$ Less than 18

2/ Includes pumped storage.

Note: For the purposes of these comparisons, the pump storage output figures have heen deleted as they generally require fossil fuel input for hydro output.

Slow growth in peak demands and increased oil conservation efforts have increased the demand for base load coal-fired generation and decreased the demand for oil and gas. As such, oil generation has been reduced in a manner that is not necessarily in proportion to the coal output increase. It is interesting to note that after the second oil embargo, there was a decided shift away from oil generation, with a small increase in gas usage. The drop in nuclear use experienced in 1979 is a direct result of the Three Mile Island Incident. 
The traditional load growth enjoyed prior to the first oil embargo was sharply reduced in 1977 with still another growth reduction experienced after the 1978 shortage which resulted from conservation efforts. Actual figures, as obtained from ERA Forms 119 and 411 , are shown in Table $3 \mathrm{~A} .2$ together with percentage of growth.

$\underline{\text { Table }} \underline{3 A} \cdot \underline{2}$

Actual Annual Net Energy, Peak Demands, and Load Factors Pennsy Ivania-New Je rsey-Mary land Interconnection Region

\begin{tabular}{|c|c|c|c|c|c|c|c|}
\hline \multirow[b]{2}{*}{ YeaI } & \multirow[b]{2}{*}{$\underline{G} \underline{W} \underline{H}$} & \multirow{2}{*}{ 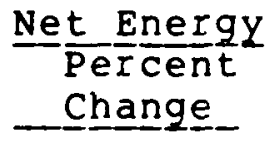 } & \multicolumn{2}{|c|}{ Summe $\frac{\text { Peak }}{\text { Percent }}$} & \multicolumn{2}{|c|}{ Winter Peak } & \multirow{2}{*}{$\begin{array}{l}\text { Load } \\
\text { Factor I }\end{array}$} \\
\hline & & & $\underline{M} \underline{W}$ & Change & $M \underline{w}$ & Change & \\
\hline $\begin{array}{l}1977 \\
1978 \\
1979\end{array}$ & $\begin{array}{l}163,377 \\
169,036 \\
171,810\end{array}$ & $\begin{array}{l}3.5 \\
1.6\end{array}$ & $\begin{array}{l}32,180 \\
31,686 \\
31,654\end{array}$ & $\begin{array}{l}-2.0 \\
-0.1\end{array}$ & $\begin{array}{l}27,967 \\
28,529 \\
27,967\end{array}$ & $\begin{array}{l}2.0 \\
(2.0)\end{array}$ & $\begin{array}{l}58 \\
61 \\
62\end{array}$ \\
\hline $\begin{array}{l}\text { Grow } \\
1977\end{array}$ & & 2.6 & & -1.1 & & 0 & \\
\hline
\end{tabular}

While the average annual growth over the 3-year actual period is 2.68 for load and a negative 18 for peak, this cannot be used to extrapolate future growth with any degree of reliability. Also, as a result of comparatively mild weather, the load factor is somewhat above normal.

Table 3A.3 shows a breakdown of the actual 1978 generation by fuel type for comparative purposes. The summer plant capability is also indicated in the table. 
Table 3 A. 3

Planned Capability and Generation by Prime Mover PennsyIvania-New Jersey-MaIy Iand Interconnection Region

PJM Capability and Generation by PIime Mover and Fuel Type = 1978

Capacity Type

Steam

Steam

Steam

Steam

Hyd ro

Pump Storage

Gas Turbine \& Diesel

Gas Turbine

Combine Cycle

Combine Cycle

Other

Total.

\section{Fuel Type}

Nuclear

Coal

Oil

Gas

-

$-$

oil

Gas

Oil

Gas

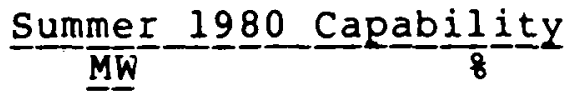

$$
7,076
$$

15,510

11,980

956

1,280

7,239

254

460

0

-

44,755
15.8

34.7

26.7

2.1

2. 9

16.2

0.6

1. 0

. 0

-

100.0

To meet these generation requirements, tuel consumption was:
31.9 million tons of coal.
9.0 million barrels of distillable oil.
$79.0 \mathrm{milli}$ ion barrels of residual oil.
9.4 millinn MCP of natural qas.

Since the Federal Energy Regulatory Commission. (FERC) gave only a temporary exemption to the prohibition of gas use by the utilities until the spring of 1980, future use of this fuel for electric generating purposes is in doubt until a new ruling is provided. 
There are at present eight nuclear units in the region and eight more under construction. The future of Three Mile Island No. 2 remains in doubt at this time with, at best, an unknown return date for the unit. Three Mile Island unit No. 1 could be available for service almost immediately, but projected NRC hearings indicate that this unit will be out of service for most of 1980 .

The PJM system had adequate reserves to meet the load during the 1977-1979 peak periods with planned reserves varying between 378 and 418 for the summer and up to 598 in the winter. After considering net sales and purchases and capacity out of service, actual reserves were reduced to 98 to 208 for summer and 78 to 268 for winter. While the reserve criteria as dictated by the PJM Agreement approximates 228 , Table 3A.4 indicates actual reserves by months for the 3-year period.

Table $\underline{3 A} . \underline{4}$

Actual Reserve Margins in Percent Pennsylvania-New Jer sey-Mar yland Inter connection Region

\begin{tabular}{|c|c|c|c|}
\hline Year & $\begin{array}{l}\text { Planned } \\
\text { Reserves }\end{array}$ & $\begin{array}{l}\text { Available } \\
\text { Reserves }\end{array}$ & $\begin{array}{l}\text { Actual } \\
\text { Reserves }\end{array}$ \\
\hline
\end{tabular}

Summer

1977

1978

1979

37.0

38.1

40.9

27.2

25.7

8.8

34.6

19.7

14.0

Winter

1977

1978

1979

58.1

56.5

59.1

43.9

38.9

36.2

19.6

25.8

6.6

The reserve policy for MAAC states that the operating reserve is generating capability and equivalent generation in excess of forecast system peak load which is available within thirty minutes or less to provide primarily for adequate tie-line regulation in the event of load variations due to equipment failure and, under certain conditions, area protection. The operating reserve is divided into primary and secondary reserves, as follows: 
1. Primary Reserve is that amount of generating capability or equivalent generation in excess of system load which is synchronized to the system or on standby and ready for immediate startup, and which is capable of being loaded within ten minutes or less to provide for adequate tie-line regulation in the event of load variations or equipment failure. The Primary Reserve is subdivided into spinning Reserve and Quick-Start Reserve.

a. Spinning Reserve is that portion of Primary Reserve synchronized to the system.

b. Quick-Start Reserve is any remaining portion of Primary Reserve, adjusted by a factor to allow for the probability of failure of equipment to start. The pumping load of pumped storage hydro plants, when counted as Primary Reserve, is considered to fall within this category.

2. Secondary Reserve is that generating capability or equivalent generation in excess of system load which is either synchronized to the system or on standby and ready for startup, and which is capable of being loaded within from ten to thirty minutes of the occurrence of a contingency.

In addition, there are load reduction programs to meet emergencies in the event of insutticient operaring reserve. Table $3 \mathrm{~A} .5$ indicates the reduction procedures and the estimated load reduction: 
Táble

Emergency Curtailment procedures

Pennsylvania-New Jersey-Maryland Interconnection Region

\section{Procedure}

1. Curtailment of nonessential power company station light and power load

2. Voltage reduction of 38 Voltage reduction of 58

3. Curtailment of nonessential load in power company buildings

4. Voluntary customer load curtailment as required up to a maximum of -- Summer

$$
\text { -- Winter }
$$

5. Radio and television load curtailment appeal

6. Manual load dumping.
Estimated Peak Load Reduction

$75 \mathrm{MW}$

$425 \mathrm{MW}$

$500 \mathrm{MW}$

$25 \mathrm{MW}$

$1,400 \mathrm{MW}$

$600 \mathrm{MW}$

Dependent upon public response

As required, up to $10,000 \mathrm{MW}$ on a procedural basis

The need for load reduction procedures is assessed for the interconnection as a whole by the PJM Interconnection Dispatcher, who then notifies the PJM member systems of the total requirement and their share. In the absence of constraining local conditions, each member system initiates the specified procedure to reduce load in an amount equal to its prearranged share of the interconnection requirement.

In addition to these manual procedures, underfrequency relays are installed to shed load automatically in the event of a power shortage which has caused system frequency to decay. Approximately 308 of the inter-connection load can be shed in this manner:

$\begin{array}{cc}\text { Freguency } & \text { Minimum Load Dumped } \\ 59.3 \mathrm{~Hz} & 108 \\ 58.9 \mathrm{~Hz} & 108 \\ 58.5 \mathrm{~Hz} & 108\end{array}$


The underfrequency relays are sufficiently distributed throughout PJM so that if any major area becomes isolated with generation deficiency and experiences declining frequency, 108 of that area's load will automatically be shed at each frequency listed above.

The system companies also have a number of interruptible load contracts with fourteen customers. The total load that can be interrupted is $206 \mathrm{MW}$ from industrial accounts with a normal aggregate load of 250 , MW. Table 3 A.6 shows the additional detaj.l.

Table 3 A. 6

Interruptible Load contracts *

Pennsylvania-New Jersey-Maryland Interconnection Region

\begin{tabular}{|c|c|c|c|c|}
\hline & DEEPL & GPU & PSEG & TOTAL \\
\hline No. of Customers & 3 & 1 & 10 & 14 \\
\hline Total Load (KW) & 119.4 & 17.0 & 113.7 & 250.1 \\
\hline Interrupt Load ( $\mathrm{KW})$ & 98.5 & 10.0 & 93.5 & 206.0 \\
\hline Max. Time (Hrs./IR) & - & 150 & 150 & - \\
\hline Max. Fiéci. (l'lme/IK) & - & 20 & 15 & - \\
\hline Lead Time (Mins.) & 30 & 15 & 120 & - \\
\hline Reaction Time (Mins.) & 30 & 15 & 120 & - \\
\hline Vehicle for Interruption & Phone & Phónè & thone & - \\
\hline Cause of Interruption & $\begin{array}{r}\text { High } \\
\text { Demand }\end{array}$ & $\begin{array}{r}\text { High } \\
\text { Demand }\end{array}$ & $\begin{array}{r}\text { High } \\
\text { Demand }\end{array}$ & - \\
\hline
\end{tabular}

* Based on 1978 ERA study. 
The geographic situation of PJM puts it into an ideal location for wheeling of energy for the purposes of fuel conservation. This was more than adequately demonstrated when, during the coal strike, oil-fueled generation was moved from East to West (from the oil-fired plants of New England and New York to the coaldependent utilities of the West). More recently, the reverse has been proven in the coal-by-wire oil conservation transfers of energy West to East. The transmission is basically strong in both the East and West portions of the system. There are approximately 1,263 circuit miles of $500 \mathrm{KV}$ lines, 160 circult miles of $345 \mathrm{KV}$ lines, and 4,400 circuit miles of $230 \mathrm{KV}$ lines. Included are 53 inter-system connection points and 27 interpool connection points with New York Power Pool, The Cleveland Electric Illuminating Co., Allegheny Power System and Virginia Electric Power Company. At present, East-West intra-regional energy transfers are somewhat constrained due to construction slippage of the HossensackElroy $500 \mathrm{KV}$ line and the $500 \mathrm{KV}$ loop around washington, D.C. The delays in completion of these lines are primarily regulatory oriented with particular problems resulting from state commissions in the area of environmental impacts.

\section{Current}

The anticipated 1980 summer peak demand for the PJM system is $33,550 \mathrm{MW}$ and is expected to occur in August. This would be an increase of 5.68 over the previous summer and is a reversal of the decreasing trend the area has been experiencing for the past two years, and only 4.38 above the previous highest peak of $32,180 \mathrm{MW}$ in 1977. The winter peak is expected to be $29,850 \mathrm{MW}$, an increase of 6.78 over 1978. Total net energy for 1980 is anticipated at 177,848 GWH which is 3.58 above 1979--a somewhat larger increase than experienced in the previous year. The annual load factor on the summer peak would then be 608 . The 1980 planned winter capability to meet the load is $48,809 \mathrm{MW}$; and the summer capability is $44,755 \mathrm{MW}$. Table $3 \mathrm{~A} .7$ indicates the loads, resources and reserves for the 1980 summer and winter peaks. 
Table $3 \mathrm{~A} .7$

1980 Reserve Margins *

Pennsylvania-New Je $\frac{1}{I}$ Sey

\begin{tabular}{lrr} 
& Summer & Winter \\
\cline { 3 - 3 } Planned Capability - MW & 44,755 & 48,809 \\
Peak Demand - MW & 33.550 & 29,850 \\
Planned Reserve- & 33.4 & 63.5 \\
Net Transaction -MW & 157 & 157 \\
Total Reserves - MW & 11,362 & 19,116 \\
Total Reserves - 8 & 33.9 & 64.0 \\
Available Reserve - MW & 10,034 & 14,285 \\
Available Reserve - & 29.9 & 47.9 \\
* Based on ERA 4l1 Report & &
\end{tabular}

As indicated in Table $3 \mathrm{~A} .7$ for the year 1980 , the region will have adequate reserves well above the PJM Agreement criterion of 22 percent. The reserves indicated in lable $3 \mathrm{~A} .7$ do not include forced outages which generally run 15 percent daily, but are now at about 17 percent, due to the Three Mile Island outage. Thus, including the Three Mile Island outage in the available reserves, would adjust these figures downward to the 27.8 percent and 45.9 percent respectively.

To meet the system requirements of $177,848 \mathrm{GWH}$, it is expected that the region's plants will consume approximately 35 million tons of coal, 8 million barrels of distillate oil, $63 \mathrm{million}$ barrels of residual oil and $10 \mathrm{million}$ MCF natural gas.

The transmission system for 1980 is adequate for scheduled energy transfers, but has little reserve capacity for economy transfers without adversely affecting the reliability for emergency interchange. Among the constraints are the HoosensackElroy $500 \mathrm{KV}$ line, for which regulatory approval to begin construction was granted in December 1979. The line was originally scheduled for service in 1974; however, with a 12- to 16-month construction time, it will not be ready for service until the summer of 1981 . When completed, it will be a third west-East $500 \mathrm{KV}$ transmission path and will increase the capability of Eastern MAAC to import power. Another critical line under construction is the $500 \mathrm{KV}$ Baltimore-Washington Loop. The absence of these two lines reduces the GAP ability of the system to transfer coal by wire to the Northeast. 
The Three Mile Island Plant outage (which is considered a forced outage for the purpose of this report) is creating a voltage problem in Central Pennsylvania; and until salem $\$ 2$ Nuclear Plant comes on line in October 1980, there will also be a voltage problem in Eastern PJM.

In addition to the $500 \mathrm{KV}$ lines under construction, approximately 180 miles of $230 \mathrm{KV}$ transmission lines are scheduled for installation during 1980. These lines are primarily for local area protection and increased load-carrying capacity.

\section{Future}

Forecasts for the 1981-1989 time frame include a summer peak load growth of $2.6 \%$ per year average. However, for the first five years of the period, the anticipated peak growth is projected at 2.88. During the same 9-year period, the energy requirements are expected to grow by approximately 3.28. Detailed tables of the period load and capability growth are included in Tables $3 \mathrm{~A} .14 .1$ and $3 \mathrm{~A} .14 .2$. Table $3 \mathrm{~A} .8$ outlines the projected energy and peak demand growth during this period.

Table 3 A. 8

Projected Energy and Peak Demand Pennsylvania New Jer se y-Mary and Inter connection Region

\begin{tabular}{|c|c|c|c|c|c|c|c|}
\hline & $\begin{array}{r}\text { EI } \\
\text { Regu }\end{array}$ & $\begin{array}{l}\text { ergy } \\
\text { ements }\end{array}$ & $\begin{array}{r}\text { Su } \\
\text { Peak } \\
\end{array}$ & $\begin{array}{l}\text { mmer } \\
\text { Demand }\end{array}$ & $\begin{array}{r}W i \\
\text { Peak }\end{array}$ & $\begin{array}{l}\text { nter } \\
\text { Demand }\end{array}$ & $\begin{array}{l}\text { Annual } \\
\text { Load } \\
\text { Factor }\end{array}$ \\
\hline & $\bar{G}$ Wh & $\underset{8}{\mathrm{G}}$ & $\bar{M} \bar{W}$ & $\begin{array}{c}\text { Growth } \\
8\end{array}$ & $\overline{M W}$ & $\underset{8}{\text { Growth }}$ & 8 \\
\hline $\begin{array}{l}1981 \\
1982 \\
1983 \\
1984 \\
1985\end{array}$ & $\begin{array}{l}184476 \\
191391 \\
197578 \\
204058 \\
210729\end{array}$ & $\begin{array}{l}3.7 \\
3.7 \\
3.2 \\
3.3 \\
3.3\end{array}$ & $\begin{array}{l}34550 \\
35610 \\
36590 \\
37000 \\
38600\end{array}$ & $\begin{array}{l}2.9 \\
3.0 \\
2.7 \\
2.7 \\
2.6\end{array}$ & $\begin{array}{l}30980 \\
32000 \\
33080 \\
34230 \\
35370\end{array}$ & $\begin{array}{l}3.8 \\
3.3 \\
3.4 \\
3.5 \\
3.2\end{array}$ & $\begin{array}{l}61.0 \\
61.4 \\
61.7 \\
62.0 \\
62.4\end{array}$ \\
\hline th $81-85$ & & 3.4 & & 2.8 & & 3.4 & \\
\hline $\begin{array}{l}1986 \\
1987 \\
1988 \\
1989\end{array}$ & $\begin{array}{l}217542 \\
223997 \\
230362 \\
236938\end{array}$ & $\begin{array}{l}3.2 \\
3.0 \\
2.8 \\
2.9\end{array}$ & $\begin{array}{l}39600 \\
40550 \\
41440 \\
42370\end{array}$ & $\begin{array}{l}2.6 \\
2.4 \\
2.2 \\
2.2\end{array}$ & $\begin{array}{l}36530 \\
37560 \\
38610 \\
39670\end{array}$ & $\begin{array}{l}3.2 \\
2.8 \\
2.8 \\
2.7\end{array}$ & $\begin{array}{l}62.8 \\
63.1 \\
63.5 \\
63.9\end{array}$ \\
\hline $\begin{array}{ll}\text { wth } & 86-89 \\
\text { wth } & 81=89\end{array}$ & & $\begin{array}{l}2.9 \\
3.2\end{array}$ & & $\begin{array}{l}2.3 \\
2.6\end{array}$ & & $\begin{array}{l}2.8 \\
3.1\end{array}$ & \\
\hline
\end{tabular}


$\mathrm{XI} \cdot 3.12$

Table 3A.9

Projected Reserves *

Pennsylvania-New Jersey-Maryland Interconnections Region

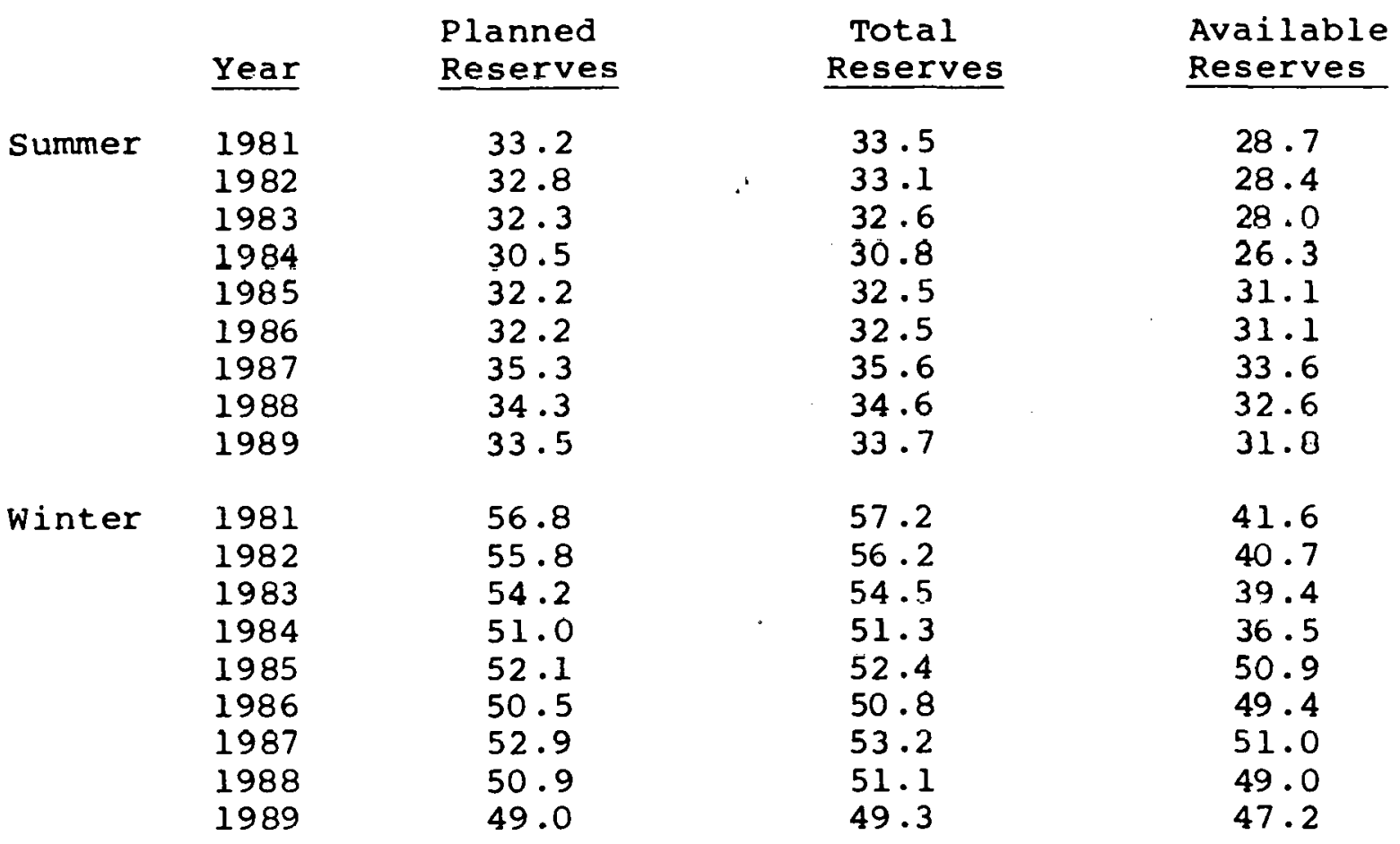

* Bascd on ERA Form 411.

These reserves do not include forced outages and are somewhat larger than the PJM Agreement criteria, but are based on timely completion of all new equipment. Historically, this has not been the situation; and to reinforce this premise, unit slippages are outlined later in this report.

To meet the projected increases, approximately 13,100 MW of new base load generating capacity is planned, of which about $8,900 \mathrm{MW}$ will be nuclear and 4,200 MW coal-fired. The nuclear additions will increase its proportional share of energy output from $20 \%$ in 1979 to about 288 in 1989. By 1989, the capacity breakdown would be $28 \%$ nuclear, 358 coal and 338 oil. 
Table 3A.10 indicates the fuel percentages for each capacity type for the years 1984 and 1989, at the time of the summer peak.

Table 3A.10

Summer Capacity by Fuel Type

Pennsylvania-New Jersey-Maryland Interconnection Region

\begin{tabular}{|c|c|c|c|}
\hline Capacity Type & Fuel Type & $\begin{array}{l}\frac{1984}{8 \text { of }} \\
\text { Total }\end{array}$ & $\begin{array}{l}\frac{1989}{8 \text { of }} \\
\text { Total } \\
\end{array}$ \\
\hline $\begin{array}{l}\text { Steam } \\
\text { Steam } \\
\text { steam } \\
\text { steam }\end{array}$ & $\begin{array}{l}\text { Nuclear } \\
\text { Coal } \\
\text { Oil }\end{array}$ & $\begin{array}{l}20.7 \\
33.6 \\
25.1\end{array}$ & $\begin{array}{l}27.7 \\
35.2 \\
20.2\end{array}$ \\
\hline $\begin{array}{l}\text { Steam } \\
\text { Hydro }\end{array}$ & Gas & - & - \\
\hline $\begin{array}{l}\text { Hydro } \\
\text { Pumped storage }\end{array}$ & - & 2.0 & 1.9 \\
\hline $\begin{array}{l}\text { Pumped Storage } \\
\text { Gas Turbine }\end{array}$ & - & 2.6 & 2.3 \\
\hline $\begin{array}{l}\text { Gas Turbine } \\
\text { Gas Turbine }\end{array}$ & Oil & 14.6 & 11.5 \\
\hline Gas Turbine & Gas & 0.5 & 0.4 \\
\hline $\begin{array}{l}\text { Combined Cycle } \\
\text { Combined Cycle }\end{array}$ & Oil & 0.9 & 0.8 \\
\hline Combined Cycle & Gas & - & - \\
\hline
\end{tabular}


Table $3 \mathrm{~A} .11$ shows the major nuclear and coal units planned or under construction for the region. Shown in the table is the slippage experienced for each of the units, indicating the probability of a reduction in reserves should the forecast materialize as predicted.

Table 3A.11

Major Future Generating Unit In-Service Dates Pennsylvania-New Jersey-Maryland Interconnection Region

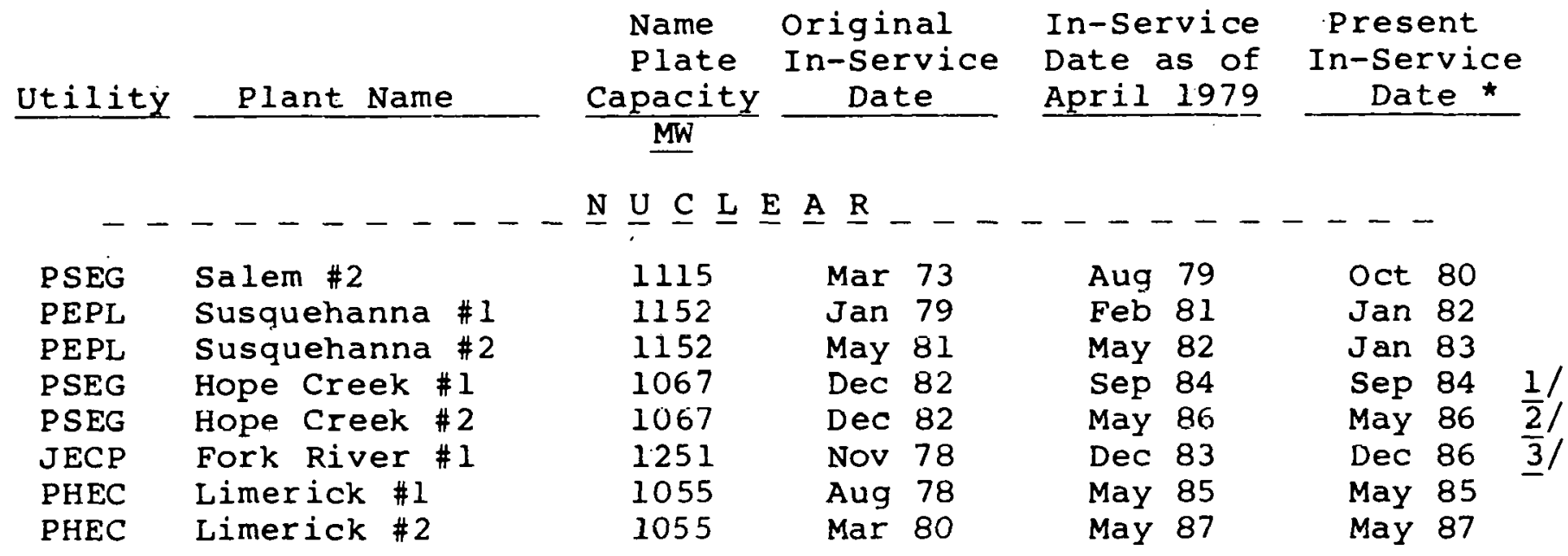

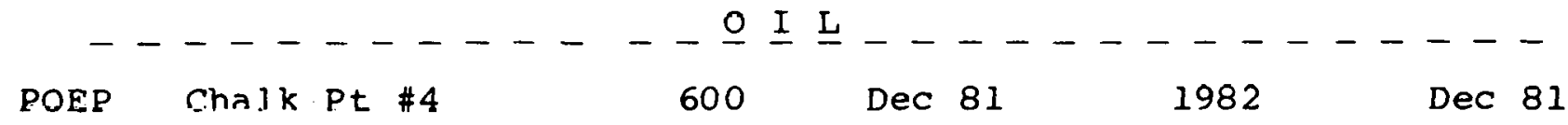
C_O_A_L_ - - - - - - - - - -

$\begin{array}{llllll}\text { DEPL } & \text { Indian River \#4 } & 446 & \text { May 79 } & \text { Sep 80 } & \text { Sep 80 } \\ \text { BAGE } & \text { Brandon Shores \#1 } & 625 & \text { Jan 81 } & \text { Jan 82 } & \text { May } 84 \\ \text { BAGE } & \text { Brandon Shores \#2 } & 625 & \text { May 85 } & \text { Jan 84 } & \text { Jan 88 }\end{array}$




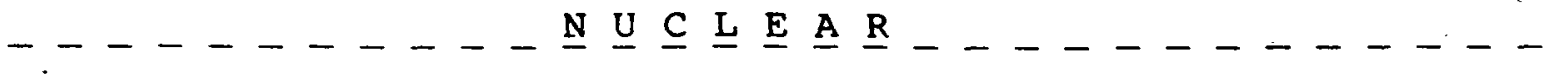

$$
\begin{aligned}
& \text { - None - } \\
& --------\ldots \text { - } \underline{\mathrm{I}} \underline{\mathrm{L}}--\ldots \\
& \text { - Non e - } \\
& --\ldots--\ldots-\ldots-C_{-} \mathrm{O}_{-} \mathrm{A}_{-} \mathrm{L}_{-}-\ldots-\ldots-\ldots
\end{aligned}
$$

$\begin{array}{llllll}\text { PUEP } & \text { Dickerson \#1 } & 800^{-1 /} & \text { Mar 82 } & 1987 & \text { May } 87 \\ \text { PEEC } & \text { Seward \#7 } & 625 & \text { May } 84 & \text { Dec } 85 & \text { May } 87 \\ \text { PEEC } & \text { COHO \#1 } & 625 & \text { May 86 } & \text { May 8 } & \text { May } 89 \\ \text { DEPL } & \text { Vienna \#9 } & 500 & \text { May } 87 & \text { May } 87 & \text { May } 87\end{array}$

* Based on Form ERA-119

1/ ERA all-service date $5 / 85$

2/ ERA all-service date $5 / 87$

3/ ERA all-service date $5 / 86$

4/ Only $400 \mathrm{MW}$ reported; $400 \mathrm{MW}$ uncommitted.

PJM companies indicate that some additional construction slippage is foreseen from the schedules prepared for this report. These are shown on Table $3 A .11$.

The most critical additional transmission line for the near term period is the $500 \mathrm{KV}$ loop around the Washington, D.C., metropolitan area. Completion of this line has been delayed until 1983 due to regulatory problems. When completed, the line will improve stability in the Baltimore/Washington area and increase MAAC transfer capability with the adjacent ECAR and VACAR regions. By 1984, the inter-regional emergency net transfer capabilities from adjacent NPCC, ECAR, and SERC (VACAR) regions are anticipated as follows:

$\begin{aligned} \text { NPCC to MAAC: } & 2,250 \mathrm{MW} \\ \text { ECAR to MAAC: } & 4,850 \mathrm{MW} \\ \text { VACAR to MAAC: } & 4,850 \mathrm{MW}\end{aligned}$

Note: Net transfers are incremental over base scheduled transfers or incremental over owned generation outside a company's boundary. 
XI. 3.16

Planned, under construction, or comnitted transmission lines for the future are:

\begin{tabular}{|c|c|c|}
\hline $\mathrm{KV}$ & $\begin{array}{c}\text { Miles } \\
(1979-1983)\end{array}$ & $\begin{array}{c}\text { Miles } \\
(1984-1988)\end{array}$ \\
\hline $\begin{array}{l}230 \\
345 \\
500\end{array}$ & $\begin{array}{r}789 \\
16 \\
376\end{array}$ & $\begin{array}{l}496 \\
17 \\
83\end{array}$ \\
\hline
\end{tabular}

Total existing and planned as of December 31,1988 :

\begin{tabular}{lr} 
KV & Miles \\
\hline 230 & 5,580 \\
345 & 193 \\
500 & 1,722
\end{tabular}

[Based on NERC 9 th Annual Review.]

Scheduled imports for the 1980 through 1989 period include $50 \mathrm{MW}$ from APS (through 1980) and $107 \mathrm{MW}$ from PASNY. There are no scheduled exports. 
HISTORICAL CAPABILITY (MW) AND RESERVES (MW and Percent).

PJM Region

\begin{tabular}{|c|c|c|c|c|c|c|}
\hline & \multicolumn{2}{|c|}{1977} & \multicolumn{2}{|c|}{1978} & \multicolumn{2}{|c|}{1979} \\
\hline & Summer & Winter & Summer & Winter & Summer & Winter \\
\hline 1. Planned Capability & 44084 & 44212 & 43748 & 44660 & $4461 \cdot 3$ & 44499 \\
\hline 2. Peak Demand & 32180 & 27967 & 31686 & 28529 & 31654 & 27967 \\
\hline 3. Planned Reserves (1-2) & 11904 & 16245 & 12062 & 16131 & 12959 & 16532 \\
\hline 4. Planned Reserves $(x)(3 / 2) \times 100$ & 37.0 & 58.1 & 38.1 & 56.5 & 40.9 & 59.1 \\
\hline 5. Net Transactions (Imports-Exports) & 50 & 50 & 180 & 180 & 180 & 180 \\
\hline 6. Total Capability $(1+5)$ & 44134 & 44262 & 43928 & 44840 & 44793 & 44679 \\
\hline 7. Total Reserves (6-2) & 11954 & 16295 & 12242 & 16311 & 13139 & 16712 \\
\hline 8. Total Reserves $(\%)(7 / 2) \times 100$ & 37.1 & 58.3 & 38.6 & 57.2 & 41.5 & 59.8 \\
\hline 9. Scheduled Maintenance & 1035 & 2154 & 1559 & 4689 & 1459 & 5414 \\
\hline 10. Capability after Maintenance (6-9) & 43099 & 42108 & 42369 & 40151 & 43334 & 39265 \\
\hline 11. Reserves after Maintenance $(10-2)$ & 10919 & 14141 & 10683 & 11622 & 11680 & 11298 \\
\hline 12. Reserves after Maintenance $(\%)(11 / 2) \times 100$ & 33.9 & 50.6 & 33.7 & 40.7 & 36.9 & 40.4 \\
\hline 13. Inoperable Capability & 2163 & 1871 & 2548 & 523 & 725 & 1167 \\
\hline 14. Available Capability (10-13), & 40936 & 40237 & 39821 & 39628 & 42609 & 38098 \\
\hline 15. Available Reserves (14-2) & 8756 & 12270 & 8135 & 11099 & 10955 & 10131 \\
\hline 16. Available Reserves (q) $(15 / 2) \times 100$ & 27.2 & 43.9 & 25.7 & 38.9 & 34.6 & 36.2 \\
\hline 17. Forced Outages & 5928 & 6802 & 1907 & 3739 & 6519 & 8283 \\
\hline 18. Actual Capability after Forced Outages (14-17) & 35008 & 33435 & 37914 & 35889 & 36090 & 29815 \\
\hline 19. Actual Reserves (18-2) & 2828 & 5468 & 6228 & 7360 & 4436 & 1848 \\
\hline 20. Actual Reserves (\%) $(19 / 2) \times 100$ & 8.8 & 19.6 & 19.7 & 25.8 & 14.0 & 6.6 \\
\hline
\end{tabular}


Table $3 A .13$

CURRENT CAPABILITY (MW) AND RESERVES (MW and Percent) PJM Region

1. Planned Capability

2. Peak Demand

3. Planned Reserves (1-2)

4. Planned Reserves (\%) $(3 / 2) \times 100$

5. Net Transactions (Imports-Exports)

6. Total Capability $(1+5)$

7. Total Reserves (6-2)

8. Total Reserves (\%) $(7 / 2) \times 100$

9. Scheduled Maintenance

10. Capability after Maintenance (6-9)

11. Reserves after Maintenance (10-2)

12. Reserves after Maintenance (\%) (11/2) $\times 100$

13. Inoperable Capability

14. Available Capability (10-13)

15. Available Reserves (14-2)

16. Available Reserves (\%) $(15 / 2) \times 100$

17. Forced Outages

18. Actual Capability after Forced Outages (14-17)

19. Actual Reserves (18-2)

20. Actual Reserves (\%) $(19 / 2) \times 100$
1980

Summer

44755

33550

11205

33.4

157

44912

11362

33.9

1300

43612

10062

30.0

28

43584

10034

29.9

0

43584

10034

29.9
1980/81

Winter

48809

29850

18959

63.5

157

48966

19116

64.0

4550

44416

14566

48.8

281

44135

14285

47.9

0

44135

14285

47.9 
Table 3A.14.1

FUTURE CAPABILITY (MW) AND RESERVES (MW and Percent) - 1981-84

PJM Region

1. Planned Capability

2. Peak Demand

3. Planned Reserves (1-2)

4. Planned Reserves (\%) (3/2) $\times 100$

5. Net Transactions (Imports-Exports)

6. Total Capability $(1+5)$

7. Total Reserves (6-2)

8. Total Reserves ( $\%)(7 / 2) \times 100$

9. Scheduled Maintenance

10. Capability after Maintenance (6-9)

11. Reserves after Maintenance (10-2)

12. Reserves after Maintenance (\%) $(11 / 2) \times 100$

13. Inoperable Capability

14. Available Capabitity (10-13)

15. Available Reserves (14-2)

16. Available Reserves ( $\%)(15 / 2) \times 100$

17. Forced Outages 1/

18. Actual Capability after Forced Outages (14-17)

19. Actual Reserves (18-2)

20. Actual Reserves $(x)(19 / 2) \times 100$
1981

Summer

46010

34550

11460

33.2

107

46117

11567

33.5
1400

44717

10167

29.4

259
4458

44458

9908

28.7
0

44458

9908

28.7 Wint

Nuclear Unit_Delays as_Projected_by Nuclear Regulation_Comission

21. Nuclear Delays

22. Actual Capability (18-21)

23. Actual Reserves with Nuclear Delays (22-2)

24. Actual Reserves with Nuclear Delays $(\%)(23 / 2) \times 100$

44458
9908

9908

0
43864
12884

12884
41.6
1983

Summer

\section{1}

35610

11691

11691
32.8

107

47408

11798

33.1

1450

45958

10348

29.1

23

45727

10117

28.4

45727

10117

28.4
882 Winter

32000

55.8

107

49976

17.776

55.2

$$
4700
$$

45276

13276

41.5

253
45023

13023

40.7

45023

13023

40.7

\begin{tabular}{rr}
\multicolumn{2}{c}{1983} \\
\cline { 1 - 1 } Summer & Winter \\
48413 & 51000 \\
36590 & 33080 \\
11823 & 17920 \\
32.3 & 54.2 \\
107 & 107 \\
48520 & 51107 \\
11930 & 18027 \\
32.6 & 54.5 \\
1550 & 4850 \\
46970 & 46257 \\
10380 & 13177 \\
28.4 & 39.8 \\
120 & 128 \\
46850 & 46129 \\
10260 & 13049 \\
28.0 & 39.4 \\
0 & 0 \\
46850 & 46129 \\
10260 & 13049 \\
28.0 & 39.4
\end{tabular}

1984

Summer Winter

$49085 \quad 51683$

$37600 \quad 34230$

$11.485 \quad 17453$

$30.5 \quad 51.0$

$\begin{array}{rr}107 & 107 \\ 49192 & 51790\end{array}$

$11592 \quad 17560$

$30.8 \quad 51.3$

$1600 \quad 4950$

$47592 \quad 46840$

$9992 \quad 12610$

$26.6 \quad 36.8$

$120 \quad 128$

$47472 \quad 46712$

$9872 \quad 12482$

$26.3 \quad 36.5$

$47472 \quad 46712$

$9872 \quad 12482$

$26.3 \quad 36.5$

I/ Information not available. 
FUTURE CAPABILITY (MW) AND RESERVES (MW and Percent) - 1985-89

P JM Region

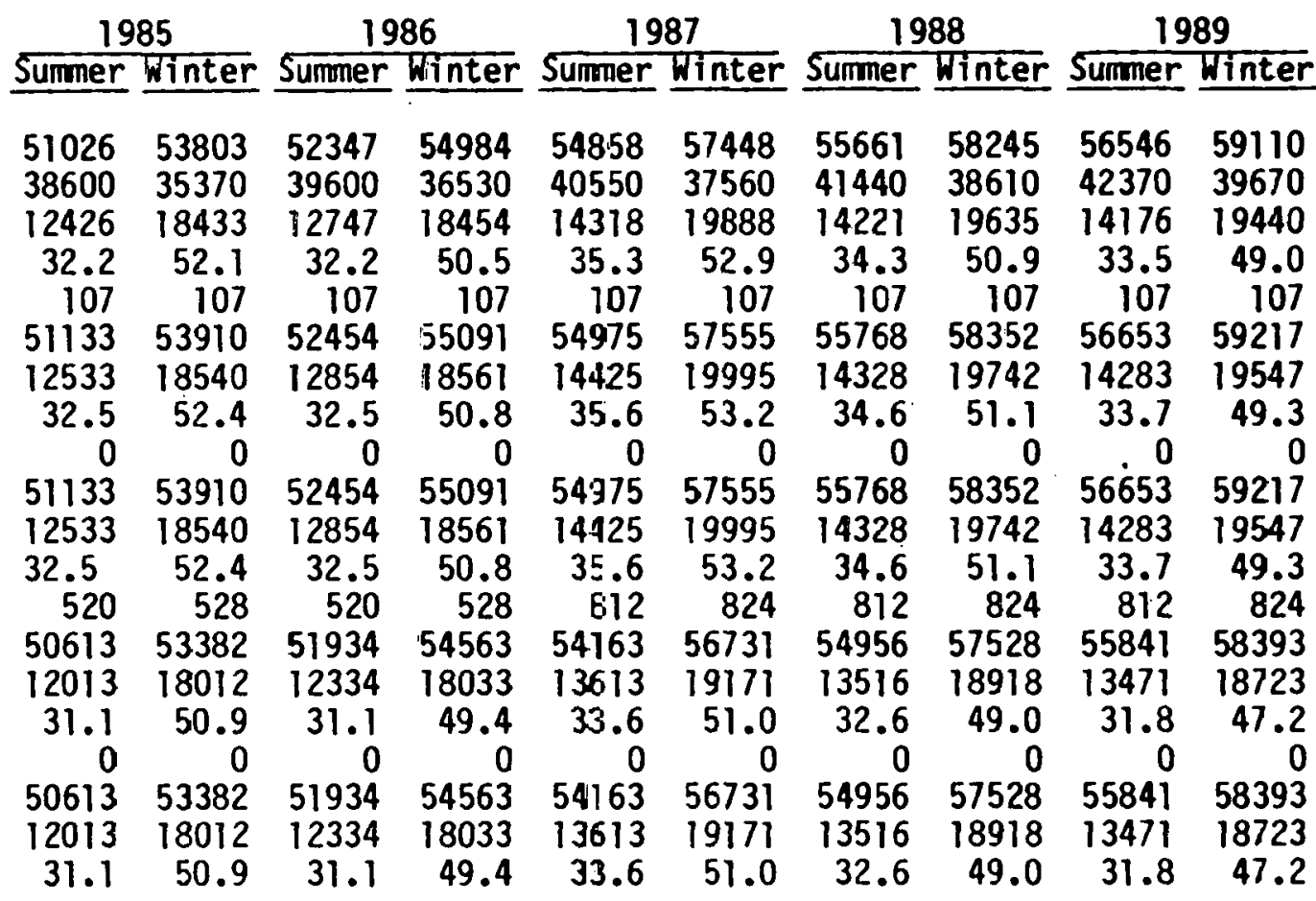

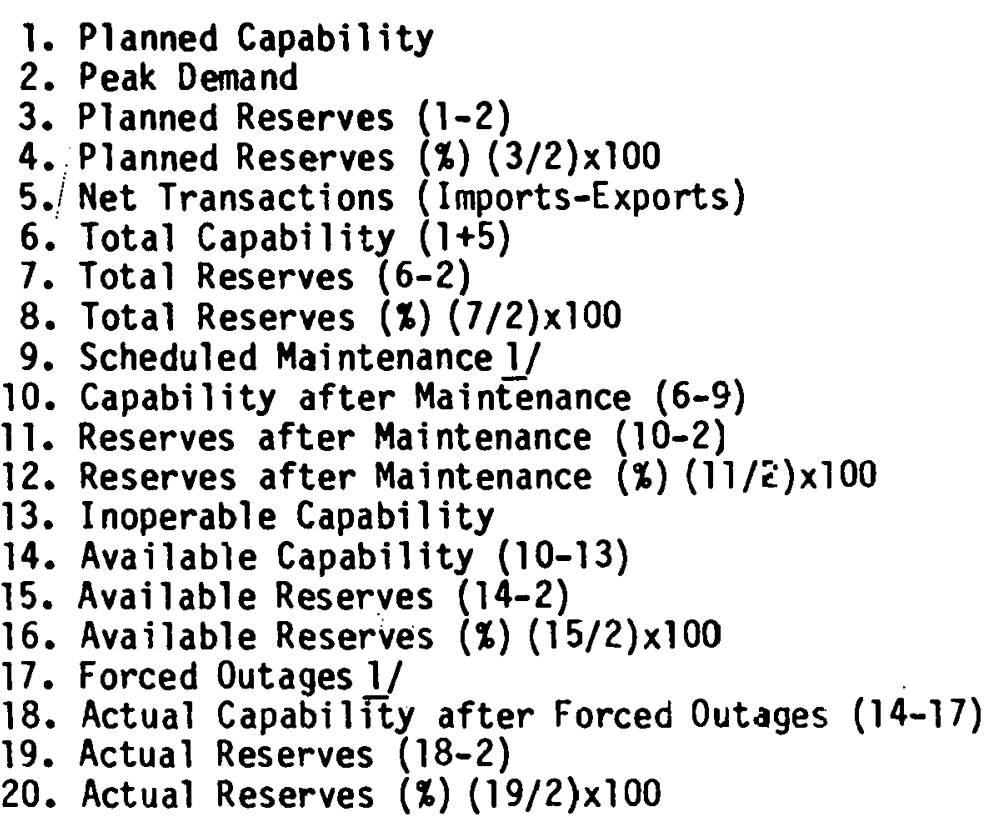

Nuclear U-it_Delays as. Frojected by Nuclear Regulation_Commission

21. Nuclear Delays

22. Actual Capability (18-21)

$\begin{array}{rrrrrrrrrr}0 & 0 & 0 & 1067 & 0 & 0 & 0 & 0 & 0 & 0 \\ 50613 & 53382 & 51934 & 53496 & 54163 & 56731 & 54956 & 57528 & 55841 & 58393 \\ 12013 & 18012 & 12334 & 16939 & 13513 & 19171 & 13516 & 18918 & 13471 & 18723\end{array}$

23. Actual Reserves with Nuclear Delays $(22-2)$

$\begin{array}{rrrrrrrrrr}12013 & 18012 & 12334 & 16939 & 13513 & 19171 & 13516 & 18918 & 13471 & 18723 \\ 31.1 & 50.9 & 31.1 & 46.4 & 33.6 & 51.0 & 32.6 & 49.0 & 31.8 & 47.2\end{array}$

I/ Information not available. 
SECTION XI. 4

MID-AMERICA INTERPOOL NETWORK

(MAIN) 
The Main region includes all of Illinois and parts of Michigan, Wisconsin and Missouri. The planning of construction and the utilization of generation and transmission facilities for purposes of improved reliability and adequacy of bulk power supply within the region are coordinated through a formal agreement, the Mid-America Interpool Network (MAIN), which was originally signed by participants in 1964. There are 13 regular members of MAIN, composed of investor-owned, rural cooperatives and municipal power suppliers, and four associate members. Collectively, these utilities represent essentially all the power resources within the region.

Additional coordination within MAIN is effected through agreements among the various utility systems and several power pooling groups have been formed: the Illinois-Missouri Pool (ILLMO); the Wisconsin Power Pool (WIPP) and the Wisconsin-Upper Michigan Systems (WUMS).

The power pools can be geographically grouped within the following DOE Electric Region boundaries:

Electric: Region 6 - Commonwealth Electric Company: Commonwealth Edison Company

Electric Region 17 - Illinois-Missouri Group: ILLMO Pool

Electric Region 19 - Wisconsin-Upper Michigan Systems Group: WUMS and WIPP Pools 


\section{COMMONWEALTH EDIISON}

ELECTRIC REGION 6

Electric Region 6 geographically covers the northern portion of Illinois and is comprised essentially of the service area of the Commonwealth Edison Company. In addition to Commonwealth Edison, data for two small Illinois municipal electric systems within the same geographic area are included in this report -Rochelle, Illinois and winnetka, Illinois. These electric systems data are included also in the main ERA-4ll report. The region has a diverse mixture of commerce, industry and agriculture.

The electric systems in the region provide service to eight million people in an 11,525 square mile area including about 400 municipalities and the city of Chicago. They serve approximately $2.9 \mathrm{milli}$ on customers, $2.6 \mathrm{million}$ are residential and the remainder commercial and industrial customers. The utility has $765 \mathrm{kV}$ and $345 \mathrm{kV}$ interconnections with the Indiana and Michigan Electric Company in ECAR and $345 \mathrm{kV}$ ties with Northern Indiana Public service company, also in ECAR. In addition, there are $345 \mathrm{kV}$ ties with the Illinois Power Company, Central Illinois Light Company and Wisconsin Electric Power in MAIN and with Iowa-Illinois in MARCA.

The Commonwealth Edison Company has approximately 40 percent of the total generating capability in MAIN and is a major subgroup of the MAIN organization.

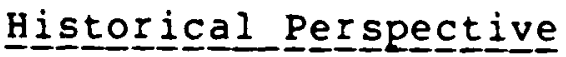

CECO has historically been a summer-peaking region. The summer and winter peaks for the period 1977-1979 are shown below.

Table 4 A. .1

Historical Peak Demand-MW CE $\bar{C}$ CO Regín

$S$ U M M E R

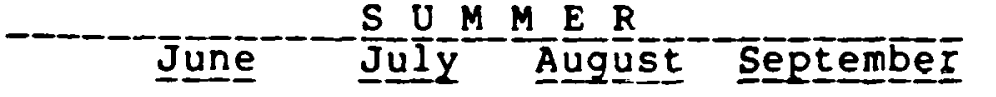

$1977 \quad 12,236$

$1978 \quad 12,851$

$1979 \quad 12,146$

10,733

$\frac{1}{1} \frac{3}{3}, \frac{9}{5} \frac{32}{1}$

10,211

13,675

12,553

13,804

$\frac{1}{1} \frac{3}{1}, \frac{720}{446}$

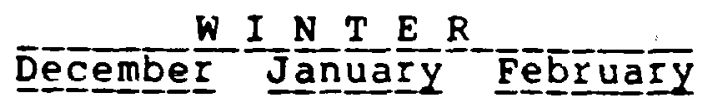

Underline indicates seasonal peak 
The summer peak demands are dependent on climatic conditions ano are temperature/humidity sensitive. usually the peak will occur in July or August, but in 1978 it occurred in september.

The winter peak usually occurs in January and generally is in the order of 20 percent less than the summer peak. Advantage is taken of this difference in magnitude between the summer and winter peaks for the performance of scheduled maintenance. The following table shows the scheduled maintenancc ferfusllit each period and also the capability unavailable because of forced outages or otherwise inoperatle.

Table 4 A .2

\section{SCYYEIUIEE NAINTENANCE ALI UNAVAILAEIE_CAFAPIIITIES} $\underline{C} \bar{E} \overline{C O} \bar{R} \bar{E} \bar{C} \overline{I O N}$

\begin{tabular}{|c|c|c|c|c|c|}
\hline$\underline{S} \underline{I}$ & $N \underline{F} R$ & & & $N T E$. & \\
\hline Schedù $\overline{\mathrm{e}}$ & $\overline{O t h} \bar{e} \bar{r}$ & Total & $\bar{s} \bar{c} \bar{e} \bar{d} \bar{l} \bar{e} \bar{d}$ & other & T̄OĒ \\
\hline $\begin{array}{l}\text { Mainten- } \\
\text { ance } \\
\text { (1:vit) }\end{array}$ & $\begin{array}{l}\text { Unavail- } \\
\left.\text { ab } \frac{1}{(\bar{M}} \overline{\mathrm{K}}\right)\end{array}$ & $\begin{array}{l}\text { Unavail- } \\
\left.\text { able } \frac{1}{(\mathrm{M}} \overline{\mathrm{M}} \overline{\mathrm{h}}\right)-\end{array}$ & $\begin{array}{l}\text { Mainten- } \\
\text { ance } \frac{(\bar{M} \bar{h})}{}\end{array}$ & $\begin{array}{l}\text { Unavail- } \\
\text { atele } \\
\text { (Miti) }\end{array}$ & $\begin{array}{l}\text { Unavail- } \\
\left.\text { able } \frac{1}{(M} \frac{e}{M}\right)--\end{array}$ \\
\hline
\end{tabular}

$\begin{array}{rrrrrrr}1977 & 207 & 4,104 & 4,311 & 1,186 & 5,953 & 7,139 \\ 1978 & 0 & 4,070 & 4,070 & 1,803 & 5,040 & 6,843 \\ 1979 & 207 & 4,841 & 5,048 & 1,261 & 7,785 & 9,046\end{array}$

The capatility unavailable for reasons other than scheduled maintenance varied from 21-28 percent of the flanned capability in summer and from 29-44 percent in winter.

The reserve margins for the $1977-1979$ seasonal periods are shown below, considering the effects of scheduled maintenance and other outages. 
$\mathrm{XI} \cdot 4.3$

Table 4A.3

HISTORICAL SEASONAL RESERVES

CECO REGION

$S$ U M M E R.

\begin{tabular}{|c|c|c|c|c|c|c|}
\hline $\begin{array}{l}\text { Peak } \\
\frac{\text { Demand }}{(M W)}\end{array}$ & $\begin{array}{l}\text { Total } \\
\text { Capa- } \\
\frac{\text { bility }}{(M W)}\end{array}$ & $\begin{array}{c}\begin{array}{c}\text { Total } \\
\text { Reserves }\end{array} \\
(8)\end{array}$ & $\begin{array}{l}\text { Avail- } \\
\text { able } \\
\text { Capa- } \\
\frac{\text { bility }}{(M W)}\end{array}$ & $\begin{array}{l}\text { Avail- } \\
\text { able } \\
\frac{\text { Reserves }}{(8)}\end{array}$ & $\begin{array}{l}\text { Available } \\
\text { Capability } \\
\text { After } \\
\text { Forced } \\
\text { Outages } \\
\frac{(\mathrm{MW})}{}\end{array}$ & $\begin{array}{l}\text { Actual } \\
\frac{\text { Reserves }}{(8)}\end{array}$ \\
\hline \multirow[t]{2}{*}{$\begin{array}{l}13,932 \\
13,720 \\
13,804\end{array}$} & $\begin{array}{l}18,459 \\
17,947 \\
19,212\end{array}$ & $\begin{array}{l}32.5 \\
30.8 \\
39.2\end{array}$ & $\begin{array}{l}18,252 \\
17,947 \\
19,005\end{array}$ & $\begin{array}{l}31.0 \\
30.8 \\
47.6\end{array}$ & $\begin{array}{l}14,148 \\
13,877 \\
14,164\end{array}$ & $\begin{array}{l}1.6 \\
1.1 \\
2.6\end{array}$ \\
\hline & & W I & $\begin{array}{llll}N & T & E & R \\
\end{array}$ & & & + \\
\hline $\begin{array}{l}10,726 \\
11,068 \\
10,715\end{array}$ & $\begin{array}{l}17,966 \\
18,144 \\
20,630\end{array}$ & $\begin{array}{l}67.5 \\
63.9 \\
92.5\end{array}$ & $\begin{array}{l}16,780 \\
16,341 \\
19,369\end{array}$ & $\begin{array}{l}56.4 \\
47.6 \\
80.8\end{array}$ & $\begin{array}{l}10,827 \\
11,301 \\
11,584\end{array}$ & $\begin{array}{l}0.9 \\
2.1 \\
8.1\end{array}$ \\
\hline
\end{tabular}

The actual reserves were able to meet the peaks in the 1977-1979 period after taking into account both scheduled and unscheduled outages and still have a small excess of capacity. It should be noted that without a large amount of power import each year, the available capability to meet the peak requirements would have been insufficient. Purchases varied from 12 to 19 percent of summer peak demand in 1977-1979. The energy requirements, summer demands, winter demands, and annual load factors for the 1977-1979 period are shown below.

Table 4A. 4

HISTORICAL ENERGY, PEAKS AND LOAD FACTORS CECO REGION

Energy Requirement (GWH) Growth

1977

1978

1979

$$
65,103
$$

67,927

67,650

\&

\begin{tabular}{|c|c|}
\hline Summer & Demand \\
\hline (MW) & $\begin{array}{c}\text { Growth } \\
8\end{array}$ \\
\hline
\end{tabular}

$$
4.3
$$

13,932

$(0.4)$

13,720

13,804
$-$
(1.5)
0.6
Winter Demand (MW) Growth \&

$(0.5)$

$1 \cdot 9$

11.068

3.2

10.715

(3.2)

0.0

Growth
$1977-1979$

1.9

Annual

Lead

Factor

8

53.3

56.5

55.9 
During the 1977-1979 period, the energy requirements grew at a compound growth rate of 1.9 percent. This was considerably below the previous long-term growth rate. The reduction in the energy growth was due essentially to conservation efforts and slow down in economic growth of the area.

The summer and winter peak demands have essentially zero growth in this period. This no-growth in the demands was caused by a combination of economics, climatic conditions and conservation efforts. The depressed demands have resulted in increased load factors in 1978 and 1979 compared with 1977 .

Current Perspective

The projected 1980 summer and winter demands are shown below.

$\frac{\frac{\text { Table } 4 \text { A.5 }}{\text { PRUJECTED } 1980 \text { SEASONAL FEAK DEMAND* MW }}}{\text { CECO REGION }}$

Summer
June $\quad$ July

\begin{tabular}{lll}
\multicolumn{3}{c}{ Winter } \\
\hline December & January & February \\
11,068 & 11,178 & 10,736
\end{tabular}

$14,382 \quad 15,139 \quad 14,838$

* Coincident as to month

These demands are projected to occur, respectively, in July and January, which is consistent with previous occurrences. The winter demand is estimated to be 26 percent less than the summer demand. The reduced level of the winter demand will afford time to perform scheduled maintenance. There are 2,839 MW of capacity scheduled for maintenance during the winter period. No maintenance is scheduled for the summer period. This is approximately 15 percent of the winter planilod capa bility. The 1980 summer planned capability of CECO is estimated to be $17,352 \mathrm{MW}$ and the summer peak demand is projected to be $15,139 \mathrm{MW}$, resulting in planned reserve of $2,213 \mathrm{MW}$ or 14.6 percent. After adjustments for scheduled receipts and deliveries the total reserve is increased to 2,844 or 18.8 percent. With adjustments for the scheduled unavailable capacity during the summer peak period, the available reserve is projected to be $2,647 \mathrm{MW}$ or 17.5 percent. The summer and winter 1980 reserve margins for the electric region are shown below. 
$\mathrm{XI} \cdot 4 \cdot 5$

Table 4 A. 6

$\frac{1980 \text { RESERVE MARGINS* }}{\text { CECO REGION }}$

$S$ U M M E R

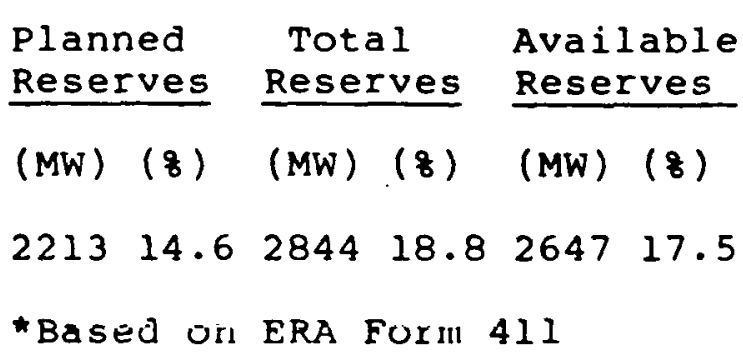

W I I N T

$\begin{array}{llll}\begin{array}{l}\text { Planned } \\ \text { Reserves }\end{array} & \begin{array}{c}\text { Total } \\ \text { Reserves }\end{array} & \begin{array}{l}\text { Available } \\ \text { Reserves }\end{array} \\ (\mathrm{MW})(8) & (\mathrm{MW}) 98) & (\mathrm{MW})(8) \\ 778669.7 & 841775.3 & 537148.0\end{array}$

The margins shown above are not adjusted for unscheduled outages of capacity as the amount of these outages are unknown at present. If these outages are in the order of magnitude that they were in the 1977-1979, large amounts of power will have to be imported as in the 1977-1979 period to cover deficits. Transfer could be as high as 2,200 MW based on outage rates of 29 percent, the maximum in the 1977-1979 period. However, it is standard procedure for the area to depend on the transmission network to supply two-thirds of its reserve obligation and its own capability to supply one-third.

The planned reserve requirement of. systems in this Region is governed by MAIN operating guide $\mathrm{H}-6$, "Procedure for Determination of Generating Reserve Requirements." Currently, Commonwealth Edison Company's reserve margin criteria is 14 percent $(2,119 \mathrm{MW})$ during summer 1980 and 24 percent $(2,682 \mathrm{MW})$ during winter 1980. The company's forecasted margins of 2,213 MW and $7,786 \mathrm{MW}$, respectively, exceeds the established criteria.

In addition to planned reserve criteria, the MAIN Operating Guide No. 5 governs the "Minimum Operating Reserve of Generating Capacity." Operating reserve is defined as the sum of spinning reserve connected to the bus which can be fully applied within ten minutes plus capacity not connected to the bus but which is capable of being effected in ten minutes or less. 
The minimum operating reserve required in MAIN is 1.5 times the winter normal capability of the largest generating unit in commercial service in MAIN. The minimum spinning reserve is 50 percent of the operating reserve requirements. The operating reserve of MAIN is distributed among the three subgroups of MAIN in proportion to the winter normal rating of the largest unit in service in each subregion to the sum of the ratings of the largest unit in service in the three subgroups, which for CECO is 47.9 percent. This allocation assures the best distribution of the reserves. The current operating and spinning reserve requirements of the CECO subgroup are shown below.

Winter normal rating of largest unit in MAIN

Total operating reserve obligation of MAIN ( 1.5 x largest unit)

Operating reserves-CECO portion ( 47.9 percent)

Minimum level of spinning reserves $(50$ percent of operating reserves)
$1.040 \mathrm{MW}$

$1,560 \mathrm{MW}$

$747 \mathrm{MW}$

$374 \mathrm{MW}$

The summer planned generating capability in CECO, for 1980 was $17,352 \mathrm{MW}$, and is shown below by type of fuel.

8 of

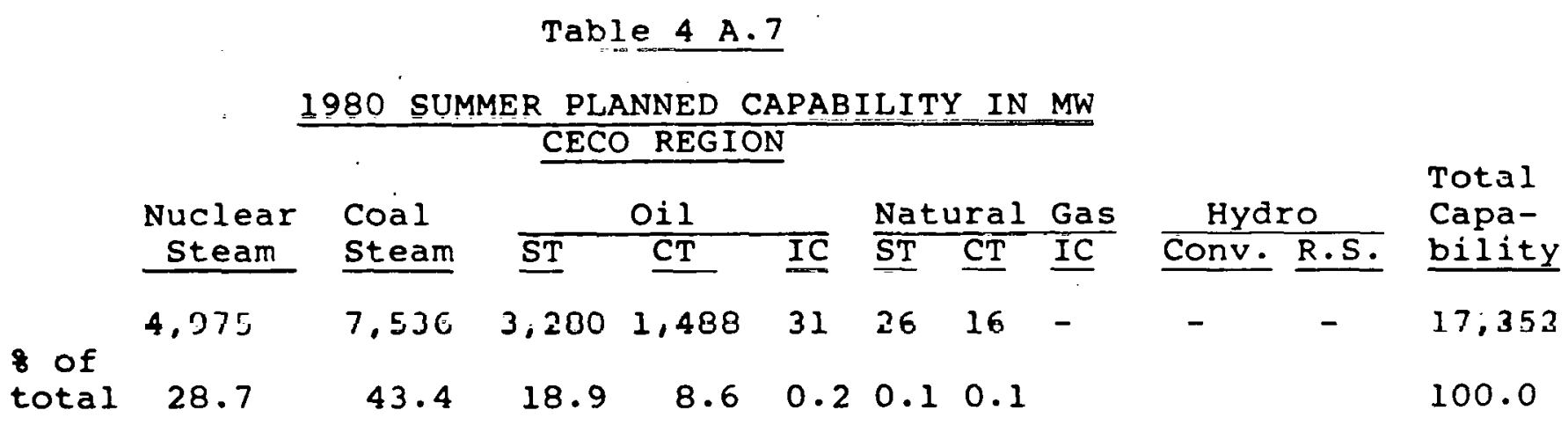

There are seven nuclear units installed in the region, comprising 29 percent of the current capability. Coal-fired steam units represent 43 percent of the total capability and oil-fired steam units, represent 19 percent. There are no new coal units scheduled for installation before December 1980 in the region, so the summer reserve situation will not be affected. 
There is a $1,048 \mathrm{MW}$ nuclear unit (LaSalle county 1) scheduled for installation in December 1980 . If this unit were delayed beyond the start of the winter peak season, the available reserves would be reduced to $4,323 \mathrm{MW}(38.7$ percent). This is within the region's reserve requirement winter criteria of 24 percent.

The projected 1980 energy reguirements, summer and winter demands, and annual load factor of the region are shown below.

Table $\underline{4 A} \cdot \underline{8}$

\section{REQUIREMENTS \\ CEE $\underline{C} \underline{O}-\underline{R} \bar{E} \bar{G}$ ION}

\begin{tabular}{|c|c|c|c|c|}
\hline - Ener & g.y $\frac{\text { Reguirement }}{(G)}$ & S & $\left.\underline{\text { Winte }} \frac{\underline{\text { Demand }}}{(\mathrm{M}} \underline{\mathrm{W}}\right) \underline{\underline{W}}$ & $\begin{array}{l}\text { Annual } \\
-\frac{\text { L. F. }}{\left(\frac{F}{8}\right)}\end{array}$ \\
\hline & 69,244 & 15,139 & 11,178 & 52.2 \\
\hline $1980-79$ & 2.4 & 9.7 & 4.3 & \\
\hline
\end{tabular}

The 1980 summer and winter demands are projected to grow at considerably higher rates than they did during the 1977-1979 period. This is do in part to the result of over estimation of the 1979/1980 winter peak, and also the summer of 1979 . Although the peaks and energy are forecasted to grow at a rate faster than during the 1977-1979 period, the projected 1980 values are considerably below what were projected last year. If lower than projected 1980 demands occur, there will be an enhancement of the reserve situation.

The projected 1980 annual load factor, 52.2 percent, is lower than that experienced during the 1977-1979 period. Delays of future critical bulk power transmission facilities that will not be in service when needed are required to be reported under I tem 5-C of the ERA 411 report. In the April 1l, 1980 MAIN report, no delays are reported for the CECO region.

\section{Future Pererspective}

The range of total reserves for the CECo region for the periods 1981-1985 and 1986-1989 are tabulated below. 
Table 4 A.9

RANGE OF TOTAL RESERVE-PERCENT

CECO REGION

\section{$1981-1985$

Summer Winter

$19.1-29.0 \quad 77.8-90.0$ $\frac{1986-1989}{\underline{\text { Summer }} \text { Winter }}$

$13 \cdot 3-22 \cdot 964 \cdot 1-74 \cdot 2$

The summer reserve margin exceeds the 14 percent MAIN reserve requirements criteria for all years in the 1981-1985 period but drops below it in 1988. It is anticipated that arrangements will be made to purchase the capacity trom the excess available to purchase in MAIN if additional capacity is not installed. The winter reserve margin exceeds the 24 percent reserve criteria in all years. Scheduled maintenance is not shown for the 1986-1989 period in the MAIN ERA 411 report. These are usually in the order of 2,000-3,000 MW. Allowance for 2,500 MW for maintenance outages in the 1986-1989 period would reduce the range of available reserve to $47.7-58.1$ percent.

The projected growth rates of demand and energy for each period and the overall rates for 1981-1989 are shown below.

Table 4A.10

PROJECTED ENERGY AND DEMAND GROWTH RATES CECO REGION

Annuล 1

Load

Energy Reguirements 1000

(MWH)

8

Summer Demand

Winter Demand

Factor

$1981 \quad 72,561$

198276,108

198379,687

$1984 \quad 82,954$

198586,352

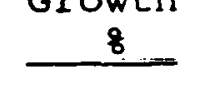

(MW) 8

(MW)

8

$4 \cdot 6$

15.011

$4 \cdot E$

11,628

4.0

12.090

4.0

4.7

17,344

4.9

4.5

12,581

4.1

18,036

4.0

13,083

4.0

13,604

4.0

4.0

4.0

53.3

4.1

18,758

$4 \cdot 3$

4.0

8 Growth 81-85

$4 \cdot 4$

4.0

$4 \cdot 2$

19.509

4.0
4.0

20,291

4.0
3.9

21,084

3.9

14,146
14,706
15,298
15,909

4.0

4.0

4.0

4.0

52.3

52.4

52.4

4.3

21,906

3.9

4.0

8 Growth 86-89

4. 3

$4 \cdot 3$

4.1

4.0 
The 1981-1985 summer demands are projected to grow at a compound rate of 4.3 percent; $1986-1989,3.9$ percent; and overall 1981-1989, 4.1 percent. These rates are considerably higher than the 1977-1979 period. However, the projected growth rates are close to those of the other regions in MAIN.

The winter demand growth rates are projected to increase to a constant 4.0 percent for the total $1981-1989$ period from no growth in the 1977-1979 period.

The energy requirements are projected to grow 4.4 percent from 1981-1.985; 4.3 percent from 1986-1989; and 4.3 percent for the overall period 1981-1989. Historically, the energy grew 1.9 percent during the period 1977-1979.

The summer capability of units planned in the region for the period 1980-1989 is shown by type of fuel on Table 4A.19. Generating unit additions during the period are indicated on Table 4 A.20. The capacity percentages for each type of fuel use for the target years 1980, 1984 and 1989 are given below.

Table 4A.11

PLANNED GENERATING CAPABILITY BY TYPE OF FUEL-PERCENT

CECO REGION

\begin{tabular}{|c|c|c|c|c|c|c|c|c|c|c|c|}
\hline & \multirow{3}{*}{$\begin{array}{l}\text { Coal } \\
\text { Steam }\end{array}$} & \multirow{2}{*}{\multicolumn{3}{|c|}{ oil }} & \multirow{2}{*}{\multicolumn{2}{|c|}{ Natural }} & \multirow[b]{2}{*}{ Gas } & \multirow{2}{*}{\multicolumn{2}{|c|}{ Hydro }} & \multirow{3}{*}{$\begin{array}{l}\text { Total } \\
\text { Capa- } \\
\text { bility }\end{array}$} \\
\hline & & & & & & & & & & & \\
\hline & & & $\overline{S T}$ & $\mathrm{CT}$ & IC & $\overline{S T}$ & $\mathrm{CT}$ & $I C$ & Conv. & $\overline{R . S .}$ & \\
\hline $\begin{array}{l}1980 \\
1984\end{array}$ & $\begin{array}{l}28.7 \\
45.6 \\
47.0\end{array}$ & $\begin{array}{l}43.4 \\
33.1 \\
33.1\end{array}$ & $\begin{array}{l}18.9 \\
14.4 \\
13.4\end{array}$ & $\begin{array}{l}8.6 \\
6.5 \\
6.1\end{array}$ & $\begin{array}{l}0.2 \\
0.1 \\
0.1\end{array}$ & $\begin{array}{l}0.1 \\
0.1 \\
0.1\end{array}$ & $\begin{array}{l}0.1 \\
0.1 \\
0.1\end{array}$ & $\begin{array}{l}-\overline{1} \\
0.1 \\
0.1\end{array}$ & - & - & $\begin{array}{l}100.0 \\
100.0 \\
100.0\end{array}$ \\
\hline
\end{tabular}

There are currently 7 nuclear reactors installed in CECO. and one scheduled for December 1980. The following nuclear generating units are scheduled for installation during the 1981-1989 period. 
Table $4 \quad$ A.12

SCHEDULED NUCLEAR ADDITIONS-1981-1989

CECO REGION

\begin{tabular}{clllll} 
System & \multicolumn{2}{c}{ Station } & MW & Type & $\begin{array}{c}\text { Effective } \\
\text { Date }\end{array}$ \\
\multirow{2}{*}{ CECO } & Lasalie county 2 & 1,048 & BWR & $12 / 81$ \\
& Byran 1 & 1,120 & PWR & $10 / 82$ \\
& Braidwood 1 & 1,090 & PWR & $10 / 83$ \\
& Byron 2 & 1,120 & PWR & $10 / 83$ \\
& Braidwood 2 & 1,090 & PWR & $10 / 84$
\end{tabular}

All of the units are scheduled to be in service prior to the start of the corresponding winter peak season. If these units are delayed until after the peak occurred in each year they are to be in-service, the effects on the reserve would be minimal. The resultant reserves available each year would still exceed the winter MAIN reserve criteria of 24 percent by a large margin.

A $550 \mathrm{MW}$ fossil-fired steam unit is scheduled for october 1988 and another $550 \mathrm{MW}$ unit, for April 1989. A delay in the first unit would reduce the winter 1988 available reserve to 60.5 percent. A delay in the second unit would reduce the summer 1989 available reserve to 11.6 percent which would be below the 14 percent minimum sumer reserve requirements.

The adequacy and reliability of the region's transmission network is tested periodically for contingency conditions in accordance with the MAIN operating guide No. 2 . The results of the investigation for the 1984 Emergency Transfer Capabilities (ETC's) for the CECO are outlined below.

\section{General Observations}

The Edison system modeled in this study was the currently planned generation and transmission system for 1984. System additions during the period 1979 to 1984 include $7166 \mathrm{MW}$ of generation and 4000 MVA of EHV transformer capability. Anticipated EHV line additions include several lines associated with new generating capacity plus other lines required for bulk power system reinforcement. No additional tie lines are proposed for this time period. 


$$
\text { XI. } 4.11
$$

The transmission system ETC as determined by this study is considered adequate to meet Edison's currently projected needs for 1984. Except for CE exports to WUMS $(900 \mathrm{MW})$ and.MINN $(400$ MW), all ETC's were equal to. or greater than those found in the previous 1982 study. CE exports to WuMs were only $100 \mathrm{MW}$ lower and $C E$ exports to MINN were $150 \mathrm{MW}$ lower.

\section{Table 4 A. $1 \underline{3}$}

\section{EMERGENCY TRANSFER CAPABILITY (ETC)}

\section{CECOO REGION}

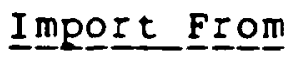

ECAR

IOWA

MINN

MO

SCILL

TVA

WUMS

Export To

ECAR

IOWA

$M I N N$

MO

SCIL

TVA

WUMS
ETC $(M \underline{H})$

3400

1700

1700 (1)

$900(1)$

350 (1)

500

450 (1)

200(1)

1400

1800

3500

1200

$450(1)$
Limiting Element

Dumont-Babcock $345 \mathrm{kV}$ :

Marshfield-Clark Co. $115 \mathrm{kV}$

Wien-T Corners $115 \mathrm{kV}$

Cassel-wien $115 \mathrm{kV}$

$T$ Corners-Wissota $115 \mathrm{kV}$

Alma-Wabaco $161 \mathrm{kV}$

Cassel-Wien $115 \mathrm{kV}$

T Corners-Wissota $115 \mathrm{kV}$

Dardenne-Pike $161 \mathrm{kV}$

Ind. Park-Meredosia $138 \mathrm{kV}$

Electric Jct.-Lombard $345 \mathrm{kV}$

Zion-Pleasant Prairie $345 \mathrm{kV}$

Waukegan-Kenosha $138 \mathrm{kV}$
ETC_ (MW)

$5000+$

800

400

1100

$2000+$

3600

900

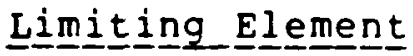

No Limit Found

Cal amus-Maquoketa $161 \cdot \mathrm{kV}$

Genoa-Lacrosse Tap $161 \mathrm{kV}$

Cahokia $345 / 138 \mathrm{kV}$ Trfr.

No Limit Found

Quad Cities-sub $91345 \mathrm{kV}$

Electric Jct.-Lombard $345 \mathrm{kV}$

(1) Limitation is not recognized as a valid constraint on transfer capability because line $c$ an be opened under emergency conditions.

The interregional transfer capabilities as determined from this study are as follows. These are approximate nonsimultaneous values above contracted schedules, based on emergency transfer capabilities. 
$X I .4 .12$

Táble $\underline{4} \underline{4}$ A.14

1984 MAIN EMERGENCY TRANSFER CAPABILITYYMW C $\bar{E} \bar{C} \bar{O}-\bar{R} \bar{E} \bar{I} \bar{O} \bar{N}$

$\begin{array}{llrl}\text { ECAR } & \text { to MAIN } & 2900 & \mathrm{MW} \\ \text { MARCA } & \text { to MAIN } & 800 \mathrm{MW} \\ \text { SERC } & \text { to MAIN } & 2800 \mathrm{MW} \\ \text { SPP } & \text { to MAIN } & 1900 \mathrm{MW} \\ & & & \\ \text { MAIN } & \text { to ECAR } & 4000+ & \mathrm{MW} \\ \text { MAIN } & \text { to MARCA } & 550 & \mathrm{MW} \\ \text { MAIN } & \text { to SERC } & 3200 & \mathrm{MW} \\ \text { MAIN } & \text { to SPP } & 1800 & \mathrm{MW}\end{array}$


Table 4 A. 15

LIST OF PROPOSED BULK POWER LINES - 1/1/80 TO 1/1/90

COMMONWEALTH EDISON COMPANY REGION

Line

Ownership

List

CECO

CECO

CECO

CECO

CECO

CECO

CECO

CECO

CECO

CECO

CECO

CECO

CECO

CECO

CECO

CECO

CECO/WILP

CECO

CECO

CECO

CECO

CECO

CECO

CECO

- CECO

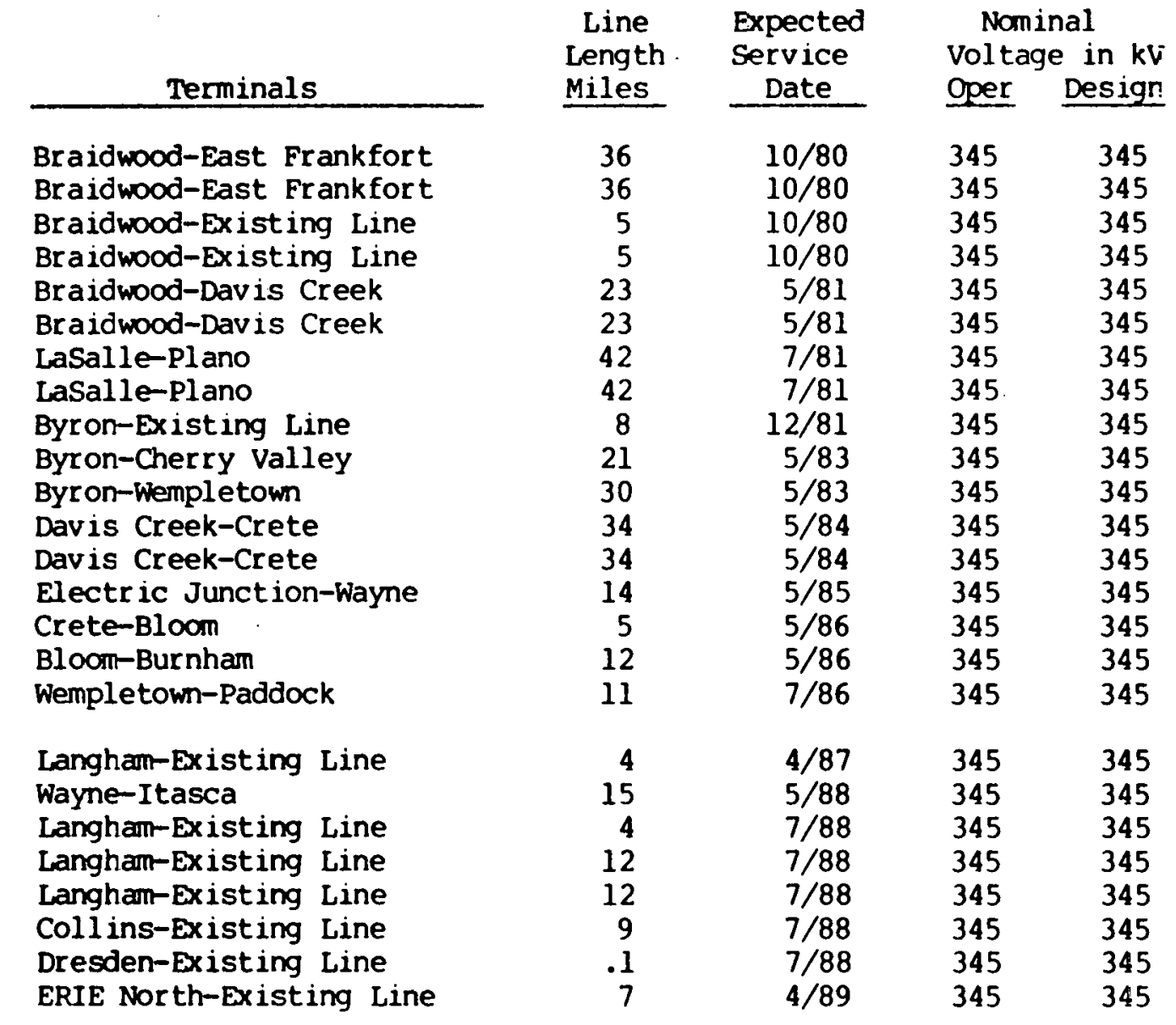

Notes

Del iver Generator output Del iver Generator output Del iver Generator output Deliver Generator output Del iver Generator output Del iver Generator Output Deliver Generator output Deliver Generator Output Deliver Generator output Del iver Generator Output Deliver Generator output Deliver Generator output Deliver Generator Output Rel ieve Overloads Rel ieve Overloads Rel ieve Overloads Increase Transfer Capability Miles Shown for CECO Portion Relieve Overloads Deliver Generator output Deliver Generator output Deliver Generator output Deliver Generator output Deliver Generator output Deliver Generator Output Deliver Generator output 
Table 4A.16

HISTORICAL CAPABILITY AND RESERVE MARGINS

COMMONWEALTH EDISON COMPANY PSGION

(1) Planned Capability (MW)

(2) Peak Demand ( $M W$ )

(3) Planned Reserve (MW) (1-2)

(4) Planned Reserve (8) (3-2) x 100

(5) Net Transactions 1/ (MW)

(6) Total Capability (MW) $(1+5)$

(7) Total Reserve (MW) (6-2)

(8) Total Reserve (8) (7-2) × 100

(9) Scheduled Maintenance (MW)

(10)

(11)

(12)

(13)

(14)

(15)

(16)

(17)

(18)

(19)

(20)
Capabil ity after Maintenand

(10-2)

Reserve after Maintenance ( 8$)(11-2) \times 100$

Inoperable Capability (MW)

Available Capability (MW) (10-113)

Available Reserve (MW) (14-2)

Available Reserve (8) (15-2) × 10C

Forced Outages (F.O.) (MW)

Available Capability after F.O. (MW) (14-17) 14,148

Actual Reserve (MW) (18-2)

Actual Reserve (8) (19-2) × 100

1) Net Transactions $=$ Purchases - Sales

18,252

1. 4,320

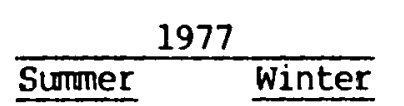

$\frac{1978}{\text { Summer } \quad \text { Winter }}$

15,865

13,932

1,933

13.9

16,909

$$
10,726
$$

2,594

18,459

4,527

32.5

207

31.0
0
18,252
4,320
31.0
4,104
14,148
216
1.6

6,183

57.6

16,264

13,720

2,544

1,057

17,966

7,240

1,186

16,780

6,054

56.4

56.4
0

16,780

6,054

56.4

5,953

10,827

101

0.9

1,683

17,947

4,227

30.8

0
17,947

4,227

30.8

0
17,947

4,227

30.8
4,070

4,070
13,877

17,303

11,068

6,235

157

157

\section{8,144}

7,076

1,803
16,341

5,273

47.6

16,341

5,273

47.6

5,040

11,301

233

2.1

1979

Summer Winter

$17,290 \quad 17,824$

$13,804 \quad 10,715$

$3,486 \quad 7,109$

$25.3 \quad 66.3$

1,922

19,212

2,806

20,630

$5,408 \quad 9,915$

$39.2 \quad 92.5$

207

19,005

5,201

37.7

1,261

19,369

8,654

0
19,005

5,201

37.7

4,841

14,164

360

2.6

80.8

0

19,369

8,654

80.8

7,785

11,584

869

8.1 
Table 4A.17

CURRENT CAPABILITY AND RESERVE MARGINS

COMMONWEALTH EDISON COMPANY REGION

(1) Planned Capability (MW)

(2) Peak Demand (MW)

(3) Planned Reserve (MW) (1-2)

(4). Planned Reserve (8) (3-2) × 100

(5) Net Transactions 1/ (MW)

(6) Total Capability (MW) $(1+5)$

(7) Total Reserve (MW) (6-2)

(8) Total Reserve (8) (7-2) x 100

(9) Scheduled Maintenance (MW)

(10) Capability after Maintenance (MN) (6-9)

(11) Reserve after Maintenance (MW) (10-2)

(12) Reserve after Maintenance (8) (11-2) × 100

(13) Inoperable Capability (MW)

(14) Available Capabil ity (MW) (10-13)

(15) Available Reserve (MW) (14-2)

(16) Available Reserve (8) (15-2) × 100

(17) Forced Outages (F.O.) (MW)

(18) Available Capability after F.O. (MW) (14-17)

(19) Actual Reserve (MW) (18-2)

(20) Actual Reserve (8) (19-2) × 100

\begin{tabular}{cc}
\multicolumn{2}{c}{1980} \\
\hline Summer & Winter \\
\hline 17,352 & 18,964 \\
15,139 & 11,178 \\
2,213 & 7,786 \\
14.6 & 69.7 \\
631 & 631 \\
17,983 & 19,595 \\
2,844 & 8,417 \\
18.8 & 75.3 \\
0 & 2,839 \\
17,983 & 16,756 \\
2,844 & 5,578 \\
18.8 & 49.9 \\
197 & 207 \\
17,786 & 16,549 \\
2,647 & 5,371 \\
17.5 & 48.0 \\
0 & 0 \\
17,786 & 16,549 \\
2,647 & 5,371 \\
17.5 & 48.0
\end{tabular}

1/ Net Transactions $=$ Purchases - Sales 
FUTURE CAPABILITY AND RESERVE MARGINS

COMMONWEALTH EDISON COMPANY REGICN

(1) Planned Capability (MW)

(2) Peak Demand (MW)

(3) Planned Reserve (MW) (1-2)

(4) Planned Reserve (8) (3-2) × 100

(5) Net Transactions 1/ (MW)

(6) Total Capability (MW) $(1+5)$

(7) Total Reserve (MW) (6-2)

(8) Total Reserve (8) (7-2) x 100

(9) Scheduled Maintenance (MW)

(10) Capability after Maintenance (MW) (6-9)

(11) Reserve after Maintenance (MW) (10-2)

(12) Reserve after Maintenance (8) (11-2) × 100

(13) Inoperable Capability (MW)

(14) Available Capability (MW) (10-13)

(15) Available Reserve (MW) (14-2)

(16) Available Reserve (8) (15-2) x 100

(17) Forced Outages (F.0.) (MW)

(18)

(19)

(20)

Available Capability after F.O. (MW)

Actual Reserve (MW) (18-2)

Actual Reserve (8) $(19-2) \times 100$

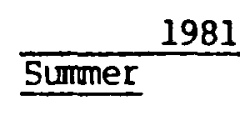

1/ Net Transactions = Purchases - Sales

\begin{tabular}{|c|c|c|c|c|c|c|}
\hline \multicolumn{2}{|c|}{1981} & \multicolumn{2}{|c|}{1982} & \multicolumn{2}{|c|}{1983} & \\
\hline Summer & Winter & Surmer & Winter & Summer & Winter & \\
\hline 18,400 & 20,042 & 19,448 & 21,174 & 20,580 & 23,414 & \\
\hline 15,831 & 11,628 & 16,603 & 12,090 & 17,344 & 12,581 & \\
\hline 2,569 & 8,414 & 2,845 & 9,084 & 3,236 & 10,833 & \\
\hline 16.2 & 72.4 & 17.1 & 75.1 & 18.7 & 86.1 & \\
\hline 631 & 631 & 332 & 332 & 320 & 320 & \\
\hline 19.031 & 20,673 & 19,780 & 21,506 & 20,900 & 23,734 & \\
\hline 3.200 & 9,045 & 3,177 & 9,416 & 3,556 & 11,153 & \\
\hline 20.2 & 77.8 & 19.1 & 77.9 & 20.5 & 88.6 & \\
\hline 0 & 1,936 & 0 & 1,960 & 0 & 3,147 & \\
\hline 19,031 & $18,7.37$ & 19,780 & 19,546 & 20,900 & 20,587 & \\
\hline 3,200 & 7,109 & 3,177 & 7,456 & 3,556 & 8,006 & \\
\hline 20.2 & 61.1 & 19.1 & 61.7 & 20.5 & 63.6 & \\
\hline 197 & 207 & 197 & 207 & 197 & 207 & \\
\hline 18,834 & 18,530 & 19.583 & 19,339 & 20,703 & 20,380 & \\
\hline 3,003 & 6,902 & 2,980 & 7,249 & 3,359 & 7,799 & 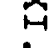 \\
\hline 19.0 & 59.4 & 17.9 & 60.0 & 19.4 & 62.0 & is \\
\hline 0 & 0 & 0 & 0 & 0 & 0 & is \\
\hline 18,834 & 18,530 & 19.583 & 19.339 & 20,703 & 20,380 & $\sigma$ \\
\hline 3,003 & 6,902 & 2,980 & 7.249 & 3,359 & 7,799 & \\
\hline 19.0 & 59.4 & 17.9 & 60.0 & 19.4 & 62.0 & \\
\hline
\end{tabular}


FUTURE CAPABILITY AND RESERVE MARGINS

COMMONWEALTH EDISON COMPANY RDGION

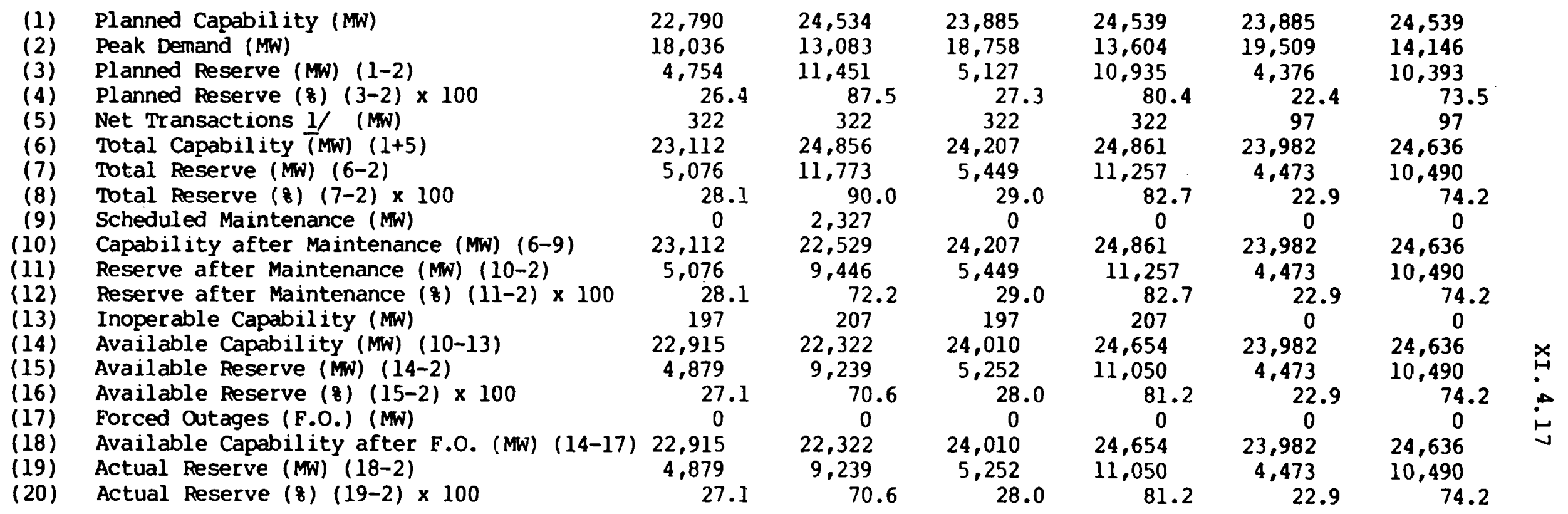

1/ Net Transactions = Purchases - Sales 
FUTURE CAPABILITY AND RESERVE MARGINS COMMONWEALTH EDISON COMPANY REGION

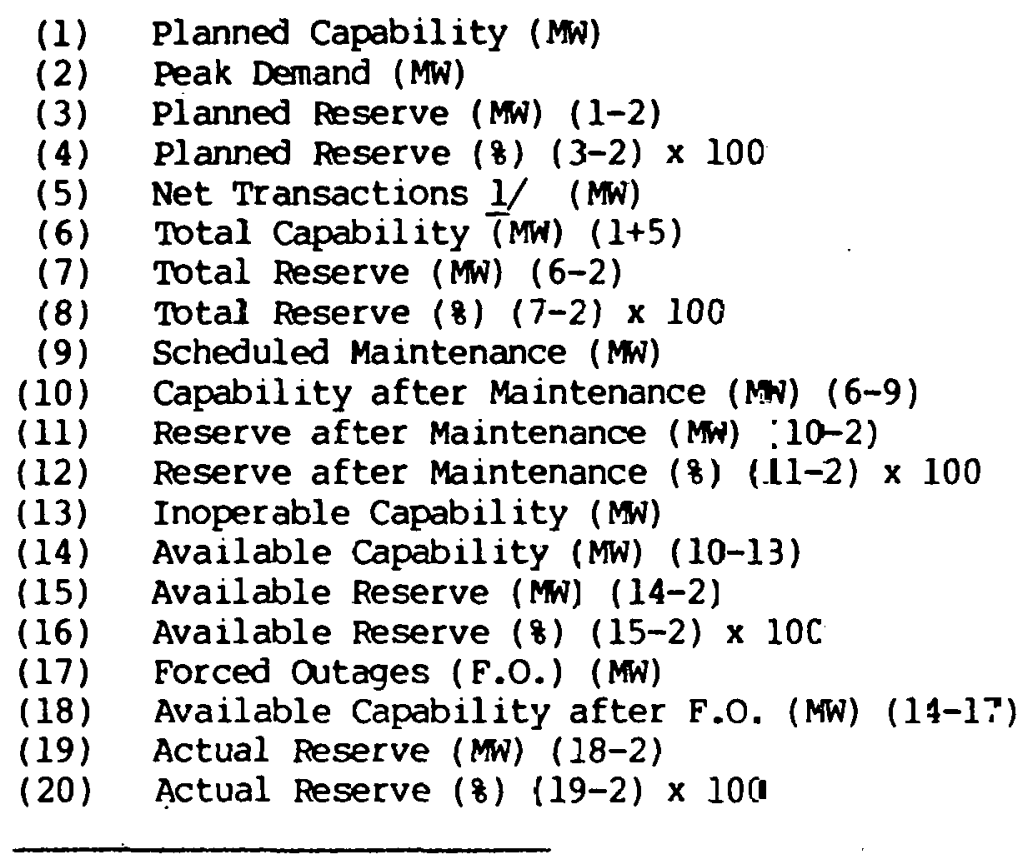

\begin{tabular}{c}
1987 \\
\hline Summer \\
23,885 \\
20,291 \\
3,594 \\
17.7 \\
323 \\
24,208 \\
3,917 \\
19.3 \\
0 \\
24,208 \\
3,917 \\
19.3 \\
0 \\
24,208 \\
3,917 \\
19.3 \\
0 \\
24,208 \\
3917
\end{tabular}

Winter

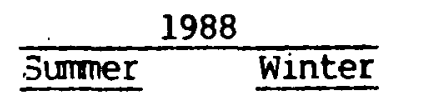

$\frac{1989}{\text { Summer } \quad \text { Winter }}$

1/ Net Transactions $=$ Purchases - Sales

24,539
14,706
9,833
66.9
323
24,862

10,156

69.1

0
24,862

10,156

69.1
0
24,862
10,156
69.1

24,862

10,156

19.3
23,885

21,084

2,801

13.3

11

23,896

2,812

13.3

0
23,896

2,812

13.3

0
23,896

2,812

13.3

23,896

2,812

69.1

13.3
64.1

0

0
25,100

9,802
64

64.1

25,100

9,802

64.1
24,985

21,906

3,079

14.1

11

24,996

3,090

14.1

0
24,996

3,090

14.1

0
24,996

3,090

14.1

26,189

15,909

10,280

64.6

11

26,200

10,291

64.7

26,200

10,291

64.7

0
26,200

10,291

64.7

24,996

26,200

$3,090 \quad 10,291$

$14.1 \quad 64.7$ 
Table 4A.19

INSTALLED NET CAPABILITY AS OF JANUARY 1, BY TYPE OF FUEL - MW COMMONWEALTH EDISON COMPANY REGION

Summer Capability

\begin{tabular}{|c|c|c|c|c|c|c|c|c|c|c|c|}
\hline \multirow{2}{*}{$\begin{array}{c}\text { Electric } \\
\text { Region } \\
6-C E C O \\
\end{array}$} & \multirow[b]{2}{*}{$\begin{array}{c}\text { Nuclear } \\
\text { Stean } \\
\end{array}$} & \multirow[b]{2}{*}{$\begin{array}{l}\text { Coal } \\
\text { Steam }\end{array}$} & \multicolumn{3}{|c|}{ Oil } & \multicolumn{3}{|c|}{ Natural Gas } & \multicolumn{2}{|c|}{ Hydro } & \multirow[b]{2}{*}{$\begin{array}{c}\text { Total } \\
\text { Capability }\end{array}$} \\
\hline & & & Steam & $\begin{array}{l}\text { Combust } \\
\text { Turbine }\end{array}$ & $\begin{array}{l}\text { Internal } \\
\text { Combust. }\end{array}$ & Steam & $\begin{array}{l}\text { Combust. } \\
\text { Turbine }\end{array}$ & $\begin{array}{l}\text { Internal } \\
\text { Combust. }\end{array}$ & Convent. & $\begin{array}{l}\text { Pumped } \\
\text { Storage }\end{array}$ & \\
\hline $\begin{array}{c}1980 \\
8 \text { Total }\end{array}$ & $\begin{array}{l}4975 \\
28.7\end{array}$ & $\begin{array}{l}7536 \\
43.4\end{array}$ & $\begin{array}{l}3280 \\
18.9\end{array}$ & $\begin{array}{r}1488 \\
8.6\end{array}$ & $\begin{array}{r}31 \\
0.2\end{array}$ & $\begin{array}{r}26 \\
0.1\end{array}$ & $\begin{array}{l}16 \\
0.1\end{array}$ & - & - & - & $\begin{array}{l}17352 \\
100.0\end{array}$ \\
\hline $\begin{array}{c}1981 \\
8 \text { Total }\end{array}$ & $\begin{array}{l}6023 \\
32.7\end{array}$ & $\begin{array}{l}7536 \\
41.0\end{array}$ & $\begin{array}{l}3280 \\
17.8\end{array}$ & $\begin{array}{r}1488 \\
8.1\end{array}$ & $\begin{array}{r}31 \\
0.2\end{array}$ & $\begin{array}{r}26 \\
0.1\end{array}$ & $\begin{array}{r}16 \\
0.1\end{array}$ & - & - & - & $\begin{array}{l}18400 \\
100.0\end{array}$ \\
\hline $\begin{array}{c}1982 \\
8 \text { Total }\end{array}$ & $\begin{array}{l}7071 \\
36.4\end{array}$ & $\begin{array}{l}7536 \\
38.7\end{array}$ & $\begin{array}{l}3280 \\
16.9\end{array}$ & $\begin{array}{r}1488 \\
7.6\end{array}$ & $\begin{array}{r}31 \\
0.2\end{array}$ & $\begin{array}{r}26 \\
0.1\end{array}$ & $\begin{array}{l}16 \\
0.1\end{array}$ & - & - & - & $\begin{array}{l}19448 \\
100.0\end{array}$ \\
\hline $\begin{array}{c}1983 \\
8 \text { Total }\end{array}$ & $\begin{array}{l}8191 \\
39.8\end{array}$ & $\begin{array}{l}7536 \\
36.6\end{array}$ & $\begin{array}{l}3280 \\
15.9\end{array}$ & $\begin{array}{r}1488 \\
7.2\end{array}$ & $\begin{array}{r}31 \\
0.2\end{array}$ & $\begin{array}{r}26 \\
0.1\end{array}$ & $\begin{array}{l}16 \\
0.1\end{array}$ & $\begin{array}{l}12 \\
0.1\end{array}$ & - & - & $\begin{array}{l}20580 \\
100.0\end{array}$ \\
\hline $\begin{array}{c}1984 \\
\text { Total }\end{array}$ & $\begin{array}{r}10401 \\
45.6\end{array}$ & $\begin{array}{l}7536 \\
33.1\end{array}$ & $\begin{array}{l}3280 \\
14.4\end{array}$ & $\begin{array}{r}1488 \\
6.5\end{array}$ & $\begin{array}{r}31 \\
0.1\end{array}$ & $\begin{array}{r}26 \\
0.1\end{array}$ & $\begin{array}{l}16 \\
0.1\end{array}$ & $\begin{array}{r}12 \\
0.1\end{array}$ & - & - & $\begin{array}{l}22790 \\
100.0\end{array}$ \\
\hline $\begin{array}{c}1985 \\
8 \text { Total }\end{array}$ & $\begin{array}{r}11491 \\
48.1\end{array}$ & $\begin{array}{l}7536 \\
31.6\end{array}$ & $\begin{array}{l}3280 \\
13.7\end{array}$ & $\begin{array}{r}1488 \\
6.2\end{array}$ & $\begin{array}{r}31 \\
0.1\end{array}$ & $\begin{array}{r}26 \\
1.1\end{array}$ & $\begin{array}{r}16 \\
0.1\end{array}$ & $\begin{array}{r}12 \\
0.1\end{array}$ & - & - & $\begin{array}{l}23880 \\
100.0\end{array}$ \\
\hline $\begin{array}{c}1986 \\
8 \text { Total }\end{array}$ & $\begin{array}{r}11491 \\
48.1\end{array}$ & $\begin{array}{l}7536 \\
31.6\end{array}$ & $\begin{array}{l}3280 \\
13.7\end{array}$ & $\begin{array}{r}1488 \\
6.2\end{array}$ & $\begin{array}{r}36 \\
0.1\end{array}$ & $\begin{array}{r}26 \\
0.1\end{array}$ & $\begin{array}{r}16 \\
0.1\end{array}$ & $\begin{array}{l}12 \\
0.1\end{array}$ & - & - & $\begin{array}{l}23885 \\
100.0\end{array}$ \\
\hline $\begin{array}{c}1987 \\
\text { \& Total }\end{array}$ & $\begin{array}{r}11491 \\
48.1\end{array}$ & $\begin{array}{l}7536 \\
31.6\end{array}$ & $\begin{array}{l}3280 \\
13.7\end{array}$ & $\begin{array}{r}1488 \\
6.2\end{array}$ & $\begin{array}{r}36 \\
0.1\end{array}$ & $\begin{array}{r}26 \\
0.1\end{array}$ & $\begin{array}{r}16 \\
0.1\end{array}$ & $\begin{array}{r}12 \\
0.1\end{array}$ & - & - & $\begin{array}{l}23885 \\
100.0\end{array}$ \\
\hline $\begin{array}{c}1988 \\
8 \text { Total }\end{array}$ & $\begin{array}{r}11491 \\
40.1\end{array}$ & $\begin{array}{l}7536 \\
31.6\end{array}$ & $\begin{array}{l}3280 \\
13.7\end{array}$ & $\begin{array}{r}1488 \\
6.2\end{array}$ & $\begin{array}{l}36 \\
0.1\end{array}$ & $\begin{array}{r}26 \\
0.1\end{array}$ & $\begin{array}{r}16 \\
0.1\end{array}$ & $\begin{array}{r}12 \\
0.1\end{array}$ & - & - & $\begin{array}{l}23885 \\
100.0\end{array}$ \\
\hline $\begin{array}{c}1989 \\
8 \quad \text { Total }\end{array}$ & $\begin{array}{r}11491 \\
47.0\end{array}$ & $\begin{array}{l}8086 \\
33.1\end{array}$ & $\begin{array}{l}3280 \\
13.4\end{array}$ & $\begin{array}{r}1488 \\
6.1\end{array}$ & $\begin{array}{r}36 \\
0.1\end{array}$ & $\begin{array}{r}26 \\
0.1\end{array}$ & $\begin{array}{r}16 \\
0.1\end{array}$ & $\begin{array}{r}12 \\
0.1\end{array}$ & - & - & $\begin{array}{l}24435 \\
100.0\end{array}$ \\
\hline
\end{tabular}


Table 4A.20

MAJOR FUTURE GENERATING CAPABILITY INSTALLATICNS AND REMOVALS COMMONWEALTH EDISON COMPANY REGION

\begin{tabular}{|c|c|}
\hline $\begin{array}{l}\text { DOE/ERA } \\
\text { Electr ic } \\
\text { Region }\end{array}$ & System \\
\hline $\begin{array}{l}6 \\
6 \\
6 \\
6 \\
6 \\
6 \\
6 \\
6 \\
6 \\
6\end{array}$ & $\begin{array}{l}\text { CECO } \\
\text { CECO } \\
\text { CECO } \\
\text { CECO } \\
\text { CECO } \\
\text { CECO } \\
\text { CECO } \\
\text { CECO } \\
\text { CECO } \\
\text { CECO }\end{array}$ \\
\hline
\end{tabular}

Station
Lasalle Cty \$1
LaSalle Cty \#2
Byron \#1
Braidwood \#1
Byron \#2
Braidwood \#2
Langham \#2
Langham \#1
Unidentified \#1
Carroll Cty 1

\begin{tabular}{|c|c|}
\hline Unit Type & Fuel Ty \\
\hline $\mathrm{NB} 2 /$ & UR \\
\hline NB $\overline{2} /$ & UR \\
\hline NI $\overline{3} /$ & UR \\
\hline 당 & UR \\
\hline Nㅡ $\sqrt{3} /$ & UR \\
\hline Nㅡ $\frac{1}{3}$ & UR \\
\hline $\mathrm{ST}$ & - \\
\hline ST & - \\
\hline $\mathrm{ST}$ & - \\
\hline NP $3 /$ & UR \\
\hline
\end{tabular}

Net Summer

Capability

1,048
1,048
1,120
1,090
1,120
1,090
550
550
550
$8174 /$

\begin{tabular}{|c|c|}
\hline \multicolumn{2}{|r|}{ ate 1} \\
\hline $4 / 1 / 79$ & $4 / 1 / 8$ \\
\hline Report & Report \\
\hline $9 / 79$ & $12 / 80$ \\
\hline $9 / 80$ & (81 \\
\hline $9 / 81$ & $10 / 82$ \\
\hline $10 / 81$ & $10 / 8$ \\
\hline $10 / 82$ & $10 / 83$ \\
\hline $10 / 82$ & $10 / 84$ \\
\hline $4 / 87$ & $10 / 88$ \\
\hline $10 / 87$ & $4 / 89$ \\
\hline $4 / 88$ & $10 / 89$ \\
\hline $10 / 88$ & \\
\hline
\end{tabular}

1) Comparison of scheduled in-service dates in the April 1, 1979 and April 1, 1980 Regional Reliability Council Reports.

2/ Boiling water Reactor.

3/ Pressurized Water Reactor.

4/ Jointly owned by CECO and Iowa Company; Iowa Company's share of $25 \%$ is not included in the 1980 "411" report. 


\section{ILLINOIS-MISSOURI GROUP (ILLMO) \\ ELECTRIC REGION 17}

\section{Historical Perspective}

Electric Region 17 includes all of Illinois except the northern portion plus the eastern portion of Missouri. The major power suppliers in the region are the Central Illinois Public service Co.. Illinois Power Co., and the Union Electric Co. These three electric systems formed a formal power pool in 1952, which coordinates their planning and installation of generating and transmission facilities and the operation of their systems, including emergency and economy exchanges, spinning reserves, and maintenance schedules.

In addition to the three power pool systems, data are included in this electric region for the Central Illinois Light Co.; City of Springfield, Illinois; Southern Illinois Power Cooperative; Western Illinois Power Cooperative; Missouri Power and Light Company; and the City of Columbia, Missouri.

All of the above systems are members or associate members of the Mid-American Interpool Network (MAIN) organization which oversees the coordination of planning, construction, and utilization of generation and transmission facilities of its participants in order to improve the reliability of the electric bulk power supply in the region. The utilities in DOE's Electric Region 17-ILLMO are members of the Illinois and Missouri Groups of MAIN.

The Associatod Electric Cooperative, which has been a member of the Missouri Group of MAIN has given notice that it intends to withdraw from MAIN in June 1980. Accordingly, data for this system is not included in this Electric Region and the historical 1977-1979 data has been extracted.

Utilities in the ILLMO Region serve about 1.6 million customers, of which 1.4 million are residential, 161,000 are commercial, and 8,000 are industrial customers.

The utilities in ILLMO have 345 interconnections among themselves; with Indiana Michigan Electric Co. and Public Service Company of Indiana in ECAR; with Illinois Gas and Electric Co. and Iowa Southern Utilities in MARCA; with TVA; and with the Kansas Gas and Electric Co., Public Service Company of Oklahoma, and the Kansas City Power and Light Company in the Southwest Power Pool.

MAIN does not have facilities for regional control of generating capacity or major switching stations nor are such facilities planned in the future. Each system controls its own generating capacity in accordance with procedures established by the NERC (formerly NAPSIC) Operating Committee. 
The MAIN Coordination Center is located in Lombard, Illinois, a suburb of chicago. The principal responsibility of the Center is to assure that the region will meet its load requirements with maximum interconnected system reliability.

ILLMO has historically been a summer peaking region. The region's summer and winter monthly coincident peaks for the period 1977-1979 are shown in Table $4 \mathrm{~B} .1$.

Table $4 \mathrm{~B} .1$

\section{HISTORICAL PEAK DEMAND* - MW} ILLMO REGION

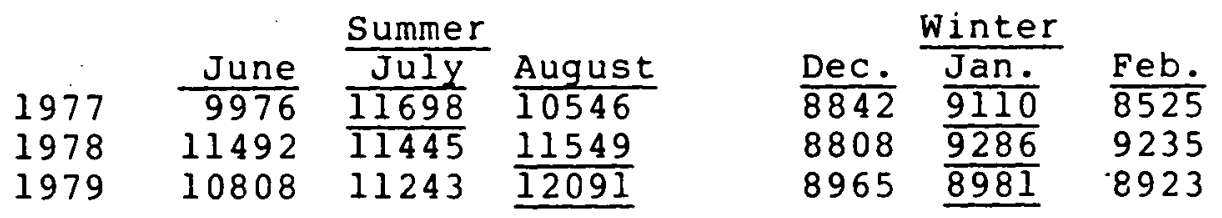

Underline indicates seasonal peak.

* Coincident as to month

The summer peak demands are dependent on climatic conditions and are temperature/humidity sensitive. Usually the peak will occur in July or August.

The winter peak usually occurs in January, but it may occur in any winter month, depending on the combination of weather and economic activity in the region. The winter peak during the 1977-1979 period was 20-26 percent less than the corresponding summer peak. Advantage was taken of the difference in magnitude between the seasonal peaks to perform scheduled maintenance. The following table shows the scheduled maintenance performed each period and also the capability unavailable because of forced outages or otherwise inoperable.

Table 4B.2

SCHEDULED MAINTENANCE AND UNAVAILABLE CAPABILITIES ILLMO REGION

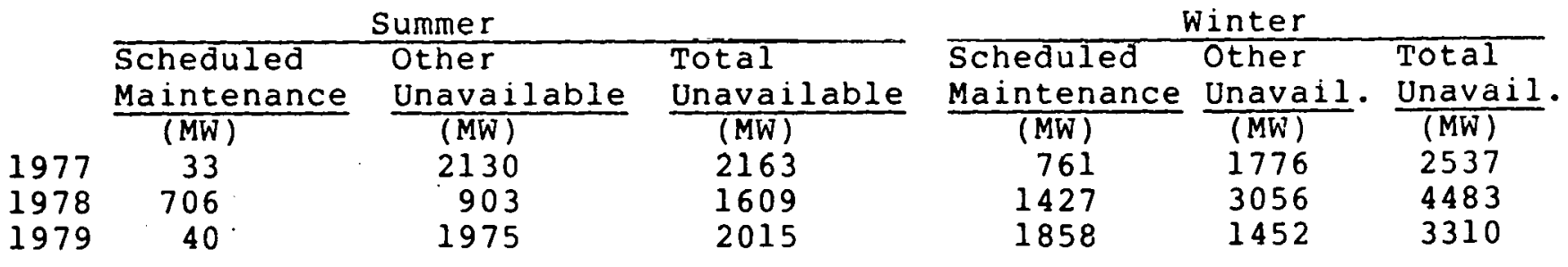

The capability unavailable for reasons other than scheduled maintenance varied from 6-16 percent of the planned capability in summer and from 10-20 percent in winter. 
The reserve margins for the 1977-79 peak periods are shown below, considering the effects of scheduled maintenance and other outages.

\author{
Table 4 B. 3 \\ HISTORICAL SEASONAL RESERVES \\ ILLMO REGION
}

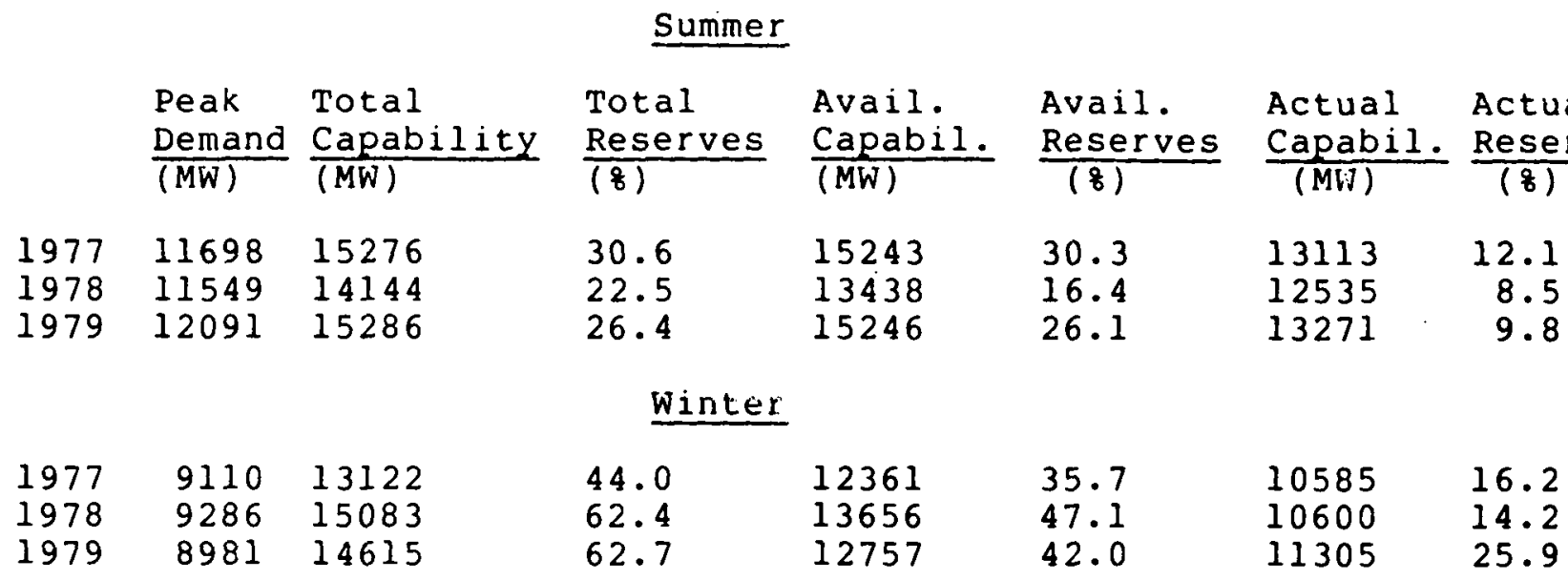

The actual reserves were more than adequate to meet the peak demands in the 1977-79 period, after taking into account both scheduled and unscheduled outages, although somewhat larger than usually planned. This was caused by a smaller than usual growth in the peak demand.

The energy requirements, summer and winter demands, and annual load factors for the 1977-79 period are shown below.

Table $4 \mathrm{~B} \cdot 4$ $\frac{\text { HISTORICAL ENERGY, PEAKS, AND LOAD FACTORS }}{\text { ILLMO REGION }}$

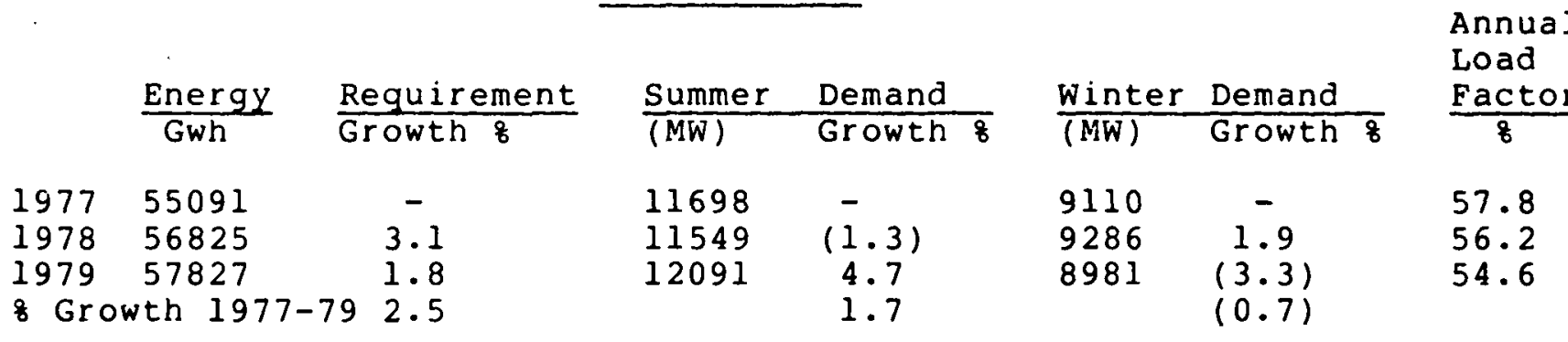

During the period 1977-79 energy requirements grew at a compound rate of 2.5 percent. This is consistent with other regions but is much lower than the previous historical patterns. Both summer and winter demand rates of growth experienced similar declines. The energy and demand low growth rates were a result of conservation efforts, slackening economic conditions, and climatic conditions. 


\section{Current Perspective}

The projected 1980 summer and winter demands are shown below.

Table 4B.5

$\frac{\text { PROJECTED } 1980 \text { SEASONAL PEAK DEMAND* - MW }}{\text { ILLMO REGION }}$

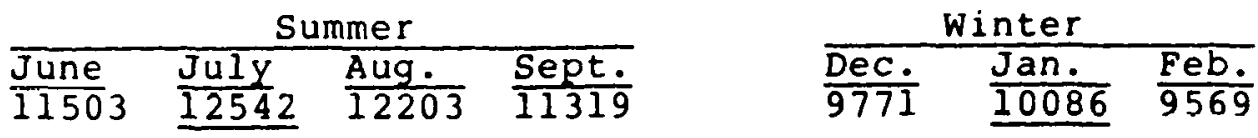

* Coincident as to month

The winter demand is projected to be 19.6 percent less than the summer demand, which, as in the past, affords opportunity for the performance of scheduled maintenance. There are $1667 \mathrm{MW}$ of capacity scheduled to be out during the winter 1980 peak compared to none during the 1980 summer peak period. This is about 11 percent of the region's planned capability.

The 1980 summer planned capability of the ILLMo region is estimated to be $15,623 \mathrm{MW}$ and the non-coincident summer peak demand is projected to be $12,596 \mathrm{MW}$, resulting in planned reserves of $3,027 \mathrm{MW}$ or 24.0 percent. After adjustment for scheduled unavailable capacity during the summer peak period, the available reserves are projected to be $3129 \mathrm{MW}$ or 24.8 percent.

The summer and winter 1980 reserve margins for the electric region are shown below.

Table 4B.6

\section{RESERVE MARGINS*}

\section{ILLMO RFGION}

\begin{tabular}{|c|c|c|c|c|c|}
\hline \multicolumn{3}{|c|}{ summer } & \multicolumn{3}{|c|}{ winter } \\
\hline 1 & tal & $\vec{e}$ & $\overline{n e d}$ & Total & Available \\
\hline $\begin{array}{l}\text { Reserves } \\
\frac{(\mathrm{MW})(8)}{302724.0}\end{array}$ & $\begin{array}{l}\frac{\text { Reserves }}{(M W) \quad(8)} \\
3164 \quad 25.1\end{array}$ & $\begin{array}{l}\frac{\text { Reserves }}{(M W) \quad(8)} \\
313924.8\end{array}$ & $\begin{array}{l}\text { Reserves } \\
\begin{array}{l}(M W)(8) \\
5.54054 .9\end{array}\end{array}$ & $\begin{array}{l}\frac{\text { Reserves }}{(M W)(8)} \\
509950.6\end{array}$ & $\frac{\text { Reserves }}{(M W)(8)}$ \\
\hline
\end{tabular}

* Based on ERA Form 411

The margins shown above are not adjusted for unscheduled outages of capacity as the amount of these outages are unknown ahead of time. If these outages do not exceed the maximum outages of the 1977-79 period, 168 of planned capacity during the summer period and 208 during the winter, the resultant reserves would be $629 \mathrm{MW}$ or 5.08 and $270 \mathrm{MW}$ or 2.78 , respectively, in excess of reserve requirements. 
The reserve requirements in ILLMO are governed by MAIN Operating Guide \#6, "Procedure for Determination of Generator Reserve Requirements." Currently, the minimum reserve requirement for MAIN as a whole is 158 . The available reserves of the Electric Region for the 1980 summer and winter seasons (24.88 and 33.78 respectively) are well above the minimum requirements.

In addition to reserve criteria, the MAIN Operating Guide \#5 governs the "Minimum Operating Reserve of Generating Capacity." Operating Reserve is defined as the sum of spinning reserve connected to the bus which can be fully applied within ten minutes plus capacity not connected to the bus but which is capable of being effected in ten minutes or less.

The Minimum Operating Reserve required in MAIN is 1.5 times the winter normal capability of the largest generating unit in commercial service. The Minimum Spinning Reserve is 50 percent of these Operating Reserve requirements. The Operating Reserve of MAIN is distributed among the three subgroups of MAIN in proportion to the winter normal rating of the largest unit in service in each subregion to the sum of the ratings of the largest unit in service in the three subgroups, which for ILLmo is 27.9 percent. This allocation assures the best distribution of the reserves. The current operating and spinning reserve requirements of the ILLMO subgroup is shown below.
Winter Normal Rating of Largest Unit in MAIN - 1040 MW Total Reserve Obligation of MAIN ( $1.5 \mathrm{x}$ Largest Unit) - $1560 \mathrm{MW}$ Operating Reserves - ILLMO Portion (27.98) - $435 \mathrm{MW}$ Minimum Level of Spinning Reserves ( 508 of Operating Reserves - $2.17 \mathrm{MW}$

The 1980 summer planned generating capability in ILLMO was $15,623 \mathrm{MW}$, and is shown below by type of fuel.

\section{Table $4 \mathrm{~B} .7$ \\ 1980 SUMMER PLANNED CAPABILITY (MW) ILLMO REGION}

\begin{tabular}{|c|c|c|c|c|c|c|c|c|c|c|}
\hline \multirow{2}{*}{$\begin{array}{l}\text { Nuclear } \\
\text { Steam }\end{array}$} & \multirow{2}{*}{$\begin{array}{l}\text { Coal } \\
\text { Steam }\end{array}$} & \multicolumn{3}{|c|}{ Oil } & \multicolumn{3}{|c|}{ Natural Gas } & \multicolumn{2}{|c|}{ Hydro } & \multirow{2}{*}{$\begin{array}{l}\text { Total } \\
\text { Capability }\end{array}$} \\
\hline & & $\overline{\mathrm{ST}}$ & $\mathrm{CT}$ & $\overline{I C}$ & ST & $C T$ & IC & Conv. & P.S. & \\
\hline \& of Total & $\begin{array}{r}13041 \\
83.5\end{array}$ & $\begin{array}{r}1010 \\
6.5\end{array}$ & $\begin{array}{l}765 \\
4.9\end{array}$ & $\begin{array}{r}38 \\
0.2\end{array}$ & $\begin{array}{r}57 \\
0.4\end{array}$ & $\begin{array}{r}79 \\
0.5\end{array}$ & - & $\begin{array}{l}333 \\
2.1\end{array}$ & $\begin{array}{l}300 \\
1.9\end{array}$ & $\begin{array}{l}15623 \\
100.0\end{array}$ \\
\hline
\end{tabular}

Almost 848 of the current capacity is coal-fired steam; 68 oil-fired steam; and 58 oil-fired combustion capacity. There are no nuclear units installed in the region and hydro is an insignificant portion of the total. There are no new coal-fired steam units scheduled in the region for 1980 . 
The projected 1980 energy requirements, summer and winter demands, and annual load factor of the region are shown on Table $4 \mathrm{~B} .8$

\author{
Table $4 \mathrm{~B}-8$ \\ 1980 LOAD REQUIREMENTS \\ ILLMO REGION
}

\begin{tabular}{|c|c|c|c|}
\hline $\begin{array}{c}\frac{\text { Energy Reguirement }}{(\text { GWH })} \\
59742 \\
980 / 79: 3.3\end{array}$ & $\begin{array}{c}\text { Summer Demand } \\
\begin{array}{c}(M W) \\
12596 \\
4.2\end{array}\end{array}$ & $\begin{array}{c}\text { Winter Demand } \\
\text { (MW) } \\
10086 \\
12.3\end{array}$ & $\frac{\text { Annual L.F. }}{(8)}$ \\
\hline
\end{tabular}

8 Growth $1980 / 79: 3.3$

The 1980 energy and summer demand requirements are projected to grow at reasonable though somewhat higher rates than they did during the 1977-79 period. The 1980 winter demano rate is inflated, probably the result of an over-estimation of the 1979/80 winles peak. If indeed the 1980 winter forecast is high, reserve inalgins could benefit throughout the 1980-89 period.

Delays of future critical bulk power transmission facilities that will not be in service when needed is required to be reported under Item 5-C of the ERA 411 report. In the April 1, 1980 MAIN report, it is reported that the Illinois Power Company's Kansas to Sidney $345 \mathrm{kV}$ line originally scheduled for completion in 1977 is now expected to be completed no earlier than the summer of 1983. The delay is primarily due to the intervention of farm groups concerned with land utilization and structure type. The delay could result in some $r$ isk to the company's customers in the form of local outages. It was necessary to develop emergency operating plans for the area to minimize impacts on system reliability.

The Central Illinois Public Service Company is also reported to be experiencing a delay of the $345 \mathrm{kV}$ Casey-Kansas-Sidney CLPS-IP line oriqinally scheduled for service in 1977. CLPS section of the line from Casey to Kansas has been completed; but the continued. delay of the IP Kansas-sidney section resulted in some reduction of service reliability to local areas.

\title{
Future Perspective
}

The range of total reserves for ILLMo for the periods $1981-8 b$ and 1986-89 are shown below.

Table $4 B .9$

RANGE OF TOTAL RESERVES - 8 ILLMO REGION

$\frac{1981-1985}{\frac{\text { Summer }}{18.8-33.3} \frac{\text { Winter }}{40.8-63.3}} \quad \frac{1986-1989}{\frac{\text { Summer }}{23.1-27.3} \frac{\text { Winter }}{32.9-40.2}}$


As indicated above, the reserves exceeds the $158 \mathrm{minimum}$ margin criteria for all the years in each time period based on the posted projected demands and capabilities. The projected growth rates of demand and energy for each period and the overall rates for 1981-1987 are shown on Table 4B.10.

Table 4B. 10

PROJECTED ENERGY AND DEMAND GROWTH RATES ILLMO REGION

Annual

Load

$\frac{\text { Energy Requirements }}{\text { (GWH) Growth } 8} \frac{\text { Summer Peak Demand }}{(\text { MW) Growth } 8}$

Winter Peak Demand (MW) Growth \&

$\frac{\text { Factor }}{8}$

$\begin{array}{llll}1981 & 62439 & 4.5 & 13039 \\ 1982 & 64639 & 3.5 & 13468 \\ 1983 & 66996 & 3.6 & 13863 \\ 1984 & 69020 & 3.0 & 14308 \\ 1985 & 71499 & 3.6 & 14750 \\ \text { Growth } & 1981-85 & 3.4 & \\ 1986 & 74230 & 3.8 & 15205 \\ 1987 & 76658 & 3.3 & 15713 \\ 1988 & 80014 & 4.4 & 16194 \\ 1989 & 83123 & 3.9 & 16667\end{array}$

\begin{abstract}
3.5
3.3

2.9

3.2

3.1

3.1
\end{abstract}

10541

11173

11584

12305

12508

$\begin{array}{ll}3.1 & 13284 \\ 3.3 & 13934 \\ 3.1 & 14570 \\ 2.9 & 15660\end{array}$

3.1

3.1
4.5

6.0

3.7

6.2

1.6

4.4

54.7

54.8

55.0

54.9

55.3

$\begin{array}{ll}6.2 & 55.7 \\ 4.9 & 55.7 \\ 4.6 & 56.2 \\ 7.5 & 56.9\end{array}$

5.6

5.1

Growth $1986-89 \quad 3.8$

The summer demands are projected to grow at a compound rate of growth of 3.18 throughout the entire study period. These rates are considerably higher than the historical 1977-1979 rate of 1.78, however the period 1977-1979 may be atypical. The winter demand growth rates are projected to increase to 4.48 for the 1981-1985 period and to 5.68 for the 1986-1989 period with an overall 1981-1989 rate of 5.18. The projected increase in growth rate of the winter demands may not be warranted, especially in view of the negative growth in the 1977-1979 period.

Energy requirements are projected to grow 3.48 from 1981-1985, 3.88 from 1986-1989, and 3.68 for the overall period 1981-1989. Historically, 1977-1979, the energy grew 2.58. The energy requirements projected growth would indicate optimistic economic activity in the region.

The summer capability of units planned in the region for the period 1980-1989 are shown by type of fuel in Table 4B.22. Major generating unit additions during the period are given in Table 4B.23. Future capability by percent, each type of prime mover, and fuel type for the target years 1980, 1984, and 1989 are shown on Table 4B.11. 
Table 4 B. 11

PLANNED GENERATING CAPABILITY BY TYPE OF FUEL - 8

ILLMO REGION

Summer Capability

\begin{tabular}{|c|c|c|c|c|c|c|c|c|c|c|c|}
\hline & & \multirow{3}{*}{$\begin{array}{l}\text { Coal } \\
\text { Steam } \\
83.5 \\
74.8 \\
71.8\end{array}$} & \multicolumn{3}{|c|}{ Oil. } & \multicolumn{3}{|c|}{ Natural Gas } & \multicolumn{2}{|c|}{ Hydro } & \multirow{2}{*}{$\begin{array}{l}\text { Total } \\
\text { Capability }\end{array}$} \\
\hline & & & $\overline{S T}$ & $\mathrm{CT}$ & IC & ST & $\mathrm{CT}$ & $\underline{I C}$ & Conv. & $=0$ & \\
\hline & $11 \cdot 3$ & & $\begin{array}{l}\overline{6.5} \\
5.0 \\
4.3\end{array}$ & & & & $\begin{array}{l}\overline{0.5} \\
0.4 \\
0.4\end{array}$ & $\begin{array}{l}\bar{z} \\
\overline{-}\end{array}$ & $\begin{array}{l}1.8 \\
1.6\end{array}$ & & \\
\hline
\end{tabular}

Currently, coal is the primary fuel for about 848 of the planned capability of the region. This percentage is projected to decrease to 728 by 1989 due to the installation of three nuclear units in the region; Callaway \#1, $1150 \mathrm{MW}$ scheduled for Uctober 1982, Clinton \#1, $948 \mathrm{MW}$ scheduled for December 1982 and Callaway \#2, $1150 \mathrm{MW}$ scheduled for April 1988. If the in-service dates of the two 1982 units were delayed beyond the start of winter 1982 peak period, reserve requirements would still be greater than the area's reserve requirements. Similarly, a delay in the 1988 unit for one year would not seriously effect reserves.

A major $575 \mathrm{MW}$ coal-fired steam unit Newton \#2, is scheduled for service in December 1982. If this unit were delayed past the winter 1982 peak in addition to the planned nuclear units the available reserves would decrease to 17.88 , which still is greater than the minimum MAIN reserve criteria for this region. Five other coal units planned for the area are in the order of 100-450 MW and delays of these units past their respective peak periods should not appreciably reduce the ILLMo reserve margins.

Oil-fired steam units comprise only 6.58 or $1010 \mathrm{MW}$ of the 1980 capability. This is scheduled to decrease tu $905 \mathrm{MW}$ by 1985 and to remain at that level in the study period.

The adeguacy and reliability of the region's transmission network is evaluated periodically for contingency conditions in acculdalle with the MAIN Guide No. 2. The results of the investigation of the 1984 Emergency Transfer Capabilities (ETC's) for the South Central Illinois (SCILL) area and the Missouri area follows.

During the time period 1979-1984 generation additions in the South Central Illinois (SCILL) Area totaled $1925 \mathrm{MW}$. These additions are scheduled for the existing sites of Newton and Duck Creek, as well as the previously undeveloped generating locations of Clinton and an unidentified CWL\& $P$ site. Anticipated $345 \mathrm{kV}$ line additions include several lines associated with the new generating additions, plus lines internal to the SCILL Area for the purpose of strengthening the bulk power transmission system. Proposed $345 / 138 \mathrm{kV}$ transformer additions total approximately 2200 MVA. 
Using the criteria of MAIN Guide No. 2, the 1984 SCILL Area was tested to determine interchange capabilities with other areas. The results of this investigation show that SCILL Emergency Transfer Capabilities (ETC's) are judged to be adequate, however, some are lower than desired.

The following tabulation summarizes SCILL ETC's for 1984.

Table 4 B. 12

\section{Emergency Transfer Capability - Imports ILLMO REGION - (SOUTH CENTRAL ILLINOIS)}

\begin{tabular}{lc} 
Import From & ETC (MW) \\
\cline { 1 - 2 } CE & \\
ECAR & $2000+$ \\
IOWA & $1900(\mathrm{a})$ \\
MINN & 100 \\
MO & 150 \\
SPP & 550 \\
TVA & 100 \\
WUMS & $2500+$ \\
& $1300(\mathrm{~b})$
\end{tabular}

Limiting Facility

No Limit Found

Bunsonville-Eugene $345 \mathrm{kV}$ Lakeshire-Watson $138 \mathrm{kV}$ Lakeshire-Watson $138 \mathrm{kV}$ Meramec 3-Lemay Tap $13 \varepsilon \mathrm{kV}$ Lakeshire-Watson $138 \mathrm{kV}$ No Limit Found $\mathrm{Zion-Pleasant}$ Prairie $345 \mathrm{kV}$.

(a) The Bunsonville-Eugene $345 \mathrm{kV}$ line is scheduled to be upgraded in 1982. However, the prescnt MVA rating has been used in this study to determine the most restrictive case.

(b) WUMS to SCILL emergency transfers are more restricted by the Waukegan to Kenosha $138 \mathrm{kV}$ line. This limit is not listed because it is considered to be a local problem.

The Emergency Transfer Capability into SCILL from IOWA, MINN, MO, and SPP are lower than desired. These limitations are due to the Lakeshire-Watson and Meramec 3-Lemay Tap $1138 \mathrm{kV}$ lines. The area that encompasses these lines is currently under review by UE. 
The following tabulation summarizes SCILL's emergency export capability.

Table 4B.13

\section{Emergency Transfer Capability - Export ILLMO REGION - (SOUTH CENTRAL ILLINOIS)}

\begin{tabular}{lcll} 
Export To & ETC (MW) & & \multicolumn{1}{c}{ Limiting Facility } \\
CE & 1800 & & Industrial Park-Meredosia i38 kV \\
ECAR & 1600 & & Industrial Park-Meredosia $138 \mathrm{kV}$ \\
IOWA & 800 & & Maryville-St. Joseph $161 \mathrm{kV}$. \\
MINN & 350 & Genoa-Lac Tap $161 \mathrm{kV}$ & \\
MO & 1000 & Cahokia $345 / 138 \mathrm{kV} \mathrm{TRFR}$ \\
SPP & $1600(\mathrm{a})$ & Montgomery $345 / 161 \mathrm{kV}$ TRFR \\
TVA & 1600 & Industrial Park-Meredosia $138 \mathrm{kV}$ \\
WUMS & 800 & Electric Junction-Lombard $345 \mathrm{kV}$
\end{tabular}

(a) SCILL to SPP emergency transfers are more lestricted by the Montgomery-Montgomery Tap $161 \mathrm{kV}$ line. This line is not listed because it is considered to be a local problem.

The ETC limits of SCILL are judged acceptable. However, SCILL's ETC to MINN is lower than desired.

During the 1979-1984 time period generation additions in Missouri (MO) include $2030 \mathrm{MW}$ of base and $312 \mathrm{MW}$ of peaking generation. Anticipated EHV line additions include several lines for new plant outlet capacity as well as a $500 \mathrm{kV}$ UE-ASEC-MSUI tie in southeast Missouri. Proposed additional $345 / 138 \mathrm{kV}$ and $345 / 161 \mathrm{kV}$ transformation capabilities in MO amount to $1680 \mathrm{MVA}$ and 2168 MVA, respectively, for this time period.

From the results of the study it appears that with presently planned generation and transmission additions, import capabilities under ETC criteria are adequate to meet MO's needs in 1984 except from the IOWA and MINN areas. Imports from these ateds ale limiled by the facilities outside the Mo area. Export capabilities under ETC criteria seem to be adequate except to the MINN and SCILL areas. Export to the MINN area is limited by a facility outside the MO area while export to SCILL area is limited by a $138 \mathrm{kV}$ MO facility. Transmission in the area around the limiting facility is currently being studied by Union Electric. 
The following tabulation summarizes MO's ETC.

Table 4B.14

1984 Emergency Transfer Capability - Import ILLMO REGION - (MO AREA)

Import From ETC (MW) Limiting Element

$\begin{array}{ll}\text { CE } & 1100 \\ \text { ECAR } & 1100 \\ \text { IOWA } & 500 \\ \text { MINN } & 450(a) \\ \text { SCILL } & 1000 \\ \text { SPP } & 2000 \\ \text { TVA } & 1200 \\ \text { WUMS } & 1300(b)\end{array}$

Cahokia $345 / 138 \mathrm{kV}$ Xfmr. Cahokia $345 / 138 \mathrm{kV}$ Xfmr. St. Joe $345 / 161 \mathrm{kV} \times \mathrm{xmr}$. Alma-Wabco $161 \mathrm{kV}$ Cahokia $345 / 138 \mathrm{kV}$ Xfmr. Cahokia $345 / 138 \mathrm{kV}$ Xfmr. Cahokia $345 / 138 \mathrm{kV}$ Xfmr. Cahokia $345 / 138 \mathrm{kV} \times f m r$.

(a) MINN to MO transfers are limited to 250 MW by the T Corners-Wissota $115 \mathrm{kV}$ line. However, this limiting element is considered to be a local problem and is, therefore, not listed.

(b) WUMS to Mo transfers are limited to 500 MW by the Waukegan-Kenosha $138 \mathrm{kV}$ line. However, this limiting element is considered to be a local problem and is, therefore, not listed.

It can be ecen that Mo's import capability is limited from all the directions except IOWA and MINN by the Cahokia $345 / 138 \mathrm{kV}$ Transformer \#9. The limitation is based on the emergency rating of 560 MVA for this transformer for the sudden outage of Cahokia $345 / 138 \mathrm{kV}$ Transformer \#8 which requires a breaker to open at Cahokia in the Cahokia-Campbell-Roxford $345 \mathrm{kV}$ line. Since both Cahokia transformers have a two hour emergency rating of 660 MVA, the Cahokia transformer limitation can be removed by switching at Cahokia which would reestablish the CahokiaCampbell-Roxford $345 \mathrm{kV}$ Iine within two hours. - With the Cahokia transformer limitation removed, MO's import from all the directions will be limited by facilities outside the Mo area. 
The following tabulation summarizes MO's ETC.

Table 4B.15

1984 Emergency Transfer Capability - Export ILLMO REGION (MO AREA)

\begin{tabular}{lll} 
Export To & & ETC $(M W)$ \\
\cline { 1 - 1 } CE & & 1400 \\
ECAR & & 2700 \\
IOWA & & $900(\mathrm{a})$ \\
MINN & & 400 \\
SCILL & & 550 \\
SPP & & $1500(\mathrm{a})$ \\
TVA & & 1900 \\
WUMS & & $800(\mathrm{~b})$
\end{tabular}

Limiting Element

(a) MO to IOWA transfers are limited to $400 \mathrm{MW}$ by the Montgomery-Montgomery Tap $161 \mathrm{kV}$ line. The same line limits MO to SPP transfers to zero MW:

However, the emergency rating of this $0.2 \mathrm{mile}$ long line is limited by terminal equipment, and hence it is considered a local problem, which is. expected to be corrected.

(b). MO to WuMs transfers are. 1 imited to $400 \mathrm{MW}$ by the $\mathrm{T}$ Corners-Wissota $115 \mathrm{kV}$ line. However, this limiting element is considered to be a local problem and is, therefore, not 1 isted.

The interregional transfer capabilities as determined from this study are as follows. These are approximate non-simultaneous values for emergency assistance above contracted schedules.

l'able 4B.16

1984 MAIN Emergency Transfer Capability ILLMO REGION

$\begin{array}{lcccc}\text { ECAR } & \text { to MAIN } & 3950 & \mathrm{MW} \\ \text { MARCA } & \text { to MAIN } & 900 & \mathrm{MW} \\ \text { SERC } & \text { to MAIN } & 4000+ & \mathrm{MW} \\ \text { SPP } & \text { to MAIN } & 1100 & \mathrm{MW} \\ & & & & \\ \text { MAIN to ECAR } & 3800 & \mathrm{MW} \\ \text { MAIN to MARCA } & 900 & \mathrm{MW} \\ \text { MAIN to SERC } & 1100 & \mathrm{MW} \\ \text { MAIN to SPP } & 1500 & \mathrm{MW}\end{array}$


TabIe 4B.17

List of Proposed Bulk Power Lines $(1 / 1 / 80$ to $1 / 1 / 90)$

I LLMO REGION

Line

Ownership
List

01

Terminals

02

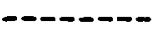

UNEC

UNEC

UNEC

UNEC

UNEC

UNEC

UNEC

ILPC

ILPC

ILPC

ILPC

ILPC

CEIL

CEIP

ILPC

WEIL

Campbel1-Belt

Sidney-Paxton
Expected

Service

Date

KM Miles

$03 \quad 04$

Cahokia-Roxford Tap-Campbell

Montgomery-Callaway 7

Montgomery-Callaway 8

Callaway-Bland 1

Mason-sioux Tap-Belt

Callaway-Bland 2

Maroa E.-Oreana

Clinton-Brokaw

Clinton-Maroa E.

Clinton-Maroa W.

W. Kansas-Sidney

Duck Creek-Fargo

Maroa W. -Oreana

Pawnee-Rees Station

$\begin{array}{rr}3 & 2 \\ 37 & 23 \\ 37 & 23 \\ 48 & 30 \\ & \\ 18 & 11 \\ 48 & 30 \\ 14 & 9 \\ 13.5 & 8.4 \\ 36.2 & 22.5 \\ 20.1 & 12.5 \\ 20.1 & 12.5 \\ 57.1 & 35.5 \\ 53 & 33 \\ 61 & 38 \\ 13.5 & 8.4 \\ 50 & 31\end{array}$

Nominal

Voltage In $\mathrm{KV}$

Oper

06

07

$5 / 80$

$7 / 80$

345

345

$10 / 81$

$10 / 81$

$5 / 86$

$3 / 88$

$5 / 88$

$6 / 80$

$6 / 81$

$6 / 81$

$6 / 81$

$12 / 85$

$3 / 86$

6,86

6,87
Notes

08

Provide Area Protection

Increase Transfer Capability

Pre-Operational Power

Deliver Generator Output

Deliver Generator Output

NRC- Separate Facility Require-

ment: Deliver Generator Output

Relieve Overloads

Deliver Generator Output

Provide Area Protection

Relieve Overloads

Deliver Generator Output

Deliver Generator Output

Deliver Generator Output

Relieve Overloads

Relieve Overloads

Provide Area Protection

Relieve Overloads

Relieve Overloads 
1. Planned Capability

2. Peak Demand

3. Planned Reserves (1-2)

4. Planned Reserves $(8)(3 \div 2) \times 1003$

5. Net Transactions (Imports-Exports)

6. Total Capability $(1+5)$

7. Total Reserves $(6-2)$

8. Total Reserves (8) $(7+2) \times 1038$

9. Scheduled Maintainence

10. Capability after Maintenance $: 6-9)$

11. Reserves after Maintenance $(10-2)$

12. Reserves after Maintenance $(1,(11 ; 2) \times 170 \%$

13. Inoperable Capability 1

14. Available Capability (100-13)

15. Available Reserves $(14-2)$

16. Available Reserves (8) $(15 \div 2) \times 1008$

17. Forced Outages

18. Actual Capability after Forces Outages (14-17)

19. Actual Reserves (18-2)

20. Actual Reserves (8) $(19 \div 2) \times 1008$

1) Included in Item 17

\begin{tabular}{rr}
\multicolumn{2}{c}{1977} \\
\hline Summer & vinter \\
13,547 & 14,063 \\
11,698 & 9,110 \\
1,849 & 4,953 \\
15.8 & 54.4 \\
1,729 & -941 \\
15,276 & 13,122 \\
3,578 & 4,012 \\
30.6 & 44.0 \\
33 & 761 \\
15,243 & 12,361 \\
3,545 & 3,251 \\
30.3 & 35.7 \\
0 & 0 \\
15,243 & 12,361 \\
3,545 & 3,251 \\
30.3 & 35.7 \\
2,130 & 1,776 \\
13,113 & 10,585 \\
1,415 & 1,475 \\
12.1 & 16.2
\end{tabular}

1978

\begin{tabular}{rr}
\multicolumn{2}{c}{1978} \\
Summer & Winter \\
14,643 & 14,891 \\
11,549 & 9,286 \\
3,094 & 5,605 \\
26.8 & 60.4 \\
-499 & 192 \\
14,144 & 15,083 \\
2,595 & 5,797 \\
22.5 & 62.4 \\
706 & 1,427 \\
13,438 & 13,656 \\
1,889 & 4,370 \\
16.4 & 47.1 \\
0 & 0 \\
13,438 & 13,656 \\
1,889 & 4,370 \\
16.4 & 47.1 \\
903 & 3,056 \\
12,535 & 10,600 \\
986 & 1,314 \\
8.5 & 14.2
\end{tabular}

\begin{tabular}{rr}
\multicolumn{2}{c}{1979} \\
Summer & Winter \\
15,012 & 14,919 \\
12,091 & 8,981 \\
2,921 & 5,938 \\
24.2 & 66.1 \\
274 & -304 \\
15,286 & 14,615 \\
3,195 & 5,634 \\
26.4 & 62.7 \\
40 & 1,858 \\
15,246 & 12,757 \\
3,155 & 3,776 \\
26.1 & 42.0 \\
0 & 0 \\
15,246 & 12,757 \\
3,155 & 3,776 \\
26.1 & 42.0 \\
1,975 & 1,452 \\
13,271 & 11,305 \\
1,180 & 2,324 \\
9.8 & 25.9
\end{tabular}


1. Planned Capability

2. Peak Demand

3. Planned Reserves $(1-2)$

4. Planned Reserves (8) $(3 \div 2) \times 1008$

5. Net Transactions (Imports-Exports)

6. Total Capability $(1+5)$

7. Total Reserves $(6-2)$

8. Total Reserves ( 8$)(7 \div 2) \times 1008$

9. Scheduled Maintainence

10. Capability after Maintenance (6-9)

11. Reserves after Maintenance $(10-2)$

12. Reserves after Maintenance (8) (11:2) x 1008

13. Inoperable Capability.

14. Available Capability (10-13)

15. Availabile Reserves (14-2)

16. Available Reserves (8) $(15 \div 2) \times 1008$

17. Forced Outages $1 /$

18. Actual Capability after Forced Outages (14-17)

19. Actual Reserves (18-2)

20. Actual Reserves (8) $(19 \div 2) \times 1008$

1/ No information supplied.

\begin{tabular}{rr}
\multicolumn{2}{c}{1980} \\
\cline { 1 - 1 } Summer & \multicolumn{1}{c}{ Winter } \\
15,623 & 15,626 \\
12,596 & 10,086 \\
3,027 & 5,540 \\
24.0 & 54.9 \\
137 & -441 \\
15,760 & 15,185 \\
3,164 & 5,099 \\
25.1 & 50.6 \\
0 & 1,667 \\
15,760 & 13,518 \\
3,164 & 3,432 \\
25.1 & 34.0 \\
35 & 37 \\
15,725 & 13,481 \\
3,129 & 3,395 \\
24.8 & 33.7 \\
0 & 0 \\
15,725 & 13,481 \\
3,129 & 3,395 \\
24.8 & 33.7
\end{tabular}


Table 4B.20

Future Capajility (MW) and Reserves (MW and Percent)

ILLMO REGION

1. Planned Capability

2. Peak Demand

3. Planned Reserves $(1-2)$

4. Planned Reserves ( 8$)(3+2) \times 1008$

5. Net Transactions (Imports-Exports)

6. Total Capability $(1+5)$

7. Total Reserves $(6-2)$

8. Total Reserves $(8)(7+2) \times 1008$

9. Scheduled Maintenance

10. Capability after Maintenance (6-9)

11. Reserves after Maintenance $(10-2)$

12. Reserves after Maintenance (8) $(11+2) \times 1008$

13. Inoperable Capability

14. Available Capability $(10-13)$

15. Available Reserves $(14-2)$

16. Available Reserves $(8)(15 \div 2) \times 1008$

17. Forced Outages $1 /$

18. Actual Capability after Forced Outages:14-17)

19. Actual Reserves $(18-2)$

20. Actual Reserves (8) $(19 \div 2) \times 1008$

1/ No information supplied.
1982 Summer hir

$\begin{array}{llll}15764 & 15806 & 15922 & 18708\end{array}$

$13039 \quad 10541 \quad 13468$

2725

$\begin{array}{lll}0541 & 13468 & 11173\end{array}$

$\frac{1983}{\text { Summer Winter }}$

$\frac{1984}{\text { Summer Winter }} \frac{1985}{\text { Summer Winter }}$

20.9

5265

$2454 \quad 7535$

$18658 \quad 18713$

$\begin{array}{ll}18618 & 18678 \\ 14308 & 12126\end{array}$

$18607 \quad 18664$

$\begin{array}{llll}170 & -761 & 113 & -461\end{array}$

$\begin{array}{llll}15934 & 15045 & 16035 & 18247\end{array}$

$\begin{array}{llll}2895 & 4504 & 2567 & 7074\end{array}$

$\begin{array}{llll}22.2 & 42.7 & 19.1 & 63.3\end{array}$

0

42.7
1421

19.1

1372
16875

$\begin{array}{rrrr}2895 & 3083 & 2567 & 5702 \\ 22.2 & 29.2 & 19.1 & 51.0\end{array}$

35

15899

29.2

286

$13587 \quad 16000 \quad 16838$

$\begin{array}{rrr}13587 & 16000 & 16838 \\ 3046 & 2532 & 5665\end{array}$

21.9

5899
2860

28.9

18.

1358716000

3046253

50.7
0
16838

21.9

28.9
$4795 \quad 7134$

$\begin{array}{ll}34.6 & 61.5\end{array}$

$18474 \quad 17957$

$4611 \quad 6373$

33.355 .0

$0 \quad 1214$

$18474 \quad 16743$

$4611 \quad 5159$

33.3
35

18439

$\begin{array}{rr}18439 & 16743 \\ 4576 & 5159\end{array}$

$33.0 \quad 44.5$

$\begin{array}{rr}0 & D \\ 18439 & 16743\end{array}$

$4576 \quad 5159$

$33.0 \quad 44.5$
$4310 \quad 12126 \quad 14750 \quad 12719$

$\begin{array}{llll}4310 & 6552 & 3857 & 5945 \\ 30.1 & 54.0 & 26.1 & 46.7\end{array}$

$\begin{array}{llll}-181 & -625 & -178 & -761\end{array}$

$\begin{array}{llll}18437 & 18053 & 18429 & 17903\end{array}$

$\begin{array}{llll}4129 & 5927 & 3679 & 5184\end{array}$

$\begin{array}{llll}28.9 & 48.9 & 24.9 & 40.8\end{array}$

$18437 \quad 16839$

$4129 \quad 4713$

$\begin{array}{rr}24.9 & 40.8 \\ 0 & 0\end{array}$

1842917903

$24.9 \quad 40.8$

$28.9 \quad 38.9$

$18437 \quad 16839$

41294713

28.938 .9

$\begin{array}{rr}0 & 0 \\ 18437 & 16839\end{array}$

41294713

$28.9 \quad 38.9$

$18429 \quad 17903$

$3679 \quad 5184$

$24.9 \quad 40.8$

$18429 \quad 17903$

$3679 \quad 5184$

24.940 .8
$3679 \quad 5184$ 
Table 4B.21

Future Capability (MW) and Reserves (MW and Percent)

1. Planned Capability

2. Peak Demand

3. Planned Reserves $(1-2)$

4. Planned Reserves $(8)(3+2) \times 1008$

5. Net Transactions (Imports-Exports)

6. Total Capability $(1+5)$

7. Total Reserves $(6-2)$

8. Total Reserves $(8)(7 \div 2) \times 100$

9. Scheduled Maintenance $1 /$

10. Capability after Maintenance (6-9)

11. Reserves after Maintenance $(10-2)$

12. Reserves after Maintenance $(8)(11+2) \times 1008$

13. Inoperable Capability $1 /$

14. Available Capability $(10-13)$

15. Available Reserves $(14-2)$

16. Available Reserves $(8)(15+2) \times 1008$

17. Forced Outages $1 /$

19. Actual Reserves $(18-2)$

20. Actual Reserves (8) $(19+2) \times 1008$

1/ No information supplied
1986

\begin{tabular}{rr}
\multicolumn{2}{c}{1986} \\
\cline { 1 - 1 } Summer & Winter \\
19704 & 19161 \\
15805 & 13284 \\
3899 & 5877 \\
25.6 & 44.2 \\
-205 & -791 \\
18899 & 18370 \\
3694 & 5086 \\
24.3 & 38.3 \\
0 & 0 \\
18899 & 18370 \\
3694 & 5086 \\
24.3 & 38.3 \\
0 & 0 \\
18899 & 18370 \\
3694 & 5086 \\
24.3 & 38.3 \\
0 & 0 \\
18899 & 18370 \\
3694 & 5086 \\
24.3 & 38.3
\end{tabular}

\section{ILLMO REGION}

\begin{tabular}{rr}
\multicolumn{2}{c}{1987} \\
\cline { 1 - 1 } Summer & Winter \\
19541 & 19598 \\
15713 & 13934 \\
3828 & 5664 \\
24.4 & 40.6 \\
-204 & -791 \\
19337 & 18807 \\
3624 & 4873 \\
23.1 & 35.0 \\
0 & 0 \\
19337 & 18807 \\
3624 & 4873 \\
23.1 & 35.0 \\
0 & 0 \\
19337 & 18807 \\
3624 & 4873 \\
23.1 & 35.0 \\
0 & 0 \\
19337 & 18807 \\
3624 & 4873 \\
23.1 & 35.0
\end{tabular}

1989

Summer Winter

$21021 \quad 21078$

$16667 \quad 15198$

$4354 \quad 5880$

$\begin{array}{ll}4354 & 5880 \\ 26.1 & 38.7\end{array}$

$\begin{array}{ll}26.1 & 38.7\end{array}$

$\begin{array}{rr}-196 & -887 \\ 20825 & 20191\end{array}$

$4158 \quad 4993$

$24.9 \quad 32.9$

00

2082520191

$4158 \quad 4993$

$24.9 \quad 32.9$

$\begin{array}{rr}0 & 0 \\ 20825 & 20191\end{array}$

$4158 \quad 4993$

$24.9 \quad 32.9$

2082520191

$4158 \quad 4993$ 
Table 4B.22

Planned Capability $\exists$ s of January 1 by Type of Fuel - MW ILLMO REGION

\section{Summer Capability}

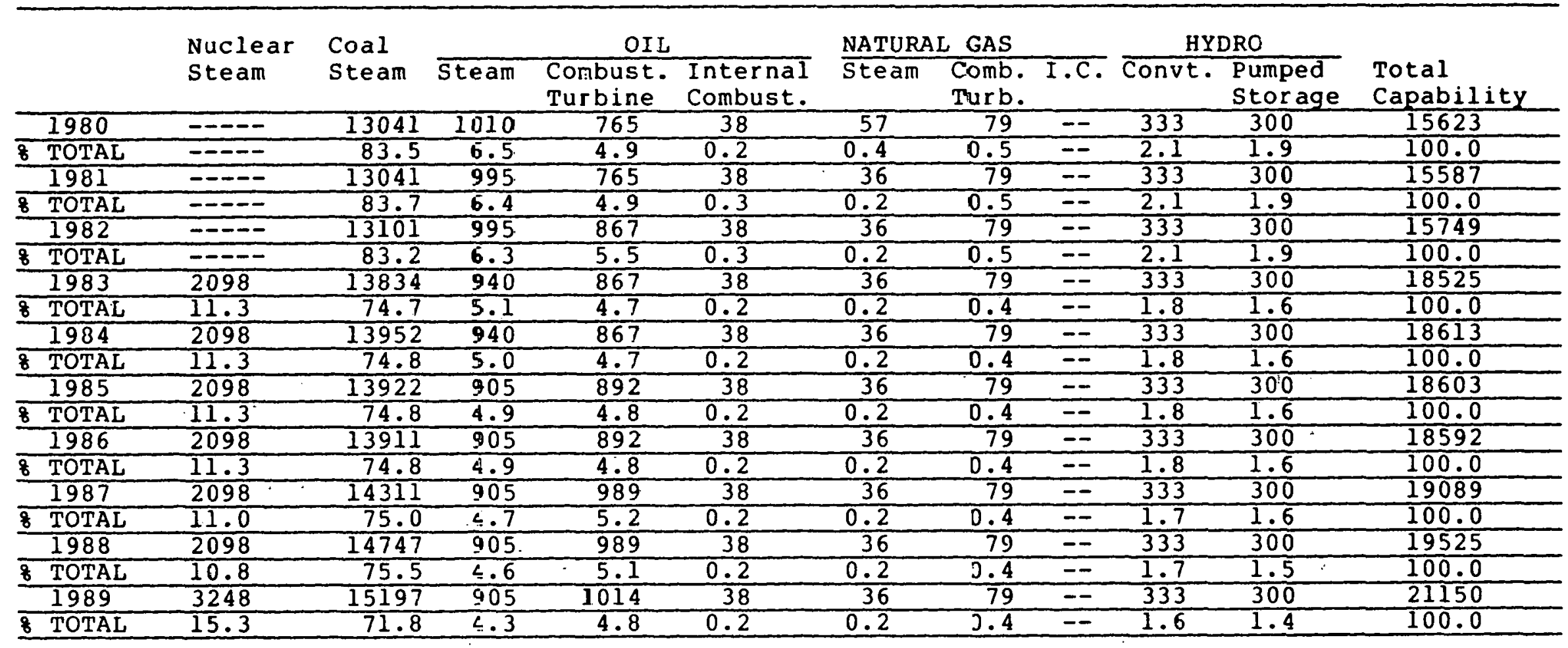




\section{Table 4B.23}

Major Future Generating Capability (Installations ard Removals)

\section{ILLMO REGION}

\begin{tabular}{|c|c|c|c|c|c|c|c|}
\hline \multirow[b]{3}{*}{ System } & \multirow[b]{3}{*}{ Station } & \multirow{3}{*}{$\begin{array}{l}\text { Unit } \\
\text { Type }\end{array}$} & \multirow{3}{*}{$\begin{array}{l}\text { Fue } 1 \\
\text { Type }\end{array}$} & \multirow{3}{*}{$\begin{array}{l}\text { Net } \\
\text { Summer } \\
\text { Capability } \\
(M W)\end{array}$} & \multicolumn{3}{|c|}{ Effective Date } \\
\hline & & & & & ERA 4 & 11 & ERA 38 \\
\hline & & & & & & & 1979 \\
\hline Union EL Co. & Peaking & GT & FO2 & 102 & $5 / 81$ & & $5 / 80$ \\
\hline Union El.Co. & Meramac & ST & BIT & 158 & $5 / 82$ & & $10 / 82$ \\
\hline Union El.Co. & Callaway \# 1 & NP & UR & 1150 & $10 / 82$ & & $10 / 82$ \\
\hline Cent.Il.Pub.Ser. & Newton \#2 & ST & COL & 575 & $12 / 82$ & & $1.2 / 81$ \\
\hline Il. Power Co. & Clinton \#I & NB & UR & 760 & $12 / 82$ & & $12 / 82$ \\
\hline Soyland Coop. & Clinton \#1 & NB & UR & 100 & $12 / 82$ & & $12 / 82$ \\
\hline Western Il.Pwr.Coop. & Clinton \#1 & NB & UR & 88 & $12 / 82$ & & $12 / 82$ \\
\hline Cent.Il.Light Co. & Duck Creek \#2 & ST & $\mathrm{COL}$ & 400 & $3 / 86$ & & $3 / 84$ \\
\hline Soyland Coop. & Undetermined & ST & $\mathrm{COL}$ & 450 & $5 / 87$ & & $5 / 87$ \\
\hline Union El.Co. & Callaway \#2 & NP & UR & 1150 & $4 / 88$ & & $4 / 87$ \\
\hline Southern Il.Pwr.Coop. & Marion \#5 & ST & COL & 350 & $9 / 88$ & & $6 / 88$ \\
\hline Il. Power Co. & Clinton \#2 & NB & UR & 760 & * & & $6 / 88$ \\
\hline $\begin{array}{l}\text { Western Il.Pwr.Coop. } \\
\text { Cent. }\end{array}$ & $\begin{array}{l}\text { Undetermined } \\
\text { Wallace } 3-6,7\end{array}$ & $\begin{array}{l}S T \\
S T\end{array}$ & $\begin{array}{ll}\mathrm{COL} \\
\mathrm{COL}\end{array}$ & 100 & $9 / 88$ & & $\star$ \\
\hline & & & COL & $(145)$ & $6 / 89$ & & \\
\hline
\end{tabular}

* Unit Not Reported 
ELECTRIC REGION 19

Wisconsin-Upper

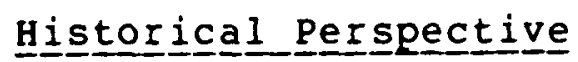

Electric Region 19 (ER19-WUMS) includes the eastern portion of wisconsin and all of Upper Michigan except for the small portion at the eastern end which is in the ECAR region. The major power suppliers in the reglon are the wisconsin Electric power. Co.. wisconsin power and Light. Co., Wisconsin public Eervice Corp., and Madison Gas and Electric Co. Collectively, the four companies own about 88 of the total capacity in the region and serve $1.44 \mathrm{milli}$ ion customers, of which $1.40 \mathrm{mill}$ ion are residential custumels, about 17,000 are farm rustomers, 137,000 are commercial customers, and 1300 are industrial customers. These electric systems are interconnected with $345 \mathrm{kV}$ ties as well as at lower voltages. The systems also have $345 \mathrm{kV}$ ties with the Commonwealth Electric CO. (ER6-CECO) and with Northern states Power Co. in the MARCA region.

The above companies, except for the Wisconsin Electric Power Co., are members of a formal power pool-the wisconsin Power Pool (WIPP). The participants in the WIPP coordinate their planning and installation of generating and transmission facilities and the operation of their systems, including emergency and economy exchanges, spinning reserves and maintenance schedule.

The WIPP systems are also members of the wisconsin-Upper Michigan systems (WUMS).. In addition to the three WIPP members, the Wisconsin Electric Power Co.. and the Upper Peninsula Power Co., are participants in WUMS. Differentiating the two groups, WUMS is primarily concerned with the reliability and adequacy of power supply of its members, whereas wIPP primarily is concerned with the economy of supply for its members. WIPP members have constructed several joint power projects to achieve their objectives.

All of the members of wuMs are also members of the MAIN organization and WUMS is a major subgroup of MAIN. Other systems located geographically within the wuMs region which report to MAIN are: Kaukauna, WI., Manitowoc, WI., Marshfield, WI., and Marquette, MI. Data for these for systems are included in this report for WUMS.

WuMs has historically been a summer-peaking region. Table 4C.l shows the region's summer and winter peaks for the period 19771979 . 


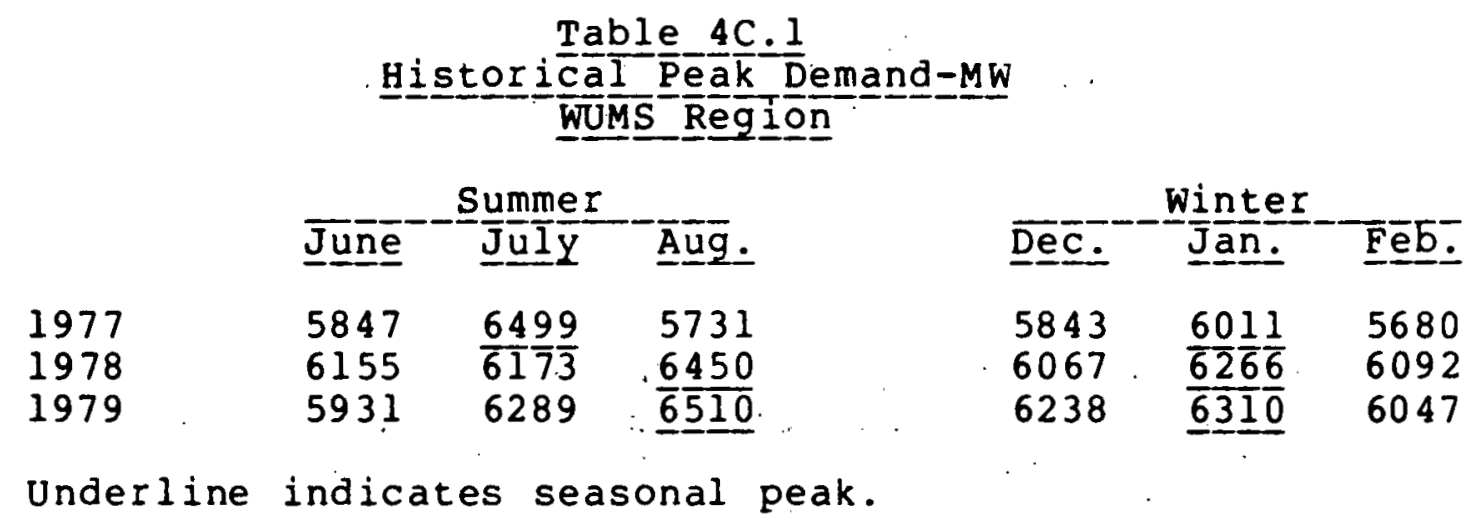

The summer peak demands are dependent on climatic conditions and are temperature/humidity sensitive. . Usually the peak will occur in July or August.

The winter peak. usually occurs in January, but it may occur in any winter month, depending on the combination of weather and economic activity in the region. The winter peak during the 1977-79 period was 3-8\% less: than the corresponding summer peak.

Table 4C. 2 shows the scheduled maintenance performed each period and also the capability unavailable due to forced outages or otherwise inoperable

Table 4 C. 2

Scheduled Maintenance and Unavailable Capabilities WUMS Region.

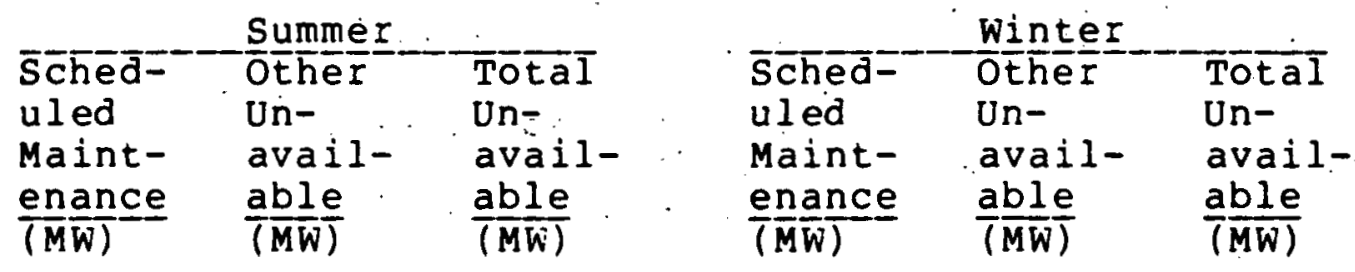

$\begin{array}{rrrrrrr}1977 & 223 & 272 & -495 & -504 & 467 & 971 \\ 1978 & 211 & 341 & 552 & 648 & 508 & 1156 \\ 1979 & 168 & 1281 & 1449 & 596 & 911 & 1506\end{array}$

The capability unavailable for reasons other than scheduled maintenance varied from 4-15\% of the installed capability in summer and from 6-118 in winter.: 
The reserve margins for the 1977-79 seasonal periods are shown below, considering the effects of scheduled maintenance and other outages.

$$
\begin{aligned}
& \text { Table }{ }^{i} \mathrm{i} \cdot 3 \\
& \text { HistoricaI Seasonal Reserve }
\end{aligned}
$$

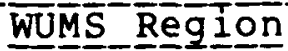

\begin{tabular}{|c|c|c|c|c|c|c|c|}
\hline & $\begin{array}{l}\text { Peak } \\
\text { Demand } \\
\text { ( } \overline{M W})\end{array}$ & $\begin{array}{l}\text { Total } \\
\text { Capa- } \\
\frac{b}{\left(\frac{1}{M} W\right)}-\frac{i t y}{}\end{array}$ & $\begin{array}{l}\text { Total } \\
\text { Reserves } \\
\left.\frac{(\$)}{(}\right)\end{array}$ & $\begin{array}{l}\text { Avail- } \\
\text { able } \\
\text { Capa- } \\
\text { b-il } \frac{i t y}{(M \bar{W})}\end{array}$ & $\begin{array}{l}\text { Avail- } \\
\text { able } \\
\text { Reserves } \\
\text { (q) }\end{array}$ & $\begin{array}{l}\text { Actual } \\
\text { Capa- } \\
\text { bi } \frac{1}{(M W} \frac{i t y}{(W)}\end{array}$ & $\begin{array}{c}\text { Actual } \\
\text { Reserves } \\
\left(\frac{8}{8}\right)\end{array}$ \\
\hline \multirow[t]{2}{*}{$\begin{array}{l}1977 \\
1978 \\
1979\end{array}$} & $\begin{array}{l}6499 \\
6450 \\
6510\end{array}$ & $\begin{array}{l}7711 \\
8218 \\
8844\end{array}$ & $\begin{array}{l}18.6 \\
27.4 \\
35.9\end{array}$ & $\begin{array}{l}7488 \\
8007 \\
8676\end{array}$ & $\begin{array}{r}15.2 \\
24.1 \\
33.3\end{array}$ & $\begin{array}{l}7216 \\
7666 \\
7395\end{array}$ & $\begin{array}{l}11.0 \\
18.9 \\
13.6\end{array}$ \\
\hline & & & $\underline{W} \underline{N}$ & EE_R & & : & \\
\hline $\begin{array}{l}1977 \\
1978 \\
1979\end{array}$ & $\begin{array}{l}6011 \\
6266 \\
6310\end{array}$ & $\begin{array}{l}7821 \\
8554 \\
8833\end{array}$ & $\begin{array}{l}30.1 \\
36.5 \\
40.0\end{array}$ & $\begin{array}{l}7317 \\
7906 \\
8237\end{array}$ & $\begin{array}{l}21.7 \\
26.2 \\
30.5\end{array}$ & $\begin{array}{l}6850 \\
7398 \\
7326\end{array}$ & $\begin{array}{l}14.0 \\
18.1 \\
16.1\end{array}$ \\
\hline
\end{tabular}$$
\text { G U M M E } R
$$

The reserve margins shown above indicate that for the 1977-79 period sufficient capability was available to meet the demand requirements in both. the summer and winter periods, after taking into account both scheduled and forced outayes, and still have ample actual reserves to meet other contingencies. However, the reserves are somewhat larger than usually planned. This was caused by less growth in the peak demands than typically would be expected.

Table 4C. 4 shows the energy requirements, summer and winter demands, and annual load factors for the 1977-79 period. 
Table 4C. 4

Historical Energy Peaks and Load Factorors WUM S Region

Energy

Requirement (GWh) (Growth \&)

$1977 \quad 34601$

$1978 \quad 37128$

197938398.

8 Growth

1977-79

Requirement
(GWh) (Growth 8 )

3.4

\section{WuMs Region}

Summer Demand

(MW) (Growth 8 )

\section{9}

6450

6510

0.9
Winter Demand
(MW) (Growth
6011
6266
6310
0.7

Annual

Load

Factor $(\underline{z})$

60.8

65.7

67.3

0.1

2.5

Over the period, the energy requirements grew at a compound growth rate of 5.3\%. This is considerably greater than the other regions in MAIN. The summer and winter demands show little growth during the period, which is consistent with the other MAIN regions. The lesser rate of the growth of the demands with respect to the energy resulted in higher than usual annual load factors.

\section{Current Perspective}

The projected summer and winter demands are shown below.

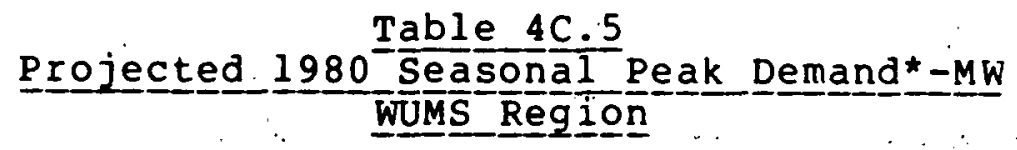

Summe I

$\begin{array}{lll}\text { Junne } & \text { July } & \text { Aug. } \\ 6466 & 6778 & \underline{6863} 3\end{array}$

* Coincident as to month.

\section{winter}

Dec.

Jan.

Fe․․

6743

6875

6548 
The 1980 summer and winter demands are projected to occur in August and January, respectively. This is consistent with previous occurrences. However, the peak may occur in any month of the seasons depending on economic and climatic conditions.

The monthly coincident winter peak is slightly greater than the summer monthly coincident peak. However, the summer and winter non-coincident peaks are $6915 \mathrm{MW}$ and $6878 \mathrm{MW}$, respectively. On this basis, the region would still be summer peaking in 1980. Long range projections indicate that the region will probably shift to winter peaking.

The 1980 summer planned capability of WuMS is estimated to be $9018 \mathrm{MW}$ and the non-consistent summer peak demand is projecred to be $6915 \mathrm{MW}$, resulting in planned reserves of $2103 \mathrm{MW}$ or $30.4 \%$. After adjustment for scheduled receipts and deliveries, the total reserves are slightly increased to $2121 \mathrm{MW}$ or 30.78 ; and after adjustment for scheduled unavailable capacity during the summer peak period, the operating reserves are projected to be 30.18 .

The summer and winter 1980 reserve margins for the electric region are shown below.

\section{Táble $\underline{4}$ C. 6

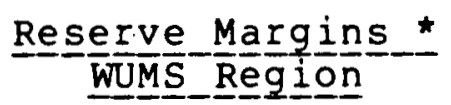

$S \underline{M} M \underline{E} \underline{P}$

\begin{tabular}{|c|c|c|c|c|c|}
\hline Planned & Total & $\begin{array}{l}\text { Avail- } \\
\text { able }\end{array}$ & Planned & Total & $\begin{array}{l}\text { Avail- } \\
\text { able }\end{array}$ \\
\hline 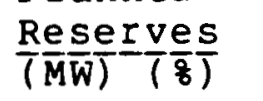 & $\left.\frac{\text { Re }}{(\bar{M}} \frac{s e}{\mathrm{~W}}\right) \frac{\text { rves }}{(8)}$ & $\frac{\text { Reserves }}{(\mathrm{MW})} \frac{(z)}{(z)}$ & 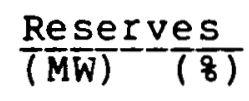 & 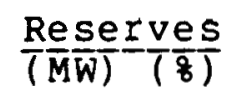 & $\frac{\text { Reserves }}{(\bar{M} \bar{W})} \frac{{ }^{\prime}}{(q)}$ \\
\hline $2103 \quad 30.4$ & $2121 \quad 30.7$ & 208330.1 & $2382 \quad 34.6$ & 240535.0 & $2073 \quad 30.1$ \\
\hline
\end{tabular}

The margins shown above have not been adjusted for unscheduled outages of capacity as the amount of these outages are unknown ahead of time. If these outages do not exceed the maximum outages of the 1977-79 period, 158 of installed capacity during the summer period and 108 during the winter, the resultant available reserves of $730 \mathrm{MW}, 8.18$ and $1054 \mathrm{MW}$, 11.48 , respectively, would be in excess of peak requirements. 
Almost two-thirds of the current capacity is coal-fired steam capacity; 48, oil-fired steam; and 98, oil-fired combustion turbine capacity. There are 3 nuclear units installed in wUMS with westinghouse reactors comprising 188 of the total capability. A $580 \mathrm{MW}$ coal-fired steam unit is scheduled for service in July 1980. If this unit is delayed beyond the start of the summer peak period, the operating reserves would be reduced to 21.78 . This is still within the required minimum reserve limit. There are no new nuclear plants planned for service in 1980 .

The projected 1980 energy reguirements, summer and winter demands, and annual load factor of the region are shown below.

$$
\begin{aligned}
& \text { Table } 4 \text { C. } 8 \\
& 1980 \text { Reguirements }
\end{aligned}
$$

$\begin{array}{cccc}\begin{array}{c}\text { Energy } \\ \text { Reguirement }\end{array} & \begin{array}{l}\text { Summer } \\ \text { Demand }\end{array} & \begin{array}{c}\text { Winter } \\ \text { Demand }\end{array} & \text { Annual L.F. } \\ \text { (GWH) } & \text { (MW) } & (\mathrm{MW}) & (8) \\ 40487 & 6915 & 6878 & 66.7 \\ 5.4 & 6.2 & 9.0 & \end{array}$

The 1980 projected summer and winter demands are projected to grow at considerably higher rates than they did during the 1977-79 period - 0.18 and 2.58 , respectively.

This is due in part to the result of the previous forecast overestimating the 1979 summer peak and also the 1979/80 winter peak. Although the peaks and energy are forecasted to grow at a faster rate than during the 1977-79 periods, the projected 1980 values are considerably below those which were projected last year for the corresponding period.

The projected 1980 energy requirement growth rate of 5.48 over 1979 requirement is in line with the historic 1977-79 rate of 5.38 .

The projected 1980 annual load factor, 66.78, is about normal for the region, which has large mining loads in the northern portion. 
Delays of future critical bulk power transmission facilities that will not be in service when needed are required to be reported under Item 5-C of the ERA 411 report. In the April 1 , 1980, MAIN report, no delays are reported for the WUMS region.

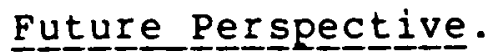

The range of total reserves for the wUMS region for the perlods 1981-85 and 1986-89 are tabulated below.

Table $\underline{4}$ C. .9

Range of Total Reserves $=$ 을 WUMM

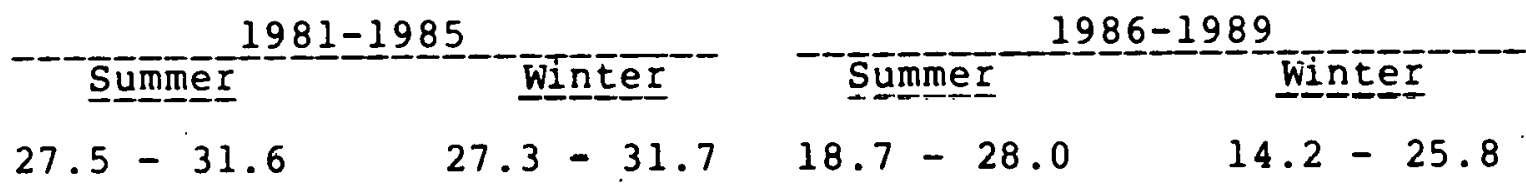

As seen above, the projected summer reserve exceeds the 158 MAIN minimum reserve margin criteria for all the years in each time period. However, the winter reserve margin drops below the 158 requirement in 1988 and 1989. An additional $61 \mathrm{MW}$ and $77 \mathrm{MW}$ are needed to bring it up to that level. It is expected that arrangements will be made to purchase the capacity from the excess available in MAIN if this is required. A $225 \mathrm{MW}$ reserve capacity purchase from Commonwealth Edison Co. was contracted for 1986 when it was first forecasted that reserve reguirements would be deficient in that year. However, the latest figures indicate that this is not necessary.

Projected growth rates of demand and energy for each period and the overall rates for 1981-1989 are shown below. 
Table $\underline{4}$ C. 10

Projected Energy and Demand Growth Rate WUMS Regiㅡㅁㅡ

Energy Reguirements Summer Demand Winter $\frac{\text { Demand }}{\text { Grow }}$

Annual

\begin{tabular}{lll} 
(GWh) & ( 8$)$ & $(\mathrm{MW})$ \\
\hline
\end{tabular}

1981

1982

41278

2.0

7103

2.7

42526

3.0

7291

2.6

2.8

7475

2.5

1984

44910

$2.8 \quad 7652$

2.4

$2.7 \quad 7855$

2.7

$(\mathbf{M} W)$

(흐)

Load

1985

46144

\section{2.}

2. 5

$3.0 \quad 8068$

3.0

8297

2.8

8514

3.6

8787
$2: 7$

2.8

2.6

3.2
7124

7357

7606

7852

8127

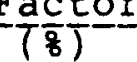

3.3

3.4

3.4

3.2

3.5

66.1

66.0

65.6

65.1

64.8

8 Growth

86-89

\section{$\underline{3} .1$}

느모

3. 6

8 Growth

8l-89

\section{0}

2.7

3.5

$\begin{array}{ll}8405 & 3.4 \\ 8697 & 3.5 \\ 9042 & 4.0 \\ 9352 & 3.4\end{array}$

64.5

64.2

63.4

63.6

$\underline{3} \cdot 3$

.4 
The summer capability of units installed in the region for the period 1980-1989 is shown by type of fuel in Table 4C.18. Major generating unit additions during the period are given in Table 4C.19. The percentages of each type of capability for the target years 1980 , 1984, and 1989 are given below.

Table 4C.11

Install led Generating Capability by Type of Fuél WUMS Regín

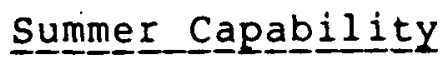

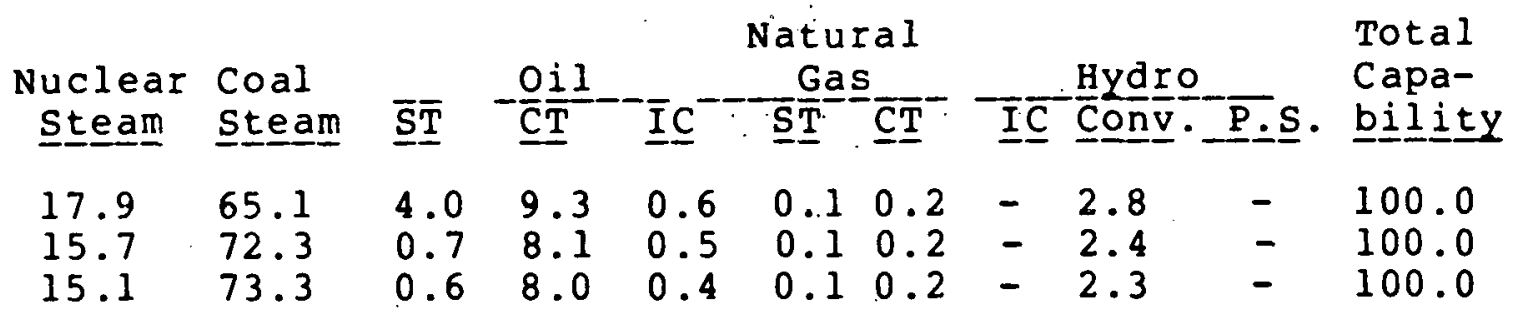

Currently, coal is the primary fuel for about 65 of the planned capability of the region. This percentage is projected to increase to 728 by 1984 and to 738 by 1989 , due to the installation of the Wisconsin Electric Power $580 \mathrm{MW}$ Pleasant Prairie No. 1 coal unit in July, 1980; the weston No. 3320 $M W$ coal unit of Wisconsin Public service in March, 1982; the $580 \mathrm{MW}$ Pleasant Prairie No. 2 coal unit of Wisconsin Electric in April 1983; and the joint $400 \mathrm{MW}$ Edgewater No. 5 unit of Wisconsin Electric and Wisconsin Public Service scheduled for April 1984. If the inservice date of the 1982 unit is delayed beyond the start of the summer 1982 peak period, the available reserve would be reduced from 25.98 to $21.5 \%$, which is still greater than the planned reserve requirements. A delay in the 1983 and 1984 unit would reduce the actual reserve in those years to 20.78 and 25.18 , respectively. These are also greater than the planned reserve requirements.

Oil-fired steam generating units comprise only 48 of the 1980 capability and consists of $336 \mathrm{MW}$. This is scheduled to decrease to $67 \mathrm{MW}$ by 1984 and to $61 \mathrm{MW}$ by 1985 , and to remain at that level through 1989 .

The adequacy and reliability of the region's transmission network is tested periodically for contingency conditions in accordance with MAIN Guide No. 12. The results of the investigation of the 1984 Emergency Transfer Capabilities. (ETC's) for the WUMS area follow: 
The 1984 model used to represent wums in this study incorporates the addition of $1860 \mathrm{MW}$ of new generating capacity between 1979 and 1984 inclusive. This additional capacity will be located at Pleasant Prairie, Weston, and Edgewater.

WUMS Emergency Transfer Capability (ETC), as determined by this study, illustrates a decrease from the levels of previous future system studies, as tabulated here.:

Táble $\underline{4} \underline{\underline{C}} . \underline{12}$

Emergency Transfer Capability - MW WUMS Region

$\begin{array}{cccc}\text { From/Year } & \underline{1980}(1) & \underline{1982}(2) & 1984 \\ \text { CE } & 1600 & 1000 & 900 \\ \text { IOWA } & 1500 & 1000 & 800 \\ \text { MINN } & 1100 & 750 & 600 \\ \text { MO } & 1600 & 1000 & 800 \\ \text { SCILL } & 1700 & 1000 & 800\end{array}$

(1) This data was taken from the 1980 Interchange Capability Study that was published in November 1975 .

(2) This data was taken. from the 1982 Interchange Capability study that was published in september 1977 .

The reduction in the MINN-WuMs interchange level is a matter of concern and will be considered when evaluating future:system additions. The values reported above for 1984, however, are considered adequate.

The import capability for wuMs is described below..

The non-simultaneous Emergency Transfer Capability (ETC) from $\mathrm{CE}$ is $900 \mathrm{MW}$ for loss of the Lockport to Lisle $345 \mathrm{kV}$ line with the Electric Junction to Lombard $345 \mathrm{kV}$ line as the limiting element. 
The Electric Junction to Lombard $345 \mathrm{kV}$ line limits the ETC from IOWA to $800 \mathrm{MW}$ for loss of the Lockport to Lisle $345 \mathrm{kV}$ line.

The ETC from MINN is limited to $600 \mathrm{MW}$ by the Alma to Wabaco $161 \mathrm{kV}$ line with the Adams to Zumbrota $345 \mathrm{kV}$ line out.

The Electric Junction to Lombard $345 \mathrm{kV}$ line is the limiting element for a loss of the Lockport to Lisle $345 \mathrm{kV}$ line for the ETC imports from MO. The interchange limits are $800 \mathrm{MW}$ for the ETC.

The ETC from SCILL is limited to $800 \mathrm{MW}$ for an outage of the Lockport-Lisle $345 \mathrm{kV}$ line with the Electric Junction to Lombard $345 \mathrm{kV}$ line being the limiting element.

The export capabilities for wuMs are described below.

The ETC to CE is $1200 \mathrm{MW}$ with the $\mathrm{Z}$ ion to Pleasant Prairie $345 \mathrm{kV}$ line as the limiting element for loss of the zion to Arcadian $345 \mathrm{kV}$ line.

The Sycamore to Montezuma $345 \mathrm{kV}$ line limits the ETC to IOWA to $800 \mathrm{MW}$ for loss of the Cooper to Booneville $345 \mathrm{kV}$ line.

The outage of the Lacrosse to Genoa $161 \mathrm{kV}$ line limits the ETC to MINN to 500 MW with the Genmoa to Lacrosse tap as the limiting element.

The WUMS exports to MO are limited to $1300 \mathrm{MW}$ for the ETC with the Cahokia $345 / 138 \mathrm{kV}$ transformer as the limiting element for the double outage of the other Cahokia $345 / 138 \mathrm{kV}$ transformer and the Cahokia to Campbell $345 \mathrm{kV}$ line.

The ETC to SCILL is limited to $1300 \mathrm{MW}$ by the $\mathrm{zion}$ to pleasant Prairie $345 \mathrm{kV}$ ine when the $\mathrm{zi}$ ion to Arcadian $345 \mathrm{kV}$ line is out of service.

The interregional transfer capabilities as determined from this study are as follow. These are approximate non-simultaneous values above contracted schedules, based on emergency transfer capabilities. 
Table 4 C. .13

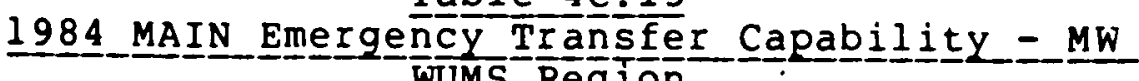

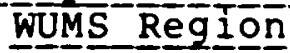

$\begin{array}{llr}\text { ECAR } & \text { to MAIN } & 2900 \mathrm{MW} \\ \text { MARCA to MAIN } & 800 \mathrm{MW} \\ \text { SERC to MAIN } & 2800 \mathrm{MW} \\ \text { SPP } & \text { to MAIN } & 1900 \mathrm{MW}\end{array}$

MAIN to ECAR" $4000+M W$

MAIN to MARCA $550 \mathrm{MW}$

MAIN to SERC $3200 \mathrm{MW}$

MAIN to SPP $1800 \mathrm{MW}$

Table 4C.14 lists proposed bulk power lines. Many of these lines are required to provide area protection, and increase transfer capability. 
Table $4 C .14$

List of Proposed Bulk Power Lines

$1 / 1 / 80$ to $1 / 1 / 90$

\section{WUMS Region}

\begin{tabular}{|c|c|}
\hline $\begin{array}{c}\text { Line } \\
\text { Ownership } \\
\text { List } \\
\end{array}$ & Terminals \\
\hline WIEP & Pleasant Praire-Arcadian \\
\hline WIPS & Black Brook-Venus \\
\hline WIPL & Paddock-Paddock Tap \\
\hline WIPL & Paddock-Paddock Tap \\
\hline MAGE & N. Madison-S. Madison \\
\hline WIEP & Brookdale-Granville \\
\hline WIEP & Brookdale-Racine \\
\hline WIPL & South Madison - Paddock \\
\hline WIPL/CECO & Paddock-Wemp l et own \\
\hline WIEP/WIPS & Venus-Plains \\
\hline WIEP & Wesbay-Existing \\
\hline WIPS & Wesbay-Existing \\
\hline
\end{tabular}

\begin{tabular}{|c|c|c|c|c|c|}
\hline \multicolumn{2}{|c|}{$\begin{array}{l}\text { Line } \\
\text { Length } \\
\end{array}$} & \multirow{2}{*}{$\begin{array}{c}\text { Planned } \\
\text { Service } \\
\text { Date }\end{array}$} & \multicolumn{2}{|c|}{$\begin{array}{l}\text { Nominal } \\
\text { Yoltage } \\
\text { in KV }\end{array}$} & \multirow[b]{2}{*}{ Remarks } \\
\hline KM & $\overline{M I}$ & & Dper & $\overline{\text { Dsgn }}$ & \\
\hline 87 & 54 & $4 / 32$ & 345 & 345 & Deliver Generator Output \\
\hline 51 & 32 & $8 / 32$ & 115 & 345 & Relieve Overloads \\
\hline .6 & .4 & $6 / 83$ & 345 & 345 & Provide Area Protection \\
\hline .6 & .4 & $6 / 83$ & 345 & 345 & Provide Area Protection \\
\hline 58 & 36 & $6 / 85$ & 345 & 345 & Provide Area Protection \\
\hline 23 & 14 & $6 / 86$ & 345 & 345 & Provide Area Protection \\
\hline 50 & 31 & $6 / 86$ & 345 & 345 & Provide Area Protection \\
\hline 64 & 40 & $6 / 86$ & 345 & 345 & Provide Area Protection \\
\hline 8 & 5 & $7 / 86$ & 345 & 345 & $\begin{array}{l}\text { Increase Transfer Capability } \\
\text { Miles Shown for WIPL Portion }\end{array}$ \\
\hline 103 & 64 & $6 / 87$ & 345 & 345 & Provide Area Protection \\
\hline 43 & 27 & $6 / 87$ & 345 & 345 & Provide Area Protection \\
\hline 11 & 7 & $6 / 87$ & 345 & 345 & Provide Area Protection \\
\hline
\end{tabular}

Note: WUMS $=$ WIEP + W-PS + WIPL 
HISTORICAL CAPABILITY (MW) AND RESERVES (MW and Percent)

Wisconsin - Upper Michigan Systems Group - WUMS

1. Planned Capability

2. Peak Demand

3. Planned Reserves (1-2)

4. Planned Reserves $(\%)(3 / 2) \times 100$

5. Net Transactions (Imports-Exports)

6. Total Capability $(1+5)$

7. Total Reserves (6-2)

8. Total Reserves $(\%)(7 / 2) \times 100$

9. Scheduled Maintenance

10. Capability after Maintenance (6-9)

11. Reserves after Maintenance (10-2)

12. Reserves after Maintenance (\%) $(11 / 2) \times 100$

13. Inoperable Capability

14. Available Capability (10-13)

15. Available Reserves (14-2)

16. Available Reserves (\%) (15/2) ×100

17. Forced Outages I/

18. Actual Capability after Forced Outages (14-17)

19. Actual Reserves (18-2)

20. Actual Reserves (\%) $(19 / 2) \times 100$

I/ Information not reported separately.

\begin{tabular}{|c|c|c|c|c|c|}
\hline \multicolumn{2}{|c|}{1977} & \multicolumn{2}{|c|}{1978} & \multicolumn{2}{|c|}{1979} \\
\hline Summer & Winter & Summer & Winter & Summer & Winter \\
\hline 7419 & 7563 & 8099 & 8403 & 8295 & 8630 \\
\hline 6499 & 6011 & 6450 & 6266 & 6510 & 6310 \\
\hline 920 & 1552 & 1649 & 2137 & 1785 & 2320 \\
\hline 14.2 & 25.8 & 25.6 & 34.1 & 27.4 & 36.8 \\
\hline 292 & 258 & 119 & 151 & 549 & 203 \\
\hline 7711 & 7821 & 8218 & 8554 & 8844 & 8833 \\
\hline 1212 & 1810 & 1768 & 2288 & 2334 & 2523 \\
\hline 18.6 & 30.1 & 27.4 & 36.5 & 35.9 & 40.0 \\
\hline 223 & 504 & 211 & 648 & 168 & 596 \\
\hline 7488 & 7317 & 8007 & 7906 & 8676 & 8237 \\
\hline 989 & 1306 & 1557 & 1640 & 2166 & 1927 \\
\hline 15.2 & 21.7 & 24.1 & 26.2 & 33.3 & 30.5 \\
\hline 272 & 467 & 341 & 508 & 1281 & 911 \\
\hline 7216 & 6850 & 7666 & 7398 & 7395 & 7326 \\
\hline 717 & 839 & 1216 & 1132 & 885 & 1016 \\
\hline 11.0 & 14.0 & 18.9 & 18.1 & 13.6 & 16.1 \\
\hline 0 & 0 & 0 & 0 & 0 & 0 \\
\hline 7216 & 6850 & 7666 & 7398 & 7395 & 7326 \\
\hline 717 & 839 & 1216 & 1132 & 885 & 1016 \\
\hline 11.0 & 14.0 & 18.9 & 18.1 & 13.6 & 16.1 \\
\hline
\end{tabular}


Table 4C.16

CURRENT CAPABILITY (MW) AND RESERVES (MW and Percent)

Wiscons in - Upper Michigan Systems Group - WUMS

1. Planned Capability I/

$\begin{array}{rrr}\begin{array}{rr}1980 \\ \text { Summer }\end{array} & & \begin{array}{r}1980 / 81 \\ \text { Winter }\end{array} \\ 9018 & & 9260 \\ 6915 & & 6876 \\ 2103 & & 2384 \\ 30.4 & 34.7 \\ 18 & 23 \\ 9036 & 9283 \\ 2121 & 2407 \\ 30.7 & 35.0 \\ 0 & 332 \\ 9036 & 8951 \\ 2121 & 2075 \\ 30.7 & 30.2 \\ 38 & 0 \\ 8998 & 8951 \\ 2083 & 2075 \\ 30.1 & 30.2 \\ 0 & 0 \\ 8998 & 8951 \\ 2083 & 2075 \\ 30.1 & 30.2\end{array}$

2. Reak Demand

3. Planned Reserves (1-2)

4. Planned Reserves (q) (3/2) $\times 100$

5. Net Transactions (Imports-Exports)

6. Total Capability $(1+5)$ 283

7. Total Reserves (6-2) 35.0

8. Total Reserves (q) $(7 / 2) \times 100$

10. Capability after Maintenance (6-9) 2075

11. Reserves after Maintenance (10-2)

12. Reserves after Maintenance $(\%)(11 / 2) \times 100$

30.2

13. Inoperable Capability

14. Available Capability (10-13)

8951

15. Available Reserves (14-2)

16. Available Reserves (\%) $(15 / 2) \times 100$

1\%. Forced Outages 21

18. Actual Capability after Forced Outages (14-17)

19. Actual Reserves (18-2)

30.2

20. Actual Reserves (\%) (19/2) $\times 100$

1/ No delays are anticipated in new generating units since submittal of 1980 EKA-411

2/ Information not reported separately. 
Table 4C.17.1

FUTURE CAPABILITY (MW) AND RESERVES (MW and Percent) - 1981-84

Wisconsin-Upper Michigan Systems Group - WUMS

1. Planned Capability

2. Peak Demand

3. Planned Reserves $(1-2)$

4. Planned Reserves $(\%)(3 / 2) \times 100$

5. Net Transactions (Imports-Exports)

6. Total Capability $(1+5)$

7. Total Reserves (6-2)

8. Total Reserves (\%) (7/2) $\times 100$

9. Scheduled Maintenance

10. Capability after Maintenance (6-9)

11. Reserves after Maintenance (10-2)

12. Reserves after Maintenance ( $(x)(11 / 2) \times 100$

13. Inoperable Capability I/

14. Available Capability (10-13)

15. Available Reserves (14-2)

16. Available Reserves (\%) (15/2) ×100

17. Forced Outages I/

18. Actual Capability after Forced Outages (14-17)

1981

Summer Winter

$9031 \quad 9260$

$7103 \quad 7124$

$1928 \quad 2136$

$27.1 \quad 30.0$

$22 \quad 27$

$9053 \quad 9287$

$1950 \quad 2163$

$27.5 \quad 30.4$

$112 \quad 282$

89419005

$1838 \quad 1881$

25.926 .

0
$8941 \quad 9005$

$1838 \quad 1881$

25.926 .4

$0 \quad 0$

8941

1838

25.9

20. Actual Reserves $(\%)(19 / 2) \times 100$

1/ Information not available.
1982 Summer Winter

$9331 \quad 9592$

$7291 \quad 7357$

$2040 \quad 2235$

$28.0 \quad 30.4$

$25 \quad 31$

$9356 \quad 9623$

$2065 \quad 2266$

$28.3 \quad 30.8$

$175 \quad 406$

$9181 \quad 9217$

$1890 \quad 1860$

$25.9 \quad 25.3$

$0 \quad 0$

$9181 \quad 9217$

$1890 \quad 1860$

$25.9 \quad 25.3$

0

9181

9217

1881

26.4

1890

25.9

1860

25.3
1983

Summer Winter

$9650 \quad 9876$

$7475 \quad 7606$

$2175 \quad 2270$

$29.1 \quad 29.8$

28

9678

2203

29.

74

9604

9604

2129

28.5

.

9604

2129

28.5

0

9604

2129

28.5

25.

9512

1906

25.1

9512

1906

25.1
1984

Summer Winter

$10044 \quad 10304$

$7652 \quad 7852$

$2392 \quad 2452$

$31.3 \quad 31.2$

$27 \quad 36$

$10071 \quad 10340$

$2419 \quad 2488$

$31.6 \quad 31.7$

$95 \quad 384$

$9976 \quad 9956$

$2324 \quad 2104$

$30.4 \quad 26.8$ 
FUTURE CAPABILITY (MK) AND RESERVES (MW and Percent) - 1985-89

Wisconsin - Upper Michigan Systems Group - WUMS

1. Planned Capability

2. Peak Demand

3. Planned Reserves (1-2)

4. Planned Reserves $(\%)(3 / 2) \times 100$

5. Net Transactions (Imports-Exports)

6. Total Capability $(1+5)$

7. Total Reserves (6-2)

8. Total Reserves (\%) $(7 / 2) \times 100$

9. Scheduled Maintenance 1/

10. Capability after Maintenance ( $\epsilon-9)$

11. Reserves after Maintenance (10-?)

12. Reserves after Maintenance (\%) $(11,2) \times 100$

13. Inoperable Capability $1 /$

14. Available Capability (10-13)

15. Available Reserves (14-2)

16. Availlable Reserves (\%) (15/2) $\times 100$

17. Forced Outages ]/

18. Actual Capability after Forced Dutages (14-17)

19. Actual Reserves (18-2)

20. Actual Reserves (\%) $(19 / 2) \times 100$
1985

$\frac{1985}{\text { Summer Winter Summer Winter Sumrer }} \frac{1987}{\text { Sin }}$

\begin{tabular}{|c|c|c|c|c|c|c|c|c|c|}
\hline 10070 & 10304 & 10070 & 10304 & 10070 & 10304 & 10060 & 10282 & 10450 & 10682 \\
\hline 7855 & 8127 & 8068 & 8405 & $82 \cdot 37$ & 8679 & 8514 & 9042 & 8787 & 9352 \\
\hline 2215 & 2177 & 2002 & 1899 & 1773 & 1607 & 1546 & 1240 & 663 & 1330 \\
\hline 28.2 & 26.8 & 24.8 & 22.6 & 21.4 & 18.5 & 18.2 & 13.7 & 18.9 & 14.2 \\
\hline 14 & 40 & 258 & 270 & 37 & 50 & 42 & 55 & 46 & 50 \\
\hline 10084 & 10344 & 10328 & 10574 & 10197 & 10354 & 10102 & 10337 & 10496 & 10732 \\
\hline 2229 & 2217 & 2260 & 2169 & 1810 & 1657 & 1588 & 1295 & 1709 & 1380 \\
\hline 28.4 & 27.3 & 28.0 & 25.8 & 21.8 & 19.1 & 18.7 & 14.3 & .4 & 14.8 \\
\hline 0 & 0 & 0 & 0 & 0 & 0 & 0 & 0 & 0 & 0 \\
\hline 10084 & 10344 & 10328 & 10574 & 10107 & 10354 & 10102 & 10337 & 10496 & 10732 \\
\hline 2229 & 2217 & 2260 & 2169 & 1810. & 1657. & 1.588 & 1295 & 1709 & 1380 \\
\hline 28.4 & 27.3 & 28.0 & 25.8 & 21.8 & 19.1 & 18.7 & 14.3 & 19.4 & 14.8 \\
\hline 0 & 0 & $\therefore 0$ & 0 & 0 & 0 & 0 & 0 & 0 & 0 \\
\hline 10084 & 10344 & 10328 & 10574 & $101: 07$ & 10354 & 10102 & 10337 & 10496 & 10732 \\
\hline 2229 & 221.7 & 2260 & 2169 & 18.10. & 1657 & 1588 & 1295 & 1709 & 1380 \\
\hline 28.4 & 27.3 & 28.0 & 25.8 & 21.8 & 19.1 & 18.7 & 14.3 & 19.4 & 14.8 \\
\hline 0 & 0 & 0 & 0 & 0 & 0 & 0 & 0 & 0 & 0 \\
\hline 10084 & 10344 & 10328 & 10574 & $1010 ?$ & 10354 & 10102 & 10337 & 10496 & 107.32 \\
\hline 2229 & 2217 & 2260 & 2169 & 1810 & 1657 & 1588 & 1295 & 1709 & 1380 \\
\hline 28.4 & 27.3 & 28.0 & 25.8 & $2 i .8$ & 19.1 & 18.7 & 14.3 & 19.4 & 14.8 \\
\hline
\end{tabular}

- I/ Information not available. 
Table 4C. 18

PLANNED NET CAPABILITY AS OF JANUARY 1 , BY TYPE OF FUEL - MW Wiscons in - Upper Michigan Systems Group - WUMS

Summer_Capability

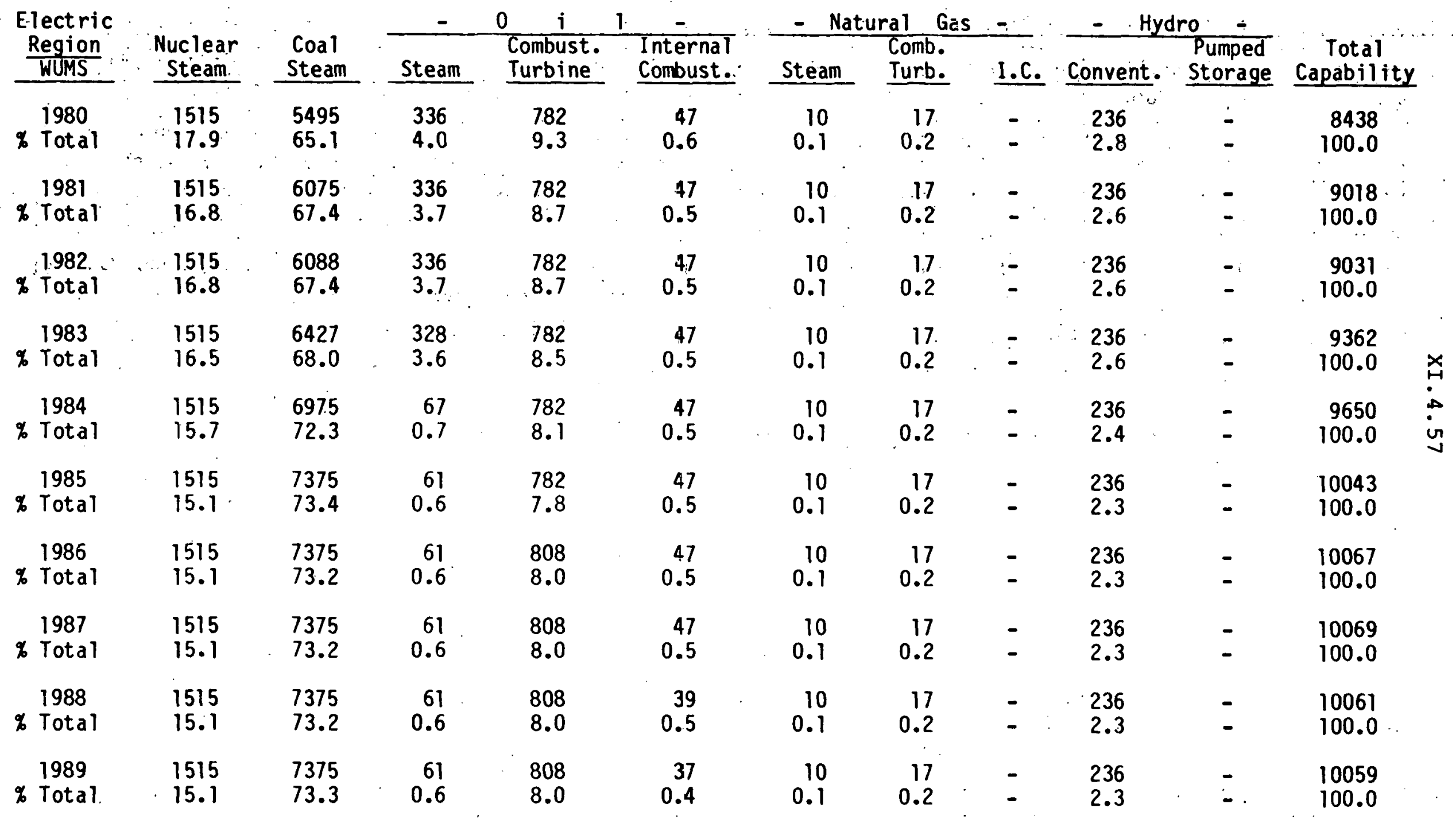




$$
X I .4 .58
$$

\section{Table 4C.19}

MAJOR FUTURE GENERATING CAPABILITY, INSTALLATIONS, AND (REMOVALS) WUMS Region

\begin{tabular}{|c|c|c|c|c|c|c|}
\hline System & Station & $\begin{array}{l}\text { Unit } \\
\text { Type }\end{array}$ & $\begin{array}{l}\text { Fuel } \\
\text { Type } \\
\text { (MW) }\end{array}$ & $\begin{array}{c}\text { Net } \\
\text { Sumner } \\
\text { Capability }\end{array}$ & $\begin{array}{c}\text { Effecti } \\
(4 / 1 / 80) \\
(\text { ERA-411) }\end{array}$ & $\begin{array}{l}\text { (4/1/79) } \\
(\text { ERA-383 } \\
\end{array}$ \\
\hline EL. PWR. & Pleas. Prairie \#1 & ST & SUB & 580 & $7 / 80$ & $7 / 80$ \\
\hline PUB. SER. & Weston \#3 & ST & SUB & 320 & $3 / 82$ & $3 / 82$ \\
\hline EL. PWR. & Lakeside & ST & $\mathrm{FO} 2$ & $(261)$ & $4 / 83$ & $1 / 82$ \\
\hline EL. PWR. & Pleas. Prairie \#2 & ST & SUB & 580 & $4 / 83$ & $4 / 82$ \\
\hline EL. PWR. & EDGEWATER \#5 & ( ST & SUB & 2001 & $3 / 84$ & $6 / 83$ \\
\hline PUB. SER. & & ( ST & SUB & $200)$ & & \\
\hline PUB. SER. & Undetermined & ST & SUB & 400 & $6 / 89$ & - \\
\hline PWR. \& LT. & Haven & $(N P$ & UR & $172)$ & $6 / 89 *$ & $6 / 87$ \\
\hline PUB. SER. & Haven & ( NP & UR & $165)$ & & \\
\hline EL. PWR. & Haven & ( NP & UR & $563)$ & & \\
\hline
\end{tabular}

- Source: Nuclear News, February 1980; but not included in totals. 
SECTION XI. 5

MID-CONTINENT AREA RELIABILITY COORDINATION AGREEMENT (MARCA) 


\section{$X I .5 .1$ \\ MID-CONTINENT AREA POWER POOL (MAPP) \\ ELECTRIC REGION 20}

Historical Perspective

The Mid-Continent Area keliability Coordination Agreement (MARCA) was organized in 1968 and is one of the nine regional reliability councils comprising the National Electric Reliability Council (NERC). The MAPCA region covers all of the states of Iowa, Minnesota, Nebraska, North Dakota, most of South Dakota, and portions of the states of Illinois, Montana, and wisconsin.

The MAFCA organization provides an overview of the planning and operating activities in the region with respect to reliability. It fresently has a membership of 28 systems consisting of 12 investor-owned utilities, $9 \mathrm{G} \& \mathrm{~T}$ cooperatives, 3 public power districts, 3 municipal utilities, and 1 federal agency. Otter Tail Power Company, Northweet Iowa Power Cuoperative, Heartland Consumers Power District, Muscatine Power and water, and Lincoln Electric system became MARCA members during 1979. Missouri Basin Municipal Power Agency became a MARCA member during 1980. Data for these six utilities is included in MARCA summaries. Manitoba Hydro-Electric Eoard is an associate member of MARCA; however, data for this Canadian utility is not included in this report.

A list of the systems for which data is included is shown below.

\section{SYSTEMS INCLUDED IN MARCA}

MAPP REGION

Basin Electric Power Cooperative Cooperative Power Association

Dairyland Power Cooperative

Eastern Iowa Light and Power Cooperative

Heartland Consumers Power District

Interstate Power Company

Iowa Electric Light and Power Company/

Central Iowa Power Cooperative

Iowa-Illinois Gas and Electric Company

Iowa Public Service Company/

Corn Belt Power Cooperative

Iowa Southern utilities Company

Lake Superior District Power Company

Lincoln Electric System

Minnesota Power and Light Company

Minnkota Power Cooperative, Inc.

Missouri Basin Municipal Power Agency

Montana-Dakota Utilities Co.

Muscatine Power and Water

Nebraska Public Power District

Northern States Power Company 


$$
\text { XI.5.2. }
$$

Northwest Iowa Power Cooperative Northwestern Public Service Company Omahe Public Power District

Otter Tail Power Company

United Power Association

Western Area Power Administration Billings Area

MARCA regional operating practices and policies are established by the Mid-Continent Area Power Pool. (MAPP) Operating Committee and are implemented by each system control center working in close cooperation with MAPP Coordination Center operating personnel. The MAPP control center is located in Minneapolis, Minnesota.

The MAPP organization is the regional power pool covering the same geographical area as MARCA and includes the same members. The difference in the two organizations is in their objective. MAPP's furpose is to promote the development of economy of service, as well as reliable and environmentally acceptable facilities. Pate schedules for various classes of service have been established for MAPF members and are on file with the Federal Energy Regulatory

Commission (FERC).

Another major coordinating group in the region is the MPSG (Missouri Easin systems Group). The MPSG conducts long-range fower studies for its members with the objective of assuring that generation and transmission facilities are planned in the most efficient and economical manner. The MRSG coordinates closely with DOF's Western Area Power Administration (WAPA). A Joint Trarsmission system (JTS) has been established which is a jointly planned, jointly-owned system administered by MBSG and operated by ViAPA.

Utilities in the MAPP region serve a populaticn of 15 million with over 4 million electric customers. The MAPF region is the second largest in terns of geographical area of the NERC councils.

The transmission system is extensive with over 2000 miles of HVDC transmission at $+400 \mathrm{kV}, 3500 \mathrm{miles}$ of $345 \mathrm{kV}$ and $9000 \mathrm{miles}$ of $230 \mathrm{kV}$. The region is interconnected with all neighboring regional councils, MAIN, SPP, anci WSCC.

Coordination of MARCA with the Mia-America Interpool Network (MAIN) is effected through an Inter-Region Reliability Coordination Agreement which establishes an Inter-Region Review Committee with responsibilities relating to bulk power supply reliability of both planning and operating. Additionally, a statement concerning inter-regional cooperation with the southwest power Pool (SPP) has been exchanged, and a letter of agreement has been signed with the Western systems Coordinating Council ( $\dot{\text { wSCC}}$ ) which provides for inter-regional planning and operating liaison, planning coordination committees as required, and an understanding that the coordination of operations relating to the East-West ties will be performed by the East-West work croup of the wSCC Operations Committee. 


$$
X I .5 .3
$$

The MAPP region historically has been a summer peaking region, with the monthly coincident summer peak exceeding the winter peak by $4-14 \%$ n the past three years. The 1977-1979 summer and winter peaks are yiven below.

TAELE 5A. I

HISTCRICA $\overline{\text { PEAK DEMAND }-M W}$

MAP P REGION

Summer

June July Aug.' Sept. 'Dec. Jan. Eeb.

\section{7}

1978

1979

$\begin{array}{llll}15801 & 17549 & 14078 & 13038 \\ 16141 & 16981 & 17580 & 17596 \\ 15632 & 17136 & 18011 & 16473\end{array}$

$15632 \quad 17136 \quad 18011, \overline{16473}$

Underline indicates seasonal peak

Shown below is a comparison of the region's non-coincident and coincident summer and winter peak demands for 1977-79.

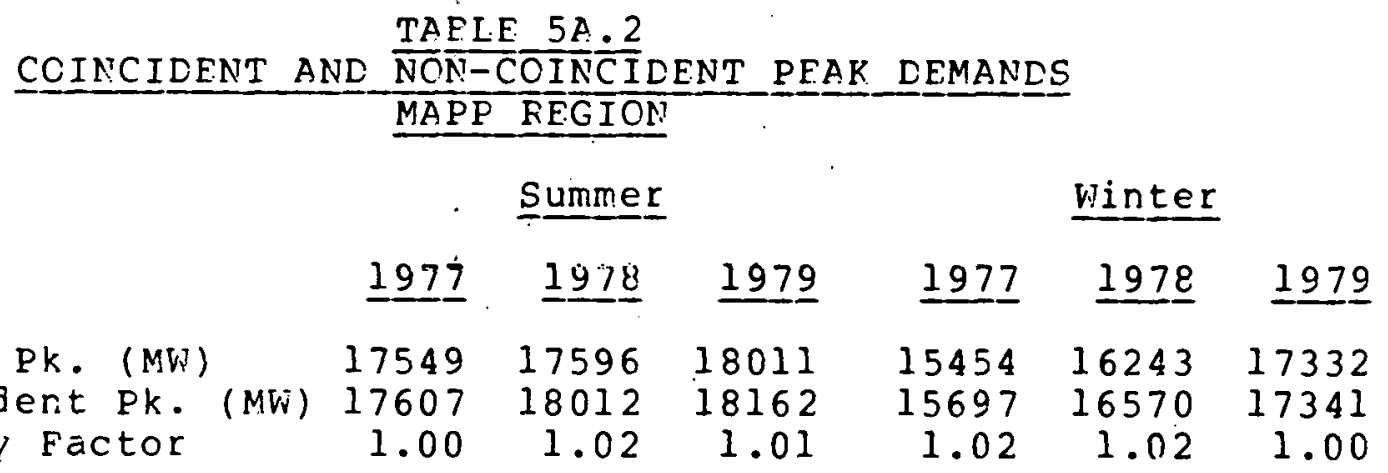

As seen in the above table, little regional diversity exists between the systems in the summer or winter period. However, there is seasonal diversity between the northern systems which peak in winter and the southern systems which peak in summer.

WINTEP ANE SUMME R PEAKING SYSTEM DIVERSITY

1978

\begin{tabular}{|c|c|c|}
\hline $\begin{array}{c}\text { Summer } \\
\text { Peak }\end{array}$ & $\begin{array}{c}\text { Winter } \\
\text { Peak }\end{array}$ & fference \\
\hline (MW) & $\overline{(M W)}$ & $(\overline{M W})$ \\
\hline
\end{tabular}

Winter Peaking systems Summer Peaking systems

$\begin{array}{rrr}3214 & 5362 & 2148 \\ 14798 & 11208 & 3590\end{array}$

1979

\begin{tabular}{rrr} 
Summer Winter & \\
Peak & Peak & Difference \\
\hline$\left(\frac{M}{M}\right)$ & $\left.\frac{1979}{(M W}\right)$ & $\left.\frac{953}{M W}\right)$ \\
3351 & 4304 & 9774 \\
14811 & 13037 & 1774
\end{tabular}


XI.5.4

In 1978 there was a potential $2148 \mathrm{MW}$ which could have been exported to the south during the summer period and 3590 MW availabie for import to the northern systems during the winter period; in 1979 , there were $953 \mathrm{MW}$ and $1774 \mathrm{MW}$, respectively. Although the seasonal differences available for transfer varies each year, some can be utilized to delay installation of additonal capacity in the region. Various contracts are in effect amorig the systems to utilize this geographic seasonal diversity. In addition, starting in 1980 there are also seasonal diversity exchanges of $500 \mathrm{MW}$ into MARCA from Canada during the summer season and exports of $300 \mathrm{MW}$ during the winter season.

The following table shows the scheduled maintenance performed each period and also the capability unavailable as a result of forced outages, or otherwise inoperable.

TABLE 5A. 4

SCHEDULED MAINTENANCE AND UNAVAILARLE CAPAEILITIES MAPP REGION

Summer

\begin{tabular}{lc}
\hline Scheduled & Other \\
$\frac{\text { Maintenance }}{(M W)} \frac{\text { Unavailable }}{(M W)} \frac{\text { Unavailable }}{(M W)}$
\end{tabular}

1977

1978

436

685

1979
1342
1696
1442
1778 .

2381 .

2057

\begin{tabular}{|c|c|c|}
\hline $\begin{array}{l}\text { Scheduled } \\
\text { Maintenance }\end{array}$ & $\begin{array}{c}\text { Other } \\
\text { Unavailable }\end{array}$ & $\begin{array}{c}\text { Total } \\
\text { Unavailable }\end{array}$ \\
\hline$(\mathrm{MW})$ & $T(\overline{M W})$ & $(\overline{M W})$ \\
\hline
\end{tabular}

winter

2427

.1888

1491
.3359

2509

4068

The capability unavailable for reasons other than scheduled maintenance varied from 6-88 of the planned capability; in summer and from 6-138 in winter.

The rceerve margins for the 1977-1979 seasonal periods are shown, considering the effects of scheduled maintenance and other outages.

TABLE 5A. 5

HISTORICAL SEASONTAL RESERVES

MAPP REGION

Eummer

Total Total Total Capability After: Avai
Demand Capability Reserves Maintenance Reserves Capability Reserves

$(M W)(M W)$

(8)

(MW)

(8)

(MW)

(क)

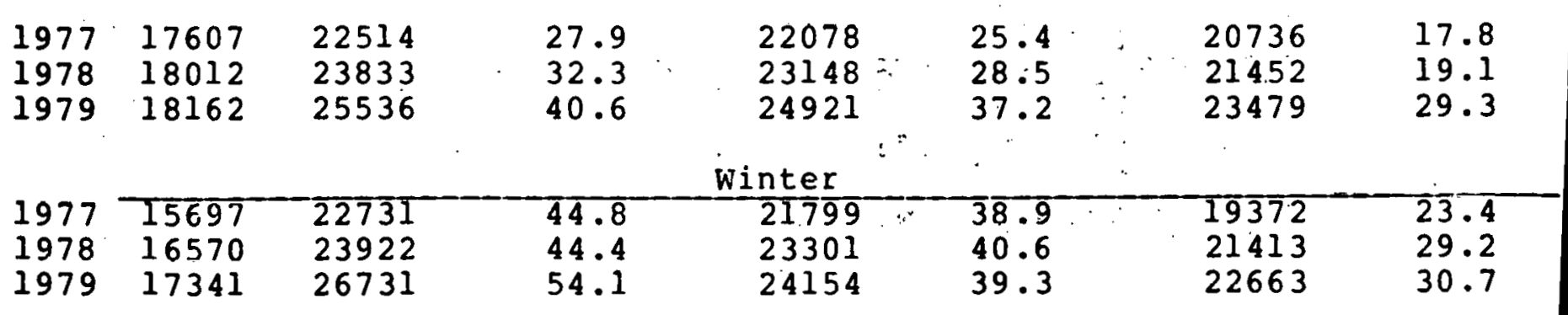




$$
X I .5 .5
$$

The reserve margins shown on Table 5A.5 indicate that for the 1977-79 Feriod sufficient capability was available to meet the demand requirements in both the summer and winter periods, after taking into account both scheduled and forced outages.

The energy reguirements, summer and winter demands and annual load: factors for the 1977-79. period are shown below.

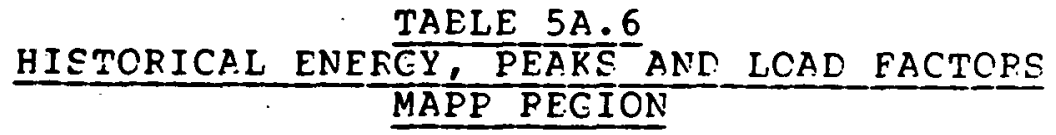

Energy Reguirement Summer Demand winter Demand Annual Load Factor

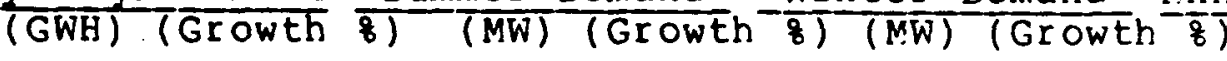
$(z)$

$\begin{array}{llllllll}1977 \quad 85738 & - & 17607 & - & 15697 & - & 55.6 \\ 1978 \quad 32477 & 7.9 & 18012 & 2.3 & 16570 & 5.6 & 58.6 \\ 1979 \quad 96518 & 4.4 & 18162 & 0.8 & 17341 & 4.7 & 60.7 \\ 8 \text { Growth } & & & & & \\ 1977-79 & 6.1 & & 1.6 & & 5.1 & --\end{array}$

The energy reguirements grew at a compound growth rate of 6.18 . This can be compared to the 5.38 growth rate of WUMS in MAIN which is adjacent to MAPP on the east, and to the overall growth rate of MAIN of 3:08. Appparently, the effects of conservation and economic slow down.are not as pronounced. in this region as in MAIN.

The summer demand shows little growth over the period, which is consistent with the growth of: weather sensitive demands of the MAIN? electric region. However, the winter demand growth rate is considerably higher than that of the adjacent MAIN Region ( 0.38 ).

This is probably due to the fact that the northern systems of MAPP usually experience considerably colder winters than systems of other adjacent regions.

\section{Current perspective}

The projected 1980 summer and winter demands are shown below.

$$
\text { PROJECTED } 1980 \frac{\text { TAELE } 5 \text { A. } 7}{\text { SEASONAL PEAK DEMAND* - MW }}
$$

\begin{tabular}{|c|c|c|c|c|c|}
\hline \multicolumn{3}{|c|}{ Summer } & \multicolumn{3}{|c|}{ Winter } \\
\hline June & $\overline{J u} \bar{y}$ & Aug. & $\overline{\text { Dec. }}$ & Jan. & Feb. \\
\hline 17542 & 19834 & 19413 & 17759 & 18674 & 17828 \\
\hline
\end{tabular}

*Coincident as to month". 


$$
X I .5 .6
$$

The 1980 summer and winter demands are projected to occur in July and January, respectively. However, the peaks may occur in any month of the season depending on economic and climatic conditions. During the 1977-1979 period, the summer peak occurred in three different months.

The 1980 noncoincident summer peak-19949 MW is projected to be 0.68 greater than the summer coincident peak; and the noncoincident winter peak $18687 \mathrm{MW}, 0.18$ greater than the winter coincident peak reflecting a summer peak growth of 9.88 over 1979 and a winter peak growth of 7.88 over 1979-80. This growth is considerably higher than historical trends. The high rates of growth between 1979 and 1980 is probably due to the over estimation of the 1979 peaks, and the use of long term growth rate trends to estimate short term growth.

With little diversity, no opportunity exists for capacity savings due to monthly peak diversity in either season. However, as explained in the section on the Historic perspective there is geographic diversity between northern and southern systems of which advantage is taken through contracts between the individual systems.

Another method of reducing capacity requirements is through load management techniques. An example of this is the extensive load management practice employed by a North Dakota power cooperative which resulted in an increase in the system's annual load factor of 558 in 1978 from 498 in 1977. The cooperative also advocates the use of electric heat, which is generated fron non-scarce fuels, to replace oil-fired home and industrial heating use.

The 1980 winter demand is projected to be 6.38 less than the summer demand. Because of the nearly equal seasonal demands, scheduled maintenance is projected for both winter and summer periods. There are $932 \mathrm{MW}$ scheduled for maintenance during the 1980 summer period and $1230 \mathrm{Mk}$ during the winter. These are 4.88 and 4.58 of the planned capability, respectively.

The 1980 summer planned capability of the MARCA region is estimated to be $25645 \mathrm{MW}$ and the non-coincident peak demand is projected to be $19949 \mathrm{MW}$. The resultant reserve margins are shown below, taking into account receipts, deliveries and scheduled unavallable capacity.

$$
\frac{1980 \frac{\text { TABLE }}{\text { RESERVE }} \frac{5}{\text { MARGINS }} \text { * }}{\text { MAPP REGION }}
$$

Summer

\begin{tabular}{|c|c|c|c|c|c|}
\hline \multicolumn{2}{|c|}{$\begin{array}{l}\text { Planned } \\
\text { Reserves }\end{array}$} & \multicolumn{2}{|c|}{$\begin{array}{c}\text { Total } \\
\text { Reserves }\end{array}$} & \multicolumn{2}{|c|}{$\begin{array}{l}\text { Available } \\
\text { Reserves }\end{array}$} \\
\hline$(M W)$ & $(8)$ & $\left(M W^{\top}\right)$ & $(8)$ & $(M W)$ & $(8)$ \\
\hline 3635 & 6.2 & 8451 & 45.2 & 7221 & 38 \\
\hline
\end{tabular}

\begin{tabular}{llllll}
$\begin{array}{l}\text { Planned } \\
\text { Reserves }\end{array}$ & $\begin{array}{l}\text { Total } \\
\text { Reserves }\end{array}$ & & $\begin{array}{l}\text { Available } \\
\text { Reserves }\end{array}$ \\
\cline { 1 - 1 }$(\mathrm{MW})$ & $(8)$ & $(\mathrm{MW})$ & $(\&)$ & $(\mathrm{MW})$ & $(8)$ \\
5696 & 28.6 & 6366 & 31.9 & 5434 & 27.2
\end{tabular}

*Based on ERA Form 411
Winter 
The planned reserve requirements for systems in the MARCA region. which are members of MAPP are determined by terms of the MAPP agreement. Currently, capacity obligation for each system is 158 greater than its annual system demand for a thermal system and 108 for a hydro system. The actual reserve margins for the 1980 summer and winter seasons are considerably greater than their requirements.

In addition to planned reserve margins, the systems in MARCA are reguired to maintain minimum operating reserves. The operating reserve is reguired to be sufficient to cover loss of capacity equal to 10 of the capability of the largest unit in service in MARCA. The spinning reserve portion of the operating reserve is required to be: at least 758 of the capability of the largest unit in MARCA.

The peak load data includes $184 \mathrm{MW}$ of interruptible demands during the summer peak and $337 \mathrm{MW}$ during the winter peak. The summer and winter reserve margins would increase to 28.68 and 39.48 , respectively, if the peaks were adjusted to account for these loads.

The margins shown above have not been adjusted for unscheduled outages of capacity, as the amount of these outages are unknown ahead of time. If these outages do not exceed the maximum outages of the 1977-79 period, 88 of planned capacity during the summer period and 11 d during the winter, the actual reserves would be $3382 \mathrm{MW}$ or 17.08 and $4216 \mathrm{MW}$ or 2.68 respectively, both in excess of reserve reguirements.

The summer capability of the generating capacity planned in MAPP as of January 1,1980 was $24950 \mathrm{MW}$. The capacity is shown below by type of fuel.

TARLE 5A. 9

PLANNED SUMMER CAPAEILITY, JANUAPY $1,1980-\mathrm{MW}$ MAPP REGION

\begin{tabular}{|c|c|c|c|c|c|c|c|c|c|c|}
\hline Nuclear & coal & & IL & & NATL & RAL & GAS & P. $\mathrm{H}$ & DRC & Total \\
\hline st & $\mathrm{am}$ & $\underline{\mathrm{ST}}$ & $\underline{\mathrm{CT}}$ & IC & $\underline{S T}$ & $\mathrm{CT}$ & IC & Conv. & $\underline{P} . \mathrm{S}$. & Capability \\
\hline $\begin{array}{l}3666 \\
14.7\end{array}$ & 57.0 & . & $\begin{array}{l}290 \\
11 .\end{array}$ & 1.2 & $\begin{array}{l}208 \\
0.8\end{array}$ & $\begin{array}{l}46 \\
0.2\end{array}$ & $\begin{array}{l}27 \\
0.1\end{array}$ & $\begin{array}{l}3034 \\
12.2\end{array}$ & -- & 100 \\
\hline
\end{tabular}

The region depends heavily on non-scarce fuels, mostly coal, as the primary supply for its generating plants. Hydroelectric power however, comprising 128 of the regional capability is a very important factor. About $2500 \mathrm{MW}$ of hydro capacity is installed in eight Federal projects located in the Missouri River Basin in the states of Montana, North Dakota, and South Dakota. The power output of these projects is marketed by DOE's Western Area Power Administration (WAPA). 


$$
X I .5 .8
$$

Baseload oil capability is insignificant, comprising only $543 \mathrm{MW}$ or 28 of the current regional capability. However, there is a considerable amount of oil-fired combustion turbine capability ( $2900 \mathrm{MW})$. oil conservation generation is employed in MAPP, primarily through import of Canadian hydro energy from Manitoba Hydro. The DOE Electric Power Monitoring Center in Washington, D.C. reported an estimated average daily savings of 10,700 barrels of oil in MAPP from April 1979 through February 1980 by importing hydroelectric energy.

The projected 1980 energy requirements, summer and winter demands, and annual load factor of the region are shown on table $5 \mathrm{~A} .10$.

$$
\frac{1980 \text { LAAD REQUIREMENTS }}{\text { MAPP REGION }}
$$

$\frac{\text { Energy Reguirement }}{(\mathrm{GWH})} \underset{\text { Summer Demand* }}{(\mathrm{MW})} \frac{\text { Winter Demand* }}{(\mathrm{MW})}$ AnnuaI L.F.

$\begin{array}{ccrrr} & 102285 & 19949 & 18687 & 58.1\end{array}$

*Non-Coincident

The 1980 projected summer and winter demands are projected to grow at considerably higher rates than they did during the 1977-79 period 1.68 and $5.1 \%$, respectively, as previously discussed.

The projected 1980 energy reguirements growth rate of 6.08 over 1979 requirements is in line with the historic 1977-79 rate of 6.18 .

Delays of future critical bulk power transmission facilities that will not be in service when needed are required to be reported under Item 5-C of the ERA-411 report. In the April 1, 1980 MARCA report 5 transmission lines were in this category. They are listed bclow in Table 5A.11.

$$
\begin{aligned}
& \text { TARLE 5A.11 } \\
& \text { POWER TRANSMISSION FACILITIES THAT } \\
& \text { WILL NOT BE IN SERVICE WHEN REOUIRED } \\
& \text { MAPP }
\end{aligned}
$$

System Critical Facility Reguired Expected $\begin{gathered}\text { In-Service Date } \\ \text { Operating/Eesign }\end{gathered}$

1. DPC Genoa-Lansing $1978 \quad 7 / 81 \quad 161 / 161$

Peason for Delay

Original line route application denied by U.S. Fish and wildife service. 


$$
\text { XI. } 5.9
$$

Revised line route permit approved by U.S. Fish and Wildife Service. U.S. Corps of Engineers will not issue a permit for the river crossing in time to allow construction of the crossing during January/February, 1980. River crossing construction must be delayed until January/February, 1981.

Right-of-way to be acquired in Minnesota and Iowa for new line route.

System Critical Facility Required Expected $\begin{gathered}\text { In-Service Date } \\ \text { Operating/Eesign }\end{gathered}$

II. DPC Alma-Crystal Cave $\quad 12 / 79 \quad 7 / 81 \quad 161 / 161$

Feason for Delay

Because a permit was not granted for the original line route, a six to eight month delay in application resulted. This was due to the state of Wisconsin passing legislation, in the interim, which required an Agricultural Impact Statement (A.I.S.) to accompany a refiled application.

The Wisconsin Department of Natural Resources (DNR) objected to the original line route because the right-of-way near the Chippewa River crossing infringed on the Tiffany wildlife Refuge.

Recently a permit for a river crossing which is acceptable to the Wisconsin DNR, the U.S. Corps of Engineers, and the U.S. Fish and wildife service was received from the corps of Engineers.

Subsequent to that the A.I.S. had to be resubmitted prior to purchase of right-of-way.

III. ISU Ottumwa-Montezuma $\quad 1 / 1 / 80 \quad 12 / 80 \quad 345 / 345$

Reason for Delay

Fegulatory hearings.

IV. NPPD Hoskins-Raun $\quad 1979 \quad 11 / 81 \quad 345 / 345$

Reason for Delay

Delay due to litigation. Line must cross an Indian reservation.

$\begin{array}{llll}\text { V. NSP Crystal Cave- Now } & 11 / 80 & 161 / 161\end{array}$ Apple River

Reason for Delay

Problems securing right-of-way. 


$$
X I .5 .10
$$

\section{Future Perspective}

The range of net reserves for the MAPP region for the periods 1981-85 and 1986-89 are tabulated below:

TA.BLE. 5A. 12

RANGE OF TOTAL RESERVES - 8

$M \overline{P P} \overline{R E} \overline{G I C N}$

$\frac{\frac{1981}{\text { summer }}}{22-33}-\frac{1985}{33-47}$

$\frac{\frac{1986}{\text { Summer }}}{14.5-20}=\frac{1989}{23-31}$

As shown, the low of $14.5 \%$ occurs in the summer of 1989 and the high of 478 in the winter of $1981 / 82$. The MARCA Criteria for minimum. reserves is $15 \%$ of the annual system demand and will be met for each feak season of the study period except in the summer of 1989 . Using the MARCA criteria a deficit of $154 \mathrm{MW}$ will result. The annual system demands in this report however do not reflect interruptible loads. If the 1989 summer interruptible demand of $251 \mathrm{NW}$ are included, the reserves would be $727 \mathrm{MW}, 97 \mathrm{MW}$ above the minimum requirements or $15.3 \%$ as shown in the MARCA ERA 411 report.

Tatle 5A.13 shows the projected summer and winter peak demands and energy reguirements for each of the study periods and the overall rate for the 1981-89 period. 
TARLE 5A.13

LOAD RECUIREMENTS

MAPP REGION

\begin{tabular}{|c|c|c|}
\hline & $\frac{\text { Energy }}{\text { GHW }}$ & $\frac{\text { Requirements }}{\text { Growth } 8}$ \\
\hline $\begin{array}{l}1981 \\
1982 \\
1983 \\
1984 \\
1985 \\
\text { Growth } 81-85\end{array}$ & $\begin{array}{l}107963 \\
112274 \\
118079 \\
124320 \\
130016\end{array}$ & $\begin{array}{l}5.6 \\
4.0 \\
5.2 \\
5.3 \\
4.6 \\
4.8\end{array}$ \\
\hline $\begin{array}{l}1986 \\
1987 \\
1988 \\
1989\end{array}$ & $\begin{array}{l}135913 \\
142090 \\
148265 \\
154652\end{array}$ & $\begin{array}{l}4 \cdot 5 \\
4.5 \\
4.3 \\
4.3\end{array}$ \\
\hline Growth $86-89$ & & 4.4 \\
\hline Growth $81-89$ & & 4.6 \\
\hline
\end{tabular}

$\begin{aligned} & \text { Summer Peak } \\ & \text { Demand }\end{aligned}$
GHW

\section{5}

22529

23678

24911

26096

27257

28417

29636

30865

6.6

5.7

5.1

5.2

4.8

5.2

$4 \cdot 4$

$4 \cdot 3$

4.3

4.1
Winter Peak
Demand
GHW Growth 8

4.2

4.8
5.1

5.1

5.6

5.0

4.9

5.1

25094

26226

27423

28736

4.6

4.5

4.6

4.8 .

4.6

4.9
Annual Load

$\frac{\text { Factor }}{8}$

57.9

56.9

56.9

5 . 8

56.9

56.9

57.1

57.0

57.2 
The 1981-1985 summer demands are projected to grow at a compound rate of 5.28 ; 1986-1989, 4.28; and overall, 1981-1989, at 4.88. These rates are considerably higher than the historic 1977-79 rate of 1.68 . However, since the historic 1977-79 winter demand and also the energy requirements are growing at much higher rates, the low growth of the summer peak may be atypical due to cooler than usual summers and therefore not represent a long-term slackening of demand. If lower summer demands than have been projected do occur, this will enhance the reserve situation.

The winter demand growth during the $1981-85$ period is projected to be 5.18 and then to decrease to 4.68 in the 1986-89 period, with an overall rate of 4.98 . These are in the same range as the historic growth rate of 5.18 .

The energy requirements are projected to grow $4.8 \%$ during the 1981-85 period and 4.48 during 1986-89, with an overall growth rate of 4.68 for the 1981-89 period. This compares with a 6.18 historic rate fur the 1977-79 period and a 6.08 rate projected for 1980 . The growth rate of this region is somewhat greater than the $4.0 \%$ rate of the adjacent MAIN region.

The summer capability of units planned in the region during the 1980-1989 period is shown by type of fuel in Table 5A.19. Major generating unit additions during the period are given in Table 5A.20. The planned generating capacity by fuel type and prime mover for the target years 1980,1984 , and 1989 are given below.

$$
\text { PLANNED GENERATING CAPAE I IITY PY TYPE CF FUEL - }
$$

EUMMEF: CAFAIILITY

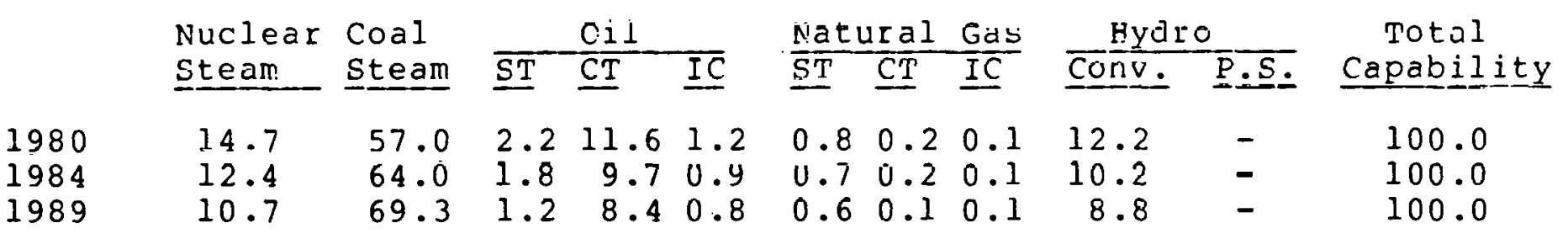

Currently, coal is the primary fuel for $57 \%$ of the planned capacity of the region. This percentage is projected to increase to 648 by 1984 and to 698 by 1989 , due to the addition of more than 20 new coal units. Nuclear units comprise about 158 of the total capability currently and is projected to decrease to 118 by 1989 . No new nuclear units are planned for the 1981-89 period. There is only $543 \mathrm{MW}$ of oil-fired steam capacity and $2904 \mathrm{MW}$ of combustion turbine oil-fired capacity in the region. Natural gas steam capacity is $208 \mathrm{MW}$. No new oil or gasfired capacity is scheduled for installation. 
The adequacy and reliability of the region's transmission network is examined periodically for contingency response under various conditions by MARCA. An appraisal of the projected bulk - power transmission network 4 to 6 years in the future is given under Item 6-B of the 1980 MARCA 411 report. It is stated in the appraisal that the MARCA bulk power transmission system will continue to be adeguate so long as future facilities are placed in operation on a timely schedule, with no delays in licensing, or obtaining right-of-way, or other problems.

Results from the 1984 Summer MAIN Interchange Capability study Including MAIN-MARCA and MAIN-ECAP-TVA Inter-Regional Peviews indicate that MARCA can export to MAIN $880 \mathrm{MW}$ and import from MAIN $550 \mathrm{MW}$. These values based upon the study results have not been fine tuned for possible future operating conditions: It is expected that these values represent minimum expected values, with the export and import values actually realized being higher.

Results from informal joint MARCA/SPP transfer capability studies for 1984 Summer indicate that MARCA can export to SPP $475 \mathrm{MW}$ and import from SPF $1300 \mathrm{Mh}$. With an optimized generation pattern and transmission line configuration, both the export and import capabilities would be higher. 
HISTORICAL CAPABILITY (MW) AND RESERVES (MW and Percent) MAPP Region

\begin{tabular}{|c|c|c|c|c|c|c|c|}
\hline & \multicolumn{2}{|c|}{1977} & \multicolumn{2}{|c|}{1978} & \multicolumn{2}{|c|}{1979} & \\
\hline & Summer & Winter & Summer & Winter & Surmer & Winter & \\
\hline 1. Planned Capability & 21079 & 22092 & 22096 & 22850 & 24904 & 26040 & \\
\hline 2. Peak Demand & 17607 & 15697 & 18012 & 16570 & 18162 & 17341 & \\
\hline 3. Planned Reserves (1-2) & 3472 . & 6395 & 4084 & 6280 & 6742 & 8699 & \\
\hline 4. Planned Reserves $(\%)(3 / 2) \times 103$ & 19.7 & 40.7 & 22.7 & 37.9 & 37.1 & 50.2 & \\
\hline 5. Net Transactions (Imports-Exports) & 1435 & 639 & 1737 & 1072 & 632 & 691 & \\
\hline 6. Total Capability $(1+5)$ & 22514 & $2 \check{2} 731$ & 23833 & 23922 & 25536 & 26731 & \\
\hline 7. Total Reserves (6-2) & 4907 & 7034 & 5821 & 7352 & 7374 & 9390 & \\
\hline 8. Total Reserves $(\%)(7 / 2) \times 1.00$ & 27.9 & 44.8 & 32.3 & 44.4 & 40.6 & 54.1 & $\stackrel{x}{\stackrel{x}{H}}$ \\
\hline 9. Scheduled Maintenance & 436 & 932 & 685 & 621 & 615 & 2577 & in \\
\hline 10. Capability after Maintenance (6-9! & 22078 & 21799 & 23148 & 23301 & 24921 & 24154 & is \\
\hline 11. Reserves after Maintenance $(10-2)$ & 4471 & 6102 & 5136 & 6731 & 6759 & 6813 & \\
\hline 12. Reserves after Maintenance $(\%)(11 / 2)=100$ & 25.4 & 38.9 & 28.5 & 40.6 & 37.2 & 39.3 & \\
\hline 13. Inoperable Capability & 0 & 0 & 0 & 0 & 0 & 0 & \\
\hline 14. Available Capability $(10-3)$ & 22078 & 21799 & 23148 & 23301 & 24921 & 24154 & \\
\hline 15. Available Reserves (14-2) & 4471 & 5102 & 5136 & 6731 & 6759 & 6813 & \\
\hline 16. Available Reserves $(\%)(1 \leqslant / 2 i \times 100$ & 25.4 & 38.9 & 28.5 & 40.6 & 37.2 & 39.3 & \\
\hline 17. Forced Outages & 1342 & 2427 & 1696 & 888 & 1442 & 1491 & \\
\hline 18. Actual Capability after Forced Outages (14-17) & 20736 & 19372 & 21452 & 21413 & 23479 & 22663 & \\
\hline 19. Actual Reserves $(18-2)$ & 3129 & 3675 & 3440 & 4843 & 5317 & 5322 & \\
\hline 20. Actual Reserves $(\%)(19 / 2: \times 150$ & 17.8 & 23.4 & 19.1 & 29.2 & 29.3 & 30.7 & \\
\hline
\end{tabular}


Table 5A.16

\section{Current Capability (MW) and Reserves (MW and Percent) \\ MAPP Region}

1. Planned Capability

2. Peak Demand

3. Planned Reserves $(1-2)$

4. Planned Reserves (8) $(3 \div 2) \times 1008$

5. Net Transactions (Imports-Exports)

6. Total Capability $(1+5)$

7. Total Reserves $(6-2)$

8. Total Reserves (8) $(7 \div 2) \times 1008$

9. Scheduled Maintenance

10. Capability After Maintenance (6-9)

11. Reserves After Maintenance (10-2)

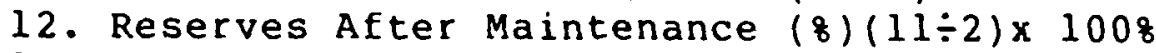

13. Inoperable Capability*

14. Available Capability (10-13)

15. Available Reserves $(14-2)$

16. Available Reserves (z) $(15 \div 2) \times 1008$

17. Forced Outages*

18. Actual Capabiity After Forced Outages (14-17)

19. Actual Reserves (18-2)

20. Actual Reserves $(8)(19 \div 2) \times 1008$

\begin{tabular}{rr}
\multicolumn{2}{c}{1980} \\
summer & Winter \\
25645 & 27322 \\
19949 & 18687 \\
5696 & 8635 \\
28.6 & 46.2 \\
670 & -184 \\
26315 & 27138 \\
6366 & 8451 \\
31.9 & 45.2 \\
932 & 1230 \\
25383 & 25908 \\
5434 & 7221 \\
27.2 & 38.6 \\
0 & 0 \\
25383 & 25908 \\
5434 & 7221 \\
27.2 & 38.6 \\
0 & 0 \\
25383 & 25908 \\
5434 & 7221 \\
27.2 & 38.6
\end{tabular}

* No data provided. 
Table. $5 A \cdot 17$

Future Capabiliti (MW) and Reserves (MW and Percent)

MAPP Region

1. Planned Capability

2. Peak Demand

3. Planned Reserves $(1-2)$

4. Planned Reserves (b)(3:2) x 1008

5. Net Transactions (Imports-Exports)

6. Total Capability $(1+5)$

7. Total Reserves $(6-2)$

8. Total Reserves $(8)(7 \div 2) \times 1008$

9. Scheduled Maintenance-No data prov. after ' 81

10. Capability After Maintenance (6-9)

11. Reserves After Maintenance $(10-2)$

12. Reserves After Maintenance $(8)(11 \div 2) \times 1008$

13. Inoperable Capability-No data provided

14. Available Capability (10-13)

15. Available Reserves (14-2)

16. Available Reserves (8) (15:2) x $10 \mathrm{C}$

17. Forced Outages-No data provided

18. Actual Capabiity After Forced Outages (14-17)

19. Actual Reserves $(18-2)$

20. Actual Reserves $(8)(19 \div 2) \times 1008$
1981

Summer Winter

2761929093

$21275 \quad 19636$

1982

Summer Winter

$29449 \quad 30712$

$23678 \quad 21797$

57718915

$24.4 \quad 40.9$

$660-228$

$30109 \quad 30484$

$\begin{array}{lll}565 & -219 & 525\end{array}$

$28184 \quad 28874 \quad 29232 \quad 29209$

$\begin{array}{llll}6909 & 9238 & 6703 & 8575\end{array}$

$32.5 \quad 47.0$

$837 \quad 1570$

$27347 \quad 27304$

29.8

0

$5072 \quad 7668$

29323

$41 . \epsilon$

6431

30484
8687

$27.2 \quad 39.9$

$30109 \quad 304 E 4$

$6431 \quad 868.7$

$27.2 \quad 39.9$

0

39.1

29.8

8575

27304

$6072 \quad 7668$

$28.5 \quad 39.1$

27347

6072

28.5 $\begin{array}{rr}0 & 0 \\ 29232 & 29209\end{array}$

$6703 \quad 8575$

29.8

0

27304

2923229209

$6703 \quad 8575$

29.841 .5
1984

Summer Winter

$29842 \quad 31343$

2491122887

$4931 \quad 8456$

$19.8 \quad 36.9$

$30493 \quad 31108$

$5582 \quad 8221$

$\begin{array}{rr}22.4 & 35.9 \\ 0 & 0\end{array}$

$30493 \quad 31108$

$5582 \quad 8221$

22.435 .9

$\begin{array}{rr}0 & 0 \\ 30493 & 31108\end{array}$

$5582 \quad 8221$

$22.4 \quad 35.9$

$30493 \quad 31108$

$5582 \quad 8221$

$22.4 \quad 35.9$
1985

Summer Winter

$31274 \quad 32199$

2609624001

$5178 \quad 8198$

$19.8 \quad 34.2$

$31917 \quad 31959$

$5821 \quad 7958$

$22.3 \quad 33.2$

$31917 \quad 31959$

$5821 \quad 7958$

$22.3 \quad 33.2$

$\begin{array}{rr}0 & 0 \\ 31917 & 31959\end{array}$

$5821 \quad 7958$

$22.3 \quad 33.2$

$1917 \quad 31959$

$5821 \quad 7958$

$22.3 \quad 33.2$ 
Table 5A.1B

Future Capability (MW) and Reserves (MW and Percent)

MAPP Region

\author{
1. Planned Capability \\ 2. Peak Demand \\ 3. Planned Reserves (1-2) \\ 4. Planned Reserves (8)(3-2) $\times 1008$ \\ 5. Net Transactions (Imports-Exports) \\ 6. Total Capability $(1+5)$ \\ 7. Total Reserves $(6-2)$ \\ 8. Total Reserves (8) $(7-2)$ \\ 9. Scheduled Maintenance \\ 11. Reserves After Maintenance $(10-2)$ \\ 12. Reserves After Maintenance (8) (11-2) x 1008 \\ 13. Inoperable Capability \\ 14. Available Capability (10-13) \\ 15. Available Reserves $(14-2)$ \\ 15. Available Reserves $(14-2)$
16. Available Reserves (8) $(15-2) \times 100 \%$ \\ 17. Forced Outages* \\ 18. Actual Capabiity After Forced Outages (14-17) \\ 19. Actual Reserves $(18-2)$ \\ 20. Actual Reserves $(8)(19-2) \times 1008$
}

No data provided.

\begin{tabular}{|c|c|c|c|}
\hline \multicolumn{2}{|c|}{1986} & \multicolumn{2}{|c|}{1987} \\
\hline Summer & Winter & Summer & Winter \\
\hline 31593 & 32362 & 33497 & 34753 \\
\hline 27257 & 25094 & 28417 & 26226 \\
\hline 4336 & 7268 & 5080 & 8527 \\
\hline 15.9 & 29.0 & 17.9 & 32.5 \\
\hline 738 & -246 & 730 & -353 \\
\hline 32331 & 32116 & 34227 & 34400 \\
\hline 5074 & 7022 & 5810 & 8174 \\
\hline 18.6 & 28.0 & 20.4 & 31.2 \\
\hline & 0 & 0 & 0 \\
\hline 32331 & 3211.6 & 34227 & 34400 \\
\hline 5074 & 7022 & 5810 & 8174 \\
\hline 18.6 & 28.0 & 20.4 & 31.2 \\
\hline 0 & 0 & 0 & 0 \\
\hline 32331 & 32116 & 34227 & 34400 \\
\hline 5074 & 7022 & 5810 & 8174 \\
\hline 18.6 & 28.0 & 20.4 & 31.2 \\
\hline & 0 & 0 & 0 \\
\hline 32331 & 32116 & 34227 & 34400 \\
\hline 5074 & 7022 & 5810 & 8174 \\
\hline 18.6 & 28.0 & 20.4 & 31.2 \\
\hline
\end{tabular}

\begin{tabular}{rr}
\multicolumn{2}{c}{1988} \\
Summer & Winter \\
33901 & 35382 \\
29636 & 27423 \\
4265 & 7959 \\
14.4 & 29.0 \\
626 & -356 \\
34527 & 35026 \\
4891 & 7603 \\
16.5 & 27.7 \\
0 & 0 \\
34527 & 35026 \\
4891 & 7603 \\
16.5 & 27.7 \\
0 & 0 \\
34527 & 35026 \\
4891 & 7603 \\
16.5 & 27.7 \\
0 & 0 \\
34527 & 35026 \\
4891 & 7603 \\
16.5 & 27.7
\end{tabular}

\begin{tabular}{rr}
\multicolumn{2}{c}{1989} \\
Summer & Winter \\
\cline { 1 - 1 } 34726 & 35582 \\
30865 & 28736 \\
3861 & 6846 \\
12.5 & 23.8 \\
615 & -264 \\
35341 & 35318 \\
4476 & 6582 \\
14.5 & 22.9 \\
0 & 0 \\
35341 & 35318 \\
4476 & 6582 \\
14.5 & 22.9 \\
0 & 0 \\
35341 & 35318 \\
4476 & 6582 \\
14.5 & 22.9 \\
0 & 0 \\
35341 & 35318 \\
4476 & 6582 \\
14.5 & 22.9
\end{tabular}


PLANNED SUMMER CAPABILITY AS OF JANUARY 1 , EY TYPE OF FUEL MAPP Region

\begin{tabular}{|c|c|c|c|c|c|c|c|c|c|c|c|}
\hline \multirow{2}{*}{$\begin{array}{c}\text { Electric } \\
\text { Region } \\
20 \text {-MAPP } \\
\end{array}$} & \multirow[b]{2}{*}{$\begin{array}{l}\text { Nuclear } \\
\text { Steam }\end{array}$} & \multirow[b]{2}{*}{$\begin{array}{l}\text { Coal } \\
\text { Steam }\end{array}$} & \multirow{2}{*}{\multicolumn{2}{|c|}{$---\frac{i 1}{\text { Combist. }}$}} & \multirow[b]{2}{*}{$\begin{array}{l}\text { Internal } \\
\text { Combust. }\end{array}$} & \multicolumn{3}{|c|}{ _ Natural Gas _ } & \multicolumn{2}{|c|}{ Hydro } & \multirow[b]{2}{*}{$\begin{array}{c}\text { Total } \\
\text { Capability } \\
\end{array}$} \\
\hline & & & & & & Steam & $\begin{array}{l}\text { Comb. } \\
\text { Turt:. }\end{array}$ & I.C. & Convent. & $\begin{array}{l}\text { Pumped } \\
\text { Storage }\end{array}$ & \\
\hline 1980 & 3666 & 14232 & 543 & 296.4 & 290 & 208 & 46 & 27 & 3034 & -- & 24950 \\
\hline$\%$ Total & 14.7 & 57.0 & 2.2 & 11.6 & 1.2 & 0.8 & 0.2 & 0.1 & 12.2 & -- & 100 \\
\hline 1981 & 3691 & 15930 & 543 & $29(13$ & 296 & 208 & 46 & 27 & 2984 & - & 26628 \\
\hline$\%$ Total & 13.9 & 59.8 & 2.0 & 10.9 & 1.1 & 0.8 & 0.2 & 0.1 & 11.2 & -- & 100 \\
\hline 1982 & 3695 & 17405 & 543 & 29014 & 296 & 208 & 46 & 27 & 2946 & - & 28070 \\
\hline$\%$ Total & 13.2 & 62.0 & 1.9 & 10.3 & 1.1 & 0.7 & 0.2 & 0.1 & 10.5 & - & 100 \\
\hline 1983 & 3695 & 17910 & 523 & 29014 & 289 & 208 & 46 & 27 & 2977 & -- & 28579 \\
\hline$\%$ Total & 12.9 & 62.7 & 1.8 & 10.2 & 1.0 & 0.7 & 0.2 & 0.1 & 10.4 & -- & 100 \\
\hline 1984 & 3695 & 19112 & 523 & 2904 & 282 & 208 & 46 & 27 & 3059 & -- & 29856 \\
\hline$\%$ Total & 12.4 & 64.0 & 1.8 & 9.7 & 0.9 & 0.7 & 0.2 & 0.1 & 10.2 & -- & 100 \\
\hline 1985 & 3695 & 19762 & 523 & 2904 & 282 & 208 & 46 & 27 & 3057 & -- & 30504 \\
\hline$\%$ Total & 12.1 & 64.7 & 1.7 & 9.5 & 0.9 & 0.7 & 0.1 & 0.1 & 10.2 & -- & 100 \\
\hline 1986 & 3695 & 20687 & 523 & 2904 & 282 & 208 & 46 & 27 & 3057 & -- & 31429 \\
\hline$\%$ Total & 11.8 & 65.8 & 1.7 & 9.2 & 0.9 & 0.7 & 0.1 & 0.1 & 9.7 & -- & 100 \\
\hline 1987 & 3695 & 20967 & 498 & 2904 & 680 & 208 & 46 & 27 & 3015 & - & 31640 \\
\hline$\%$ Total & 11.7 & 66.3 & 1.6 & 9.2 & 0.9 & 0.6 & 0.1 & 0.1 & 9.5 & -- & 100 \\
\hline 1988 & 3695 & 23457 & 435 & 2904 & 266 & 199 & 46 & 27 & 3015 & -- & 34044 \\
\hline$\%$ Total & 10.8 & 68.9 & 1.3 & 8.5 & 0.8 & 0.6 & 0.1 & 0.1 & 8.9 & -- & 100 \\
\hline 1989 & 3695 & 23957 & 435 & 2904 & 266 & 199 & 46 & 27 & 3045 & - & 34574 \\
\hline$\%$ Total & 10.7 & 69.3 & 1.2 & 8.4 & 0.8 & 0.6 & 0.1 & 0.1 & 8.8 & -- & 100 \\
\hline
\end{tabular}


$\mathrm{XI} .5 .19$

Table 5A.20

MAJOR FUTURE GENERATING CAPABILITY INSTALLATIONS AND (REMOVALS)

MAPP Region

System

MN. Pwr. \& Lt. Coop. Pwr. Assn. United Pwr. Assn.

Ia. El. Lt. \& Pwr.

Ia. Lt. Gas \& El.

Ia. Pwr. \& Lt.

Ia. Pub. Ser.

Ia. So. Utils.

Basin El. Pwr. Coop. Heart land C.P.D.

Lincoln, NE

Mo. Bas in Mun. Pup.

Mont. Dak. Utils.

Minnkota Pub. Coop.

MN. Pwr. \& Lt.

N.W. Pub. Serv.

Otter Tail Pwr.

Neb. P.O.D.

Basin El. Pwr. Coop.

Muscatine, Ia

Ia. 11. Gas \& El.

Ia. Pwr. \& Lt.

Ia. Pub. Serv.

Eastern Ia. Lt \& Pwr.

Basin El. Pwr. Coop.

Ia. El. Lt. \& Pwr.

Ia. Pwr. \& Lt.

Ia. So. Utils.
Station

Clay Boswell

Coal Creek

Coal Creek

Ottumwa

Ottumwa

Ottumwa

Ottumwa

Ottumwa

Laramie

Laramie

Laramie

Laramie

Coyote

Coyote

Coyote

Coyote

Coyote

Gent lemen

Antelope Valley 1

Muscant ine

Louisa

Louisa

Louisa

Louisa

Antelope Valley 2 St

Guthrie Cty.

Guthrie Cty.

Guthrie Cty.

St. Col
April '80 April '79

ERA-411 ERA-383

Effective Effective

Unit Fuel $\begin{gathered}\text { Summer } \\ \text { Type }\end{gathered}$ Type
Capability

St Sub 500

St Lib

238.36

222.64

St. Sub

100

125

100

125

225

1681

St Sub

174

28

133.3

164.7

St $\quad$ Lig $\quad 82$

123
20.5

41

143.5

St Sub

600

1510

$11-01-81$

5-81

4-01-81

$10-80$

$5-01-81$

5-81

St Lig

416

$\frac{150}{566}$

4-15-82

5-01-82

4-82

5-82

566

St Sub

300

211

100

7-01-83

$1-83$

30

Lig $\quad \frac{416}{1057}$

$11-01-83$

$11-83$

400

100

$12-31-84$

$12-84$ 
$X I .5 .20$

Table 5A.20

MAJOR FUTURE GENERATING CAPABILITY INSTALLATIONS AND (REMOVALS) (Cont.) MAPP Region

System

Northern St. Pwr. Lake Sup. Dist. Pub. Otter Tail Pwr.

Station

Sherburne Cty.

Sherburne Cty.

Spiritwood

Eastern Ia. Lt. \& Pwr. Allied

Heartland C.P.D.

Ia. Pub. Serv.

Mo. Basin Mun. Pwr.

N.W. Ia. Pwr. Coop.

Basin El. Pwr. Coop. Mont. Dak. Utils.

Neb. P.P.D.

Ia. Pub. Serv.

Northern St. Pwr.

Lake Sur Dist. Pwr.

Dairyland Pwr. Coop.

Mn. Pwr. Lt.

Northern St. Pwr.

ottertail Pwr.

Northern St. Pwr.
Allied

Allied

Allied

Allied

Antelope Valley 3

Not Given

Not Given

Neal

Not Given

Not Given

Not Given

Not Given

Not Given

Not Given

Not. Given

\begin{tabular}{|c|c|c|c|c|}
\hline $\begin{array}{l}\text { Unit } \\
\text { Type }\end{array}$ & $\begin{array}{l}\text { Fuel } \\
\text { Type }\end{array}$ & $\begin{array}{c}\text { Summer } \\
\text { Capability }\end{array}$ & $\begin{array}{c}\text { April ' } 80 \\
\text { ERA-4l } \\
\text { Effective } \\
\text { Date }\end{array}$ & $\begin{array}{c}\text { April } 179 \\
\text { ERA-383 } \\
\text { Effective } \\
\text { Date }\end{array}$ \\
\hline St & Sub & $\begin{array}{r}780 \\
20\end{array}$ & $5-01-85$ & $\begin{array}{c}5-84 \\
-\end{array}$ \\
\hline St & Lig & $\frac{125}{925}$ & $11-01-85$ & - \\
\hline
\end{tabular}

St Bit

5-01-85

5-86

30

50

50

280

St Lig $\quad 400$

St Lig 100

St Lig 600

St Sub 200

St Sub 620

50

St Sub $\frac{520}{2490}$

St $\quad$ Lig

275

175

50

500

St. Sub 200
4-01-87

$5-01-87$

5-01-87

$5-01-87$

$5-01-87$

$11-01-87$

5-01-89

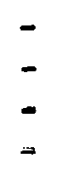

$-$

$-$

$-$

$-$

$-$

-

$11=01-00$

-

-

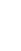


SECTION XI. 6

NORTHEAST POWER COORDINATING COUNCIL.

(NPCC) 
NORTHEAST POWER COORDINATION COUNCIL

\section{Introduction}

The Northeast Power Coordinating Council (NPCC) includes twenty-one utility system members located in the six New England states, New York, Ontario and New Brunswick. There are four operating entities or subregions--two in the United States, and two in Canada. This report primarily addresses the United States portion of the Council, a relatively small area geographically. It has a high population density and accounts for about ten percent of the total generation in the contiguous United States.

The U.S. portions of the NPCC are heavily dependent on oil as a boiler fuel and approximately one half of all the electric energy produced in the region was supplied by imported oil-fired generation, requiring in excess of $160 \mathrm{million}$ barrels of oil in 1979. As such; it is the largest oil consumer of all the regions in NERC.

The two U.S. subregions, or operating pools, are the New England Power POOl (NEPOOL) and the New York Power POOl (NYPP). The New England Power Pool operates in the states of Maine, Vermont, New Hampshire, Massachusetts, Rhode Island and Canada. This region was the seat of the industrial revolution in the United States. However, today these states are no longer as industrially-intensive as a result of the general exodus of the textile industry and reduced lumber production. Many small factories that were once located in these states have closed down due to a variety of economic constraints. Industry originally located in the New England states because the many rivers provided an economical source of hydro power. When industry departed, several of these sources fell into disuse. However, the present high cost of imported oil used to provide energy has resulted in a re-evaluation of the generating sites for new small hydro electric generation.

The New York Power Pool is unique in that it is the only integrated operating region within a single state. As a result of low cost hydro-electric energy in the northern tier of the State, particularly Niagara Falls, several large power intensive industries are located here. Included are aluminum refineries and chemical plants. The area has a large capacity transmission interconnection with Canada. 


$$
X I \cdot 6 \cdot 2
$$

The New England Power Pool is a winter peaking system, while NYPP is a summer peaking group. However, there is a little inter-pool diversity. Each pool takes advantage of intrasystem diversity in establishing reserve criteria.

For the 1981-1989 period, the aggregate electric non-coincidental peak load growth for New England and New York is forecasted at 2.5 percent compounded annually. About $5,786 \mathrm{MW}$ of the planned major additions to meet this growth is nuclear. However, if no new capacity--either coal or nuclear--were to come on Iine after 1979, oil consumption would increase by about $100 \mathrm{million}$ barrels per year. 
Table 6.1

Planned Capacity Exchanges

Northeast Power Coordinating Council

\begin{tabular}{|c|c|c|c|c|c|c|c|c|c|c|}
\hline \multirow[b]{2}{*}{ Imports } & \multicolumn{2}{|c|}{1981} & \multicolumn{2}{|c|}{1982} & \multicolumn{2}{|c|}{1983} & \multicolumn{2}{|c|}{1984} & \multicolumn{2}{|c|}{1989} \\
\hline & Summer & Winter & Summer & Winter & Summer & Winter & Summer & Winter & Summer & Winter \\
\hline Hydro Quebec & 800.0 & 0 & 800.0 & 0 & 800.0 & 0 & 800.0 & 0 & 800.0 & 0 \\
\hline Metro District & 1.0 & 1.0 & 1.0 & 1.0 & 1.0 & 1.0 & 1.0 & 1.0 & 1.0 & 1.0 \\
\hline N.E. Industrials & 4.5 & 4.5 & 4.5 & 4.5 & 4.5 & 4.5 & 4.5 & 4.5 & 4.5 & 4.5 \\
\hline New Brunswick & 431.0 & 431.0 & 431.0 & 430.0 & 430.0 & 430.0 & 430.0 & 430.0 & 29.0 & 29.0 \\
\hline So. Canada & 19.9 & 0 & 21.5 & D & 23.1 & 0 & 24.8 & 0 & 28.6 & 0 \\
\hline Ontario Hydro & 13.8 & 15.7 & 15.7 & 17.7 & 17.7 & 19.6 & 19.6 & 19.6 & 0 & 0 \\
\hline
\end{tabular}

NOTE: There are no scheduled exports. 
Tabie 6.2

EMERGENCY INTERREGIONAL TRANSFER CAPABILITIES * Northeast Power Coordinating Council

$\therefore$

$\frac{1979 \text {-Summer }}{(\mathrm{MW})} \cdot \frac{1988-\text { Summer }}{(\mathrm{MW})}$

$\begin{array}{lll}\text { NPCC-MAAC } & 3,300 & 4,400 \\ \text { MAAC-NPCC } & 1,900 & 2,450 \\ \text { NPCC-ECAR } & 3,300 & 2,000 \\ \text { ECAR-NPCC } & 2,200 & 3,100\end{array}$

* Based on NERC 9 th Annual Review.

The above figures are incremental over assumed base ochedulec.

Anticipated inter-area transfer capabilities for the summer of 1984 are shown in the following table:

Table 6.3

\section{INTER-AREA TRANSEER CAPABILITIES NORMAL/EMERGENCY - MW Northeast Power Coordinating Council}

$\begin{array}{lr} & \text { 1984-Summer } \\ \text { New York-New England } & 1,600 / 1,800 \\ \text { New England-New York } & 1,375 / 1,375 \\ \text { New York-Ontario Hydro } & 1,050 / 1,300 \\ \text { Ontario Hydro-New York } & 1,250 / 1,650 \\ \text { New England-New Brunswick } & -280 \star / 600 \\ \text { New Brunswick-New England } & 600 / 600\end{array}$

* A long-term contract for $400 \mathrm{MW}$ sale to New England exists in this time period. The indicated $-280 \mathrm{MW}$ limitation in transfer capability to New Brunswick is actually 120 MW above base. 


$$
\mathrm{XI} .6 .5
$$

The transfer capabilities shown are non-simultaneous and are calculated on the basis of total power flow on all direct interconnections between the two participating areas and, therefore, are independent of base schedule transfers between areas, and also consider parallel paths rather than only the direct ties.

The DOE Division of Power Supply and Reliability/ERA is conducting preliminary investigations into strengthening the transmission system between Ohio and Canada via Pennsylvania and New York. 
Table 6.4

\section{Utility Name}

NYPP

Central Hudson Gas \& Electric Co.

Consolidated Edison CD. of N.Y., Inc. Long I sland Lighting Co.

Niagara Mohawk Power Corp.

Orange Rockland Utilities, Inc.

Power Authority of the State of N.Y.

New York State Electric Corp.

Rochester Gas \& Electric Corp.

TOTAL

\section{MEPEX}

Bangor Hydro-electric Company

Boston Edison Co.

Cambridge Electric Light Co.

Central Main Power Hortheast Power Coordinat ing Council

\begin{tabular}{|c|c|c|c|c|c|c|c|c|}
\hline \multirow[b]{2}{*}{$\begin{array}{c}\text { Nuniber } \\
\text { cf } \\
\text { Customers }\end{array}$} & \multicolumn{4}{|c|}{$\begin{array}{l}\text { INTERRUPTABLE LOAD CONTRACTS } \\
\text { Hortheast Power Coord inat ing Council } \\
\end{array}$} & \multirow[b]{2}{*}{$\begin{array}{l}\text { Lead } \\
\text { Time } \\
\text { (Mins) }\end{array}$} & \multirow[b]{2}{*}{$\begin{array}{l}\text { Reaction } \\
\text { Time } \\
\text { (Mins) } \\
\end{array}$} & \multirow[b]{2}{*}{$\begin{array}{c}\begin{array}{c}\text { Vehicle } \\
\text { for }\end{array} \\
\text { Interruption } \\
\end{array}$} & \multirow[b]{2}{*}{$\begin{array}{c}\text { Cause of } \\
\text { Interrupted Load }\end{array}$} \\
\hline & $\begin{array}{l}\text { Tota } 1 \text { Load } \\
(K W) \\
\end{array}$ & $\begin{array}{c}\text { Interrupt } \\
\text { Load } \\
\text { (KW) } \\
\end{array}$ & $\begin{array}{c}\text { Maximum } \\
\text { Time } \\
\text { (Hrs/Yr) }\end{array}$ & $\begin{array}{l}\text { Maximum } \\
\text { Frequency } \\
\text { (Time/Yr) }\end{array}$ & & & & \\
\hline None & & - & - & - & - & - & - & - \\
\hline None & & - & - & - & - & - & - & - \\
\hline None & & - & - & - & - & - & - & - \\
\hline 3 & $5, ? 84,000$ & $1,430,000$ & - & - & - & - & Phone & Pre-planned Schedule \\
\hline Nc.ne & - & - & - & - & - & - & - & - \\
\hline 2 & 265,000 & 39,000 & - & - & 14400 & 1440 & Letter/Plione & $\begin{array}{l}\text { Lowflow of water } \\
\text { and ice condition }\end{array}$ \\
\hline Nane & - & - & - & - & - & - & - & - \\
\hline - & $1,000,000$ & 25,000 & - & - & 15 & 15 & Phone & High Demand \\
\hline 5 & $6,549,000$ & $1,494,000$ & - & - & - & - & - & - \\
\hline 1 & $50, \div 00$ & 45,000 & 600 & 10 & 30 & 10 & Phone/switch & $\begin{array}{l}\text { High Energy Cost } \\
\text { at peak }\end{array}$ \\
\hline 1 & $6, \equiv 00$ & 6,000 & 200 & 5 & 10 & 10 & Phone/switch & $\begin{array}{l}\text { NEPEX requested. and due } \\
\text { to the load condition }\end{array}$ \\
\hline 2 & - & 30,000 & - & 2 & - & - & Phone & Voltage reduction \\
\hline 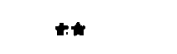 & 128,00 & 33,500 & - & 10 & 4 & 4 & Radio/TY & High Demand \\
\hline
\end{tabular}




\section{Historical Perspective}

NEPOOL, the operating pool for over forty variously sized privately and publicly-owned utilities, has its power coordinating center in springfield, Massachusetts. From there, operations are coordinated with four satellite centers in Connecticut, Vermont, New Hampshire, and Maine, where electric plant generation is actually dispatched. While most of the geographical area is suburban and rural, there are several large cities, particularly along the costal regions. As a result of its geography, the Region is almost totally dependent on expensive mid-east imported oil--a supply which, at best, is insecure--to meet fossil fuel requirements. Thus, all major capacity planning has been focused on nuclear power. While the Region is now favored with large reserves as a result of planning scenarios that did not materialize, the present attitudes toward nuclear plants could present major reliability problems should any of the now planned and under construction units be cancelled. At best, even if these nuclear generators are not needed to meet immediate power, their output would be useful toward reducing oil imports.

The climate of the area, particularly the northern states, is such that the area is a winter peaking system. However, the difference between the summer and winter peak is only five percent, thus providing little intra-regional, seasonal diversity. With the high cost of oil, a primary heating fuel, electric heating is developing a resurgence, thus creating an increase in the winter peak.

Growth in the area since 1977 has been very small, with an average annual winter peak growth of 1.5 percent and eneray growth of 2.6 percent. This can be attributed to mild weather and the increasing costs of electric power. Actual figures as obtained from respondent reports are shown below: 
$\mathrm{XI} .6 .8$

Table 6A.1

\section{HISTORICAL PEAK DEMAND AND ENERGY * \\ New England Power Pool}

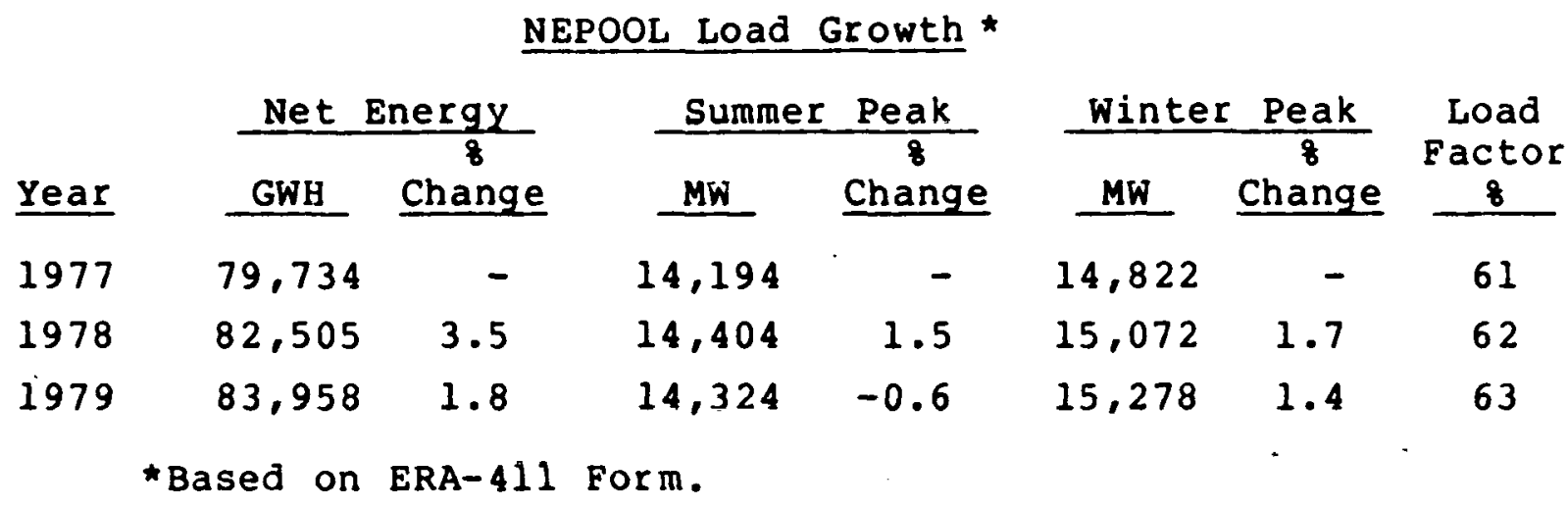

The table indicates that extrapolating average annual growth based on several years could lead to erroneous conclusions, as the growth in the later years is well below those of the earlier years.

The New England companies anticipated the present fuel supply situation many years ago, and thus committed the area to nuclear power. As early as 1978, the Region included nine percent of the total nuclear capacity of the united states and generated in the contiguous states. This translales inlo twenty percent of New Enqland capacity and thirty-five percent of the Region's plant output for that year. 
The following table indicates the plant output percentage by fuel type for NEPOOL:

Table 6A. 2

PERCENT GENERATION BY FUEL TYPE *

New England Power Pool

\begin{tabular}{|c|c|c|c|c|c|}
\hline Year & Nuclear & Hydro & Coal & Oil & Gas \\
\hline 1977 & 33 & 7 & 3 & 57 & 0 \\
\hline 1978 & 35 & 5 & 3 & 57 & 0 \\
\hline 1979 & 34 & 6 & 4 & 55 & 1 \\
\hline
\end{tabular}

Table 6A.3

PERCENT NET DEPENDABLE CAPABILITY BY FUEL TYPE New Engl and Power Pool.

Year Nuclear Hydro Coal oil

$\begin{array}{lllllll}\text { [Winter] } & 1978-79 & 22.6 & 6.2 & 2.3 & 68.8 & 0.1\end{array}$

*Based on EIA Form 4 data and 1979 NERC Summary.

For the purposes of these comparisions, the pump storage figures have been deleted as they generally require fossil fuel input for hydro output.

The total nuclear generation for 1979 was below that of 1978 due to several administrative outages and a prolonged outage of the Maine Yankee Plant. The total plant output for the Region was also reduced as a result of increased purchases from coalburning utilities in the West. This transfer of energy helped to reduce the amount of oil generation even though there was a reduction in nuclear plant output. 
A breakdown of the actual 1978 generation by fuel type is listed below for comparative purposes. The winter capability is also indicated in the table:

Table 6A.4

1978 NET DEPENDABLE CAPABILITY AND GENERATION BY PRIME MOVER AND FUEL TYPE *

New England Power Pool

\begin{tabular}{|c|c|c|c|c|c|}
\hline Prime Mover & Type & $\begin{array}{l}\text { Fuel } \\
\text { MW }\end{array}$ & 8 Total & $\mathrm{G}$ W H & 8 Total \\
\hline Steam & Nuclear & 4,250 & 19.4 & 27,980 & 35.0 \\
\hline Steam & Coal & 456 & 2.1 & 1,969 & 2.5 \\
\hline Steam & Oil & 11,807 & 53.9 & 45,571 & 57.1 \\
\hline Steam & Gas & 0 & 0 & 0 & 0 \\
\hline Hydro & - & 1,232 & 5.6 & 4,409 & 5.5 \\
\hline Pump Storage & - & 1,633 & 7.5 & -444 & -0.6 \\
\hline Gas Turbine & Oil & 1,735 & 7.9 & 104 & 0.1 \\
\hline Gas Turbine & Gas & 0 & - & 0 & - \\
\hline Combine Cycle & Oil & 206 & 0.9 & 293 & 0.4 \\
\hline Combine Cycle & Gas & 0 & 0 & 0 & 0 \\
\hline $\begin{array}{l}\text { Other } \\
\text { (Interchange) }\end{array}$ & - & 600 & 2.7 & 0 & 0 \\
\hline
\end{tabular}

To produce this energy, fuel requirements were:

802,000 tons of coal.

595,000 barrels of distillate oil.

75 million barrels of residual oil.

2.6 million MCF natural gas. 
Thus, 13.6 percent of the total residual oil used to produce electricity in the United States is consumed in New England. The Region is not predicting any future use of natural gas as a fuel, as only a temporary exemption for its use has been given by FERC.

There are six nuclear units in operation in the Region. Outage of these units to upgrade safety features as a result of the Three Mile Island lessons learned will not adversely affect system reliability. There were adequate reserves to meet the peak loads during 1977, 1978, and 1979.

The minimum planned reserves as a percent of the peak load varied between 38 percent and 40 percent for the winter and was up to 43 percent in the summer as a percent of the peak load. After considering net sales and purchases and unavailable capacity over the peak, these figures were reduced to as low as zcro in the summer and 11 percent in the winter. The Table $6 \mathrm{~A} .8$ shows reserves for the 3-year period 1977-1979, and it can be seen that this compares favorably with the planned reserve criteria of 23 percent to 24 percent as established by the NEPOOL Agreement.

As a result of intra-pool diversity, the individual company reserves can be as low as 18 percent and still meet the overall pool criteria. The planned reserves are the results of forecast decisions in 1975, which was a time of 7.5 percent load growth. Since then, there has been a 5,000 MW reduction in forecasted load growth due to economic changes and the oil embargo.

In general, the reserve criterion is a function of the $\mathrm{mix}$ and maturity of the net dependable capacity. With the recent increase in system load factor, this figure has had to increase as there is less off-peak excess capacity available for plannned maintenance. Also, since the inter-regional ties to the North are of low capacity, the area is assumed to be a peninsular system and thus requires higher reserves than a region with interconnections on several sides. Consequently, NEPOOL has transmission ties equal to about four percent of installed capacity as compared to NYPP where the interconnection ties equal about ten percent of installed capacity.

The NEPOOL Agreement states that operating reserves equal to one and one-half times the capacity of the largest unit on the 1 ine must be maintained. Of this, one-half must be available in thirty minutes. Capacity equal to the largest possible system contingency must be available in ten minutes-of this, one-third of that capacity must be syncronized. 
Additional load relief of two percent is available with a five percent voltage reduction and, generally, public appeals result in another one and one-half percent of load reduction. NEPOOL companies have interruptable load contracts with seven customers providing an additional $130 \mathrm{MW}$ of capacity during emergencies. This information is detailed in Table 6.4 .

The transmission system includes $444 \mathrm{miles}$ of $230 \mathrm{KV}$ lines and $1,539 \mathrm{miles}$ of $345 \mathrm{KV}$ lines. The transmission is adequate for handling the area loads and energy transfers with reserve for economy and oil conservation transactions. All transmission system constraints are thermal rather than stability limited.

With rising fuel oil prices, home heating with electricity is becoming more attractive in the area even though the cost of electric power is increasing. In an area with a winter peak, this situation is less than ideal for the power companies and, as such, some form of load management is becoming important. Several companies in the area have timers on water heaters to reduce peak loads, and experimental systems with ripple control have been installed. Additionally, some companies have seasonal rates. The companies are also assisting their customers in the use of heat storage systems for home heating rather than baseboard or similar types of heating systems. With the area's prevailing cool summer temperatures and lack of need for airconditioning, heat pumps for home climate control are not economically viable.

\section{Current Perspective}

The anticipated winter 1980-81 peak for the NEPOOL system is $16,110 \mathrm{MW}$ and is expected to occur in January 1981, which would then be an increase of 3.2 percent over the $1979 \cdots 80$ winter peak. This is a decrease in estimated growth as compared to the previous forecast for this period. The summer 1980 peak is forecast at $14,190 \mathrm{MW}$ and is a one percent decrease from the 1979 forecast for the corresponding period. Total net energy for 1980 is anticipated at 86,219 GWH, representing a 2.6 percent growth over 1979--a somewhat larger increase than was experienced in the previous year. The annual load factor anticipated in 1980 is 62 percent. To meet this load, the planned capability and resultant margins to meet the 1980 summer and winter peaks are shown in Table $6 \mathrm{~A} .9$.

While the reserves after maintenance do not reflect the additional daily forced outages of about fifteen percent, the Region will have reserves well in excess of agreement criteria for the year 1980 . 
To meet the forecasted energy requirements of 86,219 GWH, fuel requirements are anticipated at one million tons of coal, one million barrels of distillate oil, and over $100 \mathrm{million}$ barrels of residual oil. These figures are based on normal hydro plant operation. However, the Region experienced abnormally dry

weather during the early part of 1980 , resulting in very little snow cover. The lack of run-off from snow will reduce hydro output in the spring unless there is a change in the precipitation cycle. Without spring run-off, there could be an increase in residual oil consumption of 800,000 barrels to make up for the loss in hydro plant output.

There are no major transmission projects scheduled for completion during 1980. The transmission system is adequate to cover load commitments for the year with no stabllity problem areas. In general, thermal rating is the controlling factor limiting transfers. Transmission additions scheduled for 1980 include 52.4 miles of 115 and $138 \mathrm{KV}$ and twelve miles of $345 \mathrm{kV}$.

\section{Future Perspective}

The 1981 through 1989 period forecasts include an average winter peak growth of 2.6 percent per year, an increase from the previous average of 1.5 percent per year--for 1978 and 1979. In the first five years of the period, the expected growth is at the 2.4 percent rate with the balance of the period at 2.8 percent per year. Tables 6A.10.1 and 6A.10.2 show projected reserve margins for the 1981-1989 period. Energy requirements during the same 9 -year period are expected to increase at a rate of 2.6 percent.

While these reserves exceed the NEPOOL Agreement criteria, they are based on a very moderate load growth and timely completion of capacity--planned and under construction. As can be noted in the table listing the future plants (shown later in this report), original planned in-service dates are rarely met. Thus, either unit construction slippage or increased load growth could rapidly errode these margins.

To meet the projected load growth, approximately 5,521 MW of new base load generating capacity additions are planned. This will include 4,612 MW of nuclear, $568 \mathrm{MW}$ of coal-fired, and 341 MW of oil capacity. 
The following tabulation indicates the proportioning of capacity for the years 1984 and 1988 at the time of the winter peak:

Table 6A.5

WINTER PLANNED CAPABILITY (\&) BY PRIME MOVER AND FUEL TYPE* New England Power Pool

Prime Mover

Steam

Steam

Steam

Gtcam

Hyaro

Pumped Storage

Gas Turbine

Gas Turbine

Combined cycle

Combined cycle

Other
Fue 1 Type

Nuclear

Coal

Oil

Gạs

Oil
Gas
Oil
Gas

6.9

8.0

0

2.3

0
1984

8 of Total

$\begin{array}{rr}22.9 & 34 \\ 6.9 & 8 \\ 45.0 & 36 \\ 0 & \end{array}$

1988

8 of Total

8

36

5

6

7

2

2.6

2

* Based un the 1979 NERC Summary of projeoted Paak Load \& Capability, modified to reflect latest ERA-4ll Form data.

The estimated plant output for 1984 is $109,785 \mathrm{GWH}$, and the forecasted fuel requirements to meet this generation are 2.9 million tons of coal, 106 million barrels of residual oll, and $2.6 \mathrm{million}$ barrels of distillate oil. The corresponding requirements to meet the 1988 generation of 130,444 GWH are 5.7 million tons of coal, 82.7 million barrels of residual oil, and $2.4 \mathrm{mill}$ ion barrels of distillate oil. These figures also indicate the regional commitment to reducing dependence on imported oil.

Listed below are the major nuclear and coal units planned and under construction for the Region. Shown in the table is the historical slippage experienced for each of the planned units. 
$\mathrm{XI} \cdot 6.15$

Table 6A.6

PLANNED MAJOR CAPACITY ADDITIONS

New England Power Pool

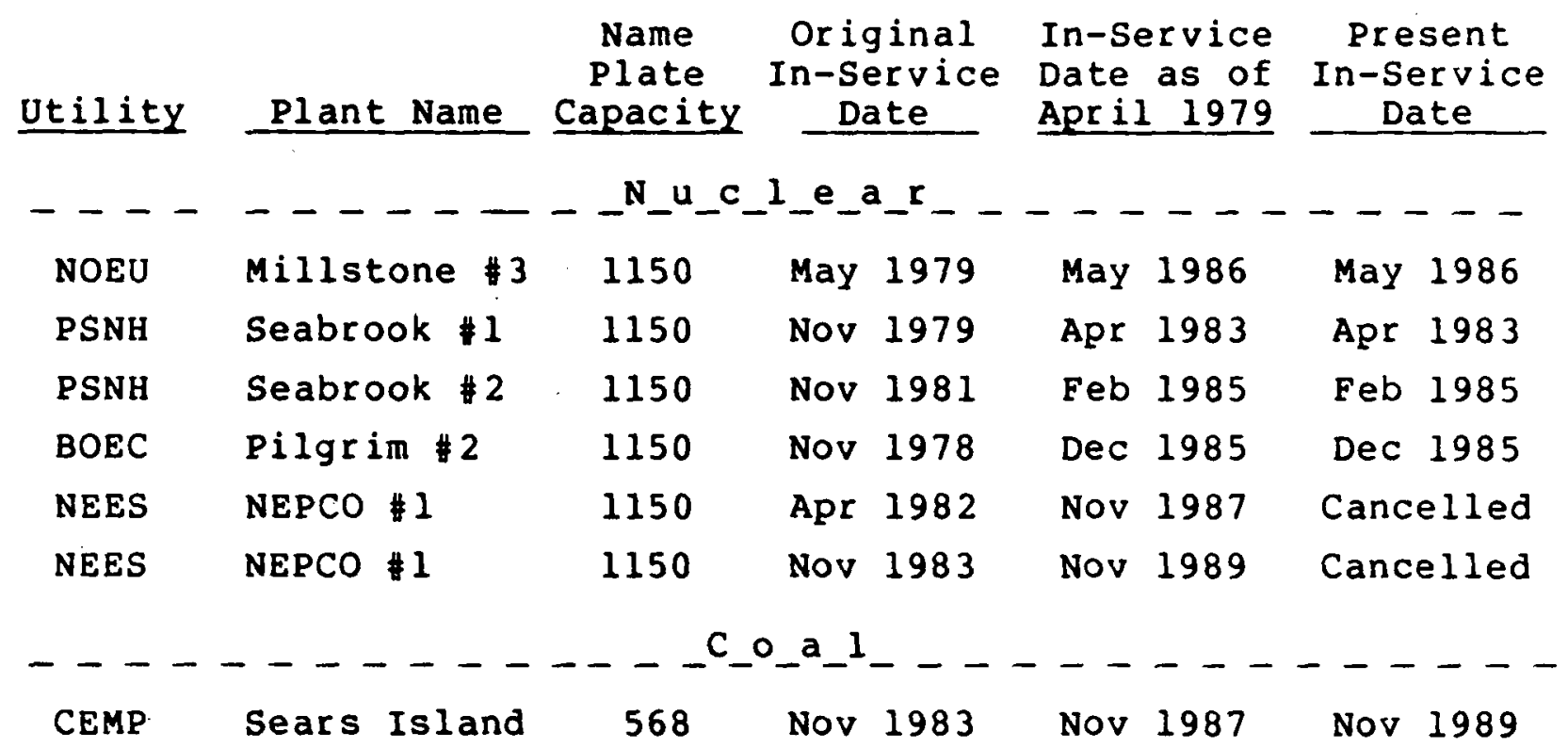

The above dates are based on data in the April 1980 ERA-411 Form. A recent survey made of the individual system companies reveals no additional slippage since that time.

A critical transmission addition for the period is the west Walpole-Needham $345 \mathrm{KV}$ line, located in the Boston area. Completion of this line has been delayed two years due to regulatory hearings and approvals. The delay will impact the reliability of the transmission system supplying the Boston area in that satisfactory system voltages may not be maintained during heavy load conditions. 


$$
\mathrm{XI} .6 .16
$$

Planned, under construction, or committed transmission lines for the future are:

Table $6 \mathrm{~A} .7$

FUTURE TRANSMISSION ADDITIONS * New England Power Pool

Miles Miles

$\frac{\mathrm{KV}}{345} \quad \frac{(1979-1983)}{113} \frac{(1984-1988)}{673}$

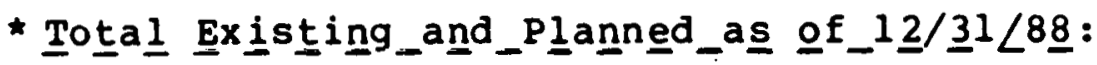

$\begin{array}{rr}\text { KV } & \frac{\text { M1les }}{230} \\ 345 & 2,325\end{array}$

* Based on NERC 9 th Annual Review. 
HISTORICAL CAPABILITY (MW; AND RESERVES (MW and Percent) New Engl and Power. Pool

1. Planned Capability

2. Peak Demand

3. Planned Reserves $(1-2)$

4. Planned Reserves (\%) $(3 / 2) \times 100$

5. Net Transactions (Imports-Exports)

6. Total Capability $(1+5)$

7. Total Reserves $(6-2)$

8. Total Reserves $(\%)(3 / 2) \times 100$

9. Scheduled Maintenance

10. Capability after Maintenance (6-9)

11. Reserves after Maintenance (10-2)

12. Reserves after Maintenance (\%) (11/2) $\times 100$

13. Inoperable Capability I/

14. Available Capability (10-13)

15. Available Reserves (T4-2)

16. Available Reserves (\%) (15/2) ×100

17. Forced Outages

18. Actual Capability after Forced Outages (14-17)

19. Actual Reserves (18-2)

20. Actual Reserves (\%) $(19 / 2) \times 100$

\begin{tabular}{rr}
\multicolumn{2}{c}{1977} \\
\hline 20075 & 20790 \\
14194 & 14822 \\
5881 & 5968 \\
41.4 & 40.3 \\
164 & 162 \\
20239 & 20952 \\
6045 & 6130 \\
42.6 & 41.4 \\
- & - \\
20239 & 20952 \\
6045 & 6130 \\
42.6 & 41.4 \\
5043 & 4322 \\
15196 & 16630 \\
1002 & 1808 \\
7.1 & 12.2 \\
- & - \\
15196 & 16630 \\
1002 & 1808 \\
7.1 & 12.2
\end{tabular}

\begin{tabular}{|c|c|}
\hline \multicolumn{2}{|c|}{1978} \\
\hline Summer & Winter \\
\hline 19921 & 21198 \\
\hline 14404 & 15072 \\
\hline 5517. & 6126 \\
\hline 38.3 & 40.6 \\
\hline 162 & 163 \\
\hline 20083 & 21361 \\
\hline 5679 & 6289 \\
\hline 39.4 & 41.7 \\
\hline- & - \\
\hline 20083 & 21361 \\
\hline 5679 & 6289 \\
\hline 39.4 & 41.7 \\
\hline 5775 & 4366 \\
\hline 14308 & 16995 \\
\hline-96 & 1923 \\
\hline-0.7 & 12.8 \\
\hline - & - \\
\hline$\cdot 14308$ & 16995 \\
\hline-96 & 1923 \\
\hline-0.7 & 12.8 \\
\hline
\end{tabular}

1979

$\begin{array}{rrr}\text { Summer } & \text { Winter } \\ 20550 & 21168 \\ 14324 & 15278 \\ 6226 & 5890 \\ 43.5 & 38.6 \\ 150 & .150 \\ 20700 & 21318 \\ 6376 & 6040 \\ 44.5 & 39.5 \\ - & - \\ 20700 & 21318 \\ 6376 & 6040 \\ 44.5 & 39.5 \\ 4841 & 4332 \\ 15859 & 16986 \\ 1535 & 1708 \\ 10.7 & 11.2 \\ - & . \\ 15859 & 16986 \\ 1535 & : & 1708 \\ 10.7 & 11.2\end{array}$

1/ Includes outages due to scheduled maintenance, inoperable, and forced. 
Table 6A.9

CURRENT CAPABILITY (MW) AND RESERVES (MW and Percent) New Engl and Power Pool

1. Planned Capability I/

2. Peak Demand

3. Planned Reserves $(1-2)$

4. Planned Reserves (\%) (3/2) $\times 100$

5. Net Transactions (Imports-Exports)

6. Total Capability $(1+5)$

7. Total Reserves (6-2)

8. Total Reserves (\%) $(7 / 2) \times 100$

9. Scheduled Maintenance

10. Capability after Maintenance (6-9)

11. Reserves after Maintenance (10-2)

12. Reserves after Maintenance (\%) $(11 / 2) \times 100$

13. Inoperable Capability

14. Available Capability (10-13)

15. Available Reserves (14-2)

16. Available Reserves (\%) (15/2) $\times 100$

17. Forced Outages $2 /$

18. Actual Capability after Forced Outages (14-17)

19. Actual Reserves (18-2)

20. Actual Reserves (\%) (19/2) $\times 100$
1980

Summer

20720

14190

6530

46.0

625

21345

7155

50.4

1203

20142

5952

41.9

306

19836

5646

39.8

19836

5646

39.8
1980/81

Winter

21429

16110

5319

33.0

548

21977

5867

36.4

242

21735

5625

34.9

296

21439

5329

33.1

21439

5329

33.1

I/ No delays anticipated in new units since submittal of 1980 ERA-411.

2/ Information not reported. 
Table 6A.10.1

FUTURE CAPABILITY (MW) AND RESERVES (MW and Percent) - 1981-84 New England Power Pool

1. Planned Capability $1 /$

2. Peak Demand

3. Planned Reserves (1-2)

4. Planned Reserves (\%) (3/2) ×100

5. Net Transactions (Imports-Exports)

6. Total Capability $(1+5)$

7. Total Reserves (6-2)

8. Total Reserves (\%) $(7 / 2) \times 100$

9. Scheduled Maintenance

10. Capability after Maintenance (6-9)

11. Reserves after Maintenance (10-2)

12. Reserves after Maintenance (\%) (11/2) x100

13. Inoperable Capability

14. Available Capability (10-13)

15. Available Reserves (14-2)

16. Available Reserves (\%) (15/2) $\times 100$

17. Forced Outages 2/

18. Actual Capability after Forced Outages (14-17)

19. Actual Reserves (18-2)

20. Actual Reserves (\%) $(19 / 2) \times 100$

\section{1}

Summer Winter

20745

$14210 \quad 16250$

$6535 \quad 5529$

$46.0 \quad 34.0$

$618 \quad 458$

$21363 \quad 22237$

$7153 \quad 5987$

$50.3 \quad 36.8$

$1836 \quad 133$

$19527 \quad 22104$

$5317 \quad 5854$

$37.4 \quad 36.0$

$306 \quad 296$

$19221 \quad 21808$

$5011 \quad 5558$

$35.3 \quad 34.2$

$19 ? 21 \quad 21808$

$5011 \quad 5558$

$35.3 \quad 34.2$

\begin{tabular}{rr}
\multicolumn{2}{c}{1982} \\
\hline Summer & Winter \\
\cline { 2 - 2 } 21035 & 21955 \\
14400 & 15590 \\
6635 & 5365 \\
46.1 & 32.3 \\
621 & 601 \\
21656 & 22556 \\
7256 & 5966 \\
50.4 & 36.0 \\
531 & 913 \\
21125 & 21643 \\
6725 & 5053 \\
46.7 & 30.5 \\
301 & 273 \\
20824 & 21370 \\
6424 & 4780 \\
44.6 & 23.8 \\
- & - \\
20824 & 21370 \\
6424 & 4780 \\
44.6 & 28.8
\end{tabular}

1983 Summer Winter 22324 14630 7694

52.6

624

22948

8318

56.9

$$
479
$$

22469

7839

53.6

284

22185

7555

51.6

22185

7555

51.6
23115

16960

6155

36.3

603

23718

6758

39.8

133

23585

6625

39.1

273

23312

6352

37.5

23312

6352

37.5
1984 Summer Winter $22320 \quad 23109$ $14910 \quad 17390$ $7410 \quad 5719$

$49.7 \quad 32.9$

$627 \quad 583$

$22947 \quad 23692$

$8037 \quad 6302$

$53.9 \quad 36.2$

$2000 \quad 1000$

2094722692

$6037 \quad 5302$

$40.5 \quad 30.5$

$284 \quad 273$

$20663 \quad 22419$

$5753 \quad 5029$

$38.6 \quad 28.9$

$20663 \quad 22419$

$5753 \quad 5029$

$38.6 \quad 28.9$ 
FUTURE CAPABILITY (MW) AND RESERVES (MW and Percent) - 1985/89 New England Power Pool

1. Planned Capability

2. Peak Demand

3. Planned Reserves $(1-2)$

4. Planned Reserves (\%) (3/2) $\times 100$

5. Net Transactions (Imports-Exports)

6. Total Capability $(1+5)$

7. Total Reserves (6-2)

8. Total Reserves (\%) $(7 / 2) \times 100$

9. Scheduled Maintenance 1/

10. Capability after Maintenance (6-9)

11. Reserves after Maintenance (10-2:

12. Reserves after Maintenance $(\%)(11 / 2) \times 100$

13. Inoperable Capability

14. Available Capability (10-13)

15. Available Reserves (14-2)

16. Available Reserves (\%) (15/2) x10C

17. Forced Outages 1/

18. Actual Capability after Forced 0 dtages (74-17)

19. Actual Reserves (18-2)

20. Actual Reserves $(\%)(19 / 2) \times 100$ $\frac{1985}{\text { Summer Winter }} \frac{1986}{\text { Summer Ninter Summer Winter }} \frac{1987}{\text { Summer Winter }} \frac{1988}{\text { Summer Winter }}$

$\begin{array}{rrrrrrrrrr}23464 & 25409 & 25764 & 26542 & 25751 & 26416 & 25631 & 26416 & 25631 & 26986 \\ 15180 & 17870 & 15530 & 18420 & 15920 & 18960 & 16300 & 19500 & 16660 & 20040 \\ 8284 & 7539 & 10234 & 8122 & 9831 & 7456 & 9331 & 6916 & 8971 & 6946 \\ 54.6 & 42.2 & 65.9 & 44.1 & 61.8 & 39.3 & 57.2 & 35.5 & 53.8 & 34.7 \\ 608 & 381 & 410 & 181 & 210 & 180 & 209 & 180 & 209 & 180 \\ 24072 & 25790 & 26174 & 26723 & 25961 & 26596 & 25840 & 26596 & 25840 & 27166 \\ 8892 & 7920 & 10644 & 8303 & 10041 & 7636 & 9540 & 7096 & 9180 & 7126 \\ 58.6 & 44.3 & 68.5 & 45.1 & 63.1 & 40.3 & 58.5 & 36.4 & 55.1 & 35.6 \\ - & - & - & - & - & - & - & - & - & - \\ 24072 & 25790 & 26174 & 26723 & 25961 & 26596 & 25840 & 26596 & 25840 & 27166 \\ 8892 & 7920 & 10644 & 8303 & 10041 & 7636 & 9540 & 7096 & 9180 & 7126 \\ 58.6 & 44.3 & 68.5 & 45.1 & 63.1 & 40.3 & 58.5 & 36.4 & 55.1 & 35.6 \\ 284 & 273 & 284 & 252 & 263 & 252 & 263 & 252 & 263 & 252 \\ 23788 & 25517 & 25890 & 25471 & 25698 & 26344 & 25577 & 26344 & 25577 & 26914 \\ 8608 & 7647 & 10360 & 3051 & 9778 & 7384 & 9277 & 6844 & 8917 & 6874 \\ 56.7 & 42.8 & 66.7 & 43.7 & 61.4 & 38.9 & 56.9 & 35.1 & 53.5 & 34.3 \\ - & - & - & - & - & - & - & - & - & - \\ 23788 & 25517 & 25890 & 25471 & 25698 & 26344 & 25577 & 26344 & 25577 & 26914 \\ 8608 & 7647 & 10360 & 8051 & 9778 & 7384 & 9277 & 6844 & 8917 & 6874 \\ 56.7 & 42.8 & 66.7 & 43.7 & 61.4 & 38.9 & 56.9 & 35.1 & 53.5 & 34.3\end{array}$

I) Information not available. 
NEW YORK POWER POOL

\section{Historical Perspective}

ow York Power Pool (NYPP) maintains an operating center near

bany, New York, for the eight major electric utility comanies in New York state. Included in this group is a state iystem - - Power Authority of the state of New York (PASNY). This Authority has developed several large hydro-electric generating stations, including Niagara Falls. Additionally, it has built some of the major transmission lines in the state, including a $765 \mathrm{KV}$ line that is used for heavy imports of Canadian hydro-electric power. While the heavy industry is located in the northern portion of the state, the southern portion includes the country's most densely populated metropolitan area--New York City.

NYPP is the major importer of Canadian power for the eastern portion of the United states and provides a transmission link for transporting power to New England from the coal-burning plants of the West, and hydro-electric power from Canada. The State has a good mix of generating capacity divided between coal and nuclear generating units, as well as many small low-head hydro plants. However, due to the large amount of oil-fired capacity, the Region is dependent on imported oil for more than $1 / 3$ of the electricity generated.

Tabulated below is a breakdown of the Pool's capability by fuel type for 1978, along with plant output for the years 1977 through 1979 :

Table 6B.1

PERCENT GENERATION BY FUEL TYPE * New York Power Pool

$\begin{array}{lccccc}\text { Year } & \text { Nuclear } & \text { Hydro } & \text { Coal } & \text { Oil } & \text { Gas } \\ 1977 & 18 & 23 & 13 & 46 & \\ 1978 & 19 & 23 & 12 & 46 & \\ 1979 & 18 & 25 & 13 & 38 & 6\end{array}$


$\mathrm{XI} .6 .22$

Table 6B. 2

PERCENT INSTALLED CAPABILITY BY FUEL TYPE * New York Power Pool

$\begin{array}{llccccc}\text { Year } & \text { Nuclear } & \text { Hydro } & \text { Coal } & \text { Oil } & \text { Gas } \\ \text { (Summer) } & 1978 & 12.4 & 14.1 & 12.3 & 61.1 & 0.1\end{array}$

* Based on EIA Form 4 data and 1979. NERC Summary.

lFor the purpose of these comparisons, the pump storage figures have been deleted as they generally require fossil fuel input. for hydro output.]

The coal generating plants are located in the northern portion of the state, except for one jointly-owned plant, Homer City, located in Pennsylvania and owned by New York state Electric \& Gas Co., and General Public Utilities (a system within the MAAC area).

The reduction in nuclear plant output in 1979 is due to prolonged outages of three units, namely: Fitzpatrick (PASNY); Indian Point \#3 (PASNY); and Indian Point \#2 (Con Edison)--all of which had outages for safety upgrading resulting from the lessons learned from Three Mile Island.

A comparison between total plant output and energy requirements for the 3-year is shown in the following table:

Table 6B.3

HISTORICAL GENERATION AND ENERGY REQUIREMENT * New York Power Pool

\begin{tabular}{lccccc} 
& \multicolumn{2}{c}{ Plant } & Output & & \multicolumn{2}{c}{ Energy Reguirement } \\
\cline { 2 - 4 } Year & GWH & Change & GWH & Change \\
1977 & 112,538 & & 113,483 & \\
1978 & 113,124 & +1 & 114,860 & 1.2 \\
1979 & 105,245 & -7 & 117,189 & 2.0
\end{tabular}

* Based on EIA-4 Form data and Form 12E-2 data. 
This reduction in total output for 1979, though there was an increase in energy requirements, is a result of increased imports from Canada and the coal-burning utilities in the West. It resulted in the substantial decrease in the portion of the load allocated to oil-burning plants from 30 percent of total generation in 1978 to 21 percent in 1979.

The annual peak load and reserve margins are shown for the period 1977-1979 on Table 6B.8.

Tables $6 \mathrm{~B} .3$ and $6 \mathrm{~B} .8$ indicate total area energy requirements have continued to grow, but peak loads have decreased during the period shown. This decrease is due to mild weather and the increasing cost of electricity. As a result, each year the forecasts for load growth have been reduced. However, due to the long lead time required for building new capacity, today's apparently sizeable reserve margins are a result of the change in growth. Minimum planned reserves during the period range from 41 percent to 45 percent for the summer and as high as 64 percent for the winter. After considering net interchange and unavailable capacity, these numbers are reduced to as low as 15 percent for the summer and 21 percent for the winter.

Reserves were well above the established pool planned reserve criteria of approximately 22 percent. However, even with this sizeable capacity margin, some areas of the pool were not in as comfortable a position as the numbers might indicate. In a recent study to review the effects of a prolonged simultaneous outage of Indian Point Units 2 and 3 , it was determined that New York City reliability would be questionable for a l-year outage of this capacity. 
Plant output, by fuel type, to meet the 1978 load requirements are tabulated below:

Table 6B.4

1978 NET DEPENDABLE CAPABILITY (MW) AND GENERATION BY PKIME MOVER AND FUEL TYPE *

New York Power Pool

\begin{tabular}{|c|c|c|c|c|c|}
\hline \multirow[b]{2}{*}{ Prime Mover } & \multirow[b]{2}{*}{$\begin{array}{l}\text { Fuel } \\
\text { Type }\end{array}$} & \multicolumn{2}{|c|}{ Capability } & \multicolumn{2}{|c|}{ Generation } \\
\hline & & $\mathrm{MW}$ & $\begin{array}{c}8 \\
\text { Total }\end{array}$ & G $\mathbf{W H}$ & $\begin{array}{c}8 \\
\text { Total } \\
\end{array}$ \\
\hline Steam & Nuclear & 3,602 & 12.1 & 21,694 & 18.4 \\
\hline steam & Coal & 3,484 & 11.6 & 18,723 & 15.9 \\
\hline Steam & oil & 13,991 & 47.1 & 51,183 & 43.5 \\
\hline Steam & Gas & & & & \\
\hline Hydro & & 4,035 & 13.6 & 26,080 & 22.1 \\
\hline Pump storage & & 1,000 & 3.4 & -568 & -0.5 \\
\hline Gas Turbine & Oil & 3,582 & 12.1 & 554 & 0.5 \\
\hline Gas Turbine & Gas & 30 & 0.1 & 90 & 0.1 \\
\hline Combine Cycle & 011 & . & & & \\
\hline Combine Cycle & Gas & & & & \\
\hline nther & & & & & \\
\hline (Interchange) & & & & & \\
\hline
\end{tabular}

To produce this energy, fuel requirments were:

8.1 million tóns of coal.

1.7 million barrels of distillate oil.

87.4 million barrels of residual oil.

1.1 million MCF natural gas.

* Based on 1979 NERC Summary of Peak Load and Capacity. 
Sixteen and one-half percent (16.5\%) of all of the residual oil used in the United States for electric generation is burned in the NYPP Region and 30 percent of all residual is burned in the NPCC Area, where almost all of the oil used is imported.

During 1979, there was an appreciable increase in the use of gas ( 65 percent of total plant output); however, the future of this fuel for utility use is uncertain. At present, FERC has granted an exemption only through the spring of 1980 .

The Region is still heavily dependent on imported oil as a source of fuel, although every effort is being made to reduce its consumption. Even with an 8 percent reduction in oil-fired plant output, it was still 38 percent of the total energy generated within the state.

The percent of NYPP planned reserves are quite large for the present. The design criteria call for a pool reserve of 22 percent. To maintain this figure, the individual members must provide 18 pecent reserve over its annual peak. The lower reserve is permitted because of load diversity between the various members. With a company reserve of 18 percent, a 5 percent voltage reduction would result in a 4 percent reduction in peak, while customer appeals could shave the peak an additional 3 percent. In addition. to the reserves, the pool companies have five interruptable customer contracts that permit a total load reduction of $1,500 \mathrm{MW}$. This information is contained in Table 6.1.

The transmission system includes 1,075 miles of $230 \mathrm{KV} 1$ ines; 2,109 miles of $345 \mathrm{KV}$ lines; 5 miles of $500 \mathrm{KV}$ lines; and 155 miles of $765 \mathrm{KV}$ lines. There are no stability constraints in the transmission system, and usually the thermal ratings of the lines control the limits of transfers which are frequently heavy from North to South.

Environmental constraints preclude the use of any fuel except low sulfur oil in the densely populated southern metropolitan area of the state. This, coupled with an unusual New York City utility fuel use tax, makes it economically desirable to import as much energy into these regions as possible.

Additionally, several municipalities on Long Island are preferential customers of PASNY and; as such, are entitled to low cost hydro electric energy which must be wheeled from upstate. Much of the imported Canadian hydro power also follows this route. This movement of energy creates two problems:

First, in the area around Albany, close to the southern terminus of the Canadian-New York $765 \mathrm{KV}$ line, there is heavy loading of 
the transmission system during off-peak periods when Canadian energy is being imported. This causes a backing off of the base loaded coal-fired plants which could normally be displacing oil capacity at this time. Second, in the transmission corridor between Albany and New York City, normal transmission loading is sufficiently high so as to preclude prolonged outages of certain generating units; e.g. Indian Point. Any increase in Canadian hydro imports into this system would further aggravate this situation.

New York City has the highest electric rates in the contiguous United states, with Long Island not being much lower. As such, both the utilities serving these areas are experimenting with time-of-day rates. However, since the programs have been operating only a short time, there is no conclusive evidence of the system's success or failure.

\section{Current Perspective}

During the summer of 1980 , the NYPP is expected to experience a peak demand of $21,230 \mathrm{MW}$. This would be an increase of 2.3 percent over the previous summer peak and an increase in growth as compared to 2.1 percent for the 1978-1979 period. The winter 1980-1981 peak is anticipated to be 19,870 MW, also an increase of 2.3 percent over the previous year. Total net energy for 1980 is expected to reach $117,814 \mathrm{GWH}$, a small increase of 0.5 percent over the previous year. Annual load factor based on these forecasts would be 63.2 percent. The summer planned capability to meet this load will be 30,467 MW. The loads, resources and margins anticipated for 1980 are listed in the Table 6B.9.

This table indicates a comfortable reserve margin after maintenance for 1980 that is higher than the Pool. Agreement criteria. However, daily forced outages of approximately 14 percent of installed capacity. are not included in the figures.

With estimated 1980 system regirements of $117,814 \mathrm{GWH}$, it is anticipated that the NYPP subregion will consume about $8.5 \mathrm{mill}$ ion tons of coal, over $88 \mathrm{million}$ barrels of residual oil, and 280,000 barrels of distillate oil.

The transmission system for 1980 is adequate for system reliability and scheduled transfers of energy. As explained in the previous section, there is still the constraint of the Utica-Pleasant Valley bottleneck with regard to economy and oil conservation transfers. The critical unit in terms of voltage support is Oswego 6--an oil-fired unit due in mid-1980. 
There are no other major projects scheduled for completion during 1980. Transmission lines scheduled for completion during the period include 0.2 miles of $345 \mathrm{KV} l$ ines and 46.9 miles of $115 / 138 \mathrm{KV} 1$ ines.

\section{Future Perspective}

The 1981-1989 forecasts indicate a growth in the summer peak load averaging 2.0 percent annually. During the same time frame, the energy requirements are expected to increase at an average annual growth of 2.2 percent. Tables 6B.10.1 and 6B.10.2 show anticipated reserve margins for the period 1981-1989. These reserves exceed the NYPP Agreement criteria and indicate comfortable marginc; however, that load could grow more rapidly than the modest rate indicated, and there will very likely be slippages in the construction schedule of various generating units. Indicated later in the report are slippages presently being experienced for projects under construction.

To meet the load increases projected, approximately 4,425 MW of new base load generating capacity has been scheduled. This will include 2,015 MW nuclear, and 2,410 MW coal-fired plants. The nuclear additions will increase the proportional share of capacity from 12 percent to 16 percent by 1988 , and coal from 12 percent to 17 percent. The long $r$ ange plans of the New York State Energy office are committed to a future of coal rather than nuclear plants, and prohibition orders for several oilfired plants in the state have already been issued by DOE. However, there is the question of the ability of the state rail transportation system to handle the required increased coal tonnage.

The New York State Energy Board, in its formal order on the state's first energy master plan of March $20 t h$, opposed new nuclear plants at this time and proposed a state panel to evaluate nuclear power, including the potential impact of phasing down or eliminating existing plants. The objective of reducing oil use for the 1990 time frame cannot be fully achieved with this new plan. The state plan included oil savings from increased conservation and management, the conversion of $3,281 \mathrm{MW}$ in thirteen existing oil-fired plants to coal, the addition of 271 MW from small hydro electric projects, the development of $397 \mathrm{MW}$ by burning solid waste, and continued purchases of Hydro Quebec Power. 
The following table indicates the proportion of capacity by fuel type for the years 1984 and 1988:

Table 6B. 5 SUMMER PLANNED CAPABILITY BY PRIME MOVER AND FUEL TYPE*
New YORK POWEI POOI

\begin{tabular}{|c|c|c|c|}
\hline Prime Mover & $\begin{array}{l}\text { Fuel } \\
\text { Type }\end{array}$ & $\begin{array}{r}19848 \\
\text { of Total } \\
\end{array}$ & $\begin{array}{r}19888 \\
\text { of Total } \\
\end{array}$ \\
\hline Steam & Nuclear & 14.3 & 16 \\
\hline steam & Coal & 14.0 & 17 \\
\hline steam & oil & 44.1 & 39 \\
\hline steam & Gas & & \\
\hline Hydro & & 12.9 & 12 \\
\hline Pumped storage & & 3.2 & 6 \\
\hline Gas Turbine & Oil & 11.3 & 10 \\
\hline Gas Turbine & Gas & 0.1 & 0 \\
\hline Combined Cycle & Oil & & \\
\hline Combined Cycle & Gas & & \\
\hline \multirow[t]{2}{*}{ Other } & & 0.1 & 0 \\
\hline & & 1008 & 1008 \\
\hline
\end{tabular}

To meet the 1989 plant output of 131,178 . GWH will require almost $9 \mathrm{mili}$ ion tons of coal, 99 million barrels of residual oil, and 350,000 barrels of distillate oil. The 1988 plant output of $146,800 \mathrm{GWH}$ will require over $10 \mathrm{mill}$ ion tons of coal, 100 million barrels of residual oil, and 420,000 barrels of distillate oil.

Table 6B.6 shows the major nuclear and coal-fueled units planned and under construction for the Region. The listing includes the slippage experienced for each of the units, indicating the probability of reduced reserves for future years should the forecast materialize as anticipated.

At present, no slippage is anticipated by the individual pool utilities from the dates shown in the table except for 
Shoreham $\$ 1$ which now has an anticipated in-service date of January 1983. This delay will require an additional 15 million barrels of residual oil for replacement energy from within the New York Power Pool.

The only critical transmission project is the installation of additional transmission capacity to overcome the Utica-pleasant Valley bottleneck which limits future increases in Canadian hydro imports.

\section{Table 6B. 6 \\ PLANNED MAJOR CAPACITY ADDITIONS * New York POWer POOI}

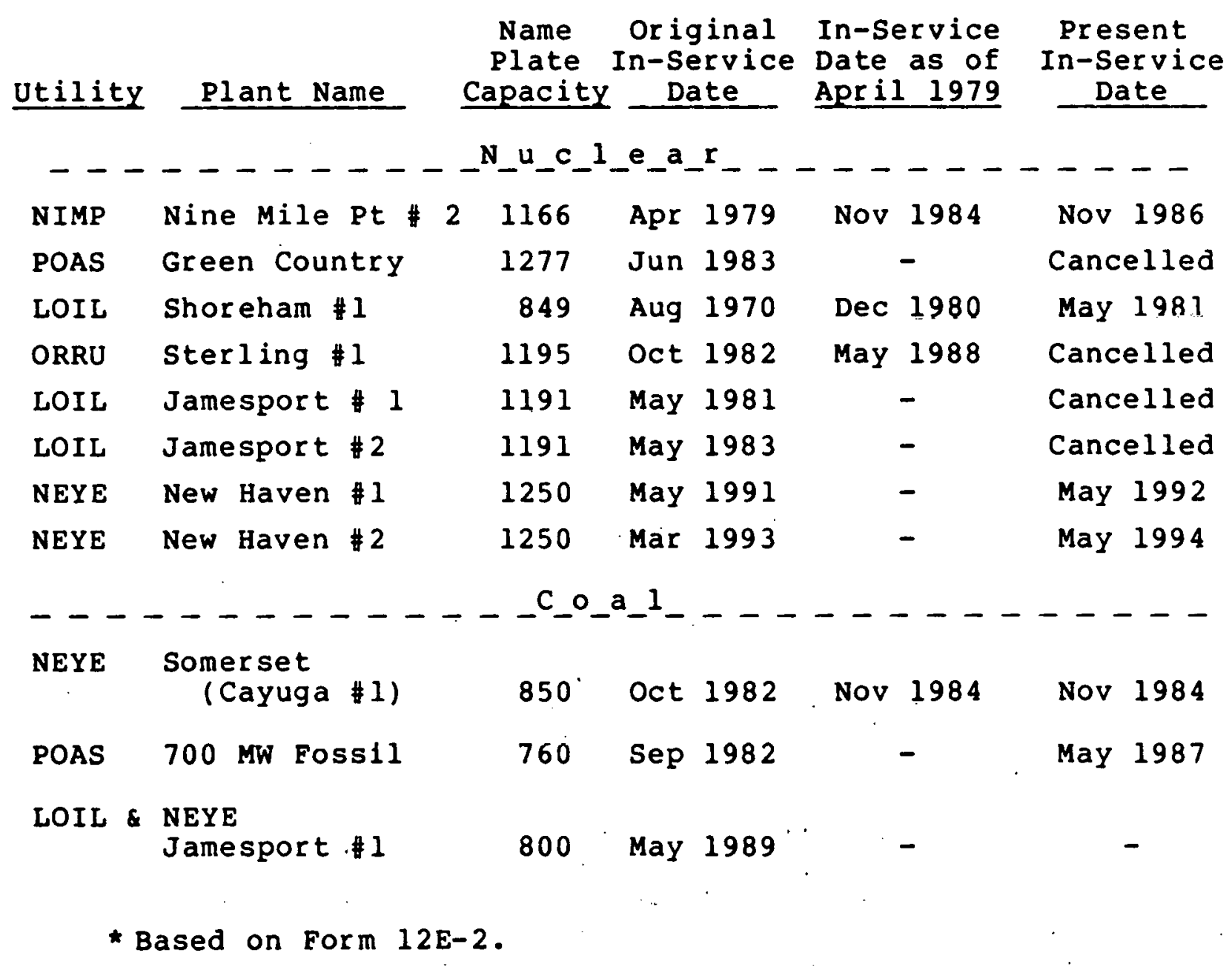


$\mathrm{XI} \cdot 6.30$

The following table shows transmission lines which are planned, committed, or under construction:

\section{Table 6B.7}

PLANNED TRANSMISSION ADDITIONS *

New York Power Pool

$\begin{array}{ccc}\text { KV } & \begin{array}{c}\text { Miles } \\ (1979-1983)\end{array} & \begin{array}{c}\text { Miles } \\ (1984-1988)\end{array} \\ 230 & 44 & 0 \\ 345 & 304 & 259 \\ 765 & 9 & 80\end{array}$

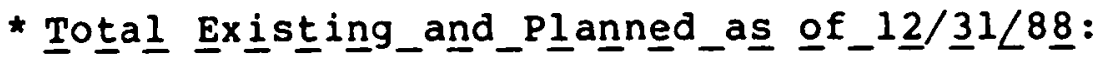

$\begin{array}{lr}\text { KV } & \text { Miles } \\ 230 & 1,119 \\ 345 & 2,662 \\ 500 & 5 \\ 765 & 244\end{array}$

* Based on NERC 9 th Annual Review. 
HISTORICAL CAPABILITY (MW) AND RESERVES (MW and Percent) New York Power Pool

1. Planned Capability

2. Peak Demand

3. Planned Reserves (1-2)

4. Planned Reserves (\%) (3/2) $\times 100$

5. Net Transactions (Imports-Exports)

6. Total Capability $(1+5)$

7. Total Reserves (6-2)

8. Total Reserves (\%) (7/2) $\times 100$

9. Scheduled Maintenance

10. Capability after Maintenance (6-9)

11. Reserves after Maintenance (10-2)

12. Reserves after Maintenance (\%) $(11 / 2) \times 100$

13. Inoperable Capability I/

14. Available Capability (10-13)

15. Available Reserves (14-2)

16. Available Reserves (\%) $(15 / 2) \times 100$

17. Forced Outages

18. Actual Capability after Forced Outages (14-17)

19. Actual Reserves (18-2)

20. Actual Reserves (\%) (19/2) ×100
1977

29

$\begin{array}{ll}29728 & 30856 \\ 21103 & 18838 \\ 8625 & 12018\end{array}$

$8625 \quad 12018$

$40.9 \quad 63.8$

$-130 \quad-150$

$29598 \quad 30706$

$8495 \quad 11868$

40.3

$\begin{array}{rr}- & 63.0 \\ 29598 & 30706 \\ 8495 & 11868\end{array}$

$8495 \quad 11868$

$40.3 \quad 63.0$

$6434 \quad 5794$

23164

24912

2061

9.8

6074

32.2

23164

2061

9.8

1/ Includes outages for scheduled maintenance, inoperable, and forced.

\begin{tabular}{rrrrr}
\multicolumn{2}{c}{1978} & \multicolumn{2}{c}{1979} \\
\cline { 5 - 5 } sumner & Winter & & Summer & Winter \\
29435 & 31125 & 30032 & 31083 \\
20316 & 19598 & 20746 & 19417 \\
9119 & 11527 & 9286 & 11666 \\
44.9 & 58.8 & 44.8 & 60.1 \\
159 & -150 & 668 & -49 \\
29594 & 30975 & 30700 & 31034 \\
9278 & 11377 & 9954 & 11617 \\
45.7 & 58.1 & 48.0 & 59.8 \\
- & - & - & - \\
29594 & 30975 & 30700 & 31034 \\
9278 & 11377 & 9954 & 11617 \\
45.7 & 58.1 & 48.0 & 59.8 \\
5841 & 8124 & 8264 & 8309 \\
23753 & 22851 & 22436 & 22725 \\
3437 & 3253 & 1690 & 3308 \\
16.9 & 16.6 & 8.1 & 17.0 \\
- & - & - & - \\
23753 & 22851 & 22436 & 22725 \\
3437 & 3253 & 1690 & 3308 \\
16.9 & 16.6 & 8.1 & 17.0
\end{tabular}


Table 6B.9

CURRENT CAPABILITY (MW) AND RESERVES (MW and Percent) New York Power Pool

1. Planned Capability I/

2. Peak Demand

3. Planned Reserves (1-2)

4. Planned Reserves (\%) $(3 / 2) \times 100$

5. Net Transactions (Imports-Exports)

6. Total Capability $(1+5)$

7. Total Reserves (6-2)

8. Total Reserves (\%) $(7 / 2) \times 100$

9. Scheduled Maintenance

10. Capability after Maintenance (6-9)

11. Reserves after Maintenance (10-2)

12. Reserves after Maintenance (\%) $(11 / 2) \times 100$

13. Inoperable Capability

14. Available Capability (10-13)

15. Avaflable Reserves (14-2)

16. Available Reserves (\%) (15/2) $\times 100$

17. Forced Outages 2 /

18. Actual Capability after Forced Outages (14-17)

19. Actual Reserves (18-2)

20. Actual Reserves (\%) $(19 / 2) \times 100$

$\begin{array}{rrr}\begin{array}{rr}1980 \\ \text { Summer }\end{array} & \begin{array}{r}1980 / 81 \\ \text { Winter }\end{array} \\ 30467 & 31540 \\ 21230 & 19870 \\ 9237 & 11670 \\ 43.5 & 58.7 \\ 650 & -100 \\ 31117 & 31440 \\ 9887 & 11570 \\ 46.6 & 58.2 \\ 700 & 2200 \\ 30417 & 29240 \\ 9187 & 9370 \\ 43.3 & 47.2 \\ - & - \\ 30417 & 29240 \\ 9187 & 9370 \\ 43.4 & 47.2 \\ - & - \\ 30417 & 29240 \\ 9187 & 9370 \\ 43.3 & 47.2\end{array}$

1/ No delays anticipated in new units since submittal of 1980 ERA-411.

2/ Information not reported. 
Table 6B.10.1

FUTURE CAPABILITY (MW) AND RESERVES (MW and Percent) - 1981-84. New York Power Pool

1. Planned Capability I/

2. Peak Demand

3. Planned Reserves (1-2)

4. Planned Reserves (\%) (3/2) $\times 100$

5. Net Transactions (Imports-Exports)

6. Total Capability $(1+5)$

7. Total Reserves (6-2)

8. Total Reserves (\%) $(7 / 2) \times 100$

9. Scheduled Maintenance

10. Capability after Maintenance (6-9)

11. Reserves after Maintenance (10-2)

12. Reserves after Maintenance (\%) $(11 / 2) \times 100$

13. Inoperable Capability $2 /$

14. Available Capability (10-13)

15. Available Reserves (14-2)

16. Available Reserves (\%) (15/2) ×100

17. Forced Outages $2 /$

18. Actual Capability after Forced Outages (14-17)

19. Actual Reserves (18-2)

20. Actual Reserves ( $($ ) $(19 / 2) \times 100$

I/ Assuming no delays in projected units.

2/ Information unavailable.

\section{1}

Summer Winter

3125232343

$21610 \quad 20310$

$9642 \quad 12033$

$44.6 \quad 59.2$

$550 \quad-8$

$31902 \quad 32335$

$10292 \quad 12025$

$4 ? .6 \quad 59.2$

$1200 \quad 1300$

$30702 \quad 31035$

$9092 \quad 10725$

$42.1 \quad 52.8$

$\begin{array}{rr}- & - \\ 30702 & 31035\end{array}$

$9692 \quad 10725$

$42.1 \quad 52.8$

$30702 \quad 31035$

$9092 \quad 10725$

$42.1 \quad 52.8$
1982 Summer Winter $31277 \quad 32388$ 2207020800 $9207 \quad 11588$

$41.7 \quad 55.7$

$650 \quad-150$

$31927 \quad 32 ? 38$

$9857 \quad 11738$

$44.7 \quad 55.0$

$1200 \quad 1300$

$30727 \quad 30938$

$8657 \quad 10138$

$39.2 \quad 48.7$

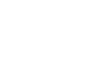

3072

8657

39.

3072

865

39.2

\begin{tabular}{rr}
\multicolumn{2}{c}{1983} \\
Summer & Winter \\
31327 & 3241.8 \\
22480 & 21200 \\
8847 & 11218 \\
39.4 & 52.9 \\
650 & -150 \\
31977 & 32268 \\
9497 & 11068 \\
42.2 & 52.2 \\
1200 & 1300 \\
30777 & 30968 \\
8297 & 9768 \\
36.9 & 46.1 \\
- & - \\
30777 & 30968 \\
8297 & 9768 \\
36.9 & 46.1 \\
- & - \\
30777 & 30968 \\
8297 & 9768 \\
36.9 & 46.1
\end{tabular}

1984

Summer Winter

$31321 \quad 33288$

$22850 \quad 21630$

$8471 \quad 11658$

$37.1 \quad 53.9$

$650 \quad-150$

$31971 \quad 33138$

$9121 \quad 11508$

$39.9 \quad 53.2$

$1200 \quad 1300$

$30771 \quad 31838$

$7921 \quad 10208$

$34.7 \quad 47.2$

$30771 \quad 31838$

$7921 \quad 10208$

$34.7 \quad 47.2$

$30771 \quad 31838$

$7921 \quad 10208$

$34.7 \quad 47.2$ 
Table 6B.10.2

FUTURE CP.PABILITY (Mi*) AND RESERVES (MW and Percent) - 1985/89 New York Power Pool

1. Planned Capability I/

2. Peak Demand

3. Planned Reserves $(1-2)$

4. Planned Reserves (\%) (3;2) $\times 100$

5. Net Transactions (Imports-Exports)

6. Total Capability $(1+5)$

7. Total Reserves (6-2)

8. Total Reserves $(\%)(7 / 2 i \times 100$

9. Scheduled Maintenance $2 i$

10. Capability after Maintenance (6-9)

11. Reserves after Maintenance (10-2)

12. Reserves after Maintenance ( $(x)(11 / 2) \times 100$

13. Inoperable Capability 2 !

14. Available Capability (10-13)

15. Available Reserves (14-2)

16. Available Reserves (\%) (15/2) ×100

17. Forced Outages 21

18. Actual Capability after Forced Outages (14-17)

19. Actual Reserves (18-2)

20. Actual Reserves (\%) $(19 / 2) \times 100$

1/ Assumes no new unit delays.

2f Information unavailable.
1985 Summer Winter Summer Winter Summer Winter Surmer Winter summer Winter

\begin{tabular}{|c|c|c|c|c|c|c|c|c|c|}
\hline 32230 & 33321 & 32271 & 34338 & 34974 & 35999 & 34936 & 36040 & 35709 & 36797 \\
\hline 3250 & 22070 & 23720 & 22550 & 24230 & 23100 & 24710 & 23630 & 25300 & 24260 \\
\hline 8980 & 11251 & 8551 & 11788 & 10744 & 12899 & 10226 & 12410 & 10409 & 12537 \\
\hline 38.6 & 51.0 & 36.0 & 52.3 & 44.3 & 55.8 & 41.4 & 52.5 & 41.1 & 51.7 \\
\hline 650 & -150 & 650 & -150 & 650 & -150 & 650 & -150 & 650 & -150 \\
\hline 32880 & 33171 & 32921 & 34188 & 35624 & 35849 & 35586 & 35890 & 36359 & 36647 \\
\hline 9630 & 11101 & 9201 & 11638 & 11394 & 12749 & 10876 & 12260 & 11059 & 12387 \\
\hline 41.4 & 50.3 & 38.8 & 51.6 & 47.0 & 55.2 & 44.0 & 51.9 & 43.7 & 51.1 \\
\hline- & - & - & - & - & - & - & - & - & - \\
\hline 32880 & 33171 & 32921 & 34188 & 35624 & 35849 & 35586 & 35890 & 36359 & 36647 \\
\hline 9630 & 1101 & 9201 & 11638 & 11394 & 12749 & 10876 & 12260 & 11059 & 12387 \\
\hline 41.4 & 50.3 & 38.8 & 51.6 & 47.0 & 55.2 & 44.0 & 51.9 & 43.7 & 51.1 \\
\hline- & - & - & - & - & - & - & - & - & - \\
\hline 32880 & 33171 & 32921 & 34188 & 35624 & 35849 & 35586 & 35890 & 36359 & 36647 \\
\hline 9630 & 11101 & 9201 & 11638 & 11394 & 12749 & 10876 & 12260 & 11059 & 12387 \\
\hline 41.4 & 50.3 & 38.8 & 51.6 & 47.0 & 55.2 & 44.0 & 51.9 & 43.7 & 51.1 \\
\hline- & - & - & - & - & - & - & - & - & 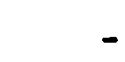 \\
\hline 32880 & 33171 & 32921 & 34188 & 35624 & 35849 & 35586 & 35890 & 36359 & 36647 \\
\hline 9630 & 11101 & 9201 & 11638 & 11394 & 12749 & 10876 & 12260 & 11059 & 12387 \\
\hline 41.4 & 50.3 & 38.8 & 51.6 & 47.0 & 55.2 & 44.0 & 51.9 & 43.7 & 51.1 \\
\hline
\end{tabular}


SECTION XI. 7

SOUTHEASTERN ELECTRIC RELIABILITY COUNCIL (SERC) 


$$
X I .7 .1
$$

Southeastern Electric Reliability Council Area

$$
\text { Power Supply and Demand }
$$

Introduction

The southeastern Electric Reliability Council (SERC) region includes all of the states of Alabama, Georgia, Florida, North Carolina, South Carolina and Tennessee and parts of Mississippi, Kentucky and virginia. The SERC region represents about 10 percent of the nation's contiguous area but accounts for about 20 percent of the nation's electric energy.

Within SERC there are four subregional groups which coordinate their planning and operation. There is the southern subregion which includes all of Georgia, most of Alabama, the southeast one-quarter of Mississippi and the northwest corner of Florida; the florida subregion which covers the Florida Peninsula; the TVA Subregion which covers all of Tennessee and small parts of Alabama, Mississippi and Kentucky; and the VACAR Subregion which includes North Carolina, South Carolina and most of Virginia. Each of these subregions has their own unique characteristics which affects their electric bulk power supply.

The TVA subregion is a definite winter peaking area while the southern subregion is a definite summer peaking region. The Florida subregion can peak in either summer or winter as can the VACAP subregion. Due to the proximity of the southern, TVA, and VACAF to the Appalachian coal mines the fuel mixes of these subregions are similar. These subregions are heavily dependent upon coal for electric power generation. Most of the generating capacity in the Florida subregion was originally designed to burn natural gas as a primary fuel with oil as an alternate fuel. The sudden attrition of natural gas supplies coupled with the expiration of natural gas supply contracts has left the florida subregion heavily dependent upon high cost oil for electric generation.

Geographical location has not only affected the fuel mixes but has influenced the pattern of transmission development within and between each of these subregions. The TVA Subregion is very close to the geographical center of the seven eastern interconnected reliability council areas and is perhaps the key link between these areas. Consequently, a high capacity $500 \mathrm{kV}$ transmission network has been developed in the TVA subregion. There is a significant amount of $500 \mathrm{kV}$ in the VACAR subregion, some $500 \mathrm{kV}$ in the southern subregion and isolated segments of $500 \mathrm{kV}$ in the Florida subregion. Therefore, the opportunities to interconnect at $500 \mathrm{kV}$ tend to diminish withi distance from the TVA subregion, particularly in a southward direction. Nevertheless, it is generally important for each subregion to maintain an intra-regional transmission import, capability equal to the composite spinning reserve for the total council area, over and above firm scheduled purchases and sales. The current spinning reserve of the SERC is approximately $3,500 \mathrm{MW}$. 
$\mathrm{XI} .7 .2$

Generating unit forced outages varied from a low average of 128 of peak demand in the Florida Subregion to a high average of 218 in VACAR and TVA subregions during 1977 through 1979 period. Generating unit forced outages averaged 168 of the peak demand in the southern subregion. Generating unit maintenance outages during the peak season varied from a low average of 38 in the southern subregion to a high average of 168 in the Florida subregion during this period. Maintenance outages in the TVA and VACAR Subregions averaged 6 and 108 , respectively.

Assessment Methodology

The assessments in this report are not analytical but are statistical and are based on information reported to the Department of Energy on Forms $12 \mathrm{E}-2$, form 1 and ERA-411 by the eleclic utilities, information developed through fersonal contacts with electric utility officials and from information reported by the electric utilities to the National Electric Reliability Council.

A three-part examination entitled Historical perspertive, current Perspective and Future Perspective is included in the report for each subregion. The Historical perspective reviews the 1977 through 1979 period, the Current perspective covers the near-term 1980 situation and the Future Perspective covers the 1981-1989 period.

Each region's bulk power supply was assessed based essentially on five statistical parameters as follows:

1. Load Growth - annual energy, seasonal peak demand and annual load factor in percent.

2. Planned Reserves - in percent of peak demand.

3. Reserve after maintenance - in comparison to the region's operating criteria.

4. Fuel Mix - in percent of total generating capacity.

5. Transmission Capacity - in MW miles per MW of generating capacity as well as emergency import capability in percent of peak demand.

Table 7.1 summarizes representaive portions of the five statistical parameters by SERC subregions. A list of the reporting entities covered by each subregion is shown on attached Table 7.2. 
TAPLE 7.1

Load Growth, Planned and Actual Peserve, Fuel Mix and Transmission Capacity

SERC Pegion

Florida Southern TVA VACÁE

1. Electric Energy Growth in 8 l/

$$
\begin{aligned}
& 1977-1979 \\
& 1980-1989
\end{aligned}
$$

$4 \cdot 5$

3.0

4.1

3.7

3.9

2.5

4.8

2. Lowest Planned/Total Reserves in $z$
$1977-19792 /$
$1980-1989 \underline{\underline{3}} /$
30.4
8.0
15.8
$26.9 \quad 19.2$

3. Lowest Actual Reserve in $M W$

$$
\begin{aligned}
& 1977-19794 \\
& 1980-1989
\end{aligned}
$$

$\begin{array}{rr}974 & 1,083 \\ 1,120 & 2,577\end{array}$

63

1,107

$(2,706)$

(427)

4. Non-oil/gas Cepacity in
1978
1980
1984
1989

22.7
23.8
30.5
44.0

86.3

87.7

89.5

92.0
91.4

92.2

93.5

94.7
79.6

81.1

84.9

87.3

5a. Transmission in MW-miles/Mh

Total as of $(1977-1979)$
Incremental from $1980-1989$

70 5/ 150 6/

110 I/

$115 \underline{6}$

95

110

80

124

5b. Emergency Import Capacity in 8

$$
\begin{aligned}
& 1980 \\
& 1984
\end{aligned}
$$

1.5

1.3

18.0
16.4

30.2

40.7

27.8

20.3

1/ Figure 7.1 is a graphical summary of the actual and forecast electric energy use by SERC Subregions.

2/ Does not include historical purchases and sales because these included emergency transfers.

3/ Includes firm scheduled purchases and sales.

4/ Emergency transfers are included in the historical available reserve figures.

5/ As of 1977.

6/ As of 1978 .

7 As of 1979 . 


\section{Florida Subregion}

Eistorical Perspective

Until recently, the Florida subregion was a vigorous electrical energy and peak demand growth area. As late as 1974, annual electric energy use was predicted to increase at an average annual rate of 10.0 percent and annual peak demand was forecasted to increase at an average annual rate of 10.6 percent, over the next ten years. Both electric energy use and electric demand growth have moderated considerably since that time. Price of electricity may be a factor in this reduction. The cost of electricity production (\$1979) in Florida ranged from approximately 50 to $60 \mathrm{mills} / \mathrm{kwh}$. Econometric estimates indicate that for each 1 percent $r$ ise in the real price of electricity a 0.4 percent to 0.8 percent decrease in demand for electricity wili result in Florida. Actual average annual growth in net energy for load for 1977 through 1979 was 4.5 percent. Over this period, the summer peak demand increased at a rate of 3.7 percent and the winter ceak demand grew at a rate of 3.4 percent. Table $7 \mathrm{~A} .1$ shows actual figures for each of these years along with computed average load factor.

TABLE 7A.1

$\frac{\text { Actual Annual Net Energy for Load, Summer and winter Peak Demands anc }}{\text { Load Factors I/ }}$

Florida Coordinating Group Region

Item:

Annual Electric Enelyy ili $\mathrm{GWH}$

Summer Peak Demand in $\mathrm{MW}$

winter Peak Demand in $M W \underline{2}$

Annual Load Factor in

$$
1977
$$

79,717

15,444

16,965

$53 \cdot \bar{c}$ $\underline{1978}$

1979

87,017

$8.4,314$

16,599

16,014

17,131

18,142

56.2

54.8

Actual mid-period (1978) summer generating capacity by fuel type and resulting 1978 actual energy production is shown on Table 7A.2. oil and natural gas accounted for 69 percent of electric generation in the Florida Peninsula in 1978.

17 Source - Form No. $12 \mathrm{E}-2$

2/ Winter period for each year includes December of that year plus January and February of the following year. 
$\mathrm{XI} .7 .5$

TARLE 7A. 2

Actual 1978 Summer Generating Capacity by Fuel Type Florida coordinating Group Region

\begin{tabular}{|c|c|c|c|c|c|}
\hline \multirow[b]{2}{*}{ Capacity Type } & \multirow[b]{2}{*}{ Fuel Type } & \multicolumn{2}{|c|}{ Capacity } & \multicolumn{2}{|c|}{ Generation } \\
\hline & & $\mathbf{M W}$ & $\begin{array}{l}8 \text { of } \\
\text { Total }\end{array}$ & GWh & $\begin{array}{l}8 \text { of } \\
\text { Total }\end{array}$ \\
\hline steam & Nuclear & 2.876 & 13.2 & 15,763 & .18 .5 \\
\hline steam & Coal & 2,012 & 9.3 & 10,369 & 12.2 \\
\hline steam & Oil & 12,299 & 56.6 & 40.468 & 47.6 \\
\hline Steam & Gas & 0 & 0.0 & 15,322 & 18.0 \\
\hline Hydro & Water & 36 & 0.2 & 224 & 0.3 \\
\hline Pumped storage & Water & 0 & 0.0 & 0 & 0.0 \\
\hline Gas Turbine & Oil & 4,035 & 18.6 & 1,607 & 1.9 \\
\hline Gas Turbine & Gas & 0 & 0.0 & 497 & 0.6 \\
\hline Combined Cycle & Oil & 460 & 2.1 & 706 & 0.8 \\
\hline Combined Cycle & Gas & 0 & 0.0 & 109 & 0.1 \\
\hline other & & 0 & $\underline{0.0}$ & $\underline{0}$ & 0.0 \\
\hline Total & & 21,718 & 100.0 & 85,065 & 100.0 \\
\hline
\end{tabular}

A total of 144 million Mcf of natural gas was used during 1978 to produce electricity in the Florida Subregion. Of this amount, 112 million Mcf or 78 percent was supplied under firm contracts and the., rest was interruptible. Two natural gas supply contracts for a total of 140 million cubic feet per day expired in June 1979. This is expected to reduce natural gas supply by about 35 percent for 1980. The remaining major natural gas supply contracts will expire by 1988 .

There are currently four nuclear generating units $1 /$ in operation at the present time in Florida and one more unit $2 /$ is scheduled for operation in the next ten years.

A total of $76 \mathrm{million}$ barrels of oil were used in the Florida subregion during 1978 and almost all of this ( 96 percent) was residual oil. This amount was about 12 percent of that used by all electric? utilities in the United States during 1978 .

I/ Crystal Ríver No. $3(7827807 \mathrm{MW}), \mathrm{St}$. Lucie No. 1 (777/795 MW), Turkey Point No. $3(666 / 696 \mathrm{MW})$, and Turkey Point No. $4(666 / 696 \mathrm{MW})$.

2/ St. Lucie No. $2(795 / 812 \mathrm{MW})$. 
The Florida Feninsula utilities maintain an operating reserve equal to twice the size of the largest generating unit. One-half of this is to be spinning at all times and the remainder is to be available within thirty minutes. The largest generating unit in the Florida subregion is $800 \mathrm{MW}$. There is no criteria covering the amount of planned reserve, but 20 to 25 percent of peak demand is generally considered adequate by Florida electric utilities. Tables $7 \mathrm{~A} .3$ through $7 \mathrm{~A} .5$ give the actual reserve situations that occurred in the Florida Subregion for 1977 through 1979 for each of the three summer months (June, July and August) and the three winter months (December, January and February). Flanned reserve exceeded 20 percent of peak demand during each of the eighteen historical peak periods. The lowest planned reserve was 30.4 fercent and occurred in February 1980. Actual reserve, however, did not meet the operating reserve reguirement of $1,600 \mathrm{MW}$ on two occasions. The lowest available reserve was $974 \mathrm{MW}$ and occurred in January $19 / y$.

Transmission in Florida has historically been installed on the basis of service territory. There has been no allocation of costs or sharing of costs based on benefits received. Although there are isolated segments of $500 \mathrm{kV}$ in operation, the workhorse transmission voltage is $230 \mathrm{kV}$. In 1977 there was about $1.5 \mathrm{mill}$ ion megawatt-miles of transmission lines in service consisting of about $230 \mathrm{miles}$ of $500 \mathrm{kV}$ line, about 3,000 miles of $230 \mathrm{kV}$ line and about 4,500 miles of $115 \mathrm{kV}$ and $138 \mathrm{kV}$ lines. This resulted in a transmission capacity to generating capacity ratio of about $70 \mathrm{MW}-\mathrm{miles}$ fer $\mathrm{MW}$.

Until Lecember 1979 the Florida subregion was interconnected to the southern subregion by one $230 \mathrm{kV}$ line and several $115 \mathrm{kV} l$ ines having a combined import capability of $300 \mathrm{MW}$. This represented about 1.9 percent of the 1978 summer peak demand. An additional $230 \mathrm{kV}$ tie was installed in December 1979 which is expected to increase the import capability to about 600 MW for 1980 .

There have been continuing stability and transient voltage problems at the Florida-Southern interface that cannot be resolved at the $230 \mathrm{kV}$ voltage level due to the fact that the electrical centers of these respective areas are about $400 \mathrm{miles}$ apart. "coalby-wire" transfers to Florida greatly aggravated these problems to where there were approximately 10 load shedding incidents in the Florida subregion during 1979.

Florida subregion systems have instituted a unigue broker energy exchange arrangement which has produced significant dollar savings to the participants. During 1979 the energy broker saved over $\$ 22$ million. Pool dispatch is currently being evaluated as a further possible step to increase operation savings. 


\section{Current Perspective}

The 1980 summer peak demand of 17,534 is expected to occur in the Florida Subregion in August. This forecast represents a 5.6 percent increase over the actual 1979 summer peak demand. Although the summer peak demand is predicted to occur in August, the month of June can be more critical in the Florida subregion because the peak can potentially occur in June at a time when scheduled maintenance and overhaul of generating equipment is still relatively heavy. Should this occur, reserve after maintenance could be reduced to about 2,500 MW this June. Otherwise reserve after maintenance should exceed $3,000 \mathrm{MW}$ during the 1980 summer season.

No additional new generating units are scheduled for operation prior to the 1980 summer season. The Crystal River No. 3 nuclear generating unit, rated at $782 \mathrm{MW}$, underwent modifications and refueling in late February and is due back by mid-May. Should this unit not return as expected, June operating reserve would be close to the Florida Subregion's minimum operating criteria. The Anclote plant $(1,007 \mathrm{MW})$ has an environmental permit which restricts its operation when water temperature is high. The unavailability of some of this plant's capability for environmental reasons could also affect the reserve situation for this summer.

The projected 1980 winter peak demand is expected to increase by 7.8 percent over the 1979 winter peak demand, to 19,552 Mh. Traditionally, the winter peak forecasts in the Florida subregion are based on extremely cold conditions which typically occur only about once every four years. Should this forecast materialize as estimated, reserve after maintenance is expected to exceed 3,900 $\mathrm{MW}$. This, however, is contingent upon successful completion of the Martin No. I generating unit, rated at $787 \mathrm{MW}$, prior to the winter peak season. Even without the Martin No. 1 unit, reserve for the 1980 winter season should be adequate. Table 7 A.6 gives the current reserve picture for the three summer months and three winter months for 1980 .

The interconnection import capability of the Florida subregion, over and above scheduled purchases and sales, is about $300 \mathrm{MW}$. This is 1.5 percent of the projected 1980 winter peak demand.

The Florida subregion has a curtailment program whereby a total of $797 \mathrm{MW}$ or 4.1 percent of the projected 1980 winter peak demand could be reduced manually in the event of an extreme emergency. of this amount, relief of $200 \mathrm{MW}$ can be achieved through a 5 percent voltage reduction, intercuption of interruptible contract load can bring $552 \mathrm{MW}$ relief and curtailment of non-essential utility load can result in $45 \mathrm{MW}$ load reduction 


\section{Future}

The Florida subregion is forecasting their annual electric energy use to increase from $92,723 \mathrm{GWH}$ in 1980 to 136,897 GWH in 1989 . This is an average annual growth rate of 4.4 percent and is consistent with their electric energy growth rate during the past three years. Their summer peak demand is estimated to grow at an average annual rate of 4.7 percent, from $17,534 \mathrm{MW}$ in 1980 to $26,459 \mathrm{NW}$ in 1989. Their winter peak demand is expected to increase from $19,552 \mathrm{MW}$ in 1980 to $29,166 \mathrm{NW}$ in 1989 , an average annual growth rate of 4.5 percent. Annual load factor is expected to remain in the 53 to 54 percent range during the 1980 through 1989 period.

Florida Subregion's load forecast for the 1980 through 1984 period is higher than either the past three year average or the overall future ten year average. The summer peak demand for the 1980 through 1984 period is predicted to increase at an average annual rate of 5.1 percent and the winter peak is estimated to increase at 4.9 percent.

While Florida Subregion's load forecasts may be optimistic in view of present economic conditions, the timing of future generating unit additions should be unaffected by this since it is considerably more important to aim at changing the fuel $\mathrm{mix}$ as rapidly as possible rather than aiming to meet load growth alone.

Almost all of the future generating capacity additions in the Florida Subregion (see attached Table $7 \AA .8$ for details) are planned to be coal-fired. The impact of these additions on the overall generating capacity fuel $\mathrm{mix}$ is shown in Table $7 \mathrm{~A} .7$ for mid-year 1980, 1984 and 1989, respectively. The amount of nuclear and coalfired generating capacity expected to be in service by 1989 represents a threefold increase over that which existed in 1978. Nuclear and coal-tired generating capacity is expected to represent 43.4 percent of the total generating capacity by 1989 compared to 22.5 percent for 1978 . 
Possibly the least capital intensive option available to accelerate the reduction of oil use for generation in the Florida subregion is the construction of extra-high voltage transmission between the Florida and Southern subregions to increase coal-by-wire transfers into the Florida Peninsula. A fully integrated transmission network consisting of about 420 miles of additional $500 \mathrm{kV}$ lines in Florida would be required to implement this strategy in a reliable manner.1/ Essentially, two parallel $500 \mathrm{kV}$ circuits are needed. One circuit, already in the planning stage, when completed, would extend from Plant Hatch in southeast Georgia down the east coast of Florida to the Midway substation north of Miami. A second circuit, which is not currently planned, from Tifton, Georgia needs to be extended in south central Georgia to the central. Florida area. These circuits would connect the isolated $500 \mathrm{kV}$ segments in Florida to the integrated $500 \mathrm{kV}$ system in the rest of the SERC region. Oil savings of about $10 \mathrm{million}$ barrels per year at an average annual investment cost of about $\$ 10$ per barrel saving appear possible with this system.1/ It is estimated that the reliability of the Florida subregion would also be improved by an estimated 20 to 30 percent and the transmission import capability would be increased to between $2,500 \mathrm{MW}$ and $3,000 \mathrm{MW}$ when fully implemented.2/

Since construction of these interconnections will be staged, reliability could be lessened during the implementation phase because weaker lower voltage lines will be interfacing higher voltage systems within the Florida Peninsula. This is particularly true following completion of the first leg of the east coast line from plant Hatch to Jacksonville in mid-1983. The east coast $500 \mathrm{kV}$ line is scheduled for completion between 1985 to 1987. Legislation is being considered ir Florida to change the transmission certification process from a county-by-county to a one-stop state level basis. This is imperative for prompt construction of these lines and facilities.

A total of $40 \mathrm{miles}$ of $115 \mathrm{kV}$ and $138 \mathrm{kV}$ lines, $910 \mathrm{miles}$ of $230 \mathrm{kV}$ lines and 740 miles of $500 \mathrm{kV}$ lines are planned for installation between 1980 and 1989 . This represents a transmission capacity addition of about 1.1 million MW-miles. The net generating capacity additions for this same period are about $11,600 \mathrm{MW}$ resulting in a transmission to generating capacity additions ratio of $95 \mathrm{MW}$ miles per MW. This is a commendable increase in transmission capacity relative to generation capacity but is possibly short of what is needed by virtue of the fact that the present transmission design is so far below what is needed.

Electric region's ten-year baseline projections of generating capacity, seasonal peak demand and reserve margins are shown on Table 7A.9. Total reserve is expected to exceed 20 percent of peak demand during all of the next eighteen peak load seasons between 1981 and 1989.

If Alternatives Available to Reduce Oil Consumption by Florida's Electric Utilities (October 1979, pp. 139-140). Florida Power Coordinating Group.

2/ ERA Atlanta Field office study. 
The Florida subregion does not plan to add generating units of any greater size during this period than already exists. This will limit their single contingency generating unit liability to about $800 \mathrm{MW}$ and double contingency generating unit loss to about $1,600 \mathrm{MW}$. Reserve after taking into account scheduled maintenance is expected to exceed $3,400 \mathrm{MW}$ during the next foreseeable eight peak periods between 1981 and 1984 .

The Florida Peninsula electric utilities, during the past year were able to arrest the slippage of new generating unit planned inservice date schedules. During the past year, major coal-fired generating unit installation dates slipped only $571 \mathrm{MW}$-months between 1981 and 1984 and $5,280 \mathrm{MW}$-months between 1985 and 1989 . The net effect is an estimated increase in oil use of about $6 \mathrm{million}$ barrels. There were some significant advances of soine schedules but these were largely offset by a two-year delay of the Martin No. 3 generating unit from 1985 to 1987 (16,800 MW-months). Every effort should be made to accelerate and return this unit to its 1985 in-service date. Most of the generating unit delays were made for financial reasons according to statements by the utilities involved. 
XI. 7.11

FIGURE 7.1

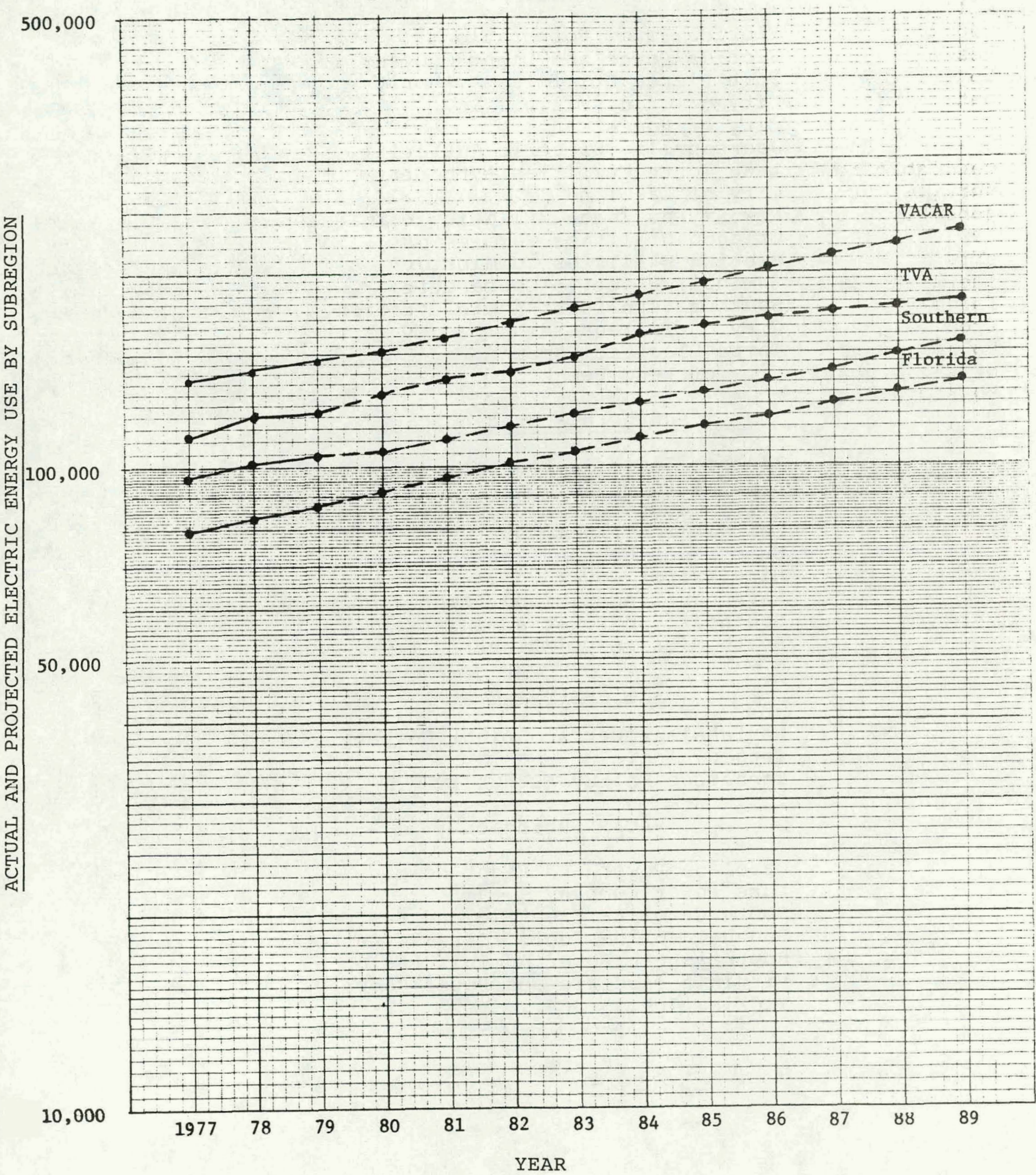



Florida subregion

Florida Power Corporation Florida Power and Light Comfany Fort Pierce Utilities Authority City of Cainesville City of Ilomestead. Jacksonville Electric Authority Lake Worth Utilities Authority City of Lakeland New Smyrna Beach Utilities Commission Orlando Utilities Commission Sebring Utilities Commission Seminola Electric Cooperative Southeastern Power Administration City of Tallahassee

Tampa Electric Company City of Veno Eeach

\section{Southern Subregion}

Alabama Electric Cooperative, Inc. Alabama Power Company Crisp County Power Commission Georgia Power Company Gulf Fower Company Mississippi Power Company Savannah Electric and Power Company Southeastern Power Administration South Mississippi Electric Fuwer Assn.

$$
\text { TVA_Subregion }
$$

Nantahala Power and Light Company Tapoco, Inc.

Tennessee Valley Authority

\section{VACAR S Subreg}

Carolina Power and Light Company Duke Power Company

South Carolina Electric and Gas Company South Carolina Fublic Service Authority Southeastern Power Administration Virginia Flectric and Power Company Yadkin, Inc. 
Table 7A.3

HISTORICAI CAPABIIITY AND RESERVE MARGINS FLORIDA COORDINATING GROUP REGION

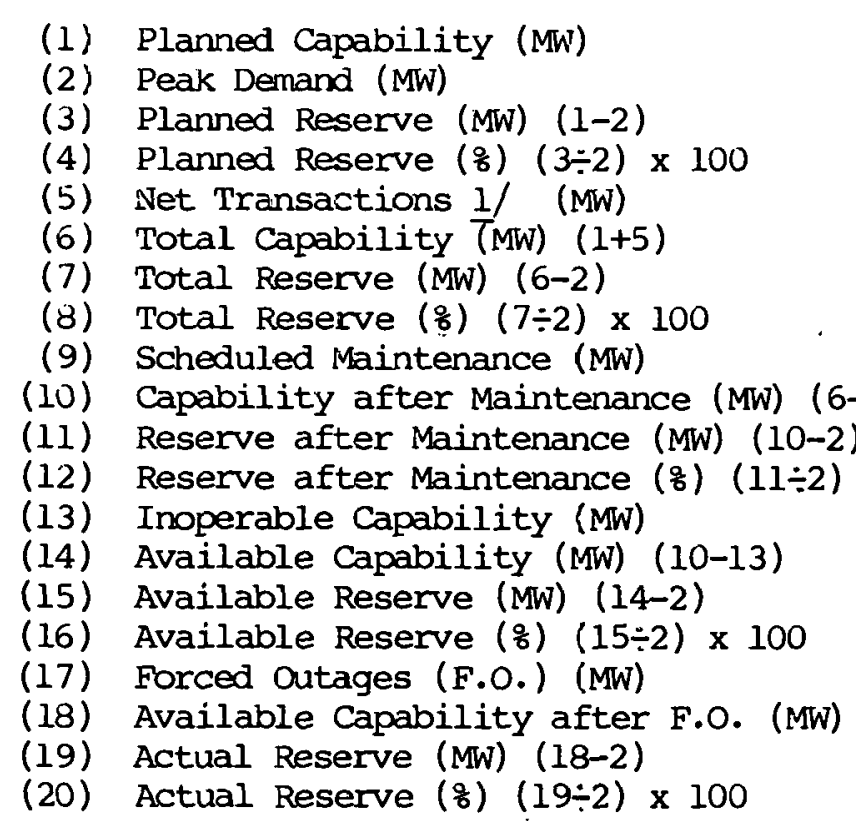

1) Net Transactions = Purchases - Sales

2/ ( ) denotes negative number
1977/1978 Winter

\begin{tabular}{|c|c|c|c|c|c|c|}
\hline \multicolumn{3}{|c|}{1977 Sunmer } & \multicolumn{3}{|c|}{ 1977/1978 Winter } & \\
\hline June & July & August & December & January & February & \\
\hline 20,485 & 20,470 & 20,726 & 22,600 & 22,943 & 22,943 & \\
\hline 15,444 & 14,924 & 14,447 & 14,688 & 16,238 & 16,965 & \\
\hline 5,041 & 5,546 & 6,279 & 7,912 & 6,705 & 5,978 & \\
\hline 32.6 & 37.2 & 43.5 & 53.9 & 44.3 & 35.2 & \\
\hline 108 & 218 & 483 & (11) $2 /$ & $(17) 2 /$ & 58 & \\
\hline 20,593 & 20,688 & 21,209 & 22,589 & 22,926 & 23,001 & \\
\hline 5,149 & 5,764 & 6,762 & 7,901 & 6,688 & 6,036 & \\
\hline 33.3 & 38.6 & 46.8 & 53.8 & 41.2 & 35.6 & \\
\hline 1,914 & 1,941 & 1,389 & 2,007 & 1,937 & 1,660 & \\
\hline 18,679 & 18,747 & 19,820 & 20,582 & 20,989 & 21,341 & \\
\hline 3,235 & 3,823 . & 5,373 & 5,894 & 4,751 & 4,376 & \\
\hline 21.0 & 25.6 & 37.2 & 40.1 & 29.3 & 25.8 & \\
\hline 0 & 0 & 0 & 0 & 0 & 0 & \\
\hline 18,679 & 18,747 & 19,820 & 20,582 & 20,989 & 21,341 & \\
\hline 3,235 & 3,823 & 5,373 & 5,894 & 4,751 & 4,376 & $\tilde{H}$ \\
\hline 21.0 & 25.6 & 37.2 & 40.1 & 29.3 & 25.8 & 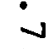 \\
\hline 1,610 & 1,260 & 1,771 & 2,536 & 2,232 & 2,564 & i \\
\hline 17,069 & 17,487 & 18,049 & 18,046 & 18,757 & 18,777 & $\omega$ \\
\hline 1,625 & 2,563 & 3,602 & 3,358 & 2,519 & 1,812 & \\
\hline $10.5^{\circ}$ & 17.2 & 24.9 & 22.9 & 15.5 & 10.7 & \\
\hline
\end{tabular}


Table 7A.4

HISTORICAL CRPABILITY AND RESERVE MA.RGINS FLCRIDA COORDINATING GROUP REGICN

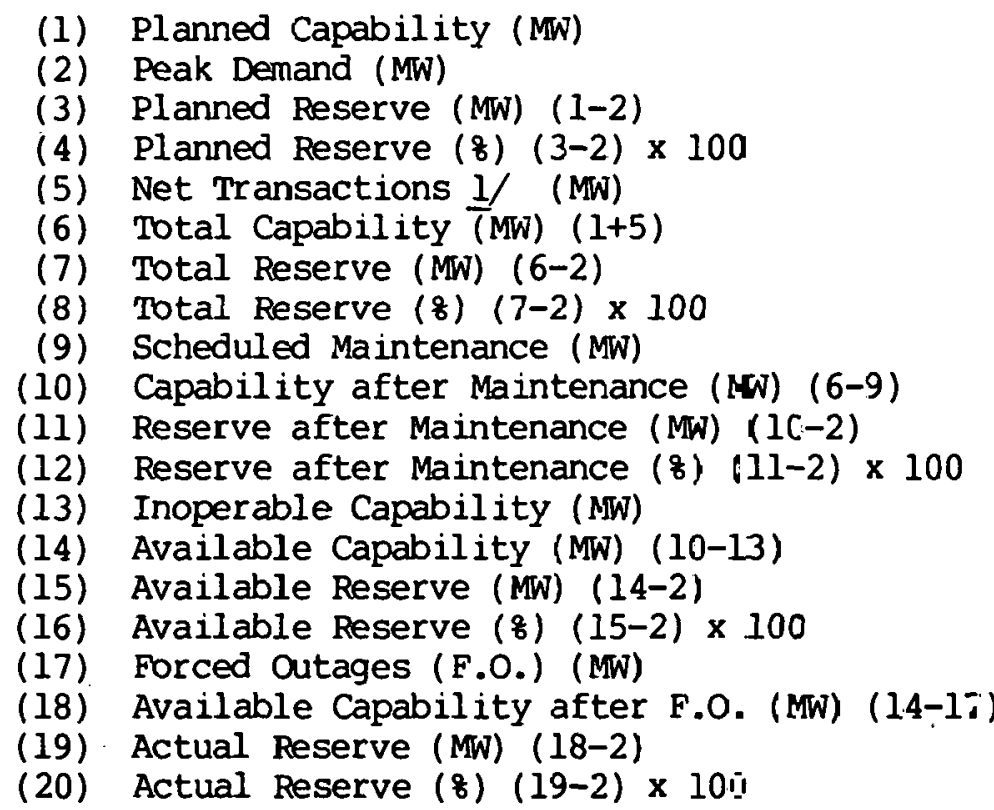

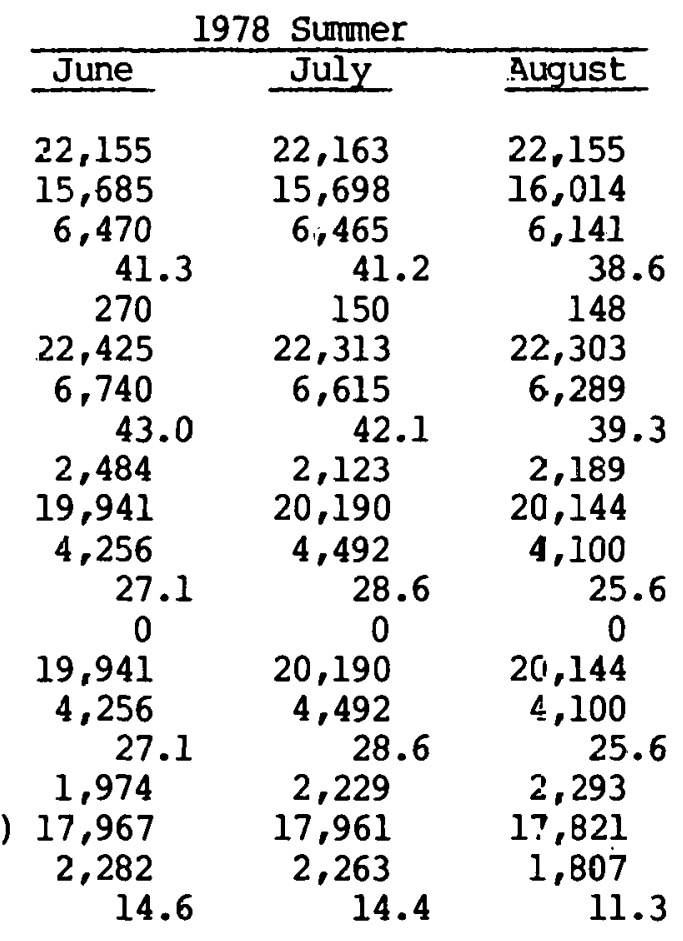

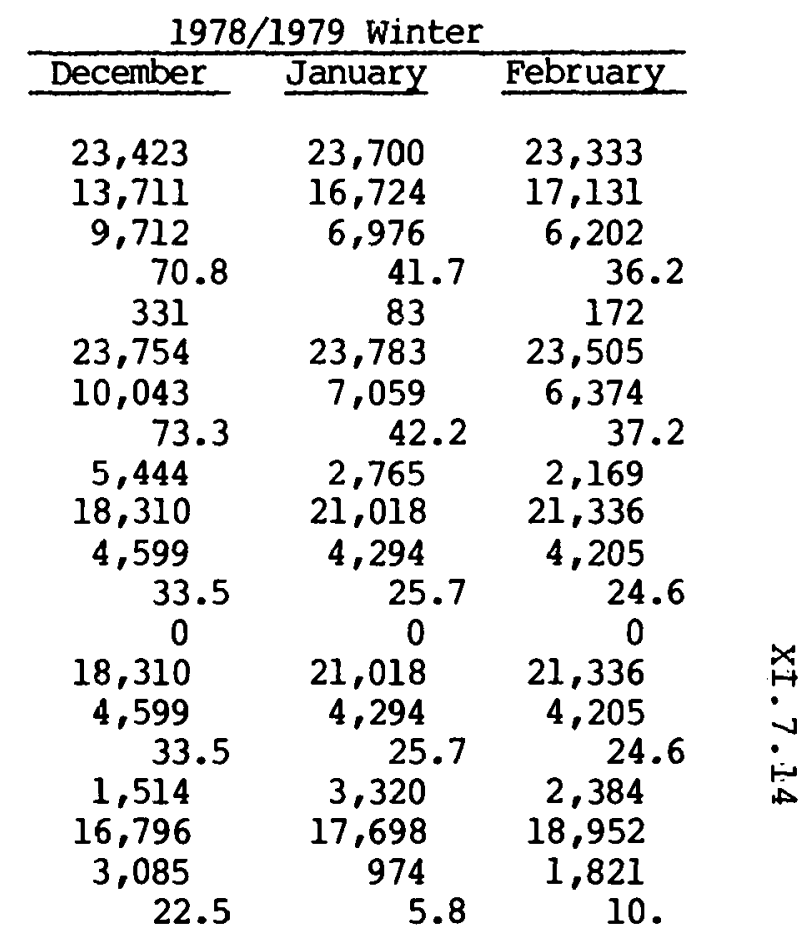

1/ Net Transactions $=$ Purchases - Sales 
Table 7A.5

HISTORICAI CAPABILITY AND RESERVE MARGINS FLORIDA COORDINATING GROUP REGION

(1) Planned Capability (MW)

(2) Peak Demand (MW)

(3) Planned Reserve (MW) (1-2)

(4) Planned Reserve (\%) (3\%2) x 100

(5) Net Transactions 1/ (MW)

(6) Total Capability (MW) $(1+5)$

(7) Total Reserve (MW) (6-2)

(8) Total Reserve (\%) (7\%2) x 100

(9) Scheduled Maintenance (MW)

(10) Capability after Maintenance (MW) (6-9)

(11) Reserve after Maintenance (MW) (10-2)

(12) Reserve after Maintenance (\%) (11-2) x 100

(13) Inoperable Capability (MW)

(14) Available Capability (MW) (10-13)

(15) Available Reserve (MW) (14-2)

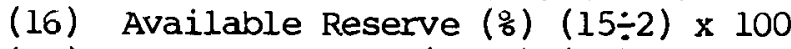

(17) Forced Outages (F.O.) (MW)

(18) Available Capability after F.O. (MW) (14-17)

(19) Actual Reserve (MW) (18-2)

(20) Actual Reserve (o) $(19 \div 2)$ x 100

\begin{tabular}{lll}
1979 Summer & \\
\hline June & July & August
\end{tabular}

$\begin{array}{cc}22,546 & 22,546 \\ 16,180 & 16,599 \\ 6,366 & 5,947 \\ 39.3 & 35.8 \\ 344 & 296\end{array}$

$22,890 \quad 22,842$

6,710

$$
41.5
$$

2,034

20,856

4,676

28.9

20,856

4,676

28.9

3,123

17,733
1,553

9.6
6,243

1,976

20,866

$.4,267$

25.7

20,866

4,267

$$
\begin{array}{r}
25.7 \\
1,629
\end{array}
$$

19,237

2,638

15.9
22,536

16,470

6,066

36.8

$$
171
$$

22,707

6,237

37.9

1,846

20,861

4,391

26.7

20,861

4,391

26.7

1,783

19,078

\begin{tabular}{|c|c|c|}
\hline December & January & February \\
\hline 23,330 & 23,286 & 23,651 \\
\hline 13,884 & 16,080 & 18,140 \\
\hline 9,446 & 7,206 & 5,511 \\
\hline 68.0 & 44.8 & 30.4 \\
\hline 457 & 155 & 617 \\
\hline 23,787 & 23,441 & 24,268 \\
\hline 9,903 & 7,361 & 6,128 \\
\hline 71.3 & 45.8 & 33.8 \\
\hline 3,309 & 3,020 & 1,686 \\
\hline 20,478 & 20,421 & 22,582 \\
\hline 6,594 & 4,341 & 4,442 \\
\hline 47.5 & 27.0 & 24.5 \\
\hline 0 & 0 & 0 \\
\hline 20,478 & 20,421 & 22,582 \\
\hline 6,594 & 4,341 & 4,442 \\
\hline 47.5 & 27.0 & 24.5 \\
\hline 2,195 & 1,583 & 2,275 \\
\hline 18,283 & 18,838 & 20,307 \\
\hline 4,399 & 2,758 & 2,167 \\
\hline 31.7 & 17.2 & 12.0 \\
\hline
\end{tabular}

2,608

15.8
$1979 / 1980$ Winter

1/ Net Transactions = Purchases - Sales 
Table 7A.6

CURRENT CAPABILITY AND RESERVE MARGINS FLC2IDA. COORDINATING GROUP REGION

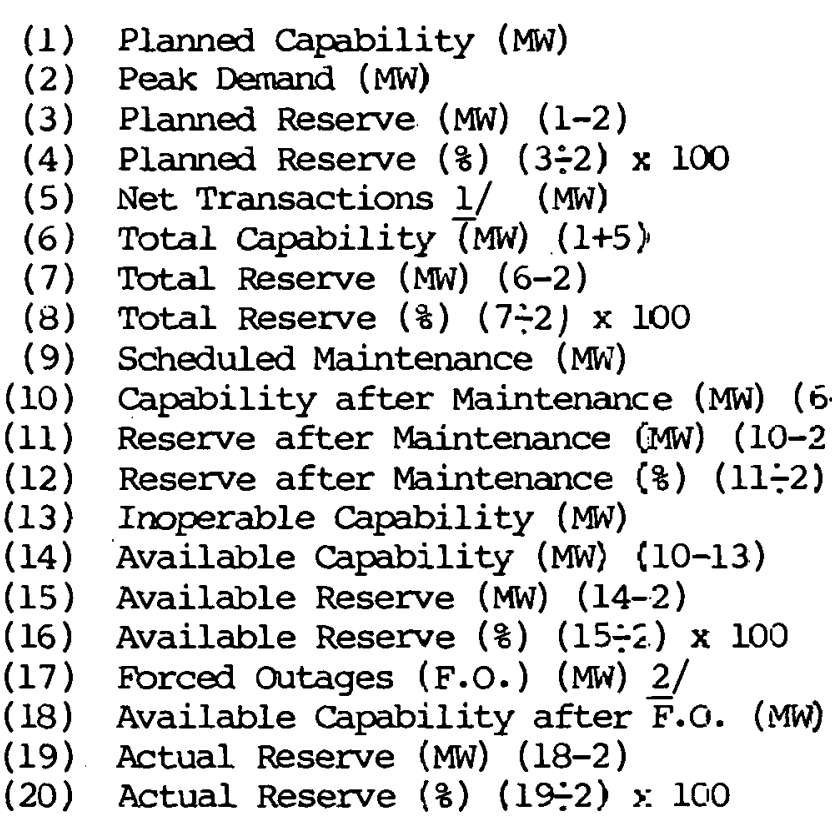

(1) Planned Capability (MW)

(4) Planned Reserve (\%) (32) x 100

8) Total Reserve (\%) (7:2) x 100

(9) Scheduled Maintenance (MW)

(12) Reserve after Maintenance (\%) (11-2) x $10 \mathrm{~J}$

13) Inoperable Capability (MW)

(15) Available Reserve (MW) (14-2)

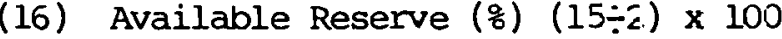

(20) Actual Reserve (\%) (19:2) $: 100$

\begin{tabular}{ccc}
\multicolumn{3}{c}{1980 Sumer } \\
\hline June & July & August \\
\cline { 3 - 4 } 21,851 & 21,851 & 21,851 \\
16,957 & 17,486 & 17,536 \\
4,894 & 4,365 & 4,317 \\
28.9 & 25.0 & 24.6 \\
265 & 265 & 265 \\
22,116 & 22,116 & 22,116 \\
5,159 & 4,630 & 4,582 \\
30.4 & 26.5 & 26.1 \\
2,075 & 1,287 & 998 \\
20,041 & 20,829 & 21,118 \\
3,084 & 3,343 & 3,584 \\
18.2 & 19.1 & 20.4 \\
0 & 0 & 0 \\
20,041 & 20,829 & 21,118 \\
3,084 & 3,343 & 3,584 \\
18.2 & 19.1 & 20.4 \\
1,964 & 1,964 & 1,964 \\
18,077 & 18,865 & 19,154 \\
1,120 & 1,379 & 1,620 \\
6.6 & 7.9 & 9.2 \\
& & .9
\end{tabular}

1/ Net Transactions = Purchases - Seles

2/ Derived from the historic seasonal forced outage rate by the ERA Field Office Staff
1980/1981 Winter

\begin{tabular}{|c|c|c|}
\hline December & January & February \\
\hline 24,177 & 24,281 & 24,516 \\
\hline 16,093 & 19,552 & 18,800 \\
\hline 8,084 & 4,729 & 5,716 \\
\hline 50.2 & 24.2 & 30.4 \\
\hline 265 & 265 & 265 \\
\hline 24,442 & 24,546 & 24,781 \\
\hline 8,349 & 4,994 & 5,981 \\
\hline 51.9 & 25.5 & 31.8 \\
\hline 2,432 & 1,052 & 1,036 \\
\hline 22,010 & 23,494 & 23,745 \\
\hline 5,917 & 3,942 & 4,945 \\
\hline 36.8 & 20.2 & 26.3 \\
\hline 0 & 0 & 0 \\
\hline 22,010 & 23,494 & 23,745 \\
\hline 5,917 & 3,942 & 4,945 \\
\hline 36.8 & 20.2 & 26.3 \\
\hline 2,289 & 2,289 & 2,289 \\
\hline 19,721 & 21,205 & 21,456 \\
\hline 3,628 & 1,653 & 2,656 \\
\hline 22.5 & 8.5 & 14.1 \\
\hline
\end{tabular}


TABLE 7A.7

\section{Mid-Year Generating Capacity}

\section{Florida Coordinating Group Region}

\begin{tabular}{|c|c|c|c|c|c|c|}
\hline \multirow{2}{*}{$\begin{array}{c}\text { Unit-Fuel } \\
\text { Type }\end{array}$} & \multicolumn{2}{|r|}{1980} & \multicolumn{2}{|r|}{1984} & \multicolumn{2}{|r|}{1989} \\
\hline & MW & 8 of Total & $\underline{M W}$ & 8 of Total & $\underline{M W}$ & of Total \\
\hline ST-NuC & 2,903 & 12.8 & 3,698 & 13.8 & $3,69 \varepsilon$ & 11.0 \\
\hline ST-Coal & 2,443 & 10.8 & 4,357 & 16.3 & 10,880 & 32.4 \\
\hline ST-Oil & 12,477 & 55.1 & 13,493 & 50.3 & 13,657 & 40.7 \\
\hline ST-GaS & 0 & 0.0 & 0 & 0.0 & c & 0.0 \\
\hline Hydro & 36 & 0.2 & 44 & 0.2 & 44 & 0.1 \\
\hline PS & 0 & 0.0 & 0 & 0.0 & c & 0.0 \\
\hline GT-Oil & 4,035 & 17.8 & 4,393 & 16.4 & 4,404 & 13.1: \\
\hline GT-Gas & 0 & 0.0 & 0 & 0.0 & c & 0.0 \\
\hline CC-Oil & 702 & 3.1 & 702 & 2.6 & 702 & 2.1 \\
\hline CC-Gas & 30 & 0.2 & 30 & 0.1 & 30 & 0.1 \\
\hline Other & $\underline{0}$ & $\underline{0.0}$ & 90 & $\underline{0.3}$ & 170 & 0.5 \\
\hline Total & 22,626 & 100.0 & 26,807 & 100.0 & $33,58=$ & 100.0 \\
\hline
\end{tabular}




$$
\mathrm{XI} .7 .18
$$

TABLE 7A. 8

Major Future Generating Unit In-Service Dates Florida Coordinating Group Region

\section{Unit Designation}

Martin No. 1

Deerhaven No. 2

Martin No. 2

McIntosh No. 3

Crystal River No. 4

St. Tuncie No. 2

Seminole No. 1

Crystal River No. 5

Big Bend No. 4

Seminole No. 2

FLPL/JACO JOint No. 1

LALW/ORLA JOint NO. I

Osceola No. 1

Osceola No. 2

FLPL/JACO JOInt No. 2

Martin No. 3

Martin No. 4
Capacity

in $\mathrm{MW}$

775

235

775

334

670

812

600

670

417

600

600

350

660

660

600

700

700
Fuel

Type

As of

$4 / 79$

As of

$4 / 80$

oil

$11 / 80$

$11 / 80$

Coal

$1 / 81$

$2 / 81$

$11 / 81 \quad 11 / 81$

oil

Coal

$11 / 81$

$10 / 81$

Coal

$12 / 82$

$12 / 82$

Nuc.

$11 / 83$

$11 / 83$

Coal

$5 / 83$

$5 / 83$

Coal

$5 / 84$

$6 / 84$

$3 / 85$

$3 / 85$

$5 / 85$

$5 / 85$

Coal

$21 / 87$

$12 / 85$

$5 / 87$

$5 / 86$

$6 / 86$

$10 / 87$

$6 / 87$

$6 / 88$

$11 / 85$

$11 / 87$

Coal

Coal

$11 / 87$

$11 / 88$

\section{Coal}

$10 / 85$

Coal 10/8
Change in MW-months

$(7,200)$

16,800

8,400 
Table 7A.9

FUTURE CAPABIL ITY AND RESERVE MARGINS FLORIDA COORIINATINO SRXIV RADION

\begin{tabular}{|c|c|c|c|}
\hline & & 19 & \\
\hline & & Summer & Winter \\
\hline (1) & Planned Capabllity (MN) & 24,276 & 25,859 \\
\hline (2) & Peak Demand (MW) & 18,489 & 20.554 \\
\hline (3) & Planned Reserve (MN) $(1-2)$ & 5,787 & 5,305 \\
\hline (4) & Planned Reserve $(8)(3 \div 2) \times 100$ & 31.3 & 25.8 \\
\hline (5) & Net Transactions l/ (Mv) & 215 & 215 \\
\hline (6) & Total Capability (MW) $(1+5)$ & 24,491 & 26,074 \\
\hline (7) & Total Reserve (in) $(6-2)$ & 6,002 & 5,520 \\
\hline (४) & Total Reserve (8) $(7 \div 2) \times 100$ & 32.5 & 26.9 \\
\hline (9) & Scheduled Maintenance (MN) & 1,393 & 1,570 \\
\hline (iv) & Capability after Maintenance (MW) $(6-9)$ & 23,098 & 24,504 \\
\hline (11) & Reserve after Maintenance (MW) $(10-2)$ & 4,609 & 3,950 \\
\hline 2) & Regerve after Maintenance $(8)(11 \div 2) \times 100$ & 24.9 & 19.2 \\
\hline (13) & Inoperable Capability (MW) & 0 & 0 \\
\hline (14) & Available Capability (MW) (10-13) & 23,098 & 24,504 \\
\hline 5) & Available Reserve (MN) (14-2) & 4,609 & 3,950 \\
\hline 6$)$ & Available Reserve (8) $(15 \div 2) \times 100$ & 24.9 & 19.2 \\
\hline (17) & Forced Outages (F.O.) (MW) $2 /$ & 1,964 & 2,289 \\
\hline 18) & Available Capability after F.O. (MW) $(14-17)$ & 21,134 & 22,215 \\
\hline & Actual Reserve (MW) $(18-2)$ & 2,645 & 1.661 \\
\hline & Actual Reserve (8) $(19 \div 2) \times 100$ & 14.3 & 8.1 \\
\hline
\end{tabular}

\begin{tabular}{|c|c|}
\hline \multicolumn{2}{|c|}{1982} \\
\hline Suminer & Winter \\
\hline 24,797 & 25.831 \\
\hline 19,580 & 21.706 \\
\hline 5,217 & 4,125 \\
\hline 26.6 & 19.0 \\
\hline 215 & 250 \\
\hline 25,012 & 26.081 \\
\hline 5,432 & 4,375 \\
\hline 27.7 & 20.2 \\
\hline 1,156 & 890 \\
\hline 23.856 & 25.191 \\
\hline 4.276 & 3,485 \\
\hline 21.8 & 16.1 \\
\hline$u$ & $u$ \\
\hline 23,856 & 25,191 \\
\hline 4,276 & 3,485 \\
\hline 21.8 & 16.1 \\
\hline 1,964 & 2,289 \\
\hline 21,492 & 22,902 \\
\hline 2,312 & 1,196 \\
\hline 11.8 & 5.5 \\
\hline
\end{tabular}

\begin{tabular}{cc}
\multicolumn{2}{c}{1983} \\
\hline S.miner & Winter \\
26,789 & 27,976 \\
20,528 & 22,497 \\
6,261 & 5.479 \\
30.5 & 24.4 \\
250 & 250 \\
27.039 & 28,226 \\
6,511 & 5,729 \\
31.7 & 25.5 \\
1,269 & 859 \\
25,770 & 27,367 \\
5,242 & 4,870 \\
25.5 & 21.7 \\
0 & 0 \\
25,770 & 27,367 \\
5,242 & 4,870 \\
25.5 & 21.7 \\
1.964 & 2,289 \\
23.806 & 25,078 \\
3,278 & 2,581 \\
16.0 & 11.5
\end{tabular}

\begin{tabular}{cc}
\multicolumn{2}{c}{1994} \\
\hline summer & winter \\
\hline 26,807 & 28,614 \\
21.441 & 23,734 \\
5,366 & 4,880 \\
25.0 & 20.6 \\
250 & 250 \\
27,057 & 28,864 \\
5.616 & 5,130 \\
26.2 & 21.6 \\
1,094 & 817 \\
25,963 & 28,047 \\
4,522 & 4,313 \\
21.1 & 18.2 \\
0 & 0 \\
25,963 & 28,047 \\
4,522 & 4,313 \\
21.1 & 18.2 \\
1,964 & 2,289 \\
23,999 & 25,758 \\
2,558 & 2.024 \\
11.9 & 4.5
\end{tabular}

1/ Net Transactions $=$ Purchases - Sales

Derived from the historic seasonal forced outage rate by the ERA Field office Staff. 
Table 7A.9

FUTRRE CAPABILITY AND RESERNE MARGINS F-OFIDA COONUINATING GPRII" RAIION

(1) Plamed Capability (Mw)

(2) Peak Demand (Mw)

(3) Plamed Reserve (IN) (1-2)

(4) Planned Peserve (8) $(3 \div 2) \times 100$

(5) Net Transactions $1 /$ (MW)

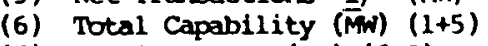

(7) Total Reserve (MW) $(6-2)$

(8) Total Reserve (8) $(7 \div 2) \times 100$

(9) Scheduled Maintenance (Mw)

10) Capability after Maintenance (vv) (6-9)

(11) Reserve after Maintenance (MW) (10-2)

(12) Reserve after Maintenance (8) $(11 \div 2) \times 100$

13) Inoperable Capability (MW)

(14) Available Capability (MN) (10-13)

(15) Available Reserve (MW) (14-2)

(16) Available Reserve (B) $(15 \div 2)=100$

(17) Available Reserve (8) (15\%2)

(18) Available Capability after

(19) Actual Reserve (MW) $(10-2)$
(20) Actual Reserve (8) $(19 \div 2) \times 100$ (Mw) (14-17) 28, $\frac{2 /}{45}$

198
$\frac{\text { summer }}{28,606}$
22,438
6,168
27.5
250
28,856
6,418
28.6
$2 /$
28,856
6,418
28.6
0
28,856
6,718
28.6
$2 /$
28,356
6,418
24.6

198

Winter

29,765

24,21

168

$27.5 \quad 5,-44.4$

200

$29, \quad 65$

21.2

29,05

5,244

21.2

29. 36

5.244

21.2

$\frac{21}{365}$

$29 . \overline{365}$

. 244

\begin{tabular}{cc}
\multicolumn{1}{c}{1986} & \\
\hline sumer & winter \\
29,519 & 31,351 \\
23,408 & 25,644 \\
6,111 & 5,667 \\
26.1 & 22.1 \\
200 & 0 \\
29.719 & 31.351 \\
6.311 & 5.567 \\
27.0 & 22.1 \\
$2 /$ & $2 /$ \\
29,719 & 31,351 \\
6,311 & 5.607 \\
27.0 & 22.1 \\
0 & 0 \\
29,719 & 31,351 \\
6.311 & 5.667 \\
27.0 & 22.1 \\
21 & 21 \\
29.719 & 31.351 \\
6.311 & 5.367 \\
27.0 & 22.1
\end{tabular}

\section{Surme}

24,416
6.511

$6.511 \quad 6,388$

26

0
30,927

6.511

26.7

$30 . \frac{21}{927}$

6.511

26.7

3., 927

$\epsilon, 511$

26.7

3. $\frac{2}{927}$

6.511

26.7

\section{3,369}

6,388

23.

33,369

6,384

$33, \frac{21}{369}$

6,3884

23.7

33,369

6,384

13. $\frac{21}{369}$

6,384

.388
23.7

\begin{tabular}{cc}
\multicolumn{2}{c}{1984} \\
\hline Summer & Wnter \\
32,492 & 34,365 \\
25,461 & 28,100 \\
7,031 & 6,265
\end{tabular}

6,265

27.6
$u$

32,492

7.031

$32, \frac{2 /}{492}$

32,492
7,031

7,031

27.6
0

7,031

7.031
27.6

$32 . \frac{2}{4} 92$

32.492
7.031

7.031
27.6

.22 .3
0
34,365

34.365
6.265

34. $\frac{2 /}{365}$

6.265

34,365

22.3

$34, \frac{27}{365}$

34. 365
6.265
22.3

22.3

6,265
22.3

22.3

\begin{tabular}{c}
1989 \\
\hline Sunmar \\
33,585 \\
26,459 \\
7,126 \\
26.9 \\
0 \\
33.585 \\
7.126 \\
26.9 \\
$2 /$ \\
33,585 \\
7,126 \\
26.9 \\
0 \\
33,585 \\
7.126 \\
26.9 \\
$2 /$ \\
33.585 \\
7.126 \\
26.9
\end{tabular}

Ninter

35.404

29,166

6,238

21.4

35,404

6.238

21.4

$35, \frac{21}{404}$

6,238

21.4

35,404

6,238

21.4

$2 /$

6.238

238

1/ Net Transactlons = Purchases - Sales

2f Information on scheduled maintenance and forced cutages are not available 
$\mathrm{XI} .7 .21$

\section{Southern Subregion}

\section{Historical Perspective}

In terms of generating capacity and fuel $m i x$, the southern subregion has been in an extremely good position. About 93 percent of this Subregion's electric generation during 1978 came from non-oil sources. A total of 11.5 million barrels of oil were used for electric generation in 1978 and about 36 percent of this was distillate. A total of $33 \mathrm{million}$ Mcf of natural gas and 32 million tons of coal were also burned during that year. The Southern Subregion was a major exporter of coal-by-wire during 1979 to both Middle south Utilities in the southwest Power Pool and the Florida subregion in SERC.

Actual mid-period (1978) summer generating capacity by fuel type and resulting 1978 actual energy production is shown on Table 7B.l.

TABLE 7R.1

Actual 1978 Summer Generating Capacity By Fuel Type

Southern Company Group Region

\begin{tabular}{|c|c|c|c|c|c|}
\hline \multirow[b]{2}{*}{ Capacity Type } & \multirow[b]{2}{*}{ Fuel Type } & \multicolumn{2}{|c|}{ Capacity } & \multicolumn{2}{|c|}{ Generation } \\
\hline & & $\underline{M W}$ & $\begin{array}{l}8 \text { of } \\
\text { Total }\end{array}$ & GWE & $\begin{array}{l}\& \text { of } \\
\text { Total }\end{array}$ \\
\hline steam & Nuclear & 1.575 & 6.4 & 10,197 & 10.1 \\
\hline Steam & Coal & 16,494 & 67.2 & 74,509 & 73.5 \\
\hline steam & oil & 1,705 & 6.9 & 7,016 & 6.9 \\
\hline steam & Gas & 413 & 1.7 & 2,015 & 2.0 \\
\hline Hydro & Water & 2,982 & 12.1 & 6,900 & 6.8 \\
\hline Pumped storage & water. & 145 & 0.6 & $(196)$ & $(0.2)$ \\
\hline Gas Turbine & oil & 1,225 & 5.0 & 594 & 0.6 \\
\hline Gas Turbine & Gas & 21 & 0.1 & 271 & 0.3 \\
\hline Combined Cycle & oil & 0 & 0.0 & 0 & 0.0 \\
\hline Combined Cycle & Gas & 0 & 0.0 & 0 & 0.0 \\
\hline Other & & 0 & $\underline{0.0}$ & $\underline{0}$ & $\underline{0.0}$ \\
\hline Total & & 24,560 & 100.0 & 101,306 & 100.0 \\
\hline
\end{tabular}


Load Growth in the Southern Subregion increased at an average annual rate of about 9.0 percent between 1968 and 1972 and at a rate of about 4.5 percent between 1972 and 1977 . This has continued to moderate during the last three years as shown on Table 7R.2.

TABLE $7 \mathrm{E} .2$

Actual Annual Net Energy for Load, Summer and Winter Peak Demands and Load Factor $1 /$

Southern Company Group Region

Item

$\underline{1977}$

1978

1979

Annual Electric Energy in Gwil

38,185

103,706

104.048

Summer Peak Demand in Mh

19,115

20.464

20,372

winter Peak Demand in $M W$

16,674

17,368

16,969

Annual Load Factor in 8

58.6

57.9

$58 \cdot 3$

The average annual growth rate of electric energy use in the Southern Subregion covering 1977 through 1979 was 3.0 percent. The summer peak demand growth rate was 3.3 percent while the winter peak demand has not shown any consistent growth. This slower growth rate will enable the southern subregion to maintain their favorable fuel mix position in the future with just incremental generation additions sincc they are not in an all out fuel conversion situation.

The Southern subregion attempts to maintain planned generation reserve of between 17 all 20 percent of annual poak. demand. Their operating criteria reguires that an operating reserve equal to 1.5 times the largest generating unit in service be maintained at all times. At least 50 percent of this amount must be spinning. The largest generating unit in the southern subregion is currently about $880 \mathrm{MW}$. Talbes $7 \mathrm{R} .3$ through $7 B .5$ give the actual reserve situations that occurred in the southern Subregion for 1977 through 1979 for each of the three summer months (June, July and August) and the three winter months (December, January and February). Planned reserve fell below 17 percent of monthly peak demand during five of the past

\section{I) Source - Form No. I2E-2.}

2/ Winter period for each year includes December of that year plus January and February of the following year. 
nine summer peak periods. The lowest planned reserve as a percent of monthly peak was 8.0 percent and occurred in July 1977. The smallest actual reserve percentage was 5.9 percent and occurred in June 1977. Actual reserve exceeded the operating reserve requirement of $1,320 \mathrm{MW}$ during all but one of the peak periods examined.

There were about $11,600 \mathrm{miles}$ of $115 \mathrm{kV}$ and $161 \mathrm{kV}, 5,600$ miles of $230 \mathrm{kV}$ and 900 miles of $500 \mathrm{kV}$ transmission lines in operation in 1978 with a capability of about 3.6 million MW-miles. This resulted in a transmission to generating capacity ratio of about $150 \mathrm{MW}-\mathrm{miles}$ per $\mathrm{MW}$.

The southern subregion operates as a single control area or power pool.

\section{Current Perspective}

The 1980 summer peak demand for the southern Subregion is expected to be in the range of $21,341 \mathrm{Mh}$ to $21,909 \mathrm{MH}$. This represents an increase over the 1979 summer peak of between 4.8 and 7.5 percent, respectively. While the lower figure may be more realistic, using the higher number produces a conservative planned generation reserve of over 31 percent for the 1980 summer peak. Two conventional hydroelectric, two pumped storage, one gas turbine and one coal-fired generating units representing a total of $487 \mathrm{MW}$ capacity or 2.2 percent of peak demand are scheduled for service prior to the summer peak.

Planned reserve for the 1980 winter peak is expected to be 59 percent or greater. The Farley No. 2 nuclear generating unit rated at $807 \mathrm{MW}$ or 4.3 percent of the winter peak demand is scheduled for operation in september 1980 .

Reserve after maintenance is expected to exceed $5,900 \mathrm{Mh}$ for both the 1980 summer and winter peak demand periods, even discounting the planned 1980 generating unit additions. This far exceeds the operating reserve requirement of $1,320 \mathrm{MW}$. Table 7B.6 gives the current reserve picture for the three summer and three winter months for 1980 .

The Southern Subregion has a curtailment program whereby a total of about $3,450 \mathrm{MW}$ of load could be reduced by manual means in the event of an extreme emergency. This represents about 16 percent of their forecast summer peak demand. The amounts and methods of reducing loads are shown on Table $7 \mathrm{~B} .7$. 


$$
X I .7 .24
$$

TARLE $7 \mathrm{~B} \cdot 7$

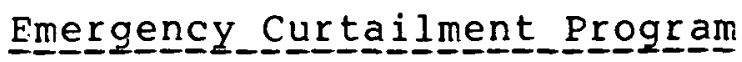

Southern_Company_Group_Region

\section{Method}

Curtailment of non-essential utility load

Interruption of contract interruptible load

Voltage reduction $1 /$

Voluntary industrial curtailment- 6 to 10 hour notice required

Rotating distribution feeder outages--3 to 4 hour hotice réulired

Load shedding by supervisory control
Amount

in $M \underline{\text { MW }}$

75

211

0

90

$45-85$

3,000

The non-simultaneous transmission import capability of the Southern Sukregion over and above scheduled purchases and sales, is $3,850 \mathrm{MW}$. This is about 18 percent of the projected summer peak demand.

\section{Futurure Per}

The summer pcak demand of the Southern subrcgion is forccasted to increase at an average annual rate of 4.1 percent between 1980 and 1989; from 21,366 $\mathrm{MW}$ to $30,629 \mathrm{MW}$. This includes a contract interruptible load of $211 \mathrm{MW}$. The winter peak demand is projected to increase from $18,116 \mathrm{MW}$ in 1980 to $27,122 \mathrm{MW}$ in 1989, an annual growth rate of 4.6 percent. The Southern Subregion is expected to continue to be a summer peaking region during this period even though the winter demand is projected to increase at a slightly greater rate than the summer peak demand. Electric energy use is expected to increase at an average annual rate of 4.1 percent, from $108,168 \mathrm{GWH}$ in 1980 to $155,753 \mathrm{GWH}$ in 1989. Annual load factor is expected to remain relatively constant at about 58 percent between 1980 and 1989. While the Southern Subregion load forecasts appear to be optimistic, their generating capacity addition program could readily be adjusted to a lower growth, if it becomes necessary.

IT No apreciabie reduction in load has been observed in the Southern Subregion during voltage reduction tests of up to 5 percent. 
Three nuclear units are scheduled for addition in the Southern Subregion between 1980 and 1989 . The remainder of the planned capacity additions for this period are scheduled to be hydro and coal-fired units. Planned unit additions are shown In detail on attached Table 7B.8. Southern estimates that between 16,000 and 24,000 GWP of non-oil/gas electric generation could be available for sale during this period because of their favorable fuel mix position. This will also permit them to retire a number of oil-fired units and improve their peaking economics. The capacity $\mathrm{mix}$ is shown on Table $7 \mathrm{E} .9$ for midyear 1980,1984 and 1989 , respectively.

TAELE $7 B .9$

Mid-year Generating Capacity

Southern Company Group Region

Urit-Fuel

Type

ST-NUC

ST- $\cos$

ST-Oil

ST-Gas

Hyd ro

PS

GT-OII

GT-Gas

CC-Oil

CC-Gas

other

$\frac{1984}{\text { MW } \text { of Total }}$

2,340

$8 \cdot 5$

$18,264 \quad 66.6$

1,705

6.2

382

1.4

3.095

11.3

357

1.3

1,268

4.6

30

0.1

$0 \quad 0.0$

$0 \quad 0.0$

$0 \quad-0.0$

Total

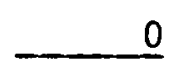

27,441
100.0

$$
10.1
$$

21.161

67.2

1,650

5.2

382

1.2

3,484

11.1

357

1.1

1,268

4.0

0.1

0.0

0.0

0.0

$31,516 \quad 100.0$

30

0

0
1989

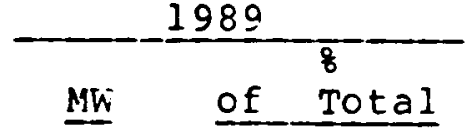

5,521

14.6

$24,32.5$

64.4

1,524

4.0

382

1.0

3,898

10.3

1,032

2.7

1,111

3.0

0.0

0.0

0.0

0

0.0

0

0.0

$\frac{0}{37.793} \quad-\frac{0.0}{100.0}$


Electric region's ten-year baseline projections of generating capacity, seasonal. peak demands and reserve margins are shown on attached Table 7B.10. Total reserve, shown on Table 7R.10 in percent of peak demand, are expected to be more than adequate in the Southern subregion during the 1981 through 1989 period. Total reserve is expected to exceed 23 percent of peak demand during each of the next eighteen peak load seasons. The largest generating unit liabilities during this period will be the vogtle No. 1 and No. 2 nuclear generating units rated at 1,150 MW each. These units are scheduled for service in November of 1984 and 1987 , respectively. The addition of these units will increase the operating reserve requirement from $1.320 \mathrm{MW}$ to $1,72.5 \mathrm{MW}$, effective in November 1984. Reserve after maintenance is is expected to exceed $6,000 \mathrm{MW}$ during the 1981 through 1984 period.

possibly the only bulk power supply weakness of the region is in the transmission system in lower Alabama. Concomittant with the installation of the second generating unit in 1981 at the Daniel Plant near Mobile, Alabama, power flows are expected to be altered to where the Logtown-Slidell $230 \mathrm{kV}$ tie between SWPP and SERC will load up before the $500 \mathrm{kV}$ lines between these respective council areas. A $500 \mathrm{kV}$ line interconnecting the existing $500 \mathrm{kV}$ system at New Orleans in SWPP with the existing $500 \mathrm{kV}$ system near Montgomery, Alabama in SERC via Mobile appears to be necessary in order to relieve this bottleneck.

Planned transmission line additions during $1980-1989$ period consist of $750 \mathrm{miles}$ of $500 \mathrm{kV}, 1,100$ miles of $230 \mathrm{kV}$ and $100 \mathrm{miles}$ of $115 \mathrm{kV}$ lines representing a combined transmission capacity of about 1.2 million MW-miles. Generating capacity additions during this period amount to about $10,800 \mathrm{MW}$, resulting in a transmission to generating capacity additions ratio of about $110 \mathrm{MW}-\mathrm{mil}$ es per MW. 


\section{Table 7B. 3}

HISTORICAI CAPABILITY AND RESERVE MARGINS SOUTHERN COMPANY GROUP REGION

(1) Planned Capability (MW)

(2) Peak Demand (MW)

(3) Planned Reserve (MW) (1-2)

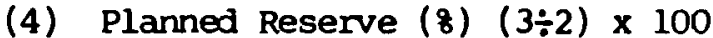

(5) Net Transactions 1/ (MW)

(6) Total Capability $T_{M W}(1+5)$

(7) Total Reserve (MW) (6-2)

(8) Total Reserve (8) $(7 \div 2) \times 100$

(9) Scheduled Maintenance (MW)

(10) Capability After Maintenance (MW) (6-9)

(11) Reserve After Maintenance (MW) (10-2)

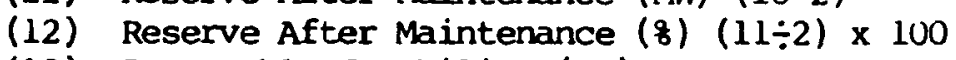

(13) Inoperable Capability (MW)

(14) Available Capability (MW) (10-13)

(15) Available Reserve (MW) (14-2)

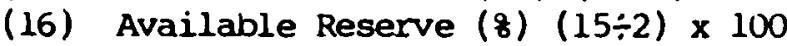

(17) Forced Outages (F.O.) (MW)

(18) Available Capability After F.O. (MW) (14-17)

(19) Actual Reserve (MW) (18-2)

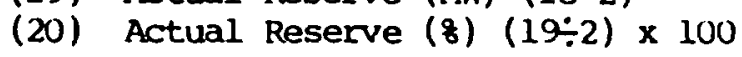

\begin{tabular}{ccc} 
June & 1977 Summer & \\
\cline { 3 - 3 } 20,637 & July & August \\
\cline { 3 - 3 } 13,525 & 20,637 & 20,637 \\
2,112 & 19,115 & 18,575 \\
11.4 & 1,522 & 2,062 \\
3,821 & 8.0 & 11.1 \\
24,458 & 3,155 & 3,098 \\
5,933 & 23,792 & 23,735 \\
32.0 & 4,677 & 5,160 \\
451 & 24.5 & 27.8 \\
24,007 & 18 & 17 \\
5,482 & 4,774 & 23,718 \\
29.6 & 24.4 & 5,143 \\
0 & 0 & 27.7 \\
24,007 & 23,774 & 23,718 \\
5,482 & 4,659 & 5,143 \\
29.6 & 24.4 & 27.7 \\
4,399 & 2,739 & 3,144 \\
19,608 & 21,035 & 20,574 \\
1,083 & 1,920 & 1,999 \\
5.9 & 10.0 & 10.8
\end{tabular}

$1977 / 1978$ Winter

\begin{tabular}{|c|c|c|}
\hline December & January & February \\
\hline 21,909 & 21,773 & 21,786 \\
\hline 15,258 & 16,674 & 16,643 \\
\hline 6,651 & 5,099 & 5,143 \\
\hline 43.6 & 30.6 & 30.9 \\
\hline 3,129 & 1,353 & 2,410 \\
\hline 25,038 & 23,126 & 24,196 \\
\hline 9.780 & 6,452 & 7.553 \\
\hline 64.1 & 38.7 & 45.4 \\
\hline 3,400 & 2.224 & 1,666 \\
\hline 21,638 & 20,902 & 22,530 \\
\hline 6,380 & 4,228 & 5.887 \\
\hline 41.8 & 25.4 & 35.4 \\
\hline U & U & 0 \\
\hline 21,638 & 20,902 & 22.530 \\
\hline 6,380 & 4,228 & 5,887 \\
\hline 41.8 & 25.4 & 35.4 \\
\hline 4,752 & 2,078 & 3,429 \\
\hline 16,886 & 18,824 & 19,101 \\
\hline 1,628 & 2,150 & 2,458 \\
\hline 10.7 & 12.9 & 14.8 \\
\hline
\end{tabular}

1/ Net Transactions = Purchases - Sales 
Table 7B. 4

HISTORICAL CAPABILITY AND RESERVE MARGINS SOUTHERN OOMPANY GROUP REGION

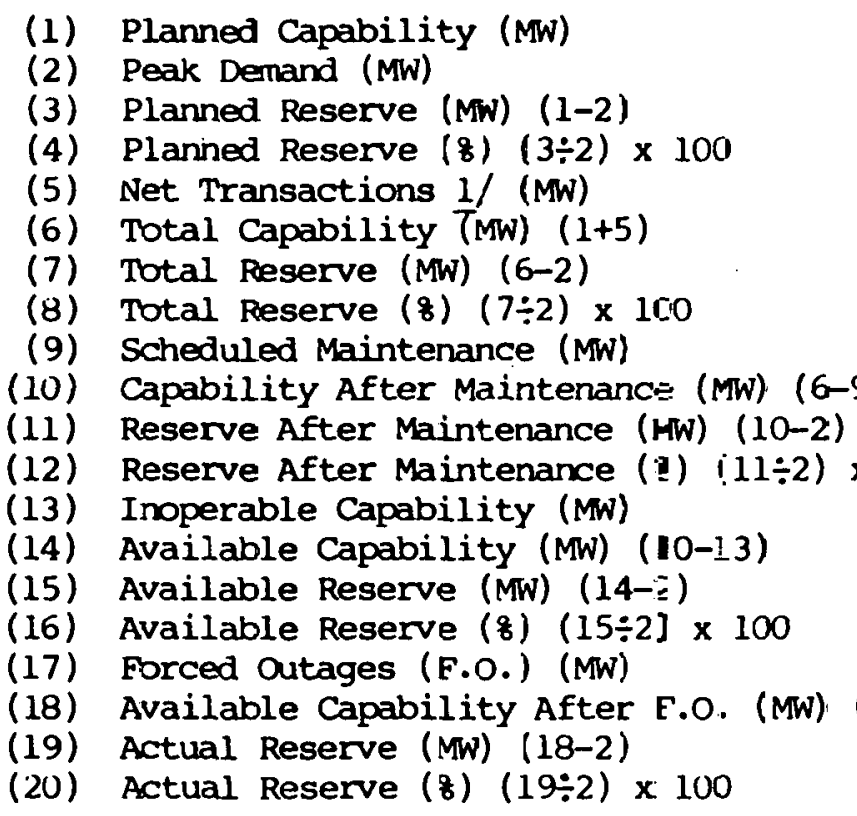

1978 Summer

\begin{tabular}{ccc}
\multicolumn{3}{c}{1978 Summer } \\
\cline { 1 - 1 } 23,097 & July & August \\
\cline { 4 - 4 } 20,464 & 23,083 & 23,061 \\
2,633 & 19,332 & 19,603 \\
12.9 & 3,751 & 3,458 \\
2,624 & 19.4 & 17.6 \\
25,721 & 2,171 & 4,700 \\
5,257 & 5,254 & 27,761 \\
25.7 & 5,922 & 8,158 \\
59 & 30.6 & 41.6 \\
25,662 & 25,195 & 27,755 \\
5,198 & 5,863 & 8,152 \\
25.4 & 30.3 & 41.6 \\
0 & 0 & 0 \\
25,662 & 25,195 & 27,755 \\
5,198 & 5,863 & 8,152 \\
25.4 & 30.3 & 41.6 \\
3,861 & 3,286 & 5,116 \\
21,801 & 21,909 & 22,639 \\
1,337 & 2,577 & 3,036 \\
6.5 & 13.3 & 15.5
\end{tabular}

1978/1979 Winter

\begin{tabular}{|c|c|c|}
\hline December & January & February \\
\hline 23,929 & 23,518 & 23,677 \\
\hline 15,642 & 17,368 & 17,004 \\
\hline 8.287 & 6.150 & 6.673 \\
\hline 53.0 & 35.4 & 39.2 \\
\hline 2,401 & 2,529 & 2,185 \\
\hline 26.330 & 26.047 & 25,862 \\
\hline 10,688 & 8,679 & 8,858 \\
\hline 68.3 & 50.0 & 52.1 \\
\hline 3,590 & 1.670 & 2,490 \\
\hline 22,740 & 24,377 & 23,372 \\
\hline 7.098 & 7,009 & 6,368 \\
\hline 45.4 & 40.4 & 37.5 \\
\hline 0 & 0 & 0 \\
\hline 22,740 & 24,377 & 23,372 \\
\hline 7,098 & 7,009 & 6,368 \\
\hline 45.4 & 40.4 & 37.5 \\
\hline 1,875 & 4,323 & 3,964 \\
\hline 20,865 & 20,054 & 19,408 \\
\hline 5,223 & 2,686 & 2,404 \\
\hline 33.4 & 15.5 & 14.1 \\
\hline
\end{tabular}


Table 7B. 5

\section{HISTORICAL CAPABILITY AND RESERVE MARGINS} SOUTHERN COMPANY GROUP RFGION

(1) Planned Capability (MW)

(2) Peak Demand (MW)

(3) Planned Reserve (MW) (1-2)

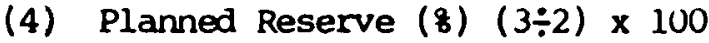

(5) Net Transactions 1/ (MW)

(6) Total Capability (MW) $(1+5)$

(7) Total Reserve (MW) (6-2)

(8) Total Reserve (8) (7\%2) x 100

(9) Scheduled Maintenance (MW)

(10) Capability After Maintenance (MW) (6-9)

(11) Reserve After Maintenance (MW) (10-2)

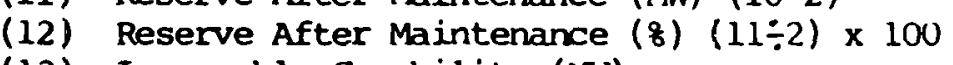

(13) Inoperable Capability (MW)

(14) Available Capability (MW) (10-13)

(15) Available Reserve (MW) (14-2)

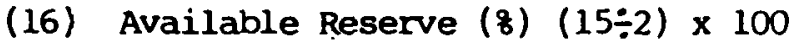

(17) Forced Outages (F.O.) (MW)

(18) Available Capability After F.O. (MW) (14-17)

(19) Actual Reserve (MW) (18-2)

(20) Actual Reserve (8) (19:2) × 100

\begin{tabular}{ccc}
\multicolumn{3}{c}{1979 Summer } \\
\cline { 1 - 2 } June & July & August \\
23,557 & 23,543 & 23,566 \\
19,111 & 19,831 & 20,372 \\
4,446 & 3,712 & 3,194 \\
23.3 & 18.7 & 15.7 \\
2,392 & 1,788 & 3,227 \\
25,949 & 25,331 & 26,793 \\
6,838 & 5,500 & 6,421 \\
35.8 & 27.7 & 31.5 \\
$1,84 C$ & 1,645 & 1,657 \\
24,109 & 23,686 & 25,136 \\
$4,99 \varepsilon$ & 3,855 & 4,764 \\
26.2 & 19.4 & 23.4 \\
C & 0 & 0 \\
24,109 & 23,686 & 25,136 \\
$4,99 \varepsilon$ & 3,855 & 4,764 \\
26.2 & 19.4 & 23.4 \\
2,559 & 2,030 & 2,960 \\
21,550 & 21,656 & 22,176 \\
2,439 & 1,825 & 1,804 \\
12.8 & 9.2 & 8.9 \\
& &
\end{tabular}

1979/1980 Winter

\begin{tabular}{|c|c|c|}
\hline December & January & February \\
\hline 24.357 & 24,540 & 24,753 \\
\hline 16,330 & 16,634 & 16,969 \\
\hline 8.027 & 7,906 & 7.784 \\
\hline 49.2 & 47.5 & 45.9 \\
\hline 890 & 535 & 1,027 \\
\hline 25,247 & 25,075 & 25,780 \\
\hline 8,917 & 8,441 & 8,811 \\
\hline 54.6 & 50.7 & 51.9 \\
\hline 3,108 & 2,651 & 3,329 \\
\hline 22,139 & 22,424 & 22,451 \\
\hline 5,809 & 5,790 & 5,482 \\
\hline 35.6 & 34.8 & 32.3 \\
\hline 0 & U & U \\
\hline 22,139 & 22,424 & 22,451 \\
\hline 5,809 & 5,790 & 5,482 \\
\hline 35.6 & 34.8 & 32.3 \\
\hline 2,773 & 697 & 1.287 \\
\hline 19.366 & 21,727 & 21,164 \\
\hline 3,036 & 5,093 & 4,195 \\
\hline 18.6 & 30.6 & 24.7 \\
\hline
\end{tabular}

1/ Net Transactions = Purchases - Sales 
Table 7B.6

CURRENT CAPABILITY AND RESERVE MARGINS SOUTHERN COMPANY GROUP REGION

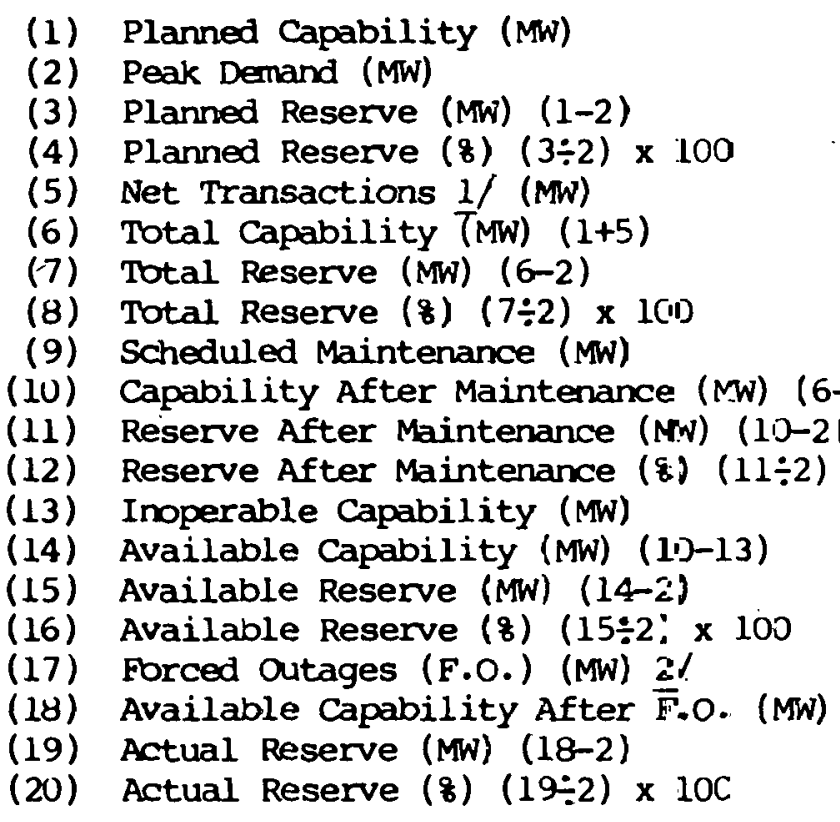

\begin{tabular}{|c|c|c|}
\hline \multicolumn{3}{|c|}{1980 Summer } \\
\hline Jume & July & August \\
\hline 28,793 & 28,834 & 28,812 \\
\hline 20,260 & 21,366 & 21,909 \\
\hline 8,533 & 7,468 & 6,903 \\
\hline 42.1 & 35.0 & 31.5 \\
\hline (487) $3 /$ & (487) 3/ & (487) $3 /$ \\
\hline 28,306 & 28,347 & 28,325 \\
\hline 8,046 & 6,981 & 6,416 \\
\hline 39.7 & 32.7 & 29.3 \\
\hline 10 & 0 & 0 \\
\hline 28,296 & 28,347 & 28,325 \\
\hline 8,036 & 6.981 & 6,416 \\
\hline 39.7 & 32.7 & 29.3 \\
\hline 0 & 0 & 0 \\
\hline 28,296 & 28,347 & 28,325 \\
\hline 8,036 & 6,981 & 6.416 \\
\hline 39.7 & 32.7 & 29.3 \\
\hline 3,344 & 3,344 & 3,344 \\
\hline 24,952 & 25,003 & 24,981 \\
\hline 4,692 & 3,637 & 3,072 \\
\hline 23.2 & 17.0 & 14.0 \\
\hline
\end{tabular}

\begin{tabular}{|c|c|c|c|}
\hline December & January & February & \\
\hline 29,789 & 29,807 & 29,822 & \\
\hline 17,785 & 18,742 & 18,182 & \\
\hline 12,004 & 11.065 & 11,640 & \\
\hline 67.5 & $\begin{array}{c}59.0 \\
(779)\end{array}$ & 64.0 & 31 \\
\hline 29.010 & 29,028 & 29,043 & \\
\hline 11,225 & 10,286 & 10,861 & \\
\hline 63.1 & 54.9 & 59.7 & \\
\hline 2,025 & 1,611 & 1,801 & \\
\hline 26,9835 & 27.417 & 27.242 & \\
\hline 9,200 & 8,675 & 9.060 & \\
\hline 51.7 & 46.3 & 49.8 & \\
\hline U & u & u & \\
\hline 26,985 & 27,417 & 27,242 & $x$ \\
\hline 9,200 & 8,675 & 9.060 & 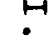 \\
\hline 51.7 & 46.3 & 49.8 & $\checkmark$ \\
\hline 2,798 & 2,798 & 2,798 & $\omega$ \\
\hline 24,187 & 24,619 & 24,444 & \\
\hline 6,402 & 5,877 & 6.262 & \\
\hline 36.17 & . 31.4 & 34.4 & \\
\hline
\end{tabular}

1/ Net Transactions = Purahases - Sales

2/ Derived from the historic seasonal forced outage rate by the ERA Field office Staff

3/ ( ) denotes negative number 
$X I .7 .31$

TABLE $7 \mathrm{~B} .8$

Major Future Generating Unit In-Service Dates

Southern Company Group Region

\section{Unit Designation}

Tombigbee No. 3

Farley No. 2

Daniel No. 2

Scherer No. 1

Miller No. 2

Scherer No. 2

Vogtle No. 1

Milier No. 3

Scherer No. 3

Effingham No. 2

Rocky Mountain

Miller No. 4

Vogtle No. 2

Scherer No. 4

Site A-1

Site A-2
Capacity Fuel $\frac{\text { In-Service Date }}{\text { As of As of }}$

in MW

Type

$4 / 79$

$4 / 80$

Coal

$6 / 79$

$4 / 80$

$4 / 81 \quad 9 / 80$

$6 / 81$

$6 / 81$

$2 / 82$

$2 / 82$

$6 / 82$

$6 / 83$

$2 / 84$

$2 / 84$

Change in

MW-months

808

Coal

Nuc.

$11 / 84$

$11 / 84$

2,250

1,150

654

Coal

$6 / 83$

$6 / 85$

15,696

808

Coal

$2 / 85$

$2 / 87$

19,392

163

Coal

$3 / 86$

$3 / 87$

1,956

675

Hydro

$6 / 84$

$4 / 87$

22,950

654

Coal

$6 / 84$

$6 / 87$

23,544

1,150

808

783

783
Nuc.

$11 / 87$

Coal

$2 / 87$

$6 / 87$

$6 / 88$

Coal

Coal
$11 / 87$

$2 / 89$

19,392

$6 / 90$

28,188

$6 / 91$

28,188 


\section{FUTRE CAPABILITY AMD RESERNE MARGINS 1981-1989}

SOUTRET OCMPANY GRUUP RBSION

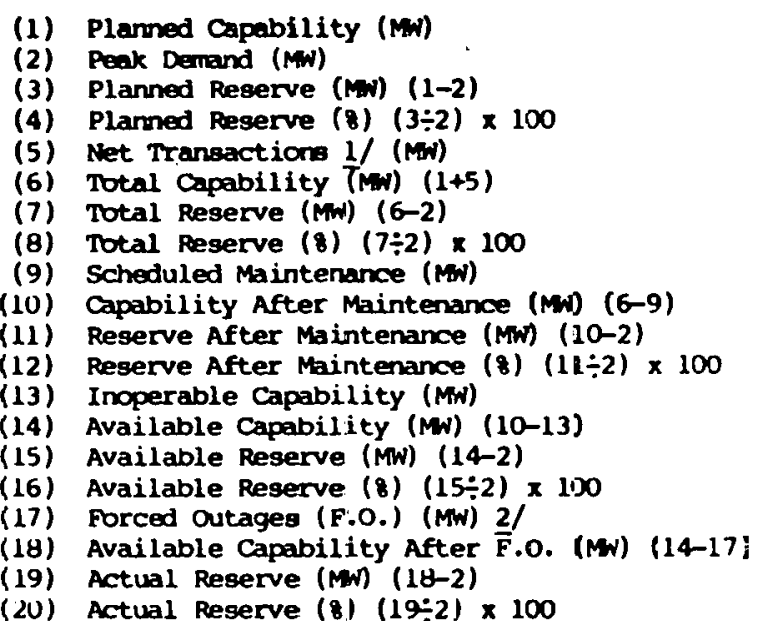

\begin{tabular}{|c|c|}
\hline \multicolumn{2}{|c|}{1981} \\
\hline Sumer & Winter \\
\hline 29,144 & 29.156 \\
\hline 22.145 & 18.992 \\
\hline 6,999 & 10.164 \\
\hline 31.6 & 53.5 \\
\hline$(110) 3 /$ & $\therefore 39013$ \\
\hline 29,034 & 28.766 \\
\hline 6,1889 & 9.774 \\
\hline 31.1 & 51.5 \\
\hline 0 & 2.159 \\
\hline 29.034 & 26,607 \\
\hline 6,889 & 7,615 \\
\hline 31.1 & 40.1 \\
\hline 0 & 0 \\
\hline 29,034 & 26.607 \\
\hline 6,689 & 7,615 \\
\hline 31.1 & 40.1 \\
\hline 3,344 & 2,798 \\
\hline 25,690 & 23,609 \\
\hline 3,545 & 4,817 \\
\hline 16.0 & 25.4 \\
\hline
\end{tabular}

\begin{tabular}{|c|c|}
\hline \multicolumn{2}{|c|}{1982} \\
\hline Summer & Winter \\
\hline 29,952 & $29, \div 64$ \\
\hline 22,945 & 19,356 \\
\hline 6,967 & 10,008 \\
\hline$\left\{\begin{array}{l}30.3 \\
(110)^{3} 3 /\end{array}\right.$ & $\begin{array}{c}50.2 \\
(390)^{3} 3 /\end{array}$ \\
\hline $29.442=$ & 29,574 \\
\hline 6,8157 & 9.518 \\
\hline 29.8 & 48.2 \\
\hline i) & 2,566 \\
\hline 29,842 & 26.908 \\
\hline 6.857 & 6.952 \\
\hline 29.8 & 34.8 \\
\hline 0 & 0 \\
\hline 29.842 & 26.908 \\
\hline 6.857 & 6.952 \\
\hline 29.8 & 34.8 \\
\hline 3,344 & 2,794 \\
\hline 26.498 & $24, \therefore 10$ \\
\hline 3.513 & 4,154 \\
\hline 15.3 & 20.6 \\
\hline
\end{tabular}

\begin{tabular}{|c|c|}
\hline \multicolumn{2}{|c|}{1983} \\
\hline Suminer & Wintex \\
\hline 30,723 & $30,72 \mathrm{~J}$ \\
\hline 24,207 & 20,924 \\
\hline 6,516 & 9,75 \\
\hline 26.9 & $\begin{array}{c}45.8 \\
(39 j) \quad 3\end{array}$ \\
\hline 30.613 & 30,330 \\
\hline 6,406 & 9,405 \\
\hline 26.5 & 45.0 \\
\hline 0 & 2,935 \\
\hline 30,613 & 27,395 \\
\hline 6,406 & 6,471 \\
\hline 26.5 & 30.9 \\
\hline 0 & i) \\
\hline $\begin{array}{r}30,613 \\
6,406\end{array}$ & $\begin{array}{r}27,395 \\
6,471\end{array}$ \\
\hline 26.5 & $\begin{array}{r}0.410 .9 \\
30.9\end{array}$ \\
\hline 3,344 & 2,799 \\
\hline 27,269 & 24,597 \\
\hline 3,062 & 3,673 \\
\hline 12.6 & 17.6 \\
\hline
\end{tabular}

\begin{tabular}{|c|c|}
\hline \multicolumn{2}{|c|}{1934} \\
\hline smmer & wintar \\
\hline 31.516 & 32.790 \\
\hline 25,385 & 21.754 \\
\hline 6,131 & 11.036 \\
\hline $\begin{array}{c}24.2 \\
(110)^{3} 3 /\end{array}$ & $\begin{array}{r}50.7 \\
(390)\end{array}$ \\
\hline 31,406 & 32,400 \\
\hline 6,021 & 10,646 \\
\hline 23.7 & 48.9 \\
\hline 0 & 3,546 \\
\hline 31,406 & 28.854 \\
\hline 6.021 & 7,100 \\
\hline 23.7 & 32.6 \\
\hline 0 & 0 \\
\hline 31,406 & 28,854 \\
\hline 6.021 & 7,100 \\
\hline 23.7 & 32.6 \\
\hline 3,444 & 2,798 \\
\hline 27,962 & 26,056 \\
\hline 2,577 & 4,302 \\
\hline 10.2 & 19.8 \\
\hline
\end{tabular}

1/ Net Transactions = Purchases - Sales

3/ Derived from the historic seasonal forced sutage rate by the ERA Field office Staff 
Table 7B. 10

Page 2 of 2

FUTURE CAPABILITY AND RESERNE MARGINS T्XTTYF:RN OOMPANY GRXIE RAGITN

(1) Planned Capability (MN)

(2) Peak Dernand (Mw)

(3) Planned Reserve (nw) $(1-2)$

(4) Planned Peserve (8) (3\%2) × 100

(5) Net Transactions $1 /$ (Mi)

(6) Total Capability (

(7) Total Reserve (MW) (6-2)

(8) Total Reserve (8) $(7 \div 2) \times 100$

(9) Scheduled Maintenance (Mw)

(10) Capability after Maintenance (NW) (6-9)

(11) Reserve after Maintenance (MW) $(10-2)$

(12) Reserve after Maintenance (8) (11:2) $\times 100$

(13) Inoperable Capability (MW)

(14) Available Capability (MW) (10-13)

(15) Available Reserve (MW) (14-2)

(16) Available Reserve (8) $(15 \div 2) \times 100$

(17) Forced outages (F.o.) (MW)

(18) Available Capability after

(20) Actual Reserve (8) $(192) \times 100$

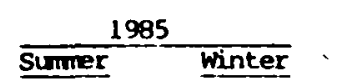

33.571

33.571

$\begin{array}{rr}26,348 & 22.728 \\ 7.223 & 10.812\end{array}$

$\begin{array}{cc}27.4 & 47.6 \\ (110) & (340)\end{array}$

33,461

7,113

27.0
.113

2/

33,461

7.113
27.0

27.0
0
461

33,461

7.113
27.0

27.0

33,461

7.113
27.0

$(340)$
33,200

10,472

46.1

21

$33 . \frac{2}{200}$

10,472

46.1

33.195

10,467

33. $\frac{21}{195}$

10,467

46.1

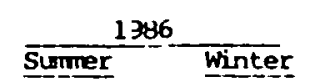

$33.948 \quad 33,793$

33,948

27.291
6,657

23.825

$24.7 \quad 4.968$

33. 16018

6,597

$597 \quad 33,653$

$24.2 \quad 9.828$

$33, \frac{21}{488}$

6,597

$24.2 \quad, 828$

0
33,888

33,888

24.2

$33, \frac{2 /}{13}$

6,597

.597 .2

5

33. 648

9.823
41.2

41.
33.648
9.1123

9.823
41.2
Susme

36.059

36,059
28,540

28,540

7.519
26.3

140

36.199

7,659

26.8

$36, \frac{21}{1} 99$

36,199
7,659

26.8

36,199

36,199
7,659

7,659
26.8

$36.2 / 199$

36,199
7,659

20.8
Wiriter

35.947

24.909

11.038
44.3

(140)

35.607

10.899

23.8

$35, \frac{2}{607}$

10,898

43.8
5

35.02

35.802

43.7

$35 . \frac{2 /}{802}$

10,893

43.7

\begin{tabular}{c}
1988 \\
\hline summex \\
37.045 \\
29.656 \\
7.349 \\
24.9 \\
140 \\
37.185 \\
7,529 \\
25.4 \\
$2 /$ \\
37.185 \\
7.529 \\
25.4 \\
0 \\
37.185 \\
7.529 \\
25.4 \\
21 \\
37.185 \\
7.529 \\
25.4
\end{tabular}

25.4 knter

\subsection{8}

25,966

10,942

(140)

36,768

10,802

41.6

21

$36 . \overline{7} 68$

10.802

41.6

36,763

10,797

41.6

$36 . \frac{2 /}{763}$

10.797
41.6

\section{Summer Knter}

$37,793 \quad 37,734$

$30,629 \quad 27,122$

$7,164 \quad 10,612$

$\begin{array}{cc}23.4 & 39.1 \\ 140 & (140)\end{array}$

17.933

23.8

21

$37 . \overline{933}$

7.304

23.8

0
37.933

7.304

23.8

$37 . \overline{9} 33$

7,304

23.8

37.594

10,472

38.6

$37 . \frac{21}{594}$

10,472

38.6

37,509

10,467

38.6

$37, \frac{2}{589}$

10,467

1/ Net Transactions $=$ Purchases - Sales

2/ Information on scheduled maintenance and forced outages are not availatile

( ) denotes negative number 


\section{TVA Subregion}

\section{Historical Perspective}

Load growth over the past three years has been somewhat of an anomaly in the TVA Subregion. Electric energy use has increased at an average annual rate of 3.7 percent while both the summer and winter peak demands have decreased. Details are shown on Table 7C.I.

Table 7C.I

Actual Annual Net Energy for Load, Summer and winter Peak Demands and Load Factors

Tennessee Valley Authority Group Region I/

Item

Annual Electric Energy in GWh

Summer Peak Demand in $M W$

Winter Peak Demand in $\mathrm{MW}$

Annual Load Factor in 8 $\underline{1977}$

114,978

$\underline{1978}$

$\underline{1979}$

123,456

$18,953 \quad 18,740 \quad 18,795$

21,992

21,540

20.745

59.7

65.0

67.9

The TVA subregion is a relatively high load factor system. This, coupled with the number of large sized units in the subregion generally requires that generation reserves of between 25 and 30 percent be installed for this area. The exact reserve criteria is determined by loss-of-load probability mathematics. Reserves are planned to meet a risk index of one day in ten years. The TVA Subregion maintains operating reserves equal to the largest generating unit in service plus a $200 \mathrm{MW}$ margin for scheduling error and regulation. One-half of the operating reserve is to be spinning at all time and the other one-half is to be available within ten minutes. The largest generating unit in the TVA Subregion is rated at 1.275 MW. Tables 7C.2 through 7C.4 give the actual reserve situations that occurred in the TVA Subregion for 1977 through 1979 for each of the three summer months (June, July and August) and the three winter months (December, January and February). There were five peak periods when planned reserves fell below 25 percent of monthly peak. The lowest planned reserve was 15.8 percent and occurred during January 1978. Actual reserve 


$$
\mathrm{XI} .7 .35
$$

did not meet the operating reserve reguirement during eight of the eighteen historical peak periods. The lowest actual reserve level was 0.3 percent of peak demand and occurred in January 1978 .

Generating capacity (summer rating) by fuel type for 1978 and resulting energy production is shown on Table $7 \mathrm{C} .5$

A total of $6.8 \mathrm{mill}$ ion barrels of oil was burned in the TVA Subregion during 1978 to produce electricity, all of which was distillate. No natural gas was used but about 35.9 million tons of coal was consumed in electric production during 1978. There were three nuclear generating units in service in the TVA subregion between 1977 and 1979 .

The TVA subregion had about 9,000 miles of $161 \mathrm{kV}$, about 1,800 miles of $500 \mathrm{kV}$ and about 200 miles of other miscellaneous transmission lines at or above $115 \mathrm{kV}$ at the end of 1979. This is a transmission capability of about 3.1 million MW-miles which translates to a transmission to generating capacity ratio of about $110 \mathrm{MW}-\mathrm{miles}$ per MW.

TVA has a seasonal diversity interchange agreement with numerous Southwest Power Pool (SWPP) companies where TVA exports power in the summer and imports power during the winter. The original agreement was signed in 1962 for interchange of 1,500 MW. This was changed to $1,100 \mathrm{MW}$ during 1979 and will be reduced again to $700 \mathrm{MW}$ during 1980 . The 1980 schedule is to be followed for the next ten years. The original diversity agreement justified the installation of about 940 miles of $500 \mathrm{kV}$ and 220 miles of $345 \mathrm{kV}$ lines between TVA and SWPP and is a major reason for the high interconnection capacity $(4,500 \mathrm{MW})$ between SERC and SWPP.

Forced outages of generating equipment on the TVA system currently exceed scheduled maintenance outage hours by about three times. Boiler tube failures have been a major cause of generating unit forced outages. Luring 1977 TVA undertook an intense program to improve the productivity of its generating units. The success of this program is important to the future generation reliability of the TVA Subregion.

The TVA Subregion operates as a single control area or power pool.

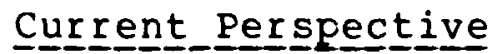

The 1980 summer peak demand of the TVA subregion is expected to be in the range of $20,188 \mathrm{MW}$ to $20,370 \mathrm{MW}$. The 1980 winter peak demand is expected to be in the range of $22,290 \mathrm{MW}$ to $23,543 \mathrm{MW}$. Table 7C.6 gives the current reserve picture for three summer and three winter months for 1980 .

Actual reserve for the summer peak period are not expected to meet 
the operating reserve requirement for the region and may not be adequate to replenish the loss of the largest generating unit. This does not include any contribution from the Sequoyah No. 1 nuclear unit rated at $1,148 \mathrm{MW}$. A temporary license for this unit was issued on February 29, 1980 to permit testing at power levels not exceeding 5 percent. It is doubtful that this unit can be commercially available for this summer but some increased output from this unit appears possible. Some relief is possible from hydro capacity since reservoir storages are full and no adverse hydrologic condition is expected. Also, the summer peak forecast represents an 8.4 percent increase over the 1979 actual summer peak demand and there is a possibility that this may not materialize.

A great strength of the TVA subregion is the import capability of the transmission system. Non-simultaneous import capability, over and above scheduled interchange, is $6,150 \mathrm{MW}$ for the 1980 summer peak period. IVA has a load relief program whereby $2,043 \mathrm{MW}$ of load could be reduced in an emergency. This is about 10 percent of the estimated 1980 summer peak demand. The amounts and methods of reducing load are shown in Table $7 \mathrm{C} .7$.

\section{Table 7C. 7}

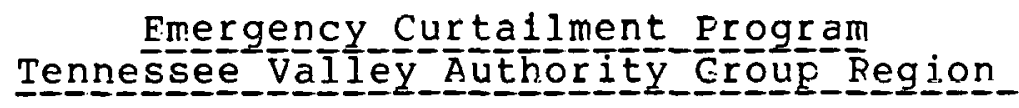

Metho으

Curtailment of non-essential utility load

Interruption of contract interruptible load

Voltage reduction (58)

Fublic appeal
Amount in $M \underline{W}$

35

888

120

1,000

Operating reserve for the 1980 winter feak period should be adequate particularly if the Sequoyah No. I nuclear unit becomes fully licensed by this time.

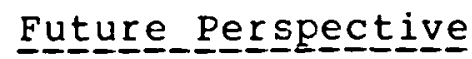

The TVA Subregion is forecasting their annual electric energy use to increase from 130,150 GWh in 1980 to 182,927 GWh in 1989 . This is an average annual growth rate of about 3.9 percent which is comparable to their electric energy growth rate during the past three years. Their summer peak demand is estimated to grow at an average annual 
rate of 3.8 percent, from $20,188 \mathrm{MW}$ in 1980 to 28,292 in 1989 . Their winter peak demand is expected to increase from 23,543 MW in 1980 to $31,752 \mathrm{MW}$ in 1989, an average annual growth rate of 3.4 percent. Although TVA is expected to remain a winter peaking area, the summer peak is forecasted to increase. at a slightly greater rate than the winter. Annual load factor is expected to increase slightly from 63.1 percent in 1980 to 65.8 percent in 1989.

All of TVA's future generating units are scheduled to be nuclear. These are shown on attached Table 7C.8. A total of 13 nuclear units are planned for operation between 1980 and 1989. Since TVA does not use oil except for peaking purposes, additional nuclear generation will not substantially reduce oil use but will greatly reduce dependence on coal and improve the flexibility of their fuel supply over the long term. The capacity mix as currently planned is shown on Table 7C.9 for mid-year 1980, 1984 and 1989, respectively.

Electric region's ten-year baseline projections of generating capacity, peak demand and reserve margins are shown on attached Table 7C.10. As shown on this Table total reserve are 29 percent or higher in every year between 1981 and 1989 .

During the past year nuclear units in the TVA Subregion have been delayed a total of $505,128 \mathrm{MW}$-months. This is almmost three times the region's current annual electric energy use. Assuming a oneyear delay in the present planned installation dates to allow for unforeseen construction, certification and licensing developments would still allow TVA to maintain planned reserve of at least 25 percent for all but essentially three peak seasons. A two-year delay after 1984 would lower the planned reserve below 25 percent for six of ten peak periods between 1985 and 1989, however, planned reserve below 20 percent is not expected. Possibly the most critical period is the winter of 1981 where planned reserve would drop to 19.7 percent if the Sequoyah No. 2 and watts Bar No. 1 nuclear generating units are not installed as presently planned. These units are currently scheduled for operation in June 1981 and September 1981, respectively. Their total combined capability is 2,325 $\mathrm{MW}$.

The largest generating unit to be added during the period is rated at 1,285 MW which is comparable to the existing largest size unit on the system.

A total of 1,060 miles of $500 \mathrm{kV}$ lines with a transmission capacity of about $1.3 \mathrm{mill}$ ion MW miles are planned for addition between 1980 and 1989. The net generating capacity additions during this period are about $15,800 \mathrm{MW}$. 
HISTORICAL CAPABILITY AND RESERVE MARGINS TENNESSEE JALLEY AUTHORITY GROUP REGION

\author{
(1) Planned Capability (MW) \\ (2) Peak Demand (MW) \\ (3) Planned Reserve (MW) (1-2)

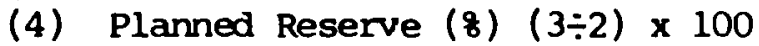 \\ (5) Net Transactions 1/ (MW) \\ (6) Total Capability (MW) (1+5) \\ (7) Total Reserve (MW) (6-2) \\ (8) Total Reserve (8) (7\%2) × 100 \\ (9) Scheduled Maintenance (MW) \\ (10) Capability after Maintenance (MW) (6-9) \\ (11) Reserve after Maintenance (MW) (10-2) \\ (12) Reserve after Maintenance (8) (11-2) × 10 J \\ (13) Inoperable Capability (MW) \\ (14) Available Capability (MW) (10-13) \\ (15) Available Reserve (MW) (14-2)

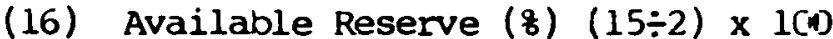 \\ (17) Forced Outages (F.O.) (MW) \\ (18) Available Capability after F.O. (MW) (14-17) \\ (19) Actual Reserve (MW) (18-2) \\ (20) Actual Reserve (8) $(19 \div 2) \times 100$
}

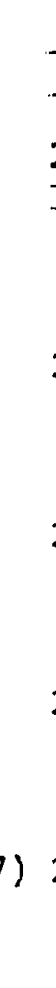

\begin{tabular}{|c|c|c|}
\hline \multicolumn{3}{|c|}{1977 Summer } \\
\hline June & July & August \\
\hline 25,155 & 25,180 & 25,128 \\
\hline 18,345 & 18,953 & 18,833 \\
\hline 6,810 & 6,227 & 6,295 \\
\hline 37.1 & 32.9 & 33.4 \\
\hline (243) $2 /$ & 10 & $(1,969) 2$ \\
\hline 24,912 & 25,190 & 23,159 \\
\hline 6,567 & 6,237 & 4,326 \\
\hline 35.8 & 32.9 & 23.0 \\
\hline 1,142 & 341 & 551 \\
\hline 23,770 & 24,849 & 22,608 \\
\hline 5,425 & 5,896 & 3,775 \\
\hline 29.6 & 31.1 & 20.0 \\
\hline 0 & 0 & 0 \\
\hline 23,770 & 24,849 & 22,608 \\
\hline 5,425 & 5,896 & 3,775 \\
\hline 29.6 & 31.1 & 20.0 \\
\hline 3,584 & 4,921 & 2,157 \\
\hline 20,186 & 19,928 & 20,451 \\
\hline$\therefore 841$ & 975 & 1,618 \\
\hline 10.0 & 5.1 & 8.6 \\
\hline
\end{tabular}

\begin{tabular}{|c|c|c|}
\hline \multicolumn{3}{|c|}{ 1977/1978 Winter } \\
\hline December & January & February \\
\hline 25,383 & 25,456 & 25,473 \\
\hline 20,733 & 21,992 & 20,844 \\
\hline 4,650 & 3,464 & 4,629 \\
\hline 22.4 & 15.8 & 22.2 \\
\hline 4,184 & 2,536 & 3,274 \\
\hline 29,567 & 27,992 & 28,747 \\
\hline 8,834 & 6,000 & 7,903 \\
\hline 42.6 & 27.3 & 37.9 \\
\hline 1,622 & 487 & 1.280 \\
\hline 27,945 & 27,505 & 27,467 \\
\hline 7,212 & 5,513 & 6,623 \\
\hline 34.8 & 25.1 & 31.8 \\
\hline 0 & $u$ & $u$ \\
\hline 27,945 & 27,505 & 27,467 \\
\hline 7,212 & 5,513 & 6,623 \\
\hline 34.8 & 25.1 & 31.8 \\
\hline 7,114 & 5,450 & 5,861 \\
\hline 20,831 & 22,055 & 21,606 \\
\hline 98 & 63 & 762 \\
\hline 0.5 & 0.3 & 3.7 \\
\hline
\end{tabular}


Table 7C.3

HISTORICAL CAPABILITY AND RESERVE MARGINS TENNESSEE VALLEY AUTHORITY GROUP REGION

(1) Planned Capability (MW)

(2) Peak Demand (MW)

(3) Planned Reserve (MW) (1-2)

(4) Planned Reserve (8) (3\%2) x 100

(5) Net Transactions 1/ (MW)

(6) Total Capability ( $\bar{M} W)(1+5)$

(7) Total Reserve (MW) (6-2)

(8) Total Reserve (8) (7\%2) x 100

(9). Scheduled Maintenance (MW)

(10) Capability after Maintenance (MW) (6-9)

(11) Reserve after Maintenance (MW) (10-2)

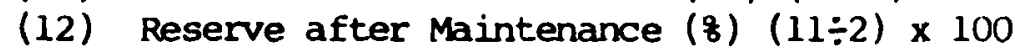

(13) Inoperable Capability (MW)

(14) Available Capability (MW) (10-13)

(15) Available Reserve (MW) (14-2)

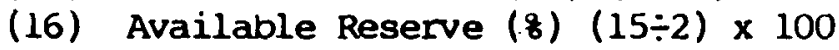

(17) Forced Outages (F.O.) (MW)

(18) Available Capability after F.O. (MW) (14-17)

(19) Actual Reserve (MW) (18-2)

(20) Actual Reserve (8) $(19 \div 2) \times 100$

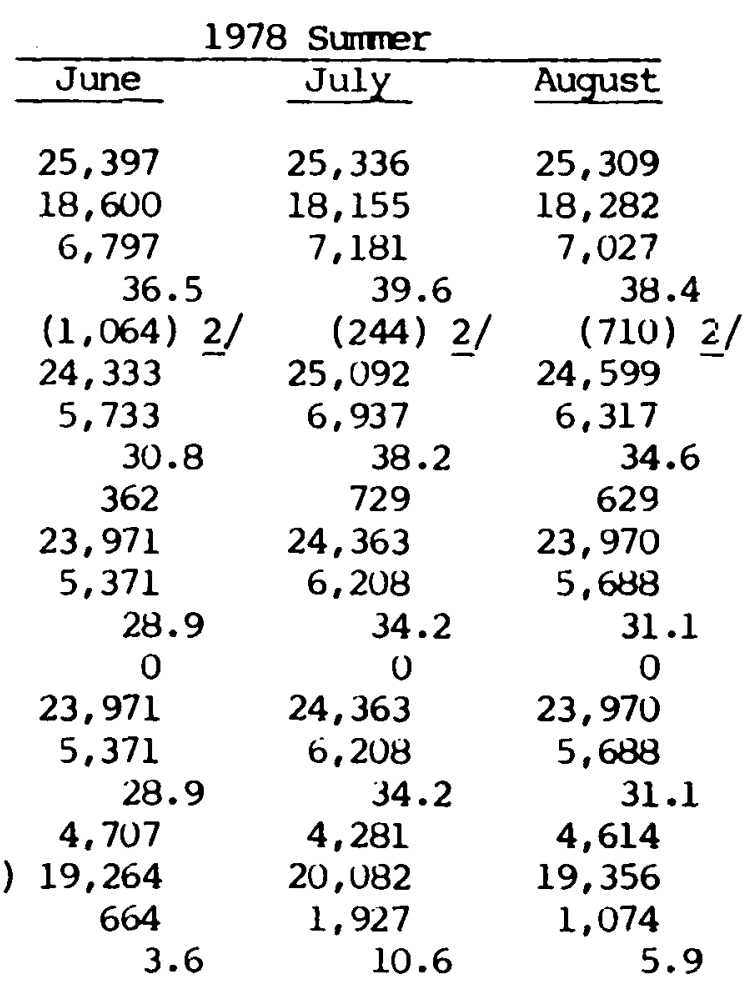

1978/1979 Winter

\begin{tabular}{|c|c|c|}
\hline December & January & February \\
\hline 25.354 & 25,639 & 26,106 \\
\hline 18,928 & 21,540 & 21,179 \\
\hline 6.426 & 4,099 & 4,927 \\
\hline 33.9 & 19.0 & 23.3 \\
\hline 2,292 & 2,578 & 1,552 \\
\hline 27,646 & 28,217 & 27,658 \\
\hline 8,718 & 6,677 & 6,479 \\
\hline 46.1 & 31.0 & 30.6 \\
\hline 3.063 & 2,255 & 371 \\
\hline 24,583 & 25,962 & 27,287 \\
\hline 5,655 & 4,422 & 6,108 \\
\hline 29.9 & 20.5 & 28.8 \\
\hline U & U & U \\
\hline 24,583 & 25,962 & 27,287 \\
\hline 5,655 & 4,422 & 6.108 \\
\hline 29.9 & 20.5 & 28.8 \\
\hline 4,190 & 4,103 & 4,354 \\
\hline 20,393 & 21,859 & 22.933 \\
\hline 1,465 & 319 & 1,754 \\
\hline 7.7 & 1.5 & 8.3 \\
\hline
\end{tabular}

1/ Net Transactions = Purchases - Sales

2/ ( ) denotes negative number 
Table $7 \mathrm{C} .4$

HISTORICAL CAPABILITY AND RESERVE MAPGINS TENNESSEE VAL EEY AUTHORITY GROUP RUOION

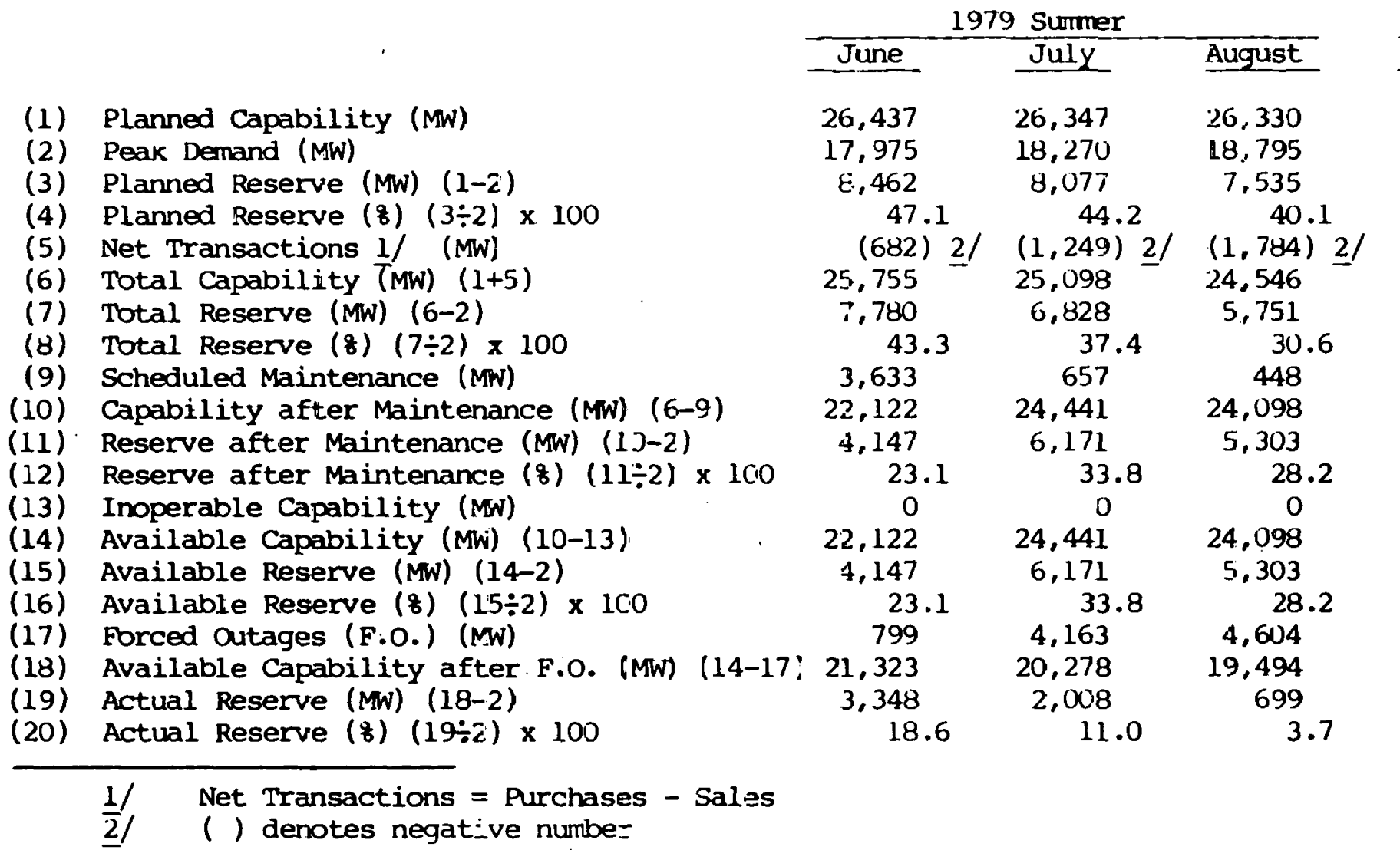

$1979 / 1980$ Winter

\begin{tabular}{|c|c|c|}
\hline December & January & February \\
\hline 26,865 & 26,951 & 26,946 \\
\hline 19,529 & 20,387 & 20,745 \\
\hline 7,336 & 6,564 & 6,201 \\
\hline 37.6 & 32.2 & 29.9 \\
\hline 1,375 & (158) $2 /$ & 798 \\
\hline 28,240 & 26,793 & 27,744 \\
\hline 8,711 & 6,406 & 6,999 \\
\hline 44.6 & 31.4 & 33.7 \\
\hline 579 & 1,540 & 1,540 \\
\hline 27,661 & 25,253 & 26,204 \\
\hline 8,132 & 4,866 & 5,459 \\
\hline 41.6 & 23.9 & 26.3 \\
\hline 0 & 0 & 0 \\
\hline 27,661 & 25,253 & 26,204 \\
\hline 8,132 & 4,866 & 5,459 \\
\hline 41.6 & 23.9 & 26.3 \\
\hline 4,521 & 1,732 & 2,962 \\
\hline 23,140 & 23,521 & 23,242 \\
\hline 3,611 & 3,134 & 2,497 \\
\hline 18.5 & 15.4 & 12.0 \\
\hline
\end{tabular}




$$
\mathrm{XI} .7 .41
$$

Table 7C.5

\section{Actual 1978 Summer Generating Capacity by Fuel Type \\ Tennessee Valley Authority Group Region}

\begin{tabular}{llrrrr} 
Capacity Type & Fuel Type & MW & $\begin{array}{r}\text { of } \\
\text { Total }\end{array}$ & GWh & $\begin{array}{r}\text { of of } \\
\text { Total }\end{array}$ \\
Steam & Nuclear & 3,201 & 12.3 & 16,911 & 14.7 \\
Steam & Coal & 16,249 & 62.5 & 78,469 & 68.1 \\
Steam & Oil & 0 & 0.0 & 0 & 0.0 \\
Steam & Gas & 0 & 0.0 & 0 & 0.0 \\
Hydro & Water & 4,306 & 16.6 & 17,023 & 14.8 \\
Pumped Storage & Water & 0 & 0.0 & $(25)$ & 0.0 \\
Gas Turbine & Oil & 2,224 & 8.6 & 2,838 & 2.4 \\
Gas Turbine & Gas & 0 & 0.0 & 0 & 0.0 \\
Combined Cycle & Oil & 0 & 0.0 & 0 & 0.0 \\
Combined Cycle & Gas & 0 & 0.0 & 0 & 0.0 \\
Other & & 0 & 0.0 & 0 & 0.0 \\
\multicolumn{1}{r}{ Total } & & 25,980 & 100.0 & 115,216 & 100.0
\end{tabular}


CURRENT CAPABILITY AND RESERVE MARGINS TENNESSEE VALLEY AUTHHRITY GROUP RHOION

(1) Planned Capability (MW)

(2) Peak Demand (MW)

(3) Planned Reserve (MW) (1-2)

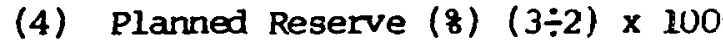

(5) Net Transactions l/ (MW)

(6) Total Capability $(M W)(1+5)$

(7) Total Reserve (MW) (6-2)

(8) Total Reserve (8) $(7 \div 2) \times 100$

(9) Scheduled Maintenance (MW)

(10) Capability after Maintenance (MW) (6-9)

(11) Reserves after Maintenance (MW) (10-2)

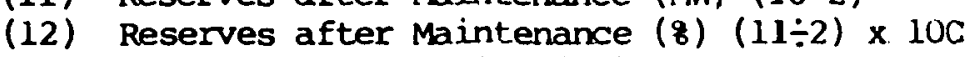

(13) Inoperable Capability (MW)

(14) Available Capability (MW) (10-13)

(15) Available Reserve (MW) (14-2)

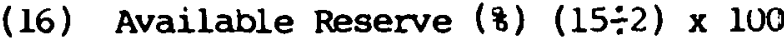

(17) Forced outages (F.O.) (MW) $2 /$

(18) Available Capability after F.O. (MW) (14-1.)

(19) Actual Reserve (MW) (18-2)

(20) Actual Reserve (8) $(19 \div 2) \times 100$

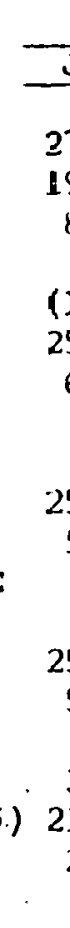

1980 Summer

\begin{tabular}{|c|c|c|}
\hline June & July & August \\
\hline 27,454 & 27,434 & 27,424 \\
\hline 19,350 & 20,370 & 20,370 \\
\hline 8,104 & 7,064 & 7,054 \\
\hline 41.9 & 34.7 & 34.6 \\
\hline $\begin{array}{l}(1,580) \quad 3 / \\
25,874\end{array}$ & $\begin{array}{l}(1,580) \quad 3 / \\
25,854\end{array}$ & $\begin{array}{l}(1,580) 3 / \\
25,844\end{array}$ \\
\hline 6,524 & 5,484 & 5,474 \\
\hline 33.7 & 26.9 & 26.9 \\
\hline 665 & 704 & 704 \\
\hline 25,209 & 25,150 & 25,140 \\
\hline 5,859 & 4,780 & 4,770 \\
\hline 30.3 & 23.5 & 23.4 \\
\hline 0 & 0 & U \\
\hline 25,209 & 25,150 & 25,140 \\
\hline 5.859 & 4,780 & 4,770 \\
\hline 30.3 & 23.5 & 23.4 \\
\hline 3,663 & 3,663 & 3,663 \\
\hline 21,546 & 21,487 & 21,477 \\
\hline 2,196 & 1,117 & 1,107 \\
\hline 11.3 & 5.5 & 5.4 \\
\hline
\end{tabular}

$1980 / 1981$ Winter

\begin{tabular}{|c|c|c|}
\hline December & January & February \\
\hline 28,838 & 28,808 & 28,878 \\
\hline 20,890 & 22,290 & 21,790 \\
\hline 7,948 & 6,518 & 7,088 \\
\hline 38.0 & 29.2 & 32.5 \\
\hline 1,100 & 1,100 & 1,100 \\
\hline 29,938 & 29,908 & 29,978 \\
\hline 9,048 & 7,618 & 8,188 \\
\hline 43.3 & 34.2 & 37.6 \\
\hline 2,597 & 747 & 1,087 \\
\hline 27,341 & 29,161 & 28,891 \\
\hline 6,451 & 6,871 & 7,101 \\
\hline 30.9 & 30.8 & 32.6 \\
\hline 0 & u & U \\
\hline 27,341 & 29,161 & 28,891 \\
\hline 6,451 & $6.871 \because$ & 7,101 \\
\hline 30.9 & 30.8 & 32.6 \\
\hline 3,680 & 3,974 & 3,908 \\
\hline 23,661 & $25,187 \ldots$ & 24,983 \\
\hline 2,771 & 2,897 & 3,193 \\
\hline 13.3 & 13.0 & 14.7 \\
\hline
\end{tabular}

\footnotetext{
1/ Net Transactions = Purchases - Sales

2/ Estimated by TVA

3) ( ) denotes negative number
} 
Table $7 \mathrm{C.8}$

Major Future Generating Unit In-Service Dates

Tennessee Valley Authority Group Region

\begin{tabular}{|c|c|c|c|c|c|}
\hline Unit Designation & $\begin{array}{c}\text { Capacity } \\
\text { in MW } \\
\end{array}$ & $\begin{array}{l}\text { Fuel } \\
\text { Type }\end{array}$ & $\begin{array}{l}\text { In-serv } \\
\text { As of } \\
4 / 79\end{array}$ & $\begin{array}{l}\text { e Date } \\
\text { As of } \\
4 / 80\end{array}$ & $\begin{array}{l}\text { Change in } \\
\text { MW-months }\end{array}$ \\
\hline Sequoyah No. 1 & 1,148 & Nuc. & $10 / 79$ & $6 / 80$ & 9,184 \\
\hline Sequoyah No. 2 & 1,148 & Nuc. & $6 / 80$ & $6 / 81$ & 13,776 \\
\hline Watto Bar No. 1 & 1,177 & Nuc. & $6 / 80$ & $9 / 81$ & 17.655 \\
\hline Watts BaI No. 2 & 1,177 & Nuc. & $3 / 81$ & $6 / 82$ & 17,655 \\
\hline Bellefonte No. 1 & 1,213 & Nuc. & $9 / 81$ & $9 / 83$ & 29,112 \\
\hline Bellefonte No. 2 & 1.213 & Nuc. & $6 / 82$ & $6 / 84$ & 29,112 \\
\hline Yellow Creek No. 1 & 1,285 & Nuc. & $5 / 85$ & $11 / 85$ & 7,710 \\
\hline Hartsville No. 1 & 1,233 & Nuc. & $6 / 83$ & $7 / 86$ & 45,621 \\
\hline Phipps Bend No. 1 & 1,233 & Nuc. & $8 / 84$ & $3 / 87$ & $38,2 \overline{23}$ \\
\hline Hartsville No. 2 & 1.233 & Nuc. & $6 / 84$ & $7 / 87$ & 45,621 \\
\hline Yellow Creek No. 2 & 1,285 & Nuc. & $5 / 86$ & $4 / 88$ & 29,555 \\
\hline Hartsville No. 3 & 1,233 & Nuc: & $12 / 83$ & $6 / 89$ & 81,378 \\
\hline Phipps Bend No. 2 & 1,233 & Nuc. & $8 / 85$ & $8 / 89$ & 59,184 \\
\hline Hartsville No. 4 & 1,233 & Nuc. & $12 / 84$ & $6 / 90$ & 81,378 \\
\hline
\end{tabular}


Table 7C.9

\section{Mid-year Generating Capacity}

Tennessee Valley Authority Group Region

Unit Fuel

Type

ST-NuC

ST-Coal

ST-OiI

ST-Gas

Bydro

PS

GT-Oil

GT-Gas

CC-oil

CC-Gas

Other

Total

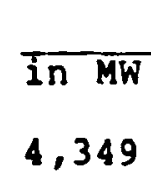

1980

of Total

15.3

57.2

0.0

0.0

4,306

15.1

4.6

7.8

0.0

0.0

0.0

0.0

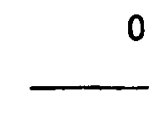

28,428

100.0

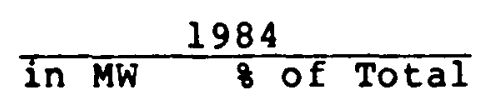

10,277

16,249

0

0

4,306

1,300

2,224

0

0

0

0

34,356

29.9

47.3

0.0

0.0

12.5

3.8

6.5

0.0

0.0

0.0

0.0

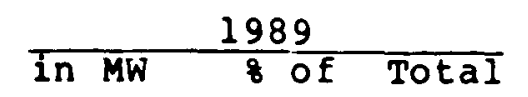

17.779

42.5

16,249

38.8

0

0.0

0

0.0

4.306

10.3

1,300

3.1

2,224

5.3

0.0

0.0

0.0

0.0

0

41.858

100.0 
(1) Plamed Capability (Mw)

(2) Peak Demand (MW)

(3) Plamed Reserve (Mw) (1-2)

(4) Planned Reserve (8) $(3 \div 2) \times 100$

(5) Net Transactions 1/ (MW)

(6) Total Capability (Mw) $(1+5)$

(7) Total Reserve (Ma) $(6-2)$

(8) Total Reserve (8) $(7 \div 2) \times 100$

(9) Scheduled Maintenance (Mw)

(10) Capability after Maintenance (MW) (6-9)

(11) Reserves after Maintenance (MW) $(10-2)$

(11) Reserves after Maintenance (MW) $(10-2)$

(13) Inoperable Capability (MW)

(13) Inoperable Capability (MW)

(15) Available Regerve (MW) (14-2)

(16) Available Reserve (8) $(15 \div 2) \times 100$

(17) Forced artages (E.0.) (Mw) 2 /

(18) Available Capability after $\bar{F}$.

(19) Actual Reserve (MW) (16-2)

(20) Actual Reserve (8) (19-2) $\times 100$
IURE CAPABILITY AND RESERVE MARGINS

TTENFSSEE VNLLEY NUTHKORJTY GROUN PFOIUN

\begin{tabular}{|c|c|c|c|}
\hline \multicolumn{2}{|l|}{1981} & \multicolumn{2}{|l|}{1982} \\
\hline Summer. & Winter & Summer & Winter \\
\hline 29,576 & 30,872 & 31.930 & 32.049 \\
\hline 21,108 & 24,779 & 22.572 & 25.410 \\
\hline 8,468 & 6.093 & 9.358 & 6.039 \\
\hline 40.1 & 24.6 & 41.5 & 26.1 \\
\hline$(1,100) 3 /$ & 1.100 & $(1,100) 3 /$ & $1,1(0)$ \\
\hline 28,476 & 31,972 & 30,830 & 33,149 \\
\hline 7.368 & 7.193 & 8,258 & 7.739 \\
\hline 34.9 & 29.0 & 36.6 & 30.5 \\
\hline 1,400 & 1,199 & 959 & 1,919 \\
\hline 27.076 & 30,773 & 29.871 & 31.230 \\
\hline 5,968 & 5,994 & 7,299 & 5.820 \\
\hline 28.3 & 24.2 & 32.3 & 22.9 \\
\hline 0 & 0 & 0 & 0 \\
\hline 27.076 & 30.773 & 29.871 & 31,230 \\
\hline 5,968 & 5,994 & 7,299 & 5,820 \\
\hline 28.3 & 24.2 & 32.3 & 22.9 \\
\hline 3,759 & 4,476 & 3.759 & 4.476 \\
\hline 23,317 & 26,297 & 26,112 & 26.754 \\
\hline 2,209 & 1,518 & 3,540 & 1,344 \\
\hline 10.5 & 6.1 & 15.7 & 5. \\
\hline
\end{tabular}

\begin{tabular}{cc}
\multicolumn{2}{c}{1983} \\
\hline Sumuer & Winter \\
31.930 & 33.262 \\
23,129 & 26.496 \\
8,401 & 6,766 \\
38.1 & 25.5 \\
$(1,1,00)^{3} 3 /$ & 1,100 \\
30,830 & 34,362 \\
7,701 & 7,866
\end{tabular}

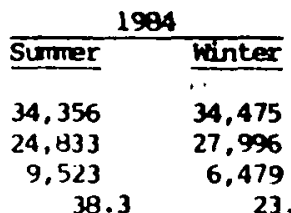

$(1,100) 3 / 1,100$

$33,256-35,575$

30,830
7,711

$\begin{array}{rr}33.3 \quad & 7.866 \\ 320 & 2.7\end{array}$

$$
320
$$

2.042

8,423

$30,510 \quad 32,320$

5.824

1. 334

$\begin{array}{rr}33.9 & 7.579 \\ & 27.093\end{array}$

1.084

i. 083

$32,172 \quad 34,492$

$\begin{array}{cc}31.9 & 22.0 \\ 0 & u \\ 30,510 & 32,320 \\ 7,381 & 5,824\end{array}$

29.6

$\begin{array}{rr}31.9 & 5,824 \\ .381 & \end{array}$

3,759

26,751

4,476
27,444

3,622

27,844

0
32.172

6,496

32.172
7.339

.339
29.6

3.759

28,413

3,560

$$
25.2
$$

34,492

6,496

23.2

4,476

30,016

$15.7 \quad 5.1$

14.4

1) Net Transactions = Purchases - Sales

Derived from the historic seasonal forced outage rate by the FRA Field of fice Staff () denotes negative number 
Table 7C. 10

FUTUEE CAPABILITY AND RESERVE MARGINS

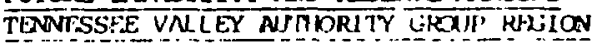

(1) Planned Capability (MW)

(2) Peak Demand (Mw)

(3) Planned Regerve (nW) (1-2)

(4) Planned Reserve (8) $(3 \div 2) \times 100$

(5) Net Transactions if (MW)

(6) Total Capability (

(7) Total Peserve (M(W) $(6-2)$

(8) Total Peserve (8) $(7 \div 2) \times 100$

(9) Scheduled Maintenance (Mw)

(10) Capability after Maintenance (MN) (6-9)

11) Reserve after Maintenance (MW) $(10-2)$

12) Reserve after Maintenance $(8)(11 \div 2) \times 100$

(13) Inoperable Capability (MW)

(14) Available Capability (Mw) (10-13)

(15) Available Reserve (MW) (14-2)

(16) Available Peserve (8) $(15 \div 2) \times 100$

(17) Porced Outages (F,O.) (MW)

(18) Available Capability after

(19) Actual Reserve (MW) $(14-2)$

(20) Actual Reserve (MW) $(14-2) \times 100$

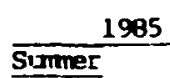

Winte:

$\begin{array}{ll}34,356 & 35,760 \\ 2 E .395 & 28.579\end{array}$

$\begin{array}{rr}28.395 & 28.579 \\ 8.961 & 7,18.1\end{array}$

$(1,100)^{35.3} \quad 1,1(0) .1$

$(1,100)$
$3 \equiv, 255$

$\therefore, 861$

$31.0 \quad 8,284.0$

3..,$\frac{2}{255}$

7.861

$36, \bar{x}(0)$
8,280

3. 28

36.860

8,2 리

31.0

31.0

(MV) $(14-17) 32 \frac{21}{25}$

36

36.851

$8,2 E 1$
29.0

\begin{tabular}{|c|c|}
\hline \multicolumn{2}{|c|}{1986} \\
\hline Summer & Winter \\
\hline 36.874 & 36,993 \\
\hline 26.039 & 29,305 \\
\hline 10.835 & 7,6488 \\
\hline 41.6 & 26 \\
\hline$(1,100)$ & 1.100 \\
\hline 35,774 & 38.093 \\
\hline 9,735 & 8,788 \\
\hline 37.4 & 30 \\
\hline $2 /$ & $2 i$ \\
\hline $35, \overline{774}$ & $38, \bar{v} 93$ \\
\hline 9.735 & $8,78 B$ \\
\hline 37.4 & 30. \\
\hline$u$ & 0 \\
\hline 35.774 & 38,093 \\
\hline 9.735 & 8,788 \\
\hline 37.4 & Ju \\
\hline $35, \frac{2 /}{774}$ & $38, \frac{2 i}{093}$ \\
\hline 9,735 & 8.788 \\
\hline 37.4 & 30 \\
\hline
\end{tabular}

\begin{tabular}{|c|c|}
\hline \multicolumn{2}{|c|}{1947} \\
\hline Suminer & Winter \\
\hline 39,340 & 39.459 \\
\hline 26.775 & 30,087 \\
\hline 12.565 & 9,372 \\
\hline 46.9 & 31. \\
\hline$(1,100)$ & 1,100 \\
\hline 38,240 & 40,559 \\
\hline 11,465 & 10,472 \\
\hline 42.8 & 34. \\
\hline 21 & $2 /$ \\
\hline $38, \overline{2} 40$ & $40, \overrightarrow{5} 59$ \\
\hline 11,465 & 10,472 \\
\hline 42.8 & 34 \\
\hline 0 & 0 \\
\hline 38,240 & 40,559 \\
\hline 11.465 & 10,472 \\
\hline 42.8 & 34. \\
\hline$\underline{2}$ & \\
\hline $38, \overline{2} 40$ & $40 . \overline{5} 59$ \\
\hline$\$ 1,465$ & 10.472 \\
\hline
\end{tabular}

\begin{tabular}{|c|c|}
\hline \multicolumn{2}{|c|}{1968} \\
\hline Summer & Winter \\
\hline 40.625 & 40.744 \\
\hline 27.545 & 30,800 \\
\hline $13,0 \leq 0$ & 9,864 \\
\hline 47.5 & 31.9 \\
\hline$(1,1 \omega 0)$ & 1,100 \\
\hline 39.525 & 41,844 \\
\hline 11,930 & 10,964 \\
\hline 43.5 & 35.5 \\
\hline 21 & $2 /$ \\
\hline 39,525 & $41, \overline{844}$ \\
\hline $\begin{array}{l}11,400 \\
43.5\end{array}$ & 10,964 \\
\hline 43.5 & 35.5 \\
\hline 0 & 0 \\
\hline 39,525 & 41.844 \\
\hline 11,950 & 10,964 \\
\hline 43.5 & 35. \\
\hline $39 . \frac{27}{525}$ & 54 \\
\hline $\begin{array}{l}11,925 \\
11,960\end{array}$ & 10,964 \\
\hline 43.5 & 5 \\
\hline
\end{tabular}

\begin{tabular}{c}
1 \\
Summer \\
\hline 41.858 \\
28,292 \\
13.566 \\
47.9 \\
$(1.100)$ \\
40,758 \\
12.466 \\
44.1 \\
$2 /$ \\
40.758 \\
12.466 \\
44.1 \\
0 \\
40,758 \\
12.466 \\
44. \\
2.21 \\
40.758 \\
12.466
\end{tabular}

.

Enter

43.210

31.752

11,458

136.1

1,100

44,310

2,558

4

$2^{39.6}$

4. $\frac{2 /}{310}$

12.558

39.6

44,310

12,558

39.6

$2 /$

$44, \frac{21}{31}$

44,310

44.1

39.6

$x$
$ن$
$ن$
0 


\section{Histororical_Perspective}

The VACAR Subregion contains the greatest amount of installed dependable capacity of the four subregions making up the Southeastern Electric Reliability Council. Included in this capacity is $7,317 \mathrm{MW}$ of nuclear units representing 33 percent of the SERC total and 15 percent of the total installed in the contiguous United states. The VACAR Subregion also has the first nuclear unit installed in the Southeast, the Robinson No. 2 (700 MW) of Carolina Power and Light Company.

For the years from 1960 through 1975 the VACAR subregion had a vigorous load growth rate of about 8.9 percent per year. There appears to be, however, a leveling off for the three years covered in the Historical Perspective with an average growth rate of 2.1 percent for the summer peak demand and 1.5 percent for the winter peak demand. The figures below also show that there is little difference between the summer and winter peak demands.

TABLE 7D.1

Actuㄹ. Annual Net Energy For Load, summer and

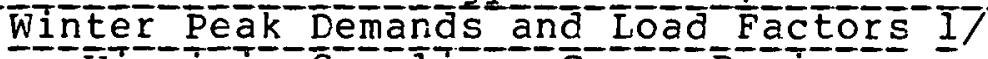
Vi 1 rg

\section{Item}

Annual Electric Energy in GWh

Summer Peak Demand in MW

Winter Peak Demand in $M W$

Annual Load Factor in 8
1977

$\underline{1} 9 \underline{7} \underline{8}$

$19 \underline{9} 9$

136,911

142,084

26,370

26,200

26,063

61.9

143,995

27,494

25,814

59.3
26,627

59.8

1/ Source - Form No. 12E-2.

2/ Winter feriod for each year includes December of that year plus January and February of the following year. 
Using 1978 as a typical year in the three-year study period, the nuclear units had a net generation of 43,894 GWh or 31 percent of the total net generation for the subregion. This energy produced by 20.7 percent of the installed capacity, represents a 68.5 percent clant factor. As shown on Table 7D.2 the coal units and nuclear units produced 81.3 percent of the net generation with a combined plant factor of 54.1 percent and made up 69.5 percent of the installed capacity.

TAELE 7D. 2

Actual_1978 Summer Generating Cakacity by_Fuel_Type Ví

\begin{tabular}{|c|c|c|c|c|c|c|}
\hline \multirow[b]{2}{*}{ Capacityy_Type } & \multirow[b]{2}{*}{ Fue I_Type } & \multicolumn{2}{|c|}{ Capacity } & \multicolumn{3}{|c|}{ Generation } \\
\hline & & $\underline{M W}$ & Totaㅣ & GWW & & otal \\
\hline Steám & Coal & 17,245 & 48.8 & 72,509 & & 50.6 \\
\hline steam & Nuclear & 7,317 & 20.7 & 43,894 & & 30.6 \\
\hline steam & oil & 4,267 & 12.1 & 18,917 & & 13.2 \\
\hline Steam & Gas & 0 & 0 & 0 & & 0 \\
\hline Hyäro & Water & 2,463 & 6.9 & 7,052 & & 4.9 \\
\hline Pumped storage & hater & 1,122 & 3.2 & $(152)$ & $1 /$ & $(0.1)$ \\
\hline Gas Turhine & cil & 2,400 & 6.8 & 833 & & 0.6 \\
\hline Gas Turbine & Gas & 265 & 0.7 & 109 & & 0.1 \\
\hline Combined Cycle & Oil & 282 & 0.8 & 70 & & $0: 1$ \\
\hline Combined Cycle & Gas & $n$ & 0 & 0 & & 0 \\
\hline other & & $--\underline{0}$ & $\underline{0}$ & $\underline{0}$ & & $\ldots$ \\
\hline Total & & 35,361 & 100.0 & 143,232 & & 100.0 \\
\hline
\end{tabular}

I/ ( ) Denotes negative number. 
Planned reserve criteria for VACAR utilities generally ranges from 15 to 20 percent of peak demand. Operating reserve l/ is coordinated among the VACAR companies. Ey agreement, each member system maintains operating reserve of four percent of the annual peak demand plus eight percent of the largest generating unit. The largest generating unit is currently $1,140 \mathrm{MW}$. Using the reported data for 1978 the operating reserve would be as follows:

$$
\begin{aligned}
& 1978 \text { Peak demand } 2 / 26,200 \text { (Aug.) x .04 } \\
& =1,048 \mathrm{MW} \\
& \text { CP\&L Unit - Brunswick No. } 1 \text { - } 790 \mathrm{x} .08 \\
& =63.2, \mathrm{~W} \\
& \text { Duke Unit - Bellows Creek No. } 1 \text { - } 1140 \text { x .08 } \\
& =91.2 \mathrm{MW} \\
& \text { SCE\&G Unit - Williams N!O. } 1 \text { - } 580 \times .08 \\
& =46.4 \mathrm{MW} \\
& \text { SCPSA Unit - Winyah No. } 1-280 \times .08 \\
& \text { VEPCO Unit - Surry No. } 1 \text { - } 775 \times .08 \\
& \text { Yadkin Unit - Narrows No. } 1 \text { - } 24 \times .08 \\
& =22.4 \mathrm{MW} \\
& =62.0 \mathrm{MW} \\
& =\underline{1.9} \mathrm{MW}
\end{aligned}
$$

Tables 7D.3 through 7D.5 show the historical reserve margins for 1977 through 1979. As shown in Table 7D.3, actual reserve in January of 1978 was $689 \mathrm{MW}$, or 2.7 percent. For the same month, there was 6,571 MW of forced outages (Item 17 ) in addition to the $1.783 \mathrm{MW}$ capacity scheduled for maintenance. If half of the capacity shown in Item (17) were available the resultant actual reserve would have been a comfortable 15.6 percent instead of 2.7 percent. The forced outages shown on Tables 7D.3-7D.5 ranges from a low of $4,299 \mathrm{MW}$ to a high of 7,071 MW. While these two extreme unavailable capacities formed 16.1 percent and 29.8 percent of the peak demand respectively, the corresponding actual reserves were 6 percent and 12.4 percent respectively. It could be assumed that due to the large amount of nuclear capacity in this subregion that much of the capacity was unavailable due to various checks, inspections and other regulatory requirements. As the "Three Mile Island Lessons Learned" program is completed, a substantial reduction in forced outages may be noted.

The transmission to gererating capacity ratio in VACAR for 1978 was about $115 \mathrm{MW}$ miles per MW. There were 1,300 miles of 500 $\mathrm{kV}$ lines, 5,200 miles of $230 \mathrm{kV}$ lines and 10,600 miles of 100 to $132 \mathrm{kV}$ Iines in operation in 1978 with a transmission capability of about 3.9 million $\mathrm{NW}$ miles.

İ Reserve áf tér maintenance. 2/ Total VACAR. Subregion 
Although VACAR does not operate as a power pool or disfatch economy energy on coordinated basis, it is one of the most thermally efficient electric regions in the country. Table 7D.6 gives the resulting steam-electric heat rates by major systems in VACAR for 1977.

TARLE 7D.6

$\frac{\text { Steami-Electric Heat Rates by Major Systems }}{\text { Virginia-Carolinas Croup Pegion }}$

System

Carolina Power and Light Duke Power Company

South Carolina Electric and Gas Company South Carolina Public Service Authority Virginia Electric and Power Company

V $\triangle \cap \wedge R$
Heat Pate Ptu/krh

10,009

9,451

9,952

10,000

$\underline{10,779}$

9,996

\section{Current Perspective}

The peak demand in the VACAR subregion for the summer of 1980 is projected to be $28,353 \mathrm{MW}$. This is an increase of 3 percent over the previous year and is slightly higher than the averaoe annual growth $r$ ate of 2.1 percent over the previous three years. The 1980 winter peak demand is expected to be $28,128 \mathrm{Mr}^{\prime}$, an increase of 5.3 percent over the previous winter. It is anticipaced that by the mid-1980's, the subregion will be a winter peaking area.

The total reserve for this period is expected to range from 8,182 Mh to 9,951 (29.3 to 39.4 percent) for the summer months, and $9,933 \mathrm{MW}$ to $11,757 \mathrm{Mk}$ ( 35.3 to 44.7 percent) for the winter monchs. If the in-service dates for McGuire No. I and North Anna No. 2 nuclear units slip beyond the 1980 summer season, the total reserve still would exceed the 15-20 percent VAcAp criterid. Reserve after maintenance however, will vary from a low of $5,106 \mathrm{Mh}^{\top}\left(20.2\right.$ percent) in June, to a high of $7,852 \mathrm{MW}^{7}$ ( 27.7 percent) in August. Again it should be noted that if the above two nuclear units are not available, the pugust reserve decreases by $2,087 \mathrm{MW}$, leaving a 20.3 percent reserve margin. 
While the total reserve and reserve after maintenance situation appear to be adeguate, the actual reserve based on the hiscoric data for the previous three years, are sorewhat tenuous. The historic data show that during the peak seasons, 15-16 percent of the dependable capacity was experiencing forced outage problems. Assuming that this condition could continue in 1980, Table 7D.7 shows that June and possibly July would be critical periods if all other items in this Table remain unchanged.

The non-simultaneous import capabilities for VACAP are shown in Table 7D.8.

\section{TAELE $7 D .8$}

Non-Simultaneous Import Capahilities virginia-Carolinas Group Region

Transfer Parties

Southern tO VACAR

TVA LO VACAR.

ECAR tO VACAF

MAAC TO VACAR
Fmeraency Transfer Capability-Mh

$$
\begin{aligned}
& 1,700 \\
& 2,200 \\
& 2,200 \\
& 1,800
\end{aligned}
$$

In addition to the emergency transfor capabilities, vacap is able co obcain emergency load relief in the following manner:

\section{Opcion}

Curcailment of non-essential utility system load

Intercuption of interruptible concract system load

Voltage reduction- -58

Public appeals for voluntary conservation

Total

\section{Estimated Mr Relief}

\section{2}

586

$8281 /$

1.568

I/ Public Appeals for Voluntary Conservation $=(28,353$ Mr Summer Peak $-12 \mathrm{MW}-142 \mathrm{MW}-586 \mathrm{MW}) \mathrm{x} .03=828 \mathrm{Mh}$.

The $1.568 \mathrm{Mh}$ emergency load relief amounts to 5.5 percent of the anticipated 1980 summer peak load. 


\section{Furure Perspective}

The VACAR subregion is forecasting the annual electric eneroy use to increase from $151,578 \mathrm{GWh}$ in 1980 to 231,770 GW in 1989 . This represents an average growth rate of 4.8 percent and is approximately twice the average annual growth rate of 2.5 percent recorded during the 1977 through 1979 period. The past three years, however, could be reflecting some inttial conservation on part of the consumer which atter a perlod ur ajjustment may not continue as noticeably. The summer peak demand is estimated to grow from $28,353 \mathrm{MW}$ in 1980 to $43,433 \mathrm{MW}$ in 1989. This annual growth rate of 4.8 percent reflects a reduction from the annual growth rate of 6.5 percent which was projected in 1977. The accual summer peak demand growth rate for the past three years was 2.0 percent. The winter peak demand is estimated to increase from $28,128 \mathrm{MW}$ in 1980 to $43,458 \mathrm{MW}$ in 1989. The winter growth rate of 4.9 percent is slightly higher than the summer rate of 4.8 percent and by 1987 the subregion will be a winter peaking area.

Assuming that current projections for load growth and the resultant need for additional capacity are realistic, the vacap subregion will continue to have the greatest amount of nuclear capacity during the 1980's. The capacity mix as currently planned (see Table 7D.9) shows that nuclear units increase from 22.8 percent in 1980 to 35.2 percent in 1989 of the generating capacity in the subregion. 
$X I .7 .53$

TABLE 7D.9

Mid-year Generating Capacity

virginid-Carolinas Group Pegion

Unit-Fuel

Type

$\frac{1980}{\text { Mh } 8 \text { of Total }}$

$\mathrm{ST}-\mathrm{NU}$

8,171

22.8

1984
$\mathrm{Mh}$ of Total

$\frac{1989}{\text { MW } \quad \text { of Total }}$

ST-Coal

17,258

48.3

13,476

30.4

18,235

35.2

ST-OII

4,194

11.8

19,448

43.9

22,068

$42 . F$

ST-Gas

0

0.0

4,194

9.5

4,194

8.1

Hydro

2,475

6.9

0.0

0.0

PS

1,122

3.1

2,515

5.7

2,749

5.3

GT-Oil

2,010

5.6

2,172

4.9

2,172

4.2

GI-Gas

249

0.7

2,010

4.5

1,807

3.5

CC-Oil

282

249

0.5

249

0.5

cr-gas

0.8

282

0.6

282

0.6

0

0.0

0.0

0.0

other

Total

$\frac{0}{35,761} \quad \frac{0.0}{100.0}$

$\frac{0}{44,346}$

$\frac{0.0}{100.0}$

$\frac{0}{51,756} \cdot \frac{0.0}{100.0}$

Bistorically, the nuclear units in the VACAP subreaion have produced more energy per installed MW of capacity than any other type of unit and operate at a plant factor as high as 70 percent. The effect of slippage for the in-service dates for the flanned nuclear units is shown on Table 7 D.10 
Effect of Contruction slippage for planned Nuclear Unit Additions Virginia-Carolinas Group Pegion

Current schedule of Planned Nuclear Additions

$\begin{array}{lccc} & 1980 & 1984 & 1980 \\ \text { Planned Capability }(M W) & 35,761 & 44,346 & 51,756 \\ \text { Summer Peak Demand }(\mathrm{MW}) & 28,447 & 34,904 & 43,433 \\ \text { Planned Reserve }(M h) & 7,314 & 9,442 & 8,323 \\ \text { Planned Reserve }(8) & 25.7 & 27.1 & 19.2\end{array}$

One-Year slippage of Planned Nuclear Additions

\begin{tabular}{|c|c|c|c|}
\hline & 1980 & 1984 & 1989 \\
\hline Planned Capability ( $M W$ ) & $34,863 \underline{1} /$ & $42,301 \leq 2 /$ & 49.949 \\
\hline Summer Peak Demand (MW) & 28,447 & 34,904 & 43,433 \\
\hline Flanned Reserve (MW) & 6,416 & 7,397 & 6,516 \\
\hline Planned Reserve (8) & 22.6 & 2]. 2 & 15.0 \\
\hline
\end{tabular}

$1 /$ North Anna-2 (898 Mhi) not avallable.

2/ Harris-1 ( $900 \mathrm{MW}$ ) not available. Catawba-1 (1,145 MW) not available.

3/ North Anna-4 (907 MW) not available. Harris-4 ( $900 \mathrm{MW}$ ) not available. 
The impact of slippage can be noted when it is compared to the Mid-year Generating Capacity summary (Table 7D.9). If all the non-oil/gas units were ideally available for the summer of 1989 , the planned reserve would amount to $1,791 \mathrm{MW}$. With the slippage of the two nuclear units, $1 /$ there would be a deficiency of $16 \mathrm{~m}$. Based on practical expectations and/or historical records, there will always be a dependence on the oil/gas units to meet unusual load conditions, a dependence that increases with in-service date slippage. Such a condition is contrary to the national commitment to reduce oil consumption.

There is another condition to be considered when examining electric supply and demand. As noted previously, the forecast growth rate has decreased from 6.5 percent in 1977 to 4.8 percent in 1980 . At this time, the 1980 forecast appears to be a reasonable one for planning purposes. If, however, the actual growth rate is less, say 3.8 percent, the peak demand would be reduced by $1,880 \mathrm{MW}^{\circ}$ in 1984 and $3,649 \mathrm{MW}$ in 1989. This would negate the effects of unit slippage and perhaps lead to a re-evaluation of the need and cypes of new capacity.

Each member of VACAR has its own planned reserve criteria which generally ranges liuiu 15 tu 20 percent of the profected peak load. Except for the summer of 1989 , VACAP exceeds the upper criteria in all peak seasons between 1981 and 1989 (see Table 7D.11). Study of the summer of 1989 peak season shows that a delay in the in-service date for North Anna No. 4 (907 MV) and Harris No. 4 (900 MW) units will result in a minimum Flanned reserve of 15 percent.

In 1981, the largest unit in the subregion will be Mccuire po. 1, $1,180 \mathrm{MW}$ nuclear unit, scheduled for operation in necember 1980. The second largest unit in 1981 will be the existing pellews Creek, 1,120 MW coal-fired unit (there are two 1,120 MW units at Bellews Creek). In July 1982 the McGuire No. 2, 1,180 MW nuclear unit is scheduled to become operational.

1/ Harris No. 4 ( $900 \mathrm{MW})$, and North Anna No. 4 (907 Mrp). 
Based on the VACAR criteria for operational or spinning reserve of 4 percent of the estimated peak load plus 8 percent of the rating of each member's largest unit, there will be a low reoulrement of $1,477 \mathrm{MW}$ in the summer of 1981 to a high reaulrement of. $1,683 \mathrm{MW}$ in the summer of 1984 of operating reserve. This ecuates to the largest unit plus $297 \mathrm{MW}$ in 1981 and the largest unit plus $503 \mathrm{Mh}^{-}$in 1984. Planned reserve after maintenance exceeds the operating reserve requirement by at least 5,000 $\mathrm{MH}$ between 1981 and 1984 . This should be adeouate to cover unexpected forced ourages of generating equipement.

Table 7D.12 shows the projected energy requirements, anticipater seasonal demands and annual load factors for the beainning year mid-yedr, and the last year of the study period.

TAPIE 7D. 12

Projected Energy Reaulrements, Anticipated Seasonal Demands and Annual load Factors Virginia-Carolinias Group Reglon

$\underline{\text { I tem }}$

Annual Electric Energy in GWh

Summer Peak Demand in $M K^{\prime}$

winter Peak Demand in $M K^{\circ}$

Annual Load Factor in 8

\begin{tabular}{|c|c|c|}
\hline 1980 & 1984 & 1099 \\
\hline 151,578 & 185,340 & 231,770 \\
\hline 28,447 & 34,904 & 43.433 \\
\hline 28,125 & 34,714 & 43,458 \\
\hline 60.7 & 60.5 & 60.9 \\
\hline
\end{tabular}

By the end of 1979, the bulk power transmission system in the VACAP Subregion consisted of approximately 5,866 miles of $230 \mathrm{kV}$, $1,475 \mathrm{miles}$ of $500 \mathrm{kV}$ and $10,600 \mathrm{miles}$ of 100 to $132 \mathrm{kV}$. To this existing system the following seọuence of additions are planned through 1989 : 
XI. 7.57

\section{Additional Transmission Lines in Miles}

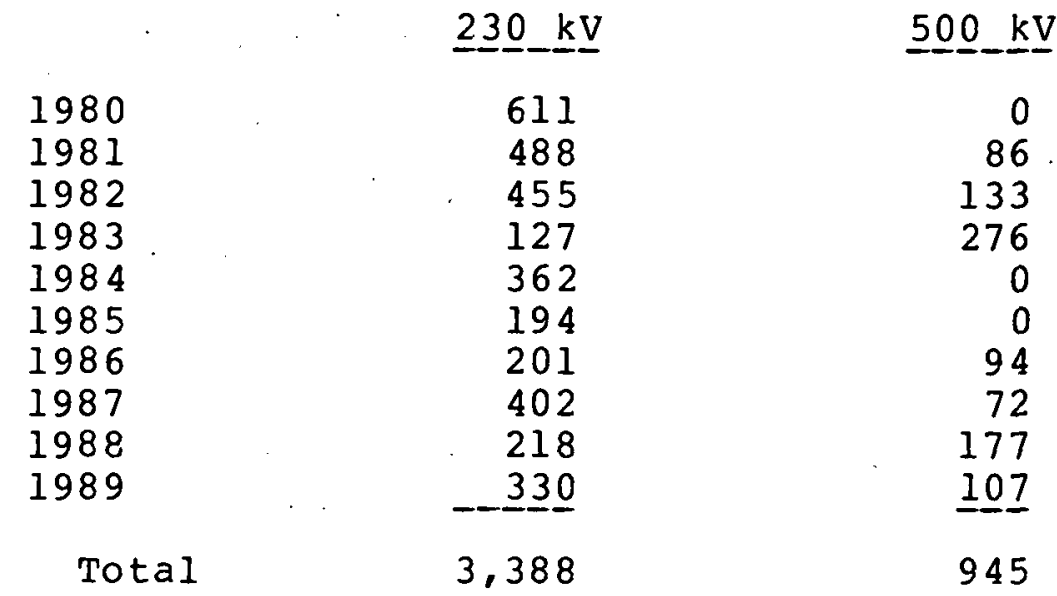

The transmission additions above to generating capacity addition during the same period amounts to $124 \mathrm{MW}$ miles per $\mathrm{MW}$. Ey the end of 1989 the VACAR Subregion will have a planned transmission capability of 5.2 million megawatt miles.

The in-service dates for the majority of the planned generating unit additions during 1980-1989 period have slipped for a total of $228,240 \mathrm{MW}$-months. The greatest portion of this slippage occurred in nuclear units with a total of $175,740 \mathrm{MW}$-mont.hs. Cf this amount, $139,980 \mathrm{MW}$-months is identified with four of the seven units delayed. There is $1,800 \mathrm{MW}$ of nuclear capacity still on schedule. In-service dates for six coal units have slipped for a total of $63,960 \mathrm{MW}$-months, while in-service dates for two units have advanced 11,460 MW-months for a net slippage of $52,500 \mathrm{MW}$-months. A ninth coal unit of $720 \mathrm{MW}$ capacity is on schedule. Since most of the slippage occurs after 1985 and the subregion is predominantly of coal and nuclear capacity, the slippage may not be critical from an intra-subregion fuel use standpoint. The effects of delays of in-service dates from the load-supply standpoint, would be dependent on the load growth in the next few years. 
Table 7D.3

HISTORICAL CAPABILITY AND RESERVE MARGINS VERGINIA-CAROL INAS GROUP REGION

\begin{tabular}{|c|c|c|c|c|}
\hline & \multicolumn{3}{|c|}{1977 Summer } \\
\hline & & June & July & August \\
\hline (1) & Planned Capability (MW) & 32,468 & 32,748 & 32,733 \\
\hline (2) & Peak Demand (MW) & 23,686 & 26,370 & 25,486 \\
\hline (3) & Planned Reserve (MW) $(1-2)$ & 8,782 & 6,378 & 7,247 \\
\hline (4) & Planned Reserve $(q)(3 \div 2) \times 1 C 0$ & 37.1 & $24 \cdot \tilde{2}$ & 28.4 \\
\hline (5) & Net Transactions 1/ (MW) & 243 & 2,720 & 1,858 \\
\hline (6) & Total Capability TMW $(1+5$. & 32,711 & 35,468 & 34,591 \\
\hline (7) & Total Reserve (MW: (6-2) & 9,025 & 9,098 & 9,105 \\
\hline (8) & Total Reserve $(*)(7 \div 2) \times=00$ & 38.1 & 34.5 & 35.7 \\
\hline (9) & Scheduled Maintenance (MW) & 2,359 & 1.292 & 867 \\
\hline (10) & Capability After Maintenance iMW) (6-9: & 30,352 & 34,176 & 33,724 \\
\hline 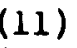 & Reserve After Maintenance (MWI (10-2) & 6,666 & 7,806 & 8,238 \\
\hline 12) & Reserve After Maintenance $1 z)(11 \div z) \times 100$ & 28.1 & 29.5 & 32.3 \\
\hline (1) & Inoperable Capability (MW) & 0 & 0 & 0 \\
\hline 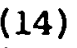 & Available Capability (MW) :10-13) & 30,352 & 34,176 & 33,724 \\
\hline 15) & Available Reserve (MW) (14-2) & 6,666 & 7,806 & 8,238 \\
\hline 16) & Available Reserve (q) $(15 \div 2) \times 100$ & 28.1 & 29.6 & 32.3 \\
\hline ) & Forced outages (F.O.) (MW) & 4,508 & 5,646 & 5,978 \\
\hline 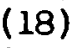 & Available Capability After F.O. (MW) (14-17) & 25,844 & 28,530 & 27,746 \\
\hline & Actual Reserve (MW) $(18-2)$ & 2,158 & 2,160 & 2,260 \\
\hline 20 & Actual Reserve $(q)(19 \div 2) \times 100$ & 9.1 & 8.2 & 8.9 \\
\hline
\end{tabular}

$1977 / 1978$ winter

\begin{tabular}{|c|c|c|}
\hline December & January & February \\
\hline 33,339 & 33,339 & 33,306 \\
\hline 23,453 & 25,441 & 25,814 \\
\hline 9,886 & 7,898 & 7,492 \\
\hline 42.2 & 31.0 & 29.0 \\
\hline 1,127 & 1,145 & 589 \\
\hline 34,466 & 34,484 & 33,895 \\
\hline 11,013 & 9,043 & 8,081 \\
\hline 47.0 & 35.5 & 31.3 \\
\hline 2,460 & 1,783 & 2,473 \\
\hline 32.006 & 32,701 & 31,422 \\
\hline 8,553 & 7,260 & 5,608 \\
\hline 36.5 & 28.5 & 21.7 \\
\hline 0 & 0 & 0 \\
\hline 32,006 & 32,701 & 31,422 \\
\hline 8,553 & 7,260 & 5,608 \\
\hline 36.5 & 28.5 & 21.7 \\
\hline 6,709 & 6,571 & 4,448 \\
\hline 25,297 & 26,130 & 26,974 \\
\hline 1,844 & 689 & 1,160 \\
\hline 7.9 & 2.7 & 4.5 \\
\hline
\end{tabular}

1/ Net Transactions = Furchases - Sales 
Table 7D.4

HISTORICAL CAPABILITY AND RESERVE MARGINS VIRGINIA-CAROLINAS GROUP REGION

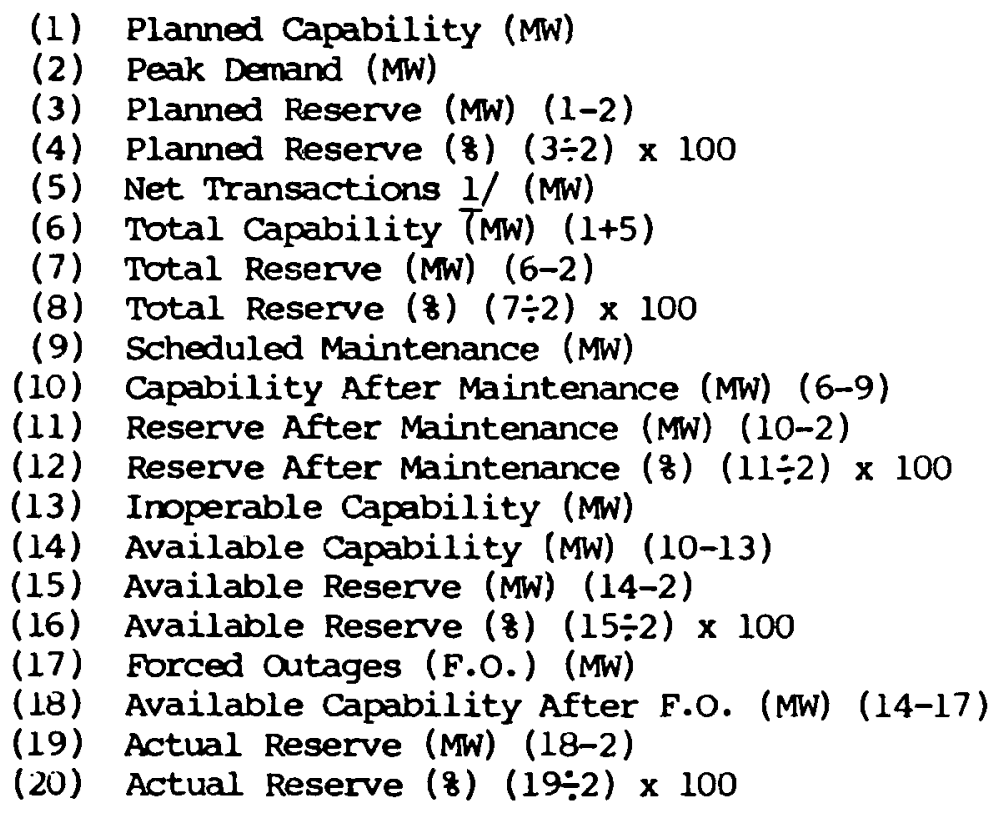

\begin{tabular}{|c|c|c|}
\hline \multicolumn{3}{|c|}{1978 Summer } \\
\hline June & July & August \\
\hline 33,864 & 33,892 & 33,892 \\
\hline 25,750 & 26,006 & $26,20 \mathrm{C}$ \\
\hline 8,114 & 7,886 & 7,692 \\
\hline 31.5 & 30.3 & 29.5 \\
\hline 2,014 & 1.530 & 2,178 \\
\hline 35,878 & 35,422 & 36,070 \\
\hline 10,123 & 9,416 & $9,87 a$ \\
\hline 39.3 & 36.2 & 37.7 \\
\hline 2,484 & 1,490 & 1,828 \\
\hline 33,394 & 33,932 & 34,242 \\
\hline 7,644 & 7,926 & 8,042 \\
\hline 29.7 & 30.5 & 30.7 \\
\hline D & 0 & 0 \\
\hline 33,394 & 33,932 & 34,242 \\
\hline 7,644 & 7,926 & 8,042 \\
\hline 29.7 & 30.5 & 30.7 \\
\hline 6,233 & 5,325 & 5,505 \\
\hline 27,16 & 28,607 & 28,737 \\
\hline $1,41:$ & 2,601 & 2,537 \\
\hline 5.5 & 10.0 & 9.7 \\
\hline
\end{tabular}

1978/1979 winter

\begin{tabular}{|c|c|c|}
\hline December & January & February \\
\hline $\begin{array}{l}34.513 \\
23.753\end{array}$ & $\begin{array}{l}34,768 \\
26.063\end{array}$ & $\begin{array}{l}34.768 \\
25.943\end{array}$ \\
\hline 10,760 & 8,705 & 8,825 \\
\hline 45.3 & 33.4 & 34.0 \\
\hline 414 & 289 & 1,528 \\
\hline 34,927 & 35,057 & 36,296 \\
\hline 11,174 & 8,994 & 10,353 \\
\hline 47.0 & 34.5 & 39.9 \\
\hline 2,669 & 1,252 & 1,992 \\
\hline 32,258 & 33,805 & 34,304 \\
\hline 8,505 & 7,742 & 8,361 \\
\hline 35.8 & 29.7 & 32.2 \\
\hline 0 & 0 & 0 \\
\hline 32,258 & 33,805 & 34,304 \\
\hline 8,505 & 7,742 & 8,361 \\
\hline 35.8 & 29.7 & 32.2 \\
\hline 7,071 & 6,033 & 5,777 \\
\hline 25,187 & 27,772 & 28,527 \\
\hline 1,434 & 1,709 & 2,584 \\
\hline 6.0 & 6.6 & 10.0 \\
\hline
\end{tabular}

1/ Net Transactions = Purchases - Sales 
Table 7D.5

HISTORICAL CAPABILITY AND RESERVE MARGINS VIRGINIA-CAROLINAS GROUP RASION

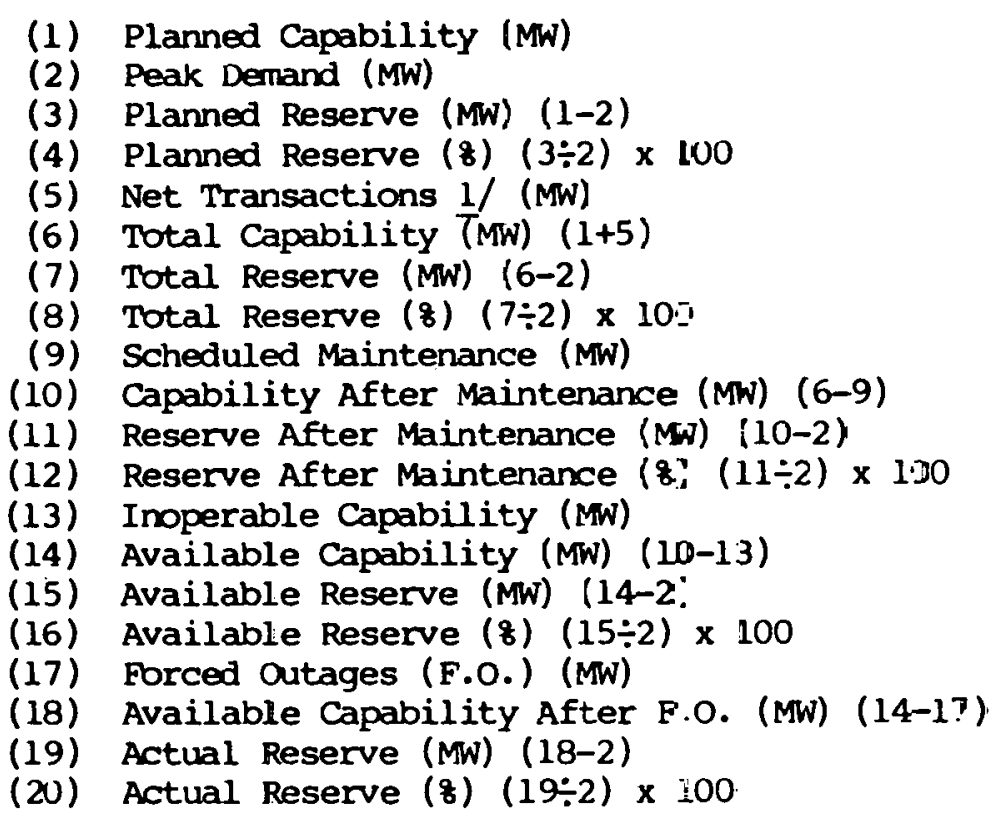

\begin{tabular}{|c|c|c|}
\hline & Sunmer & \\
\hline June & July & August \\
\hline 34,300 & 34,195 & 34,195 \\
\hline 22,474 & 25,475 & 27,494 \\
\hline 11,826 & 8,720 & 6,701 \\
\hline 52.6 & 34.2 & 24.4 \\
\hline 1,511 & 3.079 & 2,309 \\
\hline 35,811 & 37,274 & 36,504 \\
\hline 13,337 & 11,799 & 9,010 \\
\hline 59.3 & 46.3 & 32.8 \\
\hline 5,244 & 3,744 & 6,285 \\
\hline 30,567 & 33,530 & 30,219 \\
\hline 8,093 & 8,055 & 2,725 \\
\hline 36.0 & 31.6 & 9.9 \\
\hline 0 & 0 & 0 \\
\hline 30,567 & 33,530 & 30,219 \\
\hline 8.093 & 8,055 & 2,725 \\
\hline 36.0 & 31.6 & 9.9 \\
\hline 4,889 & 6,285 & 5,431 \\
\hline 25,678 & 27,245 & 24,788 \\
\hline 3,204 & 1.770 & $(2,706) \underline{2}$ \\
\hline 14.3 & 7.0 & $(9.8) \overline{2}$ \\
\hline
\end{tabular}

\begin{tabular}{cccc}
\multicolumn{3}{c}{$1979 / 1980$ Winter } \\
\cline { 1 - 1 } Decenber & January & February \\
\cline { 5 - 5 } 34,540 & & 34,492 & 34,498 \\
24,806 & 24,774 & 26,627 \\
9,734 & 9,718 & 7,871 \\
39.2 & 39.2 & 29.6 \\
2,227 & 2,000 & 2,894 \\
36,767 & 36,492 & 37,392 \\
11,961 & 11,718 & 10,765 & \\
48.2 & 47.3 & 40.4 & \\
4,896 & 2,845 & 3,158 & \\
31,871 & 33,647 & 34,234 & \\
7,065 & 8,873 & 7,607 & \\
28.5 & 35.8 & 28.6 & \\
0 & 0 & 0 & \\
31,871 & 33,647 & 34,234 & $\times$ \\
7,065 & 8,873 & 7,607 & 0 \\
28.5 & 35.8 & 28.6 & - \\
4,847 & 5,042 & 4,299 & $\circ$ \\
27,024 & 28,605 & 29,935 & $\circ$ \\
2,218 & 3,831 & 3,308 & \\
8.9 & 15.5 & 12.4 &
\end{tabular}

\footnotetext{
1/ Net Transactions = Purchases - Sales

2/ ( ) denotes negative rumber
} 
Table 7D.7

CURRENT CAPABILITY AND RESERVE MARGINS VIRGINIA-CAROLINAS GROUP REGION

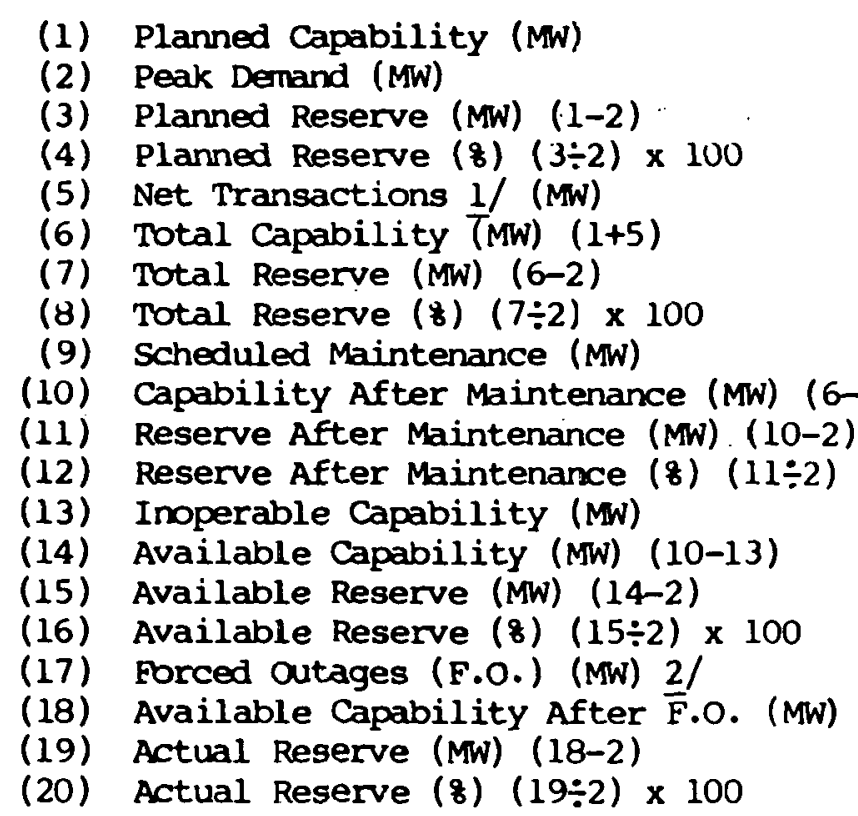

1/ Net Transactions = Purchases - Sales

2/ Derived from the historic seasonal forced outage rate by the ERA Field office Staff
1980 Summer

\begin{tabular}{|c|c|c|}
\hline June & July & August \\
\hline 34,344 & 35,242 & 36,422 \\
\hline 25,236 & 27,903 & 28,353 \\
\hline 9,108 & 7,339 & 8,069 \\
\hline 36.1 & 26.3 & 28.5 \\
\hline 843 & 843 & 843 \\
\hline 35,187 & 36,085 & 37,265 \\
\hline 9.951 & 8,182 & 8,912 \\
\hline 39.4 & 29.3 & 31.4 \\
\hline 4,845 & 2,045 & 1.060 \\
\hline 30,342 & 34,040 & 36,205 \\
\hline 5,106 & 6,137 & 7,852 \\
\hline 20.2 & 22.0 & 27. \\
\hline 0 & 0 & 0 \\
\hline 30,342 & 34,040 & 36,205 \\
\hline 5,106 & 6,137 & 7,852 \\
\hline 20.2 & 22.0 & 27. \\
\hline 5,533 & 5,533 & 5,533 \\
\hline 24,809 & 28,507 & 30,672 \\
\hline (427) 3/ & 604 & 2,319 \\
\hline$(1.7)$ & 2.2 & 8 \\
\hline
\end{tabular}

1980/1981 Winter

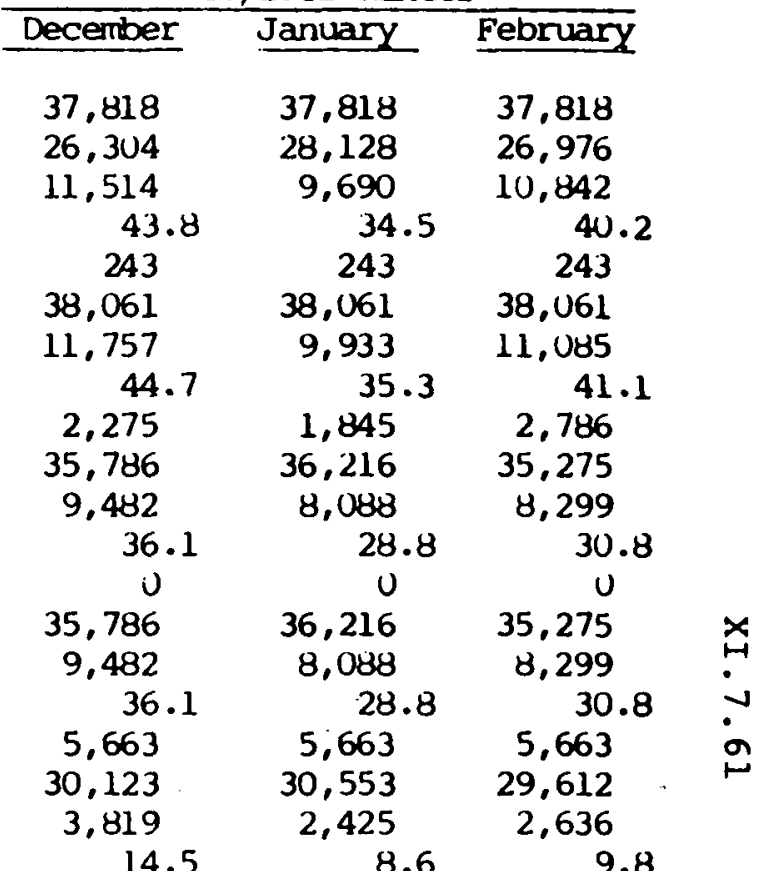

/ ( ) denotes negative number 
FUTURE CAPABILITY AND RESERVE MARGINS 1941-1984

$$
\text { VI RGINIA-DAROLINNS GROIP RPIION }
$$

1) Planned Capability (Mu)

2) Peak Denand (MW)

3) Planned Reserve (mw) (1-2)

4) Planned Peserve (8) $(3 \div 2) \times 100$

5) Net Transactions 1/ (MW)

6) Total Capability $T(w)(1+5)$

7) Total Reserve (MW) (6-2)

8) Total Regerve (8) $(7 \div 2) \times 100$

9) Scheduled Maintenance (MW)

0) Capability After Maintenance (Mv) (6-9)

1) Reserve After Maintenance (MW) $(10-2)$

2) Reserve After Maintenance (B) $(11 \div 2) \times 100$

3) Inoperable Capability (MW)

4) Available Capability (MW) (10-13)

15) Available Reserve (MW) (14-2)

16) Available Reserve (8) $(15 \div 2) \times 100$

(7) Forced Outages (F.O.) (MW) $2 /$

(8) Available Capability After $\bar{F} .0$. (MW) (14-17)

19) Actual Reserve (MW) (18-2)

20) Actual Reserve (8) $(1 \%: 2) \times 100$

\begin{tabular}{cc}
1981 & \\
\hline Suminer & Wnter \\
\hline 38,861 & 39,538 \\
39,774 & 10,157 \\
9,787 & 9,381 \\
30.5 & 31.1 \\
300 & $(300) 3 /$ \\
39,161 & 39,238 \\
9,387 & $9, j 81$ \\
31.5 & 30.1 \\
64 & 1,533 \\
$39,097$. & 37,505 \\
9,323 & 7,748 \\
31.3 & 24.7 \\
0 & 0 \\
39,097 & 37,505 \\
9,323 & 7,748 \\
31.3 & 24.7 \\
5,533 & 5,563 \\
33.564 & 31,342 \\
3,790 & 1,785 \\
12.7 & 5.9
\end{tabular}

\begin{tabular}{|c|c|}
\hline \multicolumn{2}{|c|}{1982} \\
\hline Summer & Winter \\
\hline 40.041 & 40,718 \\
\hline 31,966 & 31,572 \\
\hline 8,075 & 9,146 \\
\hline 25.3 & 29.0 \\
\hline 300 & $(300) 3 i$ \\
\hline 40,341 & 40,418 \\
\hline 8,375 & 8,846 \\
\hline 26.2 & 28.0 \\
\hline $15 u$ & 2,460 \\
\hline 40,191 & 37.958 \\
\hline 8.225 & 6,386 \\
\hline 25.7 & 20.2 \\
\hline $\mathrm{u}$ & 0 \\
\hline 40,191 & 37.958 \\
\hline 8,225 & 6,336 \\
\hline 25.7 & 20.2 \\
\hline 5.533 & 5.663 \\
\hline 34.558 & 32.295 \\
\hline 2.592 & 723 \\
\hline 8.4 & 2.3 \\
\hline
\end{tabular}

\begin{tabular}{cc}
\multicolumn{2}{c}{1983} \\
\hline Summer & winter \\
\hline 40,761 & 43,590 \\
33,374 & 33.079 \\
7.347 & 10.519 \\
22.1 & 31.8 \\
300 & $(300) 3 /$ \\
41.061 & 43.298 \\
7.697 & 10,219 \\
23.0 & 30.9 \\
215 & 1.180 \\
40,846 & 42,118 \\
7.472 & 9,039 \\
22.4 & 27.3 \\
0 & 0 \\
40.846 & 42.118 \\
7.472 & 9.039 \\
22.4 & 27.3 \\
5.533 & 5,663 \\
35.313 & 36,455 \\
1.939 & 3.376 \\
5.8 & 10.2
\end{tabular}

1994

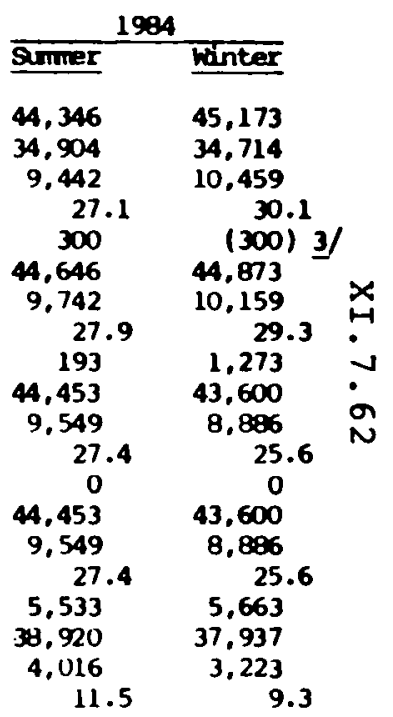

$1 /$ Net Transactions = Purchases - Sales

2/ Derived from the hlstoric seasonal foxced ontage rate by the ERA Field office Staff

3/ ( ) denotes negative number 
Table 70.11

Page 2 of 2

FUTURE CAPABILITY AND RESERVE MARGINS VIRGININ-CNODINUS GR UII' RPGIUN

(1) Planned Capablilty (Mw)

(2) Peak Demand (Mw)

(3) Planned Regerve (MW) (1-2)

(4) Planned Reserve (8) $(3 \div 2) \times 100$

(5) Net Transactions $1 /$ (MW)

(6) Total Capability (MN) $(1+5)$

(7) Total Reserve (MW) (6-2)

(b) Total Reserve (8) $(7 \div 2) \times 100$

(9) Scheduled Maintenance (MW)

(10) Capability after Maintenance (MW) (6-9)

11) Reserve after Maintenance (MW) (10-2)

(12) Reserve after Maintenance (8) $(11 \div 2) \times 100$

(13) Inoperable Capability (MW)

(14) Available Capability (MN) $(10-13)$

(15) Available Reserve (MW) (14-2)

(16) Available Regerve (8) $(15 \div 2) \times 100$

(16) Available Regerve (8) (15-2)

(17) Forced Outages (F.0.) (MW) $\times 100 \quad 2 /$

(19) Actual Reserve (MW) (18-2)

(20) Actual Reserve (8) $(19 \div 2) \times 100$

\begin{tabular}{c}
198 \\
\hline Summer \\
\hline 46.445 \\
36,531 \\
9.914 \\
27.1 \\
300 \\
46,745 \\
10,214 \\
28.0 \\
$2 /$ \\
46,745 \\
10,214 \\
28.0 \\
0 \\
46,745 \\
10.214 \\
28.0 \\
$2 /$ \\
46,745 \\
10.214 \\
28.0
\end{tabular}

Winter

46,987

36,390

10.597

29.1

46,667

10.297

28.3

$46, \frac{21}{687}$

10,297

28.3

46,687

46,687
10,297

28.3

$46, \frac{2 /}{687}$

10.297

28.3

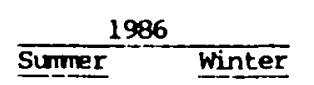

\section{$46.510 \quad 47,544$}

$38,149 \quad 38,100$

$8.361 \quad 9.444$

$\begin{array}{cc}21.9 & 24.8\end{array}$

$46,510 \quad 47,544$

8. 361

24.9

$46, \frac{21}{51}$

8,361

2L. 9

$46,511)$

8,361

$2 \mathrm{~L} .9$

46. 510

8. 361

2.. 9

9,444
24.8

$47, \frac{2 /}{544}$

9.444

0

47,544

9.444
24.8

$\frac{21}{544}$

$47, \overline{5} 44$
9,444

24.8
Summer

n

49.996

41.635
8.361

8. 361

20.1
0

49.996

8,361
20.1

४, 394

21.1

$48, \frac{21}{267}$

H. 398

21.1

48. 267

8.398

21.1

44. $\frac{21}{267}$

8. 398

21.1

24.9

49.851

$49, \frac{21}{996}$

9.949

4.361
8

20.1

0

49,996

24.9

49. पे51

8. 361

8.361
20.1

$49, \frac{21}{996}$

49.996
8.361

24.9

20.1

winter

51.033

41,701

9,332
22.4

0
51.033

9,332

$22 /$

$51 . \overline{0} 33$
9.332

9.332
22.4

51.033

9,332

22.4

$51 ., 033$

9,332
22.4

\section{$\frac{1989}{\text { Suminer }}$}

$51.756 \quad 52.325$

$43.433 \quad 43.458$

$\begin{array}{rr}8.323 & 8.867 \\ 19.2 & 20.4\end{array}$

$\begin{array}{cr}0 & 0 \\ 51,756 & 52,325\end{array}$

$8,323 \quad 8,867$

19.2

21

$51, \overline{756}$

B, 323

19.2

51.756

8,323

19.2

$51 . \frac{2 /}{756}$

8. 323

19.2

20.4

$52, \frac{21}{325}$

$\mathbf{8 , 8 6 7}$

20.4

52,325

20.4

$52 \frac{21}{325}$

52,325

8.867

$\frac{1}{2}$ Net Transactions $=$ Purchases - Sales

2/ Information on scheduled maintenance and forced outayes are not available

( ) denotes negative number 
TARLE 7D. 13

Major Future Generating Unit In-Service Dates Virginia-Carolinas Group Region

\begin{tabular}{|c|c|c|c|c|c|}
\hline Unit Designation & $\begin{array}{c}\text { Capacity } \\
\underline{M W}\end{array}$ & $\begin{array}{l}\text { Fuel } \\
\text { Type }\end{array}$ & $\begin{array}{l}\text { AS of } \\
4 / 79 \\
\end{array}$ & $\begin{array}{l}\text { As of } \\
4 / 80\end{array}$ & $\begin{array}{l}\text { Change in } \\
\text { Mri-months }\end{array}$ \\
\hline North Anna No. 2 & 907 & Nuc. & $7 / 79$ & $7 / 80$ & 10,884 \\
\hline McGuire No. 1 & 1,180 & Nuc. & $1 / 80$ & $8 / 80$ & 8,260 \\
\hline Roxboro No. 4 & 720 & Coal & $3 / 80$ & $9 / 80$ & 4,320 \\
\hline Summer No. 1 & 900 & Nuc. & $12 / 80$ & $12 / 80$ & 0 \\
\hline winyah No. 4 & 280 & Coal & $5 / 82$ & $5 / 81$ & $(3,360)$ \\
\hline McGuire No. 2 & 1,180 & Nuc. & $7 / 81$ & $7 / 82$ & 14,160 \\
\hline Mayo No. 1 & 720 & Coal & $3 / 82$ & $3 / 83$ & 8,640 \\
\hline Harris No. 1 & 900 & NuC. & $3 / 84$ & $3 / 84$ & 0 \\
\hline Catawba No. 1 & 1,145 & Nuc. & $1 / 82$ & $12 / 83$ & 26,335 \\
\hline Cross Site No. 2 & 450 & Coal & $5 / 85$ & $11 / 83$ & $(8,100)$ \\
\hline Mayo No. 2 & 720 & Coal & $3 / 85$ & $3 / 85$ & 0 \\
\hline Catawba No. 2 & 1,145 & NuC. & $7 / 83$ & $7 / 85$ & 27,480 \\
\hline Hatis No. 2 & 900 & Nuc. & $3 / 86$ & $3 . / 87$ & 10.900 \\
\hline Plant "A" & 500 & Coal & $5 / 85$ & $5 / 87$ & 12,000 \\
\hline Cross site No. 1 & 450 & Coal & $5 / 83$ & $11 / 86$ & 18,900 \\
\hline North Anna No. 3 & 907 & Nuc. & $10 / 83$ & $10 / 87$ & 43,536 \\
\hline North Anna No. 4 & 907 & Nuc. & $9 / 84$ & $8 / 88$ & 42,629 \\
\hline Harcis No. 4 & 900 & Nuc. & $3 / 88$ & $3 / 89$ & 10.800 \\
\hline Plant " $\mathrm{B}$ " & 500 & Coal & $5 / 87$ & $5 / 89$ & 12,000 \\
\hline Cross site No. 3 & 450 & Coal & $5 / 87$ & $11 / 88$ & 8,100 \\
\hline
\end{tabular}



Southwest Power Pool

\section{Introduction}

The Southwest Power Pool (SPP) area includes all of the states of Arkansas, Kansas, Louisiana and Oklahoma and part of the states of Mississippi, Missouri, New Mexico, and Texas, and serves a population of around 21,000,000. The SPP area is divided into four regions: Region 8 (Middle South Utilities Group), Region 10 (Gulf States Group), Region 21 (Missouri-Kansas Group), and Region 22 (Oklahoma Group ).

Region 8 (Middle South Utilities Group) encompasses most of Arkansas, approximately vite-lialf uf both Mlssissippi and Louisiana, and a small portion of southeast Missouri. Approximately 95 percent of the electric load served in Region 8 is supplied by the Middle South Utilities Company, Inc. Middle South is a holding company consisting of Arkansas Power \& Light Company, Louisiana Power \& Light Company, Mississippi Power \& Light Company, New Orleans Public Service Company and Arkansas-Missouri Power Company.

Region 10 (Gulf States Group) includes the southern portion of Louisiana, excluding the New orleans area, and the east central portion of Texas that is within the SPP. Regions 8 and 10 are combined into a single group by SPP and systems operating within the two Regions coordinate their planning through the SPP planning subcommittee.

Region 21 (Missouri-Kansas Group) covers almost the entire state of Kansas and the remaining part of Missouri that is in the SPP. The majority of the electric systems operating in Region 21 are members of the MOKAN Power Pool.

Region 22 (Oklahoma Group) covers the largest area of the four electric regions in SPP ranging from western Louisiana to eastern New Mexico. It includes all of oklahoma and portions of Arkansas, Kansas, Louisiana, Texas, and New Mexico.

All Electric Regions within SPP experience their annual peak demand in the summer, usually during prolonged hot-dry periods called heat storms. The growth of peak demand for the entire 
SPP has been declining since the early 1970's, and as a result, the systems have been revising and reducing their projected rate of growth annually. Table 8.1 shows projected rates of growth for summer and winter peak demands and annual energy as reported by SPP in its 1970, 1975 and 1980 reliability reports. The growth rates are for ten. year periods.

\section{Table 8.1}

Compound Annual Growth Rate Southwest Power Pool

Report Year

1970

1975

1980

$\frac{\text { Peak Demand }}{\frac{\text { Summer }}{(8)}} \frac{\text { Winter }}{(8)}$

10.7

8. 2

$5 \cdot 1$

$$
\begin{array}{r}
10.1 \\
8.5 \\
5.3
\end{array}
$$

Annual Energy

1.3 .4

$8 \cdot 3$

$5 \cdot 3$

Although each Electric Region in SPP has coal-fired generating units either in service or under construction, and one, Region 8 , has two nuclear units in operation, the area is heavily dependent upon natural gas and oil for electric generation. During the year 1978 SPP obtained 59.2 percent of its electric generation from natural gas, 18.7 percent from fuel oil, 16.8 percent from coal, 2.7 percent from nuslear and 2.6 percent from hydroelectric plants. SPP burned $61,618,000$ barrels of oil in 1978, 86.8 percent of which was residual oil. During the period 1980 through 1989 systems in SPP are projectin 927,215 megawatts of new coal-fired capacity, 6,311 megawatts combustion turbine and internal combustion capacity and 380 megawatts of capacity which is undecided. Tables 8.2 and 8.3 provide lists of projected coal-fired capacity and nuclear-fueled capacity, respectively.

The SPP has a backbone transmission system at the 500-kV level in Regions 8 and 10 and $345-\mathrm{kV}$ in Regions 21 and 22 . The 500-kV system was developed primarily to effect a 1,500 MW diversity interchange with the Tennessee Valley-Authority which commenced in June 1967. The interchange was reduced to $1,100 \mathrm{MW}$ in 1979 and will be further decreased to $700 \mathrm{MW}$ in 1981 and $200 \mathrm{MW}$ in 1984. 
The Central and South west Operating Company (Public Service Company of oklahoma and Southwestern Electric Power Company in SPP and Central Power \& Light Company and West Texas Utilities Company in ERCOT) made application to the F.E.R.C. on February 9, 1979, for an interconnection between SPP and ERCOT. The interconnecting lines proposed by central \& South West were shown on the map furnished by SPP in its 1980 ERA-4ll; however, they were not included in the list of proposed bulk lines in Item 5-B of ERA-4l1.

In the remainder of this report a four-part examination, consisting of historical perspective, current perspective, near-term future perspective, and long-term future perspective, is made for each electrical region in SPP. The historical section covers actual load and supply conditions in 1977 through 1979 for systems reporting on the monthly EIA Form 12E-2. The current near-term and long-term sections report the projected load and supply conditions for members of SPP gas, therefore, the coferage is not exactly synonymous. Table 8.4 provides a list of Form $12 \mathrm{E}-2$ respondents and members of SPP and indicates the difference in coverage. In addition, the final section of each electric region text discusses peak demand and annual energy projections and the resulting annual load factors for the period 1980 through 1989. 
Middle South Utilities Area (Region 8)

Historical Perspective

Until the early 1970's, the Middle South area experienced high growth rates for both peak demand and energy. The compound annual growth rate from 1960 to 1976 was 9.6 percent. The following table illustrates the high rate of growth during the first twenty years of this period and the sharp decline in peak demand and energy requirements after 1970 .

Tabié 8A.1

HISTORICAL COMPOUND ANNUAL GROWTH RATES Middle South Utilities Group (Region 8)

\begin{tabular}{|c|c|c|}
\hline Period & $\frac{\frac{\text { Compound }}{\text { Peak Demand }}}{(8)}$ & $\frac{1 \text { Growth Rate }}{\frac{\text { Annual Energy }}{(8)}}$ \\
\hline $1950-60$ & 10.4 & 9.3 \\
\hline $1960-70$ & 10.2 & 10.2 \\
\hline $1970-76$ & 7.4 & 6.9 \\
\hline
\end{tabular}

Due to the growth rate reductions experienced in the $1970^{\prime} \mathrm{s}$, projections. of future requirements have been reduced annually for the last several ycare. The average compound rate of growth for the 1980-1989 period in Region 8 is approximately 5.5 percent (see Table 8A.8). This compares to a forecasted growth rate of 7.2 percent in 1979. The latesl reduction indicates that the systems in Region 8 still anticipate substantial reductions in electric growth due to a number of factors all related to inflation.

Additional evidence of the decline in electric growth rates is shown by Table $8 \mathrm{~A} .3$, which provides summer and winter peak demands, annual energy requirements and annual load factors for the years 1977 through 1979. Annual growth rates for 1977 to 1978 and 1978 to 1979 are also shown.

Although much of the existing generating capacity in Region 8 , which was originally designed to burn natural gas, has been either converted or adapted to burn oil, the area continues to obtain a majority of its electric generation from natural gas fuel. 
The following table ${ }^{1 /}$ shows the 1979 end-of-year installed capacity by fuel type and the resulting annual generation each fuel contributed:

Table 8A.2

HISTORICAL INSTALLED CAPACITY AS OF DECEMBER 1979 Middle South Utilities Group (Region 8 )

\begin{tabular}{|c|c|c|c|c|}
\hline Fuel Type & \multicolumn{2}{|c|}{$\begin{array}{l}\text { Installed Capacity } \\
\text { (MW) (8of Total) }\end{array}$} & \multicolumn{2}{|c|}{$\begin{array}{l}\text { Annual Generation } \\
\text { (Gwh) (8of Total) }\end{array}$} \\
\hline $\begin{array}{l}\text { Nuclear } \\
\text { Coal } \\
\text { Natural Gas } \\
\text { Oil } \\
\text { Hydro }\end{array}$ & $\begin{array}{r}902 \\
39 \\
9,479 \\
2,307 \\
65\end{array}$ & $\begin{array}{r}7.1 \\
0.3 \\
74.1 \\
18.0 \\
0.5\end{array}$ & $\begin{array}{r}3,873 \\
153 \\
25,344 \\
14,115 \\
252\end{array}$ & $\begin{array}{r}8.9 \\
0.3 \\
57.9 \\
32.3 \\
0.6\end{array}$ \\
\hline Total & 12,792 & 100.0 & 43,737 & 100.0 \\
\hline
\end{tabular}

There are two operating nuclear units owned by Arkansas Power \& Light Company, Arkansas Nuclear One Units No. 1 and No. 2. Unit No. 2 of Arkansas Nuclear One was placed in service on March 27, 1980.

Systems operating in Region 8 plan for a minimum total reserve of 16 percent of forecasted peak demand and in accordance with the SPP Coordination Agreement must maintain, with system capacity or contractural arrangements, actual reserves of 6 percent of peak demand, 3 percent of which must be spinning. During the past several years, systems in the Middle South Area have been experiencing a high amount of forced outages on their generating units, due primarily to the increased use of fuel oil in boilers designed for natural gas operation. Tables $8 \mathrm{~A} .4 .1$ and $8 \mathrm{~A} .4 .2$ provide the actual reserve situation which occurred in Region 8 for the summer and winter periods for 1977 through 1979. Capability out of service on forced outage during the summer peak periods varied from a low of 3.3 percent in August 1977 to a high of 22 percent in June 1979. During the last two (1978 and 1979) summer peak periods, Region 8 would have experienced negative actual reserves without the benefit of capacity purchases.

The Middle south has strong intra-regional and interregional interconnections at the $500 \mathrm{kV}$ level. This backbone transmission system was developed mainly as a result of the diversity interchange agreement between the South Central Electric Companies and the Tennessee valley Authority.

1/ Source of information is EIA-4 Form data, based on Form $12 \mathrm{E}-2$ respondents. 
Due in a large part to the escalation of fuel prices and the curtailment of natural gas supplies, Region 8 has been a net energy purchaser during the last three years. The net energy purchased during 1977, 1978, and 1979, was 5961 GWh, 7104 GWh and 15339 GWh, respectively. In terms of percent of energy for load, these purchases were 11.0 percent in $1977,12.4$ percent in 1978 , and 25.8 percent in 1979 .

\section{Current Perspective}

The Middle South Utilities Group is projecting to install the 740-MW White Bluff No. I coal-fired unit by the 1980 summer peak. Ninety-eight percent of the capacity belongs to the Middle south Group. Present information shows no delays in this in-service date.

Total installed reserves are projected to be 25.4 percent in the 1980 summer and 61.2 percent during the 1980/81 winter peak. No inoperable capability is expected and scheduled maintenance, performed in the winter, would result in available reserves of 25.4 percent and 39.9 percent for the summer and winter peaks, respectively. Estimated forced outages create actual reserves of 11.9 percent in the summer and 18.6 percent in the winter. All reserves are well above the SPP criteria for both planned and available reserves. Table $8 \mathrm{~A} .5$ shows the reserve situation for the 1980 summer peak and $1980 / 81$ winter peak.

Excess capacity should be available to supply the Gulf states Group with emergency power if needed. (See the Gulf states group's current perspective for more detail.)

During the evening of April 8, 1980 , tornadoes occurred in North Arkansas damaging approximately eighty-nine $500 \mathrm{kV}$ towers and eighty 115- and 161-kV wood pole structures belonging to the Arkansas Power \& Light Company. The Arkansas Nuclear One generating station (1748 MW) was shut down due to a lack of transmission out of the plant. Sufficient 161-kv circuits were restored within 12 days to operate Unit No. 2 at a reduced capacity of approximately $720 \mathrm{MW}$. The Company reports that repairs to transmission lines should be completed before the summer peaking season so that the full capability of the plant will be available during that period.

\section{Future Perspective}

The Middle South Utilities Group is projecting 1450 MW of coalfired capacity and $2,235 \mathrm{MW}$ of nuclear capacity in this time period. 
Total (summer) reserves are projected to range from 20.9 percent to 34.9 percent (see Table $8 \mathrm{A.6}$ ) which is well above the SPP criteria. Since Region 8 projects no scheduled maintenance or inoperable capability during the summer period, the available reserves are the same as total reserves. Actual reserves, which include 13.4 percent of forced outages based on historical summer trends, range from 7.5 to 21.5 percent. An NRC projected nuclear delay of the Waterford No. 3 nuclear unit beyond the 1982 summer peak would result in actual reserves from 7.5 percent to 17.4 percent (which appears to be adequate). With possible coal unit delays, the available reserves would range from 7.5 percent to 12.9 percent (also adequate).

The Middle South Group appears to have enough capacity to handle expected demand with possible forced outages and nuclear and coalfired unit delays. The Region, however, may be needed to supply emergency power to the Gulf states Group (Region 10) during the 1981-1985 period as discussed in the Gulf States Perspective. Middle South and Gulf States should have enough existing and proposed interchange capability to allow the necessary emergency transfer of power during the peak periods. In addition to the proposed tie with Region 10, Middle south is projecting a $161-k V$ tie in 1981 with ILLMO (Region 17) to increase interchange capability. This tie will be increased in voltage to $500-\mathrm{kV}$ in 1984.

The Middle South Utilities Group is projecting 3,725 MW of coalfired capacity and $1,125 \mathrm{MW}$ of nuclear capacity in the 1985-1989 period.

Reserve margins, not including the effects of scheduled maintenance and forced outages, would range from 16.3 to 26.4 percent, which should be adequate (see Table 8A.7). The Region would have enough excess capacity to handle forced outages based upon historical rates and should have enough reserve to help the Gulf states Group if necessary. There are no nuclear delays projected in this time period.

Interregional interchange capability should be increased with a proposed 500-kV tie with TVA in 1986.

It would appear that the Middle South Utilities Group would have ample capacity to supply all of its own load requirement throughout the decade and help the neighboring Gulf states Group with emergency power.

During the 10-year period from 1980 to 1989, summer and winter peak is projected to increase at an average rate of 5.5 percent per year (see Table 8A.8). Annual energy requirements are forecasted to increase at a rate of 5.4 percent. The annual load factor is expected to vary only slightly from 57.0 percent to 57.3 percent during the decade. 
Table 8A.9 shows that the Middle South Utilities Group is and will continue to be heavily dependent upon natural gas and oil-fired capacity. Gas and oil-fired generation is expected to constitute 78.9 percent of total net capability during the 1980 summer peak. This percentage is projected to decrease to 55.1 percent in 1985 and 46.8 percent in 1989. Assuming purchases of 590 MW during the 1989 summer peak, the Region's total capability would have an average plant factor of 49.1 percent based upon a net capability of $21980 \mathrm{MW}$ and energy requirements of $94528 \mathrm{GWh}$. If half of the $10015 \mathrm{MW}$ of gas and oil-fired capacity were unavailable, the remaining units would have to operate at an average plant factor of 65.9 percent.

Table 8A.3

HISTORICAL LOAD GROWTH

Middle South Utilities Group (Region 8)

\begin{tabular}{|c|c|c|c|c|c|c|}
\hline & $\mathrm{D}$ & $\mathbf{a} \mathbf{n} \mathbf{d}$ & - & $\begin{aligned} & A \\
\text { Energy } & R\end{aligned}$ & $\begin{array}{l}\text { Annual } \\
\text { Requirement.s }\end{array}$ & $\begin{array}{c}\text { Anniva]. } \\
\text { Load }\end{array}$ \\
\hline $\begin{array}{l}\text { (Mmmer } \\
\text { (MW) }\end{array}$ & $\begin{array}{l}\text { Growth } \\
\text { ( } 8)\end{array}$ & $\begin{array}{l}\text { Winter } \\
\text { (MW) }\end{array}$ & $\begin{array}{c}\text { Growth } \\
\text { (8) }\end{array}$ & $\begin{array}{l}\text { Amount } \\
\text { (GWh) }\end{array}$ & $\begin{array}{l}\text { Growth } \\
\text { (8) }\end{array}$ & $\begin{array}{c}\text { Factor } \\
\text { (\&) }\end{array}$ \\
\hline
\end{tabular}

$\begin{array}{llclllll}1977 & 11,480 & - & 7,980 & - & 53,954 & - & 53.7 \\ 1978 & 11,322 & -1.38 & 8,591 & 7.66 & 57,453 & 6.49 & 57.9 \\ 1979 & 11,433 & 0.98 & 8,613 & 0.26 & 59,482 & 3.53 & 59.4\end{array}$


HISTORICAL CAPABILITY (MW) AND RESERVES (MW and Percent) Middle South Utilities Group (Region 8)

1. Planned Capability

2. Peak Demand

3. Planned Reserves (1-2)

4. Planned Reserves $(\%)(3 / 2) \times 100$

5. Net Transactions (Imports-Exports)

6. Total Capability $(1+5)$

7. Total Reserves (6-2)

8. Total Reserves $(\%)(7 / 2) \times 100$

9. Scheduled Maintenance

10. Capability after Maintenance (6-9)

11. Reserves after Maintenance (10-2)

12. Reserves after Maintenance $(\%)(11 / 2) \times 100$

13. Inoperable Capability

14. Available Capability (10-13)

15. Available Reserves (14-2)

16. Available Reserves (\%) (15/2) x 100

17. Forced Outages

18. Actual Capability after Forced Outages (14-17)

19. Actual Reserves (18-2)

20. Actual Reserves (\%) $(19 / 2) \times 100$

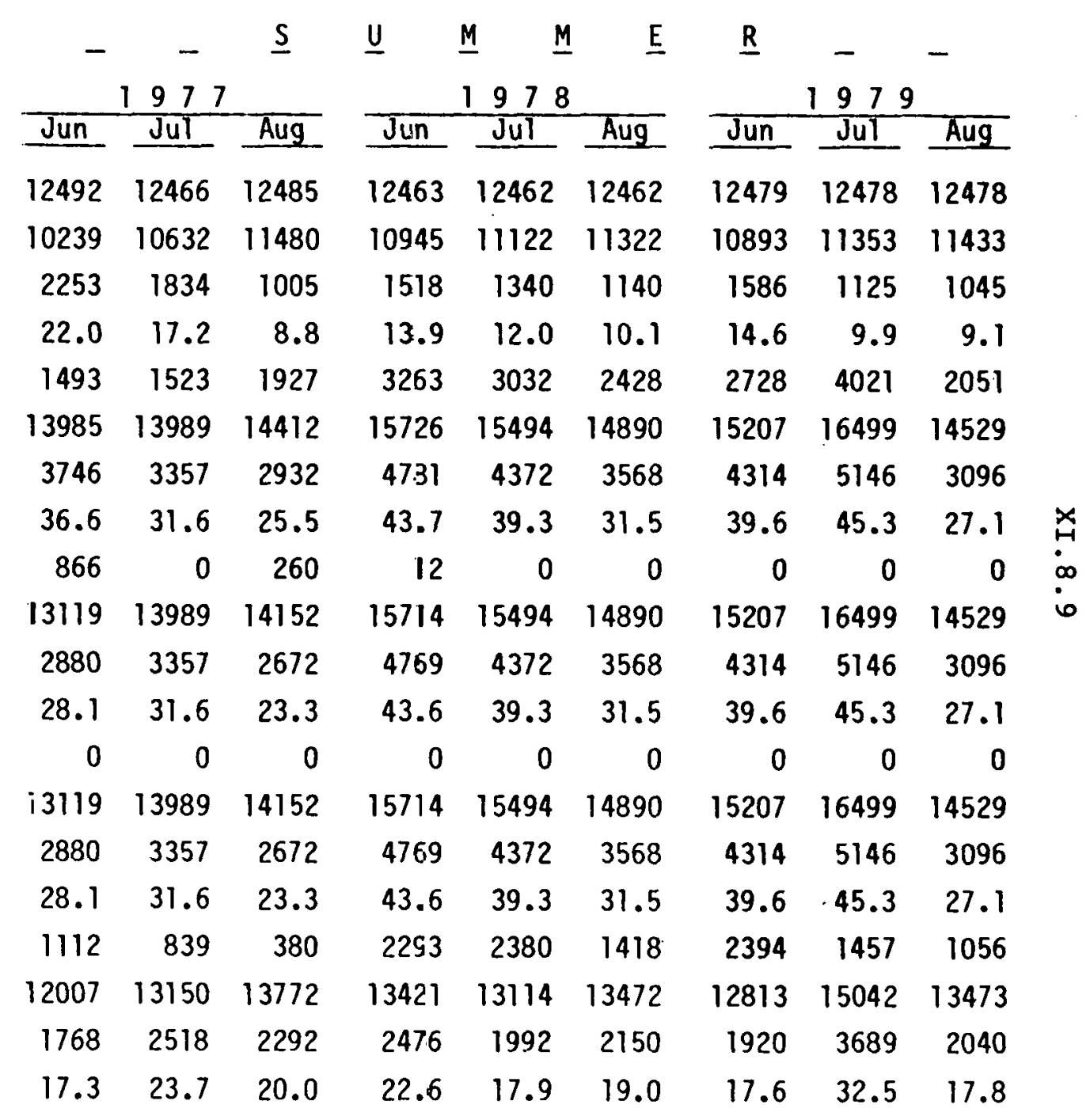


HISTORICAL CAPABILITY (MW) AND RESERVES (MW and Percent) Middle South Utilities Group (Region 8)

1. Planned Capability

2. Peak Demand

3. Planned Reserves (1-2)

4. Planned Reserves (\%) (3/2) $\times 100$

5. Net Transactions (Imports-Exports)

6. Total Capability $(1+5)$

7. Total Reserves (6-2)

8. Total Reserves (\%) $(7 / 2) \times 100$

9. Scheduled Maintenance

10. Capability after Maintenance (6-9)

11. Reserves after Maintenance ( $70-2)$

12. Reserves after Maintenance (q) $\{11 / 2) \times 100$

13. Inoperable Capability

14. Available Capability (10-13)

15. Available Reserves (14-2)

16. Available Reserves (\%) $(15 / 2)=100$

17. Forced Outages

18. Actual Capability after Forced Outages (14-17)

19. Actual Reserves (18-2)

20. Actual Reserves (\%) $(19 / 2) \times 100$

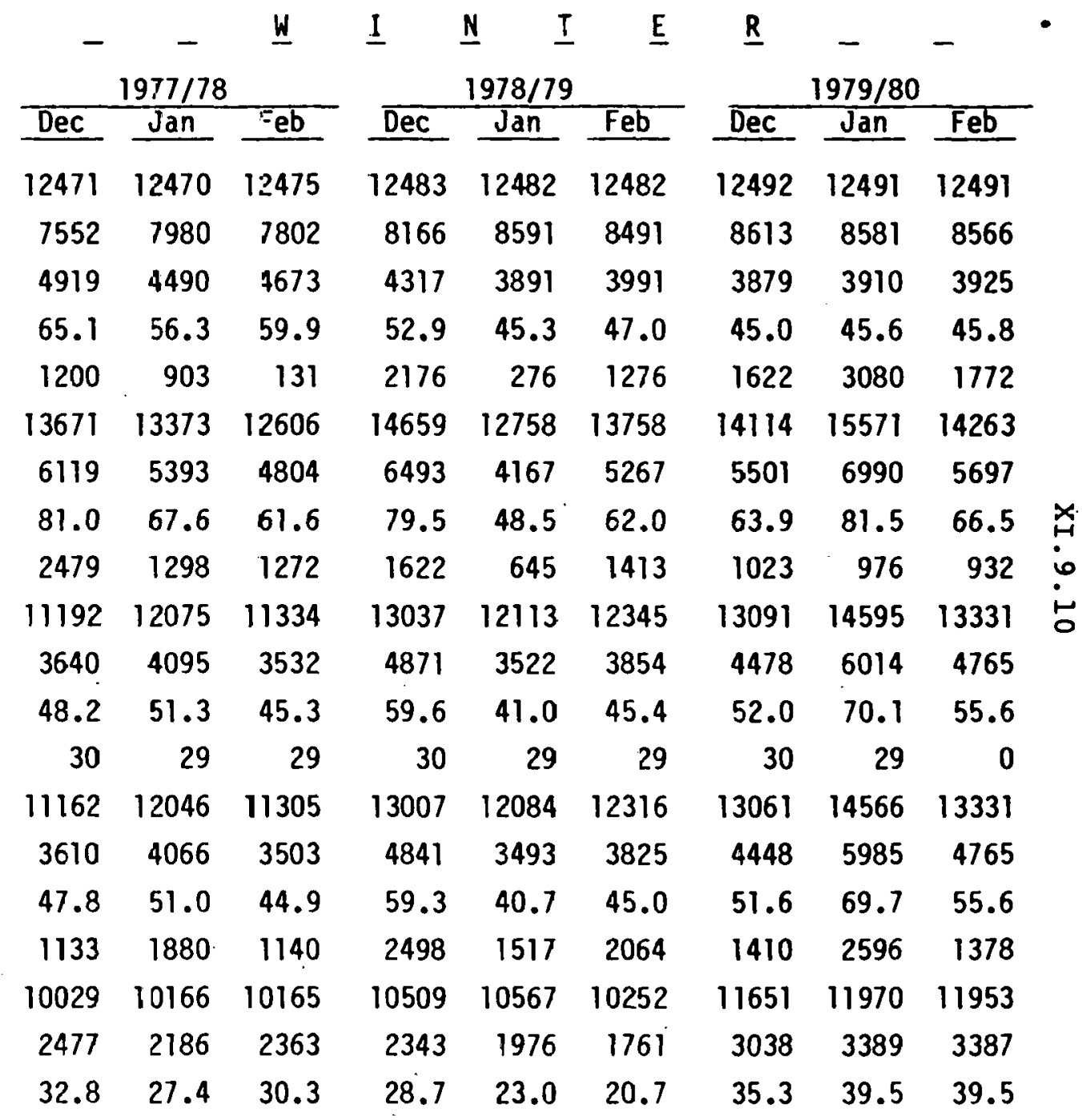




\section{Table 8A.5}

CURRENT CAPABILITY (MW) AND RESERVES (MW and Percent) Middle South Utilities Group (Region 8)

1. Planned Capability

\begin{tabular}{|c|c|}
\hline $\begin{array}{c}1980 \\
\text { Summer }\end{array}$ & $\begin{array}{l}1980 / 8 \\
\text { Winter }\end{array}$ \\
\hline 13508 & 13405 \\
\hline וודו. & 8705 \\
\hline 1797 & 4700 \\
\hline 15.3 & 54.0 \\
\hline 1173 & 627 \\
\hline 14681 & 14032 \\
\hline 2970 & 5327 \\
\hline 25.4 & 61.2 \\
\hline 0 & 1856 \\
\hline 14681 & 12176 \\
\hline 2970 & 3471 \\
\hline 25.4 & 39.9 \\
\hline 0 & 0 \\
\hline 14681 & 12176 \\
\hline 2970 & 3471 \\
\hline 25.4 & 39.9 \\
\hline 1571 & 1856 \\
\hline 13110 & 10320 \\
\hline 1399 & 1615 \\
\hline 11.9 & 18.6 \\
\hline
\end{tabular}

2. Peak Demand

3. Planned Reserves $(1-2)$

4. Planned Reserves (\%) $(3 / 2) \times 100$

6. Total Capability $(1+5)$

14032

7. Total Reserves (6-2)

61.2

8. Total Reserves $(\%)(7 / 2) \times 100$

1856

9. Scheduled Maintenance

12176

10. Capability after Maintenance (6-9)

3471

12. Reserves after Maintenance $(\%) \cdot(11 / 2) \times 100$

13. Inoperable Capability

14. Available Capability (10-13)

12176

15. Available Reserves (14-2)

16. Available Reserves (\%) (15/2) × 100

18. Actual Capability after Forced Outages (14-17)

10320

19. Actual Reserves (18-2)

18.6

20. Actual Reserves (\%) $(19 / 2) \times 100$

1/ No Delays Anticipated since Submission of 1980 ERA-411.

2/ Estimated by ERA staff based on historical forced outage amounts. 
Table 8A.6

FUTURE CAPAB:LITr MW) AND RESERVES (MW and Percent) - 1981-84 Middle South Utilities Group (Region 8)

1. Planned Capability

2. Peak Demand

3. Planned Reserves (1-2)

4. Planned Reserves ( $\%)(3 / 2) \times 10 C$

5. Net Transactions (Imports-Exforts)

6. Total Capability $(1+5)$

7. Total Reserves $(6-2)$

8. Total Reserves $(\%)(7 / 2) \times 100$

9. Scheduled Maintenance

10. Capability after Maintenance (6-9)

11. Reserves after Maintenance (15-2)

12. Reserves after Maintenance ( $(1)(11 / 2) \times 100$

13. Inoperable Capability

14. Available Capability (10-13)

15. Available Reserves (14-2)

16. Available Reserves (\%) (15/2) 6101

17. Forced Outages

18. Actual Capability after Forced Ciutages (14-17)

19. Actual Reserves (18-2)

20. Actual Reserves $(\%)(19 / 2) \times 10]$

\begin{tabular}{rr}
\multicolumn{2}{c}{1981} \\
\cline { 1 - 1 } Summer & Winter \\
14240 & 14137 \\
12300 & 9145 \\
1940 & 4992 \\
15.8 & 54.6 \\
1002 & 578 \\
15242 & 14715 \\
2942 & 5570 \\
23.9 & 60.9 \\
0 & 1922 \\
15242 & 12793 \\
2942 & 3648 \\
23.9 & 39.9 \\
0 & 0 \\
15242 & 12793 \\
2942 & 3648 \\
23.9 & 39.9 \\
1650 & 1950 \\
13592 & 10843 \\
1292 & 1698 \\
10.5 & 18.6
\end{tabular}

1982

Summer Winter

$16422 \quad 16319$

3487

3487

27.0

1027

17449

4514

6700

603

16922

02250

17449

4514

14672
5053

34.9

52.5

0
17449

4514

34.9

1730

15719

2784

21.5
$12935 \quad 9679$

$34.9 \quad 75.9$
1983

Summer

17064

13836

3228

23.3

1028

18092

4256

30.8

0

18092

4256

30.8

0
18092

18092

4256

30.8

1855

16237

2401

17.4
3

Winter

10290

6671

64.8

605

17566

7276

70.7

15263

4973

48.3

15263

4973

48.3

2190

13073

2783

27.0

Nuclear Unit_Delays as_Projected_by Nuclear Regulation_Commiss ion

21. Nuclear Delays

22. Actual Capability (18-21)

23. Actual Reserves with Nuclear Delays (22-2)

$\begin{array}{rr}0 & \\ 13592 & 1084 \\ 1292 & 1698\end{array}$

\section{0}

24. Actual Reserves with Nuclear Delays

$(\%)(23 ; 2) \times 100$

18.6

1110
14609
1674
12.9
0
12622
3003
12622
3003

31.2
16237
2401
17.4

Coal_Unit Delays_Assumed_Possitble by_ERA

25. Possible Coal Delays

26. Actual Capability w/Nuclear \& Coal Delays (22-25)

27. Actual Reserves w/Nuclear \& Eoa T Delays (26-2)

28. Actual Reserves w/Nuclear \& Eoal Delays

$$
\text { (\%) }(27 / 2) \times 100
$$

$\begin{array}{rr}0 & 0 \\ 13592 & 10843 \\ 1292 & 1698 \\ 10.5 & 18.6\end{array}$

$\begin{array}{rr}0 & 0 \\ 14609 & 12622 \\ 1674 & 3003 \\ 12.9 & 31.2\end{array}$

725
15512
1676
12.1

1984

Summer Winter

$16940 \quad 16862$

$14613 \quad 10869$

$2327 \quad 5993$

$15.9 \quad 55.1$

$727 \quad 605$

$\begin{array}{ll}17667 & 17467\end{array}$

$3054 \quad 6598$

20.960 .7

02288

$17667 \quad 15179$

$3054 \quad 4310$

$20.9 \quad 39.7$

$\begin{array}{rr}0 & 0 \\ 17667 & 15179\end{array}$

$3054 \quad 4310$

$20.9 \quad 39.7$

$1960 \quad 2320$ क

$15707 \quad 12859$

$1094 \quad 1990$

$\begin{array}{ll}7.5 & 18.3\end{array}$

1/ Estimated by ERA staff based on histcrical forced outage amounts.

0
13073
2783
27.0

0
13073

2783

27.0

$\begin{array}{rr}0 & 0 \\ 15707 & 12859 \\ 1094 & 1990 \\ 7.5 & 18.3\end{array}$

18.3$$
\begin{array}{ll}
7.5 & 18.3
\end{array}
$$

$$
\begin{array}{rr}
0 & 0 \\
15707 & 12859 \\
1094 & 1990 \\
7 & 18.5
\end{array}
$$


FUTURE CAPABILITY (MW) AND RESERVES (MW and Percent) - 1985-89 Middle South Utilities Group (Region 8)

1. Planned Capability I/

2. Peak Demand

3. Planned Reserves (1-2)

4. Planned Reserves $(\%)(3 / 2) \times 100$

5. Net Transactions (Imports-Exports)

6. Total Capability $(1+5)$

7. Total Reserves (6-2)

8. Total Reserves ( $\%)(7 / 2) \times 100$

9. Scheduled Maintenance

10. Capability after Maintenance (6-9)

11. Reserves after Maintenance (10-2)

12. Reserves after Maintenance (\%) (11/2) ×100

13. Inoperable Capability

14. Available Capability (10-13)

15. Available Reserves (14-2)

16. Available Reserves (\%) (15/2) $\times 100$

17. Forced Outages

18. Actual Capability after Forced Outages (14-17)

19. Actual Reserves (18-2)

20. Actual Reserves (\%) (19/2) $\times 100$

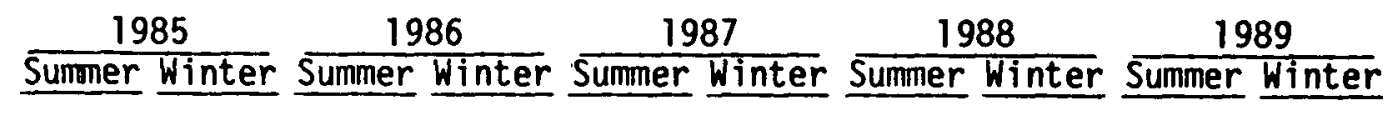

$\begin{array}{rrrrrrrrrrr}18667 & 18604 & 18508 & 18508 & 19428 & 19428 & 20222 & 20222 & 21390 & 21390 \\ 15345 & 11417 & 16129 & 12002 & 17034 & 12677 & 17997 & 13397 & 18902 & 14077 \\ 3322 & 7187 & 2379 & 6506 & 2394 & 6751 & 2225 & 6825 & 2488 & 7313 \\ 21.6 & 62.9 & 14.7 & 54.2 & 14.1 & 53.3 & 12.4 & 50.9 & 13.2 & 51.9 \\ 730 & 608 & 686 & 564 & 704 & 582 & 705 & 583 & 590 & 468 & \\ 19397 & 19212 & 19194 & 19072 & 20132 & 20010 & 20927 & 20805 & 21980 & 21858 & \\ 40152 & 7795 & 3065 & 7070 & 3098 & 7333 & 2930 & 7408 & 3078 & 7781 & \\ 26.4 & 68.3 & 19.0 & 58.9 & 18.2 & 57.8 & 16.3 & 55.3 & 16.3 & 55.3 & \\ - & - & - & - & - & - & - & - & - & - & . \\ 19397 & 19212 & 19194 & 19072 & 20132 & 20010 & 20927 & 20805 & 21980 & 21858 & \infty \\ 4052 & 7795 & 3065 & 7070 & 3098 & 7333 & 2930 & 7408 & 3078 & 7781 & \omega \\ 26.4 & 68.3 & 19.0 & 58.9 & 18.2 & 57.8 & 16.3 & 55.3 & 16.3 & 55.3 & \\ 0 & 0 & 0 & 0 & 0 & 0 & 0 & 0 & 0 & 0 & \\ 19397 & 19212 & 19194 & 19072 & 20132 & 20010 & 20927 & 20805 & 21980 & 21858 & \\ 4052 & 7795 & 3065 & 7070 & 3098 & 7333 & 2930 & 7408 & 3078 & 7781 & \\ 26.4 & 68.3 & 19.0 & 58.9 & 18.2 & 57.8 & 16.3 & 55.3 & 16.3 & 55.3 & \\ - & - & - & - & - & - & - & - & - & - & \\ 19397 & 19212 & 19194 & 19072 & 20132 & 20010 & 20927 & 20805 & 21980 & 21858 & \\ 4052 & 7795 & 3065 & 7070 & 3098 & 7333 & 2930 & 7408 & 3078 & 7781 & \\ 26.4 & 68.3 & 19.0 & 58.9 & 18.2 & 57.8 & 16.3 & 55.3 & 16.3 & 55.3 & \end{array}$

I/ No Nuclear or Coal Unit Delays are anticipated in this time frame. 
Table 8 A.8

FUTURE LOAD GROWTH

Middle South Utilities Group (Region 8)

\begin{tabular}{|c|c|c|c|c|c|c|c|}
\hline & $\frac{\text { Summer }}{(\mathrm{MW})}$ & $\begin{array}{c}\text { De m } \\
\begin{array}{c}\text { Growth } \\
(\%)\end{array} \\
\end{array}$ & $\begin{array}{c}\text { a } n d \\
\text { Winter } \\
\text { (MW) }\end{array}$ & $\begin{array}{c}\text { Growth } \\
(\%)\end{array}$ & $\begin{array}{r}\frac{\text { Energy } \mathrm{Re}}{\text { Amount }} \\
\text { (GWh) }\end{array}$ & $\begin{array}{c}\text { uirements } \\
\text { Growth } \\
(\text { q })\end{array}$ & $\begin{array}{c}\begin{array}{c}\text { Annual } \\
\text { Load } \\
\text { Factor }\end{array} \\
\frac{(\%)}{(\%)}\end{array}$ \\
\hline 1980 & 11,711 & - & 8,705 & - & 58,906 & - & 57.3 \\
\hline 1981 & 12,300 & 5.0 & 9,145 & 5.1 & 61,790 & 4.9 & 57.3 \\
\hline 1982 & 12,935 & 5.2 & 9,619 & 5.2 & 64,897 & 5.0 & 57.3 \\
\hline 1983 & 13,836 & 7.0 & 10,290 & 7.0 & 69,404 & 6.9 & 57.3 \\
\hline 1984 & 14,613 & 5.6 & 10,869 & 5.6 & 73,269 & 5.6 & 57.1 \\
\hline 1985 & 15,345 & 5.0 & 11,417 & 5.0 & 76,889 & 4.9 & 57.2 \\
\hline 1986 & 16,129 & 5.1 & 12,002 & 5.1 & 80,780 & 5.1 & 57.2 \\
\hline 1987 & 17,034 & 5.6 & 12,677 & 5.6 & 85,274 & 5.6 & 57.1 \\
\hline 1988 & 17,997 & 5.7 & 13,397 & 5.7 & 90,054 & 5.6 & 57.0 \\
\hline 1989 & 18,902 & 5.0 & 14,077 & 5.1 & 94,528 & 5.0 & 57.1 \\
\hline $1980-89$ & & 5.5 & & 5.5 & & 5.4 & \\
\hline
\end{tabular}


Table 8 A.9

GENERATION MIX BY FUEL TYPE

Middle South Utilities.Group (Region 8)

Summer 1980 Capability of of otal (MW)

Type Fue]

Nuclear

Coal

Gas

$0 i 1$

Hydro

Total
1,748

13.0

1,022

7.6

8,785

65.0

13.9

1,884

69

0.5

100.0
Summer 1985 Capability \& of Total (MW) (\%)

27.4

17.1

45.0

10.1

0.4

$18,667 \quad 100.0$
Summer 1989 Capability \% of Total (MW) \%)

23.9

29.0

38.0

8,131

8.8

1,884

0.3

$21,390 \quad 100.0$ 


\section{Historical Perspective}

The Gulf States Region encompasses portions of Louisiana and Texas with Gulf States Utilities Company owning about 65 percent of the total capability of the region. Historically, all of the Gulf States Region's generation has been obtained from either oil or gas. However, by 1989 the region is projecting the installation of coal-fired and nuclear capacity which will constitute 49.5 percent of its total installed capability.

The annual peak demand (which occurs in the summer) and annual energy requirements for the Gulf States Region has shown a steady decrease in growth rates from 1950 to 1976. This data is shown in the fullowing Lable.

Table 8B. 1

Historical Load Growth Rates Gulf states Group

Period

$1950-60$

$1960-70$

$1970-76$
Compound Annual Growth Rate

$\frac{\text { Peak Demand }}{(z)} \quad \frac{\text { Annual Energy }}{(z)}$

$$
\begin{array}{r}
12.2 \\
10.5 \\
6.0
\end{array}
$$

Table 8B.5 shows the actual summer and winter peak demands and the annual net energy for load for the years 1977 through 1979. The annual growth rates for demand and energy for these periods are also tabulated. This shows very little growth from 1978 to 1979.

From 1977 to 1979, Gulf States had adequate total generating reserves at the time of the peak to satisfy the SPP criteria (see Region 8 Historical Perspective for Criteria). However, actual reserves during the summer were below the 6 percent SPP criteria during the 1977-79 summer peaks (see Table 8B.5). During February 1979 the actual reserves fell well below this figure due to power sales and high unit outages. The low reserves available during the summer were due to generating outages other than normal scheduled maintenance. These outages have ranged from a low of 15.4 percent to a high of 22.7 percent of Gulf states' own generating resources during the months when the peak demand occurs. The large amount of 
unavailable capacity in the region is mainly due to the use of oilfired units that were originally designed to burn natural gas. Unreliable supplies of natural gas has necessitated the use of oil. These units are the willow Glen Units Nos. 3 and 4 (1,000 MW total), and Nelson Unit No. $4(500 \mathrm{MW})$.

The following table shows the actual December 1979 generating capability by fuel type and the 1979 actual energy generation.

$\frac{1979 \text { Net Dependable } \frac{\text { Table } 8 \text { Capability }}{\text { Capd Generation by Fuel Type }}}{\text { Gulf States Group }}$
Gulf states Group

Fuel Type

Coal

Oil

Natural Gas

Nuclear

Hydro

Other $\frac{\text { Net Dependable Capability }}{(\overline{M W})} \frac{(\overline{8} \text { of }}{\text { Total })}$

$$
\begin{array}{r}
0 \\
25.3 \\
74.7 \\
0 \\
0
\end{array}
$$

100.0
Generation (GWh) (8 of Total)

Total

8,093

$35,003.0$

100.0

As depicted in the above table, Gulf states is heavily dependent upon natural gas for the generation of electric power. Rel ief in this situation will occur beginning in 1980 when its first coalfired unit (Big Cajun No. 2, Unit $1540 \mathrm{MW}$ ) goes into service. This will start a steady increase in the amount of coal-fired capacity in the region with a total of $6,970 \mathrm{MW}$ projected to be added by 1989. An additional $846 \mathrm{MW}$ of nuclear capacity (River Bend No. 1) is projected for 1984 .

Historically, the Gulf States Region has been a net purchaser of capacity and energy during the 1977-79 summer peak periods. This power has been transmitted via $500 \mathrm{kV}$ interconnections with the Middle South Systems (Louisiana Power \& Light Company, the Mississippi Power \& Light Company, and Arkansas Power \& Light Company). Included in these purchases is a portion of the SCEC-TVA diversity exchange. Gulf states was a net seller of energy in: 1977 (222.2 GWh), a slight net purchaser in 1978 (40.1 GWh), and a large net purchaser in 1979 (3,600 GWh). The 1979 purchases represented 9.3 percent of its net energy for load. 
The Gulf states Group is projecting two $540 \mathrm{Mw}$ coal-fired generating units between summer 1980 and winter 1980-81 (Big Cajun No. 2 , units 1 and 2). Unit No. 1 will be in by the 1980 summer peak and Unit No. 2 will be in by the 1980-81 winter peak. At present, these target dates are still considered realistic by the owner, Cajun Electric Power Cooperative. This office sees no reason at this time that these two units should not be placed in service as scheduled.

The winter peak for the region is projected to be about 24 percent lower than the summer peak. With expected unit additions the actual reserves for the 1980-81 winter peak would be 16.0 percent (see Table $8 B .7$ ). This appears adequate under all but abnormal circumstances.

A total reserve of 22.0 percent is projected for this summer, which is well above the SPP criteria. Since no maintenance was scheduled and Gulf states projects no inoperable capability the available reserve was also 22.0 percent. The dclual reserve (which includes ERA's estimate of possible forced outages) is 1.6 percent. The forced outages for the region were estimated based on a historical average of 20.4 percent for the summer peak and 26.5 percent for the winter peak during the 1977-79 period. The figure includes both full forced outages and inoperable capability (partial forced outages would be in this category). Historically, Region 10 has had a considerable amount of capacity out for forced outages, or inoperaable for other reasons, at the time of the summer peak. However, in ERA-411, Gulf states predicts no inoperable capability during the summer peak period. Thus, the historical 20.4 percent outage figure has been applied entirely to forced outages.

The Gulf States Group would appear to be able to supply all of its load requirements during the 1980 summer peak even if historical forced outages do occur again. If necessary, emergency power would probably be available over istrong 500-kV ties with the Middle South Utilities Group (Region 8). Gulf states presently has three 500-kV interconnections with Middle South Utilities. These three lines each have a maximum capacity rating of $1,000 \mathrm{MW}$. A load flow diagram supplied in the 1980 ERA-4ll predicts an import of $448 \mathrm{MW}$ by the Gulf states area over these 500-kV lines during the 1980 summer peak period. The ability to transfer additional capacity between the two regions would appear very good. However, under no circumstances should it be assumed that since the three Iines have ratings of $1,000 \mathrm{MW}$ each that corresponding large amounts of additional power can be transferred. The transfer of capacity is only partly dependent on tie line capacity. In most cases the 
$X I .8 .19$

limitation of the lower voltage transmission network of both systems and the location of generating sources dictate how such power can safely be transferred.

The Gulf States Group is projecting a 5.9 percent growth in the 1981-1984 period. Capacity additions during this period will be $2,150 \mathrm{MW}$ of coal-fired capacity, $846 \mathrm{MW}$ of nuclear capacity, and $180 \mathrm{MW}$ of combustion turbines.

Total reserves for this region (see Table 8E.8) range from 18.3 percent to 24.6 percent during the summer and appear adequate. Reserves after maintenance are also projected to range from 18.3 to 24.6 percent. Actual reserves (which include estimated forced outages and inoperable capability) are expected to range between -2 .1 percent and 4.2 percent. The region would appear to be capacity deficient during the 1981 summer peak period if forced outages, as they have previously encountered, occur again.

If projected nuclear delays and possible coal unit delays are also considered, 1,070 MW and $856 \mathrm{MW}$ would be unavailable resulting in actual reserves of -8.1 percent in 1982 and -7.1 percent in 1984, which would appear inadequate without any help from neighboring systems. The actual reserves during the 1983 and 1984 winter peak period could be below the SPP criteria. However, neighboring systems are also summer peaking areas and emergency transfers would be highly probable during the winter.

The Gulf states Group could very possibly have trouble meeting its peak load requirements in the 1981-1984 period. Assuming forced outages and unit delays (which this office feels are very possible) the Region would have to purchase additional capacity of $175 \mathrm{MW}$ in $1981,703 \mathrm{MW}$ in 1982, and $685 \mathrm{MW}$ in 1984 during the peak period just to meet projected load with no reserves

The emergency power needed by Gulf states could possibly come from the Oklahoma Group, but more likely would come from the Middle South Utilities Group via its existing 500-kV ties. In addition, there is a proposed $345-\mathrm{kV}$ tie with the Oklahoma Group in 1981 to relieve overloads, a 500-kV tie with Middle South in 1984, and a. $230-k V$ tie in 1986 with Louisiana Power \& Light Company for the purpose of increasing interchange capability. The following table depicts the projected capacity deficiency in the Gulf states Group.. and the possible excess capacity in the Middle South Group assuming forced outages and generating unit delays. 
$\frac{\text { Potential Eme } \frac{\text { Table } \frac{8 \mathrm{~B} \cdot 3}{\mathrm{rgency}} \text { Capacity Sources }}{\text { Gulf States Group }}}{\text { Sulf }}$

Year

1981

1982

1984
Gulf states

$\frac{\text { Capacity Deficiency }}{(M \bar{W})}$

175

703

685
Middle South

$\frac{\text { Excess Capacity }}{(M W)}$

1,292

1,674

1,094

The Gulf states Group needs to meet their projected generating unit schedules (even a delay of less than a year may be disastrous), since 1mproved availablity is needed from their oil burning units to assure that peak demand and energy reguirements are met.

The long term reserve situation for the Region is not as dismal as the near term. A total of $3,740 \mathrm{MW}$ of coal-fired capacity is projected in the 1985-1989 time period to supply a peak demand increase of $2,413 \mathrm{MW}$ during the same time frame. With this differential in capacity, actual summer reserves would range from 21.0 percent to 26.4 percent (see Table 8B.9). A possible nuclear delay of $846 \mathrm{MW}$ in 1985 would only decrease the reserve to 16.8 percent, which appears adequate.

These reserves do not reflect any scheduled maintenance or forced outages. Assuming that there would not be any maintenance scheduled during the summer peak period and applying the same 20.4 percent for forced outages as assumed in the current Perspective the reserves would be as follow:

Table 8B. 4

Estimated Actual Summer Rcscrves GuIf states Group

Year

1985

1986

1987

1988

1989
Estimated Actual

Summer Reserves

$$
\begin{array}{r}
-3.68 \\
5.98 \\
2.48 \\
3.98 \\
0.68
\end{array}
$$


It would appear that Gulf states may still need some emergency capacity assistance, but with the previously mentioned 500-kV tie with Middle South Utilities in 1984 and also a proposed 230-kV tie with the region planned for 1986, sufficient transmission paths should be available to facilitate the transfer of any needed power in the Gulf States Group.

\section{Future Perspective}

The growth of summer peak demand, winter peak demand and annual energy requirements are all projected to average 5.7 percent during the 1980-89 report period. Table 8B.6 provides estimates for the three items and shows annual growth in percent. The annual load factor is predicted to be 62.2 percent in 1980 and 63.4 percent in 1981, declining to 62.4 percent in 1989 .

Projected annual energy requirements can be met throughout the report period, assuming that emergency capacity can be purchased when and if needed and a sufficient supply of natural gas and oil for boiler use can be maintained. During the sumer of 1989 the Gulf states Group is projecting a capacity mix of 5.6 percent nuclear, 41.9 percent coal, and 52.5 percent gas and oil (see Table 8B.11) for a total planned summer capability of $15,211 \mathrm{MW}$. The total capability $(15,415 \mathrm{MW}$ which includes $204 \mathrm{MW}$ of net purchases) would have an average plant factor of 51.6 percent in 1989 . If 50 percent of the gas and oil capability were inoperable, the remaining capability would be required to operate at an average plant factor of 69.6 percent to serve the annual energy requirement of $69,639 \mathrm{GWh}$ in 1989 .

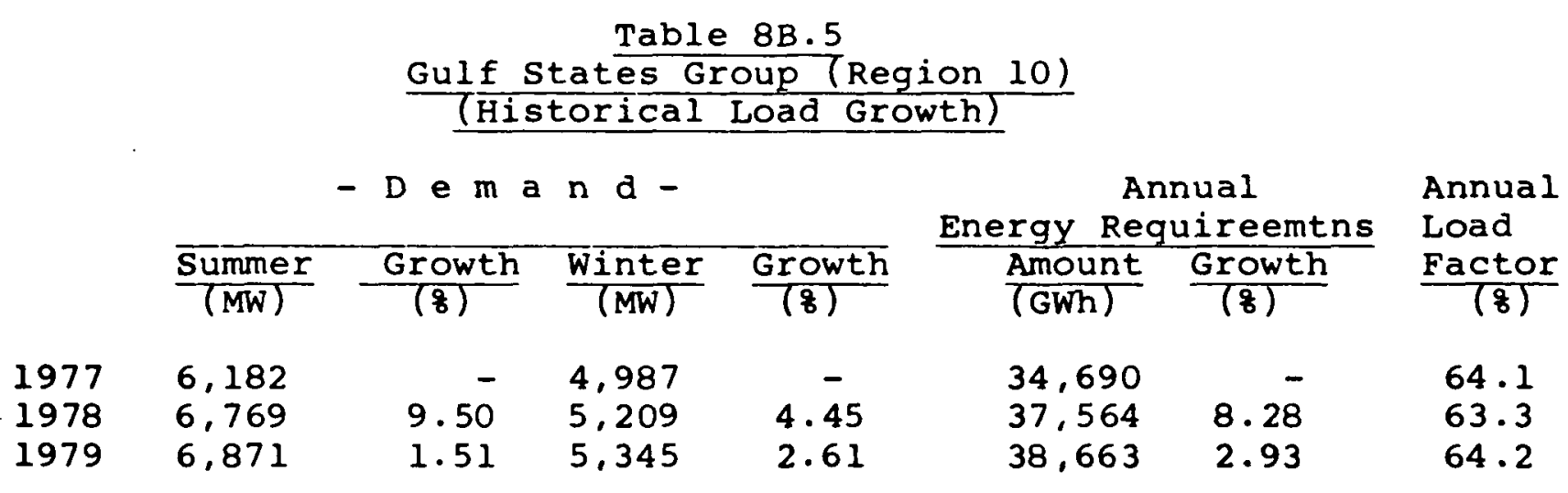


Table 8B.6.1

HISTORICAL CAFABILITY (MW) AND RESERVES (MW and Percent)

Gulf States Group

1. Planned Capability

2. Peak Demand

3. Planned Reserves $(i-2)$

4. Planned Reserves (\%) (3/2) ×100

5. Net Transactions (Imports-Exports)

6. Total Capability $(1+5)$

7. Total Reserves (6-2)

8. Total Reserves (\%) (7/2) $\times 100$

9. Scheduled Maintenance

10. Capability after Maintenance (6-9)

11. Reserves after Maintenance (10-?)

12. Reserves after Maintenance $\left({ }^{\circ}\right)(11 / 2) \times 100$

13. Inoperable Capability

14. Available Capability (10-13)

15. Available Reserves (14-2)

16. Available Reserves (\%) (15/2:x100

17. Forced Outages

18. Actual Capability after Forced Dutages ( $4-17)$

19. Actual Reserves (18-2)

20. Actual Reserves $(\%)(19 / 2) \times 10 J$

\begin{tabular}{|c|c|c|c|c|c|c|c|c|}
\hline & - & $S$ & $v$ & $M$ & $\underline{E}$ & $R$ & - & \\
\hline T & 97 & $\gamma$ & 0 & & 8 & & 97 & 9 \\
\hline un. & Jul. & Aug. & Jurie & Jut. & Aug. & Jun. & JuT. & Aug. \\
\hline 7666 & 7666 & 7666 & 7680 & 7680 & 7680 & 7665 & 7665 & 7665 \\
\hline 5912 & 6182 & 601 & 6628 & 6636 & 6769 & 6575 & 6871 & 6796 \\
\hline 1754 & 1484 & 1655 & 1052 & 1044 & 911 & 1090 & 794 & 869 \\
\hline 29.7 & 24.0 & 27.5 & 15.9 & 15.7 & 13.5 & 16.6 & 11.6 & 12.8 \\
\hline 145 & 377 & 22 & 236 & 57 & 1351 & 1011 & 71 & 1087 \\
\hline 7811 & 8043 & 7588 & 7916 & 7737 & 9031 & 8676 & 8376 & 8752 \\
\hline 1899 & 1861 & $157 ?$ & 1288 & 1101 & 2262 & 2101 & 1505 & 1956 \\
\hline 32.1 & 30.1 & 27.9 & 19.4 & 16.6 & 33.4 & 32.0 & 21.9 & 28.8 \\
\hline 10 & 0 & 0 & 0 & 0 & 265 & 12 & 0 & 0 \\
\hline 7801 & 8043 & 7588 & 7916 & 7737 & 8766 & 8664 & 8376 & 8752 \\
\hline 1889 & 1861 & $157 ?$ & 1288 & 1101 & 1997 & 2089 & 1505 & 1956 \\
\hline 32.0 & 30.1 & 27.9 & 19.4 & 16.6 & 29.5 & 31.8 & 21.9 & 28.8 \\
\hline 876 & 569 & 565 & 294 & 649 & 1222 & 918 & 548 & 453 \\
\hline 6925 & 7474 & 7.323 & 7622 & 7088 & 7544 & 7746 & 7828 & 8299 \\
\hline 1013 & 1292 & בוכי & 994 & 452 & 775 & 1171 & 957 & 1503 \\
\hline 17.1 & 20.9 & 15.8 & 15.0 & 6.8 & 11.4 & 17.8 & 13.9 & 22.1 \\
\hline 774 & 1090 & 0 & 665 & 100 & 522 & 635 & 635 & 1280 \\
\hline 6151 & 6384 & 7.023 & 6957 & 6988 & 7022 & וווו7 & 7193 & 7019 \\
\hline 239 & 202 & 2וכו & 329 & 352 & 253 & 536 & 322 & 223 \\
\hline 4.0 & 3.3 & 15.8 & 5.0 & 5.3 & 3.7 & 8.2 & 4.7 & 3.3 \\
\hline
\end{tabular}


HISTORICAL CAPABILITY (MW) AND RESERVES (MN and Percent)

Gul $\div$ States Group

1. Planned Capability

2. Peak Demand

3. Planned Reserves (1-2)

4. Planned Reserves (\%) (3/2) ×100

5. Net Transactions (Imports-Exports)

6. Total Capability $(1+5)$

7. Total Reserves (6-2)

8. Total Reserves $(\%)(7 / 2) \times 100$

9. Scheduled Maintenance

10. Capability after Maintenance (6-9)

11. Reserves after Maintenance (10-2)

12. Reserves after Maintenance (\%) (11/2) x100

13. Inoperable Capability

14. Available Capability (10-13)

15. Available Reserves (14-2)

16. Available Reserves (\%) (15/2) $\times 100$

17. Forced Outages

18. Actual Capability after Forced Outages (14-17)

19. Actual Reserves (18-2)

20. Actual Reserves (\%) $(19 / 2) \times 100$

\begin{tabular}{|c|c|c|c|c|c|c|c|c|}
\hline & 5 & W & 1 & II & 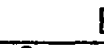 & $R$ & - & \\
\hline 19 & 71 & 8 & 19 & 781 & 9 & 19 & 797 & 0 \\
\hline Dec. & Jan. & Feb. & Dec. & Jan. & Feb. & Dec. & $\operatorname{Jan}$. & $\mathrm{Feb}$ \\
\hline 7670 & 7666 & 7657 & 7679 & 7679 & 7679 & 8145 & 8145 & 8135 \\
\hline 4413 & 4987 & 4722 & 4876 & 5209 & 5128 & 5338 & 5277 & 5345 \\
\hline 3257 & 2679 & 2935 & 2803 & 2470 & 2551 & 2807 & 2868 & 2790 \\
\hline 73.8 & 53.7 & 62.2 & $5 \pi .5$ & 47.4 & 49.7 & 52.6 & 54.3 & 52.2 \\
\hline-21 & 316 & 344 & $-\hat{2} 78$ & וומ5 & -376 & 681 & 346 & 674 \\
\hline 649 & 7982 & 8001 & 7401 & 8190 & 7303 & 8826 & 8491 & 8809 \\
\hline 3236 & 2995 & 3279 & $25: 25$ & 2981 & 2175 & 3888 & 3214 & 3464 \\
\hline 3.3 & 60.1 & 69.4 & $5 \pi .8$ & 57.2 & 42.4 & 65.3 & 60.1 & 64.8 \\
\hline 825 & 911 & 911 & 1182 & 1129 & 629 & 1269 & 1162 & 1162 \\
\hline 6824 & 7071 & 7090 & 6019 & 7061 & 6674 & 7557 & 7329 & 7647 \\
\hline 2411 & 2084 & 2368 & 1343 & 1852 & 1546 & 2219 & 2052 & 2302 \\
\hline 54.6 & 41.8 & 50.1 & 27.5 & 35.6 & 30.1 & 41.6 & 38.9 & 43.1 \\
\hline 521 & 779 & 1182 & 935 & 733 & 1022 & 459 & 428 & 248 \\
\hline 6303 & 6292 & 5908 & 5284 & 6328 & 5652 & 7098 & 6901 & 7399 \\
\hline 1890 & 1305 & 1186 & 408 & 1119 & 524 & 1760 & 1624 & 2054 \\
\hline 42.8 & 26.2 & 25.1 & 8.4 & 21.5 & 10.2 & 33.0 & 30.8 & 38.4 \\
\hline 1072 & 550 & 550 & 0 & 500 & 500 & 0 & 995 & 1450 \\
\hline 5231 & 5742 & 5358 & 5284 & 5828 & 5152 & 7098 & 5906 & 5949 \\
\hline 818 & 755 & 636 & 408 & 619 & 24 & 1760 & 629 & 604 \\
\hline 18.5 & 15.1 & 13.5 & 8.4 & 11.9 & 0.5 & 33.0 & 11.9 & 11.3 \\
\hline
\end{tabular}




\section{Current Capability (MW) and Reserves (MW and Percent)} GULF STATES GROUP

1. Planned Capability I/

\begin{tabular}{rrr}
$\begin{array}{rrr}1980 \\
\text { Summer }\end{array}$ & & $\begin{array}{r}1980 / 81 \\
\text { Winter }\end{array}$ \\
\hline 8405 & & 8945 \\
7694 & & 5865 \\
711 & & 3080 \\
9.2 & & 52.5 \\
981 & & 603 \\
9386 & & 9548 \\
1692 & & 3683 \\
22.0 & & 62.8 \\
0 & & 1191 \\
9386 & & 8357 \\
1692 & & 2492 \\
22.0 & & 42.5 \\
0 & & 0 \\
9386 & 8357 \\
1692 & 2492 \\
22.0 & 42.5 \\
1570 & 1554 \\
7816 & 6803 \\
122 & 938 \\
1.6 & 16.0
\end{tabular}

2. Peak Demand

3. Planned Reserves $(1-2)$

4. Planned Reserves (\%) (3/2) ×100

5. Net Transactions (Imports-Exports)

6. Total Capability $(1+5)$

9548

7. Total Reserves $(6-2)$

3683

8. Total Reserves (\%) (7/2) ×100

9. Scheduled Maintenance

10. Capability after Maintenance (6-9)

11. Reserves after Maintenance (10-2)

12. Reserves after Maintenance $(\%)(11 / 2) \times 100$

13. Inoperable Capability

14. Available Capability (10-13)

15. Available Reserves (14-2)

16. Available Reserves (\%) (15/2) ×100

554

17. Forced Outages, 2/

6803

18. Actual Capability after Forced Outages (14-17)

938

19. Actual Reserves (18-2)

6.0

20. Actual Reserves (\%) (19/2) x100

1/ No delays anticipated in new generating units since submission of 1980 ERA-411.

2/ Estimated by ERA staff based on historical forced outage amounts. 
Table 8B.8

FUTURE CAPABILITY (MW) AND RESERVES (MW and Percent) - 1981-84 Gulf States Group

1. Planned Capability

2. Peak Demand

3. Planned Reserves (1-2)

4. Planned Reserves (\%) (3/2) $\times 100$

5. Net Transactions (Imports-Exports)

6. Total Capability $(1+5)$

7. Total Reserves $(6-2)$

8. Total Reserves (\%) (7/2) $\times 100$

9. Scheduled Maintenance

10. Capability after Maintenance (6-9)

11. Reserves after Maintenance (10-2)

12. Reserves after Maintenance (\%) $(11 / 2) \times 100$

13. Inoperable Capability

14. Available Capability (10-13)

15. Available Reserves (14-2)

16. Available Reserves (\%) (15/2) x100

17. Forced Outages

18. Actual Capability after Forced Outages (14-17)

19. Actual Reserves (18-2)

20. Actual Reserves (\%) $(19 / 2) \times 100$

\begin{tabular}{rr}
\multicolumn{2}{c}{1981} \\
\cline { 1 - 1 } summer & Winter \\
\cline { 1 - 1 } 9035 & 9300 \\
8173 & 6212 \\
862 & 3088 \\
10.5 & 49.7 \\
630 & 223 \\
9665 & 9523 \\
1492 & 3311 \\
18.3 & 53.3 \\
0 & 899 \\
9665 & 8624 \\
1492 & 2412 \\
18.3 & 38.3 \\
0 & 0 \\
9665 & 8624 \\
1492 & 2412 \\
18.3 & 38.3 \\
1667 & 1646 \\
7998 & 6978 \\
-175 & 766 \\
-2.1 & 12.3
\end{tabular}

$198 \varepsilon$

Sumner

\section{5}

8657

1538

17.8

595

10790

2133

24.6

0
10790

2133

24.6

10790

2133

24.6

1766

9024

367

4.2
Winter

10735

6584

4151

63.0

398

11133

4549

69.1

810
10323

10323

56.8

0
10323
3739

3739

56.8

1745

8578

1994

30.3
1983

Summer Winter

10735

9173

1562

17.0

596

11331

2158

23.5

11331

2158

23.5

11331

2158

23.5

1871

9460

287

3.1
10735

6972

3763

54.0

245

10980

4008

57.5

1846

9134

2162

31.0

9134

2162

31.0

1848

7286

314

4.5
1984

Summer Winter

$11581 \quad 12121$

$9710 \quad 7411$

$1871 \quad 4710$

$19.3 \quad 63.6$

$271 \quad 170$

$11852 \quad 12291$

$2142 \quad 4880$

$22.1 \quad 65.8$

0 1764

$11852 \quad 10527$

$2142 \quad 3116$

$22.1 \quad 42.0$

$11852 \quad 10527$

$2142 \quad 3116$

$22.1 \quad 42.0$

$1981 \quad 1964$

$9871 \quad 8563$

$161 \quad 1152$

$1.7 \quad 15.5$

Nuclear Unit_Delays as 마ojected_by Nuclear Regulation_Comisssion

21. Nuclear Delays

22. Actual Capability (18-21)

23. Actual Reserves with Nuclear Delays (22-2)

24. Actual Reserves with Nuclear Delays

$(\%)(23 / 2) \times 100$

\section{$\begin{array}{rr}0 & 0 \\ 7998 & 6978\end{array}$}

$-175$

$-2.1$

$\begin{array}{rr}0 & 0 \\ 9024 & 8578 \\ 367 & 1994\end{array}$

4.2
0
8578
1994

30.3

0
9460
287

287

7286

314

314
4.5

846
9025

-685
-7.1

846

7717

306

Coal_Unit Dejlays_Assumed_Possible by ERA

25. Possible Coal Delays

26. Actual Capability w/Nuclear \& Coal Delays (22-25)

27. Actual Reserves w/Nuclear \& Coal Delays (26-2)

28. Actual Reserves w/Nuclear \& Coal Delays (\%) $(27 / 2) \times 100$

$\begin{array}{rrrr}0 & 265 & 1070 & 805 \\ 7998 & 6713 & 7954 & 7773 \\ -175 & 501 & -703 & 1189 \\ -2.1 & 8.1 & -8.1 & 18.1\end{array}$


FUTURE CAPABILITY :MW) AND RESERVES (MW and Percent) - 1985-89 Gulf States Group

1985

1926

1987

1988

1989

Summer Winter Summer Winter Summer Winter Summer Winter Summer Winter

1. Planned Capability

2. Peak Demand

3. Planned Reserves (1-2)

4. Planned Reserves $(\%)(3 / 2) \times 100$

5. Net Transactions (Imports-Exports)

6. Total Capability $(1+5)$

7. Total Reserves (6-2)

8. Total Reserves $(\%)(7 / 2) \times 100$

9. Scheduled Maintenance 1/

10. Capability after Maintenance (6-9)

11. Reserves after Maintenance (10-2)

12. Reserves after Maintenance (\%) (11/2) x100

13. Inoperable Capability 1/

14. Ava ilable Capability (10-13)

15. Available Reserves (14-2)

16. Available Reserves (\%) $(15 / 2) \times 100$

17. Forced Outages 1/

18. Actual Capability after Forced Outages (14-1?)

19. Actual Reserves (18-2)

20. Actual Reserves (\%) $(19 / 2) \times 100$

$\begin{array}{rrrrrrrrrr}12661 & 13201 & 13521 & 13871 & 13871 & 14676 & 14811 & 15211 & 15211 & 15811 \\ 10322 & 7821 & 10893 & 8237 & 11474 & 8677 & 12087 & 9142 & 12735 & 9634 \\ 2339 & 5380 & 2628 & 5634 & 2397 & 5999 & 2724 & 6069 & 2476 & 6177 \\ 22.7 & 68.8 & 24.1 & 68.4 & 20.9 & 69.1 & 22.5 & 66.4 & 19.4 & 64.1 \\ 242 & 160 & 232 & 151 & 223 & 141 & 213 & 132 & 204 & 123 \\ 12903 & 13361 & 13753 & 14022 & 14094 & 14817 & 15024 & 15343 & 15415 & 15934 \\ 2581 & 5540 & 2860 & 5785 & 2620 & 6140 & 2937 & 6201 & 2680 & 6300 \\ 25.0 & 70.8 & 26.3 & 70.2 & 22.8 & 70.8 & 24.3 & 67.8 & 21.0 & 65.4 \\ 0 & 0 & 0 & 0 & 0 & 0 & 0 & 0 & 0 & 0 \\ 12903 & 13361 & 13753 & 14022 & 14094 & 14817 & 15024 & 15343 & 15415 & 15934 \\ 2581 & 5540 & 2860 & 5785 & 2620 & 6140 & 2937 & 6201 & 2680 & 6300 \\ 25.0 & 70.8 & 26.3 & 70.2 & 22.8 & 70.8 & 24.3 & 67.8 & 21.0 & 65.4 \\ 0 & 0 & 0 & 0 & 0 & 0 & 0 & 0 & 0 & 0 \\ 12903 & 13361 & 13853 & 14022 & 14094 & 14817 & 15024 & 15343 & 15415 & 15934 \\ 2581 & 5540 & 2860 & 5785 & 2620 & 6140 & 2937 & 6201 & 2680 & 6300 \\ 25.0 & 70.8 & 26.3 & 70.2 & 22.8 & 70.8 & 24.3 & 67.8 & 21.0 & 65.4 \\ 0 & 0 & 0 & 0 & 0 & 0 & 0 & 0 & 0 & 0 \\ 12903 & 13361 & 13853 & 14022 & 14094 & 14817 & 15024 & 15343 & 15415 & 15934 \\ 2581 & 5540 & 2860 & 5785 & 2620 & 6140 & 2937 & 6201 & 2680 & 6300 \\ 25.0 & 70.8 & 26.3 & 70.2 & 22.8 & 70.8 & 24.3 & 67.8 & 21.0 & 65.4\end{array}$

Nuclear Unit_Delays ass_Projected_by Nuclear Regulation_Commission

21. Nuclear Delays

22. Actual Capability (18-21)

23. Actual Reserves with Nuclear Delays $(22-2)$

24. Actual Reserves with Nuclear Delays (\%) (23/2ixi00

\section{$846 \quad 846$}

12057

17354694

13853
2860
26.3

\section{0}

$\begin{array}{lll}4022 & 14094 & 1481\end{array}$

$\begin{array}{rrr}5785 & 2620 & 6140\end{array}$

70.2

22.8
0

15024

2937

$\begin{array}{rrr}0 & 0 & 0 \\ 15343 & 15415 & 15934 \\ 6201 & 2 & 6300\end{array}$

I/ Information not available for this period. 
Table 8B.10

FUTURE LOAD GROWTH

Gulf States Group

\begin{tabular}{|c|c|c|c|c|c|c|c|}
\hline & $\frac{-}{\substack{\text { Summer } \\
(M W)}}$ & $\begin{array}{c}D \text { e m } \\
\text { Growth } \\
(q)\end{array}$ & $\begin{array}{c}\text { a } n d d \\
\text { Winter } \\
(M W)\end{array}$ & $\begin{array}{c}- \\
\text { Growth } \\
(q)\end{array}$ & $\begin{array}{r}\frac{\text { Energy } R e}{\text { Amount }} \\
(\text { GWh })\end{array}$ & $\begin{array}{c}\text { equirements } \\
\text { Growth } \\
(\%)\end{array}$ & $\begin{array}{c}\begin{array}{c}\text { Annual } \\
\text { Load } \\
\text { Factor }\end{array} \\
(\%)\end{array}$ \\
\hline 1980 & 7,712 & - & 5,847 & - & 42,125 & - & 62.2 \\
\hline 1981 & 8,173 & 6.0 & 6,192 & 5.9 & 45,359 & 7.7 & 63.4 \\
\hline 1982 & 8,657 & 5.9 & 6,563 & 6.0 & 47,975 & 5.8 & 63.3 \\
\hline 1983 & 9,172 & 5.9 & 6,950 & 5.9 & 50,764 & 5.8 & 63.2 \\
\hline 1984 & 9,710 & 5.9 & 7,387 & 6.3 & 53,768 & 5.9 & 63.0 \\
\hline 1985 & 10,322 & 6.3 & 7,796 & 5.5 & 56,865 & 5.8 & 62.9 \\
\hline 1986 & 10,893 & 5.5 & 8,211 & 5.3 & 59,907 & 5.3 & 62.8 \\
\hline 1987 & 11,475 & 5.3 & 8,649 & 5.3 & 62,976 & 5.1 & 62.6 \\
\hline 1988 & 12,088 & 5.3 & 9,112 & 5.4 & 66,327 & 5.3 & 62.5 \\
\hline 1989 & 12,736 & $\underline{5.4}$ & 9,603 & $\underline{5.4}$ & 69,639 & $\underline{5.0}$ & 62.4 \\
\hline 980-89 & & 5.7 & & 5.7 & & 5.7 & \\
\hline
\end{tabular}


XI. 8.28

Table 8B.11

Capacity Mix (MW) By Fuel Type GULF STATES GROUP

\begin{tabular}{|c|c|c|c|c|c|c|}
\hline Type Fuel & $\frac{\frac{\text { Summer }}{\text { Capability }}}{(M W)}$ & $\frac{1980}{\frac{\% \text { of Total }}{(\%)}}$ & $\frac{\frac{\text { Summe }}{\text { Capability }}}{(\mathrm{MW})}$ & $\frac{1985}{\frac{\% \text { of Total }}{(\%)}}$ & $\frac{\text { Summer }}{\frac{\text { Capability }}{(M W)}}$ & $\frac{\frac{1989}{\% \text { of Total }}}{(\%)}$ \\
\hline Nuclear & 0 & 0.0 & 846 & 6.7 & 846 & 5.6 \\
\hline Coal & 540 & 6.4 & 3,770 & 29.8 & 6,370 & 41.9 \\
\hline Gas & 5,815 & 69.2 & 5,995 & 47.3 & 5,995 & 39.4 \\
\hline $0 i 1$ & 2,050 & 24.4 & 2,050 & 16.2 & 2,000 & 13.1 \\
\hline Hydro & $\underline{0}$ & $=$ & $\underline{0}$ & - & $\underline{0}$ & $=$ \\
\hline Total & 8,405 & 100.0 & 12,661 & 100.0 & 15,211 & 100.0 \\
\hline
\end{tabular}




\section{Historical Perspective}

Although the historical growth rate for the Missouri-Kansas Group (MOKAN) has been slightly less than the other Electric Regions within SPP, it has also been experiencing growth rate reductions in both peak demand and annual energy requirements. The following table illustrates this reduction in electric usage during the period 1950 through 1976 :

Table 8C.1

Historical Load Growth

Missouri-Kansas Group

$\underline{\text { Period }}$

$1950-60$

$1960-70$

$1970-76$

$\begin{array}{cr}\frac{\text { Compound Annual Growth Rate }}{\text { Peak Demand }} & \frac{\text { Energy }}{(8)} \\ 10.4 & 8.7 \\ 8.1 & 7.7 \\ 5.5 & 5.2\end{array}$

Table 8C. 3 shows actual summer and winter peak loads, annual energy requirements, annual growth rates and annual load factors for 1977, 1978 and 1979 for the MOKAN Region. The MOKAN Region experienced a reduction in load of 4.2 percent between the summer of 1978 and the summer of 1979 with corresponding reduction in energy of one percent for the 1978-1979 period. Systems in the region attribute about 70 percent of this reduction to cooler than normal temperatures during the summer of 1979 and the remainder to

customer conservation efforts.

Due to this reduction in load growth, the MOKAN area has been reducing its load estimate annually for the past several years. For the period 1980 through 1989 MOKAN is estimating an average compound growth rate of 4.4 percent. This compares to projected growth rates of 4.5 percent in 1979 and approximately 6 percent in 1978 .

The MOKAN Region is the only region in SPP which obtains more than one-half of its annual generation from coal-fired generating units. The following table gives a breakdown of generating capacity by fuel type and generation in the Region as of the end 
of 1979. The information was obtained from data reported to the Energy Information Administration via their Form 4 .

Table $8 . \mathrm{C2}$

Installed Capacity and Generation by Fuel Type

Missouri-Kansas Group

\begin{tabular}{|c|c|c|c|c|}
\hline Fuel Type & Instal & Capacity & $\mathrm{Ge}$ & ation \\
\hline & $(M W)$ & of Total) & $(G W h)$ & of Total) \\
\hline Nuclear & 0 & 0.0 & 0 & 0.0 \\
\hline Coal & 6,900 & 60.1 & 21,912 & 65.0 \\
\hline Natural Gas & 3,442 & 30.0 & 10,143 & 30.1 \\
\hline Oil & 1,128 & 9.8 & 1,582 & 4.7 \\
\hline Hydro & 16 & 0.1 & 56 & 0.2 \\
\hline other & - & 0.0 & 0 & 0.0 \\
\hline Total & 11,486 & 100.0 & 33,693 & 100.0 \\
\hline
\end{tabular}

During the 1980 summer peak period, the generating capacity mix by fuel type will be approximately 69.7 percent coal, 9.3 percent oil, 20.9 percent natural gas, and 0.1 percent hydroelectric. The first nuclear unit in the MOKAN Region is not scheduled for service until April 1983.

Eight of the electric systems included in the MOKAN Region are members of the MOKAN POOl, which is a formal organization formed to achieve operating economies and reliability through coordinated planning and operations. As members of SPP, most of the Region adheres to the SDPP planning reserve criteria of 15 percent of peak demand although several of the MOKAN Pool members are now planning for a 20 percent reserve margin. Table $8 \mathrm{C} .4 .1$ and 8C.4.2 present the actual reserve situations that occurred in the MOKAN Region for 1977 through 1979 for three summer months and three winter months. It is noted that total reserves during the summer peak periods varied from a low of 26.8 percent of peak demand in July 1977 to a high of 52.6 percent in June 1979 . Actual reserves varied from a low of 13.8 percent in July 1978 to a high of 29.1 percent in June 1979. The amount of generating capacity out of service during the peak months as a percent of the peak demand was 8.9 percent in July 1977, 8.9 percent in August 1978, and 17 percent in August 1979.

The MOKAN Region is strongly interconnected internally through backbone $345 \mathrm{kV}$ transmission circuits which were constructed mainly 
after the MOKAN Coordination Agreement was signed. The Region is also strongly interconnected with the oklahoma Region of SPP and the MAIN Reliability Council. During 1977, 1978, and 1979, MOKAN was a net purchaser of energy in the amounts of $2,292 \mathrm{GWh}, 2,027 \mathrm{GWh}$ and $3,108 \mathrm{GWh}$, respectively.

The members of the MOKAN Coordination Group instituted a manual economy energy brokerage system on March 3, 1980, in order to maximize economy energy transactions among the members. The system is planned to be computerized in the near future.

\section{Current Perspective}

The Missouri-Kansas Group is projecting the addition of 1,565 MW of coal-fired capacity by the 1980 summer peak period. There are presently no delays anticipated for the three projected units.

The reserves for the upcoming summer and winter peak appear excellent. Actual reserves (assuming scheduled maintenance, inoperable capability and ERA-estimated forced outages) would be 13.1 percent in the summer and 46.9 percent in the winter (see Table 8C.5).

The total generating resources, $13,121 \mathrm{MW}$, during the 1980 summer period include 69.7 percent coal-fired generation, 20.9 percent gas-fired, 9.3 percent oil-fired, and 0.1 percent hydroelectric as shown on Table 8C.9.

During 1980, the systems in MOKAN plan to place one 345-kV line and one $230 / 345-\mathrm{kV}$ line in operation. Total circuit miles to be installed are 86. Both circuits are intra-regional and are needed to deliver the generator output of new coal-fired capacity.

\section{Future Perspective}

The MOKAN Region is expecting $1,590 \mathrm{MW}$ of additional coal-fired capacity and a $955 \mathrm{MW}$ share of a nuclear unit in the 1981-1984 time period. The Wclf Creek No. I nuclear unit is projected by NRC to be delayed one year to 1984 from what was predicted in the 1980 ERA-411. It is estimated by ERA that the $280 \mathrm{MW}$ Holcomb No. 1 coal-fired unit might also be delayed one year to 1984 .

Total reserves are projected to range from 21.8 percent to 29.5 percent for the summer peak periods (see Table 8C.6). Winter reserves, for all cases, are excellent. Available reserves (which include scheduled maintenance and inoperable capability) would range from 20.2 percent to 28.1 percent. With estimated forced outages, the actual reserves would range from 7.7 percent to 15.5 percent. These 
reserves appear adequate. The projected nuclear and coal-fired delay totaling $1,235 \mathrm{MW}$ in 1983 would result in low summer peak actual reserves of 5.4 percent in 1983. This figure also appears adequate.

The Region currently has several 345-kV interconnections with Middle South Utilities, ILLMO Region, MAPP, and the Oklahoma Group. Additional 345-kV interconnections are projected with MAPP in 1981 and 1983 for the purpose of increasing interchange capability. In addition to these inter-regional ties, a $230-\mathrm{kV}$ interconnection to the Oklahoma Group is planned for 1984 for the purpose of increasing interchange capability. MOKAN plans to construct 378 miles of $345-\mathrm{kV}$ circuits and $322 \mathrm{miles}$ of $230-\mathrm{kV}$ circuits during this 4-year period, all intra-regional. The purpose of the intra-regional lines in order of importance is to deliver generator output, increase interchange capability, provide for local area protection, and relieve overload.

In this time frame, MOKAN is projecting 1,930 MW of additional coal-fired capacity and a $250 \mathrm{MW}$. share of a nuclear unit.

Actual reserves are projected to be from 13.6 percent to 23.6 percent for the summer peak period (see Table 8C.7). With a projected nuclear unit delay, these reserves would range from 12.0 to 23.6 percent.

A 345-kV tie with the MAPP Region is projected for 1986 for increased interchange capability. Intra-regional transmission line construction is projected to include 387 miles of $345-\mathrm{kV}$ circuits and 209 miles of $230-\mathrm{kV}$ circuits. The purpose of the majority of these lines is for increased interchange capability and area protection.

The Missouri-Kansas Group appears to be in a very reliable state throughout the entire decade, barring any unforeseen occurrences.

During the 10-year report period (1980-1989), the MOKAN Group is projecting its summer peak demand, winter peak demand, and annual energy requirement to have average annual growth rates of 4.4 percent, 5.0 percent and 4.5 percent, respectively. Annual load factor is expected to vary slightly during this period from 49.8 percent in 1980 to 51.8 percent in 1989 . Table $8 \mathrm{C} .8$ gives a list of the estimated amounts and annual growth rates. 
XI. 8.33

The MOKAN Group is less dependent on natural gas and oil for boiler fuel than the other three groups within the SPP. As shown on Table $8 \mathrm{C} .9$, gas and oil capacity represents 30.2 percent of the total generating resources during the summer of 1980 and is projected to be 21.1 percent in 1989. The disruption of natural gas and oil supplies would present some problems for the MOKAN system in meeting its energy requirements; however, the impact would be less severe than in the other Regions. 
$X I .8 .34$

Table 8C.3

HISTORICAL LOAD GROWTH

Missouri-Kansas Group (Region 21)

\begin{tabular}{|c|c|c|c|c|c|c|c|}
\hline & $\frac{\text { Summer }}{(M W)}$ & $\frac{-D e}{\frac{\text { Growth }}{(\%)}}$ & $\frac{m a n d}{\frac{\text { Winter }}{(M W)}}$ & $\frac{\text { Growth }}{(\%)}$ & $\frac{\text { Annual Energy }}{\frac{\text { Amount }}{(\text { GWh })}}$ & $\frac{\text { Requirements }}{\frac{\text { Growth }}{(\%)}}$ & $\begin{array}{c}\begin{array}{c}\text { Annual } \\
\text { Load } \\
\text { Factor }\end{array} \\
\frac{(\%)}{}\end{array}$ \\
\hline 1977 & 7,966 & - & 5,587 & - & 34,624 & - & 49.6 \\
\hline 1978 & 8,454 & 6.13 & 5,772 & 3.31 & 37,086 & 7.11 & 50.1 \\
\hline 1979 & 8,103 & -4.15 & 5,617 & -2.69 & 36,826 & -0.70 & 51.9 \\
\hline
\end{tabular}


HISTORICAL CAPABILITY (MN) AND RESERVES (MW and Percent)

Missouri-Kansas Group

1. Planned Capability

2. Peak Demand

3. Planned Reserves (1-2)

4. Planned Reserves ( $\%)(3 / 2) \times 100$

5. Net Transactions (Imports-Exports)

6. Total Capability $(1+5)$

7. Total Reserves (6-2)

8. Total Reserves $(\%)(7 / 2) \times 100$

9. Scheduled Maintenance

10. Capability after Maintenance (6-9)

11. Reserves after Maintenance (10-2)

12. Reserves after Maintenance (\%) (11/2) x100

13. Inoperable Capability

14. Available Capability (10-13)

15. Available Reserves (14-2)

16. Available Reserves (\%) (15/2) ×100

17. Forced Outages

18. Actual Capability after Forced Outages (14-17)

19. Actual Reserves (18-2)

20. Actual Reserves (\%) $(19 / 2) \times 100$

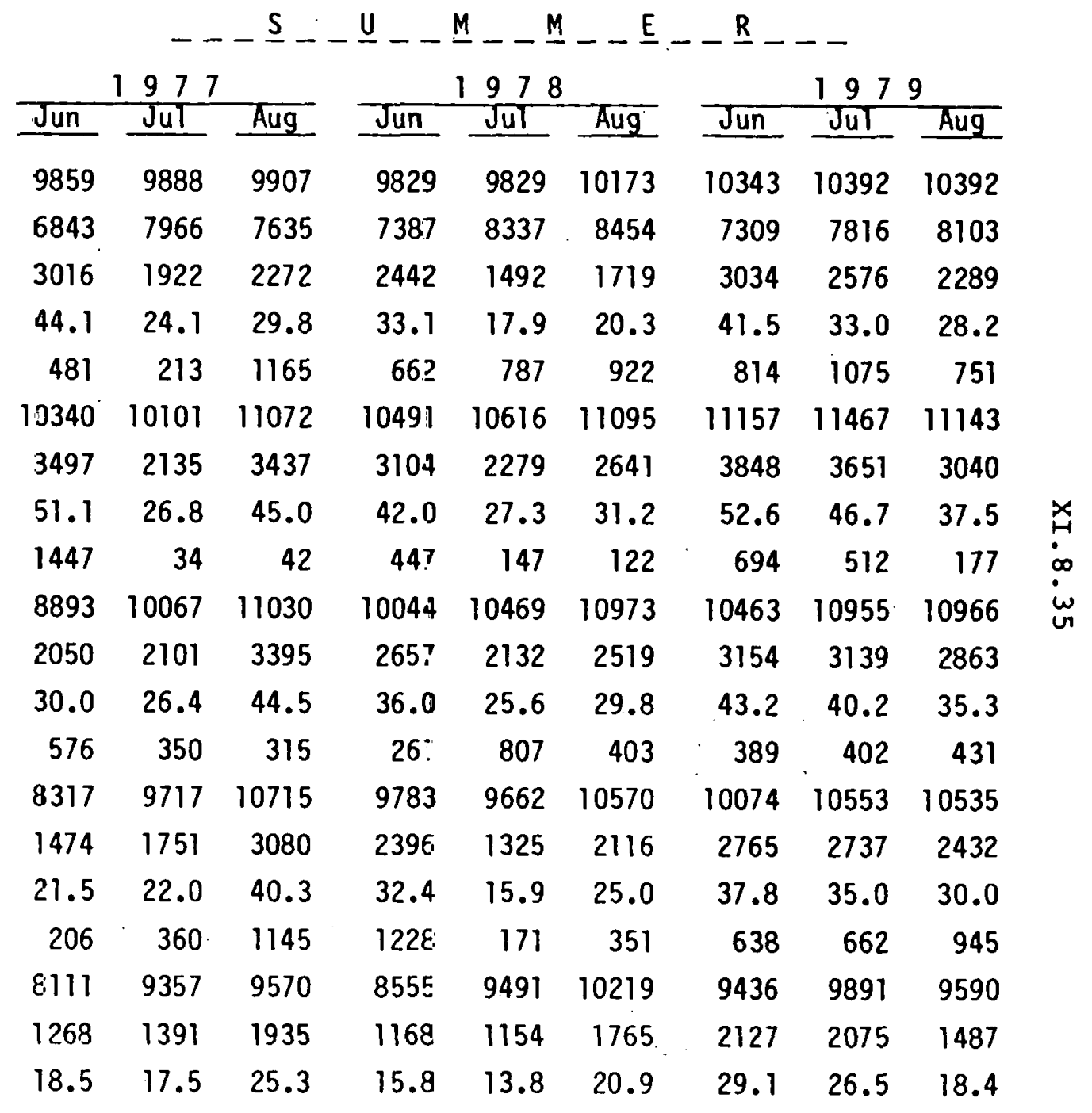


Table 8C.4.2

HIङTORICAL CAPABILITY (MA) AND RESERVES M Mi and Percent)

Missouri-Kansas Group

1. Planned Capability

2. Peak Demand

3. Planned Reserves (1-2)

4. Planned Reserves (\%) (3/2) $\times 10$ 0

5. Net Transactions (Imports-Exports)

6. Total Capability $(1+5)$

7. Total Reserves (6-2)

8. Total Reserves $(\%)(7 / 2) \times 100$

9. Scheduled Maintenance

10. Capability after Maintenance (6-9)

11. Reserves after Maintenance (70-2)

12. Reserves after Maintenance (a) $(11 / 2) \times 10 \mathrm{C}$

13. Inoperable Capability

14. Available Capability (10-13)

15. Available Reserves (14-2)

16. Available Reserves (\%) (15/2)/k100

17. Farced Outages

18. Actual Capability after Forced Dutages (i4-17)

19. Actual Reserves (18-2)

20. Actual Reserves $(\%)(19 / 2) \times 100$

\begin{tabular}{|c|c|c|c|c|c|c|c|c|}
\hline \multicolumn{3}{|c|}{$977 / 78$} & \multicolumn{3}{|c|}{$1978 / 79$} & \multicolumn{3}{|c|}{$1979 / 80$} \\
\hline $\mathrm{Dec}$ & Jan & Fet & Dec & Jan & Feb & Dec & Jan & Feb \\
\hline 1840 & 9846 & 9846 & 10121 & 10333 & 10333 & 10451 & 10442 & 10399 \\
\hline 5466 & 5587 & 55018 & 5634 & 5772 & 5767 & 5617 & 5571 & 5528 \\
\hline 4374 & 4259 & 4338 & 4487 & 4551 & 4566 & 4834 & 4871 & 4871 \\
\hline 80.0 & 76.2 & 78.8 & 79.6 & 79.0 & 79.2 & 86.1 & 87.4 & 88.1 \\
\hline-98 & 17 & -94 & 566 & 576 & 460 & 984 & -124 & 239 \\
\hline 742 & 9863 & 9752 & 10687 & 10909 & 10793 & 1435 & 10318 & 10638 \\
\hline 4276 & 4276 & $42<4$ & 5053 & 5137 & 5026 & 5818 & 4747 & 5110 \\
\hline 78.2 & 76.5 & 77.1 & 89.7 & 89.0 & 87.2 & 103.6 & 85.2 & 92.4 \\
\hline 1413 & 738 & 482 & 1457 & 775 & 973 & 1711 & 1256 & 959 \\
\hline 8329 & 9125 & 9270 & 9230 & 10134 & 9820 & 9724 & 9062 & 9679 \\
\hline 2863 & 3538 & 3762 & 3596 & 62 & 4053 & 4107 & 91 & 4151 \\
\hline 52.4 & .3 & 68.3 & 63.8 & 6 & 70.3 & 73.1 & 7 & 75.1 \\
\hline 603 & 40 & 4 & 2 & 5 & 583 & 340 & 344 & 264 \\
\hline 7726 & 8085 & 8836 & 8598 & 9779 & 9237 & 9384 & 8718 & 9415 \\
\hline 2260 & 2498 & 3328 & 2964 & 4007 & 3470 & 3767 & 3147 & 3887 \\
\hline 41.3 & 44.7 & 60.4 & 52.6 & 69.4 & 60.2 & 67.1 & 56.5 & 70.3 \\
\hline 160 & 255 & 920 & 450 & 1615 & 841 & 1156 & 351 & 1059 \\
\hline 7566 & 7830 & 7916 & 8148 & 8164 & 8396 & 8228 & 8367 & 8356 \\
\hline 2700 & 2243 & 24108 & 2514 & 2392 & 2629 & 2611 & 2796 & 2828 \\
\hline 38.4 & 40.1 & 43.7 & 44.6 & 41.4 & 45.6 & 46.5 & 50.2 & 51.2 \\
\hline
\end{tabular}




\section{Table 8 C. .5}

\section{CURRENT CAPABILITY (MW) AND RESERVES (MN and Percent)} Missouri-Kansas Group

1. Planned Capability I/

2. Peak Demand

3. Planned Reserves (1-2)

4. Planned Reserves (\%) $(3 / 2) \times 100$

5. Net Transactions (Imports-Exports)

6. Total Capability $(1+5)$

7. Total Reserves (6-2)

8. Total Reserves $(\%)(7 / 2) \times 100$

9. Scheduled Maintenance

10. Capability after Maintenance (6-9)

11. Reserves after Maintenance (10-2)

12. Reserves after Maintenance (\%) (11/2) $\times 100$

13. Inoperable Capability

14. Available Capability (10-13)

15. Available Reserves (14-2)

16. Available Reserves (\%) (15/2) ×100

17. Forced Outages $\underline{2} /$

18. Actual Capability after Forced Outages (14-17)

19. Actual Reserves (18-2)

20. Actual Reserves (\%) $(19 / 2) \times 100$ $\begin{array}{ll}1980 & 1980 / 81 \\ \text { Summer } & \text { Winter }\end{array}$

13121

13110

10674

2447

22.9

429

13550

2876

26.9

44

13506

2832

26.5

96

13410

2736

25.6

1338

12072

1398

13.1
7874

5236

66.5

430

13540

5666

72.0

183

13357

5483

69.6

105

13252

5378

68.3

1683

11569

3695

46.9

I/ No delays are anticipated in new generating units since submission of ERA-411.

2/ Estimated by ERA staff based on historical amounts. 
FUTUR E CAPABILITY (MW) AND RESERVES (MW and Percent) - 1981-84 Missouri-Kansas Group

1. Planned Capability

2. Peak Demand

3. Planned Reserves $(1-2)$

4. Planned Reserves (\%) (3/2) $\times 100$

5. Net Transactions (Imports-Exports)

6. Total Capability $(1+5)$

7. Total Reserves $(6-2)$

8. Total Reserves $(\%)(7 / 2) \times 100$

9. Scheduled Maintenance

10. Capability after Maintenance (E-9)

11. Reserves after Maintenance (10-2)

12. Reserves after Maintenance (\%) $(11 / 2) \times 100$

13. Inoperable Capability

14. Available Capability (10-13)

15. Available Reserves (14-2)

16. Available Reserves (\%) $(15 / 2) \times 130$

17. Forced Outages

18. Actual Capability after Forced Outages (14-1 $i$ )

19. Actual Reserves (18-2)

20. Actual Reserves $(\%)(19 / 2) \times 100$

\begin{tabular}{rr}
\multicolumn{2}{c}{1981} \\
Summer & Winter \\
\cline { 3 - 3 } 13207 & 13238 \\
11183 & 8308 \\
2024 & 4930 \\
18.1 & 59.3 \\
413 & 420 \\
13620 & 13658 \\
2437 & 5350 \\
21.8 & 64.4 \\
83 & 436 \\
13537 & 13222 \\
2354 & 4914 \\
21.0 & 59.1 \\
96 & 105 \\
13441 & 13117 \\
2258 & 4809 \\
20.2 & 57.9 \\
1400 & 1774 \\
12041 & 11343 \\
858 & 3035 \\
7.7 & 36.5
\end{tabular}

1983

\begin{tabular}{|c|c|}
\hline Summer & Winter \\
\hline 15490 & 15491 \\
\hline 12245 & 9179 \\
\hline 3245 & 6312 \\
\hline 26.5 & 68.8 \\
\hline 373 & 425 \\
\hline 15863 & 15916 \\
\hline 3618 & 6737 \\
\hline 29.5 & 73.4 \\
\hline $\begin{array}{r}83 \\
\end{array}$ & 472 \\
\hline 15780 & 15444 \\
\hline $\begin{array}{l}3535 \\
28.9\end{array}$ & $\begin{array}{r}6265 \\
68 \quad 2\end{array}$ \\
\hline $\begin{array}{r}28.9 \\
96\end{array}$ & $\begin{array}{r}68.3 \\
105\end{array}$ \\
\hline 15684 & 15339 \\
\hline 3439 & 6160 \\
\hline 28.1 & $\begin{array}{l}67.1 \\
1972\end{array}$ \\
\hline 14139 & 13367 \\
\hline 189 & 4188 \\
\hline 15. & 45.6 \\
\hline
\end{tabular}

1984

Summer Winter

\section{$15474 \quad 15491$}

$12791 \quad 9620$

$2683 \quad 5871$

$21.0 \quad 61.0$

$304 \quad 408$

$15778 \quad 15899$

$2987 \quad 6279$

$23.4 \quad 65.3$

$60 \quad 651$

$15718 \quad 15248$

$2927 \quad 5628$

$22.9 \quad 58.5$

$96 \quad 89$

$15622 \quad 15159$

$2831 \quad 5539$

$22.1 \quad 57.6$

1618

1618
14004

9.5

2087
13072

3452

35.9

Nuclear Unit_Del ays as Projected_by Nuclear Regulation_Commisssion

21. Nuclear Delays

22. Actual Capability (18-21)

23. Actual Reserves with Nuclear DElays (22-2)

$\begin{array}{rr}0 & 0 \\ 12041 & 11343 \\ 858 & 3035\end{array}$

$\begin{array}{rr}0 & 0 \\ 12676 & 11805 \\ 982 & 3078\end{array}$

955
13184
939

955
12412
3233

$\begin{array}{rr}0 & 0 \\ 14004 & 13072 \\ 1213 & 3452\end{array}$

Coal_Linit Delays_Assumed_Possible $\underline{\text { e by_ERA }}$

25. Possible Coal Delays

26. Actual Capability W/Nuclear \& Zoal Delays $(2 \hat{c}-25)$

27. Actual Reserves w/Nuclear \& CoEl Delays $(25-\hat{c})$

$\begin{array}{rr}0 & 0 \\ 12041 & 11343 \\ 858 & 3035 \\ 7.7 & 36.5\end{array}$

28. Actual Reserves w/Nuclear \& Cozl 1 Delays

(\%) $(27 / 2) \times 100$

$\begin{array}{rr}0 & 0 \\ 12676 & 11805 \\ 982 & 3078 \\ 8.4 & 35.3\end{array}$

280
12904
659
5.4

280
12132
2953

32.2

35.9

1/ Estimated by ERA staff based on historical forced outage amounts. 
FUTURE CAPABILITY (MW) AND RESERVES (MW and Percent) - 1985-89 Missouri-Kansas Group

1. Planned Capability

2. Peak Demand

3. Planned Reserves (1-2)

4. Planned Reserves (\%) (3/2) $\times 100$

5. Net Transactions (Imports-Exports)

6. Total Capability $(1+5)$

7. Total Reserves $(6-2)$

8. Total Reserves $(\%)(7 / 2) \times 100$

9. Scheduled Maintenance

10. Capability after Maintenance (6-9)

11. Reserves after Maintenance (10-2)

12. Reserves after Maintenance $(\%)(11 / 2) \times 100$

13. Inoperable Capability

14. Available Capability (10-13)

15. Available Reserves (14-2)

16. Available Reserves (\%) (15/2) x100

17. Forced Outages

18. Actual Capability after Forced Outages (14-17)

20. Actual Reserves (\%) $(19 / 2) \times 100$
19. Actual Reserves (18-2)

1985

Sumrer Winter Summer Winter Summer

\begin{tabular}{|c|c|c|c|c|c|c|c|c|c|}
\hline $\begin{array}{r}16331 \\
13357 \\
2974 \\
22.3 \\
230 \\
16611 \\
3234 \\
24.4\end{array}$ & $\begin{array}{r}16328 \\
10157 \\
6171 \\
60.8 \\
395 \\
16723 \\
6566 \\
64.6\end{array}$ & $\begin{array}{r}16595 \\
13884 \\
2711 \\
19.5 \\
151 \\
16746 \\
2862 \\
20.6\end{array}$ & $\begin{array}{r}16659 \\
10640 \\
6019 \\
56.6 \\
277 \\
16936 \\
6296 \\
59.2\end{array}$ & $\begin{array}{r}16959 \\
14493 \\
2466 \\
17.0 \\
122 \\
17081 \\
2588 \\
17.9\end{array}$ & $\begin{array}{r}17163 \\
11153 \\
6010 \\
53.9 \\
253 \\
17416 \\
6263 \\
56.2\end{array}$ & $\begin{array}{r}17199 \\
15109 \\
2090 \\
13.8 \\
210 \\
17409 \\
2300 \\
15.2\end{array}$ & $\begin{array}{r}17263 \\
11695 \\
5568 \\
47.6 \\
348 \\
17611 \\
5916 \\
50.6\end{array}$ & $\begin{array}{r}17716 \\
15756 \\
1960 \\
12.4 \\
175 \\
17891 \\
2135 \\
13.6\end{array}$ & $\begin{array}{r}17776 \\
12188 \\
5588 \\
45.8 \\
317 \\
18093 \\
5905 \\
48.4\end{array}$ \\
\hline $\begin{array}{r}0 \\
16611\end{array}$ & $\begin{array}{r}0 \\
16723\end{array}$ & $\begin{array}{r}0 \\
16746\end{array}$ & $\begin{array}{r}0 \\
16936\end{array}$ & $\begin{array}{r}0 \\
17081\end{array}$ & $\begin{array}{r}0 \\
17416\end{array}$ & $\begin{array}{r}0 \\
17409\end{array}$ & $\begin{array}{r}0 \\
17611\end{array}$ & $\begin{array}{r}0 \\
17891\end{array}$ & $\begin{array}{r}0 \\
18093\end{array}$ \\
\hline $\begin{array}{l}3254 \\
24.4\end{array}$ & $\begin{array}{r}6566 \\
64.6\end{array}$ & $\begin{array}{l}2862 \\
20.6\end{array}$ & $\begin{array}{l}6296 \\
59.2\end{array}$ & $\begin{array}{l}2588 \\
17.9\end{array}$ & $\begin{array}{l}6263 \\
56.2\end{array}$ & $\begin{array}{l}2300 \\
15.2\end{array}$ & $\begin{array}{l}5916 \\
50.6\end{array}$ & $\begin{array}{l}2135 \\
13.6\end{array}$ & $\begin{array}{l}5905 \\
48.4\end{array}$ \\
\hline 36 & 89 & & 40 & & 40 & & 40 & 0 & 40 \\
\hline 16515 & 16634 & 16746 & 16896 & 17081 & 17376 & 17409 & 17571 & 17891 & 18053 \\
\hline 3158 & 6477 & 2862 & 6256 & 2588 & 6223 & 23 & 5876 & 2135 & 586 \\
\hline & $\begin{array}{r}63.8 \\
0\end{array}$ & 20.6 & 58.8 & 17.9 & & & 50.2 & 13.6 & \\
\hline | & 16634 & 16747 & 6896 & 7081 & 17376 & 17409 & 17571 & 178 & 180 \\
\hline & & 2862 & $\forall$ & 25 & 6223 & 230 & 5876 & & \\
\hline & 63.8 & 20.6 & 58.8 & 17 & 55.8 & 15.2 & 50.2 & 13.6 & 48. \\
\hline
\end{tabular}

\section{Nuclear Unit_Delays as Projected by Nuclear Regulation_Commission}

21. Nuclear Delays

22. Actual Capability (18-21)

$\begin{array}{rrrrrr}0 & 0 & 0 & 0 & 250 & 250 \\ 16515 & 16634 & 16746 & 16896 & 16831 & 17126\end{array}$

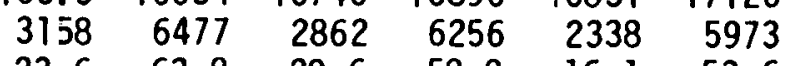

63.8

20.6

24. Actual Reserves with Nuclear Delays $(\%)(23 / 2) \times 100$

23.6

1/ Information on Scheduled Maintenance and Forced Outages not available for the 1985/89 time period. 
Table 8C.8

FUTURE LOAD GROWTH :

Missouri-Kansas Group

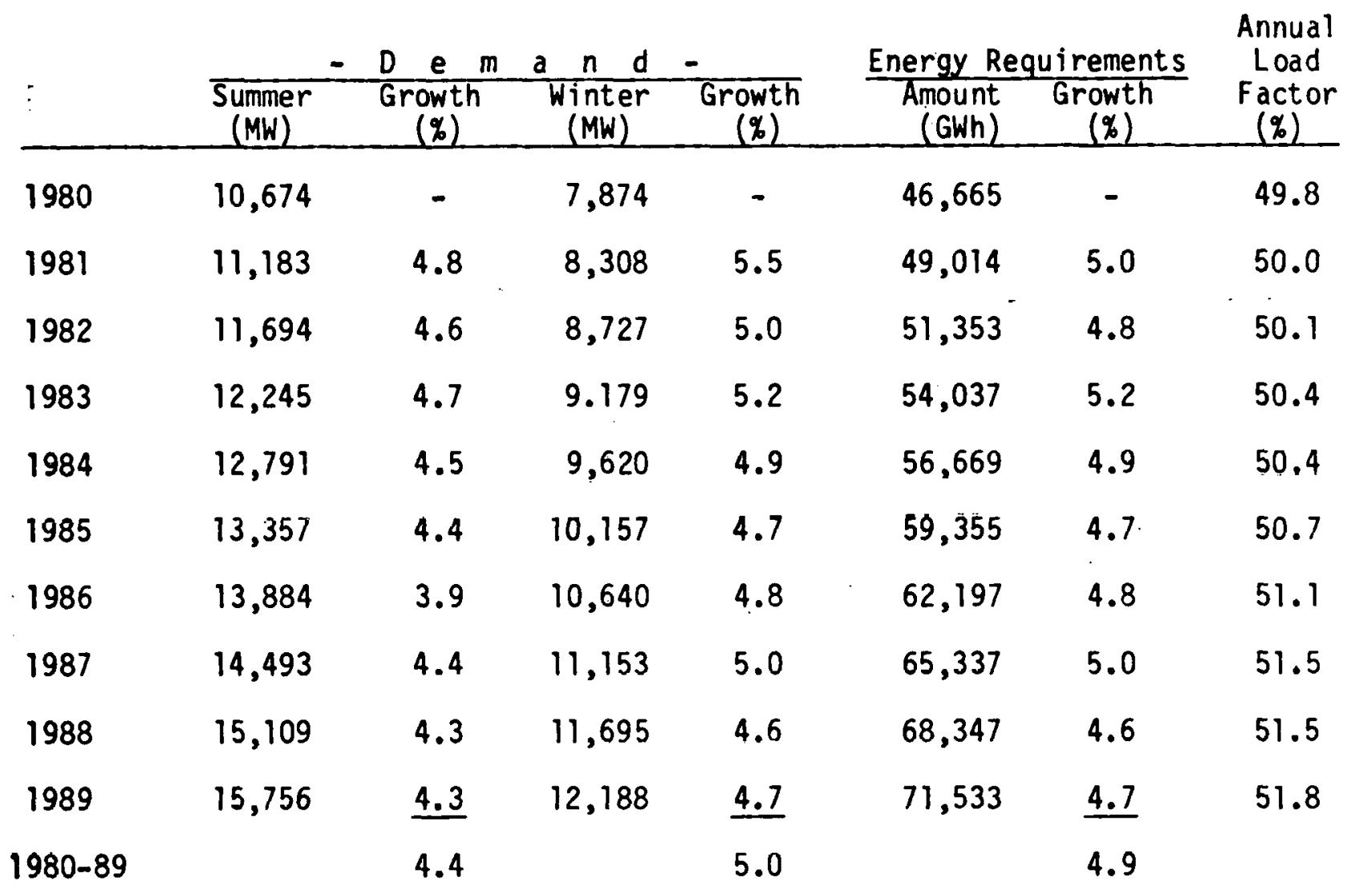




$$
X I .8 .41
$$

Table 8C.9

\section{GENERATION MIX BY FUEL TYPE}

Missouri-Kansas Group

\begin{tabular}{|c|c|c|c|c|c|c|}
\hline Type Fuel & $\frac{\text { Summer }}{\frac{\text { Capability }}{(\mathrm{MW})}}$ & $\begin{array}{l}1980 \\
\% \text { of Tota1 } \\
(\%)\end{array}$ & $\frac{\frac{\text { Summer }}{\text { Capability }}}{\text { (MW) }}$ & $\frac{1985}{\frac{\% \text { of Total }}{(\%)}}$ & $\frac{\text { Summer }}{\frac{\text { Capability }}{(M W)}}$ & $\frac{1989}{\% \text { of Total }}$ \\
\hline Nuclear & 0 & - & - 955 & 5.8 & 1,205 & $6.8 \ldots$ \\
\hline Coal & 9,147 & 69.7 & 11,417 & 69.9 & 12,667 & $71.5:$ \\
\hline Gas & 2,743 & 20.9 & 2,486 & 15.2 & 2,257 & 12.7 \\
\hline 011 & 1,215 & 9.3 & 1,457 & 9.0 & 1,488 & 8.4 : \\
\hline Hydro & 16 & 0.1 & 16 & - & 16 & $0.1 \vdots$ \\
\hline Other & $\underline{0}$ & - & 0 & $=$ & 83 & $0.5:$ \\
\hline Total & 13,121 & 100.0 & 16,331 & 100.0 & 17,716 & 100.0 \\
\hline
\end{tabular}


Oklahoma Group (Region 22)

\section{Historical Perspective}

The Oklahoma Group includes all of Oklahoma and portions of Arkansas, Louisiana, New Mexico, and Texas. The Region has been a predominantly natural gas burning area, but it does use some coal and a little oil. As has occurred in most areas of the country, the growth rates for demand and energy have been declining. The historical growth rates are listed in Table 8D.1.

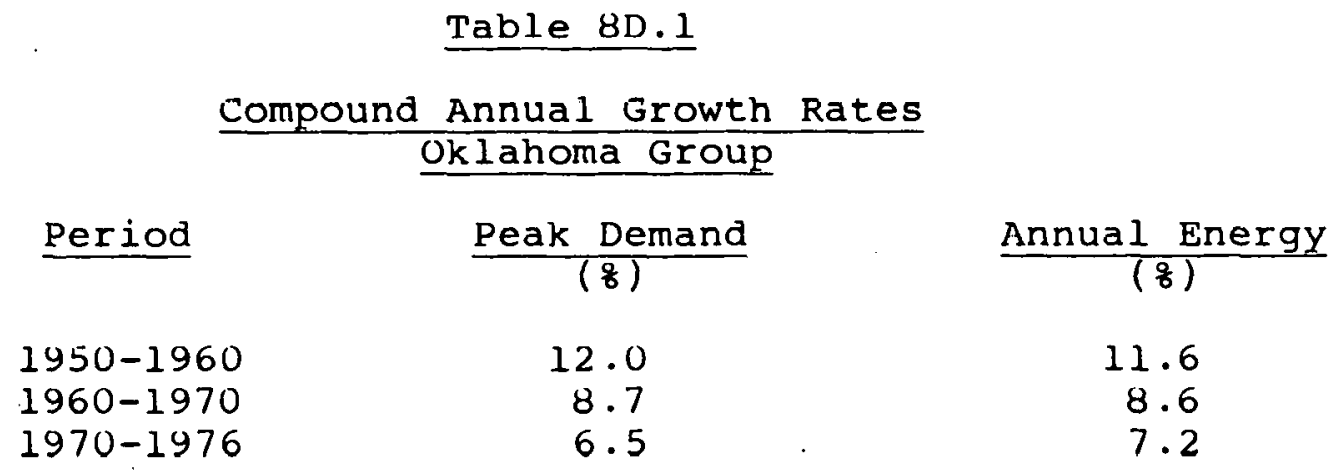

In addition, the historical growth rates from 1977 to 1979 have shown an even more drastic decrease (see Table 8D.3). The 1979 peak demand and annual energy were less than 1978 figures with growth rates of -3.88 percent and $-U .53$ percent, respectively.

Tables 8D.4.1 and 8D.4.2 show the 1977-79 actual reserves for three summer and three winter months. The oklahoma Group has had total reserves that ranged from 19.8 percent to 32.6 percent during the summer, and actual reserves that ranged from 16.9 percent to 22.9 percent.

Table 8D.2 shows the capacity mix by fuel type and the generation by fuel type for 1979 . 


\section{Table 8D.2}

Capacity Mix and Generation by Fuel Type for 1979 Oklahoma Group

Fuel Type
Coal
Oil
Natural Gas
Nuclear
Hydro
Other

Total

\begin{tabular}{rr}
\multicolumn{2}{c}{ Capacity } \\
\hline (GWh (8 of & Total) \\
3.458 & 19.2 \\
293 & 1.6 \\
11.767 & 65.5 \\
$-0-$ & 0.0 \\
2.438 & 13.5 \\
42 & 0.2 \\
\hline 17,998 & 100.0
\end{tabular}

\begin{tabular}{rr}
\multicolumn{2}{c}{ Annual Generation } \\
\hline (GWh) (8 of Total) \\
$13,554.9$ & 18.6 \\
166.2 & 0.2 \\
$52,953.7$ & 72.7 \\
$-0-$ & 0.0 \\
$6,075.5$ & 8.4 \\
85.5 & 0.1 \\
\hline $72,835.8$ & 100.0
\end{tabular}

* Includes a co-generation unit and an expander turbine using hot inert gas from a chemical process.

During the 1980-89 period, the Oklahoma Region is projecting 9.259 MW of additional coal-fired capacity, $900 \mathrm{MW}$ of nuclear capacity (Black Fox No. 1) and $214 \mathrm{MW}$ of hydro capacity. This will result in the following capacity mix, by the winter of 1989-90, as a percent of the total: Coal - 48.2 percent, oil - 1.1 percent, natural gas - 36.7 percent, nuclear 3.5 percent, hydro - 10.3 percent, and other -0.2 percent.

The Oklahoma Region has, for the 1977-79 summer and winter periods, been a net seller of power. This is due in part to the Department of Energy's Southwestern Power Administration which sells power to the MOKAN systems (Region 2l) and Middie South Systems (Region 8). For the entire Region 22, net energy sales were $5,939.8 \mathrm{GWh}$ for $1977,9,735.0 \mathrm{GWh}$ for 1978 , and $13.039 .7 \mathrm{GWh}$ in 1979, which constitutes 9.6 percent, 14.1 percent, and 18.1 percent of their system's net generation. respectively. 


\section{Current Perspective}

The Oklahoma Group is projecting 866 MW of coal-fired capacity in service by the 1980 summer peak and an additional $965 \mathrm{MW}$ by the winter peak. There are no anticipated delays of these units.

Total, available, and actual reserves appear adequate for the summer and winter periods as shown on Table 8D.5. Total reserves will be 25.1 percent and 71.7 percent for the summer and winter, respectively. There is no scheduled maintenance or inoperable capability projected for the 1980 summer and $126 \mathrm{MW}$ of scheduled maintenance for the winter. This results in available resrves of 25.1 percent for the summer and 70.4 percent for the winter. Estimated forced outages based on historical forced outage trends would result in actual reserves of 20.4 percent and 62.2 percent for the summer and winter, respectively.

Table $8 D .9$ provides projected generation mix by fuel type during the summers of 1980, 1985, and 1989. During the 1980 summer peaking period, the Oklahoma Group plans to have $4,324 \mathrm{MW}$ of coal-fired capability, 10,790 MW fired by natural gas, $295 \mathrm{MW}$ by oil, 2,542 $\mathrm{MW}$ of hydro capability and $42 \mathrm{MW}$ of other (includes a co-generation unit and an expander turbine using hot inert gas).

\section{Future Perspective}

The Oklahoma Group is projecting a peak demand growth rate of 5.5 percent for the 1981-1984 period. This is slightly higher than the 5.2 percent growth rate for the 1985-1989 period. As stated previously in the Historical Perspective, most of the capacity additions in the 1980-1989 period will be coal-fired. During the 1981-1984 period, 2,417 MW of coalfired capacity and $58 \mathrm{MW}$ of hydro capacity is projected. Due to the limited number of viable hydroelectric sites remaining, hydro will not play much of a role in future capacity expansion plans.

Total reserves for the summer peak (which are based upon planned generating resources and any power purchases and sales) are projected to range from 18.4 percent to 28.9 percent (see Table 8D.6). This is above the SPP criteria of 
15 percent. Available reserves (which show the effect of scheduled maintenance and any inoperable capability) will range freom 17.2 percent to 28.9 percent. Again, this is well above the criteria.

Actual reserves (which reduce available reserves by estimated forced outages) range from 13.7 percent to 24.2 percent. This is considerably above the SPP actual reserve criteria of 6 percent. The forced outages were estimated using 1977-1979 historical outage rates obtained from Form 12E-2 data. This average summer rate was approximately 4.7 percent for Region 22 .

In addition, possible nuclear and coal unit delays were examined to see what effect they might have on operating reserves. There were no nuclear delays expected but it was estimated using status codes in ERA-4li and other available information that GRDA No. I (490 MW), welsh No. 3 (528 MW), Hugo No. I ( $376 \mathrm{MW}$ ), and Tolk No. I (508 MW) may be delayed as much as one year each. This would result in $490 \mathrm{MW}$ and $1,412 \mathrm{MW}$ of additional capability unavailable for the 1981 and 1982 summer peaks, respectively. The resultant actual reserve margins for these two years would be 20.7 percent and 13.9 percent which would appear quite adequate.

The Region is interconnected via EHV transmission lines to the Middle South Group ( $500 \mathrm{kV}$ ) and to the Missouri-Kansas Group with two $345-\mathrm{kV}$ lines.

A $345-\mathrm{kV}$ tie with the Gulf states Group to relieve overloads is projected to 1981 and a $345-\mathrm{kV}$ tie is proposed for 1983 with MOKAN in order to deliver Associated Electric Cooperative's share of the Black Fox No. I nuclear unit. In addition, two internal $345-\mathrm{kV}$ lines and a $230-\mathrm{kV}$ interconnection with MOKAN are projected for 1984 to increase interchange capability.

The Oklahoma Group should have adequate reserves to cover possible outages and possible unit delays during the 19811984 period.

Region 22 is projecting 5,011 MW of coal-fired capacity in the 1985-1989 period along with a $900 \mathrm{MW}$ share of Black Fox No. 1 nuclear unit and $52 \mathrm{MW}$ of hydro capacity. 
Table $8 \mathrm{D} .7$ shows that summer actual reserves will range from 17.9 percent to 21.4 percent. Reserves which do not include any estimated scheduled maintenance or forced outages, but do include projected nuclear delays range from 15.8 percent to 21.4 percent for the summer peak period. The Black Fox No. l unit is estimated to be delayed from its 1987 date beyond the 1989 period by NRC.

In addition to those transmission lines previously mentioned, the Oklahoma Group is projecting two $345-\mathrm{kV}$ internal lines. for 1986 to increase interchange capability.

The Oklahoma Group should have adequate reserves throughout the 1980-1989 period to cover all but abnormal circumstances.

During the 10-year period (1980-1989), the Oklahoma Group is projecting that its summer peak demand, winter peak demand and annual energy requirements will grow at an average rate of 5.4 percent, 5.7 percent, and 5.5 percent, respectively.

Table 8D.8 presents the numerical estimates and shows annual projected growths for each of the three items. Table 8D.8 also shows the calculated annual load factor. The Oklahoma Group is projecting that its annual load factor will remain fairly constant at a 54 percent level throughout the period.

In order for annual energy requirements to be served by the Region, an adequate supply of natural gas must be maintained. During the 1989 summer peak period, it is projected that 38.6 percent of the Region's generating capability will be fueled by natural gas (see Table 8D.9). 


$$
X I .8 .47
$$

Table 8D.3

HISTORICAL LOAD GROWTH

\section{Oklahoma Group (Region 22)}

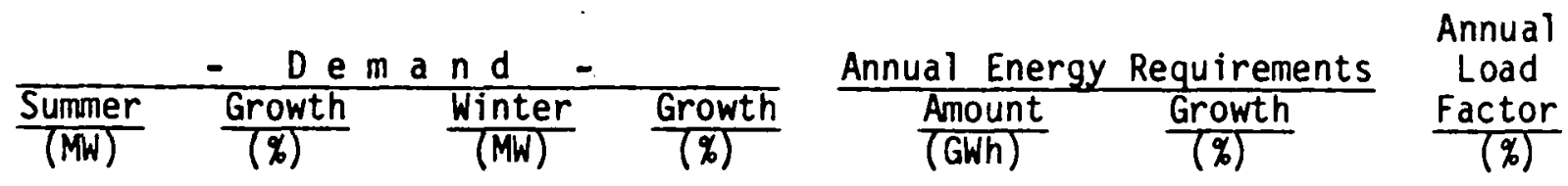

$\begin{array}{llllllll}1977 & 12,010 & - & 9,403 & - & 56,246 & - & 53.5 \\ 1978 & 12,576 & 4.71 & 9,156 & -2.63 & 59,429 & 5.66 & 53.9 \\ 1979 & 12,088 & -3.88 & 8,981 & -1.95 & 59,115 & -0.53 & 55.8\end{array}$


Table 80.4.1

F.STORICAL CAPABILITY (MW) AND RESERVES (MW and Percent)

(Ik lahoma Group (Region 22)

1. Planned Capability

2. Peak Demand

3. Planned Reserves (1-2)

4. Planned Reserves $(\%)(3 / 2) \times 10)$

5. Net Transactions (Imports-Exports)

6. Tatal Capability $(1+5)$

7. Total Reserves (6-2)

8. Total Reserves (\%) $(7 / 2) \times 100$

9. Scheduled Maintenance

10. Capability after Maintenance (6-9)

11. Reserves after Maintenance (10-2)

12. Reserves after Maintenance (z) $(11 / 2) \times 100$

13. Inoperable Capability

14. Available Capability (10-13)

15. Available Reserves (14-2)

16. Available Reserves (\%) (15/2:×1C0

17. Forced Outages

18. Actual Capability after Forced Dutages (-4-17)

19. Actual Reserves (18-2)

20. Actual Reserves (\%) $(19 / 2) \times 100$

\begin{tabular}{|c|c|c|c|c|c|c|c|c|}
\hline- & $\begin{array}{r}- \\
1977 \\
\end{array}$ & $\underline{S}$ & U & 1978 & $\underline{E}$ & $\underline{\kappa}$ & 197 & - \\
\hline un & Jul & Alog & Jun & JuI & Aug & Jun & Jul & Aug \\
\hline 655 & 14650 & 14681 & 5825 & 16140 & 16131 & 6530 & 16527 & 16526 \\
\hline 698 & 12010 & 11625 & 1716 & 12576 & 12561 & 460 & 11941 & 12088 \\
\hline 3957 & 2640 & 3056 & 4109 & 3564 & 3570 & 5070 & 4586 & 4438 \\
\hline 37.0 & 22.0 & $26 . .3$ & 35.1 & 28.3 & 28.4 & 44.2 & 38.4 & 36.7 \\
\hline-722 & -260 & -558 & -1037 & -1070 & -907 & -1455 & -694 & -537 \\
\hline 3933 & 14390 & 14123 & 14788 & 15070 & 15224 & 15075 & 15833 & 15989 \\
\hline 3235 & 2380 & 2498 & 3072 & 2494 & 2663 & 3615 & 3892 & 3901 \\
\hline 30.2 & 19.8 & 21.5 & 26.2 & .8 & 21.2 & 3.1 .5 & 6 & 32.3 \\
\hline 216 & 1 & D & 477 & 18 & 137 & 52 & 423 & 35 \\
\hline 3717 & 14372 & 14 & 311 & 15 & 15087 & 13 & 15 & 5954 \\
\hline 3019 & 2362 & 2498 & 2595 & 16 & 2526 & 2853 & 3469 & 3866 \\
\hline 28.2 & 19.7 & 21.5 & 22.1 & 19.7 & 20.1 & 24.9 & 29.1 & 32.0 \\
\hline 198 & 148 & 156 & 33 & 152 & 271 & 82 & 225 & 187 \\
\hline 13519 & 14224 & 13967 & 14278 & 14900 & 14816 & 14231 & 15185 & 15767 \\
\hline 2821 & 2214 & 2342 & 2562 & 2324 & 2255 & 27.71 & 3244 & 3679 \\
\hline 26.4 & 18.4 & 20. & 21.9 & 10 & 18 & 2 & 27.2 & 0.4 \\
\hline 538 & 0 & ? & 583 & 0 & 128 & 52 & 694 & 1159 \\
\hline 2981 & 14130 & 13686 & 13695 & 14730 & 14688 & 14079 & 14491 & 14608 \\
\hline 2283 & 2120 & 2061 & 1979 & 2154 & 2127 & 2619 & 2550 & 2520 \\
\hline 21.3 & 17.7 & 17.7 & 16.9 & 17.1 & 16.9 & 22.9 & 21.4 & 20.8 \\
\hline
\end{tabular}


HISTORICAL CAPABILITY (MW) AND RESERVES (MW and Percent)

Oklahoma Group (Region 22)

1. Planned Capability

2. Peak Demand

3. Planned Reserves (1-2)

4. Planned Reserves (\%) (3/2) $\times 100$

5. Net Transactions (Imports-Exports)

6. Total Capability $(1+5)$

7. Total Reserves (6-2)

8. Total Reserves (\%) $(7 / 2) \times 100$

9. Scheduled Maintenance

10. Capability after Maintenance (6-9)

11. Reserves after Maintenance (10-2)

12. Reserves after Maintenance (\%) (11/2) $\times 100$

13. Inoperable Capability

14. Available Capability (10-13)

15. Available Reserves (14-2)

16. Available Reserves (\%) (15/2) $\times 100$

17. Forced Outages

18. Actual Capability after Forced Outages (14-17)

19. Actual Reserves (18-2)

20. Actual Reserves ( $($ ) $(19 / 2) \times 100$

\begin{tabular}{|c|c|c|c|c|c|c|c|c|}
\hline 8 & $\begin{array}{c}- \\
1977 / 78 \\
\end{array}$ & $\underline{W}$ & I & (1) & $\underline{E}$ & $\underline{R}$ & $\begin{array}{l}- \\
979 / 80 \\
\end{array}$ & - \\
\hline ec & Jan & $\overline{F e b}$ & $\overline{\mathrm{Dec}}$ & Jan & $\overline{F e b}$ & Dec & Jan & Feb \\
\hline 509 & 15474 & 68 & 655 & 16609 & 16599 & 7054 & 17473 & 17501 \\
\hline 466 & 8705 & 03 & 344 & 9156 & 893 & 8973 & 3981 & 8836 \\
\hline 43 & 6769 & o & 7811 & 7453 & 7667 & 8081 & 8492 & 8665 \\
\hline 3.2 & 77.8 & ( & 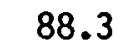 & 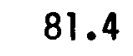 & 0.0 & 90.1 & 44.6 & 98.1 \\
\hline ? & -2048 & 7 & 2281 & -1651 & 642 & -1795 & -2349 & -2704 \\
\hline 877 & 13426 & 13738 & 374 & 14958 & 14957 & 15259 & 15124 & 14797 \\
\hline 411 & 4721 & 335 & 5530 & 5802 & 6025 & 6286 & 6143 & 5961 \\
\hline 63.9 & 54.2 & 46.1 & 62.5 & 63.4 & 67.5 & 70.1 & .4 & 67. \\
\hline 76 & 57 & 1074 & $?$ & 36 & 1150 & 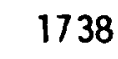 & & 1013 \\
\hline 201 & 269 & & 2 & & 13 & 21 & 48 & 1010 \\
\hline 25 & & 2461 & & 16 & 4875 & 548 & 367 & 4948 \\
\hline 44.1 & 40.9 & 6.2 & 46.6 & 40.6 & 54.6 & 50.7 & 18.6 & 56.0 \\
\hline 20 & 57 & 3 & 58 & 98 & 215 & 141 & 46 & 199 \\
\hline 2063 & 12212 & 11833 & 12904 & 12774 & 13592 & 3380 & 302 & 13585 \\
\hline 3597 & 3507 & 2430 & 600 & 3618 & 60 & 107 & 1 & 749 \\
\hline 42.5 & 40.3 & 258 & 45.9 & 39.5 & $5 ?$ ? & 1 & 1 & 53.7 \\
\hline 61 & 171 & 100 & 2 & 632 & 10נית & 08 & 34 & 198 \\
\hline 199 & 11738 & 11393 & 2741 & 12142 & 12195 & 472 & 1.2718 & 13387 \\
\hline 2733 & 3033 & 0 & 3897 & 2986 & 3263 & 3499 & 3737 & 4551 \\
\hline 32.3 & 34.8 & 21.2 & 44.1 & 32.6 & 36.5 & 39.0 & 41.6 & 51.5 \\
\hline
\end{tabular}


1. Planned Capability I/

2. Peak Demand

3. Planned Reserves (1-2)

4. Planned Reserves (\%) $(3 / 2) \times 100$

5. Net Transactions (Imports-Exports)

6. Total Capability $(1+5)$

7. Total Reserves $(6-2)$

8. Total Reserves (\%) $(7 / 2) \times 100$

9. Scheduled Maintenance

10. Capability after Maintenance (6-9)

11. Reserves after Maintenance (10-2)

12. Reserves after Maintenance (\%) (11/2) $\times 100$

13. Inoperable Capability

14. Available Capability (10-13)

15. Available Reserves (14-2)

16. Available Reserves (\%) (15/2) ×100

17. Forced Outages 2 f

18. Actual Capability after Forced Outages (14-17)

19. Actual Reserves (18-2)

20. Actual Reserves (\%) $(19 / 2) \times 100$

1980
Summer $\cdot \begin{aligned} & 1980 / 81 \\ & \text { Winter }\end{aligned}$

$17993 \quad 18819$

$13391 \quad 9776$

$4602 \quad 9043$

$34.4 \quad 92.5$

$-1240 \quad-2038$

$16753 \quad 16781$

$3362 \quad 7005$

$25.1 \quad 71.7$

$0 \quad 126$

$16753 \quad 16655$

$3362 \quad 6879$

$25.1 \quad 70.4$

0

16753

3362

25.1

629

16124

2733

20.4
16655

6879

70.4

802

15853

6077

62.2

I/ No Nuclear Unit delays.

2/ Estimated by ERA staff based on historical forced outage amounts. 
Table 80.6

FUTURE CAPABILITY (MW) AND RESERVES (MW and Percent) - 1981-84 Oklahoma Group (Region 22)

2. Peak Demand

3. Planned Reserves $(1-2)$

5. Net Transactions (Imports-Exports)

6. Total Capability $(1+5)$

7. Total Reserves (6-2)

8. Total Reserves $(\%)(7 / 2) \times 100$

9. Scheduled Maintenance

10. Capability after Maintenance (6-9)

11. Reserves after Maintenance (10-2)

12. Reserves after Maintenance (\%) $(11 / 2) \times 100$

13. Inoperable Capability

14. Available Capability (10-13)

15. Available Reserves (14-2)

17. Forced Outages

18. Actual Capability after Forced Outages (14-17)

19. Actual Reserves (18-2)

20. Actual Reserves (\%) (19/2) x100
1. Planned Capability

4. Planned Reserves $(\%)(3 / 2) \times 100$

16. Available Reserves $(\%)(15 / 2) \times 100$

\begin{tabular}{|c|c|c|c|}
\hline \multicolumn{2}{|c|}{1981} & \multicolumn{2}{|c|}{1982} \\
\hline Summer & Winter & ummer & Winter \\
\hline 19510 & 1937 & 20975 & 207 \\
\hline & & & \\
\hline & 9093 & 067 & 9850 \\
\hline & & 0.7 & \\
\hline-1324 & -2 & 76 & -2 \\
\hline 18186 & 170 & 19 & 18584 \\
\hline 4076 & & 4191 & 10 \\
\hline 28.9 & & 28.1 & 9.8 \\
\hline & & 0 & 61 \\
\hline 18186 & 16696 & 19099 & 1802 \\
\hline 4076 & & 4191 & 708 \\
\hline 28.9 & & 1 & 4.7 \\
\hline & & 93 & 19 \\
\hline 18186 & 16696 & 18906 & 178 \\
\hline 4076 & 6419 & 399 & 0000 \\
\hline 28.9 & 62. & 26 & \\
\hline & & & \\
\hline 17523 & 1585 & 18398 & 17126 \\
\hline 3 & & & \\
\hline & & 20.4 & \\
\hline
\end{tabular}

1983

Summer Winter

$20881 \quad 20763$

15757

5124

32.5

$-1460$

19421

3664

23.3

0
19421

19421
3664

23.3

193

19228

3471

22.0

548

18680

2923

18.6
11634
9129

78.5

$-1559$

19204

7570

65.1

661

18543

6909

59.4

193
18350

6716

57.7

761

17589

5955

51.2
1984

Summer Winter

$20783 \quad 21085$

$\begin{array}{ll}16607 & 12317\end{array}$

$4176 \quad 8768$

$25.1 \quad 71.2$

$-1119-1295$

$19664 \quad 19790$

$3057 \quad 7473$

$18.4 \quad 60.7$

0775

$19664 \quad 19015$

$3057 \quad 6698$

$18.4 \quad 54.4$

$193 \quad 193$

$19471 \quad 18822$

$2864 \quad 6505$

$17.2 \quad 52.8$

$588 \quad 817$

$18883 \quad 18005$

$2276 \quad 5688$

$13.7 \quad 46.2$

Nuclear Unit_Del ays as Projected by Nuclear Regulation Commission

21. Nuclear Delays

22. Actual Capability (18-21)

17523

3413

$\begin{array}{rr}0 & 0 \\ 15853 & 18398 \\ 5576 & 3490 \\ 54.3 & 23.4\end{array}$

0
17126
6184
56.5

54.3

23.4

24. Actual Reserves with Nuclear Delays

$(\%)(23 / 2) \times 100$

24.2
0
18680

2923

18.6
0
17589
5955
51.2

18883

2276

13.7

Coal_ Unit Delays_Assumed Possible by_ERA

25. Possible Coal Delays

490
17033

27. Actual Reserves w/Nuclear \& Coal Delays (26-2)

28. Actual Reserves w/Nuclear \& Coal Delays (\%) $(27 / 2) \times 100$

490
15363
5086
49.5

1412
16986

16986
2078

13.9

1412
15714
4772
43.6

1/ Estimated by ERA staff based on historical forced outage amounts. 
FUTURE CAPABILITY (MW) AND RESERVES (MW and Percent) - 1985-89 Ok lahoma Group (Region 22)

1. Planned Capability

2. Peak Demand

3. Planned Reserves (1-2)

4. Planned Reserves $(\%)(3 / 2) \times 100$

5. Net Transactions (Imports-Expor:s)

6. Total Capability $(1+5)$

7. Total Reserves (6-2)

8. Total Reserves (\%) $(7 / 2) \times 100$

9. Scheduled Maintenance 1/

10. Capability after Maintenance $(\epsilon-9)$

11. Reserves after Maintenance (10-?)

12. Reserves after Maintenance $(\%)(11 ; 2) \times 100$

13. Inoperable Capability

14. Available Capability (10-13)

15. Available Reserves (14-2)

16. Available Reserves $(\%)(15 / 2) \times 150$

17. Forced Outages I/

18. Actual Capability after Forced Jutages (14-17)

19. Actual Reserves (18-2)

20. Actual Reserves (\%) $(19 / 2) \times 100$
1986

1987

1985

Summer Winter

$22526 \quad 22487$

17517

13042

$\begin{array}{rr}5009 & 9445 \\ 28.6 & 72.4\end{array}$

$\begin{array}{ll}-1068 & -1244\end{array}$

21458

394

22.5

21458

394

22.5

193
21265
3748

21265
3748

21.4

0

21265
3748

3748
21.4
-1244
21243

8201

62.9

\section{summer}

\section{5}

18464

13812

4872

26.4

$-1369$

9153

21967

66.3

$-1645$

21320

7508

19.0

0

21243

21967

0

21310

$\begin{array}{ll}3503 & 7508 \\ 19.0 & 54.4\end{array}$

62.9

21050

193

2177.

193
21127

21127
7315

61.4

17.9

21050

21774

53.0

61.4
$3503 \quad 7508$

21050
8008

24947

493

23614

157
23457
4036

23457

20.8

$21127 \quad 23457$

Nuclear Unit_Del ays as Projected by Nuclear Regulation_Commission

21. Nuclear Delays

22. Actual Capability with Nuclear Delays (18-27)

23. Actual Reserves with Nuclear Delays (22-2)

24. Actual Reserves with Nuclear Delayis

$$
\text { (\%) }(23 / 2) \times 100
$$

$\begin{array}{rrrrrrrrrr}0 & 0 & 0 & 0 & 900 & 900 & 900 & 900 & 900 & 900 \\ 21265 & 21050 & 21774 & 21127 & 22557 & 22242 & 23624 & 23010 & 24825 & 24329 \\ 3748 & 8008 & 3310 & 7315 & 3136 & 7679 & 3218 & 761 & 3394 & 8166 \\ 21.4 & 61.4 & 17.9 & 53.0 & 16.1 & 52.7 & 15.8 & 49.9 & 15.8 & 50.5\end{array}$

1988

1989

ummer Winter Summer Winter Summer Winter

24908

25879

$20406 \quad 15349$

2554126940

14563

5473

10192

21431

26720

$-1333-11.0$

2361423299

26.8
-1236

66.4

10557

$\begin{array}{rrrrr}8736 & 4237 & 8680 & 4377 & 9149\end{array}$

24643

$-1512$

$-1132$

0
23299

20.8

56.6

20.4

56.6

$4193 \quad 8736$

24643

24029

25808

25312

$21.6 \quad 60.0$

157
23142

20.8

8680

4377

9149

119

24524

119

23910

83
25725

58.9

20.2

0

55.8

23910

23142

24524

4118

8561

$\begin{array}{ll}8561 & 4294 \\ 55.8 & 20.0\end{array}$

56.5

25229

9066

56.1

25229

9066

56.1

1/ Information on Scheduled Maintenance and Farced Outages not available for the 1985/89 period. NOTE: No Coal Unit Delays Ant-cifated by ERA. 
Table 80.8

FUTURE LOAD GROWTH

Oklahoma Group (Region 22)

\begin{tabular}{|c|c|c|c|c|c|c|}
\hline & $D$ e $m$ & a 11 & $\pi$ & $R_{E}$ & Re & $\begin{array}{c}\text { Annual } \\
\text { Load }\end{array}$ \\
\hline (MW) & $\begin{array}{c}\text { Growth } \\
(\%)\end{array}$ & $\begin{array}{l}\text { Winter } \\
\text { (MW) }\end{array}$ & $\begin{array}{c}\text { Growth } \\
(\%)\end{array}$ & $\begin{array}{l}\text { Amount } \\
\text { (GWh) }\end{array}$ & (\%) & $\frac{\text { Factor }}{(\%)}$ \\
\hline
\end{tabular}

\begin{tabular}{|c|c|c|c|c|c|c|c|}
\hline 1980 & 13,391 & - & 9,776 & - & 63,100 & - & 53.6 \\
\hline 1981 & 14,110 & 5.4 & 10,277 & 5.1 & 66,800 & 5.9 & 54.0 \\
\hline 1982 & 14,908 & 5.7 & 10,942 & 6.5 & 70,500 & 5.5 & 54.0 \\
\hline 1983 & 15,757 & 5.7 & 11,634 & 6.3 & 74,300 & 5.4 & 53.8 \\
\hline 1984 & 16,607 & 5.4 & 12,317 & 5.9 & 78,400 & 5.5 & 53.7 \\
\hline 1985 & 17,517 & 5.5 & 13,042 & 5.9 & 82,800 & 5.6 & 54.0 \\
\hline 1986 & 18,464 & 5.4 & 13,812 & 5.9 & 87,300 & 5.4 & 54.0 \\
\hline 1987 & 19,421 & 5.2 & 14,563 & 5.4 & 92,000 & 5.4 & 54.1 \\
\hline 1988 & 20,406 & 5.1 & 15,349 & 5.4 & 96,800 & 5.2 & 54.0 \\
\hline 1989 & 21,431 & $\underline{5.0}$ & 16,163 & 5.3 & 101,900 & 5.3 & 54.3 \\
\hline $1980-89$ & & 5.4 & & 5.7 & & 5.5 & \\
\hline
\end{tabular}


$X I .8 .54$

Table 80.9

GENERATION MIX BY FUEL TYPE

Oklahoma Group (Region 22)

Summer 1980.

Summer 1985

Summer 1989

Capability o of Total Capability \& of Total Capability o of Total

Type Fuel (MW) (\%) (MW) (\%) (MW)

\begin{tabular}{lrrrrrr} 
Nuclear & 0 & - & 0 & - & 900 & 3.3 \\
Coal & 4,324 & 24.0 & 8,854 & 39.3 & 12,717 & 47.2 \\
Gas & 10,790 & 60.0 & 10,739 & 47.6 & 10,394 & 38.6 \\
0 i1 & 295 & 1.6 & 239 & 1.1 & 235 & 0.9 \\
Hydro & 2,542 & 14.2 & 2,652 & 11.8 & 2,652 & 9.8 \\
Other & 42 & 0.2 & -42 & $\underline{0.2}$ & -42 & -0.2 \\
\multicolumn{1}{r}{ Total } & 17,993 & 100.0 & 22,526 & 100.0 & 26,940 & 100.0
\end{tabular}




\section{SECTION XI. 9}

WESTERN SYSTEMS COORDINATING COUNCIL (WSCC) 


$$
X I .9 .1
$$

Western Systems Coordinating Council (WSCC)

\section{Introduction}

Western systems Coordinating Council (WSCC) was organized in 1967 to promote bulk power system reliability through coordinated planning and operation. Present membership includes 47 Member systems and 14 Affiliate Members. These utility systems provide substantially all of the electric service in the states of Arizona, California, Colorado, Idaho, Montana, Nevada, New Mexico, Oregon, Utah, Washington and Wyoming, as well as portions of Nebraska, South Dakota, West Texas, and the Provinces of Alberta and British Columbia, Canada 1/. The region extends over approximately 1.8 million square miles and represents a service area equivalent to more than onehalf of the continguous land area of the United States.

The WSCC consists of five subregions or areas. These subregions are the Northwest Power Pool Area, consisting of the states of Washington, Oregon, Idaho, and Utah, and parts of Montana, Wyoming, Nevada and California; the Rocky Mountain Power Area, consisting of the states of Colorado and part of Wyoming, South Dakota, and Nebraska; the Arizona-New Mexico Power Area, consisting of the states of Arizona and parts of New Mexico and Texas; the Southern California-Nevada Power Area consisting of the southern portion of the states of California and Nevada; and the Northern California-Nevada Power Area, consisting of the northern portions of the states of California and Nevada. Electric Regions identified in this report are consistent with the WSCC Areas and may differ slightly from the ERA Electric Regions currently defined. Identification of reporting utilities within the respective Regions is attached.

I/ This report excludes Canadian portions of wscc. 


$$
\text { Xi.9.2 }
$$

Table 9.1

\section{Electric Regions Within WSCC}

\section{WSCC Area}

Northwest Power Pool Rocky Mountain Power Pool Arizona-New Mexico Group Southern California-Nevada Group Northern California-Nevada Group

\section{Electric Region}

25 and 30
24
26
27
28

To the east WSCC abuts the mid-Continent Area Power Pool, the Southwest Power Pool and Electric Reliability Council of Texas; wscc abuts Mexico to the South and Canada to the North. 
Table 9.2

Utility Systems within wSCC Electric Regions

Electric Regions $25^{\circ}$ and 30

Northwest Power Pool Area (NWPP)

Bonners Ferry

Bonneville Power Administration

B.C. Hydro \& Power Authority

Bountiful, City of

Calgary Poer Ltd.

centralia, city of

Chelan County PUD

Cowlitz County. PUD

Douglas County PUD

Eugene Water \& Electric Board

Grant County PUD

Grays Harbor PUD

Idaho Powr Company

Montana Power Company

Pacific Power \& Light Company

Pend Oreille county PUD

Portland General Electric Company

Puget Sound Power \& Light Company

Seattle City Light

Snohomish PUD

st. George, City

Tacoma City Light

U.S.V.P. - Pacific Northwest Region -

BPA (So. Idaho System)

USUC Loads Wheeled by Utah Power \& Light co.

U.S. Corps of Engineers (North Pacific Div.)

Utah Powr \& Light Company

Washington Water Power Company

West Kootnay Power \& Light Company 
Table 9.2 (Cont'd)

Utility Systems Within WSCC Electric Regions

Electric Region 24

Rocky Mountain Power Area (RMPA)

Basin Electric Power Cooperative (Wyoming and Black Hills Power and Light Company

Colorado Springs, City of

Colorado-Ute Electric Association

Lamar, City

Platte River Power Authority

Public Service Co. of Colorado

So. Culorado Power Division, Central

Telephone \& Utilities Corp.

Tri-state Generation \& Transmission

Association, Inc.

U.S.W.P - Lower Missouri Region

U.S.W.P. - Upper Colorado Region

Western Area Power Administration

Denver Area

Western ARea Power Administration

Salt Lake Area

\section{Electric Region 26}

Arizona-New Mexico Power Area (AZ-NM)

Arizona Electric Power Cooperative

Arizona Power Authority

Arizona Public Service Company

Citizens Utilities Company

El Paso Electric Company

Imperial Irrigation District

Los Alamns systems

Navajo Tribal Utility Authority

Plains Electric $G \& T$ Cooperative

Public Service co. of New Mexico

Salt River Project

San Carlos Irrigation project

Southern California Edison Company

(Blythe District)

Tucson Electric Power Company

U.S.W.P. - Lower Colorado Region (Including USUC Loads in LC Region)

U.S.W.P. Rio Grande Project (SW Region)

Western Area Power Administration

Boulder City Area 
Table 9.2 (Cont'd)

Utility Systems within wSCC Electric Regions

Electric Region 27

Southern California-Nevade Power Area (S.CA-NV)

Anaheim, City of

Burbank, City of

California Dept. of Water Resources

California-Pacific Utilities Company

Glendale, City of

Tntermountain Consumer Power Aseociation

Lincoln County Power District

Los Angeles Dept. of Water \& Power, City of

Metropolitan water District/So. California

Nevada Power Company

Pasadena, City of

Riverside, City of

San Diego Gas \& Electric Company

Southern California Edison Company

State of Nevada

U.S.W.P. at Boulder City

Electric Region 28

Northern California-Nevade Power Area (N.CA-NV)

California Dept. of Water Resources

Pacific Gas \& Electric Company

Sacramento Municipal Utility District

San Francisco, City and County of

Sierra Pacific Power Company

Turlock and Modesto Irrigation Districts

U.S.W.P. - Mid Pacific Region

Western ARea Power Administration - Mid

Pacific Region 


\section{Electric Region $2 \underline{4}$ - Rocky Mountain Power Area}

\section{Historical Perspective}

The Rocky Mountain Power Area (RMPA) encompasses the entire state of Colorado, the eastern half of Wyoming, and a portion of southwestern South Dakota.

Major utilities in the area include: Public service company of Colorado (PSCC) which serves more than 50 percent of area electric demand; D.O.E., Western Area Power Administration (WAPA) which serves various public utilities within (and outside) the area; Colorado-UTE Electric Association (CUEA); City of Colorado springs (CCS); Tri-state Generation and Transmission Assoclation (TSG\&T); and Black Hills Power and Light Company (BHP\&L) serving loads in eastern woming and southwest South Dakota.

Coordinated operation within the area has been minimal in the past, basically limited to planning and emergency assistance. However, the Colorado utilities are now beginning to operate on a much more closely coordinated basis in conjunction with other members of the Inland Power pool.

Historically, area load growth has been relatively high. Energy for load growth averaged 8.4 percent from 1960 through 1973, 7.7 percent. from 1973 through 1976, and.5.9 percent from 1976 through 1979. Reasons for the continued high growth relative to most other areas of the WSCC include strong demographic growth and extensive conversion of irrigation pumping from natural gas to electricity.

Electric usage is nearly constant in winter and summer, and in recent years the area has experienced annual peaks during both seasons. PSCC's winter peak is presently growing at a faster rate than the summer peak because of increased use of electric heating.

\section{Table $\underline{\text { 9A. }} .1$ \\ Historical Load Growth

Rocky Mountain Power Area

$\begin{array}{lrrr} & 1977 & 1978 & 1979 \\ \text { Energy Load (Gwh) } & 24,367 & 25,923 & 27,718 \\ \text { Growth from Previous } & 4.4 & 6.4 & 6.9 \\ \text { Year (8) } & 4,518 & 4,606 & 4,857 \\ \begin{array}{l}\text { Peak Demand (Mw) } \\ \text { Growth from Previous }\end{array} & 11.3 & 1.9 & 5.4 \\ \quad \text { Year (8) } & 61.2 & 64.2 & 65.1\end{array}$


The predominant type of generating capability in the area is the $2904 \mathrm{MW}$ of coal-fired steam generation which represented 45.2 percent of total planned capability and 59.7 percent of total generation in 1979 .

A significant amount of hydroelectric capability exists within the area totalling 35 percent of the planned capability and accounting for approximately 28 percent of the total area energy generation during average water conditions. The majority of this hydro

generation is owned and operated by the U.S. Water and Power Resources Service (formerly UBR) and marketed by WAPA's Upper Colorado and Lower Missouri Regions.

The only nuclear generating plant in the area. is the $330 \mathrm{MW}$ Fort St. Vrain high temperature gas reactor which was declared commercially operable at reduced power in January 1979. This PSCC owned facility originally produced energy in 1977 but technical problems resulted in the extended delay for commercial operation.

Seventeen percent of the area's planned capability is gas and/or oil fired which produced 11.7 percent of total electric energy generation in 1978. Consumption of these fuels for electricity production in 1979 was 832 thousand barrels of oil and 35.2 bililon cublc feet of natural gas $(5590$ thousand equivalent oil barrels).

The area's utilities plan on the basis of a planned reserve margin of approximately 20 percent. Data for the past 3 years indicate that reserve margins have been sufficient.

\begin{tabular}{|c|c|c|c|c|c|c|}
\hline \multicolumn{7}{|c|}{ Rock $\frac{\text { Reserve Margins }(z)}{\text { Mounta }}$} \\
\hline & \multicolumn{2}{|c|}{-1977} & \multicolumn{2}{|c|}{1978} & \multicolumn{2}{|c|}{-1979} \\
\hline & Suumér & Winter & Summe & Winter & Summe $\bar{r}$ & (est imated) \\
\hline $\begin{array}{l}\text { Planned } \\
\text { Reserves }\end{array}$ & 32.4 & 41.3 & 26.1 & 29.3 & 24.2 & 26.3 \\
\hline $\begin{array}{l}\text { Reservesg } \\
\text { After } \\
\text { Scheduled } \\
\text { Maintenance }\end{array}$ & 13.9 & 24.5 & 17.3 & 18.6 & 17.2 & 22.6 \\
\hline $\begin{array}{l}\text { Actual } \\
\text { Reserves }\end{array}$ & 9.4 & 19.7 & 15.1 & 12.6 & 5.5 & 20.8 \\
\hline
\end{tabular}


Table 9A. 3 $\frac{1979 \text { Operation by Type of Plant }}{\text { Rocky Mountain Power Area }}$

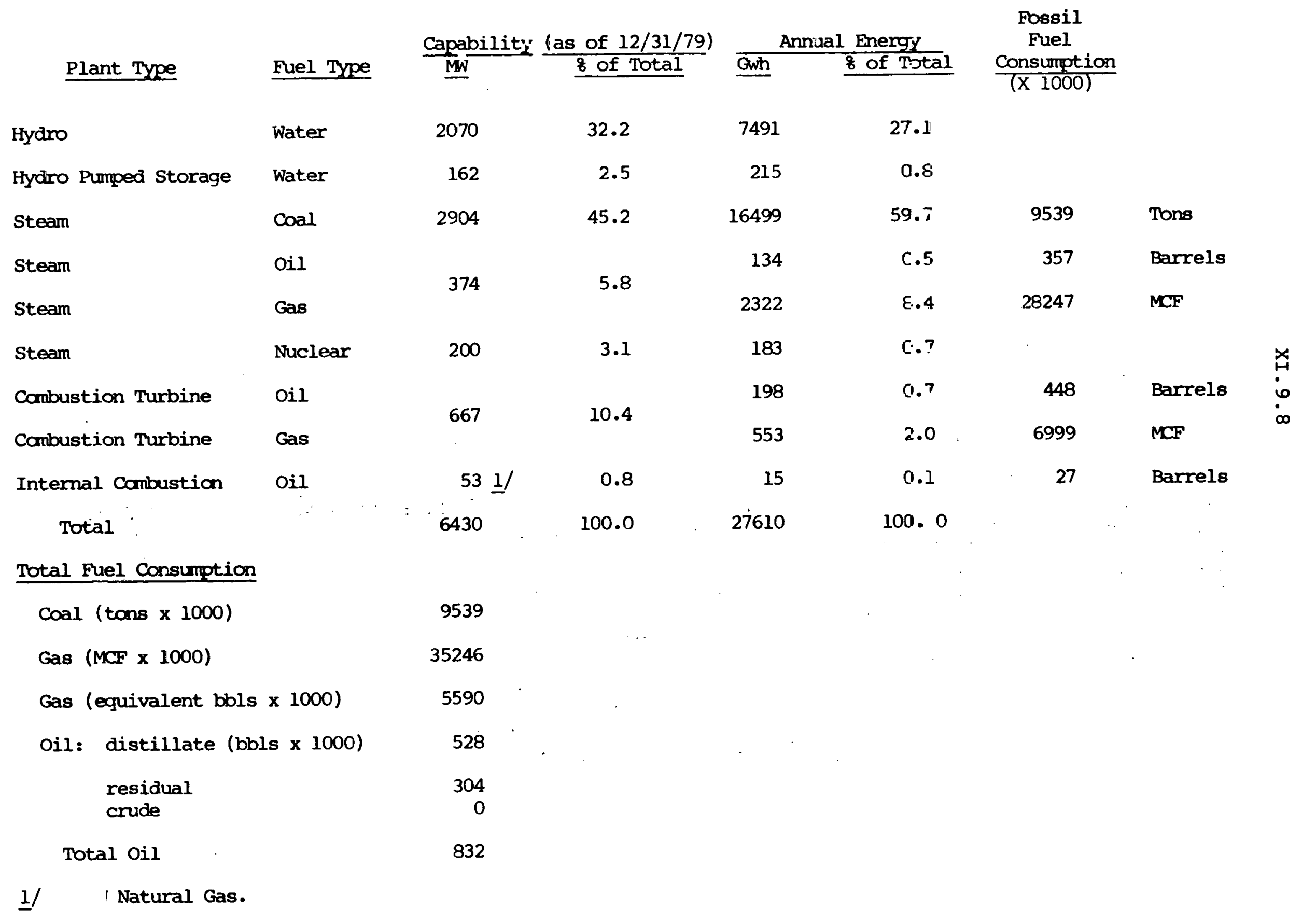


Table 9A.4

Historical Capability (MW) and Reserves (MW) and Percent)

Rocky Mountain Power Area

1. Planned Capability

2. Peak Demand

3. Planned Reserves (1-2)

4. Planned Reserves (8) $(3 / 2) \times 1008$

5. Net Transactions (Imports-Exports)

6. Total Capability $(1+5)$

7. Total Reserves (6-2)

8. Total Reserves ( 8$)(7 / 2) \times 1008$

9. Scheduled Maintenance

10. Capability After Maintenance $(6-9)$

11. Reserves After Maintenance (10-2)

12. Reserves After Maintenance (z) $(11 / 2) \times 1008$

13. Inoperable Capability

14 Available Capability (10-13)

15. Available Reserves (14-2)

16. Available Reserves (8) (15/2) × 1008

17. Forced Outages 1/

18. Actual Capability After Forced Outage (14-17)

19. Actual Reserves (18-2)

20. Actual Reserves (8) $(19 / 2) \times 1008$

1/ Information not reported separately

\begin{tabular}{|c|c|}
\hline \multicolumn{2}{|c|}{1977} \\
\hline Summer & Winter \\
\hline 5981 & 5894 \\
\hline 4518 & 4170 \\
\hline 1463 & 1724 \\
\hline 32.4 & 41.3 \\
\hline-729 & -296 \\
\hline 5252 & 5598 \\
\hline 734 & 1428 \\
\hline 16.2 & 34.2 \\
\hline 106 & 408 \\
\hline 5146 & 5190 \\
\hline 628 & 1020 \\
\hline 13.9 & 24. \\
\hline 202 & 200 \\
\hline 4944 & 499 \\
\hline 426 & 82 \\
\hline 9.4 & 19. \\
\hline 0 & \\
\hline 4944 & 499 \\
\hline 426 & 82 \\
\hline 9.4 & $\begin{array}{l}9 . \\
.0 .1\end{array}$ \\
\hline
\end{tabular}

\begin{tabular}{rr}
\multicolumn{2}{c}{1978} \\
\hline Summer & winter \\
\cline { 3 - 3 } 5808 & 6219 \\
4605 & 4810 \\
1200 & 1409 \\
26.1 & 29.3 \\
-285 & -153 \\
5521 & 6066 \\
915 & 1256 \\
19.9 & 26.1 \\
120 & 359 \\
5401 & 5707 \\
795 & 897 \\
17.3 & 18.6 \\
100 & 290 \\
5301 & 5417 \\
695 & 607 \\
15.1 & 12.6 \\
0 & 0 \\
5301 & 5417 \\
695 & 607 \\
15.1 & 12.6
\end{tabular}

1979

\begin{tabular}{|c|c|}
\hline Summer & Winter \\
\hline 6030 & 6424 \\
\hline 4857 & 5085 \\
\hline 1173 & 1339 \\
\hline 24.2 & 26.3 \\
\hline-308 & -76 \\
\hline 5722 & 6348 \\
\hline 865 & 1263 \\
\hline 17.8 & 24.8 \\
\hline 30 & 115 \\
\hline 5692 & 6233 \\
\hline 835 & 1148 \\
\hline 17.2 & 22.6 \\
\hline 570 & 92 \\
\hline 5122 & 6141 \\
\hline 265 & 1056 \\
\hline 5.5 & 20.8 \\
\hline 0 & 0 \\
\hline 5122 & 6141 \\
\hline 265 & 1056 \\
\hline 5.5 & 20.8 \\
\hline
\end{tabular}


Despite adequate reserve margins, reliability problems are substantial in the area as explained following.

Within the RMPA there are significant documented transmission bottlenecks which plague systems' reliability. Transmission limitations in western Colorado and southwestern Wyoming exist due to the delay of line additions needed to cover outage contingencies. These limitations coupled with generation shortages at individual utilities in the area have caused service disruptions and high risk situations on several occasions during the past few years. The bottlenecks also restrict transfers trom outside the area and expecially into the state of Colorado, a net energy importer. For example, the $1200 \mathrm{MW}$ interconnection with the Arizona - New Mexico Power Area in southern Colorado is limited to $350 \mathrm{MW}$ south to north because of transmission limitations internal to the Rocky Mountain Power Area.

Numerous transmission additions are under construction to alleviate many of the aforementioned limitations, but completion schedules have slipped due to various problems including regulatory requirements, labor force insufficiency, and project coordination.

Existing transmission in the area as of December 31,1979 consists of: 5154 miles of $115 \mathrm{kV} ; 2960 \mathrm{miles}$ of $230 \mathrm{kV}$; and $181 \mathrm{miles}$ of $345 \mathrm{kV}$. Interconnection to the east is limited to TSG\&T's single $100 \mathrm{MW}$ DC tie to the MARCA Region in Nebraska.

\section{Current Perspective}

Reserve margins in the Rocky Mountain Power Area (RMPA) are expected to be numerically well above requirements for 1980 as illustrated in the accompanying Table 9A.5. However, the aforementioned transmission deficiencies may cause reliability problems despite the scheduled addition of 77 miles of $115 \mathrm{kV}$ Iine and $656 \mathrm{miles}$ of $230 \mathrm{kV}$ (operating voltage) line in 1980 . Much of this construction is aimed specifically at relieving transmission overioads and improving reliability.

Prior to the forecasted summer peak only $187 \mathrm{miles}$ of $230 \mathrm{KV}$ additions are scheduled to be in service. As a result, the west west to east transfer capability within Colorado remains severely restricted and generator output in northwestern Colorado may also be restricted. Transfer capability into colorado from either the north or the south also will likely remain insufficient through the summer peak period. No transmission exists westward to Utah. 
Table 9A. 5

Current Capability (MW) and Reserves (MW) and Percent) - 1980

Rocky Mountain Power Area

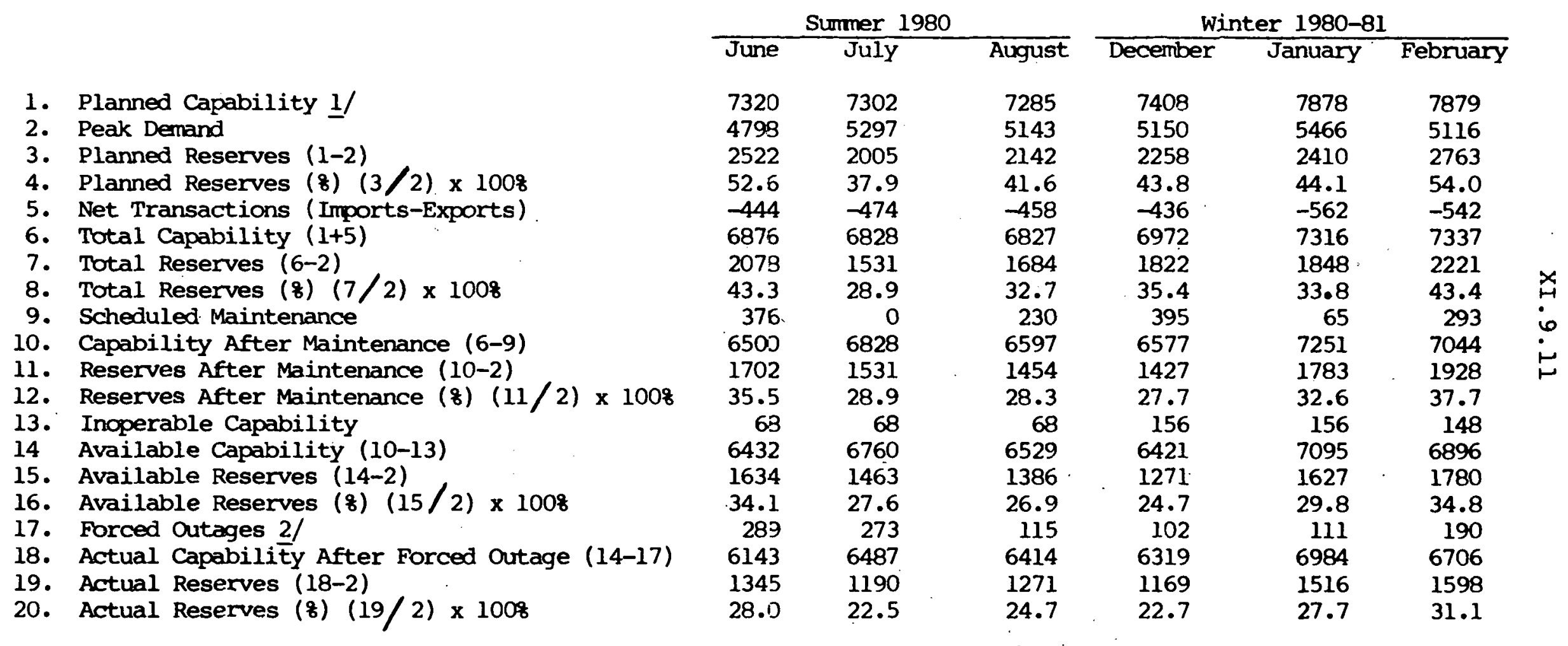

1/ No delays anticipated in new generating units since submittal of 1980 ERA-411

2/ Three year historical average forced outage (1977-79) 
Tabie 9A. 6

Estimatec 1980 Operation by Type of Plant Pocky Mountain Power Area

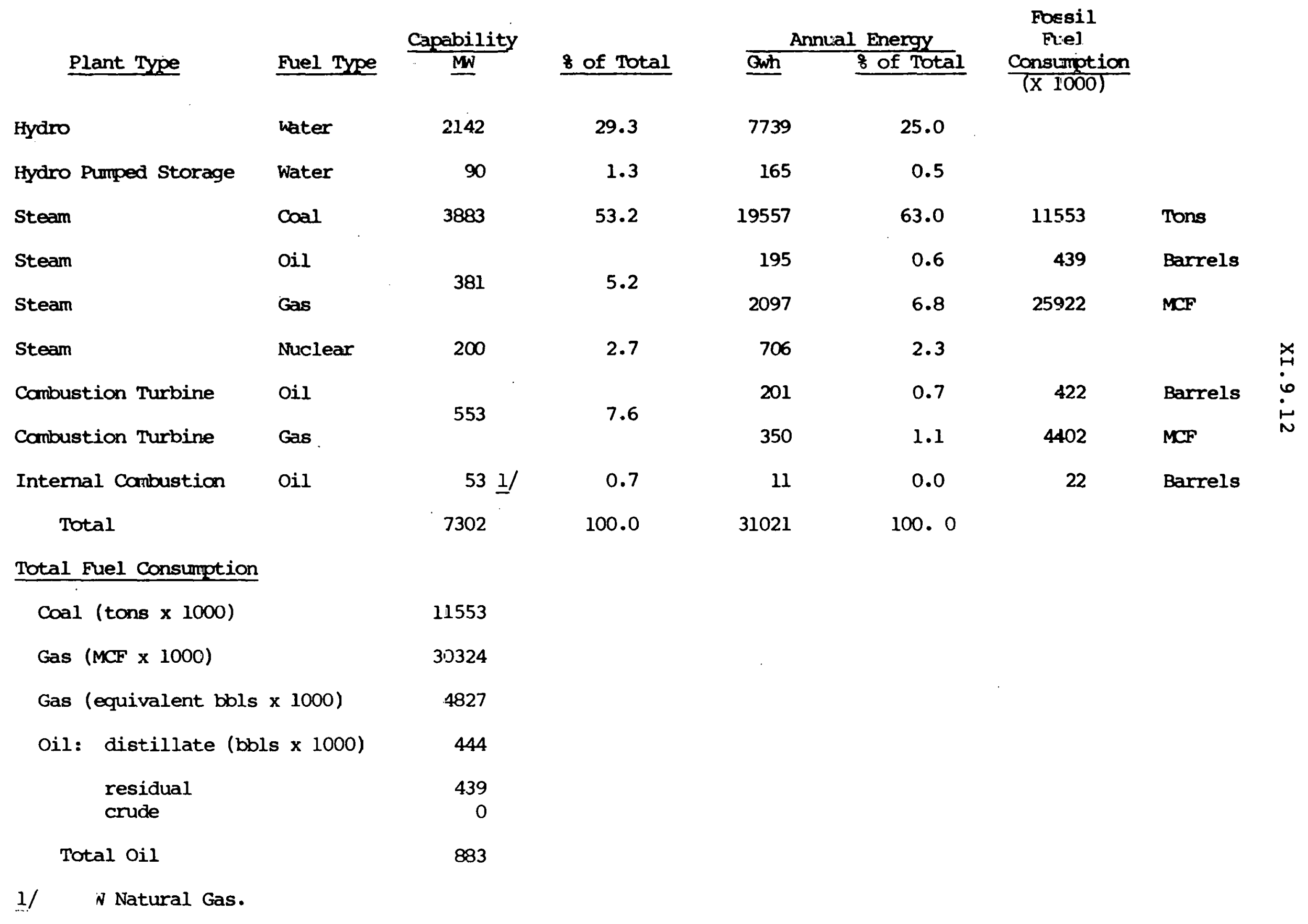


Load growth for the Region is forecast at 9.1 percent for peak demand from the actual summer of 1979 to that projected for the summer of 1980 and 8.6 percent in 1980 annual energy for load over 1979. These projects appear high, possibly due to mild weather conditions experienced in 1979 which may have contributed to less than usual energy usuage.

During 1980, scheduled additions to generating capacity are significant and consist of $110 \mathrm{MW}$ of coal-fired generation including: Unit No. I of the Laramie River Station ( $500 \mathrm{MW}$ ) which was undergoing testing as of April 1980; Ray D. Nixon Unit No. I $(200 \mathrm{MW})$ which was placed into commercial operation on April 4, 1980; and Craig Unit No. 1 (400 MW) which remains on schedule for a June in-service date.

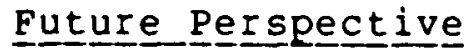

Utilities in the Rocky Mountain Power Area (RMPA) forecast their combined annual peak demand to increase an average of 6.0 percent per year from 1980 through 1985 and 4.8 percent per year from 1985 through 1989. Energy growth is projected to increase 7.1 percent annually through 1985 and 5.4 percent from 1985 through 1989 . These peak demand and energy growth rate projections are higher than those experienced during the past three years. Load factors are expected to increase from 62.8 percent in 1980 to 67.8 percent in 1989.

In addition to $110 \mathrm{MW}$ of coal-fired generation expected to come on-line in $1980,2190 \mathrm{MW}$ are scheduled through 1985 and $2480 \mathrm{MW}$ in 1986 through 1989. Coal fired capacity is expected to account. for 75 percent of total area electric energy generation in 1985 and 80 percent in 1989 compared to 61.2 percent in 1978 . Other additions include hydro and pumped storage plants. Table 9 A.9 lists significant capacity additions scheduled for the Region.

Several major resource additions reported by the wSCC as of January 1, 1979 for the five year period have been rescheduled.

These units are tabulated below along with the current anticipated in-service date and the respective delay or acceleration with respect to the previously reported date. 
$\mathrm{XI} .9 .14$

Table 9 A. 7

Scheduled Capability Additions that have been Delayed Rocky Mountain Power Area

$\begin{array}{lcccc}\text { Unit } & \begin{array}{c}\text { Capacity } \\ \text { (MW) }\end{array} & \begin{array}{c}\text { Previous } \\ \text { Date }\end{array} & \begin{array}{l}\text { New } \\ \text { Date }\end{array} & \begin{array}{c}\text { Delay } \\ \text { (Months) }\end{array} \\ \text { Mount Elbert 1 } & 100 & 10 / 79 & 7 / 18 & 19 \\ \text { Ray D. Nixon 1 } & 200 & 12 / 79 & 4 / 80 & 4 \\ \text { Craig 1 } & 400 & 12 / 79 & 6 / 80 & 6 \\ \text { Pawnee 1 } & 470 & 7 / 80 & 1 / 81 & 6 \\ \text { Mount Elbert 2 } & 100 & 4 / 81 & 8 / 83 & 28 \\ \text { Southeast 1 } & 470 & 4 / 84 & 4 / 85 & 12 \\ \text { Rawhide 1 } & 250 & 1 / 85 & 4 / 84 & -9 \\ \text { Southeast 2 } & 470 & 4 / 85 & 7 / 86 & 15 \\ \text { Osage 1 } & 100 & 6 / 85 & 10 / 84 & -8\end{array}$

Delays in bringing new coal-fired capability on-line in the area vary substantially from unit to unit. For example, the City of Colorado Spring's Ray D. Nixon Unit No. 1 which was originally scheduled for start-up in October 1979, actually became commercially operational in April 1980. Public Service Co. of Colorado's Pawnee unit No. I which was originally scheduled for April 1979 and had slipped to Julyl980 is now scheduled for January 1981, a 21 month delay, which could further be extended.

Any energy shortages created by slippage of expected coal or hydro resources would result in increased imports of coal-fired generation (if available) and increased generation from existing area oil and gas fueled units. An estimate of additional oil/gas to replace delayed additions is difficult to calculate for this region.

The area presently has a total of $1067 \mathrm{MW}$ of oil/gas fired generation consisting of steam, combustion turbine, and diesel units. No additions of these types of capability are planned. The primary fuel at most of the steam and combustion turbine units is natural gas. Estimated fuel consumption averages $4.1 \mathrm{million}$ equivalent barrels of oil and natural gas over the next ten years. Increasing the annual capacity factor to 50 percent, under energy shortage conditions, would increase the gas/oil consumption to approximately 9.3 million equivalent barrels, or an additional 5.2 million equivalent barrels per year over the estimated consumption with no unit delays. 
The Public service co. of colorado is participating in the Western Utilities coal-fired plant Standardization Group and many of the planned coal-fired additions are standardized in design. Some of the expected benefits of the common design are reduced lead times, capital cost savings, increased availability, and operations savings.

Projected reserves are more than adequate based on timely additions to generating capability. Table 9 A.8 summarizes expected reserves for the five years 1981 through 1985 .

\section{Table 9 A.}

Projojected Reserve Margins winter ( 8$)$

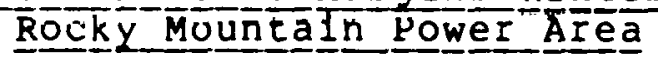

$1981 \quad \underline{1982} \quad \underline{1983} \quad \underline{1984} . \quad \underline{1985}$

Planned

Reserves

44.7

43.6

43.6

42.2

40.4

Reserves after

Scheduled

25.3

25.4

27.0

28.2

29.6

Maintenance

$\begin{array}{cccccc}\begin{array}{c}\text { Available } \\ \text { Reserves }\end{array} & 23.8 & 24.0 & 25.4 & 26.9 & 28.4\end{array}$

Based on the assumed delay of 6 months from the new schedule shown on Table 9 A.9 for all coal-fired additions, available reserve margin shown below remain sufficient.

\begin{tabular}{|c|c|c|c|c|c|c|}
\hline & & lab $\underline{\text { la }}$ & ves M & s win & (8) & \\
\hline & & 1981 & 1982 & $19 \underline{8} \underline{3}$ & 1984 & 1985 \\
\hline Delayed & schedule & 23.8 & 24.0 & 19.4 & 25.5 & 28.4 \\
\hline
\end{tabular}

Scheduled additions of transmission facilities from 1980 through 1989 consist of $10 \mathrm{l}$ miles of $115 \mathrm{kV}, 1424 \mathrm{miles}$ of $230 \mathrm{kV}$, and 1101 miles of $345 \mathrm{kV}$ line. These additions are designed to transport power from added generating units as well as eliminate existIng transmission inadequacies. Continued delays in bringing these facilities into service, could result in a continuation of past reliability problems and possible additional consumption of natural gas and oil. 
Table $\underline{9}$ A. 9

Significant planned Additions to Generating Capability Rocky Mountain Power Are a

Unit Name_ No.
Ray D. Nixon 1
Lamramie R. Str. 1
Craig 1
Pawnee 1
Cabin Creek
Mt. Elbert 1
Craig 3
Laramie R. Str. 3
Mt. Elbert 2
Rawhide 1
Osage 4
Southeast 1
Southeast 2
Pawnee 2
Ray D. Nixon 2
Unsited
Southwest 1
Glen Canyon $9-10$
Dominguezz - 5
Wyoming Coal 1
Flaming Gorge 4
Diamond Fork Cup
Diam

\section{Type}

Coal

Coal

Coal

Coal

Hyd ro

Pumped storage

Coal

Coal

Pumped storage

coal

Coal

coal

coal

coal

coal

coal

Coal

Hydro

Pumped storage

Coal

Hyd ro

Hydto

$$
\text { Capacit } \frac{\text { tM }}{(M)}
$$

In Servíce Datte

200
500
400
470
106
100.
400
500
100
250
100
470
470
470
200.
470
400
250
500
47.0
40.
47.6

$4 / 80$

$4 / 80$

$6 / 80$

$1 / 81$

$7 / 81$

$7 / 81$

$7 / 83$

$4 / 82$

$8 / 83$

$4 / 84$

$10 / 84$

$4 / 85$

$7 / 86$

$4 / 87$

$12 / 87$

$4 / 88$

$10 / 88$

$12 / 88$

$12 / 88$

$4 / 89$

$12 / 89$

$12 / 89$ 
Table 9A.10.1

Future Capability (MW) and Reserves (MW and Percent) 1981/1984 Rocky Mountair: Area

\author{
1. Planned Capability 1/ \\ 2. Peak Demand \\ 3. Planned Reserves (1-2) \\ 4. Planned Reserves ( 8$)(3 / 2) \times 1008$ \\ 5. Net Transactions (Imports-Exports) \\ 6. Total Capability $(1+5)$ \\ 7. Total Reserves (6-2) \\ 8. Total Reserves $(8)(7 / 2) \times 1008$ \\ 9. Scheduled Maintenance \\ 10. Capability After Maintenance (6-9) \\ 11. Reserves After Maintenance (10-2) \\ 12. Reserves After Maintenance $(z)$ \\ $(11 / 2) \times 1008$ \\ 13. Inoperable Capability \\ 14 Available Capability (10-13) \\ 15. Available Reserves (14-2) \\ 16. Available Reserves ( 8$)(15 / 2) \times 1008$ \\ 17. Forced outages 2/ \\ 18. Actual Capability After Forced Outage \\ (14-17) \\ 19. Actual Reserves (18-2) \\ 20. Actual Reserves (8) $(19 / 2) \times 100 \%$
}

\section{1}

Summer winter

$\frac{1982}{\text { Summer Winter }}$

8324

5776

2548

44.1

$-941$

7383

1607

27.8

0
7383

7383

1607

27.8

\section{8}

$$
5857
$$

\section{1}

44.7

$$
-915
$$

7563

29.1

7340

$\begin{array}{rr}2 & 89 \\ 7381 & 7251 \\ 1605 & 1394\end{array}$

27.8

7381

23. 8

1605

27.8

\section{8}

.6154

2684

43.6

$-960$

7878

1724

28.0

68

7810

1656

26.9

1

7809

1655

26.9

$-$

7809

1655

26.9
1983 Summer Winter

9001

6268

2733

43.6

$-912$

8089

1821

29.1

228

7861

1593

25.4

89

7772

1504

24.0

7772

1504

24.0

927.2

6585

2687

40.8

$-953$

8319

1734

26.3

8319

8319

1734

26.3

1
8318

1733

26.3

8318

1733

1733
26.3

\section{3}

6631

2892

43.6

$-854$

8669

2038

30.7

247

8422

1791

27.0

\section{5}

8317

1686

25.4

$-$

8317

1686

25.4
1706

223

1483

25.3

-

1394
238
1984

Summer Winter

96339873

$6933 \quad 6941$

$2700 \quad 2932$

$38.9 \quad 42.2$

$-896 \quad-798$

$8737 \quad 9075$

$1804 \quad 2134$

$26.0 \quad 30.7$

$0 \quad 178$

$8737 \quad 8897$

$1804 \quad 1956$

$26.0 \quad 28.2$

$1 \quad 89$

$8736 \quad 8808$

$1803 \quad 1867$

26.826 .9

$8736 \quad 8808$

$1803 \quad 1867$

$26.0 \quad 26.9$

1/ No delays anticipated in new generating units since submittal of 1980 ERA-4li

2) Information on forced outage not available 
Table 9A.10.2

i

Future Capebility (MN) and Reserves (MW and Percent) 1985/1989

Rocky Mountain Power Area

sur.

1. Planned Capability

2. Peak Demand

4. Planned Reserves (8) (3/2) x 1008

5. Net Transactions (Inports-Exports)

6. Total Capability $(1+5)$

7. Total Reserves (6-2)

8. Total Reserves (8) (7/2) x 1008

9. Scheduled Maintenance 1/

10. Capability After Maintenance (6-9)

11. Reserves After Maintenance (10-2)

12. Reserves After Maintenance ( 8$)$

$$
(11 / 2) \times 1008
$$

13. Inoperable Capability

14. Available Capability (10-13)

15. Available Reserves (14-2)

16. Available Reserves (q) (15/2) x 1008

17. Forced Outages 1/

18. Actual Capability After Forced Outage (14-17)

19. Actual Reserves (18-2)

20. Actual Reserves (8) (19/2) x 1008
1985

Summer

\section{Winte}

10
7
2
39
9
2
2
2
2

10153

7331

$2861 \quad 2962$

40.4

$-840 \quad-791$

93139502

$2021 \quad 2171$

$27.7 \quad 29.6$

- $\quad-$

9313

2021

95C:2

2171

29.6

$\begin{array}{rr}1 & 89 \\ 9312 & 9413\end{array}$

2020

27.7

2082

28.4

$\overline{-} \quad \overline{9312} \quad \overline{413}$

2020

27.7

2082

28.4
1986

Summer Winter

\section{3}

$7650 \quad 7720$

$2923 \quad 3048$

$38.2 \quad 39.5$

$-832$

9741

$2091 \quad 2265$

$27.3 \quad 29.3$

-

9741

2091

27.3

9985

2265

29.3

9740

9740
2090

27.3

89

\section{6}

9896
2176

28.2$$
-
$$

$\overline{9740}$

$\overline{9896}$

2090

27.3

2176

28.2
1987

Summer

\section{9}

7982

2997

37.5

$-824$

10155

2173

$2 ? .2$

$-$

10155

2173

$$
27.2
$$

1

1015

2172

27.2
$19 \overline{154} \quad 10 \overline{454}$

2172

27.2

10454

2306
$2 E .3$
$113: 8$

8148

3170

38.9

$-775$

10543

2395

29.4

10543

2395

29.4

89

10454

2306

28.3
1988

Summer Winter

Summer Winter

$11429 \quad 12538$

$8370 \quad 8644$

$3059 \quad 3894$

$36.5 \quad 45.0$

$-819 \quad-770$

$10610 \quad 11768$

$2240 \quad 3124$

26.8

36.1

-

10610

2240

11768

3124

36.1

109

10609

2239

26.8

11679
3035

35.1

10609

10609

2239

26.8
11679

3035

35.1
$12599 \quad 13254$

$8831 \quad 8775$

$42.7 \quad 51.0$

$-815 \quad-785$

$2953 \quad 3694$

33.4 42.1

-

11784

2953

33.4

12469

3694

42.1

89

11783 . 12380

$2952 \quad 3605$

$33.4 \quad 41.1$

$-$

$-$

12380

$\begin{array}{ll}2952 & 3605 \\ 33.4 & 41.1\end{array}$
$3768 \quad 3379$

$11784 \quad 12469$

1/ Information on scheduled maintenance and forced outages not available 
Table 9A.11

Estimated 1985 Operation by Type of Plant Rocky Mountain Power Area

Plant Type

Hydro

Hydro Pumped Starage

Steam

Steam

Steam

Steam

Cambustion Turbine

Combustion Turbine

Internal Combustion

Total

Total Fuel Consumption

coal (tans $\times 1000)$

Gas (MCP x 1000)

Gas (equivalent bbls $\times 1000$ )

Oil: distillate (bbls $\times 1000$ )

residual

crude

Total Oil

\section{Fuel Type}

Water

Water

Coal

Oil

Gas

Nuclear

Oil

Gas

Oil
8 of Total

$$
2199
$$

362

6200

381

200

553

$$
53 \underline{1}
$$$$
9950
$$

22.1

3.7

62.3

3.8

2.0

5.6

.

20682

18819

2988

777

331

$0 \div-1$.

1108
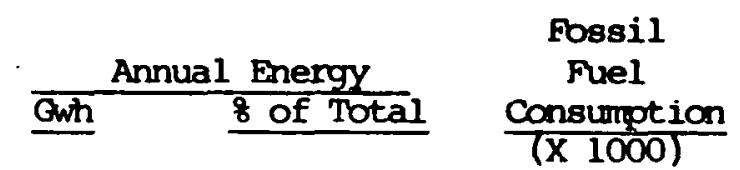

Fossil

$\frac{\text { Consumption }}{(\times 1000)}$

$\begin{array}{ll}7918 & 17.5\end{array}$

433

1.0

34178

75.5

0.6

258

1281

2.8

1.5

(221

0.5

0.6

0.0

20682

Tons

577

15375

Barrels

MCF

$x$
0
0
$\vdots$
100. 0 
Table 9A.12

Estimated 1989 Operation by Type of Plant

Rocky Mountain Power Area

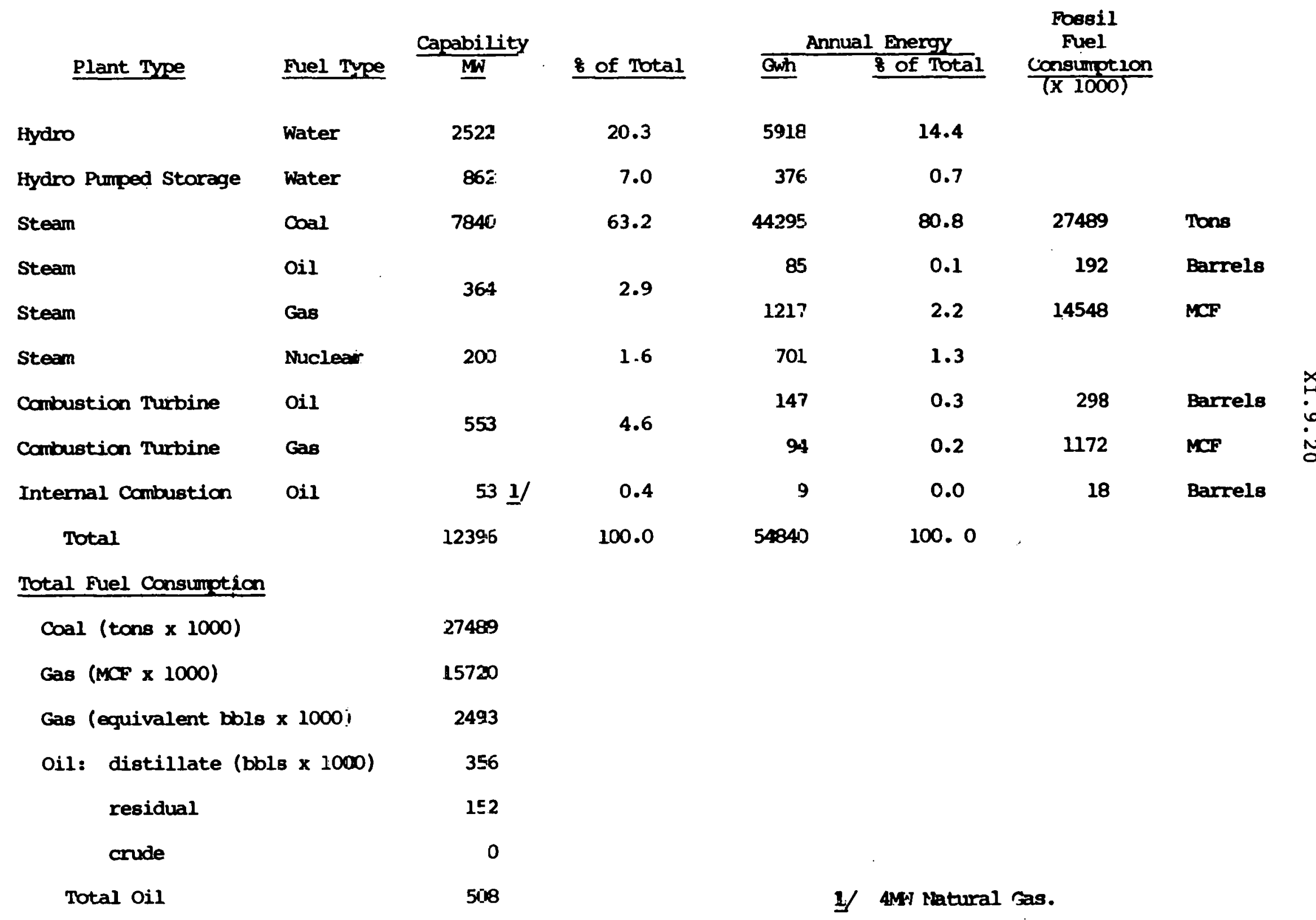


$X I .9 .21$

Electric Regions 25 and 30 - Northwest Power Pool Area

\section{Historical Perspective}

The Northwest Power Pool Area (NWPP) includes 25 reporting systems which voluntarily operate on a coordinated basis. The pool area is comprised of the states of Washington, Oregon, Idaho, Utah, most of Montana and parts of Wyoming, Nevada and a small part of Northern California. Originally, the pool was divided into an East Group and West Group; however, increased interconnections between the two groups resulted in designation of the area as one entity. The Pacific Northwest Utilities Conference Committee (PNUCC), which is an outgrowth of the Northwest Power Pool, maintains the designation of west Group area. The PNUCC coordinates regional power planning and provides regional suport for the Federal Marketing Agency for electric power by the U.S. Corps of Engineers and U.S. Water and Power Resources services (formerly U.S. Bureau of Reclamation).

The Northwest Power Pool Area has a pronounced winter peak that is heavily influenced by a significant saturation of electric heating loads. During the 1960's the area experienced an average annual growth rate of 6.9 percent. For the $1970-75$ period the gruwth rates was about $3.8 \%$ which represents a substantial reduction from the 1960 decade. This reduction is generally attributed to a downturn of the economy, the 1973 oil embargo, and the 1973 drought, and resultant effects of customer conservation.

The conservation theme plus other load reduction efforts carried into the latter half of the 1970's resulted in a continuing lower growth rate. Since the area is heavily dependent on hydroelectric generation, power supply is very much affected by annual precipitation. In 1977, a serious drought occurred and in fact affected the entire WSCC area. Consequently, Northwest utilities curtailed secondary energy deliveries and issued appeals for voluntary customer curtailments of 10 percent. Additionally, procedures were adopted for mandatory curtailments in a four-state area. Because of hydroelectric generation deficiencies, the area imported significiant amounts of energy to meet its load requirements. The drought ended in 1978 with a return to near normal water conditions. By fall of 1978, however, precipitation was again below normal in the Northwest resulting in lower than normal hydroreservoir storage entering the 1978-79 winter peak period. The effects of these water conditions are reflected in the growth rates for the 1977-79 period. 
The below normal precipitation continued into 1979. On July 31 , 1979, the date that Coordinated system reservoirs are programmed to refill, reservoir storage was only 90.7 percent of normally full contents, equivalent to 4.4 billion kilowatt hours of energy deficiency. During August the reservoirs deficiency increased to 5.4 billion kilowatt hours below normal.

Precipitation continued below normal during the remainder of 1979 creating a serious power supply situation for the 1979-80 water peak period.

No surplus hydro-generation was available from the frederal Columbia River Power system during the last half of 1979 .

Actual load requirement data for the years 1977 through 1979 including annual growth rates and load factors are shown in the following table.

Table $9 \underline{9} .1$

Bistorical Load Growth

№rthwest Powe

$\underline{19} 7 \underline{7}$

$$
\begin{array}{r}
153,023 \\
-1.5 \\
25,584 \\
-1.0 \\
68.2
\end{array}
$$

1978

$$
\begin{array}{r}
165,288 \\
8.0 \\
31,495 \\
23.1 \\
59.9
\end{array}
$$

1979

173,193

4.8

$32,021 \underline{1} /$

1.7

61.7

1/ Estimated for January 1980.

In 1979 hydroelectric generation supplied 70.3 percent of the total generation. Capability of oll and gas-fired steam-electric generating plants as of December 31,1979 totaled only 316 MW or 0.8 percent of the total capacity. These plants are old and are used only for emergency peaking purposes. The sole combined cycle plant in the area is the $534 \mathrm{MW}$ Beaver plant installed in 1977 by Portland General Electric Company. The plant normally burns distillate oil but is capable of burning No. 4 oil. Facilities are now being installed at the Beaver plant to accomodate use of natural gas. The lone coalfired generating plant in the west Group area is the two-unit $1300 \mathrm{MW}$ Centralia Plant located in Centralia, Washington. 
Presently, there is one nuclear generating plant operating in the Northwest: Trojan $(1130 \mathrm{MW})$, operating by Portland General Electric Company (PGE). The Hanford, WA. Nuclear Power Reactor facility is not considered dependable capability for planning purposes.

The remainder of the Regions supply emanates primarily from East Group area coal-fired plants. Within the Regions, a total of 11.7 billion MCF of natural gas was burned in 1979 - equivalent to 1.9 million barrels of oil. Oil consumption was 1.64 million barrels.

Table 9B.7 shows operation by type of plant and fuel consumption for 1979 .

Because of heavy dependency on hydroelectric generation a unique feature of the Northwest is that, during adverse water conditions, capability may be sufficient but energy supply can be simultaneously deficient. This was evident during the 1977 drought when the area imported large amounts of energy to met load requirements but maintained sufficient capability margins.

Generally, high capacity reserve margins occur during the summer peak season. Excess summer capacity and associated energy serves secondary markets and interruptible loads: Historically, summer and winter capacity reserve margins have been more than adequate in the Northwest Power Pool Area.

Forced shutdown of the $1130 \mathrm{MW}$ Trojan Nuclear Plant during the latter half of 1978 , due to regulatory action, necessitated imports of oil fired energy from California and Canada. These imports resulted in a larger oil burn within the wSCC region than would have otherwise been required. Trojan was again shut down in October 1979 for maintenance and NRC required modifications. The loss of the Trojan plant coupled with below normal water conditions in the Northwest resulted in a very tight power supply situation for PGE entering the 1979-80 winter peaking season. The problem was alleviated somewhat when Trojan returned to service on December 31 and precipitation increased.

Table 9B.8 shows summer and winter peak loads, resources, and reserve margins for the years 19.77 through 1979 . 
The Northwest Power pool Area is a highly interconnected area. As of January 1,1979 , there were 38,900 circuit miles of transmission which represents 478 of the total transmission miles in the entire WSCC region. Bonneville Power Administration provides the electric power transmission network for marketing power for the Federal Columbia River Power system to major load centers of the Northwest. The BPA transmission system also serves as the backbone grid for all the Northwest utilities and covers a service area of some 300,000 square miles.

The lack of adequate east-west transmission across the Northwest Power Pool Area due princludily lo construction delays has frequently limited transfers of Montana and Wyoming area coalfired generation to Paciflc coast load centers and has contributed to increased vulnerability of the interconnected system to major disturbances. A case in point was the major disturbance of November 27, 1979 when the Grand Coulee Power Plant lost $720 \mathrm{MW}$ of generation. This loss of generation coupled with the scheduled outage of the $500 \mathrm{kV}$ Pacific Northwest - Southwest Intertie resulted in conditions severe enough to cause islanding of the entire WSCC interconnected system. Construction has been chronically delayed on several major lines: notably the colstrip, $M T$ - Hot Springs, WY, double circuit $500 \mathrm{kV}$ line; the Midpoint, ID - Malin, OR, $500 \mathrm{kV}$ line; and the kinport, ID - Midpoint, ID $345 \mathrm{kV}$ line.

Northwest Power Pool Area is strongly interconnected to the Northern and Southern California Areas by three major transmission lines. Two of the lines are $500 \mathrm{kV}$ (AC) with a total transfer capability of $2500 \mathrm{MW}$. The third is an $800 \mathrm{kV}$ (DC) line with a capacity of $1440 \mathrm{MW}$. These interties are used to transmit surplus NWPP secondary energy to the south and southwest and for diversity exchange between the areas.

\section{Euiseril Perspective}

For the 1980-81 winter peak season, reguirements are estimated to increase by 9.98 for energy and 5.88 for peak load over that experienced during the 1979-80 winter season in the Northwest Power pool area.

Since November 1979, adjusted monthly energy for loads have shown small amounts of growth over the previous year's corresponding monthly loads. December 1979 energy for load was 2 percent above the energy for load of December 1978 - 3.3 percent below forecast. Energy for loads for January, February and March 1980 increased by about 1 percent over the loads of corresponding 
$X I .9 .25$

months of 1979. The annual growth rate had been consistently above five percent for several years preceding this period. This low growth in recent months is partly due to the curtailment of BPA's direct service industrial load. Other likely factors are a general economic slowdown and conservation effects.

Heavy precipitation was recorded in most of the Region during December 1979 and near normal water conditions continued through the first guarter of 1980. Reservoir storage at the end of March 1980 was very close to the level required for refill this summer. The outlook is for the area's reservoirs to be substantially full

by mid-August. However, performance of thermal generating plants, electric energy demands and upcoming fisheries operations in May will have major effects on the actual refill program. In any case, studies indicate there will be very little surplus hydro-generated energy available for non-firm loads, displacement of thermal generation, or export from the Northwest before next fall.

Capability additions scheduled in service for 1980 include $1,075 \mathrm{MW}$ of hydroelectric, $930 \mathrm{MW}$ of coal-fired and $178 \mathrm{MW}$ of gas/oil fired generation. Utah Power \& Light Company's Hunter No. $2400 \mathrm{MW}$, and Portland General Electric Company's Boardman, $530 \mathrm{MW}$, both coalfired units, are scheduled for service in June and November, respectively. In November, Puget Sound Power \& Light Company is planning to install two combustion turbine units totalling $178 \mathrm{MW}$ which will burn either natural gas or distillate oil.

The Trojan nuclear plant was shut down April 11 for refueling and maintenance. Trojan is expected to return to service by summer 1980 .

The following table shows the schedule in-service dates for major generating units during 1980 .

Table 9 B. 2

Major Capability Additions in 1980 No은 thwest Power Pool A

$\begin{array}{llcc} & \text { Type } & \text { Capability MW } & \text { In-Service } \\ \text { Grand Coulee No. } 24 & \text { Hydro } & 700 & \text { - } \\ \text { Hunter No.2 } & \text { Coal } & 400 & \text { May } 80 \\ \text { Boardman } & \text { Coal } & 530 & \text { Jun } 80 \\ & & & \text { Nov } 80\end{array}$


The Boardman plant in-service date is the probable energy date which is determined by the PNUCC from a standardized schedule reflecting anticipated average planning and construction times. The estimated commercial operation date is July 1980.

Estimated operation by type of plant and fuel use under median hydro conditions (energy) is shown in Table 9B.9.

For reserve study purposes the U.S. portion of the Northwest Power pool Area is assumed to be an infinite bus. Present transfer capability between the East Group and west Group is Iimited to an extent which may limit transfer of energy to the west Group area.

Anticipated available and planned reserve margins for the 1980 winter peaking season appear sufficient based on WSCC's "Power Supply Design Criteria," criterion 1 and the Pacific Northwest Coordination Agreement Method (Lolp - one day in 20 years), but not the PNUCC West Group Criterion $1(b)(13$ percent of firm peak load). Reserve margins shown in Table $9 \mathrm{~B} .10$ are much lower than those listed prior to last year. This reduction is due to BPA changing the representation of the Federal hydro capability from a one hour peak to a ten hour sustained peaking capability. Grand coulee hydro capability has been reduced by $1543 \mathrm{Mw}$ through the summer of 1983 due to a tailwater problem. Also, it should be noted that in Table 9B.10, dependable capability includes hydro resources based on adverse water conditions. It is difficult to obtain median or average water condition ratings for hydro plants; however, it is known that, based on magnitudes of scale, dependable hydro capabllity based on median conditions is less than five percent above those rated on adverse cundilions.

\section{Future Perspective}

The Northwest Power Pool Area loads are projected to increase in the five-year period from 1980-85 at an average annual rate of 4.4 percent for winter peak demand and 4.5 percent for annual energy use. This energy growth rate is somewhat higher than the 3.7 percent experienced during the 1977-79 period when below normal water conditions occurred twice in three years.

For the years 1985 through 1989 peak demand average annual growth rate is forecast at 2.8 percent while energy use is estimated to increase at a 3.5 percent average annual rate. 
Although grow th rates are declining, total growth nevertheless is forecasted to be substantial. Energy use is estimated to increase from $173,193 \mathrm{GWh}$ in 1979 to 272,025 GWh in 1989. Peak demand is forecast to increase from $32,021 \mathrm{MW}$ to $46,378 \mathrm{MW}$ during that same period.

Additions to generating capacity for the Regions total 7,056 Mw for the period 1981 through 1985. Table 9B.3 lists the significant units by type and delays of in-service dates.

\section{Table 9 B. 3}

Scheduled Capability Additions Northwest Power Pool Area

\begin{tabular}{|c|c|c|c|c|c|}
\hline Generating Unit & Type & $\begin{array}{c}\text { MW } \\
\text { Capability }\end{array}$ & Or In-Ser & Ce Date & $\begin{array}{c}\text { Total Delay } \\
\text { (Months) }\end{array}$ \\
\hline WNP 2 & Nuclear & 1100 & $3 / 78$ & $1 / 831 /$ & 58 \\
\hline $\begin{array}{l}\text { Hunter } 3 \\
\text { Colstrio } 3\end{array}$ & $\begin{array}{l}\text { Coal } \\
\text { Coal }\end{array}$ & $\begin{array}{l}400 \\
700\end{array}$ & $7 / 78$ & $\begin{array}{l}6 / 83 \\
1 / 84\end{array}$ & 66 \\
\hline WNP 1 & Nuclear & 1250 & $9 / 80$ & $6 / 851 /$ & 57 \\
\hline Junter 4 & Coal & 400 & & $6 / 85$ & \\
\hline Colstrip 4 & Coal & 700 & $7 / 79$ & $9 / 85$ & 64 \\
\hline WNP 3 & Nuclear & 1240 & & $6 / 861 /$ & \\
\hline
\end{tabular}

1/ Revised from 1980 ERA-411 by Washington Public Power Supply System.

Significant additions include $2200 \mathrm{MW}$ of coal-fired and $3,590 \mathrm{MW}$ of nuclear units. Current in-service dates are "Probable PNUCC Energy Dates" using the Milestone procedure based on critical path analys is methods. The milestone procedure reflects the possible plant delays in excess of those considered in scheduled commercial operation dates.

As shown in the Table 9B.3, significant delays have occurred since conception for four major plants. Even since the report of April 1, 1979, one year ago, there have been several delays. Units affected and the months of delay since last year's report. are listed in Table 9B.4. 


$$
X I .9 .28
$$

Table 9 B. 4

Unit Delays from $3 / 79-3 / 80$

Northwest Power Pool Area

Generating Unit

Colstrip 3

Colstrip 4

Boardman

WNP 1

WNP 2

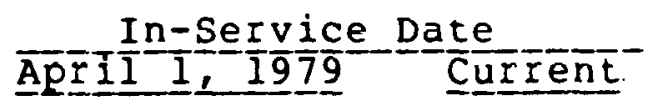

$3 / 83$
$3 / 85$
$7 / 80$
$12 / 83$
$9 / 81$

$3 / 83$

$3 / 85$

$2 / 83$

$9 / 81$
Delay (Mo.)

$1 / 84$

$9 / 85$

$11 / 80$

$6 / 851 /$

$1 / 83$ I/
6

6

18

16

1/ Revised from 1980 ERA-411 by washington Public Power Supply System.

For the period 1986 through 1990 a total of $8,908 \mathrm{MW}$ is planned for addition to the Regions capability. Significant unit additions for this period are listed by type in Table 9B.5.

\section{Table le 9 B .5}

Major Capability Additions 1986 - 1990

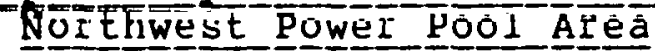

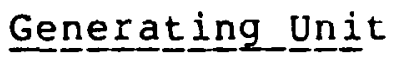

WNP 4

WNP 5

Intermountain 1 Intermountain 2 Wellington 1 Intermountain 3 Intermountain 4 skagit 1

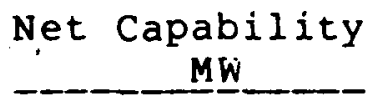

Nurileat

Nuclear

Coal

Coal

Coal

coal

Coal

Nuclear
1250

1240

750

750

500

750

750

1285
Schedule in service Date

$6 / 861 /$

$6 / 87$ I/

$7 / 86$

$7 / 87$

$6 / 88$

$7 / 88$

$7 / 89$

$7 / 90$

1/ Revised from 1980 ERA-411 by washington Public Power Supply system. 
Intermountain coal plant is a joint project: forty-two percent of the project's output will be shared by Utah utilities and the remainder will be transmitted to southern California utilities.

There are also $453 \mathrm{MW}$ of combustion turbine generation planned for installation during the 1981-89 period. Of this amount, $178 \mathrm{MW}$ is specified to use distillate oil as the primary fuel.

Tables 9 B.13 and 9 B.14 show the estimated operation by type of plant and fuel use for the years 1985 and 1989. Under median hydro conditions estimated oil/gas-fired generation will supply 0.9 percent of the total generation in 1985 and 0.6 percent in 1989 .

The PNUCC "West Group Forecast" reports that nearly every unit of planned resources for the West Group area is behind schedule by three years since the 1977 forecast. A noteworthy change in its latest forecast is the planned deferrals of two unlicensed nuclear plants: Skagit and Pebble springs. Only skagit unit No. 1, now scheduled for July 1990, is shown in the current PNUCC forecast.

Presently, Colstrip Unit Nos. 3 and 4 are on schedule but inservice dates of WNP 1 and 2 are being reviewed. Delays in unit installations have produced only small peak deficiencies to date; however, peak demand reserve margins are projected to decrease and energy deficits are projected to increase significantly with each additional unit delay.

The estimated reserve margins for the Northwest Power Pool Area are indicated in Table 9B.12.1 and 9B.12.2. During the period July 1981 through June 1983 the Pool does not meet wsCC criteria 1 for desired reserve margins. It should be noted that BPA, for planning purposes, includes approximately $1000 \mathrm{MW}$ of interruptible loads in its firm load. If these interruptible loads were to be used for reserve, there could be sufficient reserve margin for the entire ten-year period. Also, for this forecast, hydro resource capabilities are estimated on an adverse water year basis.

Reserve requirements vary considerably depending on the criteria used. WSCC reliability criteria is defined on Table 9 B.ll. The Pacific Northwest Coordination Agreement reserve criteria provides for capability reserves based on a loss of load probability of one day in 20 years. The most stringent requirements are those of the 
West Group which basically requires a reserve margin of twelve percent of firm peak. load the first year, increasing one percent per year to twenty percent, and remaining at twenty percent thereafter. The West Group reliability criteria indicates deficiencies in reserve margin for the entire period through June 1984 .

Since the Pool Area is basically a hydro oriented system energy resources are important in assessing the forecasted load-supply situation.

Studies conducted in conjunction with the west Group Forecast indicate there is a probability that the resources in the western portion of the Pool will be insufficient to meet total energy load under adverse water conditions during the ten year forecast period.

In addition, for purposes of this report, a delay of 6 months was assumed for the major coal plants, shown in Table 9B.3.

Table 9B.6 shows the affects on reserve margins of nuclear plants' delays and an assumed 6 months delay in specified coal plant units.

\section{Taㅡ므르 9 B .6}

Estimated Available Reserve Margins ( 8 )

Nor thwest Power Pool A $\overline{\text { I }}$ aㅡ Winter Peak period

\begin{tabular}{|c|c|c|c|c|c|}
\hline 1980 & 1981 & $1 \underline{19} \underline{\underline{z}}$ & $\frac{1}{n} \frac{9}{t} \underline{\underline{t}}=$ & 1984 & 1985 \\
\hline $\begin{array}{l}7.7 \\
7.7\end{array}$ & $\begin{array}{l}6.2 \\
6.2\end{array}$ & $\begin{array}{l}5.0 \\
5.0\end{array}$ & $\begin{array}{l}8.8 \\
8.8\end{array}$ & $\begin{array}{l}9.7 \\
6.6\end{array}$ & $\begin{array}{l}15.3 \\
10.7\end{array}$ \\
\hline
\end{tabular}

There are three critical bulk power transmission facilities that will not be in service when desired. A discussion of each line and its effects on the bulk power system follows.

The Rinport, ID - Midpoint, ID $345 \mathrm{kV}$ line is to be constructed, owned and operated by Idaho Power Company (IPC) to permit transfer of woming resources through IPC's service area. This line was scheduled for service concurrent with the start-up of Jim Bridger Unit 4 in December 1979, but has now been delayed to October 1981 due to delays in obtaining necessary construction permits. 
XI.9:31

Pacific Power and Light Company's (PP\&L) Midpoint, ID - Malin Medford, OR $5.00 \mathrm{kv}$ line will serve as an interconnection between IPC and PP\&L. The line represents a critical link in the transmission system that is being constructed in cooperation with IPC to permit transfer of PP\&L's Wyoming resources to the west Group area. In addition, the proposed line is purportedly required to reinforce the bulk power supply to PP\&L's Southern oregon load area.

It is estimated that the 445 mile Malin-Midpoint section of the line will be delayed approximately three years from the originally scheduled in-service date of October 1978. Final Federal permits were received in October and construction of the line was started in December 1979. The completion date is now scheduled for september 1981. As a result of this delay west Group area deficiencies will be increased by up to $900 \mathrm{MW}$ of capability and $400 \mathrm{MW}$ of average energy.

The Montana Power Company's Bozeman-Dillion $161 \mathrm{kV}$ line and associated facilities were scheduled for November 1978. The 1 ine has been postponed pending resolution of a law suit relating to environmental concerns. This delay adversely affects the reliability of service in the Dillion, MT area. 
Table 9B.7

1979 Operation by Type of Plant

Northwest Power Pool Area

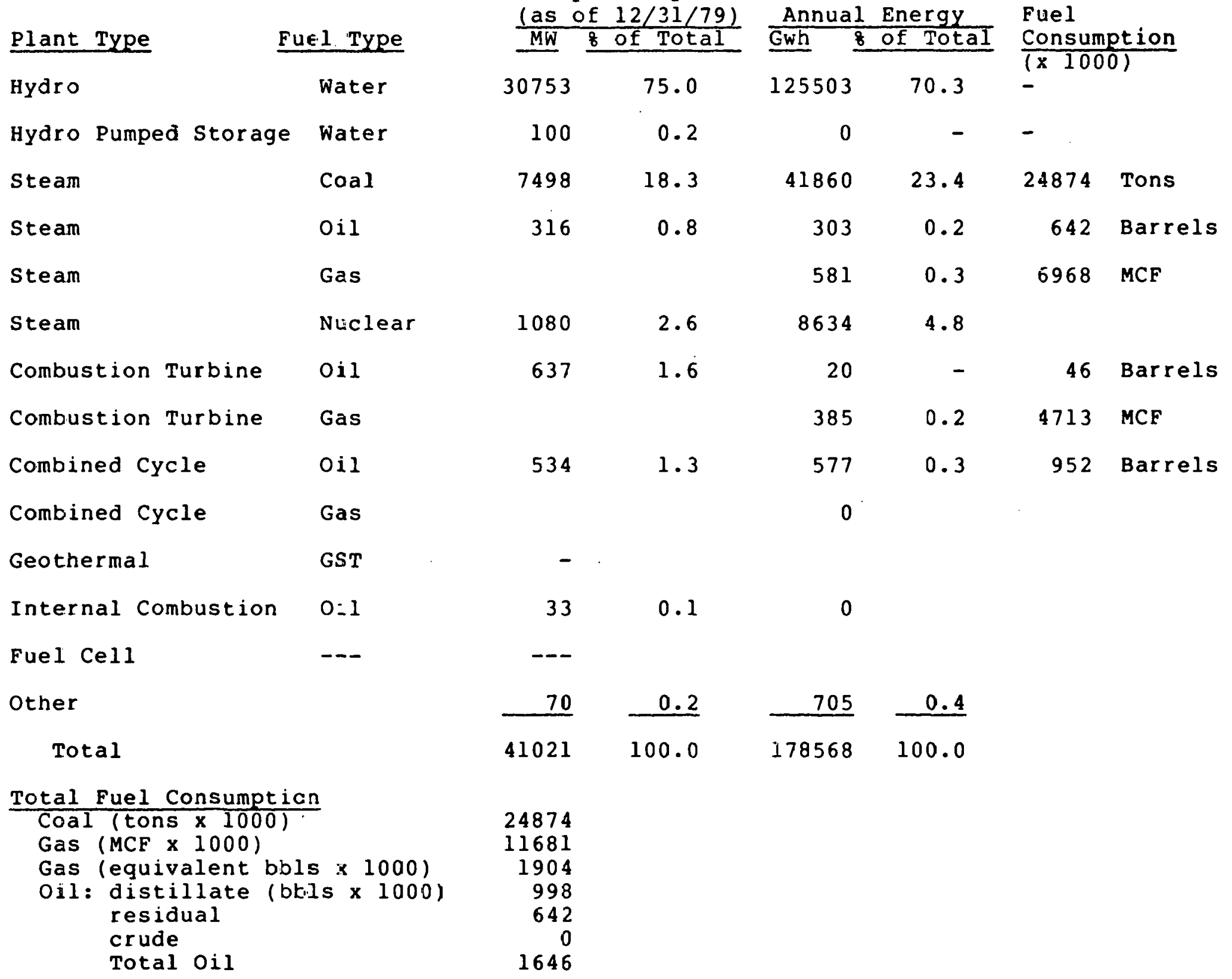




\section{HISTORICAL CAPABILITY (MW) AND RESERVES (MW and Percent)}

Northwest Power Pool Area

1. Planned Capability 1/

2. Peak Demand

3. Planned Reserves (1-2)

4. Planned Reserves (\%) (3/2) ×100

5. Net Transactions (Imports-Exports)

6. Total Capability $(1+5)$

7. Total Reserves (6-2)

8. Total Reserves (\%) $(7 / 2) \times 100$

9. Scheduled Maintenance

10. Capability after Maintenance (6-9)

11. Reserves after Maintenance (10-2)

12. Reserves after Maintenance $(\%)(11 / 2) \times 100$

13. Inoperable Capability

14. Available Capability (10-13)

15. Available Reserves (14-2)

16. Available Reserves (\%) (15/2) ×100

17. Forced Outages 21

18. Actual Capability after Forced Outages (14-17)

19. Actual Reserves (18-2)

20. Actual Reserves (\%) (19/2) ×100

1/ Excludes Canadian Systems.

2/ Information not reported separately.

\begin{tabular}{|c|c|c|c|c|c|}
\hline \multicolumn{2}{|c|}{1977} & \multicolumn{2}{|c|}{1978} & \multicolumn{2}{|c|}{1979} \\
\hline Summer & Winter & Summer & Winter & Summer & Winter \\
\hline 34694 & 34280 & 37859 & 39784 & 39169 & 37641 \\
\hline 20501 & 25584 & $2228: 3$ & 31495 & 23014 & 32021 \\
\hline 14193 & 8696 & 15576 & 8289 & 16155 & 5620 \\
\hline 69.2 & 34.0 & 69.9 & 26.3 & 70.2 & 17.6 \\
\hline-3135 & -1655 & -3281 & -1747 & -3075 & -1730 \\
\hline 31559 & 32625 & 3457.8 & 38037 & 36094 & 35911 \\
\hline 11058 & 7041 & 12295 & 6542 & 13080 & 3890 \\
\hline 53.9 & 27.5 & 55.2 & 20.8 & 56.8 & 12.1 \\
\hline 7051 & 2602 & 5136 & 4689 & 7398 & 776 \\
\hline 24508 & 30023 & 29442 & 33348 & 28696 & 35135 \\
\hline 4007 & 4439 & 7159 & 1853 & 5682 & 3114 \\
\hline 19.5 & 17.4 & 32.1 & 5.9 & 24.7 & 9.7 \\
\hline 0 & 100 & ] & 130 & 30 & 167 \\
\hline 24508 & 29923 & $2944 ?$ & 33218 & 28666 & 34968 \\
\hline 4007 & 4339 & 7159 & 1723 & 5652 & 2947 \\
\hline 19.5 & 17.0 & $32 . i$ & 5.5 & 24.6 & 9.2 \\
\hline 0 & 0 & 0 & 0 & 0 & 0 \\
\hline 24508 & 29923 & 29442 & 33218 & 28666 & 34968 \\
\hline 4007 & 4339 & 7159 & 1723 & 5652 & 2947 \\
\hline 19.5 & 17.0 & $32 .:$ & 5.5 & 24.6 & 9.2 \\
\hline
\end{tabular}


Table 9B. 9

Estimated 1980 Operation by Tupe of Plant

Northwest Power Fool Area

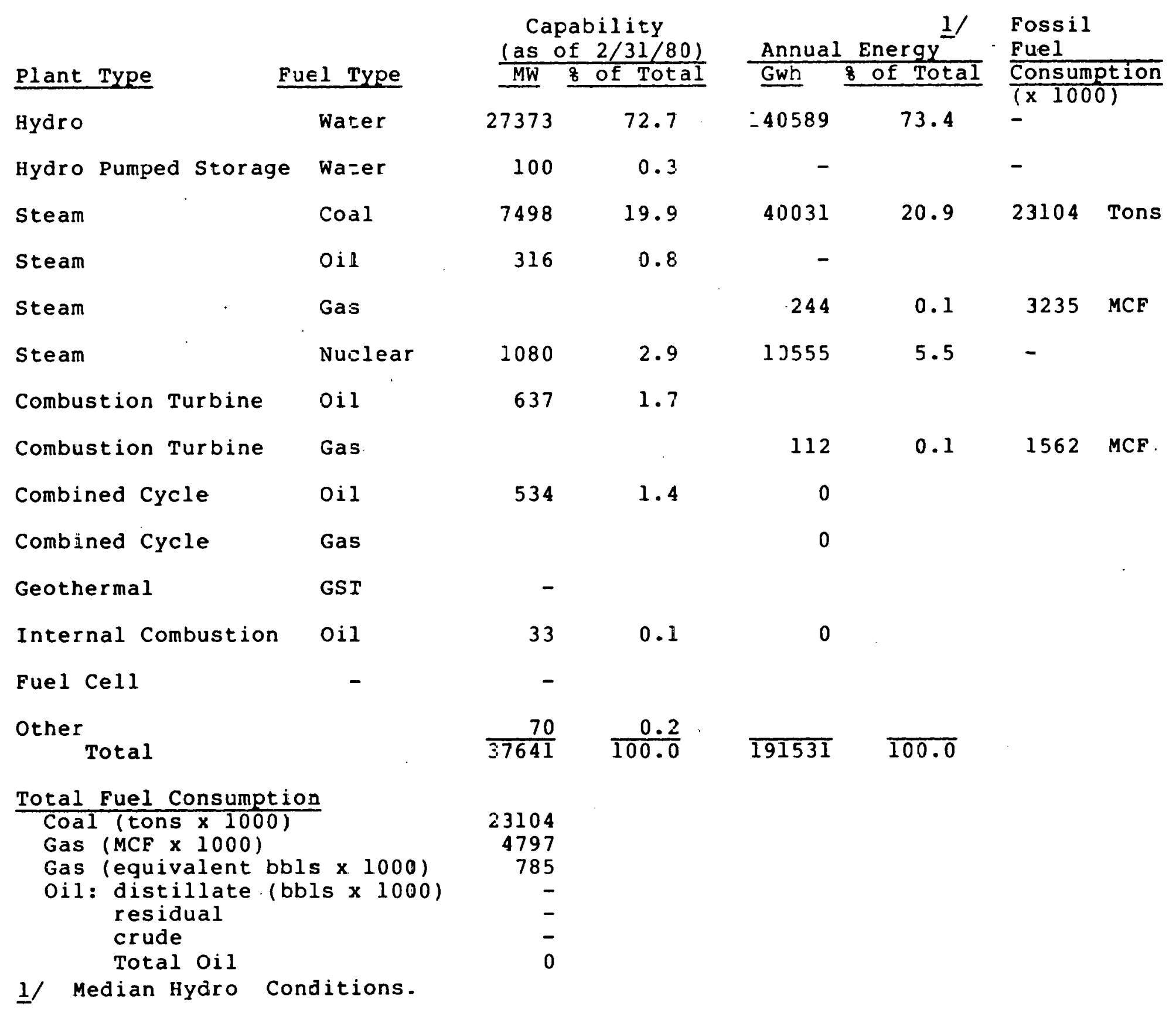


CURRENT CAPABILITY (MW) AND RESERVES (MW and Percent) - 1980/81 Northwest Power Pool Area

1. Planned Capability I/

2. Peak Demand 2/

3. Planned Reserves (1-2)

4. Planned Reserves (\%) $(3 / 2) \times 100$

5. Net Transactions (Imports-Exports)

6. Total Capability $(1+5)$

7. Total Reserves (6-2)

8. Total Reserves $(\%)(7 / 2) \times 100$

9. Scheduled Maintenance

10. Capability after Maintenance (6-9)

11. Reserves after Maintenance (10-2)

12. Reserves after Maintenance $(\%)(11 / 2) \times 100$

13. Inoperable Capability

14. Available Capability (10-13)'

15. Available Reserves (14-2)

16. Available Reserves (\%) (15/2) x100

17. Forced Outages 3 /

18. Actual Capability after Forced Outages (14-17)

19. Actual Reserves (18-2)

20. Actual Reserves (\%) (19/2) $\times 100$

\begin{tabular}{|c|c|c|c|c|c|}
\hline \multicolumn{3}{|c|}{ Summer_1980 } & \multicolumn{3}{|c|}{ Winter $1980 / 81$} \\
\hline $\bar{D} \overline{e c}$ & $\bar{J} \mathrm{an}$ & $\bar{F} \bar{e} \bar{b}$ & $\overline{e c}$ & & $\overline{F e b}$ \\
\hline 36611 & 38241 & 38238 & 39351 & 39059 & 38534 \\
\hline 26010 & 25898 & 25550 & 32801 & 33888 & 32147 \\
\hline 12601 & 12343 & 12688 & 6550 & 5171 & 6387 \\
\hline 48.4 & 47.7 & 49.7 & 20.0 & 15.3 & 19.9 \\
\hline-2956 & -2939 & -2954 & -1585 & -1605 & -1622 \\
\hline 35655 & 35302 & 35284 & 37766 & 37454 & 36912 \\
\hline 9645 & 9404 & 9734 & 4965 & 3566 & 4765 \\
\hline 37.1 & 36.3 & 38.1 & 15.1 & 10.5 & 14.8 \\
\hline 2633 & 3058 & 3192 & 988 & 781 & 894 \\
\hline 33022 & 32244 & 32092 & 36778 & 36673 & 36018 \\
\hline 7012 & 6346 & 6542 & 3977 & 2785 & 3871 \\
\hline 27.0 & 24.5 & 25.6 & 12.1 & 8.2 & 12.0 \\
\hline 167 & 167 & 167 & 167 & 167 & 167 \\
\hline 32855 & 32077 & 31925 & 36611 & 36506 & 35851 \\
\hline 6845 & 6179 & 6375 & 3810 & 2618 & 3704 \\
\hline 26.3 & 23.9 & 25.0 & 11.6 & 7.7 & 11.5 \\
\hline 0 & 0 & 0 & 0 & 0 & 0 \\
\hline 32855 & 32077 & 31925 & 36611 & 36506 & 35851 \\
\hline 6845 & 6179 & 6375 & 3810 & 2618 & 3704 \\
\hline 26.3 & 23.9 & 25.0 & 11.6 & 7.7 & 11.5 \\
\hline
\end{tabular}

I/ No delays anticipated in new generating units since submittal of 1980 ERA-411. 2/ Includes $461 \mathrm{MW}$ of interruptible capability.

3/ Information not available. 
Table 9 B. 11

\section{WSCC Power Supply Design Criteria Recommended Minimum Performance Table Northwest Power Pool Area}

It is recommended that areas or systems defined for analysis should meet or exceed at least one of the following WSCC criteria for installed and planned generating capacity:

\section{Criteria}

1. Monthly Reserve Capability After Deducting Scheduled Maintenance $(M W)$

2. Monthly Reseve Capability After Deducting Scheduled Maintenance

3. Annual reliability criterion based on probability of loss of load, either
a. Frequency of loss of load or,
b. probability of meeting all
loads in a year

Minimum
Design Performance

Greater of $R$, or the largest Risk plus 58 of Load Responsibility

2 largest Risks

\section{Def $\underline{\text { initions }}$}
$R=\left(.05 \underset{H}{\mathrm{H}}+\frac{+}{\mathrm{T}}-\frac{15}{\mathrm{~T}}\right) \times \mathrm{L}$
$\mathrm{H}=$ Monthly hydro capability after deducting scheduled maintenance.
- $T$ = Monthly thermal capability after deducting scheduled maintenance.
L - Load Responsibility: System or area monthly firm peak load demand plus those firm sales minus those firm purchases for which reserve capacity must be provided by the supplier.

Reserve Capability after Deducting Scheduled Maintenance $=H+T-L$

Risk: Capability reduction caused by outage of a generator or transmission line.

Performance Table Adopted by Executive Committee - September 19, 1974. 
FUTURE CAPABILITY (MW) AND RESERVES (MW and Percent) - 1981-84 Northwest Power Pool Area

1. Planned Capability

2. Peak Demand $1 /$

3. Planned Reserves $(1-2)$

4. Planned Reserves (\%) (3/2) $\times 100$

6. Total Capability $(1+5)$

7. Total Reserves (6-2)

8. Total Reserves $(\%)(7 / 2) \times 100$

9. Scheduled Maintenance

11. Reserves after Maintenance (10-2)

12. Reserves after Maintenance $(\%)(11 / 2) \times 100$

13. Inoperable Capability

14. Available Capability (10-13)

15. Available Reserves (14-2)

16. Available Reserves $(\%)(15 / 2) \times 100$

17. Forced Outages $2 /$

18. Actual Capability after Forced Outages (14-17)

19. Actual Reserves (18-2)

20. Actual Reserves (\%) $(19 / 2) \times 100$
5. Net Transactions (Imports-Exports)

10. Capability after Maintenance (6-9)
1981

\begin{tabular}{|c|c|c|c|}
\hline Summer & Winter & Summer & Winter \\
\hline 39464 & 39750 & 41171 & 41151 \\
\hline 272 & & 3 & 37181 \\
\hline 1219 & 4301 & 12868 & 3970 \\
\hline 44.7 & 12.1 & & \\
\hline-3135 & -1136 & -2389 & -1139 \\
\hline 36329 & 38614 & 38782 & 40012 \\
\hline 906 & 3. & 10479 & 2831 \\
\hline 33.2 & 0.7 & 37.0 & .0 \\
\hline 3951 & & 819 & \\
\hline 32378 & 37826 & 34963 & 39219 \\
\hline 5109 & 2377 & 6660 & 2038 \\
\hline 18.7 & 6.7 & 23.5 . & 5.5 \\
\hline 167 & & & \\
\hline 32211 & 37659 & 34796 & 39052 \\
\hline 4942 & 2210 & 6493 & 1871 \\
\hline 18.1 & 6. & 22.9 & 5.0 \\
\hline & & & \\
\hline 3221 & 37659 & 34796 & 39052 \\
\hline 4942 & 2210 & 6493 & 1871 \\
\hline 18. & 6 & 22.9 & 5. \\
\hline
\end{tabular}

1983 Summer Winter

41679

29760

11919

40.1

$-2242$

39437

9677

32.5

3986

35451

5691

19.1

167

35284

5524

18.6

0

35284

5524

18.6

Nuclear Unit_Delays as Projected by Utilities

21. Nuclear Delays $3 /$

22. Actual Capability (18-21)

$\begin{array}{rrr}0 & 0 & 1100 \\ 32211 & 37659 & 33696 \\ 49<2 & 2210 & 5393\end{array}$

23. Actual Reserves with Nuclear Delays (22-2)

24 . Actual Reserves with Nuclear Delays $(\%)(23 / 2) \times 100$

18.1

6.2

19.1

\section{39052
1871}

44277

38843

5434

14.0

$-1058$

43219

4376

11.3

803

42416

3573

9.2

167
2249

42249
3406

8.8

0
42249

3406

8.8
0
35284
5524

18.6

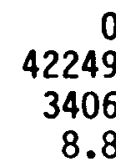

1984

Summer Winter

44175

30875

13300

43.1

$-2371$

41804

10929

35.4

4698

37106

6231

20.2

167

36939

6064

19.6

0

36939

6064

19.6

46344

40404

5940

14.7

$-1046$

45298

4894

12.1

804

44494

4090

10.1

167

44327

3923

9.7

0

44327

3923

9.7

1) Includes $461 \mathrm{MW}$ of interruptible load.

$\overline{2} /$ Information not available.

3/ Washington Public Power Supply System update of 1980 ERA-411. 
FUTURE CAPA3ILITY (MW) AND RESERVES (MW and Percent) - 1985-89 Nortinwest Power Pool Area

1. Planned Capability

2. Peak Demand $y$

3. Planned Reserves (1-2)

4. Planned Reserves (\%) (3/2) $\times 100$

5. Net Transactions (Imports-Exports)

6. Total Capability $(1+5)$

7. Total Reserves (6-2)

8. Total Reserves $(\%)(7 / 2) \times 100$

9. Scheduled Maintenance $2 /$

10. Capability after Maintenance (6-9)

11. Reserves after Maintenance (10-2)

12. Reserves after Maintenance $(\%)(11 / 2) \times 100$

13. Inoperable Capability

14. Available Capability (10-13)

15. Available Reserves (14-2)

16. Available Reserves (\%) (15/2) $\times 100$

17. Forced Outages 21

18. Actual Capability after Forced Outage (14-17)

19. Actual Reserves (18-2)

20. Actual Reserves $(\%)(19 / 2) \times 100$
1986

1985 Summer Winter Summer Winter Summer Wint

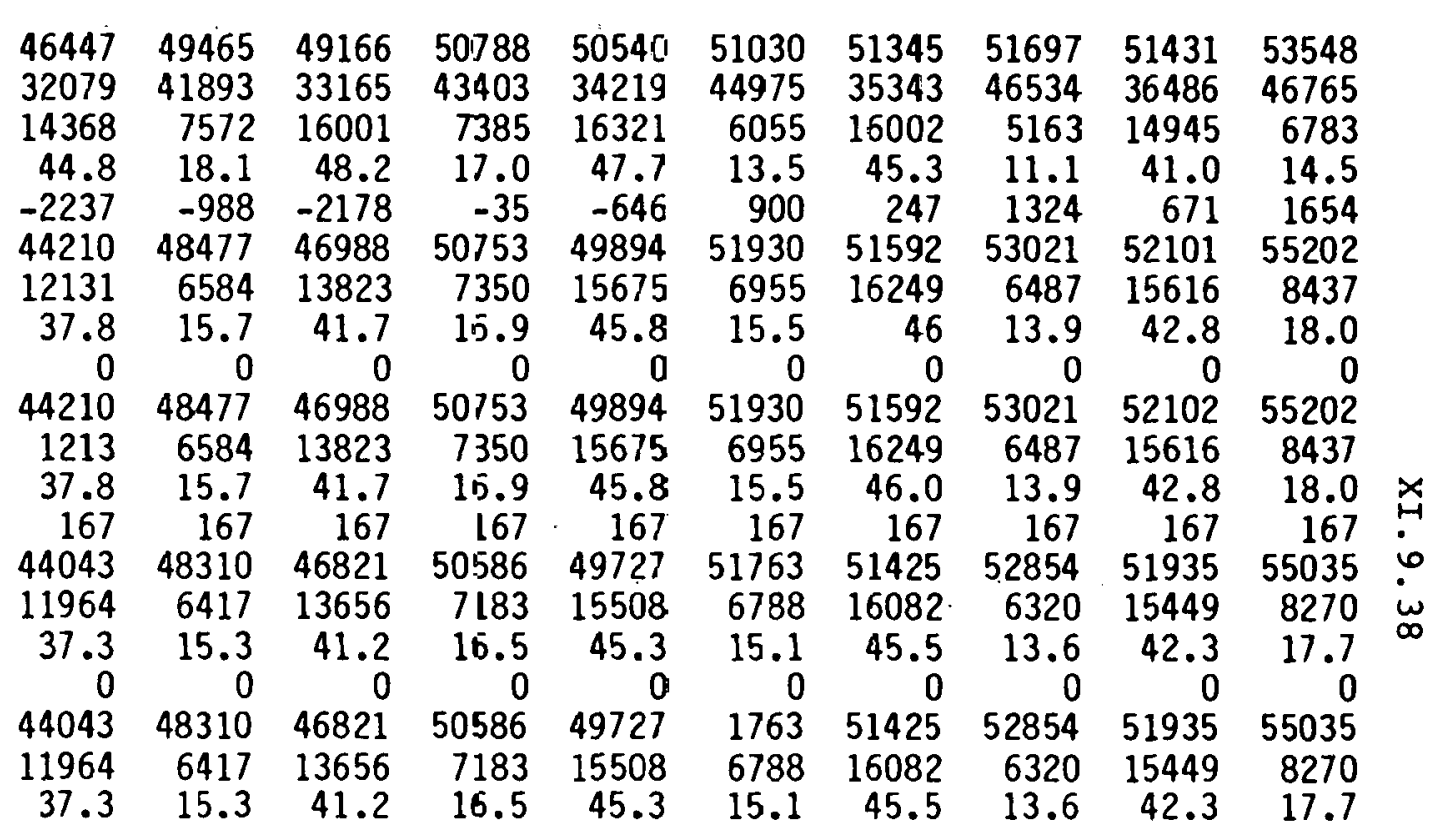

Nuclear Unit Del ays s as Projected by Utilities

21. Nuclear Delays $3 /$

22. Actual Capability (18-21)

23. Actual Reserves with Nuclear Delays $(\Sigma 2-2)$

$\begin{array}{rrr}0 & 1240 & 0 \\ 44043 & 47070 & 46821 \\ 11964 & 5177 & 13656\end{array}$

2

0
51763
6788
15.1

0
51425
16082

45.5
1988

1989

umer Winter

Actual Reserves with Nuclear Delays $(\kappa)(23 / 2) \times 100$

$2.4 \quad 41.2$

$\begin{array}{rr}16.5 & 45.3\end{array}$

1/ Includes $461 \mathrm{MW}$ (Summer 1985) and $387 \mathrm{MN}$ all other periods of interruptible load.

2/ Information on scheduled maintenance and forced outages not available.

$\overline{3}$ / Washington Public Power Supply System update of 1580 ERA-4II. 
Table 9B.13

Estimated 1985 Operation by Type of Plant

Northwest Power Pool Area

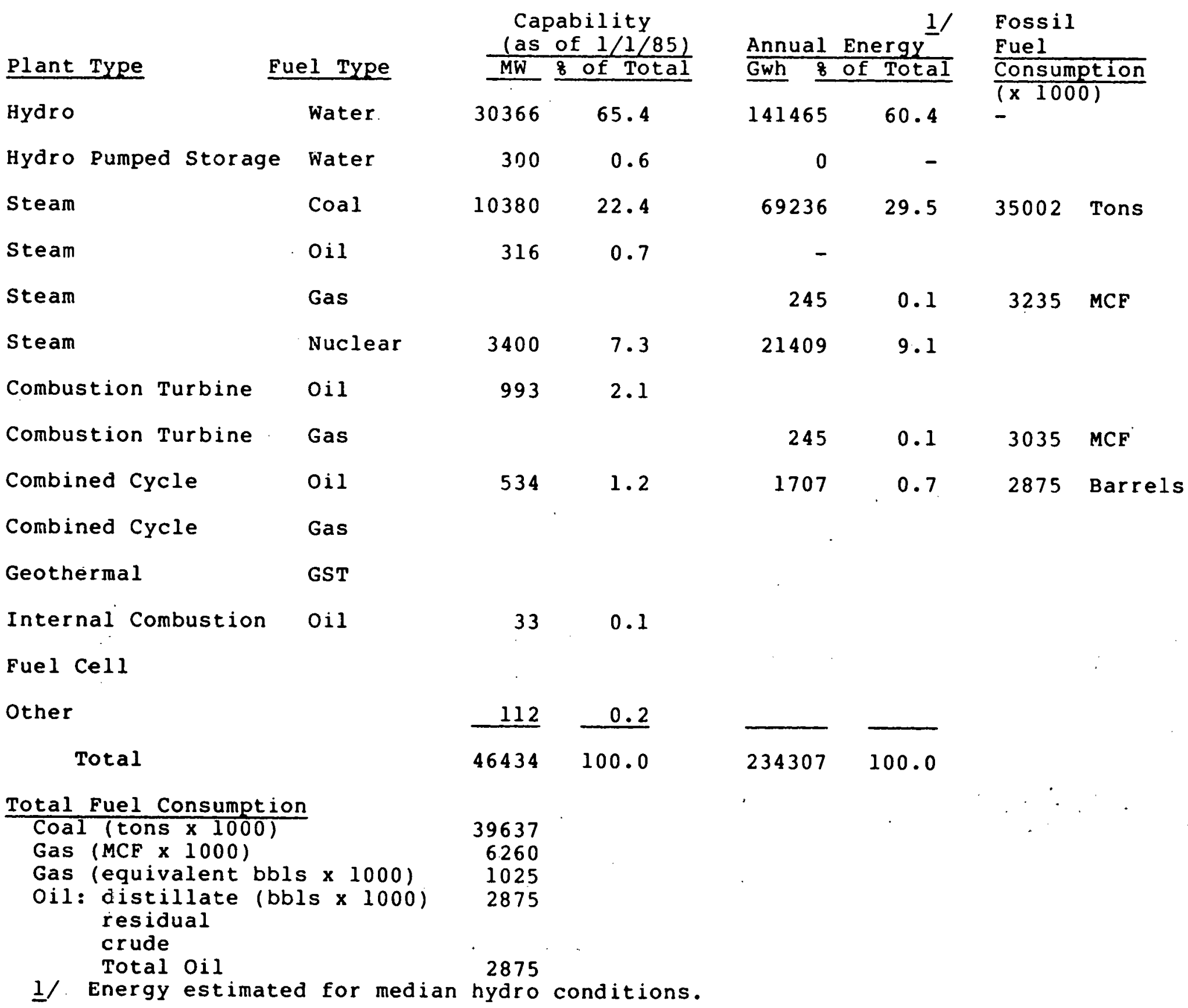


Table 9B.14

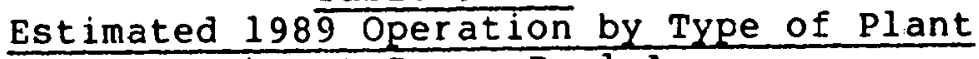
Northwest Power Pool Area

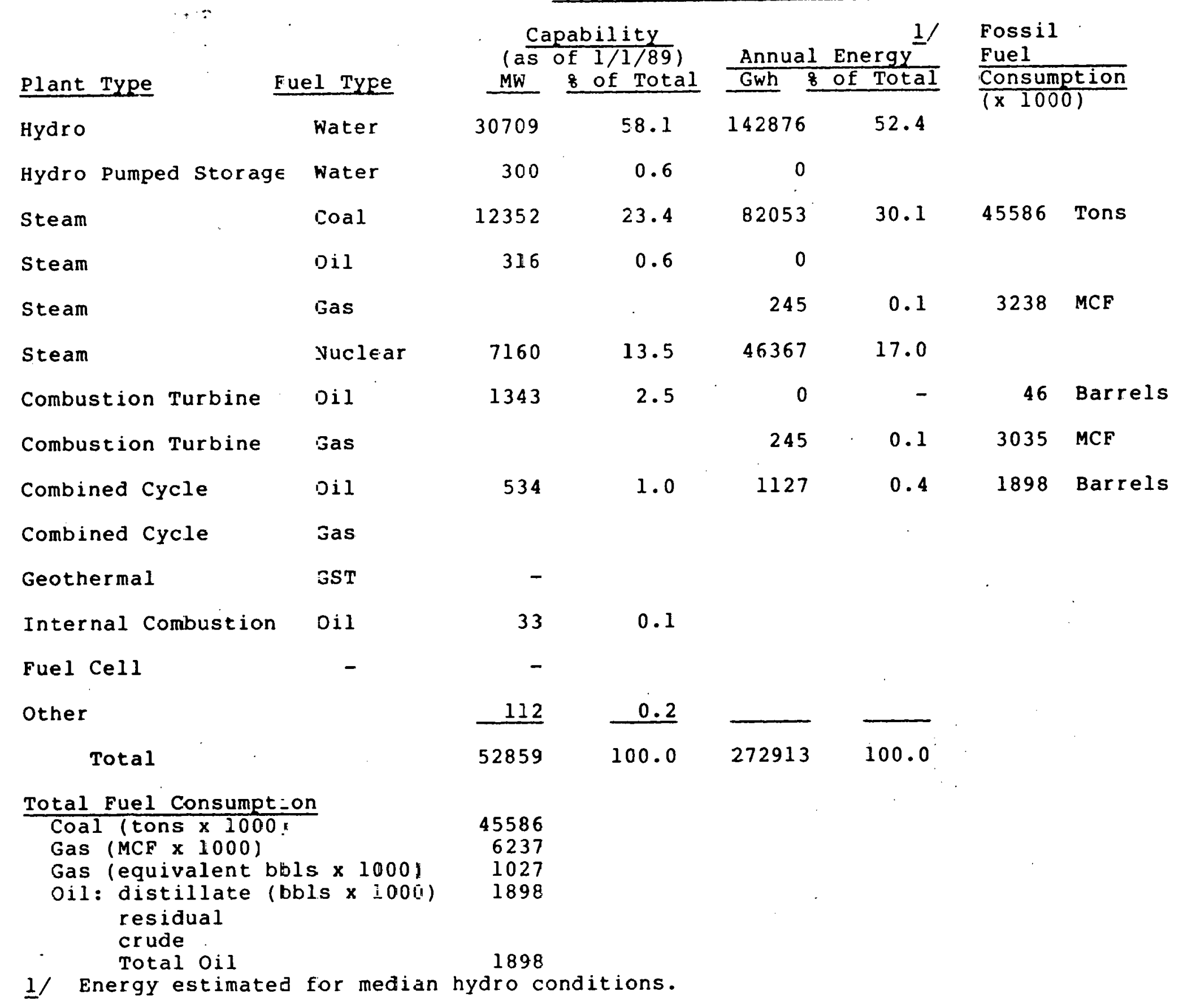


Electric Region 26 Arizona - New Mexico Power Area

\section{Historical Perspective}

Arizona-New Mexico Power Area (AZ-NM) encompasses Arizona, most of New Mexico, and small portions of southeast California and northwestern Texas. The Region is served by 49 utility systems.

The summer peaking region historically was a high growth area in terms of peak demand and energy. During the 1960's decade, the average annual growth rate was approximately 8 percent for peak and 7.6 percent for energy. This growth rate continued in the early 1970's when the average annual growth rate for the five year period 1970 through 1975 was about 7.6 percent for peak and 7.1 percent for energy. These energy growth rates have decreased cunsiderably during the last half of the 1970's. Average annual growth rate for the years 1977 through 1979 was 5.4 percent for energy use and 4.5 percent for peak demand. Actual loads data for 1977 through 1979 are shown on Table 9C.l.

\section{Table 9C.1}

Historical Load Growth

Arizona-New Mexico Area

\begin{tabular}{|c|c|c|c|c|c|}
\hline & & & 1977 & 1978 & 1979 \\
\hline \multirow[t]{2}{*}{ Annual } & Electric & Energy (GWh & 35787 & 37387 & 39734 \\
\hline & & Growth Rate & 5.2 & 4.5 & 6.3 \\
\hline \multirow[t]{3}{*}{ Summer } & Peak Dem & and $(M \bar{w})$ & 7266 & 7942 & 79.42 \\
\hline & & Growth Rate & $3 \cdot 3$ & 9.3 & 0.0 \\
\hline & & Load Factor & 56.2 & 53.7 & 57.1 \\
\hline
\end{tabular}

The Region's peak demand for 1979 was equal to that experienced in 1978. This is attributed to the mild weather that was prevalent during the summer and fall of 1979.

The major portion of the area's generation emanates from coal-fired generating plants which supplied 60.4 percent of the Region's total generation in. 1979. About 32 percent of the total Regional generation was from oil/gas-fired power plants. For 1979, natural gas consumption amounted to $104.3 \mathrm{million}$ MCF, equivalent to 17.4 million barrels of oil. 
Two major additions were made to the Region's coal-fired generating capability during 1979. The $480 \mathrm{MW}$ San Juan unit No.3 and the first of three units of the coronado project $(350 \mathrm{MW}$ ea) were put into service the latter part of the year.

Operation by type of plant and fuel consumption for 1979 is shown in Table $9 \mathrm{C} .2$.

During December 1978 and January 1979, the area experienced one of the coldest winters on record. Sub-normal temperatures caused higher than anticipated loads and forced outages of numerous coalfired generating units. As a consequence, oil inventories were minimal throught the Southwest at the end of 1978. Emergency assistance was provided by California utilities to the AZ-NM. Region.

Table 9C.11 shows reserves for summer and winter peak months for the years 1977 through 1979. During this period, actual reserve margins have equalled or exceeded 15 percent of the region's peak demand except fur the unusual 1978 winter season when the available reserve dropped to 8.3 percent.

As of January. 1980, the AZ-NM transmission system included 3930 miles of 115-16l kV, 1900 miles of $230 \mathrm{kV}, 2859$ miles of $287-345 \mathrm{kV}$ and 1340 miles of $500 \mathrm{kV}$ lines. Interconnections with the Southern California - Nevada Power area (Electric Region 27) consist of two $500 \mathrm{kV}$, one $287 \mathrm{kV}$ and five $230 \mathrm{kV}$ tie lines. The two $500 \mathrm{kV}$ lines transfer other Regional utility shares of power output from the Navajo and Four Corners power plants. Interregional transfer capability is $2300 \mathrm{MW}$ from east to west.

An interconnection to the Northwest Power Pool, East Group area (Region 30), is through a $345 \mathrm{kV}$ line from the Four Corners plant. This interconnection is considered adequate with it' $\varepsilon 600 \mathrm{MW}$ rated transfer capability.

Interconnections between the Rocky Mountain Power Area (Electric Region 24) consist of one $230 \mathrm{kV}$ ine and two $345 \mathrm{kV}$ lines. Transfer capability is $1200 \mathrm{MW}$ north to south and $350 \mathrm{MW}$ south to north. The lower transfer limit from south to north is restricted by transmission limitations within the Rocky Mountain area. 


\section{Table 9C. 2}

1979 Operation by Type of Plant

Arizona - New Mexico Power Area

lant Type

Hydro

Hydro Pumped storage

\begin{tabular}{|c|c|c|c|c|c|}
\hline & $y \quad$ as of & $12 / 317$ & Annual & Ene & $\begin{array}{l}\text { Fossil } \\
\text { Fuel }\end{array}$ \\
\hline ue 1 Typ & 8 of & Total & $\underline{\text { Gwh }}$ & of Total & $\frac{\text { Consumption }}{(x 1000)}$ \\
\hline & 6063 & & 3008 & 7.4 & \\
\hline
\end{tabular}

water

137

1.3

0

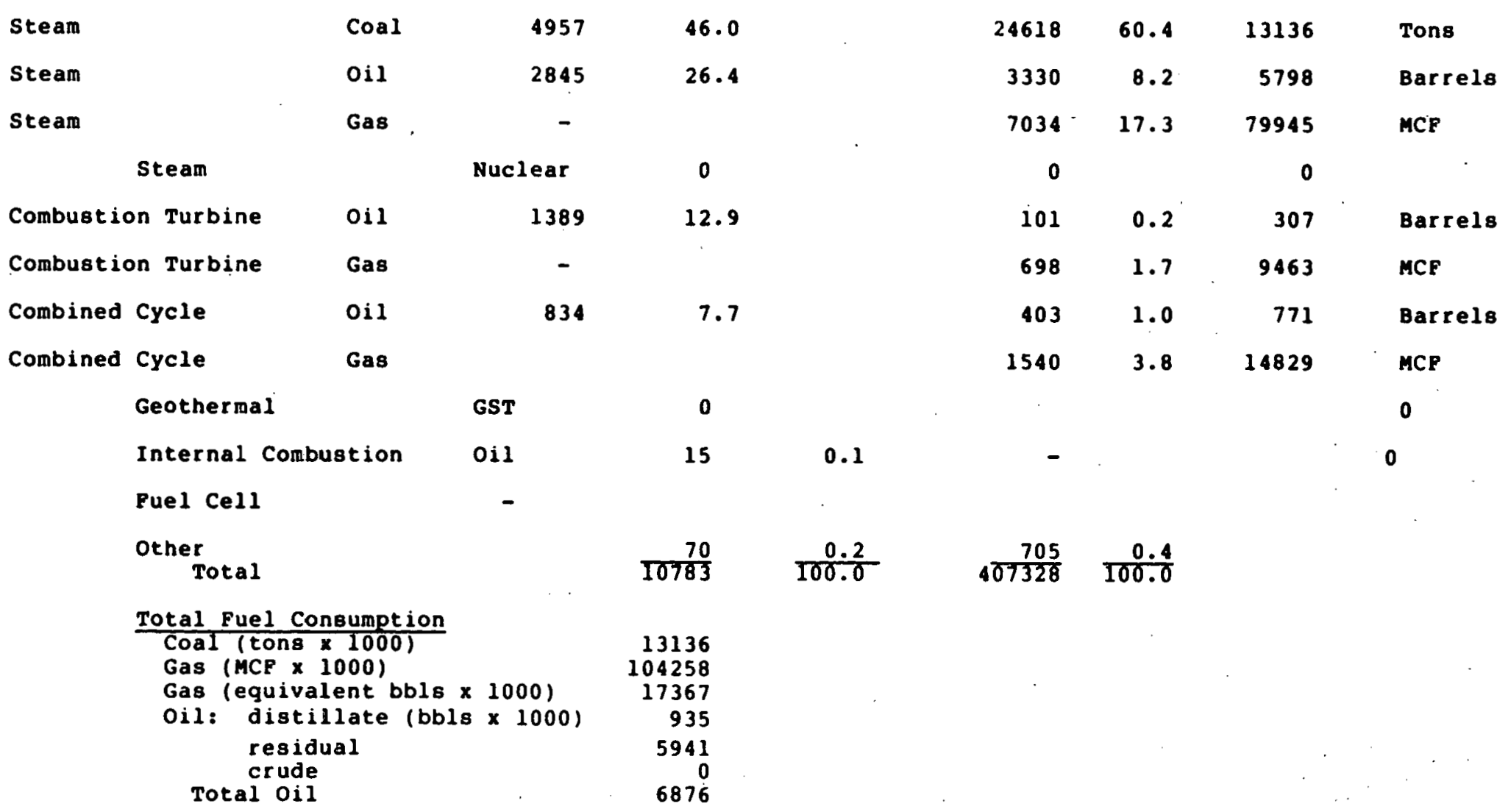




$$
X I .9 .44
$$

\section{Current Perspective}

The 1980 forecast for the Arizona - New Mexico Power Area estimated electric energy consumption will increase from $39,734 \mathrm{GWh}$ in 1979 to 43,732 GWh in 1980 , representing an increase of 10.1 percent. Summer peak demand is estimated to increase by 10.3 percent over 1979. However, because of a mild summer experienced in 1979, the average annual growth rate over the two year period from 1978 is expected to be 5 percent for the peak demand. The energy growth estimate appears high for 1980 when considering that the previuus three years' increase averaged only 5.4 percent.

During 1980, 679 MW of generating capability is planned to be added to the regions' supply. Major additions include two coal-fired units totaling $592 \mathrm{MW}$. I'he two untes alt listed in Tablc 9c.3.

Table 9C.3

Additional Capability -1980

Arizona - New Mexico Power Area

Unit \& No.

Cholla 3

Coronado 2
Capabilty

350
Scheduled In-Service Date

Aug. 1980

Oct. 1980

It is not likely that these units will be available for the opening summer peak season. Salt River project will share 30 percent of the Coronado projects' output with Los Angeles Department of Water and Power (LADWP) until May 1983. At that time LADWP will commence receiving its share of Palo Verde Unit 1.

Two units ( $98 \mathrm{MW})$ of combustion turbines are being installed for the summer peak season. The units will have the capability of burning distillate oil or natural gas.

The 1980 estimated operation by type of plant and fuel consumption for the Region is shown in Table $9 \mathrm{C} .4$.

Table 9C.12 indicates the reserve margins expected for 1980. More than adequate reserve margins are projected for the summer peak season when the annual peak occurs.

The bulk power transfer capability between the Arizona - New Mexico and adjacent regions is considered adequate for planned transfers. Presently there are no internal transmission limitations in the Region which would limit transfer capabilities or degrade adequacy. 
Table 9C. 4

Estimated 1980 Operation by Type of Plant

Plant Type

Hydro

Hydro Pumped storage

Steam

Steam

Steam

Steam

Combustion Turbine

Combustion Turbine

Combined Cycle

Combined cycle

Geothermal

Internal Combustion

Fuel Cell

Other

$$
\text { Total }
$$

Total Fuel Consumption

Coal (tons $x$ 1000)

Gas (MCF $x$ 1000)

Gas (equivalent bbls $\times 1000$ )

Oil: distillate (bbls $\times 1000$ )

residual

Total oil

\section{Fuel Type}

Water

Water

Coal

Oil

Gas

Nuclear

oil

Gas

oil

Gas

GST

Opil

$\longdiv { 1 1 1 3 4 }$

$\overline{100.0}$

137

5203

2843

-

0

1470

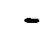

822

$-$

5

5.8

1.2

46.7
17298

71514

12120

856

5075

5931 $\begin{array}{rr}\text { Annual Energy } \\ \text { Gwh } & \text { of Total }\end{array}$

2689

Fossil

Fuel

Consumption

31514

3089

5426

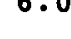

-

$-$

17298 Tons

4620 Barrels

$56884 \quad \mathrm{MCF}$

-

158

158
346

416 Barrels

4654 MCF

892 Barrels

9976 MCP

9312.1

3

Barrels 


\section{Future Perspective}

The combined Arizona - New Mexico Power Area peak loads are projected to increase at an average annual rate of 6.3 percent from 1980 to 1985. Energy consumption is estimated to increase at an average annual rate of 6.9 percent during the same period. While these growth rates are somewhat lower than the 7.6 and 7.1 percent rates for peak and energy experienced during the early $1970^{\prime} \mathrm{s}$, the rates are significantly higher than 4.5 and 5.4 percent peak and energy average annual growth rates recorded from 1976 through 1979.

During the period 1985 through 1989 the annual growth rates for peak demand and energy are projecred to decrease considerably. The average annual growth rates are estimated to be 4.5 ard 4.8 percent respectively.

Planned additions to the Region's generating capability total 4,332 MW during the period 1981 through 1985. Included in that total aie $1,726 \mathrm{MW}$ of coal-fired and 2,510 MW of nuslear generating capacity. The major unit additions are listed on Table 9C. 5 .

\section{Table 9 C. 5}

\section{Scheduled Capability Additions (1981 - 1985)}

\section{Arizona - New Mexico Power Area}

Generating Unit and sumber

Chollà 4

San Juan

Falu vierde 1

Palo Verde 2

Escalante 1

Challo 5

Springerville 1
Type

Cual

Coal

Nuclear

Nuclear

Coal

Coal

Coal
Net Capahility

347

472

1270

1270

210

347

3.50
Schedule in Service Date

$6 / 81$

$6 / 82$

$5,1 \cap 7$

$5 / 84$

$6 / 84$

$5 / 85$

$6 / 85$ 
Coal-fired generating capability is expected to increase to 49.2 percent of the total Region's generating capability in 1985. The two Palo Verde nuclear unit additions, the first in the Region, will contribute 12.6 percent of the total capability.

During the 1986 through 1989 period an additional 910 MW of coalfired and $1270 \mathrm{MW}$ of nuclear generating capability are planned to be added to the Region's generating capability. The total estimated capability additions for the same period amount to $2,538 \mathrm{MW}$.

The schedule for the major additions are listed on Table 9C.6.

Table 9C.6

Schedule Capability. Additions (1986-1989) Arizuna - New Mexico Power Area

Generating Unit \& No.

Palo Verde

Springerville 2

Escalante 2

Pumped Storage

Coronado

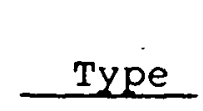

Nuclear

Coal

Coal

Hydro

coal
Net

Capability

1270

350

210

300

350
Scheduled

Service Date

$6 / 86$

$6 / 87$

$6 / 88$

$5 / 89$

$5 / 89$

Fifty percent of the scheduled capability additions during the 1980 through 1989 periods are nuclear units followed by coal-fired units which account for 41.9 percent. Only $198 \mathrm{MW}$ of new peaking oil/gasfired units are scheduled to be installed during that period.

Considering the planned retirement of $140 \mathrm{MW}$ of old oil/gas-fired units, the net addition amounts to only $58 \mathrm{MW}$.

Tables 9C.14 and 9C.15 show the estimated operation by type of plant and fuel consumption for the years 1985 and 1989 .

Since the previous wSCC report, (formerly filed under FPC order 383-4) April 1, 1979, Palo Verde unit 1, $1270 \mathrm{MW}$, has been delayed one year to May 1983.

The first geothermal demonstration unit in the Imperial Valley, California is being planned for construction by $S a n$ Diego Gas and Electric Company. (SDG\&E). The $50 \mathrm{MW}$ Heber, California, project, will be tied in with Imperial Irrigation District's (IID) transmission system. IID will market the project's output. A 10 MW East Mesa pilot project has been under development for some time by SDG\&E and Magma Corp. Indications are that the $50 \mathrm{MW}$ binary demonstration unit will not be operational before 1983 . 
The planned additions schedule showing the amounts of capability to be added yearly for the years 1980 through 1989 is shown in Table 9C.16.

Delays in construction of new generating units would most likely result in increased fuel oil consumption. For the purpose of this report, a six months delay of the nuclear units was assumed to estimate the effects on fuel consumption. The estimated additional fuel oil burn as the result of delays is shown below.

$$
\begin{gathered}
\frac{\text { Table 9C.7 }}{\frac{\frac{\text { Additional Fuel Consumption }}{\text { For Delayed Generation Case }}}{\text { Azona-New Mexico Power Area }}} \\
\frac{1982}{\text { (Equivalent Barrels } \times 1,000)}
\end{gathered}
$$

$1981 \quad \underline{1982} \quad \underline{1983} \quad \underline{1984} \quad \underline{1985}$

$1,600 \quad 2,200 \quad 5,100 \quad 2,900 \quad 2,900$

Part of the additional fuel comsumption could be natural gas but no attempt was made to estimate that portion.

The forecasted Regional reserve margins for the 1980 through 1985 period range from 25.1 percent to 32.6 percent during the annual summer peak season. Projected reserves appear adequate and the estimated combined area reserve margins will meet the wscC criteria 1 and 2 of the "Power Supply and Design Criteria" for all months in the 1980 to 1984 time period.

While the delay of Palo Verde has reduced expected reserve margins in 1982, no adverse consequences are anticipated. However, additional delays could result in inadequate reserves.

Table 9C.13 exihibits reserve margin projections for the summer and winter peak periods for the years 1981 through 1989 . The effects of forced outage were considered using the average forced outage rate as recorded for the latest four years.

Although no further delays in construction are anticipated, the following table of estimated reserve margins indicated the effects of an additional one year delay in the palo verde units and a six months delay of the major coal-fired units during the 1980 through 1985 period. 


\section{Table 9 C. 8}

Estimated Actual Reserve Margins ( 8$)$ Annual Summer Peak Period

Arizona - New Mexico Power Area

$1980 \quad \underline{1981} \quad \underline{1982} \quad \underline{1983} \quad \underline{1984} \quad \underline{1985}$

$\begin{array}{llllll}\text { Present Schedule } 22.0: 29.4 & 24.5 & 28.5 & 30.8 & 20.9\end{array}$

$\begin{array}{lllllll}\text { Delayed Schedule } & 22.0 & 25.7 & 19.8 & 16.4 & 17.4 & 23.1\end{array}$

Planned critical bulk power transmission facilities that will not be in service when desired are reported by Public service Company of New Mexico (PNM).

The OJO to Norton to B-A station $345 \mathrm{kV}$ transmission line and the associated Norton $345 / 115$. $\mathrm{kV}$ substation has been delayed from November 1980 to December 1982 due to $r$ ight-of-way acquisition problems. This delay will stress the existing northern New Mexico transmission system and may result in marginal or unacceptable system performance under certain conditions. 
Table 9C.11

Historical Cacability(MW) and Reserves (MW and Present) Arizona - New Mexico Power Area

1. Planned Capability

2. Peak Demand

3. Planned Reserves (1-2)

4. Planned Reserves (8) (32) $\times 1008$

5. Net Transactions (Imports-Exports)

6. Total Capability $(1+5)$

7. Total Reserves $(6-2)$

8. Total Reserves (8) (7)

10. Capability After Maintenance $(6-9)$

11. Reserves After Maintenance $(10-2)$

12. Reserves After. Maintenance (8) $(11+2)$ I 1008

13. Inoperable Capability

14. Available Capability (10-13)

15. Available Reserves (14-2)

16. Available Reserves $(8)(15+2) \times 1008$

17. Forced Outages $1 /$

18. Actual Capability After Forced Outage (14-17)

19. Actual Reserves $(18-2)$

20. Actual Reserves (8) $(19+2) \times 1008$

1/ Information not reported separately.

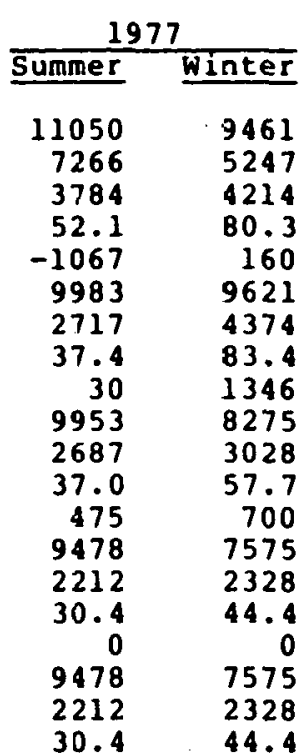

\begin{tabular}{rr}
\multicolumn{2}{c}{1978} \\
\cline { 1 - 1 } Summer & winter \\
\cline { 3 - 3 } 9633 & 9685 \\
7942 & 6065 \\
1691 & 3620 \\
21.3 & 59.7 \\
391 & 86 \\
10024 & 9771 \\
2082 & 3706 \\
26.2 & 61.1 \\
175 & 1465 \\
9849 & 8306 \\
1907 & 2241 \\
24.0 & 36.9 \\
317 & 1736 \\
9532 & 6570 \\
1590 & 505 \\
20.0 & 8.3 \\
0 & 0 \\
9532 & 6570 \\
1590 & 505 \\
20.0 & $B .3$
\end{tabular}

\begin{tabular}{rrr}
\multicolumn{2}{c}{1979} \\
\cline { 1 - 1 } Summer & Winter \\
9911 & & 10727 \\
7942 & & 6191 \\
1969 & & 4536 \\
24.8 & & 73.3 \\
174 & & 137 \\
10085 & & 10590 \\
2143 & & 4399 \\
27.0 & & 71.1 \\
198 & & 1352 \\
9887 & & 9238 \\
1945 & & 3047 \\
24.5 & & 49.2 \\
437 & & 12 \\
9450 & & 9226 \\
1508 & & 3035 \\
19.0 & & 49.0 \\
0 & & 0 \\
9450 & & 9226 \\
1508 & & 3035 \\
19.0 & 49.0
\end{tabular}




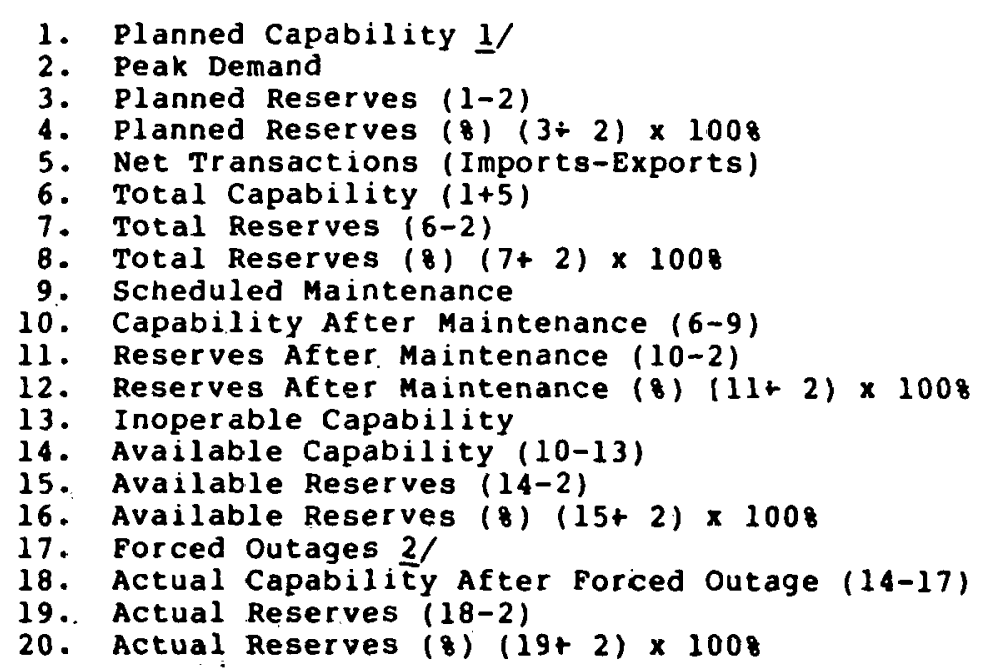

\begin{tabular}{rrr}
\multicolumn{3}{c}{ Summer 1980} \\
\cline { 2 - 2 } 11083 & 11088 & August \\
\cline { 2 - 3 } 8624 & 8757 & 11080 \\
2459 & 2331 & 8669 \\
28.5 & 26.6 & 2411 \\
23 & 35 & 27.8 \\
11106 & 11123 & 11114 \\
2482 & 2366 & 2445 \\
28.9 & 27.0 & 28.2 \\
2.3 & 0 & 50 \\
1107.3 & 11123 & 11064 \\
2459 & 2366 & 2395 \\
28.5 & 27.0 & 27.6 \\
11 & 11 & 11 \\
11067 & 11112 & 11053 \\
2443 & 2355 & 2384 \\
28.3 & 26.9 & 27.5 \\
430 & 430 & 430 \\
10637 & 10682 & 10623 \\
2013 & 1925 & 1954 \\
23.3 & 22.0 & 22.5
\end{tabular}

\begin{tabular}{rrrr}
\multicolumn{3}{c}{ Winter $1980-81$} \\
\cline { 1 - 1 } December & January & February \\
11541 & & 11542 & 11551 \\
6367 & & 6475 & 6188 \\
5174 & & 5067 & 5363 \\
81.3 & & 78.3 & 86.7 \\
148 & 53 & 46 \\
11393 & 11595 & 11597 \\
5026 & 5120 & 5409 \\
78.9 & & 79.1 & 87.4 \\
1361 & 1573 & 1965 \\
10032 & & 10022 & 9632 \\
3665 & 3547 & 3444 \\
57.6 & & 54.8 & 55.7 \\
11 & & 11 & 11 \\
10021 & 10011 & 9621 \\
3654 & 3536 & 3433 \\
57.4 & 54.6 & 55.5 \\
660 & 660 & 660 \\
9361 & 9351 & 8961 \\
2994 & 2876 & 2773 \\
47.0 & 44.4 & 44.8
\end{tabular}

if No delays anticipated in new generating units since submission of 1980 ERA-411 $\underline{2}$ four year historical average forced outage (1976-1979). 
Table 9C.13.1

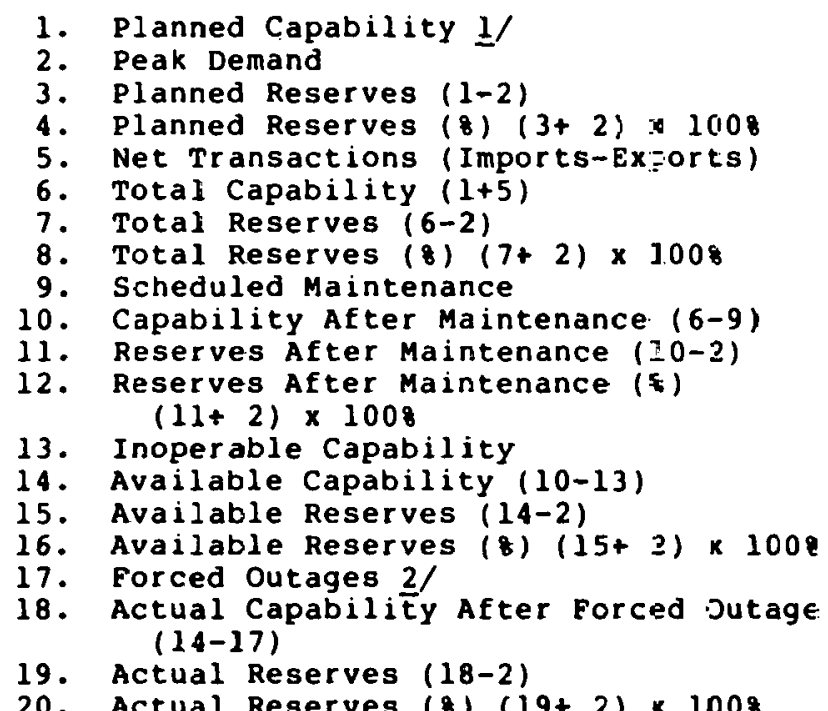

\begin{tabular}{rr}
\multicolumn{2}{c}{1981} \\
\cline { 2 - 2 } Summer & Winter \\
13556 & 13549 \\
9431 & 6823 \\
4125 & 6726 \\
43.7 & 98.5 \\
-1346 & -1495 \\
12210 & 12054 \\
2779 & 5231 \\
29.5 & 76.7 \\
0 & 1007 \\
12210 & 11047 \\
2779 & 4224 \\
29.5 & 61.9
\end{tabular}

\begin{tabular}{rr}
\multicolumn{2}{c}{1982} \\
\cline { 1 - 1 } Summer & Winter \\
14024 & 13991 \\
9937 & 7220 \\
4087 & 6771 \\
41.1 & 93.8 \\
-1640 & -1703 \\
12384 & 12288 \\
2447 & 5068 \\
24.6 & 70.2 \\
0 & 778 \\
12384 & 11510 \\
2447 & 4290 \\
24.6 & 59.4
\end{tabular}

\begin{tabular}{rr}
\multicolumn{2}{c}{1983} \\
\hline Summer & Winter \\
15369 & 15337 \\
10484 & 7581 \\
4885 & 7756 \\
46.6 & 102.3 \\
-1810 & -1880 \\
13559 & 13457 \\
3075 & 5876 \\
29.3 & 77.5 \\
79 & 1136 \\
13480 & 12321 \\
2996 & 4740 \\
28.6 & 62.5 \\
&
\end{tabular}

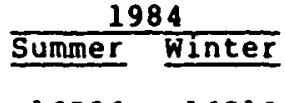

$16526 \quad 16519$

$11061 \quad 8200$

54658319

$49.4 \quad 101.5$

$-2046-1898$

$14480 \quad 14621$

$3419 \quad 6421$

30.978 .3

00653

$\begin{array}{rr}14480 & 13968 \\ 3419 & 5768\end{array}$

30.970 .3

$\begin{array}{rrrr}11 & 27 & 11 & 27 \\ 12199 & 11020 & 12373 & 1: 483 \\ 2768 & 4197 & 2436 & 1263 \\ 29.4 & 61.5 & 24.5 & 59.0 \\ 0 & 0 & 0 & 0 \\ 12199 & 11020 & 12373 & 11483 \\ & & & \\ 2768 & 4197 & 2436 & \$ 263 \\ 29.4 & 61.5 & 24.5 & 59.0\end{array}$

$\begin{array}{rr}11 & 27 \\ 13469 & 12294 \\ 2985 & 4713 \\ 28.5 & 62.2 \\ 0 & 0 \\ 13469 & 12294 \\ & \\ 2985 & 4713 \\ 28.5 & 62.2\end{array}$

$\begin{array}{rr}11 & 27 \\ 14469 & 13941 \\ 3408 & 5741 \\ 30.8 & 70.0 \\ 0 & 0 \\ 14469 & 13941 \\ & \\ 3408 & 5741 \\ 30.8 & 70.0\end{array}$

$1 /$ No delays anticipated in new jenerating units since submission of 1980 ERA-411.

2/ Information on forced outages not ava:lable. 
Table 9C.1 1.2

Future Capability (MW) and Reserves (MW and Percent) $1985 / 1989$

Arizona- New Mexico Power Area

\begin{tabular}{|c|c|c|c|c|c|}
\hline \multicolumn{2}{|c|}{1985} & \multicolumn{2}{|c|}{1986} & \multicolumn{2}{|c|}{1987} \\
\hline Summer & Winter & Summer & winter & Summer & Winter \\
\hline $\begin{array}{r}17174 \\
11887 \\
5287 \\
44.5 \\
-1836 \\
15338 \\
3451 \\
29.0\end{array}$ & $\begin{array}{r}17167 \\
8795 \\
8372 \\
95.2 \\
-1920 \\
15247 \\
6452 \\
73.4\end{array}$ & $\begin{array}{r}18126 \\
12513 \\
5613 \\
44.9 \\
-2010 \\
16116 \\
3603 \\
28.8\end{array}$ & $\begin{array}{r}18108 \\
9220 \\
8888 \\
96.4 \\
-2094 \\
16014 \\
6794 \\
73.7\end{array}$ & $\begin{array}{r}18833 \\
13155 \\
5678 \\
43.2 \\
-2134 \\
16699 \\
3544 \\
26.9\end{array}$ & $\begin{array}{r}18826 \\
9572 \\
9254 \\
96.7 \\
-2218 \\
16608 \\
7036 \\
73.5\end{array}$ \\
\hline $\begin{array}{r}0 \\
15338 \\
3451 \\
29.0\end{array}$ & $\begin{array}{r}0 \\
15247 \\
6452 \\
73.4\end{array}$ & $\begin{array}{r}0 \\
16116 \\
3603 \\
28.8\end{array}$ & $\begin{array}{r}0 \\
16014 \\
6794 \\
73.7\end{array}$ & $\begin{array}{r}0 \\
16699 \\
3544 \\
26.9\end{array}$ & $\begin{array}{r}0 \\
16608 \\
7036 \\
73.5\end{array}$ \\
\hline $\begin{array}{r}11 \\
15327 \\
3440 \\
28.9\end{array}$ & $\begin{array}{r}27 \\
15220 \\
6425 \\
73.1\end{array}$ & $\begin{array}{r}11 \\
16105 \\
3592 \\
28.7\end{array}$ & $\begin{array}{r}27 \\
15987 \\
6767 \\
73.4\end{array}$ & $\begin{array}{r}11 \\
16688 \\
3533 \\
26.9\end{array}$ & $\begin{array}{r}27 \\
16581 \\
7009 \\
73.2\end{array}$ \\
\hline $\begin{array}{r}0 \\
15327\end{array}$ & $\begin{array}{r}0 \\
15220\end{array}$ & $\begin{array}{r}0 \\
16105\end{array}$ & $\begin{array}{r}0 \\
15987\end{array}$ & $\begin{array}{r}0 \\
16688\end{array}$ & 16581 \\
\hline $\begin{array}{l}3450 \\
28.9\end{array}$ & $\begin{array}{l}6425 \\
73.1\end{array}$ & $\begin{array}{l}3592 \\
28.7\end{array}$ & 73.4 & $\begin{array}{l}3533 \\
26.9\end{array}$ & $\begin{array}{l}7009 \\
73.2\end{array}$ \\
\hline
\end{tabular}

\begin{tabular}{|c|c|c|c|}
\hline \multicolumn{2}{|c|}{1988} & \multicolumn{2}{|c|}{1989} \\
\hline Summer & Winter & Summer & Winte \\
\hline $\begin{array}{r}19259 \\
13632 \\
5627 \\
41.3 \\
-1899 \\
17360 \\
3728 \\
27.3\end{array}$ & $\begin{array}{r}19207 \\
9932 \\
9275 \\
93.4 \\
-1624 . \\
17583 \\
7651 \\
77.0\end{array}$ & $\begin{array}{r}19909 \\
14149 \\
5760 \\
40.7 \\
-1549 \\
18360 \\
4211 \\
29.8\end{array}$ & $\begin{array}{r}19901 \\
10223 \\
9678 \\
94.7 \\
-1633 \\
18268 \\
8045 \\
78.7\end{array}$ \\
\hline $\begin{array}{r}0 \\
17360 \\
3728 \\
27.3\end{array}$ & $\begin{array}{r}0 \\
17583 \\
7651 \\
77.0\end{array}$ & $\begin{array}{r}0 \\
18360 \\
4211 \\
29.8\end{array}$ & $\begin{array}{r}18268 \\
8045 \\
78.7\end{array}$ \\
\hline $\begin{array}{r}11 \\
17349 \\
3717 \\
27.3\end{array}$ & $\begin{array}{r}27 \\
17556 \\
7624 \\
76.8\end{array}$ & $\begin{array}{r}11 \\
18349 \\
4200 \\
29.7\end{array}$ & $\begin{array}{r}27 \\
18241 \\
8018 \\
78.4\end{array}$ \\
\hline $\begin{array}{r}0 \\
17349\end{array}$ & $\begin{array}{r}0 \\
17556\end{array}$ & $\begin{array}{r}0 \\
18349\end{array}$ & 1824 \\
\hline $\begin{array}{l}3717 \\
27.3\end{array}$ & $\begin{array}{l}7624 \\
76.8\end{array}$ & $\begin{array}{l}4200 \\
29.7\end{array}$ & $\begin{array}{l}8018 \\
78.4\end{array}$ \\
\hline
\end{tabular}

1/ Information on scheduled maintenance and forced outages not available. 
Table 9C.14

Estimated 1985 Operation by Type of Plant

$$
\text { Arizona New Mexico Power Area }
$$

Plant Type

Hydro

Hydro Pumped Storage

steam

steam

steam

steam

Combustion Turbine

Combustion Turbine

Combined Cycle

Combined Cycle

Geothermal

Internal Combustion

Fuel Cell

Other

Total

Total Fuel Consumption

Coal (tons $x 1000$

Gas (MCF $x$ 1000)

Gas (equivalent bbls $\times 1000$

Oil: distillate (bbls $\times 1000$ )

residual

crude

Total Oil
Fuel Type

Water

water

Coal

oil

Gas

Nuclear

Oil

Gas

oil

Gas

GST

Oil

MH

645

137

$77 \mathbf{5}$

2701

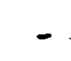

1996

1498

$-$

534

822

155

15

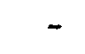

$\overline{52859}$

20652

41420

6818

612

$75 \times 9$
Fossil

Euel

Consumption

Gwh 8 of Total

$(x 1000)$

\section{1}

2553

4.0

0.9

49.2

40164

62.4

4.8

.4 .5

2864

20.5

0.5

13197

0.5

296

118

0.2

1127

505

0.4

0.8

-

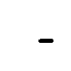

\section{2}

5328

30355

$$
\begin{aligned}
& 1.0 \\
& 5.2 \\
& 1.0
\end{aligned}
$$

679

$$
0.1
$$

1

1.1

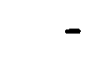

$\underset{H}{*}$
$i$ 
9c. 15

$\frac{\text { Estimated } 1989 \frac{\text { Operation by Type of Plant }}{\text { Arizona-New Mexico Power Area }}}{\text { A }}$

Plant Type

Hydro

Hydro Pumped Storage

Steam

Steam

Steam

Steam

Combustion Turbine

Combustion Turbine

Combined cycle

Combined Cycle

Geothermal

Internal Combustion

Fuel Cell

Other

Total

Total Fuel Consumption

Coal (tons $x 1000$

Gas (MCF X 1000)

Gas (equivalent bbls $\times 1000$ )

0il: distillate (bbls $x$ 1000) residual

crude

Total Oil
Fuel Type

Capability (as of $7 ; 89$ )

$$
\text { MW }
$$

8 of Total

645

287

3.6

1.6

8787

2689

oil

Gas

Nuclear

oil

Gas

oil

Gas

GST

Oii

$-$

48.7

14.9

2994

1548

1548

822

255

15

J. 4

C. 1 $\overline{18047}$

21621

19250

3101

1079

4406

5485

\section{Annual Energy Gwh}

2560

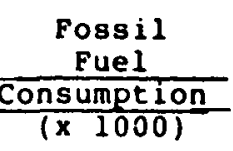

3.5

58.3

3.1

1.5

30.3

0.3

0.0

0.6

1.0

1.4

999

3

73221

700.0
Barrels

11844 MCF

661 Barrels

77 MCF

786 Barrels

7329 MCE

\section{$-$}

8 Barrels

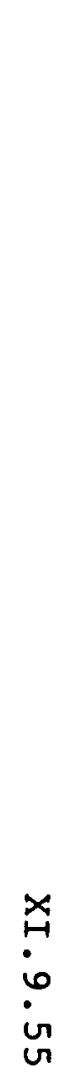


Summary of $\frac{\text { Table 9C.16 }}{\text { Generation Additions }}$

Arizona - New Mexico Power Area

(wirter Capability - MW)

\begin{tabular}{|c|c|c|c|c|c|c|c|c|c|c|c|c|c|}
\hline Generation Type & 1980 & 1981 & $=982$ & 1983 & 1984 & 1985 & 1986 & 1987 & 1988. & 1989 & $\begin{array}{l}\text { 10-Yr. } \\
\text { Period }\end{array}$ & $\begin{array}{c}\text { Percent } \\
\text { of } \\
\text { Total } \\
\end{array}$ & \\
\hline Hydro-Conventional & 0 & 1 & D & 0 & $\mathbf{0}$ & 0 & 0 & 0 & 0 & 0 & 1 & .08 & \\
\hline Hydro-Pump Storage & 0 & 0 & D & 0 & 0 & 0 & 0 & 0 & 0 & 300 & 300 & 4.08 & \\
\hline Steam-Coal & 592 & 347 & 445 & -15 & 210 & 697 & 0 & 350 & 210 & 350 & 3186 & 2.28 & \\
\hline Steam-Gas and $O i l$ & -11 & 0 & -11 & 0 & -26 & 0 & -11 & 0 & -81 & 0 & -140 & -1.88 & \\
\hline Nuclear & 0 & 0 & 0 & 1270 & 1270 & 0 & 2270 & 0 & 0 & 0 & 3810 & 50.08 & \\
\hline Combustion Turbine & 98 & 0 & $\mathbf{0}$ & 50 & 0 & 0 & 0 & 0 & 0 & 50 & 198 & 2.68 & \\
\hline Cobmined Cycle & 0 & 0 & 0 & 0 & 0 & 0 & 0 & 0 & 0 & 0 & 0 & .08 & \\
\hline Geothermal & & & 45 & 50 & 0 & 0 & 50 & 0 & 50 & 0 & 195 & 2.68 & \\
\hline Internal Combustion & 0 & 0 & 0 & 0 & 0 & 0 & 0 & 0 & 0 & 0 & 0 & .08 & H \\
\hline other & $\underline{0}$ & .0 & $\underline{0}$ & $\underline{0}$ & $\underline{0}$ & $\underline{0}$ & $\underline{0}$ & $\underline{0}$ & $\underline{0}$ & 0 & $\underline{0}$ & .08 & $\because$ \\
\hline Total & 679 & 347 & 479 & i355 & 1454 & 697 & 1309 & 350 & 179 & 700 & 7550 & 100.08 & s \\
\hline
\end{tabular}




$$
\mathrm{XI} \cdot 9.57
$$

\section{Southern California-Nevada Power Area - Region 27}

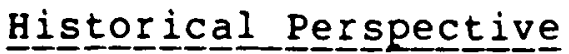

The Southern California-Nevada Power Area (S.CA-NV) consists mainly of the service areas of Southern California Edison Company (SCE), San Diego Gas and Electric Company (SDG\&E), Los Angeles Department of Water and Power (LADWP), and Nevada Power Company (NPC). These utilities operate independently but are joint participants in several generating plants.

The S.CA-NV experiences a pronounced summer peak. During the period 1960 through 1973 the region experienced an average annual growth in energy for load of 7.6 percent. However, for the period 1973 through 1979, this growth rate was reduced to less than two percent despite continued economic and population growth. SDG\&E experienced the fastest energy for load growth rate with a 3.6 percent annual average increase from 1973 through 1978 ; conversely, LADWP has had a slightly negative load growth rate during the corresponding period.

Table 9D.1 presents electric load data for the years 1977-1979. Growth rate data appear high for 1978 because of the effects of conversion spurred by the 1976-1977 drought in California. The energy load decrease for 1979 is a probable reporting error as each utility in the Region experienced an actual load increase.

$$
\begin{aligned}
& \text { Table 9D. } 1 \\
& \text { Histor } 1 \text { i } \\
& \text { Southern California-Nevada Power Area }
\end{aligned}
$$

Energy Load (GWh)
Growth rate from previous year $(\&)$
Peak Demand (MW)
Growth rate from previous year $(8)$

Load Factor ( 8$)$

\begin{tabular}{rrr}
$19 \underline{7} 7$ & \multicolumn{1}{c}{1978} & \multicolumn{1}{c}{$19 \underline{79}$} \\
96666 & 102317 & 102014 \\
1.0 & 5.8 & -0.3 \\
18815 & 20150 & 20507 \\
1.6 & 7.1 & 1.8 \\
58.6 & 58.0 & 56.8
\end{tabular}

The California utilities have historically relied heavily upon oil/gas fired additions to meet load growth requirements. Coal supplies are practically non-existent within the state and past economics and environmental concerns precluded major importation of coal for generating purposes. 
As of December 1979 fully 67.8 percent of the Electric Region 27 installed generating capability was oil and/or gas fired. Gas and oil accounted for 63.7 percent of the total electric energy generation in 1978. For 1978, fuel oil consumption amounted to $70.8 \mathrm{million}$ barrels and natural gas consumption was 18.4 billion cubic feet, which is equivalent to $31.4 \mathrm{milli}$ ion barrels of oil. Fuel consumption and generation data is not available for this Region for 1979.

This pronounced dependence on oil and gas as a fuel for generating purposes makes the California portion of this Region the largest consumer of oil and gas within the WSCC. The Nevada portion of the Region contains substantial amounts of coal-fired generation. Southern California utilities jointly own coal-fired generating capacity located in Southern Nevada and elsewhere. Their share of these units is included in Table 9D.10.

Oil and gas consumption is substantially reduced when better than adverse water conditions are experienced in the pacific Northwest. During these periods surplus PNW hydroelectric energy is transferred to southern California consequently displacing incremental generation (usually oil) in the area. During the past several years Pacific Northwest secondary transfers to S.CA-NV averaged roughly $5,000 \mathrm{GWh}$, equivalent to $8 \mathrm{million}$ barrels of oil per year.

Reliability criteria vary from utility to utility within the southern California-Nevada area. However, the various criteria applied by each utility result in an area installed planning reserve margin requirement of approximately 20 percent at the time of the dinual peak.

\begin{tabular}{|c|c|c|c|c|c|c|}
\hline & south & 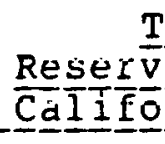 & 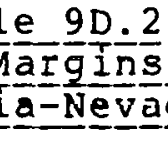 & $\frac{(8)}{8} \frac{1}{p}$ ower & rea & \\
\hline & Summe $\frac{1}{\frac{1}{r}}$ & winter & 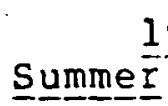 & $\frac{78}{\text { Winter }}$ & S summe $\frac{19}{9}$ & $\frac{79}{\text { Winter }}$ \\
\hline $\begin{array}{l}\text { Total } \\
\text { Reserves }\end{array}$ & 33.3 & 68.5 & 29.9 & 60.2 & 22.2 & 67.9 \\
\hline $\begin{array}{l}\text { after Main- } \\
\text { tenance }\end{array}$ & 24.1 & 54.9 & 18.4 & 43.6 & 22.2 & 67.9 \\
\hline Actual & 19.6 & 37.8 & 6.1 & 35.0 & 3.1 & 31.7 \\
\hline
\end{tabular}

Reserve margins have been low at the time of the past two summer peak periods due to excessive forced outage caused by the continuous 
operation of system capacity in order to assist utilities to the north during energy shortages. Additionally, in 1979 the area experienced an early heat storm while scheduled maintenance of some major units was still in progress. SCE has been pursuing an aggressive maintenance program which is expected to reduce system forced outages by one third.

As of December 1979 the majority of the region's high voltage transmission was rated at $230 \mathrm{kV}$ and totaled more than 4600 circuit miles. Strong $500 \mathrm{kV}$ interties exist between Los Angeles, southern Nevada, Arizona, and New Mexico to the east, and to the north through northern California to the Pacific Northwest. The $800 \mathrm{kV}-\mathrm{DC}$ Pacific Northwest/Southwest intertie connects southern California with the Pacific Northwest. There are no intermediary taps along the $D C$ intertie.

The combined northern $A C$ and $D C$ intertie is designated as the Pacific Intertie and in addition to firm transfers and significant seasonal diversity exchange the interties are used to transfer the aforementioned surplus hydro energy from the pacific Northwest.

The total transfer capability between Electric Region 27 and northern utilities is approximately $3300 \mathrm{Mw}$. Eastern transfer capability is $2300 \mathrm{MW}$ from east to west and $900 \mathrm{MW}$ from west to east.

While the existing transmission system is more than adequate to support intra-area and inter-area transfers, a problem area does exist in the region: the single $230 \mathrm{kV}$ interconnection between SCE and SDG\&E which carries participants' output of the San Onofre Nuclear Unit \#l and other transfers to SDG\&E. This line is susceptible to outage brush fires and no appropriate back-up transmission exists.

Table 9D. 3

1979 Capability by Souther

Plant Type

Hydro

Hydro Pumped Storage

Steam

Steam

Steam

Combustion Turbine

Combustion Cycle

Internal Combustion
Capability(as of $12 / 31 / 79$ )

Fue I Type

water

Water

Coal

Oil/Gas

Nuclear

Oil/Gas

Oil/Gas

oil
2692

1247

3871

14698

436

1501

1113

30
10.5

4.9

15.1

57.5

1.7

5.9

4.3

0.1
Total

$\overline{2} \overline{5} \overline{5} \overline{8} \overline{8}$

$\overline{100 . \overline{0}}$ 
HISTORICAL CAPABILITY (MW) AND RESERVES (MW and Percent) Southern Cal ifornia - Nevada Power Area

1. Planned Capability

2. Peak Demand

3. Planned Reserves (1-2)

4. Planned Reserves (\%) (3/2) x100

5. Net Transactions (Imports-Exports)

6. Total Capability $(1+5)$

7. Total Reserves (6-2)

8. Total Reserves $(\%)(7 / 2) \times 100$

9. Scheduled Maintenance

10. Capability after Maintenance (6-9)

11. Reserves after Maintenance (10-2)

12. Reserves after Maintenance $(\%)(11 / 2) \times 100$

13. Inoperable Capability

14. Available Capability (10-13)

15. Available Reserves (14-2)

16. Available Reserves (\%) $(15 / \%) \times 100$

17. Forced Outages 1/

18. Actual Capability after Forced Outages (14-17)

19. Actual Reserves (18-2)

20. Actual Reserves (\%) $(19 / 2) \times 100$

1/ Information not reported separately.

2/ Includes scheduled outages.

\begin{tabular}{rrr}
\multicolumn{2}{c}{1977} \\
22197 & 22314 \\
18815 & 15125 \\
3382 & 7189 \\
18.0 & 47.5 \\
2877 & 3167 \\
25074 & 25481 \\
6259 & 10356 \\
33.3 & 68.5 \\
1730 & 2050 \\
23344 & 23431 \\
4529 & 8306 \\
24.1 & 54.9 \\
840 & 2582 \\
22504 & 20849 \\
3689 & 5724 \\
19.6 & 37.8 \\
0 & 0 \\
22504 & 20849 \\
3689 & 5724 \\
19.6 & 37.8 \\
&
\end{tabular}

\begin{tabular}{|c|c|}
\hline \multicolumn{2}{|c|}{1978} \\
\hline Summer & Winter \\
\hline 24771 & 25131 \\
\hline 20150 & 16355 \\
\hline 4621 & 8776 \\
\hline 22.9 & 53.7 \\
\hline 1404 & 1065 \\
\hline 26175 & 26196 \\
\hline 6025 & 9841 \\
\hline $29 . \subseteq$ & 60.2 \\
\hline 231E. & 2711 \\
\hline $2385 i$ & 23485 \\
\hline זٓ & 7130 \\
\hline 18.4 & 43.6 \\
\hline 2482 & 1404 \\
\hline 21375 & 22081 \\
\hline 1225 & 5726 \\
\hline $6 . i$ & 35.0 \\
\hline 0 & 0 \\
\hline 21375 & 22081 \\
\hline 1225 & 5726 \\
\hline $60^{\circ}$ & 35.0 \\
\hline
\end{tabular}

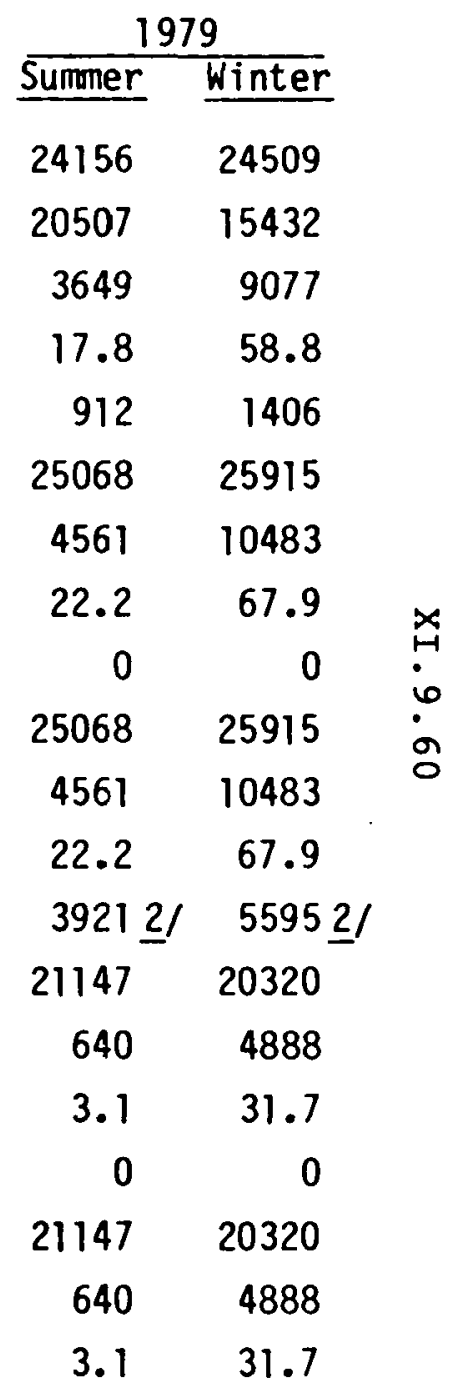


Table 90.5

- CURRENT CAPABILITY (MW) AND RESERVES (MW and Percent) Southern Cal ifornia - Nevada Power Area

1. Planned Capability I/

2. Peak Demand

3. Planned Reserves $(1-2)$

4. Planned Reserves (\%) (3/2) ×100

5. Net Transactions (Imports-Exports)

6. Total Capability $(1+5)$

7. Total Reserves (6-2)

8. Total Reserves $(\%)(7 / 2) \times 100$

9. Scheduled Maintenance

10. Capability after Maintenance (6-9)

11. Reserves after Maintenance (10-2)

12. Reserves after Maintenance $(\%)(11 / 2) \times 100$

13. Inoperable Capability

14. Available Capability (10-13)

15. Available Reserves (14-2)

16. Available Reserves (\%) (15/2) x100

17. Forced Outages $2 /$

18. Actual Capability after Forced Outages (14-17)

19. Actual Reserves (18-2)

20. Actual Reserves (\%) (19/2) $\times 100$
1980

Summer

22096

20805

1291

6.2

4008

26104

5299

25.5

934

25170

4365

21.0

459

24711

3906

18.8

1632

23079

2274

10.9
1980/81

Winter

22303

17111

5192

30.3

3745

26048

8937

52.2

3100

22948

5837

34.1

459

22489

5378

31.4

1575

20914

3803

22.2

1/ No delays anticipated in new generating units since submission of 1980 ERA-411.

2/ 3-Year historical average forced outage (1976-78). 
$X I .9 .62$

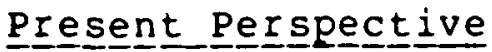

Reserves above forecasted 1980 peak demands are expected to be adequate for the Southern California-Nevada Power Area. Expected 1980 reserves are in excess of minimum criteria partially as a result of peak demand growth reductions due primarily to expected increased energy conservation. Annual peak demand growth from 1979 to 1980 is projected to be 1.5 percent and energy load growth to be 3.4 percent.

The only scheduled resource additions in the area during 1980 are $57 \mathrm{MW}$ of hydroelectric capacity in southern California and a $70 \mathrm{MW}$ gas turbine unit planned by the Nevada Power Company.

The San Onofore Nuclear Unit No. 1 (436 MW) is scheduled for refueling from April 11 to June 1, 1980. Turbine blading problems have been experienced in units of similar age and type. Discovery of turbine trouble could extend the shutoown or cause derating of the unit.

The major southern California utilities participate in the statewide emergency reserve sharing and demand reduction program (see discussion for Electric Region 28) and under this plan they may be called upon to assist the northern California utilities during possible capacity shortages there.

No surplus energy is expected from the Pacific Northwest, and Northwest economy receipts are anticipated to be significantly below average during 1980 due to below normal runoff predictions and already overdratted reservoir cuildilions in the Northwest. This situation is estimated to result in an increased 1980 oil consupmtion in southern California of approximately 9 million barrels. Power plant fuel supplies are generally abundant throughout California.

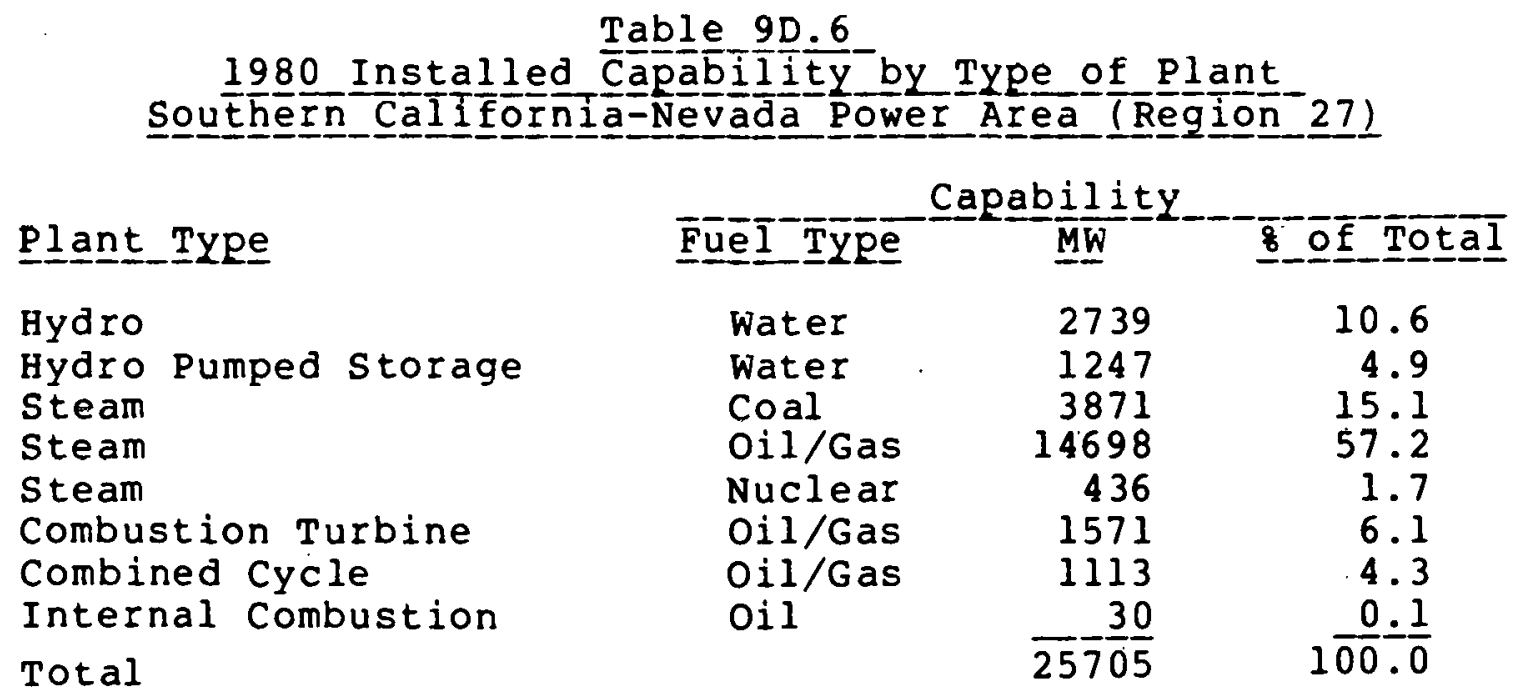




\section{Futur $\underline{\text { e }}$ Perspectivive}

The utilities in the Southern California-Nevada Power Area (S.CA-NV) project load growth for the Region to average 3.0 percent in peak demand from 1980 to 1985 and 3.2 percent from 1985 through 1989. Associated annual energy load growth projections are 3.0 percent through $1985^{\circ}$ and 3.3 percent from 1985 through 1989. These projections are significantly higher than actual growth rates experienced during the past several years.

In contrast to the utilities' forecast, the California Energy Commission (CEC) in its 1979 Biennial Report forecasts only a 2 percent growth in energy load through the 1980 's for the major Southern California utilities which serve 90 percent of the Region's load. The CEC forecast is used in determining the need for additional generating resources during the state's powerplant site certification process.

Within the S.CA-NV, generating resource additions planned through 1985 include $2200 \mathrm{MW}$ of nuclear capability (San Onofre $2 \& 3$ ), $500 \mathrm{MW}$ of coal-fired cabability in southern Nevada and $530 \mathrm{MW}$ of combustion turbines.

Beyond 1985 significant amounts of coal-fired additions are planned. Continued expansion of combustion turbine capability is also scheduled. Other planned resources include hydro, geothermal, and wind. No nuclear units are planned within the area after the scheduled san Onofre unit additions. However, area utilities are joint participants in scheduled nuclear capacity outside of the S.CA-NV. These utilities' will share a total of $819 \mathrm{MW}$ by 1990 .

Table 9D.10 lists significant capability additions scheduled through 1989 for the Region. Table 9D.12 illustrates the utilities' projected generating capability listed by types for the years 1985 and 1989 .

In conjunction with the CEC's recently adopted load forecast, the Commission has proposed a preferred resource mix which is significantly different from that foreseen by the California utilities. This CEC outlook capitalizes on alternative and renewable resources including increased development of geothermal, cogeneration, wind, and conservation with a proposed limit on coal-fired generation of $5800 \mathrm{MW}$. In contrast, present statewide utilities' plans include a total of nearly $12,000 \mathrm{MW}$ of coal-fired generation by 1990. 
Delays in construction of nuclear or coal-fired resources would most likely result in additional fuel oil consumption. Additional oil consumption is estimated to be nearly one million barrels per year per $100 \mathrm{MW}$ of slippage. Assuming a one-year delay from the utilities' present scheduled inservice dates for nuclear, and six-months' delay for all coalfired additions, fuel oil consumption would increase by about 2.1 million barrels in 1981, 10.4 million barrels in 1982, and 9.5 million barrels in 1983. During the five-year period through 1985, the resulting annual average increased oil burn is estimated to be $4.5 \mathrm{mill}$ ion barrels per year for S.CA-NV.

A recent development which will result in reduced area oil burn is Southern California Edison's agreement with Arizona Public Service Company (APS) to purchase power from APS's 350 MW coalfired Cholla unit No. 4 for a five-year period starting in June 1984. Under the terms of the agreement, SCE will receive 35 percent of the unit's capability the first year, 100 percent for the next three years and 41 percent for the final year. The purchase will reduce equivalent oil consumption by an estimated 12.5 million barrels during the five-year period.

Under the utilities' present resource schedule and peak load forecast, the actual reserve margins at the time of the system peak for the S.CA-NV area are projected to range from 10.9 percent in 1980 and 1981 to 23.5 percent in 1989 .

\begin{tabular}{|c|c|c|c|c|c|}
\hline & Souther & $\frac{T}{\mathrm{v}} \frac{\mathrm{a}}{\mathrm{e}} \frac{\mathrm{b}}{\mathrm{M}}$ & $\frac{7}{a} \frac{1}{a} \frac{1}{\mathrm{a}}$ & A- A들 & \\
\hline & 19981 & 19982 & $198 \underline{=} 3$ & $\underline{19} \underline{\underline{9}} \underline{\underline{4}}$ & 1985 \\
\hline Total & 26.2 & 26.6 & 28.5 & 25.6 & 22.2 \\
\hline $\begin{array}{l}\text { Reserves after } \\
\text { Maintenance }\end{array}$ & 21.0 & 21.9 & 22.0 & 21.3 & 27.2 \\
\hline Actual & 18.8 & 19.8 & 19.7 & 21.0 & 21.4 \\
\hline
\end{tabular}

Table 9D.8 shows the estimated installed reserve margins reflecting the effect of the delayed case for nuclear and coal-fired units. Reserves remain within desired margin requirements.

Table 9D. 8

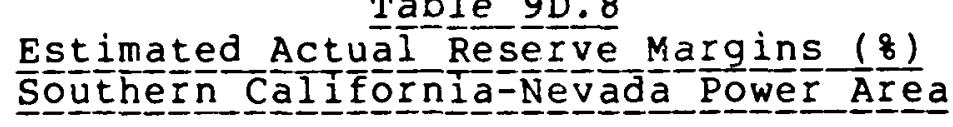

$\begin{array}{llllll} & \underline{1} \underline{9} \underline{8} 1 & \underline{1} \underline{9} \underline{8} \underline{2} & \underline{1} \underline{9} \underline{8} \underline{3} & \underline{19} \underline{8} \underline{4} & \underline{19} \underline{8} \underline{5} \\ \text { Delayed schedule } & 18.8 & 14.8 & 13.7 & 21.0 & 20.8\end{array}$


Use of the lower CEC load forecast to determine reserves results in installed margins of up to 30 percent (1983) using the utilities presently scheduled capability additions. It may be assumed that scheduled additions will necessarily be delayed if the CEC's rigorous "need" determination continues as in past licensing hearings.

For S.CA-NV, only the effective dates for rerating two oil-fired units have been rescheduled since the April 1, 1979, WSCC report.

\begin{tabular}{|c|c|c|c|c|}
\hline nit Name \& №. & 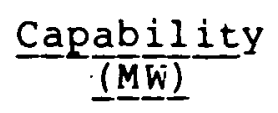 & Previous & $\frac{\text { New }}{\text { Da-te }}$ & 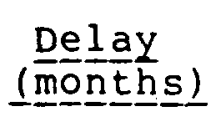 \\
\hline $\begin{array}{lll}\text { Sool Water } & 4 \\
\text { Jong Beach } & \text { 11 }\end{array}$ & $\begin{array}{l}+61 \\
+56\end{array}$ & $\begin{array}{l}6 / 79 \\
7 / 79\end{array}$ & $\begin{array}{l}9 / 79 \\
1 / 81\end{array}$ & $\begin{array}{r}3 \\
17\end{array}$ \\
\hline
\end{tabular}

Proposed bulk power 1 ine additions for the area through 1989 consist of 13 miles of $138 \mathrm{kV}$ line, 342 miles of $230 \mathrm{kV}$ line, 300 miles of $345 \mathrm{kV}$ line, $1508 \mathrm{miles}$ of $500 \mathrm{kV}$ line, and $986 \mathrm{miles}$ of $1000 \mathrm{kV}( \pm 500 \mathrm{kV})$ DC line. The DC line is scheduled to deliver Utah coal-fired capacity to southern California in the late 1980's. Also, the $540 \mathrm{mile}$ existing $800 \mathrm{kV}$ DC line from the Pacific Northwest to sylmar is scheduled to be upgraded to $1000 \mathrm{kV}$ in 1984 .

The addition of two $230 \mathrm{kV}$ lines by San Diego Gas and Electric Company is planned to overcome the existing deficiency associated with the San Onofre 1 ine as well as deliver added generator output in the early 80 's. Additional $230 \mathrm{kV}$ and $500 \mathrm{kV}$ lines are proposed by the company to provide substantial ties with Mexico and eastern utilities by 1985 . 
Table 9 D. 10

Significant planned $\bar{d}$ dit ions to Generating Capacity Souther

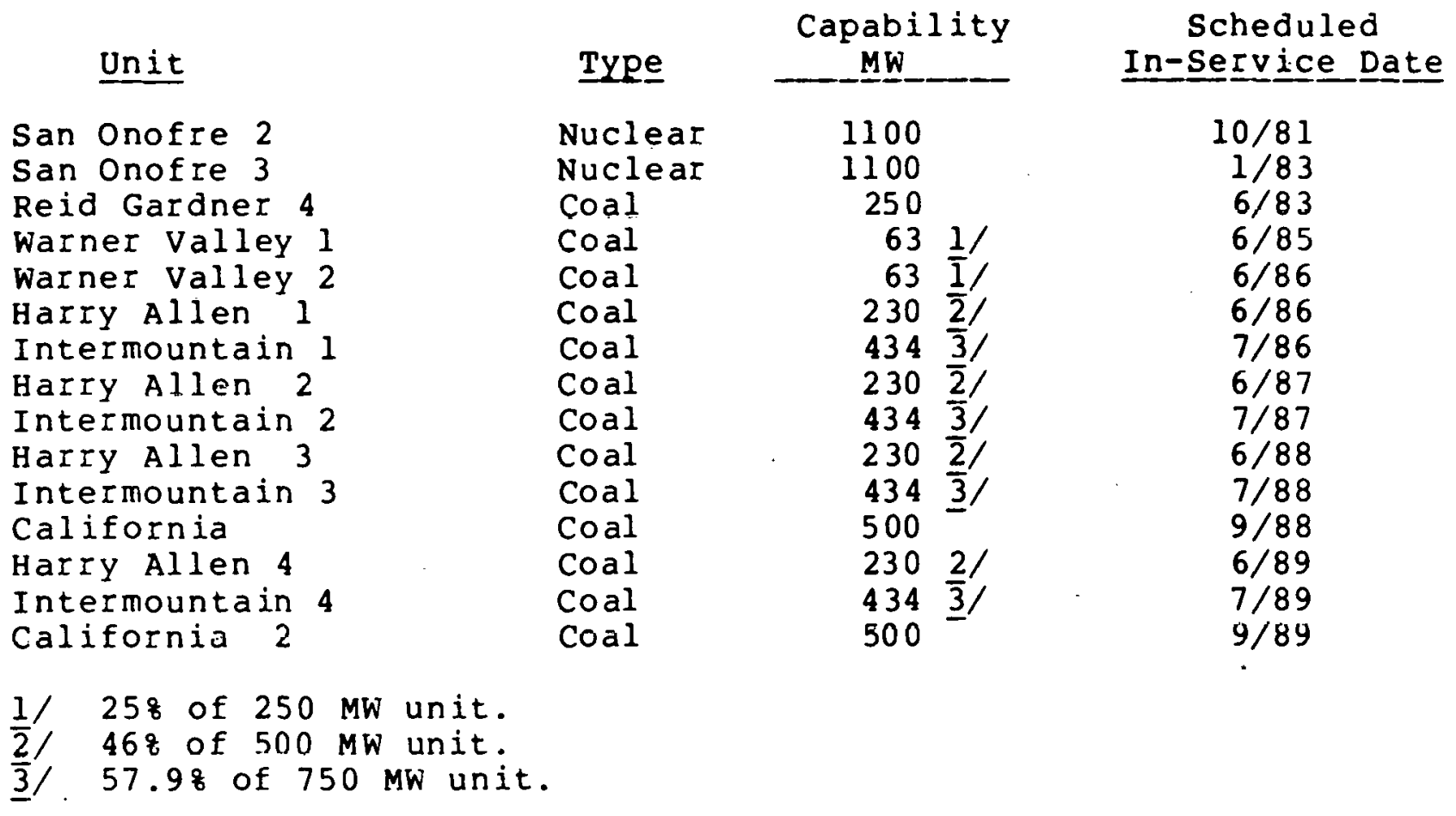

Table 9D.12

1985 and 1989 - Installed Capability by Type of Plant Southern California-Nevada Power Area

\begin{tabular}{|c|c|c|c|c|c|}
\hline \multirow[b]{2}{*}{ Plant Type } & \multirow[b]{2}{*}{$\begin{array}{l}\text { Fuel } \\
\text { Typeㄹ }\end{array}$} & \multicolumn{2}{|c|}{1200} & \multicolumn{2}{|c|}{1989} \\
\hline & & $\begin{array}{c}\text { Capability } \\
\text { Mw }\end{array}$ & $\begin{array}{l}\text { Percent } \\
\text { of Total }\end{array}$ & $\begin{array}{c}\bar{c} \overline{p a b i l i t} \bar{y} \\
M w\end{array}$ & $\begin{array}{l}\text { Percent } \\
\text { of Total }\end{array}$ \\
\hline $\begin{array}{l}\text { Hydro } \\
\text { Pumped storage } \\
3 \text { tam } \\
\text { Steam } \\
\text { Steam } \\
\text { Combustions } \\
\text { Turbine }\end{array}$ & $\begin{array}{l}\text { Water } \\
\text { Water } \\
\text { Coal } \\
\text { Oil/Gas } \\
\text { Nuclear } \\
\text { Oil/Gas }\end{array}$ & $\begin{array}{c}2875 \\
1247 \\
4141 \\
14688 \\
3182 \\
1854\end{array}$ & $\begin{array}{r}9.8 \\
4.3 \\
14.2 \\
50.3 \\
10.9 \\
6.3\end{array}$ & $\begin{array}{c}3195 \\
1247 \\
7582 \\
14567 \\
3455 \\
2949\end{array}$ & $\begin{array}{r}9.3 \\
3.6 \\
22.1 \\
42.3 \\
10.0 \\
8.6\end{array}$ \\
\hline $\begin{array}{l}\text { Combined Cycle } \\
\text { Geothermal } \\
\text { Internal } \\
\text { Combustion }\end{array}$ & $\begin{array}{l}0 i 1 / \text { Gas } \\
\text { oil }\end{array}$ & $\begin{array}{r}1144 \\
9 \\
30\end{array}$ & $\begin{array}{l}3.9 \\
0.0 \\
0.1\end{array}$ & $\begin{array}{r}1144 \\
88 \\
30\end{array}$ & $\begin{array}{l}3.3 \\
0.3 \\
0.1\end{array}$ \\
\hline $\begin{array}{l}\text { Cogeneration } \\
\text { wind }\end{array}$ & & $\begin{array}{r}47 \\
-3 \\
-\end{array}$ & $\begin{array}{l}0.2 \\
0.0\end{array}$ & $\begin{array}{r}60 \\
-84\end{array}$ & $\begin{array}{l}0.2 \\
0.2\end{array}$ \\
\hline Total & & 29220 & 100.0 & 34401 & 100.0 \\
\hline
\end{tabular}


FUTURE CAPABILITY (MW) AND RESERVES (MW and Percent) - 1981-84 Southern Cal ifornia - Nevada Power Area

1. Planned Capability I/

2. Peak Demand

3. Planned Reserves (1-2)

4. Planned Reserves (\%) $(3 / 2) \times 100$

5. Net Transactions (Imports-Exports)

6. Total Capability $(1+5)$

7. Total Reserves (6-2)

8. Total Reserves $(\%)(7 / 2) \times 100$

9. Scheduled Maintenance

10. Capability after Maintenance (6-9)

11. Reserves after Maintenance (10-2)

12. Reserves after Maintenance (\%) $(11 / 2) \times 100$

13. Inoperable Capability

14. Available Capability (10-13)

15. Available Reserves (14-2)

16. Available Reserves (\%) (15/2) ×100

17. Forced Outages 21

18. Actual Capability after Forced Outages (14-17)

19. Actual Reserves (18-2)

20. Actual Reserves (\%) $(19 / 2) \times 100$

$$
1981
$$

$\frac{1981}{\text { Summer Winter }}$

1982

$\begin{array}{ll}22525 & 23616 \\ 21238 & 17542\end{array}$

$1287 \quad 6074$

6.134 .6

$4275 \quad 3834$

$26800 \quad 27450$

$5562 \quad 9908$

$26.2 \quad 56.5$

$1111 \quad 2518$

2568924932

44517390

$21.0 \quad 42.1$

$459 \quad 459$

$25230 \quad 24473$

$3992 \quad 6931$

$18.8 \quad 39.5$

$\begin{array}{rr}0 & 0 \\ 25230 & 24473\end{array}$

$39 \subseteq 2 \quad 6931$

$18.8 \quad 39.5$

\begin{tabular}{rr}
\multicolumn{2}{c}{1982} \\
\cline { 1 - 1 } Summer & Winter \\
23587 & 23798 \\
21975 & 18055 \\
1612 & 5743 \\
7.3 & 31.8 \\
4212 & 3995 \\
27799 & 27793 \\
5824 & 9738 \\
26.5 & 53.9 \\
1003 & 1679 \\
26796 & 26114 \\
4821 & 8059 \\
21.9 & 44.6 \\
459 & 459 \\
26337 & 25655 \\
4362 & 7600 \\
19.8 & 42.1 \\
0 & 0 \\
26337 & 25655 \\
4362 & 7600 \\
19.8 & 42.1
\end{tabular}

1983 Summer Winter

$24726 \quad 25005$

$22633 \quad 18604$

$2093 \quad 6401$

$9.2 \quad 34.4$

$4284 \quad 3981$

$29010 \quad 28986$

$6377 \quad 10382$

$28.2 \quad 55.8$

$1754 \quad 2491$

$27256 \quad 26495$

$4623 \quad 7891$

$20.4 \quad 42.4$

$175 \quad 175$

$27081 \quad 26320$

$4448 \quad 7716$

19.7

0

2708

4448

19.7
1984

Summer Winter

$24814 \quad 25054$

$23369 \quad 19227$

$1445 \quad 5827$

6.230 .3

$4529 \quad 4063$

$29343 \quad 29117$

$5974 \quad 9890$

$25.6 \quad 51.4$

$827 \quad 1912$

28516.27205

$5147 \quad 7978$

$22.0 \quad 41.5$

$245 \quad 245$

2827126960

$4902 \quad 7733$

$21.0 \quad 40.2$

$0 \quad 0$

$28271 \quad 26960$

$4902 \quad 7733$

$21.0 \quad 40.2$

1/ No delays anticipated in new generating units since submission of 1980 ERA-411.

2/ Information on forced outages not available. 
FUTURE CAPABILITY (MW) AND RESERVES (MW and Percent) - 1985-89

Southerri Cal ifornia - Nevada Power Area

1. Planned Capability

2. Peak Demand

3. Planned Reserves (1-2)

4. Planned Reserves (\%) (3/2) x100

5. Net Transactions (Imports-Exports)

6. Total Capability $(1+5)$

7. Total Reserves (6-2)

8. Total Reserves $(\%)(7 / 2) \times 100$

9. Scheduled Maintenance $1 /$

10. Capability after Maintenance (6-9)

11. Reserves after Maintenance (10-2)

12. Reserves after Maintenance $(\%)(11,2) \times 100$

13. Inoperable Capability

14. Available Capability (10-13)

15. Available Reserves (14-2)

16. Available Reserves (\%) (15/2) ×100

17. Forced Outages I/

18. Actual Capability after Forced Ou:ages (14-17)

19. Actual Reserves (18-2)

20. Actual Reserves (\%) (19/2) $\times 100$

I/ Information not available.

$\frac{1985}{\text { Summer Winter }} \frac{1986}{\text { Summer Winter }} \frac{1987}{\text { Summer Winter }} \frac{1988}{\text { Summer Winter Summer Winter }}$

\begin{tabular}{|c|c|c|c|c|c|c|c|c|c|}
\hline 25298 & 25759 & 27614 & 23070 & 29339 & 29800 & 31567 & 31675 & 33779 & 33840 \\
\hline 24172 & 19835 & 24962 & 20520 & 25814 & 21149 & 26664 & 21775 & 27461 & 22411 \\
\hline 1126 & 5924 & 2652 & 7550 & 3525 & 8651 & 4903 & 9900 & 6318 & 11429 \\
\hline 4.7 & 29.9 & 10.6 & 36.8 & 13.7 & 40.9 & 18.4 & 45.5 & 23.0 & 51.0 \\
\hline 4229 & 3945 & 3206 & 2909 & 2156 & 1855 & 1226 & 933 & 405 & 109 \\
\hline 29527 & 29704 & 30820 & 30979 & 31495 & 31655 & 32793 & 32608 & 34184 & 33949 \\
\hline 5355 & 9869 & 5858 & 10459 & 5681 & 10506 & 6129 & 10833 & 6723 & 11538 \\
\hline 22.2 & 49.8 & 23.5 & 51.0 & 22.0 & 49.7 & 23.0 & 49.7 & 24.5 & 51.5 \\
\hline 0 & 0 & 0 & 0 & 0 & 0 & D & 0 & 0 & 0 \\
\hline 29527 & 29704 & 30820 & $\Xi 0979$ & 31495 & 31655 & 3279.3 & 32608 & 34184 & 33949 \\
\hline 5355 & 9869 & 5858 & 10459 & 5681 & 10506 & 6129 & 10833 & 6723 & 11538 \\
\hline 22.2 & 49.8 & 23.5 & 51.0 & 22.0 & 49.7 & 23.0 & 49.7 & 24.5 & 51.5 \\
\hline 175 & 175 & 269 & 269 & 269 & 269 & 269 & 269 & 269 & 269 \\
\hline 29352 & 29529 & 30551 & 30710 & 31226 & 31386 & 32524 & 32339 & 33915 & 33680 \\
\hline 5180 & 9694 & 5589 & 10190 & 5412 & 10237 & 5860 & 10564 & 6454 & 11269 \\
\hline 21.4 & 48.9 & 22.4 & 49.7 & 21.0 & 48.4 & 22.0 & 48.5 & 23.5 & 50.3 \\
\hline 0 & 0 & 0 & 0 & 0 & 0 & 0 & 0 & 0 & 0 \\
\hline 29352 & 29529 & 30551 & 30710 & 31226 & 31386 & 32524 & 32339 & 33915 & 33680 \\
\hline 5180 & 9694 & 5589 & 10190 & 5412 & 10237 & 5860 & 10564 & 6454 & 11269 \\
\hline 21.4 & 48.9 & 22.4 & 49.7 & 21.0 & 48.4 & 22.0 & 48.5 & 23.5 & 50.3 \\
\hline
\end{tabular}


$X I .9 .69$

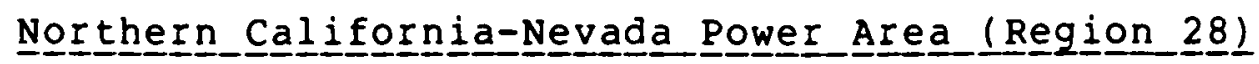

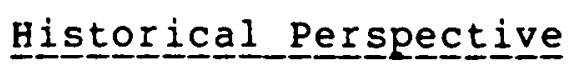

The major service area within the Northern California-Nevada Power area (N.CA-NV) of the WSCC is the combined Pacific Gas and Electric Company (PG\&E)/Sacramento Municipal Utility District (SMUD) area in northern California. The two utilities operate together (central dispatch) and serve approximately 90 percent of the total area electric load. In northern Nevada the major utility is the Sierra Pacific Power Company (SPP).

The N.CA-NV energy load growth averaged 6.6 percent annually from 1960 through 1973 and approximately 3 percent from 1973 through 1979. The area experiences a summer peak dominated by air conditioning and irrigation pumping loads. However, Sierra Pacific Power Company is a winter peaking utility.

During the winter of 1976-77 California experienced its worst drought record, consequently, hydroelectric powerplant output was dramatically reduced. The impact of the drought resulted in significant voluntary conservation and negative load growth from 1976 to 1977 . The high peak demand growth figures for 1978 are artificially high because of this. 1979 showed a return to a more normal growth rate.

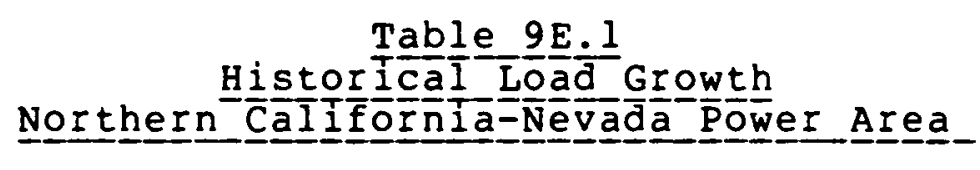

\begin{tabular}{crrr} 
& 1977 & 1978 & 1979 \\
Energy Load (GWh) & \multicolumn{1}{c}{19044} & 79220 & 82690 \\
Growth from previous year (8) & -1.3 & 4.2 & 4.4 \\
Peak Demand (MW) & 14461 & 15772 & 16016 \\
Growth from previous year (8) & -1.1 & 9.1 & 1.5 \\
Load Factor (8) & 60.0 & 57.3 & 58.9
\end{tabular}

In 1978, an above average water year, hydro generation amounted to $28407 \mathrm{GWh}$ or 41.2 percent of the area's total generation. At the end of 1979, the region's hydroelectric resources accounted for 36.8 percent of total area dependable capability. Other generating capability includes oil/gas-fired, geothermal, and nuclear, representing $53.1,4.2$, and 5.9 percent of the 1979 total capability, respectively. 
Ninety-five percent of the area's oil and gas-fired generation is owned and operated by PG\&E (SPP owns the remainder). The amount of natural gas burned in PG\&E's steam units, which are capable of burning both oil and gas, varies depending on the fuel availability. Natural gas use has been averaging about 50 percent on a total Btu basis over the past several years. For 1978 the area's total oil burn for powerplant generating purposes was 31.2 million baliels and natural gas usage was 12.6 billion cubic feet, equivalent to $20.4 \mathrm{million}$ barrels of oil. 1979 generation and fuel consumption data is not available for this area.

Geothermal development has continued at the Geysers location with $161 \mathrm{MW}$ of capacity added in 1979 for a total of $663 \mathrm{MW}$ of base load capability.

As of December 31, 1979, nuclear capacity in the area totalled $966 \mathrm{MW}$ consisting of SMIID's Rancho Seco plant $(875 \mathrm{MW}$ summer and $903 \mathrm{MW}$ winter capability) and PG\&E's Humbolt Bay Unit \#3 (63 MW) which has been out of service for the past 3 years. PG\&E's Diablo Canyon Nuclear Units No. 1 and No. 2 (2190 MW) are essentially complete but remain off-line pending NRC licensing. To date, commercial operation of these units has been delayed nearly four years due to various licensing requirements. The licensing delay has been mainly the result of seismological safety design requirements as well as Three Mile Island related concerns. During the interim, additional oil consumption (the incremental fuel) is estimated at $20 \mathrm{million}$ barrels per year.

Because of the delayed installation of the Diablo Canyon units coupled with the effect of higher than normal outages at thermal power plants, actual reserve margins for the PG\&E/SMUD service area have been relatively low. N.CA-NV reserves have ranged from 10.38 to 12.98 for the past three summer and winter peak periods.

T르느로 9 E. 2

Reserve Margins (8)

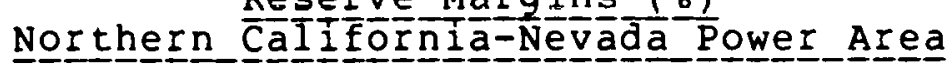

\begin{tabular}{|c|c|c|c|c|c|c|}
\hline & & 77 & & & 19 & \\
\hline & Suㅡㅛㅡㄹ & WInter & Sugumme $\overline{\underline{r}}$ & 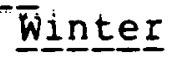 & 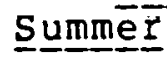 & wInte드 \\
\hline $\begin{array}{l}\text { otal } \\
\text { eserves after }\end{array}$ & $\begin{array}{l}21.5 \\
18.9\end{array}$ & $\begin{array}{l}49.6 \\
29.6\end{array}$ & $\begin{array}{l}15.4 \\
14.6\end{array}$ & $\begin{array}{l}35.9 \\
20.9\end{array}$ & $\begin{array}{l}20.2 \\
20.2\end{array}$ & $\begin{array}{l}37 \cdot 3 \\
37 \cdot 3\end{array}$ \\
\hline Actual & 10.5 & 11.4 & 10.3 & 11.7 & 10.7 & 12.9 \\
\hline
\end{tabular}


XI.9.71

PG\&E estimates northern California reserve requirements based on a loss of load probability of one day in ten years. The resultant installed reserve margin requirement is approximately 15 percent above the annual peak. Sierra Pacific requires a 17 percent reserve margin.

PG\&E/SMUD service area available reserves have been down to 7 percent on several occasions over the past 3 years and PG\&E officials have indicated concern over the high probability of load loss.

The bulk transmission network within N.CA-NV consists of. 6668 miles of $115 \mathrm{kV}$ lines, $6978 \mathrm{miles}$ of $230 \mathrm{kV}$ lines, and 1419 miles of $500 \mathrm{kV}$ lines. The $500 \mathrm{kV}$ system is part of the Pacific Intertie and is capable of inter-area transfers of approximately $2500 \mathrm{MW}$ with the West Group of the Northwest Power Pool and $2000 \mathrm{MW}$ with the N.CA-NV. The transfer capabilities are based on stability studies and are a function of load period and specific system conditions. In addition to contractual exchange, intertie capacity is used to transmit Northwest secondary hydro energy to California, to purchase economy energy, to exchange power and reserve support, and to accommodate major loop circulating flow.

The only existing interconnection between northern california and northern Nevada consists of two $115 \mathrm{kV}$ lines which are limited to $160 \mathrm{MW}$ west to east and $35 \mathrm{MW}$ east to west. As such, SPP operates separately from nothern California with the exception of a $108 \mathrm{MW}$ firm contract with PG\&E. The only other existing major line into the SPP service area is a $230 \mathrm{kV}$ interconnection with the East Group of the Northwest Power Pool in Utah.

Another interconnection with the East Group which was originally scheduled for operation in 1977 was delayed to mid-1980 completion. This $400 \mathrm{MW} 345 \mathrm{kV}$ line presently under construction will link northern Nevada and southern Idaho. The major effects of the line delay reportedly have been increased oil consumption by SPP and reduced system reliability. 


\section{HISTORI LAL CAPABILITY (MW) AND RESERVES (MW and Perzent)}

Nor-hern California - Nevada Power Area

1. Planned Capability

2. Peak Demand

3. Planned Reserves (1-2)

4. Planned Reserves (\%) (3/2) $=100$

5. Net Transactions (Imports-Exports)

6. Total Capability $(1+5)$

7. Total Reserves (6-2)

8. Total Reserves (\%) (7/2) $\times 100$

9. Scheduled Maintenance

10. Capability after Maintenance (6-9:

11. Reserves after Maintenance (i0-2)

12. Reserves after Maintenance ( $(6)(11 / 2): 100$

13. Inoperable Capability

14. Available Capability (10-13)

15. Available Reserves (14-2)

16. Available Reserves (\%) (15/2) $\times 100$

17. Forced Outages I/

18. Actual Capability after Forced Ousages (14-17)

19. Actual Reserves (18-2)

20. Actual Reserves (\%) $(19 / 2) \times 100$

1/ Information not reported separately.

2/ Includes scheduled outages.
1977

$\frac{1977}{\text { Summer Winter }}$

$15539 . \quad 16086$

$14461 \quad 11974$

$1073 \quad 4112$

$7.5 \quad 34.3$

$2035 \quad 1822$

$17575 \quad 17908$

$3114 \quad 5934$

$21.5 \quad 49.6$

$375 \quad 2394$

$17200 \quad 15514$

$2739 \quad 3540$

$18.9 \quad 29.6$

1215

15985

1524

10.5

0

15985

1524

10.5 $\frac{1978}{\text { Sumner Winter }}$

$16 \check{278} 16432$

$15.72 \quad 12591$

$506 \quad 3841$

$3.2 \quad 30.5$

$1925 \quad 681$

18203

2431

15.4

132

18071

2299

14.6

$$
571
$$

17400

1528

10.3

0

17700

1528

10.3
17113

4522

35.9

1892

15221

2630

20.9

.1151

14070

1479

11.7

0

14070

1479

11.7 $\frac{1979}{\text { Summer Winter }}$

$16926 \quad 16517$

$16016 \quad 12566$

$910 \quad 3951$

$\begin{array}{ll}5.7 & 31.4\end{array}$

$2327 \quad 730$

$19253 \quad 17247$

$3237 \quad 4681$

$20.2 \quad 37.3$

$0 \quad 0$

$19253 \quad 17247$

$3237 \quad 4681$

$20.2 \quad 37.3$

$152321 \quad 306221$

$17730 \quad 14185$

$1714 \quad 1619$

$10.7 \quad 12.9$

0 . 0

$17730 \quad 14185$

$1714 \quad 1619$

$10.7 \quad 12.9$ 
Table $9 \mathrm{E} .4$

1979 Capability by Type of Plant Northern California-Nevada Power Área

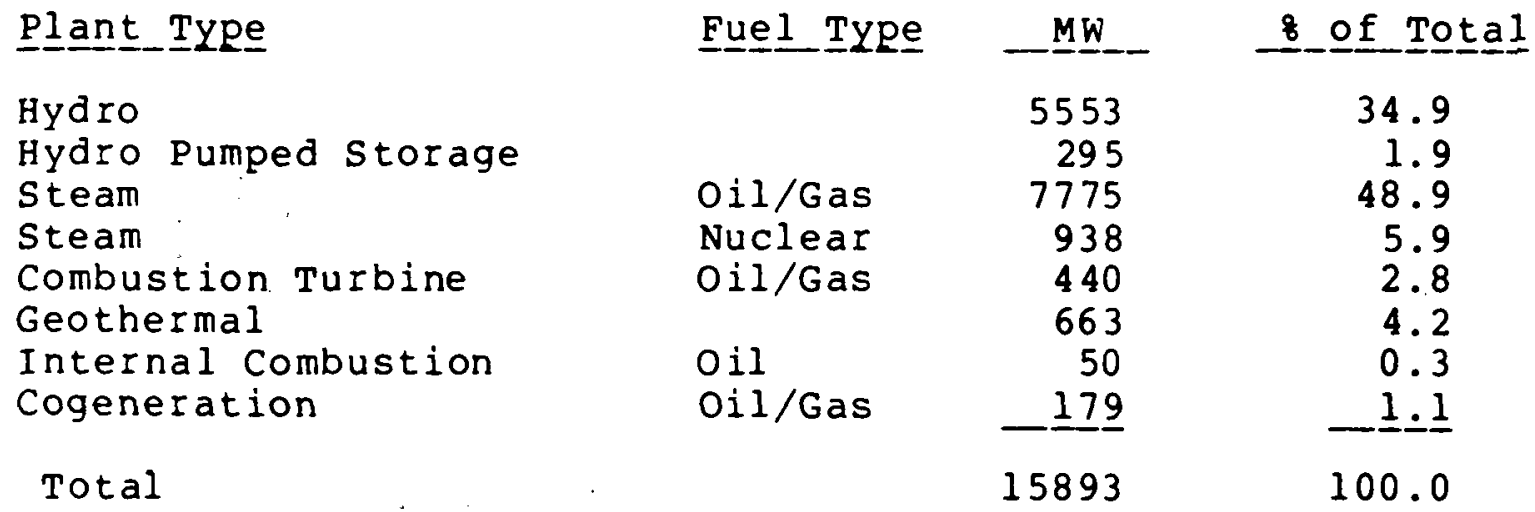

\section{Curient Perspective}

Northern California utilities continue to operate under a high risk situation mainly because of the delay of bringing the Diablo Canyon nuclear units into service. Available reserve margins for N.CA-NV are expected to be only 9.14 percent this summer. This does not include the effects of forced outage. The 1980 margins reflect the expectcd above average hydru conditions and include more than $800 \mathrm{MW}$ of short-term capacity for which $P G \& E$ has made arrangements.

Summer and winter peaks are forecast to grow 5.5 and 8.6 percent respectively over the same period of the preceding year. The only significant resource additions scheduled for 1980 consist of $245 \mathrm{MW}$ of geothermal capability at the Geysers.

The estimated summer peak reserve margins for the area are higher than indicated: in earlier studies because of late seasonal precipitation. Summer margins for the combined PG\&E/SMUD service area were revised by the utilities based upon February 29, 1980 , hydrological data as well as updated information on system thermal capacity and available purchases. Revised load forecasts were prepared based on the assumption that utility customers will observe approximately the same level of conservation as in 1979 (which presumes active utility appeals). These data indicate that northern California reserve margins will approximate 10 percent this summer, which is estimated to be the minimum acceptable margin necessary to cover expected forced outages. 
The utilities' calculated reserve margins include the assumption that SMUD's Rancho seco nuclear unit will be back on-line in early April following refueling and NRC required modification. Latest information indicates that Rancho seco is presently on line.

Because of delays in bringing new resources on line and recent adverse hydrological conditions, California thermal-electric plants have operated at relatively high capacity factors leading to unusually high forced outage rates. After consideration of the historic five year-average forced outage, the northern California utilities' projected 1980 reserve margins are reduced to as little as 1.8 percent with Rancho seco in service. Should PG\& experience higher than average forced outage rates, as was the case last year, utility officials state that either additional unidentified short-term capacity purchases will be required or rotating service outages will become necessary.

While some additional purchases from the Pacific Northwest have been included in the utilities' resource calculations, unused firm intertie capability remains available. However, the Northwest has experienced below normal precipitation this year and further purchases if available would probably be limited to capability with energy payback reguired within 24 hours of receipt.

The statewide critical period reserve sharing and load reduction plan remains in effect this year. Under this plan the state's five major electric utilities will share reserves if the operating reserve margin of any utility drops below 7 percent. Peak demand diversity between northern and southern callfornia averages approximately $1000 \mathrm{MW}$. Load reduction measuies w111 be implemented in three stages beginning when statewide reserves drop to 5 percent and calling for rotating circuit interruptions when reserves drop to 1.5 percent.

Transmission systems within the Northern California-Nevada Power Area are expected to be adequate to accommodate planned peak and energy transfers with one possible exception. Completion of the Mid-point-Valmy-Tracy $345 \mathrm{kV}$ line between the Idaho and northern Nevada areas may result in relatively large magnitudes of circulating loop flow on the northern Nevada northern California interconnection. Under certain conditions the northern Nevada-northern California interconnection may have to be opened to prevent overloading of the $115 \mathrm{kV}$ system in the northern California area. 


\section{Table 9E.5}

\section{CURRENT CAPABILITY (MW) AND RESERVES (MW and Percent)} Northern Cal ifornia - Nevada Power Area

1. Planned Capability l/

2. Peak Demand

3. Planned Reserves (1-2)

4. Planned Reserves $(\%)(3 / 2) \times 100$

5. Net Transactions (Imports-Exports)

6. Total Capability $(1+5)$

7. Total Reserves (6-2)

8. Total Reserves (\%) $(7 / 2) \times 100$

9. Scheduled Maintenance

10. Capability after Maintenance (6-9)

11. Reserves after Maintenance (10-2)

12. Reserves after Maintenance (\%) $(11 / 2) \times 100$

13. Inoperable Capability

14. Available Capability (10-13)

15. Available Reserves (14-2)

16. Available Reserves (\%) (15/2) $\times 100$

17. Forced Outages 2 I

18. Actual Capability after Forced Outages (14-17)

19. Actual Reserves (18-2)

20. Actual Reserves (\%) $(19 / 2) \times 100$

1/ No delays anticipated innew generating units since submission of 1980 ERA-411.

2/ 3-Year historical average forced outage (1976-78).

\begin{tabular}{rrr}
$\begin{array}{rr}1980 \\
\text { Summer }\end{array}$ & & $\begin{array}{r}1980 / 81 \\
\text { Winter }\end{array}$ \\
\cline { 1 - 1 } 17782 & & 16709 \\
16896 & & 13647 \\
886 & & 3062 \\
5.2 & & 22.4 \\
1265 & & 395 \\
19047 & & 17104 \\
2151 & 3457 \\
12.7 & & 25.3 \\
12 & 705 \\
19035 & 16399 \\
2139 & 2752 \\
12.7 & 20.2 \\
550 & 368 \\
18485 & 16031. \\
1589 & 2384 \\
9.4 & 17.5 \\
1206 & 1160 \\
17279 & 14871 \\
383 & 1224 \\
2.3 & 9.0
\end{tabular}




\section{Table $9 \mathrm{E} .6$ \\ 1980 Installed Capability by Type of plant Northern California-Nevada Powe}

Plant Type
Hydro
Pumped Storage
Steam
Steam
Combustion Turbine
Geothermal
Internal Combustion
Cogeneration

Total
Fuel Type

\begin{tabular}{rr} 
& \multicolumn{1}{c}{ Capacity } \\
\hline$\underline{M} \bar{W}$ & Percent \\
5560 & 34.5 \\
295 & 1.8 \\
7775 & 48.2 \\
938 & 5.8 \\
440 & 2.7 \\
908 & 5.6 \\
50 & 0.3 \\
179 & -1.1 \\
16145 & 100.0
\end{tabular}

\section{Future Pcrepective}

Electric loads in northern California and northern Nevada have been projected by the area's utilities to increase at the rates of 3.3 percent per peak demand and 3.8 percent for energy for load over the five-year period from 1980 through 1985 . For the following fouryear period through 1989 , the forecasted increase is 4.2 percent peak growth and 4.6 percent energy growth.

The recently adopted California Energy Commission (CEC) forecast for the northern California region is lower than that projected by the Region's utilities. The CEC forecast will be used by the commission to determine the need for new generating facilities during the state's certification process. This forecast indicates a growth rate for the PG\&E/SMUD service area of 2 percent in peak demand and energy through the decade of the $1980^{\prime} \mathrm{s}$.

PG\&E has very recently (April 1980) announced the results of a new load forecast which has not yet been incorporated into the resource plan. The revised forecast is much closer to that projected by the Energy Commission, averaging 2.7 percent growth per year between 1980 and 2000 .

The addition of the Diablo Canyon nuclear units is now scheduled for 1981. Any further delay could seriously jeopardize system reliability and cause additional fuel oil burn of nearly two million barrels per month. Other near-term scheduled capability additions through 1985 include $959 \mathrm{MW}$ of geothermal, $552 \mathrm{MW}$ of conventional hydro, $1120 \mathrm{MW}$ of pumped storage hydro, $313 \mathrm{MW}$ of coal-fired (including joint ownership in facilities outside of the Region), $378 \mathrm{MW}$ of gas-fired combined cycle, and $691 \mathrm{MW}$ of 
cogeneration. If the Diablo Canyon nuclear units were delayed an additional year, and all coal and geothermal additions were delayed six months, the effect on fuel oil consumption would total about $25 \mathrm{million}$ barrels over the five-year period through 1985, and coal and geothermal delays would account for approximately one million additional barrels of oil consumption annually.

Beyond 1985 the area's predominant scheduled additions include the continued development of geothermal potential and significant amounts of coal-fired capability. Major capacity additions lover $100 \mathrm{MW})$ are listed in Table 9E.10. In addition, PG\&E's coal-fired plants planned for northern California in the late 1980's have tentatively been slipped one to two years due to reduced load growth. This slippage will result in a total of about $30 \mathrm{milli}$ ion barrels of additional fuel oil consumption per year of delay.

Table 9E.7 shows the major planned additions during the next five years which have been delayed from the schedule of one year ago.

$$
\text { Nor } \text { Un }
$$

Scheduled In-Service

Under Construction

-_unit_\& No. Type

Geysers 13

Geysers 14

Diablo Canyon 1

Diablo Canyon 2

Helms P.S. 1

Helms P.S. 2

Helms P.S. 3

Geysers 17

Under Licensing

Potrero $\frac{\text { Un }}{7}=$

\footnotetext{
Kerckhoff 2

Geysers 16
}

Geothermal Geothermal Nuclear Nuclear Hyd ro

Hydro

Hydro

Geothermal
Capability (MW)

$$
135
$$

110

1084

1106

374

373

373

110 Date

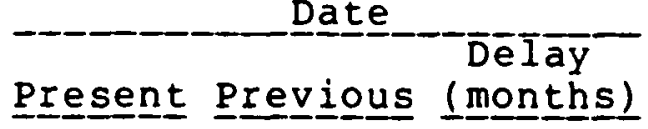

$4 / 80$

$8 / 80$

$2 / 81$

$8 / 81$

$12 / 81$

$4 / 82$

$5 / 82$

$7 / 82$
$10 / 79$

$4 / 80$

$7 / 79$

$3 / 80$

$6 / 81$

$6 / 81$

$6 / 81$

$6 / 82$

\section{6}

4

19

17

6

10

11

13

$$
\begin{gathered}
\text { Combined } \\
\text { Cycle }
\end{gathered}
$$

Hydro

Geothermal
378

151

110
$6 / 83$

$6 / 81$

24

$10 / 83$

$11 / 83$
$12 / 82$

$9 / 82$
10 
The PG\&E/SMUD service area reserve margins are short of meeting even the minimum Reliability Council criterion for 1980 and 1981. Following the full commercial operation of Diablo Canyon, present schedules indicate adequate reserve margins for the Region.

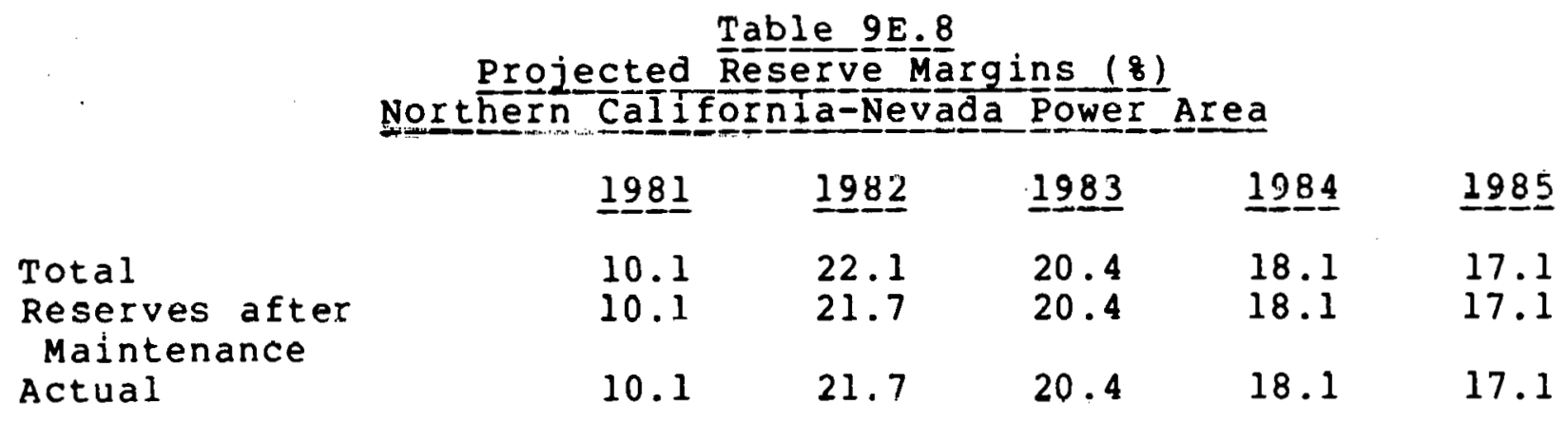

Further delays in bringing new generating units on-line could worsen the reserve shortage as indicated below. The delayed schedule is based on the aforementioned one year nuclear and six months coal and geothermal slippage.

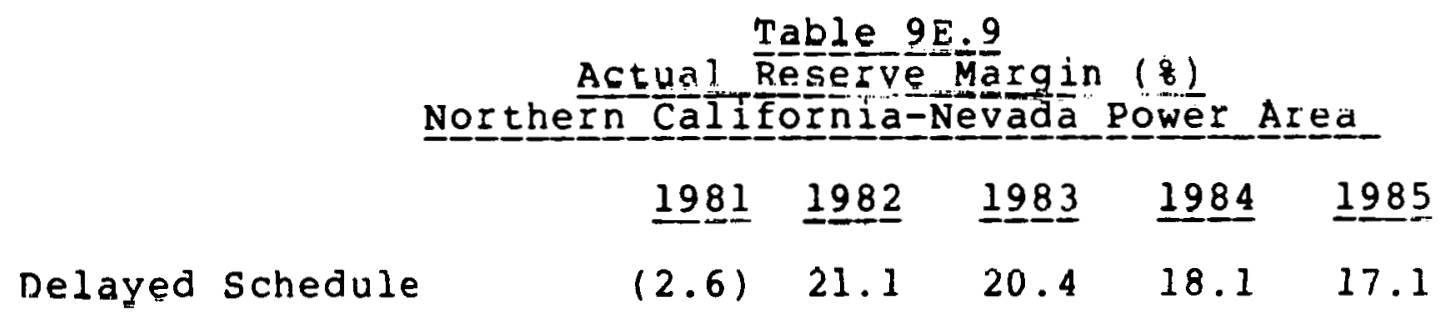

Scheduled transmission additions from 1980 through 1985 include 531 miles of $230 \mathrm{kV}, 564 \mathrm{miles}$ of $345 \mathrm{kV}, 52$ miles of $500 \mathrm{kV}$ line. Additionally PG\&E plans $357 \mathrm{miles}$ of $500 \mathrm{kV}$ line in the second half of the decade to deliver proposed northern California coal-fired generator output and to increase Pacific intertie capability.

The 52 mile Gates to Gregg $500 \mathrm{kV}$ line has been rescheduled to May 1983, a 3 year delay resulting from State regulatory denial of certification. This delay will limit pump-back operation at the Helms pumped storage project and also restrict interconnection capability with the Southern California-Nevada Region. 
Table 9 E. 10

Significant Planned Additions to Generating Capacitty Nor thern Ca

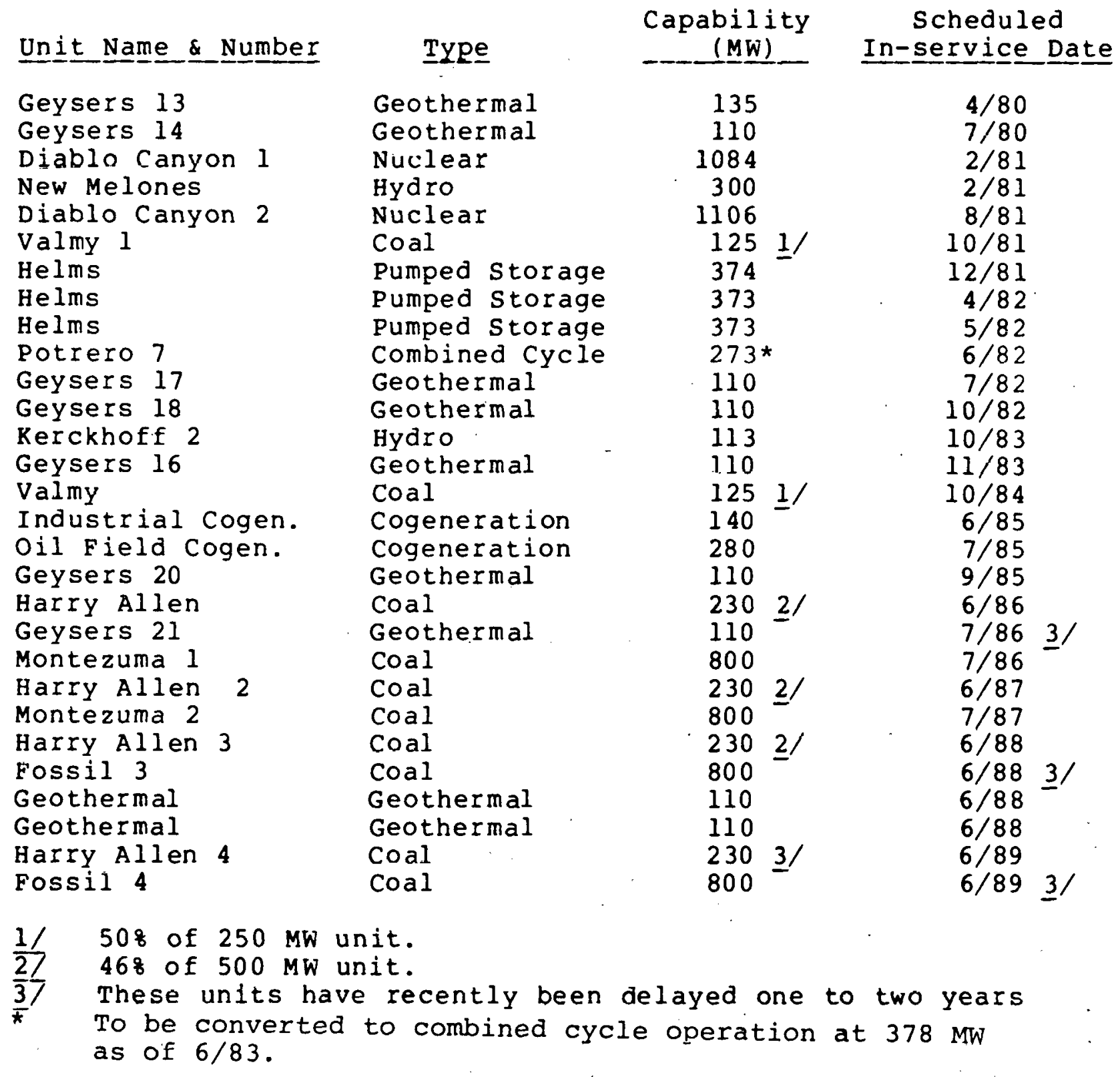


FUTURE CAPABILITY (MW) AND RESERVES (MW and Percent) - 1981-84 Northern California - Nevada Power Area

1. Planned Capability I/

2. Peak Demand

3. Planned Reserves (1-2)

4. Planned Reserves (\%) (3/2) $\times 100$

5. Net Transactions (Imports-Exports)

6. Total Capability $(1+5)$

7. Total Reserves (6-2)

8. Total Reserves (\%) $(7 / 2) \times 100$

9. Scheduled Maintenance

10. Capability after Maintenance (6-9)

11. Reserves after Maintenance (10-2)

12. Reserves 'after Maintenance (\%) $(11 / 2) \times 100$

13. Inoperable Capability

14. Available Capability (10-13)

15. Available Reserves (14-2)

16. Available Reserves (\%) (15/2) ×100

17. Forced Outages 2/

18. Actual Capability after Forced Oatages (14-17)

19. Actual Reserves (18-2)

20. Actual Reserves (\%) (19/2) x100
1981

Summer Winter

$17875 \quad 19281$

$17407 \quad 14206$

$468 \quad 5075$

$2.7 \quad 35.7$

$1291 \quad 295$

$19166 \quad 19576$

$1759 \quad 5370$

$10.1 \quad 37.8$

$0 \quad 1413$

$19166 \quad 18163$

$1759 \quad 3957$

$10.1 ;-27.9$

$\begin{array}{rr}5 & 7 \\ 19161 & 18156\end{array}$

17543950

$10.1 \quad 27.8$

$\begin{array}{rr}0 & 0 \\ 19161 & 18156\end{array}$

$1754 \quad 3950$

$10.1 \quad 27.8$ $\frac{1932}{\text { Summer }}$

$21023 \quad 20547$

$17844 \quad 14610$

$3179 \quad 5937$

$17.8 \quad 40.6$

$7 \in 2 \quad-148$

$21785 \quad 20399$

$3941 \quad 5789$

$22.1 \quad 39.6$

$54 \quad 1631$

$21721 \quad 18768$

$3877 \quad 4158$

$21.7 \cdot 28.5$,

21716

21716

3872

$$
21.7
$$

$$
0
$$

21716

3372

21.7

\begin{tabular}{rr}
\multicolumn{2}{c}{1983} \\
\cline { 1 - 1 } 21230 & 21531 \\
18264 & 15138 \\
2966 & 6393 \\
16.2 & 42.2 \\
762 & -189 \\
21992 & 21342 \\
3728 & 6204 \\
20.4 & 41.0 \\
0 & 1812 \\
21992 & 19530 \\
3728 & 4392 \\
$20: 4$ & 29.0 \\
5 & 8 \\
21987 & 19522 \\
3723 & 4384 \\
20.4 & 29.0 \\
0 & .0 \\
21987 & 19522 \\
3723 & 4384 \\
20.4 & 29.0
\end{tabular}

\begin{tabular}{rr}
\multicolumn{2}{c}{1984} \\
\hline Summer & Winter \\
\cline { 2 - 2 } 21760 & 21626 \\
19026 & 15876 \\
2734 & 5750 \\
14.4 & 36.2 \\
711 & -321 \\
22471 & 21305 \\
3445 & 5429 \\
18.1 & 34.2 \\
0 & 1227 \\
22471 & 20078 \\
3445 & 4202 \\
18.1 & 26.5 \\
5 & 8 \\
22466 & 20070 \\
3440 & 4194 \\
18.1 & 26.4 \\
0 & 0 \\
22466 & 20070 \\
3440 & 4194 \\
18.1 & 26.4
\end{tabular}


Table 9E.11.2

FUTURE CAPABILITY (MW) AND RESERVES (MW and Percent) - 1985-89

Northern Cal ifornia - Nevada Power Area

1985

1986

1987

1988

1989

Summer Winter Summer Winter Summer Winter Summer Winter Summer Winter

1. Planned Capability

2. Peak Demand

3. Planned Reserves $(1-2)$

4. Planned Reserves (\%) (3/2) $\times 100$

5. Net Transactions (Imports-Exports)

6. Total Capability $(1+5)$

7. Total Reserves (6-2)

8. Total Reserves $(\%)(7 / 2) \times 100$

9. Scheduled Maintenance 1/

10. Capability after Maintenance (6-9)

11. Reserves after Maintenance (10-2)

12. Reserves after Maintenance ( $\%)(11 / 2) \times 100$

13. Inoperable Capability

14. Available Capability (10-13)

15. Available Reserves (14-2)

16. Available Reserves (\%) (15/2) x100

17. Forced Outages 1/

18. Actual Capability after Forced Outages (14-17)

19. Actual Reserves (18-2)

20. Actual Reserves (\%) $(19 / 2) \times 100$

$\begin{array}{rrrrrrrrrr}22616 & 22773 & 23852 & 23889 & 25531 & 24795 & 26493 & 25785 & 27351 & 26374 \\ 19902 & 16644 & 20720 & 17455 & 21611 & 18250 & 22505 & 19139 & 23442 & 19794 \\ 2714 & 6129 & 3132 & 6434 & 3920 & 6545 & 3988 & 6646 & 3909 & 6580 \\ 13.6 & 36.8 & 15.1 & 36.9 & 18.1 & 35.9 & 17.7 & 34.7 & 16.7 & 33.2 \\ 698 & -246 & 943 & 3 & 540 & 238 & 777 & 475 & 1007 & 655 \\ 23314 & 22527 & 24795 & 23892 & 26071 & 25033 & 27270 & 26260 & 28358 & 27029 \\ 3412 & 5883 & 4075 & 6437 & -4450 & 6783 & 4765 & 7121 & 4916 & 7235 \\ 17.1 & 35.3 & 19.7 & 36.9 & 20.6 & 37.2 & 21.2 & 37.2 & 21.0 & 36.6 \\ 0 & 0 & 0 & 0 & 0 & 0 & 0 & 0 & 0 & 0 \\ 23314 & 22527 & 24795 & 23892 & 26071 & 25033 & 27270 & 26260 & 28358 & 27029 \\ 3412 & 5883 & 4075 & 6437 & 4460 & 6783 & 4765 & 7121 & 4916 & 7235 \\ 17.1 & 35.3 & 19.7 & 36.9 & 20.6 & 37.2 & 21.2 & 37.2 & 21.0 & 36.6 \\ 5 & 8 & 5 & 8 & 5 & 8 & 5 & 8 & 5 & 7 \\ 23309 & 22519 & 24790 & 23884 & 2606.6 & 25025 & 27265 & 26252 & 28353 & 27022 \\ 3407 & 5875 & 4070 & 6429 & 4455 & 6775 & 4760 & 7113 & 4911 & 7228 \\ 17.1 & 35.3 & 19.6 & 36.8 & 20.6 & 37.1 & 21.2 & 37.2 & 20.9 & 36.5 \\ 0 & 0 & 0 & 0 & 0 & 0 & 0 & 0 & 0 & 0 \\ 23309 & 22519 & 24790 & 23884 & 26066 & 25025 & 27265 & 26252 & 28353 & 27022 \\ 3407 & 5875 & 4070 & 6429 & 4455 & 6775 & 4760 & 7113 & 4911 & 7228 \\ 17.1 & 35.3 & 19.6 & 36.8 & 20.6 & 37.1 & 21.2 & 37.2 & 20.9 & 36.5\end{array}$

Coal_Unit Delays_Assumed_Possible
21. Possible Coal Delays $2 /$

22. Actual Capability w/Nuclear \& Coal Delays (18-21)

23. Actual Reserves $w / N u c l e a r \&$ Coal Delays (22-2)

24. Actual Reserves w/Nuclear \& Coal Delays (\%) $(23 / 2) \times 100$

\section{$\begin{array}{rrrr}0 & 0 & 800 & 800 \\ 23309 & 22519 & 23990 & 23084\end{array}$ \\ $\begin{array}{lrrr}3407 & 5875 & 3270 & 5629\end{array}$}

$\begin{array}{llll}17.1 & 35.3 & 15.8 & 32.2\end{array}$
800
25266
3655

3655
800
24225
5975
32.7

$\begin{array}{rrrr}800 & 800 & 800 & 800 \\ 26465 & 25452 & 27553 & 26222 \\ 3960 & 6313 & 4111 & 6428 \\ 17.6 & 33.0 & 17.5 & 32.5\end{array}$

1/ Information not available.

2) These units have recently been delayed 1 to 2 years from the dates shown. 
Table $9 \mathrm{E} .12$

1985 and 1989 Insta $\frac{1}{1 e d}$ Capacity by Type of plant

\begin{tabular}{|c|c|c|c|c|c|}
\hline Pl ant Type & $\begin{array}{l}\text { Fuel } \\
\text { Type }\end{array}$ & Capability & $\begin{array}{l}8 \frac{5}{\mathrm{P}} \text { ercent } \\
\text { 의 Totaㅡ }\end{array}$ & $\begin{array}{c}\text { Capabilitity } \\
-\end{array}$ & $\begin{array}{l}\text { Percent } \\
\text { of } \text { Total }\end{array}$ \\
\hline $\begin{array}{l}\text { Hydro } \\
\text { Pumped Storage } \\
\text { Steam } \\
\text { Steam } \\
\text { Steam }\end{array}$ & $\begin{array}{l}\text { water } \\
\text { Water } \\
\text { Coal } \\
\text { Oil/Gas } \\
\text { Nuclear }\end{array}$ & $\begin{array}{r}5818 \\
1430 \\
313 \\
7669 \\
3128\end{array}$ & $\begin{array}{r}26.7 \\
6.6 \\
1.4 \\
35.2 \\
14.4\end{array}$ & $\begin{array}{l}6023 \\
1430 \\
3145 \\
7319 \\
3128\end{array}$ & $\begin{array}{r}23.8 \\
5.7 \\
12.4 \\
28.9 \\
12.4\end{array}$ \\
\hline $\begin{array}{l}\text { Combustion } \\
\text { Turbine } \\
\text { Combined Cycle }\end{array}$ & $\begin{array}{l}\text { U1l/Gas } \\
0 i l / G \text { as }\end{array}$ & $\begin{array}{l}440 \\
378\end{array}$ & $\begin{array}{l}2.0 \\
1.7\end{array}$ & $\begin{array}{l}530 \\
378\end{array}$ & $\begin{array}{l}2.1 \\
1.5\end{array}$ \\
\hline $\begin{array}{l}\text { Internal } \\
\quad \text { Combustion } \\
\text { Geothermal } \\
\text { Cogeneration } \\
\text { Other }\end{array}$ & $\begin{array}{l}\text { Oil } \\
\text { GST }\end{array}$ & $\begin{array}{r}50 \\
1622 \\
870 \\
80 \\
\end{array}$ & $\begin{array}{l}0.2 \\
7.4 \\
4.0 \\
0.4\end{array}$ & $\begin{array}{r}50 \\
2112 \\
1120 \\
80 \\
\end{array}$ & $\begin{array}{l}0.2 \\
8.3 \\
4.4 \\
0.3 \\
\end{array}$ \\
\hline Total & & 21798 & 100.0 & 25315 & 100.0 \\
\hline
\end{tabular}




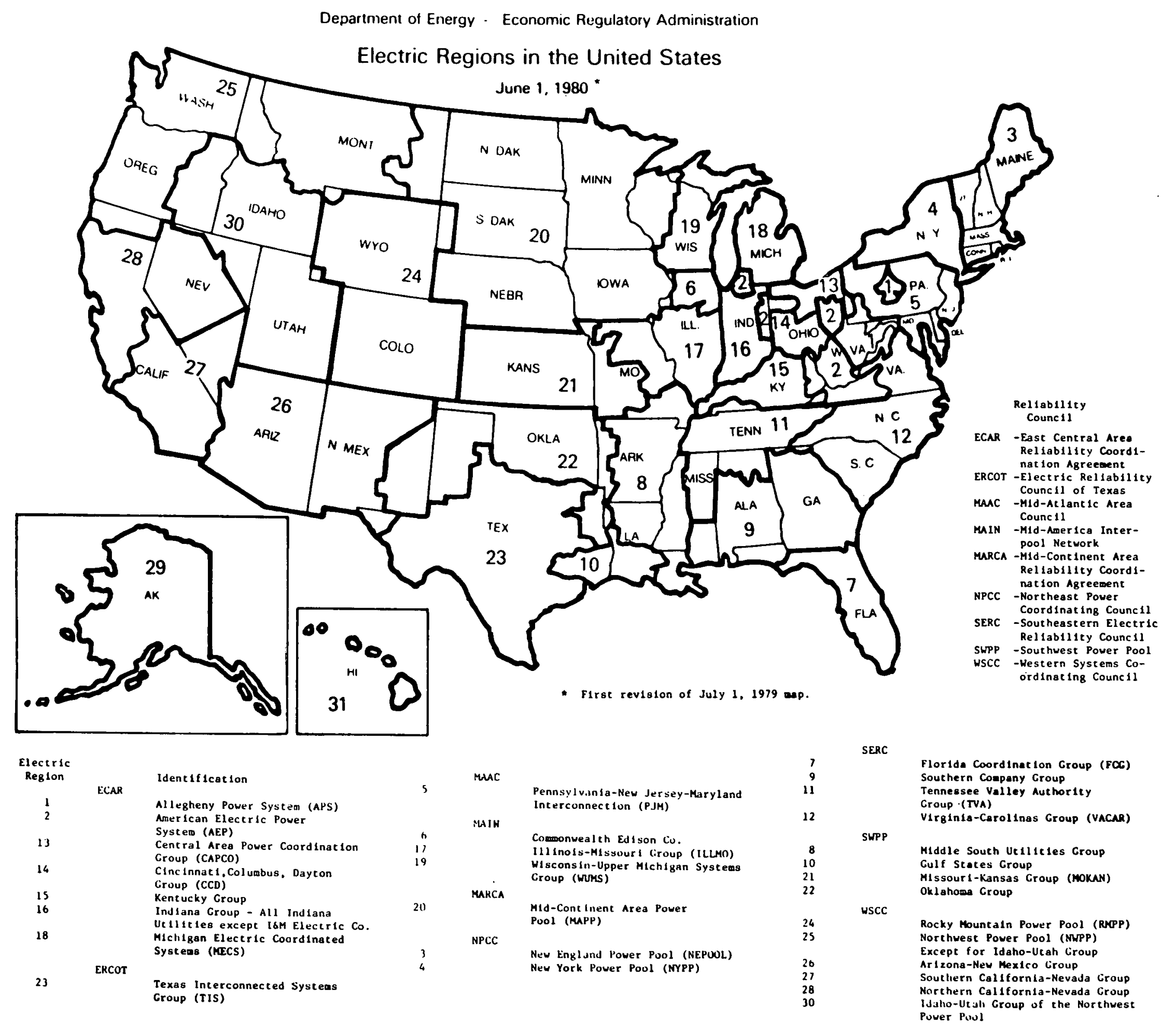

